
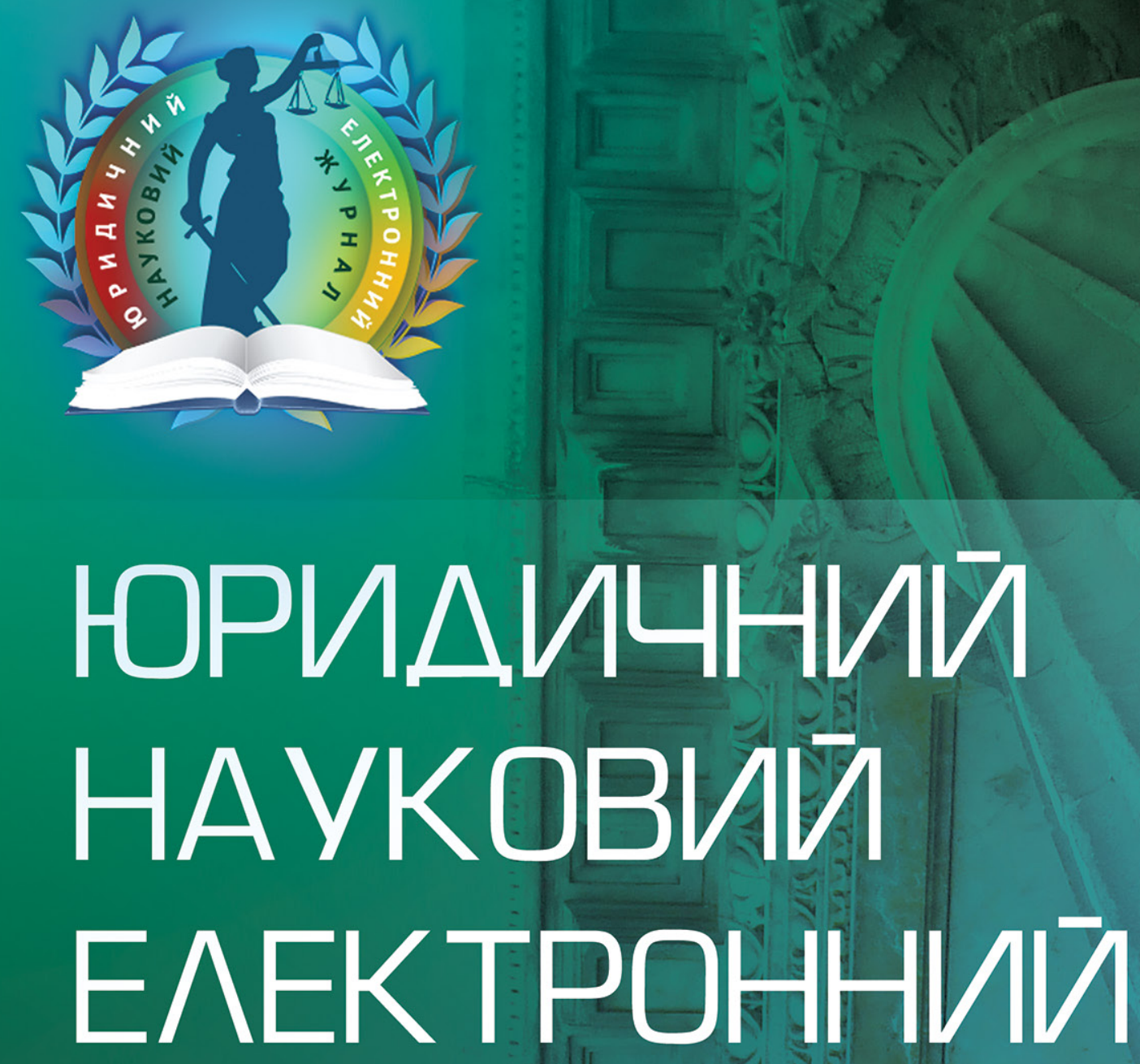

ЖУРНА^

ЕЛЕКТРОННЕ НАУКОВЕ ФАХОВЕ ВИДАННЯ

www.Isej.org.ua 4'2020 


\section{Запорізький національний університет \\ Міністерства освіти і науки України}

\section{Електронне наукове фахове видання «Юридичний науковий електронний журнал»}

№ 4, 2020

На підставі Наказу Міністерства освіти та науки України № 409 від 17.03.2020 р. (додаток 1) журнал внесений до переліку фахових видань категорії «Б» у галузі юридичних наук (081 - Право, 262 - Правоохоронна діяльність, 293 - Міжнародне право)

Журнал включено до міжнародної наукометричної бази Index Copernicus International (Республіка Польща) 
Юридичний науковий електронний журнал - електронне наукове фахове видання юридичного факультету Запорізького національного університету

\title{
РЕДАКЦЙННА КОЛЕГІЯ:
}

\section{Головний редактор:}

Коломоєць Тетяна Олександрівна - доктор юридичних наук, професор

Заступник головного редактора:

Бондар Олександр Григорович - доктор юридичних наук, професор

Відповідальний секретар:

Віхляєв Михайло Юрійович - доктор юридичних наук, доцент

Члени редакційної колегії:

Биргеу Михайло Михайлович - доктор юридичних наук, професор (Республіка Молдова);

Болокан Інна Вікторівна - доктор юридичних наук, доцент;

Верлос Наталя Володимирівна - кандидат юридичних наук;

Галіцина Наталя Вікторівна - доктор юридичних наук, доцент;

Діхтієвський Петро Васильович - доктор юридичних наук, професор;

Дугенець Олександр Сергійович - доктор юридичних наук, професор (Російська Федерація);

Дудоров Олександр Олексійович - доктор юридичних наук, професор;

Ібрагімов Соліджон Ібрагімович - доктор юридичних наук, професор (Республіка Таджикистан);

Колпаков Валерій Костянтинович - доктор юридичних наук, професор;

Курінний Євген Володимирович - доктор юридичних наук, професор;

Кушнір Сергій Миколайович - доктор юридичних наук, професор;

Сильченко Микола Володимирович - доктор юридичних наук, професор (Республіка Білорусь);

Стеценко Семен Григорович - доктор юридичних наук, професор;

Уільям Дж. Уоткінс - доктор юридичних наук (США);

Федчишин Дмитро Володимирович - кандидат юридичних наук;

Шарая Анна Анатоліївна - кандидат юридичних наук.

\author{
Рекомендовано до опублікування вченою радою \\ Запорізького національного університету, \\ протокол № 12 ві 23.06.2020 p.
}




\section{РОЗДІЛ 1 \\ ТЕОРІЯ ТА ІСТОРІЯ ДЕРЖАВИ І ПРАВА; ІСТОРІЯ ПОЛІТИЧНИХ І ПРАВОВИХ УЧЕНЬ}

Бахновська І.П., Сова Ю.В. ЗАГАЛЬНОЛЮДСЬКІ ПРИНЦИПИ ПРАВА ЯК УНІВЕРСАЛЬНІ

НОРМАТИВНІ ЗАСАДИ

Погосян М.А. ФОРМИ ПРАВОВОЇ КОМУНІКАЦІЇ В КОНТЕКСТІ ВЗАСМОДІЇ

ПРАВООХОРОННИХ, ПРАВОЗАХИСНИХ ТА СУДОВИХ ОРГАНІВ:

ТЕОРЕТИКО-ПРАВОВИЙ АНАЛІЗ.

\section{РОЗДІЛ 2}

\section{КОНСТИТУЦІЙНЕ ПРАВО; МУНІЦИПАЛЬНЕ ПРАВО}

Завгородня В.М. МЕЖІ ПРАВА ПУБЛІЧНИХ ОСІБ НА ІНФОРМАЦІЙНУ ПРИВАТНІСТЬ:

ДОСВІД США.

Загурський О.Б., Король В.С. КОНЦЕПТУАЛЬНІ ПІДХОДИ ДО РОЗУМІННЯ ФЕНОМЕНУ

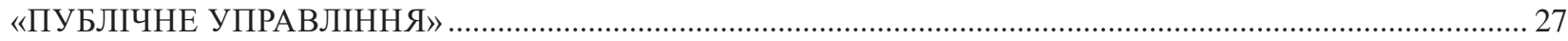

Коваль Т.В. ОКРЕМІ ПИТАННЯ ПРАВОВОГО СТАТУСУ МОВНОГО ОМБУДСМЕНА В УКРАЇНІ.... 30 Нікітенко Л.О. ЩОДО ПРИНЦИПУ НЕДИСКРИМІНАЦІЇ ЗА ОЗНАКОЮ МІСЦЯ ПРОЖИВАННЯ (НА ПРИКЛАДІ ВИБОРЧОГО ПРАВА ВНУТРІШНЬО ПЕРЕМІЩЕНИХ ОСІБ)

\section{РОЗДІЛ 3}

\section{ЦИВІЛЬНЕ ПРАВО І ЦИВІЛЬНИЙ ПРОЦЕС; \\ СІМЕЙНЕ ПРАВО; МІЖНАРОДНЕ ПРИВАТНЕ ПРАВО}

Andrusiv U.B., Maikut Ch.V., Vovk M. Z. TENDENCIES AND PROSPECTS OF TRAINING OF INTELLECTUAL PROPERTY SPECIALISTS IN HIGHER EDUCATION INSTITUTIONS OF THE MINISTRY OF INTERNAL AFFAIRS.

Баранкова В.В. ПРОЦЕСУАЛЬНІ ОСОБЛИВОСТІ СПРАВ ЩОДО ВІДШКОДУВАННЯ ШКОДИ, ЗАПОДІЯНОЇ НОТАРІУСАМИ

Бончук Н.В. ПРАВОВА ПРИРОДА ІПОТЕКИ ТА ЇЇ ХАРАКТЕРНІ ОЗНАКИ .......................................... 48

ГУзе К.А. НАБУТТЯ ПРОКУРОРОМ СТАТУСУ ПОЗИВАЧА У ЦИВІЛЬНОМУ ПРОЦЕСІ КРІЗЬ ПРИЗМУ ВИСНОВКІВ ВЕЛИКОЇ ПАЛАТИ ВЕРХОВНОГО СУДУ .

Долинська М.С. ОСНОВНІ ПРИНЦИПИ НОТАРІАЛЬНОГО

ПРОЦЕСУАЛЬНОГО ПРАВА УКРАЇНИ 55

КИЯшко О.О. ДОКАЗИ ТА ДОКАЗУВАННЯ У СПРАВАХ ПРО ВИДАЧУ ОБМЕЖУВАЛЬНОГО

ПРИПИСУ В ОКРЕМОМУ ПРОВАДЖЕННІ: АНАЛІЗ СУДОВОЇ ПРАКТИКИ

Кулібаба О.О. НЕУСТОЙКА ЯК СПОСІБ ЗАБЕЗПЕЧЕННЯ ВИКОНАННЯ

ДОГОВІРНИХ ЗОБОВ' ЯЗАНЬ: ОКРЕМІ АСПЕКТИ ЗАСТОСУВАННЯ

Погребняк В.Я. СУБ’ЄКТИВНЕ ЦИВІЛЬНЕ ПРАВО ЯК ВИД І МІРА

МОЖЛИВОЇ ПОВЕДІНКИ ОСОБИ 66

СвітЛИчна Г.О. ФУНКЦІЯ ПРЕДСТАВНИЦТВА ТА ПРОЦЕСУАЛЬНИЙ СТАТУС ПРОКУРОРА

В УМОВАХ РЕФОРМУВАННЯ СИСТЕМИ ПРАВОСУДДЯ ТА СУДОЧИНСТВА.

РОЗДІЛ 4

ГОСПОДАРСЬКЕ ПРАВО, ГОСПОДАРСЬКО-ПРОЦЕСУАЛЬНЕ ПРАВО

Богатир В.К. ДИСКУСІЙНІ АСПЕКТИ ПОРЯДКУ ЗАДОВОЛЕННЯ ВИМОГ КРЕДИТОРІВ У ЛІКВІДАЦІЙНІЙ ПРОЦЕДУРІ ЗА КОДЕКСОМ УКРӒ̈НИ З ПРОЦЕДУР БАНКРУТСТВА Бочков П.В. ОСОБЛИВОСТІ УЧАСТІ ПІДПРИЄМСТВ РЕЛІГІЙНИХ ОРГАНІЗАЦІЙ У ГОСПОДАРСЬКИХ ПРАВОВІДНОСИНАХ

Діхтієвський В.П. НОРМАТИВНО-ПРАВОВІ ЗАСАДИ ДОСТУПУ ДО ІНФОРМАЦІЇ ПРО СТАН ВИКОРИСТАННЯ ПРИРОДНИХ РЕСУРСІВ

Зальотін В.М. ПЕРЕОСМИСЛЕННЯ ПІДХОДІВ ДО ТЕРИТОРІАЛЬНОЇ КОМПЕТЕНЦІЇ НОТАРІУСІВ У КОНТЕКСТІ СПРОЩЕННЯ ВЕДЕННЯ БІЗНЕСУ В УКРАЇНІ. 
Кулага Е.В., Шаталова Л.М. ОКРЕМІ ПИТАННЯ ПРАВОВОГО РЕГУЛЮВАННЯ ВПРОВАДЖЕННЯ ЕЛЕКТРОННИХ ДОВІРЧИХ ПОСЛУГ 88

Рєзнік О.М., Андрійченко Н.С., Ярусевич Є.Ю. ПРАВОВЕ РЕГУЛЮВАННЯ СКЛАДУ

АУДИТОРСЬКОГО КОМІТЕТУ ДЕРЖАВНИХ УНІТАРНИХ ПІДПРИЄМСТВ В УКРАЇНІ 92

РОЗДІЛ 5

ТРУДОВЕ ПРАВО; ПРАВО СОЦІАЛЬНОГО ЗАБЕЗПЕЧЕННЯ

Боднарчук О.Г. ТЕОРЕТИЧНА СУТНІСТЬ ПОНЯТЬ «СОЦІАЛЬНИЙ ЗАХИСТ»

ТА «СОЦІАЛЬНЕ ЗАБЕЗПЕЧЕННЯ»: ОКРЕМІ ДИСКУСІЙНІ ПИТАННЯ 96

Новіков Д.О., Лук'янчиков О.М. ЦИВІЛІСТИЧНИЙ ХАРАКТЕР ЗМІН У КОДЕКСІ ЗАКОНІВ ПРО ПРАЦЮ УКРАЇНИ, ПОВ' ЯЗАНИХ ІЗ ВПРОВАДЖЕННЯМ ПРАВОВОГО РЕГУЛЮВАННЯ ДИСТАНЦІЙНОЇ РОБОТИ.

\section{РОЗДІЛ 6}

\section{ЗЕМЕЛЬНЕ ПРАВО; АГРАРНЕ ПРАВО; ЕКОЛОГІЧНЕ ПРАВО; ПРИРОДОРЕСУРСНЕ ПРАВО}

МаксИМчук О.О. СУТНІСТЬ ТА ПРАВОВА ПРИРОДА ПЛАТИ ЗА ЗЕМЛЮ

Чабаненко М.М., Волох П.В., Левченко В.Р. ЮРИДИЧНА КАТЕГОРІЯ «РЕКУЛЬТИВАЦІЯ ЗЕМЕЛЬ»: СУЧАСНІ НАУКОВО-ПРАВОВІ ПІДХОДИ ДО ЗАКОНОДАВСТВА . 110

Шеховцов В.В. ПРАВОВЕ РЕГУЛЮВАННЯ РЕАЛІЗАЦІЇ МОНІТОРИНГОВОЇ ФУНКЦІЇ УПРАВЛІННЯ

У СФЕРІ ФАУНІСТИЧНИХ ПРАВОВІДНОСИН І ШЛЯХИ ЙОГО ВДОСКОНАЛЕННЯ. 115

Яремак 3.В. ЕФЕКТИВНІСТЬ СПОСОБІВ ЗАХИСТУ ПРАВ НА ЗЕМЛЮ:

ПРОБЛЕМИ СУДОВОЇ ПРАКТИКИ.

\section{РОЗДІЛ 7}

\section{АДМІНІСТРАТИВНЕ ПРАВО І ПРОЦЕС; ФІНАНСОВЕ ПРАВО; ІНФОРМАЦІЙНЕ ПРАВО}

Бабич Я.С. ЗЛОВЖИВАННЯ ПРАВАМИ УЧАСНИКАМИ ВИКОНАВЧОГО ПРОВАДЖЕННЯ:

ПРАКТИКА ТА ШЛЯХИ ВИРІШЕННЯ 123

Басараб О.Т., Басараб О.К., Ларіонова І.Т. АКТУАЛЬНІ ПИТАННЯ НОРМАТИВНО-ПРАВОВОГО РЕГУЛЮВАННЯ КІБЕРБЕЗПЕКИ В ДЕРЖАВНІЙ ПРИКОРДОННІЙ СЛУЖБІ УКРАЇНИ....................... 128 Braverman O.O. THE GROUNDS OF THE INTEGRITY TEST OF EMPLOYEES

OF THE NATIONAL ANTI-CORRUPTION BUREAU OF UKRAINE.

БУрченко Ю.В. АДМІНІСТРАТИВНО-ПРАВОВЕ ЗАБЕЗПЕЧЕННЯ МЕХАНІЗМУ ПРИТЯГНЕННЯ ДО ВІДПОВІДАЛЬНОСТІ ЗА ПОРУШЕННЯ УМОВ КАРАНТИНУ

Василенко С.О. ВСТАНОВЛЕННЯ ОСОБИ ДЛЯ ПРИТЯГНЕННЯ ІІЇ ДО АДМІНІСТРАТИВНОЇ ВІДПОВІДАЛЬНОСТІ ЯК ПРЕВЕНТИВНИЙ ПОЛІЦЕЙСЬКІЙ ЗАХІД ....... 139 Волков Ю.М., Казначеєв Д.Г. АКТУАЛЬНІ ПРОБЛЕМИ ЗАСТОСУВАННЯ ВОГНЕПАЛЬНОЇ ЗБРОЇ ПОЛІЦЕЙСЬКИМИ В УКРАЇНІ ...

Деменко К.Е. ДЖЕРЕЛА АДМІНІСТРАТИВНО-ПРАВОВОГО РЕГУЛЮВАННЯ

У СФЕРІ ПРОФЕСІЙНОГО СПОРТУ В УКРАЇНІ 146

Землякова Д.О., Червякова О.Б. ЗАПРОВАДЖЕННЯ КАРАНТИННОГО РЕЖИМУ В УКРАЇНІ ТА ЙОГО ПРАВОВЕ ЗАБЕЗПЕЧЕННЯ 149

ІЛьченко О.В. ДЕЦЕНТРАЛІЗАЦІЯ ВЛАДИ В УКРАЇНІ ЯК ШЛЯХ ДО ПОДОЛАННЯ КОРУПЦІЇ:

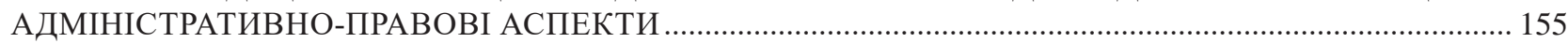
Кириченко Ю.М. ЮРИДИЧНА ВІДПОВІДАЛЬНІСТЬ ОРГАНІВ МІСЦЕВОГО САМОВРЯДУВАННЯ: БАГАТОАСПЕКТНІСТЬ ВИЗНАЧЕННЯ.

Ковальова О.В., Дубенко О.М. СПЕЦІАЛЬНІ ЗАХОДИ ЩОДО ПРОТИДІЇ

ДОМАШНЬОМУ НАСИЛЬСТВУ: СУЧАСНІ ВИКЛИКИ ТА НАПРЯМИ ЇХ ВИРІШЕННЯ ...................... 163

КотЛЯреНко О.П. ВІЙСЬКОВО-ПРАВОВА РЕФЛЕКСІЯ УКРАЇНИ

НА ЗБРОЙНУ АГРЕСІЮ РОСІЙСЬКОЇ ФЕДЕРАЦІЇ

Максименко Н.В. ТЕОРЕТИКО-ПРАВОВИЙ АНАЛІЗ КАТЕГОРІЇ СТАНДАРТУ ДОКАЗУВАННЯ

ЯК ОДНОГО ЗІ СКЛАДНИКІВ ЗАБЕЗПЕЧЕННЯ ПРАВА НА СПРАВЕДЛИВИЙ СУД ............................. 173

Мачуська І.Б. ФОРМУВАННЯ ІНСТИТУТУ КОНТРОЛЬНО-НАГЛЯДОВОЇ ДІЯЛЬНОСТІ

У СФЕРІ НАДРОКОРИСТУВАННЯ В КИЇВСЬКІЙ РУСІ (ІХ-ХІІ СТ.):

ІСТОРИКО-ПРАВОВИЙ АСПЕКТ . 
МельнИк В.І. АДМІНІСТРАТИВНО-ПРАВОВИЙ СТАТУС ПРАВООХОРОННИХ ОРГАНІВ ЯК СУБ'ЄКТІВ СИСТЕМИ ЕКОНОМІЧНОЇ БЕЗПЕКИ УКРАЇНИ ........................................................... 181

Міщук І.В. АДМІНІСТРАТИВНО-ПРАВОВІ ЗАСАДИ ОХОРОННОЇ ДІЯЛЬНОСТІ..................................... 185 Назар Т.Я. АДМІНІСТРАТИВНО-ПРАВОВИЙ СТАТУС ПІДРОЗДІЛІВ ЮВЕНАЛЬНОЇ ПРЕВЕНЦІЇ НАЦІОНАЛЬНОЇ ПОЛІЦІЇ ЯК СУБ'ЄКТІВ ПРОФІЛАКТИКИ ПРАВОПОРУШЕНЬ .................................. 188 Настюк В.Я., Коропатнік І.М., Карелін В.В. СУТНІСТЬ ТА ЗНАЧЕННЯ АДМІНІСТРАТИВНО-ПРАВОВОГО РЕЖИМУ ЦИВІЛЬНО-ВІЙСЬКОВОГО СПІВРОБІТНИЦТВА ..... 191 Обрусна С.Ю., Іванова І.В., Чубань В.С. ПРОБЛЕМИ АДМІНІСТРАТИВНО-ПРАВОВОГО ЗАБЕЗПЕЧЕННЯ ЕЛЕКТРОННОГО СУДУ В УКРАЇНІ В УМОВАХ ПАНДЕМІЇ СОVID-19.................... 196 Овчаренко А.С. ПРАВОВЕ РЕГУЛЮВАННЯ ВІРТУАЛЬНИХ АКТИВІВ ТА КРИПТОВАЛЮТ В УКРАЇНІ: СУЧАСНИЙ СТАН І ПЕРСПЕКТИВИ 200 Плетньова А.Є. ОСОБЛИВОСТІ ЗДІЙСНЕННЯ МИТНИХ ФОРМАЛЬНОСТЕЙ НА ПОВІТРЯНОМУ ТРАНСПОРТІ В УКРАЇНІ 203

Руденко Л.Д. МЕХАНІЗМ ПРИТЯГНЕННЯ ДО АДМІНІСТРАТИВНОЇ ВІДПОВІДАЛЬНОСТІ ІНОЗЕМЦІВ ТА ОСІБ БЕЗ ГРОМАДЯНСТВА. 207

СахНюк В.В. ПРАВО НА БЕЗОПЛАТНУ ПРАВОВУ ДОПОМОГУ

ЯК ОБ'ЄКТ АДМІНІСТРАТИВНО-ПРАВОВОГО ЗАБЕЗПЕЧЕННЯ 211

Слободенюк І.В. МЕТОДИ ДІЯЛЬНОСТІ СЕРВІСНИХ ЦЕНТРІВ МВС УКРАЇНИ:

СУТНІСТЬ, ПОНЯТТЯ ТА ВИДИ 215

Тімашов В.О. АДМІНІСТРАТИВНО-ПРАВОВІ ЗАСАДИ ЗАБЕЗПЕЧЕННЯ

ЕНЕРГЕТИЧНОЇ ГАЛУЗІ В УКРАЇНІ 219

Timashov V.O., Oliinyk O.V. ADMINISTRATIVE AND LEGAL QUALIFICATIONS

IN DOMESTIC THEORY OF ADMINISTRATIVE LAW 222

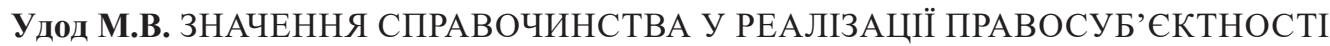
ЮРИДИЧНОЇ КЛІНІКИ ЯК СУБ’ЄКТА АДМІНІСТРАТИВНО-ПРАВОВИХ ВІДНОСИН. 226 Удод М.В., Пирогов В.С. ПУБЛІЧНИЙ ІНТЕРЕС У ВИЗНАЧЕННІ ЮРИСДИКЦІЙНОЇ НАЛЕЖНОСТІ ЗЕМЕЛЬНИХ СПОРІВ 231

Хом'яков Д.О., Коропатнік І.М. СИСТЕМА ЗДІЙСНЕННЯ НОРМАТИВНО-ПРАВОВОГО РЕГУЛЮВАННЯ КІБЕРБЕЗПЕКИ У США

Швець О.М. ПУБЛІЧНА БЕЗПЕКА Й ПОРЯДОК В УМОВАХ КАРАНТИНУ ……………………………..... 238

Shkolyk A.M. CONTEMPORARY TREND TO E-ADMINISTRATION AND MODERNIZATION

OF UKRAINIAN DRAFT LAW ON ADMINISTRATIVE PROCEDURE 242

\section{РОЗДІЛ 8}

\section{КРИМІНАЛЬНЕ ПРАВО ТА КРИМІНОЛОГІЯ;} КРИМІНАЛЬНО-ВИКОНАВЧЕ ПРАВО

БодУНова О.М. ЗАПОБІГАННЯ ЗЛОЧИННОСТІ У СФЕРІ ІНФОРМАЦИЙНИХ ТЕХНОЛОГІЙ: МІЖНАРОДНО-ПРАВОВИЙ АСПЕКТ . 246

Гальцова В.В. ДЕЯКІ АСПЕКТИ ІМПЛЕМЕНТАЦІЇ ПОЛОЖЕНЬ СТАМБУЛЬСЬКОЇ КОНВЕНЦІЇ В КК УКРАЇНИ ТА ПРОБЛЕМИ КРИМІНАЛЬНОЇ ВІДПОВІДАЛЬНОСТІ ЗА ДОМАШНЕ НАСИЛЬСТВО. 249

Данільченко І.Р. НОРМАТИВНІ ПЕРЕДУМОВИ АНАЛІЗУ ПРОБЛЕМИ

НАСИЛЬСТВА ЩОДО ДІТЕЙ 253

Ларченко М.О. МОДЕЛІ ЗАЛЕЖНОЇ ПОВЕДІНКИ ТА ПОВ’ЯЗАНІ 3 НИМИ ФАКТОРИ

КРИМІНОЛОГІЧНОГО РИЗИКУ

Мудрак І.В. КОМУНІКАТИВНА ПОЗИЦІЯ ПОТЕРПІЛОГО

У КРИМІНАЛЬНОМУ ПРОВАДЖЕННІ НА ПІДСТАВІ УГОД.

Парамонова О.С. ДО ПИТАННЯ КРИМІНАЛЬНОГО ПРОТИПРАВНОГО НЕВІГЛАСТВА

(НА ПРИКЛАДІ СТАТТІ 140 КРИМІНАЛЬНОГО КОДЕКСУ УКРАЇНИ «НЕНАЛЕЖНЕ ВИКОНАННЯ

ПРОФЕСІЙНИХ ОБОВ'ЯЗКІВ МЕДИЧНИМ АБО ФАРМАЦЕВТИЧНИМ ПРАЦІВНИКОМ»)................. 264

Ситайло О.І. ЗАСТОСУВАННЯ ЗАСТАВИ У КРИМІНАЛЬНОМУ ПРОВАДЖЕННІ:

ТЕОРЕТИЧНІ ТА ПРАКТИЧНІ ПИТАННЯ

Старко О.Л. ОСОБЛИВОСТІ КІЛЬКІСНО-ЯКІСНИХ ВИМІРІВ

УМИСНИХ ВБИВСТВ В УКРАЇНІ ЗА ПЕРІОД 1992-2019 РР.

Толкач А.М. СУЧАСНИЙ ПОГЛЯД У КРИМІНОЛОГІЇ НА ПОНЯТТЯ

ТА ОЗНАКИ ЕКОНОМІЧНОЇ ЗЛОЧИННОСТІ

ХмИз М.В. ПРОБЛЕМИ ВИЗНАЧЕННЯ ЗМІСТУ ОЗНАК СУБ'ЄКТА

ВИМАГАННЯ НЕПРАВОМІРНОЇ ВИГОДИ. 
Шепотько М.А. НАПРЯМИ СУЧАСНИХ ДОСЛІДЖЕНЬ ПРОБЛЕМ ВІДПОВІДАЛЬНОСТІ

\section{РОЗДІЛ 9}

\section{КРИМІНАЛЬНИЙ ПРОЦЕС ТА КРИМІНАЛІСТИКА;} СУДОВА ЕКСПЕРТИЗА; ОПЕРАТИВНО-РОЗШУКОВА ДІЯЛЬНІСТЬ

Благодир А.А., Благодир В.С., Благодир С.М. НЕДОПУСТИМІСТЬ ДОКАЗІВ, ОТРИМАНИХ ІЗ ПОРУШЕННЯМ ПІДСЛІДНОСТІ. 290

Давиденко С.В. ТИМЧАСОВИЙ ТА ЕКСТРАДИЦЙНИЙ АРЕШТ У КРИМІНАЛЬНОМУ

ПРОВАДЖЕННІ: ОКРЕМІ ПРОБЛЕМИ ПРАВОЗАСТОСУВАННЯ.

ДавчеНко Т.М. ПІДСТАВИ ДЛЯ ВІДКРИТТЯ КРИМІНАЛЬНОГО ПРОВАДЖЕННЯ

ЗА ФАКТОМ ДОВЕДЕННЯ ДО БАНКРУТСТВА: ОЗНАКИ ТА ДЖЕРЕЛА ІНФОРМАЦІЇ 299

ЗамуЛа Б.А. ВСТАНОВЛЕННЯ ПОДІЇ ВБИВСТВА ЯК ОБСТАВИНА, ЩО ПІДЛЯГАЄ ВСТАНОВЛЕННЮ НА ПОЧАТКОВОМУ ЕТАПІ РОЗСЛІДУВАННЯ ВБИВСТВ,

УЧИНЕНИХ ІНОЗЕМЦЯМИ НА ТЕРИТОРІЇ УКРАЇНИ

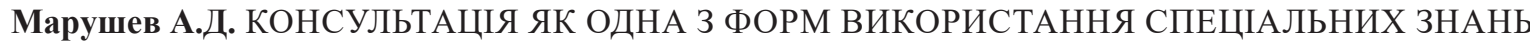

У КРИМІНАЛЬНОМУ ПРОВАДЖЕННІ.

Мещанінова Г.П. ОСОБЛИВОСТІ ОТРИМАННЯ ДЕЗОКСИРИБОНУКЛЕЇНОВОЇ КИСЛОТИ

3 БІОЛОГІЧНИХ ОБ’ ЄКТІВ, ФІКСОВАНИХ У ПАРАФІНІ. 311

Молдован Е.С., Жданова В.П. ЗАРУБІЖНИЙ ДОСВІД ОПЕРАТИВНО-РОЗШУКОВОЇ ДІЯЛЬНОСТІ

МИТНИХ ОРГАНІВ: УРОКИ ДЛЯ УКРАЇНИ

Омельчук Л.В., Бичок Т.П. ПОКАЗАННЯ ІЗ ЧУЖИХ СЛІВ

ЯК ПРОЦЕСУАЛЬНЕ ДЖЕРЕЛО ДОКАЗІВ

Parfylo I.V. TACTICS OF THE SUSPECT INTERROGATION IN THE INVESTIGATION

OF FALSIFICATION AND TURNOVER OF FALSIFIED MEDICINES

Пчеліна О.В. ПЕРСПЕКТИВНІСТЬ ПОБУДОВИ МЕТОДИКИ РОЗСЛІДУВАННЯ

ДОМАШНЬОГО НАСИЛЬСТВА

Сіренко О.В., Мурза І.В. ОКРЕМІ ПИТАННЯ ІНСТИТУТУ СЛІДЧОГО СУДДІ

У КРИМІНАЛЬНОМУ ПРОВАДЖЕННІ.

Січковська І.В. ОСОБЛИВОСТІ ВЗАСМОДІЇ СЛІДЧОГО З ОПЕРАТИВНИМИ ПРАЦІВНИКАМИ

НА ПОЧАТКОВОМУ ЕТАП ДОСУДОВОГО РОЗСЛІДУВАННЯ СЕКСУАЛЬНИХ УБИВСТВ...................... 336

Торбас О.О., Касьянова В.А. ВИЗНАЧЕННЯ РОЗМІРУ ЗАСТАВИ У КРИМІНАЛЬНОМУ ПРОЦЕСІ

УКРАЇНИ: СТАТИСТИЧНИЙ АНАЛІЗ СУДОВОЇ ПРАКТИКИ

Федорчук М.А. ФОРМИ ВИКОРИСТАННЯ СПЕЦІАЛЬНИХ ЗНАНЬ У РОЗСЛІДУВАННІ

КРИМІНАЛЬНИХ ПРАВОПОРУШЕНЬ, ПОВ' ЯЗАНИХ ІЗ РЕЙДЕРСЬКИМИ ЗАХОПЛЕННЯМИ ........ 351

Харченко С.В. ПРАВОВИЙ СТАТУС НЕПОВНОЛІТНІХ ПІДОЗРЮВАНИХ

У КРИМІНАЛЬНОМУ ПРОЦЕСУАЛЬНОМУ ЗАКОНОДАВСТВІ УКРАЇНИ 355

Шевчук В.М. СУЧАСНІ НАУКОВІ КОНЦЕПЦІЇ ФОРМУВАННЯ ТИПОВОЇ СТРУКТУРИ

ОКРЕМОЇ КРИМІНАЛІСТИЧНОЇ МЕТОДИКИ

РОЗДІЛ 10

СУДОУСТРІЙ; ПРОКУРАТУРА ТА АДВОКАТУРА

Богданевич Т.С., Федченко О.С. НАПРЯМИ ВДОСКОНАЛЕННЯ ТА ГАРМОНІЗАЦІЇ

ЧИННОГО ЗАКОНОДАВСТВА В РОБОТІ ОРГАНІВ СИСТЕМИ МВС ТА ПРАВОСУДДЯ

В КОНТЕКСТІ СУЧАСНИХ РЕФОРМ

Вітренко Л.Р., Дяченко С.В. ПРАВОВЕ РЕГУЛЮВАННЯ УСИНОВЛЕННЯ

3 ІНОЗЕМНИМ ЕЛЕМЕНТОМ: СУДОВА ПРАКТИКА

Подкопаєв С.В. МІЖНАРОДНІ (СВРОПЕЙСЬКІ) СТАНДАРТИ

ОЦІНЮВАННЯ РОБОТИ ПРОКУРОРІВ

\section{РОЗДІЛ 11}

\section{МІЖНАРОДНЕ ПРАВО}

Андрейченко С.С. МІЖНАРОДНЕ СПОРТИВНЕ ПРАВО: ДОКТРИНАЛЬНЕ ОБГРУНТУВАННЯ......... 377

Задорожна С.М., Кирилюк Н.В., Маник А.З. ЗАГАЛЬНІ ПРИНЦИПИ В КЛАСИЧНОМУ

МІЖНАРОДНОМУ ПРАВІ: ВІД ВЕСТФАЛЬСЬКОГО МИРУ ДО ООН ……………................................. 381

Kachynska M.O. UKRANIAN EFFORTS TO ELIMINATE DISCRIMINATION AGAINST WOMEN …….... 386 


\section{РОЗДІЛ 12}

ФІЛОСОФІЯ ПРАВА

МеЛЬНИК Я.Я. АНТРОПОЛОГІЯ СОЦІАЛЬНОЇ БЕЗПЕКИ ЗА ЛОКАЛЬНОЮ ОЗНАКОЮ «МАСОВОЇ ОСІЛОСТІ»У ПРИЗМІ ПАРАДИГМИ УРБАНІСТИКИ

\section{РОЗДІЛ 13}

\section{АКТУАЛЬНІ ПИТАННЯ ЮРИСПРУДЕНЦІЇ}

Ідесіс І.В. ПРОЦЕСУАЛЬНІ ПИТАННЯ ПРИЙНЯТТЯ МІСЬКИХ СТАТУТІВ:

РЕЦЕПЦІ ЄВРОПЕЙСЬКОГО ДОСВІДУ

Лахова О.В. ОСОБЛИВОСТІ ВИЗНАЧЕННЯ СУСПІЛЬНОЇ НЕБЕЗПЕЧНОСТІ ЗЛОЧИНУ

Князєв В.С. ПРИНЦИПИ ПРАВОВОГО РЕГУЛЮВАННЯ РЕАЛІЗАЦЙНИХ ПРОЦЕДУР

У ДІЯЛЬНОСТІ МИТНИХ ОРГАНІВ УКРАЇНИ 403

Кудін А.В. НАДАННЯ АДМІНІСТРАТИВНИХ ПОСЛУГ ЯК ІНСТРУМЕНТ ПУБЛІЧНОГО

АДМІНІСТРУВАННЯ ПАТЕНТНОЇ ДІЯЛЬНОСТІ В УКРАЇНІ.

Верлос Н.В. МЕХАНІЗМ РЕЦЕПЦІЇ В КОНСТИТУЦІЙНОМУ ПРАВІ:

ПРОБЛЕМИ КОНЦЕПТУАЛІЗАЦІЇ ТА ПРАКТИЧНОЇ РЕАЛІЗАЦЇ̈

Кочеров М.В. СУЧАСНА ДОКТРИНА КАДРОВОГО ЗАБЕЗПЕЧЕННЯ

НАЦІОНАЛЬНОЇ ПОЛІЦІЇ УКРАЇНИ

Малетич М.М. ПРО ЗМІСТ ГЛОБАЛЬНИХ СТАНДАРТІВ АДМІНІСТРАТИВНИХ ПРОВАДЖЕНЬ .... 416

ПавЛютін Ю.М. СУЧАСНА ФІСКАЛЬНА ПОЛІТИКА ЯК ЕЛЕМЕНТ ЗОВНІШНЬОГО СЕРЕДОВИЩА ПУБЛІЧНОГО АДМІНІСТРУВАННЯ У СФЕРІ СЛУЖБОВО-БОЙОВОГО ЗАБЕЗПЕЧЕННЯ

НАЦІОНАЛЬНОЇ БЕЗПЕКИ....

ТетерятнИк Г.К. ДІЯ У ПРОСТОРІ ТА ЧАСІ НОРМ, ЯКІ РЕГУЛЮЮТЬ ПОРЯДОК

КРИМІНАЛЬНОГО ПРОВАДЖЕННЯ В УМОВАХ НАДЗВИЧАЙНИХ ПРАВОВИХ РЕЖИМІВ .. 424

Єрмак О.О. ПРАВА ДЕРЖАВНИХ СЛУЖБОВЦІВ ПРАВООХОРОННИХ ОРГАНІВ

ЯК ЕЛЕМЕНТ АДМІНІСТРАТИВНО-ПРАВОВОГО СТАТУСУ

Кравченко І.О. ВИЗНАЧЕННЯ МІСЦЯ ЮРИДИЧНОЇ ОСВІТИ

В СТРУКТУРІ ПРАВОВОЇ СИСТЕМИ

РУбеЛЬ А.М. ЗНАЧЕННЯ ТА СТРУКТУРА КРИМІНАЛІСТИЧНОЇ ХАРАКТЕРИСТИКИ СТВОРЕННЯ, КЕРІВНИЦТВА ЗЛОЧИННОЮ СПІЛЬНОТОЮ ЧИ ЗЛОЧИННОЮ ОРГАНІЗАЦІЕЮ,

А ТАКОЖ УЧАСТІ У НІЙ

Бігняк О.В., ВЛадишевська В.В. ЗАСТЕРЕЖЕННЯ ПРО ПУБЛІЧНИЙ ПОРЯДОК

В МІЖНАРОДНОМУ ПРИВАТНОМУ ПРАВІ УКРАЇНИ ТА ЄС .438

Бурносенкова І.А. УЧАСНИКИ ГОСПОДАРСЬКИХ ТОВАРИСТВ

ЯК СУБ'ЄКТИ ВІДПОВІДАЛЬНОСТІ (ЦИВІЛЬНО-ПРАВОВИЙ АСПЕКТ) 443

Власик Д.О. ДОКТРИНАЛЬНІ ПІДХОДИ ДО РОЗКРИТТЯ СУТНОСТІ КАТЕГОРІЇ

«ШТУЧНИЙ ІНТЕЛЕКТ»

Грезіна О. ПРИРОДА ПРАВОВИХ КОНФЛІКТІВ У СФЕРІ ОСВІТИ

Букіна Л.Є. ДЕЯКІ АСПЕКТИ ОСКАРЖЕННЯ НОРМАТИВНО-ПРАВОВИХ АКТІВ

В ПОРЯДКУ АДМІНІСТРАТИВНОГО СУДОЧИНСТВА 454

Літвіщенко Г.О. ПРАВОВА ОХОРОНА ТЕЛЕФОРМАТУ ЯК ОБ'ЄКТА ПРАВА

ІНТЕЛЕКТУАЛЬНОЇ ВЛАСНОСТІ 457

ПодоЛєв О.О. ЗАКОНОДАВЧІ ЗАСАДИ КОЛЕКТИВНОГО УПРАВЛІННЯ АВТОРСЬКИМИ

ТА СУМІЖНИМИ ПРАВАМИ. 


\section{CONTENTS}

\section{SECTION 1 \\ THEORY AND HISTORY OF THE LAW AND THE STATE; HISTORY OF POLITICAL AND LEGAL DOCTRINES}

Bakhnovska I.P., Sova Yu.V. GENERAL PRINCIPLES OF LAW

AS A UNIVERSAL REGULATORY FRAMEWORK

Pohosian M.A. FORMS OF LEGAL COMMUNICATION IN THE CONTEXT OF INTERACTION

OF LAW ENFORCEMENT, HUMAN RIGHTS AND JUDICIAL BODIES:

THEORETICAL AND LEGAL ANALYSIS.

\section{SECTION 2}

\section{CONSTITUTIONAL LAW; MUNICIPAL LAW}

Zavhorodnia V.M. THE LIMITS OF THE INFORMATION PRIVACY OF PUBLIC FIGURES:

THE US EXPERIENCE

Zahurskyi O.B., Korol V.S. CONCEPTUAL APPROACHES TO UNDERSTANDING

THE PHENOMENON OF "PUBLIC GOVERNANCE" 27

Koval T.V. SOME ISSUES OF A LEGAL STATUS OF THE LANGUAGE OMBUDSMAN IN UKRAINE.... 30 Nikitenko L.O. REGARDING THE PRINCIPLE OF NON-DISCRIMINATION BY PLACE OF RESIDENCE (ON THE EXAMPLE OF THE VOTING RIGHT OF INTERNALLY DISPLACED PERSONS).

\section{SECTION 3}

\section{CIVIL LAW AND CIVIL PROCESS;} FAMILY LAW; INTERNATIONAL PRIVATE LAW

Andrusiv U.B., Maikut Ch.V., Vovk M.Z. TENDENCIES AND PROSPECTS OF TRAINING OF INTELLECTUAL PROPERTY SPECIALISTS IN HIGHER EDUCATION INSTITUTIONS OF THE MINISTRY OF INTERNAL AFFAIRS 38

Barankova V.V. THE PROCEDURE FEATURES OF CIVIL CASES FOR DAMAGES BY A NOTARY ...... 42

Bonchuk N.V. LEGAL NATURE OF THE MORTGAGE AND ITS CHARACTERISTICS ........................... 48

Huze K.A. ACQUISITION BY THE PROECUTOR STATUS OF THE PLAINTIFF

IN CIVIL PROCEEDINGS THROUGH THE PRISM OF THE CONCLUSIONS

OF THE GRET HOUSE OF SUPREME COURT .

Dolynska M.S. BASIC PRINCIPLES OF NOTARIAL PROCEDURAL LAW OF UKRAINE ........................ 55

Kyiashko O.O. EVIDENCE AND PROOF IN CASES OF ISSUANCE OF A RESTRAINING ORDER

IN A SEPARATE PROCEEDING: ANALYSIS OF CASE LAW

Kulibaba O.O. PENALTY AS A WAY TO ENSURE THE FULFILLMENT

OF CONTRACTUAL OBLIGATIONS: SOME ASPECTS OF APPLICATION.

Pohrebniak V.Ya. SUBJECTIVE CIVIL RIGHT AS KIND AND MEASURE OF PERSON'S BEHAVIOR .... 66 Svitlychna H.O. THE PROCURATOR'S REPRESENTATION FUNCTION

AND HIS PROCEDURAL STATUS IN CONDITIONS OF REFORMING THE SYSTEM

OF JUSTICE AND LEGAL PROCEEDINGS 69

\section{SECTION 4}

\section{ECONOMIC LAW; ECONOMIC PROCEDURAL LAW}

Bohatyr V.K. CONTROVERSIAL ASPECTS REGARDING THE PROCEDURE FOR SATISFYING CREDITORS' CLAIMS IN THE LIQUIDATION PROCEDURE UNDER THE BANKRUPTCY CODE OF UKRAINE.

Bochkov P.V. FEATURES OF PARTICIPATION OF ENTERPRISES

OF RELIGIOUS ORGANIZATIONS IN ECONOMIC LEGAL RELATIONS

Dikhtiievskyi V.P. LEGAL PRINCIPLES OF ACCESS TO INFORMATION

ON THE STATE OF USE OF NATURAL RESOURCES . 81

Zalotin V.M. RETHINKING APPROACHES TO THE TERRITORIAL COMPETENCE OF NOTARIES IN THE CONTEXT OF SIMPLIFYING DOING BUSINESS IN UKRAINE .... 85

Kulaha E.V., Shatalova L.M. SOME ISSUES OF LEGAL REGULATION OF THE IMPLEMENTATION OF ELECTRONIC TRUST SERVICES 
Rieznik O.M., Andriichenko N.S., Yarusevych Ye.Yu. LEGAL REGULATION OF THE COMPOSITION OF THE AUDIT COMMITTEE OF STATE UNITARY ENTERPRISES IN UKRAINE. 92

\section{SECTION 5}

\section{LABOUR LAW; SOCIAL SECURITY LAW}

Bodnarchuk O.H. THEORETICAL ESSENCE OF THE CONCEPTS OF "SOCIAL PROTECTION" AND "SOCIAL SECURITY": INDIVIDUAL DISCUSSION ISSUES 96

Novikov D.O., Lukianchykov O.M. THE CIVIL NATURE OF CHANGES IN THE LABOR CODE OF UKRAINE RELATED TO THE INTRODUCTION OF LEGAL REGULATION OF TELEWORK.

\section{SECTION 6}

\section{LAND LAW; AGRARIAN LAW;}

\section{ENVIRONMENTAL LAW; NATURAL RESOURCE LAW}

Maksymchuk O.O. THE ESSENCE AND LEGAL NATURE OF LAND FEES ....

Chabanenko M.M., Volokh P.V., Levchenko V.R. LEGAL CATEGORY "LAND RECLAMATION":

MODERN SCIENTIFIC AND LEGAL APPROACHES TO LEGISLATION.

Shekhovtsov V.V. LEGAL REGULATION OF THE IMPLEMENTATION

OF THE MONITORING FUNCTION OF MANAGEMENT IN THE FIELD

OF FAUNAL LEGAL RELATIONS AND WAYS TO IMPROVE IT.

Yaremak Z.V. THE EFFECTIVENESS OF LAND RIGHTS PROTECTION METHODS:

\section{SECTION 7}

\section{ADMINISTRATIVE LAW AND PROCESS; FINANCIAL LAW; INFORMATION LAW}

Babych Ya.S. ABUSE OF RIGHTS BY PARTICIPANTS IN EXECUTIVE PROCEEDINGS:

PRACTICE AND WAYS OF SOLUTION.

Basarab O.T., Basarab O.K., Larionova I.T. TOPICAL ISSUES OF THE REGULATORY FRAMEWORK

IN THE SPHERE OF CYBER SECURITY OF THE STATE BORDER GUARD SERVICE OF UKRAINE ...128

Braverman O.O. THE GROUNDS OF THE INTEGRITY TEST OF EMPLOYEES

OF THE NATIONAL ANTI-CORRUPTION BUREAU OF UKRAINE.

Burchenko Yu.V. ADMINISTRATIVE AND LEGAL PROVISION OF THE MECHANISM

OF LIABILITY FOR VIOLATION OF QUARANTINE CONDITIONS

Vasylenko S.O. ESTABLISHING A PERSON TO BRING HIM

TO ADMINISTRATIVE RESPONSIBILITY AS A PREVENTIVE POLICE MEASURE

Volkov Yu.M., Kaznacheiev D.H. CURRENT PROBLEMS OF POLICE USE

OF FIREARMS IN UKRAINE

Demenko K.E. SOURCES OF ADMINISTRATIVE AND LEGAL REGULATION

IN THE SPHERE OF PROFESSIONAL SPORTS IN UKRAINE 146

Zemliakova D.O., Cherviakova O.B. IMPLEMENTATION OF THE QUARANTINE REGIME

IN UKRAINE AND ITS LEGAL PROVISION.

Ilchenko O.V. DECENTRALIZATION OF POWER IN UKRAINE AS WAYS

TO OVERCOME CORRUPTION: ADMINISTRATIVE AND LEGAL ASPECTS 155

Kyrychenko Yu.M. LEGAL RESPONSIBILITY OF LOCAL SELF-GOVERNMENT BODIES:

MULTIPLICITY OF DEFINITION 158

Kovalova O.V., Dubenko O.M. SPECIAL MEASURES TO COMBAT DOMESTIC VIOLENCE:

CHALLENGES AND DIRECTIONS OF THEIR SOLUTION

Kotliarenko O.P. MILITARY AND LEGAL REFLECTION OF UKRAINE

ON THE ARMED AGGRESSION OF THE RUSSIAN FEDERATION .... 168

Maksymenko N.V. THEORETICAL AND LEGAL ANALYSIS OF THE CATEGORY OF STANDARD OF PROOF AS ONE OF THE COMPONENTS OF ENSURING THE RIGHTS TO A FAIR TRIAL

Machuska I.B. FORMATION OF THE INSTITUTE OF CONTROL AND SUPERVISION ACTIVITY

IN THE FIELD OF SUB-USE IN KIEVAN RUS (IX-XII CENTURY):

HISTORICAL AND LEGAL ASPECT

Melnyk V.I. ADMINISTRATIVE AND LEGAL STATUS OF LAW ENFORCEMENT AGENCIES

AS SUBJECTS OF THE ECONOMIC SECURITY SYSTEM OF UKRAINE

Mishchuk I.V. ADMINISTRATIVE AND LEGAL BASIC SECURITY ACTIVITIES 
Nazar T.Ya. ADMINISTRATIVE AND LEGAL STATUS OF JUVENILE PREVENTION UNITS OF THE NATIONAL POLICE AS SUBJECTS OF CRIME PREVENTION .... 188

Nastiuk V.Ya., Koropatnik I.M., Karelin V.V. THE ESSENCE AND IMPORTANCE

OF THE ADMINISTRATIVE LAW REGIME OF CIVIL-MILITARY COOPERATION.

Obrusna S.Yu., Ivanova I.V., Chuban V.S. PROBLEMS OF ADMINISTRATIVE

AND LEGAL SUPPORT OF ELECTRONIC COURT IN UKRAINE

UNDER THE CONDITIONS OF THE COVID-19 PANDEMIC

Ovcharenko A.S. VIRTUAL ASSETS AND CRYPTOCURRENCY IN UKRAINE:

CURRENT STATE AND PROSPECTS

Pletnova A.Ye. SPECIAL FEATURES OF IMPLEMENTING CUSTOMS FORMALITIES

IN AIR TRANSPORT IN UKRAINE

Rudenko L.D. MECHANISM FOR BRINGING TO ADMINISTRATIVE RESPONSIBILITY

FOREIGNERS AND STATELESS PERSONS.

Sakhniuk V.V. THE RIGHT TO FREE LEGAL AID

AS AN OBJECT OF ADMINISTRATIVE AND LEGAL SUPPORT

Slobodeniuk I.V. OPERATING METHODS OF THE SERVICE CENTERS OF THE MINISTRY

OF INTERNAL AFFAIRS OF UKRAINE: ESSENCE, CONCEPT AND TYPES

Timashov V.O. ADMINISTRATIVE AND LEGAL FRAMEWORKS

OF ENERGY SUPPLY IN UKRAINE.

Timashov V.O., Oliinyk O.V. ADMINISTRATIVE AND LEGAL QUALIFICATIONS

IN DOMESTIC THEORY OF ADMINISTRATIVE LAW

Udod M.V. THE IMPORTANCE OF REPRESENTATION IN THE IMPLEMENTATION

OF LEGAL ENTITY OF THE LEGAL CLINIC AS A SUBJECT

OF ADMINISTRATIVE AND LEGAL RELATIONS

Udod M.V., Pyrohov V.S. PUBLIC INTEREST IN DETERMINING THE JURISDICTION

OF LAND DISPUTES.

Khomiakov D.O., Koropatnik I.M. SYSTEM OF LEGISLATIVE REGULATION

OF CYBER SECURITY IN THE USA.

Shvets O.M. PUBLIC SECURITY AND PROCEDURE UNDER QUARANTINE.

Shkolyk A.M. CONTEMPORARY TREND TO E-ADMINISTRATION AND MODERNIZATION

OF UKRAINIAN DRAFT LAW ON ADMINISTRATIVE PROCEDURE

\section{SECTION 8}

\section{CRIMINAL LAW AND CRIMINOLOGY; PENAL LAW}

Bodunova O.M. CRIME PREVENTION IN THE FIELD OF INFORMATION TECHNOLOGIES:

INTERNATIONAL AND LEGAL ASPECT.

Haltsova V.V. SOME ASPECTS OF INTEGRATION OF ISTANBUL CONVENTION PROVISIONS

INTO PENAL CODE OF UKRAINE AND PROBLEMS OF CRIMINAL LIABILITY

FOR DOMESTIC VIOLENCE

Danilchenko I.R. REGULATORY PREREQUISITES FOR ANALYSIS OF THE PROBLEM

OF VIOLENCE AGAINST CHILDREN

Larchenko M.O. DEPENDENT BEHAVIOR MODELS AND RELATED CRIMINAL RISK FACTORS ........ 256

Mudrak I.V. COMMUNICATIVE POSITION OF THE VICTIM IN CRIMINAL PROCEEDINGS

ON THE BASIS OF THE AGREEMENTS

Paramonova O.S. TO THE QUESTION OF CRIMINAL UNLAWFUL IGNORANCE

(ON EXAMPLE OF THE ARTICLE 140 OF THE CRIMINAL CODE OF UKRAINE

"IMPROPER PERFORMANCE OF PROFESSIONAL DUTY

BY A MEMBER OF MEDICAL OR PHARMACEUTICAL PROFESSION").

Sytailo O.I. APPLICATION OF BAIL IN CRIMINAL PROCEEDINGS:

THEORETICAL AND PRACTICAL ISSUES

Starko O.L. PECULIARITIES OF QUANTITATIVE-QUALITATIVE MEASUREMENTS

OF WILLFUL MURDERS IN UKRAINE FOR THE PERIOD 1992-2019...

Tolkach A.M. MODERN VIEW IN CRIMINOLOGY ON THE CONCEPTS

AND SIGNS OF ECONOMIC CRIME

Khmyz M.V. PROBLEMS OF DETERMINATION OF MAINTENANCE OF SIGNS

OF SUBJECT OF SHAKEDOWN OF ILLEGAL BENEFIT

Shepotko M.A. MODERN AREAS OF RESEARCH ON THE ISSUES OF RESPONSIBILITY

FOR THE PROVOCATION OF BRIBERY IN THE THEORY OF CRIMINAL LAW..... 
SECTION 9

\section{CRIMINAL PROCESS AND FORENSIC SCIENCE;}

FORENSIC EXAMINATION; OPERATIVELY-SEARCH ACTIVITY

Blahodyr A.A., Blahodyr V.S., Blahodyr S.M. INADMISSIBILITY OF EVIDENCE

OBTAINED IN VIOLATION OF JURISDICTION. 290

Davydenko S.V. TEMPORARY AND EXTRADITIONAL ARREST IN CRIMINAL PROCEEDINGS:

INDIVIDUAL PROBLEMS OF LAW ENFORCEMENT.....

Davchenko T.M. GROUNDS FOR THE OPENING OF CRIMINAL PROCEEDINGS

ON THE FACT OF BRINGING TO BANKRUPTCY: SIGNS AND SOURCES OF INFORMATION 299

Zamula B.A. ESTABLISHING THE EVENT OF A KILLING AS THE CIRCUMSTANCES

TO BE INSTALLED AT THE INITIAL STAGE OF THE INVESTIGATION

OF THE KILLING ATTENDED BY ALIENS IN THE UKRAINE. 303

Marushev A.D. CONSULTATION AS ONE OF THE FORMS OF USE OF SPECIAL KNOWLEDGE

IN CRIMINAL PROCEEDINGS

Meshchaninova H.P. FEATURES OF DNA OBTAINING FROM FIXED

AND PARAFFIN-EMBEDDED BIOLOGICAL OBJECTS

Moldovan E.S., Zhdanova V.P. FOREIGN EXPERIENCE OF OPERATIONAL

AND INVESTIGATIVE ACTIVITIES OF CUSTOMS AUTHORITIES .................................................. 315

Omelchuk L.V., Bychok T.P. HEARSAY EVIDENCE AS A PROCEDURAL SOURCES OF EVIDENCE..... 320

Parfylo I.V. TACTICS OF THE SUSPECT INTERROGATION IN THE INVESTIGATION

OF FALSIFICATION AND TURNOVER OF FALSIFIED MEDICINES .

Pchelina O.V. PROSPECTIVENESS OF CONSTRUCTION OF METHODOLOGY

OF INVESTIGATION OF DOMESTIC VIOLENCE.

Sirenko O.V., Murza I.V. SEPARATE ISSUES OF THE INSTITUTE OF INVESTIGATIVE JUDGE

IN CRIMINAL PROCEEDINGS

Sichkovska I.V. ORGANIZATION OF INTERACTION OF INVESTIGATOR AND OPERATUVE BODIES

DURING THE PRE-TRIAL INVESTIGATION OF SEXUAL MURDERS …….................................................. 336

Torbas O.O., Kasianova V.A. DETERMINING THE AMOUNT OF BAIL IN THE CRIMINAL PROCESS

OF UKRAINE: A STATISTICAL ANALYSIS OF JUDICIAL PRACTICE

Fedorchuk M.A. FORMS OF USE OF SPECIAL KNOWLEDGE IN THE INVESTIGATION

OF CRIMINAL OFFENSES RELATED TO RIDER HOBBIES....

Kharchenko S.V. THE LEGAL STATUS OF MINORS SUSPECTED

OF CRIMINAL PROCEDURAL LAW OF UKRAINE

Shevchuk V.M. MODERN SCIENTIFIC CONCEPTS OF FORMATION OF A TYPICAL STRUCTURE

OF A SEPARATE CRIMINALISTIC METHODICS.

\section{SECTION 10}

\section{JUDICATURE; PUBLIC PROSECUTION AND ADVOCACY}

Bohdanevych T.S., Fedchenko O.S. DIRECTIONS FOR IMPROVEMENT AND HARMONIZATION OF CURRENT LEGISLATION IN THE WORK OF THE BODIES OF THE MINISTRY

OF INTERNAL AFFAIRS AND JUSTICE IN THE CONTEXT OF MODERN REFORMS 366

Vitrenko L.R., Diachenko S.V. LEGAL ADJUSTING OF ADOPTION IS WITH FOREIGN ELEMENT: JUDICIAL PRACTICE

Podkopaiev S.V. INTERNATIONAL (EUROPEAN) STANDARDS

FOR EVALUATING THE WORK OF PROSECUTORS

\section{SECTION 11}

INTERNATIONAL LAW

Andreichenko S.S. INTERNATIONAL SPORTS LAW: DOCTRINAL BASIS

Zadorozhna S.M., Kyryliuk N.V., Manyk A.Z. GENERAL PRINCIPLES

IN CLASSICAL INTERNATIONAL LAW:

FROM THE PEACE OF WESTPHAL TO THE UN.

Kachynska M.O. UKRANIAN EFFORTS TO ELIMINATE DISCRIMINATION AGAINST WOMEN.......... 386 


\section{SECTION 12 PHILOSOPHY OF LAW}

Melnyk Ya.Ya. ANTHROPOLOGY OF SOCIAL SECURITY BY THE LOCAL SIGN OF "MASS ASSETS" IN THE PRISM OF THE PARADIGM OF URBANISM 389

\section{SECTION 13 \\ TOPICAL ISSUES OF JURIDICAL SCIENCE}

Idesis I.V. PROCEDURAL ISSUES OF THE APPROVAL OF MUNICIPAL STATUTES:

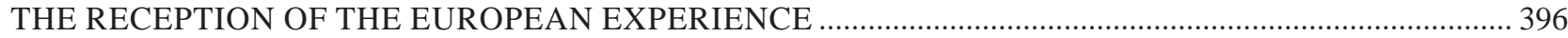

Lakhova O.V. PECULIARITIES OF DETERMINING THE SOCIAL DANGER OF A CRIME .......................400

Kniaziev V.S. PRINCIPLES OF LEGAL REGULATION OF IMPLEMENTATION PROCEDURES

IN THE ACTIVITIES OF THE CUSTOMS AUTHORITIES OF UKRAINE ……………………...................... 403

Kudin A.V. PROVISION OF ADMINISTRATIVE SERVICES AS AN TOOL

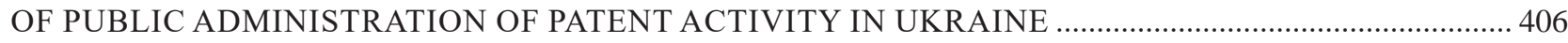

Verlos N.V. MECHANISM OF RECEPTION IN CONSTITUTIONAL LAW:

PROBLEMS OF CONCEPTUALIZATION AND PRACTICAL IMPLEMENTATION ..................................... 409

Kocherov M.V. MODERN DOCTRINE OF HUMAN RESOURCING

OF THE NATIONAL POLICE OF UKRAINE.

Maletych M.M. ON THE ESSENCE OF GLOBAL STANDARDS

OF ADMINISTRATIVE PROCEEDINGS

Pavliutin Yu.M. MODERN FISCAL POLICY AS AN ELEMENT OF EXTERNAL ENVIRONMENT

OF PUBLIC ADMINISTRATION IN THE SECTOR OF SERVICE AND COMBAT SUPPORT

OF NATIONAL SECURITY

Teteriatnyk H.K. EFFECT IN SPACE AND TIME OF NORMS REGULATING THE PROCEDURE

OF CRIMINAL PROCEEDINGS UNDER CONDITIONS OF EXTRAORDINARY LEGAL REGIMES ...... 424

Yermak O.O. RIGHTS OF CIVIL LAW ENFORCEMENT SERVANTS

AS AN ELEMENT OF ADMINISTRATIVE AND LEGAL STATUS

Kravchenko I.O. DETERMINATION OF THE LEGAL EDUCATION PLACE

IN THE LEGAL SYSTEM'S STRUCTURE

Rubel A.M. SIGNIFICANCE AND STRUCTURE OF CRIMINALISTIC CHARACTERISTICS

OF CREATION, LEADERSHIP BY A CRIMINAL COMMUNITY OR CRIMINAL ORGANIZATION,

AS WELL AS PARTICIPATION IN IT

Bihniak O.V., Vladyshevska V.V. PUBLIC POLICY CLAUSE IN UKRAINIAN

AND EU PRIVATE INTERNATIONAL LAW 438

Burnosenkova I.A. PARTICIPANTS OF BUSINESS ASSOCIATIONS AS SUBJECTS

OF LIABILITY (CIVIL LAW ASPECT).

Vlasiuk D.o. DOCTRINAL APPROACHES TO DEFINING THE CATEGORY

OF "ARTIFICIAL INTELLIGENCE"

Hrezina O. THE NATURE OF LEGAL CONFLICTS IN THE FIELD OF EDUCATION ……………………..... 450

Bukina L.Ye. SOME ASPECTS OF APPEALS OF REGULATORY LEGAL ACTS

IN THE PROCEDURE OF ADMINISTRATIVE JUDICIARY

Litvishchenko H.O. LEGAL PROTECTION OF TV FORMAT AS INTELLECTUAL PROPERTY ................. 457

Podoliev O.O. LEGISLATIVE PRINCIPLES OF COLLECTIVE MANAGEMENT OF COPYRIGHT 


\title{
РОЗДІЛ 1 \\ ТЕОРІЯ ТА ІСТОРІЯ ДЕРЖАВИ І ПРАВА; ІСТОРІЯ ПОЛІТИЧНИХ І ПРАВОВИХ УЧЕНЬ
}

УДК 340.12:37(045)

DOI https://doi.org/10.32782/2524-0374/2020-4/1

ЗАГАЛЬНОЛЮДСЬКІ ПРИНЦИПИ ПРАВА ЯК УНІВЕРСАЛЬНІ НОРМАТИВНІ ЗАСАДИ GENERAL PRINCIPLES OF LAW AS A UNIVERSAL REGULATORY FRAMEWORK

\author{
Бахновська І.П., к.ю.н., \\ доцент кафедри права \\ Вінницький торговельно-економічний інститут \\ Київського національного торгово-економічного університету
}

Сова Ю.В., студент II курсу факультету економіки, менеджменту та права Вінницький торговельно-економічний інститут Київського національного торгово-економічного університету

Досліджено, що термін «принцип» уживається у різних значеннях: 1) в основних засадах вихідних ідей, що характеризуються універсальністю, загальною значущістю, вищою імперативністю і відображають суттєві положення теорії, вчення, науки, системи внутрішнього і міжнародного права, політичної, державної чи громадської організації; 2) у внутрішньому переконанні людини, що визначає ії ставлення до дійсності, суспільних ідей і діяльності. Визначено, що в праві систему суспільного порядку, засіб суспільної згоди, шлях засіб запобігання і вирішення розбіжностей потрібно відповідно конструювати і принципи права. З'ясовано, що принципи охоплюють усю правову матерію: й ідеї, й норми, й відносини, а також надають їй логічності, послідовності, збалансованості. Досліджено, що у принципах права синтезуються світовий досвід розвитку права, досвід цивілізації, принципи відіграють роль орієнтирів у формуванні права. Зокрема, еволюція права походить від ідей до норм, потім через реалізацію норм - до суспільної практики. Саме починаючи з появи ідей, а ідея досить часто формується у вигляді правового принципу, принцип визначає, спрямовує розвиток права. Загальнолюдські (цивілізаційні) принципи права безпосередньо визначаються досягнутим рівнем розвитку людства (політичним, економічним, соціальним, моральним тощо) і повинні виступати універсальним критерієм становлення національних правових систем. Вони закріплені в міжнародних правових документах і частково у внутрішньому законодавстві окремих держав. Досліджено, що загальнолюдські принципи права ґрунтуються на таких різних правах (принципи їх концентрованого вироблення), як: гуманізм - використовується через визначену гідність людини та її основоположних прав і свобод; демократизм - реально використовується через утілення загадко-найрізноманітніших службовців, установлюючи компроміси різних груп, які виконують їх (треба); свобода - реально використовується для кожного вибору варіантів поведінки людини, дотримуючись загальнодозволеного типу правового регулювання «дозволити все, що прямо не заборонено законом»; рівність реально використовується через взаємодію (рівність) правдивих і обов'язкових, дотримуючись рівних стандартних норм поведінки для однорідних суб'єктів; справедливість - реально пропонується через пропорційність (відповідь) вкладеного й отриманого в результаті формальної життєдіяльності людини та її правового життя, через збалансованість людей, необхідних для суб'єктів громадськості. У цьому принципі було зрозуміло уявлення про особистість людини, яка має, використовуючи особистість самозбереження людей.

Ключові слова: загальнолюдські принципи права, принцип гуманізму, принцип демократизму, принцип справедливості, принцип свободи, принцип рівності.

It is investigated that the term "principle" is used in different meanings: 1) in the basic principles of the original ideas, characterized by universality, general significance, higher imperative and reflect the essential provisions of theory, doctrine, science, domestic and international law, political, state or public organization 2) in the inner conviction of man, which determines his attitude to reality, social ideas and activities. Recognizing in law the system of public order, the means of public consent, the means of preventing and resolving differences, it is necessary to construct the principles of law accordingly. It was found that the principles cover the entire legal matter - and ideas, and norms, and relationships, as well as give it logic, consistency, balance. It is investigated that the principles of law synthesize the world experience of law development, the experience of civilization, the principles play the role of guidelines in the formation of law. In particular, the evolution of law comes from ideas to norms, then through the implementation of norms - to social practice. It is from the emergence of ideas, and the idea is often formed in the form of a legal principle, the principle determines, directs the development of law.

Universal (civilizational) principles rights directly determined by the achieved level of humanity (political, economic, social, moral, etc.) and must act as a universal criterion for the formation of national legal systems. They are enshrined in international legal documents and partially in domestic legislation of individual states

It is studied that universal principles of law are based on the following different rights (principles of their concentrated development): humanism - is used because of a certain human dignity and its fundamental rights and freedoms; democracy - is actually used through embodiment mysterious and diverse employees, establishing compromises between different groups that perform them (necessary); freedom is actually used for each choice of options for human behavior, adhering to the generally accepted type of legal regulation: "allow everything that is expressly prohibited by law"; equality - really used through the interaction (equality) of true and obligatory, adhering to equal standard norms of behavior for homogeneous subjects; justice - is really offered because of the proportionality (response) of what is invested and received as a result of a person's formal life and legal life, because of the balance of people needed for public figures. In this principle it was clear the idea of the personality of a person who has, using the personality of self-preservation of people.

Key words: universal principles of law, principle of humanism, principle of democracy, principle of justice, principle of freedom, principle of equality.

Постановка проблеми. Загальнолюдські принципи права $€$ визначальними в юридичній науці і практиці, оскільки належать до фундаментальних, містять широке

коло багатогранних питань, які важко охопити одним загальним підходом чи дефініцією. 3 одного боку, принципи права відображають духовні, історичні, соціальні, 
політичні, культурні та інші особливості суспільства, трансформуючи i модифікуючи їх у концентрованому вигляді. 3 іншого - через принципи права відбувається впровадження загальновизнаних соціальних цінностей у життя, їх реалізація та застосування у правовій діяльності. Окрім того, принципи права є об'єктом наукових досліджень не лише представників загальної теорії та філософії права, галузевих наук, а й міжнародного права. Тому в основі нашого дослідження принципів права буде спроба поєднання наукових здобутків представників різних наукових шкіл та галузей права через призму ціннісного підходу до проблеми, а також нових потреб і викликів до їхнього практичного застосування.

Загалом українські правознавці сформували достатню методологічну основу, яка допомагає розібратися в окресленій проблематиці запропонованого дослідження. Відзначимо доробки таких науковців, як: О.П. Васильченко, М.I. Козюбри, А.М. Колодія, Н.М. Оніщенко, Н.М. Пархоменко, В.Ф. Погорілко, С.П. Погребняка, М.В. Савчина, Ю.М. Тодики, О.О. Уварової, Т.I. Фулей, В.I. Цоклана, С.В. Шевчука та багатьох інших.

Мета дослідження - вивчити та дослідити всі види загальнолюдських принципів права.

Виклад основного матеріалу. Загальнолюдські принципи формуються в перебігу продуктивної взаємодії людського суспільства на тлі виникнення цивілізаційної ідентичності народів і являють собою одне 3 найкращих досягнень людства. Будучи визнаними загальнолюдськими і закріпленими в міжнародно-правових документах, ці принципи стають обов'язковими для всіх держав (наприклад, принципи, закріплені в Статуті Організації Об'єднаних Націй від 26 червня 1945 р., у Заключному акті Наради з безпеки і співробітництва в Свропі від 1 серпня 1975 р., Декларації про принципи міжнародного права, що стосуються дружніх відносин і співробітництва між державами відповідно до Статуту Організації Об'єднаних Націй від 24 жовтня 1970 р., та ін.). Підкреслюючи практичне значення принципів права, Р.3. Лівшиц писав, що вони пронизують процес реалізації права, а тому і в разі застосування законів, i в разі заповнення прогалин у правовому регулюванні вони слугують векторами правозастосовної діяльності. Принципи права концентрують результат розвитку права, у них втілюється нерозривний зв'язок минулого, теперішнього і майбутнього [1, с. 200].

Водночас прогресивна правова думка сформулювала такі загальні засади, які не можуть реалізуватися незалежно від принципів організації і функціонування всієї соціальної системи, включаючи й правову. До них належать принципи гуманізму, демократизму, справедливості, свободи, рівноправності та ін., тобто ті, без яких право не може функціонувати. Кожен із них знаходить свій вияв як у системі права загалом, так і в окремих його галузях та інститутах.

Розвиток теорії принципів права відображений у роботах видатного радянського вченого проф. С.С. Алексєєва. На його думку, загальнолюдські принципи права - це керівні ідеї, що характеризують зміст права, його сутність та призначення в суспільстві. 3 одного боку, вони виражають закономірності права, а 3 іншого - $є$ найбільш загальними нормами, які діють у всій сфері правового регулювання і поширюються на всіх суб'єктів. Ці норми або прямо сформульовані в законі, або виводяться із загального змісту законів [2, с. 496]. Окрім того, загальнолюдські принципи права визначають шляхи вдосконалення правових норм, виступаючи керівними ідеями для законодавця. Вони є сполучною ланкою між основними закономірностями розвитку і функціонування суспільства та правовою системою. Завдяки принципам правова система адаптується до найважливіших інтересів і потреб людини й суспільства, стає сумісною 3 ними.
Одним із перших науковців, які звернулися до проблематики принципів прав у 50-х роках минулого століття, був завідувач кафедри історії та теорії держави і права Львівського державного університету імені Івана Франка проф. П.О. Недбайло. На думку вченого, загальнолюдські принципи права - найбільш абстрактні поняття, які виражають сутність держави і права в їхній основі та $є$ вихідним елементом структури науки загальної теорії держави і права. Особливо проблема загальнолюдських принципів права загострюється під час подолання прогалин у правовому регулюванні, зокрема через застосування та конкретизацію загальних (загальноправових) принципів права.

Окрім того, загальнолюдські принципи права вчені розглядають як один із видів юридичних гарантій правильного застосування правових норм i здійснення суб'єктивних прав громадян; вони забезпечують правомірність учинків суб'єктів права, зміцнюють законність і правозастосування, підвищують обгрунтованість та доцільність у реалізації норм, сприяють справедливому оцінюванню вчинків у межах формальних вимог правових норм. П.О. Недбайло наголошував, що підвищення дієвості цього виду юридичних гарантій потребує посилення наукового дослідження загальнолюдських принципів права під тим кутом зору, що принципам права властива нормативність [3, с. 46].

Професор А.М. Колодій уважає, що категорію «принципи права» потрібно використовувати у всіх випадках, коли йдеться про відправні ідеї і положення, які належать до юриспруденції.

Тому принципи права - це такі відправні ідеї його буття, які виражають найважливіші закономірності і підвалини цього типу держави й права, $є$ однопорядковими із сутністю права. та. становлять.його. головні.риси, відрізняються.універсальністю,.вищою.імперативністю.і.заг альнозначимістю, відповідають об'єктивній потребі побудови і зміцнення певного суспільного ладу [4, с. 19].

Учений зазначає, що головні засади, які ще не відображені й не закріплені у праві, не можна зарахувати до юридичних принципів (принципів права). Вони є соціальними закономірностями, які вимагають правового опосередкування, ідеями, науковими висновками, а не принципами права [5, с. 23].

На нашу думку, саме принципи права відображають визнані у суспільстві цінності, регулюють суспільні відносини через ієрархічну єдність та створюють систему вимог щодо належної і можливої поведінки людей.

Найбільша цінність принципу верховенства права полягає саме в його «незрівнянній універсальності», завдяки чому його «слід сприймати не просто, як універсальний принцип права, а як інтегральний», як «мегапринцип» [6, с. 162].

Загальнолюдські принципи права вказують на рівень розвитку людства і повинні виступати універсальним критерієм становлення національних правових систем. Вони закріплені в документах і частково у внутрішньому законодавстві окремих держав. Із погляду юридичної природи загальнолюдські загальноцивілізаційні принципи права $\epsilon$ принципами позитивного права, які слід відрізняти від правових принципів як більш широкого поняття, яким охоплюються основні, визначальні правові ідеї. Разом iз тим правові принципи - це найперше принципи правової свідомості або доктрини, тоді як принципи права $\epsilon$ загальнозначущими, нормативними, обов'язковими засадами, а їх здійснення гарантується державою. Тому варто зазначити, що поняття «загальнолюдські принципи права» та «загальнолюдські правові принципи» також не $\epsilon$ тотожними, оскільки серед загальнолюдських принципів можна виділити як принципи права, так і принципи правової свідомості, доктрини (правові принципи), які не фіксовані у позитивному праві. Варто додати, що за своєю суттю загальнолюдські принципи права, як і будь-які інші, 
є нормативними засадами, визначають сутність і спрямованість правового регулювання.

Загальнолюдські принципи права мають найвищий (максимально можливий) ступінь абстрактності, що дає їм змогу бути придатними для будь-якої системи права. Крім того, вони виступають гнучким інструментом правової регламентації широкого спектру можливих ситуацій, які вирішуються за допомогою правових засобів між будь-якими суб' єктами права. Загальнолюдські принципи права $\epsilon$ основою формування як принципів міжнародного права, так і принципів права регіональних спільнот та принципів внутрішньодержавного (національного) права, тому ці принципи виступають зв'язуючою ланкою між національними правовими системами різних держав, а також між національним і міжнародним правом; можуть слугувати інструментом зближення міжнародного і національного права, універсалізації правового регулювання у всесвітньому масштабі. Вони виступають орієнтирами для реформування національних правових систем у країнах, які бажають увійти в європейський правовий простір, у тому числі і в Україні.

Наявний ступінь абстрактності цих принципів зумовлює їх конкретизацію відповідно до регіональних чи національних правових традицій, особливостей правової системи та сфери відносин, що регулюються. Статут Міжнародного Суду, згідно зі ст. 38, оперує категорією загальних принципів права, визнаних цивілізованими націями, які характерні лише для держав із демократичною і гуманістичною орієнтацією. При цьому буває досить важко 3'ясувати, про які принципи йдеться: про принципи права, які визнаються усіма націями, більшістю держав, групою держав 3 демократичним режимом, чи про інші. Водночас прогресивна правова думка сформулювала такі загальні засади, які не можуть реалізуватися незалежно від принципів організації і функціонування всієї соціальної системи, включаючи й правову. До них належать принципи гуманізму, демократизму, справедливості, свободи, рівноправності та ін., тобто ті, без яких право не може функціонувати. Кожен із них знаходить свій вияв як у системі права у цілому, так і в окремих його галузях та інститутах.

Принцип гуманізму - одна з найважливіших ціннісних характеристик цивілізованого суспільства. Саме він $є$ критерієм прогресивності соціальних інститутів та визнає благо людини, його право на свободу, щастя, виявлення своїх здібностей. Ідеї гуманізму мають загальнолюдський (загальноцивілізаційний) характер, та у праві прояв принципу гуманізму означає закріплення у правових формах відносин між людиною, державою і суспільством. Принцип гуманізму визнання цінності людської особистості, невід'ємності ії прав і свобод, поважання її гідності, захисту від свавільного.втручання.у.сферу.особистого.життя.

Своє втілення принцип гуманізму у праві знаходить у низці нормативних положень різноманітної галузевої належності [7, с. 7].

Принцип верховенства права $є$ одним із провідних елементів загальних засад конституційного ладу будь-якої сучасної демократичної, правової держави. Своє втілення принцип верховенства права у праві знаходить в ідеї справедливості, рівності, свободи і гуманізму. Крім того, формує відповідну правову систему і визначає ті умови, що дають змогу перетворити цю ідею на реальність Там він $\epsilon$, на думку відомого дослідника цієї тематики Б. Таманаги $[8$, c. 11$]$, «виключним і легітимуючим політичним ідеалом», який поступово поширюється на весь сьогоднішній світ, покликаний якісно змінити як основоположн засади, так і практичний складник системи правового регулювання суспільних відносин у напрямі загальновизнаних гуманітарних цінностей та критеріїв соціальної ефективності.

Сьогодні принцип верховенства права розглядається, на думку O.В. Петришина, у двох аспектах: по-перше, у широкому значенні - як принцип правової організації державної влади у суспільстві, так би мовити, у сенсі «верховенства права над державою»; по-друге, у вузькому розумінні, а саме у контексті співвідношення однорідних правових категорій - права та закону в системі регулювання суспільних відносин, їх ролі та місця в забезпеченні правопорядку, тобто у сенсі «верховенства права над законом». Саме на такий підхід орієнтує ст. 8 Конституції України, що закріплює визнання та дію принципу верховенства права і роз'яснює відповідно до цього його зміст.

Спеціальний підхід до розуміння принципу верховенства права дає змогу розглядати питання панування права в суспільних відносинах і більш загальні проблеми організації державної влади як відносно самостійні, сконцентрувати увагу правознавців на власне правовій складовій як першої, так і другої проблематики, зокрема ролі судових органів як остаточного арбітра з правових питань, насамперед щодо захисту прав та свобод людини і громадянина [9, с. 24-25]. На думку одного з творців доктрини верховенства права А. Дайсі, цей принцип грунтується на визнанні та беззастережному сприйнятті найвищої цінності людської особи, її невідчужуваних прав і свобод, які $€$ «основою, а не результатом права країни», а правила, що лежать в основі конституційного кодексу, $є$ «не джерелом, а наслідком прав осіб» $[10$, с. 522,527$]$.

Принцип демократизму виявляється у тому, що право та законодавство виражають волю народу, волю всіх і кожного. Прояв принципу демократизму відбувається через форми народовладдя: безпосередню та представницьку демократію, тому в праві він проявляється шляхом закріплення в нормах правового становища людини, порядку участі народу у формуванні органів державної влади, у здійсненні правової політики, у створенні й удосконаленні законодавства; крім того, принцип демократизму поєднує та взаємопов'язує два аспекти: внутрішньодержавний та міжнародно-правовий.

Принцип рівності виражається у рівності правового становища всіх перед законом, наявності рівних загальногромадянських прав і обов'язків, рівному захисті перед судом незалежно від національної, статевої, релігійної належності, походження, місця мешкання, посадового стану та інших обставин. Утворення об'єктивних зв'язків і відносин Г. Гегель обгрунтовував формальну, правову рівність людей: люди рівні саме як вільні особистості, рівні в однаковому праві на приватну власність, але не в розмірі володіння власністю. Вимога ж рівності в розподілі майна розцінюється ним як нерозумна точка зору $[11$, .c. 208$]$.

T. Тарахонич зауважує, що у принципах права отримує відображення рівень розвитку різних сфер суспільних відносин, а саме економічної, політичної, ідеологічної, соціальної та ін.; у них відтворюються сутність і соціальна природа права, закономірності його розвитку та функціонування; для принципів права характерним є взаємозв 'язок 3 іншими соціальними регуляторами [13, с. 136-137].

Розглядаючи принцип справедливості, видається доречним навести позицію відомого британського юриста лорда Денніса Ллойда, котрий розрізняє формальну справедливість, яка втілена в принципі однакового підходу до однакових справ і передбачає наявність трьох умов існування норм, що приписують необхідну поведінку в конкретних умовах; їх загальний характер, тобто застосування до всіх і до кожного чи до певних категорій осіб, а не вибірково; безпристрасність, тобто їх застосування без жодної дискримінації, примусу чи, навпаки, поблажок, та «реальну» справедливість, що передбачає, окрім трьох зазначених, формальних атрибутів.

Цінність такого підходу полягає не тільки в тому, що він дає змогу зробити цілком відкритими принципи, покладені в основу правової системи, а й у тому, що він може 
зробити їх обов'язковими юридичними нормами, порушення котрих переслідується в законодавчому порядку.

Принцип свободи як можливість вибору варіанта поведінки являє собою абсолютне благо і може бути обмежений лише необхідністю забезпечити свободу інших осіб, що досягається шляхом установлення певної міри свободи окремої особи. Діяльність органів держави і посадових осіб має бути спрямована на створення умов для реалізації і захисту свободи людини.

Висновки. Отже, загальнолюдські принципи права це зафіксовані у позитивному праві його універсальні нормативні засади, які напрацьовані людством як глобальною макроцивілізаційною системою, об'єктивно зумовлені потребами і рівнем розвитку людської цивілізації та втілюють ії найкращі здобутки у правовій сфері, визначають сутність і спрямованість правового регулювання й придатні до застосування у будь-якій системі права. Прогресивна правова думка сформулювала такі загальні засади, які не можуть реалізуватися незалежно від принципів організації і функціонування всієї соціальної системи, включаючи й правову. До них належать принципи гуманізму, демократизму, справедливості, свободи, рівноправності та ін., тобто ті, без яких право не може функціонувати. Кожен із них знаходить свій вияв як у системі права у цілому, так і в окремих його галузях та інститутах.

1. Лившиц Р.3. Теория права : учебник. Москва : БЕК, 1994. 224 с.

2. Алексеев С.С. Теория государства и права : учебник для юридических вузов и факультетов. Москва : Норма, 2005. 496 с.

3. Недбайло П.Е. Система юридических гарантий применения советских правовых норм. Правоведение. 1971. № 3. С. 44-53.

4. Колодій А.М. Принципи права України. Київ : Юрінком Інтер, 1998. 19 с.

5. Колодій А.М. Конституція і розвиток принципів права України (питання методології) : автореф. дис. ... докт. юрид. наук : 12.00.02 «Конституційне право». Київ, 1999. 39 с.

6. Головатий С. Верховенство права (правовладдя): як його тлумачить Венеційська комісія. Право України. 2011. № 10. С. $154-184$. URL : https://www.venice.coe.int/files/articles/Holovathy_RoL.pdf.

7. Гуманистическая природа социалистических общественных отношений / науч. ред. Б.К. Лебедев. Казань : Казан. ун-т, 1990. 192 c.

8. Таманага Б. Верховенство права: історія, політика, теорія / пер. з англ. А. Іщенка. Київ : Києво-Могил. акад., 2007. 208 с.

9. Петришин О.В. Верховенство права в системі правового регулювання суспільних відносин. Право України. 2010. № 3. С. 24-34.

10. Дайсі А. Вступ до вчення про право Конституції. Анатомія лібералізму. Політико-правничі вчення та верховенство права. 2008. $678 \mathrm{c}$.

11. Гегель Г.В. Основи фрілософрії права, або Природне право і державознавство / пер. з нім. Р. Осадчука та М. Кушніра. Київ : Юнівepc, 2000. $336 \mathrm{c}$.

12. Тарахонич Т.І. Місце і роль рівності в системі принципів права та правового регулювання. Принцип рівності у праві: теорія $i$ практика : монографрія. Київ : Юрид. думка, 2014. С. 133-150. 


\title{
ФОРМИ ПРАВОВОЇ КОМУНІКАЦІЇ В КОНТЕКСТІ ВЗАЕМОДІЇ ПРАВООХОРОННИХ, ПРАВОЗАХИСНИХ ТА СУДОВИХ ОРГАНІВ: ТЕОРЕТИКО-ПРАВОВИЙ АНАЛІЗ
}

\author{
FORMS OF LEGAL COMMUNICATION IN THE CONTEXT OF INTERACTION \\ OF LAW ENFORCEMENT, HUMAN RIGHTS AND JUDICIAL BODIES: \\ THEORETICAL AND LEGAL ANALYSIS
}

\author{
Погосян М.А., адвокат, \\ аспірант кафедри історії і теорії держави та права \\ Запорізький начіональний університет
}

\begin{abstract}
У статті здійснено теоретико-правовий аналіз форм правової комунікації правоохоронних, правозахисних органів та органів судової влади як важливої складової частини встановлення ефективної та якісної комунікаційної взаємодії між ними. Підкреслено, що комунікація в сучасному суспільстві виступає фундаментальною основою побудови й розвитку якісно нових правових відносин через комунікаційні канали взаємодії, які динамічно розвиваються. Акцентовано увагу на тому, що у зв'язку з розвитком інформаційно-комунікативних технологій розвиток правових відносин державних і недержавних інститутів супроводжується підвищенням відповідальності між взаємодійними органами. Зазначено, що комунікативна взаємодія правоохоронних, правозахисних і судових органів реалізується у формах інформування, діалогу й співробітництва, однак під час практичної реалізації вони перебувають у тісній взаємодії. Запропоновано авторське визначення поняття «форми правової комунікації правоохоронних, правозахисних і судових органів» із метою всебічного й повного розкриття сутнісних ознак категорії. Зроблено висновок про те, що комунікація між правоохоронними, правозахисними й судовими органами повинна бути побудована на засадах незалежності, прозорості, пропорційності, рівноправності й взаємовідповідальності. Зазначено, що в сучасному українському суспільстві правова комунікація здійснюється з використанням інформаційно-комунікативних технологій, що сприяє підвищенню довіри до правоохоронних, правозахисних і судових органів, оскільки інформація про їхню діяльність знаходиться у відкритому доступі. Зауважено, що ефективна комунікативна взаємодія між правоохоронними, правозахисними й судовими органами можлива після подолання комунікативних бар'єрів, пов'язаних із недосконалістю нормативно-правового регулювання, недостатньою практикою налагодження правової комунікації між зазначеними органами й низьким рівнем захищеності інформації. Підкреслено, що формування конструктивного партнерства між правоохоронними, правозахисними й судовими органами можливе виключно за умов паритетного діалогу, тому надзвичайно актуальною нині є проблема розроблення та реалізації новітніх технологій і засобів комунікації та відповідної інтеракції суб’єктів комунікаційної взаємодії.

Ключові слова: комунікація, правова комунікація, комунікативні правові відносини, взаємодія, суб'єкти права, правоохоронні органи,
\end{abstract} правозахисні органи, органи судової влади.

The article provides a theoretical and legal analysis of the forms of legal communication of law enforcement, human rights and judicial authorities as an important component of establishing effective and high-quality communication between them. It is emphasized that communication in modern society is a fundamental basis for the construction and development of qualitatively new legal relations through communication channels that are developing dynamically. Emphasis is placed on the fact that in connection with the development of information and communication technologies, the development of legal relations between state and non-state institutions is accompanied by increased responsibility between the interacting bodies. It is noted that the communicative interaction of law enforcement, human rights and judicial bodies is realized in the forms of information, dialogue and cooperation, but during the practical implementation they are in close cooperation. The author's definition of the concept of "forms of legal communication of law enforcement, human rights and judicial authorities" is proposed in order to comprehensively and fully disclose the essential features of the category. It is concluded that communication between law enforcement, human rights and the judiciary should be based on the principles of independence, transparency, proportionality, equality and mutual responsibility. It is noted that in modern Ukrainian society, legal communication is carried out using information and communication technologies, which helps to increase confidence in law enforcement, human rights and judicial authorities, as information about their activities is publicly available. It is noted that effective communicative interaction between law enforcement, human rights and judicial bodies is possible after overcoming communication barriers related to imperfect legal regulation, insufficient practice of establishing legal communication between these bodies and low level of information security. It is emphasized that the formation of a constructive partnership between law enforcement, human rights and the judiciary is possible only in a parity dialogue, so the problem of developing and implementing new technologies and means of communication and appropriate interaction of communication entities is extremely relevant today.

Key words: communication, legal communication, communicative legal relations, interaction, subjects of law, law enforcement agencies, human rights bodies, judicial authorities.

Постановка проблеми. Сучасний розвиток української держави супроводжується якісним оновленням іï інститутів та налагодженням взаємодії між ними, чому сприяють також виклики міжнародного співтовариства, євроінтеграційні та глобалізаційні процеси. Зважаючи на кризові явища та процеси, які тривалий час впливали на розвиток державності, інститути публічної влади характеризувались інституційною слабкістю та структурною незбалансованістю. Діяльність правоохоронних, правозахисних та судових органів провадилась з урахуванням особистих інтересів, що мало наслідком порушення прав та свобод громадян. Доцільно зазначити, що формуванню деструктивних механізмів сприяла відсутність налагодженої комунікації між зазначеними органами, тому сьогодні, відповідно до Стратегії національної безпеки України, реалізація різних форм правової комунікації між правоохоронними, правозахисними органами та органами судо- вої влади є одним 3 найважливіших напрямків розвитку державної політики.

Аналіз останніх досліджень та публікацій. Теоретичні основи встановлення комунікації між правоохоронними, правозахисними органами та органами судової влади досліджено у роботах вітчизняних та зарубіжних науковців, серед яких Г. Атаманчук, С. Алексєєв, І. Бачила, М. Бойчук, М. Василик, І. Воронов, М. Гурицька, А. Колодій, В. Князєв, Р. Кирилюк, О. Корнієвський, С. Кулешов, М. Козюбра, В. Колісник, О. Михайловська, Н. Нижник, В. Нікітін, А. Поляков, В. Погорілко, Г. Почепцов, П. Рабінович, П. Стецюк, А. Соколов, І. Ситар, Л. Сердюк, М. Слободяник, О. Скрипнюк, Н. Савінова, Ю. Тодика, А. Токарська, В. Федоренко, Ю. Хабермас, В. Цимбалюк, I. Честнов, В. Шаповал, І. Юрченко, К. Ясперс. Однак, незважаючи на висвітлення деяких аспектів комунікаційних процесів у внутрішній діяльності правоохорон- 
них, правозахисних та судових органів, звернемо увагу, що більшість робіт спрямовані на розгляд особливостей комунікаційних зв'язків із громадянським суспільством. Зазначимо, що сьогодні комплексного дослідження потребує проблема визначення форм правової комунікації всередині системі «правоохоронні органи - правозахисні органи - органи судової влади» як триєдиної системи захисту прав, свобод та законних інтересів людини і громадянина в Україні.

Метою статті є теоретико-правовий аналіз поняття форм правової комунікації правоохоронних, правозахисних органів та судів різних інстанцій як одного з найважливіших аспектів встановлення взаємодії між зазначеними органами, а також розкриття особливості зазначених форм.

Виклад основного матеріалу. У науковій літературі поняття та особливості комунікації органів державної влади досліджено достатньо грунтовно. Так, О. Усманова зазначає, що правова комунікація становить певний порядок взаємодії суб'єктів, заснований на юридичних нормах і пов'язаний з обміном правової інформації, необхідної для задоволення їх потреб і законних інтересів [21, с. 1]. До основних елементів змісту правової комунікації дослідниця відносить цільове призначення комунікації; правові принципи; суб'єкти, які взаємодіють; відповідну нормативну базу; юридичну інформацію та зворотний зв'язок $[21$, c. 2]. Доповнимо визначення, запропоноване дослідницею, зазначивши, що правова комунікація спрямована на пошуки шляхів компромісу під час діалогу, усунення конфліктів, а також на встановлення справедливості, чи блокування протиправних діянь.

Цікавою є позиція 3. Єрмакової, яка наголошує, що під час комунікативної взаємодії суб'єктів, конфлікти $\epsilon$ неминучими, однак конфлікт може бути представлений у конструктивній формі, виключно у разі застосування сторонами успішних комунікативних стратегій, серед яких слід виділити активне обговорення, створення умов для вільного обміну правовою позицією, фокусування на конкретних проблемах, дотримання норм права тощо $[7$, c. 44]. Підтримуємо позицію дослідниці та зазначимо, що в контексті взаємодії правоохоронних, правозахисних та судових органів надзвичайно важливим аспектом $€$ побудова дієвої комунікаційної стратегії для здійснення якісної комунікації, оскільки важливість правових відносин, в межах яких побудована взаємодія, потребує особливої уваги.

У межах розгляду правової комунікації актуальним $\epsilon$ твердження вітчизняної вченої А. Токарської, яка наголошує, що комунікація як фактор сприяння рухові до правового суспільства та національної безпеки є чинником трансформації «монологічної» системи взаємодії на «діалогічну» $[19$, с. 143]. Дійсно, реалізація комунікаційної взаємодії між правоохоронними, правозахисними та судовими органами сприяє переходу до якісно нової моделі прийняття правових рішень, а також ефективного розвитку державності.

Досліджуючи сутність правової комунікації, О. Макеєва зазначає, що правова комунікація - це система суспільних комунікативних відносин, у межах якої формуються й реалізуються механізми утвердження ідей та цінностей права. Правова комунікація є одним із основних чинників формування громадянської демократичної правосвідомості та правової культури, засобом забезпечення діалогу держави та суспільства. Ефективність правової комунікації, як зазначає дослідниця, скоординована рівнем сучасного праворозуміння, правовою культурою, суб'єктною етикою у суспільстві, виробленим оціночно-стереотипним iï сприйняттям і репрезентуванням іiї носіїв [12, с. 192]. Зазначимо, що правова свідомість особи, в такому випадку суб'єкта, який провадить правоохоронну, правозахисну або судову діяльність прямо пропорційна ефективності комунікативних процесів між ними.
Вітчизняні дослідники Є. Мануйлов та Ю. Калиновський підкреслюються, що правова комунікація характеризується послідовністю дій, визначених відповідними юридичними засобами, серед яких засоби-дії та засобивизначення, які мають диспозитивний та імперативний характер. Комунікаційний процес складається з відповідних елементів, має складну структуру і вимагає стійкості зв'язків, які забезпечують цілісність під час внутрішніх та зовнішніх змін [1, с. 24]. Підтримуємо позицію авторів, зазначимо також, що правова комунікація сприяє створенню нових інструментів зміцнення ціннісної ролі права в Україні.

У межах побудови правової комунікації між правозахисними, правоохоронними та судовими органами, доцільно зазначити думку Є. Романюк, який стверджує, що комунікативна взаємодія стає можливою лише за умови відсутності комунікативних бар'єрів, які традиційно існують у системі взаємодії між різними інститутами $[18$, с. 192]. Дійсно, для налагодження системи правової комунікації надзвичайно важливо усунути перешкоди у професійній взаємодії між правоохоронними, правозахисними та судовими органами. Так, з метою здійснення такої діяльності, доцільно налагодити канали правової комунікації.

Дослідники Є. Мануйлов та Ю. Калиновський визначають канали правової комунікації як «носії» конкретних цінностей, необхідні для встановлення контакту між суб'єктами взаємодії, а також запровадження та реалізації демократичних стандартів правової культури [1, с. 24]. Каналами комунікації з представниками суб'єктів владних повноважень та органами судової влади різних інстанцій, як зазначає О. Овсяннікова, можуть бути такі:

1) надання інформації через вебсайти судів;

2) підготовка висновків і пропозицій до законопроєктів;

3) видання й поширення офіційних друкованих органів вищих судів та Верховного Суду України;

4) обмін інформацією шляхом офіційного листування тощо [14, с. 29].

Серед запропонованих дослідницею каналів комунікації, вважаємо, що в межах комунікаційної взаємодії органів судової влади 3 правоохоронними та правозахисними органами доцільним є обмін інформацією через офіційні вебсайти.

Цікавою в межах дослідження є думка О. Макєєвої, яка зазначає, що основною метою обговорення актуальних проблем у демократичному суспільстві широко застосовуються методи та прийоми правової комунікації, серед яких дебати і дискурси [12, с. 192]. Зауважимо, що вказані методи комунікаційної взаємодії доречні під час комунікаційного процесу між правоохоронними, правозахисним та судовими органами, однак лише в межах наукової комунікації між представниками зазначених органів.

Досліджуючи форми комунікації між, доцільно звернутись до етимології поняття. Так, під формою у правовій науці розуміють спосіб внутрішньої організації та зовнішнього вияву правових явищ та процесів [22, с. 106]. У контексті розвитку взаємовідносин правоохоронних, правозахисних та судових органів, вважаємо доцільним розглядати комунікацію як форму взаємодії визначених органів. Так, Н. Гаєва під взаємодією пропонує розуміти взаємний зв'язок та взаємну підтримку двох або більше явищ правової дійсності [5, с. 135]. Ю. Костенко, досліджуючи особливості мовної комунікації, визначає форми комунікації як історично складені форми виробництва та поширення соціальної інформації, які залежать від суспільних відносин, рівня економічного, технічного, культурного розвитку суспільства, структури влади та форм управління $[15$, с. 12]. О. Висоцька звертає увагу, що форми комунікативного процесу відрізняються насамперед одно- чи багатовекторністю процесу спілкування i здатністю перерозподіляти роль комуніканта в серед- 
овищі комунікаторів [4, с. 43]. О. Піддубчак наголошує, що форми комунікації держави і суспільства створюють передумови розвитку інститутів та організацій громадянського суспільства, сприяють демократизації українського суспільства [16]. На підставі вищевикладеного, пропонуємо авторське визначення форм комунікації зазначених органів. Так, форма комунікації правоохоронних, правозахисних та судових органів - це спосіб внутрішньоорганізованої взаємодії вказаних органів через відповідні комунікативні канали, а також зовнішнє вираження такої взаємодії з метою налагодження діалогу або полілогу під час здійснення професійної діяльності для встановлення справедливості та блокування правопорушень з боку учасника комунікаційної взаємодії.

Наголосимо, що у науковій літературі немає єдиного підходу до класифікації форм правової комунікації. О. Овсяннікова зазначає, що сьогодні комунікація представлена в таких типах: соціальна комунікація як процес спілкування між людьми та іншими соціальними суб'єктами; телекомунікація або зв'язок за допомогою технічних засобів; певна система, за допомогою якої забезпечується сполучення між віддаленими об'єктами. Останню категорію пропонується розглядати як технічну, наприклад, підземні та наземні транспортні комунікації тощо [14, с. 24]. Погоджуємось із позицією Н. Моісєєвої, яка зазначає, що соціальна комунікація виникає під час взаємодії між відповідними суб'єктами [13, с. 114]. На основі зазначених вище позиції вчених, правову комунікацію пропонуємо розуміти як вид соціальної комунікації. Правовий аналіз форм правової комунікації між правоохоронними, правозахисними та судовими органами розглядаємо через відповідні форми соціальної комунікації у діловій сфері. Так, найбільш дієвими формами комунікації є інформування, діалог та партнерство. В контексті налагодження комунікації між вказаними органами, зауважимо, специфіка правових відносин між правоохоронними, правозахисними та судовими органами впливає на особливості побудови визначених форм комунікації.

Досліджуючи інформування як форму правової комунікаційної взаємодії між зазначеними органами, звернемо увагу, що комплексного термінологічного визначення поняття у вітчизняній юридичній науці не надано. У зв'язку з цим, пропонуємо розглянути дефініцію правового інформування громадськості як основу. Так, інформування громадськості - систематична робота 3 поширення інформації через усі доступні канали інформування, тобто способи донесення інформації, спрямована на громадськість у цілому, певний іiї сегмент або окремих індивідів $[6$, c. 3]. У межах побудови якісної комунікації між правоохоронними, правозахисними та судовими органами, доцільно розглядати двостороннє інформування, зважаючи на специфіку діяльності зазначених органів. До того ж, сучасна комунікація реалізується за допомогою інформаційно-комунікативних технологій, що підвищує оперативність та доступність обміну інформації.

Розглядаючи особливості діалогу як форми правової комунікації, зазначимо, що традиційне розуміння його як форми комунікаційної взаємодії пов'язують 3 його протиставленням монологу. Так, М. Бахтін визначає діалог як взаємодію двох чи кількох повноцінних взаєморозумінь, що не зведені до однієї чи до іншої з наявних позицій [2, с. 42], С. Кримський виокремлює специфічну ознаку діалогу, яка полягає не в доведенні однобічної правоти, а у переконаності, що обидва учасники належать до якогось третього світу правди, що перевищує переконання їх самих і який для них є однаковою цінністю [9, с. 231], українська дослідниця Л. Безугла оцінює дискурс будь-якого типу, як функціонально діалогічний за своєю природою [3].

Аналіз діалогу як форми комунікативної взаємодії здійснено у монографічному досліджені А. Токарської,
Л. Франків. Автори зазначають, що взаємодія полягає у встановленні взаємозв'язку комунікації зі значенням і використанням знання як основи для дискусії, з метою формування нових значень для «мирного» і ефективного взаємозв'язку та співпраці $[19$, с. 8]. Доповнимо думку дослідників зазначивши, що вказана програмна мотивація допомагатиме розробляти стратегію професійної комунікації.

Діалог між правоохоронними, правозахисними та судовими органами повинен бути побудований шляхом використання новітніх інформаційно-комунікативних технологій. Сучасне інформаційне суспільство вимагає впровадження у взаємну правову діяльність модернових тенденцій розвитку комунікативних технологій, які забезпечують доступність та швидкість комунікації між зазначеними органами.

Більш змістовною і соціально значимою формою комунікації, яка зазвичай розвивається протягом тривалого часу, є партнерство. Воно виникає між двома сторонами, що спілкуються, якщо між ними встановлюється більш глибокий зв'язок, наприклад, коли вони поділяють спільні цінності та/або коли загальні цілі становлять взаємний інтерес та вигоду [11, с. 13]. Партнерство зазвичай передбачає постійність контактів упродовж тривалого часу і грунтується на певній системі взаємовідносин, у контексті дослідження - правових відносин правоохоронних, правозахисних та судових органів.

Доцільно зауважити, що партнерство як форма правової комунікації між вищевказаними органами будується на відповідних принципах, серед яких можемо виділити незалежність суб'єктів правової комунікації, прозорість їх діяльності, звітування перед партнерами про результати діяльності органу, забезпечення стратегії розвитку правової комунікації між ними, а також забезпечення ресурсного потенціалу для розвитку комунікаційної взаємодії.

Розглядаючи партнерство в контексті нашого дослідження, підкреслимо, що зазначені органи реалізують комунікативний процес з використанням сучасних інформаційно-комунікативних технологій, 3 метою забезпечення ефективної взаємодії на офіційних вебсторінках, електронного документообігу тощо. Таким чином, технічний аспект правової комунікації представлений відповідними електронними засобами.

Цікавою в межах дослідження є позиція С. Жданенко, яка розглядає партнерство як особливий тип соціальної взаємодії, що базується на принципах рівноправності автономних суб'єктів, їхнього взаємного визнання і взаємної відповідальності [8, с. 8]. Дійсно, партнерство як форма комунікаційної взаємодії між правоохоронними, правозахисними та судовими органами можлива лише за умови визнання зазначених принципів. Для підтвердження вищезазначеного наведемо позицію О. Радченка та С. Погорєлого, які переконані, що кожен із суб'єктів діалогу володіє певними ресурсами, які підтверджують їх суб'єктність та визначають потенціал участі [17].

Актуальною є думка науковців щодо особливих форм партнерства у сучасному суспільстві. Так, однією з таких форм $\epsilon$ «інформаційно-комунікативне партнерство», завдяки якому комунікація між відповідними суб'єктами побудована на принципі довіри, оскільки інформація знаходиться у відкритому доступі, що унеможливлює зловживання повноваженнями правоохоронних, правозахисних та судових органів [17].

Партнерство як форма комунікації вимагає від суб'єктів розвитку певних навиків, зокрема й психологічного змісту. О. Крутій, О. Радченко наголошують, що це стосується усіх представників взаємодії. При цьому автори зазначають, що необхідним є узгодження, принаймні, двох аспектів - рівня готовності суб'єктів до партнерської взаємодії та комунікації, а також визначення особистісних якостей, які становлять основу готовності до правового 
діалогу [10, с. 74]. Доцільно акцентувати увагу на тому, що рівень партнерської взаємодії між правоохоронними, правозахисними та судовими органами слід визначати як їх готовність до формування конструктивних стратегій комунікаційної взаємодії.

Зауважимо, що партнерські правові відносини як форма комунікації між суб'єктами взаємодії потребує постійного розвитку, враховуючи напрями та специфіку діяльності кожного учасника, а також ризики, які можуть виникнути під час взаємодії. Проте, фундаментальною основою партнерської діяльності є визнання незалежності та рівноправності кожного партнера. Наголосимо, що рівноправність під час комунікаційної взаємодії між правоохоронними, правозахисними та судовими органами пропонуємо розуміти як можливість рівнозначної участі кожного суб'єкта такої взаємодії у процесі прийняття спільних рішень, побудови правових відносин, заснованих на спільних засадах. Наслідком такої діяльності прогнозується підвищення взаємодовіри та взаємоповаги між органами комунікації, а також мінімізації конфліктів.

Ефективні партнерські правові відносини мають бути побудовані на засадах взаємної інтеграції та пропорційності. Формування конструктивного партнерства між правоохоронними, правозахисними та судовими органами можливе виключно за умов паритетного діалогу, тому надзвичайно актуальною сьогодні $є$ проблема розроблення та реалізації новітніх технологій та засобів комунікації та відповідної інтеракції суб'єктів комунікаційної взаємодії.

Висновки. Отже, правова комунікація правоохоронних, правозахисних та судових органів - це один 3 найважливіших аспектів розбудови демократичної та правої держави, оскільки має наслідком формування грунтованої, динамічно розвиненої співпраці з метою захисту прав i свобод людини і громадянина. На основі зазначених наукових позицій щодо особливостей правової комунікаційної взаємодії між вказаними суб'єктами, пропонуємо розуміти форми правової комунікації між правоохоронними, правозахисними та судовими органами як спосіб внутрішньо-організованої взаємодії вказаних органів через відповідні комунікативні канали, а також зовнішнє вираження такої взаємодії з метою налагодження діалогу або полілогу під час здійснення професійної діяльності для встановлення справедливості та блокування правопорушень зі сторони учасника комунікаційної взаємодії.

Підвищення ефективності зазначених форм комунікації між правоохоронними, правозахисними та судовими органами різних інстанції потребує забезпечення належної імплементації вимог законодавства щодо налагодження комунікації між зазначеними органами з метою підвищення ефективності їх діяльності; подолання формального та вибіркового підходу до реалізації комунікаційної взаємодії між правоохоронними, правозахисними та судовими органами; забезпечення доступу до повної та достовірної інформації про діяльність кожного органу комунікаційної взаємодії; посилення механізмів захисту інформації під час комунікації правоохоронних, правозахисних та судових органів, зважаючи на специфіку та особливий предмет їх діяльності; підвищення якості ресурсного забезпечення діяльності кожного органу в процесі комунікації; підвищення кваліфікації та правової компетенції посадових та службових осіб правоохоронних, правозахисних та судових органів; дотримання вимог законодавства щодо організації взаємодії між зазначеними органами та врахування конструктивних пропозицій щодо підвищення якості їх комунікації як одного з найважливіших аспектів побудови демократичної, правової та соціальної держави.

\section{ЛITEPATYPA}

1. Manuilov E.M., Kalynovsky Y.Y. Legal communication as a factor of national state building. Вісник Національного університету «Юридична академія України імені Ярослава Мудрого». 2018. № 3. С. 21-30.

2. Бахтин М.М. Автор и герой: К философским основам гуманитарных наук. Санкт-Петербург : Азбука, 2000. 336 с.

3. Безугла Л.Р. Діалог, діалогічний текст та діалогічний дискурс. Вісник Харківського національного університету ім. В.Н. Каразіна. 2009. № 867. URL: http://dspace.univer.kharkov.ua/handle/123456789/4934.

4. Висоцька О.Є. Засоби та форми комунікації як «дзеркало» світосприйняття людини. Філософрія і соціологія в контексті сучасної культури. 2009. С. 43-51.

5. Гаєва Н.П. Форми взаємодії органів державної влади і об’єднань громадян: теоретичний аспект. Держава і право. Серія «Юридичні та політичні науки». 2010. № 49. С. 133-140.

6. Дзяна Г.О., Дзяний Р.Б. Налагодження комунікації між владою і суспільством у період проведення реформ. Теорія та практика державного управління. 2017. № 2 (57). С. 1-7.

7. Єрмакова 3.І. Комунікаційні процеси в суспільстві. Вісник післядипломної освіти. 2011. Вип. 4. С. 43-51.

8. Жданенко С.Б. Партнерська взаємодія у процесі становлення громадянського суспільства (соціально-філософрський аналіз) : автореф. дис. ... канд. фрілос. наук : 09.00.03. Харків, 2003. 16 с.

9. Кримський С.Б. Запити філософських смислів. Київ : Пара-пан, 2003. 240 с.

10. Крутій О.М., Радченко О.В. Основи партнерської взаємодії держави і приватного сектору. Ефективність державного управління. 2018. № 1 (54). C. $72-79$.

11. Логунова М.М., Лашкіна М.Г., Гвоздик П.О., Алєксєєв А.Г. Комунікації судової влади : науково-практичний посібник. Київ : АДЕФУкраїна, 2011. 276 с.

12. Макєєва О.М. Правова комунікація як складова прогресивного розвитку суспільства. 2016. Вип. 7. С. 191-194.

13. Моісєєва Н.І. Соціально-комунікаційна діяльність як історико-суспільна практика : монографія. Харків : ХНТУСГ, 2015. 392 с.

14. Овсяннікова О.О. Комунікаційна стратегія судової влади: поняття, цілі, основні напрями реалізації. Вісник Запорізького національного університету. 2015. № 1. С. 23-30.

15. Основи теорії мовної комунікації : навчальний посібник / Ю.В. Косенко. Суми : Сумський державний університет, 2011. 187 с.

16. Піддубчак О.А. Нові форми комунікації державних інститутів та громадянського суспільства в контексті впровадження «електронного уряду». URL: http://academy.gov.ua/ej/ej13/txts/Piddubchak.pdf.

17. Радченко О.В., Погорєлий С.С. Моделювання інформаційної взаємодії між органами публічної влади та суспільством. Державна політика. 2012. URL: http://www.kbuapa.kharkov.ua/e-book/putp/2012-3/doc/2/06.pdf.

18. Романюк Є.О. Комунікативна взаємодія органів державної влади та громадськості: сутність та особливості налагодження. Державне управління та місцеве самоврядування. 2018. Вип. 2 (21). С. 190-201.

19. Токарська А.С. Комунікативні напрями розвитку раціональності як складова національної безпеки. Вісник Національного університету «Львівська політехніка». Серія «Юридичні науки». 2017. № 865. С. 142-146.

20. Токарська А.С., Франків Л.С. Діалогічна проєкція взаємодії правоохоронних органів (ОВС - митна служба) : монографрія. Львів : ЛьвДУВС, 2015. 224 с.

21. Усманова Е.Ф. Понятие и элементы правовой коммуникации. Мир науки и образования. 2018. № 1 (13). С. 1-5.

22. Чубоха Н.Ф. Співвідношення категорій «форма» та «джерело» права. Історико-правовий часопис. 2018. № 2 (12). С. $105-110$. 


\title{
РОЗДІЛ 2 \\ КОНСТИТУЦІЙНЕ ПРАВО; МУНІЦИПАЛЬНЕ ПРАВО
}

УдК $342.4(73)$

DOI https://doi.org/10.32782/2524-0374/2020-4/3

МЕЖІ ПРАВА ПУБЛІЧНИХ ОСІБ НА ІНФОРМАЦІЙНУ ПРИВАТНІСТЬ: ДОСВІД США THE LIMITS OF THE INFORMATION PRIVACY OF PUBLIC FIGURES: THE US EXPERIENCE

\author{
Завгородня В.М., к.ю.н., \\ завідувачка кафедри міжнародного, свропейського права \\ та цивільно-правових дисциплін \\ Сумський державний університет
}

Статтю присвячено аналізу основних положень конституційного законодавства та судової практики США щодо визначення поняття публічних осіб та меж їхнього права на інформаційну приватність. Розглянуто ключові справи Верховного суду США та окружних апеляційних судів, у рішеннях яких сформовано підходи до вирішення конфлікту між правом на свободу вираження поглядів, правом громадськості на доступ до інформації, з одного боку, та правами окремих індивідів на повагу до приватного життя - 3 іншого. Установлено, що до кола публічних осіб судова практика США відносить як політичних діячів та службовців публічної адміністрації, так і інших людей, які через свою громадську активність, роботу у сфері медіа чи шоу-бізнесу, спортивні, наукові, мистецькі досягнення, проявлений героїзм тощо опиняються у центрі публічних дискусій. Окрім того, ситуативно публічними особами можуть бути визнані індивіди, які мимоволі стали свідками або учасниками суспільно значущих подій.

Критеріями визнання особи публічною слугують наявність у неї більшого, ніж у пересічних громадян, доступу до ЗМІ, а отже, можливості ефрективніше протидіяти помилковим твердженням; особлива роль у суспільстві; добровільність рішення про прийняття на себе публічної ролі, свідомий розрахунок на публічну увагу і коментарі; публічний характер обставин, подій чи суспільних дискусій, до яких така особа залучена.

На основі аналізу судових прецедентів зроблено висновок, що право США створює різні стандарти захисту права на інформаційну приватність публічних осіб та інших громадян. Свобода слова загалом переважає над правом публічних осіб на інформаційну приватність, що зумовлено важливою і законною метою надання громадськості суспільно необхідної інформації, потребою забезпечити простір діяльності для 3MІ. Аргументовано доцільність виокремлення особливого правового статусу для публічних осіб у частині їх інформаційної приватності у вітчизняному законодавстві.

Ключові слова: публічна особа, інформаційна приватність, дифамація, публічний інтерес, суспільно необхідна інформація, Перша поправка до Конституції США, Верховний суд США

The article is devoted to the analysis of the main provisions of the US constitutional legislation and jurisprudence concerning definition of public figures and limits of their right to information privacy. The key cases of the US Supreme Court and US Courts of Appeals are considered. The approaches to resolving the conflict between the rights to freedom of expression, the public's right to access information, on the one hand, and, on the other, the rights of individuals to respect private life are investigated. The United States case law definition of public figures covers politicians and public officials, as well as other people involved to public activity, media or show business, sports, scientific researches, art, etc. In addition, situationally, public figures may be individuals who have inadvertently witnessed or participated in socially significant events.

The criteria for recognizing a person as a public figure are his/her priority access to the media, and, consequently, the ability to more effectively counter erroneous allegations; special role in society; voluntary decision to take on a public role, consciously counting on public attention and comments, inviting invasion of privacy risks; engagement into significant events or public controversy.

Based on the analysis of court precedents, it is concluded that US law creates different standards for the protection of the right to information privacy of public figures and other citizens. Freedom of speech in general prevails over the right of public figures to information privacy, due to the important and legitimate purpose of providing the public with the information of public concern, as well as the need of creating of prover environment for the media. The expediency of a special legal status for public figures in terms of their information privacy in Ukrainian law is argued.

Key words: public figure, information privacy, defamation, public interest, information of public significance, First Amendment to the United States Constitution, US Supreme Court.

Конфлікт між правом на свободу вираження поглядів, правом громадськості на доступ до інформації, з одного боку, та правами окремих осіб на повагу до приватного життя - 3 іншого, значно посилюється в сучасних умовах. Це пов'язано передусім із повсюдним використанням Інтернету, діджиталізацією низки сфер суспільного життя, перетворенням соціальних мереж на своєрідну форму засобів масової інформації, які дають змогу користувачам не лише отримувати певні відомості, а й взаємодіяти між собою у рамках онлайн-платформ та безперешкодно поширювати інформацію через різноманітні інструменти (пости, твіти, хеш-теги тощо), ділитися відео та фотографіями. Особливо вразливими, з огляду на можливості захисту права на приватність, стають у цьому контексті так звані «публічні особи», до кола яких належить низка категорій людей, відомих і цікавих широкому загалу в силу певних обставин: професійної діяльності у сфері шоу-бізнесу або медіа, походження (наприклад, представники монархічних династій), соціального статусу, ролі в політичному житті, перебування на певних посадах публічної служби, громадської активності, спортивних досягнень та ін. Як слушно зазначає К.В. Можаровська, діяльність таких осіб завжди викликає підвищений інтерес у суспільстві, що має різноманітні прояви - від захоплення і наслідування до заздрості та відкритої агресії, жорсткої критики, пародіювання, навіть висміювання, невиправданих звинувачень та наклепів [1, с. 178-179].

На разі українське законодавство практично не торкається цього конфлікту та не вирішує проблем, які з нього випливають. Відповідно до ст. 32 Основного Закону України, ніхто не може зазнавати втручання в його особисте i сімейне життя, крім випадків, передбачених Конституцією України. Не допускається збирання, зберігання, використання та поширення конфіденційної інформації про особу без іiї згоди, крім випадків, визначених законом, і лише в інтересах національної безпеки, економіч- 
ного добробуту та прав людини [2]. Серед таких випадків - покладення на осіб, визначених положеннями Закону України «Про запобігання корупції», обов'язку подання декларацій, які вміщують достатньо широкий перелік відомостей (ст. 46 згаданого Закону України), що стосуються персональних даних, майнового стану цих осіб та членів їхніх сімей [3]. Окрім того, закони України «Про державну службу» (ст. 7) [4] та «Про службу в органах місцевого самоврядування» (ст. 9) [5] передбачають право відповідних службовців на повагу до своєї особистості, честі та гідності, справедливе і шанобливе ставлення з боку керівників, колег та інших осіб.

Зрозуміло, що коло «публічних осіб» не обмежується державними службовцями та службовцями органів місцевого самоврядування, а також те, що наведені норми самі по собі не спроможні забезпечити справедливий баланс між правом громадськості на інформацію (правом суспільства знати правду про чиновників та політичних діячів або отримувати інформацію про «селебрітіз», які заробляють собі на життя власною популярністю) і правом указаних осіб на повагу до приватного життя. Своєю чергою, ч. 2 ст. 25 Закону України «Про захист персональних даних» дозволяє обробку персональних даних без застосування обмежувальних положень закону «виключно для журналістських та творчих цілей, за умови забезпечення балансу між правом на повагу до особистого життя та правом на свободу вираження поглядів» [6].

Примітно, що для знаходження цього балансу вітчизняні суди звертаються до практики Європейського суду 3 прав людини (далі - ЄСПЛ), який виробив низку ключових критеріїв, що дають змогу встановити в конкретних ситуаціях ту межу, за якою закінчується свобода вираження думок і починається сфера приватного життя публічної особи [7-9]. Однак комплексно на законодавчому рівні питання меж утручання у приватне життя публічних осіб залишається невирішеним.

При цьому проблемні аспекти в контексті охорони права на інформаційну приватність публічних осіб в Україні виникають регулярно та здобувають розголосу в Інтернет і медіапросторі. Наприклад, у 2019 р. Інтернет-ресурс «Громада Приірпіння» поширив інформацію про профіль депутата місцевої ради на сайті знайомств [10]; доволі розповсюдженою практикою стало оприлюднення журналістами особистої переписки парламентарів під час засідань Верховної Ради України тощо.

Загалом проблематика захисту права на невтручання в особисте i сімейне життя $є$ достатньо дослідженою в Україні як у загальнотеоретичному аспекті (О. Панкевич [11], В. Породько [12], О. Стогова [13] та ін.), так і в міжнародно-правовому та галузевому контекстах (О. Басай [14], О. Горпинюк [15], Л. Смчук [16], С. Мішуровська [17], В. Серьогін [18], В. Сивухін [19] та ін.). Водночас питанням реалізації цього права публічними особами присвячено лише окремі публікації (О. Нагнічук [20]), або ж дослідники розглядають його у більш загальному розрізі як дотичне до інших аспектів захисту персональних даних (А. Кардаш [21, с. 150-168]). У дисертаційному дослідженні, присвяченому особистим немайновим правам фізичної особи у цивільному праві, Р. Стефанчуком було запропоновано закріплення у цивільному законодавстві спеціального правового статусу (правового модусу) «фізична особа публічного права». Цей статус, на думку вченого, має бути застосовним до фізичної особи, яка $\epsilon$ посадовою чи службовою особою органу державної влади, органу місцевого самоврядування, іншим суб'єктом під час здійснення ним владних управлінських функцій на основі законодавства, у тому числі на виконання делегованих повноважень. Автором обгрунтовувалася необхідність визначення підстав та порядку обмеження здійснення та захисту такою особою особистих немайнових прав $[22$, с. 4]. Однак описана юридична конструкція, яка охоплює лише частину осіб, котрі можуть визначатися «публічними», не була сприйнята законодавцем.

Вочевидь, правове регулювання статусу публічних осіб у частині їхнього конституційного права на повагу до приватного життя потребує особливих підходів, які можуть бути вироблені з урахуванням як практики ЄСПЛ, так i національного законодавства розвинених країн. Отже, дослідження у цій сфері залишаються актуальними. При цьому особливий інтерес становить досвід Сполучених Штатів Америки як країни, де концепція приватності, у тому числі інформаційної, еволюціонувала впродовж тривалого часу, що дало змогу сформулювати чіткі критерії для встановлення балансу між правом публічних осіб на приватність та правом громадськості на доступ до інформації.

Метою цієї статті $\epsilon$ аналіз основних положень конституційного законодавства та судової практики США щодо визначення поняття публічних осіб та меж їхнього права на інформаційну приватність.

На федеральному рівні основу охорони права на приватність становлять, в першу чергу, положення Першої, Третьої, Четвертої та Дев'ятої поправок до Конституції США [23]. Сформоване на цій основі прецедентне право виходить із того, що різні конституційні гарантії створюють «зони приватності», які є суттєвими та необхідними для життя будь-якої людини [24, с. 15]. Питання конфіденційності інформації про особу здебільшого регулюються законодавством штатів, тому різні штати гарантують різний, іноді більш високий, аніж передбачено федеральними законами, рівень захисту у конкретних сферах. Конституції одинадцяти штатів (Аляска, Арізона, Каліфорнія, Флорида, Гаваї, Іллінойс, Луїзіана, Монтана, Нью-Гемпшир, Південна Кароліна та Вашингтон) мають чіткі положення, що стосуються права на приватне життя. Захист приватності, що надається в деяких із цих штатів, відображає Четверту поправку до Конституції США (право на охорону особистості, житла, документів і майна від необгрунтованих обшуків, затримань та арештів), але й додає більш конкретні положення щодо конфіденційності інформації про особу. Так, § 12 ст. 1 Конституції Флориди передбачає право людини не зазнавати «необгрунтованого перехоплення приватних комунікацій будь-якими способами»; конституції Луїзіани ( $\$ 5$ ст. 1) та Нью-Гемпширу (ст. 2-б) захищають громадян від «вторгнень у приватне життя», а Конституція штату Вашингтон (§ 7 ст. 1) прямо забороняє будь-яке втручання в приватні справи чи вторгнення в житло без прямого припису закону [25].

Незважаючи на значні гарантії інформаційної приватності в законодавстві та прецедентному правів, категорія «публічні особи» (public figures) тлумачиться в судовій практиці США доволі широко. Як зазначають американські дослідники, до них можуть включатися, зокрема: селібрітіз - знаменитості, що є популярними через свою діяльність у шоу-бізнесі; політики, чиновники, інші публічні службовці, у тому числі й ті, хто вже втратив такий статус, але займав відповідні посади в минулому; винахідники, дослідники та науковці; герої війни; кримінальні злочинці та навіть так звані «несподівані публічні фігури», наприклад особи, які перебували на місці злочину чи іншої події, яка цікавить суспільство [26, с. 980-981]. Таке розширене тлумачення істотно відрізняється від європейського підходу, у рамках якого під публічними особами зазвичай розуміють лише осіб, які обіймають посади публічної служби та/або користуються публічними ресурсами, або відіграють певну роль у громадському житті: у політиці, економіці, мистецтві, соціальній сфері, спорті тощо [27].

Однією з ключових справ, які поклали початок становленню концепції права публічних осіб на інформаційну приватність та його обмежень, стала справа New York Times Co. v. Sullivan (1964 p.) [28]. Хоча ця справа стосувалася захисту честі та ділової репутації публічного 
службовця, а не розголошення відомостей про його приватне життя, позиції, сформовані Верховним судом США у рішенні, значно вплинули на подальший розвиток підходів до врегулювання конфлікту між приватними інтересами публічних осіб та інтересами громадськості щодо отримання суспільно значущої інформації. У 1960 p. газета The New York Times розмістила як оплачену політичну рекламу публікацію під назвою «Дослухайтесь до голосів, що міцніють» (Heed Their Rising Voices). Стаття була націлена на висвітлення утисків прав афроамериканців на Півдні США, закликала припинити ганебну практику расової дискримінації, а також допомогти грошима проповіднику і поборнику прав чорношкірого населення Мартіну Лютеру Кінгу. Вказувалося, що громадські активісти зазнають переслідувань у штаті Алабама, поліцейські чинять насилля проти студентів, які виступають за рівні з білими права афроамериканців на отримання освіти, а сам Кінг уже сім разів арештовувався правоохоронними органами, тоді як насправді на той час він був заарештований лише чотири рази.

3 огляду на це, обраний комісар міста Монтгомері пан Л. Салліван, до обов'язків якого належав нагляд за діяльністю місцевої поліції, подав до суду позов про наклеп та зазіхання на його професійну честь і ділову репутацію. При цьому прізвище пана Саллівана в публікації не згадувалося. Проте позивач як посадовець, відповідальний за роботу поліції Монтгомері (яка, за його твердженнями, не чинила незаконних і жорстоких насильницьких дій), уважав, що його права порушені, та вимагав компенсації моральних збитків. Суд Алабами задовольнив позов, однак Верховний суд США в апеляційній інстанції повністю скасував присудження компенсації пану Саллівану. У рішенні Верховного суду було обгрунтовано позицію, згідно з якою офіційні особи не можуть вимагати відшкодування шкоди, заподіяної наклепом чи дифамацією, якщо не можуть переконливо довести actual malice - злий умисел або грубу необережність із боку поширювача такої інформації. Таким чином, суд підтвердив, що право на обговорення державних справ та критику уряду має бути безумовним, і засоби масової інформації, з огляду на суспільний інтерес, повинні мати «простір для добросовісноі помилки», а також поклав тягар доказування actual malice на публічних службовців. При цьому описані вимоги не діють стосовно приватних осіб, яким отримати відшкодування у разі дифамації значно простіше. Слід також відзначити, що до ухвалення рішення у цій справі питання наклепу і дифамації, у тому числі й стосовно публічних осіб, підпадали виключно під дію законодавства штатів, однак у 1964 р. Верховний суд США увів їх до сфери свобод слова і друку, рамки регулювання яких визначаються Першою поправкою до Конституції США. Таким чином, і інформація про публічних службовців почала розглядатися як суспільно значуща, поширення якої є необхідним у демократичному суспільстві.

Уточнення поняття «публічна особа» здійснювалося Верховним судом США впродовж багатьох років. Так, справа Curtis Publishing Co. v. Butts (1967 р.) [29] стосувалася позову про наклеп, який подав колишній тренер футбольної команди Університету Джорджії Уоллес Баттс проти компанії-власника видання The Saturday Evening Post. Позов виник через статтю, в якій стверджувалося, що Баттс та головний тренер іншого клубу зі штату Алабама Пол Брайант домовилися між собою про результат матчу між командами. Джерелом інформації для статті став страховий агент, який нібито підслухав телефонну розмову між тренерами. Позов пан Баттса був задоволений, однак відповідач оскаржував рішення, і у Верховному суді США цю справу було об'єднано з іншою - Associated Press v. Walker (1967 p.) [30]. Остання стосувалася репортажів про заворушення, які відбулися в Університеті Міссісіпі 30 вересня 1962 р. Кореспондент із місця подій у цих репортажах повідомляв, що Едвін А. Волкер, приватна особа і політичний активіст, особисто керував юрбою, яка намагалася насильницьким шляхом перешкодити федеральним маршалам виконати судове рішення, винесене проти афроамериканця. Пан Волкер подав позов про спростування інформації і наклеп.

Обидві справи були вирішені Верховним судом США виходячи $з$ тієї позиції, що і Баттс, який здобув визнання в сфері спорту, і Волкер через свій громадський активізм мають розглядатися як публічні фігури, а отже, як такі, що підпадають під правило, сформоване в рішенні у справі New York Times Co. v. Sullivan.

Важливою для визначення кола осіб, що належать до публічних, стала справа Gertz v. Robert Welch, Inc. (1974р.) [31]. У 1968 р. поліцейський у Чикаго Річард Нуччіо був засуджений за вбивство другого ступеня. Родина потерпілого найняла Елмера Герца, поважного адвоката, який представляв їх у цивільних судових справах проти Нуччіо. У статті, що з'явилася у виданні American Opinion праворадикальної та антикомуністичної організації John Birch Society, засновником якої був Роберт Велч, стверджувалося, що суд над Нуччіо був частиною змови комуністів задля дискредитації місцевої поліції. Самого ж пана Герца звинувачували як учасника цієї змови та називали «леніністом». Під час розгляду справи за позовом пана Герца про дифамацію неодноразово поставало питання про те, чи $є$ у цьому разі адвокат публічною фігурою, а отже, чи може бути у цій ситуації застосовано правило про доказування actual malice.

Вирішуючи цю справу, а також у подальших рішеннях Верховний суд США встановив декілька критеріїв, які дають змогу визначити публічну особу. По-перше, це доступ до ЗМІ або контроль над ними. Відповідно до позиції Суду, політики, чиновники та громадські діячі зазвичай мають значно більший доступ до ЗМI, володіють каналами ефективної комунікації з ними, а отже, мають більш реалістичну можливість протидіяти помилковим твердженням, аніж пересічні індивіди. Отже, приватні особи є більш вразливими до дифамації, і зацікавленість держави в їхньому захисті, відповідно, більша. По-друге, публічні фігури мають особливу роль в очах суспільства, є відомими постатями у суспільному житті, політиці, економіці, мистецтві, спорті або будь-якій іншій сфері. Особа, яка бере на себе таку роль, повинна прийняти й відповідні наслідки, у тому числі ретельніший контроль громадськості. При цьому інтерес суспільства до таких осіб суворо не обмежується формальним виконанням службових обов'язків, чи громадською активністю. Верховний Суд США вказав, що пан Герц не відповідав названим вимогам, не маючи пріоритетного доступу до ЗМІ чи «загальної слави» або «широкої відомості в громаді». Скоріше, питання про належність до кола публічних осіб слід визначати, посилаючись на участь пана Герца в конкретній справі, що мала наслідком дифамацію. За висновком Суду надання позивачем адвокатських послуг у справі Нуччіо не зробило його публічним діячем. Більше того, будучи адвокатом, зобов'язаним дотримуватися низки етичних правил та юридичних приписів стосовно свого клієнта, він не обговорював свою діяльність у пресі і не мав можливості спростувати претензії в ході публічної дискусії [31].

Третім критерієм виступає добровільність рішення про прийняття на себе ролі публічної особи, розрахунок на публічну увагу і коментарі, а отже, і прийняття підвищених ризиків вторгнення у приватність. Наприклад, не слід розглядати як публічних осіб жертв злочинів, що хоча і можуть відповідати критерію особливої ролі в очах громадськості, проте опинилися у цьому становищі поза своєю волею [26, с. 984]. Водночас відома низка справ, у яких Суд, визнаючи право постраждалих на конфіденційність, відмовлявся, проте «карати» ЗМІ шляхом 
зобов'язання відшкодувати шкоду, завдану розголошенням інформації про жертв згвалтувань, у разі якщо така інформація: 1) була отримана в законний спосіб та 2) стосувалася фактів, пов'язаних із розслідуванням злочинів, що мають велике суспільне значення (Cox Broadcasting Corp. v. Cohn, [32]; Florida Star v. B.J.F. [33]).

Четвертим критерієм виступають не стільки характеристики самої особи, скільки публічний характер обставин, подій чи суспільних дискусій, до яких вона залучена. У справі Time, Inc. v. Firestone (1976 р.) [34] Мері Еліс Файрстоун - дружина Рассела А. Файрстоуна-молодшого, представника однієї з найбагатших родин США, обставини розлучення якої, включаючи звинувачення ії чоловіком у «жорстокості та перелюбстві», потрапили до 3МI, не була визнана публічною особою, оскільки розлучення як приватна справа не має бути предметом публічних дискусій та не становить суспільного інтересу. Крім того, й сама пані Файрстоун не мала широкої популярності і не прагнула громадської уваги до своєї справи.

У рамках останніх двох критеріїв у практиці Верховного суду США сформувалася концепція «несподіваних» або «мимовільних» (unexpected or unwilling) публічних фігур, котрі в силу життєвих обставин опинилися у центрі подій, що становлять інтерес для суспільства. Наприклад, рішенням у справі Dameron v. Washington Magazine, Inc. (1983 р.) [35] до таких був віднесений диспетчер повітряного руху, який відповідав за політ авіалайнера компанії Air Florida, що зазнав катастрофи, врізавшись у міст через річку Потомак.

Наведені позиції демонструють класичний підхід, вироблений у судовій практиці США, до визначення поняття «публічна особа» та меж права таких осіб на інформаційну приватність. У сучасних умовах суди все частіше опиняються в ситуаціях, коли питання про право на приватність постає в контексті використання Інтернету та, зокрема, соціальних мереж. Наприклад, у рішенні Апеляційного суду США по другому округу в справі Knight Institute v. Trump (2018 p.) [36] аккаунт президента Дональда Трампа в мережі Twitter був визнаний «публічним форумом» у розумінні Першої поправки в Конституції США, яким із моменту інавгурації Трампа вже не можна вільно оперувати, блокуючи окремих користувачів через їхні критичні висловлювання. Однак на момент написання цієї статті справа ще не завершена остаточно, оскільки 23 серпня 2019 р. уряд подав клопотання про іiї повторний розгляд. При цьому правило про «публічні форуми» поширюється не тільки на президента і вищих посадових осіб, а й на інших публічних службовців. У рішенні по справі Davison v. Randall (2019 p.) [37] суд також підтвердив, що облікові записи у соціальних медіа чиновників мають визнаватися «публічними форумами» в контексті Першої поправки. Питання про те, чи можуть визнаватися такими «публічними форумами» сторінки інших осіб, які в американській правовій традиції включаються до публічних фігур, наприклад зірок шоу-бізнесу, поки що не здобуло вирішення в подібного роду прецедентах. Вочевидь, воно $€$ більш складним і неоднозначним, оскільки такі особи не представляють публічну владу i, відповідно, не ретранслюють їі позицію у соціальних мережах.

У висновках зазначимо, що у США свобода слова загалом переважає над правом публічних осіб на приватне життя. Як результат, такі особи, відмовляючись від певної частини своїх прав у силу свого становища в суспільстві, мають дуже обмежені можливості захисту інформаційної приватності, навіть коли оприлюднені про них відомості $€$ помилковими. Така ситуація зумовлена важливою і законною метою надання громадськості суспільно необхідної інформації, потребою забезпечити простір діяльності для 3МI (до яких нині фактично може бути прирівняна низка соціальних мереж), щоб вони могли ефективно виконувати свої функції. При цьому на відміну від України право США не лише створює різні стандарти захисту права на інформаційну приватність публічних осіб та інших громадян, а й містить чіткі критерії для розрізнення цих категорій фізичних осіб. Розглянуті нами справи мають значення не лише для національної правової системи США, вони істотно вплинули на законодавство та практику судів інших країн західної цивілізації та Європейського суду 3 прав людини, підтвердивши цим ефективність визначених ними підходів. Убачається, що ідея виокремлення особливого правового статусу для публічних осіб (не лише політиків чи державних службовців, а й інших категорій) у частині їхньої інформаційної приватності може бути досить продуктивною та доцільною для втілення у вітчизняному законодавстві, особливо з урахуванням викликів сучасної цифрової епохи.

\section{ЛITEPATYPA}

1. Можаровська К.В. Зміст категорії «публічна особа» в контексті ії права на захист честі, гідності та ділової репутації. Науковий вісник Ужгородського національного університету, Серія «Право». 2013. Вип. 22. Ч. І. Т. 1. С. 178-182.

2. Конституція України : Закон України від 28 червня 1996 р. № 254к/96-ВР. Відомості Верховної Ради України. 1996. № 30. Ст. 141.

3. Про запобігання корупції : Закон України від 14 жовтня 2014 року № 1700-VII / Верховна Рада України. URL : https://zakon.rada.gov. ua/laws/show/1700-18\#n38.

4. Про державну службу : Закон України від 10 грудня 2015 року № 889-VIIII / Верховна Рада України. URL : https://zakon.rada.gov.ua/ laws/show/889-19\#Text.

5. Про службу в органах місцевого самоврядування : Закон України від 7 червня 2001 року № 2493-III / Верховна Paда України. URL : https://zakon.rada.gov.ua/laws/show/2493-14\#Text.

6. Про захист персональних даних : Закон України від 1 червня 2010 року № 2297-VI / Верховна Рада України. URL : https://zakon.rada.gov.ua/laws/show/2297-17\#Text.

7. Von Hannover v. Germany (No. 2). App. № 40660/08 and 60641/08 / ECHR 7 February 2012. URL : https://hudoc.echr.coe.int/eng\#\{\%2 2appno\%22:[\%2240660/08\%22],\%22itemid\%22:[\%22001-109029\%22]\}.

8. Krone Verlags Gmbh \& Co. KG v. Austria. App. № 39069/97 / ECHR 19 June 2012. URL : https://hudoc.echr.coe.int/fre\#\{\%22item id\%22:[\%22001-111526\%22]\}.

9. Axel Springer AG v. Germany. App. № 39954/08. / ECHR 7 February 2012. URL : https://hudoc.echr.coe.int/fre\#\{\%22item id\%22:[\%22001-109034\%22]\}.

10. Профріль депутата на «Тіндері» та реклама велопрокату Плешка у статті «Де покохатися в Ірпені». Громада Приірпіння. 6 травня 2019 p. URL : http://surl.li/ekqn.

11. Панкевич О.З. Право на приватність: царина незалежності особи. Науковий вісник Львівського державного університету внутрішніх справ. Серія юридична. 2017. № 2. С. 47-56.

12. Породько В. Право на недоторканність особистого життя людини: проблема термінології. Підприємництво, господарство і пра8о. 2018. № 11. С. 146-149.

13. Стогова О.В. Особисте життя людини: проблема визначення поняття. Правовий вісник Української академії банківської справи. 2014. № 1(10). C. 6-10.

14. Басай О.В. Неприпустимість свавільного втручання у сферу особистого життя як загальна засада цивільного законодавства України. Часопис Національного університету «Острозька академія». Серія «Право». 2013. № 2(8). URL : http://lj.oa.edu.ua/articles/2013/ n2/13bovtzu.pdf. 
15. Горпинюк О.П. Стан дослідження проблеми кримінально-правової охорони приватності в юридичній літературі. Науковий вісник Львівського державного університету внутрішніх справ. 2009. № 4. С. 198-206.

16. Ємчук Л.В. Конституційно-правове регулювання особистого та сімейного життя людини і громадянина : автореф. дис. ... канд. юрид. наук. : 12.00.02. Ужгород, 2015. 22 с.

17. Мішуровська С.Т. Міжнародно-правовий захист права на приватне життя (сучасна практика) : автореф. дис. ... канд. юрид. наук : 12.00.11. Харків, 2011. 21 с.

18. Серьогін В.О. Право на недоторканість приватного життя у конституційно-правовій теорії та практиці : монографрія. Харків : ФІНН, 2010. $608 \mathrm{c}$.

19. Сивухін В.С. Конституційне право людини і громадянина на невтручання в їх особисте і сімейне життя та його забезпечення органами внутрішніх справ : дис. ... канд. юрид. наук : 12.00.02. Київ, 2007. 238 с.

20. Нагнічук О.І. Співвідношення права на свободу вираження щодо публічних осіб та права на повагу до приватного та сімейного життя публічних осіб у практиці Європейського суду з прав людини. Наукові записки НаУКМА. 2015. Т. 168. Юридичні науки. С. 73-76.

21. Кардаш А.В. Конституційно-правовий захист інформації про особу (порівняльно-правовий аспект) : дис. ... канд. юрид. наук : 12.00.02. Харків, 2019. 244 с.

22. Стефанчук Р.О. Особисті немайнові права фізичних осіб у цивільному праві : автореф. дис. ... канд. юрид наук : 12.00.03. Київ, 2007. $22 \mathrm{c}$

23. Конституція США (17 вересня 1787 року) / Конституційна Асамблея. Конституції країн світу. Електронна бібліотека HБУВ. URL : http://nbuviap.gov.ua/asambleya/constitutions.php.

24. Weber R.H., Staiger D.N. Bridging the gap between individual privacy and public security. Groningen Journal of International Law. Vol. 2 (2). Issue 2. P. 14-32. URL : https://grojil.files.wordpress.com/2015/04/grojil_volume-2_issue-2.pdf.

25. Privacy Protections in State Constitutions / National Conference of State Legislation. URL : https://www.ncsl.org/research/ telecommunications-and-information-technology/privacy-protections-in-state-constitutions.aspx.

26. Yanisky-Ravid S., Lahav B.Z. Public Interest vs. Private Lives -Affording Public Figures Privacy in the Digital Era: the Three Principle Filtering Model. Journal of Constitutional Law. 2017. Vol. 19:4. P. 975-1014.

27. Рекомендації щодо захисту приватності у роботі ЗМІ / Центр демократії та верховенства права (CEDEM). URL : http://cedem.org.ua/ analytics/rekomendatsiyi-shhodo-zahystu-pryvatnosti-u-roboti-zmi/.

28. New York Times Co. v. Sullivan, 376 U.S. 254 (1964) / Justia US Supreme Court. URL : https://supreme.justia.com/cases/federal/ us/376/254/.

29. Curtis Publishing Co. v. Butts, 388 U.S. 130 (1967) / Justia US Supreme Court. URL : http://supreme.justia.com/us/388/130/case.html.

30. Associated Press v. Walker, 389 US 28 (1967) / Justia US Supreme Court. URL : https://supreme.justia.com/cases/federal/us/389/28/.

31. Gertz v. Robert Welch, Inc., 418 U.S. 323 (1974) / Justia US Supreme Court. URL : https://supreme.justia.com/cases/federal/us/418/323/.

32. Cox Broadcasting Corp. v. Cohn, 420 U.S. 469 (1975) / Justia US Supreme Court. URL : https://supreme.justia.com/cases/federal/ us/420/469/.

33. Florida Star v. B.J.F., 491 U.S. 524 (1989) / Justia US Supreme Court. URL : https://supreme.justia.com/cases/federal/us/491/524/.

34. Time, Inc. v. Firestone, 424 U.S. 448 (1976) / Justia US Supreme Court. URL : https://supreme.justia.com/cases/federal/us/424/448/.

35. Dameron v. Washington Magazine, Inc., 575 F. Supp. 1575 (D.D.C. 1983) / Justia US Supreme Court. URL : https://law.justia.com/cases/ federal/district-courts/FSupp/575/1575/1462430/.

36. KnightInstitutev. Trump/JustiaUnitedStatesLaw.URL:https://cases.justia.com/federal/appellate-courts/ca2/18-1691/18-1691-2019-07-09 pdf?ts $=1562682609$.

37. Davison v. Randall / Justia United States Law. URL : https://law.justia.com/cases/federal/appellate-courts/ca4/17-2002/17-20022019-01-07.html. 
УДК 342(477)

DOI https://doi.org/10.32782/2524-0374/2020-4/4

\title{
КОНЦЕПТУАЛЬНІ ПІДХОДИ ДО РОЗУМІННЯ ФЕНОМЕНУ «ПУБЛІЧНЕ УПРАВЛІННЯ»
}

\section{CONCEPTUAL APPROACHES TO UNDERSTANDING THE PHENOMENON OF "PUBLIC GOVERNANCE"}

\author{
Загурський О.Б., к.ю.н, доцент, \\ доцент кафедри міжнародної економіки, маркетингу та менеджменту \\ Івано-Франківський навчально-науковий інститут менеджменту \\ Тернопільського начіонального економічного університету
}

Король В.С., к.е.н, доцент, доцент кафедри міжнародної економіки, маркетингу та менеджменту Івано-Франківський навчально-науковий інститут менеджменту Тернопільського начіонального економічного університету

У статті розглядаються актуальні підходи щодо розуміння феномену публічного управління в контексті реформування державної влади. Проаналізовано наукові підходи вітчизняних та зарубіжних учених щодо правової природи публічного управління. Автором досліджується феномен публічного управління, а також формулюються авторські підходи щодо особливостей удосконалення ефективних механізмів функціонування публічного управління в контексті реалізації національної політики України.

Обґрунтовано, що натепер державні інституції відіграють ключову роль у визначенні правильних стимулів, зменшенні невизначеності та досягненні довгострокового процвітання кожної держави. Водночас слабкі сторони функціонування публічного управління можуть створити значні перешкоди для функціонування єдиного ринку, інвестицій на регіональному та місцевому рівні, а також інновацій.

Конкретизовано, що публічні управлінці, по-перше, регулюють діяльність суб'єктів господарювання, тим самим опосередковано впливаючи на добробут населення; по-друге, окремі її представники здійснюють діяльність, пов'язану з національною таємницею, а тому належать не до публічного, а до державного управління.

Встановлено, що відповідно до європейських стандартів держава повинна забезпечувати громадянам право брати участь в управлінні державними справами з метою створення демократичного та правового суспільства.

На основі проведеного дослідження зроблено висновок про те, що термін «публічне управління» слід тлумачити як відкритий (у межах власних і делегованих повноважень) вплив наділених владою інституцій на взаємовідносини між державою, місцевим самоврядуванням, бізнесом і населенням задля узгодження їхніх інтересів і максимізації вигод. Основними рисами публічного управління $є$ гуманістичний характер прийнятих управлінських рішень, задоволення приватноправових інтересів, залучення громадськості до процесу реалізації державної політики, прозорість управління тощо. До того ж вимогою реалізації принципів публічного управління в усіх сферах суспільного життя $€$ необхідність упровадження дієвих механізмів відповідальності органів державної влади, дотримання принципів прозорості та можливості громадського обговорення під час прийняття управлінських рішень і актів.

Ключові слова: публічне управління, національна політика, державна влада, держава, управління, законодавство.

The article considers current approaches to understanding the phenomenon of public administration in the context of public reform. Scientific approaches of domestic and foreign scholars on the legal nature of public administration are analyzed. The author studies the phenomenon of public administration, as well as formulates the author's approaches to the peculiarities of improving the effective mechanisms of public administration in the context of the implementation of national policy of Ukraine.

It is substantiated that today state institutions play a key role in determining the right incentives, reducing uncertainty and achieving long-term prosperity of each state. At the same time, weaknesses in the functioning of public administration can create significant barriers to the functioning of the single market, investment at regional and local level, and innovation.

It is specified that public administrators, first, regulate the activities of economic entities, thereby indirectly influencing the welfare of the population; secondly, some of its representatives carry out activities related to national secrets, and therefore belong not to public but to public administration.

It is established that in accordance with European standards, the state must ensure the right of citizens to participate in the management of public affairs in order to create a democratic and legal society.

Based on the study, it was concluded that the term "public administration" should be interpreted as open (within their own and delegated powers) the influence of government institutions on the relationship between government, local government, business and the public to reconcile their interests and maximize benefits. The main features of public administration are the humanistic nature of management decisions, satisfaction of private law interests, public involvement in the implementation of public policy, transparency of management and more. In addition, the requirement to implement the principles of public administration in all spheres of public life is the need to implement effective mechanisms of accountability of public authorities, compliance with the principles of transparency and the possibility of public discussion in management decisions and acts.

Key words: public administration, national policy, state power, state, administration, legislation.

Сучасна криза публічного управління виступає як наслідок дисбалансів, спричинених інноваційним розвитком, вказує на нездатність національних урядів правильно реагувати на нові форми викликів. Недовіра до урядів, відсутність багатьох глобалістичних ініціатив, економічна нестабільність, поява численних міжнародних конфліктів та спроби багатьох країн знайти свій шлях - все це грунтується на тому, що уряди втрачають владу через опір вирішенню адміністративного кризису.

Аналіз певних аспектів публічного управління в розвитку громадянського суспільства здійснений у працях таких авторів, як: Р. Апресин, Е. Арато, Н. Баранов, А. Борд, Є. Белокурова, К. Гаджиєв, А. Герасимов, А. Дегтярьов,
В. Затонський, 3. Зотов, Дж. Кін, І. Колотай, В. Комаровський, Л. Дж. Коен, Л. Коновалов, Ю. Красін, І. Левін, Ж. Лачестаре, Г. Мальцев, В. Міхеєв, Б. Модель, Т. Нешта$є в а$, С. Патрушев, С. Перегудов, В. Петухов та ін.

На особливу увагу заслуговують наукові розробки вітчизняних учених О. Андрійко, Е. Афоніна, М. Білинської, Р. Войтович, Л. Гонюкової, В. Голубь, І. Грицяка, I. Ібрагімової, Ю. Кальниша, В. Кампо, А. Крупника, I. Надольного, Н. Нижник, О. Оболенського, О. Резніка, В. Рижих, С. Рябова, В. Селіванова, С. Сьоміна, О. Сушинського, С. Телешуна, В. Тертички, В. Трощинського та ін.

Метою статті $\epsilon$ дослідження концептуальних підходів щодо феномену публічного управління в контексті рефор- 
мування державної влади, а також формулювання авторських підходів щодо особливостей удосконалення ефективних механізмів функціонування публічного управління в контексті реалізації національної політики України.

Досліджуючи концептуальні засади щодо ефективності публічного управління, насамперед доцільно з'ясовувати правову природу публічного управління, тобто його реалізацію як у колективних, так і в приватних інтересах.

Зміст ефективного публічного управління виражається в задоволенні державними та місцевими органами влади потреби громадян, водночас визначальним фактором оцінки публічного управління є соціально сприйнятний ступінь задоволення таких потреб.

До того ж публічне управління - це складна система, і до неї застосовуються організаційна структура, організаційні правила та директиви, раціональність їхньої дії. Структури та функції публічного управління повинні відповідати чинному законодавству. Зміни, які відбуваються в державному секторі, стосуються впровадження нових рішень

Натепер державні інституції відіграють ключову роль у визначенні правильних стимулів, зменшенні невизначеності та досягненні довгострокового процвітання кожної держави. Слабкі сторони функціонування публічного управління можуть створити значні перешкоди для функціонування єдиного ринку, інвестицій на регіональному та місцевому рівні, а також інновацій.

Для прикладу, в деяких країнах ЄС доклали усвідомлених та послідовних зусиль для підвищення ефективності своїх адміністрацій, водночас потрібно було суттєво переосмислити фундаментальні блоки своєї адміністративної системи. Нинішній темп соціальних, технологічних та економічних змін вимагає від усіх публічних адміністрацій адаптації до нових реалій.

Публічне управління доцільно розглядати в декількох аспектах:

1) публічне управління відображає інституційні засади управління державою;

2) публічне управління орієнтоване на потреби громади та діє на основі організаційних структур, процесів, ролей, взаємозв'язків, політики та програм;

3) публічне управління відповідає за стале економічне процвітання, соціальну згуртованість та добробут людей;

4) публічне управління впливає на довіру населення та створює умови для створення суспільної цінності [1-3].

П. Кравчук вважає, що «стратегічний менеджмент має значний вплив на функціонування державного управління» $[4$, с. 364$]$

С. Цієслак зауважує, що «публічне управління - це сукупність різних типів управління, що діють у сфері державних справ, зокрема державної адміністрації та адміністрації місцевого самоврядування. Державне управління - це призначення для визначення структур, діяльності та людей усіх цих типів управління» [5, с. 14].

На думку Я. Пенса, «стратегічний менеджмент стосується довготривалого прагнення організації до успіху, інтегруючи різні підходи та знання з різних галузей, воно також передбачає визначення ключових факторів, дослідження та визначення взаємозалежностей між ними та їх вплив на майбутнє, пристосовуючи концепцію розвитку до передбачуваних, мінливих ситуацій, що створюються ринковими та екологічними умовами» [6, с. 125].

У публічному управлінні «об'єктом управління можуть бути особи, організації, речі, пов'язані з плануванням та виконанням суспільних завдань, які, на відміну від організацій, не обов'язково повинні управляти менеджером. Управління означає сукупність дій, що вживаються для досягнення бажаного перебігу процесів та явищ у межах місцевого самоврядування» [7, с. 7].
Досліджувана проблематика порівняно нова для вітчизняної науки, тому допоки не має законодавчо затвердженого тлумачення термина «публічне управління», а також серед науковців відсутня одностайність щодо сутності цього поняття.

На окрему увагу заслуговує позиція А.М. Волкова, який вважає, що «влада, відкрита народу та його інтересам, публічна за характером, що здатна залучати до управління широкі верстви населення» [8, с. 15].

Але подекуди запропоновані тлумачення поняття «публічне управління», радше за все, більшою мірою відповідають змісту поняття «державне управління» [9, с. 9; 10$, c. $57 ; 11]$, «муніципальне управління» [12, с. 4], «управління» [13, с. 60]

Тим не менше, існують також думки, що публічне управління реалізують публічні особи, приймаючі владні політичні рішення [14, с. 119], відображаючи лише незначну частину впливу суб'єктів управління на суспільні процеси.

Варто погодитись, що «головна мета будь-якого управлінця в публічній чи приватній сфері - досягнути максимальної ефективності, дієвості й результативності 3 мінімальними затратами ресурсів, часу і зусиль. Основне ж завдання, яке стоїть перед публічним управлінцем, відмінне від завдання бізнесового управлінця. Якщо бізнесовий управлінець своєю діяльністю прямо впливає на отримання прибутку певної підприємницької одиниці, то публічний управлінець - на якість життя громадян певної адміністративно-територіальної одиниці чи держави в цілому» [11, с. 73].

При цьому не варто нехтувати тим, що бізнесові управлінці, по-перше, впливають на рівень добробуту населення через встановлення розміру фактичної оплати праці та забезпечення своєчасної ії виплати, формування цін на товари та послуги, участь у соціально значущих проектах тощо; по-друге, відкрито здійснюють значну частину своєї діяльності (за виключенням того, що стосується комерційної таємниці), а тому ії можна вважати публічною.

Тим не менше, публічні управлінці, по-перше, регулюють діяльність суб'єктів господарювання, тим самим опосередковано впливаючи на добробут населення; по-друге, окремі іiі представники здійснюють діяльність, пов'язану 3 національною таємницею, а тому належать не до публічного, а до державного управління. До речі, такий вплив $\epsilon$ відмінним для різних його категорій (інвестори, власники бізнесу, самозайняті, наймані працівники), а тому далеко не всім вдається повною мірою реалізувати прагнення максимізувати власний добробут - «забезпеченість матеріальними й духовними благами та послугами».

Відповідно до європейських стандартів держава повинна забезпечувати громадянам право брати участь в управлінні державними справами 3 метою створення демократичного та правового суспільства. Згідно з рекомендаціями Ради Європи про статус неурядових організацій у Європі (70 пунктів) та Білою книгою належного врядування у Європейському Союзі, яка дала чіткі стандарти щодо роботи публічних адміністрацій, держава має: забезпечити сприятливе законодавство для створення та реєстрації різних форм неурядових організацій;

- створити сприятливі податкові умови;

- надати певну державну фінансову підтримку проектам, ініціативам громадських організацій; участі;

запровадити механізми консультацій, механізми

- дати можливості громадським організаціям та іншим об'єднанням долучатися до розроблення політики, іï контролю, реалізації.

Побудова стратегії управління людськими ресурсами в публічному управлінні випливає 3 таких умов, як:

- чітке вирівнювання організаційної структури та децентралізація процесів прийняття рішень; 
- необхідність постійно підвищувати рівень кваліфікації та навичок, продиктований зростаючим попитом на фахівців;

- нова філософія управління людськими ресурсами в громадській організації, що підкреслює стратегічний аспект посадових осіб;

- нові тенденції управління, наприклад, управління проектами, орієнтовані на ефективну командну роботу;

- технологічні зміни, орієнтовані на спілкування та функціонування інформаційного суспільства;

- ефективність управління за цілями;

- зростаюча роль знань у громадських організаціях $[15$, c. 20$]$.

Види публічного управління зображено на рис. 1.

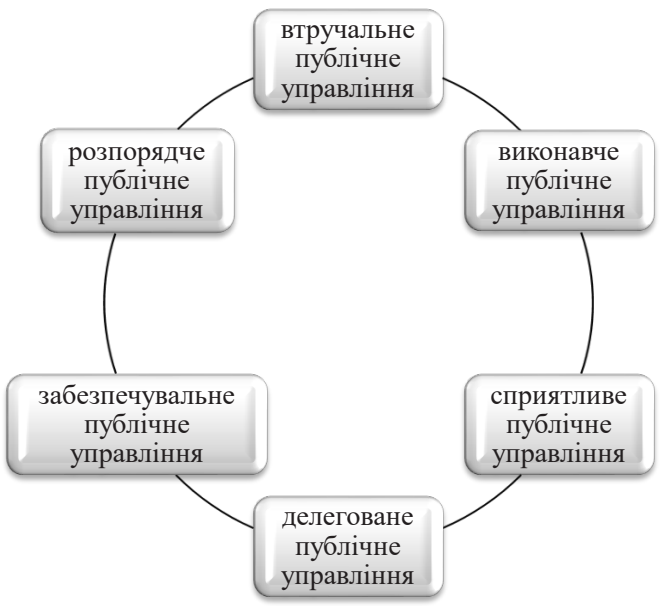

Рис. 1. Види публлічного управління
Термін «публічне управління» слід тлумачити як відкритий (у межах власних і делегованих повноважень) вплив наділених владою інституцій на взаємовідносини між державою, місцевим самоврядуванням, бізнесом і населенням задля узгодження їхніх інтересів і максимізації вигод.

Як наслідок, замість глобалізації публічного управління на основі багатонаціональних угод та координації ієрархічної стабільності нова реальність управління впливає на кожну країну без виключення в умовах нестабільності та невизначеності. В останнє десятиліття чітко показано, що адміністративні інструменти та процедури управління (так звані адміністративні механізми) слід суттєво та неодноразово переробляти та модернізувати.

Більшість рішень суб'єктів публічного управління частіше за все вирізняються багатоваріантністю, але водночас $є$ такими, де вкрай складно обрахувати не лише його кінцевий результат (передусім економічний ефект), а й можливі наслідки (параметри) альтернативних варіантів. Результати впливу публічного управління на добробут населення оцінюються на підставі аналізу переважно кількісних показників, тим самим мінімізуючи їх суб'єктивність.

Таким чином, основними рисами публічного управління $\epsilon$ гуманістичний характер прийнятих управлінських рішень, задоволення приватноправових інтересів, залучення громадськості до процесу реалізації державної політики, прозорість управління тощо. До того ж вимогою реалізації принципів публічного управління в усіх сферах суспільного життя є необхідність впровадження дієвих механізмів відповідальності органів державної влади, дотримання принципів прозорості та можливості громадського обговорення під час прийняття управлінських рішень і актів.

\section{ЛITEPATYPA}

1. Кохан С.О. Зарубіжний досвід організації системи контролю. Науковий вісник Академії муніципального управління. 2013. Вип. 2. С. 284-290. URL: http://www.irbis-nbuv.gov.ua/cgi Nvamu_upravl_2013_2_35

2. Контроль менеджменту в сучасному державному управлінні: деякі порівняльні практики / пер. з англ. С.Ю. Полянського. Д.: ДФ УАДУ при Президентові України, Вид-во «Центр економічної освіти», 1999. 258 с.

3. Державний контроль в органах виконавчої влади Словаччини. Президентський контроль : інфоорм.-аналіт., наук.-метод. бюлетень. 2004. № 4. С. 76-79.

4. США: президент, конгрес, контроль. Президентський контроль: інформ.-аналіт., наук.-метод. бюлетень. 2004. № 1. С. 75-80.

5. Система федерального державного контролю в Канаді. Президентський контроль : інфрорм.-аналіт., наук.-метод. бюлетень. 2004. № 2. C. 77-78.

6. Писаренко В.П. Державний контроль у системі органів виконавчої влада зарубіжних країн. Актуальні проблеми державного управління: зб. наук. пр. Д. : ДРІДУ НАДУ, 2005. Вип. 3 (21). С. 91-96.

7. Принципи контролю у Франції. Президентський контроль: інфрорм.-аналіт., наук.-метод. бюлетень. 2004. № 4. С. $72-76$.

8. Волков А.М. Публичное управление недропользованием в России (современный период). Правовая инициатива. 2013. № 7. C. 15.

9. Мельник Р.С. Категорія «публічне управління» у новій інтерпретації. Адміністративне право і процес. 2013. № 1. С. 8-14.

10. Обушна Н.І. Публічне управління як нова модель організації державного управління в Україні: теоретичний аспект. Ефективність державного управління. 2015. Вип. 44. С. 53-63.

11. Чернов С.І., Гайдученко С.О. Публічне адміністрування: текст лекцій. Харків : Вид-во ХНУМГ, 2014. 150 с.

12. Оболенський О.Ю. Публічне управління: цивілізаційний тренд, наукова теорія і напрям освіти. Публічне управління: шляхи розвитку : матеріали наук.-практ. конфр. за міжнар. уч., 26 листоп. 2014 р. : у 2 т. / за наук. ред. Ю.В. Ковбасюка, С.А. Романюка, О.Ю. Оболенського. Київ : Вид-во НАДУ, 2014. Т. 1. С. 3-10.

13. Базарна О.В. Поняття, суть, природа публічного управління та державного управління. Вісник Східноукраїнського національного університету імені Володимира Даля. 2012. Ч. 2. № 1. С. 59-64.

14. Лазор О.Я., Лазор О.Д. Публічне управління та адміністрування: ретроспектива деяких теоретичних аспектів. Університетські наукові записки. 2015. № 4. С. 111-121.

15. Друкер П. Классические работы по менеджменту. Москва : Альпина Паблишер, 2015. 349 с. 


\title{
ОКРЕМІ ПИТАННЯ ПРАВОВОГО СТАТУСУ МОВНОГО ОМБУДСМЕНА В УКРАЇНІ
}

\section{SOME ISSUES OF A LEGAL STATUS OF THE LANGUAGE OMBUDSMAN IN UKRAINE}

\author{
Коваль Т.В., к.і.н., \\ доцент кафедри державно-правових дисциплін \\ Черкаський національний університет імені Богдана Хмельницького
}

У статті висвітлено окремі питання правового статусу Уповноваженого із захисту державної мови (мовного омбудсмена). На основі аналізу нормативно-правових актів, зокрема Закону України «Про забезпечення функціонування української мови як державної», встановлено, що мовний омбудсмен діє в системі органів виконавчої влади України. Він є посадовою особою, яка призначається і звільняється з посади Кабінетом Міністрів України. Водночас Уповноважений здійснює свою діяльність незалежно від інших державних органів та посадових осіб.

Автором проаналізовано критерії (цензи) до кандидатури на посаду мовного омбудсмена. Вказано, що в цілому вони подібні до загальноприйнятих, хоча $є$ й особливості. Наприклад, мовний ценз для Уповноваженого передбачає володіння не лише державною, а й англійською (не просто іноземною) мовою, а ценз осілості взагалі відсутній. Окремо розкрито вимоги щодо несумісності 3 вказаною посадою. Охарактеризовано процедуру призначення на посаду Уповноваженого, яка складається з двох основних етапів: вибір та подання кандидатур до Кабінету Міністрів України та розгляд кандидатур і призначення мовного омбудсмена. Встановлено коло суб'єктів, які мають право подавати відповідні кандидатури до уряду.

Розкрито завдання та повноваження мовного омбудсмена. Так, до його завдань належить захист української мови як державної, захист права громадян на отримання державною мовою інформації та послуг у сферах суспільного життя, усування перешкод та обмежень у користуванні державною мовою. Вказано, що для реалізації завдань мовний омбудсмен наділений як правозахисними, так і контрольно-наглядовими повноваженнями (за явною перевагою останніх). Це, зокрема, контроль органів державної влади, розгляд скарг, складання протоколів та стягнення штрафів. Окрему увагу приділено допоміжній структурі Уповноваженого - секретаріату.

Ключові слова: спеціалізований омбудсмен, мовне питання, Уповноважений із захисту державної мови, мовний омбудсмен, захист української мови, захист права на отримання інформації державною мовою.

The article covers some issues of a legal status of the Commissioner for the Protection of the State Language (language ombudsman). Based on the analysis of normative legal acts, in particular the Law of Ukraine "On Ensuring the Functioning of the Ukrainian Language as the State Language", the study found that the language ombudsman operates in the system of executive bodies of Ukraine. He is an official who is appointed and dismissed by the Cabinet of Ministers of Ukraine. At the same time, the Commissioner performs his duties independently of other state bodies and officials.

The author analyzes the criteria (qualifications) for the candidate for the position of the language ombudsman. It is mentioned that in general they are similar with the commonly accepted, although there are some specificities. For example, the language qualification for the Commissioner requires good command not only of state, but also of English (not just foreign) languages, and there is no residency requirement at all. The requirements for incompatibility are also disclosed in a paper. The procedure of appointment to the position of the Commissioner is described. It consists of two main stages: selection and submission of applicants to the Cabinet of Ministers of Ukraine and consideration and appointment the language ombudsman.

The tasks and powers of the language ombudsman are described. His tasks include the protection of the Ukrainian language as the state language, the protection of the right of citizens to receive information and services in the state language in the spheres of public life, etc. It is set out that the language ombudsman has human rights mandate and control powers (with the obvious advantage of the latter). These include the control of public authorities, the handling of complaints, the drawing up of reports and the collection of fines. Special attention is paid to the support service of the Commissioner - the Secretariat.

Key words: specialized ombudsman, language issue, Commissioner for the Protection of the State Language, language ombudsman, protection of the Ukrainian language, protection of the right to receive information in the state language.

Інститут спеціалізованого омбудсмена в Україні розвивається надзвичайно стрімкими темпами. Кожного року в структурі органів виконавчої влади, офісу Президента України з'являються посади нових уповноважених, покликаних захищати права і свободи населення. Як правило, їхня діяльність пов'язана з певною соціальною групою, якою вони опікуються (діти, особи з інвалідністю, учасники бойових дій та ін.), або певною сферою суспільного життя - освітою, підприємництвом, волонтерством, а також мовою та мовною політикою. Саме сприяння функціонуванню української мови як державної у сфеpax суспільного життя, визначених відповідним законом, $\epsilon$ метою діяльності Уповноваженого із захисту державної мови (мовного омбудсмена), посаду якого було запроваджено 25 квітня 2019 р.

Упродовж року ця «абсолютно нова інституція, якої не було в історії України», переживала не найкращі часи Так, 27 листопада 2019 р. Кабінет Міністрів України (далі - КМУ) призначив першого в історії України мовного омбудсмена - Тетяну Монахову [1], а вже 6 травня 2020 р. видав розпорядження про їі звільнення [2]. Його ініціатором виступила сама Уповноважена, відзначивши, що протягом усього терміну іiі роботи так і не було вирішено питання належного фінансування. Ситуація усклад- нилася й тим, що 27 травня 2020 р. (після спливу шести місяців із дня призначення омбудсмена) мали запрацювати положення щодо його окремих повноважень. Зрештою, 8 липня 2020 р., після численних обговорень було призначено нового Уповноваженого - Тараса Кременя [3].

Мусимо констатувати, що діяльність мовного омбудсмена в силу різних причин $є$ предметом політичних спекуляцій, а інколи й відвертого популізму. Зрозуміло, що надмірна чутливість українського суспільства до мовного питання активно використовується національним політикумом залежно від партійної ідеології, етапів виборчого процесу, міжнародної ситуації тощо. На нашу думку, подібні дискусії слід перенести з політичної в наукову площину, тим паче, що особливості функціонування спеціалізованих омбудсменів традиційно привертають увагу широкого кола дослідників. Різні аспекти їх правового статусу вивчали Л. Голяк, К. Закоморна, В. Закриницька, Н. Коломоєць, Л. Корчевна, А. Левенець, Н. Лесько, О. Марцеляк, Ю. Палєєва, А. Сирота, І. Хомишин, Ю. Шешученко та ін. Втім, робіт, присвячених омбудсменам з мови та мовної політики, дуже мало, тому звернення до вибраної теми вбачається вельми доцільним.

Очевидно, що обсяг статті дозволяє розкрити лише окремі питання правового статусу мовного омбудсмена, 
зокрема порядок його призначення (кваліфікаційні вимоги (цензи), подання та розгляд відповідних кандидатур), завдання та повноваження, організацію діяльності, підстави припинення повноважень (у тому числі й дострокового) тощо. Вказане вище $\epsilon$ і метою нашого дослідження.

Правовий статус мовного омбудсмена і порядок здійснення ним повноважень визначено Законом України «Про забезпечення функціонування української мови як державної» від 25 квітня 2019 р. [4], а також Постановами КМУ «Про затвердження Порядку взаємодії Уповноваженого із захисту державної мови з органами державної влади, органами влади Автономної Республіки Крим, органами місцевого самоврядування» від 21 серпня 2019 р. [5], «Деякі питання Уповноваженого із захисту державної мови» від 25 червня 2020 р. [6] тощо.

Уповноважений із захисту державної мови діє в системі органів виконавчої влади України (як i, наприклад, освітній омбудсмен). Він $є$ посадовою особою, яку призначає і звільняє з посади КМУ. Водночас у законі вказано, що Уповноважений здійснює свою діяльність незалежно від інших державних органів та посадових осіб. Вказане положення повністю ідентичне з ч. 2. ст. 4 Закону України «Про Уповноваженого Верховної Ради України з прав людини» [7]. Для прикладу, нормативно-правові акти, що регламентують діяльність освітнього омбудсмена, не містять жодних згадок про його самостійність і незалежність [8]. Термін повноважень мовного омбудсмена становить п'ять років. Одна і та ж сама особа може бути призначена на цю посаду повторно, але не може обіймати ії втрете (тобто максимальний термін роботи становить 10 років).

Законодавець передбачив низку критеріїв (цензів) до кандидатури на посаду Уповноваженого. До них, зокрема, належать: 1) громадянство України (ценз громадянства); 2) досягнення 35-річного віку на день подання кандидатури (віковий ценз); 3) вища освіта (освітній ценз); 4) володіння державною та англійською мовами (мовний ценз); 5) досвід правозахисної діяльності або досвід діяльності із захисту державної мови; 6) здатність за своїми діловими i моральними якостями, освітнім і професійним рівнями виконувати відповідні посадові обов’язки [4].

Зауважимо, що в переліку вимог відсутній ценз осілості (на противагу освітньому омбудсмену, який має проживати в Україні останні п’ять років), а також не визначений мінімальний термін правозахисної діяльності або діяльності із захисту державної мови (вже загаданий освітній омбудсмен повинен мати досвід роботи у сфері освіти або науки не менше п’яти років) [8]. Натомість наявна вимога щодо володіння не лише державною, а й англійською (не просто іноземною) мовою. Цікаво, що згідно із Законом України «Про державну службу» від 10 грудня 2015 р. володіння іноземною мовою, яка $є$ однією 3 офіційних мов Ради Європи (не лише англійською), є обов'язковою вимогою лише для осіб, які претендують на зайняття посад державної служби категорії «А» [9]. Нагадаємо, що відповідно до закону мовний омбудсмен не є державним службовцем (ч. 13 ст. 50).

У законі також наведено перелік підстав, за яких особу не може бути рекомендовано на посаду Уповноваженого: 1) притягнення до відповідальності за порушення вимог Закону України «Про забезпечення функціонування української мови як державної»; 2) участь у спробах запровадження офіційної багатомовності всупереч Конституції України і встановленій конституційній процедурі. Водночас вимоги щодо відсутності судимості, обмеження в дієздатності або недієздатності кандидата, очевидно, сприймаються як належне, а тому не вказані.

Окрім того, згідно із законом мовний омбудсмен не може мати представницького мандата; займатися іншою оплачуваною або підприємницькою діяльністю (крім викладацької, наукової і творчої діяльності, медичної практики, інструкторської та суддівської практики зі спорту); входити до складу органу управління чи наглядової ради підприємства або організації, що має на меті одержання прибутку; бути членом політичної партії, тобто повинен бути політично нейтральною особою [4].

Наявність указаних вимог до кандидатури на посаду мовного омбудсмена вигідно відрізняє його від уповноважених Президента України, критерії щодо обрання яких практично відсутні. Так, лише в Положенні про повноваження Уповноваженого Президента України з питань контролю за діяльністю СБУ вказано, що на посаду, як правило, призначається військовослужбовець СБУ, який має досвід практичної роботи не менш як десять років [10]. Більше за те, особливий порядок призначення на посаду, заборона належати до політичних партій, мати представницький мандат тощо $є$ важливою гарантією забезпечення незалежності Уповноваженого.

Процедура призначення на посаду мовного омбудсмена складається 3 двох основних етапів: 1) вибір та подання кандидатур до КМУ; 2) їх розгляд в уряді та призначення ним Уповноваженого. Кандидатури на посаду мовного омбудсмена подають три суб'єкти - Уповноважений Верховної Ради України з прав людини, керівник центрального органу виконавчої влади, що забезпечує формування та реалізує державну правову політику (Міністерство юстиції України) та керівник центрального органу виконавчої влади у сфері державної мовної політики (Міністерство культури та інформаційної політики України). Кожен із суб'єктів пропонує уряду по одній кандидатурі. Наприклад, згідно з Положенням про проведення відкритого конкурсу 3 добору кандидатури на посаду Уповноваженого із захисту державної мови для подання Уповноваженим Верховної Ради України з прав людини до КМУ, затвердженим наказом Уповноваженого Верховної Ради України з прав людини від 8 серпня 2019 р., конкурс включає декілька етапів, зокрема: прийняття та оприлюднення рішення про оголошення конкурсу; прийняття документів від осіб, які виявили бажання взяти участь у конкурсі; попередній розгляд поданих документів на відповідність установленим законом вимогам; розгляд мотиваційного листа та проведення співбесіди 3 кандидатами; ухвалення рішення про визнання кандидатури, яка набрала більшу кількість голосів членів конкурсної комісії, переможцем конкурсу; оприлюднення результатів конкурсу [11].

Подання кандидатур закінчується за три місяці, що передують закінченню строку повноважень, на який було призначено Уповноваженого. У разі дострокового припинення повноважень Уповноваженого кандидатури подаються впродовж 30 днів із дня дострокового припинення [4].

Рішення щодо призначення на посаду Уповноваженого приймається КМУ протягом одного засідання. Перед розглядом кожний із кандидатів на посаду Уповноваженого має право виступити перед членами уряду. Втім, під час обговорення та голосування вони вже не можуть бути присутніми. КМУ ухвалює рішення стосовно призначення на посаду Уповноваженого відкритим голосуванням членів уряду особисто. На посаду Уповноваженого призначається кандидат, який набрав найбільшу кількість голосів.

У законодавстві міститься перелік випадків дострокового припинення повноваження мовного омбудсмена, які в цілому відповідають загальній практиці. Це, зокрема: 1) подання ним особистої заяви про складення повноважень; 2) наявності медичного висновку про неможливість виконувати обов'язки за станом здоров'я; 3) порушення ним вимог щодо несумісності; 4) притягнення його до відповідальності за порушення вимог Закону України «Про забезпечення функціонування української мови як державної»; 5) його участі у спробах запровадження офіційної багатомовності всупереч Конституції України і встановленій конституційній процедурі; 6) набрання законної сили обвинувальним вироком щодо нього; 7) припинення 
ним громадянства України; 8) визнання його безвісно відсутнім або оголошення померлим; 9) його смерті [4].

Відповідно до закону (ч. 2 ст. 49) Уповноважений має такі завдання: захист української мови як державної та захист права громадян України на отримання державною мовою інформації та послуг у сферах суспільного життя, визначених законом, на всій території України й усунення перешкод та обмежень у користуванні державною мовою.

Для реалізації вказаних завдань мовний омбудсмен наділений як правозахисними, так і контрольно-наглядовими повноваженнями (за явною перевагою останніх). До них, зокрема, належать: подання КМУ пропозицій щодо забезпечення ефективної реалізації державної політики, спрямованої на захист державної мови, всебічний розвиток і функціонування державної мови у сферах суспільного життя, визначених законом, на всій території України, сприяння задоволенню мовних потреб українців, які проживають за межами України; забезпечення моніторингу виконання законодавства про державну мову, державних цільових програм забезпечення всебічного розвитку і функціонування української мови як державної; розгляд скарг фізичних і юридичних осіб на дії та бездіяльність органів державної влади, органів місцевого самоврядування, підприємств, установ і організацій всіх форм власності, інших юридичних і фізичних осіб щодо дотримання вимог законодавства про державну мову; спрямування до Комісії з питань вищого корпусу державної служби, міністерств та інших центральних органів виконавчої влади, Ради міністрів Автономної Республіки Крим, обласних, Київської та Севастопольської міських державних адміністрацій подання про проведення службових розслідувань, а також притягнення до дисциплінарної відповідальності посадових осіб, винних у порушенні законодавства про державну мову, що є обов'язковими до розгляду; складання протоколів та застосування стягнень у випадках, встановлених законом; здійснення контролю за виконанням повноважень його представниками; затвердження форми акту про результати здійснення контролю за застосуванням державної мови, а також форми відповідних протоколу та постанови [4].

Законом розмежовано повноваження мовного омбудсмена у сфері захисту державної мови та захисту прав людини щодо застосування державної мови. Так, з метою захисту державної мови від публічного приниження чи зневажання, від навмисного спотворення державної мови в офіційних документах і текстах, зокрема навмисного застосування iĭ з порушенням стандартів державної мови, а також від нехтування вимогами обов'язкового застосування державної мови, визначеними законом, Уповноважений: 1) здійснює державний контроль за застосуванням державної мови органами державної влади, органами влади Автономної Республіки Крим, органами місцевого самоврядування, підприємствами, установами та організаціями державної і комунальної форм власності, їхніми посадовими та службовими особами, а також громадськими об'єднаннями, політичними партіями та іншими юридичними особами, їхніми посадовими особами; 2) надає висновки і рекомендації органам державної влади, органам влади Автономної Республіки Крим та органам місцевого самоврядування в Україні щодо застосування української мови як державної в їхній діяльності; 3) оприлюднює висновки про ознаки публічного приниження чи зневажання державної мови в публічних виступах посадових осіб органів державної влади, органів влади Автономної Республіки Крим, органів місцевого самоврядування в Україні, підприємств, установ та організацій державної і комунальної форм власності, громадських об'єднань, політичних партій та інших юридичних осіб, а також посадових осіб іноземних держав; 4) подає пропозиції Кабінету Міні- стрів України щодо внесення змін до законодавства щодо захисту державної мови.

Для здійснення вказаних повноважень мовний омбудсмен за потреби може залучати працівників Національної поліції, центрального органу виконавчої влади, що формує та забезпечує реалізацію державної політики у сфері захисту прав споживачів, центрального органу виконавчої влади, що реалізує державну політику у сфері державного контролю за додержанням законодавства про захист прав споживачів, працівників місцевих державних адміністрацій, інших органів державної влади [4]

3 метою захисту прав людини щодо застосування державної мови кожна особа може звернутися до Уповноваженого зі скаргою про порушення вимог закону та щодо усунення перешкод та обмежень у користуванні державною мовою. Йдеться, зокрема, про оскарження рішень, дій або бездіяльності органів державної влади, органів влади АР Крим, органів місцевого самоврядування, підприємств, установ та організацій державної та комунальної форм власності, їхніх посадових і службових осіб та працівників. Відповідний механізм визначено у ст. ст. 54 і 55 закону. Окрім того, Уповноважений здійснює державний контроль за застосуванням державної мови.

Слід вказати, що контрольно-наглядові повноваження омбудсмена неоднозначно сприймаються суспільством, у тому числі й міжнародними інстанціями. Так, у висновку Венеціанської комісії щодо Закону України «Про забезпечення функціонування української мови як державної» від 6 грудня 2019 р. йдеться про те, що попри очевидну виправданість моніторингу дотримання положень закону, окремі повноваження «перероджуються в засоби контролю внутрішнього життя політичних партій та інших юридичних осіб, які піднімають питання щодо їх відповідності ст. 11 Європейської конвенції з прав людини про свободу асоціацій» [12].

Порядок взаємодії Уповноваженого із захисту державної мови 3 органами державної влади, органами влади АР Крим, органами місцевого самоврядування затверджений Постановою КМУ від 21 серпня 2019 р. [5].

Необхідно згадати і про спеціальний допоміжний орган - секретаріат Уповноваженого, покликаний здійснювати організаційне, експертно-аналітичне, правове, інформаційне та матеріально-технічне забезпечення діяльності Уповноваженого. Згідно із законом його структуру затверджує мовний омбудсмен, а штатний розпис та кошторис - керівник секретаріату за погодженням із центральним органом виконавчої влади, що забезпечує формування державної бюджетної політики (Міністерством фінансів України). Цікаво, що на відміну від Уповноваженого, керівник та працівники секретаріату є державними службовцями. Вони призначаються та звільняються 3 посади у порядку, передбаченому Законом України «Про державну службу». Відповідно до Постанови КМУ «Деякі питання Уповноваженого із захисту державної мови» секретаріат Уповноваженого є юридичною особою публічного права (до речі, ці зміни було внесено лише після звільнення Т. Монахової). Гранична чисельність його працівників становить 50 одиниць [6].

Втім, як і у випадку з освітнім омбудсменом, законодавством не передбачено наявність посади заступника (першого заступника) омбудсмена, запровадження якої доречно «хоча б у контексті пошуку відповіді на питання про те, хто буде виконувати відповідні обов'язки у період тимчасової відсутності омбудсмена» $[13$, с. 6]. Видається доцільним покласти їх на керівника секретаріату.

Про необхідність більш чіткого і виваженого підходу до функціонування секретаріату як невід'ємної частини забезпечення роботи мовного омбудсмена свідчить і подання законопроекту О.В. Савчук про внесення змін до статті 52 Закону України «Про забезпечення функціонування української мови як державної» щодо секре- 
таріату Уповноваженого із захисту державної мови від 6 травня 2020 p. [14].

Важливо, що законом передбачено контроль за діяльністю самого Уповноваженого. Так, Уповноважений щороку готує і не пізніше 1 травня року, наступного за звітним, подає КМУ та представляє громадськості річний публічний звіт про свою діяльність і про стан дотримання закону разом із висновками та рекомендаціями Рахункової палати, наданими за результатами здійснення заходів державного зовнішнього фінансового контролю (аудиту) діяльності Уповноваженого, та інформацією про стан виконання відповідних рекомендацій. Одночасно з поданням річного звіту Уповноважений розміщує його на своєму офіційному веб-сайті для відкритого доступу [4].

У підсумку відзначимо, що Уповноважений із захисту державної мови є дійсно новою інституцією для України.
Попри різне, часом діаметрально протилежне ставлення до нього (в тому числі й наукової спільноти), сьогодні він $\epsilon$ частиною правозахисного механізму держави. Разом 3 освітнім омбудсменом, урядовим Уповноваженим з прав осіб з інвалідністю він діє в системі органів виконавчої влади. Законом встановлено систему вимог (цензів), яким має відповідати претендент на посаду мовного омбудсмена, порядок призначення його на посаду, вимоги щодо несумісності, підстави звільнення тощо. Слід вказати, що пріоритетним завданням Уповноваженого є захист не лише права громадян України на отримання державною мовою інформації та послуг у сферах суспільного життя, визначених законом, а й захист української мови як державної. Для виконання вказаних завдань мовний омбудсмен наділений низкою повноважень, серед яких переважають контрольно-наглядові.

\section{ЛITEPATYPA}

1. Про призначення Монахової Т.В. Уповноваженим із захисту державної мови : Розпорядження Кабінету Міністрів України від 27.11.2020 p. № 1136-2019 p. URL: https://www.kmu.gov.ua/npas/pro-priznachennya-monahovoyi-t-v-u-a1136r (дата звернення: 20.07.2020).

2. Про звільнення Монахової Т.В. з посади Уповноваженого із захисту державної мови : Розпорядження Кабінету Міністрів України від 06.05.2020 р. № 491-p. URL: https://www.kmu.gov.ua/npas/pro-zvilnennya-monahovoyi-t-v-z-pos-a491r (дата звернення: 20.07.2020).

3. Про призначення Кременя Т.Д. Уповноваженим із захисту державної мови : Розпорядження Кабінету Міністрів України від 08.07.2020 р. № 852-p. URL: https://www.kmu.gov.ua/npas/pro-priznachennya-kremenya-t-d-upovnovazhenim-iz-zahistuderzhavnoyi-t80720 (дата звернення: 20.07.2020).

4. Про забезпечення функціонування української мови як державної : Закон України від 25.04.2019 р. № 2704-VIII. URL: https://zakon.rada.gov.ua/laws/show/2704-19 (дата звернення: 21.07.2020).

5. Про затвердження Порядку взаємодії Уповноваженого із захисту державної мови з органами державної влади, органами влади Автономної Республіки Крим, органами місцевого самоврядування : Постанова Кабінету Міністрів України від 21 серпня 2019 р. № 819-2019-п. URL: https://zakon.rada.gov.ua/laws/show/819-2019-п (дата звернення: 21.07.2020).

6. Деякі питання Уповноваженого із захисту державної мови : Постанова Кабінету Міністрів України від 25 червня 2020 р. № 530. URL: https://zakon.rada.gov.ua/laws/show/530-2020-п\#Tеxt (дата звернення: 21.07.2020).

7. Про Уповноваженого Верховної Ради України з прав людини : Закон України від 23.12.1997 р. № 776/97-BP. URL: https://zakon.rada.gov.ua/laws/show/776/97-вр\#Tеxt (дата звернення: 21.07.2020).

8. Декі питання освітнього омбудсмена : Постанова Кабінету Міністрів України від 06. 06. 2018 р. № 491-2018-п. URL: https://zakon.rada.gov.ua/laws/show/491-2018-п\#Техt (дата звернення: 21.07.2020).

9. Про державну службу : Закон України від 10.12.2015 р. № 889-VIII. URL: https://zakon.rada.gov.ua/laws/show/889-19\#Text (дата звернення: 21.07.2020).

10. Про повноваження та гарантії здійснення постійного контролю за діяльністю Служби безпеки України : Указ Президента України від 18.05.2007 р. № 427/2007. URL: https://zakon.rada.gov.ua/laws/show/427/2007\#Text (дата звернення: 21.07.2020).

11. Про проведення відкритого конкурсу з добору кандидатури на посаду Уповноваженого із захисту державної мови для подання Уповноваженим Верховної Ради України з прав людини до Кабінету Міністрів України : Наказ Уповноваженого Верховної Ради України з прав людини від 8 серпня 2019 р. № 75.15/19. URL: http://www.ombudsman.gov.ua/ua/all-news/pr/ogoloshennya-pro-konkurs-z-doborukandidata-na-posadu-upovnovazhenogo-iz-zaxistu-derzhavnoï-movi (дата звернення: 21.07.2020).

12. Висновок щодо Закону України «Про забезпечення функціонування української мови як державної», прийнятий Венеціанською Комісією на 121-ому пленарному засіданні (Венеція, 6-7 грудня 2019 р.). URL: http://kmf.uz.ua/wp-content/uploads/2019/12/Висновок-венеціанської-комісії-960-2019.pdf (дата звернення: 21.07.2020).

13. Рябовол Л.Т. Основи правового статусу освітнього омбудсмена. Наукові записки Центральноукраїнського державного педагогічного університету імені Володимира Винниченка. Серія : Право. 2019. Випуск 7. Кропивницький : ТОВ «ПолімедСервіс», 2019. С. 4-7.

14. Проект Закону про внесення змін до статті 52 Закону України «Про забезпечення функціонування української мови як державної» щодо секретаріату Уповноваженого із захисту державної мови від 06.05.2020 p. № 3441. URL: http://w1.c1.rada.gov.ua/pls/zweb2/ webproc4_1?id=\&pf3511=68764 (дата звернення: 22.07.2020). 


\title{
ЩОДО ПРИНЦИПУ НЕДИСКРИМІНАЦЇ̈ ЗА ОЗНАКОЮ МІСЦЯ ПРОЖИВАННЯ (НА ПРИКЛАДІ ВИБОРЧОГО ПРАВА ВНУТРІШНЬО ПЕРЕМЩЩЕНИХ ОСІБ)
}

\section{REGARDING THE PRINCIPLE OF NON-DISCRIMINATION BY PLACE OF RESIDENCE (ON THE EXAMPLE OF THE VOTING RIGHT OF INTERNALLY DISPLACED PERSONS)}

\author{
доцент кафедри конституційного, міжнародного і кримінального права
}

Донеиький національний університет імені Василя Стуса

\begin{abstract}
Стаття присвячена питанням принципу недискримінації за ознакою місця проживання в контексті активного виборчого права внутрішньо переміщених осіб за виборчим законодавством України до прийняття Виборчого Кодексу 19 грудня 2019 року. Ці питання залишаються актуальними й в умовах оновленого виборчого законодавства, оскільки суди загальної юрисдикції продовжують розглядати справи про порушення виборчого права внутрішньо переміщених осіб на місцевих виборах 2015 року й виборах народних депутатів 2019 року. 3 набранням чинності 3 серпня 2017 року нової редакції Закону «Про Конституційний Суд України» громадяни України отримали можливість звертатись до Конституційного Суду з конституційною скаргою щодо перевірки на відповідність Конституції України (конституційність) закону України (його окремих положень), що застосований в остаточному судовому рішенні, якою вони нині активно користуються. Автором статті з'ясовується фракт недотримання принципу недискримінації за ознакою місця проживання у виборчому законодавстві України щодо внутрішньо переміщених осіб до прийняття Виборчого Кодексу України. На підставі аналізу міжнародно-правових актів, практики Європейського Суду з прав людини, норм національного законодавства й практики діяльності Конституційного Суду України з питань прав людини, зокрема в частині обмеження/порушення прав, доведено, що в ситуації з активним виборчим правом внутрішньо переміщених осіб на місцевих виборах 2015 року й виборах народних депутатів 2019 року через недосконалість виборчого законодавства України, чинного на той час, відбулось порушення виборчого права внутрішньо переміщених осіб і принципу недискримінації за ознакою місця проживання. Наведене вище свідчить про те, що не відповідають Конституції України положення частин другої та третьої статті 3 Закону України «Про місцеві вибори», положення частини другої статті 8 Закону України «Про Державний реєстр виборців». Отже, в компетенції Конституційного Суду України внести ясність у питання захисту й відновлення порушеного виборчого права ВПО на місцевих виборах 2015 року й виборах народних депутатів 2019 року, що нині є предметом розгляду в судах загальної юрисдикції.

Ключові слова: дискримінація, обмеження права, порушення права, принцип недискримінації за ознакою місця проживання, виборче право, внутрішньо переміщені особи.
\end{abstract}

The article is devoted to the principle of non-discrimination by place of residence in the context of active suffrage of internally displaced persons (IDPs) under the electoral legislation of Ukraine before the adoption of the Electoral Code on December 19, 2019. These issues remain relevant in the context of updated electoral legislation, as courts of general jurisdiction continue to hear cases of violations of the voting rights of IDPs in the 2015 local elections and the 2019 parliamentary elections. With the entry into force of the new version of the Law "On the Constitutional Court of Ukraine" on August 3,2017, citizens of Ukraine had the opportunity to appeal to the Constitutional Court to verify the constitutionality of the law of Ukraine (its separate provisions) applied in the final court decision, which they are actively using today. The author of the article finds out the fact of non-compliance with the principle of non-discrimination on the grounds of residence in the electoral legislation of Ukraine in relation to IDPs before the adoption of the Electoral Code of Ukraine. Based on the analysis of international legal acts, the case law of the European Court of Human Rights, national legislation and the case law of the Constitutional Court of Ukraine on human rights, in particular in terms of restriction / violation of rights, it is proved that in a situation of active suffrage of IDPs in local elections in 2015 and the elections of people's deputies in 2019 , due to the imperfection of the electoral legislation of Ukraine in force at that time, there was a violation of the suffrage of IDPs and the principle of non-discrimination on the basis of residence. The above indicates that the provisions of parts two and three of Article 3 of the Law of Ukraine "On Local Elections" and the provisions of part two of Article 8 of the Law of Ukraine "On the State Register of Voters" do not comply with the Constitution of Ukraine. Thus, it is within the competence of the Constitutional Court of Ukraine to clarify the issue of protection and restoration of the violated suffrage of IDPs in the local elections of 2015 and elections of people's deputies in 2019, which is currently being considered in courts of general jurisdiction.

Key words: discrimination, restriction of law, violation of law, principle of non-discrimination by place of residence, suffrage, internally displaced persons.

Постановка проблеми. Принцип недискримінації відіграє досить вагому роль серед принципів права, оскільки його реалізація впливає, передусім, на можливість використання людиною її конституційних прав і свобод. Він створює умови, за яких встановлюється неприпустимість обмеження прав, свобод та обов'язків людини залежно від антропологічних чи соціальних ознак. Цей принцип $\epsilon$ невідчужуваним і тісно пов'язаний не лише 3 принципом рівності, а й із засадами справедливості, об'єктивності, пропорційності, верховенства права й поваги до прав людини. Ефективна реалізація принципу недискримінації в практичній площині має результатом досягнення справедливості й верховенства права, оскільки приводить до такої ситуації в правовій системі, коли права осіб не утискаються на підставі належності до певної групи чи особливої ознаки.

Питання дотримання принципу недискримінації за ознакою місця проживання гостро постали в нашій країні у зв’язку зі збройною агресією Російської Федерації на Сході України у 2014 році. Мільйони громадян України вимушені були залишити місця свого постійного прожи- вання та отримали статус внутрішньо переміщених осіб (далі - ВПО). Законами України «Про місцеві вибори» від 14 липня 2015 року [1], «Про вибори народних депутатів України» від 17 листопада 2011 року [2], «Про Державний реєстр виборців» від 22 лютого 2007 року [3] ці громадяни були обмежені у своїх виборчих правах, зокрема в активному виборчому праві на місцевих виборах 2015 року (ВПО були позбавлені права обирати голів і депутатів місцевих рад) і на виборах народних депутатів України у 2019 році (ВПО були обмежені в праві обирати парламентаріїв за мажоритарними списками). Положення цих законів, які зумовлюють належність громадянина до відповідної територіальної громади й визначають перелік документів, які засвідчують місце проживання виборця та є підставою для включення до списку виборців на відповідній виборчій дільниці, порушують конституційні приписи й права громадян. 31 січня 2020 року набрав чинності Виборчий кодекс України від 19 січня 2019 року, який усунув дискримінаційні положення названих вище законів, надавши ВПО можливість користуватись виборчими правами в повному обсязі [4]. Однак на розгляді 
судів залишаються справи за заявами ВПО щодо порушення їх виборчого права в ретроспективі [5]. До того ж, відповідно до ч. 2 ст. 8 Закону України «Про Конституційний Суд України» від 13 липня 2017 року з метою захисту й відновлення прав особи Конституційний Суд розглядає питання щодо відповідності Конституції України (конституційності) акту (його окремих положень), який втратив чинність, але продовжує застосовуватись до правовідносин, що виникли під час його чинності. Згідно зі ст. ст. 55 і 56 цього Закону, особа, яка вважає, що застосований в остаточному судовому рішенні в ії справі закон України (його окремі положення) суперечить Конституції України, має право подати до Суду конституційну скаргу щодо перевірки на відповідність Конституції України (конституційності) закону України (його окремих положень), що застосований в остаточному судовому рішенні в справі суб'єкта права на конституційну скаргу [6]. Такою можливістю активно користуються ВПО нині [7].

Тому мета статті полягає в 3'ясуванні факту недотримання принципу недискримінації за ознакою місця проживання у виборчому законодавстві України щодо ВПО до прийняття Виборчого Кодексу України.

Виклад основного матеріалу. Захист від дискримінації $є$ одним із фундаментальних прав людини, яке визнане міжнародним правом і повинне забезпечуватися сучасними демократичними державами. Крім того, Рада Європи та Європейський союз мають широкий досвід боротьби 3 дискримінацією, який, без сумніву, корисний для України.

Так, у ст. 1 Загальної декларації прав людини говориться: «Всі люди народжуються вільними й рівними у своїй гідності й правах», тоді як ст. 2 зазначає: «Кожна людина повинна мати всі права й всі свободи, проголошені цією Декларацією, незалежно від раси, кольору шкіри, статі, мови, релігії, політичних або інших переконань, національного чи соціального походження, майнового, станового або іншого становища». У цій Декларації наводиться відмінність між рівністю гідності й прав людини й забороною дискримінації цих прав за переліченими ознаками [8].

У ст. 3 Конвенції ООН про права інвалідів зазначається, що до принципів Конвенції належить принцип недискримінації, а в ст. 5, що має назву «Рівність і недискримінація», проводиться відмінність між цими поняттями. Так, рівність розглядається в тому значенні, що всі особи рівні перед законом і мають право на рівний захист закону, а також рівне користування ним без будь-якої дискримінації [9].

У праві Ради Європи принцип недискримінації знайшов своє втілення в ст. 14 Конвенції про захист прав людини й основоположних свобод, яка забороняє дискримінацію за будь-якою ознакою в процесі користування визнаними в ній правами й свободами [10]. Ст. 14 також визначає, що дискримінація відбувається, якщо об'єктивно наявні три елементи: виявлені факти свідчать про упередженість (наявність різного ставлення та підходів); різний підхід розумно не виправданий; відсутня належна пропорційність між використаними засобами й метою, що ставиться. Також Протокол № 12 до Конвенції встановлює загальну заборону дискримінації за будь-якою ознакою.

Європейська соціальна хартія містить заборону будьякої дискримінації під час здійснення прав, передбачених цією Хартією, а також положення, що зобов'язують держав-учасниць створювати переваги для окремих груп населення [11].

Положення про захист від дискримінації також містяться в Рамковій конвенції про захист національних меншин, Конвенції Ради Європи про заходи щодо протидії торгівлі людьми, а також Конвенції Ради Європи про доступ до офіційних документів. Гарантії захисту від пропаганди дискримінації передбачені також Додатковим протоколом до Конвенції про кіберзлочинність.
ООН у Керівних принципах із питання про переміщення осіб всередині країни вказує, що переселенці не підлягають жодній дискримінації під час користування правом голосувати й брати участь у веденні державних і суспільних справ [12].

Важливо звернутися до практики Європейського суду 3 прав людини (далі - Суд або ССПЛ), який неодноразово трактував поняття «дискримінація» [13]. Найвідомішою розглянутою Судом справою стала «Справа про мови в Бельгії» 1968 р. У цій справі серед критеріїв порушення ст. 14 Конвенції - так званих «елементів стандарту принципу недискримінації» - Суд виокремив такі:

1) наявність «конкретних розрізнень у поводженні щодо користування якимось із визнаних прав чи свобод»;

2) відсутність «об' єктивного й розумного обгрунтування» відмінностей у підході;

3) відсутність «розумної пропорції між використаними засобами й тією метою, для досягнення якої вони здійснювалися».

У справі «Stummer v. Austria» 2011 р. Суд розглядає дискримінацію як будь-яке відмінне ставлення з особами, що перебувають в однаковій ситуації, коли таке поводження грунтується на певній ознаці людини й не має об'єктивного виправдання. У справі «D.H. and others v. Czech Republic» 2007 р. Суд зазначає, що принцип недискримінації може ототожнюватися 3 принципом рівного поводження, але не з принципом рівності загалом. Розглядаючи справи про дискримінацію, ЄСПЛ використовує не тільки принцип рівності, а й принцип пропорційності й об'єктивності. У своїх прецедентах ССПЛ установив, що дискримінація означає різне поводження 3 людьми в порівняно аналогічних ситуаціях, не зумовлене жодними розумними чи об'єктивними причинами, що «грунтується на ознаці, яку можна ідентифікувати». Слід враховувати також позицію Суду, що «коли внаслідок загальної політики або заходів окрема група опиняється в особливо невигідному положенні, не можна виключати, що це може бути визнано дискримінацією, незважаючи на те, що такий захід або політика не були спеціально спрямовані або націлені на цю групу» (Рішення у справі Hugh Jordan v. United Kingdom 2001 p.).

Практика Європейського суду з прав людини також склалась і з питань виборчого права. Так, у рішеннях Суду зазначається, що право на вільні вибори не має абсолютного характеру, існує можливість для імпліцитних обмежень (Рішення у справі Голдера 1975 р.). У правових системах держав-учасниць право голосу й виборність зумовлюються рядом моментів, які в принципі не суперечать статті 3. У цій області в цих держав значні межі розсуду, але остаточне рішення про дотримання вимог Першого протоколу приймає Суд. Він повинен упевнитися, що такі обмеження не обмежують ці права до такої міри, що вони втрачають реальний зміст, що ці обмеження переслідують правомірну мету й що використовувані засоби $є$ співмірними (Рішення у справі Літгоу 1986 р., Рішення у справі Ахмед та інші проти Сполученого Королівства 1998 р.; Рішення у справі Херст проти Сполученого Королівства 2004 р.). У Рішенні по справі «Азіс проти Кіпру» 2004 р. Суд визнав дискримінацією позбавлення права участі в парламентських виборах турків-кіпріотів, які проживають на контрольованій Кіпром території. Під час розгляду справи «Сейдіч та Фінци проти Боснії і Герцеговини» 2009 р. ЄСПЛ також назвав дискримінацією позбавлення права обиратись громадян інших національностей.

Наявна практика Європейського суду 3 прав людини щодо України в питаннях виборчих прав. Так, у 2004 р. у справі Мельниченко проти України визнано порушення Україною ст. 3 Протоколу № 1 Європейської Конвенції про захист прав людини й основних свобод (право на вільні вибори). Справа стосувалася відмови центральної виборчої комісії реєструвати Мельниченко кандидатом 
на парламентських виборах 2002 р. на підставі відомостей про прописку. Суперечка пішла про питання, що було закладено в законі про вибори: юридичне проживання чи фактичне. I тут на допомогу прийшло ще чинне радянське законодавство в нашій країні, коли такого поняття, як фактичне проживання, взагалі не існує. Тому Європейський Суд визнав порушення Україною ст. 3 Протоколу № 1 Конвенції та призначив до виплати Мельниченко 5000 Свро.

Отже, в міжнародному праві склався описовий підхід до визначення поняття «дискримінація», в рамках якого передбачено основні прояви дискримінації: розрізнення, виняток або обмеження, обов'язковим наслідком яких є позбавлення, обмеження чи перешкоди в здійсненні прав і свобод людини.

В Україні основним нормативно-правовим актом, що розкриває законодавче визначення дискримінації та встановлює основні засади боротьби з дискримінацією в різних сферах, $є$ Закон України «Про засади запобігання та протидії дискримінації в Україні» від 6 вересня 2012 р. [14]. Ст. 1 цього закону закріплює, що дискримінація - це ситуація, за якої особа та/ або група осіб за їх ознаками раси, кольору шкіри, політичних, релігійних та інших переконань, статі, віку, інвалідності, етнічного й соціального походження, громадянства, сімейного й майнового стану, місця проживання, мовними або іншими ознаками, які були, є та можуть бути дійсними або припущеними (далі - певні ознаки), зазнає обмеження у визнанні, реалізації або користуванні правами й свободами в будь-якій формі, встановленій цим Законом, крім випадків, коли таке обмеження має правомірну, об'єктивно обгрунтовану мету, способи досягнення якої є належними й необхідними. Цим Законом встановлено перелік ознак, за якими заборонена дискримінація, серед яких є ознака - за місцем проживання.

Закладена в Законах України «Про Державний реєстр виборців» і «Про місцеві вибори» перешкода для голосування внутрішньо переміщених осіб на виборах полягає у відсутності приналежності громадянина до громади, що визначається зареєстрованим місцем проживанням. За оцінкою Уповноваженого Верховної Ради України з прав людини, така ситуація порушує принцип недискримінації в частині забезпечення як рівності прав і свобод, так і рівності можливостей, становить непряму дискримінацію за ознаками місця проживання та належності до ВПО й суперечить стандартам міжнародного права, Конституції, законам України, а також зобов'язанням України щодо забезпечення сталої інтеграції ВПО за місцем переміщення [15].

Конституційні права не повинні залежати від місця проживання або його відсутності, про що вказується, зокрема, в Законі України «Про свободу пересування та вільний вибір місця проживання в Україні» від 11 грудня 2003 р. [16]. Відмінне поводження визнається дискримінацією.

У Рішенні від 22 травня 2018 року № 5-p/2018 Конституційний Суд України зазначив, що «Верховна Рада України повноважна ухвалювати закони, що встановлюють обмеження, відповідно до таких критеріїв: обмеження щодо реалізації конституційних прав і свобод не можуть бути свавільними й несправедливими, вони мають встановлюватися виключно Конституцією та законами України, переслідувати легітимну мету, бути зумовленими суспільною необхідністю досягнення цієї мети, пропорційними й обгрунтованими, в разі обмеження конституційного права або свободи законодавець зобов'язаний запровадити таке правове регулювання, яке дасть можливість оптимально досягти легітимної мети з мінімальним втручанням у реалізацію цього права або свободи й не порушувати сутнісний зміст такого права» [17].

Загальні вимоги щодо виправданості втручання в права гарантовані статтями 8-11 Європейської Конвенції. Негативна відповідь на будь-яке з таких трьох питань свідчить про порушення права: Чи вчинене втручання «згідно із законом»? Чи вчинене втручання з легітимною метою? Чи $\epsilon$ втручання «необхідним у демократичному суспільстві»? Законність, легітимна мета й необхідність у демократичному суспільстві є умовами правомірності обмеження реалізації прав і свобод людини.

3'ясуємо, чи дотримано зазначені критерії у випадку 3 виборчим правом ВПО за виборчим законодавством України до прийняття Виборчого Кодексу України.

Перша складова частина трискладового тесту, а саме законність, була дотримана, оскільки вказане обмеження було здійснене згідно із законом.

Легітимною метою обмеження виборчого права ВПО є захист певних цінностей. Конвенція про захист прав та основоположних свобод і Конституція України не містять універсального переліку критеріїв і підстав обмеження реалізації прав і свобод особи, однак аналіз окремих статей цих актів дає змогу стверджувати про наявність спільних цінностей, із метою захисту яких запроваджуються обмеження реалізації прав особи, до яких можна віднести національну й громадську безпеку, громадський порядок, економічний добробут країни, здоров'я чи мораль, права й свободи інших осіб, територіальну цілісність [18, с. 22]. Жодну з перелічених цінностей не можна вважати легітимною метою позбавлення можливості громадянина реалізувати своє виборче право повною мірою. Отже, відсутня легітимна мета як умова правомірності обмеження реалізації прав і свобод людини.

Щодо такої умови, як необхідність у демократичному суспільстві, то чітких універсальних критеріїв того, що саме має містити це поняття, в Конвенції не має. Не даючи вичерпної відповіді на питання про те, що ж Конвенція вважає «демократичним суспільством», Європейський Суд із прав людини вказує на такі його ознаки, як толерантність, плюралізм, верховенство права, відсутність свавільного втручання в передбачені Конвенцією права людини (Рішення у справі «Dudgeon v. United Kingdom» 1981 р.). У справі «Savin v. Ukraine» 2012 р. ЄСПЛ вказав, що визначаючи, чи було конкретне втручання «необхідним у демократичному суспільстві», Суд повинен встановити, чи були мотиви, наведені на виправдання втручання в реалізацію прав особи, доречними й достатніми, й чи був відповідний процес прийняття рішень справедливим і здатним забезпечити належний захист інтересів. У демократичних державах гідність людини цінується дуже високо, тому вони усіляко уникають проявів державного примусу чи насильства $[19$, с. 48$]$. Отже, довести, що обмеження виборчого права ВПО є необхідністю в демократичному суспільстві, здається неможливим, враховуючи той факт, що на законодавчому рівні немає відповіді на це питання.

Таким чином, дві $з$ трьох складових частин тесту на правомірність обмеження реалізації прав і свобод людини не дотримано, що свідчить про порушення виборчого права внутрішньо переміщених осіб.

Для констатації порушення принципу недискримінації за ознакою місця проживання варто скористатись алгоритмом, використовуваним ЄСПЛ, який полягає у встановленні, що:

1) державний захід, дія чи бездіяльність, які оскаржуються, підпадають під сферу дії іншого матеріального положення Конвенції або належать до будь-якого передбаченого національним законом права;

2) існує розрізнення в поводженні порівняно з іншими особами, які перебувають в аналогічному становищі («тест на порівнянність» - «соmparability test»). Цей елемент вимагає доведення того, що:

a) поводження із заявником є суттєво відмінним і менш сприятливим, аніж з іншими;

б) підставою для розрізнення є особиста характеристика (якість) або статус заявника, які належать до заборонених підстав дискримінації; 
в) інші особи, з якими заявник порівнює себе, перебувають в аналогічній ситуації;

3) таке розрізнення не має «розумного й об'єктивного» виправдання («тест на виправданість» - «justification test»). Водночас «наявність такого виправдання має оцінюватися 3 огляду на цілі й вплив заходу, що розглядається, зважаючи за такої умови на принципи, які панують у демократичних суспільствах, передусім принцип пропорційності».

Щодо першого пункту - належить до передбаченого національним законом виборчого права.

Щодо другого пункту - існує розрізнення в поводженні порівняно 3 іншими особами, які перебувають в аналогічному становищі (позбавлення/обмеження активного виборчого права громадянина); поводження із заявником $€$ суттєво відмінним і менш сприятливим, аніж з іншими (інші громадяни України мають можливість повною мірою скористатись своїм активним виборчим правом); підставою для розрізнення є особиста характеристика (якість) або статус заявника, які належать до заборонених підстав дискримінації (наявність статусу внутрішньо переміщеної особи); інші особи, з якими заявник порівнює себе, перебувають в аналогічній ситуації (обмеження виборчого права стосується усіх ВПО).

Щодо третього пункту - порушення виборчого права ВПО не має «розумного й об’єктивного» виправдання.
Позбавлення права голосу повинне проходити суворішу перевірку на пропорційність. Втручання не може вважатися пропорційним, якщо воно не здійснюється «згідно із законом» і не може розглядатись як «необхідне в демократичному суспільстві» (Рішення ЄСПЛ у справі «Савіни проти України» 2008 р.). Щодо відсутності такого критерію, як «необхідність у демократичному суспільстві», було зазначено вище.

Отже, існують усі три складові частини, що дозволяють констатувати порушення принципу недискримінації за ознакою місця проживання.

Висновки. Таким чином, як слідує 3 викладеного, в ситуації з активним виборчим правом ВПО на місцевих виборах 2015 р. і виборах народних депутатів 2019 р. через недосконалість виборчого законодавства України, чинного на той час, необхідно констатувати порушення виборчого права ВПО й принципу недискримінації за ознакою місця проживання. Наведене вище свідчить про те, що не відповідають Конституції України положення ч. ч. 2 та 3 ст. 3 Закону України «Про місцеві вибори», положення ч. 2 ст. 8 Закону України «Про Державний реєстр виборців». Отже, в компетенції Конституційного Суду України внести ясність у питання захисту й відновлення порушеного виборчого права ВПО на місцевих виборах 2015 р. і виборах народних депутатів 2019 р., що нині є предметом розгляду в судах загальної юрисдикції.

\section{ЛITEPATYPA}

1. Про місцеві вибори : Закон України від 14 липня 2015 р. № 595-VIII / Верховна Рада України Відомості Верховної Ради України. 2015. № 37-38. Ст. 366.

2. Про вибори народних депутатів України : Закон України від 17 листопада 2011 р. № 4061-VI / Верховна Рада України. Відомості Верховної Ради України. 2012. № 10-11. Ст. 73.

3. Про Державний реєстр виборців: Закон України від 22 лютого 2007 р. № 698-V / Верховна Рада України. Відомості Верховної Ради України. 2007. № 20. Ст. 282.

4. Виборчий кодекс України : Закон України від 19 грудня 2019 р. № 396-ІХ / Верховна Рада України. Відомості Верховної Ради України. 2020. № 7, № 8, № 9. Ст. 48.

5. Єдиний державний реєстр судових рішень. URL: http://www.reyestr.court.gov.ua (дата звернення: 11.06.2020).

6. Про Конституційний Суд України : Закон України від 13 липня 2017 р. № 2136-VIII / Верховна Рада України. Відомості Верховної Ради України. 2017. № 35. Ст. 376.

7. Офіційний вебсайт Конституційного Суду України. URL: http://www.ccu.gov.ua (дата звернення: 11.06.2020).

8. Загальна декларація прав людини : Міжнародний документ від 10 грудня 1948 р. № 995_015. Офріційний вісник України. 2008. № 93. Ст. 3103.

9. Конвенція про права осіб з інвалідністю : Міжнародний документ від 13 грудня 2006 р. № 995 g71. Офріційний вісник України. 2010. № 17, 101 (2009. Ст. 3496). Ст. 799.

10. Конвенція про захист прав людини та основоположних свобод : Міжнародний документ від 4 листопада 1950 р. № 995004 . Урядовий кур'єр. 2010. № 215.

11. Європейська соціальна хартія : Міжнародний документ від 3 травня 1996 р. № 994_062. Офріційний вісник України. 2006. № 40. Стор. 37. Ст. 2660.

12. Керівні принципи з питань внутрішнього переміщення. URL: https://www.ohchr.org/Documents/lssues/IDPersons/GPUkrainian.pdf (дата звернення: 12.06.2020).

13. Практика Європейського Суду з прав людини. URL: https://www.echr.com.ua/rishennia-espl/ (дата звернення: 12.06.2020).

14. Про засади запобігання та протидії дискримінації в Україні : Закон України від 6 вересня 2012 р. № 5207-VI / Верховна Рада України. Відомості Верховної Ради України. 2013. № 32. Ст. 412.

15. Відкрите звернення Уповноваженого Верховної Ради України з прав людини до народних депутатів України. URL: http://www.ombudsman.gov.ua/ua/all-news/pr/12915-nm-vidkrite-zvernennya-upovnovazhenogo-verxovnoii-radi-ukraiini-z-prav-ly/ (дата звернення: 12.06.2020).

16. Про свободу пересування та вільний вибір місця проживання в Україні : Закон України від 11 грудня 2003 р. № 1382-IV / Верховна Рада України. Відомості Верховної Ради України. 2004. № 15. Ст. 232.

17. Рішення Конституційного Суду України від 22 травня 2018 р. № 5-р/2018. Вісник Конституційного Суду України. 2018. № 4. Стор. 12.

18. Дахова І.І. Обмеження реалізації прав і свобод людини: конституційне регулювання та практика Європейського Суду з прав людини. Форум права. 2018. № 4. С. 17-25.

19. Буткевич В.Г., Речицкий В.В. Права і свободи та обов'язки людини і громадянина. Національна безпека і оборона. 2015. № 4. C. 44-49. 


\title{
РОЗДІЛ 3 \\ ЦИВІЛЬНЕ ПРАВО І ЦИВІЛЬНИЙ ПРОЦЕС; СІМЕЙНЕ ПРАВО; МІЖНАРОДНЕ ПРИВАТНЕ ПРАВО
}

UDC 347.378.1

DOI https://doi.org/10.32782/2524-0374/2020-4/7

\author{
TENDENCIES AND PROSPECTS OF TRAINING \\ OF INTELLECTUAL PROPERTY SPECIALISTS IN HIGHER EDUCATION INSTITUTIONS \\ OF THE MINISTRY OF INTERNAL AFFAIRS
}

\author{
ТЕНДЕНЦІЇ ТА ПЕРСПЕКТИВИ ПІДГОТОВКИ ФАХІВЦІВ \\ З ІНТЕЛЕКТУАЛЬНОЇ ВЛАСНОСТІ В ЗАКЛАДАХ ВИЩОЇ ОСВІТИ МВС
}

\author{
Andrusiv U.B., Candidate of Law, Associate Professor, \\ Associate Professor at the Civil Law Disciplines Department \\ Lviv State University of Internal Affairs \\ Maikut Ch.V., Candidate of Law, Associate Professor, \\ Associate Professor at the Civil Law Disciplines Department \\ Lviv State University of Internal Affairs \\ Vovk M.Z., Candidate of Law, \\ Associate Professor at the Civil Law Disciplines Department \\ Lviv State University of Internal Affairs
}

The article deals with the issue of providing training for intellectual property specialists in higher education institutions within the system of the Ministry of Internal Affairs.

The current state of teaching intellectual property disciplines to both future lawyers and law enforcement officers, who will be directly responsible for protecting intellectual property from infringements and illegal encroachments, is described. The negative consequences of the higher education reform, which abolished the obligation to teach the fundamental aspects of intellectual property, are determined.

In order to form better professionally oriented knowledge and skills of intellectual property issues and to train competitive specialists, it is proposed to introduce the study of the obligatory discipline "Intellectual Property Law" in educational programs in the specialties "Law" and "Law Enforcement". It is considered expedient to open master's programs in intellectual property and innovation, introducing the study of disciplines of the latest direction.

It is stated that acquiring knowledge of intellectual property in the higher education system will contribute to the quality of protection of intellectual property rights, innovation and commercialization; will create the conditions for training a new generation of professionals, including units to combat cybercrime.

In order to effectively teach and improve the professional level of research and teaching staff of higher education institutions of the Ministry of Internal Affairs, it is proposed to introduce distance learning courses in intellectual property, technology transfer and innovation, as well as compulsory internships in relevant national and international institutions.

It is concluded that the introduction of teaching intellectual property to both students and cadets in higher education institutions of the Ministry of Internal Affairs will contribute to the qualitative improvement of the legal education system in Ukraine as an indispensable precondition for its successful high-tech and innovative prosperity.

Key words: intellectual property, higher legal education, innovative development, higher education institutions in the system of the Ministry of Internal Affairs.

Статтю присвячено дослідженню питання забезпечення підготовки фахівців з інтелектуальної власності у закладах вищої освіти у системі Міністерства внутрішніх справ.

Охарактеризовано існуючий стан викладання дисциплін з інтелектуальної власності як майбутнім юристам, так і працівникам правоохоронних органів, на яких безпосередньо покладатимуться обов'язки захисту інтелектуальної власності від порушень і протиправних посягань. Визначено негативні наслідки освітньої реформи вищої освіти, якою скасовано обов'язковість викладання основ інтелектуальної власності.

Для формування більш якісних професійно орієнтованих знань і навичок із питань інтелектуальної власності та підготовки конкурентоспроможних спеціалістів запропоновано запровадити в освітні програми за спеціальностями «Право» та «Правоохоронна діяльність» вивчення обов'язкової навчальної дисципліни «Право інтелектуальної власності». Визнано доцільним відкриття магістерських програм з інтелектуальної власності та інновацій, запровадивши вивчення навчальних дисциплін новітнього спрямування.

Констатовано, що отримання знань з інтелектуальної власності у системі вищої освіти сприятиме якісному забезпеченню захисту прав інтелектуальної власності, активізації інновацій та комерціалізації, створить передумови для підготовки фахівців нового покоління, у тому числі для підрозділів із боротьби з кіберзлочинністю.

Задля ефективного викладання та підвищення професійного рівня науково-педагогічних працівників закладів вищої освіти МВС запропоновано запровадити курси дистанційного навчання з професійної підготовки у сфері інтелектуальної власності, трансфреру технологій та інноваційної діяльності, а також обов'язкове стажування у профрільних національних та міжнародних установах.

Зроблено висновок, що запровадження викладання навчальних дисциплін з інтелектуальної власності як студентам, так і курсантам у закладах вищої освіти МВС сприятиме якісному вдосконаленню системи юридичної освіти в Україні як неодмінної передумови їі успішного високотехнологічного та інноваційного процвітання.

Ключові слова: інтелектуальна власність, вища юридична освіта, інноваційний розвиток, заклади вищої освіти у системі MBC.

The aspiration of Ukraine for European integration has aroused the entire world community and clearly showed the trend of the development chosen by our state. One of the ways to join the European space is to create an effec- tive system of safeguarding and protection of intellectual property rights. Intellectual property is the key to economic prosperity, dynamic innovative development and investment in Ukraine. 
However, it should be noted that Ukraine remains one of the largest pirate countries in the world. Thus, according to the Special 301 Report of the USA Trade Representative (USTR), published on April 29, 2020, Ukraine is placed on the Priority Watch List. This is the so-called list of global countries that infringe intellectual property. The precondition for placing on it is the presence of the following factors: a high level of Internet piracy and passive fight against this phenomenon; use of unlicensed software in government agencies; non-transparent management of the system of collective management organizations that are responsible for the collection and distribution of remuneration to right holders [1]. This status gives warning of an insufficient level of intellectual property protection and provides for the exclusion of our country from the "Generalized System of Preferences" - a program of the USA government to support the economic growth of developing countries.

The current condition of intellectual property infringements not only leads to financial losses of right holders, but also threatens the economic security of the State. Promoting the protection of intellectual property is one of the tasks of the police agencies. Today, the interregional territorial body of the National Police of Ukraine, which provides protection of intellectual property rights, is the Cyberpolice Department, which was established by the Resolution of the Cabinet of Ministers of Ukraine No. 831 of October 13, 2015. In accordance with the instructions, the Cyberpolice Department ensures state policy in combating cybercrime and infringement of intellectual property rights on the Internet. Therefore, law enforcement officers must have a thorough knowledge in the field of intellectual property law.

The problems of ensuring an effective and efficient mechanism for safeguarding and protection of the rights to the results of intellectual and creative activity in Ukraine are largely due to the lack of highly qualified specialists who require a significant amount of special theoretical knowledge and practical skills in this area.

As O. Orliuk emphasizes in her paper, the development of an innovative society based on the support of the intellectual capital of the nation concerns a high level of training of specialists involved in the innovative process at any stage, and the national education system should contribute to this process [2, p. 149].

Taking into consideration that intellectual property is constantly evolving and is a priority for all spheres of public life, higher education institutions, including within the Ministry of Internal Affairs, should become generators of new innovative ideas, develop students' and cadets' ability to think creatively and innovatively, to guarantee a profound study of various aspects of implementation of rights to the results of intellectual activity.

Providing comprehensive and equitable quality education, encouraging lifelong learning opportunities for all citizens, and promoting inclusive and sustainable industrialization and innovation are recognized as guidelines for Ukraine's sustainable development up to 2030 [3]. In order to achieve these goals, it is necessary to provide training of specialists with knowledge of intellectual property, introduce teaching the principles of protection and enforcement of the rights to the results of intellectual and creative activities in higher education institutions.

At the state level, compulsory teaching of the subject "Intellectual Property" in higher educational institutions of III-IV levels of accreditation for students enrolled in educational and professional programs of specialist's and master's degree was introduced by the Order of the Ministry of Education and Science of Ukraine No. 811 of October 20, 2004. The study of the discipline was aimed at raising the level of awareness of applicants by mastering the basic principles of legal and economic aspects of intellectual property.

The Resolution of the Cabinet of Ministers of Ukraine "On approval of the list of specialties for training specialists in higher educational institutions at the educational and quali- fication levels of specialist and master" No. 787 of August 27, 2010 provided for training of specialists at educational and qualification levels of specialist and master in a particular specialty "Intellectual Property".

According to the results of the Parliamentary Hearings "National Innovation System: Status and Legislative Support of Development", held on March 21, 2018, there is the need to form a market of intellectual property and innovative culture of society and provide Ukraine with personnel capable of professional providing innovative development [4].

Thus, the recognition of the priority role of intellectual property in the development of the economy sets the task of training qualified professionals who should take an active part in these processes. This knowledge acquires special significance in the training of lawyers and law enforcement officers. Legal education, including in the system of the Ministry of Internal Affairs, should promote innovative economic development and provide training for professionals who are able to apply effectively in practice the knowledge and skills necessary for the implementation and protection of subjective rights to intellectual property.

The negative impact on the training of intellectual property professionals was caused by the new Law of Ukraine "On Higher Education" of July 1, 2014, due to the entry into force of which the above mentioned Order of the Ministry of Education and Science of Ukraine lost validity; and the specialty "Intellectual Property" is excluded from the list of specialties for training higher education students.

Experts in the field of intellectual property consider these changes not only unreasoned, but also harmful to the interests of society, the formation of the investment environment and economic development of Ukraine [5]

According to the educational reform, educational institutions have the right to independently elaborate and implement educational programs within the licensed specialty (paragraph 1 , part 2 of Article 32 of the Law of Ukraine "On Higher Education"). Therefore, the decision on the expediency of teaching the discipline "Intellectual Property" and its introduction into the curriculum is given to the complete control of universities.

As a result, higher education institutions, acting within the right of autonomy, apply different approaches to teaching fundamental aspects of intellectual property to students. There is a practice of teaching the discipline "Intellectual Property Law" for bachelors or masters, but in some educational institutions, intellectual property relations are studied only within the discipline "Civil Law of Ukraine". Only a few faculties have full courses in intellectual property. Thus, in the leading law schools there are departments of intellectual property, which provide teaching of special disciplines in this area.

The question of the obligatory teaching of such discipline to future law-enforcement officers, who will be directly responsible for protecting intellectual property from infringements and unlawful encroachments, also remains open. There is no doubt that the lack of thorough knowledge in the field of intellectual property in law enforcement has a very negative impact on the fight against counterfeit and pirated products.

In order to implement the Cybercrime Training Project, a Memorandum of Cooperation between the State Intellectual Property Service (currently under the authority of the Intellectual Property Development Department of the Ministry of Economy, Trade and Agriculture of Ukraine) and the National Academy of Internal Affairs was signed on March 17, 2017. Within the framework of this Memorandum, training courses for law enforcement officers on specialization aimed at protection of intellectual property rights have been introduced on the basis of the National Academy of Internal Affairs, and they shall become a platform for developing a new educational program to train lawyers of new generation to protect Ukraine's innovation potential [6].

Despite the positive trends, it should be noted that this special course is taught to students and cadets studying 
at the academy. In addition, it is designed to train only specialists in the fight against cybercrime and piracy, i.e. specialists in the protection of copyright and related rights. Such institutions of intellectual property law as patent law, means of individualization of participants in civil circulation, goods and services are left out of consideration.

In our opinion, the importance of including the discipline "Intellectual Property Law" in the curriculum of higher education institutions, in particular in the system of the Ministry of Internal Affairs, is undeniable. Its study should become a necessary component of modern legal education. After all, the term "intellectual property" has long acquired the features of economic and legal category and the results of intellectual activity are a product (commodity) of a market economy, which brings in significant returns to the right holders of subjective rights.

The need to master the basic principles of intellectual property is confirmed by the formation of the High Court of Intellectual Property in Ukraine.

In view of this, it seems expedient to introduce the study of the obligatory discipline "Intellectual Property Law" in the educational programs in the specialties "Law" and "Law Enforcement", and moreover, not at the master's degree, as provided by the Order of Ministry of Education and Science No. 811, but at the $3^{\text {rd }}-4^{\text {th }}$ year of studying. At the same time, we share with the position of scholars who propose to determine the place of the discipline "Intellectual Property Law" after studying the disciplines that form the basis of studying intellectual property law: "Civil Law", "Civil Procedure", "Administrative Law", "Criminal Law" [7, p. 101; 8, p. 79]. It is obvious that writing qualification paper for obtaining the degree of higher education, a student should know how to use properly existing scientific and technical information.

Acquiring knowledge of intellectual property in the higher education system will contribute to the quality of protection of intellectual property rights, innovation and commercialization; will create the conditions for training a new generation of professionals, including units to combat cybercrime. Having mastered this knowledge, students and cadets will be ready to successfully solve problems in the field of intellectual property, as well as be able to explain to society the importance of protecting the rights to intellectual property.

In addition, under modern conditions, we consider it appropriate to not only separate the material on intellectual property into independent disciplines, but also deepen and specialize this area of knowledge in future.

Therefore, it is necessary to provide training for applicants of master's degree in the specialization "Intellectual Property", because within obtaining the bachelor's degree applicants only get acquainted with the system of intellectual property rights and subjective rights, while for practical work it is necessary to obtain practical skills, in particular, acquaintance with the procedure for obtaining a patent, trademark registration document, copyright certificate, etc.

Specialization of legal education by separating the direction of intellectual property will allow to establish the relationship between legal and economic disciplines, to provide training for specialists who will not only have theoretical training, but will be able to perform tasks to effectively protect and combat intellectual property infringements, which, in turn, will meet the requirements of the Bologna Process.

Such graduates will face the task of further development and improvement of the system of legal protection of intellectual property.

As part of the preparation of the master's program, it is necessary to provide for the possibility of studying disciplines of the modern trends: technology transfer; intellectual property rights on the Internet; intellectual property management; protection of rights to non-traditional intellectual property; intellectual property rights to inventions and utility models, intellectual property in innovative activity; patenting in Ukraine and abroad; acquisition and disposal of intellectual property rights; protection of the rights to the results of intellectual activity. At the same time, I. Koval states that it is expedient to introduce the discipline "Commercialization of intellectual property rights" for applicants of master's degree, which aims to form the competencies necessary for students to understand the theoretical knowledge of legal regulation, methods and legal forms of commercialization of intellectual property rights $[9, \mathrm{p} .68]$

Advanced courses on intellectual property should be introduced for those who obtain scientific degrees, as they are the scientific potential of the nation and should know how to protect their rights to the results of intellectual and creative activity.

Although there is no doubt about the need to teach intellectual property in higher education institutions, such activities face certain difficulties that have both objective and subjective determinants. One such reason is the lack of an adequate number of specialists who are able to provide teaching disciplines in the field of intellectual property, especially special courses. Now specialists in civil and economic fields, who may not have the necessary thorough scientific and theoretical knowledge and practical experience, provide this process. The work on heightening professional qualification of research and educational personnel who are involved in the teaching of intellectual property disciplines, both within its basic principles and specialized master's programs, is practically not conducted.

In order to solve this problem, it is necessary to study the international experience of training relevant specialists. Thus, the World Intellectual Property Organization (WIPO), which for the first time introduced a system of distance learning courses in the field of protection and enforcement of intellectual property, plays an important role in the development of education in the field of intellectual property and training specialists.

Therefore, in order to effectively teach and master the knowledge of disciplines in the field of intellectual property, it is advisable to work out distance-learning courses developed by WIPO.

One of the distance learning courses offered by WIPO is the course DL-101 "Fundamental Aspects of Intellectual Property" translated by the Intellectual Property Institute.

It should be noted that the experts of the State Enterprise "Ukrainian Institute of Intellectual Property" study at WIPO courses DL-320, DL-318, DL-301, DL-202, and DL-204. In addition, they are always involved in online training organized by the European Patent Office and WIPO. Considerable attention is also paid to workshops and seminars organized by WIPO to exchange experiences of representatives of recipient agencies in the PCT system.

We believe that in order to increase the intellectual and professional potential of research and teaching staff of higher education institutions of the Ministry of Internal Affairs it is necessary to introduce similar distance learning courses in intellectual property, technology transfer and innovation, as well as compulsory internships in relevant national and international institutions.

Summarizing the above, we can conclude that for creative support of the educational process, development of research and cultural-educational activities in higher education institutions of the Ministry of Internal Affairs it is necessary to reassess and form better professionally oriented knowledge and skills of intellectual property, as well as to introduce process of the latest educational and methodical complexes, special courses for training of competitive specialists of the new generation. In addition, it should be created preconditions for the opening of master's programs in intellectual property and innovation, taking into account the best practices of WIPO.

The introduction of teaching intellectual property disciplines to both students and cadets in higher education institutions of the Ministry of Internal Affairs will contribute to the qualitative improvement of the legal education system in Ukraine as indispensable precondition for its successful hightech and innovative prosperity. 


\section{REFERENCES}

1. 2020 Special 301 Report. APRIL 2020. URL : https://ustr.gov/sites/default/files/2020_Special_301_Report.pdf

2. Орлюк О. Освіта з інтелектуальної власності у системі вищої освіти України: проб̆леми та завдання. Теорія $і$ практика інтелектуальної власності. 2019. № 6. С. 148-159.

3. Про Цілі сталого розвитку України на період до 2030 року : Указ Президента України № 722/2019 від 30 вересня 2019 р. URL : https://www.president.gov.ua/documents/7222019-29825.

4. Проєкт постанови про Рекомендації парламентських слухань на тему: «Національна інноваційна система: стан та законодавче забезпечення розвитку». URL : http://w1.c1.rada.gov.ua/pls /zweb2/webproc4_1?pf3511=64374.

5. Українські фахівці стурбовані рішенням Міносвіти щодо відміни викладання предмету інтелектуальної власності у BH3. URL : http://vnz.org.ua/novyny/podiyi/7809-ukrayinski-fahivtsi-sturbovani-rishennjam-minosvity-schodo-vidminy-vykladannja-predmetu-intelektualnoyivlasnosti-u-vnz.

6. В Україні на базі Національної академії внутрішніх справ готуватимуть спеціалістів по боротьбі з кіберзлочинністю та піратством. URL : http://mvs.gov.ua/ua/news/6544_V_Ukraini_na_bazi_Nacionalnoi_akademii_vnutrishnih_sprav_gotuvatimut_specialistiv_po_borotbi_z_ kiberzlochinnistyu ta piratstvom.htm.

7. Зайцев О.Л. Дисципліна «Право інтелектуальної власності» в системі підготовки кадрів для національної поліції України. Актуальні проблеми приватного права : матеріали наук.-практ. конф., присвяч. 96-й річниці зі дня народження д-ра юрид. наук, проф., чл.-кор. АН УРСР В.П. Маслова, м. Харків, 14 лютого 2018 р. Харків : Право, 2018. С. 100-103.

8. Швець Д.В. Місце дисципліни «Право інтелектуальної власності» в системі професійної підготовки кадрів для Національної поліції України. Проблеми цивільного права та процесу : тези доповідей учасників наук.практ. конф., присвяч. світлій пам'яті Олександра Анатолійовича Пушкіна, м. Харків, 24 травня 2019 р. Харків : ХНУВС, 2019. С. 77-80.

9. Коваль І. Щодо розвитку національної системи юридичної освіти у сфері інтелектуальної власності. Теорія $і$ практика інтелектуальної власності. 2018. № 2. С. 65-72. 


\title{
ПРОЦЕСУАЛЬНІ ОСОБЛИВОСТІ СПРАВ ЩОДО ВІДШКОДУВАННЯ ШКОДИ, ЗАПОДІЯНОЇ НОТАРІУСАМИ
}

\section{THE PROCEDURE FEATURES OF CIVIL CASES FOR DAMAGES BY A NOTARY}

\author{
Баранкова В.В., к.ю.н., \\ доцент кафедри цивільного процесу \\ Національний юридичний університет імені Ярослава Мудрого
}

У статті досліджено процесуальні особливості цивільних справ за позовами про відшкодування шкоди, заподіяної внаслідок незаконних дій або недбалості нотаріуса. Визначено правову природу таких справ як складника системи гарантій забезпечення законності нотаріальної діяльності та дотримання прав заінтересованих осіб - учасників нотаріальної дії. Надано загальну правову характеристику таким справам як різновиду справ позовного провадження, у межах яких предметом судового розгляду є спір про право цивільне, що може базуватися на спричиненні шкоди нотаріусом унаслідок порушень закону під час учинення нотаріальної дії, окремої нотаріальної процесуальної дії або відмови у вчиненні нотаріальної дії.

Виокремлено та проаналізовано такі процесуальні особливості справ про відшкодування, заподіяної нотаріусами: суб'єктний склад, зміст позовної заяви, визначення правил підсудності, предмет доказування й специффіка реалізації доказових функцій та зміст судового рішення.

Висновується, що суб'єктний склад таких справ буде різним залежно від того, діями державного чи приватного нотаріуса було заподіяно шкоду. Визначено особливості змісту позовної заяви, що є засобом порушення такої цивільної справи, зумовлені предметом ті підставами позову. Проаналізовано правила визначення підсудності таких справ та сформульовано пропозиції щодо внесення змін у процесуальне законодавство через необхідність унормування спеціального правила підсудності у разі подання позову про відшкодування шкоди до приватного нотаріуса. Визначено скпад юридичних фактів, що входять до предмету доказування у таких справах, виходячи з необхідності встановлення передбачених законом умов притягнення нотаріуса до цивільно-правової відповідальності. Об'рунтовано висновок про необхідність поширення правил щодо звільнення приватного нотаріуса від відповідальності, передбачених у ч. 2 ст. 27 Закону «Про нотаріат», й на ситуації спричинення шкоди державним нотаріусом.

У науково-практичному аспекті сформульовано пропозиції щодо викладення мотивувальної частини рішень, у межах якої обов'язково мають висвітлюватися джерела формування предмету доказування у справі, а також висновки суду щодо встановлення наявності або відсутності умов притягнення нотаріуса до відповідальності за спричинення шкоди.

Ключові слова: відповідальність нотаріуса, предмет доказування, спричинення шкоди нотаріусом, відшкодування шкоди нотаріусом, справи щодо відшкодування шкоди нотаріусом.

The article examines the procedure features of civil cases for damages by notary's illegal acts or negligence. The article considers the legal nature of such cases as a component of the legality guarantee system in notary actions and respect for the rights of interested persons - the participants of the notary action. The author makes the general legal characteristic of such cases as a kind of the claims deal with the dispute about civil law based on damage caused by notary owing to violation of the law during a notary action, separate notary procedure action or its refusal.

The author provides and analyzes the procedure features of civil cases for damages by a notary such us: the subjects composition, the content of statement of claim, the jurisdiction determination rules, the fact in proof and the specificity of realization of evidential functions and the content of a judicial decision. It is concluded in the article the subjects' composition in such cases could be different and depends on what kind of notary cause damage: public or private. The article considers some features the content of statement of claim as a way to open such civil case due to the subject matter and cause of action. The author analyzes the jurisdiction determination rules of such cases and proposes amendment to the procedure law in connection with the necessity of regulation special jurisdiction determination rule if the claim about damage is to the private notary. The article considers the legal facts composition of fact in proof in such cases based on the necessity to establish the legal conditions for notary's civil accountability. The author presents a conclusion about the necessity of spread of the rules about an exemption from liability for private notary provided by the part 2 article 27 of the law «About the notariat» also to the damage by a pubic notary.

The article discusses in the scientific and practical aspect the propositions for the content of the court decision's reasoning that definitely should contained sources for the formation of fact in proof in case and the conclusions about the existence or absence of the conditions for notary's civil accountability.

Key words: a responsibility of a notary, a fact in proof, a damage by notary's acts, damage compensation by a notary, cases for damage compensation by a notary.

Вступ. Діяльність нотаріату є різновидом правозастосовної, юрисдикційної діяльності, зачіпає найбільш важливі й істотні аспекти здійснення прав фізичних та юридичних осіб і тому має здійснюватися в процесуальній формі, що забезпечує єдність і адекватність правового змісту та юридичної форми договору чи іншої юридично значущої дії; виявлення дійсного волевиявлення сторін; баланс публічних і приватних інтересів. Вирішення таких завдань пов'язане 3 необхідністю утворення системи міцних правових гарантій, однією з яких є можливість притягнення нотаріуса до цивільно-правової відповідальності. Принциповим для нотаріальної діяльності $\epsilon$ той факт, що визнати нотаріуса зобов'язаним відшкодувати шкоду, заподіяну внаслідок порушення ним закону, може винятково суд у межах розгляду конкретної цивільної справи.

Процесуальний порядок розгляду позовів про відшкодування шкоди, заподіяної нотаріусами, становить значний науковий інтерес з огляду на чималу кількість таких справ у сучасній судовій практиці, учасники якої мають бути забезпечені адекватними засобами правового захисту та мати можливість через реалізацію належних їм процесуальних повноважень реалізовувати свій юридичний інтерес.

Проблемам відповідальності нотаріусів (зокрема, цивільно-правової) приділялася увага у роботах таких науковців, як С.С. Бичкова, В.В. Комаров, С.Я. Фурса та ін., але переважно в аспекті характеристики організаційних засад нотаріальної діяльності та меншою мірою в межах дослідження особливостей державного контролю над нотаріальною діяльністю. Процедурно-процесуальні аспекти розгляду цивільних справ за позовами про відшкодування шкоди, заподіяної нотаріусами, предметом спеціальних наукових досліджень досі не були.

Постановка завдання. Метою даної роботи є визначення специфіки процесуального порядку розгляду наве- 
дених справ з огляду на необхідність забезпечення належного встановлення обставин справи, постановлення законних та обгрунтованих судових рішень, дотримання прав заінтересованих осіб та ефективності судової й нотаріальної діяльності. Завданнями роботи також $\epsilon$ формування науково-практичних рекомендацій щодо реалізації повноважень суду під час здійснення правосуддя у справах про відшкодування шкоди, заподіяної нотаріусом, та вдосконалення реалізації права на судовий захист учасників цих справ.

Результати дослідження. Відшкодування шкоди, заподіяної внаслідок незаконних дій або недбалості нотаріуса, $€$ однією з гарантій забезпечення законності нотаріальної діяльності та дотримання прав заінтересованих осіб - учасників нотаріальної дії. У разі коли така шкода не відшкодована у добровільному порядку, заінтересована особа має право звернутися до суду з відповідним позовом.

Судові справи, які виникають за такими позовами, характеризуються низкою специфічних ознак, що визначають їхню правову природу.

По-перше, розглядаються такі справи в межах позовного провадження за правилами цивільного судочинства, при цьому засобом захисту порушеного права $€$ відшкодування збитків та інші способи відшкодування майнової шкоди, а також відшкодування моральної (немайнової) шкоди.

По-друге, предметом судового розгляду тут є спір про право цивільне, що може базуватися на спричиненні шкоди нотаріусом унаслідок порушень закону під час учинення нотаріальної дії, відмови у вчиненні нотаріальної дії або окремої нотаріальної процесуальної дії.

По-третє, неодмінною передумовою звернення з позовною заявою про відшкодування шкоди є попереднє вирішення судом питання про незаконність дій або бездіяльності нотаріуса (наявність окремого судового рішення із цього приводу або об'єднання в одній позовній заяві, а через це і в одному судовому процесі, двох вимог: про визнання незаконними дій нотаріуса та про відшкодування шкоди, спричиненої такими діями).

По-четверте, розгляд таких справ відбувається за ініціативою заінтересованих осіб - суб'єктів вчинюваної нотаріальної дії або осіб, що отримали відмову в учиненні нотаріальної дії.

Серед процесуальних особливостей розгляду справ, які випливають із пред'явлених до нотаріусів позовів про відшкодування шкоди, заподіяної їхніми діями, слід указати на специфічний суб'єктний склад, зміст позовної заяви, визначення правил підсудності, предмет доказування та зміст судового рішення.

Суб'єктний склад таких цивільних справ буде різним залежно від того, діями державного чи приватного нотаріуса було заподіяно шкоду.

Згідно зі ст. 21 Закону «Про нотаріат» (далі - Закон), шкода, заподіяна особі внаслідок незаконних або недбалих дій державного нотаріуса, відшкодовується в порядку, передбаченому законодавством України. Це означає, що такий позов має бути звернений до нотаріальної контори або нотаріального архіву, де працює нотаріус і які $\epsilon$ юридичними особами (ст. 1172 ЦК). Останні, своєю чергою, можуть звернутися до нотаріуса, 3 вини якого була відшкодована шкода і виплачені певні грошові суми (ст. 1191 ЦК, ст. 130 КЗПП). Зазначене зумовлює можливість залучення або допуску нотаріуса до участі у справ як третьої особи, яка не заявляє самостійних вимог щодо предмету спору (ст. 53 ЦПК).

Отже, у такому разі можливий такий суб'єктний склад: позивач - заінтересована особа, яка вважає, що внаслідок незаконних або недбалих дій нотаріуса їй спричинено шкоду; відповідач - державна нотаріальна контора чи державний нотаріальний архів; третя особа, яка не заявляє самостійних вимог щодо предмета спору, - державний нотаріус, незаконними або недбалими діями якого спричинено шкоду позивачу (на думку останнього).

Відповідно до вимог ст. 27 Закону «Про нотаріат», шкода, заподіяна особі внаслідок незаконних дій чи недбалості приватного нотаріуса, відшкодовується у повному розмірі. Це означає, що суб'єктний склад у таких справах буде таким: позивач - заінтересована особа, якій завдано шкоди, та відповідач - приватний нотаріус, незаконними чи недбалими діями якого, на думку позивача, йому спричинено шкоду. Як третя особа, що не заявляє самостійних вимог щодо предмета спору (або, за бажанням позивача, як співвідповідач), участь може брати страхова компанія, 3 якою приватний нотаріус уклав договір страхування цивільно-правової відповідальності.

У літературі висловлювалися інші точки зору щодо визначення суб'єктного складу таких справ. Наприклад, C.C. Бичкова вважає, що відповідачем у таких справах нотаріус має бути тільки у випадках, коли ним не укладено договору страхування цивільно-правової відповідальності (що за правилами нотаріального законодавства $€$ неможливим: нотаріус зобов'язаний до початку зайняття приватною нотаріальною діяльністю укласти договір страхування цивільно-правової відповідальності (ст. 28 Закону «Про нотаріат»)) або немає підстав для відшкодування шкоди страховиком, або коли розмір завданої шкоди перевищує розмір страхової суми. За відсутності таких умов відповідачем має бути страховик, а нотаріус третьою особою, яка не заявляє самостійних вимог щодо предмета спору [1, с. 29].

Уважаємо, що така точка зору є спірною, оскільки обставини, зазначені автором, можуть бути враховані під час постановлення рішення тільки за умови їх доведення у судовому процесі, а відповідач визначається позивачем значно раніше.

Окрім того, зазначена позиція суперечить положенням чинного законодавства. Відповідно до ст. 1166 ЦК, майнова шкода, завдана неправомірними рішеннями, діями чи бездіяльністю особистим немайновим правам фізичної або юридичної особи, відшкодовується в повному обсязі особою, яка іiї завдала. Отже, суб'єктом цивільно-правової відповідальності є саме нотаріус, а не страховик. Стаття 27 Закону «Про нотаріат» визначає підстави відповідальності (та умови звільнення від неї) саме нотаріуса, а не страховика. Інша справа, що відшкодування буде в першу чергу здійснюватися за рахунок страхової суми, але ж для того страхувальник має заявити страховику про настання страхового випадку, а це стане можливим тільки після постановлення відповідного рішення.

Підставою для задоволення позову про відшкодування шкоди є обставини, пов'язані з поведінкою нотаріуса, а не страховика, $\mathrm{i}$, постановляючи рішення у справі, суд неминуче вирішить питання про обов'язки нотаріуса, а це буде неможливим, якщо нотаріус буде третьою особою, яка не заявляє самостійних вимог щодо предмету спору, а не відповідачем.

Далі, особа, яка завдала шкоди, звільняється від її відшкодування, якщо вона доведе, що шкоди завдано не з її вини (ч. 2 ст. 1166 ЦК). До того ж ч. 2 ст. 27 Закону «Про нотаріат» закріплює спеціальні підстави звільнення нотаріуса (а не страховика) від відповідальності. Як можна покласти обов'язок доказування таких фактів на страховика?

Відповідно до ст. 1194 ЦК, особа, яка застрахувала свою цивільну відповідальність, у разі недостатності страхової виплати (страхового відшкодування) для повного відшкодування завданої нею шкоди зобов'язана сплатити потерпілому різницю між фактичним розміром шкоди i страховою виплатою (страховим відшкодуванням). А згідно 3 ч. 5 ст. 28 Закону «Про нотаріат», розмір відшкодування заподіяної шкоди визначається за згодою сторін або в судовому порядку. Якщо відповідачем у справі 
буде страховик, а розмір відшкодування буде визначений у судовому порядку і перевищить розмір страхової суми, то має виникнути новий судовий процес, адже у цьому нотаріус $є$ третьою особою, яка не заявляє самостійних вимог, і рішення у справі не може містити висновків про його права та обов'язки.

Також, відповідно до ст. 979 ЦК, за договором страхування одна сторона (страховик) зобов'язується у разі настання певної події (страхового випадку) виплатити другій стороні (страхувальникові) або іншій особі, визначеній у договорі, грошову суму (страхову виплату), а страхувальник зобов'язується сплачувати страхові платежі та виконувати інші умови договору. У договорі страхування цивільно-правової відповідальності нотаpiуса просто неможливо наперед визначити особу, якій у подальшому буде спричинено шкоду, отже, страхова виплата має бути виплачена страхувальнику (тобто нотаpiycy), а не позивачу.

Окрім зазначеного, позивач може заявити вимогу про відшкодування шкоди в натурі. Наприклад, у судовій справі за позовом ОСОБА 3 до приватного нотаріуса Донецького міського нотаріального округу ОСОБА 4 позивач просив суд зобов'язати нотаріуса ОСОБА_4 відшкодувати в натурі матеріальний збиток шляхом придбання на його ім'я автомобілю SUBARU OUTBACK із пробігом не більше ніж 061248 км та не пізніше 2009 р. випуску та стягнути 3 нотаріуса ОСОБА_4 моральну шкоду в розмірі 200 тис грн. [2]. Як таку вимогу можна зобов'язати задовольнити страхувальника?

Таким чином, відповідачем у справах про відшкодування шкоди, заподіяної приватним нотаріусом, має бути сам нотаріус. Участь же страховика може бути передбачена або як співвідповідача, або як третьої особи, що не заявляє самостійних вимог щодо предмета спору залежно від обставин справи та розсуду позивача.

Засобом порушення цивільної справи, що розглядається, є позовна заява, що закріплює вимогу про відшкодування матеріальної та (або) моральної шкоди. Загальні вимоги до форми та змісту позовної заяви передбачені у ст. 175 ЦПК, однак позовна заява про відшкодування шкоди, заподіяної нотаріусом, має свої особливості, зумовлені предметом та підставами позову, що заслуговують на увагу.

Передусім, зміст такої позовної заяви має відбивати специфіку суб'єктного складу даної справи, про яку йшлося вище. Позивачем у таких справах може бути будьяка особа, яка має визначити у позовній заяві свою заінтересованість, що полягає у тому, що саме їй внаслідок дій або бездіяльності нотаріуса було спричинено матеріальну або моральну шкоду. Имовірність спричинення шкоди зумовлюється участю позивача у нотаріальному провадженні як суб'єкта, що брав участь у вчиненій нотаріальній дії або отримав відмову нотаріуса у їі вчиненні. Відповідачем у позовній заяві має бути зазначений або приватний нотаріус, або державна нотаріальна контора чи державний нотаріальний архів у разі спричинення шкоди державним нотаріусом. Участь самого державного нотаріуса у справі також можна забезпечити, визначивши у позовній заяві необхідність залучення його як третьої особи, що не заявляє самостійних вимог щодо предмета спору. Зважаючи на особливий правовий статус нотаріуса, не можна вимагати від позивача зазначення у позовній заяві тих відомостей про нотаріуса, що подаються для відповідача - фізичної особи (наприклад, номер і серію паспорта), проте обов'язковим $\epsilon$ зазначення найменування нотаріального округу, в якому розташоване робоче місце нотаріуса.

Необхідним є також зазначення у позовній заяві ціни позову, яка в даному разі обраховується за правилами п. 1 ч. 1 ст. 176 ЦПК.

Зважаючи на те, що у позовній заяві позивач викладає свої вимоги щодо предмета спору та їх обгрунтування, слід наголосити, що вимога про відшкодування шкоди, заподіяної нотаріусом, має бути обгрунтована, серед іншого, протиправністю поведінки нотаріуса або під час учинення нотаріальної дії, або у разі відмови у вчиненні нотаріальної дії. Саме тому особливістю позовної заяви у даній категорії цивільних справ $€$ посилання на незаконність дій (бездіяльності) нотаріуса, що мають бути визнані такими у судовому порядку. Отже, позовна заява обов'язково має містити посилання на конкретне судове рішення, яким дії нотаріуса попередньо було визнано незаконними як обгрунтування позовних вимог, або ж у разі відсутності такого рішення у позовній заяві має бути поєднано дві позовні вимоги: про визнання дій (бездіяльності) нотаріуса незаконними та про відшкодування шкоди, заподіяної такими незаконними діями.

У позовній заяві про відшкодування моральної шкоди має бути зазначено, у чому полягає ця шкода, якими неправомірними діями чи бездіяльністю нотаріуса іiі заподіяно позивачеві, з яких міркувань він виходив, визначаючи розмір шкоди, та якими доказами це підтверджується.

За недотримання позивачем зазначених вимог настають наслідки, передбачені ст. 185 ЦПК

Певними особливостями під час розгляду справ про відшкодування шкоди, заподіяної нотаріусами, характеризуються і правила визначення підсудності. Без сумніву, зазначені справи мають розглядатися судом за правилами загальної підсудності, передбаченими ст. 27 ЦПК: позови до фізичної особи пред'являються в суд за зареєстрованим у встановленому законом порядку місцем її проживання або перебування, а позови до юридичних осіб пред'являються в суд за їх місцезнаходженням згідно 3 Єдиним державним реєстром юридичних осіб, фізичних осіб - підприємців та громадських формувань. Але застосування цих правил $\epsilon$ специфічним у справах за участю приватних нотаріусів 3 огляду на їхній особливий правовий статус. Позов до приватного нотаріуса не може розглядатися ні як позов до фізичної особи, ні як позов до юридичної особи, позаяк він є представником вільної юридичної професії, уповноважується державою на вчинення нотаріальних дій. У разі звернення позову до приватного нотаріуса він має подаватися не за місцем проживання або перебування нотаріуса, а за місцезнаходженням його робочого місця, що процесуальним законом прямо, на жаль, не передбачено. У цьому зв'язку вбачається необхідність внесення у ст. 27 ЦПК додаткового положення, що визначало б правила подання позову до приватного нотаріуса.

Також якщо попередньо вироком суду буде встановлено, що у незаконних діях нотаріуса, що спричинили шкоду заінтересованій особі, був склад злочину, це зумовить можливість застосування альтернативної підсудності за вибором позивача за правилами ч. 3 ст. 28 ЦПК (окрім правил загальної підсудності, подання позову у такому разі можливо також за зареєстрованим місцем проживання чи перебування позивача, або за місцем завдання шкоди).

Поряд із цим варто наголосити на неможливість у даному разі застосування правил альтернативної підсудності, передбачених ч. 5 ст. 28 ЦПК, що діють для подання позовів про захист прав споживачів, оскільки правові відносини між заінтересованою особою та нотаріусом мають абсолютно інший характер. Нотаріальна діяльність не $\epsilon$ наданням послуг або виконанням робіт, а являє собою різновид правозастосовної юрисдикційної діяльності у безспірній сфері, у межах якої визначається правовий статус учасників нотаріального провадження. За жодних умов нотаріальна діяльність також не може розглядатися як підприємницька, про що свідчать положення ч. 4 ст. 3 Закону України «Про нотаріат».

Серед процесуальних особливостей розгляду справ про відшкодування шкоди, заподіяної нотаріусами, слід також виокремити зміст предмету доказування, адже 
законність та обгрунтованість судового рішення завжди зумовлюються правильністю визначення складу фактичних обставин, що мають значення для вирішення справи, та їх доведеністю в ході судового розгляду.

Чинне цивільне процесуальне законодавство не містить визначення предмету доказування, а у науковій літературі це питання досі є дискусійним і досліджувалося у багатьох роботах $[3$, с. $243 ; 4$, с. $34,37-38 ; 5$, с. 34 ; 6, с. 193].

Уважаємо найбільш обгрунтованою та такою, що відповідає чинному законодавству й потребам судової практики, точку зору професора В.В. Комарова, відповідно до якої предмет доказування визначається як коло фактів матеріально-правового значення, необхідних для вирішення справи по суті. При цьому, на думку вченого, факти, які належать до предмета доказування, необхідно відрізняти від інших фактів, які встановлюються під час розгляду справи, однак не пов'язані з правильним вирішенням питання про права й обов'язки сторін [7, с. 9].

Не менш важливим із методологічного погляду є визначення джерел формування предмету доказування. Виходячи 3 твердження, що до предмету доказування належать факти, встановлення яких необхідно для розгляду справи по суті, джерелами формування предмету доказування слід визнати твердження сторін та інших учасників справи про обставини, якими вони обгрунтовують свої позовні вимоги, та заперечення проти них, а також відповідні норми матеріального законодавства, на підставі котрих буде вирішено певну цивільну справу та які підлягатимуть застосуванню під час постановлення судового рішення. При цьому друге джерело буде визначальним, адже сторона може й не послатися 3 тих чи інших причин на існування чи відсутність певного юридичного факту, але, якщо він передбачений диспозицією матеріальної норми, суд буде зобов'язаний сформулювати свій висновок щодо його встановлення в даному судовому процесі.

Досліджуючи проблему визначення змісту предмету доказування у справах про відшкодування шкоди, заподіяної нотаріусами, слід виходити з того, що заінтересовані особи мають можливість пред'явити позовні вимоги про відшкодування як матеріальної, так і моральної шкоди, яка може бути спричинена як державним, так і приватним нотаріусом, отже, предмет доказування у таких випадках зумовлюється положеннями статей 1166, 1167, 1172 ЦК, 21 та 27 Закону України «Про нотаріат», а також предметом та змістом позову та запереченнями проти нього.

Відповідно до положень наведених статей, необхідною підставою для притягнення нотаріуса до відповідальності у таких справах $є$ незаконні чи недбалі дії (чи бездіяльність) нотаріуса, наявність самої шкоди (майнової чи моральної), причинний зв'язок між неправомірною поведінкою нотаріуса та заподіяною шкодою, а також вина нотаріуса. При цьому, відповідно до ч. 2 ст. 27 Закону «Про нотаріат», нотаріус не несе відповідальності у разі, якщо особа, яка звернулася до нотаріуса за вчиненням нотаріальної дії: подала неправдиву інформацію щодо будь-якого питання, пов'язаного 3 учиненням нотаріальної дії; подала недійсні та (або) підроблені документи; не заявила про відсутність чи наявність осіб, прав чи інтересів яких може стосуватися нотаріальна дія, за вчиненням якої звернулася особа.

Незаконність дій або бездіяльності нотаріуса встановлюється винятково судом. Тому рішення про задоволення позову у справах щодо відшкодування шкоди може бути постановлене лише за умови попереднього (в тому самому чи іншому судовому процесі) розгляду судом питання про недійсність нотаріального акту через незаконність дій нотаріуса, незаконність учиненої нотаріальної дії або відмови у іiі вчиненні. При цьому факти, встановлені у попередньому судовому процесі за участі нотаріуса, матимуть преюдиціальне значення і знов доводитися у процесі щодо відшкодування шкоди не повинні на підставі правил ст. 82 ЦПК. Саме у цьому полягають особливості звільнення від доказування фактів, що охоплюються предметом доказування у досліджуваній категорії справ.

За відсутності ж попереднього вирішення судом питання щодо незаконності дій (бездіяльності) нотаріуса неможливо й задоволення позову про відшкодування шкоди, заподіяної нотаріусом, позаяк така ситуація унеможливлює встановлення наявності однієї 3 підстав настання відповідальності нотаріуса.

Безумовно, вимоги про визнання дій нотаріуса незаконними та відшкодування шкоди можуть бути поєднані в одному судовому процесі, але й за таких умов можливість задоволення вимоги про відшкодування шкоди буде зумовлюватися попереднім вирішенням питання про визнання дій нотаріуса незаконними. При цьому обидві ці вимоги мають бути заявлені у порядку, передбаченому цивільним процесуальним законодавством, тобто одночасно, а не після початку судового розгляду.

Окрім того, правила цивільного законодавства та ст. 27 Закону «Про нотаріат» передбачають необхідність установлення усіх умов відшкодування шкоди без винятків, і за відсутності будь-якої з них відповідальність нотаріуса наступати не може.

Так, предметом доказування у даних справах охоплюється й факт наявності вини нотаріуса, яка, за правилами ст. 27 Закону «Про нотаріат», унеможливлюється у разі, якщо особа, яка вернулася до нотаріуса за вчиненням нотаріальної дії: подала неправдиву інформацію щодо будь-якого питання, пов'язаного з учиненням нотаріальної дії; подала недійсні та/або підроблені документи; не заявила про відсутність чи наявність осіб, прав чи інтересів яких може стосуватися нотаріальна дія, за вчиненням якої звернулася особа.

Уважаємо на необхідне наголосити, що зазначені правила звільнення нотаріуса від відповідальності мають поширюватися і на ситуації спричинення шкоди державним нотаріусом, адже за юридичним характером, за своєю правовою сутністю діяльність приватно практикуючого нотаріуса нічим не відрізняється від діяльності державного нотаріуса. Вчинення нотаріальних дій - це особливий вид діяльності, яка $\epsilon$ правозастосовчою, юрисдикційною за своїм характером незалежно від її суб'єктного складу. Розподіл нотаріусів на види зумовлений не характером їхніх обов'язків, а особливостями внутрішньої організації та фінансового забезпечення нотаріальної діяльності [8, с. 84].

Необхідною умовою настання відповідальності нотаpiуса, що охоплюється предметом доказування у таких справах, є наявність шкоди та ііi розмір. Як зазначається у літературі, майнова шкода як умова зобов'язання з ії відшкодування виступає і мірою обов'язку відповідальної за шкоду особи, тобто розмір відшкодування визначається розміром завданої його майну шкоди [9, с. 730]. За правилами змагального цивільного процесу України і факт спричинення шкоди, і ії розмір має довести позивач. Нотаріус як відповідач також може посилатися на обставини, що дають змогу визначити розмір відшкодування, маючи у такому разі обов'язок їх доказування.

Також неодмінним складником предмету доказування у справах, що розглядаються, є причинний зв'язок між протиправними діями (бездіяльністю) нотаріуса та спричиненням шкоди заінтересованій особі. Установлення наявності причинного зв'язку означає необхідність з'ясування того факту, що шкода, заподіяна особі, була спричинена саме внаслідок протиправних дій нотаріуса, а не діями іншої особи. Якщо в межах розгляду судової справи судом буде встановлено протиправність дій нотаріуса, але не буде доведено причинного зв'язку між такими діями та шкодою, суд має визнати такий позов безпідставним та відмовити у його задоволенні. 
До нотаріуса можуть бути пред’явлені вимоги і про відшкодування моральної шкоди. Стаття 1167 ЦК передбачає, що моральна шкода, завдана фізичній або юридичній особі неправомірними рішеннями, діями чи бездіяльністю, відшкодовується особою, яка ï завдала, за наявності ії вини, крім випадків, установлених ч. 2 цієі статті. Під моральною шкодою у даному разі слід розуміти втрати немайнового характеру внаслідок моральних чи фізичних страждань або інших негативних явищ, заподіяних фізичній чи юридичній особі незаконними діями або бездіяльністю нотаріуса.

Предмет доказування у разі розгляду вимоги про відшкодування моральної шкоди є специфічним. Суд, зокрема, повинен з'ясувати, чим підтверджується факт заподіяння позивачеві моральних чи фізичних страждань або втрат немайнового характеру, за яких обставин чи якими діями (бездіяльністю) вони заподіяні, в якій грошовій сумі чи в якій матеріальній формі позивач оцінює заподіяну йому шкоду, та 3 чого він при цьому виходить, а також інші обставини, що мають значення для вирішення спору.

Розмір відшкодування моральної (немайнової) шкоди має бути розрахований та доведений позивачем. Суд визначає цей розмір залежно від характеру та обсягу страждань (фізичних, душевних, психічних тощо), яких зазнав позивач, характеру немайнових утрат (їх тривалості, можливості відновлення тощо) та з урахуванням інших обставин. Зокрема, враховуються стан здоров'я позивача, тяжкість вимушених змін у його життевих і виробничих стосунках, ступінь зниження престижу, ділової репутації, час та зусилля, необхідні для відновлення попереднього стану. При цьому суд має виходити із засад розумності, виваженості та справедливості.

Вимога про відшкодування моральної шкоди може бути задоволена судом навіть у разі відмови у задоволенні вимоги про відшкодування матеріальної шкоди.

Здійснення доказових функцій відбувається за правилами ст. 81 ЦПК, відповідно до яких кожна сторона повинна довести ті обставини, на які вона посилається як на підставу своїх вимог або заперечень, окрім випадків, установлених ЦПК. Це означає, що обов'язки доказування виникають у учасників таких справ відносно тих фактів, які визначені ними як підстави позову (позивач) або заперечення проти нього (відповідач). Але особливості розподілу обов'язків щодо доказування у досліджуваній категоpiї справ зумовлюються положеннями ч. 2 ст. 1166 ЦК, яка містить презумпцію вини спричинювача шкоди (у даному разі - нотаріуса) і покладає обов'язок доказування відсутності вини на відповідача. 3 огляду на специфічні правила визначення відсутності вини відповідача, що передбачають необхідність встановлення обставин, передбачених ч. 2 ст. 27 Закону «Про нотаріат», обов'язок доказування підстав звільнення нотаріуса від відповідальності покладається саме на відповідача.

Відповідно, такий склад предмету доказування та зміст доказової діяльності у даних справах зумовлює й особливості викладення змісту рішення суду, в якому обов'язково мають висвітлюватися висновки суду щодо встановлення наявності або відсутності підстав для притягнення нотаріуса до відповідальності, а також міститися посилання на відповідні матеріально-правові норми, які застосував суд, та мотиви їх застосування (п. 5 ч. 2 ст. 245 ЦПК).

Зокрема, у мотивувальній частині рішення має міститися посилання на судове рішення, яким попередньо було визнано незаконність дій або бездіяльності нотаріуса У разі відсутності такого посилання й у мотивувальній, й у резолютивній частинах рішення має міститися обгрунтований висновок про незаконність дій (бездіяльності) нотаріуса. Визначаючи розмір відшкодування моральної (немайнової) шкоди, суд повинен наводити в рішенні відповідні мотиви.
У резолютивній частині рішення має міститися висновок про розмір відшкодування шкоди або висновок про відмову у задоволенні позову.

Законна сила судового рішення у справах про відшкодування шкоди, заподіяної нотаріусом, розповсюджується на тих заінтересованих осіб, що були залучені до участі у справі як відповідачі (співвідповідачі). Як уже зазначалося, це можуть бути приватні нотаріуси, державні нотаріальні контори, державні нотаріальні архіви, страхові компанії. Якщо ж страхова компанія, з якою у нотаріуса укладений договір страхування відповідальності, брала участь у справі як третя особа, що не заявляє самостійних вимог щодо предмета спору, то резолютивна частина рішення не може містити висновків про іiі права та обов'язки. Рішення суду в такому разі є підтвердженням настання факту страхового випадку. Якщо страховик не виконає приписів цього рішення, це може стати підставою для пред'явлення до нього в подальшому самостійного позову. Подібна ситуація складається й у разі участі у справі державного нотаріуса як третьої особи, що не заявляє самостійних вимог щодо предмета спору. $\mathrm{У}$ резолютивній частині рішення не буде приписів щодо обов'язків державного нотаріуса. Відповідна юридична особа - відповідач (державна нотаріальна контора, державний нотаріальний архів) у подальшому набуває можливостей подання до державного нотаріуса, чиїми діями чи бездіяльністю було заподіяно шкоду, самостійного регресного позову в іншому судовому процесі.

Судове рішення у справах про відшкодування шкоди, заподіяної нотаріусами, підлягає примусовому виконанню, оскільки $€$ рішенням про стягнення.

Висновки 3 даного дослідження та перспективи подальших розвідок у даному напрямі. Отже, проведене дослідження дає змогу стверджувати, що серед процесуальних особливостей розгляду справ, які випливають із пред'явлених до нотаріусів позовів про відшкодування шкоди, заподіяної їхніми діями, слід указати на специфічний суб'єктний склад, зміст позовної заяви, предмет доказування та зміст судового рішення.

Суб'єктний склад таких цивільних справ буде різним залежно від того, діями державного чи приватного нотаріуса було заподіяно шкоду. Відповідачем у разі заподіювання шкоди державним нотаріусом має бути відповідна юридична особа, з якою такий нотаріус перебуває у трудових відносинах. Відповідачем у справах про відшкодування шкоди, заподіяної приватним нотаріусом, має бути сам нотаріус. Участь же страховика може бути передбачена або як співвідповідача, або як третьої особи, що не заявляє самостійних вимог щодо предмета спору залежно від обставин справи та розсуду позивача.

Позовна заява про відшкодування шкоди, заподіяної нотаріусом, має свої особливості, зумовлені предметом та підставами позову.

Певними особливостями при розгляді справ про відшкодування шкоди, заподіяної нотаріусами, характеризуються і правила визначення підсудності. Без сумніву, зазначені справи мають розглядатися судом за правилами загальної підсудності. У разі звернення позову до приватного нотаріуса він має подаватися не за місцем проживання або перебування нотаріуса, а за місцезнаходженням його робочого місця, що процесуальним законом прямо, на жаль, не передбачено. У цьому зв'язку вбачається необхідність внесення у ст. 27 ЦПК додаткового положення, що визначало б правила подання позову до приватного нотаріуса.

Специфіка предмету доказування визначатиметься підставами позову та положеннями відповідного матеріального законодавства.

У разі відшкодування шкоди, заподіяної діями приватного нотаріуса, правовою підставою рішення слугуватимуть статті 23, 1166, 1167 ЦК, а також статті 27 та 28 Закону 
України «Про нотаріат». Відповідно, їх положення поряд із підставами позову та запереченнями проти нього $є$ джерелами формування предмету доказування. 3 урахуванням ïх змісту у справах за такими позовами встановлюються такі юридичні факти: факт учинення нотаріальної дії (або відмови у вчиненні нотаріальної дії); порушення приватним нотаріусом закону під час учинення нотаріальної дії або відмови у вчиненні нотаріальної дії; факт наявності шкоди та її розмір; причинний зв'язок між протиправною поведінкою нотаріуса та настанням шкоди; факт винної поведінки нотаріуса; наявність або відсутність підстав, що звільняють приватного нотаріуса від відповідальності (ч. 2 ст. 27 Закону). Також у разі участі у справі приватного нотаріуса як відповідача слід установлювати наявність страхового договору та його суму.

У разі відшкодування шкоди, заподіяної діями державного нотаріуса, правова підстава рішення міститься у положеннях статей 1172, 1167 ЦК та ст. 21 Закону України «Про нотаріат», які поряд із підставами позову та запереченнями проти нього є джерелами формування предмету доказування. Ураховуючи їхні положення, до предмету доказування у справах за такими позовами входять такі юридичні факти: факт перебування нотаріуса у трудових відносинах із державною нотаріальною конторою (нотаріальним архівом); факт учинення нотаріальної дії (або відмови у вчиненні нотаріальної дії), тобто факт спричинення шкоди державним нотаріусом у зв'язку
3 виконанням трудових обов'язків; порушення державним нотаріусом закону під час учинення нотаріальної дії або відмови у вчиненні нотаріальної дії; факт наявності шкоди та її розмір; причинний зв'язок між протиправною поведінкою нотаріуса та настанням шкоди; факт винної поведінки нотаріуса. Правила ст. 27 Закону України «Про нотаріат» щодо підстав звільнення нотаріуса від відповідальності на ситуації протиправності дій державних нотаріусів не поширюються, що не можна визнати правильним 3 огляду на положення ч. 4 ст. 1 Закону України «Про нотаріат», згідно з якими документи, оформлені державними і приватними нотаріусами, мають однакову юридичну силу.

Відповідно, такий склад предмету доказування та зміст доказової діяльності у даних справах зумовлює й особливості викладення змісту рішення суду, в якому обов'язково мають висвітлюватися висновки суду щодо встановлення наявності або відсутності підстав для притягнення нотаріуса до відповідальності, а також міститися посилання на відповідні матеріально-правові норми, які застосував суд, та мотиви їх застосування (п. 5 ч. 2 ст. 245 ЦПК).

Перспективи подальших розвідок у даному напрямі пов'язані з поглибленням характеристики судового розгляду даних справ як складової частини системи судового контролю над нотаріальною діяльністю, що потребує подальшого дослідження його змісту та предмету, форм та підстав здійснення.

\section{ЛITEPATУРA}

1. Бичкова С.С. Участь нотаріуса у цивільному процесі України. Криміналістичний вісник. 2014. № 1(21). С. $26-31$.

2. Рішення Київського районного суду м. Донецька від 11 червня 2013 p. URL : http://www.reyestr.court.gov.ua/Review/31907396.

3. Гузь Л.Є. Підстави для скасування судових рішень (ухвал) та способи запобігання їх виникнення при розгляді цивільних справ в судах. Харків : Поліграфіст, 2006. 724 с.

4. Пінчук М.Г. Деякі питання щодо визначення предмета доказування та його структури. Вісник Верховного Суду України. 2007. № 2. С. 33-38.

5. Фурса С.Я., Цюра Т.В. Докази і доказування у цивільному процесі : науково-практичний посібник. Київ : КНТ, 2005. 256 с.

6. Супрун Т.С. Поняття предмета доказування у цивільному судочинстві Форум права. 2016. № 5. С. 190-198. URL : http://nbuv.gov.ua/ j-pdf/FP_index.htm_2016_5_33.pdf.

7. Комаров В.В. Доказування та докази в цивільному судочинстві : курс лекцій. Харків : Укр. юрид. акад., 1991. 36 с.

8. Комаров В.В., Баранкова В.В. Нотаріат : підручник. Харків : Право, 2019. 416 с.

9. Цивільне право : підручник : у 2-х т. / за ред. В.І. Борисової, І.В. Спасибо-Фатєєвої, В.Л. Яроцького. Харків : Право, 2011. Т. 2. 816 с. 


\title{
ПРАВОВА ПРИРОДА ІПОТЕКИ ТА ЇЇ ХАРАКТЕРНІ ОЗНАКИ
}

\section{LEGAL NATURE OF THE MORTGAGE AND ITS CHARACTERISTICS}

\author{
Бончук Н.В., студент II курсу \\ Інститут післядипломної освіти \\ Київського національного університету імені Тараса Шевченка
}

Іпотека має велике економічне та соціальне значення та слугує важливою зв'язною ланкою надходження капітальних вкладів у різні галузі економіки, а також надає можливість реалізувати та забезпечити потреби населення в житловій та кредитно-договірній сферах. Продумана ефективна іпотечна система може допомогти стабілізувати незадовільне економічне становище, оскільки сприяє зниженню інфляції, стягуючи на свій бік вільні грошові кошти фрізичних та юридичних осіб, та допомагає вирішувати соціальні та економічні проблеми в державі. Одержання оборотних коштів від застави нерухомості та земельних ділянок може збагатити економіку держави. Як фінансово-кредитний інструмент іпотека об'єднує у собі регулювання цивільно-правових, адміністративних та процесуальних відносин. Окрім того, інститут іпотеки $є$ найбільш ефективним та дієвим механізмом забезпечення виконання зобов'язання. Завдяки застосуванню іпотеки кредитор отримує матеріальні гарантії щодо виконання зобов'язання боржником. При цьому реальна загроза втрати нерухомого майна, що має значну економічну вартість і характеризується стабільністю ціни та тенденцією до ії підвищення у цивільному обороті, є додатковим стимулом для виконання його боржником. Іпотека відіграє значну роль у ринкових відносинах, а також сприяє підвищенню стабільності цивільно-правового обороту. Сьогодні іпотечні правовідносини ще тільки розвиваються і перебувають на стадії реформування. Запорукою розвитку іпотечних правовідносин $\epsilon$ наявність адекватного законодавства, яке повинно захищати інтереси як кредитора, так і позичальника та стимулювати для подальшого розвитку та вдосконалення іпотечних відносин у цивільному обороті. Відповідно до законодавства України, іпотека визначається як видозабезпечення виконання зобов'язання нерухомим майном, що залишається у володінні і користуванні іпотекодавця, згідно з яким іпотекодержатель має право в разі невиконання боржником забезпеченого іпотекою зобов'язання одержати задоволення своїх вимог за рахунок предмета іпотеки переважно перед іншими кредиторами цього боржника у порядку, встановленому законом.

Ключові слова: іпотека, застава, нерухомість, боржник, позика.

Mortgages are of great economic and social importance and serve as an important link between the inflow of capital investments in various sectors of the economy, as well as provide an opportunity to meet and meet the needs of the population in housing and credit and contractual areas. A well-thought-out effective mortgage system can help stabilize the unsatisfactory economic situation, as it helps reduce inflation by raising the funds of individuals and legal entities and helping to solve social and economic problems in the country. Obtaining working capital from the pledge of real estate and land can enrich the economy. As a financial and credit instrument, a mortgage combines the regulation of civil, administrative and procedural relations. In addition, the mortgage institution is the most effective and efficient mechanism for securing the fulfillment of the obligation. Through the application of the mortgage, the creditor receives material guarantees for the fulfillment of the obligation by the debtor. At the same time, the real threat of loss of real estate, which has a significant economic value and is characterized by price stability and a tendency to increase it in civil turnover, is an additional incentive for the debtor to fulfill it. Mortgages play a significant role in market relations, and also contributes to the stability of civil turnover. Therefore, today mortgage relations are still developing and are in the process of reform. The key to the development of mortgage relations is the availability of adequate legislation that should protect the interests of both the lender and the borrower and stimulate the further development and improvement of mortgage relations in civil turnover. According to the legislation of Ukraine, a mortgage is defined as a type of security for real estate, which remains in the possession and use of the mortgagor, according to which the mortgagee has the right in case of default by the debtor secured by the mortgage to obtain satisfaction of its claims the debtor in the manner prescribed by law.

Key words: mortgage, pledge, real estate, debtor, loan.

Постановка проблеми. Наукове дослідження такого правового явища, як іпотека, крім дослідження історії виникнення та розвитку, потребує визначення та конкретизації його понятійної характеристики та аналізу основних понять та категорій.

Аналіз останніх досліджень і публікацій. Головні дослідження та публікації, в яких започатковано розв'язання проблем правового регулювання іпотеки, належать таким провідним українським та зарубіжним дослідникам, як C.I. Кручок, I.I. Пучковська, Г.Ф. Шершневич, Ю.Є. Ходико, К.П. Побєдоносцев, В.І. Синайський, М.М. Дякович, В.М. Хвостов, Л.В. Гантовер, В.К. Райхер, М.І. Брагінський, В.В. Вітрянський, Л.А. Кассо, А.С. Звоницький, А.Р. Чанишева, І.О. Лютий, І.В. Савич, О.М. Каловішко, О.О. Нігреєва, В.Ю. Дмитренко, В.В. Стратійчук та ін.

Формулювання цілей статті. Мета статті - розкрити правову природу іпотеки та визначити ії характерні ознаки.

Виклад основного матеріалу. Сьогодні іпотека слугує важливою зв'язною ланкою надходження капітальних вкладів у різні галузі економіки. Існує достатньо багато диверсифікованих системних досліджень, предметом вивчення яких $€$ термін «іпотека» у всьому розмаїтті їі особливостей. Для розуміння сутності іпотеки необхідно розглянути даний термін за певними спек- трами груп, а саме як правову категорію, економічну категорію та фінансову.

Як економічна категорія це - грошова позика, сума, яка надається під заставу нерухомості, щодо якої виникають кредитні відносини. Прихильниками цієї категорії є українські вчені В.Т. Бусел, М.Я. Дем'яненко, П.В. Круш. При цьому М.Я. Дем'яненко зазначає, що іпотека є засобом залучення кредитних ресурсів під заставу земельних ділянок $[1$, с. 99$]$.

Іпотека як фінансова категорія - це спосіб забезпечення зобов'язань, коли предметом застави $є$ нерухоме майно. Прихильниками другої групи є вчені C.I. Кручок та О.М. Колодізєв. На їхню думку, іпотека $є$ забезпеченням виданого кредиту, а С.І. Кручок, своєю чергою, підкреслює, що це право звернення стягнення на нерухоме майно на підставі законодавства, іпотечної угоди та (або) рішення суду [2, с. 190].

Іпотека як правова категорія - це застава нерухомості, нерухомого майна 3 метою отримання спеціальної іпотечної позики. Прихильниками даного напряму $є$ такі вітчизняні вчені, як I.М. Михайловська, А.О. Афанасьєв, У.В. Владичин, В.Д. Лагутін, С.В. Мочерний, Н.О. Тимочко [3, с. 216].

Правова природа іпотеки завжди була предметом дискусій учених-правознавців. Інститут іпотеки ще в римському праві мав дуалістичний характер, 
який проявлявся присутністю ознак як речового, так і зобов'язального права.

I.I. Пучковська розглядає іпотеку як заставу нерухомості. В обгрунтування своєї позиції щодо речової природи I.I. Пучковська відзначає, що між іпотекодержателем та об'єктом іпотеки встановлюється прямий зв'язок, який виражається в наявності правомочностей, які дають йому право на річ (об'єкт іпотеки) та можливості в разі невиконання боржником свого обов'язку за основним зобов'язанням продати іiі 3 метою задоволення своєї вимоги з отриманої суми [4, с. 82$]$.

В.А. Другова, відстоюючи речову природу прав іпотеко держателя, відзначає, що іпотекодержатель «за іпотекою набуває переважне право на задоволення своїх грошових вимог за рахунок заставленого майна, що має абсолютний характер, і здійснення цього права не залежить від волі іпотекодавця та третіх осіб, що закріплено в законі» [5, с. 3]. Авторка звертає також увагу й на те, що речовий характер виявляється у закріплених законом можливостях здійснювати обмежене панування над річчю, що належить власникові, та яке, за певних умов, надає можливість отримати право власності на річ або право на iï цінність, здійснювати контроль над користуванням цією річчю власником для уникнення зниження цінності цієї речі [6, с. 93].

Цивіліст Г.Ф. Шершневич також притримується думки щодо речового характеру права застави, визначаючи його як право на чужу річ, що належить вірителю (кредитору) для забезпечення його права вимоги за зобов'язаннями і надає можливість примусового задоволення свої вимог із цінності речі [7, с. 27].

Специфіка речового характеру заставного права полягає у виключному становищі заставодержателя щодо певної частини чужого майна. Заставне право на відміну від інших речових прав не має на меті користування чи володіння річчю, а лише отримання певної суми його вартості. Л.А. Кассо підкреслює, що здійснення цього права заставодержателем пов'язане 3 припиненням самого заставного права [8, с. 33].

К.П. Побєдоносцев уважав, що право застави є самостійним та безумовним щодо всіх інших прав, оскільки внаслідок застави виникає речове право, яким установлюється виключне право заставодержателя на передане в заставу майно, незважаючи на те що майно не перестає бути чужим.

Схожої думки був і В.I. Синайський, який уважав, що «речово-правова теорія природи застави грунтується на ідеї визнання права заставодержателя речовим правом, тому що воно породжує пряме і безпосереднє відношення між особою і річчю» [8, с. 42]. Заставне право $\epsilon$ речовим незалежно від того, хто фактично володіє заставленим майном.

Підсумком міркувань В.М. Хвостова про правову природу застави було запропоноване визначення поняття заставного права, згідно з яким «застава $є$ зобов' язальним правом вимоги, за якого особа боржника, зобов'язаного сплатити борг, визначається триманням заставленої речі, а заставлена річ є тим об'єктом, який у тій чи іншій формі відповідає за несплату цього боргу».

Прихильники зобов'язальної природи іпотеки, обгрунтовуючи свою позицію, вказують на те, що заставне право $\epsilon$ акцесорним, слугує засобом забезпечення стягнення та припиняється виконанням зобов'язання. Л.В. Гантовер зазначав, що застава ніколи не має самостійного значення на відміну від інших речових прав, які завжди існують самі по собі, відокремлено та самостійно, а застава $є$ способом забезпечення іншого права, без існування якого він $є$ неможливим, тому має тільки акцесорне значення, додаткове до першого.

В.К. Райхер стверджував, що в іпотечному праві існує особливе правовідношення між заставодавцем та заставо- держателем, в якому виразно виділяється фігура заставодавця. Між ними пролягає особливий правовий зв'язок, глибоко відмінний від відносин заставодержателя до «третіх осіб». На підтвердження зобов'язальної природи іпотеки В.К. Райхер наводить такі аргументи: коротка тривалість застави; припинення іiі в результаті одноразової дії; можливість відсутності в заставі ознак «речовності»; прямий зв'язок між заставодавцем і заставодержателем та опосередкований зв'язок між заставодержателем та третіми особами [9, с. 12].

Науковці М.І. Брагінський та В.В. Вітрянський відстоювали зобов'язальну природу застави (іпотеки), обгрунтовуючи тим, що, крім речей, предметом застави можуть бути майнові права вимоги; право застави може бути встановлено на майбутню річ, відносно якої з боку будь-якого суб'єкта не може бути встановлене право власності чи будь-яке інше речове право; заставодержатель має право передати свої права за договором застави іншій особі шляхом відступлення права вимоги. При цьому відступлення права вимоги є зобов'язальним правовим інститутом, а речові права не можуть бути передані іншій особі в порядку відступлення права вимоги [9, с. 13].

С.В. Нижний відзначає: «Якщо, аналізуючи правову природу застави виключно крізь призму правовідносин, що виникають між заставодержателем та заставодавцем, то іiї зобов'язальний характер не викликає сумніву: між сторонами існує правовий зв'язок, який виражається у взаємних правах та обов'язках» [10, с. 106].

Розглянувши обидві концепції, можна дійти висновку, що іпотека має риси як речової, так і зобов'язальної природи, проте до жодної з них не може бути віднесена у своєму «чистому вигляді».

Деякі вчені акцентують увагу на тому, що дискусія про речовий чи зобов'язальний характер іпотеки повинна бути вирішена у формі визнання подвійної або змішаної природи іпотеки. До прихильників цієї концепції відносяться такі наковці, як Л.А. Кассо, К.Н. Аннєнков, А.С. Звоницький, М.М. Дякович, О.А. Загорулько, М.Б. Гончаренко, І.Й. Пучковська та ін.

Л.А. Кассо відзначав, що в заставі прослідковується таке правовідношення, за якого поєднуються особисті та речові аспекти, оскільки містять у собі як борговий зв'язок, так і речове забезпечення одночасно. Заставне правовідношення необхідно розглядати з урахуванням тієі особливості, що уповноважена особа отримує виключне право задоволення своїх вимог із певного майна, чим вичерпується його стягнення $[9$, с. 100$]$.

Жодна 3 наведених теорій, як зазначав А.С. Звоницький, не могла вирішити внутрішнього протиріччя та подвійності, присутніх у заставному праві. Науковець доводив, що належне заставодержателю право не $\epsilon$ ані речовим (оскільки можлива застава зобов'язань), ані зобов'язальним чи правом на «право», оскільки воно утверджує безпосереднє відношення до заставленого об'єкта. Підсумувавши викладене, А.С. Звоницький зазначив, що саме «звідси і випливає та подвійність, яку правильніше називати протиріччям між єдністю природи заставного права та різноманітністю його об'єктів» [6, с. 94].

Ю.Є. Ходико наголошує на тому, що жоден із наведених аргументів на користь речової або зобов'язальної природи іпотечного правовідношення не спростовує доказів, наведених на користь протилежної точки зору. Він робить висновок про поширення деяких речових або зобов'язальних конструкцій на іпотечні правовідносини, але не про їх суто речову або зобов'язальну природу $[9$, с. 94$]$.

У рамках дослідження правової природи іпотеки необхідно проаналізувати характерні ознаки іпотеки та настільки вони відповідають зобов'язальному і речовому праву. 
Характерними ознаками іпотеки є:

1) публічність - це ознака, яка вимагає фіксації іпотечного обтяження у певних реєстрах. Зацікавлені особи можуть отримати повну інформацію про предмет іпотеки. Ще за часів Стародавньої Греції іпотека мала публічний характер. Записи на стовпах, в іпотечних книгах надавали можливість кожній особі дізнатися про ступінь обтяження нерухомого майна іпотечними боргами, що забезпечувало інтереси потенційних покупців тогочасних земель $\neg н и х ~$ ділянок, та сприяли перетворенню землі на предмет торгового обороту;

2) спеціальність - установлення іпотеки щодо індивідуально визначеної речі;

3) пріоритетність - полягає у тому, що раніше встановлене право іпотекодержателя користується перевагою перед пізніше встановленим правом на ту саму річ і вирішується за принципом старшинства;

4) забезпечення виконання зобов'язання;

5) акцесорність. Іпотека має похідний (акцесорний) характер. Л.В. Гантовер досить влучно зазначив, що доля застави пов'язана з долею вимоги [9, с. 97];

6) можливість відступлення права вимоги.

Визначивши ознаки іпотеки, слід сказати, що характерними властивостями зобов'язального права, серед іншого, $\epsilon$ забезпечення виконання основного зобов'язання, виникнення на підставі договору, закону або рішення суду, акцесорний характер, взаємні права та обов'язки учасників іпотечних правовідносин, відступлення права вимоги шляхом передачі кредитором своїх прав іншій особі. При цьому головною властивістю речового права $є$ можливість звернення стягнення на майно незалежно від того, хто фактично володіє заставленим майном.

Висновки. Проаналізувавши існуючі наукові концепції щодо зобов'язальної або речової природи іпотеки, можна дійти висновку, що сьогодні відсутній чіткий та універсальний критерій поділу іпотечних правовідносин зобов'язального або речового характеру. Низка вчених, таких як I.I. Пучковська, В.А. Другова, Г.Ф. Шершневич, Л.А. Кассо, К.П. Побєдоносцев та ін., притримується точку зору щодо речової природи іпотечних правовідносин. Прихильниками зобов'язальної концепції $є$, зокрема, В.М. Хвостов, Л.В. Гантовер, В.К. Райхер, М.І. Брагінський, В.В. Вітрянський, С.В. Нижний. Проте деякі вчені вважають, що іпотечні правовідносини не мають суто речової або зобов'язальної природи та визнають подвійну або змішану природу іпотеки. Серед прихильників цієі концепції - Л.А. Кассо, К.Н. Аннєнков, А.С. Звоницький, Ю.С. Ходико та ін.

Дійсно, право іпотекодержателя на предмет іпотеки має речовий характер, адже об'єктом речового права може бути тільки річ. Речове ж право забезпечує іпотекодержателю владу над виділеною річчю 3-поміж інших матеріальних цінностей. Водночас між іпотекодавцем та іпотекодержателем виникають відносини зобов'язального характеру, що полягають у виникненні певних прав та обов'язків між ними щодо забезпечення виконання основного зобов'язання.

\section{ЛITEРАТУРА}

1. Дем'яненко М.Я. Проблеми іпотеки сільськогосподарських земель. Економіка АПК. 2003. № 2. С. 98-104

2. Кручок С.І. Іпотечне кредитування : навчальний посібник. Київ : Мета, 2002. 208 с.

3. Григорук І.О., Клімчук О.Л. Іпотека та іпотечне кредитування: теоретичний аспект. Вісник ЖДТУ. 2013. № 2(64). С. 214-218.

4. Канадаєва Д.Р. Актуальні проблеми цивільно-правового регулювання іпотечних правовідносин. Науковий вісник публічного та приватного права. 2019. Вип. 2. Т. 1. С. $81-85$

5. Другова В.А. Договір іпотеки за цивільним законодавством України : автореферат. дис. ... канд. юр. Наук : спец. 12.00.03. Київ, 2010. $18 \mathrm{c}$.

6. Стоколоса М.В. Правова природа іпотеки. Право і суспільство. 2014. № 3. С. 91-96.

7. Нігреєва О.О. Ще раз до питання про правову природу іпотеки. Правова держава. 2009. № 11. С. $27-32$.

8. Майданик Р.А. Припинення іпотеки виконанням основного зобов'язання: юридична природа та умови. Вісник Верховного Суду України. 2015. № 9 (181). С. 41-47.

9. Ходико Ю.Є. Об'єкт іпотечного правовідношення : монографрія. Харків : Право, 2012. 224 с.

10. Нижний С.В. До питання про правову природу застави. Вісник Хмельницького інституту регіонального управління та права. 2002. № 2. С. 104-107. 
УДК 347.9

DOI https://doi.org/10.32782/2524-0374/2020-4/10

\title{
НАБУТТЯ ПРОКУРОРОМ СТАТУСУ ПОЗИВАЧА У ЦИВІЛЬНОМУ ПРОЦЕСІ КРІЗЬ ПРИЗМУ ВИСНОВКІВ ВЕЛИКОЇ ПАЛАТИ ВЕРХОВНОГО СУДУ
}

\author{
ACQUISITION BY THE PROECUTOR STATUS OF THE PLAINTIFF \\ IN CIVIL PROCEEDINGS THROUGH THE PRISM OF THE CONCLUSIONS \\ OF THE GRET HOUSE OF SUPREME COURT
}

\author{
Гузе К.А., к.ю.н., \\ асистент кафедри цивільного процесу \\ Національний юридичний університет імені Ярослава Мудрого
}

\begin{abstract}
У статті проаналізовано особливості реалізації прокурором конституційної функції представництва інтересів держави у цивільному процесі та набуття ним правового статусу позивача. Досліджено теоретичні вчення про інститут сторін, висновки Конституційного Суду України, практику Великої Палати Верховного Суду, нормативні акти України, що регулюють діяльність органів прокуратури, органів державної влади (органів місцевого самоврядування) в суді, міжнародні стандарти функціонування прокуратури поза межами кримінальної сфери, що сформульовані міжнародними установами Ради Європи (Консультативною радою європейських прокурорів, Європейським судом із прав людини). Такий системний аналіз дав змогу дійти висновку, що контроль над здійсненням суб'єктами владних повноважень своїх функцій передусім повинен покладатися на вищестоящі органи та їх керівництво, а не на прокуратуру, а тому діяльність прокурора з реалізації функції представництва інтересів держави у цивільному процесі повинна носити не контрольний, а допоміжний, субсидіарний характер. Оскільки органи державної влади (органи місцевого самоврядування) уповноважені законом самостійно звертатися до суду за захистом інтересів держави, це виключає можливість для органів прокуратури посилатися у заяві на факт відсутності органу, уповноваженого державою здійснювати відповідні функції у спірних правовідносинах, i, як наслідок, нівелює випадки набуття прокурором статусу позивача в суді. На підставі цього сформульовано пропозиції щодо вдосконалення процесуального законодавства та виключення другого речення абз. 2 ч. 5 ст. 56 Цивільного процесуального кодексу України такого змісту: «У разі відсутності такого органу або відсутності у нього повноважень щодо звернення до суду прокурор зазначає про це в позовній заяві, і в такому разі прокурор набуває статусу позивача» з тексту цього Кодексу.
\end{abstract}

Ключові слова: прокурор, представництво прокурором інтересів держави у цивільному процесі, набуття прокурором статусу позивача, орган, уповноважений державою здійснювати відповідні функції у спірних правовідносинах.

The article analyzes the peculiarities of the prosecutor's implementation of the constitutional function of representing the interests of the state in civil proceedings and the acquisition of the legal status of the plaintiff. Theoretical doctrines about the institute of the parties, conclusions of the Constitutional Court of Ukraine, practice of the Grand Chamber of the Supreme Court, normative acts of Ukraine regulating the activity of prosecutor's offices, state authorities (local self-government bodies) in court, international standards of functioning of the prosecutor's office outside the criminal sphere international institutions of the Council of Europe (Advisory Council of European Prosecutors, European Court of Human Rights). This systematic analysis led to the conclusion that control over the exercise of their powers by the subjects of power, in the first place, should rely on higher authorities and their leadership, not the prosecutor's office, and therefore the prosecutor's activities to represent the state in civil proceedings. should not be a control, but ancillary, subsidiary nature. As public authorities (local governments) are authorized by law to apply to the court to protect the interests of the state, this excludes the possibility for prosecutors to refer in the statement to the absence of a body authorized by the state to perform relevant functions in disputed legal relations, and as a result the prosecutor the status of the plaintiff in court. Based on this, proposals were formulated to improve the procedural legislation and exclude the second sentence of para. $2 \mathrm{~h}$. 5 st. 56 of the Civil Procedure Code of Ukraine reads as follows: "In the absence of such a body or lack of authority to apply to the court, the prosecutor indicates this in the statement of claim and in this case the prosecutor acquires the status of plaintiff", from the text of this Code.

Key words: prosecutor, representation by the prosecutor of the interests of the state in civil proceedings, acquisition by the prosecutor of the status of the plaintiff, the body authorized by the state to carry out the corresponding functions in disputable legal relations.

Згідно з ч. 4, 5 ст. 56 ЦПК України, прокурор, який звертається до суду в інтересах держави, у позовній чи іншій заяві, скарзі обгрунтовує, у чому полягає порушення інтересів держави, необхідність їх захисту, визначені законом підстави для звернення до суду прокурора, а також зазначає орган, уповноважений державою здійснювати відповідні функції у спірних правовідносинах. У такому разі зазначений орган набуває статусу позивача. У разі відсутності такого органу або відсутності у нього повноважень щодо звернення до суду прокурор зазначає про це в позовній заяві. і в такому разі прокурор набуває статусу позивача [1].

Указані положення кореспондуються 3 приписами абз. 1, 2 ч. 3 ст. 23 Закону України «Про прокуратуру», згідно 3 якими прокурор здійснює представництво в суді законних інтересів держави у разі порушення або загрози порушення інтересів держави, якщо захист цих інтересів не здійснює орган державної влади, орган місцевого самоврядування чи інший суб'єкт владних повноважень, до компетенції якого віднесено відповідні повноваження, а також у разі відсутності такого органу. Наявність таких обставин обгрунтовується прокурором у порядку, передбаченому частиною четвертою цієї статті [2].
Системний аналіз наведених законодавчих положень дає змогу дійти висновку, що прокурор під час здійснення представництва інтересів держави може виступати в суді у двох правових статусах. Так, якщо прокурор звернувся iз заявою до суду, а законом визначений орган державної влади, орган місцевого самоврядування, який у спірних правовідносинах уповноважений представляти інтереси держави в суді, то цей орган набуває статусу позивача, а прокурор діє в суді в особі цього органу. Коли законом не визначений такий орган або він не наділений повноваженнями щодо звернення до суду в інтересах держави, у такому разі прокурор, звертаючись із заявою до суду, сам набуває правового статусу позивача.

Передбачена законом можливість набуття прокурором правового статусу позивача є доволі дискусійним питанням процесуальної науки.

Зокрема, деякі вчені вважають, що прокурор у суді займає процесуальне становище позивача, адже за його заявою може бути порушена справа, він $є$ суб'єктом доказування та наділений правом брати участь у судових засіданнях, добиваючись задоволення заявлених вимог $[3$, c. $125 ; 4$, с. $104 ; 5$, с. 66]. Схожої точки зору дотримуються інші науковці. При цьому, розмежовуючи поняття сторони в процесуальному й матеріально-правовому розу- 
мінні, вони сходяться на думці, що прокурор, який звернувся до суду 3 позовом, $є$ «процесуальним позивачем». На обгрунтування цієї точки зору її прихильники зазначають, що хоча прокурор і не має матеріальної заінтересованості в результаті справи (на нього не поширюється сила судового рішення), по суті, він виконує всі основні функції позивача (обгрунтовує позов, дає пояснення за заявленим позовом, бере участь у судових дебатах) [6, с. $35 ; 7$, с. 85 ; 8 , с. $100 ; 9$, с. 52-53].

Із вищезазначеними судженнями науковців складно погодитися, адже під час визначення правового статусу прокурора в суді необхідно враховувати зміст та характер його юридичної заінтересованості та заінтересованості позивача. У них вона різна за змістом. Якщо у позивача заінтересованість має особистий матеріально-правовий характер, то заінтересованість прокурора носить лише процесуальний характер [10, с. 31] і полягає у прагненні останнього отримати позитивне рішення для суб'єкта (громадянина, держави), представництво інтересів якої він здійснює у суді. Прокурор не є учасником спірних матеріально-правових відносин, що виникають між сторонами і становлять предмет судового розгляду. На відміну від сторони рішення суду за позовом прокурора поширюється не на нього, а на особу, в інтересах якої була порушена справа, до того ж він звільняється від сплати судових витрат [11, с. 103-104]. Ось чому прокурора не можна ототожнювати зі стороною (позивачем) у процесі, як уважають деякі вчені. Не можна також погодитися 3 думкою тих науковців, які вважають прокурора «процесуальним позивачем» («позивачем у процесуальному розумінні»), тим самим розмежовуючи поняття сторони в процесуальному та матеріально-правовому розумінні. Як справедливо підкреслює С.Ю. Кац, неправильно ділити єдине поняття сторони на дві частини: сторона в матеріальному та сторона у процесуальному сенсі, адже така конструкція є штучною [12, с. 13]. Схожої точки зору дотримується і М.Й. Штефан, який пише: «Прокурор - не сторона у процесуальному розумінні, оскільки нашому праву невідомий поділ суб' єкта процесуальних правовідносин на дві частини: матеріальну і процесуальну. Така назва не розкриває правової природи участі прокурора у цивільному процесі» [13, с. 138].

Дійсно, не можна вважати прокурора «позивачем у процесуальному розумінні», оскільки таке визначення його правового статусу суперечить сталим ученням теоpiї процесуального права про сутність та ознаки таких ii інститутів, як позивач, відповідач, сторони, процесуальна співучасть тощо. Так, позивачем $є$ особа, яка звернулася до суду за захистом свого порушеного чи оспорюваного права або інтересу, чи особа, на захист прав якої порушена справа; відповідачем - особа, яка, на думку позивача, порушила чи оспорила його суб'єктивні права чи законні інтереси; сторонами - особи, правовий спір яких вирішується у суді, які мають юридичну заінтересованість у результатах справи, наділені комплексом процесуальних прав та обов'язків, необхідних для захисту своїх прав та інтересів, що охороняються законом, а також для здійснення судової діяльності [10, с. 30-32].

Набуття прокурором статусу позивача з підстав, передбачених процесуальним законодавством (ч. 5 ст. 56 ЦПК України), не кореспондується з тлумаченнями Конституційного Суду України, висловленими їм у п. 5 мотивувальної частини рішення № 3-рп/99 від 8 квітня 1999 р. (справа про представництво прокуратурою України інтересів держави в арбітражному суді), згідно 3 якими державу в суді представляють відповідні органи державної влади (місцевого самоврядування, яким законом надано повноваження органу виконавчої влади) в межах їх компетенції через свого представника. Останній фактично $\epsilon$ позивачем у справах, порушених за позовною заявою прокурора [14].
Проблема набуття прокурором правового статусу позивача $є$ актуальною не лише в науці, а й на практиці.

Показовою у цьому питанні $є$ правова позиція, висловлена Великою Палатою Верховного Суду (далі - ВПВС) 26 червня 2019 р. у справі № 587/430/16-ц за позовом заступника керівника Сумської місцевої прокуратури Сумської області до ГУ Держгеокадастру у Сумській області та ОСОБА 1 про визнання незаконними та скасування наказів про надання дозволу ОСОБА_1 на розроблення проєктів землеустрою щодо відведення земельних ділянок, визнання недійсним договору оренди цих ділянок, укладеного між відповідачами, та повернення їх у державну власність.

Звертаючись до суду у своїй позовній заяві, прокурор посилався, зокрема, на те, що у спірних правовідносинах відсутній орган, уповноважений державою здійснювати відповідні функції, а тому він $є$ позивачем у справі за вимогами до відповідачів. Ухвалою Сумського районного суд Сумської області, залишену без змін Апеляційним судом Сумської області, позовну заяву прокурора залишено без розгляду. В обгрунтування своїх висновків суди першої та апеляційної інстанцій посилалися на те, що Держгеокадастр України в особі голови на виконання повноважень у сфері розпорядження земельними ділянками сільськогосподарського призначення державної форми власності має право у позасудовому порядку скасувати повністю або частково акти головних управлінь, у тому числі ГУ Держгеокадастру у Сумській області. Прокурор лише формально вказав про відсутність органу, уповноваженого державою здійснювати відповідні функції у спірних правовідносинах, і не надав доказів на підтвердження цього факту. Тобто наявна невідповідність позовної заяви прокурора вимогам закону. Оскільки зазначені порушення були виявлені під час розгляду справи, а прокурор їх не усунув у ході розгляду справи, суд застосував наслідки, передбачені п. 8 ч. 1 ст. 207 ЦПК України в редакції до 15 грудня 2017 р. (п. 8 ч. 1 ст. 257 ЦПК України в чинній редакції), залишивши заяву без розгляду. Не погоджуючись 3 такими висновками судів першої та апеляційної інстанцій, прокурор звернувся 3 касаційною скаргою, вважаючи, що судами неправильно застосовані норми матеріального права та порушено норми процесуального права.

Дослідивши матеріали справи, ВПВС дійшла такого правового висновку про застосування норм права.

Прокурор, який звертається до суду в інтересах держави, у позовній заяві (заяві) самостійно визначає, у чому полягає порушення інтересів держави, та обгрунтовує необхідність їх захисту, а також зазначає орган, уповноважений державою здійснювати відповідні функції у спірних правовідносинах. У разі відсутності такого органу або відсутності у нього повноважень щодо звернення до суду прокурор зазначає про це в позовній заяві, і в такому разі прокурор набуває статусу позивача (абз. 2 ч. 2 ст. 45 ЦПК України у редакції, чинній до 15 грудня 2017 р.). Аналогічний припис закріплений у ч. 4 ст. 56 ЦПК України, чинному з 15 грудня 2017 p.

Оскільки повноваження органів влади, зокрема і щодо здійснення захисту законних інтересів держави, є законодавчо визначеними, суд, згідно з принципом jura novit curia («суд знає закони»), під час розгляду справи має самостійно перевірити доводи сторін щодо наявності чи відсутності повноважень органів влади здійснювати у спосіб, який вибрав прокурор, захист законних інтересів держави у спірних правовідносинах.

Якщо підставою для представництва інтересів держави прокурор зазначив відсутність органу, до компетенції якого віднесені повноваження здійснювати захист законних інтересів держави у спірних правовідносинах, цей довід прокурора суд повинен перевірити незалежно від того, чи надав прокурор докази вчинення ним дій, спрямованих на встановлення відповідного органу. Процедура, 
передбачена абз. 3 і 4 ч. 4 ст. 23 Закону України «Про прокуратуру» (щодо обов'язку прокурора попередньо, перед зверненням до суду, повідомити про це суб'єкта владних повноважень. - доповнено К.Г.) застосовується до встановлення наявності підстав для представництва інтересів держави в суді у разі, якщо захист законних інтересів держави не здійснює або неналежним чином здійснює суб `кт владних повноважень, до компетенції якого віднесені повноваження з такого захисту [15].

Аналізуючи вищенаведену правову позицію ВПВС, 3 деякими його положеннями важко погодитися. Так, формулюючи свій висновок, Суд зазначає, що у разі коли підставою для представництва інтересів держави прокурор зазначив відсутність органу, до компетенції якого віднесені повноваження здійснювати захист законних інтересів держави у спірних правовідносинах, цей довід прокурора повинен перевірятися судами незалежно від того, чи надав прокурор докази вчинення ним дій, спрямованих на встановлення відповідного органу.

Тобто ВПВС, по суті, допускає потенціальну можливість відкриття цивільної справи за наявності у позовній заяві прокурора лише вказівки на факт порушення державного інтересу та відсутність органу державної влади (відсутність у нього повноважень) для захисту порушених інтересів держави в суді у спірних правовідносинах без доведення цього факту, що, на нашу думку, не кореспондується 3 одним із конститутивних принципів цивільного процесу - принципом змагальності. Відповідно до загальних засад цього принципу, кожна сторона повинна довести ті обставини, які мають значення для справи і на які вона посилається як на підставу своїх вимог або заперечень, окрім випадків, встановлених Кодексом (ч. 3 ст. 12, ч. 1 ст. 81 ЦПК України). Це кореспондується 3 п. 5 ч. 3 ст. 175 ЦПК України, де передбачено, що позовна заява повинна містити виклад обставин, якими позивач обгрунтовує свої вимоги, а також зазначення доказів, що підтверджують вказані обставини. Із наведеного випливає, що в позовній заяві (заяві) прокурора, згідно з вимогами закону та принципом змагальності, мають бути зазначені докази на підтвердження підстав здійснення представництва, зокрема щодо відсутності органу, уповноваженого державою здійснювати функції захисту інтересів держави у спірних правовідносинах, або відсутності повноважень у останнього звертатися до суду з позовом (заявою), який подав прокурор. При цьому, незважаючи на зазначені у позовній заяві (заяві) доводи прокурора, суди самостійно повинні перевіряти наявність підстав для здійснення посадовими органами прокуратури представництва інтересів держави, а за відсутності таких повертати цю заяву відповідно до п. 4 ч. 3 ст. 41 ЦПК України.

Як уявляється, вищенаведені висновки ВПВС, за якими не виключається можливість відкриття цивільної справи за наявності у позовній заяві прокурора лише вказівки на факт порушення державного інтересу, а також на факт відсутності у спірних правовідносинах органу державної влади (органу місцевого), уповноваженого захищати законні інтереси держави у суді, без наведення 3 боку прокуратури доводів щодо цього йде врозріз не лише $з$ принципом змагальності, а й міжнародними стандартами функціонування прокуратури в суді поза межами кримінальної сфери, що сформульовані міжнародними установами.

Так, Консультативна рада європейських прокурорів у п. 34 Висновку № 3 (2008) від 21 жовтня 2008 р. закликала держави - члени Ради Свропи, де прокуратура виконує функції за межами сфери кримінального права, забезпечити їх реалізацію, зокрема, виходячи 3 того, що прокурори мають користуватися тими ж правами й обов'язками, як будь-яка інша сторона, і не повинні мати привілейоване становище у ході судових проваджень (рівність сторін позову) [16].
Європейський суд із прав людини (далі - ЄСПЛ) у своїй прецедентній практиці також наголошує на необхідності збереження принципу змагальності, коли у справі бере участь прокурор. Наприклад, у справі «Менчинська проти Російської Федерації» (заява № 42454/2) від 15 січня 2009 р., проаналізувавши відповідність дій прокурора положенням Конвенції, ЄСПЛ дійшов висновку, що у зв'язку з його вступом у судовий процес на стороні відповідача (Норильського центру зайнятості) був порушений принцип рівності сторін, який є складовим елементом права на справедливий судовий розгляд (§ 31$)$.

Діяльність прокуратури у суді повинна відповідати не лише змагальним засадам судочинства, а й мати виключний характер. Зокрема, ЄСПЛ у наведеному рішенні наголосив, що підтримка, яка надається прокуратурою одній зі сторін, може бути виправдана за певних обставин, наприклад під час захисту інтересів незахищених категорій громадян (дітей, осіб з обмеженими можливостями та інших категорій), які, ймовірно, не в змозі самостійно захищати свої інтереси, або в тих випадках, коли відповідним правопорушенням зачіпаються інтереси великого числа громадян, або у випадках, коли потрібно захистити інтереси держави (§ 35) [17].

У цьому аспекті слід зазначити, що контроль над здійсненням суб'єктами владних повноважень своїх функцій (так саме, як і оцінка їх діяльності) передусім повинен покладатися на вищестоящі органи та їх керівництво, а не на прокуратуру. При цьому підконтрольність означає, що всю діяльність органів або якийсь ії обсяг перевіряють вищі органи або орган, спеціально створений для здійснення контролю чи нагляду $[18$, с. 79$]$. А тому діяльність прокурора з реалізації функції представництва інтересів держави у цивільному процесі повинна носити не контрольний, а допоміжний, субсидіарний характер.

Крізь призму зазначеного підходу слід критично оцінити не лише проаналізовані висновки ВПВС, сформульовані у вищезгаданій постанові від 26 червня 2019 р. у справі № 587/430/16-ц, а й доводи прокуратури, яким суд касаційної інстанції не дав оцінки, а саме, що у спірних правовідносинах, які були предметом розгляду у зазначеній справі, відсутній орган, до компетенції якого віднесено повноваження здійснення захисту законних інтересів держави. Відповідним органом, як уявляється, повинна виступати Державна служба України з питань геодезії, картографії та кадастру (далі - Держгеокадастр).

Так, згідно 3 Положенням про Державну службу України з питань геодезії, картографії та кадастру, що затверджене Постановою Кабінету Міністрів України від 14 січня 2015 р. № 15 (далі - Положення), Держгеокадастр $\epsilon$ центральним органом виконавчої влади, діяльність якого спрямовується і координується Кабінетом Міністрів України через Міністра розвитку економіки, торгівлі та сільського господарства й який реалізує державну політику у сфері топографо-геодезичної і картографічної діяльності, земельних відносин, землеустрою, у сфері Державного земельного кадастру, державного нагляду (контролю) в агропромисловому комплексі в частині дотримання земельного законодавства, використання та охорони земель усіх категорій і форм власності, родючості грунтів (п. 1 Положення). При цьому контроль над здійсненням в апараті Держгеокадастру та його територіальних органах Конституції та законів України, актів Президента України, актів Кабінету Міністрів України та наказів Мінекономіки з питань, що належать до компетенції Держгеокадастру, здійснює його Голова (підп. 2 п. 11 Положення). Іншими словами, контроль над відповідністю актів територіальних органів Держгеокадастру законодавству України покладається саме на Держгеокадастр України в особі його Голови. Він вправі не лише в адміністративному, а й в судовому порядку реалізовувати свої повноваження, адже Держгеокадастр $є$ юридичною особою 
публічного права (п. 15 Положення), а посадові особи Держгеокадастру (у тому числі Голова. - доповнено К.Г.) та його територіальних органів мають право звертатися до суду з позовом щодо відшкодування втрат сільськогосподарського і лісогосподарського виробництва, а також повернення самовільно зайнятих чи тимчасово зайнятих земельних ділянок, строк користування якими закінчився (п. 5-1 Положення) [19].

Із вищенаведеного випливає, що судовий захист у сфері розпорядження земельними ділянками сільськогосподарського призначення державної форми власності, у тому числі незаконність актів територіальних органів Держгеокадастру, передусім повинен здійснюватися саме Держгеокадастром. Коли останній не усуває незаконність актів підпорядкованих йому територіальних органів в адміністративному чи судовому порядку, прокуратура вправі звернутися до суду з позовом в особі цього центрального органу державної влади. Тобто у справі № 587/430/16-ц, яка була предметом розгляду ВПВС, прокурору підлягало звертатися із заявою до суду в особі Держгеокадастру (позивач) до ГУ Держгеокадастру у Сумській області та ОСОБА_1, а не вказувати себе позивачем, обгрунтовуючи це відсутністю органу, уповноваженого державою здійснювати відповідні функції у спірних правовідносинах.

Продовжуючи аналіз проблеми набуття прокурором статусу позивача в цивільному процесі, слід звернути увагу на те, що в останній час внесено низку змін та доповнень до законодавчих актів України, якими розширені повноваження органів державної влади, органів місцевого самоврядування щодо права самостійного звернення до суду на виконання покладених законом функцій. Наприклад, згідно зі ст. $18^{1}$ Закону України «Про місцеве самоврядування в Україні», орган місцевого самовря- дування може бути позивачем та відповідачем у судах загальної юрисдикції, зокрема звертатися до суду, якщо це необхідно для реалізації його повноважень і забезпечення виконання функцій місцевого самоврядування»; У п. 5 ст. 28 Закону України «Про місцеві державні адміністрації» закріплюється право цих органів самостійно «звертатися до суду та здійснювати інші функції і повноваження у спосіб, передбачений Конституцією та законами України»; у ст. 28 Закон України «Про центральні органи виконавчої влади» передбачено, що міністерства, інші центральні органи виконавчої влади та їхні територіальні органи звертаються до суду, якщо це необхідно для здійснення їхніх повноважень у спосіб, що передбачений Конституцією та законами України.

Оскільки органи державної влади (органи місцевого самоврядування) уповноважені законом самостійно звертатися до суду за захистом інтересів держави, це виключає можливість для органів прокуратури посилатися в заяві на факт відсутності органу, уповноваженого державою здійснювати відповідні функції у спірних правовідносинах, i, як наслідок, нівелює випадки набуття прокурором статусу позивача у суді.

Ураховуючи проведений аналіз теоретичних учень про інститут сторін, практику ВПВС, міжнародні стандарти органів Р€ щодо функціонування прокуратури поза межами кримінальної сфери, зміст нормативних актів України, що регулюють діяльність органів прокуратури, органів державної влади (місцевого самоврядування) в суді, вважаємо, що друге речення абз. 2 ч. 5 ст. 56 ЦПК України «У разі відсутності такого органу або відсутності у нього повноважень щодо звернення до суду прокурор зазначає про це в позовній заяві, і в такому разі прокурор набуває статусу позивача» необхідно виключити з тексту цього Кодексу.

\section{ЛITEPATYPA}

1. Цивільний процесуальний кодекс України від 18 берез. 2004 р. № 1618-IV. Відомості Верховної Ради України. 2004. № $40-42$. Ст. 492.

2. Про прокуратуру : Закон України від 14 жовт. 2014 р. № 1697-VII. Відомості Верховної Ради України. 2015. № 2/3. Ст. 12.

3. Абрамов С.Н. Советский гражданский процесс : учебник. Москва : Юрид. лит., 1952. 419 с.

4. Щеглов В.Н. Субъекты судебного гражданского процесса. Томск, 1987. 128 с.

5. Марочкін І.Є. Прокуратура України: проблеми становлення й розвитку. Юрист України. 2011. № 2. С. 62-68.

6. Шакарян М.С. Субъекты советского гражданского процессуального права : автореф. дис. ... д-ра юрид. наук. Москва, 1970. 41 с.

7. Советский гражданский процесс : учебник / под ред. М.К. Треушникова. Москва : МГУ, 1989. 720 с.

8. Гражданский процесс : учебник / отв. ред. В.В. Ярков ; 7-е изд., перераб. и доп. Москва : Волтерс Клувер, 2009.784 с.

9. Бородін М. Участь прокурора в цивільному процесі: окремі аспекти. Право України. 1999. № 11. С. 52-54.

10. Комаров В.В., Радченко П.І. Суб'єкти цивільного процесуального права : курс лекцій. Харків : Юрид. ін-т, 1990. 52 с.

11. Цивільне процесуальне право України : підручник / за ред. В.В. Комарова. Харків : Право, 1999. 592 с.

12. Кац С.Ю. Участие прокуратуры в советском гражданском процессе : учебное пособие. Харьков : Юрид. ин-т, 1958. 64 с.

13. Штефан М.Й. Цивільне процесуальне право України: академічний курс : підручник. Київ : Ін Юре, 2005. 624 с.

14. Рішення Конституційного Суду України у справі за конституційними поданнями Вищого арбітражного суду України та Генеральної прокуратури України щодо офріційного тлумачення положень статті 2 Арбітражного процесуального кодексу України (справа про представництво прокуратурою України інтересів держави в арбітражному суді) : справа № 1-1/99, рішення № 3-рп/99 від 8 квіт. 1999 р. Конститучійний Суд України : офіц. вебсайт. URL : http://www.ccu.gov.ua/doccatalog/document?id=9327.

15. Постанова Великої Палати Верховного Суду : справа № 587/430/16-ц від 26 червня 2019 р. Єдиний державний реєстр судових рішень. URL : http ://www.reyestr.court.gov.ua/Review/84573553.

16. The role of prosecution ser vicer outside the criminal law field : Opinion № 3(2008) of the Consultative Council of European Prosecutors. Adopted by the CCPE at its 3rd plenary meeting (15-17 October 2008), Strasbourg, 21 October 2008 / Consultative Council of European Prosecutors. Council of Europe. URL : https://wcd.coe.int/wcd/com.instranet.InstraServlet?command=com.instranet.CmdBlobGet\&InstranetIma ge $=1608160 \&$ SecMode $=1 \&$ Docld $=1609216 \&$ Usage $=2$.

17. Дело «Менчинской против России» (заявление № 42454/02) : решение Европ. суда по правам человека от 15 янв. 2009 г. Платформа стратегической судебной защиты. URL : http://www.precedent.in.ua/index.php?id=1233046517.

18. Адміністративне право України : підручник / за ред. Ю.П. Битяка. Київ : Юрінком Інтер, 2005. 544 с.

19. Положення про Державну службу України з питань геодезії, картографії та кадастру : Постанова Кабінету Міністрів України № 15 від 14 січня 2015 р. Верховна Рада України : офіц. вебсайт. URL : https://zakon.rada.gov.ua/laws/show/15-2015-\%D0\%BF\#Text. 


\title{
ОСНОВНІ ПРИНЦИПИ НОТАРІАЛЬНОГО ПРОЦЕСУАЛЬНОГО ПРАВА УКРАЇНИ
}

\author{
BASIC PRINCIPLES OF NOTARIAL PROCEDURAL LAW OF UKRAINE
}

\author{
Долинська М.С., д.ю.н., професор, \\ завідувач кафедри господарсько-правових дисциплін \\ Львівський державний університет внутрішніх справ
}

Дослідження присвячено актуальним питанням правового регулювання провадження нотаріальної діяльності в Україні. У статті висвітлюється одне із центральних питань здійснення нотаріальної діяльності - поняття принципів нотаріального процесуального права. Автор розглядає основні критерії класифікації принципів нотаріального процесуального права.

Принципи нотаріального процесуального права - це основоположні засади, керівні ідеї та постулати, які виражені передусім у нормативно-правових актах та які випливають зі змісту правових норм, нотаріальної та судової практики, нотаріальних звичаїв, правової доктрини, а також судових прецедентів. Оскільки принципи нотаріального процесуального права реалізуються у нотаріальній процесуальній діяльності, то вони виступають не тільки принципами права, а й принципами нотаріального процесу, тобто провадження нотаріальної діяльності з учинення нотаріальних дій органами нотаріату. Дослідники нотаріату розглядають принципи нотаріального процесуального права саме як принципи нотаріального процесу, тобто ототожнюючи їх.

Значущість принципів нотаріального процесу полягає у тому, що певною мірою вони можуть застосовуватися як засіб урегулювання прогалин у нотаріальному процесуальному праві. Досліджено найбільш поширені класифрікації принципів нотаріального процесу. Проведено характеристику окремих принципів нотаріального процесуального права. Усі принципи нотаріального процесу пов'язані між собою та доповнюють один одного. Принципи нотаріального процесу коригуються та змінюються відповідно до зміни державної політики у сфері нотаріату. Причинами цього є відповідні зміни у державі, у правовому регулюванні нотаріальної діяльності. Автор стверджує, що відбувається розширення видів принципів нотаріального процесуального права.

Нотаріуси у своїй щоденній нотаріальній діяльності під час здійснення нотаріального процесу з учинення конкретних нотаріальних дій повинні дотримуватися вищевказаних принципів.

Ключові слова: принципи, законність, таємниця вчинення нотаріальних дій.

The research deals with the urgent issues of legal regulation of notarial activities in Ukraine. The article covers one of the central issues of notarial activities - the concept of principles of notarial procedural law. The author considers the main criteria for classifying the principles of notarial procedural law.

The principles of notarial procedural law are the basic principles, guiding ideas and postulates, which are expressed primarily in normative and legal acts, and follow from the content of legal norms, notarial and judicial practice, notarial customs, legal doctrine, and judicial precedents. Since the principles of notarial procedural law are implemented in notarial procedural activities, they are not only the principles of law, but also function as principles of the notarial procedure, i.e. notarial activities to perform notarial acts by notaries. Researchers of the notary examine the principles of notarial procedural law as the principles of notarial procedure, i.e. identifying them.

The significance of the principles of notarial procedure lies in the fact that they can be used as a means of resolving gaps in notarial procedural law. The most widespread classifications of the principles of the notarial procedure are studied. The author describes some principles of notarial procedural law. All the principles of the notarial procedure are interconnected and complementary. The principles of the notarial procedure are adjusted and modified in accordance with changes in state policy concerning notarial activities. The reasons for this are the corresponding changes in the state, in the legal regulation of notarial activities. The author argues that there is an extension of the types of principles of notarial procedural law.

Notaries in their daily notarial activities must adhere to the above principles in carrying out the notarial procedure to perform specific notarial acts.

Key words: principles, legality, secrecy of carrying out notarial acts.

Постановка проблеми. Загальновідомо, що без основних засад або принципів не може обійтися будь-яка держава. Також на принципах побудована правова система України, яка, своєю чергою, встановлює основні засади для діяльності органів нотаріату держави, які покликані надавати нотаріальні послуги та вчиняти нотаріальні дії 3 метою захисту прав та інтересів фізичних та юридичних осіб, держави.

Як правильно вказує I. Фріс [2, с. 121], значення принципів полягає, перш за все, в тому, що вони виступають «регулятором правозастосовної діяльності», у тому числі діяльності органів нотаріату, зокрема державних та приватних нотаріусів, під час учинення ними конкретних нотаріальних дій, тобто у нотаріальному процесі. Варто зауважити, що застосування конкретних процесуальних норм права нотаріусами можливе лише з урахуванням положень, які містяться у принципах нотаріально-процесуального права.

Це зумовлює потребу у дослідженні принципів нотаріального процесуального права, у тому числі поняття принципів, їх видів, а також характеристиці окремих принципів нотаріального процесу.

Стан опрацювання. Принципи нотаріального процесу зазвичай розглядаються у підручниках та посібниках iз нотаріального права та нотаріального процесу.

Зокрема, слід відзначити праці В. Комарова та В. Баранкової, Н. Горбань, М. Дякович, С. Фурси та Є. Фурси,
Л. Сміян та Ю. Нікітіна, І. Череватенко, а також багатьох інших.

Однак переважно розглядаються принципи нотаріальної діяльності та недостатньо приділено уваги принципам саме нотаріального процесуального права. Також недостатньо опрацьованим залишається питання розширення видів принципів нотаріального процесу у незалежній Україні.

Метою статті $є$ аналіз праць дослідників принципів нотаріального процесу, а також законодавчих актів, які регулюють нотаріальні процесуальні правовідносини.

Автор розглядає основні критерії класифікації принципів нотаріального процесуального права, а також характеризує окремі з них.

Виклад основного матеріалу. Нотаріальне процесуальне право $є$ сукупністю та системою правових норм, предметом регулювання яких виступають суспільні відносини у сфері здійснення нотаріальної діяльності, що визначають процесуальний порядок здійснення нотаріальних проваджень.

Предмет нотаріального процесуального права складається з таких основних частин (складників):

1. це система процесуальних дій, які виконують нотаріальні органи держави, у тому числі державні та приватні нотаріуси, а також учасники - суб'єкти нотаріального процесу; 
2. зміст та умови виконання процесуальних - нотаріальних дій (тобто нотаріальна форма укладення правочинів);

3. система цивільних процесуальних прав та обов'язків суб'єктів цивільно-нотаріальних правовідносин, які визначають зміст цивільно- нотаріальних процесуальних дій;

4. нотаріальні гарантії реалізації цивільних прав та обов'язків суб'єктів нотаріального процесу. Варто вказати, що законодавцем передбачено лише гарантії для нотаріусів у провадженні нотаріальної діяльності. При цьому головною гарантією для безпосередніх учасників нотаріального процесу $є$ право на оскарження нотаріальної дії або визнання вчиненої нотаріусом нотаріальної дії недійсною.

Принципи нотаріального процесуального права - це основоположні засади, керівні ідеї та постулати, які виражені, в першу чергу, в нормативно-правових актах та які випливають зі змісту правових норм, нотаріальної та судової практики, нотаріальних звичаїв, правової доктрини, а також судових прецедентів.

Принципи нотаріального процесуального права не тільки основа, а й підгрунтя цілої системи норм нотаріального процесуального права. Вони виступають основою норм, які регулюють порядок учинення нотаріальних дій нотаріальними органами України. Також принципи нотаріального процесуального права здебільшого закріплені у нормах права або випливають із них.

Оскільки принципи нотаріального процесуального права реалізуються у нотаріальній процесуальній діяльності, то вони виступають не тільки принципами права, а й принципами нотаріального процесу, тобто провадження нотаріальної діяльності з учинення нотаріальних дій органами нотаріату.

Варто вказати, що дослідники нотаріату переважно розглядають принципи нотаріального процесуального права саме як принципи нотаріального процесу, тобто ототожнюючи їх

Ми погоджуємося 3 думкою науковців, що принципи нотаріального процесу є складовою частиною принципів юридичного процесу, які, своєю чергою, є складовою частиною системи принципів українського права та які є об'єктивно зумовленими відносинами, які склалися у суспільстві.

Процесуальні принципи формуються у результаті вивіреної, аргументованої та обгрунтованої діяльності вповноважених суб'єктів, унаслідок пізнання закономірностей процесуальної діяльності. Вони слугують орієнтиром для сучасного процесуального законодавства, відображають тенденції розвитку юридичного процесу і виступають мірилом законності процесуальної діяльності уповноважених суб'єктів [2, с. 47]. Принципи процесу також визначають його сутність, зумовлюють мету та завдання як правореалізаційної, так і правотворчої, а також правоохоронної діяльності [3, с. 49].

Заслуговує на увагу думка I. Череватенко, яка стверджує, що класифікація принципів нотаріального процесу повинна мати два значення: наукове (тобто теоретичне) i, що головне, - практичне [4, с. 54].

Н. Горбань правильно стверджує, що принципи діють на всіх етапах учинення нотаріальних дій органами нотаpiaту, тобто нотаріального процесу, а також покликані відображати об'єктивні закономірності суспільного життя та, як правило, є закріпленими в нормах нотаріального та цивільного права або також випливають із чисельних правових норм [5].

На формування принципів нотаріального процесу впливають різні чинники, серед яких слід виділити вплив законодавства інших зарубіжних країн, особливо членів Міжнародного союзу нотаріату; узагальнення нотаріальної практики щодо вчинення нотаріальних дій; передовий досвід нотаріусів; судову практику, а також певні нові пропозиції, які роз- роблені спільно науковцями та практикуючими нотаріусами щодо поліпшення нотаріального процесу [5].

Варто вказати, що принципи нотаріального процесуального права $\epsilon$ невід'ємним складником цілої системи нотаріально-процесуальних правовідносин, які передусім спрямовані на реалізацію головних завдань нотаріальних органів - охорону, а також захист прав та свобод клієнтів, тобто осіб, які звертаються до них за отриманням нотаріальних послуг. Тому вказані принципи повинні відповідати принципам приватного права.

Принципи нотаріального процесуального права, як і принципи інших галузей права, можна поділити на декілька видів та за різними критеріями.

Аналізуючи праці дослідників принципів нотаріального процесу, варто вказати, що більшість учених, серед яких - В. Баранкова, В. Комарова, І. Череватенко, поділяє принципи нотаріального процесу за сферою поширення на дві або три великі групи.

Ми погоджуємося 3 авторами, що до першої групи класифікації відносяться загальноправові принципи нотаріального процесу, тобто принципи, які є характерними також для всіх інших галузей національного права.

На нашу думку, до другої групи принципів нотаріального процесу відносяться міжгалузеві принципи, які певною мірою $є$ загальними також із цивільним процесом.

До третьої групи відносяться галузеві принципи нотаріального процесу, оскільки вони характерні тільки для провадження нотаріальній діяльності (щодо вчинення нотаріальних дій) $[6$, с. 91; 4, с. 53].

Наступну класифікацію принципів нотаріального процесу науковці проводять за функціональною ознакою та виділяють дві основні групи [6, с. 91].

До першої групи відносяться принципи нотаріального процесу, які передбачають організацію нотаріальної діяльності як такої, без якої не відбувається, як наслідок, сам нотаріальний процес. Таким прикладом є принцип доступу до професії нотаріуса та принцип законності надання нотаріальних послуг

До другої групи відносяться принципи нотаріального процесу, які регулюють процес здійснення нотаріальної діяльності, тобто спосіб здійснення нотаріальних проваджень залежно від вчинюваної нотаріальної дії. До вказаних принципів, на нашу думку, варто віднести такі принципи: законності вчинення органами нотаріату нотаріальних дій; диспозитивності; принцип нотаріальної таємниці та ін.

Також принципи нотаріального процесу класифікують залежно від джерел їх закріплення. Ми погоджуємося з I. Череватенко, що така класифікація є однією з найбільш прийнятних.

До першої групи науковець відносить конституційні принципи. Дійсно, вказані конституційні принципи $€$ основою для правового регулювання нотаріальної діяльності загалом та нотаріального процесу зокрема. Ми погоджуємося з Н. Ільєвою, що необхідно поглиблювати зміст конституційних принципів [7, с. 120].

Аналізуючи норми Конституції України щодо принципів нотаріального процесу, I. Череватенко виділяє такі принципи: верховенства права (ст. 8 Конституції України); рівності громадян перед законом (ст. ст. 21-24 Конституції України); пріоритетності прав та свобод людини та громадянина (ст. 3 Конституції України) [4, с. 54].

До другої групи відносяться галузеві принципи, тобто такі засади, які знаходяться в нормативно-правових актах певних галузей права, згідно з якими закріплено певні вищевказані принципи.

Слід указати, що також у нотаріальному процесі $\epsilon$ принципи, які містяться у спеціальному нотаріальному процесуальному законодавстві та які, на нашу думку, варто віднести до третьої групи принципів нотаріального процесу. 
Аналізуючи праці дослідників нотаріальної діяльності як радянської України, так і сучасної незалежної України, у тому числі В. Баранкової, В. Комарова [8, с. 100], С. Фурси, основними засадами нотаріального процесу виступають принципи: законності; обгрунтованості нотаріальних актів; диспозитивності; безпосередності; державної мови нотаріального провадження; сприяння нотаріусів громадянам, установам та організаціям щодо здійснення реалізації їхніх цивільних прав; таємниці вчинення нотаріальних дій.

Дещо іншу класифікацію принципів нотаріального процесу пропонує С. Фурса, яка здійснює поділ залежно від того, чи можуть бути вказані принципи використаними в «інших галузях права», на загальні та спеціальні.

До загальних принципів нотаріального процесу авторка відносить принципи: законності; доступності та гарантованості охорони і захисту безспірних прав як фізичних, так і юридичних осіб, які звертаються до нотаріальних органів; національної мови; сприяння фізичним та юридичним особам у здійсненні прав та інтересів, охоронюваних законом; обгрунтованості нотаріальних актів; диспозитивності.

До спеціальних принципів нотаріального процесу науковцем віднесено принципи: незалежності нотаріусів, безспірності нотаріального процесу, неупередженості нотаріусів, рівності «прав» всіх суб'єктів нотаріального процесу; нотаріальної таємниці, безпосередності, одноосібного прийняття рішення нотаріусом щодо вчинення конкретної нотаріальної дії [9, с. 105-106].

В останні роки відбувається розширення видів принципів нотаріального процесуального права. Так, новим принципом стає принцип діджиталізації, який набуває все більшого поширення та спрямовує до створення в Україні «електронного нотаріату». На нашу думку, відправним пунктом у запровадженні діджиталізації нотаріального процесу в державі слід уважати прийняття Наказу Міністерства юстиції України від 12 серпня 1996 р. № 21/5 «Про внесення доповнень до Інструкції про порядок вчинення нотаріальних дій нотаріусами України», яким 31 жовтня 1996 р. було запроваджено вчинення певних нотаріальних дій на спеціальних бланках нотаріальних документів. Діяльність сучасних українських державних та приватних нотаріусів є неможливою без використання системи єдиних реєстрів України. Так, нотаріуси у провадженні нотаріального процесу щонайперше використовують єдині та державні реєстри інформаційної системи Міністерства юстиції України [10, с. 180-185].

Результатом нотаріальної діяльності виступають нотаріальні акти, які повинні складатися та посвідчуватися нотаріусами відповідно до чинного українського законодавства. Тому головним у провадженні нотаріальної діяльності, на нашу думку, а також на думку більшості дослідників нотаріального процесу, виступає принцип законності. На думку деяких із них, принцип законності у нотаріальному процесі $€$ принципом верховенства права, оскільки цей принцип закріплений у ст. 8 Конституції України. Так, С. Фурса та С. Фурса стверджують, що «принцип верховенства права - це принцип верховенства закону», що також визначає співвідношення закону та інших нормативно-правових актів [11, с. 69].

Таким чином, законодавство, яке регулює нотаріальний процес в Україні, повинно не лише прийматися на підставі Конституції України, а й відповідати вказаній Конституції.

Нагадаємо, що норми вказаного Основного Закону України $є$ нормами прямої дії, зокрема щодо діяльності нотаріальних органів держави та щодо нотаріального процесу зокрема.

Н. Горбань зауважує, що принцип верховенства права не лише «не відображено у ЗУ «Про нотаріат» та пропонує його «відтворити» у вищевказаному законодавчому акті. Має рацію автор, стверджуючи, що процес реалізації принципів нотаріального процесу дійсно має бути узгоджений зі специфікою самої «реалізації принципу верховенства права» [5].

Принцип законності у провадженні нотаріального процесу в Україні, на нашу думку, необхідно розглядати 3 трьох боків.

По-перше, це принцип законності надання нотаріальних послуг, тобто нотаріальні органи повинні здійснювати тільки ті нотаріальні дії, які передбачені чинним законодавством України, зокрема Цивільним кодексом України, Законом України «Про нотаріат», та не виходити за межі своїх повноважень. Зокрема, це стосується випадків учинення нотаріальних дій приватними нотаріусами, діяльність яких призупинена відповідно до чинного законодавства.

По-друге, провадження нотаріального процесу як нотаріусами, так і іншими квазінотаріальними органами здійснюється у правовому полі держави, тобто вчинені нотаріальні дії повинні відповідати чинному законодавству України, а в певних випадках і законодавству інших держав.

По-третє, не тільки органи, що уповноважені вчиняти нотаріальні дії повинні дотримуватися норм законодавства, такий самий обов'язок лежить і на тих фізичних особах - представниках юридичних осіб та держави, які звертаються до нотаріальних органів за вчиненням нотаріальних дій. На це зокрема, вказують норми ст. 2 Закону України «Про нотаріат», у якій наголошено, що правовою основою діяльності нотаріату в державі $€$ Конституція України, Закон України «Про нотаріат», а також інші законодавчі акти України.

На дотримання нотаріусами принципу законності під час учинення нотаріальних дій законодавцем наголошено у Законі України «Про нотаріат» (ст. ст. 5, 7, 21, 39, 47, 49-51).

Правовою гарантією реалізації принципу законності у нотаріальному процесі $є$ право (відповідно до ст. 50 Закону України «Про нотаріат») на оскарження нотаріальної дії або відмови у її вчиненні.

Принцип обгрунтованості нотаріальних актів вимагає, щоб вчинювані нотаріальні дії здійснювалися нотаріальними органами, зокрема нотаріусами, тільки на підставі дійсних обставин, що підтверджуються документами та відомостями. Наприклад, доказом спадково-родинних відносин має бути підтверджений документально на підставі не лише свідоцтва про державну реєстрацію смерті спадкодавця, а ще й свідоцтва про державну реєстрацію народження дочки померлого, свідоцтва про державну реєстрацію ії шлюбу (у разі зміни прізвища), виданих державними органами реєстрації актів цивільного стану, або витяг iз Державного реєстру актів цивільного стану громадян, який безпосередньо отримується нотаріусом, який учиняє нотаріальну дію. Принцип обгрунтованості закріплено у ст. ст. $42,46,47,54,55$. Закону України «Про нотаріат».

Принцип рівності перед законом під час здійснення нотаріальної діяльності, перш за все, встановлений у ст. 24 Конституції України, де передбачено рівність усіх перед законом. Тобто кожна особа, яка звернулася до нотаріальних органів за вчиненням нотаріальних дій, не повинна мати привілеїв за будь-якими ознаками, зокрема щодо політичних, релігійних переконань, майнового стану, місця проживання та ін.

Варто вказати на те, що принцип рівності перед законом поширюється також на нотаріусів незалежно від того, чи вони є державними, чи займаються приватною нотаріальною практикою. Про це наголошено законодавцем у статті 1 Закону України «Про нотаріат», де зазначено, що документи, оформлені державними і приватними нотаріусами, мають однакову юридичну силу.

Мають рацію С. Фурса та Є. Фурси, що нотаріус не має жодних переваг порівняно із суб'єктами нотаріаль- 
ного процесу, оскільки нотаріус є особою, яка покликана за законом (ст. 5 Закону України «Про нотаріат», так і за присягою) до вчинення нотаріальних дій та сприяння громадянам у вчиненні нотаріальних дій [11, с. 79].

Принцип диспозитивності в нотаріальному процесі полягає у тому, що тільки за зверненням певної особи починається та відбувається нотаріальне провадження. Як правило, нотаріальні органи вчиняють нотаріальні дії тільки за наявності письмової чи усної заяви такої особи, хоча законодавцем встановлено випадки, які передбачені законом, коли нотаріальні дії можуть відбуватися за ініціативою нотаріусів чи інших осіб. Прикладом винятку $\epsilon$ вжиття нотаріусами заходів щодо охорони спадкового майна (ст. 60 Закону України «Про нотаріат»).

Принцип безпосередності передбачає, що під час учинення нотаріальних дій повинні бути присутніми всі учасники правочинів та не допускається вчинення нотаріальної дії нотаріусами у разі відсутності ії учасників або їхніх уповноважених представників. Також нотаріуси зобов'язані: встановити особу учасників цивільних відносин та перевірити дійсність і законність пред'явлених документів, а за посвідчення правочинів перевірити справжність підписів учасників правочинів та інших осіб, які звернулися до нього.

Принцип сприяння громадянам, підприємствам, установам та організаціям у здійсненні їхніх прав і законних інтересів на практиці реалізується відповідно до ст. 5 Закону України «Про нотаріат» шляхом виконання нотаріусами обов'язку щодо роз'яснення прав та обов'язків учасників правочину, а також попередження ними суб'єктів нотаріального процесу про наслідки вчинюваних нотаріальних дій для того, щоб юридична необізнаність не могла бути використана їм на шкоду.

Ми погоджуємося 3 думкою науковців та практиків, що принцип таємниці вчинення нотаріальних дій найкраще відображає специфіку провадження нотаріальної діяльності нотаріальними органами держави.

Законодавець установлює, що нотаріальна таємниця $\epsilon$ сукупністю відомостей, які отримані під час учинення нотаріальних дій або у разі звернення до нотаріуса за нотаріальною консультацією зацікавленої особи, у тому числі щодо самої особи, її майна, а також щодо особистих майнових та немайнових права та обов'язків і т. д.

Про важливість даного принципу вказує те, що законодавцем до обов'язків нотаріуса відноситься збереження в таємниці відомостей, які одержані ним у зв'язку з учиненням нотаріальних дій. Окрім цього, даючи нотаріальну присягу, особа, якій уперше надано право займатися нотаріальною діяльністю, присягає зберігати професійну таємницю [12, с. 167-168].

Висновки. Принципи нотаріального процесуального права - це основоположні засади, керівні ідеї та постулати, які виражені передусім у нормативно-правових актах та які випливають зі змісту правових норм, нотаріальної та судової практики, нотаріальних звичаїв, правової доктрини, а також судових прецедентів.

Дослідники нотаріату розглядають принципи нотаріального процесуального права саме як принципи нотаріального процесу, тобто ототожнюючи їх.

Значущість принципів нотаріального процесу полягає у тому, що певною мірою принципи можуть застосовуватися як засіб урегулювання прогалин у нотаріальному процесуальному праві.

Вищевказаний перелік принципів нотаріального-процесуального права не можна вважати вичерпним.

Усі принципи нотаріального процесу пов'язані між собою та доповнюють один одного.

Принципи нотаріального процесу коригуються та змінюються відповідно до зміни державної політики у сфері нотаріату. Причинами цього є відповідні зміни у державі, у правовому регулюванні нотаріальної діяльності.

Нотаріуси у своїй щоденній нотаріальній діяльності під час здійснення нотаріального процесу з учинення конкретних нотаріальних дій повинні дотримуватися вищевказаних принципів.

Подальші розвідки полягатимуть у більш детальній характеристиці конкретних принципів нотаріального процесуального права.

\section{ЛITEPATУРA}

1. Фріс І.П. До питання про принципи діяльності нотаріату в Україні. Актуальні проблеми вдосконалення чинного законодавства України. 2010. Вип. 22. С. 121-124.

2. Слинько Д.В. Юридичний процес: історія, теорія, практика : монографія. Харків : НТМТ, 2017. 415 с.

3. Слинько Д.В. Загальні принципи юридичного процесу. Порівняльно-аналітичне право. 2019. № 1. С. 49-53.

4. Череватенко І. Принципи безпосередності та диспозитивності у нотаріальному провадженні щодо посвідчення безспірних прав. Підприємництво, господарство і право. 2016. № 11. С. 53-57.

5. Горбань Н.С. Принципи нотаріального процесу в Україні : автореф. дис. ... канд. юрид. наук : 12.00 .03 ; Київський нац. ун-т ім. Т. Шевченка. Київ, 2014. 21 c. URL : https://mydisser.com/ua/avtoref/view/29073.html (дата звернення: 22.06.2020).

6. Комаров В.В., Баранкова В.В. Нотариат и нотариальный процесс : учебник. Харьков : Консум, 1999. 240 с.

7. Ільєва Н.В. Принципи нотаріальної діяльності в Україні. Вісник ОНУ ім. I.І. Мечнікова. Правознавство. 2014. Вип. 1(22). T. 19. C. $116-122$

8. Комаров В.В., Баранкова В.В. Нотаріат в Україні : підручник. Харків : Право, 2011. 384 с.

9. Фурса С.Я. Теоретичні основи нотаріального процесу в Україні : дис. ... д-ра юрид. наук : 12.00 .03 ; Ін-т держави і права ім. В.М. Корецького НАН України. Київ, 2003. 426 с.

10. Долинська М.С. Зародження діджиталізації нотаріальної діяльності в Україні. Теоретико-прикладні проблеми правового регулювання в Україні : збірник матеріалів наук.-практ. конф., м. Львів, 6 грудня 2019 р. / за заг. ред. І.В. Красницького. Львів : ЛьвДУВС, 2019. С. $180-185$.

11. Фурса С.Я., Фурса Є.І. Нотаріат в Україні. Теорія і практика : навчальний посібник. Київ, 2001. 975 с.

12. Долинська М.С. Нотаріат : підручник. Львів : Ліга-Прес. 398 с. 


\title{
ДОКАЗИ ТА ДОКАЗУВАННЯ У СПРАВАХ ПРО ВИДАЧУ ОБМЕЖУВАЛЬНОГО ПРИПИСУ В ОКРЕМОМУ ПРОВАДЖЕННІ: АНАЛІЗ СУДОВОЇ ПРАКТИКИ
}

\author{
EVIDENCE AND PROOF IN CASES OF ISSUANCE OF A RESTRAINING ORDER \\ IN A SEPARATE PROCEEDING: ANALYSIS OF CASE LAW
}

Кияшко О.О., аспірант кафедри цивільного процесу

Національний університет «Одеська юридична академія»

\begin{abstract}
Статтю присвячено дослідженню та оцінці доказів, на підставі котрих суд приймає рішення про видачу обмежувального припису в порядку окремого провадження. Важливість цього питання полягає в ефективному захисті постраждалої від домашнього насильства особи своїх прав та інтересів шляхом покладення тимчасових обмежень на особу, яка вчинила домашнє насильство. Водночас на практиці виникають певні проблемні питання: як саме потерпіла особа повинна довести наявність психологічного, економічного, сексуального або фізичного насильства; на підставі яких доказів суд може дійти висновку про підвищену ймовірність продовження або повторного вчинення домашнього насильства, настання тяжких або особливо тяжких наслідків його вчинення, зокрема смерті постраждалої особи; чи є відомості, внесені до Єдиного реєстру досудових розслідувань про наявність кримінального правопорушення щодо особи, яка підозрюється у вчинені домашнього насильства, достатнім доказом для визнання такої особи кривдником; які саме докази на підтвердження вчинення домашнього насильства слід відносити до беззаперечних у розумінні Закону України «Про запобігання та протидію домашньому насильству» тощо.

Аналізуючи судову практику, можна дійти висновку, що в більшості судових рішень у цій категорії справ суд відмовляє заявнику у видачі обмежувального припису з огляду на відсутність причинно-наслідкового зв'язку між наслідками, на які вказує потерпіла особа, та діями самого кривдника. Крім того, суд може дійти висновку, що подані заявником докази підтверджують інші обставини, аніж ті, які підтверджують факт скоєння акту домашнього насильства, а саме наявність правого спору між особами. У такому випадку суд відмовляє заявнику у видачі обмежувального припису та наголошує, що їхній спір повинен вирішуватися у порядку позовного провадження. Отже, з урахуванням усього вищесказаного вбачається, що питання доказування постраждалою особою факту скоєння щодо неї акту домашнього насильства є досить проблематичною та актуальною темою.
\end{abstract}

Ключові слова: обмежувальний припис, кривдник, постраждала особа, домашнє насильство, докази, окреме провадження, судова практика.

The article is devoted to the study and evaluation of evidence on the basis of which the court decides to issue a restrictive order in a separate proceeding. The importance of this issue is to effectively protect the victim of domestic violence from their rights and interests by imposing temporary restrictions on the perpetrator of domestic violence. At the same time, in practice, the following problematic issues arise: how exactly should the victim prove the existence of psychological, economic, sexual or physical violence; on the basis of which evidence the court may conclude that there is an increased likelihood of continuation or recurrence of domestic violence, the occurrence of severe or particularly severe consequences of its commission, including the death of the victim; whether the information entered in the Unified Register of Pre-trial Investigations on the existence of a criminal offense against a person suspected of committing domestic violence is sufficient evidence to recognize such a person as an offender; what evidence to prove the commission of domestic violence should be considered indisputable in the sense of the Law of Ukraine "On Prevention and Counteraction to Domestic Violence", etc.

Analyzing the case law, it can be concluded that in most court decisions in this category of cases, the court refuses to issue a restrictive order to the applicant due to the lack of causal link between the consequences indicated by the victim and the offender's actions. In addition, the court may conclude that the evidence submitted by the applicant confirms circumstances other than those confirming the fact of the act of domestic violence, namely the existence of a legal dispute between the persons. In this case, the court refuses to issue a restrictive injunction to the applicant and emphasizes that their dispute must be resolved through legal proceedings. Thus, taking into account all the above, it is seen that the issue of proving by the victim the fact of committing an act of domestic violence against him is a very problematic and relevant topic.

Key words: restrictive order, offender, victim, domestic violence, evidence, separate proceedings, court practice.

Аналізуючи судову практику 3 розгляду цивільних справ щодо видачі обмежувального припису, вбачається, що заявники у своїх заявах не приділяють достатньої уваги доказам, що подаються, та обставинам, які вони можуть підтвердити.

Так, у справі № 264/6635/18 ОСОБА 1 у своїй заяві просила суд видати обмежувальний припис щодо ії чоловіка, який, на ii думку, вчиняв фізичне, психологічне, а також фінансове насильство відносно неї та їхніх спільних малолітніх дітей. На підтвердження своїх вимог заявник надала до суду довідки щодо наявності в її чоловіка заборгованості зі сплати аліментів на утримання дітей, витяг з Сдиного реєстру досудових розслідувань щодо відкриття за її заявою кримінального провадження відносно свого чоловіка, а також витяг з Сдиного реєстру досудових розслідувань про початок кримінального провадження відносно власного чоловіка за ст. 286 ч. 1 КК України (порушення правил безпеки дорожнього руху). Дослідивши всі надані заявником докази, суд дійшов висновку, що жоден із зазначених вище доказів не підтверджує факт вчинення чоловіком заявниці фізичного, психологічного, а також фінансового насильства відносно неї чи їхніх спільних малолітніх дітей, а також ризиків настання насильства в майбутньому. Навпаки, суд встановив наявність конфлікту між сторонами, відсутність бажання знайти компроміс та домовитись в інтересах малолітніх дітей, а отже, цей спір повинен вирішуватися в порядку позовного провадження [3].

Аналогічний висновок міститься в рішенні Тернопільського міськрайонного суду від 10.09.2018 року у справі № 607/15990/18. Оцінюючи письмові докази, долучені заявником, висновки про результати розгляду ії звернень до правоохоронних органів від 23.07.2015 року, 10.03.2016 року, 02.09.2016 року, висновок про результати розгляду звернення лікаря ОСОБА_6 від 02 березня 2016 року, лист начальника Тернопільського МВ УМВС в Тернопільській області від 28.07.2015 року, листи начальника Тернопільського відділу поліції ГУНП в Тернопільській області від 11.03.2016 року, 02.09.2016 року, 02.03.2018 року, 07.03.2018 року, 02.05.2018 року як підтвердження звернення до працівників поліції з приводу застосування до неї зі сторони ОСОБА_3 психологічного та фізичного насильства, суд дійшов висновку, що самі по собі такі висновки та листи не можуть підтвердити факт 
застосування такого насильства. Заявником не долучено матеріалів у підтвердження факту притягнення іії чоловіка до адміністративної відповідальності за ст. 173-2 КУпАП, а отже, не доведено, що він $є$ кривдником своєї дружини. 3 урахуванням цих обставин суд не має правових підстав для видачі заявнику обмежувального припису [4].

У рішенні Київського районного суду м. Одеси від 05.04.2018 року у справі № 520/3921/18 судом було відмовленов задоволеннізаяви, хочазаявником було надано витяги 3 реєстру досудових розслідувань кримінального провадження № 12018161480000393 та № 12018161480000447. Суд не прийняв до уваги ці обставини, оскільки наявність таких відомостей не є доказом вини ОСОБА_1 у вчиненні кримінальних правопорушень, ураховуючи, що особа вважається невинуватою у вчиненні злочину і не може бути піддана кримінальному покаранню, доки іiі вину не буде доведено в законному порядку і встановлено обвинувальним вироком суду. Отже, зазначені вище докази не відносяться до предмету спору, й наведені обставини не є підставою для застосування обмежувального припису [5].

Цікавим є рішення Київського районного суду м. Харкова від 28.12.2018 року у справі № 640/23804/18, який відмовив заявнику у видачі обмежувального припису. Так, суд зазначив, що факт негативного ставлення дітей до батька, небажання зустрічей 3 ними не с достатньою підставою для видачі обмежувального припису [6]. У цьому випадку виникає питання: чи є зазначені вище обставини наслідком вчинення психологічного насильства 3 боку одного з батьків? Якщо так, чи є покази дітей достатнім та належним доказом, на підставі котрого суд прийме рішення про видачу обмежувального припису? Вважаємо, що таких доказів недостатньо, оскільки вони повинні доповнюватися щонайменш психологічним висновком експерта або висновком органів опіки та піклування щодо умов життя і виховання дитини.

У своєму рішенні Жовківський районний суд Львівської області від 12 грудня 2018 року в справі № 444/3602/18 також відмовив заявнику щодо видачі обмежувального припису у зв'язку з недоведеністю факту скоєння акту домашнього насильства зазначеними особами. Так, заявник надала до суду інформацію, що тривалий час проживає сумісно із власним сином, який систематично скоює по відношенню до неї фізичне насильство. На підтвердження своїх показів заявник надала до суду:

- інформацію про неодноразове звернення до місцевоі поліції, яка неодноразово проводила перевірку за адресою заявника та виносила офіційне попередження іiї сину про недопустимість вчинення ним насильства в сім'ї;

- висновок експерта, який підтверджує отримання тяжких тілесних ушкоджень;

- висновок експерта про отримання нових тяжких тілесних ушкоджень, що підтверджує систематичність побоїв заявника.

Дослідивши ці матеріали, суд дійшов висновку, що жоден із наданих заявником доказів не підтверджує той факт, що фізичне насильство по відношенню до заявника було скоєно саме іії сином, а отже, немає підстав для видачи обмежувального припису. Крім цього, офіційні попередження, які надавала місцева поліція її сину, не беруться до уваги, оскільки факт скоєння домашнього насильства має бути підтверджений постановою про адміністративні правопорушення за ст. 173-2 Кодексу України про адміністративні правопорушення [7]. Однак виникає питання щодо оцінки судом ризиків настання актів домашнього насильства. Як вбачається 3 матеріалів справи, заявник надала декілька доказів, які підтверджують систематичне отримання побоїв (фізичне насильство) та необхідність виклику поліції (психологічне насильство). Зважаючи на цей факт та на наявні складнощі в заявника похилого віку іншим чином довести причетність власного сина у вчиненні актів домашнього насильства, рішення суду вида- ється доволі спірним і таким, що не відповідає загальним засадам ЗУ «Про запобігання та протидію домашньому насильству», зокрема положенням статі 4 цього Закону щодо: гарантування постраждалим особам права безпеки; належної уваги до кожного факту домашнього насильства під час здійснення заходів у сфері запобігання та протидії домашньому насильству; врахування особливих потреб та інтересів постраждалих осіб, зокрема осіб з інвалідністю, вагітних жінок, дітей, недієздатних осіб, осіб похилого віку.

У своєму рішенні у справі 756/2072/18 Верховний Суд дійшов висновку, що обмежувальний припис $є$ заходом впливу на кривдника, який може вживатися лише в інтересах постраждалих осіб та у разі настання певних факторів і ризиків. Таким чином, заявник повинен довести наявність випадків домашнього насильства стосовно нього, а також ризики настання насильства в майбутньому. За відсутності доведеності одного із зазначених вище компонентів суд не має можливості задовільнити заяву заявника та видати обмежувальний припис щодо його кривдника [8]. При цьому суд не прийняв до уваги такі докази:

- наявність відомостей про внесення до Єдиного реєстру досудових розслідувань за зверненням заявника про наявність у діях «кривдника» складу кримінального правопорушення, оскільки наявність таких відомостей не $\epsilon$ доказом вини цієї особи у вчиненні кримінальних правопорушень 3 урахуванням тих обставин, що особа вважається невинуватою у вчиненні злочину і не може бути піддана кримінальному покаранню, доки іiі вину не буде доведено в законному порядку і встановлено обвинувальним вироком суду;

- копії довідок про захворювання дітей на ГРВI, оскільки не встановлений причинно-наслідковий зв'язок між діями «кривдника» та наслідком у формі захворювання;

- протоколи психологічних досліджень дітей заявника, інформаційна довідка за результатами роботи психолога 3 дітьми також не були прийняті судом, оскільки вони підтверджують лише факт наявності конфліктних відносин між батьками, проте не підтверджують конкретних фактів учинення особою актів домашнього насильства;

- подання позову про розірвання шлюбу або свідоцтво про розірвання шлюбу також не може свідчити про вчинення особою насильства в сім'ї.

Крім цього, Верховний суд погодився 3 висновками Апеляційного суду, який у свою чергу не погодився з доводами апеляційної скарги щодо неналежного дослідження судом першої інстанції наявних у матеріалах справи відеозаписів та фотокартки, оскільки заявник не зазначив, на підтвердження яких саме обставин нею були подані подібні докази.

Підсумовуючи все вищесказане, вбачається, що належним та достатнім доказом, на підставі якого суд може встановити наявність випадків учинення домашнього насильства, є саме постанова адміністративного суду про притягнення кривдника до відповідальності за ст. 173-2 КУПАП. У свою чергу немає чіткої відповіді щодо належної та достатньої доказової бази, на підставі якої суд може встановити високу ймовірність продовження чи повторного вчинення домашнього насильства, настання тяжких або особливо тяжких наслідків його вчинення, а також смерті постраждалої особи. Не зрозуміло, яким чином особа повинна доводити наявність психологічного насильства в сім’ї, а також причинно-наслідковий зв'язок між наслідками та діями заінтересованої особи, якщо висновок психолога або спеціалізованої установи не може містити подібні дані. Як вбачається із судової практики, заявник повинен надати всі наявні в нього докази, зокрема покази свідків, свідчення працівників поліції, які приймали виклик від заявника тощо, на підставі яких суд зможе оцінити ризики настання насильства в майбутньому на користь заявника. 


\section{ЛITEPATУРA}

1. Цивільний процесуальний кодекс України : Закон України від 18.03.2004 р. № 1618-IV (зі змінами). URL: http://zakon4.rada.gov.ua/ laws/show/1618?test=XX7MfyrCSgkyy6IIZiCSwOJHI4 AMs80msh8le6

2. Про запобігання та протидію домашньому насильству : Закон України від 07.12.2017 року № 2229-VIII. Відомості Верховної Ради України. 2018. 02.02. № 5. С. 32. Ст. 35.

3. Рішення Іллічівського районного суду м. Маріуполя від 27 листопада 2018 року № 264/6635/18. URL: http://www.reyestr.court.gov.ua/ Review/78182823

4. Рішення Тернопільського міськрайонного суду від 10.09.2018 року по справі № 607/15990/18. URL: http://www.reyestr.court.gov.ua/ Review/76373600

5. Рішення Київського районного суду м. Одеси від 05.04.2018 року по справі № 520/3921/18. URL: http://www.reyestr.court.gov.ua/ Review/73399598

6. Рішення Київського районного суду м. Харкова від 28.12.2018 року у справі № 640/23804/18. URL: http://www.reyestr.court.gov.ua/ Review/78882798

7. Рішення Жовківського районного суду Львівської області від 12 грудня 2018 року по справі № 444/3602/18. URL: http://www.reyestr.court.gov.ua/Review/78498854

8. Рішення Верховного Суду від 04.12.2018 року по справі № 756/2072/18. URL: http://www.reyestr.court.gov.ua/Review/78267811 


\title{
НЕУСТОЙКА ЯК СПОСІБ ЗАБЕЗПЕЧЕННЯ ВИКОНАННЯ ДОГОВІРНИХ ЗОБОВ'ЯЗАНЬ: ОКРЕМІ АСПЕКТИ ЗАСТОСУВАННЯ
}

\author{
PENALTY AS A WAY TO ENSURE THE FULFILLMENT \\ OF CONTRACTUAL OBLIGATIONS: SOME ASPECTS OF APPLICATION
}

\author{
Кулібаба О.О., юрист \\ Адвокатське об' $є$ днання «Капітал Правіс»
}

\begin{abstract}
Статтю присвячено дослідженню особливостей правової природи неустойки як способу забезпечення виконання договірних зобов'язань. Обґрунтовується позиція щодо неоднозначності трактування правової природи неустойки в юридичній літературі та законодавстві. Розкриваються відмінності застосування неустойки в договірних зобов'язаннях у цивільному та господарському праві, враховуючи судову практику з цього питання.

Звертається увага, що під час визначення правової природи неустойки більшість науковців визначають її як спосіб забезпечення виконання зобов'язань або визнають подвійну природу неустойки. Крім того, зазначається, що неустойка може бути одночасно і способом забезпечення виконання договірних зобов'язань, і мірою та способом відповідальності під час виконання зобов'язань. Але при цьому є обґрунтування, що неустойка належить до видів штрафних санкцій, міри, виду відповідальності за невиконання або неналежне виконання договірних зобов'язань і ніяк не може бути способом забезпечення виконання зобов'язань.

На підставі аналізу судової практики автором обґрунтовується позиція, що в господарському праві, на відміну від цивільного права, правову природу неустойки здебільшого розглядають як міру відповідальності, а не як спосіб забезпечення виконання договірних зобов'язань. Саме тому $є$ неоднозначність застосування судами питання стягнення неустойки (штрафу та пені) за неналежне виконання договірних зобов'язань у цивільних та господарських спорах. Робиться висновок про необхідність закріплення на законодавчому рівні визначення неустойки і як способу забезпечення виконання договірних зобов'язань, і як міри відповідальності за порушення договірних зобов'язань. Такий підхід зумовить вироблення єдиної судової практики щодо порядку застосування та стягнення неустойки за невиконання або неналежне виконання договірних зобов'язань.
\end{abstract}

Ключові слова: договірні відносини, договірні зобов'язання, зобов'язання, міра відповідальності, неустойка, пеня, спосіб забезпечення виконання зобов'язань, стягнення неустойки, судова практика.

The article is devoted to the study of the legal nature of the penalty as a way to ensure the fulfillment of contractual obligations. The position on the ambiguity of the interpretation of the legal nature of the penalty in the legal literature and legislation is substantiated. The differences between the application of the penalty in contractual obligations in civil and commercial law are revealed, taking into account the case law on this issue. It is noted that in determining the legal nature of the penalty, most scholars define it as a way to enforce the obligation or recognize the dual nature of the penalty. In addition, it is noted that the penalty can be both a way to ensure the fulfillment of contractual obligations, and a measure and a way of responsibility in the discharge of obligations. However, there are justifications that the penalty refers to the types of penalties, measures, types of liability for non-performance or improper performance of the contractual obligation, and cannot be a way to ensure the fulfillment of the obligation.

On the grounds of the analysis of case law, the author substantiates the position that in commercial law, in contrast to civil law, the legal nature of penalties is mostly considered as a measure of responsibility, rather than as a way to ensure the fulfillment of contractual obligations. That is why there is ambiguity in the application of the issue of collecting penalties (fines and penalties) by courts for improper performance of contractual obligations in civil and commercial disputes. It is concluded that it is necessary to enshrine at the legislative level the definition of penalties both as a way to ensure the fulfillment of contractual obligations and as a measure of liability for breach of contractual obligations. This approach will lead to the development of a common case law on the application and recovery of penalties for non-performance or improper performance of contractual obligations.

Key words: contractual relations, contractual obligations, obligation, measure of responsibility, a penalty, a fine, the method of ensuring fulfillment of obligations, collection of penalty, case law.

Постановка проблеми. Належне виконання договірних зобов'язань передбачає, що сторони, які укладають певний договір, виконують покладені на них обов'язки відповідно до закону, такого договору або звичаїв ділового обороту. Однак сьогодні все частіше на практиці виникають ситуації неналежного виконання взятих на себе зобов'язань, що створює певні правові наслідки для договірних сторін, одна 3 яких може при цьому нести певні збитки та інші негативні наслідки. Для стимулювання належного та вчасного виконання зобов'язань сторонами договору в законодавстві передбачені певні способи забезпечення виконання договірних зобов'язань як додаткові забезпечувальні заходи, що мають спеціальний (додатковий) характер i дають можливість досягнути виконання незалежно від того, чи заподіяно кредиторові збитків і чи є у боржника майно, на яке можна звернути стягнення за виконавчими документами $[1$, с. 68]. Найпоширенішим та найбільш дієвим, як свідчить практика, способом забезпечення виконання договірних зобов'язань $\epsilon$ неустойка. Ще в радянські часи, А. Травкін, вивчаючи питання поняття та правової природи неустойки, визначав, що це найбільш дієвий спосіб забезпечення виконання зобов'язання, і тому «не випадково законо- давець, наводячи перелік видів забезпечення виконання зобов'язань, поставив неустойку на перше місце в ЦК України» [2, с. 118]. Такої ж думки притримувався вже пізніше О. Ситнік, вивчаючи застосування неустойки як способу забезпечення виконання зобов'язання за договором побутового підряду [3, с. 204].

Відсутність єдиного погляду на визначення правової природи неустойки у науковій літературі, віднесення неустойки до способів забезпечення виконання зобов'язань у цивільному законодавстві та застосування неустойки як міри відповідальності у господарському праві є актуальним питанням сьогодні. Такий стан речей призводить до неоднозначності позицій судової практики про порядок та підстави стягнення неустойки у вигляді штрафу та пені, до виникнення колізії цивільного та господарського законодавства у практичному застосуванні такого способу забезпечення виконання зобов'язань.

Аналіз досліджень і публікацій. Питання правової природи неустойки як способу забезпечення виконання договірних зобов'язань завжди розглядалося вітчизняними науковцями $з$ погляду засад як цивільної, так і господарської галузі права. Науковцями проводилися дослідження як загальних засад щодо неустойки в усіх договірних зобов'язаннях, так і в аспекті окремих договірних відносин, 
де способом забезпечення виконання слугує неустойка. Здебільшого дослідники під час визначення правової природи неустойки визначають іiі як спосіб забезпечення виконання зобов'язання або визнають подвійну природу неустойки, погоджуючись, що неустойка може бути і способом забезпечення виконання договірних зобов'язань, і мірою та способом відповідальності під час виконання зобов'язань. Зокрема, такої думки дотримуються в своїх працях А. Домбругова [4], А. Гриняк [5], В. Кудрявцев [6], Н. Міловська [7], К. Москаленко [8], О. Отраднова, О. Ситник [9], Н. Федорченко [10], О. Шишка [11] та інші.

Ряд авторів заперечує приналежність неустойки до способів забезпечення виконання зобов'язань. Так, I. Пучковська в своїх дослідженнях відносила неустойку до способів захисту зобов'язань у вигляді штрафних санкцій. Автором категорично заперечувалася як подвійна природа неустойки, так і віднесення iï до способів забезпечення виконання зобов'язань $[12 ; 13 ; 14]$. У такому ж ракурсі неустойку розглядала Л. Дьоміна, визначаючи, що неустойка не покликана виконувати гарантійну функцію способу забезпечення виконання зобов'язання, що не дозволяє відносити іiї до таких способів [15].

Мета статті. Метою статті є правовий аналіз законодавства та наукової літератури щодо правової природи неустойки як способу забезпечення виконання договірних зобов'язань та порядку її застосування на практиці.

Виклад основного матеріалу. Неустойка - традиційний та найпоширеніший спосіб забезпечення виконання зобов'язання у цивільному праві, який відомий ще 3 часів римського права (Закони царя Хамурапі, Закони XII таблиць). Римське право визначало такий спосіб забезпечення виконання зобов'язань як stipulation poena, що перекладається українською, як неустойка. Неустойкою називалось додаткове зобов'язання боржника виплатити кредитору певну суму грошей у разі невиконання або неналежного виконання основного зобов'язання [4, с. 556].

У юридичній літературі щодо правової природи неустойки виникають певні дискусії, причому одними авторами беззаперечно неустойка визнається способом забезпечення виконання договірних зобов'язань, інші притримуються думки, що неустойка та її форми штраф і пеня відносяться до видів штрафних санкцій, міри, виду відповідальності за невиконання або неналежне виконання договірного зобов'язання. На сьогодні наукова спільнота не досягла однозначності в цьому питанні. Але при цьому Цивільним Кодексом України (далі-ЦК України) неустойку однозначно віднесено до способів забезпечення виконання зобов'язань, і правові положення закріплено в ст. ст. 549552 параграфу 2 глави 49 книги 5 ЦК України [17].

Відповідно до статті 549 Цивільного кодексу України неустойкою (штрафом, пенею) є грошова сума або інше майно, які боржник повинен передати кредитору у разі порушення боржником зобов'язання [17]. Нормативно правову базу регулювання неустойки становлять Цивільний кодекс України [17] ЦК України, Господарський кодекс України (далі - ГК України) [18], Закони України «Про банки і банківську діяльність» [19], «Про захист прав споживачів», «Про відповідальність за несвоєчасне виконання грошових зобов'язань» [20] та інші. Така популярність застосування неустойки викликана насамперед тим, що вона являє собою спрощений засіб відшкодування втрат кредитора, завданих невиконанням або неналежним виконанням боржником своїх обов'язків, оскільки, по-перше, підстави стягнення неустойки та ії розмір зазвичай визначають самі сторони, а по-друге, для іiї стягнення немає необхідності доводити наявність збитків, достатньо самого факту порушення договору. Неустойка чітко відіграє компенсаційну функцію, що $є$ метою будь-якого засобу забезпечення виконання зобов'язання боржником.

Відповідно до ст. 549 ЦК України формами або, як називають їх деякі цивілісти, різновидами неустойки
$€$ штраф та пеня. Штрафом $є$ неустойка, що обчислюється у відсотках від суми невиконаного або неналежно виконаного зобов'язання. Пенею $є$ неустойка, що обчислюється у відсотках від суми несвоєчасно виконаного грошового зобов'язання за кожен день прострочення виконання [17].

Як вважає $€$. Харитонов, особливостями неустойки $€: 1)$ можливість стягнення неустойки за сам факт порушення зобов'язання, коли відсутня необхідність надання доказів, які б підтверджували завдання збитків та їх розмір [21, с. 100]. Це підкреслює ії спрощений характер, на відміну від гарантії, де встановлено загальний обов'язок кредитора подати гаранту вимогу, в якій має зазначатися причина порушення боржником основного зобов'язання, забезпеченого гарантією; 2) можливість для сторін на свій розсуд сформулювати умови договору про неустойку, у тому числі в частині іiі розміру, порядку обчислення $[21$, c. 101]; 3) можливість для кредитора оперативно компенсувати збитки, завдані йому невиконанням договору, у зручній для нього грошовій формі [21, с. 101].

Слід вказати, що, хоча у ст. 551 ЦК України і вказано, що неустойка може бути стягнута у вигляді грошової суми, рухомого та нерухомого майна, на практиці все ж таки частіше застосовується компенсація у вигляді грошової суми. Отримання компенсації збитків у грошовій формі надає можливість кредитору реалізувати свої порушені права коштом інших джерел. Також це підвищує ефективність компенсаційної функції неустойки як засобу забезпечення виконання зобов'язання, оскільки у сторін є вибір, за допомогою якого предмета буде сплачуватись неустойка у разі невиконання або неналежного виконання зобов'язання [22].

Окреслюючи проблему віднесення неустойки до міри та способу відповідальності, а не до способів забезпечення виконання зобов'язань, слід згадати наукові дослідження I. Пучковської, яка, розглядаючи сутність неустойки, заперечувала визнання неустойки одним зі способів забезпечення виконання зобов'язання. На думку автора, основною ознакою способів забезпечення виконання зобов'язань є наявність джерела виконання порушеного зобов'язання, за рахунок якого кредитору надається виконання порушеного зобов'язання у порядку захисту його порушених прав. Зроблений висновок, на думку автора, спростовує двоїсту природу неустойки (як способу забезпечення виконання зобов'язання і заходи цивільноправової відповідальності) і відносить неустойку безпосередньо до міри цивільної відповідальності, штрафних санкцій, які застосовуються за невиконання або неналежне виконання цивільно-правових або господарськоправових договорів [13, с. 128]. Проаналізувавши функції та ознаки інституту неустойки, Л. Дьоміна робить аналогічний висновок, як і попередній автор, що неустойка не може бути віднесена до способів забезпечення виконання зобов'язань, оскільки однією з важливих ознак будь-якого способу забезпечення виконання зобов'язань є забезпечуваність, тобто наявність, на думку автора, додаткових ресурсів для задоволення інтересів кредитора, а отже, i не виконується головна функція способу забезпечення виконання зобов'язання - гарантійна. При цьому під час застосування неустойки має місце захисна функція, яка характеризує саме відповідальність [15], і тому неустойку потрібно розглядати як міру та засіб відповідальності.

Щодо визначення в науковій літературі подвійної природи неустойки, то слід зазначити, що в деяких дослідженнях також присутня думка, що неустойка встановлюється і як вид забезпечення виконання договірних зобов'язань і при цьому виконує стимулюючу функцію, оскільки стимулює боржника до належного виконання забезпеченого нею договірного зобов'язання. Якщо ж встановлення неустойки не досягло своєї мети, і зобов'язання все ж таки було порушене боржником, то йдеться вже про притягнення винного боржника до цивільно-правової відповідальності i, відповідно, про стягнення неустойки 
[13, с. 127]. Саме в цьому і полягає подвійна природа неустойки, яка одночасно $є$ способом забезпечення виконання зобов'язання і мірою відповідальності за невиконання і неналежне виконання зобов'язання, що, на думку автора, $є$ найбільш вірним напрямом визначення правової природи неустойки в цивільному праві.

Окремо слід розглянути питання неоднозначності застосування судами порядку стягнення неустойки (штрафу та пені) за неналежне виконання зобов'язання у цивільних та господарських спорах. Практика розгляду справ судами господарської та цивільної юрисдикції кардинально відрізняється та містить суперечливі висновки щодо питання одночасного стягнення штрафу та пені, які $\epsilon$ видами неустойки. Це пов'язано насамперед з вищезазначеним питанням правової природи неустойки, з трактуванням неустойки (штрафу та пені) у господарських та цивільних зобов'язаннях, де в першому випадку їх розуміють як штрафні санкції, міру та спосіб відповідальності за невиконання або неналежне виконання зобов'язань, а в другому випадку - як спосіб забезпечення виконання зобов'язань у вигляді штрафу та пені.

Так, у цивільних судових спорах суди доходять майже однозначного висновку про неможливість одночасного застосування і пені, і штрафу за невиконання або несвоєчасне виконання одного і того ж зобов'язання. 21 жовтня 2015 р. у справі № 6-2003цс15 [23] Верховний Суд України підкреслив неможливість притягнення позичальника за порушення грошового зобов'язання до подвійної цивільної відповідальності у виді стягнення пені і штрафу одночасно. Така позиція суду грунтується на ст. 549 ЦК України, де зазначено, що штраф та пеня є одним видом цивільно-правової відповідальності - неустойкою, а також одним засобом забезпечення виконання зобов'язань (в цьому разі грошових). Отже, кредитору під час притягнення позичальника до цивільної відповідальності через суд за порушення грошового зобов'язання слід обирати, що стягувати: пеню чи штраф. У своїх висновках по справі № 756/2999/15-ц від 31.05.2017 року [24] Вищий спеціалізований суд України з розгляду цивільних і кримінальних справ визначив, що оскільки подвійна цивільна відповідальність заборонена ст. 61 Конституції України, то банк не має право стягувати одночасно пеню і штраф за порушення позичальником грошових зобов'язань.

Щодо судової практики у господарських спорах, то рішення судів дещо відрізняються від цивільних спорів, i судами одночасне стягнення за невиконання або неналежне виконання зобов'язання i штрафу, i пені допускається. Так, Верховний Суд постановою по справі № 917/194/18 від 02.04.2019 року [25] вказав, що одночасне стягнення зі сторони, яка порушила господарське зобов'язання за договором, штрафу та пені не суперечить ст. 61 Конституції України, оскільки вони є формами неустойки та видами штрафних санкцій, тобто не є окремими та самостійними видами юридичної відповідальності. У межах одного виду відповідальності може застосовуватися різний набір санкцій. Така позиція Верховного Суду не $є$ новою і вже раніше висловлювалася у постановах Верховного Суду № 911/2813/17 від 9.02.1018 [26], № 911/1351/17 від 22.03.2018 [27], № 922/1720/17 від 25.05.2018 [28]. Тобто аналіз такої правової позиції суду грунтується на тому, що відповідно до ст. 549 ЦК України пеня та штраф є формами неустойки, а відповідно до ст. 230 ГК України - видами штрафних санкцій, тобто не $\epsilon$ окремими та самостійними видами юридичної відповідальності, і саме тому у межах одного виду відповідальності може застосовуватися різний набір санкцій. Таким чином, у цьому разі не йдеться про притягнення особи до відповідальності одного виду за одне й те саме правопорушення двічі, тому що відповідальність настає лише один раз - у вигляді сплати неустойки, яка включає у себе і пеню, і штраф як форм її сплати.
Таку різну позицію судів у господарських та цивільних спорах можна пояснити таким чином. Конституцією України в ст. 61 передбачено, що «ніхто не може бути двічі притягнений до юридичної відповідальності одного виду за одне й те саме правопорушення» (лат. - поп bis in idem «двічі за одне і те саме не карають»). Саме тому одночасне застосування штрафу i пені до порушників договорів $\epsilon$ неприпустимим навіть у тому разі, коли під час укладення договору сторони добровільно на це погодилися, оскільки зміст договору, відповідно до ст. ЦК України не може суперечити чинному законодавству. Але при цьому більшість аналітиків звертають увагу на те, що стаття 61 міститься у розділі «Права, свободи та обов'язки людини і громадянина» Конституції України [29]. Тому ії положення можуть застосовуватися винятково до фізичних, а не юридичних осіб. А оскільки юрисдикція господарських судів поширюється на спори між юридичними особами, тому і рішення господарських судів щодо одночасного стягнення штрафу та пені за невиконання / неналежне виконання зобов'язання грунтуються саме на цій основі.

Окрім того, заслуговує на увагу думка експерта С. Тенькова [30], який зазначає, що неоднозначність судової практики щодо одночасного застосування штрафу та пені виходить 3 того, що відповідно до ч. 1 ст. 230 штрафними санкціями в Господарському Кодексі визнаються господарські санкції у вигляді грошової суми (неустойка, штраф, пеня), яку учасник господарських відносин зобов'язаний сплатити в разі порушення ним правил здійснення господарської діяльності, невиконання або неналежного виконання господарського зобов'язання. У разі буквального тлумачення цієї норми виходить, що виникає три самостійних види штрафних санкцій: окремо неустойка, окремо штраф і пеня. При цьому, на думку науковця, «незрозуміло, чим, наприклад, відрізняється неустойка, як самостійний за нормами ГК вид штрафних санкцій, від штрафу і пені? Натомість у ч. 1 ст. 549 ЦК України неустойкою (штрафом, пенею) визнається визначена законом або договором грошова сума, яку боржник повинен сплатити кредиторові в разі невиконання або неналежного виконання зобов'язання, зокрема, в разі прострочення виконання» [30]. Тобто, погоджуючись 3 науковцем, доходимо висновку, що неустойка (штраф та пеня) у цивільних зобов'язаннях в розумінні статті 549 ЦК України розглядається як загальне поняття, як спосіб забезпечення виконання зобов'язання, тому не можна одночасно стягувати і штраф, і пеню, на відміну від норми ст. 230 ГК України, де штраф і пеня є видами штрафних санкцій і можуть стягуватися одночасно за невиконання зобов'язання. Тобто в господарському праві, на відміну від цивільного, правову природу неустойки здебільшого розглядають як міру відповідальності, а не як спосіб забезпечення виконання зобов'язань.

Висновки. Необхідно визнати, що правове регулювання механізму застосування неустойки у договірних відносинах визначає ії ефективність як способу забезпечення виконання зобов'язань. Неустойка $\epsilon$ одним із найпоширеніших способів забезпечення виконання договірних зобов'язань, але неоднозначність трактування ії правової природи у юридичній науці, нормах цивільного та господарського права призводить до певних проблем та колізій у правозастосуванні та судовій практиці щодо порядку та способів стягнення штрафу та пені, які є видами неустойки, відповідно до ЦК України. Для врегулювання вказаної проблеми доречно було б привести у відповідність норми цивільного і норми господарського кодексів для закріплення на законодавчому рівні визначення неустойки і як способу забезпечення виконання договірних зобов'язань (забезпечувальна функція), і як міри відповідальності за порушення договірних зобов'язань (штрафна функція), що зумовить вироблення єдиної судової практики у цивільних та господарських справах щодо порядку застосування та стягнення неустойки за невиконання або неналежне виконання договірних зобов'язань. 
1. Иоффре О.С. Обязательственное право. Москва, 1975. 880 с.

2. Травкин А.А. Вопросы развития законодательства о договорной ответственности. Труды ВВСШ МВД СССР. Волгоград. 1971. № 4. С. 111-122.

3. Ситнік О.М. Неустойка як спосіб забезпечення виконання зобов'язань за договором побутового підряду. Часопис Київського університету права. 2015. № 4. С. 203-207.

4. Домбругова А. Неустойка як спосіб забезпечення виконання зобов'язання. Юридичний вісник України. 2005. № 28. С. 14

5. Гриняк А. Неустойка як спосіб забезпечення виконання підрядних зобов'язань. Юридична Україна. 2012. № 8. С. 51-56.

6. Кудрявцев В. Відмежування непойменованих способів забезпечення виконання зобов'язань за кредитним договором від інших цивільно-правових конструкцій. Підприємництво, господарство і право. 2017. № 3. С. 31-34.

7. Міловська Н.В. Неустойка як спосіб забезпечення виконання зобов'язань за договором страхування. Приватне право і підприємництво. 2019. Вип. 19. С. 134-137.

8. Москаленко К.В. Неустойка як спосіб забезпечення виконання зобов'язань за продюсерським договором. Європейські перспективи. 2014. № 3. С. 188-192.

9. Ситнік О.М. Неустойка як спосіб забезпечення виконання зобов'язань за договором побутового підряду. Часопис Київського університету права. 2015. № 4. С. 203-207.

10. Федорченко Н.В. Неустойка як спосіб забезпечення виконання договірних зобов'язань з надання послуг. Приватне право і підприємництво. 2019. Вип. 19. С. 141-145.

11. Шишка О.Р. Неустойка як вид забезпечення виконання зобов'язання. Матеріали міжвузівської НПк «Проблеми забезпечення зобов'язань». Одеса : ОДУВС. 2011. 118 с.

12. Пучковська І.Й. Про проблему визнання видів забезпечення виконання зобов'язання способами захисту. Актуальні проблеми науки і практики цивільного, житлового та сімейного права: матеріали міжнар. наук.-практ. конфр., присвяч. 91-річчю з дня народження В. П. Маслова. Харків : Право. 2013. С. 172-176.

13. Пучковська І.Й. Аргументи проти подвійної природи неустойки. Проблеми цивільного права та процесу : матеріали наук.-практ. конф., присвяч. пам'яті проф. О.А. Пушкіна (25 трав. 2013 р.). Харків : Харк. нац. ун-т внутр. справ: Золота миля. 2013. С. 126-129

14. Пучковська І.Й. Проти визнання неустойки одним із видів забезпечення виконання зобов'язання. Сучасні проблеми цивілістики: матеріали «круглого столу», присвяч. пам'яті проф. Чингізхана Нуфатовича Азімова, м. Харків, 21 груд. 2012 р. Нац. ун-т «Юрид. акад. України ім. Ярослава Мудрого». Харків : ФОП Лібуркіна Л. М. 2013. С. 58-62

15. Дьоміна Л. Неустойка: спосіб забезпечення чи вид відповідальності. URL: https://www.businesslaw.org.ua/neustoika/.

16. Домбругова А. Неустойка як спосіб забезпечення виконання зобов'язання. Юридичний вісник України. 2005. № 28. С. 14

17. Цивільний кодекс України від 16.01. 2003 р. № 435-IV. URL: https://zakon.rada.gov.ua/laws/show/435-15\#Text (дата звернення: 19.05.2020).

18. Господарський кодекс України від 16.01. 2003 р. № 436-IV. URL: https://zakon.rada.gov.ua/laws/show/436-15\#Text (дата звернення: 19.05.2020).

19. Про банки і банківську діяльність: Закон України від 07.12.2000№ 2121-III. URL: https://zakon.rada.gov.ua/laws/show/2121-14/ card4\#Current (дата звернення: 19.05.2020).

20. Про відповідальність за несвоєчасне виконання грошових зобов'язань: Закон України від 22.11.1996 p. № 543/96-вp/. URL: https://zakon.rada.gov.ua/laws/show/543/96-\#Text (дата звернення: 19.05.2020).

21. Цивільне право України: В 2-х томах. Т. 2. Підручник. За ред. д-ра юрид. наук, проф. Є.О. Харитонова; канд. юрид. наук Н.Ю. Голубєвої. Харків : ТОВ «Одіссей». 2008. 872 с.

22. Резніченко С.В., Осадчук А.В. Неустойка як вид забезпечення виконання зобов'язань. URL: https://cutt.ly/9fwwU9w.

23. Постанова Верховного суду України від 21 жовтня 2015 р., судова справа № 6-2003цc15. URL: http://reyestr.court.gov.ua/ Review/53118512.

24. Ухвала Вищого спеціалізованого суду України з розгляду цивільних і кримінальних справ від 31 травня 2017 р., судова справа № 756/2999/15ц. URL: http://reyestr.court.gov.ua/Review/66843407.

25. Постанова Верховного суду від 02 квітня 2019 р., судова справа № 917/194/18. URL: http://reyestr.court.gov.ua/Review/80923003.

26. Постанова Верховного суду від 09 лютого 2019 р., судова справа № 911/2813/17. URL: http://reyestr.court.gov.ua/Review/72149821.

27. Постанова Верховного суду від 22 березня 2018 р., судова справа № 911/1351/17. URL: http://reyestr.court.gov.ua/Review/73081562.

28. Постанова Верховного суду від 25 травня 2018 р., судова справа № 922/1720/17. URL: http://reyestr.court.gov.ua/Review/74378024.

29. Конституція України : офіц. текст: прийнята на п'ятій сесії Верховної Ради України 28 червня 1996 р. Відомості Верховної Ради України. 1996. № 30. Ст. 141.

30. Теньков С. Подвійне покарання за одне порушення - суди досі не визначилися. URL: https://cutt.ly/yfwhxdg 


\title{
СУБ'ЄКТИВНЕ ЦИВІЛЬНЕ ПРАВО ЯК ВИД І МІРА МОЖЛИВОЇ ПОВЕДІНКИ ОСОБИ
}

\section{SUBJECTIVE CIVIL RIGHT AS KIND AND MEASURE OF PERSON'S BEHAVIOR}

\author{
Погребняк В.Я., к.ю.н., \\ докторант кафедри цивільного права № 2 \\ Національний юридичний університет імені Ярослава Мудрого \\ суддя \\ Касаиійний господарський суд у складі Верховного Суду
}

Стаття присвячена розгляду проблемних аспектів одного з найпоширеніших у цивілістичній літературі поглядів на правову природу суб'єктивного цивільного права, в рамках якого таке право розглядається як вид і міра можливої поведінки особи.

Встановлюється, що багатоаспектність наукових поглядів на правову природу суб'єктивного права демонструється сучасними пошуками з піднятої проблеми, в рамках яких підтримується один або одразу декілька історичних або сучасних концептів правової природи суб'єктивного права. Відповідні погляди мають глибший характер у порівнянні з окресленим компромісним підходом і в залежності від свого змісту належать до теорії волі, теорії інтересу, теорії влади тощо. Водночас дослідження правової природи суб'єктивного цивільного права в сучасних умовах виступає як один із факторів, які детермінують зміцнення догматичних наукових положень або їхнє вдосконалення, а тому й розвиток цивільноправової наукової думки в цілому.

Визначається, що перевагою аналізованого погляду є те, що суб'єктивне цивільне право розглядиться через категорію можливої поведінки. У зв'язку із цим існування такого права не ставиться в безпосередню залежність від фрактичного здійснення дій або бездіяльності. Однак у цілому розгляд суб'єктивного цивільного права через категорію поведінки не дозволяє розмежувати ідеальний і реальний компоненти в ньому.

Водночас категорія «міра» належить до меж суб'єктивного цивільного права. Це певний обсяг поведінки, що може бути вчинена під час здійснення суб'єктивного цивільного права. Проте закон практично ніколи не конкретизує, якими саме фрактичними діями або бездіяльністю може бути досягнутий відповідний результат. У цьому й полягає сутність юридичної конструкції. У зв'язку із цим міра характерна не для поведінки, а для правової можливості, адже саме можливість визначається юридичними категоріями й охоплює юридичні конструкції, які лаконічно поєднують однотипні моделі поведінки як резупьтат систематизації правових ситуацій та їх розвиток у правовій реальності.

Автор доходить висновку, що розмежування ідеального й реального елементів у структурі суб'єктивного цивільного права є необхідною умовою для визначення його правової природи. Водночас суб'єктивне цивільне право є визначеною нормами цивільного права та/ або актами саморегулювання цивільних відносин мірою правової можливості особи (або що належить особі), що втілюється в процесі здійснення в поведінці такої особи встановленого виду (юридичних актах).

Ключові слова: суб'єктивне цивільне право, вид поведінки, міра поведінки, юридична можливість.

The article is devoted to consideration of problem issues of one of the most popular points of view on legal nature of subjective civil right in civil law doctrine according to which such right is defines as kind and measure of person's behavior.

It is determined that multidimensionality of scientific approaches to defining the legal nature of subjective civil rights is demonstrated by scientific researches that are dedicated to appropriate problem and describes one or several historical or modern scientific concepts of subjective civil rights. Appropriate points of view are scientifically deeper than compromise approach and are referred to theory of will, theory of interest, theory of power etc. At the same time the research of legal nature of subjective civil right in modern circumstances is one of the factors that determines the strengthening of dogmatic provisions or improve them and in such way develop the civil law doctrine.

It is defined that advantage of analyzed approach is that subjective civil right is considered as possible behavior. Thus the existence of such right do not depends on realization the actions or inactivity in practice. But in general such approach within which the subjective civil right is considered from point of view of behavior does not allow differentiating ideal and real components in it.

At the same time the category "measure" relates to borders of subjective civil rights. This is some capacity of behavior that can be exercised during right-realization. But as a rule the law doesn't concrete what kind of actions or inactivity can lead to defined result. This is the essence of legal construct. In this connection the measure is related not to behavior but to a juridical ability of the person. After all the ability is determined by juridical categories and embrace the juridical constructs that unites the typical models of behavior that are the result of systematization of juridical situations and their evolution in legal reality.

The author concludes that the differentiation of ideal and real components in subjective civil right structure is the necessary condition for designation its legal nature. At the same time the subjective civil right is the measure of person's legal capacity that is defined by legislative provisions and/or by acts of self-regulation of civil relationships and is embodied in such persons behavior (juridical acts) during right-realization.

Key words: subjective civil rights, kind of behavior, measure of behavior, legal capacity.

Постановка проблеми. Звернення до цивілістичних, а також загальнотеоретичних розробок правової природи суб'єктивних прав демонструє відносну усталеність наукового підходу до розуміння відповідного правового явища. В юридичній літературі вже досить давно сформувався підхід, в рамках якого суб'єктивне право розглядається як вид і міра можливої поведінки особи [1, с. $33 ; 2$, с. 103]. Його слід вважати компромісним, адже він не розставляе відвертих акцентів на певних ознаках суб'єктивних цивільних прав, які вступають у суперечність 3 властивостями, що розглядаються як детермінуючі в межах альтернативних наукових підходів. Таким чином, окреслений концепт певною мірою в силу своєї нейтральності виступає базовим компромісним рішенням.

Проте це не означає, що наукова розробка відповідного юридичного феномену зупинилась. Багатоаспектність наукових поглядів на правову природу суб'єктивного права демонструється сучасними пошуками 3 піднятої проблеми, в рамках яких підтримується один або одразу декілька історичних або ж сучасних концептів правової природи суб'єктивного права. Відповідні погляди мають глибший характер у порівнянні з окресленим компромісним підходом і в залежності від свого змісту належать до теорії волі, теорії інтересу, теорії влади тощо.

Окреслене свідчить про розвиток наукової думки, в тому числі переосмислення базових правових явищ і процесів з урахуванням надбань сучасної юридичної науки 3 метою підтвердження їх догматичного характеру або наукового доопрацювання для підвищення доктринальної обгрунтованості у випадку виявлення прогалин та/або неточностей.

У контексті зазначеного, дослідження правової природи суб'єктивного цивільного права в сучасних умовах необхідно розглядати як одним із факторів, які детермінують зміцнення догматичних наукових положень або їхнє вдосконалення, а тому й розвитку цивільно-правової 
наукової думки в цілому. Крім того, розгляд цієї проблематики здатен розширити уявлення про сутність таких проявів динаміки суб'єктивних цивільних прав, як їх виникнення, перехід і припинення.

У контексті усталеного наукового погляду на сутність суб'єктивного цивільного права проблема постає стосовно його базових положень, зокрема, наскільки допустимо розглядати таке право як вид і міру поведінки особи.

Аналіз останніх досліджень і публікацій. Проблематика припинення суб'єктивних цивільних прав вимоги розглядалась такими вченими юристами, як С.С. Алексєєв, І.В. Венедіктова, С. Годеме, Г.В. Дождєв, І.В. Жилінкова, О.С. Іоффе, Т.С. Ківалова, А.В. Коструба, В.І. Крат, Н.С. Кузнєцова, Р.А. Майданик О.I. Міхно, Є.О. Мічурін, М.В. Мороз, В.В. Надьон, І.В. Спасибо-Фатєєва, Р.О. Стефанчук, Р.О. Халфіна, Г.Г. Харченко, В.В. Цюра, Ю.І. Чалий, Я.М. Шевченко, С.І. Шимон, Р.Б. Шишка, О.Я. Явор, В.Л. Яроцький та інші.

Постановка завдання. Мета статті полягає в науковому осмисленні таких характеристик суб'єктивного цивільного права, як вид і міра поведінки особи, що визначаються сучасною юридичною наукою як його базові атрибути.

Основний матеріал дослідження. Категорії вид і міра поведінки особи відбивають два ключових моменти, пов'язаних із суб'єктивним цивільним правом, а саме зовнішнім проявом поведінки особи, в якій втілюється здійснення відповідного суб'єктивного цивільного права, а також межами такої поведінки.

Проблема меж суб'єктивного цивільного права проходить «червоною ниткою» практично через всі основні догматичні положення в рамках спроб пояснити сутність суб'єктивного цивільного права. В радянській науковій літературі й наукових дослідженнях акцентувалась увага на тому, що суб'єктивне цивільне право, зокрема, є мірою (межами) дозволеної поведінки особи [1, с. 33]. В багатьох сучасних підручниках із цивільного права суб'єктивне цивільне право розглядається вже переважно як вид і міра можливої поведінки особи [2, с. 103].

Водночас вид і міру в контексті сутності суб'єктивного цивільного права необхідно розглядати як окремі характеристики в межах юридичної формули.

Як зазначає С.С. Алексєєв, слово «міра» під час визначення суб'єктивного права означає, що закріплені за особою юридичні можливості не безмежні, вони чітко визначені за змістом, у цих межах особа й може будувати свою поведінку [3, с. 114]. Водночас в юридичній літературі також відзначається, що суб'єктивне право не є абстрактною можливістю, а має чіткі межі, точну міру поведінки [4, с. 14]. Своєю чергою «вид» поведінки необхідно розглядати як її зовнішній прояв, зокрема як дію та/або бездіяльність. У контексті окресленого підходу із цього повинно слідувати, що суб'єктивне цивільне право визначає вид поведінки особи, якій таке право належить, тобто управоможеної особи, а також міру такої поведінки, тобто міру дії або бездіяльності.

I саме в цій частині ми стикаємося 3 одним із найскладніших феноменів цивільного права - зв'язком ідеального й реального в правовій реальності. Не всі юридичні явища настільки пов'язані із цією проблемою, як, наприклад, юридичні факти, юридичні склади, акти правореалізації та акти правозастосування, які безпосередньо забезпечують втілення ідеальних моделей поведінки в правовій реальності, а тому гарантують реалізацію визначених нормами права або актами саморегулювання цивільних відносин причинно-наслідкових моделей. Відповідні елементи механізму цивільно-правового регулювання суспільних відносин складаються 3 ідеального компоненту, яким виступає модель певного явища або процесу, й реального компоненту, яким виступає реальне (фактичне) явище й процес, що настають (реалізовуються) в правовій реальності.
Так само й суб' єктивне цивільне право поєднує в собі ідеальний і реальний компоненти. Особливо чітко це демонструється розмежуванням статичного й динамічного аспектів. Зокрема, якщо ми розглядаємо право в статичному сенсі, тобто як певне явище, тоді дуже складно визначити його через категорію фактичної (реальної) поведінки. Адже право - це лише можливість, яка може бути втілена в певній поведінці в процесі його здійснення. До моменту здійснення це лише можливість. Однак, 3 іншого боку, коли право починає здійснюватися, йдеться вже не стільки про саме суб' єктивне цивільне право, скільки про сутнісні характеристики й форму його здійснення. Зокрема, користування річчю, вимога одержання послуги - це не сутність права, а прояв процесу його здійснення.

Окреслене показує «виграшність» ракурсу погляду на суб'єктивне цивільне право, в рамках якого воно розглядається як вид і міра. Такий погляд абстрагується від процесу здійснення права, який не можна ототожнювати 3 правом. Проте в рамках такого підходу ідеальний і реальний компоненти суб'єктивного цивільного права не розмежовуються, що й демонструє його вразливі місця.

1. Суб'єктивне цивільне право с видом можсливої поведінки особи. Перевагою такого погляду є те, що суб' єктивне цивільне право розглядається через категорію можливої поведінки. Це означає, що право є певною можливістю особи, яка може знайти втілення в правовій реальності в процесі здійснення такого права, або ж така можливість може бути припинена, так і не знайшовши втілення в практиці. Проте, незалежно від здійснення або нездійснення, відповідний феномен не перестає бути правом.

Водночас розгляд суб'єктивного цивільного права через категорію поведінки не дозволяє розмежувати ідеальний і реальний компоненти в ньому. Мало того, за умови такого підходу суб'єктивне цивільне право практично ототожнюється 3 фактичною поведінкою. Адже в аналізованому погляді нічого не йдеться про правову поведінку, у зв'язку із чим відповідна поведінка набуває правового характеру лише в силу того, що вона визначається правом. Однак, у такому разі під час буквального розуміння суб'єктивного цивільного права як виду й міри можливої поведінки особи ми повинні визнати, що суб'єктивне цивільне право є, зокрема, можливою дією або бездіяльністю особи. Це приводить нас в площину процесу, під час якого суб' єктивне цивільне право й процес його здійснення фактично ототожнюються. Крім того, сама концепція розгляду суб'єктивного цивільного права як дії або бездіяльності не враховує ідеального елементу.

2. Суб'сктивне цивільне право с мірою певного виду можливої поведінки особи. Категорія «міра» належить до меж суб'єктивного цивільного права. Це певний обсяг поведінки, що може бути вчинена під час здійснення суб'єктивного цивільного права. Проте, якщо розглядати суб'єктивне цивільне право як можливу поведінку особи, міра такої поведінки визначає обсяг дій або бездіяльності, який може бути реалізований особою в ході здійснення нею відповідного суб' єктивного цивільного права.

Водночас звернення до основ нормопроєктувальної техніки показує, що відхід від казуального правового регулювання передбачає економію правових засобів, у зв'язку із чим нормативні положення будуються за принципом конструкції. Як приклад виступає право власника на розпорядження належним йому майном. Категорія «розпорядження», як правило, не конкретизується в змісті положень чинного цивільного законодавства України, проте ми розуміємо, що воно може бути здійснено в найрізноманітніших формах. Це може бути й продаж, і застава, й знищення майна. Проте закон практично ніколи не конкретизує, якими саме фактичними діями або бездіяльністю може бути досягнутий відповідний результат. У цьому й полягає сутність юридичної конструкції. В ній у концентрованій формі відбивається юридичний еле- 
мент - юридично забезпечена можливість (визначеність i забезпеченість об'єктивним правом), і фактичний елемент - втілюваність відповідної можливості в конкретній фактичній поведінці різного виду.

У зв'язку із цим лише розмежування юридичного й реального (фактичного) елементів у розумінні сутності суб'єктивного цивільного права розкриває його правову природу.

Тому як юридичний елемент суб'єктивного цивільного права виступає правова можливість особи досягти певного юридичного й в окремих випадках фактичного результату. Своєю чергою реальним (фактичним) елементом суб'єктивного цивільного права виступає втілюваність такої юридичної можливості у фактичній поведінці особи.

Розмежування правової можливості як ідеальної складової частини й поведінки як фактичної складової частини суб'єктивного цивільного права в процесі його реалізації має важливе значення, оскільки саме можливість, іії зміст, визначають поведінку, яка $є$ здійсненням права шляхом реалізації відповідної можливості. Як результат, відповідна поведінка 3 боку права $є$ правовими актами відповідного учасника цивільних правовідносин. Правова можливість конкретизується у фактичній поведінці особи, яка, відповідаючи такій можливості в рамках здійснення суб'єктивного цивільного права, набуває значення юридичних актів.

У зв'язку із цим міра характерна не для поведінки, а для правової можливості, адже саме можливість визначається юридичними категоріями й охоплює юридичні конструкції, які лаконічно поєднують однотипні моделі поведінки як результат систематиції правових ситуацій та їх розвитку в правовій реальності, зокрема й з позицій фактичної поведінки. Наприклад, правова можливість власника розпоряджатись своєю річчю містить у тому числі можливість знищити річ, що може бути здійснено або шляхом підпалу, або шляхом використання вибухових речовин, або шляхом фізичного впливу спеціальним механізмом чи технікою, наприклад, пресом для утилізації автомобілів тощо. Все це визначає міру правової можливості - знищення.

Міра правової можливості - знищення в такому разі обмежується правами інших осіб, у зв'язку із чим фактична поведінка $з$ такого знищення не повинна завдавати шкоди іншим суб'єктам цивільного права.

Водночас для поведінки учасника цивільних правовідносин характерна певна форма зовнішнього виразу, зокрема дія або бездіяльність, які конкретизуються в мовчазній згоді на вчинення правочину або передачею речі, або отриманням послуги тощо, можуть втілюватись у систематичних або послідовних актах (поведінки). Юридичні акти володіння, користування річчю, розпорядження річчю, вчинення певних дій або отримання певних благ від зобов'язаної особи втілюються в певній поведінці фактичного характеру, що відповідає характеру й мірі правової можливості й тим самим вписуються в конструкт причинно-наслідкових зв'язків, визначених нормами права в межах механізмів виникнення, здійснення, переходу й припинення суб'єктивних цивільних прав. У зв'язку із цим вид поведінки - це конкретизатор правової можливості у фактичній площині цивільних правовідносин.

Як зазначає із цього приводу О.Ф. Черданцев, у контексті розгляду міри суб'єктивного цивільного права як ідеальної, мислимої величини, дії із запланованого по мірі суб'єктивного цивільного права перетворюються в здійснювані по цій же мірі $[5$, с. 107, 109]. Тобто фактична поведінка учасника цивільного правовідношення, здійснювана відповідно до міри правової можливості, визначеної нормами права або актами саморегулювання цивільних відносин, повинна здійснюватись відповідно до цієї міри, що демонструє взаємозв'язок фактичного і юридичного в процесі здійснення суб'єктивного цивільного права.

Висновки і перспективи подальших досліджень. Таким чином, розмежування ідеального й реального елементів у структурі суб'єктивного цивільного права є необхідною умовою для визначення його правової природи. В цілому, суб'єктивне цивільне право є ідеальним феноменом, що визначається положеннями чинного цивільного законодавства України, тобто об'єктивним правом або актами саморегулювання цивільних відносин. Реальний (фактичний) компонент $є$ умовним і виникає в процесі здійснення суб'єктивного цивільного права. Це та можлива поведінка, яка може бути вчинена, якщо право буде здійснюватися, а може й не вчинятись, якщо суб'єкт не буде здійснювати відповідне суб'єктивне цивільне право.

Зміст фактичної поведінки носія суб'єктивного цивільного права визначається змістом відповідного права. Як правило, закон не визначає які саме фактичні дії можуть бути вчинені особою, якій належить відповідне суб'єктивне цивільне право, що безпосередньо відбивається і на змісті такого права. За правилами побудови юридичних конструкцій характер і зміст відповідної фактичної поведінки охоплюється спрямованістю суб' єктивного цивільного права, його межами (мірою), а також межами суб'єктивних цивільних прав інших осіб. Водночас учасники цивільних правовідносин, зокрема, договірних, можуть конкретизувати вид фактичної поведінки особи, в якій втілюється здійснення суб'єктивного цивільного права, що й знаходить активне поширення в умовах практики правореалізації. В договорах найму (оренди) землі знаходять закріплення положення, які визначають цільове призначення землі й порядок ії використання, а також види забороненої поведінки наймача стосовно відповідної речі, в договорах найму (оренди) приміщень закріплюються пункти, які конкретизують характер поточного ремонту, який зобов'язаний здійснити наймач, а в договорах про надання послуг конкретизується зміст відповідної фактичної поведінки виконавця. Всі ці дії покликані конкретизувати зміст суб'єктивних цивільних прав і кореспондуючих їм суб'єктивних цивільних обов'язків в умовах конкретних цивільних правовідносин.

З урахуванням викладеного вище, слід констатувати, що суб' єктивне цивільне право є визначеною нормами цивільного права та/або актами саморегулювання цивільних відносин мірою правової можливості особи (або що належить особі), що втілюється в процесі здійснення в поведінці такої особи встановленого виду (юридичних актах). Такий підхід підкреслює ту обставину, що суб'єктивне цивільне право втілюється в певній поведінці особи під час здійснення, проте нездійснення відповідного суб'єктивного цивільного права не означає, що воно не існує. Іншим словами, це те, що в межах поширеного наукового підходу розглядається як можлива поведінка особи.

\section{ЛІТЕРАТУРА}

1. Певзнер А.Г. Понятие и виды субъективных гражданских прав : дис. ... канд. юрид. наук : 12.00.03. Москва, $1961.242 \mathrm{c}$.

2. Цивільне право : підручник : у 2 т. / В.І. Борисова (кер. авт. кол.), Л.М. Баранова, Т.І. Бєгова та ін. ; за ред. В.І. Борисової, І.В. Спасибо-Фатєєвої, В.Л. Яроцького. Харків : Право, 2011. Т.1. 656 с.

3. Алексеев С.С. Общая теория права : курс в 2 т. Москва : Юрид. лит., 1982. Т. 2. 360 с.

4. Ломидзе О.Г. Правонаделение в гражданском законодательстве России. Санкт-Петербург : Изд-во «Юридический центр Пресс», 2003. 535 с.

5. Черданцев А.Ф. Логико-языковые феномены в юриспруденции : монография. Москва : Норма / ИНФРА-М, 2012.320 с. 


\title{
ФУНКЦІЯ ПРЕДСТАВНИЦТВА ТА ПРОЦЕСУАЛЬНИЙ СТАТУС ПРОКУРОРА В УМОВАХ РЕФОРМУВАННЯ СИСТЕМИ ПРАВОСУДДЯ ТА СУДОЧИНСТВА
}

\author{
THE PROCURATOR'S REPRESENTATION FUNCTION AND HIS PROCEDURAL STATUS \\ IN CONDITIONS OF REFORMING THE SYSTEM OF JUSTICE AND LEGAL PROCEEDINGS
}

\author{
Світлична Г.О., к.ю.н., \\ доцент кафедри цивільного процесу \\ Національний юридичний університет імені Ярослава Мудрого
}

Стаття присвячена дослідженню правової природи та змісту представницької функції прокурора, перспектив підвищення ефективності її здійснення в умовах реформування системи правосуддя та судочинства. Звертається увага на еволюційну трансформацію процесуального статусу прокурора, яка пов'язана з реформуванням системи органів прокуратури та їі функцій у сфері судочинства.

У статті аналізуються процесуальний статус прокурора та особливості здійснення прокурором функції представництва у цивільному судочинстві в контексті конституційних змін щодо правосуддя. Розглянуто проблемні аспекти правового регулювання процесуального статусу прокурора як учасника судового процесу, його процесуальних повноважень та порядку їх реалізації відповідно до нової редакції Цивільного процесуального кодексу України. Обґрунтовується необхідність нових підходів у визначенні процесуального статусу прокурора та внесення відповідних змін у правове регулювання здійснення прокурором функції представництва в судовому процесі. Пропонується диференціювати процесуальний статус прокурора у цивільному судочинстві залежно від встановлених законом умов реалізації фрункції представництва у суді. Доводиться, що на сучасному етапі реформування системи правосуддя, судочинства та суміжних правових інститутів відбувається модиффікація змісту представницької функції прокурора та його процесуального статусу відповідно до європейських стандартів, що спонукає державу до створення належного правового підґрунтя процесуальної діяльності прокурора та забезпечення ефективного механізму реалізації представницької функції прокурора поза межами кримінальної юстиції. Пріоритетним напрямом та основним завданням реформування діяльності прокуратури з метою забезпечення ефективної ролі прокуратури в процесі захисту інтересів держави та суспільства стає евроінграційний вектор трансформації представництва функції прокурора, гармонізація національного процесуального законодавства та його вдосконалення відповідно до міжнародних стандартів правосуддя. Приділено увагу пріоритетним напрямам подальшого вдосконалення правового регулювання здійснення прокурором функції представництва в цивільному судочинстві з метою підвищення ефективності реалізації покладених на нього конституційних функцій та забезпечення доступності і справедливості правосуддя.

Ключові слова: цивільне судочинство, прокурор, процесуальний статус прокурора, представництво, функція представництва, повноваження прокурора, учасники процесу.

The article deals with the investigation of legal nature and the essence of procurator's representation function and the prospects of its perfection, definition of the procurator's procedural status in civil proceedings in conditions of reforming the system of justice. Attention is paid to evolutional transformation of the procurator's procedural status that is stipulated by reforming the system of procurator's office and its functions in the sphere of legal proceedings.

The article analyses the main novels of legal regulation of the procurator's status and the peculiarities of realization of his representation function in civil proceedings in conditions of constitutional changes of the system of justice and reformation of legal proceedings.

It examines the controversial aspects of legal regulation of the procurator's procedural status as the participant of court proceedings, his procedural authorities and the ways of their realization in accordance with the new edition of Ukraine's Civil Procedure Code.

It substantiates the need of new approaches in defining the procurator's procedural status and amendments to the legal regulation of realization by the procurator of his representation function in the trial. It is proposed to differentiate the procurator's procedural status in civil proceedings depending on the conditions of realization of constitutional representation function prescribed by the law.

It is noted that at the modern stage of reforming the system of justice, court proceedings and allied legal institutions the modification of procurator's representation function takes place in accordance with european standards; also efforts are made to create effective mechanism to realize it in the sphere of civil proceedings. The priority direction and the main task of the process of reforming the activities of the procurator's office with the aim to ensure the effective role of the procurator's office in the process of defending the interests of the state and society is the eurointegration vector of transformation of procurator's representation function in court, harmonization of national proceedings legislation and its perfection in accordance with international legal norms.

The article grants attention to the ways of promotion of effectiveness and further perfection of legal regulation of realization by the procurator representation functions and insurance the effectiveness of realization of constitutional functions entrusted to him and also to other controversial aspects of the procurator's participation in civil proceedings.

Key words: civil proceedings, procurator, procurator's procedural status, representation function, representation, procurator's authorities, trial participants.

Постановка проблеми. Створення ефективного механізму захисту порушених, невизнаних та оспорюваних прав, свобод та інтересів як найвищої соціальної цінності у правовій державі зумовило реформування судової системи та посилення ефективності і дієвості суміжних правових інститутів. Реформування системи судоустрою, судочинства та суміжних правових інститутів здійснюється через створення правового підгрунтя їх ефективного функціонування, шляхом запровадження комплексних системних змін, спрямованих на вдосконалення чинного законодавства. В умовах судової реформи все більшої значущості та актуальності набуває, зокрема, приведення статусу та функцій органів прокуратури у відповідність до сучасних правових орієнтирів та європейських стандартів. Правова регламентація діяльності органів прокуратури, яка пов'язана з реалізацією покладених на неї функцій, потребує вдосконалення та має узгоджуватися з триваючою у державі реформою судочинства. 3 метою гарантованого забезпечення демократичних засад та правової визначеності сучасної моделі судочинства іiї побудова має відбуватися відповідно до європейських стандартів правосуддя, створюючи ефективний механізм належного захисту прав та інтересів на засадах верховенства права, 3 дотриманням законності та забезпеченням своєчасного виконання судових рішень, в тому числі у сфері цивільного судочинства.

Попри проведення цілого комплексу реформаторських заходів, $є$ певна низка дискусійних питань, пов'язаних із здійсненням прокурором представницької функції, які потребують системного підходу до їх вирішення. Запро- 
вадженими у чинному законодавстві змінами, на жаль, не знята проблема неоднакового визначення змісту представницької функції прокурора, його процесуального статусу у судовому процесі та порядку реалізації наданих йому повноважень, що зумовлює актуальність їх подальшого дослідження.

Ступінь розробленості проблеми. Теоретичну основу дослідження складають наукові праці таких вітчизняних та зарубіжних вчених, як Є.А. Безкровний, К.А. Гузе, Т. Дунас, С.В. Ківалов, О.Л. Копиленко, В. Кравчук, Р. Лемик, Д.Д. Луспеник, М. Руденко, Т.А. Решетникова, В.Й. Сапунков, М.М. Стефанчук, С.Я. Фурса, О.В. Хорсуненко та багато інших. Правниками досліджувалися основні засади організації та діяльності прокуратури, шляхи розвитку прокуратури в умовах побудови демократичної правової держави та основні напрями іiі реформування, правова природа та сутність представницької функції прокурора, процесуальний статус прокурора у судовому процесі, підстави та форми його участі, обсяг його повноважень та процесуальний порядок їх реалізації, які донині не втратили теоретичного та практичного значення.

Актуальність подальшого дослідження окремих аспектів здійснення прокурором функції представництва у цивільному судочинстві зумовлюється реформуванням та розвитком української правової системи в євроінтеграційному напряму та запровадженням конституційних змін щодо правосуддя у національне галузеве законодавство.

Виклад основного матеріалу. 3 прийняттям Конституції України 1996 року на прокуратуру поза межами кримінального судочинства була покладена функція представництва інтересів громадян або держави в суді. Конституційне закріплення функції представництва прокурора в суді стало початком реформування функціональної діяльності органів прокуратури в контексті євроінтеграційного вектору розвитку української правової системи.

Проведення в подальшому 3 урахуванням висновків і рекомендацій Європейської комісії «За демократію через право»(Венеціанська комісія) конституційної реформи в Україні зумовило зосередження зусиль держави на утвердженні верховенства права та вдосконаленні національного законодавства у сфері правосуддя. Указом Президента України «Про Стратегію реформування судоустрою, судочинства та суміжних правових інститутів на 20152020 роки» від 20 травня 2015 р. № 276/2015 були встановлені пріоритети реформування системи судоустрою, судочинства та суміжних правових інститутів як на рівні конституційних змін, так і на рівні впровадження першочергових невідкладних заходів, які б мали забезпечити необхідні позитивні зміни у функціонуванні відповідних правових інститутів [1, с. 38]. Одним із таких пріоритетних напрямів реформування стало приведення діяльності органів прокуратури до європейських стандартів шляхом оптимізації іiї повноважень та обмеження сфери застосування відповідно до рекомендацій Ради Свропи.

Під час поетапного реформування системи органів прокуратури та правових засад діяльності прокурора поза межами кримінальної юстиції концептуальних змін зазнали зміст та порядок реалізації представницької функції прокурора, його процесуальний статус, обсяг повноважень та процесуальний порядок їх реалізації.

Суттєвими змінами до Конституції України в частині правосуддя стало виключення розділу VII «Прокуратура» 3 тексту Конституції і віднесення норм, що регулюють діяльність прокуратури до розділу «Правосуддя», тобто на конституційному рівні статус прокуратури визначено самостійним складником системи правосуддя. Науковці в цьому контексті стверджують, що зазначені конституційні новації дозволяють на підставі проведеного порівняльно-правового аналізу основ організації і діяльності прокуратури України та країн - членів СС віднести прокуратуру України до такої моделі, де вона є організаційно відособленою від органів правосуддя, незалежною під час здійснення повноважень та посідає самостійне місце в системі правосуддя, яка $\epsilon$ характерною для Австрії, Нідерландів, Німеччини, Румунії, Франції [2, с. 9-10].

Згідно зі ст. 1 ЗУ «Про прокуратуру» прокуратура України становить єдину систему, яка в порядку, передбаченому законом, здійснює встановлені Конституцією України функції з метою захисту прав і свобод людини, загальних інтересів суспільства та держави. Відповідно до ст. $131^{-1}$ Конституції України прокуратура, зокрема, здійснює представництво інтересів держави в суді у виняткових випадках та в порядку, що визначені законом.

Отже, на відміну від попередньої редакції відповідних норм Конституції, якими передбачалося представництво прокурором інтересів держави та фізичних осіб, представницька функція прокурора була зведена винятково до представництва інтересів держави у визначених законом випадках. Оцінюючи цю законодавчу новацію, по-перше, слід зазначити, що передбачені Конституцією України обмеження сфери реалізації функції представництва прокурора узгоджуються 3 рекомендаціями Венеціанської комісії та Парламентської асамблеї Ради Свропи в рамках виконання Україною взятих на себе міжнародних зобов'язань. По-друге, закріплення на конституційному рівні обмеження представницької функції прокурора в суді винятково інтересами держави обгрунтовано пов'язується iз запровадженням та функціонуванням інституту омбудсмена, а також із створенням механізму надання безоплатної правової допомоги, які можуть забезпечити належне представництво інтересів фізичних осіб у суді з метою ефективного захисту їх прав.

Фахівці щодо цього зазначають, що особливість змісту представницької функції прокурора, закладеної у Конституції України 1996 року з урахуванням досвіду функціонування прокуратури в європейських державах, стандартів Ради Європи, а також висновків та рекомендацій, які надавалися Венеціанською Комісією щодо законопроєктів про реформування прокуратури України, полягає у тому, що представництво прокурором інтересів держави у суді має допоміжний характер, оскільки основну роль у цьому процесі мають відігравати профільні органи державної влади чи органи місцевого самоврядування, які повинні самостійно звертатися до суду за захистом порушених, невизнаних чи оспорюваних прав та інтересів [3].

Зазначене конституційне положення знайшло відтворення у галузевому процесуальному законодавстві. Водночас слід зазначити, що п. 2 ч. 1 ст. 2 ; ч. 2 ст. 23 «Про прокуратуру» закріплено право прокурора здійснювати представництво інтересів не тільки держави, а й громадянина у суді, що не відповідає Конституції України, не узгоджуються з приписами, що містяться в процесуальних нормах галузевого процесуального законодавства (ч. 4 ст. 56 ЦПК, ч. 3 ст. 53 ГПК, ч. 4 ст. 53 КАС) та не підлягає застосуванню. Отже, $є$ нагальна потреба приведення зазначених положень ЗУ «Про прокуратуру» у відповідність до Конституції України.

Закріплення на конституційному рівні представницької функції прокурора у сфері судочинства зумовило довготривалу наукову полеміку щодо іiї правої природи та змісту, форм та порядку здійснення. Висловлені у науковій літературі основні напрями щодо вирішення зазначеної проблеми зводяться до наступного. На думку одних науковців, представницька функція прокурора не $\epsilon$ різновидом процесуального представництва, а функціонує в межах іншого самостійного процесуального інституту [4, с. 9; 5, с. 5]. Інші автори, навпаки, вважають представництво, яке здійснюється прокурором у суді, одним з видів процесуального представництва, а прокурора, відповідно, - законним представником [6, с. 5-15; 7, с. 8].

Заслуговує уваги підхід до визначення процесуального статусу прокурора, який свого часу не знайшов широкої 
підтримки, утім набуває актуальності в контексті останніх конституційних змін щодо правосуддя та пов'язаного 3 цим процесу реформування функцій прокурора в судовому процесі поза сферою кримінальної юстиції. В іiі основу покладено визначення представництва, яке здійснюється прокурором, представництвом конституційного рівня, яке здійснюється офіційним органом, діючим від імені держави, тому принципово відрізняється від інших його видів у суді [8, с. 67-72; 9, с. 101-105].

На сучасному етапі судової реформи визначення змісту функції представництва прокурором інтересів держави в суді та його процесуального статусу має, на наш погляд, відбуватися у призмі правової доктрини процесуального представництва та правової природи інституту участі в судовому процесі органів та осіб, яким законом надане право звертатися до суду в інтересах інших суб'єктів. Згідно із чинним процесуальним законодавством участь у суді процесуальних представників та прокурора як суб'єкта, якому законом надане право звертатися до суду в інтересах інших осіб, мають автономний режим правового регулювання (ст.ст. 58-64 ЦПК; ст.ст. 56-57 ЦПК) що відтворено у структурі ЦПК. Отже, підстави для їх ототожнювання відсутні як за формальними, так і сутнісними правовими ознаками. Передусім слід зазначити, що, вступаючи у судовий процес, прокурор стає його учасником і має здійснювати представницькі повноваження у суді винятково на підставах, у межах та порядку, передбаченими процесуальним законодавством, які регулюють діяльність суб'єктів відповідних процесуальних відносин. Варто наголосити, що прокурор виступає захисником публічного інтересу і діє у суді від імені держави. Представницька функція прокурора суттєво відрізняється від процесуального представництва за правовою природою та підставами ії здійснення, за складом та правовими ознаками суб'єкта ії реалізації, складом осіб, інтереси яких прокурор може представляти у суді, обсягом повноважень та їх посвідченням, формою та порядком їх реалізації. 3 урахуванням правової природи та суттєвих відмінностей законодавчого регулювання неприпустимим, таким чином, $є$ змішування процесуального інституту, який відбиває публічно-правові засади цивільного судочинства, з процесуальним представництвом у традиційному, так би мовити, «класичному» розумінні цього інституту. Ігнорування особливостей правової природи та сутнісних ознак цих самостійних правових інститутів цивільного процесуального права призводить до «розмивання» меж їх правової дії, розбіжностей правового регулювання та неоднакового правозастосування.

Водночас 3 огляду на сучасний етап реформування судочинства підстав та умов здійснення прокурором представництва інтересів держави виникає, на наш погляд, необхідність диференціації процесуального статусу прокурора під час реалізації ним представницької функції. При цьому, враховуючи єдність конституційних засад здійснення прокурором представницької функції, диференційований підхід у визначенні його процесуального статусу має відбуватися у всіх видах судочинства поза межами кримінальної сфери. Критеріями диференціації процесуального статусу прокурора мають слугувати визначені законом підстави та умови здійснення ним представництва інтересів держави у суді.

Представництво прокурором інтересів держави в суді полягає у здійсненні процесуальних та інших дій, спрямованих на захист інтересів держави, у випадках та порядку, встановлених законом (ст.23 ЗУ «Про прокуратуру»).

Підставою для здійснення прокурором представництва в суді законних інтересів держави є порушення або загроза порушення інтересів держави.

За наявності зазначених підстав прокурор може реалізувати надані йому представницькі повноваження за таких умов:
1) якщо захист цих інтересів не здійснює або неналежним чином здійснює орган державної влади, орган місцевого самоврядування чи інший суб'єкт владних повноважень, до компетенції якого віднесені відповідні повноваження;

2) у разі відсутності органу, до компетенції якого віднесені відповідні повноваження (ст. 23 ЗУ «Про прокуратуру).

Прокурор, який вступає в процес у формі звернення до суду в інтересах держави, в позовній чи іншій заяві, скарзі обгрунтовує, в чому полягає порушення інтересів держави, необхідність їх захисту, визначені законом підстави для звернення до суду, а також зазначає орган, уповноважений державою здійснювати відповідні функції у спірних правовідносинах (ч. 4 ст. 56 ЦПК). У разі відкриття провадження за позовною заявою, поданою прокурором в інтересах держави в особі органу державної влади, уповноваженого здійснювати функції держави у спірних правовідносинах, за умови, якщо захист цих інтересів цей орган не здійснює або неналежним чином здійснює, зазначений орган набуває статусу позивача. Прокурор у цьому разі набуває процесуального статусу органу, якому законом надано право звертатися до суду в інтересах інших осіб, і бере участь у процесі в порядку, визначеному ст.ст. 56, 57 ЦПК, тобто здійснює покладену на нього функцію представництва інтересів держави в межах іншого, ніж представництво у суді, самостійного процесуального інституту.

У цьому разі прокурор має обмежений у порівнянні із сторонами обсяг процесуальних прав та особливий порядок їх реалізації. Прокурор наділяється процесуальними правами та несе обов'язки особи, в інтересах якої він діє, за винятком права укладати мирову угоду. Відмова прокурора від поданої заяви або зміна позовних вимог не позбавляє особу, на захист прав, свобод та інтересів якої подано заяву, права вимагати від суду розгляду справи та вирішення вимоги у первісному обсязі (ст. 57 ЦПК). Прокурор реалізує надані йому процесуальні права щодо відмови від поданої заяви або зміни позовних вимог самостійно, не узгоджуючи свою правову позицію з органом, інтереси якого він представляє у суді. Відмова органу, уповноваженого здійснювати відповідні функції у спірних правовідносинах, від поданого прокурором в інтересах держави позову (заяви), подання ним заяви про залишення позову без розгляду не позбавляє прокурора права підтримувати позов (заяву) і вимагати розгляду справи по суті.

Зазначеною нормою також передбачено, що у разі відсутності органу, уповноваженого здійснювати функції держави у спірних правовідносинах, або відсутності у нього повноважень щодо звернення до суду прокурор зазначає про це в позовній заяві. Велика Палата Верховного Суду у постанові від 11 лютого 2020 року по справі № 922/614/19, вирішуючи питання про наявність підстав для представництва інтересів держави прокурором у суді, звернула увагу, що у разі, якщо підставою для представництва інтересів держави прокурор зазначив відсутність органу, до компетенції якого віднесені повноваження здійснювати захист законних інтересів держави у спірних правовідносинах, цей довід прокурора суд повинен перевірити незалежно від того, чи надав прокурор докази вчинення ним дій, спрямованих на встановлення відповідного органу.

Законом встановлено, що у разі звернення до суду на підставі відсутності органу, уповноваженого здійснювати функції держави у спірних правовідносинах, або відсутності у нього повноважень щодо звернення до суду прокурор набуває статусу позивача. Уявляється, що зазначене положення закону не відповідає наявній у цивільному процесуальному праві доктрині, згідно 3 якою основною ознакою сторін у судовому процесі є те, що сторони - це суб'єкти спору про право, які мають структуровану юри- 
дичну заінтересованість у розгляді справи (матеріальноправову та процесуально-правову) і діють у процесі від власного імені на захист своїх порушених, невизнаних або оспорюваних прав свобод та інтересів [10, с. 238-239]. Прокурор представляє інтереси держави і діє від іiї імені. Отже, він не є суб'єктом спору про право, не має матеріально-правової заінтересованості у справі, на нього не поширюються матеріально-правові наслідки судового рішення у справі. Крім того, правова дія ст.ст. 46, 47 ЦПК, якою визначається цивільна процесуальна правоздатність та дієздатність сторін у справі, не поширюється на прокурора, його процесуальна правосуб'єктність визначається спеціальними нормами(ст.ст.56,57ЦПК). У зв'язку з цим можна стверджувати, що в контексті зазначених доктринальних положень немає підстав для набуття прокурором процесуального статусу позивача (сторони) у справі. Позивачем у такому разі $є$ саме держава. Держава бере участь у справі через відповідний орган державної влади відповідно до його компетенції, від імені якого діє його керівник, інша уповноважена особа відповідно до закону, статуту, положення, трудового договору (контракту) (самопредставництво органу державної влади) або через представника (ч. 4 ст. 58 ЦПК). Цей законодавчий припис базується на загальних положеннях, відповідно до яких держава набуває і здійснює цивільні права та обов'язки через органи державної влади у межах їхньої компетенції, встановленої законом (ст. 170-173 ЦК). Органом, уповноваженим державою здійснювати відповідні функції у спірних відносинах, $є$ орган, на який державою покладено обов'язок щодо здійснення конкретної діяльності у відповідних правовідносинах, спрямованої на захист інтересів держави. Органи державної влади мають статус юридичної особи публічного права. 3 огляду на це їх участь у процесі має вирішуватися з урахуванням особливостей структурної організації та здійснення виконавчо-розпорядчої діяльності відповідного органу.

Таким чином, тільки у виняткових випадках, тобто у разі виникнення нетипової правової ситуації - відсутності органу, уповноваженого державою здійснювати відповідні функції у спірних правовідносинах, або відсутності у нього повноважень щодо звернення до суду, законом передбачена можливість держави взяти участь у судовому процесі через спеціально уповноваженого на це суб'єкта - прокурора. Уявляється, що в цьому разі процесуальна діяльність прокурора має правові ознаки представництва у суді, якій здійснює функції офіційного представника держави у таких справах. Діючи як офіційний представник держави, прокурор набуває, відповідно, обсяг процесуальних прав та обов'язків сторони у справі, не набуваючи при цьому процесуального становища (статусу) позивача. 3 урахуванням викладеного доцільним є внесення у ЦПК відповідних змін у правове регулювання участі прокурора в цивільному судочинстві та визначення його процесуального статусу залежно від підстав та умов реалізації функції представництва інтересів держави в суді.

У разі, якщо прокурор бере участь в судовому процесі в іншій, передбаченій ч. 3 ст. 56 та ч. 6 ст. 57 ЦПК формі, тобто вступає у справу, провадження у якій відкрито за позовом іншої особи, він має набувати статусу органу, якому законом надано право діяти в інтересах держави, з відповідним обсягом процесуальних повноважень.

Висновки. Підсумовуючи, слід зазначити, що в теорії цивільного процесуального права донині залишається дискусійним та доволі актуальним визначення сутності представницької діяльності прокурора та його процесуального статусу як учасника цивільного судочинства. Зумовлюється це передусім наявними прогалинами у правовому регулюванні участі прокурора в суді та певними неузгодженостями відповідних положень Закону України «Про прокуратуру з Конституцією України і новою редакцію ЦПК, що призводить до їх неоднакового тлумачення та ухвалення різних за змістом судових рішень.

Визначення сутнісних ознак представництва прокурором інтересів держави та процесуального статусу прокурора має відбуватися у призмі правової доктрини процесуального представництва та участі в судовому процесі органів та осіб, яким законом надане право звертатися до суду в інтересах інших осіб. Змішування різних процесуальних інститутів 3 автономним режимом правового регулювання $є$ неприпустимим. Процесуальний статус прокурора за межами кримінального судочинства, форми участі та порядок здійснення повноважень у суді потребують диференціації залежно від встановлених законом підстав та умов здійснення прокурором представництва інтересів держави.

Викладене свідчить, що на сучасному етапі реформування системи правосуддя, судочинства та суміжних правових інститутів відбувається модифікація представницької функції прокурора відповідно до європейських стандартів, що спонукає державу до створення належного правового підгрунтя процесуальної діяльності прокурора та забезпечення ефективного механізму реалізації представницької функції прокурора поза межами кримінальної юстиції. Пріоритетним напрямом та основним завданням реформування діяльності прокуратури з метою забезпечення іiі ефективної ролі в процесі захисту інтересів держави та суспільства, є евроінграційний вектор трансформації функції представництва прокурора у суді, гармонізація національного процесуального законодавства та його подальше вдосконалення відповідно до міжнародних стандартів правосуддя.

1. Офріційний вісник України. 2015, № 41, стор. 38, стаття 1267;

2. Хорсуненко О.В. Прокуратура України та країн - членів європейського союзу: порівняльне дослідження : автореф. дис....канд. юрид. наук. Київ, 2018. 22 c. URL: http://dspace onua.edu.ua/bitstream/handle/11300/11976/.

3. Берназюк Я. Особливості представництва прокурором інтересів держави в суді: нове законодавство та актуальні підходи Верховного Суду: 15.05.2020 p. URL: ttps://sud.ua/ru/news/blog/168820-osoblivosti-predstavnitstva-prokurorom-interesiv-derzhavi-v-sudi-novezakonodavstv.

4. Гранін А.П. Повноваження представника та його реалізація за цивільним законодавством України : автореф. дис. ... канд. юр. наук. Одеса, 2005. 20 c.

5. Чванкін С.А. Добровільне представництво у цивільному процесі України : автореф. дис. ... канд. юр. наук. Одеса, 2005. 22 с.

6. Лазько Г.З. Правова природа цивільного представництва у цивільному процесі : автореф. дис. ... канд. юр. наук. Київ : 2006 р. 19 с.

7. Анпілогов О.В. Правове регулювання участі прокурора в адміністративному судочинстві щодо захисту прав та свобод громадянина : автореф. дис. ... канд. юрид. наук. Київ, 2008. 19 с.

8. Сапунков В.Й. Представництво як процесуальний інститут. Вісник прокуратури. 2002. № 6. С. 67-75.

9. Руденко М.В. Прокурор як учасник цивільного та адміністративного процесу. Актуальні проблеми застосування Цивільного процесуального Кодексу та Кодексу адміністративного судочинства України : Тези доп. та наук. повідомлень учасників міжнар. наук.практ. конфр. (25-26 січ. 2007 р.) / За заг. ред. В.В. Комарова. Харків : Нац. юрид. акад. України, 2007. С. 101-105.

10. Цивільне судочинство України: основні засади та інститути : монографрія / В.В. Комаров, К.В. Гусаров, Н.Ю. Сакара та інші ; за ред. В.В. Комарова. Харків :Право, 2016. 848 с. 


\title{
РОЗДІЛ 4 \\ ГОСПОДАРСЬКЕ ПРАВО, ГОСПОДАРСЬКО-ПРОЦЕСУАЛЬНЕ ПРАВО
}

УДК 346.7:343.535

DOI https://doi.org/10.32782/2524-0374/2020-4/16

\section{ДИСКУСІЙНІ АСПЕКТИ ПОРЯДКУ ЗАДОВОЛЕННЯ ВИМОГ КРЕДИТОРІВ У ЛІКВІДАЦІЙНІЙ ПРОЦЕДУРІ ЗА КОДЕКСОМ УКРАЇНИ $З$ ПРОЦЕДУР БАНКРУТСТВА}

\author{
CONTROVERSIAL ASPECTS REGARDING THE PROCEDURE \\ FOR SATISFYING CREDITORS' CLAIMS IN THE LIQUIDATION PROCEDURE \\ UNDER THE BANKRUPTCY CODE OF UKRAINE
}

Богатир В.К., аспірант

Донецький юридичний інститут Міністерства внутрішніх справ Украйни

\begin{abstract}
У статті на основі застосування методів аналізу, порівняння та інших розглянуто положення норм Кодексу України з процедур банкрутства, Закону України «Про акціонерні товариства», погляди вчених та практиків, які стосувалися порядку та черговості задоволення вимог кредиторів у ліквідаційній процедурі банкрутства та під час добровільної ліквідації акціонерного товариства. Переважно підтримано законодавця у питаннях визначення черговості. Виявлено окремі дискусійні аспекти у порядку задоволення вимог кредиторів у ліквідаційній процедурі. Запропоновано законодавцеві підтримати погляди арбітражного керуючого Є. Марченка та обмежити строк розгляду господарським судом вимог конкурсних кредиторів, заявлених після закінчення строку, визначеного для їх подання, виключно протягом судової процедури розпорядження майном боржника. У такому разі будуть подолані окремі колізії законодавства, проте частина кредиторів залишиться невдоволеною. Також порівняльний аналіз законодавства про банкрутство та про акціонерні товариства дав змогу запропонувати законодавцеві у ліквідаційній процедурі вимоги кредиторів банкрута, віднесені до другої черги задоволення (зокрема, вимоги із зобов'язань, що виникли внаслідок заподіяння шкоди життю та здоров'ю громадян, зобов'язань зі сплати страхових внесків на загальнообов'язкове державне пенсійне страхування та інше соціальне страхування та ін.), віднести до першої черги задоволення вимог кредиторів із коригуванням номерів інших черг.

Також поставлено питання, на які майбутні дослідження повинні дати відповідь: що робити кредиторам у разі виявлення у керівників чи власників майна банкрута на балансі інших суб'єктів господарювання, в яких вони мають певну частку, після його ліквідації значних грошових коштів (зокрема, і в криптовалюті) та/або майна; до якого суду і з якими вимогами звертатися; яким суддею та за правилами якого судочинства здійснюватиметься провадження та чи здійснюватиметься взагалі та ін.
\end{abstract}

Ключові слова: банкрутство, боржник, банкрут, ліквідаційна процедура, ліквідатор, суб'єкт господарювання, Кодекс України з процедур банкрутства, черговість задоволення вимог кредиторів.

The authors use the methods of analysis, comparison and others to consider the provisions of the Bankruptcy Code of Ukraine, the Law of Ukraine On Joint Stock Companies, the views of scientists and practitioners concerning the order and priority of satisfaction of creditors' claims in the liquidation procedure in bankruptcy and in the voluntary liquidation of a joint-stock company. The legislator is mostly supported in determining the priority. Some controversial aspects concerning the order of satisfaction of creditors' claims in the liquidation procedure have been revealed. It was proposed to the legislator to support the views of the insolvency officer Ye. Marchenko and to limit the period for consideration by the economic court of the bankruptcy creditors' claims declared after the expiration of the period specified for their presentation, exclusively during the judicial procedure for disposing of the debtor's property. In this case, certain conflicts of law will be overcome, but some creditors will remain unsatisfied. A comparative analysis of the legislation on bankruptcy and on joint-stock companies made it possible to propose to refer the claims of bankrupt creditors in the liquidation procedure, which referred to the second stage of satisfaction (in particular, claims for obligations arising from harm to the life and health of citizens, obligations to pay insurance premiums for compulsory state pension insurance and other social insurance, etc.), to the first stage of satisfaction of creditors' claims with adjustments to the numbers of other stages.

The issues for future studies were raised: what should creditors do if managers or owners of the bankrupt property have significant funds (including in cryptocurrency) and/or property on the balance sheets of other business entities in which they have a certain share; to which court and with what requirements to apply; by what judge and according to the rules of what legal procedure the proceedings will be carried out and whether it will be carried out in general, etc.

Key words: bankruptcy, debtor, bankrupt, liquidation procedure, liquidator, business entity, Bankruptcy Code of Ukraine, priority of satisfaction of creditors' claims.

Постановка проблеми. Провадження у справі про банкрутство відкривається через неспроможність боржника виконати свої грошові зобов'язання перед кредиторами, а ліквідаційна процедура відкривається через неспроможність боржника виконати визнані господарським судом вимоги кредиторів навіть після застосування усіх можливих санаційних заходів та механізмів. Б.М. Поляков наголошує, що у відносинах неспроможності основний інтерес - публічний, спрямований на відновлення платоспроможності боржника і збереження господарюючого суб'єкта. Однак приватний інтерес - погашення зобов'язань кредиторів не зникає, а враховується у вигляді спільного інтересу. Якщо приватний інтерес ігнорується, то втрачається зміст відносин неспроможності, бо тоді держава встановлює заборону на банкрутство. Якщо ж

надати свободу приватному інтересу, то постраждають економіка і кредитори. Отже, публічний i приватний інтереси мають підпорядковуватися спільному інтересу [1, с. 14]. Виходячи із цього, у ліквідаційній процедурі превалює приватний інтерес кредиторів. Усі заходи, спрямовані на відновлення платоспроможності боржника, а отже, і на забезпечення та реалізацію публічного інтересу, результату не дали. Проте діяльність кредиторів контрагентів боржника є господарською, що передбачає реалізацію значної кількості як приватних, так і публічних інтересів. Кредитори - органи пенсійного забезпечення, податкові органи, Фонд соціального страхування України (далі - ФСС України) - більшою мірою утворені та діють iз метою реалізації публічних інтересів. Не менш вагомий публічний інтерес реалізується під час відшкодування за 
рахунок банкрута витрат державного бюджету України понесених унаслідок виплат за рішенням ЄСПЛ та ін. Тобто наявність вагомих публічних інтересів у ліквідаційній процедурі відкидати не можна, навіть якщо видається, що головним завданням цієї процедури $є$ задоволення приватних інтересів кредиторів.

Справедливе задоволення вимог кредиторів - це те, заради чого останні ініціюють справу про банкрутство. Законодавство про банкрутство побудоване так, що процедура банкрутства $є$ продовженням виконавчого провадження, тобто останнім шансом для кредиторів отримати задоволення своїх вимог. Справедливість задоволення вимог кредиторів забезпечується існуванням черговості задоволення вимог кредиторів, що дає змогу погашати передусім соціально важливі вимоги [2, с. 25]. 3 іншого боку, зробити так, щоб грошей від реалізації ліквідаційної маси вистачило для задоволення вимог усіх кредиторів, удається вкрай рідко. Можливо, навіть ніколи. В іншому разі не ініціювалося б провадження про банкрутство, а під час нього не було б відкриття ліквідаційної процедури. Тому, у будь-якому разі, хтось із кредиторів буде не задоволений роботою ліквідатора, хтось підозрюватиме його у змові з іншими кредиторами своєї черги чи попередніх черг. А в когось із кредиторів узагалі будуть претензії до законодавця стосовно справедливості визначення черг та вимог у них саме у тому вигляді, що є чинним сьогодні.

Стан дослідження. Загалом правове регулювання відносин між учасниками процедур банкрутства досліджувалося українськими економістами та юристами, зокрема і господарниками. Зокрема, можна назвати таких учених, як О. Беляневич, А. Бутирський, В. Джунь, С. Марченко, С. Петров, Б. Поляков, Ю. Чорна та ін. Проте нетривалий час дії Кодексу України з процедур банкрутства (далі КУзПБ) вимагає проведення додаткових досліджень.

Постановка завдання. Ураховуючи викладене вище, завданням статті $\epsilon$ виявлення дискусійних аспектів порядку задоволення вимог кредиторів у ліквідаційній процедурі, пошук та пропозиція напрямів іх усунення.

Виклад основного матеріалу. Абзацом другим частини третьої статті 61 «Повноваження ліквідатора» КУзПБ визначено, що кошти, які надходять під час проведення ліквідаційної процедури, зараховуються на ліквідаційний рахунок боржника. Після оплати витрат, пов'язаних із проведенням ліквідаційної процедури, та сплати основної і додаткової винагороди арбітражного керуючого здійснюються виплати кредиторам у порядку черговості, встановленому КУзПБ [3]. Черговість задоволення вимог кредиторів визначено однойменною статтею 64 КУзПБ. Усього передбачено шість черг [3]. Потрібно окремо розглянути вимоги кожної черги.

Законодавець передбачив погашення банкрутом у першу чергу заборгованості боржника перед своїми працівниками (зокрема, і тими, що звільнилися) із зарплати, додаткових та інших доплат, виплат і відшкодувань, соціальних та інших виплат та будь-яких інших заборгованостей перед працівниками незалежно від того, чи працював працівник, чи знаходився на простої. Головним критерієм $є$ відсутність вини працівника у тому, що він не виконував роботу у робочий час. Також у першу чергу банкрут відшкодовує витрати державного бюджету України, понесені внаслідок виплат за рішенням ЄСПЛ. Очевидно, що ця норма з'явилася нещодавно у розвиток інших нормативних положень щодо прагнення України увійти до родини держав 3 європейськими цінностями та гарантування дотримання прав людини і виконання рішень міжнародних судових інстанцій, і чи не в першу чергу - ЄСПЛ. Це тим більше разюче підкреслює різницю з правом і законодавством РФ, яка нещодавно національне законодавство поставила вище міжнародного і відмовилася виконувати частину рішень ЄСПЛ (можливо, це пов'язано з витратами, адже, за даними Рахунко- вої палати РФ, у 2019 році було сплачено 1,1 млрд рублів за 1240 рішеннями ССПЛ, а керівництво держави стверджує, що виконує усі рішення ЄСПЛ [4]). Зрозуміло, що виплати на користь громадян України, осіб без громадянства та громадян (підданих) інших держав здійснюються державою Україна, яка програла спір у ССПЛ, за рахунок державного бюджету. Але вони будуть покладені на банкрута, якщо саме він винен у порушенні основоположних прав та/або свобод людини і громадянина, що призвело до судового розгляду в ЄСПЛ та задоволення ним позову. Тобто між банкрутом та справою у ЄСПЛ має існувати прямий причинно-наслідковий зв'язок, який потребує пояснень, зокрема і конкретизації у КУзПБ.

Вимоги кредиторів за договорами страхування погашаються у першу чергу в силу додаткового тиску на банкрута та впливу на відносини у процедурі ліквідації з боку спеціального законодавства про страхування та раніше взятими на себе банкрутом зобов'язання, закріплені господарсько- та цивільно-правовими договорами про страхування і похідними від них. Судові та позасудові витрати, пов'язані з провадженням у справі про банкрутство, проведенням призначеної рішенням господарського суду аудиторської перевірки боржника (банкрута) з оплатою за рахунок коштів кредиторів, також погашаються у першу чергу.

Зобов'язання, що підлягають задоволенню у першу чергу, прописано найбільш повно і ретельно. Можливо, це зроблено і через те, що кредитори за цими зобов'язаннями мають найвищі шанси повернути всі або частину своїх коштів із ліквідаційної маси банкрута.

У другу чергу задовольняється менша кількість вимог, зокрема вимоги громадян, які зазнали шкоди здоров'ю через дії боржника (банкрута), а також вимоги ФСС України та Пенсійного фонду України [3]. У цьому зв'язку може виникнути питання: чому вимоги сучасних працівників мають пріоритет перед вимогами працівників, які працювали давно та отримують пенсійні виплати? Адже вимоги перших задовольняються у першу чергу, а других - у другу.

Схоже поставленому вище питання може виникнути і стосовно третьої черги задоволення вимог кредиторів. У третю чергу задовольняються: вимоги щодо сплати податків і зборів (обов'язкових платежів); вимоги центрального органу виконавчої влади, що здійснює управління державним резервом [3]. Виходить, що збори до ФСС України та Пенсійного фонду України мають для держави пріоритет перед збором податків.

Вимоги кредиторів, не забезпечені заставою, задовольняються у четверту чергу [3]. Тобто задоволення абсолютної більшості вимог кредиторів віднесено аж на четверту чергу. $€$ велика ймовірність, що грошей банкрута, отриманих від продажу ліквідаційної маси, не вистачить на відшкодування вимог звичайних кредиторів. Але й на цьому черга не завершується.

Стосовно двох останніх черг питань виникати не повинно. Внески до статутного капіталу підприємства робилися членами трудового колективу добровільно, цілями було збереження власного робочого місця, підвищення доходів підприємства, отримання дивідендів та інше, спрямоване на отримання певних матеріальних переваг. А тому від'ємний результат роботи виправдовує ризиковий характер підприємницької діяльності. Стосовно шостої черги задоволення вимог кредиторів складається враження, що законодавець просто перестрахувався і відніс туди «інші вимоги», тобто будь-які можливі вимоги будь-яких інших осіб, що можуть виникнути на законних підставах та не включені до інших випадків.

Ю.В. Чорна у дисертаційній роботі довела, що системи банкрутства багатьох держав світу, як і вітчизняна, формувалися шляхом запозичення та адаптації правового інструментарію конкурсного законодавства зарубіжних 
країн, зокрема таких, як США, Велика Британія, ФРН та Франція, а система банкрутства Японії є прикладом практичної реалізації принципу розподілення боржників за величиною як показника гнучкості конкурсного законодавства, що $€$ ознакою ефективної системи банкрутства [5, с. 11]. Стосовно Японії, очевидно, мається на увазі запровадження диференціації боржників з урахуванням розміру боргів перед ними.

Є.В. Петров нагадує, що вимоги, які не задоволені через відсутність майна юридичної особи, що ліквідується, вважаються погашеними [6, с. 146]. На останнє вказує частина сьома названої вище статті 64 КУзПБ [3].

Викладене вище породжує постановку декількох питань. 3 одного боку, банкрут ліквідується, тому кредиторам буде нікому пред'являти вимоги. 3 іншого боку, постає питання: що робити у разі, якщо після ліквідації банкрута у його колишніх керівників чи власників майна на банківських рахунках чи у готівковій формі раптом 3'являться достатньо великі суми грошей або з'явиться коштовне майно? Вимоги кредиторів уважаються погашеними, банкрута у правовому полі України вже не існує. Якщо стосовно колишніх керівників чи власників майна банкрута було порушено кримінальне провадження за підозрою у розкраданні грошей банкрута, то виникає питання, до кого кредиторам, вимоги яких не було повністю або частково задоволено, пред’являти нові чи ті самі вимоги, за якою формою, ким, тобто яким судом та ким із суддів, і в якому порядку розглядатимуться нові/ старі вимоги кредиторів. І стосовно останніх незрозуміло, чи можна по відношенню до них застосовувати термін «колишні кредитори»?

Наведена вище ситуація не виглядає фантастичною через достатню відкритість світової банківської системи $[7 ; 8]$, повноцінне функціонування у багатьох державах світу ринку криптовалюти $[9 ; 10]$, розвиненість та постійне вдосконалення способів скоєння злочинів у сфері економіки тощо.

Із цією ситуацією має схожість і інша, на яку вказує арбітражний керуючий $Є$. Марченко. Вона пов'язана 3 так званими «відкладеними вимогами», тобто вимогами конкурсних кредиторів, заявленими після закінчення строку, встановленого для їх подання $[11$, с. 49]. У силу положень частини третьої статті 60 та абзацу вісімнадцятого частини першої статті 61 КУзПБ складається враження, що до повноважень ліквідатора зі дня його призначення прямо відноситься зобов'язання з ведення реєстру вимог кредиторів. Однак такий висновок не може бути, на думку практика, однозначним за умови наявності значної кількості факторів $[11$, с. 50]. А отже, вимоги конкурсного кредитора, заявлені уже в ліквідаційній процедурі, навряд чи будуть задоволені. КУзПБ прямо не передбачено здійснення господарським судом та ліквідатором у процедурі ліквідації банкрута повноважень щодо розгляду заяв конкурсних кредиторів із грошовими вимогами до боржника. У зв'язку із цим Є. Марченко робить висновок, що у разі заявлення конкурсними кредиторами грошових вимог до боржника в межах судової процедури ліквідації банкрута, за існуючих умов процедура розгляду таких вимог, внесення відомостей про таких кредиторів до реєстру вимог кредиторів та, відповідно, задоволення (погашення) зазначених вимог $\epsilon$ можливою шляхом застосування аналогії закону, що за наявності певних чинників може призвести до неоднозначного застосування закону. Для уникнення появи колізії практик пропонує обмежити строк розгляду господарським судом вимог конкурсних кредиторів, заявлених після закінчення строку, визначеного для їх подання, виключно протягом судової процедури розпорядження майном боржника [11, с. 53]. У такому разі колізія буде подолана, проте кредитори, які не заявили вимоги до боржника протягом процедури розпорядження його майном, пізніше не зможуть цього зробити, й їхні вимоги залишаться незадоволеними, а підсумком співпраці з боржником (банкрутом) буде отримання збитків на суму цих не заявлених у строк вимог.

3 іншого боку, пропуск на початкових стадіях процедур банкрутства строку на заявлення вимог до боржника $\epsilon$ провиною самого кредитора в особі його менеджменту або юридичної служби (у будь-якому разі це буде свідченням неякісної правової роботи на підприємстві). Усі кредитори одного боржника, по суті, $є$ конкурентами у черзі на задоволення своїх вимог щодо повернення своїх грошей. Інші конкурсні кредитори вимоги заявили своєчасно та 3 дотриманням вимог КУзПБ і спеціального законодавства. Щодо висловленого можна навести сформульовані вченими-господарниками принципи правового інституту банкрутства, якими запропоновано вважати:

- ідею конкурсу кредиторів;

- процедурний порядок задоволення вимог кредиторів;

- узгодженість нормативних приписів права із суміжними інститутами права $[12$, с. $7 ; 13$, с. $7-8]$.

Під час розгляду порядку задоволення вимог кредиторів у ліквідаційній процедурі слід звернути увагу на черговість задоволення вимог кредиторів та акціонерів акціонерного товариства (далі - АТ) під час його добровільної ліквідації. Статтею 88 «Ліквідація акціонерного товариства» Закону України «Про акціонерні товариства» передбачено можливість добровільної ліквідації АТ за рішенням загальних зборів акціонерів, у т. ч. у зв'язку із закінченням строку, на який товариство створювалося, або після досягнення мети, 3 якою воно створювалося. А статтею 89 «Розподіл майна акціонерного товариства, що ліквідується, між кредиторами та акціонерами» Закону України «Про акціонерні товариства» встановлено дев'ять черг задоволення вимог [14].

Виплати кредиторам АТ передбачено у перших чотирьох чергах. Інші п’ять черг стосуються виплат акціонерам. У цілому наведені чотири черги виплат кредиторам АТ у чомусь мають схожість із чергами задоволення вимог кредиторів у ліквідаційній процедурі, проте мають і певні відмінності. Для наочності та спрощення проведення порівняльного аналізу та полегшення візуального сприйняття можна скласти порівняльну таблицю (табл. 1).

Як наочно видно з таблиці, є певні співпадіння. Так, вимоги щодо сплати податків і зборів (обов'язкових платежів) в обох випадках задовольняються у третю чергу. У четверту (останню) чергу для задоволення вимог кредиторів у разі добровільної ліквідації АТ задовольняються усі інші вимоги кредиторів. Цій черзі кореспондують IV-VI черги ліквідаційної процедури банкрутства, що включають вимоги кредиторів, не забезпечені заставою; вимоги щодо повернення внесків членів трудового колективу до статутного капіталу підприємства та всі інші вимоги, не включені до попередніх черг.

Натомість є й певні відмінності. Так, вимоги кредиторів, забезпечені заставою, у разі добровільної ліквідації АТ задовольняються у першу чергу (у таблиці вони виділені напівжирним курсивом та підкреслені), а в ліквідаційній процедурі банкрутства вони взагалі відсутні. Майно боржника, забезпечене заставою, взагалі не включається до ліквідаційної маси, а вимоги таких кредиторів (забезпечених) погашаються до погашення усіх інших вимог, що поділені на шість черг. Мабуть, така ситуація виглядає логічною і має залишатися у законодавстві та на практиці й надалі. Також серед відмінностей слід звернути увагу на те, що у ліквідаційній процедурі банкрутства у першу чергу переважно задовольняються вимоги працівників боржника, тоді як разі добровільної ліквідації АТ вимоги працівників, пов'язані з трудовими відносинами, задовольняються у другу чергу. I навпаки, вимоги щодо відшкодування шкоди, заподіяної каліцтвом, іншими ушкодженнями здоров'я або смертю, задовольняються у разі добровільної ліквідації 
Порівняльна характеристика черг задоволення вимог кредиторів у ліквідаційній процедурі банкрутства та у разі добровільної ліквідації АТ

\begin{tabular}{|c|c|c|c|}
\hline \multicolumn{2}{|r|}{$\begin{array}{c}\text { Черга задоволення вимог кредиторів } \\
\text { у ліквідаційній процедурі банкрутства }\end{array}$} & \multicolumn{2}{|c|}{$\begin{array}{c}\text { Черга задоволення вимог кредиторів } \\
\text { при добровільній ліквідації АT }\end{array}$} \\
\hline № черги & Зміст вимог & № черги & \begin{tabular}{|c|} 
Зміст вимог \\
\end{tabular} \\
\hline I & $\begin{array}{l}\text { - вимоги щодо виплати заборгованості із заробітної плати працю- } \\
\text { ючим та звільненим працівникам банкрута, грошові компенсації за } \\
\text { всі невикористані дні щорічної відпустки та додаткової відпустки } \\
\text { працівникам, які мають дітей, інші кошти, належні працівникам у } \\
\text { зв’язку з оплачуваною відсутністю на роботі (оплата часу простою } \\
\text { не з вини працівника, гарантії на час виконання державних або } \\
\text { громадських обов’язків, гарантії і компенсації під час службових } \\
\text { відряджень, гарантії для працівників, які направляються для підви- } \\
\text { щення кваліфікації, гарантії для донорів, гарантії для працівників, } \\
\text { які направляються на обстеження до медичного закладу, соціальні } \\
\text { виплати у зв’язку з тимчасовою втратою працездатності за рахунок } \\
\text { коштів підприємства тощо), а також вихідна допомога, належна } \\
\text { працівникам у зв’язку з припиненням трудових відносин, та нара- } \\
\text { ховані на ці суми страхові внески на загальнообов’язкове державне } \\
\text { пенсійне страхування та інше соціальне страхування, у тому числі } \\
\text { відшкодування кредиту, отриманого на ці цілі; } \\
\text { - вимоги щодо виплати заборгованості з компенсації збитків, завда- } \\
\text { них державному бюджету України внаслідок виконання рішень } \\
\text { ЄСПЛ, постановлених проти України; } \\
\text { - вимоги кредиторів за договорами страхування; } \\
\text { - витрати, пов’язані з провадженням у справі про банкрутство в } \\
\text { господарському суді; } \\
\text { - витрати кредиторів на проведення аудиту, якщо аудит проводився } \\
\text { за рішенням господарського суду за рахунок їхніх коштів }\end{array}$ & II & $\begin{array}{l}\text { - вимоги працівників, пов'язані } \\
\text { трудовими відносинами, вимоги } \\
\text { автора про плату за використання } \\
\text { результату його інтелектуальної, } \\
\text { творчої діяльності }\end{array}$ \\
\hline II & $\begin{array}{l}\text { - вимоги із зобов'язань, що виникли внаслідок заподіяння шкоди } \\
\text { життю та здоров'ю громадян, шляхом капіталізації у ліквідацій- } \\
\text { ній процедурі відповідних платежів, у тому числі до ФСС Укра- } \\
\text { їни за громадян, які застраховані в цьому фонді, у порядку, вста- } \\
\text { новленому КМУ, зобов'язань зі сплати страхових внесків на } \\
\text { загальнообов’язкове державне пенсійне страхування та інше соці- } \\
\text { альне страхування, крім вимог, задоволених позачергово, з повер- } \\
\text { нення невикористаних коштів ФСС України, а також вимоги гро- } \\
\text { мадян - довірителів (вкладників) довірчих товариств або інших } \\
\text { суб’єктів підприємницької діяльності, які залучали майно (кошти) } \\
\text { довірителів (вкладників) }\end{array}$ & I & $\begin{array}{l}\text { - вимоги щодо відшкодування } \\
\text { шкоди, заподіяної каліцтвом, } \\
\text { іншими ушкодженнями здоров'я } \\
\text { або смертю, та вимоги кредито- } \\
\text { рів, забезпечені заставою } \\
\text { (виділення наше - В.Б.) }\end{array}$ \\
\hline III & $\begin{array}{l}\text { - вимоги щодо сплати податків і зборів (обов'язкових платежів); } \\
\text { - вимоги центрального органу виконавчої влади, що здійснює } \\
\text { управління державним резервом }\end{array}$ & III & $\begin{array}{l}\text { - вимоги щодо податків, зборів } \\
\text { (обов’язкових платежів) }\end{array}$ \\
\hline IV & - вимоги кредиторів, не забезпечені заставою & \multirow[t]{3}{*}{ IV } & \multirow[t]{3}{*}{ - усі інші вимоги кредиторів } \\
\hline $\mathrm{V}$ & $\begin{array}{l}\text { - вимоги щодо повернення внесків членів трудового колективу до } \\
\text { статутного капіталу підприємства }\end{array}$ & & \\
\hline VI & - інші вимоги & & \\
\hline
\end{tabular}

АТ у першу чергу, а під час ліквідаційної процедури банкрутства вимоги із зобов'язань, що виникли внаслідок заподіяння шкоди життю та здоров’ю громадян, погашаються у другу чергу. Із цього приводу вище вже піднімалося питання, чому вимоги працівників, що працюють або працювали до останнього моменту у банкрута, погашаються у першу чергу, а вимоги працівників, які не працюють відносно давно та отримують пенсію і регресні виплати у зв'язку з інвалідністю, погашаються у другу чергу (зрозуміло, опосередковано через ФСС України). До цього питання можна додати питання, чому шкода, завдана життю чи здоров'ю працівників, погашається у другу чергу, а виплати зарплат - у першу. Тим більш вагомим останнє питання виглядає ще й тому, що дуже часто грошей банкрута для погашення вимог другої черги не залишається. А отже, враховуючи соціальну і гуманістичну спрямованість політики будь-якої сучасної держави, зокрема й України, потребу у підтримці громадян (їнніх родичів), життю та здоров'ю яких було заподіяно шкоду, а також не меншу кількість публічних інтересів, що реалізуються завдяки виплатам на державне пенсійне страхування та інше соціальне страхування, аніж завдяки виплатам до державного бюджету України, пропонуємо усі вимоги, наведені у пункті 2 частини 1 статті 64 «Черговість задоволення вимог кредиторів» КУзПБ, перенести до пункту 1 частини 1 цієї статті. Іншими словами, пропонуємо ці вимоги кредиторів віднести до таких, які погашаються у першу чергу. У разі позитивної відповіді законодавця на цю пропозицію номери наступних пунктів i, власне, черги задоволення вимог кредиторів слід зменшити на один. У такому разі вимоги кредиторів, визначені та наведені сьогодні у другій черзі, будуть погашені у першу чергу. Тут слід згадати правило, описане у частині 3 названої статті 64 КУзПБ, згідно з яким у разі недостатності коштів, одержаних від продажу майна банкрута, для повного задоволення всіх вимог однієї черги вимоги задовольняються пропорційно до суми вимог, що належить кожному кредитору однісї черги [3]. Дія цього правила дасть змогу хоча б частково задовольнити вимоги із зобов'язань, що виникли внаслідок заподіяння шкоди життю та здоров'ю громадян та вимоги зобов'язань зі сплати страхових внесків на загальнообов'язкове державне пенсійне страхування та інше соціальне страхування. 
Висновки. На основі аналізу положень статті 64 «Черговість задоволення вимог кредиторів» та інших статей КУзПБ, поглядів учених і практиків стосовно порядку та черговості задоволення вимог кредиторів у ліквідаційній процедурі банкрутства, порівняння такого порядку і черговості з порядком та черговістю задоволення вимог кредиторів разі добровільної ліквідації АТ удалося виявити окремі дискусійні аспекти порядку задоволення вимог кредиторів у ліквідаційній процедурі і запропонувати законодавцеві такі напрями їх усунення:

- погодитися 3 поглядами арбітражного керуючого Є. Марченка і обмежити строк розгляду господарським судом вимог конкурсних кредиторів, заявлених після закінчення строку, визначеного для їх подання, виключно протягом судової процедури розпорядження майном боржника;

- у ліквідаційній процедурі підняти рівень вимог кредиторів другої черги (зокрема, вимог із зобов'язань, що виникли внаслідок заподіяння шкоди життю та здоров'ю громадян, зобов'язань зі сплати страхових внесків на загальнообов'язкове державне пенсійне страхування та інше соціальне страхування та ін.) до рівня першої черги задоволення вимог кредиторів із коригуванням номерів наступних черг.

Зрозуміло, що зроблені пропозиції у разі їх урахування позитивно вплинуть на інтереси одних кредиторів та їхніх груп та негативно - на інших. Узагалі, знайти способи задоволення інтересів усіх учасників процедур банкрутства (й особливо ліквідаційної процедури) навряд чи колись комусь удасться, проте всі майбутні дослідження правового забезпечення відносин у цих процедурах мають спрямовуватися на пошук оптимального врахування та задоволення публічних і приватних інтересів, що включають у себе інтереси всіх учасників цих відносин. Також майбутні дослідження повинні дати відповідь на питання, що робити у разі виявлення у керівників чи власників майна банкрута на балансі інших суб'єктів господарювання, в яких вони мають певну частку, після його ліквідації значних грошових коштів (зокрема, і в криптовалюті) та/або майна; до якого суду і з якими вимогами звертатися та ін.

\section{ЛITEPATYPA}

1. Поляков Б.М. Правові проблеми регулювання неспроможності (банкрутства) : автореф. дис. ... д-ра юрид. наук : спец. 12.00.04 «Господарське право; господарсько-процесуальне право» ; Інститут економіко-правових досліджень НАН України. Донецьк, 2003. $36 \mathrm{c}$.

2. Бутирський А.А. Значення інституту банкрутства для економічних відносин в Україні. Перші наукові читання пам'яті академіка В.К. Мамутова : матеріали круглого столу, м. Київ, 8 лютого 2019 р. Київ, 2019. С. 23-27.

3. Кодекс України з процедур банкрутства : Закон України від 18 жовтня 2018 року № 2597-VIII. Відомості Верховної Ради України. 2019. № 19. Ст. 74.

4. Россия выплатила за год более миллиарда рублей по решениям ЕСПЧ. Канал «Дождь». 20 июля 2020 г. URL : https://tvrain.ru/ news/rossija vyplatila za god bolee milliarda rublej_po reshenijam espch-512829/.

5. Чорна Ю.В. Світові системи банкрутства: господарсько-правовий аспект : автореф. дис. ... канд. юрид. наук : 12.00 .04 ; І н-т економіко-прав. досліджень НАН України. Київ, 2018. 20 с.

6. Петров Є.В. Задоволення вимог кредиторів при реорганізації та ліквідації юридичних осіб. Науковий вісник Міжнародного гуманітарного університету. Серія «Юриспруденція». 2014. № 7. С. 143-147.

7. Старинський М.В. Порівняльне банківське право. Суми : Мрія - 1 ЛТД, 2004. 168 с.

8. Кадала В.В., Хайлова Т.В., Гузенко О.П. Банківське право : навчальний посібник / за ред. д-ра юрид. наук, проф. Б.В. Деревянка ; МВС України, Донецький юридичний інститут. Львів : Магнолія - 2006, 2020. 172 с.

9. Деревянко Б.В. Ризики здійснення операцій з криптовалютою (біткойнами) громадян і суб'єктів господарювання України. Форум права. 2017. № 3. С. 33-39. URL : http://nbuv.gov.ua/j-pdf/FP_index.htm_2017_3_8.pdf.

10. Деревянко Б.В. Про порівняння господарської діяльності з видобутком криптовалюти («майнінгом») та здійсненням операцій із нею. Право України. 2018. № 5. С. 164-175.

11. Марченко Є. Конкурсні вимоги у справі про банкрутство. Новели та прогалини. Застосування норм Кодексу України з процедур банкрутства / за заг. ред. д.ю.н., судді Верховного Суду С.В. Жукова. Київ : Алерта, 2019. С. 46-54.

12. Джунь В.В. Теоретико-прикладні проблеми реформування законодавства України про банкрутство : авторефр. дис. ... д-ра юрид. наук : спец. 12.00.04 «Господарське право; господарсько-процесуальне право»; Київ. нац. ун-т ім. Т. Шевченка. Київ, 2009. 30 с.

13. Беляневич О. Про особливості застосування норм про позовну давність у справах про банкрутство. Підприємництво, господарство і право. 2017. № 10. С. 5-9.

14. Про акціонерні товариства : Закон України від 17 вересня 2008 року № 514-VI. Відомості Верховної Ради України. 2008 . № 50-51. Ст. 384. 


\title{
ОСОБЛИВОСТІ УЧАСТІ ПІДПРИЕМСТВ РЕЛІГІЙНИХ ОРГАНІЗАЦІЙ У ГОСПОДАРСЬКИХ ПРАВОВІДНОСИНАХ
}

\author{
FEATURES OF PARTICIPATION OF ENTERPRISES OF RELIGIOUS ORGANIZATIONS \\ IN ECONOMIC LEGAL RELATIONS
}

Бочков П.В., к.ю.н., доктор богослов'я, настоятель Храм святителя Луки Войно-Ясенецького

Статтю присвячено дослідженню особливостей участі підприємств релігійних організацій у господарських правовідносинах. Проаналізовано нормативно-правові акти, які регулюють діяльність релігійних організацій. Установлено, що особливість участі підприємств релігійних організацій у господарських правовідносинах зумовлена особливістю правового статусу релігійних організацій.

Визначено, що чинне законодавство не встановлює чітких рамок щодо видів діяльності, які мають право здійснювати підприємства релігійних організацій. Зроблено висновок, що релігійні організації є некомерційними суб'єктами господарювання, оскільки головною метою їхньої діяльності є створення громадянам можливості сповідувати певну релігію та здійснювати необхідні для цього дії, обряди, ритуали тощо, а не отримання прибутків. Ключовою ознакою господарсько-правового статусу підприємства релігійної організації є те, що воно створюється для реалізації мети, цілей і завдань її засновника - релігійної організації.

Установлено, що діяльність підприємств релігійних організацій регулюється не тільки державними законодавчими актами, а й внутрішньоконфесійними настановами, положеннями, статутами. Специфіка регулювання господарської діяльності підприємств релігійних організацій полягає ще й у тому, що майже кожна конфесія має свої специфічнні правила ведення такої діяльності: заборони, обмеження, регламенти певних дій.

Установлено, що господарсько-правовий статус підприємств релігійних організацій значною мірою залежить від суспільно-політичної ситуації у країні та від державно-релігійних відносин на відповідному етапі державотворення. Задекларований державою нейтралітет у питаннях світогляду й віросповідання, виконання зобов'язань із гарантування свободи віросповідання і водночас створює рівні умови для захисту прав і свобод усіх громадян. Проте, незважаючи на світський статус держави, в Україні мають місце приклади звільнення релігійних організацій від податків чи надання їм будь-яких пільг, у законодавстві міститься положення про те, що релігійні організації користуються виключним правом заснування підприємств для випуску богослужбової літератури і виробництва предметів культового призначення. Зроблено висновок, що такі преференції з боку держави можуть відбуватися лише за умови наявності спеціальної моделі державно-релігійних відносин (державної Церкви або договірної моделі відносин Церкви і держави).

Ключові слова: релігійна організація, господарські правовідносини, підприємство релігійної організації, підприємство, господарська діяльність.

In the article the author analyzed the peculiarities of the participation of enterprises of religious organizations in economic relations. The author analyzed the regulations governing the activities of religious organizations. The peculiarity of the participation of enterprises of religious organizations in economic relations is due to the peculiarity of the legal status of religious organizations.

In the article, the author analyzed that Ukrainian legislation does not establish a clear framework for the activities that have the right to carry out enterprises of religious organizations. The author concludes that religious organizations are non-profit entities, as the main purpose of their activities is to create the opportunity to practice a particular religion and perform the necessary actions, rites, rituals, etc., and not to make a profit. A key feature of the economic and legal status of the enterprise of a religious organization is that it is created to achieve the goals, objectives and objectives of its founder - a religious organization.

The activity of enterprises of religious organizations is regulated not only by state legislative acts, but also by internal confessional guidelines, regulations, and statutes. The specifics of regulating the economic activity of enterprises of religious organizations is that almost every denomination has its own specific rules for conducting such activities: prohibitions, restrictions, regulations of certain actions.

The economic and legal status of enterprises of religious organizations is highly dependent on the socio-political situation in the country and on state-religious relations at the appropriate stage of state formation. The state's declared neutrality in matters of worldview and religion, fulfillment of obligations to guarantee freedom of religion and at the same time creates equal conditions for the protection of the rights and freedoms of all citizens. However, despite the secular status of the state, there are examples in Ukraine of exempting religious organizations from taxes or granting them any benefits. The law stipulates that religious organizations have the exclusive right to establish enterprises for the production of liturgical literature and the production of religious objects. The author concluded that such preferences on the part of the state can occur only if there is a special model of state-religious relations (state church or contractual model of church-state relations).

Key words: religious organization, economic legal relations, enterprise of religious organization, enterprise, economic activity.

Вступ. Відповідно до Конституції України, Церква відділена від держави. Релігійні організації мають особливий правовий статус, оскільки їхня релігійна діяльність регулюється канонічним правом. Україна є багатоконфесійною державою та налічує велику кількість різних релігійних організацій, які для реалізації мети своєї діяльності поряд із релігійною можуть здійснювати і різні види господарської діяльності [1, с. 20]. Участь підприємств релігійних організацій у господарських правовідносинах має певні особливості, які зумовлені особливостями правового статусу релігійних організацій.

Окремі аспекти участі підприємств релігійних організацій у господарських правовідносинах досліджували у своїх працях такі науковці, як В.І. Борисова, В. Піддубна, П.В. Сергєєв, А.І. Шпомер та ін. Проте сьогодні відсутнє комплексне дослідження особливостей участі підприємств релігійних організацій у господарських відносинах.
Метою дослідження $\epsilon$ аналіз правових засад діяльності підприємств релігійних організацій, виокремлення специфічних рис, притаманних цій категорії суб'єктів господарювання, надання пропозицій, щодо внесення змін до чинного законодавства.

Виклад основного матеріалу. У науковій літературі можна виокремити декілька різних визначень релігійних організацій. Зокрема, Ю.В. Кривенко надає визначення релігійної організації як добровільного, організаційно оформленого, постійно діючого об'єднання віруючих, що базується на єдності віросповідання, культовій, обрядовій практиці, створене ними для задоволення своїх релігійних і пов'язаних із ними потреб, інтересів та проведення необхідної для нього відповідної діяльності [2, с. 228].

B.I. Борисова розглядає релігійні організації як самостійний функціональний вид непідприємницьких юридичних осіб, хоча вони можуть здійснювати підприєм- 
ницьку діяльність із метою виконання своїх статутних завдань [3, с. 53].

У проєкті концепції державно-конфесійних відносин релігійні організації розглядаються як об'єднання віруючих на основі єдиного віровчення, якому властиві всі ознаки соціальної групи та яке побудоване згідно з приписами віровчення; має право на набуття статусу юридичної особи з усіма правовими наслідками, що із цього випливають [4]. О.П. Мельничук розглядає релігійні організації як об'єднання людей у форми юридичних осіб, які сповідують однакову віру, відстоюють спільні духовні інтереси без мети отримання прибутку за винятком необхідності виконання статутних завдань [5, с. 7].

Законодавче визначення підприємства релігійної організації наведено у ч. 1 ст. 112 Господарського кодексу України. Підприємством об'єднання громадян, релігійної організації є унітарне підприємство, засноване на власності об'єднання громадян (громадської організації, політичної партії) або власності релігійної організації для здійснення господарської діяльності з метою виконання їхніх статутних завдань [6].

Право релігійних організацій виступати учасниками господарських відносин було закріплене у законодавстві 3 перших років незалежності України. Сьогодні Закон України «Про підприємства в Україні», який уперше дозволив релігійним організаціям створювати підприємства для здійснення виробничої і господарської діяльності, щодо майна яких ті були власниками (ст. 2), втратив чинність.

Зараз право релігійних організацій створювати підприємства для мети діяльності релігійних організацій передбачене ч. 1 ст. 19 Закону України «Про свободу совісті та релігійні організації», згідно з якою релігійні організації у порядку, визначеному чинним законодавством, мають право для виконання своїх статутних завдань засновувати видавничі, поліграфічні, виробничі, реставраційно-будівельні, сільськогосподарські та інші підприємства, а також добродійні заклади (притулки, інтернати, лікарні тощо), які мають право юридичної особи [7].

Релігійна діяльність є різновидом некомерційної господарської діяльності, а нерелігійна діяльність може бути підприємницькою. Нерелігійна діяльність здійснюється у позарелігійних сферах: економічній, виробничій, професійній, політичній, державній, художній, науковій. Вона може мати релігійний відтінок, одним з їі мотивів може бути й релігійний мотив. Проте за об'єктивним змістом, предметом і результатами це позарелігійна діяльність. Релігійна діяльність посідає своєрідне місце в систем суспільної діяльності. У науковій літературі виділяють два основних види релігійної діяльності: позакультову й культову $[8$, с. $117-118]$.

Позакультова діяльність здійснюється в духовній і практичній сферах. Духовну позакультову діяльність становлять розроблення релігійних ідей, систематизація й інтерпретація догматів теології, написання богословських творів тощо. Різновидами практичної позакультової діяльності є виробництво засобів релігійного культу, місіонерство, участь у роботі соборів, викладання богословських дисциплін у навчальних закладах (школах, університетах, духовних навчальних закладах), управлінська діяльність у релігійних організаціях та інститутах, пропаганда релігійних поглядів через друк, радіо, телебачення, релігійна пропаганда у сім’ї та інших контактних групах [8, с. 117].

Деякі науковці розглядають культову діяльність як сукупність релігійних (культових) дій, пов'язаних зі ставленням до надприродного: молитвами, богослужіннями, таїнствами, обрядовими, ритуальними, магічними діями Така діяльність регулюється нормами канонічного права і не підпадає під сферу державного регулювання. Водночас до позакультової діяльності відносять дії, які здійснюються для задоволення побутових потреб віруючих. Тобто нерелігійна діяльність регулюється державою, передусім нормами господарського права [1, с. 21].

Чинне законодавство не встановлює чітких рамок щодо видів діяльності, які мають право здійснювати релігійні організації. Проте, як вірно відзначає В.Ф. Піддубна, не всі види діяльності релігійних організацій спрямовані на досягнення цілей їх створення. Так, результатом деяких видів діяльності є безпосереднє досягнення мети, результат інших видів лише опосередковано слугує ії досягненню [9, с. 113].

Нині в науковій літературі тривають дискусії стосовно того, що чи можуть релігійні організації - юридичні особи приватного права засновувати структуру тієї організаційно-правової форми, яка не передбачена чинним цивільнім законодавством. Виходячи з поглядів представників господарського права, це цілком зрозуміло, оскільки такий припис містить ГК України, який регулює порядок створення юридичних осіб, але публічного права, а тому й розглядає підприємство як самостійний суб'єкт господарювання, що створений компетентним органом державної влади, органом місцевого самоврядування або іншими суб'єктами для задоволення суспільних та особистих. ЦК України не може не враховувати існуючого порядку створення публічних юридичних осіб, бо встановлює тільки порядок створення, організаційно-правові форми та правовий статус юридичних осіб приватного права.

Так, наприклад, В.І. Борисова вважає, що сьогодні редакція ст. 19 Закону увійшла у суперечність із ЦК України - основним актом цивільного законодавства України, який має особливу, підвищену юридичну силу у цій сфері. Юридичні особи приватного права, згідно з ч. 1 ст. 83 ЦК України, можуть створюватися у формі товариств, установ та в інших формах, установлених законом. Саме ця вказівка на «інші форми» разом із положеннями ст. 82 ЦК України, на думку авторів, і дала змогу господарникам розглядати підприємство як одну з організаційних форм юридичної особи, тобто визнавати його суб'єктом права. Однак підприємства як організаційно-правової форми юридичних осіб приватного права на рівні ЦК України не передбачено, підприємство - це єдиний майновий комплекс, що використовується для здійснення підприємницької діяльності й є об'єктом права [3, с. 53]. Ураховуючи, що підприємства можуть створюватися як із метою здійснення комерційної господарської комерційної діяльності (підприємництва), так і для мети некомерційної господарської діяльності, зазначене є справедливим також і для підприємств релігійних організацій.

Науковці зазначають, що безпосередньо релігійні організації не є некомерційними суб'єктами, діяльність яких не ставить за головну мету отримання прибутків. Такими суб'єктами є лише підприємства релігійних організацій, які утворюються з метою забезпечення основної діяльності релігійної організації, тобто відносно до останніх виконують допоміжні функції [10, с. 362]. 3 огляду на це, важливо розрізняти господарську діяльність безпосередньо релігійних організацій та господарську діяльність створених ними підприємств.

Релігійні організації є некомерційними суб'єктами господарювання, оскільки головною метою їхньої діяльності $\epsilon$ створення громадянам можливості сповідувати певну релігію та здійснювати необхідні для цього дії, обряди, ритуали тощо, а не отримання прибутків.

Згідно 3 ч. 3 ст. 22 Закону України «Про свободу совісті та релігійні організації», релігійні організації користуються виключним правом заснування підприємств для випуску богослужбової літератури і виробництва предметів культового призначення. Проте деякі автори звертають увагу на те, що участь релігійних організації у господарській діяльності часто пов'язана з виробництвом та реалізацією товарів широкого вжитку, використання яких можливе і поза здійснення культу. 
Специфіка регулювання господарської діяльності підприємств релігійних організацій полягає ще й у тому, що майже кожна конфесія має свої специфічні правила ведення такої діяльності: заборони, обмеження, регламенти певних дій.

У роботах багатьох авторів відзначається, що діяльність підприємств релігійних організацій регулюється не тільки державними законодавчими актами, а й внутрішньоконфесійними настановами, положеннями, статутами. Внутрішні настанови окремих конфесій можуть значною мірою визначати порядок здійснення господарської діяльності, асортимент продукції, ціну, вибір контрагента тощо.

Господарсько-правовий статус підприємств релігійних організацій значною мірою залежить від суспільно-політичної ситуації у країні та від державно-релігійних відносин на відповідному етапі державотворення.

Україна стосовно релігійних організацій так само, як і стосовно об'єднань громадян і політичних партій, здійснює політику невтручання. Це забезпечує нейтралітет у питаннях світогляду й віросповідання, виконання зобов'язань із гарантування свободи віросповідання й водночас створює рівні умови для захисту прав і свобод усіх громадян. Однак ця політика передбачає певні важелі, щоб свобода не перетворювалася на неконтрольовану вседозволеність, за якої порушуються права інших громадян, громадського порядку [11].

Державно-конфесійні відносини в Україні, незважаючи на світський статус держави, мають певний вплив на правовий статус підприємств релігійних організацій.

Підприємства релігійних організацій, незважаючи на задекларовані принципи рівності, все ж мають певну специфіку. Зокрема, звільнення релігійних організацій від податків чи надання їм будь-яких пільг може відбуватися лише за умови наявності спеціальної моделі державно-релігійних відносин (державної Церкви або договірної моделі відносин Церкви і держави). Відповідно до моделі відокремлення Церкви від держави, яка закріплена в Конституції України, релігійні організації та їхні підприємства оподатковуються як юридичні особи на загальних підставах. 3 огляду на це, низка авторів відзначає, що звільнення релігійних організацій від оподаткування може відбуватися лише у разі зміни моделі державно-релігійних відносин, оскільки в іншому разі такі дії можна розглядати як пряме порушення Конституції та законів України.

Якщо виходити з того, що відповідно до норм законодавства релігійні організації в Україні позбавлені будьякого особливого статусу і прирівнюються до звичайних юридичних осіб, а також оподатковуються на загальних підставах, то виглядає досить дивним звільнення від податків релігійних організацій, а також пряме втручання держави у фінансову діяльність релігійних організацій, що не відповідає закріпленій у Конституції моделі відділення Церкви від держави [12, с. 119].

Висновки. Для господарського забезпечення основних напрямів свого функціонування релігійні організації мають право здійснювати самостійну господарську діяльність, а також створювати відповідні підприємства. Незважаючи на задекларовані принципи рівності, підприємства релігійних організацій усе ж мають певну специфіку. Ключовою ознакою господарсько-правового статусу підприємства релігійної організації $є$ те, що воно створюється для реалізації мети, цілей і завдань ії засновника релігійної організації.

\section{ЛITEPATУРA}

1. Шпомер А.І., Шванська А.О. Релігійні організації як суб'єкти некомерційної господарської діяльності. Журнал східноєвропейського права. 2017. № 39. С. 18-23.

2. Кривенко Ю.В. Релігійні організації як суб'єкти приватного права України. Актуальні проблеми держави $і$ права. 2006. Вип. 25. С. 225-229.

3. Борисова В.І. Релігійна організація - самостійний функціональний вид непідприємницьких організацій. Юрист України. 2013. № 2. C. $49-56$.

4. Концепція державно-конфесійних відносин : проект. Національна безпека і оборона. 2007. № 8. С. 2-21.

5. Мельничук О.П. Теоретико-правовий аналіз діяльності релігійних організацій в демократичній державі : дис. .... канд. юрид. наук : 12.00.01. Київ, 2016. 206 с.

6. Господарський кодекс України. URL : https://zakon.rada.gov.ua/ laws/show/436-15.

7. Про свободу совісті та релігійні організації : Закон України від 23 квітня 1991 року. № 987-XII. Відомості Верховної Ради України. 1991. № 25. Ст. 283 .

8. Куницын И.А. Правовой статус религиозных объединений в современной России : дис. ... к.ю.н. ; Московский государственный социальный університет ; Академия экономики и права. Москва, 2000. 186 с.

9. Піддубна В. Щодо спеціальної правоздатності релігійних організацій. Право України. 2004. № 11. С. 112-114.

10. Бардашевич Н.О. Релігійні організації як суб'єкти господарського права. Вісник Донецького національного університету. 2011. Вип. 1. Т. 2. С. $361-364$

11. Росенко М. Державна політика України щодо Церкви й релігійних організацій. Їхнє місце в політичній системі суспільства. Віче. 2009. № 12. URL : http://www.viche.info/journal/1513/.

12. Шитий C.І. Окремі питання оподаткування релігійних організацій в законодавстві України і Європейського союзу. Науковий часопис НПУ імені М.П. Драгоманова. Серія 18: Економіка і право. 2016. Вип. 31. С. 117-122. 


\title{
НОРМАТИВНО-ПРАВОВІ ЗАСАДИ ДОСТУПУ ДО ІНФОРМАЦІЇ ПРО СТАН ВИКОРИСТАННЯ ПРИРОДНИХ РЕСУРСІВ
}

\author{
LEGAL PRINCIPLES OF ACCESS TO INFORMATION \\ ON THE STATE OF USE OF NATURAL RESOURCES
}

Діхтієвський В.П., аспірант кафедри адміністративного та господарського права

Запорізький національний університет

\begin{abstract}
У статті наголошено, що належний рівень адміністративно-правового забезпечення реалізації права особи на доступ до інформації про стан використання природних ресурсів є неможливим поза межами функціонування органів державної влади та місцевого самоврядування, які, по суті, виступають відносно певних видів природних об'єктів єдиною уповноваженою особою на здійснення правомочностей користування та розпорядження. До системи джерел інформації про стан використання природних ресурсів відносяться дані моніторингу довкілля, реєстри, автоматизовані бази даних, кадастри природних ресурсів, архіви, а також довідки, видані органами державної влади та їхніми посадовими особами. Установлено, що адміністративно-правове забезпечення доступу до інформації про стан використання природних ресурсів об'єктивується в нормах права, що містяться в нормативних актах - офріційних документах правотворчого характеру органів державної законодавчої та виконавчої влади. Підкреслено, що правове регулювання доступу до інформації про стан використання природних ресурсів здійснюється відповідним комплексом нормативно-правових документів, що можуть бути класифіковані за юридичною силою, за предметом правового регулювання, за сферою поширення, за суб'єктом прийняття, за характером нормативно-правового впливу. Метою наукової статті визначено характеристику нормативно-правових засад доступу до інформації про стан використання природних ресурсів. Визначено, що нормативно-правова база режиму доступу до інформації про стан використання природних ресурсів в Україні характеризується надмірною розгалуженістю відомчого регулювання з домінуванням актів підзаконної юридичної сили, що свідчить про ситуативний та фрагментарний підходи до вирішення існуючих колізійних проблем правозастосування. Обґрунтовано необхідність активізації процесів систематизації інформаційного законодавства у напрямі розроблення та прийняття проєкту Інформаційного кодексу України.
\end{abstract}

Ключові слова: адміністративно-правове регулювання, доступ, інформація про стан використання природних ресурсів, інформаційне суспільство, Інформаційний кодекс України.

The scientific article emphasizes that the proper level of administrative and legal support for the realization of the right of a person to access information on the use of natural resources is impossible outside the functioning of public authorities and local governments, which in fact act on certain types of natural objects as the only authorized person. to exercise the powers of use and disposal. The system of sources of information on the state of use of natural resources includes environmental monitoring data, registers, automated databases, cadastres of natural resources, archives, as well as certificates issued by public authorities and their officials. It is established that the administrative and legal provision of access to information on the state of use of natural resources is objectified in the rules of law contained in regulations - official documents of the lawmaking nature of the state legislative and executive authorities. It is emphasized that the legal regulation of access to information on the state of use of natural resources is carried out by an appropriate set of legal documents that can be classified by legal force, subject of legal regulation, scope, subject of adoption, the nature of regulatory impact. The purpose of the scientific article is to characterize the regulatory framework for access to information on the state of use of natural resources. It is determined that the legal framework of the regime of access to information on the state of use of natural resources in Ukraine is characterized by excessive branching of departmental regulation with dominance of bylaws, which indicates situational and fragmentary approaches to solving existing conflict of law enforcement problems. The necessity of intensifying the processes of systematization of information legislation in the direction of development and adoption of the draft Information Code of Ukraine is substantiated.

Key words: administrative and legal regulation, access, information on the state of use of natural resources, information society, Information Code of Ukraine.

Постановка проблеми. У сучасних умовах становлення та розвитку українського суспільства, беззаперечно, спостерігається взаємозв'язок між забезпеченням ефективності нормативно-правового регулювання у сфері доступу до інформації про стан використання природних ресурсів та ефективністю реалізації функцій держави у досліджуваній сфері.

Визначення формування інформаційного суспільства як пріоритетного вектору розвитку української держави було встановлено у Законі України «Про Основні засади розвитку інформаційного суспільства в Україні на 20072015 роки» від 9 січня 2007 року, де підкреслено, що інформація $є$ основою розвитку людства, вільний доступ до неї гарантує належне забезпечення прав та законних інтересів кожного [1]. Згідно з визначеною концепцією, формування інформаційного суспільства в Україні встановлено одним iз пріоритетних напрямів створення механізмів публікації інформації, яка має суспільне значення у цілому і зокрема інформації про стан використання природних ресурсів.

Ступінь наукового розроблення проблеми. Окремі проблеми забезпечення доступу до публічної інформації, здійснення характеристики нормативно-правового регулювання його реалізації досліджувалися у наукових працях Т.О. Коломоєць, Г.В. Кадникової, Ю.О. Легези,

В.А. Ліпкан, О.А. Мандзюк, Л.І. Рудник, В.С. Цимбалюк та ін. Однак питання реалізації доступу до інформації про стан використання природних ресурсів, оптимізації його нормативно-правового регулювання комплексних досліджень не присвячено.

Метою наукової статті $€$ визначення нормативно-правових засад доступу до інформації про стан використання природних ресурсів.

Виклад основного матеріалу. Забезпечення вимоги безпечності довкілля $є$ одним із пріоритетних напрямів реалізації євроінтеграційних процесів, що корелюється 3 положеннями Закону України від 28 лютого 2019 року № 2697-VIII «Про Основні засади (стратегію) державної екологічної політики України на період до 2030 року» [2]. Варто відзначити, що належний рівень адміністративноправового забезпечення реалізації права особи на доступ до інформації про стан використання природних ресурсів $€$ неможливим поза межами функціонування органів державної влади та місцевого самоврядування, які, по суті, виступають відносно певних видів природних об'єктів єдиною уповноваженою особою на здійснення правомочностей користування та розпорядження [3, с. 19; 4, с. 62-65].

Адміністративно-правове забезпечення доступу до інформації про стан використання природних ресурсів 
об'єктивується в нормах права, що містяться в нормативних актах - офіційних документах правотворчого характеру органів державної законодавчої та виконавчої влади. Правове регулювання доступу до інформації про стан використання природних ресурсів здійснюється певним комплексом нормативно-правових документів, що можуть бути класифіковані за юридичною силою, за предметом правового регулювання, за сферою поширення, за суб'єктом прийняття, за характером нормативно-правового впливу.

Адміністративно-правове забезпечення доступу до інформації про стан використання природних ресурсів характеризується значним масивом нормативно-правових актів.

Центральним актом забезпечення доступу до публічної інформації $є$ законодавство, яке регулює режим доступу до відомостей, що відображають результати діяльності суб'єктів владних повноважень, а також сукупність відомостей, котрі містяться у відповідних реєстрах, що створюються внаслідок реалізації ними публічно-управлінських функцій.

Стан правового забезпечення доступу до інформації характеризується надлишковою формалізацією. Зокрема, вже у 2008 році правове регулювання інформаційних відносин характеризувалося значним масивом законодавчих актів (їх кількість перевищувала 200), постанов Верховної Ради України, указів Президента України (їх загальна кількість становить понад 400). Нормативно-правові акти Кабінету Міністрів України у сфері інформаційного забезпечення здійснення публічного управління перевищує кількість понад 1 000. Масив підзаконних нормативноправових актів центральних органів виконавчої влади становить понад 1200 [5]. Уже у вересні 2019 року цей показник збільшився майже удвічі.

Конституційні засади забезпечення доступу до інформації про стан використання природних ресурсів визначено у Конституції України (ст. ст. 32, 34, 50 та ін.) [6].

На законодавчому рівні забезпечення доступу до інформації про стан використання природних ресурсів необхідно відзначити положення таких законодавчих актів, як кодифіковані законодавчі акти (Кодекс України про адміністративні правопорушення, Кодекс адміністративного судочинства), так і звичайні закони, серед яких виділяються закони України «Про інформацію», «Про доступ до публічної інформації», «Про державну таємницю», «Про національну безпеку України», «Про видавничу справу», «Про друковані засоби масової інформації (пресу) в Україні», «Про телебачення та радіомовлення», «Про захист інформації в інформаційно-телекомунікаційних системах», «Про доступ до судових рішень», «Про порядок висвітлення діяльності органів державної влади та органів місцевого самоврядування в Україні засобами масової інформації» тощо.

Сукупність законодавчих нормативних актів, прийнятих Верховною Радою України, встановлює організаційні процедури забезпечення доступу до інформації про стан використання природних ресурсів, особливості іiі обігу, встановлення обмежень використання тощо.

Необхідно відзначити низку галузевих нормативноправових актів, що встановлюють особливості обігу інформації про стан використання природних ресурсів, зокрема: «Про нафту і газ», Гірничий закон України, «Про Державний земельний кадастр», «Про національну інфраструктуру геопросторових даних» тощо.

Процедура реалізації матеріальних норм, установлених у вищезазначених законодавчих актах, відбувається у положеннях постанов Кабінету Міністрів України від 7 листопада 2018 р. № 939 «Питання розпорядження геологічною інформацією», від 30 травня 2011 р. № 615 «Про затвердження Порядку надання спеціальних дозволів на користування надрами», від 17 жовтня 2018 р. № 848 «Про реалізацію експериментального проєкту із запровадження проведення аукціонів із продажу спеціальних дозволів на користування надрами шляхом електронних торгів», від 27 грудня 2012 р. № 836 «Про затвердження Порядку адміністрування Державного земельного кадастру», від 8 листопада 2017 р. № 836 «Про затвердження Порядку охорони геодезичних пунктів» та ін.

Окремі акти центральних органів виконавчої влади мають роз'яснювальну природу положень. Зокрема, у Листі Державної фіскальної служби України від 13.07.2017 № 18473/7/99-99-12-02-03-17 «Шодо забезпечення адміністрування плати за землю» визначено, що до системи Державного земельного кадастру включаються відомості про величину нормативної грошової земельної ділянки, а також інформація про документацію із землеустрою та оцінки земель щодо земельної ділянки та інші документи, на підставі яких установлено відомості про земельну ділянку (частина перша ст. 15 Закону України «Про Державний земельний кадастр») [7].

Отже, до системи підзаконних нормативно-правових актів у сфері забезпечення доступу до інформації про стан використання природних ресурсів за своєю юридичною силою належать укази Президента України, постанови та розпорядження Кабінету Міністрів України, накази центральних органів виконавчої влади, рішення органів місцевого самоврядування.

Згідно зі ст. 9 Конституції України [6], до складника національної правової системи відносяться міжнародні правові акти, що ратифіковані Верховною Радою України в установленому законом порядку, тому вимагають аналізу міжнародні правові документи у розрізі забезпечення функціонування режиму доступу до інформації про стан використання природних ресурсів як різновиду публічної інформації.

Одним із визначальних етапів розвитку світових стандартів розбудови правової демократичної держави стало прийняття Загальної декларації прав людини 10 грудня 1948 року Організацією Об’єднаних Націй [8]. Статтею 19 Загальної декларації прав людини встановлено, що особа має право в межах реалізації права на свободу переконань, на свободу пошуку, одержання та поширення інформації [8]. Деталізація міжнародних стандартів забезпечення прав і свобод людини у сфері інформації в подальшому відбулася у Європейській конвенції прав людини і основоположних свобод [9], де у статті 10 визначено, що реалізація права на свободу поглядів передбачає свободу «дотримуватися своїх поглядів, одержувати і передавати інформацію та ідеї без утручання органів державної влади і незалежно від кордонів».

Спеціальні міжнародно-правові стандарти встановлюються щодо питань доступу та обігу інформації про стан довкілля, яка також за своєю сутністю належить до категорії публічної, володіння якою сприяє належному забезпеченню права кожної особи на сприятливе навколишнє природне середовище. Це закріплено Орхуською конвенцією 1999 року [10], у статті 4 якої визначено процедуру реагування державного органу на запит про надання відомостей про стан довкілля. Варто акцентувати увагу, що статтею 1 Орхуської конвенції встановлено, що під державним органом необхідно розуміти не лише орган державної чи муніципальної влади, а й приватних осіб фізичних чи юридичних осіб, «які виконують державні адміністративні функції згідно з національним законодавством, включаючи конкретні обов'язки, види діяльності та послуги, що мають причетність до навколишнього середовища, а також до державних органів - розпорядників екологічної інформації віднесено всіх інших учасників правовідносин, що виконують державні обов'язки та функції чи надають публічні послуги, предметом яких $\epsilon$ стан навколишнього природного середовища, і при цьому вони перебувають під наглядом відповідних центральних органів виконавчої влади» [10] 
До системи міжнародно-правових актів, ратифікованих Україною, що є складовою частиною законодавства у сфері доступу до публічної інформації та її складника - інформації про стан використання природних ресурсів зокрема, відносяться такі міжнародні акти, як: Рекомендація № 854 (1979) Парламентської Асамблеї Ради Європи «Про доступ громадськості до інформації, що є в розпорядженні державних органів, та свободу інформації»; Рекомендація № R (81) 19 Комітету Міністрів Ради Європи «Про доступ до інформації, що знаходиться у розпорядженні державних органів» 1981 року; «Йоганнесбурзькі принципи. Національна безпека, свобода висловлювань і доступ до інформації»; «Модельний закон про свободу інформації» міжнародної неурядової організації «Артикль 19».

Варто відзначити, що виділяється низка міжнародних актів, що, попри відсутність їх ратифікації Верховною Радою України, встановлюють основоположні засади забезпечення доступу до інформації про стан використання природних ресурсів. Зокрема, одним із таких міжнародних актів $\epsilon$ Рекомендація Rec (2004) 15 Комітету міністрів держав - членів Ради Європи щодо впровадження електронного урядування та Конвенція про доступ до офіційних документів від 18 червня 2009 року (ЕTS № 205) [11]. Однак при цьому забезпечення запровадження ідеї електронного урядування та електронного судочинства відноситься до одного 3 пріоритетних напрямів розвитку сучасної Української держави. Свідченням такого твердження є створення в Україні спеціального центрального органу виконавчої влади, до компетенції якого віднесено сприяння активізації процесів діджіталізації здійснення публічного управління, яким є Державне агентство 3 питань електронного урядування [12].

Особливе значення 3 питань нормативно-правового регулювання доступу до інформації про стан використання природних ресурсів на міжнародно-правовому рівні мають Конвенція про оцінку впливу на навколишнє природне середовище в транскордонному аспекті, ратифікована Законом України від 19.03.1999 № 534-XIV [13], та Протокол про стратегічну екологічну оцінку до Конвенції про оцінку впливу на навколишнє середовище в транскордонному аспекті, ратифікований Законом України від 01.07.2015 № 562-VIII [14]. У подальшому реалізація вимоги перегляду системи ефективності здійснення контролю над використанням природних ресурсів та імплементації європейських стандартів його здійснення в Україні поставила за необхідне здійснення у такій сфері трансформаційних змін. Реформування системи здійснення контролю над використання природних ресурсів відповідно до європейських стандартів визначило доцільність відмови на законодавчому рівні від процедури проведення державної та громадської екологічної експертизи, що спричинило втрату чинності відповідних нормативно-правових актів. Так, із набуттям чинності Законом України «Про оцінку впливу на довкілля» [15] було скасовано положення Закону України «Про екологічну експертизу» [16] та прийнято цілий масив підзаконних нормативно-правових актів. Упровадження оцінки впливу на довкілля спричинило створення відповідного загальнонаціонального реєстру, порядок ведення якого визначено Постановою Кабінету Міністрів України від 13 грудня 2017 року № 1026 [17]

До системи джерел інформації про стан використання природних ресурсів відносяться дані моніторингу довкілля, реєстри, автоматизовані бази даних, кадастри природних ресурсів, архіви, а також довідки, видані органами державної влади та їхніми посадовими особами. Нормативне закріплення процедури доступу до таких відомостей визначено у Положенні про державну систему моніторингу довкілля, затвердженому Постановою Кабінету Міністрів України від 30.03.1998 № 391 [18]; Порядку функціонування національної системи оцінки антро- погенних викидів та абсорбції парникових газів, які не регулюються Монреальським протоколом про речовини, що руйнують озоновий шар, затвердженому Постановою Кабінету Міністрів України від 21.04.2006 № 554 [19]; Вимогах до переліку та змісту документів для надання експертного висновку про рівень надзвичайної ситуації, затверджених Наказом Міністерства внутрішніх справ України від 04.09.2014 № 905 [20]; Методичних рекомендаціях із розрахунку та узагальнення індикаторних показників моніторингу якості питної води та стану питного водопостачання, затверджених Міністерством регіонального розвитку, будівництва та житлово-комунального господарства України від 04.03.2013 № 78; Методичних рекомендаціях «Оцінка ризику для здоров’я населення від забруднення атмосферного повітря», затверджених Наказом Міністерства охорони здоров'я від 13.04.2007 № 184 [21], тощо.

У цілому необхідно зробити висновок, що до проблем нормативно-правового регулювання забезпечення доступу до інформації про стан використання природних ресурсів відносяться невизначеність механізму застосування відповідальності службовців за порушення цих стандартів; підміна законодавчої регламентації регуляцією підзаконними нормативними актами; суперечність норм різних нормативно-правових актів у цій сфері; відсутність належної систематизації нормативно-правових актів. Сфера доступу до екологічної інформації характеризується значним масивом підзаконних «відомчих» нормативно-правових актів, що свідчить про фрагментарний підхід до врегулювання колізійних проблем правозастосування. Подолання проблеми надмірного відомчого регулювання суспільних відносин у цілому і 3 питань забезпечення доступу до екологічної інформації зокрема пов'язується 3 виключенням зі сфери компетенції більшості центральних органів виконавчої влади, крім вузького кола міністерств, права видавати нормативні акти, що обмежують права та свободи громадян, у першу чергу право на отримання відомостей [22, с. 57].

Забезпечення оптимізації реалізації інформаційних прав пов'язується 3 активізацією процесів систематизації національного законодавства України. Значний масив нормативно-правових актів різної юридичної сили у сфері реалізації інформаційних прав, накопичений у межах національної системи права, вимагає його систематизації, зокрема шляхом розроблення та прийняття Інформаційного кодексу України.

Попри очевидну практичну значимість розроблення та прийняття Інформаційного кодексу України, реалізація такого правотворчого завдання триває вже понад 20 років. До головних перепон, що виникають у процесі кодифікації інформаційного законодавства, належить відсутність єдиного концептуального підходу до визначення мети та об'єкта правового впливу, що виділяється окремими представниками як необхідність урегулювання відносин із застосуванням технологій обігу інформації, іншими - як встановлення механізму реалізації права на інформацію [23].

Структурно проєкт Інформаційного кодексу України, на думку Л.П. Коваленко, має складатися із Загальної та Особливої частин [24]. У межах Загальної частини проєкту Інформаційного кодексу України Л.П. Коваленко обгрунтовує доцільність урегулювання таких правових питань, як врегулювання підстав виникнення інформаційних прав та обов'язків, особливостей здійснення інформаційних прав та виконання обов'язків з урегулюванням захисту інформаційних прав та інтересів, а також інших елементів адміністративно-правового статусу як розпорядників інформації, так і споживачів інформаційних послуг. У межах Особливої частини проєкту Інформаційного кодексу України має бути встановлено обіг окремих різновидів інформації, у тому числі й інформації про стан 
використання природних ресурсів [24]. У межах проєкту Інформаційного кодексу, крім зазначених питань, на думку Ю.С. Максименка, має бути визначено концептуальні засади забезпечення інформаційної безпеки як складової частини національної безпеки України [25].

Висновки. Таким чином, нормативно-правова база режиму доступу до інформації про стан використання природних ресурсів в Україні характеризується надмір- ною розгалуженістю відомчого регулювання з домінуванням актів підзаконної юридичної сили, що свідчить про ситуативний та фрагментарний підходи до вирішення існуючих колізійних проблем правозастосування. Подолання такої проблеми вбачається шляхом активізації процесів систематизації інформаційного законодавства у напрямі розроблення та прийняття проєкту Інформаційного кодексу України.

\section{ЛITEPATYPA}

1. Про Основні засади розвитку інсрормаційного суспільства в Україні на 2007-2015 роки : Закон України від 9 січня 2007 р. № $537-V$. Відомості Верховної Ради України. 2007. № 12. Ст. 102.

2. Про Основні засади (стратегію) державної екологічної політики України на період до 2030 року : Закон України від 28 лютого 2019 року № 2697-VIII. Відомості Верховної Ради. 2019. № 16. Ст.70.

3. Улютіна О.А. Адміністративно-правові засади охорони навколишнього природного середовища та природокористування: дис. ... канд. юрид. наук : 12.00.07. Київ, 2011. 209 с.

4. Легеза Ю.О. Участь громадськості в публічному управлінні у сфері використання природних ресурсів. Право та державне управління. 2017. № 2. С. 62-69.

5. Електронне урядування : навчальний посібник / А.І. Семенченко та ін. Херсон : Грані, 2014. 391 с.

6. Конституція України від 28 червня 1996 року. Відомості Верховної Ради України. 1996. № 30. Ст. 141.

7. Щодо забезпечення адміністрування плати за землю : Лист Державної фріскальної служби України від 13.07 .2017 № 18473/7/99-99-12-02-03-17. URL : https://zakon.rada.gov.ua/rada/show/v8473872-17\#Text.

8. Загальна декларація прав людини 1948 р. Інфрормаційне законодавство : зб. законодавчих актів : у 6 т. / за заг. ред. Ю.С. Шемшученка, І.С. Чижа. Київ : Юрид. думка, 2005. Т. 5. С. 5-17.

9. Про ратифікацію Конвенції про захист прав людини і основоположних свобод 1950 року, Першого протоколу та протоколів №№ 2 , 4, 7 та 11 до Конвенції : Закон України від 17 липня 1997 р. № 475/97-ВР. Відомості Верховної Ради України. 1997. № 40. Ст. 263.

10. Конвенція про доступ до інформації, участь громадськості в процесі прийняття рішень та доступ до правосуддя з питань, що стосуються довкілля : ратифікована Законом № 832-XIV від 6 липня 1999 р. Правове регулювання інфоормаційної діяльності в Україні : станом на 1 січня 2001 р. / упоряд. С.Е. Демський ; відп. ред. С.П. Павлюк. Київ : Юрінком Інтер, 2001. С. 62-67

11. Council of Europe Convention on Access to Official DocumentsCETS № 205. URL : http://www.coe.int/en/web/conventions/full-list/-/ convenions/treaty/205?_coeconventions_WAR_coeconventionsportlet_languageld=ru_RU.

12. Відкриті дані. Державне агентство з питань електронного урядування. URL : https://www.e.gov.ua/ua/projects/opendata.

13. Про ратифікацію Конвенції про оцінку впливу на навколишнє природне середовище у транскордонному аспекті : Закон України від 19.03.1999 № 534-XIV. Відомості Верховної Ради України. 1999. № 18. Ст. 153.

14. Про оцінку впливу на довкілля : Закон України від 23 травня 2017 року № 2059-VIII. Відомості Верховної Ради України. 2017. № 29. Ст. 315 .

15. Про екологічну експертизу : Закон України від 09 лютого 1995 року (утратив чинність). URL : https://zakon.rada.gov.ua/laws/ show/45/95-вр\#Text.

16. Про затвердження Порядку передачі документації для надання висновку з оцінки впливу на довкілля та фрінансування оцінки впливу на довкілля та Порядку ведення Єдиного реєстру з оцінки впливу на довкілля : Постанова Кабінету Міністрів України від 13 грудня 2017 р. № 1026. Офріційний вісник України. 2018. № 2. Ст. 58.

17. Про затвердження Положення про державну систему моніторингу довкілля : Постанова Кабінету Міністрів України від 30 березня 1998 р. № 391. Офьіиійний вісник України. 1998. № 13. Ст. 91.

18. Про затвердження Порядку функціонування національної системи оцінки антропогенних викидів та абсорбції парникових газів, які не регулюються Монреальським протоколом про речовини, що руйнують озоновий шар : Постанова Кабінету Міністрів України від 21 квітня 2006 р. № 554. Офбіційний вісник України. 2006. № 17. Ст. 1266.

19. Про затвердження Вимог до переліку та змісту документів для надання експертного висновку про рівень надзвичайної ситуації : Наказ Міністерства внутрішніх справ України від 04.09.2014 № 905. URL : https://zakon.rada.gov.ua/laws/show/z1193-14\#Text.

20. Про затвердження Методичних рекомендацій з розрахунку та узагальнення індикаторних показників моніторингу якості питної води та стану питного водопостачання : Наказ Міністерства регіонального розвитку, будівництва та житлово-комунального господарства України від 4 березня 2013 р. № 78. URL : http://search.ligazakon.ua/l doc2.nsf/link1/FIN85472.html.

21. Методичні рекомендації «Оцінка ризику для здоров'я населення від забруднення атмосферного повітря» : Наказ Міністерства охорони здоровя України від 13.04.2007 № 184. URL : https://zakononline.com.ua/documents/show/98354

22. Державне управління в Україні / за заг. ред. В.Б. Авер'янова. Київ : Юрінком Інтер, 1999. 437 с.

23. Потреба часу - створення Інформаційного кодексу України. URL : http://comin.kmu.gov.ua/control/uk/publish/article?art_ id $=70301 \&$ cat_id $=64654$.

24. Коваленко Л.П. Деякі питання щодо систематизації інформаційного законодавства. Теорія іпрактика правознавства. 2013. Вип. 1. URL : http://nbuv.gov.ua/UJRN/tipp_2013_1_17.

25. Максименко Ю.Є. Щодо структури інфрормаційного кодексу України. URL : http://goal-int.org/shhodo-strukturi-informacijnogokodeksu-ukraini/. 


\title{
ПЕРЕОСМИСЛЕННЯ ПІДХОДІВ ДО ТЕРИТОРІАЛЬНОӤ КОМПЕТЕНЦЇ̈ НОТАРІУСІВ У КОНТЕКСТІ СПРОЩЕННЯ ВЕДЕННЯ БІЗНЕСУ В УКРАЇНІ
}

\author{
RETHINKING APPROACHES TO THE TERRITORIAL COMPETENCE OF NOTARIES \\ IN THE CONTEXT OF SIMPLIFYING DOING BUSINESS IN UKRAINE
}

\author{
Зальотін В.М., магістр права \\ юридичного факультету \\ Київський національний університет імені Тараса Шевченка
}

\begin{abstract}
Статтю присвячено питанню вдосконалення нотаріату в Україні з метою спрощення ведення бізнесу. На обґрунтування реальності існування проблеми наводиться ініціатива законодавця щодо змін меж адміністративно-територіальних одиниць, що впливатиме і на територіальну компетенцію нотаріусів. Пропонується акцентувати увагу законодавця саме на проблемних моментах впливу територіальної компетенції нотаріуса на господарські правовідносини. 3 точки зору наукової доктрини досліджено співвідношення понять «підвідомчість» та «компетенція», їх значення для визначення ролі нотаріуса у спрощенні ведення бізнесу в Україні, нотаріуса як «охоронця» прав та інтересів суб'єктів підприємницької діяльності. Доведено, що нотаріус може охороняти та захищати права й інтереси бізнесу в Україні, виходячи зі своїх повноважень. Отже, є сенс переглянути підходи до фрормування територіальної компетенції нотаріусів як складника їх підвідомчості.

Виокремлено основні незручності, з якими стикається бізнес під час необхідності вчинення нотаріальних дій. По-перше, вказується на недоречність прив'язки до місця виконання зобов'язання для надання нотаріусу коштів у депозит, враховуючи розповсюджене використання безготівкових рахунків. По-друге, згадуються проблеми учасників товариств, яким доводиться відчужувати свої частки у статутних капіталах саме за місцями реєстрації таких товариств, що пов'язано з прийняттям нового закону про товариства з обмеженою та додатковою відповідальністю. По-третє, пропонується переосмислити проблеми вчинення правочинів усередині складних багаторівневих корпоративних структур як таких, що потребують значних витрат часу, коштів та людських ресурсів. По-четверте, вказується на недослідженість правовою наукою реєстраційної територіальної компетенції нотаріуса, що має практичне значення для комплексного вчинення правочину в межах господарської діяльності і задля уникнення рейдерства. Зроблено висновок про необхідність підвищення ролі охоронної функції нотаріуса в межах господарської діяльності в Україні, що буде економити час та кошти для бізнесу.

Ключові слова: нотаріус, нотаріальні дії, господарська діяльність, територіальна компетенція, підвідомчість, захист бізнесу.
\end{abstract}

The article is devoted to the issue of improving the notary in Ukraine in order to simplify doing business. The initiative of the legislator to change the boundaries of administrative-territorial units, which will affect the territorial competence of notaries, is used to substantiate the reality of the problem. It is proposed to focus the attention of the legislator on the problematic aspects of the influence of the territorial competence of the notary on economic relations. From the point of view of scientific doctrine, the relationship between the concepts of "jurisdiction" and "competence", their significance for determining the role of the notary in simplifying business in Ukraine, the notary as a "guardian" of the rights and interests of business entities. It is proved that a notary can protect and defend the rights and interests of business in Ukraine, based on their powers. Therefore, it makes sense to reconsider the approaches to the formation of territorial competence of notaries as a component of their jurisdiction.

The main inconveniences faced by business when it is necessary to perform notarial acts are highlighted. First, it is pointed out that it is inappropriate to link the place of performance of the obligation to provide the notary with funds on deposit, taking into account the widespread use of non-cash accounts. Secondly, the problems of members of companies who have to alienate their shares in the authorized capital at the places of registration of such companies are mentioned, which is associated with the adoption of a new law on limited and additional liability companies. Third, it is proposed to rethink the problems of transactions within complex multi-level corporate structures as those that require significant expenditure of time, money and human resources. Fourth, it points to the unexplored legal science of the registration territorial competence of the notary, which is of practical importance for the complex commission of the transaction within the economic activity and to avoid raiding. It is concluded that it is necessary to increase the role of the security function of the notary within the economic activity in Ukraine, which will save time and money for business.

Key words: notary, notarial actions, economic activity, territorial competence, jurisdiction, business protection.

Вступ. Останніми роками уряд проголошує курс України на діджиталізацію, зручність взаємодії держави та громадян, спрощення реєстраційних та дозвільних процедур, залучення інвесторів тощо. Як і в багатьох інших напрямах реформування законодавства, нотаріату і в цьому випадку не приділено належної уваги.

Актуальність теми. 3 останніх законодавчих ініціатив, направлених на вирішення проблеми територіальної організації влади в Україні (що впливатиме і на господарську діяльність), можемо згадати Проект Постанови про утворення та ліквідацію районів, який подано до парламенту 15 червня 2020 року і який наразі розглядається у Верховній Раді [1].

Мета оптимізації адміністративно-територіального устрою - це насамперед зручність. Втім, зміна меж адміністративно-територіальних одиниць неминуче впливає на організацію ряду установ та органів. Для бізнесу такі реформи передусім цікаві в аспекті нотаріату, виконавчої служби, арбітражних керуючих тощо. Однак під час розроблення Проекту такі питання не розглядалися, що породжує проблему існування невиправдано малих нота- ріальних округів. Отже, завданням цього дослідження $є$ виявлення можливих шляхів удосконалення територіальної організації нотаріату в Україні для потреб бізнесу в разі подальших змін у законодавстві.

Виклад основного матеріалу. Значення нотаріату для бізнесу полягає в реалізації, захисті та охороні (у разі порушення та непорушення відповідно) прав та інтересів. Вже на рівні наукової доктрини маємо неоднозначні погляди на понятійний апарат, що породжує і складнощі для бізнесу на практиці.

На відміну від судової системи, нотаріальне законодавство не оперує таким поняттям, як «підвідомчість». Натомість усі нотаріальні дії, що вчиняються нотаріусом, охоплюються його повноваженнями та компетенцією. А.Г. Серветник пояснює таку різницю в термінології безспірністю як визначальною відмінністю діяльності судів та нотаріусів [2, с. 167].

Не заперечуючи логіку вченої, водночас додамо, що процесуальні кодекси досить детально прописують територіальну та предметну юрисдикції, коли Закон України «Про нотаріат» викладає «орієнтири» для обрання нотарі- 
уса конкретного нотаріального округу більш узагальнено (ïх ми проаналізуємо далі). Тим не менш, питання юрисдикції плутанини не викликає.

Повертаючись до теми підвідомчості та компетенції, врахуємо позицію М.В. Бондарєвої: нотаріальні процесуальні правовідносини із суб'єктом господарювання виникають не від самого факту звернення, але від дотримання процедури такого звернення, територіальної та предметної підвідомчості, документального підтвердження повноважень заявника тощо [3, с. 163].

Тобто вбачаємо в такому переліку вимоги, аналогічні передбаченим у Господарському процесуальному кодексі України, але все одно маємо підвідомчість для судів і компетенцію для нотаріусів, тому треба дослідити їх відмінність докладніше [4].

На думку М.Ю. Тихомирова, підвідомчість являє собою відношення окремих видів справ до їх ведення різними державними чи будь-якими іншими органами чи особами, які уповноважені через свою компетенцію розглядати такі справи і приймати щодо них рішення [5, с. 4].

Отже, підвідомчість - більш широке поняття, але в нотаріальному законодавстві все одно не зустрічається.

На підтвердження такої позиції наведемо висновок О.Б. Порцевої - підвідомчість визначається через компетенцію, оскільки вирішення проблеми підвідомчості полягає у встановленні меж компетенції [6, с. 8]. Також підвідомчість можна розуміти як «наочну» компетенцію нотаріату [7, с. 95]

М.О. Абрамов 3 іншого боку підійшов до розмежування компетенції та підвідомчості, зробивши висновок, що підвідомчість являє собою компетенцію лише щодо підстав звернення до господарського суду (тобто підвідомчість - це предметна компетенція) [8, с. 55].

Узагальнюючи, вкажемо, що територіальна компетенція нотаріуса в господарських правовідносинах розповсюджується лише на охорону, а не на захист прав (вибір нотаріуса для вчинення виконавчого напису - єдиного способу саме захистити свої права у нотаріуса - законом не обмежується, оскільки його обов'язковий елемент - це безспірність) [9].

Для повноти розуміння окреслимо напрацювання науковців у галузі нотаріального процесу.

С.Я. Фурса пояснює, що компетенція - це більш широке поняття за повноваження, адже включає в себе місце, час вчинення нотаріальної дії тощо. При цьому компетенція існує предметна та територіальна [10, с. 24].

Територіальна компетенція обмежує вчинення нотаріальних дій визначеними нотаріальним законодавством (нотаріальними округами) та адміністративно-територіальним устроєм України межами [11, с. 347; 12, с. 114]. Предметна компетенція натомість розмежовує повноваження залежно від уповноважених на вчинення конкретного виду нотаріальних дій осіб [11, с. 347].

Отже, в нотаріальній науці підхід до компетенції $\epsilon$ більш грунтовним і базується на їі розумінні як повноважень, доповнених іншими супутніми обставинами, а не як складника підвідомчості.

Нами наочно було продемонстровано проблематику понятійного апарату, яка «ефектом доміно» призводить до незручностей під час ведення бізнесу в Україні.

Спробуємо скомбінувати судовий та нотаріальний підходи для подальшого пошуку шляхів спрощення комунікацій з нотаріусами в господарських правовідносинах:

1. Виходячи із широти понять, можемо вивести ланцюг «підвідомчість - компетенція - повноваження» по низхідній, де переважає підвідомчість.

2. Також ми можемо вести мову про підвідомчість у нотаріальному процесі, адже а) це більш широка категорія; б) вона не суперечить положенням нотаріальної науки; в) іiі застосування допускається завдяки обов'язку нотаріуса сприяти заявникам у здійсненні їхніх прав та захисті законних інтересів, що закріплено у ст. 5 Закону України «Про нотаріат».

3. Таким чином, для бізнесу нотаріус має бути не меншим «захисником та охоронцем», ніж господарський суд, адже теж може охороняти та захищати права, в тому числі через сприяння їх реалізації.

4. Отже, треба переосмислити територіальну компетенцію нотаріусів саме в цьому напрямі, акцентуючись на існуванні підвідомчості та виходячи із спільних завдань судів і нотаріусів.

Обгрунтувавши значення нотаріату як одного з інститутів, удосконалення якого спростить ведення бізнесу в Україні завдяки вирішенню питань «підвідомчості», перейдемо до аналізу законодавства.

Територіальна компетенція нотаріуса прямо передбачена ст. 41 Закону України «Про нотаріат» та згадується протягом тексту Порядку вчинення нотаріальних дій нотаріусами України [9].

Хоч за роки незалежності територіальна компетенція нотаріусів стала більш широкою (для господарських правовідносин наведемо приклад у частині договору найму позички будівлі та транспортного засобу, які вже не обтяжені правилами територіальної компетенції), правил залишилось чимало, для бізнесу мають значення такі:

1. Нотаріальне посвідчення правочинів щодо відчуження та іпотеки нерухомості, відчуження та застави частини транспортних засобів (які реєструються) можливі лише за реєстрацією сторони правочину або майна.

2. Лише за місцезнаходженням майна видається свідоцтво про його придбання 3 прилюдних торгів, якщо воно перебувало в іпотеці.

3. Заборона відчуження або ії зняття можливі лише за місцем реєстрації майна.

4. Прийняти кошти або цінні папери в депозит нотаpiус може лише за місцем виконання зобов'язання.

5. Свідоцтво про придбання рухомого майна видається за місцем проведення аукціону.

6. Векселі опротестовуються за місцем платежу або за місцезнаходженням платника за векселем $[9 ; 13]$.

Такі обмеження призводять до незручностей у господарській діяльності, наведемо декілька прикладів.

1. Незручність пошуку нотаріуса за місием виконання зобов'язання. Відповідно до положень ст. 197 Господарського кодексу України місце виконання зобов'язання може бути різним. Зокрема, його можна прописати в договорі (для договору поставки, наприклад, ця можливість відіграє важливе значення, адже за Інкотермс товар можна доставляти до прикордонного пункту, порту, тощо). Якщо в договорі місце виконання зобов'язання не передбачене, то для грошових зобов'язань - це місцезнаходження управненої сторони, а для всіх інших зобов'язань - зобов'язаної сторони [14].

Зіставляючи положення нотаріального законодавства і ст. 197 Господарського кодексу України, доходимо висновку, що зобов'язана сторона не може надати кошти в депозит нотаріусу за своїм місцем знаходження, і це в епоху безготівкових розрахунків та 3 можливістю відкриття ескроу рахунків. Зобов'язана сторона вимушена їхати до нотаріального округу місця знаходження управненої сторони. Аналогічно викликатиме труднощі пошук нотаріуса за місцезнаходженням порту, який у договорі визначено як місце виконання зобов'язання. Такі підходи дуже застарілі, тому пропонуємо викласти п. 1.2. p. 21 ч. II Порядку вчинення нотаріальних дій нотаріусами України в такій редакції:

«1.2. Прийняття нотаріусом грошових сум і иінних паперів проводиться за місием виконання зобов'язання або за місием реєстрачії однієї зі сторін правочину».

2. Незручність вчинення правочинів учасниками/бенефіиіарами за місием реєстраиії товариства. Існування цієї проблеми пов'язане з прийняттям нового Закону України «Про товариства з обмеженою та додатковою відповідаль- 
ністю» та внесенням у зв'язку з цим змін до Закону України «Про державну реєстрацію юридичних осіб, фізичних осіб - підприємців та громадських формувань» $[15 ; 16]$.

Справа в тому, що за відчуження частки у статутному капіталі товариства сторони раніше посвідчували у нотаpiуса договір, яким відчужується частка, тепер - акт прийому-передачі. Тобто раніше можна було звертатися до нотаріуса за місцем реєстрації однієї зі сторін правочину, а тепер - за місцем реєстрації товариства, частка якого відчужується.

Виходить, що сторони можуть бути вимушені вирушити в інший кінець країни або замислюватися над пошуком довіреної особи, що створює зайві проблеми та витрати часу. Така обставина свідчить не на користь сприятливого інвестиційного клімату.

Пропонуємо додати варіативність у територіальну компетенцію нотаріуса в таких питаннях (у тому числі врахувавши реєстраційну функцію нотаріуса).

3. Незручність вчинення правочинів у корпорачіях mа багаторівневих корпоративних структурах.

У випадку зі складними корпоративними структурами ситуація ще гірше. Зазвичай директори особисто не займаються питаннями, які потребують їх присутності у нотаpiyca, тому затверджений головною компанією холдингу/ концерну/корпорації правочин щодо найнижчої ланки в ланцюгу компаній потребує залучення довірених осіб та багатьох зайвих витрат ресурсів, особливо якщо компанії зареєстровані в різних юрисдикціях.

Набагато зручніше було би вирішувати такі питання напряму (під час подання відповідного пакету документів, що доводить опосередковане підпорядкування), адже в цьому випадку принагідним буде звернутися до середньовічного принципу «васал мого васалу - мій васал», оскільки бенефіціарні власники мають зазначатись у реєстраційних справах українських юридичних осіб - підвалини до спрощення таких процедур вже закладені.
4. Незручність відокремлення нотаріальної компетенuіï від реєстраиійної.

32013 року нотаріусів наділено реєстраційними функціями, але нотаріальне законодавство у зв'язку з цим кардинальних змін на засадничому рівні так і не зазнало. Тобто територіальна компетенція нотаріуса охоплює саме нотаріальні, а не реєстраційні дії. Водночас реєстраційна територіальна компетенція нотаріуса навіть на теоретичному рівні майже не досліджена.

Підтвердимо важливість цієї проблеми судовою практикою. У рішенні Вінницького міського суду Вінницької області від 04.12.2017 р. у справі № 127/26867/16-ц зроблено висновок, що поняття «нотаріальні дії» не охоплює реєстраційні дії, адже нотаріус уповноважений на їх вчинення не положеннями Закону України «Про нотаріат», а статтею 10 Закону України «Про державну реєстрацію речових прав на нерухоме майно та їх обтяжень» $[17 ; 18]$.

Такий тривожний висновок наводить на думку, що слід переосмислити підходи законодавця до боротьби 3 рейдерством. Допоки такі питання будуть розглядатися лише депутатами, а не вченими, рейдерство продовжить своє існування, що, вочевидь, не сприятиме розвитку бізнесу в Україні. У зв'язку з цим пропонуємо передбачити в Законі України «Про нотаріат» реєстраційну територіальну компетенцію нотаріуса, яка повністю збігатиметься 3 нотаріальною територіальною компетенцією, крім випадків, передбачених законом.

Висновки. Секретом довголіття зазвичай визнається не лікування хвороб, а їх профілактика. По аналогії, висловимо припущення, що треба підвищувати ефективність охорони прав та інтересів бізнесу в аспекті вдосконалення територіальної компетенції нотаріусів. Саме тоді ведення бізнесу стане простішим та зручнішим, що у свою чергу стане підгрунтям до залучення додаткових інвестицій в Україну.

\section{ЛITEPATYPA}

1. Проект Постанови про утворення та ліквідацію районів за № 3650 від 15.06 .2020 p. URL: http://w1.c1.rada.gov.ua/pls/zweb2/ webproc4_1?pf3511=69132

2. Servetnyk A.G. Notary in the system of jurisdictional forms of protection of civil rights. Visegrad Journal of Human Rights. 2019. № 2 (Vol. 1). P. 166-175

3. Бондарєва М.В. Особливості нотаріального процесуального правовідношення. Часопис Київського університету права. 2010. № 4. C. $162-165$

4. Господарський процесуальний кодекс України від 06.11.1991 р. № 1798-XII. Відомості Верховної Ради України (ВВР). 1992. № 6. Ст. 56. URL: https://zakon.rada.gov.ua/laws/show/1798-12

5. Тихомиров М.Ю. Судебные иски. Комментарии и образцы документов. Москва : Изд-во Тихомирова М.Ю., 2004. 214 с.

6. Порцева О.Б. Подсудность уголовных дел : автореф. дис. ... на соискание учен. степени канд. юрид. наук : 12.00 .09 ; Тюмен. гос. ун-т. Ижевск, 2004. 23 с.

7. Гражданский процесс : учебник / под ред. М.К. Треушникова. Москва : Городец-издат, 2003. 720 с.

8. Абрамов Н.А. Хозяйственно-процессуальное право Украины : учеб. пособ. (курс лекций). Харьков : Одиссей, 2002. 256 с.

9. Про нотаріат : Закон України від 02.09.1993 р. № 3425-XII. Відомості Верховної Ради України (ВВP). 1993. № 39. Ст. 383. URL: https://zakon.rada.gov.ua/laws/show/3425-12

10. Фурса С.Я. Теоретичні основи нотаріального процесу в Україні : автореф. дис. ... д-ра юрид. наук : 12.00 .03 ; НАН України; Інститут держави і права ім. В.М. Корецького. Київ, 2003. 42 с.

11. Нотаріат України : підручник у трьох книгах / С.Я. Фурса та ін. ; за заг. ред. С.Я. Фурси. Київ : Алерта, 2015. Кн. 1.: Організація нотаріату з практикумом. $484 \mathrm{c}$.

12. Долинська М.С. Територіальна компетенція нотаріальних органів України як один із головних засад здійснення нотаріального процесу в Україні. Науковий вісник Львівського державного університету внутрішніх справ. 2018. № 2. С. 107-115.

13. Порядок вчинення нотаріальних дій нотаріусами України, затверджений Наказом Міністерства юстиції України від 22.02.2012 р. № 296/5. URL: https://zakon.rada.gov.ua/laws/show/z0282-12

14. Господарський кодекс України від 16.01.2003 р. № 436-IV. Відомості Верховної Ради України (ВВР). 2003. № 18, № 19-20, № 21-22. Ст. 144. URL: https://zakon.rada.gov.ua/laws/show/436-15

15. Закон України «Про товариства з обмеженою та додатковою відповідальністю» від 06.02.2018 р. № 2275-VIII. Biдомості Верховної Ради (BBP). 2018. № 13. Ст. 69. URL: https://zakon.rada.gov.ua/laws/show/2275-19

16. Закон України «Про державну реєстрацію юридичних осіб, фізичних осіб - підприємців та громадських формувань» від 15.05.2003 р. № 755-IV. Відомості Верховної Ради України (ВВP). 2003. № 31-32. Ст. 263. URL: https://zakon.rada.gov.ua/laws/show/755-15

17. Рішення Вінницького міського суду Вінницької області від 04.12.2017 р. у справі № 127/26867/16-ц. URL: http://reyestr.court.gov.ua/ Review/70867371

18. Закон України «Про державну реєстрацію речових прав на нерухоме майно та їх обтяжень» від 01.07.2004 p. № 1952-IV. Biдомості Верховної Ради України (ВВР). 2004. № 51. Ст. 553. URL: https://zakon.rada.gov.ua/laws/show/1952-15 


\title{
ОКРЕМІ ПИТАННЯ ПРАВОВОГО РЕГУЛЮВАННЯ ВПРОВАДЖЕННЯ ЕЛЕКТРОННИХ ДОВІРЧИХ ПОСЛУГ
}

\author{
SOME ISSUES OF LEGAL REGULATION OF THE IMPLEMENTATION \\ OF ELECTRONIC TRUST SERVICES
}

\author{
Кулага Е.В., к.ю.н., \\ доцент кафедри підприємницького та корпоративного права \\ Київський національний економічний університет імені Вадима Гетьмана \\ Шаталова Л.М., к.ю.н., \\ доцент кафедри підприємницького та корпоративного права \\ Київський національний економічний університет імені Вадима Гетьмана
}

У статті розглянуто ряд питань, пов'язаних з укладанням договорів за допомогою електронних довірчих послуг та транскордонних електронних послуг. Визначено специфічні ознаки електронної кваліфікованої форми е-договору, його кваліфіковані реквізити. Розглянуто перелік електронних довірчих послуг, що надаються зареєстрованими надавачами таких послуг; перелік суб'єктів господарювання, уповноважених державою на здійснення обслуговування користувачів е-підписів, визначений Довірчим списком. Окрему увагу в роботі приділено схемам електронної ідентифрікації з трьома рівнями довіри, визначено специфіку кожного.

У науковому дослідженні визначено позитивні досягнення правового регулювання сфрери електронних довірчих послуг, що стосуються можливості участі України в міжнародному співробітництві у сфрерах електронних довірчих послуг та електронної ідентифікації на основі міжнародних договорів України. Підкреслено, що передбачені законом механізми та процедури дозволяють суб'єктам господарювання ефективніше використовувати свій час та ресурси, надають гарантії ідентифікації контрагента в господарському електронному документообігу, забезпечують належність та допустимість е-договорів як е-доказів у суді.

Встановлено недоліки правового регулювання, які створюють певні бар'єри і проблеми на шляху співпраці вітчизняних суб'єктів господарювання, громадських та державних організацій у сфері міжнародного економічного співробітництва із використання транскордонних електронних довірчих послуг та транскордонних е-підписів. Визначено, що функціональна несумісність інформаційно-телекомунікаційних систем негативно впливає на реалізацію транскордонних електронних операцій та електронних довірчих послуг із застосуванням е-підписів та їх сертифікатів у сфері міжнародного бізнесу під час укладення господарських договорів, ускладнених іноземним елементом.

Окрему увагу в дослідженні приділено специфіці укладення змішаних та комплексних зовнішньоекономічних договорів (контрактів) із застосуванням сучасних транскордонних електронних операцій та електронних довірчих послуг. Визначено вплив сучасного стану українського законодавства на імідж України як партнера в міжнародних відносинах та на рівень довіри до вітчизняних електронних довірчих послуг, е-підпису, електронних операцій.

Ключові слова: електронна довірча послуга, схеми електронної ідентисікації, рівень довіри, транскордонна електронна довірча послуга.

The article discusses a number of issues related to the conclusion of contracts through electronic trust services and cross-border electronic services. electronic trust services and cross-border electronic services. The list of electronic trust services provided by registered providers of such services is considered; the list of business entities authorized by the state to provide services to e-signature users is determined by a trust list. Particular attention is paid to electronic identification schemes with three levels of trust, the specifics of each are defined.

The research identifies positive achievements in the legal regulation of electronic trust services, concerning the possibility of Ukraine's participation in international cooperation in the field of electronic trust services and electronic identification on the basis of international agreements of Ukraine. It is emphasized that the mechanisms and procedures provided by law allow businesses to use their time and resources more efficiently, provide guarantees for identification of the counterparty in the electronic business document management, ensure the ownership and admissibility of e-contracts as e-evidence in court.

Shortcomings of legal regulation have been identified, which create certain barriers and problems in the way of cooperation of domestic economic entities, public and state organizations in the field of international economic cooperation in the use of cross-border electronic trust services and cross-border e-signatures. It is determined that the functional incompatibility of information and telecommunication systems negatively affects the implementation of cross-border electronic transactions and electronic trust services with the use of e-signatures and their certificates in the field of international business when concluding business agreements complicated by a foreign element.

Particular attention in the study is paid to the specifics of concluding mixed and complex foreign economic agreements (contracts) with the use of modern cross-border electronic transactions and electronic trust services. The influence of the current state of Ukrainian legislation on the image of Ukraine as a partner in international relations and on the level of trust in domestic electronic trust services, e-signature, electronic transactions is determined.

Key words: electronic trust service, electronic identification schemes, level of trust, cross-border electronic trust service.

3 невпинним розвитком новітніх комунікативних технологій стрімке піднесення отримала електронна комерція, активізація господарського обороту з використанням інформаційно-телекомунікаційних систем та запровадження технологій електронного урядування, що супроводжується розгортанням процесів електронного документообігу із застосуванням технологій електронного підпису. Концепція розвитку цифрової економіки та суспільства України на 2018-2020 роки передбачає здійснення заходів із впровадження стимулів для цифровізації економіки, інструментів розвитку цифрових інфраструктур, набуття громадянами цифрових компетенцій, стимулювання внутрішнього ринку виробництва, використання та спожи- вання цифрових технологій. Концепція передбачає гармонізацію з європейськими цифровими ініціативами Digital Single Market, включаючи такі напрями, як інтероперабельність, електронні сервіси, електронна ідентифікація [1]. У зв'язку з цим особливої актуальності набуває дослідження проблем надання електронних довірчих послуг.

Теоретичним та практичним аспектам правового регулювання організації та функціонування електронних довірчих послуг присвятили свої праці науковці: I. Bepec, О.В. Голіна, В.П. Писаренко - правовим та організаційним засадам електронних довірчих послуг, О.М. Вінник - проблемам правового забезпечення ведення електронного бізнесу в умовах цифровізації, С.М. Жутова, О.В. Коваленко, 
В.С. Панін, Ю.О. Патинка, О.С. Хижняк - особливостям механізму укладання електронних договорів, Н.О. Кучаковська - проблемам правового регулювання укладення електронних господарських договорів, О.В. Костенко міжнародному правовому регулюванню транскордонного визнання сертифікатів електронних підписів та електронних довірчих послуг, Г.Г. Чмерук - стосовно цифрової трансформації підприємств України та інші.

Разом із тим низка питань, пов'язаних з укладанням договорів за допомогою електронних довірчих послуг та транскордонних електронних послуг, залишились не вирішеними.

За загальним правилом, вчинення правочинів у сфері господарювання відбувається в письмовій формі (ст. 208 ЦК України, ч. 1 ст. 181 ГК України) [2; 3], до якої прирівнюється електронна форма. У науковій літературі виокремлюють такі види письмової форми укладення господарських е-договорів, як електронна спрощена та електронна кваліфікована форми. При цьому зазначається, що Законом України «Про електронну комерцію» встановлено спрощену електронну форму укладення е-договору, яка передбачає обмін документами комерційної електронної оферти та акцепту в мережі Інтернет або інших інформаційно-телекомунікаційних системах шляхом надсилання електронного повідомлення в інформаційній системі або з використанням різних видів електронних підписів (далі - е-підписів). Специфічною ж ознакою електронної кваліфікованої форми е-договору $є$ його створення кваліфікованим надавачем кваліфікованих електронних довірчих послуг та наявність у документі кваліфікованих реквізитів е-договорів, які формуються, перевіряються та підтверджуються кваліфікованим надавачем кваліфікованих електронних довірчих послуг [4, с. 192].

Таким чином, до специфічних ознак електронної кваліфікованої форми е-договору відносимо: 1) наявність у документі кваліфікованих реквізитів е-договорів (удосконалених е-підписів, печаток, електронних позначок часу та сертифікатів, пов'язаних із цими послугами, тощо); 2) договір формується, перевіряється та підтверджується кваліфікованим постачальником або надавачем кваліфікованих електронних довірчих послуг.

Законом України «Про електронні довірчі послуги» (далі - Закон № 2155-VIII) визначено перелік електронних довірчих послуг (далі - ЕДП), що надаються зареєстрованими надавачами ЕДП, зокрема: створення, перевірка та підтвердження удосконаленого е-підпису чи печатки; формування, перевірка і підтвердження дії сертифікату е-підпису або друку; формування, перевірка і підтвердження дії сертифікату автентифікації веб-сайту; формування, перевірка і підтвердження дії сертифікату шифрування; формування, перевірка і підтвердження електронної позначки часу; реєстрована електронна доставка; зберігання удосконалених е-підписів, печаток, електронних позначок часу та сертифікатів, пов'язаних із цими послугами [5]. Кожна ЕДП із вказаного переліку може надаватися як окремо, так і в сукупності (ст. 16 Закону) зареєстрованим постачальником ЕДП і кваліфікованим надавачем ЕДП, який внесений до Довірчого списку, як правило, на договірних засадах всім споживачам на правомірних засадах. Довірчим списком чітко визначений перелік суб'єктів господарювання, уповноважених державою на здійснення обслуговування користувачів е-підписів (органи державної влади, органи місцевого самоврядування, підприємства, установи та організації державної форми власності, державні реєстратори, нотаріуси та інші суб'єкти, уповноважені державою на здійснення функцій державного реєстратора).

До того ж суб'єкти господарювання мають право вибирати рівень захисту е-договору, вибираючи механізми та процедури, встановлені законом. Так, у статті 15 Закону № 2155-VIII визначені схеми електронної ідентифікації
3 трьома рівнями довіри: низьким, середнім, високим [5]. Певний рівень довіри до засобів електронної ідентифікації характеризує засоби електронної ідентифікації в контексті схеми електронної ідентифікації, яка забезпечує певний ступінь довіри до ідентифікаційних даних і описується з посиланням на технічні специфікації, стандарти і процедури, включаючи технічні засоби контролю. Отже, ступінь довіри визначається складом процедури ЕДП та забезпечується сукупністю засобів електронної ідентифікації в контексті схеми електронної ідентифікації. Низький рівень довіри включає схему електронної ідентифікації, яка полягає в обмеженні ідентифікаційних даних, технічних засобів контролю, призначенням яких $\epsilon$ зниження ризику зловживання або спростування ідентичності. Середній рівень довіри включає схему електронної ідентифікації, яка дозволяє забезпечити істотне зниження ризику зловживання або спростування ідентичності, високий рівень довіри - схему електронної ідентифікації, яка включає технічні засоби контролю, призначенням яких $є$ запобігання зловживанню повноваженнями або підміні особи.

У Розділі VI Закону № 2155-VIII зроблена спроба врегулювання складної сфери міжнародного співробітництва щодо визнання іноземних ЕДП, у тому числі у сфері господарювання та зовнішньоекономічної діяльності. Позитивними досягненнями слід назвати норми статті 37 щодо можливості участі України в міжнародному співробітництві у сферах ЕДП та електронної ідентифікації на основі міжнародних договорів України та в порядку, встановленому законом. ЕДП, надані відповідно до вимог нормативно-правових актів, що регулюють відносини у сфері ЕДП в іноземних державах, не можуть визнаватися в Україні недійсними. 3 метою спрощення міжнародного співробітництва у зазначеній сфері статтею 38 закону встановлено більш розширений підхід до розуміння процедури визнання іноземних сертифікатів ключів е-підписів. Такий підхід полягає в тому, що процедура визнання ЕДП в Україні того самого виду, що надані іноземними державами відповідно до вимог нормативно-правових актів, які регулюють правові відносини у сфері ЕДП в іноземних державах, а саме, що кваліфікований надавач ЕДП іноземної держави має відповідати одній з умов: 1) вимогам Закону № 2155-VIII, що підтверджується центральним засвідчувальним органом (або засвідчувальним центром у разі надання ЕДП у банківській системі України та під час здійснення переказу коштів); 2) внесений до Довірчого списку держави, з якою Україна уклала відповідний двосторонній або багатосторонній міжнародний договір.

Передбачені Законом № 2155-VIII механізми та процедури дозволяють суб'єктам господарювання ефективніше використовувати свій час та ресурси, надають гарантії ідентифікації контрагента в господарському електронному документообігу, забезпечують належність та допустимість е-договорів як е-доказів у суді. Водночас закон не позбавлений недоліків, які створюють певні бар'єри та проблеми на шляху співпраці вітчизняних суб'єктів господарювання. Наразі необхідно привести у відповідність до даного закону й інші нормативно-правові акти, зокрема деякі норми Господарського процесуального кодексу України. Відповідно до ч. 2 ст. 96 ГПК електронні докази подаються в оригіналі або в електронній копії, засвідченій електронним цифровим підписом, прирівняним до власноручного підпису відповідно до Закону України «Про електронний цифровий підпис». У даній нормі законодавець посилається на закон, який втратив чинність [6]. Пропонуємо ч. 2 ст. 96 Господарського процесуального кодексу викласти в такій редакції: «Електронні докази подаються в оригіналі або в електронній копії, засвідченій кваліфікованим електронним підписом, прирівняним до власноручного підпису відповідно до Закону України «Про електронні довірчі послуги». Законом може 
бути передбачено інший порядок засвідчення електронної копії електронного доказу».

У сфері міжнародного економічного співробітництва 3 використанням транскордонних ЕДП та транскордонних е-підписів актуальним залишається питання визнання іноземних сертифікатів е-підписів та ЕДП. За підходами законодавців до вирішення даної проблеми пострадянські країни поділяють на чотири категорії. До першої віднесено Естонію, Латвію, Литву. Законодавство цих країн орієнтоване на використання нормативно-правових актів $€ C$. Законодавство України найбільш наближене до даної групи та характеризується тим, що деталізовано регулює лише технічний аспект визнання іноземних сертифікатів та не закріплює конкретних правових процедур їх визнання. Законодавство країн другої категорії (Азербайджан, Білорусія, Молдова) передбачає таку процедуру шляхом акредитації іноземного центру сертифікації в національному центрі. Країни третьої категорії (Вірменія, Таджикистан, Туркменістан, Узбекистан, Російська Федерація) застосовують єдину законодавчу процедуру визнання іноземних сертифікатів шляхом укладання міждержавних угод. I лише законодавство четвертої групи (Казахстан, Грузія) передбачає процедуру визнання іноземних сертифікатів е-підпису через залучення третьої сторони, на яку покладено обов'язки запровадження технічних і юридичних процедур визнання [7, с. 114].

На виконання зазначених норм Закону № 2155-VIII Кабінетом Міністрів України затверджений Порядок, яким визначено використання інформаційно-телекомунікаційної системи центрального засвідчувального органу для забезпечення визнання в Україні ЕДП, іноземних сертифікатів відкритих ключів, що використовуються під час надання юридично значущих електронних послуг у процесі взаємодії між суб'єктами різних держав [8], який містить низку дублюючих та декларативних норм, що не сприяє використанню транскордонних е-підписів. Натомість міжнародних договорів про взаємне визнання ЕДП або використання транскордонних е-підписів натепер не укладено. Проте транскордонний е-підпис $\epsilon$ основою єдиного цифрового ринку ЄС та запроваджений для засобів електронної ідентифікації в Німеччині, Італії, Естонії, Іспанії, Люксембурзі та Хорватії. 10 квітня 2020 року Міністерство цифрової трансформації України отримало підтвердження від програми EU4Digital про те, що Україну було вибрано серед країн Східного Партнерства $Є С$ для участі в пілотних проєктах для транскордонного е-підпису. У рамках пілоту Україна співпрацює 3 Естонією та Молдовою в напрямі розробки технічного забезпечення та його тестування на реальних прикладах застосування транскордонних е-підписів. На основі отриманого досвіду буде розроблено план дій для досягнення взаємного визнання транскордонних ЕДП між країнами-учасниками [9].

Зазначені недоліки та низька інтероперабельність, тобто функціональна несумісність інформаційно-телекомунікаційних систем, негативно впливають на реалізацію транскордонних електронних операцій та ЕДП із застосуванням е-підписів та їх сертифікатів у сфері міжнародного бізнесу під час укладення господарських договорів, ускладнених іноземним елементом. У науковій літературі розглядають зовнішньоекономічний договір (контракт) як різновид господарського договору, що є різновидом цивільно-правового договору, якому притаманні особливості як господарських, так і цивільно-правових договорів $[10$, с. 256$]$. Приєднуємось до думки, що такий підхід дозволяє на універсальному рівні використовувати поняття «контракт» відносно складних, комплексних і змішаних договорів, ускладнених іноземним елементом. При цьому між суб'єктами зовнішньоекономічних відносин можуть укладатися зовнішньоекономічні договори (контракти), як змішані (які містять елементи різних договорів), так і комплексні, як у простій письмовій, так і в електронній формі 3 використанням транскордонних ЕДП. Комплексні договори є підставою виникнення двох і більше зобов'язань, об'єднаних єдиною господарською метою, для досягнення якої вимагають координації зобов'язань, а отже, породжують існування організаційних відносин. Об'єднання організаційних відносин - відмінна риса комплексного договору, яка визначає міжгалузевий характер регулювання вказаних відносин. Комплексні договори - це різновид господарських договорів, які використовуються лише у відносинах між організаціями, тоді як змішані - з будь-яким суб'єктним складом. Додатково специфіка комплексних договорів, яка визначається їх міжгалузевим і міжвидовим характером [11, с. 63], ускладнена суб'єктом зовнішньоекономічної діяльності. Суттєво спрощує процедуру укладення змішаних та комплексних зовнішньоекономічних договорів (контрактів) застосування сучасних транскордонних електронних операції та ЕДП.

Прикладом таких комплексних договорів $є$ : договір підряду на капітальне будівництво, оскільки в його межах виникають зобов'язання 3 виконання підрядних робіт та низка суміжних зобов'язань (з оренди будівель, 3 надання замовником різних послуг підряднику, зберігання будівельних матеріалів тощо). Також сьогодні набувають активного розвитку правовідносин у сфері капітального будівництва та енергетики, які передбачають реалізацію проєктів електростанцій, що використовують відновлювальні джерела енергії і передбачають укладення комплексних, так званих ЕРС-контрактів (від англ. «Engineering, Procurement and Construction») з метою будівництва станцій «під ключ».

Сучасний стан українського законодавства зумовлює низький рівень довіри до вітчизняних ЕДП, е-підпису, електронних операцій та не сприяє якості ділового іміджу України як надійного партнера в міжнародних відносинах, стримує споживачів від здійснення цілісних електронних операцій між підприємствами, громадянами, суб'єктами господарювання, суб'єктами зовнішньоекономічної діяльності й державними органами та запровадження і прийняття нових послуг. Відсутність технічної сумісності форматів удосконалених та кваліфікованих е-підписів для доступу до ЕДП не надає доступу до транскордонного використання засобів електронної ідентифікації та онлайн-послуг і стримує подальший розвиток транскордонних електронних операцій між Україною і країнами світу.

\section{ЛITEPATУРA}

1. Про схвалення Концепції розвитку цифрової економіки та суспільства України на 2018-2020 роки та затвердження плану заходів щодо їі реалізації : Розпорядження Кабінету Міністрів України від 17.01.2018 р. № 67-p. URL: https://zakon.rada.gov.ua/laws/show/67-2018\%D1\%80\#Tеxt (дата звернення: 28.07.2020)

2. Господарський кодекс України від 16.01 .2003 р. № 436-IV. URL: http://zakon.rada.gov.ua/laws/show/436-15 (дата звернення: 28.07.2020).

3. Цивільний кодекс України від 16.01.2003 р. № 435-IV. URL: https://zakon.rada.gov.ua/laws/show/435-15 (дата звернення: 28.07.2020).

4. Шаталова Л.М. Загальний та спрощений порядок укладення електронних договорів. Науковий вісник Ужгородського національного університету. Серія Право.2019. Випуск 59. Том 1. С. 189-192.

5. Про електронні довірчі послуги : Закон України від 05.10.2017 р. № 2155-VIII. Відомості Верховної Ради України. 2017. № 45. Ст. 400. URL: https://zakon.rada.gov.ua/laws/show/2155-19/ (дата звернення: 28.07.2020). 
6. Господарський процесуальний кодекс України від 06.11.1991р. № 1798-XII. URL: https://zakon.rada.gov.ua/laws/show/1798-12 (дата звернення: 28.07.2020)

7. Костенко О.В. Правове регулювання транскордонного визнання сертифікатів електронних підписів та електронних довірчих послуг у законодавстві пострадянських країн. Право і суспільство. 2018. № 5. Ч. 2. С. 110-115.

8. Про затвердження Порядку взаємного визнання українських та іноземних сертифікатів відкритих ключів, електронних підписів, а також використання інформаційно-телекомунікаційної системи центрального засвідчувального органу для забезпечення визнання в Україні електронних довірчих послуг, іноземних сертифікатів відкритих ключів, що використовуються під час надання юридично значущих електронних послуг у процесі взаємодії між суб’єктами різних держав : Постанова Кабінету Міністрів України від 23 січня 2019 р. № 60. URL: https://zakon.rada.gov.ua/laws/show/60-2019-\%D0\%BF\#Text (дата звернення: 25.07.2020)

9. URL: https://news.dtkt.ua/accounting/automation/61952

10. Саксонов В.Б. Правові особливості зовнішньоекономічних договорів (контрактів) України. Науковий вісник Дніпропетровського державного університету внутрішніх справ. 2012. № 2. С. 252-260.

11. Собчак А.А. Смешанные и комплексные договоры в гражданском праве. Советское государство и право. 1989. № 11. С. 64-65. 


\title{
ПРАВОВЕ РЕГУЛЮВАННЯ СКЛАДУ АУДИТОРСЬКОГО КОМІТЕТУ ДЕРЖАВНИХ УНІТАРНИХ ПІДПРИСМСТВ В УКРАЇНІ
}

\section{LEGAL REGULATION OF THE COMPOSITION OF THE AUDIT COMMITTEE OF STATE UNITARY ENTERPRISES IN UKRAINE}

\author{
Рєзнік О.М., д.ю.н., заслужений юрист України, \\ доцент кафедри адміністративного, господарського права \\ та фінансово-економічної безпеки \\ Сумський державний університет \\ Андрійченко Н.С., к.ю.н., \\ викладач кафедри адміністративного, господарського права \\ та фінансово-економічної безпеки \\ Сумський державний університет
}

Ярусевич Є.Ю., аспірант кафедри адміністративного, господарського права та фінансово-економічної безпеки

Сумський державний університет

Стаття присвячена викладенню особливостей правового регулювання складу аудиторського комітету державних унітарних підприємств в Україні. З'ясовано, що глобалізаційні процеси на світовому ринку зумовлюють необхідність здійснення якісного внутрішнього аудиту підприємства, для чого найчастіше використовують централізовану форму організації аудиту через створення аудиторського комітету. Встановлено, що законодавство України забороняє посадовим особам органам управління державного унітарного підприємства входити до складу аудиторського комітету такого підприємства. Проаналізовано положення нормативно-правових актів України щодо визначення поняття «посадова особа». Зроблено висновок про закріплення вказаного поняття в низці законодавчих актів виключно для цілей останніх. Вказане відповідно зумовлює низку суперечностей під час порівняння змісту поняття «посадова особа», що міститься в різних нормативно-правових актах. Наголошено на тому, що в окремих законодавчих актах ототожнюються поняття «посадова особа» й «службова особа», хоча Основний закон України не вживає ці поняття як ідентичні. Не розв'язує наявної проблеми й судова практика, а така ознака, як здійснення працівником організаційно-розпорядчих, адміністративно-господарських функцій, $є$ підставою для віднесення його як до посадової особи, так і до службової особи з усіма відповідними правовими наслідками для нього. В аспекті правового регулювання складу аудиторського комітету державних унітарних підприємств відбувається ситуація, за якої забороняється лише посадовим особам органів управління підприємства входити до його складу, тоді як на службових осіб вказана заборона не поширює свою дію, хоча як посадова й службова особа можуть здійснювати організаційно-розпорядчі й адміністративно-господарські функції. Зроблено висновок про необхідність розроблення та закріплення на законодавчому рівні універсальних понять «посадова особа» й «службова особа», що дозволить уникнути суперечностей під час формування складу аудиторського комітету державних унітарних підприємств.

Ключові слова: внутрішній аудит, аудиторський комітет, державне унітарне підприємство, посадова особа, службова особа.

The article is devoted to the peculiarities of the legal regulation of the composition of the audit committee of state unitary enterprises in Ukraine. It was found that globalization processes in the world market necessitate a high-quality internal audit of the enterprise, for which a centralized form of audit organization is most often use through the establishment of an audit committee. It is established that the legislation of Ukraine prohibits officials of the governing bodies of a state unitary enterprise from being a member of the audit committee of such an enterprise. The provisions of normative-legal acts of Ukraine on the definition of the term "official" are analyzed. It is concluded that this concept is enshrined in a number of legislative acts exclusively for the purposes of the latter. This, accordingly, causes a number of contradictions when comparing the meaning of the term "official" contained in various regulations. It is emphasized that in some legislative acts the terms "official" and "service person" are identified, although the Constitution of Ukraine does not use these terms as identical. Judicial practice does not solve the existing problem, and such a feature as the implementation of organizational and administrative, administrative and economic functions by the employee is the basis for classifying him as an official and service person with all the relevant legal consequences for him. In terms of legal regulation of the audit committee of state unitary enterprises, there is a situation in which only officials of the governing bodies of the enterprise are prohibited from being part of it, while service persons are not prohibited, although as an official and service person may carry out organizational and administrative and administrative and economic functions. It is concluded that it is necessary to develop and consolidate at the legislative level the universal concepts of "official" and "service person", which will avoid contradictions in the formation of the audit committee of state unitary enterprises.

Key words: internal audit, audit committee, state unitary enterprise, official, service person.

Глобалізаційні процеси на світовому ринку зумовлюють важливість створення умов для ефективного менеджменту, а також інформаційного забезпечення підприємств в Україні. Важливим елементом ефективного менеджменту підприємства $\epsilon$ внутрішній аудит його діяльності. Відповідно до Міжнародних стандартів аудиту, внутрішній аудит є діяльністю, яка організована в межах суб'єкта господарювання та яку виконує окремий відділ [1]. Т.О. Каменська відзначає, що внутрішній аудит як функція контролю дозволяє вчасно виявити й усунути умови й чинники, що перешкоджають ефективній організації діяльності, досягненню поставленої мети. За допомогою спеціальних прийомів він дає можливість оцінити стан процесів і систем, розробити рекомендації щодо вдосконалення діяльності останніх [2, с. 61].
Д.О. Гуляєва звертає увагу на дві форми організації внутрішнього аудиту: централізовану, де функцію внутрішнього аудиту виконує служба аудиту, яка відокремлена від підрозділів підприємства, й децентралізовану, в якій аудит проводять аудитори в кожній ланці підпорядкування [3, с. 35].

Зокрема, Законом України «Про аудит фінансової звітності та аудиторську діяльність» від 21 грудня 2017 р. на великі підприємства покладено обов'язок створити аудиторський комітет або покласти відповідні функції на ревізійну комісію (наглядову раду); інші підприємства, які є такими, що становлять суспільний інтерес, можуть покласти функції аудиторського комітету на окремий підрозділ органу управління або наглядовий орган [4]. М.Ю. Шмирко зауважує, що централізована форма побу- 
дови системи внутрішнього аудиту через створення відокремленої служби аудиту поширена в Україні. Однак не слід вважати одну з форм ефективнішою за інші, оскільки має враховуватися насамперед специфіка підприємства [5, с. 176].

Законом України «Про аудит фінансової діяльності та аудиторську діяльність» передбачено, що більшість членів аудиторського комітету підприємств, що становлять суспільний інтерес, не повинні бути пов'язані з такими підприємствами, а до складу аудиторського комітету не можуть також входити посадові особи органів управління таких підприємств [4].

Враховуючи те, що до складу аудиторського комітету підприємства не можуть входити посадові особи органів управління підприємства, пропонуємо звернути увагу на законодавче розуміння поняття «посадова особа» й з'ясувати перелік посадових осіб органів управління безпосередньо державного унітарного підприємства.

Натепер поняття «посадова особа» зустрічається в низці законодавчих актів. Зокрема, у ч. 2 ст. 19 Конституції України від 28 червня 1996 р. застосоване поняття посадової особи органів державної влади й місцевого самоврядування. Митний і Податковий кодекси України також містять поняття «посадові особи органів доходів і зборів» (ч. 1 ст. 569 Митного кодексу України), «посадові особи контролюючого органу» (п. 342.1 ст. 342 Податкового кодексу України).

Відповідно до п. 2 ст. 3 Закону України «Про державну службу» від 10 грудня 2015 р., до посадових осіб віднесений керівник державної служби, тобто особа, яка займає вищу посаду державної служби в державному органі, до обов'язків якої належить здійснення повноважень із питань державної служби й організації роботи працівників у цьому органі [6].

Згідно зі ст. 2 Закону України «Про службу в органах місцевого самоврядування» від 07 червня 2001 р., посадовою особою місцевого самоврядування вважається особа, яка працює в органах місцевого самоврядування, має відповідні посадові повноваження щодо здійснення організаційно-розпорядчих i консультативно-дорадчих функцій та отримує заробітну плату коштом місцевого бюджету [7].

Закон України «Про запобігання корупції» від 14 жовтня 2014 р. до суб'єктів, на яких поширюється норма вказаного закону, відносить посадових і службових осіб органів прокуратури, Служби безпеки України, Державного бюро розслідувань, посадових і службових осіб інших державних органів, органів влади Автономної Республіки Крим (ч. 1 ст. 3), посадових юридичних осіб публічного права, які прирівнюються до осіб, уповноважених виконувати завдання держави або місцевого самоврядування (ч. 2 ст. 3) [8].

Кодекс адміністративного судочинства України від 06 липня 2005 р. серед суб'єктів владних повноважень також розрізняє посадових і службових осіб органів державної влади, місцевого самоврядування (ст. 2) [9]. Тобто фактично законодавство крім поняття «посадова особа» містить поняття «службова особа». Водночас аналіз норм Конституції України свідчить, що поняття посадових і службових осіб не ідентичні (ст. ст. 40, 55, 56) [10].

Виходячи із зазначеного, очевидно, що законодавство України часто використовує поняття «посадова особа», але кожен нормативний акт надає його різне трактування, що з боку забезпечення однакового розуміння та застосування норм законодавства недоречне й потребує узгодження між собою. Крім того, відмінним за своїм змістом $€$ поняття «службова особа».

Натепер поняття «службова особа» запропоноване ч. 3 ст. 18 Кримінального кодексу України від 05 квітня 2001 р., відповідно до якої службовими особами є особи, які здійснюють функції представників влади чи місце- вого самоврядування, а також постійно чи тимчасово обіймають в органах державної влади, органах місцевого самоврядування, на підприємствах, в установах чи організаціях посади, пов'язані з виконанням організаційнорозпорядчих чи адміністративно-господарських функцій, або виконують такі функції за спеціальним повноваженням, яким особа наділяється повноважним органом державної влади, органом місцевого самоврядування, центральним органом державного управління зі спеціальним статусом, повноважним органом чи повноважною службовою особою підприємства, установи, організації, судом або законом [11].

Зазначені нами визначення понять «посадова особа» й «службова особа» яскраво демонструють неоднозначний підхід законодавця до вказаних понять, які, зважаючи на положення Конституції України, не ідентичні, але, виходячи зі змісту нормативно-правових актів, дещо ототожнюються.

Крім того, Н.В. Янюк звертає увагу на необхідність доопрацювання поняття «службова особа», оскільки визначення, яке $\epsilon$ в Кримінальному кодексі України, не придатне для застосування в контексті інших нормативних актів, тому що: по-перше, додаткового пояснення потребують функції, через перелік яких визначено поняття «службова особа», а саме «функції представників влади чи місцевого самоврядування», виконання «організаційно-розпорядчих чи адміністративно-господарських функцій»; по-друге, некоректним $€$ формулювання «виконують такі функції за спеціальним повноваженням», яке містить поняття, що потребують додаткового уточнення, зокрема, в чому полягають спеціальні повноваження, яким $\epsilon$ коло повноважних органів та осіб, що наділяють службову особу спеціальними повноваженнями [12, с. 93].

А.А. Курова зауважує, що судова практика не має конкретної позиції щодо розмежування понять «посадова особа» й «службова особа». Про це свідчить Постанова Пленуму Верховного суду України від 26 квітня 2002 р. № 5 «Про судову практику у справах про хабарництво», якою знову ж таки службову особу виокремлено за ознакою наявності в неї організаційно-розпорядчих обов'язків (здійснення керівництва галуззю промисловості, трудовим колективом, ділянкою роботи, виробничою діяльністю окремих працівників на підприємствах, в установах, організаціях незалежно від форм власності). Зважаючи на викладене, науковець зробила висновок про те, що вичерпний перелік ознак посадової та службової осіб в законодавстві й судовій практиці України відсутній. Водночас здійснення працівником організаційно-розпорядчих/адміністративно-господарських обов'язків слугує підставою для віднесення його до розряду посадова/службова особа з усіма відповідними правовими наслідками для нього [13, с. 66].

Говорячи безпосередньо про посадових осіб органів управління державного унітарного підприємства, варто звернути увагу на те, що відповідно до ст. 73 Господарського кодексу України від 16 січня 2003 р., державне унітарне підприємство утворюється компетентним органом державної влади в розпорядчому порядку на базі відокремленої частини державної власності, як правило, без поділу iї на частки й входить до сфери його управління. Водночас до органів управління державного унітарного підприємства належать: керівник підприємства, який призначається суб'єктом управління об'єктами державної власності, що здійснює функції з управління підприємством, або наглядовою радою такого підприємства (в разі ії утворення), $\epsilon$ підзвітним органу, який його призначив; наглядова рада підприємства (в разі їі утворення), яка контролює й регулює діяльність керівника підприємства [14].

Відповідно до п. 4 ч. 1 ст. 6 Закону України «Про управління об'єктами державної власності» від 21 вересня 
2006 р., уповноважені органи управління відповідно до покладених на них завдань призначають на посаду й звільняють із посади керівників державних унітарних підприємств, в яких не утворено наглядову раду, установ, організацій і господарських структур, у статутному капіталі яких понад 50\% акцій (часток) належать державі й в яких не утворено наглядову раду, укладають і розривають 3 ними контракти, здійснюють контроль за дотриманням їхніх вимог [15]. Виходячи 3 положень вказаного нормативно-правового акту, керівник підприємства $є$ посадовою особою органу управління підприємства.

Тобто, якщо прямо трактувати положення ст. 34 Закону України «Про аудит фінансової звітності та аудиторську діяльність», згідно з якими до складу аудиторського комітету не можуть входити посадові особи органів управління підприємств, то керівник підприємства $є$ посадовою особою, а його заступник(и) й працівники підприємства, згідно з Господарським кодексом України, не $є$ органом управління.

Крім того, варто звернути увагу й на те, що згідно iз ч. 3 ст. 65 Господарського кодексу України, до складу посадових осіб підприємства віднесені: керівник підприємства, головний бухгалтер, члени наглядової ради, виконавчого органу й інших органів управління підприємства відповідно до статуту [14]. Таким чином, під час визначення посадових юридичних осіб публічного права слід керуватися ч. 3 ст. 65 Господарського кодексу України, якою визначено перелік посадових осіб підприємства. Водночас статутом підприємства посадовими особами можуть бути визнані й інші особи.

Незважаючи на місце Господарського кодексу України як кодифікованого законодавчого акту в ієрархії актів національного законодавства, в Роз'ясненні Національного агентства 3 питань запобігання корупції «Щодо застосування окремих положень Закону стосовно заходів фінансового контролю», затвердженого рішенням Національного агентства від 11 липня 2016 р. № 3, під «посадовими особами юридичних осіб публічного права» пропонується розуміти працівників юридичних осіб публічного права, які наділені посадовими повноваженнями здійснювати організаційно-розпорядчі чи адміністративно-господарські функції. Визначальним на цім є обсяг функцій (обов'язків) відповідного працівника [16]. Втім, якщо порівняти зміст поняття «посадова особа», наведене у вказаному роз'ясненні, зі змістом поняття «службова особа», надане Кримінальним кодексом України, то очевидне ототожнення двох понять Національним агентством із питань запобігання корупції. Агентство робить акцент на таких функціях працівників, які вважаються посадовими особами, як організаційно-розпорядчі, адміністративногосподарські, а Кримінальний кодекс України вказує на те, що особи, які постійно чи тимчасово обіймають на підприємствах посади, пов'язані з виконанням організаційно-розпорядчих чи адміністративно-господарських функцій, є службовими особами. Тоді як положення ч. 3 ст. 34 Закону України «Про аудит фінансової звітності та аудиторську діяльність» не забороняє службовим особам бути членами аудиторського комітету підприємства.

Крім того, не можна безсумнівно керуватися положеннями Роз'яснення Національного агентства 3 питань запобігання корупції «Щодо застосування окремих положень Закону стосовно заходів фінансового контролю», затвердженого рішенням Національного агентства від 11 липня 2016 р. № 3, під час визначення переліку посадових осіб органів управління підприємства, оскільки поняття «посадова особа», надане Національним агентством із запобігання корупції, не може суперечити нормам законодавчих актів, юридична сила яких як основного джерела права, а також їхнє місце в системі нормативних актів, закріплені в Конституції України. Зокрема, відповідно до Листа Міністерства юстиції України «Щодо порядку застосування нормативно-правових актів у разі існування неузгодженості між підзаконними актами» від 30 січня 2009 р. № Н-35267-1,8 вища юридична сила закону полягає у тому, що підзаконні акти приймаються на їхній основі й за своїм змістом не повинні суперечити їм [17].

Висновки. Таким чином, зважаючи на передбачену в ч. 3 ст. 34 Закону України «Про аудит фінансової звітності та аудиторську діяльність» заборону посадовим особам органів управління підприємства бути членами його аудиторського комітету, доцільно на законодавчому рівні узгодити визначення поняття «посадова особа» й «службова особа». Оскільки натепер поняття «посадова особа» міститься в низці нормативних актів та ототожнюється 3 поняттям «службова особа». Тоді як Закон України «Про аудит фінансової звітності та аудиторську діяльність» не забороняє службовим особам бути членами аудиторського комітету підприємства. Безсумнівно, вдосконалення чинного законодавства України у вказаному напрямку дозволить уникнути залучення до складу аудиторського комітету підприємства зацікавлених осіб i, відповідно, підвищити ефективність його діяльності.

\section{ЛITEPATУPA}

1. Міжнародні стандарти аудиту. Міністерство фрінансів України : Державний сайт України. URL: https://mof.gov.ua/uk/mizhnarodnistandar ti-auditu.

2. Каменська Т.О. Внутрішній аудит: виникнення та розвиток. Статистика України. 2015. № 4. С. 60-68.

3. Гуляєва Д.О. Організація внутрішнього аудиту на підприємстві. Управління розвитком. 2011. № 2 (99). С. 34-36.

4. Про аудит фінансової звітності та аудиторську діяльність : Закон України від 21 грудня 2017 р. № 2258-VIII / Верховна Рада України. Відомості Верховної Ради. 2018. № 9. Ст. 50

5. Шмирко М.Ю. Проблеми впровадження та оптимізації системи внутрішнього аудиту підприємства в конкурентному середовищі. Бухгалтерський облік, аналіз та аудит : проблеми теорії, методології, організації. 2015. № 2. С. 173-180.

6. Про державну службу : Закон України від 10 грудня 2015 р. № 889-VIII / Верховна Рада України. Відомості Верховної Ради. 2016. № 4. Ст. 43 .

7. Про службу в органах місцевого самоврядування : Закон України від 07 червня 2001 р. № 2493-ІІІ / Верховна Рада України. Відомості Верховної Ради. 2001. № 33. Ст. 175.

8. Про запобігання корупції : Закон України від 14 жовтня 2014 р. № 1700-VII / Верховна Рада України. Відомості Верховної Ради. 2014. № 49. Ст. 2056.

9. Кодекс адміністративного судочинства України : Закон України від 06 липня 2005 р. № 2747-IV / Верховна Рада України. Відомосmi Верховної Ради. 2005. № 35-36, № 37. Ст. 44.

10. Конституція України : Закон України від 28 червня 1996 р. № 254к/96-ВР / Верховна Рада України. Відомості Верховної Ради. 1996. № 30. Ст. 141

11. Кримінальний кодекс України : Закон України від 05 квітня 2001 р. № 2341-ІІІ / Верховна Рада України. Відомості Верховної Ради. 2001. № 25-26. Ст. 131.

12. Янюк Н.В. «Посадова» і «службова» особи публічної адміністрації: проблеми понятійного апарату в законодавстві України. Науковий вісник Міжнародного гуманітарного університету. Серія «Юриспруденція». 2014. № 10-2. Т. 1. С. 91-93.

13. Курова А.А. Щодо визначення поняття та ознак посадової особи в системі трудового права в Україні. Підприємництво, господарство і право. 2016. № 1. С. 65-69. 
14. Господарський кодекс України : Закон України від 16 січня 2003 р. № 436-IV / Верховна Рада України. Відомості Верховної Ради. 2003. № 18, № 19-20, № 21-22. Ст. 144.

15. Про управління об'єктами державної власності : Закон України від 21 вересня 2006 р. № 185-V / Верховна Рада України. Відомості Верховної Ради. 2016. № 46. Ст. 456.

16. Роз'яснення Національного агентства з питань запобігання корупції «Щодо застосування окремих положень Закону стосовно заходів фінансового контролю» : Рішення Національного агентства від 11 серпня 2016 р. № 3. База даних «Законодавство України». URL: https://www.rada.gov.ua/uploads/documents/47333.pdf.

17. Лист Міністерства юстиції України «Щодо порядку застосування нормативно-правових актів у разі існування неузгодженості між підзаконними актами» від 30 січня 2009 р. № H-35267-18. База даних «Законодавство України». URL: https://zakon.rada.gov.ua/laws/ show/v3526323-09\#Text. 


\title{
РОЗДІЛ 5 \\ ТРУДОВЕ ПРАВО; ПРАВО СОЦАЛЬНОГО ЗАБЕЗПЕЧЕННЯ
}

УДК 349.3

DOI https://doi.org/10.32782/2524-0374/2020-4/22

\author{
ТЕОРЕТИЧНА СУТНІСТЬ ПОНЯТЬ «СОЦАЛЬНИЙ ЗАХИСТ» \\ ТА «СОЦІАЛЬНЕ ЗАБЕЗПЕЧЕННЯ»: ОКРЕМІ ДИСКУСІЙНІ ПИТАННЯ
THEORETICAL ESSENCE OF THE CONCEPTS OF "SOCIAL PROTECTION" AND "SOCIAL SECURITY": INDIVIDUAL DISCUSSION ISSUES

\author{
Боднарчук О.Г., д.ю.н., професор, \\ завідувач кафедри трудового та соціального права \\ Університет державної фіскальної служби Украйни
}

\begin{abstract}
У статті досліджено співвідношення таких понять, як «соціальний захист» та «соціальне забезпечення», розкрито їх зміст.
\end{abstract}
Після закріплення в Конституції України права на соціальний захист виникло чимало наукових дискусій щодо відсутності в законодавстві чіткого розмежування права на соціальний захист і соціальне забезпечення (зокрема, ті самі заходи в одних документах названо соціальним захистом, а в інших - соціальним забезпеченням). Окрім того, оскільки в законодавстві не подано єдиного визначення понять «соціальний захист» та «соціальне забезпечення, то виникають певні складнощі у його розумінні (правозастосуванні). Науковці також застосовують різні підходи до розкриття сутності цих понять, а тому вибрана тема дослідження набуває особливої актуальності.

Автором проаналізовано чинне законодавство та норми міжнародних актів, що визначають основні гарантії прав людини і громадянина на соціальний захист (соціальне забезпечення). Визначено, що терміни «соціальний захист» та «соціальне забезпечення» $є$ загальновживаними. Виявлено, що у міжнародній правотворчій практиці здебільшого ці категорії використовують як синоніми. Автор статті погоджується з тими вченими, які обґрунтовують думку про самостійність понять «соціальний захист» та «соціальне забезпечення» і вважають перше з них ширшим за змістом, а друге - складовим елементом першого. Водночас наголошено на тому, що в чинному законодавстві має бути проведено уніфікацію понятійного апарату, зокрема запропоновано розробити фрормулювання єдиних термінів для однотипних суспільних явищ та законодавчо їх закріпити.

Автор доводить, що поняття «соціальний захист» змінило поняття «соціальне забезпечення», яке використовували в радянській економіці. Термін «соціальне забезпечення» $є$ більш вузьким порівняно з поняттям «соціальний захист», тому можна стверджувати, що термін «соціальне забезпечення» є складником поняття «соціальний захист».

Ключові слова: соціальний захист, забезпечення, соціальне забезпечення, захист, держава, державна політика, соціальна політика.

The article examines the relationship between such concepts as "social protection" and "social security", reveals their content.

After the enshrinement of the right to social protection in the Constitution of Ukraine, there were many scientific discussions about the lack of clear delineation in the legislation of the right to social protection and social security (in particular, the same measures are called social protection in some documents and social security in others). In addition, since the legislation does not provide a single definition of "social protection" and "social security", there are some difficulties in understanding it (law enforcement). Scientists also use different approaches to reveal the essence of these concepts, and therefore the chosen research topic becomes especially relevant.

The author analyzes the current legislation and norms of international acts that define the basic guarantees of human and civil rights to social protection (social security). It is determined that the terms "social protection" and "social security" are commonly used. It was found that in international law-making practice in most cases these categories are used as synonyms. The author of the article agrees with those scholars who substantiate the idea of the independence of the concepts of "social protection" and "social security" and consider the first of them broader in content, and the second - a component of the first. At the same time, it was emphasized that in the current legislation the unification of the conceptual apparatus should be carried out, in particular, it was proposed to develop the formulation of uniform terms for similar social phenomena and to enshrine them in law.

The author argues that the concept of "social protection" changed the concept of "social security", which was used in the Soviet economy. The term "social security" is narrower than the term "social protection". Therefore, it can be argued that the term "social security" is part of the concept of "social protection".

Key words: social protection, provision, social security, protection, state, state policy, social policy.

Першочергове завдання держави - формування нової національної системи соціального захисту населення щодо створення умов для достатнього життєвого рівня людини. У законодавстві Україні нині приділяється значна увага соціальному забезпеченню. Проте в сучасній науковій літературі недостатньо повно розкрито зміст соціального забезпечення, а поняття «соціальний захист» як правова категорія не визначено, у цьому напрямі зроблено лише перші кроки [1, с. 91].

Система соціального забезпечення та соціальної підтримки, створена в СРСР, значною мірою була успадкована сучасною Україною, становлення якої ознаменувало останній етап формування та розвитку державної системи соціального забезпечення [2, с. 22].

Сьогодні державну політику у сфері соціального забезпечення та соціального захисту визначають близько 30 законодавчих актів, серед яких провідне місце нале- жить законам України, указам Президента та постановам Кабінету Міністрів України, але донині в нашій країні не створено єдиного законодавчого акта, який би регулював усі аспекти у цій сфері.

За стандартами Ради Свропи та Європейського Союзу соціальне забезпечення віднесено до системи, яка включає, крім соціального забезпечення (через соціальне страхування), також інші форми соціального захисту: державну соціальну допомогу, а також спеціальний і особливий (додатковий) соціальних захист для окремих категорій населення. Таке розуміння має велике значення для національного законодавства, оскільки в Україні немає загального закону про соціальний захист населення $[3$, c. $569 ; 4$, c. $2-3]$

Отже, різне застосування термінів «соціальний захист» та «соціальне забезпечення» у міжнародно-правових актах, Основному Законі України та законодавчих актах, 
а також використання різноманітних підходів науковців до трактування сутності цих понять потребують подальшого наукового аналізу зазначеної проблеми.

Метою дослідження є розкриття сутності, юридичної природи та співвідношення понять «соціальний захист» та «соціальне забезпечення».

Виклад основного матеріалу. Наявність різних думок та позицій i, як наслідок, відсутність єдності у розумінні трактування зазначених вище понять, без сумніву, ускладнюють правозастосування, тому потребують детального дослідження для переосмислення, і в подальшому - надання власного визначення дефініціям. С.М. Синчук зазначає, проблема полягає у відсутності законодавчих дефініцій і певній невпорядкованості законодавчого використання термінів «соціальний захист» i «соціальне забезпечення» [5, с. 92]

У національному законодавстві вживають два терміни - «соціальне забезпечення» та «соціальний захист» (зокрема, Закон України «Про статус і соціальний захист громадян, які постраждали внаслідок Чорнобильської катастрофи» від 28.02.1991 № 796-XII, Закон України «Про соціальний захист дітей війни» від 18.11.2004 № 2195IV, Закон України «Про ратифікацію Угоди між Україною та Португальською Республікою про соціальне забезпечення» 21.12.2011 № 4209-VI, Наказ Міністерства оборони України «Про затвердження Інструкції з організації роботи із соціального забезпечення осіб, звільнених з військової служби, та членів їх сімей у Міністерстві оборони України» від 15.02.2010 № 61 тощо).

Зауважимо, що терміни «соціальне забезпечення» та «соціальний захист» $є$ загальновживаними в міжнародній правотворчій практиці. Так, міжнародні документи, прийняті у різні періоди, містили категорії «соціальне забезпечення» та «соціальний захист». У процесі дослідження було виявлено, що здебільшого ці категорії використовували як синоніми. Наприклад, «Соціальне забезпечення в цілях соціальної справедливості та справедливої глобалізації: періодичне обговорення проблем соціального захисту (соціального забезпечення) згідно з Декларацією МОП про соціальну справедливість у цілях справедливої глобалізації», Доповідь VI, Міжнародна конференція праці, 100-та сесія, Женева, 2011 р.; Резолюція та Висновки щодо періодично обговорюваних проблем соціального захисту (соціального забезпечення). Міжнародна конференція праці, 100-та сесія, Женева, 2011 р., у Попередньому протоколі (Женева, 2011 р.), № 24: Доповідь комітету з періодично обговорюваних проблем соціального захисту.

Термін «соціальне забезпечення» почали вживати у міжнародних документах, прийнятих у другій половині XX ст., зокрема у Загальній декларації прав людини, Міжнародному пакті про економічні, соціальні та культурні права тощо. Цей термін застосовано і в українському законодавстві (Концепції соціального забезпечення населення України та інших документах). Проте у ст. 46 Конституції України вжито термін «соціальний захист».

Р.П. Підлипна вважає, що поширення терміна «соціальний захист» пов'язане з прийняттям Закону про соціальний захист (Social Security Act) 1935 р. у США. У буквальному перекладі термін security має кілька значень, основні $з$ яких: безпека, охорона, захист, забезпечення, гарантування. У перекладі з англійської мови слово social означає «суспільний», «соціальний» [8, с. 17].

Водночас у національному законодавстві не розрізняють терміни «соціальний захист» та «соціальне забезпечення», ті самі заходи в одних документах визначено як соціальний захист, а в інших - соціальне забезпечення Якщо розглянути семантику слів, які входять до складу зазначених конструкцій, то ці терміни не можна вважати тотожними. На думку О.Ю. Кісіль, доцільно погодитися 3 позицією закордонних учених, згідно з якою під час використання слова «захист» повинно йтися про оберігання певного права, у нашому разі - права на соціальне забезпечення [6, с. 179].

М. Чорна стверджує, що «поняття соціального захисту, що почало активно використовуватися в роки незалежності України і було закріплене в Основному Законі нашої держави, порівняно із широко вживаним до 1991 року поняттям соціального забезпечення має таке специфічне навантаження, як захист від негараздів трансформаційного періоду, ризиків переходу від соціалістичної економіки до ринкової» [7, с. 153].

У ч. 1 ст. 46 Конституції України зазначено, що «громадяни мають право на соціальний захист, що включає право на забезпечення їх у разі повної, часткової або тимчасової втрати працездатності, втрати годувальника, безробіття з незалежних від них обставин, а також у старості та в інших випадках, передбачених законом» [9], тобто соціальний захист не обмежено забезпеченням у разі настання ризику [10, с. 10].

Виходячи зі змісту ст. 46 Конституції України [9], соціальний захист включає в себе і термін «соціальне забезпечення», тобто соціальний захист - це поняття ширше, що містить у собі елементи, які не входять до складу соціального забезпечення У зв'язку із цим завдання правової науки полягає у тому, щоб дати визначення та обгрунтувати це поняття [1, с. 91].

Зауважимо, що після закріплення в Конституції України права на соціальний захист виникло чимало наукових дискусій щодо відсутності в законодавстві чіткого розмежування права на соціальний захист і права на соціальне забезпечення.

Так, Ю. Кириченко вважає, що «закріплення в конституційній нормі терміна «соціальний захист» не можна вважати вдалим для позначення правової категорії, оскільки він позбавлений конкретного змісту». На думку вченого, словосполучення «соціальний захист», що включає право на забезпечення», потрібно вилучити 3 тексту ч. 1 ст. 46 Конституції України. Він пропонує включити термін «соціальне забезпечення», якого буде достатньо для охоплення всіх його форм і видів і яке, за словами П.М. Рабіновича та О.З. Панкевича, «є більш удалим, аніж «соціальний захист» ... та більш привабливим». На доцільність застосування терміна «соціальне забезпечення» вказує і Н.Б. Болотіна [11, с. 52].

На думку Ю. Кириченко, ст. 46 Конституції України потрібно викласти в новій редакції: «Кожен має право на соціальне забезпечення після досягнення пенсійного віку, у разі втрати працездатності, втрати годувальника, безробіття через незалежні від нього обставини та в інших випадках, передбачених законом» [11, с. 54].

Проте С.О. Устинов зазначає, що «без сумніву, Конституція України є Основним Законом, на якому грунтується національне законодавство, складником якого є законодавство із соціального забезпечення». Ураховуючи дефініцію, закріплену в ч. 1 ст. 46 Конституції України стосовного того, що «громадяни мають право на соціальний захист...», учений уважає, що термін «соціальне забезпечення» $є$ складником поняття «соціальний захист», і тому не буде помилкою для законодавчого визначення зазначених вище понять використовувати ці терміни як синоніми [12, с. 94].

Ми підтримуємо думку М. Чорної, що в чинному законодавстві має бути проведено уніфікацію понятійного апарату, а саме дано визначення єдиних термінів для однотипних суспільних явищ та законодавчо їх закріплено [7, с. 152].

Потрібно зазначити, що серед науковців немає єдиної думки щодо змісту поняття «соціальне забезпечення» як правової категорії та його співвідношення з поняттям «соціальний захист».

Найбільш чисельною $є$ група науковців, які обгрунтовують самостійність понять «соціальний захист» та «соці- 
альне забезпечення» і вважають перше з них ширшим за змістом, а друге - складовим елементом першого.

Соціальне забезпечення (соціальний захист) - система суспільно-економічних заходів, спрямованих на матеріальне забезпечення населення від соціальних ризиків (хвороба, інвалідність, старість, утрата годувальника, безробіття, нещасний випадок на виробництві та ін.). Як соціально-економічна категорія соціальне забезпечення $\epsilon$ відносинами щодо перерозподілу національного доходу 3 метою забезпечення встановлених соціальних стандартів життя для кожної людини в умовах дії соціальних ризиків [2, с. 8$]$

А.О. Медвідь уважає, що у поняття соціального захисту та соціального забезпечення науковці вкладають різний зміст виходячи з індивідуального тлумачення даних ними термінів, ступеня узагальнення тощо: деякі їх ототожнюють, інші розмежовують, але різниця також $\epsilon$ досить умовною та не досить зрозумілою. Проте, на його думку, «дослідження позицій учених-правників у цій сфері дає змогу стверджувати, що соціальний захист - це комплекс організаційних, юридичних, економічних і фінансових заходів, спрямованих на подолання несприятливих наслідків соціальних ризиків за рахунок не заборонених законом джерел фінансування» [13, с. 94]. Доцільно також ураховувати, що «соціальне забезпечення та соціальний захист не є тотожними поняттями та співвідносяться як частина і ціле, соціальне забезпечення являє собою організаційно-правову діяльність держави, яка виражається лише у матеріальній допомозі та соціальному обслуговуванні осіб, які зіштовхнулися з життєвими обставинами, що визначаються суспільно значимими на даному етапі розвитку держави, за рахунок державних та місцевих бюджетів та інших не заборонених законом джерел фінансування» [13, с. 94].

В.В. Криворучко категорію «соціальне забезпечення» визначає як систему державних та недержавних заходів, спрямованих на забезпечення матеріальними засобами та соціальними послугами населення у разі настання соціальних ризиків (хвороба, інвалідність, старість, утрата годувальника, безробіття, вагітність та пологи тощо) $[14$, с. 220$]$.

На думку О.В. Тищенко, соціальне забезпечення - це діяльність державних та недержавних суспільних органів із надання систематичної допомоги та підтримки тим категоріям населення, які опинилися в складних життєвих обставинах на рівні не менше встановленого державою прожиткового мінімуму [15, с. 148-149].

С.О. Устинов уважає, що соціальне забезпечення - це організаційно-правова діяльність держави, спрямована на матеріальне забезпечення громадян у разі настання обумовлених законодавством соціальних ризиків за рахунок фондів соціального страхування та виплат із державного та місцевих бюджетів та інших обумовлених законодавством коштів [12, с. 93-94].

О.Ю. Кісіль під соціальним забезпеченням пропонує розуміти «комплекс заходів, спрямованих на забезпечення гідного рівня життя особи, з огляду на виникнення соціально значущих обставин (старість, хвороба, інвалідність тощо) або характер чи умови праці» [6, с. 179].

А.В. Дутчак соціальне забезпечення визначає як систему державних і суспільних заходів із матеріального забезпечення громадян на випадок старості, інвалідності, хвороби, у разі втрати годувальника та в інших установлених законодавством випадках [3, с. 569].

М. М. Клемпарський уважає, що пропозиції науковців із цього питання можна об'єднати в три групи. Перша до соціального забезпечення належать заходи, пов'язан тільки із соціальним страхуванням найманих працівників. Друга - лише ті заходи, які пов'язані з забезпеченням матері і дитини, громадян у старості і в разі непрацездатності. Третя включає в обсяг поняття соціального забез- печення всю сукупність соціально-економічних заходів щодо надання благ із суспільних фондів споживання, які створює держава за рахунок суспільства та спрямовані на відшкодування громадянам втраченого заробітку у разі настання непрацездатності поза прямим зв'язком із результатами їхньої праці [1, с. 91].

Тлумачення поняття «соціальний захист» є досить дискусійним і неоднозначним донині. Так, Р.П. Підлипна систему соціального захисту (social safetynets) пропонує розуміти як сукупність неприбуткових програм, які грунтуються на принципах соціального партнерства держави, роботодавців і найманих працівників і їх об'єднань, із метою запобігання та подолання бідності, а також допомоги особам, які опинилися на межі бідності чи потребують допомоги з огляду на певні обставини та реалізуються як на державному рівні, так і приватному завдяки благодійним організаціям і неформальній допомозі приватних осіб [8, с. 18]

I.O. Горбань стверджує, що як на законодавчому рівні, так і на науковому рівні наявна певна невизначеність поняття «соціальний захист» та різні наукові підходи до використання цього терміна. Серед науковців немає єдиної думки та єдиного підходу до тлумачення поняття «соціальний захист». Термін «соціальне забезпечення» є більш вузьким порівняно 3 поняттям «соціальний захист». Його можна визначити як діяльність держави щодо безпосереднього матеріального забезпечення громадян у разі настання так званих «соціальних ризиків», передбачених законодавством, за рахунок грошових фондів держави, створених для таких ризиків. Водночас соціальний захист - це діяльність, точніше - політика держави, спрямована на створення таких соціально-економічних умов, які б унеможливлювали настання соціальних ризиків для суспільства. Тому I.О. Горбань уважає, що термін «соціальне забезпечення» $є$ складником поняття «соціальний захист» $[16$, с. 44$]$.

С.О. Устинов зазначає, що соціальний захист - це діяльність соціально орієнтованої держави, яка здійснюється через комплекс організаційно-правових та соціально-економічних заходів, метою яких є: по-перше, створення для працездатних громадян належних умов для забезпечення своїх соціально-економічних та духовних потреб; по-друге, гарантоване забезпечення громадянам, які потребують соціальної допомоги, рівня життя не нижче від прожиткового мінімуму [12, с. 94].

M.I. Тимофєєва пропонує таке визначення: «Соціальний захист - це комплекс організаційно-правових та економічних заходів, спрямованих на захист добробуту, гарантованого Конституцією України, кожного члена суспільства в конкретних економічних умовах, що грунтуються на соціальній справедливості й рівності прав» $[17$, с. 172$]$.

А. Гончаров визначає соціальний захист як правову категорію, яка охоплює сукупність правових норм, що регулюють суспільні відносини, спрямовані на запобігання ситуаціям соціального ризику в нормальному житті особи та підтримання оптимальних умов життя [18, с. 129].

М. Чорна вважає, що соціальний захист - це система економічних, соціальних, правових, організаційних заходів, що забезпечує працездатній людині і громадянину відповідні умови для поліпшення свого добробуту за рахунок особистого трудового внеску, а непрацездатним та соціально вразливим верствам працездатного населення - гарантії у користуванні суспільними фондами споживання, матеріальну підтримку, зниження податків [7, с. 156]

Висновки. Отже, ураховуючи зазначене вище, можна стверджувати, що «соціальний захист науковці здебільшого розглядають як функцію держави і пов'язують із соціальною політикою держави; більшість учених розрізняє поняття «соціальний захист» і «соціальне забез- 
печення» та визначає соціальне забезпечення як складник соціального захисту; соціальний захист розглядають у двох значеннях: у широкому - як систему організаційно-правових та економічних заходів щодо забезпечення соціальних прав людини і громадянина в державі, у вузькому - як систему спеціальних заходів щодо захисту окремих категорій працівників і населення з огляду на особливості їх професійного та соціального статусу» [18, с. 129].

\section{ЛITEPATУРA}

1. Клемпарський М.М. Співвідношення термінів «соціальний захист» та «соціальне забезпечення» в законодавстві України. Право $i$ безпека. 2003. № 3. Т. 2. С. 90-92.

2. Утвенко В.В. Система соціального забезпечення та соціальної підтримки : навчальний посібник. Київ : Персонал, 2018. 248 с.

3. Дутчак А.В. Соціальне забезпечення громадян: сучасний стан та перспективи розвитку. Молодий вчений. 2017. № 5 (45). С. $568-572$.

4. Клименко А.Л. Соціальний захист і соціальне забезпечення в умовах євроінтеграції України: окремі аспекти. Теорія і практика правознавства. 2017. Вип. 2(12). С. 1-10.

5. Раневич О. Про використання термінів «соціальний захист» і «соціальне забезпечення» в нормативно-правових актах України. Підприємництво, господарство і право. 2017. № 9. С. 88-92.

6. Кісіль О.Ю. Загальні підходи до розуміння категорії «соціальне забезпечення» Право і безпека. 2011. № 5. С. 176-180.

7. Чорна М. Сутність права громадян на соціальний захист. Підприємництво, господарство і право. 2019. № 4. С. 151-156.

8. Підлипна Р.П. Система соціального захисту населення в Україні в сучасних умовах: сутність і основні складники. Науковий вісник Полтавського університету економіки і торгівлі. 2015. № 1(1). С. 16-22.

9. Конституція України від 28.06.1996 № 254к/96. Відомості Верховної Ради України. 1996. № 30. Ст. 141.

10. Баранник Л.Б. Соціальний захист громадян : навчальний посібник ; вид. 2-е, доп. і перероб. Дніпро : Університет митної справи та фінансів, 2017. 246 с.

11. Кириченко Ю. Право людини на соціальне забезпечення в конституційних нормах України та зарубіжних держав: порівняльноправовий аналіз. Научно-практическое правовое издание Республики Молдова «Национальный юридический журнал : теория и практика». 2014. № 6(10). С. 51-55.

12. Устинов С.О. Співвідношення термінів «соціальний захист» та «соціальне забезпечення» в законодавстві України. Юридична наука і практика. 2011. № 2. С. 90-95.

13. Медвідь А.О. Поняття права на соціальне забезпечення. Науковий вісник Міжнародного гуманітарного університету. 2016. № 21. С. 92-94.

14. Криворучко В.В. Соціальне забезпечення: теоретичні проблеми. Вісник ХНУВС. 2013. № 4(63). С. 215-222.

15. Тищенко О.В. Сутність соціального забезпечення: доктринальні погляди. Порівняльно-аналітичне право. 2013. № 4. С. 145-149.

16. Горбань І.О. Визначення сутності та співвідношення понять «соціальний захист» та «соціальне забезпечення». Наукові праці Чорноморського державного університету імені Петра Могили комплексу «Києво-Могилянська академія». 2014. Т. 239. Вип. 237. С. $42-46$.

17. Тимофєєва М.І. Сутність соціального захисту населення. Вісник Східноукраїнського національного університету ім. Володимира Даля. 2016. № 6(230). С. 169-174.

18. Гончаров А. Поняття соціального захисту. Підприємництво, господарство і право. 2009. № 10. С. 126-129. 


\title{
ЦИВІЛІСТИЧНИЙ ХАРАКТЕР ЗМІН У КОДЕКСІ ЗАКОНІВ ПРО ПРАЦЮ УКРАЇНИ, ПОВ'ЯЗАНИХ ІЗ ВПРОВАДЖЕННЯМ ПРАВОВОГО РЕГУЛЮВАННЯ ДИСТАНЦЙНОЇ РОБОТИ
}

\author{
THE CIVIL NATURE OF CHANGES IN THE LABOR CODE OF UKRAINE \\ RELATED TO THE INTRODUCTION OF LEGAL REGULATION OF TELEWORK
}

\author{
Новіков Д.О., к.ю.н., \\ доцент кафедри цивільно-правових дисциплін і трудового права \\ імені професора О.І. Процевського \\ Харківський національний педагогічний університет імені Г.С. Сковороди
}

Лук'янчиков О.М., к.ю.н., доцент кафедри цивільно-правових дисциплін і трудового права імені професора О.І. Процевського

Харківський національний педагогічний університет імені Г.С. Сковороди

\begin{abstract}
Авторами вказується, що пандемія коронавірусу (COVID-19) позначила не тільки системні проблеми трудової сфери в Україні, пов'язані з масовим вивільненням працівників на період запровадженого урядом карантину й недотриманням мінімальних соціальнотрудових стандартів, але й потребу негайного реформування трудового законодавства, пристосування його до викликів сучасності. Адже виконання трудової функції багатьма працівниками почало провадитись із застосуванням інфоормаційних технологій поза їхнім робочим місцем. Автори вважають, що зміни, внесені в Кодекс законів про працю України Законом № 540-ІХ, пов'язані з впровадженням правового регулювання дистанційної роботи, підтверджують тенденцію, почату урядовим законопроєктом «Про працю»: трудове право як соціальна й гуманна галузь права піддається небувалому тиску з боку ідеологів «вільного ринку». Авторами підкреслюється, що дистанційна робота була визнана законодавцем формою організації праці, а не окремим видом діяльності з власним характером праці, чим порушується принцип єдності й диференціації правового регулювання трудових відносин. Відповідно, законодавцем не були закріплені правила щодо специфріки укладення трудового договору з дистанційним працівником (окрім обов'язкової письмової форми), умов та охорони праці й тому подібне, чим, по суті, було звужено обсяг мінімальних трудових стандартів для цієї категорії працівників. Автори зауважують, що Закон № 540-ІХ закріпив у Кодексі законів про працю антисоціальні положення щодо вилучення з поняття трудового договору вказівки про правила внутрішнього трудового розпорядку (разом із тим дистанційний працівник ним взагалі не підпорядковується), надав антиконституційну можливість роботодавцю змінювати істотні умови праці без згоди дистанційного працівника. На переконання авторів, це $є$ серйозним ударом як по колективних, так і по індивідуальних правах та інтересах робітників. Автори вважають, що підхід, обраний законодавцем для регулювання дистанційної роботи, за своїм характером переважно цивілістичний, а в певних деталях встановлює організаційний і дисциплінарний диктат роботодавця.
\end{abstract}

Ключові слова: дистанційна робота, єдність і диференціація, трудовий розпорядок, коронавірус, прекаріат.

The authors point out that the coronavirus pandemic (COVID-19) marked not only the systemic problems of the labor sphere in Ukraine related to the mass dismissal of employees for the period of government quarantine and non-compliance with minimum social and labor standards, but also the need to immediately reform labor legislation, its adapting to the challenges of modernity. After all, the performance of the job function by many employees began to be carried out with the use of information technology outside their workplace. The authors believe that the amendments to the Labor Code of Ukraine by Law № 540-IX, related to the introduction of legal regulation of telework, confirms the trend initiated by the government draft "On Labor": labor law as a social and humane branch of law is unprecedented pressure from the ideologues of the "free market". The authors emphasize that telework was recognized by the legislator as a form of labor organization, rather than a separate activity with its own nature of work, which violates the principle of unity and differentiation of legal regulation of labor relations. Accordingly, the legislator didn't establish rules regarding the specifics of concluding an employment contract with a teleworker (except for the mandatory written form), conditions and labor protection, etc., which, in fact, narrowed the minimum labor standards for this category of employees. The authors note that Law № 540-IX enshrined in the Labor Code antisocial provisions to remove from the concept of employment contract instructions on the rules of internal labor regulations (however, the teleworkers are not subject to it at all), gave the employer an unconstitutional opportunity to change significant working conditions without the consent of the remote. According to the authors, this is a serious blow to both collective and individual rights and interests of employees. The authors believe that the approach chosen by the legislator to regulate telecommuting is predominantly civil, and in certain details establishes the organizational and disciplinary dictates of the employer.

Key words: telework, unity and differentiation, work schedule, coronavirus, precariat.

Постановка проблеми. Пандемія коронавірусу (COVID-19) позначила не тільки системні проблеми трудової сфери в Україні, пов'язані з масовим вивільненням працівників на період запровадженого урядом карантину й недотриманням мінімальних соціально-трудових стандартів, але й потребу негайного реформування трудового законодавства, пристосування його до викликів сучасності. Адже ситуація, сполучена 3 додержанням санітарно-епідеміологічних заходів для попередження розповсюдження коронавірусу, унеможливила здійснення трудової діяльності у звичайних умовах значної кількості працівників сфери освіти й науки, сфери фінансових послуг, допоміжних до промислового виробництва структурних підрозділів і таке подічбне. Переважно виконання трудової функції цими працівниками почало провадитись із застосуванням інформаційних технологій поза їхнім робочим місцем. Тому вже не поодиноке й супутнє, а масове й суцільне виконання роботи 3 виростанням інформаційних технологій стало чинником «турбо-правотворчості» законодавця, результатом якої стало прийняття Закону України «Про внесення змін до деяких законодавчих актів України, спрямованих на забезпечення додаткових соціальних та економічних гарантій у зв'язку з поширенням коронавірусної хвороби (COVID-19)» № 540-IX від 30 березня 2020 року (далі - Закон № 540-IX) [1], котрим до Кодексу Законів про працю України (далі КЗпП) були внесені зміни щодо правового регулювання дистанційної роботи. I на перший погляд, прогресивні норми, включені до КЗПП Законом № 540-IX, відкрили «скриньку Пандори» для подальшого розповсюдження на сферу правового регулювання трудових відносин цивілістичних, а подекуди й рабовласницьких засад.

Формулювання мети статті. Автори мають на меті проаналізувати характер змін у Кодексі Законів про працю 
України, пов'язаних із впровадженням правового регулювання дистанційної роботи.

Виклад основного матеріалу статті. Як застерігав І.Я. Кисельов, «економіка високих технологій вимагає зовсім іншого права, ніж економіка димлячих труб», однак не варто сприймати абсолютно переконання вченого, що «трудове право адаптується до вимог нової епохи, до умов, які складаються на національних і міжнародних ринках під впливом технічного прогресу й глобалізації господарського життя, які все більш посилюється» [2, с. 52]. Адже «одночасно 3 нібито цілком позитивними наслідками глобальної трансформації трудових відносин у сферах, де використовуються нові інформаційні засоби виробництва, виникають цілком реальні несприятливі наслідки, пов'язані з перерозподілом капіталу в суспільстві й зменшенням соціального захисту робітників» [3, с. 102]. Наведені позиції вчених цілком відбились у змісті Закону № 540-IX, «за допомогою» якого під покровом урегулювання праці дистанційних працівників відбулось реальне зменшення обсягу прав трудящих (проблематика зауваження трудових прав розглядались нами в цілому комплексі публікацій $[4 ; 5 ; 6 ; 7])$.

Так, правове регулювання дистанційної роботи було зображене не в спеціальному розділі, а в главі IV КЗпП під назвою «Робочий час» у ст. 60 КЗПП, яка стосується гнучкого режиму робочого часу. У цій статті «дистанційна (надомна) робота» визначена як «форма організації праці, коли робота виконується працівником за місцем його проживання чи в іншому місці за його вибором, у тому числі за допомогою інформаційно-комунікаційних технологій, але поза приміщенням роботодавця». Визначення дистанційної роботи як «форми організації праці» вже $\epsilon$ нонсенсом, адже, як зазначається в словникових джерелах, термін «робота» означає «процес, дія, функціонування» [8, с. 1229]. Себто дистанційна робота не може визнаватись особливою формою організації праці в межах гнучкого режиму робочого часу. Вона є самостійним комплексом взаємопов'язаної трудової діяльності, що об'єднує працівників зі специфічним характером праці. У цьому аспекті законодавцем явно порушується принцип єдності й диференціації правового регулювання трудових відносин. Як вказував О.I. Процевський, «єдність і диференціація правового регулювання є одним із способів досягнення мети рівності усіх працівників у правах, свободах та обов'язках незалежно від місця застосування здатності до праці» $[9$, с. 40]. Виключаючи цілу категорію працівників зі сфери дії означеного принципу, хоч й із зазначенням того, що «виконання дистанційної (надомної) роботи не тягне за собою будь-яких обмежень обсягу трудових прав працівників» (ст. 60 КЗПП), законодавець вже обмежує обсяг трудових прав дистанційних працівників, не враховуючи специфіку характеру їхньої праці.

Як вказують Вітторіо Ді Мартіно й Лінда Вірт, «феномен дистанційної роботи базується на трьох основних ознаках: розташуванні, технологіях та організації» $[10$, c. 530$]$. Видається, що саме ці три ознаки (розташування, технологія та організація) характеру дистанційної роботи можуть бути визначені критеріями диференціації правового регулювання трудових відносин дистанційних працівників.

Проілюструвати зміст перших двох ознак можна на прикладі встановлення відмінностей між дистанційною роботою та надомною працею, які були ототожнені законодавцем у ст. 60 КЗПП. Згідно з Положенням про умови праці надомників, затвердженого Держкомпраці СРСР i Секретаріату ВЦРПС 29 жовтня 1981 р., надомні працівники - це «особи, які уклали трудовий договір 3 організацією про виконання роботи вдома особистою працею 3 матеріалів і з використанням знарядь і засобів праці, які виділяє підприємство, або які купуються коштом цього підприємства» [11]. Водночас за ознакою розташування, виділеною Вітторіо Ді Мартіно й Ліндою Вірт, виконання дистанційної роботи передбачає:

«1) електронну роботу вдома;

2) роботу через супутникові центри;

3) роботу в сусідніх центрах, які забезпечені електронними засобами;

4) мобільну роботу» $[10$, с. 533$]$.

Себто дистанційна робота може здійснюватись у працівника вдома, в приміщеннях, які не належать до приміщень роботодавця, а також в інших місцях (транспорті, парку, залізничній станції тощо), де можливе виконання роботи 3 використанням інформаційних технологій. Останнє стосується другої ознаки дистанційної роботи обов'язкового використання інформаційних технологій, включаючи персональні комп'ютери, смартфони, соціальні мережі, додатки Web 3.0 і хмарні обчислення тощо.

Необхідно вказати, що як перша, так і друга ознака дистанційної роботи жодним чином не були враховані в Законі № 540-ІХ. Ст. 60 КЗПП не містить ані положень щодо умов та охорони праці дистанційних працівників, окрім зазначення того, що «загальна тривалість робочого часу не може перевищувати норм, передбачених ст. ст. 50 і 51 КЗПП» (за відсутності нормативного закріплення правил обліку робочого часу дистанційних працівників ця норма має «фасадний» характер), ані положень про порядок використання та розподіл видатків сторін трудового договору на інформаційні технології (комп'ютерне обладнання, програмне забезпечення та тому подібне) й супутні витрати (електроенергія, Інтернет, приміщення тощо). Видається, що загальні засади правового регулювання в таких випадках на кшталт обов'язку роботодавця «забезпечити працівника необхідними для роботи засобами» (ст. 29 КЗПП) мають доповнюватись спеціальними нормами для дистанційних працівників.

Третя ознака дистанційної роботи - організаційна. Ця ознака передбачає наявність правового забезпечення взаємодії працівника й роботодавця в межах виконання дистанційної роботи. У такому аспекті Закон № 540-IX привніс у трудове законодавство України одну з найодіозніших трансформацій, виключивши 3 поняття трудового договору в ст. 21 КЗПП обов'язок працівника підпорядкуватись правилам внутрішнього трудового розпорядку. Як вказує О.О. Коваленко, ця трансформація «нівелює прописні істини трудового права, щодо значення правил внутрішнього трудового розпорядку для регламентації трудових відносин, а значить ставить під удар ефективну організацію трудового процесу 3 урахуванням дотримання прав та інтересів обох сторін трудових правовідносин» $[12$, с. 100]. Я.В. Сімутіна додає, що «в такий спосіб, загубивши у визначенні трудового договору положення щодо підлягання працівника правилам внутрішнього трудового розпорядку, що $є$ однією з важливих складових частин організаційного елементу трудових правовідносин і передбачає виконання роботи під контролем і вказівкою роботодавця, і водночас нічого іншого не запропонувавши, законодавець тим самим небезпечно зблизив правове регулювання виконання роботи за трудовим договором і за цивільно-правовим договором підряду чи надання послуг» [13, с. 137]. У цьому сенсі набуває актуальності проблема правових симуляцій і симулякрів, яка вже підіймалась нами $[14 ; 15]$ і яка набуває подальшого поширення: ми іменуємо відносини трудовими, але наповнюємо їх цивільно-правовим змістом.

Причому, зробивши означену «нормативну кастрацію» дефініції «трудовий договір», законодавець залишив згадування про правила внутрішнього трудового розпорядку в умовах застосування дистанційної роботи: «Під час дистанційної (надомної) роботі працівники розподіляють робочий час на свій розсуд, на них не поширюються правила внутрішнього трудового розпорядку, якщо інше не передбачено в трудовому договорі» (ст. 60 КЗПП). Як 
пише О.О. Коваленко, «дистанційний формат виконання роботи працівників за трудовим договором жодним чином не передбачає вилучення працівника 3 підпорядкування правилам внутрішнього трудового розпорядку <...> Але працівник все одне має виконувати роботу, зумовлену трудовим договором, виконуючи свої трудові обов'язки, звітувати й надавати якісний результат роботи, а отже, за результатами роботи, в тому числі, представлятися до заохочень або підпадати під заходи дисциплінарного впливу. Тому виконання роботи за трудовим договором дистанційно жодним чином «не випадає» 3 правил внутрішнього трудового розпорядку» $[12$, с. 100]. Як бачимо, викресливши 3 поняття трудового договору правила внутрішнього трудового розпорядку, законодавець через зміни у чинному КЗпП зробив те, чого не вдалось досягнути шляхом прийняття антисоціального законопроєкту «Про працю» (№ 2708) [16] (з якого, до речі, дослівно й перекочували в Закон № 540-IX положення про дистанційну роботу), а саме переніс увесь тягар правозастосування в трудових відносинах на трудовий договір, не обтяжений будь-якими обмеженнями на кшталт правил внутрішнього трудового розпорядку, які «затверджуються трудовими колективами за поданням роботодавця та виборним органом первинної профспілкової організації» (ст. 142 КЗпП). Хоча саме правила внутрішнього трудового розпорядку були тим врівноважувальним фактором, який посилював суб'єктність сторони працівників і не давав остаточно перетворити трудовий договір у цивільно-правовий. Натомість чинна редакція ст. 21 КЗПП схиляє шальки терезів виключно на бік роботодавця, для якого трудовий договір без остраху впливу трудового колективу або професійної спілки нічим не відрізняється від цивільно-правового договору послуг чи підряду.

Водночас правове становище дистанційних працівників може бути ще гіршим, якщо враховувати положення ч. 2 ст. 60 КЗПП, згідно з яким «на час загрози поширення епідемії, пандемії та/або на час загрози військового, техногенного, природного чи іншого характеру умова про дистанційну (надомну) роботу й гнучкий режим робочого часу може встановлюватися в наказі (розпорядженні) власника або уповноваженого ним органу без обов'язкового укладення в письмовій формі трудового договору про дистанційну (надомну) роботу». У наведеній нормі працівник позбавляється будь-якого вольового впливу на наявні договірні відносини, що суперечить принципу свободи договору, який є провідним як в трудовому, так і в цивільному праві. Повноваження роботодавця стають практично необмеженими; він у випадку загрози (якою б нереальною вона не була), а не під час безпосередньо пандемії, епідемії, воєнного чи надзвичайного стану, правовий режим яких встановлюється відповідними компетентними державними органами, вправі власним рішенням змінювати умови праці працівника. Цим роботодавець легко обхо- дить положення ч. 3 ст. 43 Конституції України про заборону примусової праці й правила зміни істотних умов праці, котрі передбачають обов'язкову згоду працівника (ч. 3 ст. 32 КЗПП). Законодавець також не роз'яснює, що належить до «загроз іншого характеру», що цілком вільно може тлумачитись роботодавцем у ситуаціях наявності загрози його економічних інтересам. Очевидно, що норма ч. 2 ст. 60 КЗпП неконституційна, небезпечна для суспільного порядку держави, адже передбачає використання необмежених можливостей однієї сторони правовідносин для одностороннього впливу на свідомість і поведінку іншої сторони, яка не наділена правом погоджуватись або не погоджуватись на умови, в яких здійснюватиметься ії трудова діяльність. Зміст ч. 2 ст. 60 КЗПП у редакції Закону № 540-IX чудово демонструє, як через непрофесійний підхід законодавця та відсутність протидії з боку наукової спільноти відбувається перетворення найгуманнішої галузі права, якою є трудове право, на експлуатаційний ринковий інструмент, котрому вже не досить цивілістичного поглинання сфери праці - він прагне рабовласницького повновладдя над волею працівників. За своєю сутністю реалізація організаційної ознаки дистанційної роботи в розумінні Закону № 540-IX означає закріплення в трудовому законодавстві безмежного організаційного й дисциплінарного диктату роботодавця.

Висновки. Зміни, внесені в Кодекс Законів про працю України Законом № 540-IX, пов’язані з впровадженням правового регулювання дистанційної роботи, підтверджують тенденцію, почату урядовим законопроєктом «Про працю»: трудове право як соціальна й гуманна галузь права піддається небувалому тиску з боку ідеологів «вільного ринку». Дистанційна робота була визнана законодавцем формою організації праці, а не окремим видом діяльності з власним характером праці, чим порушується принцип єдності й диференціації правового регулювання трудових відносин. Відповідно, законодавцем не були закріплені правила щодо специфіки укладення трудового договору з дистанційним працівником (окрім обов'язкової письмової форми), умов та охорони праці й тому подібне, чим, по суті, було звужено обсяг мінімальних трудових стандартів для цієї категорії працівників. Крім того, Закон № 540-IX закріпив у КЗпП антисоціальні положення щодо вилучення 3 поняття трудового договору вказівки про правила внутрішнього трудового розпорядку (разом із тим, дистанційний працівник ним взагалі не підпорядковується), надав антиконституційну можливість роботодавцю змінювати істотні умови праці без згоди дистанційного працівника. Це є серйозним ударом як по колективним, так і по індивідуальним правам та інтересам працівників. Відповідно, підхід, обраний законодавцем для регулювання дистанційної роботи, за своїм характером переважно цивілістичний, а в певних деталях встановлює організаційний і дисциплінарний диктат роботодавця.

\section{ЛІТЕРАТУРА}

1. Про внесення змін до деяких законодавчих актів України, спрямованих на забезпечення додаткових соціальних та економічних гарантій у зв'язку з поширенням коронавірусної хвороби (COVID-19) : Закон України від 30 березня 2020 р. № $540-I X$ / Верховна Рада України. URL: https://zakon.rada.gov.ua/laws/show/540-20.

2. Киселев И.Я. Новый облик трудового права в странах Запада (прорыв в постиндустриальное общество). Управление персоналом. 2002. № 4. С. 49-55.

3. Новіков Д.О. Праця в інформаційному суспільстві: висновки для трудового права. Право і суспільство. 2015. Вип. 5-2. С. 96-103.

4. Новіков Д.О. Економізація трудового права - тенденції та виклики. Вісник Луганського державного університету внутрішніх справ імені Е.О. Дідоренка. 2017. Вип. 3. С. 160-168.

5. Новіков Д.О. Штраф як вид дисциплінарного стягнення: веління часу чи черговий прояв концепції «гнучкості» (дерегулювання) у трудовому праві. Науковий вісник Міжнародного гуманітарного університету. Серія: «Юриспруденція». 2015. Вип. 10-2. Том. 2. C. $17-19$.

6. Новіков Д.О. Пригноблення пригноблених: парадокси законопроєкту «Про працю». Журнал «Cпільне» (04 березня 2020 р.). URL: https://commons.com.ua/uk/paradoksy-zakonoproyektu-pro-pratsyu/.

7. Лук'янчиков О.М., Новіков Д.О. Про перспективи трудового права у гіг-економіці. Проблеми реалізації прав громадян у сфері праці та соціального забезпечення : тези доповідей та наукових повідомлень учасників IX Міжнародної науково-практичної конференції, яка присвячена 50-річчю створення кафедри трудового права Національного юридичного університету ім. Ярослава Мудрого, м. Харків, 11 жовтня 2019 р. / за ред. О.М. Ярошенка. Харків : Право, 2019. C. 220-224. URL: http://dspace.hnpu.edu.ua/handle/123456789/3626.

8. Великий тлумачний словник української мови / уклад. і гол. ред. В.Т. Бусел. Київ : Ірпінь: ВТФ «Перун», 2005.1728 с. 
9. Процевський О.І. Окремі питання щодо єдності та диференціації правового регулювання трудових відносин. Збірник наукових праць ХНПУ імені Г.С. Сковороди. Серія «Право». 2007. Вип. 9. С. 39-48.

10. Martino Di V., Wirht L. Telework: A new way of working and living. International Labour Review. 1990. Vol. 129. No. 5. P. 529-554.

11. Положення про умови праці надомників : Постанова Держкомпраці СРСР і Секретаріату ВЦРПС від 29 жовтня 1981р. № 275/17-99. База даних «Законодавство України». URL: https://zakon.rada.gov.ua/laws/show/v0275400-81

12. Коваленко О.О. Загроза експансії трудового права цивільним у світлі зміни дефініції «трудовий договір», або до чого ведуть зміни, спрямовані на забезпечення додаткових соціальних гарантій у зв'язку з полишенням коронавірсуної хвороби (COVID-19). Проблеми розвитку соціально-трудових прав та профьспілкового руху в Україні : матеріали VIII Всеукраїнської науково-практичної конфреренції, м. Харків, 28 травня 2020 р. / за заг. ред. К.Ю. Мельника. Харків : Харків. нац. ун-т внутр. справ, 2020. С. 99-102.

13. Сімутіна Я.В. Зміна традиційного підходу до визначення поняття трудового договору та їі наслідки для правозастосування. Проблеми розвитку соціально-трудових прав та профьспілкового руху в Україні : матеріали VIII Всеукраїнської науково-практичної конференції, м. Харків, 28 травня 2020 р. / за заг. ред. К.Ю. Мельника. Харків : Харків. нац. ун-т внутр. справ, 2020. С. 136-138.

14. Лук'янчиков О.М. Стимулякри системи оплати праці. Проблеми розвитку соціально-трудових прав та профрспілкового руху в Україні : матеріали VIII Всеукраїнської науково-практичної конференції, м. Харків, 28 травня 2020 р. / за заг. ред. К.Ю. Мельника. Харків : Харків. нац. ун-т внутр. справ, 2020. С. 200-204. URL: http://dspace.hnpu.edu.ua/handle/123456789/3643.

15. Лук'янчиков О.М. Симулякр базового державного соціального стандарту. Актуальні проблеми приватного та публічного права : матеріали II Міжнародної науково-практичної інтернет-конференції, присвяченої 91-річчю з дня народження член-кореспондента НАПрН України, академіка Міжнародної кадрової академії, Заслуженого діяча науки України, доктора юридичних наук, професора О.І. Процевського, 27 березня 2020 р. Харків, 2020. С. 167-170. URL: http://dspace.hnpu.edu.ua/handle/123456789/3640.

16. Про працю : законопроєкт від 29 грудня 2019 p. URL: http://w1.c1.rada.gov.ua/pls/zweb2/webproc4_1?pf3511=67833. 


\title{
РОЗДІЛ 6 \\ ЗЕМЕЛЬНЕ ПРАВО; АГРАРНЕ ПРАВО; ЕКОЛОГІЧНЕ ПРАВО; ПРИРОДОРЕСУРСНЕ ПРАВО
}

УДК 349.4

DOI https://doi.org/10.32782/2524-0374/2020-4/24

\section{СУТНІСТЬ ТА ПРАВОВА ПРИРОДА ПЛАТИ ЗА ЗЕМЛЮ}

\author{
THE ESSENCE AND LEGAL NATURE OF LAND FEES
}

\author{
Максимчук О.О., аспірант кафедри цивільно-правових дисциплін \\ Національний університет «Острозька академія»
}

\begin{abstract}
Статтю присвячено дослідженню особливостей правової природи плати за землю на основі аналізу її сутнісних ознак, які закріплені в нормативно-правових актах, щодо підстав та порядку сплати земельних платежів, суб'єктів здійснення та одержання плати за землю, об'єкта земельних платежів, мети, досягнути якої вдається за допомогою справляння плати за землю.

Спираючись на доктринальні дослідження вітчизняних та зарубіжних науковців, розмежовано розуміння плати за землю як економічної та правової категорії. Підкреслено, що як економічна категорія плата за землю є одним із засобів, а як правова - однією із форм: 1) економічного стимулювання раціонального використання, відновлення та охорони землі; 2) наповнення місцевих бюджетів; 3) виконання цивільно-правових та господарсько-правових зобов'язань.

На основі аналізу різних нормативно-регулятивних засобів - дефініцій, принципів, мети, джерел походження - запропоновано визначення плати за землю в загальному (земельно-правовому) та спеціальному значеннях: фінансово-правовому та цивільно-правовому.

У загальному (земельно-правовому) значенні автор під платою за землю визначає передбачену законодавством або договором сукупність платежів, які сплачуються і справляються державою, територіальними громадами, фрізичними та юридичними особами, у зв'язку з реалізацією ними правомочностей власника або користувача земельної ділянки в поточному або попередніх періодах, з метою наповнення місцевих бюджетів або виконання цивільно-правових та господарсько-правових зобов'язань, які спрямовані на економічне стимулювання власників землі та землекористувачів до раціонального, ефективного використання земель за цільовим призначенням, а також до здійснення їх охорони та відновлення.

У фінансово-правовому розумінні плату за землю слід розглядати як земельний податок або орендну плату за земельні ділянки державної і комунальної власності, які є засобом та формою наповнення місцевих бюджетів.

Цивільно-правове розуміння плати за землю демонструє сукупність таких земельних платежів, які одночасно є і засобом, і формою виконання цивільно-правових та господарсько-правових зобов'язань.

Зроблено висновок про те, що кожен земельний платіж має свою, притаманну йому правову форму, що створює неабиякий інтерес для подальших наукових досліджень.
\end{abstract}

Ключові слова: плата за землю, земельний платіж, правова природа, земельна ділянка, земельний податок.

The article deals with the research of the legal nature of land fees, based on the analysis of its essential features enshrined in regulations on the grounds and procedure for land fees, subjects and the object of land fees, and the aim that can be achieved by paying for the land.

On the grounds of domestic and foreign doctrines, understanding of land fees has been differentiated as an economic and legal category. It is emphasized that land fees as an economic category is one of the means whereas within a legal category it is one of the forms of (i) economic simulation of rational use, restoration and protection of land, (ii) increasing local budgets, and (iii) fulfillment of civil and commercial legal duties.

Based on the analysis of various norms and regulations such as definitions, principles, aim, sources of origin, it has been proposed to define land fees in a general (land law) and special contexts (finance law and civil law).

In the general (land law) context, the author defines land fees as a set of payments imposed by law or a contract that are paid and received by the state, territorial communities, private individuals and legal entities. This is linked to their realization of land owner's or land user's competencies within current or previous periods with an aim of increasing local budgets or fulfillment of civil and commercial legal duties. The latter ones are targeted at an economic stimulation of land owners and land users to use land according to its intended purpose in a rational and efficient manner as well as to protect and restore it.

In the context of finance law, land fees should be considered as a land tax or rent for land plots of state and communal property as the means and form of increasing local budgets.

In the context of civil law, land fees have to be understood as the means and form of fulfillment of civil and commercial legal duties.

It has been concluded that each land fee has its own legal form, which creates an incredible interest for further researches.

Key words: land fees, payment for land, legal nature, land plot, land tax.

Постановка проблеми. Дослідження будь-якого правового явища розпочинається зі з'ясування його сутності та правової природи. Зумовлено це необхідністю розуміння його змісту, місця та значення в системі правового регулювання. Не є винятком у цьому плані й питання сутності та правової природи плати за землю.

У 2001 році, закріпивши у Главі 35 Земельного кодексу України (далі - ЗКУ) під назвою «Економічне стимулювання раціонального використання та охорони земель» [1] принцип платного використання землі, законодавець, очевидно, розглядає плату за землю як засіб, за допомогою якого можна економічно стимулювати землевласників та землекористувачів до раціонального використання та охорони землі. Щодо визначення та порядку справляння такої плати ст. 206 ЗКУ відсилає нас до спеціального закону. Натепер таким прийнято вважати Податковий кодекс України (далі - ПКУ), де плата за землю визначається як обов'язковий платіж у складі податку на майно, що справляється у формі земельного податку або орендної плати за земельні ділянки державної і комунальної власності [2].

Зазначені земельні платежі вже стали предметом дослідження широкого кола науковців різних галузей юридичної науки і продовжують залишатися постійно в полі їхнього зору. Так, представники фінансово-правової науки плату за землю розглядають як засіб наповнення місцевих бюджетів, що, варто зауважити, не повною мірою відображає їхню справжню сутність та правову природу. 
Підтвердженням цьому є наявність поряд із податковими земельними платежами інших платежів за землю, які не $\epsilon$ бюджетними, а порядок їх справляння врегульовано нормами земельного та цивільного законодавства. Йдеться, зокрема, про плату за землю у відносинах купівлі-продажу, встановлення речових прав на земельну ділянку або iї частину тощо, що ставить під сумнів виключно фінансово-правову природу плати за землю.

Незважаючи на постійну зацікавленість, відсутньою $\epsilon$ і єдність поглядів на сутність та правову природу плати за землю серед представників земельно-правової науки. Зокрема, дискусійними, поряд із вищенаведеними, натепер видаються запропоновані науковцями ті визначення плати за землю, які відображають ії виключно цивільно-правову природу. Підтвердженням цьому є існування поряд із диспозитивним (договірним) механізмом справляння плати за землю - об'єкта цивільних прав, імперативного (законодавчого) способу справляння деяких видів земельних платежів, зокрема земельного податку та орендної плати за земельні ділянки державної та комунальної власності, а також адміністрування пільг щодо їх сплаті.

Така неоднозначність у розумінні сутності та правової природи плати за землю у свою чергу породжує різне бачення та розуміння основних елементів ії правової форми: суб'єктів сплати та її справляння, об'єкта, підстав та порядку сплати, а головне - мети, на досягнення якої спрямовано справляння земельних платежів. Зазначене негативно позначається на процесі правового регулювання плати за землю, підмінюючи справжню мету справляння земельних платежів - економічно стимулювати землевласників та землекористувачів до раціонального використання та охорони земель.

Аналіз досліджень. Як показує аналіз досліджень, питання сутності та правової природи плати за землю досліджувалось переважно 3 точки зору фінансового та податкового права. Так, плата за землю як податковий платіж - засіб наповнення державного та місцевих бюджетів - виступає предметом досліджень широкого кола науковців. Серед них значну увагу даному питанню приділили Т.О. Князькова та С.М. Богатирьова, які розглядають плату за землю як податковий платіж, що є одним із джерел наповнення місцевих бюджетів [3, с. 197; 4]. Такої ж думки про правову природу плати за землю дотримуються Ш.I. Ібатулін і В.М. Гадайчук, досліджуючи такі напрями вдосконалення платності землекористування в Україні, як земельний податок та орендну плату [5]. Г.М. Білецька значну увагу приділила детальному аналізу складників поняття «плата за землю» в розрізі Податкового кодексу України, зокрема його двох видів: земельного податку та орендної плати, охарактеризувавши їхні особливості. Так, плату за землю вона визначає як узагальнююче поняття, що містить два складники: земельний податок, яким є встановлений законодавчим органом та забезпечений державним примусом грошовий платіж у бюджет, що сплачується власниками землі на засадах обов'язковості, односторонності та індивідуальної безвідплатності з метою задоволення загальносуспільних потреб; орендна плата за землі державної, комунальної форм власності, що сплачується землекористувачами відповідно до договору оренди [6, с. 13].

Про фінансово-правову природу земельних платежів свідчать дослідження М.М. Трещова, який, досліджуючи вплив плати за землю на формування фінансової незалежності місцевого самоврядування в Україні, розглядає ії як «складову системи земельного оподаткування» [7, с. 194].

3 точки зору фінансового права правову природу плати за землю дослідила і Я.А. Курдюкова, яка дійшла висновку, що плата за землю має подвійну правову природу, зумовлену подвійністю іiі структури: земельний податок відноситься до категорії податку на власність, а орендна плата за землі державної та комунальної власності висту- пає податковим платежем за користування природними ресурсами, тобто являє собою ресурсний платіж, який виступає специфічним податковим інструментом, а не цивільно-правовою категорією [8, с. 123].

Питання сутності та правової природи плати за землю або окремих ії аспектів постійно зачіпається і представниками земельно-правової науки: В.О. Костенком, П.Ф. Кулиничем, А.М. Мірошниченком, В.В. Носіком, В. Правдюком, В.І. Федоровичем, М.В. Шульгою та іншими.

Так, В.I. Федорович під платою за землю розуміє загальну назву для всіх видів обов'язкових платежів, що виплачуються у зв'язку з реалізацією права приватної власності та інших речових прав на землю [9, с. 446]. Слід зауважити, що дане визначення демонструє виключно приватно-правову природу плати за землю, не враховуючи всіх іiі сутнісних ознак, зокрема того, що земля в Україні згідно з ч. 3 ст. 78 ЗКУ може перебувати не лише у приватній, а й у комунальній і державній власності, та за користування комунальними і державними землями, відповідно, теж сплачуються земельні платежі, суб'єктами сплати та справляння яких $є$ не лише фізичні та юридичні особи як суб'єкти приватного права, а й територіальні громади та держава в тому числі як суб'єкти публічного права.

У дещо ширшому розумінні плату за землю розглядають М.В. Шульга та В.О. Костенко - як законодавчо передбачену сукупність обов'язкових земельних платежів, які необхідні для реалізації права власності та права користування земельними ділянками, що можуть отримувати і сплачувати держава, територіальні громади, фізичні та юридичні особи, метою справляння яких є стимулювання власників, користувачів земельних ділянок до цільового, раціонального та ефективного використання земель $[10$, с. $118 ; 11$, с. 12$]$. До запропонованого визначення вбачається доцільним додати, що така законодавчо передбачена сукупність обов'язкових земельних платежів $€$ необхідною не лише під час реалізації права власності в розумінні тріади правомочностей власності загалом та права користування земельними ділянками зокрема. Вона необхідна у зв'язку 3 реалізацією правомочностей власника землі, до яких належить право володіння, користування i розпорядження земельними ділянками (ст. 78 ЗКУ). Так, наприклад, земельний податок власник земельної ділянки сплачує регулярно, у встановлений законодавством строк, незалежно від того, реалізовував він свою правомочність з іiї використання протягом відповідного податкового періоду, чи ні, незалежно від причин. Земельна ж ділянка - об'єкт сплати земельного платежу хоча і не використовувалася в повній мірі чи частково, все ж перебувала в його повному володінні та розпорядженні. У даному випадку у зв'язку з реалізацією саме окремих правомочностей - володіння та розпорядження земельною ділянкою власник землі виконує свій обов'язок зі сплати земельного податку. У такий спосіб законодавець стимулює власників землі до активних дій: використовувати земельну ділянку якомога раціональніше, ефективніше, відповідно до іiі цільового призначення задля одержання вигоди, за рахунок якої потім можна сплатити земельний податок чи інший обов'язковий земельний платіж.

На незвичайну правову природу, щоправда, лише орендної плати за земельні ділянки державної та комунальної власності вказує В. Правдюк. На його переконання, 3 одного боку, це звичайний платіж за господарським чи цивільно-правовим договором, 3 іншого - різновид та форма сплати загальнодержавного податку [12].

Така різностороння зацікавленість дослідженням інституту плати за землю свідчить про важливість та актуальність дослідження його сутності та з'ясування правової природи, в тому числі й зважаючи на те, що плата за землю $€$ одним із ключових елементів економіко-правового механізму стимулювання раціонального використання та охорони земель. Втім, незважаючи на це, комплексного док- 
тринального дослідження сутності та правової природи плати за землю натепер не існує.

Вказане зумовлює мету дослідження - на підставі аналізу чинного земельного, цивільного, податкового законодавства та доктринальних джерел з'ясувати сутність та правову природу плати за землю.

Виклад основного матеріалу. Сам по собі термін «плата за землю» ще не є правовою категорією. Із синтаксичної точки зору це іменникове словосполучення з головним словом «земля» і підпорядкованим йому «плата».

Термін «земля» $є$ полісемічним, а його значення залежить від конкретної сфери застосування: «Земля - 1) місце життя і діяльності людей; 2) верхній шар земної кори; 3) земляна поверхня, площина, по якій ходять; 4) речовина темно-бурого кольору, що входить до складу земної кори; 5) суша (на відміну від водяного простору); 6) грунт, який обробляється і використовується для вирощування рослин; 7) країна, край, держава» [13].

Своє розуміння значення поняття «земля» дає економічна наука. Так, термін «земля» вона вживає у двох значеннях: 1. Як ресурс, що використовується для виробництва сільськогосподарської продукції, будівництва міст, будинків, залізничних та автомобільних шляхів, один 3 основних компонентів виробництва; 2. Як фактор виробництва, все, що надала природа людині для іiі виробничої діяльності (земля, надра, вода, повітря, ліси тощо) [14, с. 140$]$.

Термін «плата» у словникових джерелах визначається як «відшкодування вартості одержаного або використаного; те, чим відшкодовують» [15]. Тобто плату можна розглядати 3 двох позицій: як процес відшкодування вартості отриманого або використаного та як матеріальне вираження відшкодування - так це відображає економічна теорія, де плата - це «кошти, що їх належить сплачувати за придбані товари, використані ресурси, кредити» $[14$, c. 211$]$. Причому під коштами слід розуміти не лише «гроші», а й «капітал, матеріальні цінності» [16].

Вищенаведене дозволяє зробити висновок, що плата за землю в розумінні коштів, що їх належить сплачувати за землю як придбаний товар чи використаний ресурс, $\epsilon$ категорією економічною.

У правовій же сфері під терміном «земля» розуміється конкретна земельна ділянка. «Об'єктом плати за землю $є$ земельна ділянка (ст. 206 ЗКУ)» як «частина земної поверхні з установленими межами, певним місцем розташування, 3 визначеними щодо неї правами» (ст. 79 ЗКУ), плата за яку справляється відповідно до закону» (ч. 2 ст. 206 ЗКУ).

Цілком логічним вбачається плату за землю, в розумінні процесу відшкодування вартості отриманої або використаної земельної ділянки, регламентованого нормами земельного, цивільного, податкового та іншого законодавства, вважати категорією правовою, яка, як і кожне правове явище, потребує з'ясування його сутності та правової природи.

Як показав системний аналіз норм чинного законодавства та доктринальних джерел, під платою зазвичай розуміється «платіж». Правова дефініція «платіж» зустрічається сьогодні в бюджетному законодавстві, де цей термін означає виконання бюджетних, боргових, гарантійних чи податкових зобов'язань, що виникли в поточному або попередніх бюджетних періодах (ст. 2 Бюджетного кодексу України) [17]. Для з'ясування сутності земельних платежів, які частково $\epsilon$ також i бюджетними, для цілей даної статті доцільним вбачається взяття даного визначення за основу з урахуванням особливостей, що випливають із земельного, цивільного та податкового законодавства. Таким чином, під земельним платежем варто розуміти виконання бюджетних, боргових, гарантійних, податкових чи інших (договірних) зобов'язань, що виникли в поточному або попере- дніх періодах у зв'язку з реалізацією правомочностей власності та права користування землею.

Вітчизняна юридична наука нині не має єдиного підходу до визначення поняття «правова природа» попри те, що широке коло дослідників постійно оперують цим поняттям: «правова природа суперфіцію», «правова природа сервітуту», «правова природа договору оренди», «кримінально-правова природа», «правова природа принципу платності землекористування» тощо.

Сам по собі термін «природа» ще не є правовим, і під ним, як правило, в українській мові розуміють «сукупність основних якостей, властивостей чого-небудь; суть, сутність» $[18 ; 19$, с. 1129]. Під «сутністю» автори Академічного словника української мови визначають найголовніше, основне, істотне в кому-, чому-небудь; суть, зміст [20]. Аналогічної точки зору дотримується колектив авторів Великого тлумачного словника сучасної української мови за ред. В.Т. Бусела, який, щоправда, до запропонованого визначення поняття «сутності» додає ще й таке його смислове значення, як «сенс» [19, с. 1417]. Вказане дає підстави стверджувати, що природа будь-якого явища визначається через його сутність - набір найголовніших істотних ознак.

В аналізі ж термінологічного значення поняття «правова природа» визначальне значення має присутність у ньому терміна «правова», який вказує на те, що явище визначається 3 точки зору права [21, с. 25]. Правовий стосується права [19, с. 1101].

Як випливає зі змісту ст. 205 Земельного кодексу України, основними сутнісними ознаками плати за землю $€$ : нормативно-правовий акт, який закріплює підстави та порядок сплати земельного платежу, суб'єкт здійснення та суб'єкт одержання плати за землю, об'єкт земельного платежу та мета, на досягнення якої спрямовано платіж.

Комплекс нормативно-правових актів, які закріплюють підстави та порядок сплати земельних платежів, $є$ досить широким та різногалузевим. Їхню основу становить Земельний кодекс України, який у Главі 35 закріплює принцип платності землекористування та його мету, які в подальшому деталізуються в інших його главах та розділах, а також в інших законодавчих та підзаконних нормативно-правових актах: Податковому кодексі України від 2 грудня 2010 року, Цивільному кодексі України від 16 січня 2003 року, Лісовому кодексі України від 21 січня 1994 року, Законі України «Про відчуження земельних ділянок, інших об'єктів нерухомого майна, що на них розміщені, які перебувають у приватній власності, для суспільних потреб чи 3 мотивів суспільної необхідності» від 17 листопада 2009 року, Законі України «Про оренду землі» від 6 жовтня 1998 року, Законі України «Про оцінку земель» від 11 грудня 2003 року, в Порядку нормативної грошової оцінки земель населених пунктів від 25 листопада 2016 року, Порядку нормативної грошової оцінки земель несільськогосподарського призначення (крім земель населених пунктів) від 22 серпня 2013 року, Порядку нормативної грошової оцінки земель сільськогосподарського призначення від 23 травня 2017 року та ін.

Як показує системний аналіз норм земельного, податкового, цивільного законодавства, суб'єктами здійснення плати за землю є: держава, територіальні громади, фізичні та юридичні особи.

Так, держава, територіальні громади, фізичні та юридичні особи є суб'єктами сплати таких земельних платежів: земельного податку як власники земельних ділянок, земельних часток (паїв) та землекористувачі (п.П. 14.1.34 п. 14.1 ст. 14, ст. 269 ПКУ), орендної плати за користування земельними ділянками, отриманими в оренду (ст. 5, ст. 21 Закону України «Про оренду землі» від 06.10.1998р.) [22]; ціни земельної ділянки в разі набуття права власності на земельну ділянку на підставі цивільно-правових угод, в тому числі і купівлі- 
продажу (131 3К); у разі внесення плати за користування земельною ділянкою, наданою для забудови (суперфіцій) (ч. 4 ст. 415 ЦК України) [23], за користування земельною ділянкою для сільськогосподарських потреб (емфітевзис) (ч. 2 ст. 410 Цивільного кодексу України), у разі використання земельної ділянки на правах сервітуту (ч. 3 ст. 403 ЦК України) та ін.

Лише держава та територіальні громади є суб'єктами сплати викупної ціни земельних ділянок, інших об'єктів нерухомого майна, що на них розміщені, для суспільних потреб чи 3 мотивів суспільної необхідності (ч. 3 ст. ст. 1 і 7 Закону України «Про відчуження земельних ділянок, інших об'єктів нерухомого майна, що на них розміщені, які перебувають у приватній власності, для суспільних потреб чи 3 мотивів суспільної необхідності» від 17.11.2009 р.) [24].

Лише громадяни і юридичні особи України є суб'єктами внесення плати за отримання у власність замкнених земельних ділянок лісогосподарського призначення загальною площею до 5 гектарів у складі угідь селянських, фермерських та інших господарств (ч. 1 ст. 12 Лісового кодексу України) [25].

Одержувачами земельних платежів є держава, територіальні громади, фізичні та юридичні особи.

Держава і територіальні громади як суб'єкти справляння плати за землю у зв'язку 3 реалізацією права державної та комунальної власності отримують такі земельні платежі: орендну плату за земельні ділянки державної та комунальної власності як орендодавці (пП. 14.1.136 п. 14.1 ст. 14 ПКУ), плату від продажу земельних ділянок державної чи комунальної власності або прав на них громадянам, юридичним особам та іноземним державам (ст. 127 ЗКУ); плату за користування земельною ділянкою, наданою для забудови (суперфіцій) (ч. 4 ст. 415 ЦКУ), за користування земельною ділянкою для сільськогосподарських потреб (емфітевзис) (ч. 2 ст. 410 ЦКУ), за використання земельної ділянки на правах сервітуту (ч. 3 ст. 403 ЦКУ), плату за передачу у власність громадянам та юридичним особам України замкнених земельних ділянок лісогосподарського призначення загальною площею до 5 гектарів у складі угідь селянських, фермерських та інших господарств (ч. 1 ст. 12 Лісового кодексу України).

Лише територіальні громади є суб'єктами справляння земельного податку у складі податку на майно (ст. 10 ПКУ).

Фізичні та юридичні особи є одержувачами земельних платежів у зв'язку з реалізацією ними права приватної власності на земельні ділянки, зокрема: орендної плати (п. в) ч. 2 ст. 5, ст. 21 Закону України «Про оренду землі»); ціни земельної ділянки у разі відчуження земельної ділянки на підставі договору купівлі-продажу (131 ЗКУ), в тому числі викупної ціни у разі примусового відчуження земельної ділянки, інших об'єктів нерухомого майна, що на ній розміщені для суспільних потреб чи з мотивів суспільної необхідності (ч. 2 ст. 1 Закону України «Про відчуження земельних ділянок, інших об'єктів нерухомого майна, що на них розміщені, які перебувають у приватній власності, для суспільних потреб чи з мотивів суспільної необхідності» від 17.11.2009р.); плати за користування земельною ділянкою, наданою для забудови (суперфіцій) (ч. 4 ст. 415 ЦКУ), за користування земельною ділянкою для сільськогосподарських потреб (емфітевзис) (ч. 2 ст. 410 ЦКУ), за використання земельної ділянки на правах сервітуту (ч. 3 ст. 403 ЦКУ) та ін.

Об'єктом плати за землю згідно зі ст. 206 Земельного кодексу України є земельна ділянка. Стаття 79 ЗКУ вважає земельною ділянкою частину земної поверхні, яка має установлені межі, певне місце розташування, визначені щодо неї права. Податковий кодекс України (ст. 14) до наведеного визначення земельної ділянки додає ще й iiï цільове (господарське) призначення, від якого певною мірою залежить порядок здійснення іiі нормативної грошової оцінки, а отже, ставка і розмір земельного податку та орендної плати за земельні ділянки державної та комунальної власності.

Варто зауважити, що поряд із земельною ділянкою Податковий кодекс України об'єктом плати за землю визначає ще й земельну частку (пай), яка перебуває у власності (ст. 270 ПКУ), і тим самим це вступає в колізію зі ст. 206 Земельного кодексу України. Для вирішення даної проблеми слід керуватися пріоритетністю норми Податкового кодексу України, закріпленої п. 5.2. ст. 5, і якщо поняття, терміни, правила та положення інших актів суперечать поняттям, термінам, правилам та положенням цього Кодексу, для регулювання відносин оподаткування застосовуються поняття, терміни, правила та положення Податкового кодексу України.

Зважаючи на те, що поняття права на земельну частку (пай) чинне законодавство не містить, в юридичній літературі на підставі системного аналізу нормативно-правових актів пропонується визначення цієї категорії як права на оцінену в грошовому виразі та визначену в умовних кадастрових гектарах частину переданих у колективну власність сільськогосподарських угідь недержавного сільськогосподарського підприємства, яка визначає рівновелику частку участі члена підприємства в земельному пайовому фонді господарства і може бути в установленому чинним законодавством порядку витребувана в натурі (на місцевості) в самостійну земельну ділянку [26, с. 153].

Автори науково-практичного коментаря до Земельного кодексу України А.М. Мірошниченко та P.I. Марусенко правом на земельну частку (пай) вважають речове право вимагати виділення в натурі (на місцевості) земельної ділянки, що за вартістю відповідає частці особи у сільськогосподарських угіддях, переданих у колективну власність відповідної юридичної особи [27, с. 493].

Реалізація права на земельну частку (пай) можлива насамперед шляхом виділення земельної ділянки, що належить на пай, у натурі. Крім того, вона може бути здійснена шляхом передачі земельної частки (паю) в оренду.

Сертифікати на право на земельну частку (пай), отримані громадянами, вважаються правовстановлюючими документами в разі реалізації ними права вимоги на відведення земельної частки (паю) в натурі (на місцевості) відповідно до законодавства. Віднесення відповідно до статті 269 ПКУ до платників земельного податку наряду iз власниками земельних ділянок і землекористувачами власників земельних часток (паїв), на наше переконання, суперечить природі земельної частки (паю).

Таким чином, об'єктом плати за землю виступає земельна ділянка та земельна частка (пай), правова природа яких різниться. Так, земельною ділянкою є частина земної поверхні, яка має встановлені межі, певне місце розташування, цільове (господарське) призначення, визначені щодо неї права. Земельна ж частка (пай) ще не $\epsilon$ земельною ділянкою у власному розумінні, не будучи виділеною в натурі. Вона є правом вимоги на умовну земельну частку в гектарах з відповідною грошовою оцінкою без виділення в натурі, а тому віднесення земельної частки (паю) до об'єктів плати за землю, а власників земельних часток (паїв) - до суб'єктів суперечить природі земельної частки (паю) та праву на земельну частку (пай). Тому власник сертифіката на земельну частку (пай) до визначення меж земельної ділянки в натурі та отримання документа, що посвідчує право власності на землю, або державної реєстрації цього права не повинен бути платником земельного податку.

Мета плати за землю. Правова природа (певного явища - O.M.), на думку С.В. Малюгіна, може виражатися в різних нормативно-регулятивних засобах (нормативних узагальненнях): принципах, цілях, завданнях права, правових дефініціях тощо. Дані засоби наділені сутнісними 
ознаками і потребують визначення свого місця та значення в системі правового регулювання» [28, с. 50]. Закріпивши у Главі 35 Земельного кодексу України «Економічне стимулювання раціонального використання та охорони земель» принцип оплатного використання землі, законодавець, очевидно, своєю основною ціллю мав саме за допомогою плати за землю як засобу економічно стимулювати землевласників та землекористувачів до раціонального використання земель та здійснення їх охорони, а не лише наповнення місцевих бюджетів, що підпадає під сферу регулювання, головним чином, фінансового та податкового права. Зазначене дає підстави вважати, що плата за землю як економічна категорія виступає одним із засобів, а як правова - однією із форм економічного стимулювання раціонального використання та охорони землі, що також демонструє іiї земельно-правову природу.

Окрім того, доцільно зауважити, що в умовах розумного підходу до адміністрування плата за землю видається дієвим економічним засобом та правовою формою стимулювання як органів державної влади та місцевого самоврядування, так і власників та користувачів земельних ділянок до здійснення ними, поряд із раціональним використанням та охороною, ще й заходів із відновлення земель. Погоджуємось із думкою Т. Лісової, що під впливом негативних процесів, як природного, так і техногенного характеру, на стан земель сільськогосподарського, лісогосподарського та іншого призначення сьогодні вкрай необхідним $є$ вжиття комплексу відповідних адекватних заходів, серед яких самостійне місце займають рекультивація, консервація, консолідація, відшкодування втрат сільськогосподарського та лісогосподарського виробництва та ін. [29, с. $201 ; 30$, с. 127]. Реалізувати зазначені заходи можливо лише за умови наявності відповідних бюджетних коштів, які формуються в тому числі й за рахунок земельних платежів. Таким чином, плата за землю $\epsilon$ економічним стимулом для органів державної влади та місцевого самоврядування, які здійснюють повноваження власників державних і комунальних земель відповідно, до реалізації ними ряду життєво важливих заходів із відновлення земель, особливо зважаючи на теперішній критичний стан земельних ресурсів.

Водночас у впровадженні з боку держави ряду заходів, пов'язаних зі справлянням плати за землю, в тому числі й пільг щодо ії сплати, вбачається намагання законодавця стимулювати і власників та землекористувачів суб'єктів приватного права - до здійснення необхідних заходів із відновлення земель. Йдеться, зокрема, про: надання податкових і кредитних пільг фізичним і юридичним особам, які здійснюють за власні кошти заходи щодо захисту земель від ерозії, підвищення родючості грунтів та інші заходи, передбачені загальнодержавними й регіональними програмами використання та охорони земель; звільнення землевласників і землекористувачів від плати за землю, за земельні ділянки, на яких виконуються роботи з меліорації, рекультивації, консервації земель та інші роботи щодо охорони земель на період тимчасової консервації, будівництва та сільськогосподарського освоєння земель відповідно до затвердженої документації із землеустрою (ст. 27 Закону України «Про охорону земель») [31] тощо.

Втім, варто зауважити, що таку стимулюючу роль здатні виконувати не всі вищезгадані земельні платежі та пов'язані з їх сплатою пільги, що дає підстави стверджувати про плату за землю в загальному та спеціальному (земельно-правовому) розумінні.

На земельно-правову природу земельних платежів вказує і основне джерело їх походження, оскільки, «говорячи про природу явища, ми передусім маємо на увазі першооснову, вихідне начало, яке зумовлює існування самого явища (плати за землю - O.М.), його суть та сутність» $[21$, c. 25]. Саме із принципу платного використання землі, закріпленого ст. 206 Земельного кодексу України (2002 року), як «основоположної ідеї, засади, вимоги, положення, що об'єктивно відображає напрями державної політики в регулюванні земельних відносин та виступає основою для розроблення, прийняття та виконання норм земельного права» [32, с. 105], бере своє начало інститут плати за землю: «Використання землі в Україні $\epsilon$ платним...2. Плата за землю справляється відповідно до закону» (ст. 206 ЗКУ). Наведене свідчить про те, що норми земельного законодавства в частині оплатного використання землі є загальними по відношенню до норм податкового, цивільного, бюджетного законодавства, які в питаннях справляння плати за землю є спеціальними.

Висновки. Як показує аналіз сутнісних ознак, плата за землю є складною та за своєю природою багатогранною економіко-правовою категорією, яку слід розуміти в загальному (земельно-правовому) та спеціальному значеннях: фінансово-правовому і цивільно-правовому.

У загальному (земельно-правовому) значенні під платою за землю слід розуміти передбачену законодавством або договором сукупність платежів, які сплачуються і справляються державою, територіальними громадами, фізичними та юридичними особами, у зв'язку з реалізацією ними правомочностей власника або користувача земельної ділянки в поточному або попередніх періодах, 3 метою наповнення місцевих бюджетів або виконання цивільно-правових та господарсько-правових зобов'язань, i які спрямовані на економічне стимулювання власників землі та землекористувачів до раціонального, ефективного використання земель за цільовим призначенням, ïx охорони та відновлення.

Таке визначення плати за землю включає в себе його спеціальне фінансово-правове та цивільно-правове розуміння.

У фінансово-правовому розумінні плату за землю слід розглядати як земельний податок або орендну плату за земельні ділянки державної і комунальної власності, які $€$ засобом та формою наповнення місцевих бюджетів.

У цивільно-правовому розумінні плату за землю слід розглядати як сукупність земельних платежів, які є засобом та формою виконання цивільно-правових та господарсько-правових зобов'язань.

У свою чергу кожен земельний платіж має свою правову форму, визначену податковим, бюджетним та цивільним законодавством, що створює неабиякий інтерес для подальших наукових досліджень.

\section{ЛITEPATУРA}

1. Земельний кодекс України від 25 жовтня 2001 р. Відомості Верховної Ради України. 2002. № 3-4. Ст. 27. URL: http:zakon3.rada.gov.ua/ laws/show/2768-14

2. Податковий кодекс України від 2 грудня 2010 р. Відомості Верховної Ради України. 2011. № 13-14, № 15-16, № 17. Ст. 112. URL: http:zakon5.rada.gov.ua/laws/show/2755-17

3. Князькова Т.О. Плата за землю як одне з джерел наповнення місцевих бюджетів. Вісник Харківського національного технічного університету сільського господарства. Економічні науки. Харків : ХНТУСГ, 2011. Вип. 97. С. 196-207.

4. Богатирьова Є.М. Плата за землю як джерело наповнення місцевих бюджетів України. Ефрективна економіка. 2018. № 6. URL: http://www.economy.nayka.com.ua/pdf/6_2018/49.pdf

5. Ібатулін Ш.І., Гадайчук В.М. Напрями вдосконалення платності землекористування в Україні. 2013. Вип. 23.13. URL: https://cyberleninka.ru/article/n/napryami-vdoskonalennya-platnosti-zemlekoristuvannya-v-ukrayini

6. Білецька Г.М. Правове регулювання плати за землю в Україні : автореф. дис. ... на здобуття наук. ступеня кандидата юридичних наук : 12.00.07. Ірпінь, 2014. 20 с. 
7. Трещов М.М. Вплив плати за землю на формування фінансової незалежності місцевого самоврядування в Україні. Вісник Дніпропетровського державного аграрного університету. 2013. № 2 (32). С. 194-197.

8. Курдюкова Я.А. Проблемні питання правової природи плати за землю. Право і суспільство. 2014. № 4. С. 120-124.

9. Велика українська юридична енциклопедія : у 20 т. / редкол. : М.В. Шульга (голова) та ін. Нац. акад. прав. наук України, Ін-т держави і права ім. В. М. Корецького НАН України, Нац. юрид. ун-т ім. Ярослава Мудрого, 2019. Т. 16: Земельне та аграрне право. 696 с.

10. Шульга М.В. Правове забезпечення плати за землю. Науковий вісник Національного університету біоресурсів і природокористування України. 2015. Вип. 218. С. 116-121.

11. Костенко В.О. Економіко-правове забезпечення використання та охорони земель : авторефр. дис. ... на здобуття наук. ступеня кандидата юридичних наук : 12.00.06. Харків, 2015. 17 с.

12. Правдюк В. Сплата орендної плати за землі державної та комунальної власності: підходи фіскалів та позиція судів у 2014-2016 роках. URL: http://bz.ligazakon.ua/ua/magazine_article/BZ009911

13. Словник української мови : в 11 т. / AН УРCP. Інститут мовознавства ; за ред. І.К. Білодіда. Київ : Наукова думка, 1972. T. 3. 3. URL: http://sum.in.ua/s/zemlja

14. Гончаров С.М., Кушнір Н.Б. Тлумачний словник економіста / за ред. проф. С.М. Гончарова. Київ : Центр учбової літератури, 2009. $264 \mathrm{c}$.

15. Словник української мови : в 11 т. / АН УРСР. Інститут мовознавства ; за ред. І.К. Білодіда. Київ : Наукова думка, 1975. Т. 6. П-По. URL: http://sum.in.ua/s/plata

16. Словник української мови : в 11 т. / АН УРСР. Інститут мовознавства ; за ред. І.К. Білодіда. Київ : Наукова думка, 1973. Т. 4. I-M. URL: http://sum.in.ua/s/koshty

17. Бюджетний кодекс України від 08 липня 2010 року. Відомості Верховної Ради України. 2010. № 50-51. Ст. 572. URL: https://zakon.rada.gov.ua/laws/show/2456-17

18. Словник української мови : в 11 т. / АН УРСР. Інститут мовознавства ; за ред. І.К. Білодіда. Київ : Наукова думка, 1979. Т. 8. При-P. URL: http://sum.in.ua/s/pryroda

19. Великий тлумачний словник сучасної української мови (з дод. і допов.) / уклад. і голов. ред. В.Т. Бусел. Київ ; Ірпінь : ВТФ «Перун», 2005. 1719 c. URL: https://archive.org/details/velykyislovnyk/page/n1135/mode/2up

20. Словник української мови : в 11 т. / AH УPCP. Інститут мовознавства ; за ред. І.К. Білодіда. Київ : Наукова думка, 1978. T. 9. URL: http://sum.in.ua/s/sutnistj

21. Комиссарова Е.Г. Формально-логические аспекты понятия «правовая природа». Вестник Пермского университета. Юридические науки. 2012. Вып. 2 (16). С. 23-25. URL: https://cyberleninka.ru/article/n/formalno-logicheskie-aspekty-ponyatiya-pravovaya-priroda/viewer 22. Закон України від 06 жовтня 1998 року «Про оренду землі». URL: https://zakon.rada.gov.ua/laws/show/161-14

23. Цивільний кодекс України від 16 січня 2003 р. Відомості Верховної Ради України. 2003. № 40-44. Ст. 356. URL: https://zakon.rada.gov.ua/laws/show/435-15

24. Закон України від 17 листопада 2009 року «Про відчуження земельних ділянок, інших об’єктів нерухомого майна, що на них розміщені, які перебувають у приватній власності, для суспільних потреб чи з мотивів суспільної необхідності». URL: https://zakon.rada.gov.ua/ laws/card/1559-17

25. Лісовий кодекс України від 21 січня 1994 року. Відомості Верховної Ради України. 1994. № 17. Ст. 99. URL: https://zakon.rada.gov.ua/ laws/show/3852-12

26. Земельне право України : підруч. / Г.І. Балюк та ін. ; за ред. В.В. Носіка. Київ : Видавничо-поліграсрічний центр «Київський університет», 2008. 511 c.

27. Мірошниченко А.М., Марусенко Р.І. Науково-практичний коментар Земельного кодексу України. Київ : «Правова єдність», 2009. 496 c.

28. Малюгин С.В. Категория «правовая природа»: понятие, детерминанты, основные характеристики и подходы к определению. Российский юридический журнал. 2016. № 3 (108). C. 46-58. URL: https://www.elibrary.ru/contents.asp?issueid=1589515

29. Лісова Т. Щодо питання відновлення земель як виду земельних відносин. Науковий вісник Ужгородського національного універcumemy. Серія Право. 2016. Випуск 36. Том 1. С. 200-203. URL: http://dspace.nlu.edu.ua/bitstream/123456789/10125/1/Lisova_54-57.pdf

30. Лісова Т. Деякі правові питання відновлення земель. Visegrad Journal on Human Rights. 2017. C. 124-128. URL: http://vjhr.sk/ archive/2017_1/part_2/23.pdf

31. Закон України від 19 червня 2003 року «Про охорону землі». URL: https://zakon.rada.gov.ua/laws/show/962-15

32. Говорун М. Правова природа принципу платності землекористування. Підприємництво, господарство i право. 2018. № 8. C. 103-108. 


\title{
ЮРИДИЧНА КАТЕГОРІЯ «РЕКУЛЬТИВАЦІЯ ЗЕМЕЛЬ»: СУЧАСНІ НАУКОВО-ПРАВОВІ ПІДХОДИ ДО ЗАКОНОДАВСТВА
}

\author{
LEGAL CATEGORY "LAND RECLAMATION": \\ MODERN SCIENTIFIC AND LEGAL APPROACHES TO LEGISLATION
}

\author{
Чабаненко М.М., д.ю.н., професор, \\ професор кафедри цивільного, трудового та господарського права \\ Дніпровський національний університет імені Олеся Гончара \\ Волох П.В., к.с.-г.н., доцент, \\ професор кафедри загального землеробства та грунтознавства, \\ проректор з навчальної роботи \\ Дніпровський державний аграрно-економічний університет
}

Левченко В.Р., студент II курсу юридичного відділення

Дніпровський транспортно-економічний коледж

\begin{abstract}
Авторами презентується міждисциплінарний погляд на проблему рекультивації земель з точки зору юридичної науки й науки ґрунтознавства. Проаналізовано законодавство України у сфері рекультивації порушених земель. Наведено науково-практичну основу правотворчості у сфері відновлення техногенних ландшафтів. Обґрунтовано проблеми збереження ґрунтового покриву в межах гірничого відводу й шляхи його використання. Подано нагальні доктринальні тлумачення правових норм щодо рекультивації. Виділено основні проблеми правового забезпечення рекультивації земель. Обґрунтовано нагальну необхідність прийняття закону України «Про рекультивацію земель». Наголошується на необхідності послідовного розмежування правових понять «земля», «земельна ділянка» й «рунт». Особливу увагу приділено питанням рекультивації земель, що використовувалися в гірничодобувній промисловості. Наголошується на необхідності розроблення спеціальної методики визначення грошової оцінки земельної ділянки для отримання дозволу на користування надрами. Також вказується на необхідність додаткового регулювання поводження з ґрунтами під час гірничих робіт і визначення методик і нормативів рекультивації земель, зокрема нормативів оцінки родючості й складу ґрунтів, класифікаторів порушень нормативів проєктних напрямів і планових строків рекультивації, методик фітомеліорацій у період біологічного етапу рекультивації тощо. Автори висловлюють сподівання, що держава перегляне пасивне ставлення до інституту рекультивації й успішно вирішуватиме проблеми ресурсозбереження й еколого-економічної ефективності в гірничодобувному виробництві. Державні стандарти й нормативи з відновлення порушених земель мають враховувати суттєві положення, основоположні засади й ідеї природничо-технологічної дисципліни рекультознавства.

Ключові слова: земля, ґрунт, родючий шар ґрунту, техногенез, напрям рекультивації, бонітування.
\end{abstract}

The authors present an interdisciplinary approach to the problem of land reclamation from the point of view of legal science and soil science. The legislation of Ukraine in the field of reclamation of disturbed lands is analyzed. The scientific and practical basis of lawmaking in the field of restoration of man-made landscapes is given. Problems of soil cover conservation within the mining allotment and ways of its use are substantiated. Urgent doctrinal interpretations of legal norms on reclamation are given. The main problems of legal support of land reclamation are highlighted. The urgent need to adopt the Law of Ukraine "On Land Reclamation" is substantiated. Emphasis is placed on the need for consistent demarcation of the legal concepts of "land", "land plot" and "soil". Particular attention is paid to the reclamation of land used in the mining industry. Emphasis is placed on the need to develop a special method for determining the monetary value of land when obtaining a subsoil use permit. Authors also point out the need for additional regulation of soil management during mining; determination of methods and standards of land reclamation, including standards for assessing fertility and soil composition, classifiers of violations of design guidelines and planned terms of reclamation, methods of phytomelioration during the biological stage of reclamation. The authors hope that the state will reconsider its passive attitude to the institution of land reclamation and successfully address the problems of resource conservation and environmental and economic efficiency in mining. State standards and regulations for the restoration of disturbed lands should take into account the essential provisions, fundamental principles and ideas of the natural-technological discipline of land reclamation studies.

Key words: land, soil, fertile soil layer, technogenesis, direction of reclamation, land evaluation.

Постановка проблеми. Державне регулювання процесів використання природних ресурсів і зменшення антропічного навантаження на ландшафти України є важливими інструментами захисту біосфери. Промислово-аграрний Придніпровський регіон характеризується інтенсивним використанням мінерально-сировинних, земельних, водних ресурсів і зміною екологічних факторів, що забезпечують динаміку та розвиток природного середовища. Аналіз антропічного розвитку системи «регіон - навколишнє середовище» свідчить, що землемісткість (кількість розривних порід на одиницю корисних копалин) і негативний вплив на природні й аграрні ландшафти $є$ в гірничовидобувній промисловості з використанням відкритого способу розроблення корисних копалин (буре вугілля, залізна, марганцева комплексні рідкоземельні руди, каолін тощо). Деградація зональних біогеоценозів й агроландшафтів, екскавація верхнього шару педосфери й порід надрудної літосфери зумовлюють формування «місячних техногенних ландшафтів», якими є діючі й відпрацьовані кар'єри, кінцеві траншеї, хвостосховища, зовнішні відвали, терикони, золовідвали, склади корисних копалин, промислові зони тощо.
Аналіз наукового та правового забезпечення рекультивації. Земельним кодексом України (далі - ЗК України) у ст. 166 установлено природоохоронні правові норми щодо рекультивації порушених земель [1]. Вбачається, що позитивною рисою цієї статті $є$ нормування антропічного відновлення порушеної літосфери з формуванням орієнтованих до культурного стану техногенних земельних ресурсів. Другим позитивним моментом слід вважати обов'язковість селективної розробки зонального грунтового покриву в межах земельного гірничого відводу та його подальше використання в процесі гірничотехнічного етапу відновлення техногенних ландшафтів і поліпшення малопродуктивних земель.

На нашу думку, у першій частині цієї статті законодавець вдається до наукової імітації, зазначаючи про «... поліпшення стану та продуктивності порушених земель». По-перше, ст. 171 ЗК України останні відносяться до деградованих земель, які повністю втратили господарську й еколого-економічну цінність, по-друге, фітопродуктивність техногенного ландшафту (і то лише як природної кормової бази в межах відпрацьованого кар'єру) мож- 
ливо визначити щонайменше через $10-15$ років і лише за умови повного заростання його поверхні рослинністю. Зазначимо, що на розривних фітотоксичних породах відвалів (наприклад, вугільні сланці) піонерна флора не утворюється протягом десятка років. Водночас 3-поміж комплексу загальних заходів рекультивації (організаційних, технічних, біотехнологічних) ЗК України не визначає основні правові засади природоохоронного техногенезу, економічний, гірничотехнологічний й агромеліоративний складники відновлення порушених ландшафтів.

Рекультивація (від лат. re - відновлення, cultus - оброблювання, обробіток, введення у використання) - це складна правова, економічна, технічна, агротехнологічна й природоохоронна категорія, яка потребує подальшого розвитку нормотворчої та правозастосовної практики. На нашу думку, невідкладним є здійснення законотворчої роботи щодо прийняття Закону України «Про рекультивацію земель», який закріпив би загальні та спеціальні принципи відновлення техногенних ландшафтів й ефективного ресурсокористування. Площа земель, порушених лише відкритими гірничими розробками, в Україні становить понад 165 тис. га, в тому числі відпрацьованих - на рівні 60 тис. га.

У контексті антропічнопідтримуваного розвитку техногеоекосистем і рекультивованих за напрямами морфоструктур новий закон повинен дати відповідь на найбільш актуальні питання, висунуті сучасними надбаннями науки та практики - грунтознавства, рекультознавства, землеробства, економіки, екології, права. Важливими концептуальними особливостями регулювання земельних відносин за надання спеціального дозволу на користування надрами, подальшого розвитку гірничого, земельного, екологічного, господарського права, які регламентують оцінювання негативних антропічних наслідків на біосферу, слід вважати з'ясування основних (змішаних) методів регулювання впливу техногенезу гірничодобувного комплексу на природні ресурси й відновлення порушених територій (гірничотехнічна й біологічна рекультивація).

Метою цієї статті $\epsilon$ науково-практичний аналіз принципів, методів і напрямів рекультивації, які мають бути закріплені в екологічному й земельному законодавстві України.

Виклад основного матеріалу. Вдосконалюючи систему екологічного й земельного законодавства, доцільно зосередитися на реалізації суттєвих проблем інституту рекультивації 3 подальшою імплементацією правових принципів збалансованого землекористування й охорони грунтів:

1. Зв'язок, який існує між землею (територіальний базис) як об'єктом економічних відносин у землекористуванні (природні й техногенні ландшафти, агросфера, розпайовані земельні сільськогосподарські масиви, землі для користування надрами тощо) та суб'єктним правовим режимом природного ресурсу й основного засобу виробництва в агросфері - тип(и) грунту/грунтів земельної ділянки.

Усі землі у межах території України поділені на категоpiї (ст. 19 ЗК України) відповідно до їх цільового призначення й перебувають у власності тих чи інших суб'єктів (ст. 80 ЗК України). Педосфера $є$ неоднорідною за своїм якісним станом «поверхневого (грунтового) шару» (ст. 79 ЗК України), який сформовано тривалою еволюцією природного грунтогенезу (зональний тип грунту) та змінюється під інтенсивним антропічним впливом (окультурювання, деградація) на культурний едафотоп в агроландшафтах чи малопродуктивні й деградовані землі. Класифікаційний список грунтів (планетарні біосферні утворення) нашої держави містить 36 генетичних типів (дерново-підзолисті, каштанові, лучні, лучно-чорноземні, чорноземи, солонці тощо).

Сучасну природно-антропічну родючість едафотопів («якісний стан грунтів», ст. 165 ЗК України) оціню- ють за допомогою бонітування (загального чи спеціального, ст. 199 ЗК України) агровиробничих груп грунтів. Природно-сільськогосподарське районування земель (ст. 179 ЗК України) - придатність агровиробничих груп грунтів для вирощування сільськогосподарських культур, ступінь антропічного перетворення едафотопів у зональних агроландшафтах, стан деградаційних процесів (ерозія, виснаження, забруднення тощо) $\epsilon$ агрономічною базою для обліку кількості та якості земель (ст. 203 ЗК України) і визначення економічної оцінки педосфери як природного ресурсу й засобу виробництва в народному господарстві (ст. 200 ЗК України) та грошової оцінки земельних ділянок (ст. 201 ЗК України).

3 урахуванням вищенаведеного в законодавчих і нормативних актах об'єктом правових відносин $є$ «земля», «земельна ділянка», «порушені землі», «деградовані й малопродуктивні землі», «землі фермерського господарства», «землі в межах території України», «особливо цінні землі» тощо. А еколого-генетичному типу (характерні діагностичні ознаки) грунтового покриву ландшафту законодавством помилково присвоюється подвійна дефініція «земля = грунт». Наукова сутність категорій «земля» та «грунт» взагалі не $є$ тотожною.

Земельний кодекс України, Закони України «Про Державний земельний кадастр», «Про землеустрій», «Про порядок виділення в натурі (на місцевості) земельних ділянок власникам земельних часток (паїв)», підготовлений законопроєкт «Про рекультивацію земель» і всі підзаконні акти органів Держгеокадастру/Держземагентства необхідно доповнити дефініцією «грунт», а організаційним «альфа й омега» у визначенні якості й рентної здатності земельної ділянки слід вважати генетичну номенклатурну одиницю природного ресурсу - тип грунту.

Грунт - специфічне поверхневе природно-історичне органо-мінеральне утворення в різних ландшафтнокліматичних умовах земної суші, яке характеризується в біоценозах природною, а в агрофітоценозах - природноантропічною родючістю, являє собою поліфункціональну систему, засіб виробництва й базову складову земельного просторового ресурсу. Кожний тип грунту характеризується особливою морфологією, агрохімічним складом, фізичними, біологічними й екотопічними властивостями.

2. За чинним земельним і гірничим законодавством України правове регулювання правовідносин у багаторічних ланцюгах трансформаційної системи: «природний/ аграрний ландшафти - землі промисловості - деградація ландшафтів і селективна розробка грунту - техногенні ландшафти - рекультивовані землі (категорії відновлених земель) - економічна оцінка антропічного ресурсу - еколого-економічна модель використання ноосферного продукту» не містить повних і грунтовних відповідей щодо раціонального природокористування, особливо в частині змін економічного й екологічного балансу антропічних систем у межах гірничого комплексу.

У степовій зоні Придніпров'я корисні копалини розташовані під поверхнею гірничого відводу, як правило у межах земель сільськогосподарського призначення (наприклад, гірничодобувні комбінати Нікопольського родовища марганцевих руд за відкритої розробки піролюзиту вже «поглинули» майже 35 тис. га сільгоспугідь). Розміри відшкодування втрат сільгоспвиробництва при вилученні земель для цілей гірничовидобувного комплексу дотепер визначаються за регіональними нормативами, затвердженими «плановою соціалістичною» Постановою Кабінету Міністрів України (далі - КМУ) від 17 листопада 1997 р. № 1279 зі змінами, внесеними згідно з Постановами КМУ [2], та не враховують істотних цінових і вартісних змін у промислово-аграрному ринковому виробництві.

Проблемними питаннями сучасності $є$ науково обгрунтована методика визначення втрат сільськогосподарського 
виробництва за земельні ділянки агросфери, вилучені для потреб промисловості, раціональне, нормоване цільове використання коштів, які надходять у порядку ст. 209 ЗК України та формування рентних платежів гірничо-металургійним комплексом на «незавершене виробництво»рекультивацію, природоохоронну діяльність і реалізацію державних соціальних програм.

У ринкових умовах необхідно виокремити й нормувати специфічні матеріальні об'єкти й елементи продуктивних сил і прогнозувати оцінку структурних змін в економічному розвитку, наприклад, Придніпровського регіону: природні ландшафти, агросферу, мінеральні ресурси, корисні копалини та забезпечення відтворювального процесу (рекультивація). Необхідно врахувати форми власності різнорідних природних ресурсів (державна, приватна) По-перше, «наднадрові» паї орних земель і природних угідь (природний ресурс агросфери, капіталізована грошова оцінка сільськогосподарських угідь) у межах гірничого відводу, по-друге, фізична (га, м $\left.^{3}, \mathrm{~T}\right)$ та вартісна (грн, \$) оцінка зональних типів грунтів і селективно сформованого об'єму родючого шару грунту в межах кар'єрного поля, запасів корисних копалин, їхнього корисного компоненту, початкова вартість продажу дозволу на право користування надрами, встановлення розміру екологічних i рентних платежів на період розробки родовища тощо.

У надрах Придніпровського регіону розвідано майже 300 родовищ різноманітних корисних копалин, 3 яких понад 90 розробляються. На нашу думку, рентна концепція вартості природних ресурсів (у межах гірничого відводу) залишається неврегульованою у відносинах між власниками земельних ділянок, підприємствами-природокористувачами й державою, а додатковий комерційний прибуток вигодонабувача, на нашу думку, досягається шляхом зменшення індексу екологічної ефективності гірничого виробництва.

3. Грунтовий покрив гірничого земельного відводу селективно розробляється в період підготовки кар'єрного поля до початкових розривних робіт. Стабільний протягом історичного часу природний матеріально-вартісний ресурс педосфери (зональний тип грунту) трансформується (виймальні й навантажувальні роботи, транспортування, формування бурта, використання за рекультиваціі) в новий техногенний субстрат - родючий шар грунту. Природні екологічні функції (біогеохімічні, біогеоценотичні, гідрологічні тощо) земельної ділянки гірничого відводу втрачаються, а родючий шар грунту, як правило, фосилізується в буртах зберігання («омертвілий» капітал - кошти, отримані від відшкодування втрат сільськогосподарського та лісогосподарського виробництва використовуються, на нашу думку, за недостатньо вичерпним переліком ч. 2 ст. 209 ЗК України), обліковується на підприємстві не в грошовому еквіваленті, а тільки в кількісних натуральних величинах $\left(\mathrm{T}, \mathrm{m}^{3}\right)$ і використовується «...згідно 3 затвердженим проєктом рекультивації < .. > у встановлені строки» (ст. 66, ст. 166 ЗК України). Зазначимо, що регіональні темпи рекультивації земель підприємствами гірничовидобувного комплексу України за останні 15 років знизилися у 2-8 і більше разів, а «бурштинові» - взагалі законодавчо ще не визначені.

Резюмуючи викладене з приводу землекористування в гірничовидобувній промисловості, законопроєкт «Про рекультивацію земель», державні стандарти, науковопрактичні рекомендації щодо відновлення порушених земель, нормативні акти повинні мати чітку поняттєву базу, нормативи правового регулювання суспільних відносин щодо збереження й раціонального використання зонального природного ресурсу: типи грунтів, 3 урахуванням науково-практичних здобутків грунтознавства, рекультивації земель і «земельної» економіки. Селективно розроблений родючий шар зональних грунтів і рекультивовані техноземи (антропічний матеріальний актив) у результаті техногенезу і фітомеліоративних заходів змінюють свою якість, як порівняти із зональними едафотопами. Відновлена земельна ділянка має розглядатися як техногенний (вторинний) продукт, а 3 моменту обліку іiі в регіональному землеустрої - як рекультивований засіб виробництва в народному господарстві 3 відповідними показниками якості. Держгеокадастр України рекультивовані угіддя обліковує (форма 6-зем) як землі, що перебувають у стадії меліоративного будівництва та відновлення родючості грунтів. На нашу думку, необхідно розробити/ вдосконалити форму звітності 3 рекультивації. Щонайменше доповнити графу 16 форми 6-зем рядками «землі в стадії гірничотехнічної рекультивації», «планова землеємність (м³/га) рекультивації», «рекультивовані землі в стадії фітомеліоративного (біологічного) відновлення〉 та виділити кількісний облік відновлених земель за напрямами рекультивації (землезбереження).

4. У контексті земельного права необхідно встановити цілісний зв'язок ст. ст. 66 і 146 ЗК України. Гірничодобувні підприємства використовують землі промисловості, які можуть перебувати в державній, комунальній і приватній власності (п. 2 ст. 66 ЗК України). Викуп земельних ділянок, які перебувають у власності громадян і юридичних осіб, для суспільних потреб можливий тільки для розміщення виробничих об'єктів державної та комунальної власності. На нашу думку, процедура такого викупу не може вважатися вичерпною за умови зміни категорій земель (ст. 19 ЗК України) та зміни цільового призначення земельної ділянки (ст. 20 ЗК України) в складі природного земельного фонду регіону та структури (за напрямами) відновленого техногенного ландшафту. Перелік суспільних потреб раціонального природокористування повинен врегулювати не лише ринкову вартість непорушеної земельної ділянки (бал бонітету грунтового покриву, нормативна грошова оцінка земельного відводу, спецдозвіл на право користування надрами чи його продаж), а й норму прибутковості надрокористувача, диференційну рентну систему оподаткування та вартість технічної («об'ємного» гектара) й біологічної (площа, термін) рекультивації відновленого техногенного ландшафту.

5. Гострим питанням натепер є розроблення спеціальної методики визначення грошової оцінки розпайованої земельної ділянки (власник/власники паю має/мають державний акт на право власності - матеріальний актив) при отриманні дозволу на користування надрами (підприємством, установою, організацією) та проєкту відведення природного чи аграрного ландшафту для гірничого відводу. Закон України «Про відчуження земельних ділянок, інших об'єктів нерухомого майна, що на них розміщені, які перебувають у приватній власності, для суспільних потреб чи 3 мотивів суспільної необхідності» (ст. 7) [3] передбачає, що в межах гірничого відводу розпайовані сільськогосподарські угіддя (матеріальний актив) можуть бути викуплені за рішенням районної державної адміністрації й переведені в землі промисловості. Продавцем виступають всі особи (пайовики) земельної ділянки сільськогосподарського призначення майбутнього гірничого відводу. Джерелом фінансування викупу можуть бути кошти відповідних бюджетів чи юридичних осіб, що ініціювали викуп (ст. 6). Цим Законом визначається (ст. 10), що в письмових нотаріально посвідчених умовах викупу земельної ділянки вказується ії орієнтовна (?) викупна ціна, а ст. 146 ЗК України передбачає, що вартість земельної ділянки встановлюється відповідно до грошової й експертної оцінки земель. Виникатимуть варіанти правих колізій визначення адекватної вартості земельної ділянки: який рівень капіталізованого рентного доходу слід вважати базовим у визначенні вартості паю (різні за якістю грунту) та всього масиву (за категоріями угідь) з урахуванням строку користування надрами (тимчасове, тривале (5-50 років) і понад 50 років), використовувати прийнятий 
регіональний норматив орендної плати, послуговуватися нормами ст. 201 ЗК України, землевласники можуть (не можуть) отримати ліцензію на розробку корисних копалин (ст. 95 ЗК України) чи зробити внесок вартості земельної ділянки та $i$-частки корисних копалин до статутних фондів гірничого підприємства тощо?

6. В межах гірничого відводу законодавством визначено подільність різнорідних природних мінеральних, біологічних і земельних ресурсів. По-перше, типи грунтів - матеріальна основа нерухомого майна (земельна ділянка як засіб виробництва) в агросфері та їхні якісні показники (бонітування грунтів передує їхній економічній оцінці в межах земельних угідь). Цінність цього ресурсу визначається рентним доходом земельної ділянки з урахуванням взаємообумовлених показників (валова продукція / вартість і рівень дисконтної ставки оцінки сільськогосподарських угідь). Втрачена вартість земельного ресурсу може визначатися як похідна від річної ренти. Викупна вартість земельної ділянки для надрокористувача може визначатися ринковою, нормативною, експертною, економічною чи інвестиційною ціною? Рекультивовані угіддя (за напрямами, наприклад, сільгоспугіддя та землі рекреації) як антропічний ресурс будуть мати різну відновлювану собівартість та господарську цінність. Натепер відсутні методики їхньої оцінки.

По-друге, корисні копалини 3 вмістом $i$-компонента певної якості. Їхня цінність для надрокористувачів і держави визначається вартістю мінерально-сировинних ресурсів (зазначимо, геологи визначають об'єми, економісти - вартість запасів ресурсу в надрах на строк використання родовища), розміром гірничої (природносировинної, екологічної) ренти (в тому числі конституційне право громадян України на їі частину), очікуваною величиною чистого дисконтного доходу підприємства тощо.

Реєстр земельних ділянок 3 «потрійним» природномінеральним ресурсом (типи грунтів, рослинний і тваринний світ, корисні копалини) має містити багатоваріантні системи показників економічної, екологічної, соціальної оцінки та результативності й враховувати початкову ціну продажу на аукціоні спеціального дозволу на право користування надрами, дисконтування грошових потоків для агросфери й гірничодобувного комплексу на території й у часі тощо.

7. Під час підготовки проєктів гірничого відводу на користування надрами необхідно нормувати зональні параметри селективної розробки родючого шару грунту (товщину гумусового профілю едафотопу й генетичних горизонтів), способи його технологічного зняття (колісний скрепер, грейдер, механічна лопата, бульдозер тощо), місця та площі для буртування, терміни ефективного зберігання (об'єм бурта, консервація/мінералізація гумусу, фізико-хімічні властивості, запобігання ерозії тощо).

8. Привести у практичну відповідність застарілу подвійну регламентацію розробки родючого шару грунту [4]: за вмістом $\mathrm{C}_{\text {орг }}$ у гумусованій частині профілю едафотопу понад $1 \%$ і нормовано визначеним у грунтознавстві морфологічним показником ступінь чіткості (контрастності) горизонтів грунту (різкий $\pm 1 \mathrm{~cm}$, помітний $\pm 5 \mathrm{~cm}$, поступовий - понад $5 \mathrm{~cm}$ ). Водночас технічно можливим мінімальним показником механізованої селективної розробки родючого шару едафотопу (скрепер з підштовхувачем) визначено \pm 10 см. На сьогодні маємо науково-технологічну колізію в показниках генетичного грунтознавства й експлуатаційних характеристиках гірничих машин і механізмів, які використовуються у розривних роботах. Це ускладнює визначення «планової» діагностики антропічної деградації зонального грунту за морфогенетичними ознаками та трофністю сформованого вторинного ресурсу - родючого шару грунту.

9. Необхідно нормувати середній вміст гумусу (екологічно значущий фактор в рекультознавстві) в селективно розробленому родючому шарі зональних грунтів і його змінені спеціалізовані екологічні функції (особливо акумулятивну). Нами встановлено [5], що частка генетичних горизонтів чорнозему звичайного (H, Hpk, Phk) за показником «вміст гумусу в родючому шарі грунту» $\epsilon$ найбільш змінним показником і становить 63,3\%, 19,7\% і 13,8\% відповідно. Зазначимо, що антропічно сформований родючий шар грунту характеризується «техногенно набутими» властивостями: карбонатністю, полімодальним вмістом $\mathrm{C}_{\text {орг }}$ в гумусованому профілі технозему, співвідношення гумусових кислот, елементів живлення, водним, повітряним, термічним режимами, структурою тощо. Профіль технозему має різкий бімодальний (на межі з підстилковою породою) показник родючості в рекультивованому шарі.

10. 3 урахуванням вищенаведеного нами в п. 7-9 зазначимо, що ЗК України не розкриває поняття «знищення», «псування», «погіршення» як земельної ділянки гірничого відводу, так і її грунтового покриву (ст. 166, ч. 3 ст. 211). Вважаємо, що правові норми цих статей для розроблення проєктів рекультивації мають недостатню науково-практичну консолідацію та потребують додаткового обгрунтування з урахуванням негативного впливу техногенезу на зональні грунти, трофності родючого шару грунту, напрямів рекультивації та якісних показників відновлених земель.

11. Затвердити зональну структуру норм проєктних напрямів і планових строків рекультивації з урахуванням видів (поверхневий, глибокий, нагірний, бурштинові поклади тощо) відкритих (і не лише) гірничих розробок: сільськогосподарський (цільове використання - рілля, сінокоси, пасовища, багаторічні насадження), лісогосподарський, рекреаційний, заповідний, санітарно-гігієнічний, комбінований тощо. Нормувати будову (стратиграфію) профілю антропічних формувань: технозем, літозем, хемозем, для багаторічних насаджень, за іншими господарськими напрямами рекультивації тощо. Проєктні техно-економічні й технологічні рішення з рекультивації мають враховувати об'єми землеємності ( м $^{3} / г$ га нефітотоксичних порід і родючого шару грунту) у відновленні техногенних ландшафтів.

12. Розробити й затвердити зональні методики фітомеліорацій у період біологічного етапу/етапів рекультивації, їхню тривалість (з урахуванням природно-фіто-хемо-еволюційних змін за цей період), бонітування відновлених земель і їхню нормативно-грошову оцінку, преференції землекористувачам відновлених ділянок у період їхнього цільового освоєння (зменшення розміру податків і платежів чи звільнення від їх сплати, виконання додаткових планувань поверхні й підсипка родючим шаром грунту за необхідності тощо) і їхній термін.

13. У процесі поточної рекультивації створюється новий антропічний матеріальний ресурс, відновлений за напрямом геотехноландшафт. Вартість рекультивації порушених земель $є$ великозатратною й малопрогнозованою величиною - розробка родовища корисних копалин / ділянки надр передбачає довгостроковий період і характеризується змінними факторами виробництва: геологічні ризики, економічна оцінка запасів корисних копалин, ціна мінеральної сировини (внутрішня, експортна), вартість грошей і ціна матеріальних ресурсів у часі, щорічні виробничі й експлуатаційні витрати, ціна нових матеріальних ресурсів тощо. Планові витрати на проєкти рекультивації земель закладаються у вартість будівництва гірничорудного об'єкта, а поточні витрати коштів на технічний і біологічний етапи відновлення техногенного ландшафту відносять на собівартість корисних копалин. Відновлення техногенного ландшафту здійснюється за рахунок коштів забезпечення зобов'язувальної події «незавершена екобезпечна рекультивація гірничовидобувного комплексу» 3 невизначеним строком їхнього 
погашення та ситуативно-рахунковою собівартістю рекультивації (досить часто приблизною й важкопрогнозованою) тощо.

На нашу думку, зниження темпів рекультивації порушених земель в Україні можливо розглядати непрямим показником отримання надприбутків надрокористувачами шляхом привласнювання значної частини «синергетичної» ренти (екологічна, гірнича, земельна, монопольна, імпортна тощо). Зазначимо, що в період завершення експлуатації родовища корисних копалин витрати на відновлення техногенного ландшафту доходами підприємства не будуть забезпечені.
Висновок. Підсумком дослідження є висновок-сподівання, що держава має переглянути пасивне ставлення до інституту рекультивації та успішно вирішувати проблеми ресурсозбереження й еколого-економічної ефективності в гірничодобувному виробництві. Запорукою покращення природоохоронного національного законодавства має бути розроблений і прийнятий Закон України «Про рекультивацію земель». Державні стандарти й нормативи з відновлення порушених земель мають враховувати вищенаведені суттєві положення, основоположні засади та ідеї природничо-технологічної дисципліни «Рекультознавство».

\section{ЛITEPATYPA}

1. Земельний кодекс України : Закон України від 25 жовтня 2001 р. № 2768-III. URL: https://zakon.rada.gov.ua/laws/show/2768-14

2. Про розміри та Порядок визначення втрат сільськогосподарського і лісогосподарського виробництва, які підлягають відшкодуванню : Постанова Кабінету Міністрів України від 17 листопада 1997 р. № 1279. URL: https://zakon.rada.gov.ua/laws/show/1279-97-\%D0\%BF.

3. Про відчуження земельних ділянок, інших об'єктів нерухомого майна, що на них розміщені, які перебувають у приватній власності, для суспільних потреб з мотивів суспільної необхідності : Закон України від 17 листопада 2009 р. № 1559-VI. URL: https://zakon.rada.gov.ua/ laws/show/1559-17.

4. ГОСТ 17.5.3.06-85. Охрана природы. Земли. Требования к определению норм снятия почвы при производстве земляных работ. Москва, 1985. 12 с.

5. Концептуальные основы устойчивого развития нарушеных природных экосистем / А.А. Демидов и др. Днепропетровск : Изд-во «Свидлер А.Л.», 2012. 124 с. 
УДК 349.6

DOI https://doi.org/10.32782/2524-0374/2020-4/26

\title{
ПРАВОВЕ РЕГУЛЮВАННЯ РЕАЛІЗАЦІЇ МОНІТОРИНГОВОӤ ФУНКЦІЇ УПРАВЛІННЯ У СФЕРІ ФАУНІСТИЧНИХ ПРАВОВІДНОСИН І ШЛЯХИ ЙОГО ВДОСКОНАЛЕННЯ
}

\author{
LEGAL REGULATION OF THE IMPLEMENTATION \\ OF THE MONITORING FUNCTION OF MANAGEMENT IN THE FIELD \\ OF FAUNAL LEGAL RELATIONS AND WAYS TO IMPROVE IT
}

\author{
Шеховцов В.В., к.ю.н., доцент, \\ доцент кафедри екологічного права \\ Національний юридичний університет імені Ярослава Мудрого
}

Статтю присвячено дослідженню науково-теоретичних і законодавчих засад методології реалізації функції моніторингу тваринного світу як однієї з функцій екологічного управління. У роботі встановлено, що ефективність реалізації кожної з них залежить від дієвості засобів, що застосовуються для реалізації інших функцій. Акцентується на нерозривному зв'язку елементів (окремих функцій), які формують певну цілісність, єдність.

Обґрунтовується теза про те, що неефективність реалізації функції моніторингу має визначальний вплив на можливості всієї системи функцій управління у сфері охорони й використання тваринного світу. Засоби для її втілення характеризуються поверхневими й формальними підходами й не задовольняють сучасні потреби формування злагодженої системи спостереження за дикою фауною. Адже ця система має бути надійним джерелом інформації про стан і тенденції розвитку тваринного світу, необхідної для прийняття екологічно значущих рішень.

Установлено, що управління в галузі охорони й використання об'єктів тваринного світу є елементом загальної системи управління у сфері охорони навколишнього природного середовища в поєднанні з рештою пов'язаних елементів - іншими функціями управління.

Обґрунтовано, що під екологічним моніторингом можна розуміти злагоджену систему спостереження за навколишнім природним середовищем, за якого забезпечується безперервне оцінювання умов середовища проживання людини та біоти.

Робиться висновок про те, що основні завдання системи екологічного моніторингу можна звести до трьох: 1) спостереження за фракторами, що впливають на навколишнє середовище; 2) оцінка фактичного стану навколишнього середовища; 3) оцінка прогнозованого стану природного середовища.

У роботі також запропоновано перелік заходів, необхідних до впровадження задля формування перспектив розвитку фауністичного й екологічного законодавства у сфері реалізації фрункцій екологічного моніторингу.

Ключові слова: функції управління, екологічний моніторинг, моніторинг у сфері реалізації фауністичних правовідносин, фауністичне законодавство, охорона навколишнього природного середовища.

The article is devoted to the study of scientific-theoretical and legislative bases of the methodology of realization of the function of monitoring the fauna as one of the functions of ecological management.

The paper establishes that the effectiveness of each of them depends on the effectiveness of the tools used to implement other functions. Emphasis is placed on the existence of an inseparable connection of elements (individual functions), which are interrelated and form a certain integrity, unity.

The thesis is substantiated that the inefficiency of the implementation of the monitoring function has a decisive influence on the possibility of functioning of the entire system of management functions in the field of protection and use of wildlife. The tools used for its implementation are characterized by superficial and formal approaches and do not meet the modern needs of a coordinated system of wildlife monitoring, which should be a reliable source of information about the state and trends of wildlife needed to make environmentally significant decisions.

It is established that management in the field of protection and use of wildlife takes the place of an element of the general management system in the field of environmental protection in combination with other related elements - other management functions.

It is substantiated that ecological monitoring can be understood as a coordinated system of environmental monitoring, which provides a continuous assessment of human habitat and biota conditions.

It is concluded that the main tasks of the environmental monitoring system can be reduced to three: 1) observation of factors affecting the environment; 2) assessment of the actual state of the environment and 3) assessment of the forecasted state of the natural environment.

The paper also proposes a list of measures necessary for implementation in order to form prospects for the development of faunal and environmental legislation in the field of implementation of environmental monitoring functions.

Key words: management functions, ecological monitoring, monitoring in sphere of realization of faunal legal relations, faunal legislation, environmental protection.

Постановка проблеми. Моніторинг тваринного світу $\epsilon$ однією $з$ функцій екологічного управління, значення якого полягає в об'єднувальній ролі, яку відіграє його реалізація для інших функцій - прогнозування та планування. Ефективність реалізації кожної з них залежить від дієвості засобів, що застосовуються для реалізації інших функцій. Саме тому, говорячи як про функції моніторингу тваринного світу, так і екологічного моніторингу в цілому, слід наголошувати на нерозривному зв'язку елементів (окремих функцій), що є взаємовідносними один до одного й формують певну цілісність, єдність.

Неефективність реалізації функції моніторингу чинить визначальний вплив на можливість функціонування всієї системи функцій управління у сфері охорони й використання тваринного світу. Засоби, які використовуються для iii втілення, характеризуються поверхневими й формальними підходами та не задовольняють сучасних потреб формування злагодженої системи спостереження за дикою фауною, яка має бути надійним джерелом інформації про стан і тенденції розвитку тваринного світу, необхідної для прийняття екологічно значущих рішень.

Аналіз останніх досліджень і публікацій. Окремі науково-методологічні засади формування функцій управління в галузі природокористування й охорони довкілля досліджувалися такими представниками вітчизняної еколого-правової науки, як В.І. Андрейцев, А.П. Гетьман, B.M. Завгородня, В.А. Зуєв, I.I. Каракаш, Н.Р. Кобецька, В.М. Комарницький, В.В. Костицький, Н.В. Кручиніна, І.О. Солошич, Ю.О. Цибульський, Ю.С. Шемшученко, В.М. Шмандій, М.В. Шульга, та іншими вченими. Представлені дослідження більшою мірою характеризуються своєю комплексністю у підходах до розуміння, характеристики й систематизації функцій екологічного управління, що, безумовно, становить надзвичайну цінність для 
розвитку науки екологічного права. Однак, єдиної методології в побудові системи функцій екологічного управління так і не було досягнуто. Проблематика ж функцій управління в галузі охорони й використання тваринного світу $\epsilon$ малодослідженою й становить свою самостійну актуальність, зважаючи на специфічні особливості та значущість, яку отримують процеси їх реалізації в цій сфері.

Формулювання цілей статті. Зважаючи на ознаки, притаманні законодавчій моделі архітектоніки системи державного моніторингу навколишнього природного середовища i, зокрема, моніторингу тваринного світу, запропонувати заходи перспективного розвитку фауністичної нормативно-правової бази в цьому напрямі.

Виклад основного матеріалу. Термін «моніторинг тваринного світу» $є$ похідним від термінів «екологічний моніторинг», «моніторинг навколишнього природного середовища», «моніторинг довкілля», які, як зазначає А.П. Гетьман, в еколого-правовій науці вживаються як синоніми, проте їхнє визначення так і не сформовано $[1$, c. 74]. Дослідження моніторингової сфери фауністичних правовідносин досі залишаються доволі скромними, хоча іiі значення $є$ одним із найактуальніших у напрямах охорони об'єктів тваринного світу.

Виокремлюючи цю функцію 3-поміж інших функцій фауністичного управління, Н.Р. Малишева визначає моніторинг тваринного світу як систему спостережень, збирання, оброблення, передавання й аналізу інформації про стан об'єктів тваринного світу, прогнозування його змін i розроблення науково обгрунтованих рекомендацій для прийняття управлінських рішень [2, с. 419].

Такі підходи демонструють значення моніторингу тваринного світу як функції управління, адже в цьому контексті управління в галузі охорони та використання об'єктів тваринного світу є елементом загальної системи управління у сфері охорони навколишнього природного середовища в поєднанні з рештою пов'язаних елементів іншими функціями управління.

Тваринний світ як природний ресурс, елемент навколишнього природного середовища, зазначає Ю.С. Петлюк, виконує екологічну, економічну та соціальну функції, реалізація яких потребує застосування різноманітних засобів. Одним з ефективних засобів забезпечення комплексної охорони, раціонального використання й відтворення об'єктів тваринного світу є їхній моніторинг, унаслідок здійснення якого реалізується прогностична функція у вигляді своєчасного запобігання, виявлення й усунення наслідків негативних явищ і процесів 3 метою забезпечення науково обгрунтованого використання об'єктів тваринного світу зокрема та збереження біологічного різноманіття загалом [3, с. 20]. Таким чином, уже на цьому етапі можна поєднати декілька екологічних функцій у нерозривний ланцюг «моніторинг - прогнозування - планування». У цій системі функції слідують одна за одною, одночасно розвиваючи попередню.

У загальному значенні термін «моніторинг» вживається як довгострокове, стандартизоване вимірювання, спостереження, оцінювання навколишнього середовища та звітування 3 метою визначення його стану й тенденцій $[4$, c. 2]. Закон України «Про охорону навколишнього природного середовища» [5] передбачає створення в Україні системи державного моніторингу навколишнього природного середовища з метою збирання, оброблення й аналізу інформації про стан навколишнього природного середовища, прогнозування його змін і розроблення науково обгрунтованих рекомендацій для прийняття ефективних управлінських рішень (ст. 22). Порядок створення та функціонування такої системи в Україні передбачається Положенням про державну систему моніторингу довкілля [6], яким визначається, що державна система моніторингу довкілля - це система спостережень, збирання, оброблення, передавання, збереження й аналізу інформації про стан довкілля, прогнозування його змін і розроблення науково обгрунтованих рекомендацій для прийняття рішень про запобігання негативним змінам стану довкілля та дотримання вимог екологічної безпеки (п. 1).

Таким чином, під екологічним моніторингом можна розуміти злагоджену систему спостереження за навколишнім природним середовищем, за якого забезпечується безперервне оцінювання умов середовища проживання людини та біоти.

Перераховані ознаки дають змогу констатувати, що в основу побудови системи моніторингу довкілля має бути покладений принцип управління на основі систематичного аналізу отримуваної інформації про якість навколишнього природного середовища. Звісно, система моніторингу не охоплює діяльності з управління якістю середовища, але є джерелом інформації, необхідної для прийняття екологічно значущих рішень.

Основні завдання екологічного моніторингу в літературі сформульовано у вигляді декількох тез:

- спостереження за джерелом антропогенного впливу;

- спостереження за фактором антропогенного впливу; спостереження за станом природного середовища під впливом факторів антропогенного впливу й оцінка прогнозованого стану природного середовища [7, с. 14].

Інакше кажучи, основні завдання системи екологічного моніторингу можна звести до трьох: 1) спостереження за факторами, що впливають на навколишнє середовище; 2) оцінка фактичного стану навколишнього середовища; 3 ) оцінка прогнозованого стану природного середовища.

Спостереження за станом навколишнього природного середовища, рівнем його забруднення здійснюється центральним органом виконавчої влади, що реалізує державну політику у сфері охорони навколишнього природного середовища, іншими спеціально уповноваженими державними органами, а також підприємствами, установами й організаціями, діяльність яких призводить або може призвести до погіршення стану навколишнього природного середовища.

У контексті виконання управлінських обов'язків зі здійснення екологічного моніторингу важливою $є$ узгодженість завдань, що стоять перед самим екологічним моніторингом як процесом, і завдань, прописаних для суб'єктів цієї діяльності.

Положенням про державну систему моніторингу довкілля [6] передбачено ряд завдань, що мають виконувати суб'єкти системи моніторингу: 1) довгострокові систематичні спостереження за станом довкілля; 2) аналіз екологічного стану довкілля та прогнозування його змін; 3) інформаційно-аналітична підтримка прийняття рішень у галузі охорони довкілля, раціонального використання природних ресурсів й екологічної безпеки; 4) інформаційне обслуговування органів державної влади, органів місцевого самоврядування, а також забезпечення інформацією про стан довкілля (екологічною інформацією) населення країни й міжнародних організацій.

Таким чином, завдання суб'єктів системи моніторингу у своєму розширеному вигляді охоплюють завдання екологічного моніторингу як системи, що, безсумнівно, $€$ позитивним, хоча й передбачуваним. Інше питання полягає в логічності й доцільності розподілу цих завдань між суб'єктами, які покликані його здійснювати задля досягнення якомога вищої ефективності в цій діяльності, досягти якої, на жаль, як виявляється, не вдається.

Так, за результатами розгляду Рахунковою палатою України аудиту ефективності використання коштів державного бюджету, спрямованих на розвиток і функціонування єдиної державної системи моніторингу навколишнього природного середовища, визначається, що чинна система моніторингу навколишнього природного середовища не досягає мети створення, не забезпечує отримання повної, своєчасної й узгодженої інформації, унеможливлює фор- 
мування оперативних прогнозів змін навколишнього природного середовища, що створює ризики для національної безпеки держави в екологічній сфері. Зазначено, що факторами впливу на такий стан $\epsilon$, зокрема, недостатність організаційного, нормативно-методичного забезпечення й обмеженість фінансових ресурсів держави $[8 ; 9$, с. 7].

Організаційне забезпечення системи державного екологічного моніторингу здійснюють окремі органи виконавчої влади: Міністерство енергетики та захисту довкілля України, Міністерство розвитку економіки, торгівлі та сільського господарства України, Державне агентство України з управління зоною відчуження (ДАЗВ), Державна служба геології та надр України (Держгеонадра), Міністерство розвитку громад та територій України (Мінрегіон), Державне космічне агентство України (ДКА), а також Державна служба України з надзвичайних ситуацій (ДСНС), Держлісагентство, Держводагентство, Держгеокадастр і їхні територіальні органи, підприємства, установи й організації, що належать до сфери їхнього управління, обласні, Київська та Севастопольська міські держадміністрації, а також орган виконавчої влади Автономної Республіки Крим з питань охорони навколишнього природного середовища $[1$, с. 75$]$. Кожен із зазначених суб'єктів здійснює моніторинг тих об'єктів довкілля, що входять до обсягу його повноважень і передбачені Положенням про державну систему моніторингу довкілля, порядками й положеннями про державний моніторинг окремих видів.

«Моніторинг тваринного світу здійснюється за дикими тваринами, що відносяться до об'єктів полювання, та середовищем їх перебування; дикими тваринами, що відносяться до об'єктів рибальства, та середовищем їх перебування; дикими тваринами, включеними до Червоної книги України, та середовищем їх перебування; дикими тваринами, що відносяться до об'єктів міжнародно-правової охорони, та середовищем їх перебування» [10, с. 127]. Здійснення моніторингу тваринного світу, як вважає С.В. Шарапова, є недосконалим і має узагальнений, опосередкований характер [11, с. 188]. В основному акті фауністичного законодавства - Законі України «Про тваринний світ» [12] зазначено лише те, що моніторинг $€$ засобом забезпечення охорони тваринного світу (ст. 37) і складовою частиною моніторингу навколишнього природного середовища та здійснюється відповідно до Закону України «Про охорону навколишнього природного середовища» [5] (ст. 55). Можна погодитися з Ю.С. Петлюк у тому, що наявність таких дискусійних питань у зазначеній сфері правовідносин обумовлює необхідність прийняття Кабінетом Міністрів України постанови про затвердження Положення про моніторинг тваринного світу, у якому мають відображатися всі проблемні аспекти проведення цього виду екологічного моніторингу [3, с. 21].

Нагальність вжиття таких заходів обумовлюється будовою й структурою законодавства, яке засноване на загальних поняттях екологічного моніторингу та $\epsilon$ дуже скупим у розкритті окремих його форм і видів, що в цьому відношенні вносить певну дисфункціональність за впровадження цієї функції в більш вузьку сферу.

Лише з загального юридичного аналізу ми можемо встановити, що безпосередніми суб' єктами моніторингу тваринного світу 3 перерахованих вище $\epsilon$ Міністерство енергетики та захисту довкілля України, Держлісагентство та відповідно їхні територіальні органи, підприємства, установи й організації, що належать до сфери їхнього управління.

Так, Міністерство енергетики та захисту довкілля України здійснює моніторинг видів рослинного й тваринного світу, які перебувають під загрозою зникнення, та видів, що перебувають під особливою охороною; Держлісагентство - мисливської фауни (видові, кіль- кісні та просторові характеристики). Ці функції та задачі передбачені Положенням про державну систему моніторингу довкілля [6], проте слід зауважити, що, незважаючи на перелік завдань моніторингу, покладених на інші органи, які не належать до моніторингу тваринного світу, усі вони утворюють цілісну структуру, яка має грунтуватися на взаємній інформаційній підтримці, координаціï, ефективному використанні наявних організаційних структур тощо. Суттєвими повноваженнями в цій галузі наділений спеціальний орган виконавчої влади - Державна екологічна інспекція, що забезпечує реалізацію державної політики зі здійснення державного нагляду (контролю) у сфері охорони навколишнього природного середовища, раціонального використання, відтворення й охорони природних ресурсів.

На суб'єктів системи екологічного моніторингу, в тому числі й фауністичного, покладено завдання забезпечити вдосконалення підпорядкованих їм мереж спостережень за станом довкілля, уніфікацію методик спостережень і лабораторних аналізів, приладів і систем контролю, створення банків даних для їхнього багатоцільового колективного використання за допомогою єдиної комп'ютерної мережі, яка забезпечує автономне й спільне функціонування складових частин цієї системи та взаємозв'язок 3 іншими інформаційними системами, які діють в Україні й за кордоном. Однак, як підкреслюється в Аналітичній записці «Механізми мінімізації корупції в реалізації державного контролю та нагляду за довкіллям», цього так і не зроблено [9, с. 7]. Постанова ж, якою визначено ці завдання, датована 1998 p.

Щоправда, екологічне, і зокрема фауністичне, моніторингове законодавство поступово розвиваються: у 2018 р. Кабінетом Міністрів України було прийнято Постанову «Про затвердження критеріїв, за якими оцінюється ступінь ризику від провадження господарської діяльності у сфері мисливського господарства та полювання...» [13], яка загалом справила вплив на його розвиток, проте є далекою від виконання основних завдань, закладених за їхнього формування для системи екологічного моніторингу.

Також Положенням про державну систему моніторингу довкілля [6] зазначено, що організаційна інтеграція суб'єктів системи моніторингу здійснюється Мінприроди, обласними, Київською та Севастопольською міськими держадміністраціями, органом виконавчої влади Автономної Республіки Крим з питань охорони навколишнього природного середовища. Однак упровадження в практику цих положень також відсутнє.

Висновки і перспективи. Перспективи розвитку фауністичного й екологічного законодавства у сфері реалізації функцій екологічного моніторингу можуть полягати у запровадженні таких заходів, як-от:

створення умов для співпраці окремих ланок (органів) екологічного моніторингу задля реального обміну інформацією, баз даних зі спільним доступом;

запровадження єдиної моніторингової системи (загальнодержавного, регіонального та локального рівнів) діяльності управлінських органів з можливістю публічного доступу до неї;

розроблення й затвердження галузевих нормативно-правових актів (положення про моніторинг тваринного світу та інших), які б відображали специфіку здійснення моніторингу в кожній сфері відносин природоохоронного характеру;

створення бази даних фізичних осіб і суб' єктів господарювання, що отримали дозвільні документи на провадження певної діяльності;

максимальне оприлюднення діяльності органів екологічного моніторингу з зафіксованими порушеннями діяльності окремих суб'єктів і результатами розгляду таких випадків; 
- посилення й заохочення розвитку екологічних моніторингових заходів на самоврядному, громадському та внутрішньому (виробничому) рівнях.

Ратифікація Україною Орхуської конвенції «Про доступ до інформації, участь громадськості в процесі прийняття рішень і доступ до правосуддя 3 питань, що стосуються довкілля» [14] допоки жодним чином не віднайшла переважного відображення на стані як нормативної, так і практичної складової частини системи державного екологічного моніторингу. Належна реаліза- ція цієї функції має надважливе значення для системи екологічного управління, адже «інформація, що зберігається в системі моніторингу, використовується для прийняття рішень у галузі охорони довкілля, раціонального використання природних ресурсів й екологічної безпеки органами державної влади та органами місцевого самоврядування...» $[1$, с. 76$]$, а отже, є передумовою й основою прийняття таких рішень, напрямом, за яким формується практика діяльності органів екологічного управління.

\section{ЛITEPATYPA}

1. Екологічне право : підручник / А.П. Гетьман та ін. ; за ред. А.П. Гетьмана. Харків : Право, 2019, 552 с.

2. Малишева Н.Р. Основні функції управління в галузі охорони навколишнього природного середовища. Екологічне право України. Академічний курс : підручник / за заг. ред. Ю.С. Шемшученка ; Інститут держави і права ім. В.М. Корецького НАН України, Київський університет права. 2-ге вид. Київ : Юридична думка, 2008. 720 с.

3. Петлюк Ю.С. Правове забезпечення реалізації функцій управління в галузі фауністичних відносин. Науковий вісник Ужгородського національного університету, Серія «Право». 2019. Вип. 55. Т. 2. С. 19-22.

4. Aighewi I.T., Ekundayo E.O. Monitoring of the Environment as a Whole. Encyclopedia of life support systems. Vol. 1. Environmental monitoring. 2009. $449 \mathrm{p}$.

5. Про охорону навколишнього природного середовища : Закон України від 25 червня 1991 р. № 1264-XII. Biдомості Верховної Ради України. 1991. № 41. Ст. 546.

6. Про затвердження Положення про державну систему моніторингу довкілля : Постанова Кабінету Міністрів України від 30 березня 1998 р. № 391. Офьіиійний вісник України. 16 квітня 1998 р. № 13. С. 91.

7. Ашихмина Т.Я., Васильева А.Н. Экологический мониторинг : учебное пособие. Москва : Академический Проект, 2006. 416 с.

8. Рішення Комітету з питань екологічної політики, природокористування та ліквідації наслідків Чорнобильської катастрофи щодо результатів розгляду Рахунковою палатою України аудиту ефективності використання коштів державного бюджету, спрямованих на розвиток та функціонування єдиної державної системи моніторингу навколишнього природного середовища № 34/21 від 30 березня 2016 р. URL: http://consultant.parus.ua/?doc=0A0M87F9B9 (дата звернення 16.04.2020).

9. Механізми мінімізації корупції в реалізації державного контролю та нагляду за довкіллям: Аналітична записка. URL: https://rpr.org.ua/wp-content/uploads/2018/04/Analytical-note_Ecology-Final.pdf (дата звернення 30.03.2020).

10. Киселюк О.І., Тимочко В.Б. Моніторинг фауни на природно-заповідних територіях. Науковий вісник Національного лісотехнічного університету України. 2011. Вип. 21. № 16. С. 126-131.

11. Шарапова С.В. Екологічний моніторинг у правовідносинах використання природних ресурсів. Проблеми законності. 2008. Вип. 85. С. $185-188$

12. Про тваринний світ : Закон України від 13 грудня 2001 р. № 2894-III. Голос України. 2002. 16 січня. № 9.

13. Про затвердження критеріїв, за якими оцінюється ступінь ризику від провадження господарської діяльності у сфері мисливського господарства та полювання і визначається періодичність проведення планових заходів державного нагляду (контролю) Державним агентством лісових ресурсів : Постанова Кабінету Міністрів України від 27 грудня 2018 р. № 1210. Урядовий кур’єр. 6 лютого 2019 р. № 24.

14. Про ратифікацію Конвенції про доступ до інформації, участь громадськості в процесі прийняття рішень та доступ до правосуддя з питань, що стосуються довкілля : Закон України від 6 липня 1999 р. № 832-XIV. Відомості Верховної Ради України. 1999. № 34 . Ст. 296. 
УДК 349.6

DOI https://doi.org/10.32782/2524-0374/2020-4/27

\title{
ЕФЕКТИВНІСТЬ СПОСОБІВ ЗАХИСТУ ПРАВ НА ЗЕМЛЮ: ПРОБЛЕМИ СУДОВОЇ ПРАКТИКИ
}

\section{THE EFFECTIVENESS OF LAND RIGHTS PROTECTION METHODS: JUDICIAL PRACTICE PROBLEMS}

\author{
Яремак 3.В., к.ю.н., доцент, \\ доцент кафедри трудового, екологічного та аграрного права \\ Прикарпатський національний університет імені Василя Стефаника
}

У статті здійснено теоретико-правове дослідження способів захисту прав на землю, закріплених у Земельному кодексі України, на предмет оцінки їх ефективності, ґрунтуючись на новелах матеріального та процесуального законодавства. Зроблено висновок про те, що законодавче закріплення способів як юридичних гарантій захисту прав на землю $є$ недостатнім для реального захисту порушеного земельного права.

На основі проведеного аналізу змісту способів захисту прав на землю обґрунтовано, що їх роль і значення неоднакові: кожен спосіб захисту має свої особливості, різне функціонально-цільове спрямування та умови застосування. 3 огляду на різноманітність способів захисту земельних прав досліджено проблему обрання оптимального способу захисту в конкретній ситуації, за допомогою якого можна запобігти, припинити, усунути порушення права, відновити, а також компенсувати збитки, заподіяні його порушенням.

Аналіз судової практики дозволив зробити висновок про те, що неправильне обрання особою способу захисту порушених земельних прав тягне настання негативних наслідків як у процесуальному аспекті (відмова у задоволенні судом позову), так і в матеріальному плані (неможливість захистити порушене право).

Виявлену проблему правозастосування запропоновано вирішити шляхом законодавчого закріплення критеріїв належного та ефективного способу захисту порушеного права. Легітимне закріплення критеріїв ефективності способів захисту дасть можливість особі обрати найбільш оптимальний спосіб захисту порушеного права чи інтересу. 3 цього приводу досліджено наукові підходи до визначення критеріїв ефективності способів захисту.

Запропоновано дослідження ефективності способів захисту земельних прав здійснювати в контексті положень ст. 13 Конвенції про захист прав людини і основоположних свобод та на основі тлумачення ії̈ змісту Європейським судом з прав людини. Зроблено висновок про те, що ефективним буде той засіб захисту, за допомогою якого можна запобігти, припинити, усунути порушення права, відновити та компенсувати збитки, заподіяні їх порушенням; при цьому орган, що розглядає скаргу по суті, для захисту порушеного права вправі використовувати всі способи, які передбачені у національному праві.

Ключові слова: спосіб захисту прав на землю, ефективний спосіб захисту, критерії ефективності, ефективний засіб правового захисту.

The article carries out a theoretical and legal research in land rights protection ways enshrined in the Land Code of Ukraine, for effectiveness evaluation, based on the novels of Substantive and Procedural Legislation. It is concluded that the legislative consolidation of methods as legal guarantees for the land rights protection is insufficient for the actual protection of the violated land right.

Based on the analysis of the content of land rights protection methods, it is substantiated that their role and significance are different: each method of protection has its own characteristics, different functional and target direction and conditions of application. Given the variety of ways to protect land rights, the problem of choosing the optimal method of protection in a particular situation, which can prevent, stop, eliminate violations, restore and compensate for the damage caused by its violation.

The judicial practice analysis allowed us to conclude that the person's wrong choice of ways of the violated land rights protection entails negative consequences both in the procedural aspect (refusal to satisfy the claim by the court) and in material terms (inability to protect the violated right).

It is proposed to solve the identified problem of law enforcement by legislating the criteria of a proper and effective way to protect the violated right. Legitimate consolidation of the criteria for the effectiveness of protection methods will allow a person to choose the most optimal way to protect the violated right or interest. In this regard, scientific approaches to determining the criteria for the effectiveness of protection methods have been studied.

The effectiveness of methods of land rights protection is proposed to research in the context of the provisions of Art. 13 of the Convention for the Protection of Human Rights and Fundamental Freedoms and on the basis of the interpretation of its content by the European Court of Human Rights It is concluded that the effective means of protection will be the one that can be used to prevent, stop, eliminate violations of the law, restore and compensate for the damages caused by their violation; in this case, the body considering the complaint on the merits has the right to use all the means provided by the National Legislation.

Key words: way of land rights protection, effective way of protection, criteria of efficiency, effective means of legal protection.

Наявність чітких законодавчих механізмів захисту земельних прав у разі їх порушень виступає важливою гарантією стабільності земельних правовідносин, ефективного використання та охорони земель як основного національного багатства України, задоволення особистих і майнових потреб [1, с. 64]. Земельний кодекс України (далі - ЗК України) [2] містить самостійний правовий інститут гарантій прав на землю (розділ V). 3 огляду на загальні положення ст. 5 ЗК України забезпечення гарантій прав на землю є одним із визначальних у системі принципів земельного законодавства. Серед гарантій прав на землю способи захисту цих прав мають першочергове значення.

Питанням, пов'язаним із правовою природою способів захисту права, приділяли увагу багато дослідників, зокрема: А.В. Буракова, В.В. Петруня, Т.М. Шоха,
M.В. Шульга тощо. Водночас питання пошуку оптимального способу захисту прав на землю серед законодавчо закріпленого невичерпного переліку способів, який би був належним та ефективним для захисту порушеного права чи інтересу, залишається відкритим та потребує подальших наукових розвідок. Актуальність досліджуваної проблематики підтверджується багатою та неоднозначною судовою практикою, що також була предметом нашого дослідження.

Визначення способів у ЗК України як юридичних гарантій захисту прав на землю покладає на них функціональне навантаження - відновити права, які було порушено, усунути перешкоди у їх реалізації тощо. 3 огляду на це варто дослідити питання їх ефективності щодо захисту прав на землю та визнання такими, що повною мірою забезпечують відновлення порушеного, 
невизнаного, оспорюваного права, що і буде метою цієї публікації.

Закріплені в ЗК України способи захисту прав на земельні ділянки є різноманітними. Ст. 152 ЗК України містить невичерпний перелік способів, серед яких: а) визнання прав; б) відновлення стану земельної ділянки, який існував до порушення прав, і запобігання вчиненню дій, що порушують права або створюють небезпеку порушення прав; в) визнання угоди недійсною; г) визнання недійсними рішень органів виконавчої влади або органів місцевого самоврядування; відшкодування заподіяних збитків; застосування інших, передбачених законом, способів [2].

Аналіз змісту способів захисту прав на земельну ділянку показує, що їх роль і значення неоднакові: кожен спосіб захисту має свої особливості, різне функціонально-цільове спрямування та умови застосування. Як визначено доктриною земельного права, одні 3 них безпосередньо спрямовані на захист права власності на земельну ділянку чи права землекористування, інші опосередковано. Всі зазначені способи захисту прав на землю можна класифікувати на окремі, відносно самостійні групи: речово-правові, зобов'язально-правові та спеціальні способи захисту земельних прав. Речовоправові способи захисту прав на землю безпосередньо спрямовані на захист суб'єктивного права власності на землю чи права землекористування осіб, які на момент порушення права не перебувають у зобов'язальних відносинах з порушником (витребування земельної ділянки 3 чужого незаконного володіння (віндикаційний позов); вимога власника земельної ділянки або землекористувача усунути порушення у здійсненні їх прав, які не пов'язані з позбавленням володіння земельною ділянкою (негаторний позов) і таке інше). Зобов'язально-правові способи захисту мають на меті захист прав суб'єкта як учасника зобов'язальних відносин (відшкодування збитків, заподіяних невиконанням або неналежними виконанням умов договору; повернення власникові земельної ділянки, наданої у користування за договором оренди, тощо). Спеціальні способи захисту земельних прав стосуються особливих випадків порушення прав власників земельних ділянок і землекористувачів. Вони зумовлені особливим колом уповноважених чи зобов'язаних осіб та надзвичайними обставинами (визнання угоди щодо земельної ділянки недійсною; визнання недійсними рішень органів виконавчої влади або органів місцевого самоврядування, які порушують права власників земельних ділянок і землекористувачів тощо) [3, с. 143].

3 огляду на різноманітність способів захисту земельних прав нерідко проблематичним є вибір оптимального способу захисту в конкретній ситуації, за допомогою якого можна запобігти, припинити, усунути порушення права, відновити, а також компенсувати збитки, заподіяні його порушенням: «Проблема практики правозастосування, а відтак і правової науки, якраз і полягає у вирішенні питання про те, чи є обраний особою спосіб захисту земельних прав правовим, тобто таким, що передбачений законом» $[4$, с. 63-64].

Як показує судова практика, неправильне обрання особою способу захисту порушених земельних прав тягне настання негативних наслідків як у процесуальному аспекті (відмова у задоволенні судом позову), так i в матеріальному плані (неможливість захистити порушене право). Так, правовий висновок Великої палати Верховного суду у справі про усунення перешкод у користуванні земельними ділянками (постанова ВП ВС від 12.12.2018 р. у справі № 372/5635/13-ц) зводиться до того, що право користування земельною ділянкою зберігається за відповідачем до його належного переоформлення, а відтак питання про користування чужою земельною ділянкою (у тому числі про встановлення права проходу та проїзду через неї) має вирімуватись на підставі норм матеріального права, які відповідають ичи правовідносинам, а не шляхом зобов'язання усунути перешкоди. На підставі цього суд скасував рішення судів попередніх інстанцій у частині задоволення позовних вимог про усунення перешкод у користуванні майном, прийнявши у цій частині нове рішення про відмову в позові [5]. Інший приклад: Касаційний цивільний суд, переглядаючи судові рішення у справі за позовом особи до товариства про визнання права власності на земельну ділянку та за зустрічним позовом товариства про визнання відсутності у особи права власності на земельну ділянку, звернув увагу на те, що під способами захисту суб'єктивних цивільних прав розуміють визначені законом матеріально-правові заходи примусового характеру, за допомогою яких проводиться поновлення (визнання) порушених (оспорюваних) прав та вплив на правопорушника. Загальний перелік таких способів захисту цивільних прав та інтересів дається в статті 16 Цивільного кодексу України. Цей перелік не є вичерпним, і суд може захистити цивільне право або інтерес іншим способом. Однак на час розгляду справи судами такий спосіб мав бути встановлений законом або договором. Суд зазначив, що власник порушеного права міг скористатися не будь-яким, а цілком конкретним способом захисту свого права. Водночас такого способу захисту, як визнання відсутнім права власності, законодавством України не передбачено (постанова від 07.10.2019 р. у справі № 359/8381/16-ц) [6].

Відсутність критеріїв обрання зацікавленими особами конкретного способу захисту порушених земельних прав зумовлює ситуацію, коли обраний позивачем спосіб захисту суд визнає неефективним і відмовляє у задоволенні позову. Так, у справі № 802/2474/17-а (провадження № 11-1081апп1812, постанова від 12.12.2018р.) [7]. Велика Палата Верховного Суду зробила висновок, що обраний позивачем спосіб захисту прав шляхом подання позову про визнання протиправним та скасування рішення виконкому про затвердження акта щодо визначення та відшкодування збитків власникам землі та землекористувачам, а також розміру таких збитків, завданих внаслідок користування земельною ділянкою, сам собою не сприяє ефективному відновленню порушеного права.

Велика Палата Верховного Суду у справі № 916/1608/18 (постанова ВП ВС від 19.05.2020р.) здійснила узагальнення умов застосування конкретного способу захисту цивільного права: залежить як від змісту права чи інтересу, за захистом якого звернулася особа, так і від характеру його порушення, невизнання або оспорення. Такі право чи інтерес мають бути захищені судом у спосіб, який $є$ ефективним, тобто такий, що відповідає змісту відповідного права чи інтересу, характеру його порушення, невизнання або оспорення та спричиненим цими діяннями наслідкам. Саме в цій конкретній справі суд звертає увагу на характер інтересу, за захистом якого позивач звернувся до суду та який є визначальним для обрання належного способу захисту: «Позивач прагне здійснення державної реєстрації права власності на своє майно, яке він вважає об'єктом нерухомості. Саме в цьому полягає його інтерес, за захистом якого він звернувся до суду. Велика Палата Верховного Суду дійшла висновку, що належним способом захисту прав та інтересів позивача у иій справі відповідає позовна вимога про визнання права власності ..., а позовна вимога про зобов'язання здійснити державну реєстрацію права власності не відповідає належному способу захисту. Тому Велика Палата Верховного Суду погоджується 3 висновками суду апеляційної інстанції щодо відмови у задоволенні зазначеної позовної вимоги» [8].

Така проблема правозастосування природно потребує законодавчого закріплення критеріїв належного та ефективного способу захисту порушеного права. 
Навіть більше, такі законодавчі зміни є актуальними, як ніколи. Адже оновлене процесуальне законодавство передбачає невичерпність способів захисту та можливість застосування судом будь-якого із способів, визначених законом або договором, а у разі відсутності ефективного способу захисту у законі чи договорі суд відповідно до викладеної в позові вимоги вправі самостійно визначити такий спосіб захисту, який не суперечить закону (ст. 5 Кодексу адміністративного судочинства України (КАС України) [9], ст. 5 Господарського процесуального кодексу України (ГПК України) [10], ст. 5 Цивільного процесуального кодексу України (ЦПК України) [11]). 3 огляду на це не так важливо законодавчо визначити способи захисту, як доцільно в галузевому законодавстві закріпити критерії, які будуть братися судом до уваги для оцінки їх ефективності.

У юридичній доктрині пропонуються різноманітні критерії ефективності способів захисту, які в своїй сукупності (системі) сприятимуть обранню належного та ефективного способу захисту прав та законних інтересів. Так, В.В. Петруня виробила систему критеріїв-умов обрання належного та ефективного способу захисту прав суб'єктів господарювання, яку становлять: 1) відповідність способу захисту змісту порушеного права, характеру його порушення та наслідкам, спричиненим цим порушенням; 2) відповідність законодавству, договору, принципам права та призначенню судового захисту; 3) доцільність та ефективність; 4) адекватність (співрозмірність, еквівалентність) стосовно правопорушення; 5) наявність механізму реалізації (виконання); 6) недопущення порушення прав та інтересів інших суб'єктів $[12$, c. 4$]$. Схожу позицію займають і представники науки екологічного права, пропонуючи під час обрання способу захисту конкретного суб'єктивного екологічного права брати до уваги: 1) коло повноважень, які складають зміст відповідного суб'єктивного права; 2) характер, спосіб, наслідки порушення цього права, зокрема в частині обмеження або припинення усіх або окремих повноважень, що становлять його зміст; 3) достатність та допустимість способів відновлення повноважень (які за своїм характером та видом порушення можуть бути відновлені), а також достатність та допустимість способів компенсації в частині повноважень (які не підлягають відновленню) [13, с. 244].

Позитивно сприймаючи як наукові доробки, так i правові висновки та узагальнення судової практики 3 досліджуваного питання, на нашу думку, для розуміння і правильного визначення критеріїв ефективності способів захисту слід виходити із загального поняття ефективності судового захисту. Про це наголошує Конституційний Суд України в своєму рішенні від 30 січня 2003 року № 3-рп/2003, в якому визначено, що правосуддя за своєю суттю визнається таким лише за умови, що воно відповідає вимогам справедливості і забезпечує ефективне поновлення в правах [14]. Чинне процесуальне законодавство визначає, що ефективний захист порушених, невизнаних або оспорюваних прав i законних інтересів фізичних та юридичних осіб, держави є метою судочинства (ст. 2 ГПК України, ст. 2 КАС України, ст. 2 ЦПК України). Про ефективний засіб юридичного захисту йдеться в ст. 13 Конвенції про захист прав людини та основоположних свобод, відповідно до якої кожен, чиї права та свободи, визнані в цій Конвенції, було порушено, має право на ефективний засіб юридичного захисту в національному органі, навіть якщо таке порушення було вчинене особами, які здійснювали свої офіційні повноваження [15]. В Рекомендаціях $\operatorname{Rec}(2004) 6$ Комітету міністрів Ради Свропи державамчленам «Щодо вдосконалення національних засобів правового захисту», ухвалених на 114-й сесії Комітету міністрів від 12 травня 2004 р. [16], наголошується на тому, що відповідно до вимог ст. 13 Конвенції, державичлени зобов'язуються забезпечити будь-якій особі, що звертається з оскарженням порушення іiї прав і свобод, викладених в Конвенції, ефективний засіб правового захисту в національному органі; при цьому на держави покладається обов'язок впровадити такі ефективні засоби правового захисту у світлі прецедентної практики Європейського суду з прав людини; при цьому саме держави-члени повинні забезпечити ефективність таких національних засобів як з правового, так і практичного поглядів, і щоб їх застосування могло привести до вирішення скарги по суті та належного відшкодування за будь-яке виявлене порушення.

Прецедентна практика Європейського суду 3 прав людини, яка є основним джерелом тлумачення Конвенції про захист прав людини і основоположних свобод, розкриваючи зміст поняття «ефективний засіб юридичного захисту» вказує на те, що зміст зобов'язань за ст. 13 залежить від характеру скарги заявника за Конвенцією. Тим не менше, засіб захисту, що вимагається згаданою статтею, повинен бути «ефективним» як у законі, так і на практиці, зокрема, у тому сенсі, щоб його використання не було ускладнене діями або недоглядом органів влади відповідної держави (п. 75 рішення Європейського суду 3 прав людини у справі «Афанасьєв проти України» від 5 квітня 2005 року (заява № 38722/02)) [17]. Крім того, Суд указав на те, що за деяких обставин вимоги статті 13 Конвенції можуть забезпечуватися всією сукупністю засобів, що передбачаються національним правом. Отже, «ефективний засіб правового захисту» у розумінні ст. 13 Конвенції повинен забезпечити поновлення порушеного права і одержання особою бажаного результату, а у разі неможливості поновлення - відшкодування завданої шкоди.

У світлі положень ст. 13 Конвенції про захист прав людини і основоположних свобод та тлумачення іiі змісту Європейським судом 3 прав людини в контексті дослідження ефективності способів захисту земельних прав видається можливим зробити висновок про те, що ефективним буде той засіб захисту, за допомогою якого можна запобігти, припинити, усунути порушення права, відновити та компенсувати збитки, заподіяні їх порушенням. При цьому орган, що розглядає скаргу по суті, для захисту порушеного права вправі використовувати всі способи, які передбачені у національному праві. Тому внесені зміни у процесуальне законодавство щодо можливості суду самостійно визначати спосіб захисту, який не суперечить закону, є виправданими.

Як висновок, доцільно зазначити, що питання захисту прав на землю залишається вкрай актуальним, оскільки відсутність належного правового регулювання породжує багато проблем під час застосування передбачених земельних законодавством способів захисту, і як наслідок - неможливість захистити своє порушене право. Щодо визначення способів у ЗК України як юридичних гарантій захисту прав на землю констатуємо, що ця гарантія не отримує належної практичної реалізації та певною мірою має декларативний характер, оскільки лише законодавчого закріплення переліку способів недостатньо для реального захисту порушеного земельного права. 3 огляду на невичерпність способів захисту прав, можливість іх встановлення не тільки законом, але і договором, більш актуальним видається необхідність легітимного закріплення критеріїв ефективності способів захисту, які б давали можливість особі обрати найбільш оптимальний спосіб захисту порушеного права чи інтересу. У зв’язку з цим практично значущим залишається питання формування механізму судового захисту земельних прав 3 урахуванням європейських принципів та стандартів визначення ефективних засобів правового захисту. 


\section{ЛITEPATУPA}

1. Шульга М.В. Деякі питання захисту земельних прав. Збірник матеріалів Першого зібрання фрахівців споріднених кафедр з обговорення актуальних наукових проблем та методики викладання аграрного, земельного, екологічного та природоресурсного права у вищих навчальних закладах України (м. Одеса, 9-10 вересня 2016 року) / відп. ред. проф. І.І. Каракаш. Одеса : Юридична література, 2016. С. 64-67.

2. Земельний кодекс України: Закон України від 25.10.2001 р. № 2768-ІІІ. Відомості Верховної Ради України. 2002. № 3-4. Ст. 27.

3. Земельне право України: Підручник / М.В. Шульга (кер. авт. кол.), Г.В. Анісімова, Н.О. Багай, А.П. Гетьман та ін.; За ред. М.В. Шульги. Київ : Юрінком Інтер, 2004. 368 с.

4. Буракова А.М. Визнання недійсними рішень органів владних повноважень як спосіб захисту земельних прав : дис. ... канд. юрид. наук. Харків, 2018. 188 с.

5. Постанова Великої Палати Верховного Суду від 12.12.2018 p. у справі № 372/5635/13-ц. URL: http://reyestr.court.gov.ua/ Review/78977429 (дата звернення: 28.07.2020).

6. Постанова Касаційного цивільного суду від 07.10.2019 р. у справі № 359/8381/16-ц. URL: http://www.reyestr.court.gov.ua/ Review/84788742 (дата звернення: 28.07.2020).

7. Постанова Великої Палати Верховного Суду від 12.12.2018 р. у справі у справі № 802/2474/17-a. URL: https://zakononline.com.ua/ court-decisions/show/78589538 (дата звернення: 28.07.2020).

8. Постанова Великої Палати Верховного Суду від 19.05.2020 р. у справі у справі № 916/1608/18. URL: http://reyestr.court.gov.ua/ Review/89819917 (дата звернення: 28.07.2020).

9. Кодекс адміністративного судочинства України: Закон України від 06.07.2005 р. № 2747-IV. Дата оновлення: 13.02.2020. URL: https://zakon.rada.gov.ua/laws/show/2747-15 (дата звернення: 29.07.2020).

10. Господарський процесуальний кодекс України: Закон України від 06.11.1991 р. № 1798-XII. Дата оновлення: 13.02.2020. URL: https://zakon.rada.gov.ua/laws/show/1798-12 (дата звернення: 29.07.2020).

11. Цивільний процесуальний кодекс України: Закон України від 18.03.2004 р. № 1618-IV. Дата оновлення: 13.02.2020. URL: https://zakon.rada.gov.ua/laws/show/1618-15 (дата звернення: 29.07.2020).

12. Петруня В.В. Поняття та система способів захисту прав суб'єктів господарювання : автореф. дис. ... канд. юрид. наук. Одеса, 2019. 20 c.

13. Шоха Т.П. Ефективність способів судового захисту екологічних прав громадян. Еколого-правовий статус людини і громадянина: ретроспективний та перспективний погляди: зб. матеріалів міжнародної науково-практичної конфреренції (м. Київ, 31 травня 2019 р.) / за заг. ред. М.В. Краснової, Т.О. Коваленко. Чернівці : Кондратьєв А.В., 2019. С. 241-245.

14. Рішення Конституційного Суду України у справі за конституційним поданням Верховного Суду України щодо відповідності Конституції України (конституційності) положень частини третьої статті 120, частини шостої статті 234, частини третьої статті 236 Кримінальнопроцесуального кодексу України (справа про розгляд судом окремих постанов слідчого і прокурopa). URL: https://zakon.rada.gov.ua/laws/ show/v003p710-03\#Text (дата звернення: 29.07.2020).

15. Про ратифікацію Конвенції про захист прав людини і основоположних свобод 1950 року, Першого протоколу та протоколів № 2, 4, 7 та 11 до Конвенції: закон України від 17.07.1997 № 475/97-BP. URL: https://zakon.rada.gov.ua/laws/show/475/97-\%D0\%B2\%D1\%80 (дата звернення: 29.07.2020).

16. Щодо вдосконалення національних засобів правового захисту: Рекомендації Rec(2004)6 Комітету міністрів Ради Європи державам-членам, ухвалених на 114-й сесії Комітету міністрів від 12 травня 2004 p. https://zakon.rada.gov.ua/laws/show/994_718\#Text (дата звернення: 29.07.2020)

17. Рішення Європейського суду з прав людини у справі «Афранасьєв проти України» від 5 квітня 2005 року (заява № 38722/02). URL: http://zakon3.rada.gov.ua/laws/show/980_239 (дата звернення: 29.07.2020). 


\title{
РОЗДІЛ 7 \\ АДМІНІСТРАТИВНЕ ПРАВО І ПРОЦЕС; ФІНАНСОВЕ ПРАВО; ІНФОРМАЦІЙНЕ ПРАВО
}

УДК 347.9

DOI https://doi.org/10.32782/2524-0374/2020-4/28

\section{ЗЛОВЖИВАННЯ ПРАВАМИ УЧАСНИКАМИ ВИКОНАВЧОГО ПРОВАДЖЕННЯ: ПРАКТИКА ТА ШЛЯХИ ВИРІШЕННЯ}

\author{
ABUSE OF RIGHTS BY PARTICIPANTS IN EXECUTIVE PROCEEDINGS: \\ PRACTICE AND WAYS OF SOLUTION
}

\author{
Бабич Я.С., магістр права \\ юридичного факультету \\ Київький національний університет імені Тараса Шевченка
}

\begin{abstract}
У статті досліджуються наукові напрацювання щодо зловживання правами в контексті їх існування у діях учасників виконавчого провадження на практиці. Розглянуто правову природу та доктринальне розуміння таких понять, як «зловживання правом», «шикана», «естопель», «правовий пуризм». Зроблено висновок про рівні можливості та мотивацію для зловживання правами як сторонами виконавчого провадження, так і державними/приватними виконавцями. Обґрунтовано хибність невизнання можливості зловживання правами стягувачем у виконавчому провадженні. Розглянуто основні види зловживань правами у виконавчому провадженні та їх розуміння у судовій практиці останніх років усіх інстанцій, їх співвіднесення з раніше розкритими видами зловживання правами. Доведено необхідність перегляду положень про територіальну компетенцію у виконавчому провадженні через відкриття виконавчих проваджень за місцем реєстрації банків, де відкрито рахунки боржників. Зокрема, видається необхідним розробити ієрархію критеріїв для вибору місця подання заяви про відкриття виконавчого провадження та встановлення відповідальності стягувача за зміст такої заяви з метою недопущення зловживання стягувачем правами в контексті принципу диспозитивності. Розглянуто проблеми уникнення сплати податків у разі прощення боргу в межах виконавчого провадження та недоцільності оподаткування прощених боргів у цілому. Проаналізовано підстави для звільнення від сплати виконавчого збору як такого, що стягується без результативної роботи державних виконавців. Окреслено окремі способи приховування майна боржником та позитивну судову практику, спрямовану на боротьбу з окремими способами приховування майна боржниками. Констатується вплив розвитку технологій на виникнення нових шляхів ухилення боржниками від виконання своїх зобов'язань. Висловлено занепокоєння щодо впливу швидкого розвитку сучасних технологій на ефективність виконавчого провадження. Запропоновано шляхи усунення виявлених можливостей для зловживання правами у виконавчому провадженні для подальшого розроблення більш предметних проєктів змін до законодавства.

Ключові слова: стягнення, виконавче провадження, боржник, зловживання правами, учасники виконавчого провадження.
\end{abstract}

The article examines the scientific developments on the abuse of rights in the context of their existence in the actions of participants in enforcement proceedings in practice. The legal nature and doctrinal understanding of such concepts as "abuse of law", "chicane", "estopel", "legal purism" are considered. The conclusion is made about equal opportunities and motivation for abuse of rights by both the parties to the enforcement proceedings and public / private enforcement agents. The erroneousness of non-recognition of the possibility of abuse of the rights of the debt collector in the enforcement proceedings is substantiated. The main types of abuse of rights in enforcement proceedings and their understanding in the case law of recent years of all instances, their correlation with previously disclosed types of abuse of rights are considered. The need to revise the provisions on territorial competence in enforcement proceedings through the opening of enforcement proceedings at the place of registration of banks where debtors' accounts have been opened has been proved. In particular, it seems necessary to develop a hierarchy of criteria for choosing the place of filing an application for enforcement proceedings and establishing the liability of the claimant for the content of such a statement in order to prevent abuse of rights by the claimant in the context of dispositiveness. The problems of tax avoidance in debt forgiveness within the enforcement proceedings and the inexpediency of taxation of forgiven debts in general are considered. The grounds for exemption from payment of the executive fee as such, which is levied without effective work of state executors, are analyzed. Certain ways of concealing property by the debtor and positive case law aimed at combating certain ways of concealing property by debtors are outlined. The influence of technology development on the emergence of new ways for debtors to evade their obligations is stated. Concerns have been expressed about the impact of the rapid development of modern technologies on the efficiency of enforcement proceedings. The directions of ways of elimination of the revealed possibilities for abuse of the rights in executive proceedings for the further development of more substantive projects of changes to the legislation are offered.

Key words: recovery, enforcement proceedings, debtor, abuse of rights, participants in enforcement proceedings.

Вступ. Останніми роками, враховуючи появу інституту приватних виконавців, кількість виконаних судових рішень зростає, як і чисельність виконавчих проваджень. Специфічні правовідносини боржника та стягувача породжують найрізноманітніші шляхи ухилення від зобов'язань діями, спрямованими на виконання рішення всупереч принципам права у цілому та виконавчого процесу зокрема. При цьому приватний виконавець як учасник виконавчого провадження також зацікавлений у виконанні рішення будь-якими шляхами, оскільки від цього залежать його прибутки.

Саме тому темою дослідження в рамках цієї статті виступають зловживання учасників виконавчого провадження як більш широкої категорії (порівняно зі сторо- нами виконавчого провадження відповідно до положень статей 14 та 15 Закону України «Про виконавче провадження» від 02.06.2016) [1]

Актуальність вибраної теми зумовлена наявністю значної кількості недобросовісних учасників виконавчого провадження за не меншої кількості відкритих виконавчих проваджень в Україні.

Завданням у межах цієї статті $€$ дослідження можливих зловживань учасниками виконавчого провадження своїми правами та пошук шляхів їх подальшого унеможливлення.

Виклад основного матеріалу. Зловживання правом це абстрактна категорія, і на підтвердження цієї думки відзначимо, що розкриття даного явища у законодавстві України відсутне. Дійсно, процесуальне законодавство 
надає суду можливість на власний розсуд оцінити поведінку/дії/бездіяльність сторін процесу як використання своїх прав на шкоду іншим. Утім, без однозначної позиції законодавця неможливе систематичне недопущення зловживання правами, у тому числі в рамках виконавчого провадження.

Подекуди корисними виявляються напрацювання судової практики. Наприклад, у Постанові Верховного Суду у складі колегії суддів Другої судової палати Касаційного цивільного суду від 03.06.2020 у справі № 318/89/18 було зроблено висновок про наслідки зловживання різними правами - матеріальними та процесуальними. Зокрема, у разі зловживання процесуальним правом суд залишає без розгляду або повертає процесуальний документ, поданий учасником справи; у разі зловживання матеріальними правами суд може відмовити у захисті прав особи, що зловживала своїми правами [2].

Але такого тлумачення суду в контексті виконавчого провадження, на жаль, недостатньо, оскільки суддя та виконавець мають різний обсяг повноважень. Тому дещо детальніше класифікуємо види зловживань правом, а також його доктринальне розуміння.

На думку О. Вдовичена, зловживання правом являє собою особливий вид юридично значимої поведінки, що проявляється у настанні соціально шкідливих наслідків від дій/бездіяльності суб'єкта права, а також у використанні недозволених у конкретних правовідносинах форм поведінки, тобто всупереч цільовому призначенню таких форм поведінки [3, с. 49].

Погоджуючись із позицією вченого, додамо, що зловживання правом $\epsilon$ прямо протилежним дотриманню принципу добросовісності і водночас не є прямим порушенням законодавства. Така ремарка є необхідною, адже під час доказування факту зловживання правом зазвичай доводиться спиратися саме на принципи права у зв'язку 3 відсутністю інших джерел обгрунтування протиправності поведінки учасників виконавчого провадження.

Ураховуючи вищезгадану постанову Верховного Суду [2], зловживання правом можемо поділити на матеріальне і процесуальне, а також за галузевою ознакою, за метою (навмисне чи ненавмисне нанесення шкоди іншій особі реалізацією своїх прав). У зв'язку із цим зловживання правом обросло низкою суміжних категорій, які ми коротко розкриємо:

Шикана - дії, спрямовані виключно на завдання шкоди іншій особі за відсутності законного інтересу [4, с. 72]. У контексті виконавчого провадження до таких дій можна віднести будь-які дії стягувача в порушення принципу співмірності у виконавчому провадженні, які навмисне ускладнюють можливість боржника реалізувати своє право на майно тощо.

Ecmoneль - правовий принцип, відповідно до якого особа втрачає право посилатися на будь-які факти на обгрунтування своєї позиції у зв'язку з учиненням дій, які свідчать про протилежні наміри особи [5, с. 320]. Вочевидь, у контексті виконавчого провадження йдеться про проголошені боржником наміри, які не підтверджуються юридично значимими діями.

Правовий пуризм - перевага форми над змістом під час ухвалення судового рішення (надмірний формалізм) [6]. Що типово, таке зловживання може ініціюватися практично будь-яким учасником виконавчого провадження, але втілюватися у життя лише уповноваженими на те особами (принаймні виконавцем).

Отже, незважаючи на відсутність указаних різновидів зловживання правом у законодавстві (у тому числі щодо виконання судових рішень), вони вже досить докладно вивчені в межах правової доктрини. Далі спробуємо застосувати вказані надбання науки та судову практику у разі виявлення можливих зловживань у виконавчому провадженні та шляхів їх подолання.
Починаючи 3 можливих зловживань стягувача та/ або виконавця, відразу звернемо увагу на те, що не слід обманюватися статусом «жертви», який несе стягувач у виконавчому провадженні, оскільки кожна зі сторін виконавчого провадження має передбачений законодавством перелік прав і обов'язків. Законодавець сформував правовий статус сторін виходячи 3 дотримання основних прав і свобод людини, а також з урахуванням принципів виконавчого провадження. Отже, на нашу думку, зловживати правами у виконавчому провадженні може як стягував, так і боржник - виправдань такій поведінці бути не може.

1. Відкриття виконавчого провадження за місием реєстраиії банку, де відкрито банківський рахунок на ім'я боржника.

Стаття 24 Закону України «Про виконавче провадження» передбачає альтернативну територіальну компетенцію для виконавців під час відкриття виконавчого провадження, яку умовно поділимо на дві групи: за боржником (місця проживання, перебування або роботи) та за майном (закон оперує поняттям «місцезнаходження», що, як буде доведено далі, невиправдано) [1].

Оскільки банківський рахунок - місце зберігання майна боржника, стягувач може скористатися цим для відкриття виконавчого провадження далеко від місця фактичної життєдіяльності боржника. На нашу думку, такі дії безумовно, зловживання правом і порушення принципу верховенства права, адже безпідставно ускладнюється реалізація права боржника на захист майна.

Більшість банків зареєстровано в Києві, тому маємо невтішну судову практику, коли закон захищає саме право стягувача вибрати виконавця відповідно до принципу диспозитивності виконавчого провадження (наприклад, Рішення Чернігівського окружного адміністративного суду від 31.07.2019 у справі №620/2096/19, Постанова Верховного Суду від 10.09.2018 у справі № 905/3542/15 та ін.) [7; 8].

Аргументація судів зводиться до того, що кошти - це майно боржника, а банківський рахунок - абстрактне явище, тому не залишається нічого іншого, як керуватися місцем реєстрації банку.

Нами підтримується позиція, викладена у Рішенні Дніпропетровського окружного адміністративного суду від 27.12.2019 у справі № 160/12702/19: судом зроблено висновок, що відкриття виконавчого провадження Законом [1] допускається саме за місцем майна, що потребує державної реєстрації (тобто нерухомість та транспортні засоби) [9].

Схожа правова позиція висловлена в Постанові Верховного Суду від 25.06.2019 у справі № 826/7969/16 [10].

Далі судом зроблено ще більш цікавий висновок: банк це лише третя особа, що зберігає майно боржника, і відкривати виконавче провадження за місцезнаходженням банку немає правових підстав. Погодимося, навівши аналогію, якщо транспортний засіб боржника було евакуйовано на штрафмайданчик, то відкривати виконавче провадження за його місцем знаходження, м'яко кажучи, дивно, адже таке зберігання може бути нетривалим. Аналогічна ситуація виникає за договорами зберігання. Тобто саме державна реєстрація майна (а не «місцезнаходження», як це передбачено законодавством) - це найбільш стала та надійна прив'язка майна до певної території [9].

Окрім того, законодавець не пояснює як стягувачу (а головне - виконавцю) упевнитися, що на відомих банківських рахунках боржника $є$ кошти, і як упевнитися, що вони належать боржнику?

Судова практика надає нам такі орієнтири:

1. Скріншоти 3 інформацією про рахунки боржника не $\epsilon$ доведенням їх наявності (Ухвала Деснянського районного суду м. Чернігова від 23.06.2020 у справі № 750/1862/20) [11]. 
2. Довідка з банку про існування рахунку не доводить існування на ньому коштів, уу тому числі таких, що належать боржнику, адже можуть бути і кредитні кошти (Рішення Запорізького окружного адміністративного суду від 06.05.2020 у справі №280/2165/20) [12].

3. Банківський рахунок $є$ власністю банку, тому відсутність на такому рахунку коштів унеможливлює відкриття виконавчого провадження за місцем реєстрації банку (Рішення Дніпропетровського окружного адміністративного суду від 29.07.2019 у справі № 160/6743/19) [13].

4. Кредитні кошти боржника на рахунку банку є власністю банку, отже, відкривати виконавче провадження за місцем реєстрації банку немає правових підстав (Рішення Дніпропетровського окружного адміністративного суду від 19.08.2019 у справі № 160/7012/19) [14].

Виникає цілком доречне питання: що спонукає стягувача свідомо йти на таку хитрість? Видається логічним виділити два варіанти: ускладнити життя боржнику або вибрати виконавця, який здійснює свою професійну діяльність у столиці. Такий вид зловживання правом шкодить не лише боржнику, а й виконавцям у регіонах, які залишаються без роботи. При цьому маємо водночас прояви як шикани (з боку стягувача), так і правового пуризму (з боку виконавця).

На підтвердження наявності правового пуризму у вищеокресленій ситуації наведемо таку судову практику: відповідно до Рішення Волинського окружного адміністративного суду від 17.06.2020 у справі № 140/7928/20 виконавче провадження відкрито у Києві (за місцем реєстрації банку), оскільки на рахунку боржника у такому банку перебувала 1 гривня [15]

Маємо і протилежну практику: Рішенням Дніпропетровського окружного адміністративного суду від 19.03.2020 у справі № 160/2291/20 скасовано постанову про відкриття виконавчого провадження у місті Києві, оскільки суду не доведено факт проживання боржника в Києві або знаходження там його майна. Виконавче провадження відкрите виключно за місцем реєстрації банку, де боржник має рахунок, при цьому стягував достеменно знав, що боржник проживає не в Києві і майна там не має [16].

Виходячи 3 першого розглянутого зловживання правом, пропонуємо шукати вирішення проблеми у таких напрямах:

1. Обмежити диспозитивність стягувача під час вибору виконавця, запровадивши замість альтернативності критеріїв їх ієрархічність, де визначальним буде життєвий зв'язок боржника з місцем відкриття виконавчого провадження. При цьому можна запозичити критерії резидентності у розумінні пП. 14.1.213 п. 14.1 ст. 14 розділу I Податкового кодексу України для визначення такого місця відкриття провадження [17]. Оскільки виконавчим округом приватного виконавця $є$ область, Автономна Республіка Крим, Київ та Севастополь, а органи державної виконавчої служби охоплюють усю територію України, суттєвих проблем для стягувача такі нововведення не створять.

2. Дозволити виконавцю перевіряти відомості із заяви про відкриття виконавчого провадження та водночас запровадити відповідальність стягувача за неповне подання відомостей про все відоме йому майно боржника. У комплексі з вищевикладеним такий захід буде ефективним, адже дасть змогу «розв'язати виконавцю руки» і не відкривати виконавчі провадження, які мають бути відкриті в інших регіонах.

2. Уникнення «прощення боргу» для подальшої несплати податків.

Відповідно до абз. «д» пП. 164.2.17 п. 164.2 ст. 164 Податкового кодексу України від 02.12.2010, прощення боргу є підставою для сплати боржником податку на при- буток для фізичних осіб (та військового збору) у зв'язку 3 виникненням додаткового блага [17].

Уточнює цю норму Постанова Верховного Суду від 26.06.2018 у справі № 821/3787/15-а: не всі прощені борги є додатковим благом, а лише ті, що призводять до виникнення у боржника фінансової вигоди, поліпшення фінансового чи майнового стану. Тобто принаймні прощення нарахованих штрафних санкцій не є додатковим благом [18].

Відзначимо той факт, що стягнення податків із неплатоспроможного боржника, якому навіть прощено його заборгованість, не є доцільним. Утім, така норма досі не скасована у зв'язку з існуванням схем уникнення від сплати податків.

Наприклад, відповідно до статей 37 та 39 Закону України «Про виконавче провадження», існує низка підстав для повернення виконавчого документа та закінчення виконавчого провадження [1]. Цілком можлива ситуація договірного врегулювання відносин стягувача та боржника, після якої стягувач звертається до виконавця із заявою про повернення виконавчого документа, тримає у себе цей документ до моменту пропущення усіх процесуальних строків, і така поведінка не вважається прощенням боргу у розумінні податкового законодавства. Окрім того, таким чином можна уникнути сплати виконавчого збору.

Спосіб боротьби законодавця 3 подібними зловживаннями, вочевидь, невдалий. Отже, необхідно узгодити положення Закону України «Про виконавче провадження» та Податковий кодекс України. Як свідчить практика, лише платоспроможні боржники ухиляються від оподаткування прощених боргів. Якщо людина у скрутному становищі, вона не зможе залучити адвокатів для вирішення подібних питань і продовжує бути боржником навіть після прощення боргу, але вже перед податковою.

3. Безпідставне стягнення виконавчого збору та витрат виконавчого провадження.

Стаття 18 Закону України «Про виконавче провадження» зобов'язує виконавця ефективно, своєчасно та повно вживати всі необхідні заходи в межах виконавчого провадження. Але як бути, якщо виконавче провадження закінчене без участі виконавця і винесено постанову про стягнення виконавчого збору/ витрат виконавчого провадження?

3 одного боку, виконавцю треба сплатити принаймні за відкриття та закриття виконавчого провадження, з іншого - встановлено конкретний розмір виконавчого збору для державних виконавців. Якщо раніше це було $10 \%$ від стягнутої суми, то зараз - $10 \%$ від суми заборгованості [1]. Складається помилкове враження, що стягувати виконавчий збір можна навіть без учинення будь-яких дій зі стягнення самої заборгованості.

Згідно $з$ положеннями ч. 2 ст. 27 Закону України «Про виконавче провадження», виконавчий збір справляється саме за примусове виконання рішення.

Цікаве розширене тлумачення згаданої норми знаходимо у Рішенні Хмельницького окружного адміністративного суду від 21.01.2019 у справі № 560/4472/18, яке розкриває примусове виконання рішення як безпосереднє вчинення дій на примусове виконання рішення і самостійне та фактичне стягнення заборгованості з боржника на користь стягувача [19].

Тобто виконавчий збір - це винагорода державному виконавцю за успішне стягнення заборгованості. Якщо стягувач і боржник вирішили свої питання самостійно i без участі виконавця, стягнення виконавчого збору можемо трактувати як правовий пуризм (хоча й у вигляді обов'язку, прямо передбаченого для державних виконавців законом).

Здійснення дій із фактичного виконання рішення - підстава для стягнення виконавчого збору, на це вказує також Постанова Верховного Суду у складі колегії суддів Каса- 
ційного адміністративного суду від 14.05.2020 у справі № 640/685/19.

Там само зроблено висновок, що стягнення виконавчого збору під час повернення виконавчого документа стягувачу за його заявою породжує ризик повторного стягнення виконавчого збору (під час повторного звернення стягувача до органів державної виконавчої служби) [20].

Комплексно аналізуючи всі нормативно-правові акти, що регулюють виконавче провадження в Україні, судді Великої Палати Верховного Суду Постановою від 11.03.2020 у справі № 2540/3203/18 дійшли такого висновку: оскільки у постанові про повернення виконавчого документа стягувачу вказуються результати виконання (тобто фактично стягнута сума або майно), а у самому виконавчому документі має бути відмітка щодо нестягнутих залишків заборгованості, виконавчий збір має стягуватися з фактично стягнутої суми [21].

Такий висновок $є$ ретроспективним, проте справедливим. У сукупності з необхідністю вчинення реальних дій зі стягнення заборгованості державним виконавцем обгрунтування суми виконавчого збору має стимулювати органи державної виконавчої служби працювати плідніше i не зловживати своїми правами. Однак допоки такі положення прямо не передбачені законодавством, боржники вимушені доводити безпідставність стягнення виконавчого збору у суді, що тим самим порушує права боржника

4. Розмаїття способів приховування майна боржником.

Найдавніша проблема в історії виконавчого провадження - можливість боржника завчасно позбутися майна або його приховати. Зловживання правами можна знайти найрізноманітніші, а розвиток технологій дає змогу боржникам бути завжди на крок попереду, оскільки законодавство не здатне швидко адаптуватися під науково-технічний прогрес. Водночас маємо згадати і позитивну судову практику.

По-перше, суди відходять від традиційної прив'язки у вигляді реєстрації майна, якщо довести, що воно фактично належить боржнику. У Постанові Верховного Суду у складі колегії суддів Другої судової палати Касаційного цивільного суду від 10.02.2020 у справі № 676/1314/19 з боржника було стягнуто нерухоме майно, яке не було на нього зареєстроване. Справа в тім, що нерухоме майно боржник подарував сину, договір рішенням суду визнано недійсним але перереєстрації не відбулося [22].
По-друге, суди не сприймають будь-які договори щодо майна боржника, якщо вбачають у їх укладанні спроби уникнути виконання своїх зобов'язань. Відповідно до фабули Рішення Приморського районного суду м. Одеси від 27.09.2018 у справі № 522/23757/17, боржник уклав шлюбний договір під час виконання судового рішення про стягнення боргу й усе майно, що перебувало до того у спільній сумісній власності подружжя, стало власністю дружини, адже у шлюбному договорі передбачалося, що майно стає власністю того з подружжя, на кого воно зареєстроване. Тобто, зловживаючи своїми правами, боржник опосередковано позбувся свого майна, тому шлюбний договір було визнано частково недійсним для подальшого стягнення заборгованості [23].

Наостанок не можемо не повернутися до питання застосування сучасних технологій боржниками як відвертого зловживання своїми правами, адже на разі не передбачено можливостей стягнути з боржника криптовалюту або кошти 3 рахунку мобільного телефону. Боржник може перевести свої грошові кошти на десятки SIM-карт або у віртуальні гаманці, і жоден виконавець не матиме змоги їх стягнути. Якщо раніше впродовж цієї статті пропонувалися бодай якісь напрями пошуків рішень, то у цій ситуації ні законодавство, ні судова практика не дають указівок на законний алгоритм стягнення.

Висновки. У процесі дослідження зловживань правами учасниками виконавчого провадження можна дійти думки, що такі зловживання можливі і серед виконавців, i серед сторін виконавчого провадження. Комплекс проблем, пов'язаних із можливостями зловживання правами, породжений насамперед: а) помилковою та упередженою позицією про неможливість зловживання правами з боку стягувача; б) появою конкуренції між приватними та державними виконавцями, що робить їх більш зацікавленими у зловживанні своїми правами; в) реєстраційними «прив'язками» як чинниками, що понижують якість виконавчого процесу в Україні; г) активним застосуванням боржниками нових технологій тощо.

Отже, законодавство потребує комплексного та масштабного перегляду, оскільки переважання інтересів стягувачів призведе до підвищення рівня бідності, а переживання інтересів боржників - до зниження рівня життя у країні.

\section{ЛITEPATУРA}

1. Про виконавче провадження : Закон України від 15.06.2016 р. № 1404-VIII. URL : https://zakon.rada.gov.ua/laws/show/1404-19/.

2. Постанова Верховного Суду у складі колегії суддів Другої судової палати Касаційного цивільного суду від 03.06 .2020 у справі № 318/89/18. URL : http://www.reyestr.court.gov.ua/Review/89675396.

3. Вдовичен О. Поняття зловживання правом. Право і суспільство. 2008. № 4. С. 47-52.

4. Осадчук С., Осадчук М. Форми зловживання цивільним правом. Актуальні проблеми правознавства. 2016. Вип. 4. С. 68-77.

5. Новосад А.С. Процесуальний естопель: особливості застосування. Міжнародна та національна безпека: теоретичні і прикладні аспекти : матер. III Міжнар. наук.-практ. конф., м. Дніпро, 15 березня 2019 р. Дніпро : ДДУВС, 2019. С. 320-321.

6. Окрема думка судді Верховного Суду Яна Берназюка від 25.04.2018 у справі № 826/5575/17 на постанову від 11.04.2018. URL http://www.reyestr.court.gov.ua/Review/73635013.

7. Рішення Чернігівського окружного адміністративного суду від 31.07 .2019 у справі №620/2096/19. URL : http:/l www.reyestr.court.gov.ua/Review/83350786.

8. Постанова Верховного Суду у складі колегії суддів Касаційного господарського суду від 10.09.2018 у справі № 905/3542/15. URL : http://www.reyestr.court.gov.ua/Review/76445253.

9. Рішення Дніпропетровського окружного адміністративного суду від 27.12.2019 у справі №160/12702/19. URL : http://www.reyestr.court.gov.ua/Review/86925007.

10. Постанова Верховного Суду у складі колегії суддів Касаційного адміністративного суду від 25.06.2019 у справі № 826/7969/16. URL : http://www.reyestr.court.gov.ua/Review/82618556

11. Ухвала Деснянського районного суду м. Чернігова від 23.06.2020 у справі №750/1862/20. URL : http://www.reyestr.court.gov.ua/ Review/89984022.

12. Рішення Запорізького окружного адміністративного суду від 06.05.2020 у справі №280/2165/20. URL : http://www.reyestr.court.gov.ua/ Review/89085425

13. Рішення Дніпропетровського окружного адміністративного суду від 29.07.2019 у справі №160/6743/19. URL : http:// www.reyestr.court.gov.ua/Review/84160116.

14. Рішення Дніпропетровського окружного адміністративного суду від 19.08 .2019 у справі №160/7012/19. URL : http:// www.reyestr.court.gov.ua/Review/83699464.

15. Рішення Волинського окружного адміністративного суду від 17.06.2020 у справі № 140/7928/20. URL : http://www.reyestr.court.gov.ua/ Review/89853473.

16. Рішення Дніпропетровського окружного адміністративного суду від 19.03.2020 у справі №160/2291/20. URL : http:// www.reyestr.court.gov.ua/Review/88295852. 
17. Податковий кодекс України від 02.12.2010 № 2755-VI. URL : https://zakon.rada.gov.ua/laws/show/2755-17.

18. Постанова Верховного суду у складі колегії суддів Касаційного адміністративного суду від 26.06 .2018 у справі № 821/3787/15-а. URL : http://www.reyestr.court.gov.ua/Review/74989222.

19. Рішення Хмельницького окружного адміністративного суду від 21.01.2019 у справі № 560/4472/18. URL : http://www.reyestr.court.gov.ua/ Review/79280518.

20. Постанова Верховного Суду у складі колегії суддів Касаційного адміністративного суду від 14.05.2020 у справі № 640/685/19. URL : http://www.reyestr.court.gov.ua/Review/89217659.

21. Постанова Великої Палати Верховного Суду від 11.03 .2020 у справі № 2540/3203/18. URL : http://www.reyestr.court.gov.ua/ Review/88601610.

22. Постанова Верховного Суду у складі колегії суддів Другої судової палати Касаційного цивільного суду від 10.02 .2020 у справі № 676/1314/19. URL : http://www.reyestr.court.gov.ua/Review/87485250.

23. Рішення Приморського районного суду м. Одеси від 27.09.2018 у справі № 522/23757/17. URL : http://www.reyestr.court.gov.ua/ Review/77838799. 


\title{
АКТУАЛЬНІ ПИТАННЯ НОРМАТИВНО-ПРАВОВОГО РЕГУЛЮВАННЯ КІБЕРБЕЗПЕКИ В ДЕРЖАВНІЙ ПРИКОРДОННІЙ СЛУЖБІ УКРАЇНИ
}

\section{TOPICAL ISSUES OF THE REGULATORY FRAMEWORK IN THE SPHERE OF CYBER SECURITY OF THE STATE BORDER GUARD SERVICE OF UKRAINE}

\author{
Басараб О.Т., к.ю.н., \\ старший викладач кафедри теорії та історії держави і права та приватноправових дисциплін \\ Національна академія Державної прикордонної служби України імені Богдана Хмельницького \\ Басараб О.К., К.т.н., \\ доцент кафедри зв'язку, автоматизації та кібербезпеки \\ Національна академія Державної прикордонної служби України імені Богдана Хмельницького
} Ларіонова І.Т., старший викладач кафедри тактичної та спеціальної фізичної підготовки Харківський начіональний університет внутрішніх справ

Статтю присвячено вивченню актуальних питань нормативно-правового регулювання кібернетичної безпеки у Державній прикордонній службі України з огляду на сучасні виклики сьогодення.

Зазначається, що в умовах активізації кібернетичних атак на інформаційно-телекомунікаційні системи органів державної влади України, правоохоронних органів та військових формувань комп'ютерні мережі прикордонного відомства також потребують надійного захисту. Сьогодні у Державній прикордонній службі України функціонує інтегрована інформаційно-телекомунікаційна система «Гарт», яка забезпечує обробку інформації за відповідними видами оперативно-службової діяльності. Віртуальний простір, у межах якого циркулює інформація, з використанням вищезазначеної системи являє собою кібернетичний простір прикордонного відомства, безпека якого повною мірою залежить від двох основних аспектів: організаційно-технічного забезпечення та якісної нормативно-правової бази.

3 огляду на мету та завдання наукової статті, авторами детально досліджено нормативно-правовий аспект. У результаті наукових пошуків установлено, що правове регулювання кібернетичної безпеки Державної прикордонної служби України здійснюється нормативними актами різної юридичної сили: Конституцією України, законами та підзаконними актами України.

Конституція України містить вихідні положення щодо організації безпеки як національного кібернетичного простору в цілому, так і віртуального простору Державної прикордонної служби України, які знаходять своє відображення у законах та підзаконних нормативноправових актах України.

Аналіз чинного законодавства у сфері забезпечення безпеки у кібернетичному просторі прикордонного відомства дав змогу виявити деяку його недосконалість.

Зроблено висновок, що актуальними та такими, що потребують вирішення найближчим часом, $є$ питання відсутності спеціальних нормативно-правових актів у сфері забезпечення безпеки кібернетичного простору Державної прикордонної служби України, прогалини у положеннях чинних нормативно-правових актів у частині, що стосується порядку організації кібернетичної безпеки у прикордонному відомстві, а також відсутність науково обґрунтованої концепції щодо подальшого порядку розбудови кібернетичної безпеки Державної прикордонної служби України.

Ключові слова: кібернетична безпека, кібернетичний простір, нормативно-правові акти, Державна прикордонна служба України, прикордонне відомство.

The article is devoted to the study of topical issues of legal regulation of cyber security in the State Border Guard Service of Ukraine, taking into account current challenges of today.

It is noted that in the conditions of intensification of cyber attacks on information and telecommunication systems of state authorities of Ukraine, law enforcement agencies and military formations, computer networks of the border agency also need reliable protection.

Today, the State Border Guard Service of Ukraine has the integrated information and telecommunication system "Hart", which provides information processing for the relevant types of operational and service activities. The virtual space within which information circulates, using the above mentioned system, is the cyber space of the border agency, the security of which fully depends on two main aspects: organizational and technical support and qualitative regulatory framework.

Taking into account the given purpose and objectives of the scientific article, it was studied the regulatory aspect.

As a result of the scientific research, it was established that the legal regulation of cyber security of the State Border Guard Service of Ukraine is carried out by acts of different legal force: the Constitution of Ukraine, laws and subordinate legal acts of Ukraine. The Constitution of Ukraine contains basic provisions on cyber, which are reflected in the laws and subordinate legal acts of Ukraine. The analysis of all above mentioned acts revealed some of its imperfections.

It is concluded that topical issues of the regulatory framework in the sphere of cyber security of the State Border Guard Service of Ukraine are following: lack of special normative acts on cyber security of the border agency; absence of norms on cyber security of the State Border Guard Service of Ukraine in the current regulatory framework; absence of the Concept on the cyber security of the State Border Guard Service of Ukraine.

Key words: cyber security, cyber space, normative acts, State Border Guard Service of Ukraine, border agency.

Постановка проблеми. Стрімкий розвиток інформаційно-телекомунікаційних технологій значною мірою розширив сфери застосування комп'ютерної техніки. Сьогодні комп'ютеризація торкнулася практично усіх галузей суспільного життя, забезпечивши цим самим оперативність в обміні інформацією та швидкість прийняття управлінських рішень.

Разом із тим в умовах широкомасштабного використання інформаційно-телекомунікаційних систем актуальним постає питання забезпечення належного захисту інформації, особливо коли йдеться про органи державної влади, правоохоронні органи та військові формування. Так, за даними пресслужби Державної служби спеціального зв'язку та захисту інформації України, лише протягом тижня в період з 1 по 7 липня 2020 р. спеціалізованим структурним підрозділом реагування на кіберінциденти CERT-UA (Computer Emergency Response Team of Ukraine) було заблоковано 1888 кібератак на інформаційно-телекомунікаційні системи державних органів влади та зареєстровано 19514 інцидентів, 73\% з яких стосувалися розповсюдження шкідливого програмного забезпечення та 26\% - фішингу [1]. 
Інформаційно-телекомунікаційна мережа Державної прикордонної служби України (далі - ДПС України) також зазнавала впливу комп'ютерного вірусу, але завдяки вправним діям фахівців із кібербезпеки проблему було вчасно локалізовано [2].

3 огляду на зазначене, дослідження сучасного стану нормативно-правового регулювання кібербезпеки ДПС України та виявлення актуальних питань, що потребують розв'язання, набуває особливого значення.

Аналіз останніх наукових досліджень і публікацій свідчить про те, що проблема захисту інформаційно-телекомунікаційних систем неодноразово знаходила своє відображення у працях С.Г. Божок, І.В. Діордіци, В.А. Ліпкана, Н.В. Коваленка, Б.А. Кормича, І.П. Кушнір, Ю.С. Максименка, М.А. Стрельбіцького, О.К. Юдіна та ін.

Однак, незважаючи на велику кількість публікацій із цієї тематики, нормативно-правове регулювання кібербезпеки у ДПС України все ще потребує додаткового вивчення.

Метою і завданням наукової статті $є$ дослідження сучасного стану нормативно-правового регулювання кібербезпеки у ДПС України та визначення актуальних питань, що потребують вирішення.

Виклад основного матеріалу. Відповідно до статті 1 Закону України «Про Державну прикордонну службу України» від 03.04.2003, на прикордонне відомство покладаються завдання щодо забезпечення недоторканості державного кордону та охорони суверенних прав України в її прилеглій зоні та виключній (морській) економічній зоні [3]. Очевидно, що ефективне виконання зазначених завдань у сучасних умовах неможливе без використання інформаційних технологій.

Сьогодні у ДПС України функціонує інтегрована інформаційно-телекомунікаційна система «Гарт» (далі IITC «Гарт»), яка являє собою сукупність інформаційнотелекомунікаційних систем, що діють як єдине ціле і забезпечують обробку інформації за відповідними видами оперативно-службової діяльності.

Віртуальний простір, у межах якого циркулює інформація, з використанням IITC «Гарт» являє собою кібернетичний простір (кіберпростір) ДПС України [4], який в умовах численних кібернетичних атак потребує надійного захисту, оскільки інформація, що обробляється в IITC «Гарт», є власністю ДПС України і не підлягає поширенню або передачі іншим особам за винятком окремих випадків, передбачених законодавством.

У теорії інформаційного права під захистом інформації зазвичай розуміють застосування сукупності організаційно-технічних заходів і правових норм для запобігання заподіянню шкоди інтересам власника інформації чи автоматизованій системі та особам, які користуються інформацією [5, с. 216]. Відповідно до ст. 1 Закону України «Про основні засади забезпечення кібербезпеки України» від 05.10.2017, захист інформації у кібернетичному просторі $\epsilon$ не що інше, як сукупність організаційних, правових, інженерно-технічних заходів, а також заходів криптографічного та технічного захисту інформації, спрямованих на запобігання кіберінцидентам, виявлення та захист від кібератак, ліквідацію їх наслідків, відновлення сталості і надійності функціонування комунікаційних, технологічних систем [6]. Тому цілком логічно припустити, що безпека кіберпростору ДПС України повною мірою залежить від двох основних аспектів: організаційно-технічного забезпечення та якісної нормативно-правової бази.

Зупинимося детальніше на дослідженні актуальних питань нормативно-правового регулювання кібербезпеки в ДПС України.

Вихідним, на нашу думку, є положення ст. 17 Конституції України, відповідно до якого захист суверенітету і територіальної цілісності України, забезпечення іiї економічної та інформаційної безпеки $є$ найважливішими функціями держави, справою всього українського народу. Забезпечення державної безпеки і захист державного кордону України покладаються на відповідні військові формування та правоохоронні органи держави, організація і порядок діяльності яких визначаються законом [7].

Реалізація та деталізація цього конституційного положення знайшла своє відображення у низці законів України. Зокрема, відповідно до ст. 1 Закону України «Про національну безпеку України» від 21.06.2018, система органів державної влади, Збройних сил України, інших утворених відповідно до законів України військових формувань, правоохоронних та розвідувальних органів, державних органів спеціального призначення 3 правоохоронними функціями, сил цивільного захисту, оборонно-промислового комплексу України, діяльність яких за функціональним призначенням спрямована на захист національних інтересів України від загроз, утворюють собою сектор безпеки й оборони [8].

Відповідно до ст. 5 Закону України «Про основні засади забезпечення кібербезпеки в Україні» від 05.10.2017, координація діяльності у сфері кібербезпеки як складової частини національної безпеки України здійснюється Президентом України через очолювану ним Раду національної безпеки і оборони України [6].

Своєю чергою, у п. 2 ст. 12 Закону України «Про національну безпеку України» від 21.06.2018 зазначається, що ДПС України входить до складу сектору безпеки і оборони та, відповідно до п. 6 ст. 18, є правоохоронним органом спеціального призначення, що реалізує державну політику у сфері безпеки державного кордону України та охорони суверенних прав України в іiї виключній (морській) економічній зоні [8].

Згідно зі ст. 5 Закону України «Про основні засади забезпечення кібербезпеки України» від 05.10.2017, Адміністрація Державної прикордонної служби України як центральний орган виконавчої влади, що реалізує державну політику у сфері охорони державного кордону, є суб'єктом забезпечення кібербезпеки в інформаційному просторі ДПС України та у межах своєї компетенції уповноважена:

здійснювати заходи щодо запобігання використанню кіберпростору у воєнних, розвідувально-підривних, терористичних та інших протиправних і злочинних цілях;

виявляти та реагувати на кіберінциденти та кібератаки та усувати їх наслідки;

здійснювати інформаційний обмін щодо реалізації та потенційних кіберзагроз;

розробляти і реалізувати запобіжні, організаційні, освітні та інші заходи у сфері кібербезпеки, кібероборони та кіберзахисту;

- забезпечувати проведення аудиту інформаційної безпеки підпорядкованих підрозділів;

- здійснювати інші заходи у сфері забезпечення розвитку та безпеки кіберпростору [6].

Серед законів, які визначають основи правового регулювання кібербезпеки у ДПС України, варто також згадати закони України «Про захист інформації в інформаційно-телекомунікаціних системах» від 05.07.1994, «Про телекомунікації» від 18.11.2003, «Про інформацію» від 02.10.1992, «Про захист персональних даних» від 01.06.2010 тощо.

Правовим інструментарієм для виконання законів у сфері забезпечення кіберзахисту ДПС України є підзаконні нормативно-правові акти Президента України, міністра внутрішніх справ та голови ДПС України.

Серед актів Президента України, на нашу думку, особливий інтерес викликають Концепція розвитку сектору безпеки і оборони України, від 14.03.2016 № 92/2016, а також укази глави держави «Про Стратегію кібербезпеки України» від 15.03.2016 № 96/2016 та «Про затвер- 
дження доктрини інформаційної безпеки України» від 25.02.2017 № 47/2017. Однак аналіз змісту вищезазначених актів дає нам змогу говорити про значні прогалини у правовому забезпеченні кібербезпеки ДПС України.

Зокрема, у частині, що стосується «Стратегії кібербезпеки України». У ст. 31 Закону України «Про національну безпеку України» від 21.06.2018 зазначено, що Стратегія $\epsilon$ документом довгострокового планування, в якому визначаються пріоритети національних інтересів України у сфері кібербезпеки, наявні та потенційно можливі кіберзагрози життєво важливим інтересам людини і громадянина, суспільства та держави в кіберпросторі, пріоритетні напрями, концептуальні підходи до формування та реалізації державної політики щодо безпечного функціонування кіберпростору, його використання в інтересах особи, суспільства і держави, підвищення ефективності основних суб'єктів забезпечення кібербезпеки, насамперед суб'єктів сектору безпеки і оборони, щодо виконання завдань у кіберпросторі, а також потреби бюджетного фінансування, достатні для досягнення визначених цілей і виконання передбачених завдань, та основні напрями використання фінансових ресурсів. Стратегія кібербезпеки України є основою для підготовки державних програм та нормативно-правових актів, що стосуються забезпечення кібербезпеки України [8]. Однак у документі практично відсутні положення щодо організації кібербезпеки у ДПС України як одного із суб'єктів сектору безпеки й оборони [9].

Схожа ситуація також із Доктриною інформаційної безпеки України від 25.02.2017 № 47/2017 [10].

Аналіз зазначеної проблеми, на нашу думку, потребує особливої уваги та пошуку шляхів її вирішення, оскільки сукупність інформаційних та телекомунікаційних систем ДПС України утворюють окрему систему, у якій обробляються державні інформаційні ресурси, персональні дані та інформація з обмеженим доступом. Окрім того, у ст. 2 «Концепції розвитку сектору безпеки і оборони» захист державного кордону визначено одним 3 основних завдань сектору безпеки і оборони. Тоді як ст. 8 Закону України «Про Державну прикордонну службу України» від 03.04.2003 покладає координацію діяльності військових формувань та відповідних правоохоронних органів, пов'язану із захистом державного кордону України, на прикордонне відомство [3].

Щодо актів Уряду ДПС України керується постановами Кабінету Міністрів України «Про затвердження порядку формування переліку інформаційно-телекомунікаційних систем об'єктів критичної інфраструктури» від 23.08.2016 № 563, «Про затвердження правил забезпечення захисту інформації в інформаційних, телекомунікаційних та інформаційно-телекомунікаційних системах» від 29.03.2006 № 373, «Про затвердження загальних вимог до кіберзахисту об'єктів критичної інфраструктури» від 19.06.2019 № 518 тощо.

Однак зазначені документи містять загальні положення організаційних засад забезпечення захисту державних інформаційних ресурсів або інформації, вимоги щодо захисту якої встановлено законом в інформаційних, телекомунікаційних та інформаційно-телекомунікаційних системах, механізму формування переліку інформаційнотелекомунікаційних систем об'єктів критичної інфраструктури держави, організаційно-методологічні, технічні та технологічні умови кіберзахисту об’єктів критичної інфраструктури.

Про недосконалість нормативно-правової бази системи Міністерства внутрішніх справ, до якої входить ДПС України, йдеться також у Концепції програми інформатизації системи Міністерства внутрішніх справ на 2018-2020 рр. від 05.11.2018. Цей документ вартий нашої уваги, оскільки він є практично єдиним актом, виданим на рівні міністерства із цього питання. Відповідно до Концепції, відсутність належного правового забезпечення породжує наявність десятків неузгоджених наказів, угод, протоколів та регламентів, підготовка яких здійснюється не системно та вибірково. Незважаючи на значні зусилля, витрачені на розроблення цих документів, нормативно-правова база у сфері інформаційно-телекомунікаційних технологій вимагає уніфікації та гармонізації, у тому числі з нормами європейського законодавства, оскільки сьогодні не відповідає сучасним вимогам і темпу розвитку, носить суперечливий характер у різних нормативно-правових актах [11].

Нормотворча діяльність Адміністрації Державної прикордонної служби України як суб'єкта забезпечення кібербезпеки в інформаційному просторі ДПС України також потребує активізації та вдосконалення.

Сьогодні ми маємо Положення про центр кібербезпеки Головного центру зв'язку, автоматизації та захисту інформації від 15.05.2018 № 10 од, що визначає структуру та завдання структурних підрозділів центру, а також права та обов'язки персоналу [12].

Однак в умовах сучасних кібернетичних загроз для врегулювання широкого спектру суспільних відносин у сфері забезпечення кібербезпеки ДПС України цього документу недостатньо. Проблема ускладнюється ще й тим, що нині відсутня науково обгрунтована концепція 3 кібербезпеки ДПС України, яка б визначила подальшу програму розвитку у цій галузі.

Висновки. Таким чином, аналіз стану нормативноправового регулювання кібербезпеки ДПС України свідчить про деяку його недосконалість. Серед актуальних питань, які потребують вирішення, можна виділити такі:

- практично відсутні спеціальні нормативно-правові акти з кібербезпеки ДПС України, які б ураховували технічний потенціал інформаційно-телекомунікаційної мережі прикордонного відомства щодо забезпечення безперервного виконання завдань прикордонними підрозділами;

у положеннях чинних нормативно-правових актів, що визначають основи кібернетичної безпеки в Україні, не повною мірою відображена організація кібербезпеки у ДПС України як суб'єкта сектору безпеки і оборони;

відсутня концепція кібербезпеки ДПС України.

Ураховуючи вищезазначене, перспектива подальших розвідок у даному напрямі полягає у винайденні шляхів вирішення вищезазначених питань та вдосконаленні правового забезпечення кібербезпеки ДПС України.

\section{ЛІТЕРАТУРА}

1. В Україні за тиждень заблокували майже 2 тисячі кібератак на держоргани. УHIAH. URL : https://www.unian.ua/economics/telecom/ v-ukrajini-zablokuvali-mayzhe-2-tisyachi-kiberatak-na-derzhorgani-novini-11065415.html) (дата звернення: 10.07.2020).

2. Прикордонник України від 28.09.2018 № 38. Кіберварта. URL : http://dpsu.gov.ua/upload/file/pu 36 2018.pdf (дата звернення: 06.06.2020)

3. Про Державну прикордонну службу України : Закон України від 03.04.2003 p. № 661-IV. URL : http://zakon5.rada.gov.ua/laws/ show/661-15 (дата звернення: 10.07.2020).

4. Басараб О.Т., Басараб О.К., Ларіонова І.Т. Щодо визначення поняття «кібербезпека Державної прикордонної служби України»: теоретико-правовий аспект. Вісник Національної академії Державної прикордонної служби України. Серія «Юридичні науки». 2019. Вип. 3.

5. Кормич Б. Інформаційне право : підручник. Харків : Бурун і К, 2011. 335 с.

6. Про основні засади забезпечення кібербезпеки України : Закон України від 05.10.2017 № 2163-VIII. URL : https://zakon.rada.gov.ua/ laws/show/2163-19 (дата звернення: 11.07.2020). 
7. Конституція України від 28.06.1996 № 254к/96-BP. URL : http://zakon3.rada.gov.ua/laws/show/254\%D0\%BA/96-0\%B2\%D1\%80 (дата звернення: 11.07.2020).

8. Про національну безпеку України : Закон України від 21.06.2018 № 2469-VIII. URL : https://zakon.rada.gov.ua/laws/show/2469-19 (дата звернення: 12.07.2020).

9. Про рішення Ради національної безпеки і оборони України від 27 січня 2016 року «Про Стратегію кібербезпеки України» : Указ Президента України від 27.01.2016 № 47/2017. URL : https://zakon.rada.gov.ua/laws/show/96/2016\#Техt (дата звернення: 12.07.2020).

10. Про рішення Ради національної безпеки і оборони України від 29 грудня 2016 року «Про Доктрину інформаційної безпеки України»: Указ Президента України від 25.02.2017 № 47/2017. URL : https://www.president.gov.ua/documents/472017-21374 (дата звернення: 15.07.2020).

11. Концепція (нова редакція) програми інформатизації системи Міністерства внутрішніх справ України, на 2018-2020 роки : Рішення Колегії MBC від 05.11.2018 № 18 KM. URL : https://mvs.gov.ua/upload/file/koncepc_ya_nformatizac_mvs_12.12.2018.pdf (дата звернення: 15.07.2020).

12. Про затвердження положення про центр кібербезпеки Головного центру зв'язку, автоматизації та захисту інформації : Наказ Головного центру зв'язку, автоматизації та захисту інформації від 15.05.2018 № 10од. URL : https://dpsu.gov.ua/ua/structure/chastinicentralnogopidporyadkuvannya/golovniy-centr-zvyazku-avtomatizacii-ta-zahistu-informacii/ (дата звернення: 15.07.2020). 


\title{
THE GROUNDS OF THE INTEGRITY TEST OF EMPLOYEES OF THE NATIONAL ANTI-CORRUPTION BUREAU OF UKRAINE
}

\section{ПІДСТАВА ПЕРЕВІРКИ НА ДОБРОЧЕСНІСТЬ ПРАЦІВНИКІВ НАЦІОНАЛЬНОГО АНТИКОРУПЦЙНОГО БЮРО УКРАЇНИ}

\author{
Braverman O.O., Postgraduate Student \\ at the Department of Public Administration and Management \\ National Academy of Internal Affairs, \\ Senior Detective at the Devision of Internal Investigation \\ of the Department of Internal Control \\ National Anti-Corruption Bureau of Ukraine
}

The purpose of this article - to determine the legal and factual grounds for the integrity test of employees of the National Anti-Corruption Bureau of Ukraine.

The work is performed by applying general research and special methods of scientific knowledge. With the help of methods of abstraction, analysis and synthesis of the author by rejecting the insignificant properties of the integrity test at the same time managed to identify the grounds of this phenomenon. Dialectical and logical methods allowed to clarify the essence of factual and legal grounds for the integrity test, to specify the list of concepts. Using forecasting and modeling, the author is proposed a specific model of legal regulation of the grounds for the integrity test of employees of the National Anti-Corruption Bureau of Ukraine.

In the article the legal (regulatory) and factual (material) grounds for the integrity test of employees of the National Bureau are examined. It's established that the legal (regulatory) grounds is, in fact, the legislative permission for the integrity test. The definition of the factual (material) basis for the test as a certain legal fact, with the onset of which there is a need for an integrity test by the Department of Internal Control of the National Bureau is proposed.

In the course of scientific research it was established that at present there is no proper legal grounds for conducting the integrity test of employees of the National Bureau, as the legal grounds for conducting the integrity test in the National Bureau are defined in an internal document. At the same time, the author has improved the factual grounds for conducting the integrity test.

Key words: the integrity test, public service, administrative control, simulation of situations, non-integrity behavior.

Статтю присвячено висвітленню юридичних та фактичних підстав для проведення перевірки на доброчесність працівників Національного антикорупційного бюро України.

Дане дослідження виконано шляхом застосування загальних та спеціальних методів наукового пізнання. За допомогою методів абстрагування, аналізу та синтезу автору шляхом відкидання незначних властивостей перевірки на доброчесність одночасно вдалося виявити підстави цього явища. Діалектичний та логічний методи дали змог уточнити сутність фактичних та юридичних підстав перевірки на доброчесність, уточнити перелік понять. Використовуючи прогнозування та моделювання, автором запропоновано конкретну модель правового регулювання підстав для проведення перевірки на доброчесності працівників Національного антикорупційного бюро України.

У статті розглянуто юридичні (нормативні) та фактичні (матеріальні) підстави для проведення перевірки на доброчесність працівників Національного бюро. Встановлено, що юридичні (нормативні) підстави, по суті, є законодавчим дозволом на проведення перевірки на доброчесність та визначають, хто суб'єкт та об'єкт такої перевірки, їхні права та обов'язки в ході її проведення тощо.

Під фактичними (матеріальними) підставами для перевірки на доброчесність запропоновано розуміти певний юридичний факт, із настанням якого виникає необхідність проведення перевірки на доброчесність Управлінням внутрішнього контролю Національного бюро. Однак сьогодні фактична (матеріальна) підстава для проведення перевірки на доброчесність законодавчо не встановлена.

У ході наукового дослідження встановлено, що нині відсутні належні правові підстави для проведення перевірки на доброчесність працівників Національного бюро, оскільки останні визначені у внутрішньому документі, а саме Положенні про Управління внутрішнього контролю Національного антикорупційного бюро України, затвердженому Наказом Директора Національного антикорупційного бюро України від 29.11.2019 № 142 [3]

Автором також зауважено, що такі суттєві обмеження прав і свобод людини, яких зазнає працівник Національного антикорупційного бюро України під час проведення перевірки на доброчесність, мають бути обов'язково врегульовані в нормативно-правовому акті. Недопустимо, щоб указаний засіб утручання в особисте життя, підстави, порядок його застосування та межі визначалися виключно внутрішньовідомчими документами.

За результатами виконання поставлених науково-дослідницьких завдань автором виокремлено юридичні та фактичні підстави для проведення перевірки на доброчесність працівників Національного бюро, запропоновано їх доповнення та нормативне вдосконалення.

Ключові слова: перевірка на доброчесність, державна служба, адміністративний контроль, моделювання ситуації, недоброчесна поведінка.

Recent events in the country show that every measure of implemented by law enforcement agencies or the power bloc, as a result of which significant interference with human and civil rights and freedoms or their significant or long-term restriction must require clear regulation and consolidation. As the case law of the European Court of Human Rights shows, this is a priority issue that becomes the subject of litigation and research: whether legal and factual grounds were for taking this or that measure, whether the official authority was exceeded during the choosing of this or that form of reaction.

In total, during the functioning of the Department of Internal Control conducted 53 the integrity test of employees of the National Anti-Corruption Bureau of Ukraine, 3 of them were negative $(5.6 \%$ of the total number of tests) [1]
These statistics indicate the grounds and procedure for conducting the integrity test by the Department of Internal Control of the National Bureau are need to improve.

However, at present, the integrity tetst of employees of the National Anti-Corruption Bureau of Ukraine has not been the subject of research by either domestic or foreign scientists due to the specifics of the subject of the research.

The purpose of this article is to determine the legal and factual grounds for the integrity test of employees of the National Anti-Corruption Bureau of Ukraine, to formulate the stages of this procedure.

The work is performed by applying general research and special methods of scientific knowledge. With the help of methods of abstraction, analysis and synthesis of the author by rejecting the insignificant properties of the integrity test 
at the same time managed to identify the grounds and stages of implementation of this phenomenon. Dialectical and logical methods allowed to clarify the essence of factual and legal grounds for the integrity test, to specify the list of concepts. Using forecasting and modeling, the author is proposed a specific model of legal regulation of the grounds and procedure for the integrity test of employees of the National Anti-Corruption Bureau of Ukraine.

The research tasks of this article are: 1) to examine the legal (regulatory) and factual (material) grounds for the integrity test of employees of the National Bureau; 2) to define the procedure for the integrity test of employees of the National Bureau and to analyze stages of it.

The legal (regulatory) ground answers to the question whether the legislator allows the integrity test in general, who is the subject and object of such test, their rights and responsibilities during its conduct, etc.

At the same time, the integrity test is only mentioned in the Law of Ukraine "On the National Anti-Corruption Bureau of Ukraine" [2], however, it's not clearly regulated, the definition of integrity, the integrity test, the procedure of integrity test and its components are not defined.

In particular, Part 2 of Art. 13 of the Law stipulates that when appointed to a position in the National Bureau, a person is informed about the possibility of conducting a integrity test and monitoring of the lifestyle.

Paragraph 3 of Part 2 of Art. 27 of this legal act stipulates that the internal control unit of the National Bureau has, in particular, the obligation to conduct inspections of employees of the National Bureau for integrity and monitoring of their lifestyle.

At the same time, the legal grounds for conducting the integrity test in the National Bureau are not set out in a separate internal document, but in Section VII of the Regulations on the Department of Internal Control of the National Anti-Corruption Bureau of Ukraine, approved by the National Bureau Director's Order of November 29, 2019 № 142 [3]. But it allows full discretion of the Director of the National Anti-Corruption Bureau of Ukraine and the head of the internal control unit in determining the procedure of the integrity test, its grounds, arbitrary change and determination of these legal instruments of administrative control by the employer, which is excessive interference with the rights and freedoms of employees of the National Bureau, this violates the principle of legal certainty.

Therefore, in our opinion, there is currently no proper legal basis for the application of the integrity test by the National Anti-Corruption Bureau of Ukraine.

In view of the above, it should be noted that such significant restrictions on human rights and freedoms that an employee of the National Anti-Corruption Bureau of Ukraine experiences during the integrity test, in our opinion, must be regulated in a legal act. It is inadmissible that the specified means of interference in private life, the grounds, the order of its application and the limits are determined exclusively by internal documents.

As for the factual (material) basis for the test, in our opinion, it should be understood as a certain legal fact, with the onset of which there is a need for conducting the integrity test by the Department of Internal Control of the National Bureau.

The law does not establish the factual (material) basis for conducting the integrity test.

After analyzing the provisions of Part 2 of Art. 13 of the Law of Ukraine "On the National Anti-Corruption Bureau of Ukraine" [2], according to which when appointed to a position in the National Bureau a person is notified of the possibility of conducting the integrity test and lifestyle monitoring, and provisions of Section VII of the Regulations on the Department of Internal Control of the National Anti-Corruption Bureau of Ukraine [3] that the simulation of the situation is carried out with the permission of the Head of the Department of Internal Control on the basis of a memorandum of an employee of the Department, who received information indicating the possibility of non-integrity behavior of an employee of the National Bureau, the following factual (material) grounds for the integrity test should be identified: 1) notification of the employee of the National Bureau upon appointment to the position on the possibility of conducting the integrity test on him; 2) receipt by the employee of the Department of Internal Control of the National Bureau of information indicating the possibility of non-integrity behavior of the employee of the National Bureau; 3) permission of the Head of the Department of Internal Control for such test.

In order to understand whether there is such a factual (material) ground for conducting the integrity test as a notification of an employee of the National Bureau when appointing to the position about the possibility of conducting such a test on him, one should pay attention to two points. Thus, the specified notification, in our opinion, should be in writing with the corresponding mark of the newly appointed person on acquaintance with the content of such notification.

The second point to pay attention to is the time limit of such notification, namely when appointing. In our opinion, it would be a logical legislative continuation, and in case of refusal to get acquainted with the signature with the notification about the possibility of conducting the integrity test, this employee cannot be appointed to the position.

There are also uncertain legal consequences if an employee of the National Bureau is informed about the possibility of conducting the integrity test against him not at the time of appointment, but after the appointment. In our opinion, such points need legislative regulation.

Consider the following factual (material) ground for conducting the integrity test, namely the receipt of information by an employee of the Department of Internal Control of the National Bureau, which indicates the possibility of nonintegrity behavior of an employee of the National Bureau.

However, it should be noted that this wording does not preclude arbitrariness on the part of employees of the Department of Internal Control, who, guided by hostile relations with certain employees of the National Bureau, who may have formed in the performance of other duties, indicate knowingly false information in such memorandum the possibility of non-integrity behavior of a particular employee.

In view of the above, it is appropriate, in our opinion, the ground for the integrity test of employees of the National Bureau to determine information about the possibility of nonintegrity behavior of a particular employee of the National Bureau, received by the Department of Internal Control by phone, mail, e-mail address, is found during an official investigation, pre-trial investigation or criminal intelligence and is executed by a relevant memorandum with supporting documents. That is, in case of need or doubt in the impartiality of the relevant employee of the internal control unit of the National Bureau, it is possible to check the reality of such information and prevent abuse of rights by employees of the Department.

The next factual (material) ground for conducting the integrity test is the permission of the Head of the Department of Internal Control for such test.

However, it should be noted that currently neither the laws of Ukraine "On the National Anti-Corruption Bureau of Ukraine" [2], "On Civil Service" [4], nor internal documents of the National Bureau regulate such a form of administrative document as a permit.

In this regard, in our opinion, it would be more appropriate to phrase that the Head of the Department of Internal Contro provides a written proxy in the form of a resolution to conduct the integrity test, which in turn is consistent with the provisions of paragraph 27 of the Instructions on Paperwork Management in the National Anti-Corruption Bureau of Ukraine, 
approved by the order of the Director of the National Bureau February 19, 2019 № 26 [5].

It is also impossible not to pay attention to the presence of corruption risk and possible abuse by the head of the internal control unit of the National Bureau, who has the right not to grant such permission, even if there are reasonable grounds for the integrity test of a particular employee of the National Bureau. However, there is no mechanism for appealing this decision, as well as external control to ensure the objectivity and impartiality of the exercise of such discretionary powers.

In view of the above, in our opinion, the employees of the Department of Internal Control should be given the opportunity to appeal both the issuance of a permit and the refusal to issue a permit for the integrity test to the Director of the National Bureau, who would make a final decision, which based on the results of acquaintance and analysis of the materials collected by the complainant.

Thus, it should be noted that the Department of Internal Control of the National Bureau is a pioneer in Ukraine of conducting the integrity test in classic "New York" sense [6]. At the same time, the grounds for the integrity test need more balanced legislation and further improvement in order to make more effective use of this tool in the field of anti-corruption among employees of the National Bureau.

\section{REFERENCES}

1. Звіти про роботу Національного антикорупційного бюро за 2015-2019 роки. URL : https://nabu.gov.ua/reports (дата звернення: 07.07.2020).

2. Про Національне антикорупційне бюро України : Закон України № 1698-VII від 14.10.2014. URL : https://zakon.rada.gov.ua/laws/ show/1698-18 (дата звернення: 07.07.2020).

3. Положення про Управління внутрішнього контролю Національного антикорупційного бюро України : Наказ Директора Національного антикорупційного бюро України від 29.11.2019 № 142. URL : https://nabu.gov.ua/sites/default/files/page_uploads/02.12/ nakaz_uvk.pdf (дата звернення: 07.07.2020).

4. Про державну службу : Закон України № 889-VIII від 10.12.2015. URL : https://zakon.rada.gov.ua/laws/show/889-19\#Text (дата звернення: 07.07.2020).

5. Інструкція з діловодства у Національному антикорупційному бюро України : Наказ Директора Національного бюро від 19.02.2019 № 26. URL : https://nabu.gov.ua/sites/default/files/page_uploads/25.02/26_nakaz.pdf (дата звернення: 07.07.2020).

6. Narelle Willingham. 2014. To Undertake Specialized Training in Integrity Testing. Canberra: The Winston Churchill Memorial Trust of Australia. URL : https://www.churchilltrust.com.au/media/fellows/To_undertake_specialised_training_in_integrity_testing_N_Beer_2013.pdf (дата звернення: 07.07.2020). 


\title{
АДМІНІСТРАТИВНО-ПРАВОВЕ ЗАБЕЗПЕЧЕННЯ МЕХАНІЗМУ ПРИТЯГНЕННЯ ДО ВІДПОВІДАЛЬНОСТІ ЗА ПОРУШЕННЯ УМОВ КАРАНТИНУ
}

\author{
ADMINISTRATIVE AND LEGAL PROVISION OF THE MECHANISM OF LIABILITY \\ FOR VIOLATION OF QUARANTINE CONDITIONS
}

Бурченко Ю.В., аспірантка кафедри юридичних дисциплін

Навчально-науковий інститут права

Національного університету водного господарства та природокористування

Дослідження присвячене вивченню адміністративно-правового забезпечення механізму притягнення до відповідальності за порушення умов карантину. У статті наводяться думки різних науковців щодо визначення понять «механізм», «забезпечення», «механізм адміністративно-правового забезпечення», «адміністративно-правове забезпечення». Відзначено, що в адміністративному праві не міститься терміна «адміністративно-правове забезпечення механізму притягнення до відповідальності за порушення умов карантину», тому автором статті сформульовано своє визначення. Зазначено, що в юридичній літературі немає єдиної точки зору з приводу поняття адміністративно-правового забезпечення, адже науковці досліджують його в контексті своєї спеціалізації. Автором зроблено висновок, що такі категорії, як «механізм», «забезпечення», «адміністративно-правове забезпечення», «механізм адміністративно-правового забезпечення» доповнюють один одного та мають зв'язок між собою, але все ж таки відрізняються за своєю суттю. Здійснено аналіз елементів адміністративно-правового забезпечення. Сформульовано й охарактеризовано елементи адміністративно-правового забезпечення механізму притягнення до відповідальності за порушення умов карантину. Особливу увагу автор звертає на порядок оформлення матеріалів уповноваженими державними органами за порушення санітарного законодавства, які регламентуються інструкціями відповідних державних органів. Наведено статистику, відповідно до якої Національною поліцією України складено понад 6 тис адміністративних протоколів про порушення карантинних заходів. Зроблено висновок, що основними причинами закриття проваджень у справах за порушення статті 44-3 КУпАП є те, що у протоколах, які знаходяться у судах, не відзначено, яких саме нормативних актів недотрималася особа та в чому суть правопорушень, помилки в протоколах, а саме відсутня інформація, яка повинна міститися у протоколі, неправильно визначений суб'єкт правопорушення, неправильно вказана інформація про суб'єкта правопорушення, не зібрано достатньої кількості доказів, не вказана інформація про свідків. Автор статті пропонує на законодавчому рівні розробити Методичні рекомендації під час складання протоколів за порушення статті 44-3 КУпАП, для того щоб правоохоронна та судова системи діяли злагоджено.

Ключові слова: механізм, забезпечення, карантин, відповідальність, адміністративно-правове забезпечення, протокол.

The study is devoted to the study of administrative and legal support of the mechanism of prosecution for violation of quarantine conditions. The article presents the views of various scholars on the definition of "mechanism", "provision" "mechanism of administrative and legal support", "administrative and legal support". It is noted that administrative law does not contain the term "administrative and legal support of the mechanism of prosecution for violation of quarantine conditions", so the author of the article formulated his definition. It is noted that in the legal literature there is no single point of view on the concept of administrative and legal support, because scholars study it in the context of their specialization. The author concludes that such categories as "mechanism", "provision", "administrative and legal support", "mechanism of administrative and legal support" complement each other and are related to each other, but still differ in nature. The analysis of elements of administrative and legal support is carried out. The author of the article formulated and characterized the elements of administrative and legal support of the mechanism of prosecution for violation of quarantine conditions. The author pays special attention to the procedure for registration of materials by authorized state bodies for violations of sanitary legislation, which are regulated by the Instructions of the relevant state bodies. The statistics according to which the National Police of Ukraine has drawn up more than 6000 administrative protocols on violation of quarantine measures are given. It is concluded that the main reasons for closing the proceedings for violations of Article 44-3 of the Code of Administrative Offenses is that the protocols in the courts do not indicate which regulations the person did not comply with and what is the essence of offenses, errors in the protocols, namely no information that should be contained in the protocol, incorrectly identified subject of the offense, incorrectly specified information about the subject of the offense, not enough evidence was collected, not specified information about witnesses. The author of the article proposes to the legislative level to develop guidelines for the preparation of protocols for violations of Article 44-3 of the Code of Administrative Offenses in order for law enforcement and judicial systems to operate in a coordinated manner.

Key words: mechanism, provision, quarantine, responsibility, administrative and legal support, protocol.

Постановка проблеми. Нещодавно державні органи влади внесли зміни до чинних та затвердили низку нових законодавчих актів, спрямованих на запобігання поширенню інфекційних хвороб. Ефективні міри, які націлені на запобігання та протидію інфекційним хворобам, $€$ потрібною обставиною для вдалого розвитку України як суверенної і незалежної, демократичної, соціальної, правової держави.

Однак без наукового дослідження практичне застосування законодавства за правопорушення вимог карантину може бути недостатньо дієвим. Таким чином, дане питання мало вивчене й є актуальним як для адміністративного права, так і для громадськості.

Мета статті полягає у тому, щоб на основі дослідження українського законодавства, наукових праць вивчити та сформулювати своє поняття адміністративно-правового забезпечення механізму притягнення до адміністративної відповідальності за порушення вимог карантину.

Аналіз останніх досліджень та публікацій. Варто відзначити, що поняття «адміністративно-правове забез- печення» стало предметом вивчення у працях О.І. Безпалової, І.О. Ієрусалімової, К.В. Барсукова, С.С. Колесникова, О.М. Гуміна, Є.В. Пряхіна, Г.С. Римарчука, С.В. Діденка, А. Матвійчук. А що стосується питання адміністративноправового забезпечення механізму притягнення до адміністративної відповідальності за порушення вимог карантину, то воно не вивчалося, а досліджувалося як коментарі до певних положень КУпАП та електронних статей юристів.

Виклад основного матеріалу дослідження. Перш ніж перейти до дослідження адміністративно-правового забезпечення механізму притягнення до адміністративної відповідальності за порушення вимог карантину, потрібно вивчити такі категорії: «механізм», «забезпечення», «адміністративно-правове забезпечення», «механізм адміністративно-правового забезпечення».

В юридичній літературі існує багато визначень щодо згадуваних понять, тому ми спробуємо дослідити основні, які за своїм змістом відрізняються один від одного.

O.I. Безпалова у своїй монографії зазначає, що в юридичному аспекті під терміном «механізм» слід розуміти 
сукупність методів, форм, прийомів, способів, завдяки правильному використанню яких можливо буде досягти оптимальної організації всіх елементів системи, їх ефективного функціонування, що в результаті повинно призвести до отримання бажаного результату [1, с. 37-38].

Що стосується терміна «забезпечення», то під ним слід розуміти створення надійних умов для здійснення чогонебудь; гарантування чого-небудь; захист, охорону когонебудь або чого-небудь від небезпеки; надання (постачання) чогось кимось у достатній кількості, створення усіх необхідних умов для здійснення чогось, гарантування чогось [1, с. 41].

Переходячи до вивчення питання адміністративноправового забезпечення, варто відзначити, що в юридичній літературі немає єдиної точки зору з приводу цього поняття, адже науковці досліджують його в контексті своєї спеціалізації.

Так, І.О. Ієрусалімова у дисертації, яка присвячена механізму адміністративно-правового забезпечення прав і свобод людини та громадянина, виводить таке визначення адміністративно-правового забезпечення: це регулювання за допомогою норм адміністративного права суспільних відносин, що виникають для та в процесі їхньої реалізації, а також надання за допомогою цих норм відповідних гарантій, які разом з іншими правовими та неправовими гарантіями створюють стійку систему можливостей користування правовими цінностями в державі [2, с. 12].

На думку К.В. Барсукова, який досліджував адміністративно-правове забезпечення проходження служби працівниками органів внутрішніх справ у складі міжнародних миротворчих підрозділів, поняття «забезпечення міжнародної миротворчої діяльності» слід розглядати у двох значеннях: по-перше, як діяльність державних органів, працівників органів внутрішніх справ, військових Збройних сил України щодо здійснення своїх функцій, компетенції, обов'язків із метою запобігання виникненню міждержавних або внутрішніх конфліктів; i, по-друге, як підсумок, результат цієї діяльності, що виражається у фактичній реалізації правових приписів, прав і свобод громадян як нашої держави, так і громадян іноземних держав, в яких проходить миротворча місія. Автор уважає, що адміністративно-правове забезпечення проходження служби працівниками ОВС у складі міжнародних миротворчих підрозділів - це складне, багатопланове, комплексне поняття, головним змістом якого $є$ діяльність держави щодо створення належних правових умов відбору персоналу, підготовки кадрів, направлення до міжнародних миротворчих місій та гарантування правового захисту учасників міжнародних миротворчих операцій шляхом установлення відповідного нормативно-правового забезпечення проходження служби [3, с. 9].

Є.Є. Колесников дотримується думки, що адміністративно-правове забезпечення - це здійснюване державою за допомогою спеціального механізму впорядкування суспільних відносин, їх юридичне закріплення, охорона, peaлізація і розвиток [4, с. 434].

Ми погоджуємося з думкою О.М. Гуміна та Є.В. Пряхіна, що адміністративно-правове забезпечення можна розглядати у широкому та вузькому розумінні. У широкому розумінні АПЗ можна визначити як упорядкування суспільних відносин уповноваженими на те державою органами, їх юридичне закріплення за допомогою правових норм, охорона, реалізація і розвиток. Щодо вузького розуміння, то визначення буде змінюватися у зв'язку 3 тим, про які суспільні відносини йтиметься [5, с. 48].

Г.С. Римарчук уважає, що адміністративно-правове забезпечення - це здійснюване державою за допомогою правових норм, приписів і сукупності засобів упорядкування суспільних відносин, їх юридичне закріплення, охорона, реалізація і розвиток $[6$, с. 10$]$.
Переходячи до вивчення категорії «механізм адміністративно-правового забезпечення», варто зазначити, що поняття «механізм» займає значне місце у суспільних відносинах, бо регулює усі сфери життя людини.

Не можна не погодитися 3 думкою С.В. Діденко, що механізм адміністративно-правового забезпечення розповсюджується на певну сферу суспільних відносин, а його основним завданням $\epsilon$ впорядкування суспільних відносин, щоб надалі мати змогу впливати на них. Автор зазначає, що механізм адміністративно-правового забезпечення - це певний процес, тобто певний рух задля досягнення певної цілі, а його особливостями є коло учасників, на яких розповсюджується його вплив, і спосіб їхньої поведінки [7, с. 464].

Здійснивши комплексний аналіз таких понять, як «механізм», «забезпечення», «адміністративно-правове забезпечення», «механізм адміністративно-правового забезпечення», можна зробити висновок, що ці категорії доповнюють одна одну та мають зв'язок між собою, але все ж таки відрізняються за своєю суттю.

Проаналізувавши вищезгадані поняття, пропонуємо таке визначення адміністративно-правового забезпечення механізму притягнення до відповідальності за порушення умов карантину: це регулювання суспільних відносин, що виникають у сфері охорони здоров'я і становлять систему правових норм та методів, відповідно до яких держава встановлює поведінку суб'єктів таких відносин, при цьому реалізовуючи внутрішні функції з метою забезпечення їхніх прав та обов'язків.

Перед тим як перейти до розгляду елементів механізму адміністративно-правового забезпечення притягнення до адміністративної відповідальності за порушення вимог карантину, потрібно розглянути позиції науковців із цього приводу.

На думку С.В. Діденка, до елементів правового регулювання належать: юридичні норми; нормативноправові акти; акти офіційного тлумачення; юридичні факти; правовідносини; акти право реалізації; правосвідомість і режим законності та правопорядку, який упорядковується в результаті досягнення цілей правового регулювання. Кожній стадії правового регулювання відповідають специфічні елементи механізму правового регулювання, місце яких у механізмі правового регулювання зумовлене їхньою функціональною роллю. Функціонування механізму правового регулювання відрізняється послідовністю: кожен із його елементів вступає в дію на певній стадії правового регулювання. Тобто залежно від стадії адміністративно-правового забезпечення суспільних відносин різнитимуться й елементи його здійснення [7, с. 465-466].

O.I. Безпалова до числа характерних для адміністративно-правового механізму ознак відносить такі: а) системність; б) виконання кожним елементом механізму свої специфічної функції; в) особливий склад суб'єктів, на які покладено обов'язок реалізації правоохоронної функції держави; г) зв'язок суб'єктів реалізації правоохоронної функції держави між собою єдиними цілями та засадами діяльності; г) здійснення застосування даного механізму за допомогою адміністративно-правових норм; д) плановий характер; е) безперервність функціонування даного механізму; є) підконтрольний характер; ж) здійснення взаємодії між суб'єктами реалізації правоохоронної функції держави на засадах субординації та координації; з) домінуюче становище одних елементів механізму реалізації правоохоронної функції держави над іншими [1, с. 49].

А. Матвійчук до основних елементів адміністративно-правового забезпечення відносить: 1) об'єкт адміністративно-правового забезпечення; 2) суб'єкт адміністративно-правового забезпечення; 3) норми права (норми адміністративного права); 4) адміністративноправові відносини та їх зміст; 5) гарантії, заходи, засоби, 
форми та методи адміністративно-правового забезпечення [8, с. 109].

С.В. Діденко досліджуючи поняття та елементи механізму забезпечення обігу та застосування зброї, виокремив такі елементи:

1) норми права різного призначення, такі як Закон України «Про Національну поліцію», «Інструкція про порядок виготовлення, придбання, зберігання, обліку, перевезення та використання вогнепальної, пневматичної і холодної зброї, пристроїв вітчизняного виробництва для відстрілу патронів, споряджених гумовими чи аналогічними за своїми властивостями метальними снарядами несмертельної дії, та зазначених патронів, а також боєприпасів до зброї та вибухових матеріалів» тощо;

2) акти застосування права і діяльність організацій та посадових осіб з утілення їх у життя (форми та методи), як, наприклад, видання конкретній особі дозволу на володіння, зберігання, носіння зброї;

3) принципи адміністративного права, серед яких у сфері обігу та застосування зброї можна виділити принцип пріоритету прав і свобод людини та громадянина; принцип верховенства права та правового закону; принцип рівності однорідних суб'єктів адміністративного права перед законом; принцип демократизму; принцип взаємної відповідальності суб'єктів публічної адміністрації та об'єктів публічного управління тощо;

4) тлумачення адміністративних приписів у цій сфері як процес доведення та уточнення їх змісту;

5) адміністративно-правові відносини, які базуються на адміністративно-правових нормах та виникають і здійснюються на їх основі;

6) адміністративно-правовий статус суб'єктів публічної адміністрації, що здійснюють адміністративно-правове забезпечення обігу та застосування зброї;

7) адміністративно-правові режими, зокрема обігу зброї на території України, ліцензування тощо;

8) адміністративні процедури діяльності суб'єктів публічної адміністрації у сфері забезпечення обігу та застосування зброї [7, с. 467].

Аналіз різних підходів науковців дає нам підстави визначити такі елементи адміністративно-правового забезпечення механізму притягнення до адміністративної відповідальності за порушення вимог карантину:

1) суб'єкти;

2) об'єкти;

3) правові норми, такі як Кодекс України про адміністративні правопорушення, Закон України «Про захист населення від інфекційних хвороб», Постанова «Про запобігання поширенню на території України гострої респіраторної хвороби COVID-19, спричиненої коронавірусом SARS-CO V-2», Інструкція про порядок накладання і стягнення штрафів за порушення санітарного законодавства № 64, Інструкція 3 оформлення матеріалів про адміністративні правопорушення в органах поліції № 1376;

4) розпорядження місцевих органів виконавчої влади та органів місцевого самоврядування;

5) принципи адміністративного права;

6) суспільні відносини у сфері захисту населення від інфекційних хвороб;

7) правовий статус органів виконавчої влади, які здійснюють контроль над дотриманням вимог карантину;

8) адміністративно-правові режими пов'язані з дотриманням вимог карантину (надзвичайний стан, порядок перетину кордонів, обласні пропускні пункти).

Згідно зі ст. 255 КУпАП, за порушення правил карантину протоколи мають право складати: «уповноважені на те посадові особи: органів внутрішніх справ (Національної поліції); органів охорони здоров'я - щодо завідомо неправдивого виклику швидкої медичної допомоги; органів державної санітарно-епідеміологічної служби; посадові особи, уповноважені на те виконавчими комітетами (а у населених пунктах, де не створено виконавчих комітетів, - виконавчими органами, що виконують їхні повноваження) сільських, селищних, міських рад» [9].

Порядок оформлення матеріалів уповноваженими державними органами за порушення санітарного законодавства регламентуються інструкціями відповідних державних органів.

Перейдемо до вивчення таких інструкцій. Провадження у справі складається з чотирьох стадій:

- порушення справи;

- розгляд справи і винесення постанови по справі;

- оскарження постанови по справі;

- виконання постанови про накладення штрафу згідно з п. 1.20 Інструкції про порядок накладення і стягнення штрафів за порушення санітарного законодавства № 64 [10].

Підставою для складання протоколу є факт порушення санітарного законодавства [10].

Головні державні санітарні лікарі, їхні заступники та інші посадові особи державної санітарно-епідеміологічної служби адміністративних територій мають право відповідно до їх компетенції складати акти і протоколи щодо порушень санітарного законодавства, які вчинені в межах відповідних адміністративних територій (п. 2.3) [10].

Протокол складається у двох примірниках, один з яких у триденний термін передається посадовій особі, яка уповноважена розглядати справу, другий - порушнику. Протокол підписується особою, яка його склала, і особою, яка вчинила адміністративне правопорушення. За наявності свідків і потерпілих протокол може бути підписаний також і цими особами. У разі відмови особи, яка вчинила правопорушення, від підписання протоколу у ньому робиться запис про це, проте фіксація цього факту з указівкою свідків не вимагається. Особа, яка вчинила правопорушення, має право подати пояснення і зауваження щодо змісту протоколу, а також викласти мотиви своєї відмови від його підписання. Пояснення, зауваження, а також мотиви відмови від підписання протоколу, власноручно викладені особою, додаються до протоколу (п. 2.4-2.5) [10].

Суть правопорушення повинна бути описана так, щоб було зрозуміло:

- де вчинено порушення;

- коли вчинено порушення;

в якій саме дії (бездіяльності) та за яких умов це порушення відбулося 3 указівкою на конкретні статті Закону, пункти санітарних норм, що порушуються, або на конкретні постанови, розпорядження, приписи, висновки посадових осіб Держсанепідслужби, які не виконуються (п. 2.8) [10].

Посадова особа, що складає протокол, зобов'язана пояснити порушнику права особи, яка притягається до адміністративної відповідальності (знайомитися 3 матеріалами справи; давати пояснення; подавати докази; заявляти клопотання; під час розгляду справи користуватися юридичною допомогою адвоката, іншого фахівця у галузі права, який має право на надання правової допомоги особисто чи за дорученням юридичної особи; виступати рідною мовою і користуватися послугами перекладача, якщо не володіє мовою, якою ведеться провадження; оскаржити постанову за справою та ознайомити зі змістом частини першої статті 63 (Конституції України) про що робиться відмітка у протоколі (п. 2.10) [10].

До протоколу про адміністративне правопорушення долучаються інші матеріали про адміністративне правопорушення (пояснення особи, яка притягається до адміністративної відповідальності, потерпілих, свідків, висновок експерта, речові докази, протокол про вилучення речей і документів, рапорти посадових осіб, а також інші документи та матеріали, що містять інформацію про правопорушення) (п. 15) [11]. 
До протоколу можуть бути занесені й інші відомості, які, на думку особи, що його складає, підтверджують факт порушення санітарного законодавства i характеризують особу порушника, майновий стан, обставини, що пом'якшують або обтяжують відповідальність (п. 2.11) [10].

3 метою складання протоколу в разі неможливості скласти його посадовою особою на місці вчинення правопорушення працівником органів внутрішніх справ може бути доставлено порушника в поліцію (п. 2.13) [10].

У разі вчинення адміністративного правопорушення неповнолітньою особою віком від чотирнадцяти до шістнадцяти років протокол про адміністративне правопорушення складається стосовно одного 3 батьків неповнолітньої особи або особи, яка їх замінює, відповідно до частини третьої ст. 184 КУПАП (п. 17) [11].

Протокол про адміністративне правопорушення та матеріали про вчинене адміністративне правопорушення, відповідно до ст. 257 КУПАП, надсилаються (надаються) органу (посадовій особі), уповноваженому(ій) розглядати справи про адміністративні правопорушення (п. 18) [11].

Відповідно ст. 212 КУпАП, правопорушення за ст. 44-3 КУпАП розглядають судді районних, районних у місті, міських чи міськрайонних судів [9].

Сьогодні, як повідомляє пресслужба Національної поліції України, складено понад 6 тис адміністративних протоколів про порушення карантинних заходів [12].

Зокрема, 212 постанов матеріали справи про притягнення особи до адміністративної відповідальності за ст. 44-3 КУПАП повернуто до ВП ГУНП України для доопрацювання, оскільки протоколи про адміністративне правопорушення не відповідають вимогам ст. 256 КУПАП. 10 постанов - матеріали справи про притягнення до адміністративної відповідальності особи за ст. 44-3 КУпАП до ВП ГУНП направлені за належною підсудністю. 106 постанов - закрито провадження у справі щодо особи за ст. 44-3 КУпАП у зв`язку з відсутню складу адміністративного правопорушення або у зв ‘ язку з відсутністю події і складу адміністративного правопорушення. 7 постанов - закрито провадження у зв язку з малозначністю скоєного правопорушення. 10-ма постановами осіб звільнено від адміністративної відповідальності за ст. 44-3 КУпАП за малозначністю, обмежившись усним зауваженням, закривши провадження у справі. 32-ма постановами осіб визнано винними у скоєнні адміністративного правопорушення, передбаченого ст. 44-3 КУПАП [13].

На основі аналізу судових рішень їх можна поділити на такі види: 1) відсутність складу правопорушення; 2) повернення адміністративних матеріалів на доопрацювання; 3) притягнення до відповідальності за порушення ст. 44-3 КУПАП.

Отже, можна зробити висновок, що основними причинами закриття проваджень у справах за порушення ст. 44-3 КУпАП є те, що у протоколах, які знаходяться у судах, не відзначено, яких саме нормативних актів недотрималася особа та в чому суть правопорушень, помилки в протоколах, а саме відсутня інформація, яка повинна міститися у протоколі, неправильно визначений суб'єкт правопорушення, неправильно вказана інформація про суб' єкта правопорушення, не зібрано достатньої кількості доказів, не вказана інформація про свідків.

Отже, для того щоб правоохоронна та судова системи діяли узгоджено, потрібно на законодавчому рівні розробити Методичні рекомендації під час складання протоколів за порушення ст. 44-3 КУПАП. Також потрібно здійснювати навчання уповноважених осіб, які мають право складати протоколи за порушення ст. 44-3 КУПАП.

Висновки $з$ даного дослідження. Підсумовуючи викладене вище, зазначимо, що українське адміністративне право всебічно вивчає різні напрями адміністративно-правового забезпечення. Звертаємо увагу на відсутність єдиного методологічного підходу серед науковців стосовно визначення даної категорії i, як результат, - велика кількість різних визначень та характеристик.

Дотримуємося думки, що діяльність ефективного адміністративно-правового забезпечення механізму притягнення до адміністративної відповідальності за порушення вимог карантину сприяє реалізації впливу на суспільні відносини, які відбуваються у сфері охорони здоров'я, налаштуванню дієвої взаємодії між державою та громадянином, що є загальним стандартом адміністративного права у демократичних державах.

\section{ЛITEPATУРA}

1. Безпалова О.І. Адміністративно-правовий механізм реалізації правоохоронної функції держави : монографрія. Харків : Харківський національний університет внутрішніх справ, 2014. 544 с.

2. Ієрусалімова І.О. Механізм адміністративно-правового забезпечення прав і свобод людини та громадянина : автореф. дис. ... канд. юрид. наук : 12.00 .07 ; Ін-т законодавства Верх. Ради України. Київ, 2006. 20 с.

3. Барсуков К.В. Адміністративно-правове забезпечення проходження служби працівниками органів внутрішніх справ у складі міжнародних миротворчих підрозділів : автореф. дис. ... канд. юрид. наук : 12.00.07 ; Держ. НДІ МВС України. Київ, 2010.20 с.

4. Колесников Є.Є. Поняття та особливості адміністративно-правового забезпечення захисту прав споживачів. Форум права. 2011. № 2. C. 432-438.

5. Гумін О.М., Пряхін Є.В. Адміністративно-правове забезпечення: поняття та структура. Наше право. 2014. № 4. С. 46-50.

6. Римарчук Г.С. Адміністративно-правове забезпечення права інтелектуальної власності в Україні : автореф. дис. ... канд. юрид. наук : 12.00 .07 ; Національний університет «Львівська політехніка». Львів, 2013. 20 с.

7. Діденко С.В. Поняття та елементи механізму адміністративно-правового забезпечення обігу та застосування зброї в Україні. Наукові праці Національного університету «Одеська юридична академія». 2015. Т. 16. С. 463-469.

8. Матвійчук А. Адміністративно-правове забезпечення державної регуляторної політики. Підприємство, господарство $і$ право. 2019. № 1. С. 108-111.

9. Кодекс України про адміністративні правопорушення від 07.12.84 № 8074-10 : станом на 14.05.2020 / Верховна Рада України. URL : https://zakon.rada.gov.ua/laws/show/80731-10 (дата звернення: 12.06.2020).

10. Інструкція про порядок накладення і стягнення штрафів за порушення санітарного законодавства від 14.04.1995 № 64: станом на 21.11.2011 / Верховна Рада України. URL : https://zakon.rada.gov.ua/laws/show/z0291-95\#Tеxt (дата звернення: 12.07.2020).

11. Інструкція з оформлення матеріалів про адміністративні правопорушення в органах поліції від 06.11.2015 № 1376: станом на 17.01.2020 / Верховна Рада України. URL : https://zakon.rada.gov.ua/laws/show/z1496-15\#Text (дата звернення: 12.07.2020).

12. Зелена Р. Суд vs правила карантину URL : https://uz.ligazakon.ua/ua/magazine_article/EA013669.

13. Ореховський М.Л. Аналіз постанов по 44-3 КУпАП - Судді в $90 \%$ випадків відмовляються штрафувати українців за порушення правил карантину. URL : https://protocol.ua/ru/analiz_postanov_po_44_3_kupap_suddi_v_90_vipadkiv_vidmovlyayutsya_shtrafuvati_ ukraintsiv za porushennya pravil karantinu/. 


\title{
ВСТАНОВЛЕННЯ ОСОБИ ДЛЯ ПРИТЯГНЕННЯ ЇЇ ДО АДМІНІСТРАТИВНОЇ ВІДПОВІДАЛЬНОСТІ ЯК ПРЕВЕНТИВНИЙ ПОЛІЦЕЙСЬКІЙ ЗАХІД
}

\author{
ESTABLISHING A PERSON TO BRING HIM TO ADMINISTRATIVE RESPONSIBILITY \\ AS A PREVENTIVE POLICE MEASURE
}

Василенко С.О., аспірант кафедри адміністративного права та адміністративного процесу

факультету № 3

Інститут підготовки фахівичів для підрозділів Національної поліиіі

Львівського державного університету внутрішніх справ

Піднято питання, яке стосується насамперед практичного здійснення превентивних поліцейських заходів, а саме перевірки документів для встановлення особи, щоб притягнути ії до адміністративної відповідальності за вчинене нею адміністративне правопорушення.

Під час практичної діяльності поліцейських достатньо гостро стоїть питання щодо належного ознайомлення з документами особи через процес їх пред'явлення поліцейським для ознайомлення з метою встановлення особи, а також безпосередньої перевірки самого документа на наявність підробки через відсутність самостійного огляду.

Проаналізовано поняття превенції, розглянуто повноваження Національної поліції у сфері адміністративної відповідальності та превентивної діяльності, зокрема встановлення особи, притягнення її до адміністративної відповідальності, заходів реагування на правопорушення. Охарактеризовано превентивний поліцейський захід перевірки документів особи та поліцейські заходи адміністративного примусу, що виконуються у забезпеченні провадження у справах про адміністративні правопорушення.

Здійснено аналіз законів і наукових публікацій, відображених у періодичних виданнях, засобах масової інформації та мережі Інтернет, із висвітленням проблемних питань, пов'язаних із необхідністю вдосконалення превентивного поліцейського заходу перевірки документів особи.

Указано діяльність поліції з урахуванням типових ситуацій, що становить предмет подальших наукових досліджень.

Постановка проблеми полягає у виникненні проблемних моментів підчас виконання поліцейськими свої безпосередніх службових обов'язків, під час здійснення превентивних поліцейських заходів перевірки документів особи, а також установлення особи з метою притягнення ії до адміністративної відповідальності за вчинені правопорушення як здійснення заходів забезпечення провадження у справах про адміністративні правопорушення.

Метою статті є висвітлення проблематики, що виникає у практичній діяльності поліцейських під час здійснення превентивного поліцейського заходу перевірки документів особи й їі встановлення та подальшого притягнення даної особи до адміністративної відповідальності за вчинені правопорушення, а також запропонування методів для вирішення даних проблем.

Надано пропозицію рекомендаційного характеру для вдосконалення методів правового регулювання превентивних поліцейських заходів, а саме перевірки документів особи для забезпечення більше ефективної діяльності поліції щодо встановлення особи, метою якої є полегшення практичної роботи поліцейським у встановлені та притягненні особи до адміністративної відповідальності.

Ключові слова: адміністративна відповідальність, превенція, превентивна діяльність, перевірка документів особи, встановлення особи, заходи забезпечення провадження, Національна поліція України, функції поліції.

Raised a question that is primarily concerned with the practical implementation of preventive police measures, namely, verification of documents for identification to bring her to administrative responsibility for committed by them administrative offenses.

In the practical activities of police officers there is the question as to the appropriate documents, through the process of submitting a COP for review with the aim of identification and immediate verification of the document for the presence of fakes, due to the lack of self-examination.

Analyzed the concept of risk, considered the powers of the National police in the area of administrative liability and preventive action, in particular the identity of the person attracting it to administrative responsibility, the response to offense. Preventive police described the event verification of documents of persons and police measures of administrative coercion performed in the provision of production on Affairs about administrative offences.

The analysis of laws and of scientific publications reflected in journals, the media and the Internet, with coverage of problematic issues related to the need to improve preventive activities of the police checking the documents of persons.

The activity of the police with the typical situations that is the subject of further research.

The problem lies in the emergence of problematic aspects at runtime by the police of their direct official duties in the implementation of preventive measures police officers check the documents of persons and the identity of the person with the purpose of bringing him to administrative responsibility for offenses in the quality of implementation of measures of maintenance of manufacture on Affairs about administrative offences.

The aim of the article is the lighting issues that arise in the practice of the police in the implementation of preventive activities of the police checking the documents of the personality and its installation, and further bringing the person to administrative responsibility for offenses, and proposed methods of solving these problems.

Provided offer a recommendation for improvement of legal regulation of preventive police measures, namely the verification of documents of a person to ensure more effective policing for establishment of the person, the purpose of which is to facilitate the practical work of the police in a timely and bringing a person to administrative responsibility.

Key words: administrative responsibility, prevention, preventive action, verification of documents of persons, measures of provision of production, national police, functions of the police.

Стан дослідження. Теоретичною основою вивчення питань превентивної діяльності Національної поліції як правоохоронних заходів реагування на правопорушення стали публікації провідних науковців, а саме: О.М. Бандурки, О.І. Олефір, О.Ю. Салманової, О.В. Джафарова, Ю.А. Ведєрнікова, О.С. Проневича, Ю.М. Бисаги, О.І. Безпалова, С.С. Алексєєва, О.А. Банчук, О.І. Остапенка та ін.

Виклад основних положень. Превенція - це комплекс заходів, спрямованих на припинення можливого правопорушення. Таким чином, основна їі мета полягає у недопущенні вчинення злочину. Інформування суспільства, регулювання системи покарань - це основні завдання, які ставить перед собою превенція. Це полягає, насамперед, у донесенні до суспільства тієї думки, що будь-яке протиправне діяння буде покарано, причому досить серйозно [1].

Превентивна діяльність поліцейськими здійснюється для запобігання та профілактики вчинення правопорушень. 
Як зазначають українські дослідники (О.І. Олефір O.М. Бандурка, О.I. Безпалова, О.В. Джафарова та ін.), «превентивні поліцейські заходи - це дія або комплекс дій, що обмежують певні права і свободи людини, використання яких не завжди пов'язане з протиправною поведінкою конкретних осіб, застосовуються відповідно до закону для забезпечення виконання покладених на поліцію повноважень із дотриманням установлених законом вимог» $[2$, с. 37$]$.

Метою застосування превентивних поліцейських заходів $є$ забезпечення виконання поліцією своїх обов'язків.

Поліція є соціальною системою, що створена державою для реалізації певних функцій. Розуміння сутності цих функцій сприяє чіткому визначенню ролі та місця поліції в системі органів публічної влади. Із погляду адміністративно-правової науки функція є окремим видом виконавчорозпорядчої діяльності. Функції відображають зміст діяльності виконавчої влади, значною мірою характеризують сутність держави та ії соціальне призначення [3, с. 141].

Перевірка документів особи відноситься до превентивних поліцейських заходів. Виходячи зі ст. 32 ЗУ «Про Національну поліцію», поліцейський має право вимагати у особи пред'явлення нею документів, що посвідчують особу, та/або документів, що підтверджують відповідне право особи, у таких випадках:

1) якщо особа володіє зовнішніми ознаками, схожими на зовнішні ознаки особи, яка перебуває в розшуку, або безвісно зниклої особи;

2) якщо існує достатньо підстав уважати, що особа вчинила або має намір учинити правопорушення;

3) якщо особа перебуває на території чи об'єкті зі спеціальним режимом або в місці здійснення спеціального поліцейського контролю;

4) якщо у особи є зброя, боєприпаси, наркотичні засоби та інші речі, обіг яких обмежений або заборонений, або для зберігання, використання чи перевезення яких потрібен дозвіл, якщо встановити такі права іншим чином неможливо;

5) якщо особа перебуває в місці вчинення правопорушення або дорожньо-транспортної пригоди, іншої надзвичайної події;

6) якщо зовнішні ознаки особи чи транспортного засобу або дії особи дають достатні підстави вважати, що особа причетна до вчинення правопорушення, транспортний засіб може бути знаряддям чи об'єктом учинення правопорушення [4, с. 17].

Варто звернути увагу на те, що одна з підстав для перевірки документів особи поліцією звучить досить нечітко порівняно 3 іншими: якщо існує достатньо підстав уважати, що особа вчинила або має намір учинити правопорушення; Саме цей намір можна по-різному трактувати.

Без ознайомлення $з$ документом, що засвідчує особу, достатньо складно встановити відповідну особу.

Як вище було вказано, ЗУ «Про Національну поліцію» закріплює право поліцейського на перевірку документів двох типів:

- що посвідчують особу;

- що посвідчують відповідне право особи.

Документи, що посвідчують особу. Чинне законодавство не встановлює вичерпаного переліку документів, що посвідчують особу. Так, з огляду на нормативне урегулювання зазначеного питання, можна вести мову лише про документи, що підтверджують громадянство особи (ст. 5 3У «Про громадянство України»), до яких слід відносити:

- паспорт громадянина України;

- паспорт громадянина України для виїзду за кордон;

- тимчасове посвідчення громадянина України;

- дипломатичний паспорт;

- службовий паспорт;

- посвідчення особи моряка;
- посвідчення члена екіпажу;

- посвідчення особи на повернення в Україну [5].

Але під час практичної реалізації повноважень поліції виникає питання не лише підтвердження громадянства особи, а й, головне, його належної ідентифікації, наприклад із метою складання процесуальних документів про вчинення правопорушення, затримання особи тощо.

Слід наголосити, що зазначене питання залишається доволі гострим та сьогодні немає механізму його вирішення. На нашу думку, для ідентифікації особи необхідно використовувати будь-який документ, що об'єктивно дає змогу не лише визначити необхідні дані для складання процесуальних документів, а також не викликає сумнівів щодо достовірності отриманої інформації [6, с. 6].

Варто зазначити, що до документів, які посвідчують особу, згідно зі ст. 13 Закону України «Про Єдиний державний демографічний реєстр та документи, що підтверджують громадянство України, посвідчують особу чи ії спеціальний статус», відносяться документи, оформлення яких передбачається цим Законом із застосуванням засобів Реєстру відповідно до їх функціонального призначення, і поділяються на:

- документи, що посвідчують особу та підтверджують громадянство України:

- паспорт громадянина України;

- паспорт громадянина України для виїзду за кордон;

- дипломатичний паспорт України;

- службовий паспорт України;

- посвідчення особи моряка;

- посвідчення члена екіпажу;

- посвідчення особи на повернення в Україну;

- тимчасове посвідчення громадянина України;

- документи, що посвідчують особу та підтверджують її спеціальний статус:

- посвідчення водія;

- посвідчення особи без громадянства для виїзду за кордон;

- посвідка на постійне проживання

- посвідка на тимчасове проживання;

- картка мігранта;

- посвідчення біженця;

- проїзний документ біженця;

- посвідчення особи, яка потребує додаткового захисту;

- проїзний документ особи, якій надано додатковий захист [7].

Документи, що посвідчують відповідне право особи. Другу групу документів, які можуть перевірятися працівниками поліції, становлять документи, які посвідчують окреме право особи або іiї спеціальний статус. До них слід віднести низку документів дозвільного характеру, наприклад ліцензії, сертифікати, патенти тощо. Особливе місце займають дозвільні документи на зброю, що видаються органами та підрозділами Національної поліції.

Окрім зазначеного, до даної групи слід відносити документи, що посвідчують спеціальний статус особи, наприклад посвідчення на право керування транспортними засобами відповідної категорії, документи, що посвідчують іноземне громадянство, дипломатичний статус особипред'явника, перебування на військовій службі або на посаді судді, прокурора, депутата ради тощо [6, с. 7].

Зазначу, що спеціального обов'язку носити документи у чинному законодавстві не вказано.

Без належної перевірки документів та, відповідно, встановлення особи, яка здійснила правопорушення, не буде можливості здійснити притягнення іï до відповідальності. Із цього випливає, що принцип невідворотності покарання за скоєне правопорушення втрачає свій сенс.

Застосування поліцейських заходів, у тому числі перевірки документів, передбачене у низці міжнародних правових актів. Наприклад, Загальна декларація прав людини (1948р.) у ст. 3 визначає, що кожна людина має 
право на життя, свободу й особисту недоторканність, а ст. 12 Декларації прав людини (1948 р.) передбачає, що ніхто не може зазнавати безпідставного втручання у його особисте і сімейне життя, безпідставного посягання на недоторканність його житла, тайну його кореспонденції або на його честь і репутацію. Кожна людина має право на захист закону від такого втручання або таких посягань.

Стаття 13 Декларації прав людини (1948 р.) передбачає, кожна людина має право вільно пересуватися і вибирати собі місце проживання у межах кожної держави. Кожна людина має право покинути будь-яку країну, включаючи й свою власну, і повернутися у свою країну [8].

Виходячи з Конституції України (ст. 3), людина, iii життя і здоров'я, честь і гідність, недоторканність і безпека визнаються в Україні найвищою соціальною цінністю. Стаття 21 - усі люди є вільні і рівні у своїй гідності та правах. Права і свободи людини є невідчужуваними та непорушними. Стаття 29 - кожна людина має право на свободу та особисту недоторканність [9].

Перевірка документів - дослідження уповноваженими службовими особами Національної поліції України паспортних та інших документів громадян України, іноземців та осіб без громадянства в разі підозри у вчиненні правопорушення або є потерпілими, або свідками скоєного правопорушення, або встановлення їх дійсності та приналежності відповідній особі [10, с. 173].

Перевірка документів відноситься до найбільш поширених у світі поліцейських заходів превентивного характеру. За своїм змістом процедура перевірки документів включає у себе дії поліцейського, спрямовані на дослідження паспортних та інших документів, що посвідчують особу громадянина України, іноземця та особу без громадянства, а також документів, що підтверджують відповідне право даної особи, у разі підозри даних осіб у вчиненні правопорушення або якщо вони є потерпілими, свідками скоєного правопорушення. Перевірка документів здійснюється 3 метою встановлення особи, дійсності документа, приналежності відповідній особі та підтвердження відповідного права особи [11, с. 108].

Водночас це хороший превентивний захід попередження порушення закону.

Право перевіряти відповідні документи надається всім працівникам поліції. Для здійснення перевірки документів не вимагається складання якогось спеціального документа чи отримання санкції.

Виходячи 3 вищевикладеного, можна зробити висновок, що просто так, без конкретної причини у особи поліцейські не можуть вимагати пред'явити документи, які посвідчують особу.

Відмова особи пред'явити поліцейському на його законну вимогу документи для встановлення особи з метою притягнення іiі до адміністративної відповідальності тягне за собою відповідальність за ст. 185 КУПАП, а саме за злісну непокору законній вимозі або розпорядженню поліцейського. Разом із тим відсутність документів, що посвідчують особу, не передбачає відповідальності для особи. Натомість, згідно зі ст. 260 КУпАП, у контексті забезпечення провадження у справах про адміністративні правопорушення, у тому числі з метою встановлення особи, допускаються адміністративне затримання особи, особистий огляд, огляд речей і вилучення речей і документів та інші заходи, що становлять ті чи інші форми прояву поліцейських заходів (поверхнева перевірка, обмеження пересування особи або фактичного володіння річчю) [12, с. 44].

Висновки. Підсумовуючи, доходимо висновку, що для підвищення функціональної ефективності органів поліції у сфері забезпечення охорони правопорядку необхідним видається реалізація комплексу заходів, спрямованих на вдосконалення системи здійснення превентивних поліцейських заходів, а саме перевірки документів особи.

Особа може пред'явити документ занадто швидко, показати та сховати його, не даючи можливості поліцейському достатньо часу, щоб належно ознайомитися 3 викладеною у ньому інформацією, щоб перевірити iĭ, також одночасно документ особа може пред'являти через сторонні предмети (скло автомобіля, обкладинку гаманця та ін.), що безпосередньо створює не найкращі умови для перевірки інформації, яка вказана у документі. Також варто зазначити ще кілька чинників, які можуть негативно впливати на перевірку: час доби (ніч, сутінки, погане освітлення місцевості), погодні умови (сніг, дощ) тощо.

Вирішення цієї проблеми зумовлює необхідність ужиття заходів для вдосконалення діяльності органів правопорядку.

Уважаю, що вдосконалення, насамперед, полягає у передачі відповідного документа, який засвідчує особу, працівнику поліції безпосередньо в руки для візуальної перевірки документа на підробку та встановлення особи.

Таким чином, щоб поліпшити роботу поліцейських, варто прийняти зміни у чинному ЗУ «Про Національну поліцію», у ст. 32 здійснити заміну «пред'явлення» на «передачу» документів, що посвідчують особу, та/або документів, що підтверджують відповідне право особи.

Для початку будь-якої процесуальної дії потрібно насамперед встановити особу, щодо якої дана дія буде розпочата, для цього, відповідно, і потрібний належний документ, що підтверджує дані особи, а також можливість із ним ознайомитися та перевірити його на можливість підробки, а відсутність у особи документів може стати формальним приводом для застосування правоохоронцями адміністративного затримання для встановлення особи (ст. 260 КУпАП).

Ефективне виконання функцій поліцією значною мірою залежить від правильно проведених превентивних заходів, у нашому разі це перевірка документів особи.

Якісна превентивна діяльність поліції є гарантією безпеки громадян у суспільстві від злочинних посягань.

\section{ЛITEPATYPA}

1. Превенція - це основа безпеки суспільства. URL : http://poradu.pp.ua/nauka/43731-prevencya-ce-osnova-bezpeki-susplstva.html.

2. Адміністративна діяльність поліції у питаннях та відповідях : навчальний посібник / О.І. Безпалова та ін. : за заг. ред. О.М. Бандурки. Харків : ХНУВС, 2017. 242 с.

3. Проневич О.С. Функції поліції (міліції): нормативно-доктринальна інтерпретація. Право і безпека. 2010. № 4(36). С. 141-146.

4. Закон України «Про Національну поліцію» від 02.07. 2015 № 580-VIII. Офріційний вісник України. 2015. № 63. Ст. 33.

5. Закон України «Про громадянство України». Відомості Верховної Ради України (ВВР). 2001. № 13. Ст. 65.

6. Нормативно-правові засади спілкування та перевірки документів, порядок проведення зовнішнього огляду речей та одягу особи (особистого огляду та огляду речей затриманої особи) : методичні рекомендації. Дніпро, 2016.

7. Закон України «Про Єдиний державний демографічний реєстр та документи, що підтверджують громадянство України, посвідчують особу чи її спеціальний статус». Відомості Верховної Ради (ВВР). 2013. № 51. Ст. 716.

8. Загальна декларація прав людини, прийнята і проголошена в Резолюції 217 А (III) Генеральної Асамблеї від 10 грудня 1948 року.

9. Конституція України. Відомості Верховної Ради України (ВВР). 1996. № 30. Ст. 141.

10. Науково-практичний коментар Закону України «Про Національну поліцію» / кер. авт. кол. д.ю.н., доц. Т.П. Мінка. Дніпро : Дніпропетр. держ. ун-т внутр. справ, 2017. 480 с.

11. Науково-практичний коментар розділів IV «Повноваження поліції» та розділів V «Поліцейські заходи» Закону України «Про національну поліцію» : науково-практичний коментар. Харків : Право, 2016. С. 108.

12. Адміністративна діяльність поліції у питаннях та відповідях : навчальний посібник / за заг. ред. д.ю.н., професора, академіка НАПрН України О.М. Бандурки. 


\title{
АКТУАЛЬНІ ПРОБЛЕМИ ЗАСТОСУВАННЯ ВОГНЕПАЛЬНОЇ ЗБРОЇ ПОЛІЦЕЙСЬКИМИ В УКРАЇНІ
}

\section{CURRENT PROBLEMS OF POLICE USE OF FIREARMS IN UKRAINE}

\author{
Волков Ю.М., викладач кафедри тактико-спеціальної підготовки \\ Дніпропетровський державний університет внутрішніх справ
}

Казначесв Д.Г., к.ю.н., доцент, доцент кафедри тактико-спеціальної підготовки Дніпропетровський державний університет внутрішніх справ

\begin{abstract}
У статті досліджуються актуальні проблеми застосування вогнепальної зброї поліцейськими в Україні, які існують у сучасних правовідносинах. Ураховуючи невизначеність, що склалася останнім часом у вітчизняній юриспруденції щодо нормативно-виправданого застосування вогнепальної зброї поліцейськими як найбільш суворого заходу примусу через те, що ставлення інститутів громадянського суспільства до такого застосування найбільш суворого заходу примусу є неоднозначним і викликає безліч запитань до працівника Національної поліції України після такого застосування, навіть у тих випадках, коли воно було нормативно обумовленим і існували визначені Законом України «Про Національну поліцію» підстави для застосування вищезгаданого заходу примусу. У сучасних реаліях виникають ситуації, коли поліцейські уникають застосування вогнепальної зброї навіть у випадках ії виправданого застосування відповідно до норм чинного законодавства, що, своєю чергою, іноді призводить до невиконання ними своїх повноважень із боротьби зі злочинністю, а також недієвості застосування інших заходів примусу. Також у статті аналізуються випадки застосування вогнепальної зброї поліцейськими під час різних ситуацій, що виникають у процесі виконання службових обов'язків, та можливі наслідки такого застосування вогнепальної зброї як найбільш суворого заходу примусу, у тому числі заподіяння шкоди життю та здоров'ю іншим громадянам, що викликає не менший осуд, аніж застосування вогнепальної зброї.

На основі Конституції України та інших законодавчих актів розглядаються правові підстави щодо застосування вогнепальної зброї поліцейськими та характерні помилки, що припускаються поліцейськими під час застосування вогнепальної зброї. Висвітлюються шляхи вирішення проблем застосування вогнепальної зброї поліцейськими на сучасному етапі через утілення механізму контролю з боку контрольно-наглядових органів та чіткого і конкретного роз'яснення всіх аспектів застосування вогнепальної зброї для самих поліцейських відповідно до норм чинного законодавства. Також розглянуто законодавчі гарантії захисту прав поліцейського у разі правомірного застосування вогнепальної зброї та правові наслідки за перевищення заходів, необхідних для правомірного затримання правопорушників.

Ключові слова: поліцейські заходи примусу, вогнепальна зброя, застосування вогнепальної зброї, підстави застосування вогне-
\end{abstract} пальної зброї, нормативні гарантії.

The article investigates the current problems of the use of firearms by police in Ukraine, which exist in modern legal relations. Given the recent uncertainty in domestic jurisprudence regarding the use of firearms by police as the strictest coercive measure, the attitude of civil society institutions to such use of the strictest coercive measure is ambiguous and raises many questions for police officers. Ukraine after such application, even in those cases when it was normatively conditioned and there were the bases for application of the above-mentioned measure of coercion defined by the Law of Ukraine "About National police". In modern realities, there are situations when police officers avoid the use of firearms even in cases of their justified use in accordance with current legislation, which in turn sometimes leads to their failure to exercise their powers to combat crime and the ineffectiveness of other coercive measures. The article also analyzes the use of firearms by police officers in various situations that arise in the performance of official duties and the possible consequences of such use of firearms as the most severe measure of coercion, including harm to life and health of other citizens, which causes no less condemnation than the use of firearms.

Based on the Constitution of Ukraine and other legislative acts, the legal grounds for the use of firearms by police and the typical mistakes made by police during the use of firearms are considered. The ways of solving the problems of firearms use by the police at the present stage are covered, through the implementation of the control mechanism by the control and supervisory bodies and a clear and specific explanation of all aspects of the use of firearms for the police in accordance with current legislation. Legislative guarantees of protection of the rights of the police officer in case of lawful use of the firearm and legal consequences for excess of the measures necessary for lawful detention of offenders are also considered. The legislator should clearly outline in the Criminal Code such guarantees for the protection of the rights of a police officer as a citizen, where certain provisions act as a guarantee of the lawfulness of the actions of a police officer during the detention of a person who has committed a criminal offense.

Key words: police coercive measures, firearms, grounds for using firearms, regulatory safeguards.

Постановка проблеми. У вітчизняній практиці останнім часом ситуація склалася так, що поліцейські, розуміючи наслідки, хоча і нормативно виправданого застосування вогнепальної зброї, уникають приведення в дію i застосування цього заходу примусу, що іноді призводить до невиконання ними своїх повноважень, недієвості застосованих ними спеціальних засобів, а також завдання шкоди життю і здоров'ю іншим громадянам, що викликає не менший осуд, аніж застосування вогнепальної зброї. Виходячи із даної ситуації, можна поставити питання: як діяти у подібних ситуаціях працівнику Національної поліції України й яким чином слід удосконалити механізм нагляду за випадками застосування вогнепальної зброї в системі МВС України?

На законодавчому рівні закріплено, що застосування вогнепальної зброї є найбільш суворим заходом примусу [2]. Цей припис зазначено у статті 46 Закону України «Про Національну поліцію». Застосування вогнепальної зброї поліцейським завжди несе за собою певні наслідки, оцінка яких залежить від реакції громадськості і владних інституцій. Саме тому досить актуальною $є$ проблема реалізації чинного законодавства на всіх рівнях життедіяльності суспільства, усвідомлення громадянами реальної можливості поліцейським застосувати вогнепальну зброю для попередження чи припинення протиправних дій на підставі пунктів статті 46 вищезгаданого закону [2]. Сучасне вітчизняне суспільство має презюмувати принцип правомірності дій поліцейського і поставити у пріоритет усвідомлення того, що правоохоронець діє виключно в рамках закону.

Аналіз публікацій, у яких започатковано розв'язання даної проблеми. Проблема реагування громадськості на застосування вогнепальної зброї поліцейськими під час попередження або припинення протиправних дій $\epsilon$ надзвичайно актуальною і потребує розгляду і віднайдення шляхів вирішення. Дослідженням цієї проблеми 
займалися науковці-правники та фахівці з різних галузей права: В.О. Заросило, А.В. Губанов, О.С. Федченко, В.Д. Шиян тощо.

Виклад основного матеріалу дослідження. Критичне ставлення до застосування вогнепальної зброї і спеціальних засобів, фізичної сили як заходів примусу, визначених законом, законсервувалося ще з радянських часів. У свідомості громадян залишилося деформоване сприйняття роботи поліції як явне перевищення повноважень, і будьяке застосування ними заходів примусу $є$ неправомірним і таким, що порушує конституційні права і свободи, а також законні інтереси людини та громадянина [3].

Не слід випускати з уваги той факт, що Україна репрезентує себе як суверенна і незалежна, демократична, соціальна, правова держава [1]. Саме тому у такій державі має бути модернізований, оновлений до сучасних правових вимог і суспільних тенденцій правоохоронний орган Національна поліція України.

Із прийняттям Закону України «Про Національну поліцію» від 02.07.2015 розпочато реформування центрального органу виконавчої влади, який служить суспільству шляхом забезпечення охорони прав і свобод людини, протидії злочинності, підтримання публічної безпеки і порядку [2]. Ключовим словом $є$ «розпочато», тому що реорганізація неминуче призводить до хоча і незначного, проте збереження давніх устроїв або фрагментарного залишення старого механізму. Система міліції поступово відходить у небуття, сучасні стандарти світу вимагають змін, тенденції повсякденного життя країни вносять свої корективи - усе це тягне за собою й оновлення найголовнішого - порядку і правил застосування вогнепальної зброї правниками Національної поліції України [5].

Боротьба $з$ груповою злочинністю, бажання зробити життя українців спокійним і мирним, загострення криміногенної ситуації в Україні, збільшення випадків учинення тяжких і особливо тяжких злочинів групою осіб, припинення злочинів на стадії замаху або готування - усе це спонукає сучасних правоохоронців діяти більш жорстко, рішуче й ефективно попереджувати і припиняти такі суспільно-небезпечні діяння часто із застосуванням вогнепальної зброї. На такі ситуації досить гостро і критично реагують громадськість, засоби масової інформації і контрольно-наглядові гілки влади. Сьогодні ситуації застосування поліцейськими вогнепальної зброї не $\epsilon$ поодинокими, і вибір у поліцейського невеликий: застосувати вогнепальну зброю, а потім стати учасником кримінального або дисциплінарного провадження як заподіювача шкоди або ж отримати каліцтво чи взагалі загинути.

На нашу думку, негативну реакцію громадськості і 3МI на випадки застосування вогнепальної зброї поліцейськими за умови, якщо ними було дотримано всі пункти, визначені законодавцем i чинні, слід уважати деформованою правосвідомістю в аспекті реалізації правозастосовних норм. Якщо норма існує, то такий поліцейський захід, як застосування вогнепальної зброї (визначений як найбільш суворий) має бути застосований у виняткових випадках для забезпечення публічної безпеки і порядку, протидії злочинності, охорони прав і свобод людини та громадянина, тобто реалізації всіх завдань, передбачених Законом України «Про Національну поліцію» [2].

Крок до вирішення актуальної проблеми знаходиться у механізмі контролю 3 боку контрольно-наглядових органів, які мають презюмувати правомірність дій поліцейського, якщо вони підкріплені відповідним пунктом чинного законодавства. Найчастіше трапляється так, що поліцейські правомірно застосовують вогнепальну зброю, але у підсумку несуть щонайменше дисциплінарну відповідальність за неправомірне заподіяння шкоди.

Прикладом можуть слугувати дії патрульного поліцейського С. Олійника, які досить гаряче обговорюва- лися українською спільнотою. Від кулі поліцейського у 2016 році під час погоні загинув пасажир BMW. Машина мчала по Києву з максимальною швидкістю, порушуючи правила дорожнього руху і створюючи небезпеку для оточуючих, а водій не реагував на законні вимоги поліцейських зупинитися, у результаті чого був відкритий вогонь. Поліцейський обвинувачувався у навмисному вбивстві і був взятий під варту [4]. Не можна заперечувати той факт, що поліцейський намагався діяти на підставі пункту 7 статті 46 Закону України «Про Національну поліцію»: «...для зупинки транспортного засобу шляхом його пошкодження, якщо водій своїми діями створює загрозу життю чи здоров'ю людей або поліцейського» [2]. Одним із головних аспектів професійної діяльності поліцейського $є$ його юридична грамотність, тобто вміння читати і розуміти закони. У розумінні тексту норми закону вищезгаданий поліцейський припустився помилки, тому що у пункті конкретно вказано на застосування вогнепальної зброї лише з метою пошкодження транспортного засобу, а не завдання тілесних ушкоджень пасажирам, а тим паче завдання їм смерті, що, власне, i було скоєно патрульним [5]. Патрульний С. Олійник виходив із того, що протидіяти і завадити ситуації, що склалася, неможливо було іншими засобами і способами, проте його дії суперечили приписам статті 46 Закону України «Про національну поліцію».

Цілком природно, що ця подія викликала широкий резонанс у засобах масової інформації, як офіційних, так i тих, що прагнуть знайти шокуючий матеріал для своїх постійних читачів і гіперболізувати подію. Тому випадки застосування поліцейськими вогнепальної зброї стали жорстко контрольованими i, як наслідок, небажаними для самих працівників, навіть якщо вони застосували найбільш суворий захід примусу відповідно до всіх законодавчих вимог.

Не можна заперечувати той факт, що підгрунтям сукупності норм, яка існує у кожній демократичній правовій державі, є Конституція, у нашому випадку - Конституція України. У статті 3 Основного Закону України зазначено: «Людина, iii життя і здоров'я, честь і гідність, недоторканність і безпека визнаються в Україні найвищою соціальною цінністю» [1]. Водночас у статті 68 Конституції України зазначено, що «кожен зобов'язаний неухильно додержуватися Конституції України та законів України, не посягати на права і свободи, честь і гідність інших людей» [1]. На підставі цього можна зазначити цілком виправданим таку концепцію: поліцейські заходи примусу застосовуються до осіб, які посягають на положення, закріплене у Конституції України. Саме тому, враховуючи всі особливості гарантування і дотримання Україною як правовою і соціальною державою прав і свобод людини та громадянина, можна підсумувати, що Закон України «Про Національну поліцію» написаний на основі Конституції України, а у згаданому законі зазначено можливість застосування заходів примусу, у тому числі - застосування вогнепальної зброї, що регламентоване статтею 46 зазначеного Закону [2].

Не менш актуальною поряд із проблемою трактування громадськістю застосування вогнепальної зброї поліцейськими є роз'яснення для самих поліцейських випадків застосування вогнепальної зброї. Таке роз'яснення має бути конкретним і зрозумілим, єдиним для всіх, на кшталт пам'ятки для працівника поліції. Таким чином, працівник поліції буде діяти відповідно до норм чинного законодавства. Розуміння законодавства, яке стосується випадків застосування вогнепальної зброї поліцейським, не може бути у кожного своє, воно є єдиним для всіх - від штатного працівника поліції до керівника центрального органу управління поліції і відповідного прокурора [6].

Високе звання поліцейського зобов'язує діяти завжди відповідно до чинного законодавства. Поліцейський, упо- 
вноважений на носіння і зберігання, застосування і використання вогнепальної зброї, повинен володіти нормами чинного законодавства щодо застосування і використання у своїй діяльності найбільш суворого заходу примусу i знати норми Кримінального кодексу України, а також Закону України «Про Національну поліцію» [5].

Вогнепальна зброя застосовується у виняткових випадках, які наведено у статті 46 Закону України «Про Національну поліцію», а саме:

1) для відбиття нападу на поліцейського або членів його сім'ї у разі загрози їхньому життю чи здоров'ю;

2) для захисту осіб від нападу, що загрожує їхньому життю чи здоров'ю;

3) для звільнення заручників або осіб, яких незаконно позбавлено волі;

4) для відбиття нападу на об'єкти, що перебувають під охороною, конвої, житлові та нежитлові приміщення, а також звільнення таких об'єктів у разі їх захоплення;

5) для затримання особи, яку застали під час учинення тяжкого або особливо тяжкого злочину й яка намагається втекти;

6) для затримання особи, яка чинить збройний опір намагається втекти з-під варти, а також озброєної особи, яка погрожує застосуванням зброї та інших предметів, що загрожують життю і здоров'ю людей та/або поліцейського;

7) для зупинки транспортного засобу шляхом його пошкодження, якщо водій своїми діями створює загрозу життю чи здоров'ю людей та/або поліцейського [2].

Не можна вважати за істину, що наведені сім підстав виняткових випадків $є$ переліком винятків. Проте прийнятна для сучасної науки концепція про те, що подані підстави сформульовані у вигляді мети, для досягнення якої може бути застосована вогнепальна зброя. Наприклад, наявність нападу на інших осіб, що загрожує їхньому життю чи здоров'ю, є підставою для застосування зброї. Проте вирішити питання про винятковість цієї події належить поліцейському. Це він робитиме у кожному випадку по-різному, виходячи із власного юридичного і практичного досвіду, ситуації, що склалася, характеру та інтенсивності суспільно небезпечного посягання, засобів і способі усунення небезпеки в інший спосіб, виправданого ризику тощо [6].

Вище було наведено приклад про патрульного поліцейського, який застосував вогнепальну зброю для зупинки транспортного засобу, у результаті чого загинув пасажир автомобіля, який намагалися зупинити. Подібна ситуація виникає 3 актуальної в лавах Національної поліції України нормативної необізнаності деяких працівників. Відповідає дійсності судження про те, що вогнепальна зброя може застосовуватися для зупинки транспортного засобу шляхом його пошкодження, якщо водій своїми діями створює загрозу життю чи здоров'ю людей та/або поліцейського. Пошкодження транспортного засобу не є синонімічним поняття до ушкодження або вбивства водія чи пасажира, адже закон дозволяє лише виведення $з$ ладу транспортного засобу [5].

Невиконання законної вимоги поліцейського щодо зупинки транспортного засобу і при цьому створення водієм загрози життю чи здоров'ю людей та/або поліцейського є підставою для застосування вогнепальної зброї, але у виняткових випадках, і тільки поліцейському вирішувати, чи є ситуація, що склалася, винятковою.

Правомірність застосування вогнепальної зброї щоразу перевіряється органами прокуратури, які 3'ясовують, чи були достатні підстави для застосування вогнепальної зброї і чи носила ситуація винятковий характер. У кожному конкретному випадку перевірці підлягатимуть факти, чи була завдана шкода необхідною і достатньою в такій обстановці, чи припинення відповідного нападу неможливо було досягнути іншими засобами, чи мала подія винятковий характер [6]

Звісно, не менш актуальною у сучасному законодавстві є проблема гарантій прав і свобод поліцейського у разі застосування ним вогнепальної зброї. Сьогодні законодавець має чітко окреслити такі гарантії для захисту прав поліцейського як громадянина. Особливої уваги заслуговує Кримінальний кодекс України, де окремі положення виступають як гарантування правомірності дій поліцейського під час, наприклад, затримання особи, яка вчинила кримінальне правопорушення.

У Кримінальному кодексі України міститься поняття «перевищення заходів, необхідних для затримання злочинця». Відповідно до ч. 2 ст. 38 Кримінального кодексу України, це умисне заподіяння особі, що вчинила злочин, тяжкої шкоди, яка явно не відповідає небезпечності посягання або обстановці затримання злочинця. Таке перевищення заходів має наслідком відповідальність за статтями 118 та 124 КК України [7].

Власне, самою гарантією $є$ те, що представники влади, працівники правоохоронних органів, члени громадських формувань 3 охорони громадського порядку і державного кордону або військовослужбовці не підлягають кримінальній відповідальності за шкоду, заподіяну під час виконання службових обов'язків із запобігання суспільно небезпечним посяганням і затримання правопорушників, якщо вони не допустили перевищення заходів, необхідних для правомірного затримання злочинця. Також фігурує поняття «перевищення меж необхідної оборони», яке означає умисне заподіяння тому, хто посягає, тяжкої шкоди, яка явно не відповідає небезпечності посягання або обстановці захисту. Під час вирішення судом питання про перевищення меж необхідної оборони, відповідно до Постанови Пленуму Верховного Суду України від 26 квітня 2002 р. № 1 «Про судову практику у справах про необхідну оборону» [8], враховується не лише відповідність чи невідповідність знарядь захисту і нападу, а й характер небезпеки, що загрожувала особі, тощо.

Навіть судова практика виходить із того, що у кожній конкретній ситуації необхідно встановлювати винятковість випадку.

Висновок. Отже, наявність тільки підстав для застосування вогнепальної зброї, визначених у п. 4 і п. 6 статті 46 Закону України «Про Національну поліцію», без дотримання вимог, передбачених пунктами 7,8 указаного Закону та ст. ст. 36, 38 Кримінального кодексу України, не може бути визнана достатньою для правомірного застосування вогнепальної зброї. А також обов'язково контрольно-наглядовими органами й органом правосуддя вирішується питання під час розгляду справи про винятковість випадку, що, власне, вирішує, поліцейський у конкретний час і визначеному місці виходячи з характеру правопорушення, конкретної ситуації, а також індивідуальних особливостей особи, яка вчинила правопорушення. Таким чином, виходячи $з$ вищевикладеного, слід наголосити на забезпеченні правової обізнаності працівників поліції в аспекті застосування вогнепальної зброї, а також поставити їм у пріоритет бездоганне знання нормативноправових актів, якими регламентується їхня професійна діяльність у сфері зберігання і носіння, застосування та використання вогнепальної зброї. Не менш важливим аспектом є реакція громадськості на застосування вогнепальної зброї, адже нерідко застосування найбільш суворого заходу примусу відбувається на визначених законом підставах. Сприйняття застосування вогнепальної зброї працівником Національної поліції України як обов'язково неправомірного $\epsilon$ стереотипом, застарілою установкою правосвідомості, яка призводить до хвиль непорозумінь i пустих балачок. Сучасна правоохоронна система і українське суспільство мають жити за світовими стандартами. 


\section{ЛITEPATYPA}

1. Конституція України : редакція від 21.02.2019. URL : https://zakon.rada.gov.ua/laws/show (дата звернення: 27.07.2020).

2. Про Національну поліцію України : Закон України від 2 липня 2015 р. № 580. URL : https://zakon.rada.gov.ua/laws/show/580-19 (дата звернення: 24.06.2020).

3. Романов О. Зброя: законодавчий аспект. Юридичний журнал. 2005. № 2(32). С. 32-38.

4. Смертельна гонитва в Києві: прокуратура визнала винним патрульного, який застрелив у BMW підлітка. УHIAH. URL : https://www.unian.ua/incidents/1612042-smertelna-gonitva-v-kievi-prokuratura-viznala-vinnim-patrulnogo-yakiy-zastreliv-u-bmw-pidlitka.html (дата звернення: 27.07.2020).

5. Коли поліцейський має право стріляти: усі нюанси мовою закону і очима фрахівця. Українська асоціація власників зброї. URL : https:// zbroya.info/uk/blog/8901_koli-politseiskii-maie-pravo-striliati-usi-niuansi-movoiu-zakonu-i-ochima-fakhivtsia/ (дата звернення: 27.07.2020).

6. Новицький Г. Пам'ятка співробітникам поліції «Щодо застосування вогнепальної зброї». Інформаційно-аналітичний центр Національної безпеки України. URL : http://mediarnbo.org/2016/02/10/pam-yatka-spivrobitnikam-politsiyi-shhodo-zastosuvannya-vognepalnoyizbroyi/ (дата звернення: 27.07.2020).

7. Кримінальний кодекс України від 5 квітня 2001 р. № 2341. URL : https://zakon.rada.gov.ua/go/2341-14 (дата звернення: 27.07.2020)

8. Про судову практику у справах про необхідну оборону : Постанова Пленуму Верховного Суду України від 26 квітня 2002 р. № 1. URL : https://zakon.rada.gov.ua/go/v0001700-02 (дата звернення: 27.07.2020). 


\title{
ДЖЕРЕЛА АДМІНІСТРАТИВНО-ПРАВОВОГО РЕГУЛЮВАННЯ У СФЕРІ ПРОФЕСІЙНОГО СПОРТУ В УКРАЇНІ
}

\author{
SOURCES OF ADMINISTRATIVE AND LEGAL REGULATION \\ IN THE SPHERE OF PROFESSIONAL SPORTS IN UKRAINE
}

\author{
Деменко К.Е., аспірантка кафедри адміністративного, \\ господарського права та фінансово-економічної безпеки \\ Сумський державний університет
}

\begin{abstract}
Статтю присвячено висвітленню особливостей джерел адміністративно-правового регулювання у сфері професійного спорту в Україні. З'ясовано зміст поняття «правове регулювання», зважаючи на існуючі наукові підходи до його розуміння. Зауважено, що адміністративне-правове регулювання $є$ різновидом правового регулювання, тобто перше $є$ вужчим поняттям за останнє. Розкрито ознаки адміністративно-правового регулювання, зокрема, що адміністративно-правове регулювання здійснюється виключно за допомогою адміністративно-правових норм, зовнішнім виразом яких є джерела адміністративно-правового регулювання. Зважаючи на існуючу відповідно до норм Конституції України ієрархію актів національного законодавства, запропоновано розглядати джерела адміністративноправового регулювання у сфері професійного спорту в Україні з урахуванням їх місця у такій ієрархії. Наголошено на конституційному обов'язку держави дбати про підтримку та розвиток фізичної культури і спорту. Зроблено акцент на міжнародних конвенціях у сфрері професійного спорту, які були ратифіковані Україною в останні роки, що свідчить про очевидний намір держави привести у відповідність суспільні відносини у сфері професійного спорту до міжнародних та європейських стандартів. Запропоновано серед джерел адміністративно-правового регулювання професійного спорту в Украӥні розрізняти закони, які регулюють суспільні відносини безпосередньо у сфері професійного спорту, та закони, норми яких поширюють свою дію на широке коло суспільних відносин, у тому числі у сфері професійного спорту в Україні. Вагому увагу приділено підзаконним актам як джерелам адміністративно-правового регулювання професійного спорту в Україні. До таких джерел віднесено укази Президента України, постанови Кабінету Міністрів України, накази Міністерства молоді та спорту України, акти місцевих державних адміністрації, органів місцевого самоврядування. Підсумовуючи, запропоновано авторське визначення поняття «адміністративно-правове регулювання у сфері професійного спорту в Україні».
\end{abstract}

Ключові слова: регулювання, правове регулювання, адміністративно-правове регулювання, джерела, спорт, професійний спорт.

The article is devoted to highlighting the features of the sources of administrative and legal regulation in the sphere of professional sports in Ukraine. The meaning of the concept of "legal regulation" is clarified taking into account the existing scientific approaches to its understanding. It is noted that administrative-legal regulation is a kind of legal regulation, it is a narrower concept than the latter. The signs of administrativelegal regulation are revealed, in particular, that administrative-legal regulation is carried out exclusively by means of administrative-legal norms, the external expression of which is the sources of administrative-legal regulation. Given the existing hierarchy of acts of national legislation in accordance with the Constitution of Ukraine, it is proposed to consider the sources of administrative and legal regulation in the sphere of professional sports in Ukraine, taking into account their place in such a hierarchy. The constitutional obligation of the state to take care of the support and development of physical culture and sports is emphasized. Emphasis is placed on international conventions in the sphere of professional sports, which have been ratified by Ukraine in recent years, which indicates the obvious intention of the state to bring public relations in the sphere of professional sports in line with international and European standards. It is proposed to distinguish between the sources of administrative and legal regulation in the sphere of professional sports in Ukraine laws that regulate public relations directly in the shpere of professional sports and laws whose rules extend to a wide range of public relations, including professional sports in Ukraine. Significant attention is paid to bylaws as sources of administrative and legal regulation of professional sports in Ukraine. Such sources include decrees of the President of Ukraine, resolutions of the Cabinet of Ministers of Ukraine, orders of the Ministry of Youth and Sports of Ukraine, acts of local state administrations, local governments. Summing up, the author's definition of the term "administrative and legal regulation in the field of professional sports in Ukraine" is proposed.

Key words: regulation, legal regulation, administrative and legal regulation, sources, sport, professional sport.

Тема правового регулювання професійного спорту $є$ актуальною для всіх держав світу, зважаючи на те, що спорт $€$ невід'ємним складником здорового розвитку кожної особи та сприяє збільшенню працездатності, активності та утвердженню авторитету держави на світовому рівні. Однак спорт не може існувати без чітких правил і норм. Незважаючи на це, широке коло правовідносин, що пов'язані зі здійсненням професійного спорту, все ж таки залишається нерегламентованим в українському законодавстві.

Нині правове регулювання професійних спортивних відносин здійснюється переважно за допомогою норм цивільного та трудового права, що дуже часто викликає колізію. Однак сьогодні відсутня грунтовна відповідь на питання щодо співвідношення норм даних галузей права під час регулювання професійних спортивних відносин, більше того, поза межами вказаних галузей права перебувають питання щодо порядку формування спортивних команд, встановлення правил та вимог для професійних спортсменів, судових арбітрів, межі державного контролю над дотриманням регламентованих правил, види санкцій за порушення норм у сфері професійного спорту тощо. Зважаючи на вказане, окремої уваги потребує вивчення питання адміністративно-правового регулювання про- фесійного спорту в України, зокрема класифікація джерел такого регулювання. Безсумнівно, це дасть змогу не лише з'ясувати специфіку адміністративного-правового регулювання професійного спорту в України, а й виявити існуючі прогалини такого регулювання, сформулювати напрями їх усунення тощо.

Передусім звернемо увагу на поняття «правове регулювання». Деталізуючи зміст цього визначення, П.М. Рабінович наголошує на тому, що сутність правового регулювання полягає у здійснюваному державою за допомогою всіх юридичних засобів владному впливі на суспільні відносини з метою їх упорядкування, закріплення, охорони і розвитку [1, с. 151].

А.Т. Комзюк уважає, що правове регулювання є специфічним впливом, що здійснюється правом як особливим нормативним інституційним регулятором. Правове регулювання має цілеспрямований, організаційний, результативний характер і здійснюється за допомогою системи засобів, що виражають матерію права як нормативного регулятора [2, с. 47]. Наведені визначення дають змогу зробити висновок про те, що метою правового регулювання професійного спорту в Україні $є$ упорядкування, охорона та розвиток суспільних відносин у сфері здій- 
снення професійного спорту, що здійснюється за допомогою всієї сукупності юридичних засобів.

Одним із видів правового регулювання є адміністративно-правове регулювання. Н.С. Андрійченко пропонує під поняттям «адміністративно-правове регулювання» розуміти владний вплив держави, що здійснюється за допомогою закріпленої на законодавчому рівні сукупності адміністративно-правових норм, на суспільні відносини [3, с. 83]. Водночас автори видання «Права громадян у сфері виконавчої влади» виокремили такі ознаки адміністративно-правового регулювання: це вид правового регулювання, де серед регуляторів першочергову роль відіграють адміністративно-правові норми; це засіб державного регулювання, оскільки адміністративне право встановлюється і санкціонується державою, а отже, є державним регулятором суспільних відносин; здійснює певний вплив на суспільні відносини за допомогою норм позитивного права й інших правових засобів; здійснює такий вплив на суспільні відносини, що має своєю метою їх упорядкування; має за мету забезпечити належний рівень відносин між окремою особою та державою, іiї органами, посадовими особами [4, с. 157-159].

Отже, адміністративно-правове регулювання здійснюється виключно за допомогою адміністративно-правових норм, зовнішнім виразом яких $є$ джерела адміністративноправового регулювання. Зважаючи на положення Конституції України, відповідно до якого остання має найвищу юридичну силу, а закони та інші нормативно-правові акти приймаються на основі Конституції України і повинні відповідати їй (ст. 8), уважаємо за доцільне розглядати джерела адміністративно-правового регулювання професійного спорту в Україні, зважаючи на ієрархію актів законодавства в державі.

Варто зауважити, що ст. 49 Конституції України закріплює обов'язок держави дбати про підтримку та розвиток фізичної культури і спорту. Зважаючи на вказане, має бути й належне правове забезпечення здійснення професійного спорту в Україні. Окрім того, Конституція України передбачає, що чинні міжнародні договори, згода на обов'язковість яких надана Верховною Радою України, є частиною національного законодавства України (ст. 9) [5]. Положення законів України «Про дію міжнародних договорів на території України» та «Про міжнародні договори України» свідчать про те, що найважливішими серед міжнародних договорів $€$ багатосторонні міжнародні договори - конвенціï. У сфері професійного спорту Україною ратифіковано низку міжнародних конвенцій, у тому числі Міжнародну конвенцію про боротьбу з допінгом у спорті та Європейську конвенцію про насильство та неналежну поведінку з боку глядачів під час спортивних заходів, і зокрема футбольних матчів, ETS № 120 (Страсбург, 19.08.1985) тощо.

Загалом ратифікація Україною міжнародних конвенцій свідчить про те, що держава має за мету імплементувати положення міжнародних стандартів у сфері професійного спорту у національне законодавство для забезпечення упорядкованості суспільних відносин у зазначеній сфері.

Переходячи до нормативно-правових актів як джерел адміністративно-правового регулювання професійного спорту в Україні, ми не можемо не зазначити, що за своїм змістом нормативно-правовий акт являє собою акт, прийнятий уповноваженим на це суб'єктом нормотворення у визначеній законодавством формі та за встановленою законодавством процедурою, що містить норми права, має неперсоніфікований характер і розрахований на неодноразове застосування незалежно від строку його дії (постійний чи обмежений певним часом) та характеру відомостей, що в ньому міститься [6].

При цьому нормативно-правові акти класифікуються на законодавчі та підзаконні акти. Так, відповідно до Листа Міністерства юстиції України «Щодо порядку застосування нормативно-правових актів у разі існування неу- згодженості між підзаконними актами» від 30.01.2009 № Н-35267-18, закон має вищу юридичну силу порівняно 3 підзаконними актами, а останні приймаються на їх основі та за своїм змістом не повинні суперечити їм [7].

Аналіз національного законодавства дає змогу виділити дві групи законів України: закони, які регулюють суспільні відносини безпосередньо у сфері фізичної культури і спорту, та закони, норми яких поширюють свою дію на широке коло суспільних відносин, у тому числі у сфері фізичної культури та спорту в Україні. Отже, до першої групи законодавчих актів належать:

- Закон України «Про фізичну культуру і спорт» від 24.12.1993, який визначає загальні правові, організаційні, соціальні та економічні основи діяльності у сфері фізичної культури і спорту та регулює суспільні відносини у створенні умов для розвитку фізичної культури і спорту [8];

- Закон України «Про підтримку олімпійського, параолімпійського руху та спорту вищих досягнень в Україні» від 14.09.2000, має на меті сприяння створенню передумов для підготовки та участі членів збірних команд України в Олімпійських, Паралімпійських іграх, вихованню молоді засобами спорту в дусі олімпізму, залученню населення до здорового способу життя [9];

Закон України «Про антидопінговий контроль у спорті» від 05.04.2001, який визначає правові та організаційні засади здійснення антидопінгового контролю в Україні, участі відповідних закладів, установ та організацій у профілактиці, запобіганні застосуванню та поширенню допінгу у спорті [10].

Варто зауважити, що на прийняття окремих законів вплинула ратифікація міжнародних конвенцій, а це свідчить, що держава імплементує в національне законодавство міжнародні стандарти, а адміністративно-правове регулювання здійснення професійного спорту в Україні ще перебуває на стадії становлення. Переходячи до другої групи законів, пропонуємо звернути увагу на деякі з них.

1. Закон України «Про громадські об'єднання» від 22.03.2012 має вагоме значення для сфери професійного спорту, оскільки спортивні федерації, громадські організації спортивної спрямованості учнів та студентів, Національний олімпійський комітет, національні спортивні федерації інвалідів, Спортивний комітет України створюються у формі громадського об'єднання і діють відповідно до вказаного закону [11]. Тобто Закон України «Про громадські об'єднання» фактично регламентує порядок створення та діяльності одних із суб'єктів правовідносин у сфері професійного спорту.

2. Закон України «Про рекламу» від 03.07.1996 визначає засади рекламної діяльності в Україні. Законом регламентовано вимоги до реклами під час спортивних змагань, забороняється реклама допінгових речовин та/або методів для їх використання у спорті (ст. 21), реклама тютюнових виробів, реклама знаків для товарів і послуг, під якими випускаються тютюнові вироби, у місцях проведення масових заходів спортивного характеру (ст. 22), що загалом узгоджується 3 міжнародними стандартами у сфері спорту [12].

3. Закон України «Про страхування» від 07.03.1996 містить вимогу щодо обов'язкового страхування спортсменів вищих категорій [13].

4. Закон України «Про інформацію» від 24.12.1993 у ст. 46 визначає засади інформаційного забезпечення у сфері фізичної культури і спорту [14]

5. Основи законодавства України про охорону здоров'я від 19.11.1992 у ст. 32 зобов'язують державу сприяти здійсненню заходів, спрямованих на створення умов для заняття фізкультурою, спортом, на боротьбу зі шкідливими для здоров'я людини звичками тощо [15].

Законам України мають відповідати підзаконні акти. Л.М. Горбунова зазначає, що термін «підзаконний акт»-це збірна юридична категорія, яка виражає властивість вели- 
кої, найбільшої групи нормативних актів, що видаються суб'єктами виконавчо-розпорядчої діяльності в Україні, згідно з якою їх зміст має грунтуватися на положеннях закону [16, с. 13]

Варто зауважити, що підзаконні нормативні акти класифікуються за органом державного управління, що їх приймає. Пропонуємо розпочати їх розгляд з Указу Президента України «Про стипендії Президента України для видатних та молодих і перспективних спортсменів України 3 олімпійських видів спорту та їх тренерів» від 13.11.2019. Зазначеним підзаконним актом було засновано 350 стипендій Президента України для видатних та молодих і перспективних спортсменів України з олімпійських видів спорту та їх тренерів [17]. Ще одним підзаконним актом Президента України є Указ «Про Національну доктрину розвитку фізичної культури і спорту» від 28.09.2004, яким передбачено, зокрема, що держава сприяє розвитку олімпійського, параолімпійського спорту, тих видів спорту, які не входять до програм Олімпійських, Паралімпійських ігор та професіонального спорту [18].

У Постанові Кабінету Міністрів України «Про затвердження Державної цільової соціальної програми розвитку фізичної культури і спорту на період до 2020 року» від 01.03.2017 № 115 робиться акцент на підтримці та розвитку професійного спорту. Одними з її завдань є: забезпечення відбору осіб із високим рівнем підготовленості та які здатні під час проведення спортивних заходів витримувати значні фізичні та психологічні навантаження, для подальшого залучення їх до резервного спорту, підтримка та розвиток олімпійського, неолімпійського, параолімпійського, дефлімпійського руху тощо [19]. Указане свідчить, що органи державного управління відіграють значну роль у регулюванні суспільних відносин у сфері професійного спорту в Україні.

Розглядаючи підзаконні акти, окрему увагу доцільно приділити актам Міністерства молоді та спорту України, а саме його наказам, тобто розпорядчим документам, які видаються керівником установи (підрозділу) на правах єдиноначальності та в межах своєї компетенції, обов'язковим для виконання підлеглими [20]. Міністерство молоді та спорту видає низку наказів із метою врегулювання правовідносин у сфері професійного спорту в Україні, з останніх це, зокрема, такі накази: «Деякі питання формування переліку закладів фізичної культури і спорту, яким пропонується надати статус бази олімпійської, паралімпійської та дефлімпійської підготовки» від 25.06.2020 № 364; «Про затвердження Складу спортсменів державної установи «Державний центр олімпійської підготовки з біатлону» на 2020/2021 рік» від 23.06.2020 № 350; «Про кваліфікаційні категорії» від 18.06.2020 № 297 тощо.

Обласні державні адміністрації Законом України «Про місцеві державні адміністрації» наділені правом вирішувати питання у сфері фізкультури і спорту (ст. 19). Указаним питанням опікуються також органи місцевого самоврядування. Зокрема, Рішенням Сумської обласної ради від 22.12.2016 затверджено Програму розвитку фізичної культури і спорту в Сумській області на 2017-2020 рр., де визначено існуючі проблеми у сфері розвитку професійного спорту на рівні області та напрями їх розв’язання [21].

Висновки. Таким чином, адміністративно-правове регулювання у сфері професійного спорту в Україні - це здійснюваний державою за допомогою адміністративноправових норм цілеспрямований вплив на суспільні відносини, що виникають, змінюються та припиняються у сфері здійснення професійного спорту, з метою упорядкування, охорони та розвитку останніх. Сьогодні адміністративноправове регулювання правовідносин у сфері професійного спорту в України перебуває на стадії свого становлення, однак серед джерел такого виду регулювання можна виділити: 1) Конституцію України; 2) міжнародні конвенції; 3) закони, зокрема ті, що регулюють суспільні відносини виключно у сфері спорту, а також ті, норми яких поширюють свою дію на широке коло суспільних відносин, у тому числі у сфері професійного спорту; 4) підзаконні акти: укази Президента України, постанови Кабінету Міністрів України, накази Міністерства молоді та спорту України, акти місцевих державних адміністрацій, акти органів місцевого самоврядування.

\section{ЛITEPATУРA}

1. Рабінович П.М. Основи загальної теорії держави і права : навчальний посібник ; 3-є вид., зі змінами і доп. Київ : ICДО, 1995. 172 с.

2. Комзюк А.Т. Заходи адміністративного примусу в правоохоронній діяльності міліції: поняття, види та організаційно-правові питання реалізації : монографія / за заг. ред. О.М. Бандурки. Харків : Нац. ун-т внутр. справ, 2002. 336 с.

3. Андрійченко Н.С. Адміністративно-правові засади оцінювання ефективності діяльності правоохоронних органів як суб'єктів забезпечення фінансово-економічної безпеки України : дис. ... д-ра філос. : спец. 081 «Право» ; СумДУ. Суми, 2020. 234 с.

4. Права громадян у сфері виконавчої влади / за ред. В.Б. Авер'янова. Київ : Наукова думка, 2007. 588 с.

5. Конституція України від 28.06.1996. Відомості Верховної Ради. 1996. № 30. Ст. 141.

6. Про затвердження Положення про державну реєстрацію нормативно-правових актів міністерств та інших органів виконавчої влади : Постанова Кабінету Міністрів України від 28.12.1992 № 731. URL : https://zakon.rada. gov.ua/laws/show/731-92-\%D0\%BF\#Text.

7. Лист Міністерства юстиції України «Щодо порядку застосування нормативно-правових актів у разі існування неузгодженості між підзаконними актами» від 30.01.2009 № H-35267-18. URL : https://zakon.rada.gov.ua/laws/ show/v35263 23-09\#Text.

8. Про фізичну культуру і спорт : Закон України від 24.12.1993 Відомості Верховної Ради України. 1994. № 14. Ст. 80

9. Про підтримку олімпійського, параолімпійського руху та спорту вищих досягнень в Україні : Закон України від 14.09.2000. Відомості Верховної Ради України. 2000. № 43. Ст. 37.

10. Про антидопінговий контроль у спорті : Закон України від 05.04.2001. Відомості Верховної Ради України. 2017. № 11. Ст. 102

11. Тихонова М.А. Суб'єкти правовідносин, що складаються у сфері фізичної культури і спорту. Правовий часопис Донбасу. 2017. № 2(60). C. 49-55.

12. Про рекламу : Закон України від 03.07.1996. Відомості Верховної Ради України. 1996. № 39. Ст. 181.

13. Про страхування : Закон України від 07.03.1996. Відомості Верховної Ради України. 1996. № 18. Ст. 78.

14. Про інформацію : Закон України від 24.12.1993. Відомості Верховної Ради України. 1994. № 14. Ст. 80.

15. Основи законодавства України про охорону здоров'я : Закон України від 19.11.1992. Відомості Верховної Ради України. 1993. № 4. Ст. 19 .

16. Горбунова Л.М. Підзаконні нормативно-правові акти: організаційно-правові питання забезпечення законності : автореф. дис. ... канд. юрид. наук : 12.00 .07 ; Київ. нац. екон. ун-т. Київ, 2005. 21 с.

17. Про стипендії Президента України для видатних та молодих і перспективних спортсменів України з олімпійських видів спорту та їх тренерів : Указ Президента України від 13.11.2019. URL : https://zakon.rada.gov.ua/laws/ show/844/2019\#Text.

18. Про Національну доктрину розвитку фізичної культури і спорту : Указ Президента України від 28.09.2004. URL : https:// zakon.rada.gov.ua/laws/show/ 1148/2004\#Text.

19. Про затвердження Державної цільової соціальної програми розвитку фізичної культури і спорту на період до 2020 року : Постанова Кабінету Міністрів України від 01.03.2017. URL : https://zakon.rada. gov.ua/laws/show/ 115-2017-\%D0\%BF\#Text.

20. Великий тлумачний словник сучасної української мови (з дод. і допов.) / уклад. і гол. ред. В.Т. Бусел ; 5-е вид. Київ ; Ірпінь : Перун, 2005.

21. Про програму розвитку фізичної культури і спорту в Сумській області на 2017-2020рр. : Рішення Сумської обласної ради від 22.12.2016. URL : http://sm.gov.ua/images/docs/programa/programma_fk_2017-2020.pdf. 


\title{
ЗАПРОВАДЖЕННЯ КАРАНТИННОГО РЕЖИМУ В УКРАЇНІ ТА ЙОГО ПРАВОВЕ ЗАБЕЗПЕЧЕННЯ
}

\section{IMPLEMENTATION OF THE QUARANTINE REGIME IN UKRAINE AND ITS LEGAL PROVISION}

\author{
Землякова Д.О., студентка II курсу \\ Інститут прокуратури та кримінальної юстииії \\ Національного юридичного університету імені Ярослава Мудрого \\ Червякова О.Б., к.ю.н., \\ доцент кафедри адміністративного права \\ Національний юридичний університет імені Ярослава Мудрого
}

Статтю присвячено запровадженню в Україні першого загальнонаціонального карантину у зв'язку зі світовою пандемією COVID-19 та адміністративно-правовим заходам його забезпечення. Проаналізовано рішення Верховної Ради України, Кабінету Міністрів України, Ради національної безпеки і оборони, а також акти місцевих органів публічної влади, спрямовані на нормалізацію епідемічної ситуації на різних етапах боротьби з пандемією. З'ясовано, що вони ґрунтувалися на актуальних даних щодо динаміки захворюваності в Україні та її окремих регіонах. Розглянуто особливості встановлення карантинного режиму, підстави та умови посилення або послаблення заходів його забезпечення.

У статті висвітлено різні заходи: спрямовані на забезпечення карантину, а також ті, що йому передували, адміністративно-правові заходи щодо запобігання потраплянню і поширенню хвороби в Україні. Залежно від рівня було досліджено рішення центральних та місцевих органів влади - всеукраїнські та локальні заходи, за обов'язковістю - обов'язкові і рекомендаційні, за змістом - обмежувальні і зобов'язальні, за метою - попереджувальні і щодо ліквідації наслідків, також розглянуто різні заходи за характером і тривалістю дії. Досліджено, що основою забезпечення карантину стало закриття кордонів і заборона масових зібрань як основний механізм мінімізації контактів між людьми, що дало змогу попередити розвиток захворюваності. Також розглянуто введення адміністративної відповідальності за недотримання карантину, що стало важливим кроком щодо його забезпечення, хоча на практиці й викликало неабиякі складнощі та протиріччя.

Ключові слова: карантин, адміністративно-правові заходи, надзвичайна ситуація, карантинні обмеження, пандемія COVID-19.

The article is devoted to the implementation of the first national quarantine in Ukraine because of the global pandemic COVID-19 and administrative and legal measures to carry it out. The reaction of the authorities and local self-government to the development of morbidity during the threat of the disease entering the country and during its spread through the territory of the state, as well as the actions of the authorities in emergency and quarantine were studied. The decisions of the Cabinet of Ministers of Ukraine, the National Security and Defense Council, acts of local authorities, which were aimed at normalizing the epidemic situation at different stages of the fight against the pandemic were analyzed. It was investigated that they were based on current data on the dynamics of morbidity in Ukraine and its individual regions. The preconditions and features of the quarantine regime, the causes and conditions for strengthening and weakening measures to ensure it were considered.

The article covers various measures: aimed at carrying quarantine out, as well as those that preceded it, administrative and legal measures to prevent the spread of the disease in Ukraine. Depending on the level of disease, the decisions of central and local authorities were studied - allUkrainian and local measures, mandatory - mandatory and recommendatory, the content - restrictive and mandatory, the purpose - preventive and elimination of consequences, also various measures were under the consideration by its nature and duration of action. It was investigated that the basis for quarantine was the closure of borders and the prohibition of mass gatherings as the main mechanism for minimizing contact between people, which made it possible to prevent the spreading of the disease. The introduction of administrative liability for non-compliance with quarantine was also considered, that was an important step in carrying it out, although in practice it caused considerable difficulties and contradictions.

Key words: quarantine, administrative and legal measures, emergency, quarantine restrictions, COVID-19 pandemic.

Виклад основного матеріалу. В Україні досить поширеною є практика запровадження карантину як способу боротьби з поширенням інфекційних хвороб. Досліджуючи динаміку захворюваності, органи публічної влади на різних рівнях у межах своїх повноважень запроваджують запобіжні заходи. Вони діють у масштабах відповідних територій залежно від локалізації зараження: район, місто, конкретне підприємство, установа тощо. Закриття на певний період учбових закладів $є$ чи не найпопулярнішим засобом запобігання зростанню захворюваності на гострі респіраторні вірусні інфекції. До таких дій місцеві органи влади вдаються майже щозими, якщо спостерігається ускладнення епідемічної ситуації.

У грудні 2019 року світ сколихнув спалах захворювання на нову коронавірусну хворобу COVID-19 в китайському місті Ухань. Швидкість поширення, відсутність ліків та тяжкі наслідки хвороби перетворили ії на потенційну загрозу населенню планети. 30 січня 2020 року Всесвітня організація охорони здоров'я (далі - ВООЗ) оголосила спалах «надзвичайною ситуацією, що має міжнародне значення» [1]. До речі, у XXI ст. подібні випадки вже траплялися: починаючи 32009 року були ухвалені рішення щодо шести надзвичайних ситуацій у сфері охорони здоров'я, що мали міжнародне значення. Серед них свинячий грип, поліомієліт, лихоманка Ебола та ін.

Попри всі запобіжні заходи Китаю та інших держав, станом на ранок 1 лютого 2020 року у світі вже було зареєстровано понад 11,3 тис випадків нової коронавірусної інфекції, 259 з яких - смертельні. COVID-19 було підтверджено у 24 країнах світу. Серед них, на щастя, не було України, проте темпи поширення хвороби вражали, й показник смертності активно зростав. Тому надзвичайно важливо було діяти на упередження для запобігання потраплянню COVID-19 у країну. Розпорядженням КМУ від 3 лютого 2020 року № 93-р «Про заходи щодо запобігання занесенню і поширенню на території України гострої респіраторної хвороби COVID-19, спричиненої коронавірусом SARS-CoV-2» було утворено антикризовий штаб із протидії поширенню в Україні такої хвороби, а також установлено режим підвищеної готовності єдиної державної системи цивільного захисту для запобігання виникненню надзвичайної ситуації державного рівня внаслідок можливого іiї поширення. Окрім того, запроваджено особливі умови для в 'їзду та 14-денну ізоляцію 
у визначених закладах охорони здоров'я осіб, які перебували у провінції Хубей Китайської Народної Республіки (епіцентрі захворювання) [11].

Ще одним важливим положенням Постанови було затвердження Національного плану протиепідемічних заходів щодо запобігання занесенню і поширенню на території України гострої респіраторної хвороби COVID-19, спричиненої коронавірусом SARS-CoV-2, на 2020 рік. Цей перелік складається із 22 завдань, щодо кожного з яких чітко визначено відповідальні органи та строки виконання. Серед цих заходів $€$ й інформаційні, й організаційні, зокрема щодо підготовки медичного персоналу та перепрофілювання закладів охорони здоров'я, забезпечення необхідним обладнанням та індивідуальними засобами захисту, проведення температурного скринінгу та попереднього огляду осіб працівниками санітарно-карантинних постів тощо. Забезпечення виконання Національного плану покладається, перш за все, на міністерства та інші центральні органи виконавчої влади, обласні, Київську та Севастопольську міські держадміністрації, а також органи місцевого самоврядування [11].

Уряд мав ще одне важливе завдання - повернення громадян, які залишилися в Китаї. Звичайне сполучення 3 епіцентром поширення хвороби було неможливе: українські авіакомпанії одна за одною припиняли рейси до потенційно небезпечних провінцій. А тому ж на засіданні 3 лютого 2020 р. КМУ видав Розпорядження № 129-р «Про евакуацію громадян України та членів їх сімей із зони поширення коронавірусу 2019-nCoV у Китайській Народній Республіці». Відповідно до нього, Міністерство інфраструктури разом із МО3, Міністерством закордонних справ та Міністерством внутрішніх справ мало забезпечити невідкладну евакуацію громадян України та членів їхніх сімей із зазначеної зони, Державна митна служба забезпечити оперативне митне оформлення вантажу членів екіпажу та пасажирів, а Адміністрація Державної прикордонної служби - першочергове здійснення контролю під час перетинання державного кордону [12].

На виконання цієї Постанови 20 лютого в Україну прибув перший літак, який евакуював 48 українців та 24 іноземці з китайського міста Ухань. МО3 повідомило, що слідувало всім рекомендаціями ВОО3: евакуації підлягали тільки ті, хто не мав симптомів гострої респіраторної інфекції; усім було проведено скринінг температури тіла до і після польоту; засоби пересування піддавалися дезінфекції, супроводжуючий персонал був забезпечений індивідуальними засобами захисту. Усі евакуйовані повинні були витримати двотижневий карантин у визначеному медичному закладі - у санаторії Національної гвардії у Нових Санжарах на Полтавщині. Цікаво, що українці не надто привітно поставилися до співвітчизників, повернених із Китаю, вважаючи їх джерелом небезпеки поширення вірусу за недостатніх запобіжних заходів і невдалої організації евакуації.

Поміж тим 2 лютого 2020 року було зафіксовано першу смерть від коронавірусної хвороби за межами Китаю, на Філіппінах. Незабаром вірус заполонив і Європу, зокрема швидкого поширення набув в Італії, де станом на 24 лютого 2020 року медики виявили 152 випадки зараження, 3 яких три смертельні. На такий розвиток подій сталася відповідна реакція і з боку України: необхідно було убезпечити країну від можливого потрапляння вірусу через прибулих з Італії. Представники Державної прикордонної служби України під час брифінгу поінформували, що з 20:00 24 лютого всім пасажирам рейсів 3 Італії вимірюватимуть температуру. Йшлося про міжнародні аеропорти «Київ» (Жуляни) та «Бориспіль», де ще відбувалися рейсові сполучення, а також під час перетину західного кордону держави - автомобільному пункті пропуску «Тиса», що на Закарпатті. Також на пунктах про- пуску облаштували тимчасові ізолятори для осіб з ознаками коронавірусу.

25 лютого на координаційній нараді під головуванням секретаря РНБО Олексія Данилова було повідомлено про рішення проводити температурний скринінг усіх громадян, які прибувають на територію України з будь-якої країни світу, як через авіасполучення, так і через автомобільні та залізничні пункти пропуску. Такі заходи дійсно могли б виявитися ефективними, проте існували певні нюанси. Багато з тих, хто бажав потрапити додому, вдавалися до застосування медикаментів, що на певний час нормалізувало їхній стан. Температурний скринінг тіла під час перетину кордону став нормою для більшості країн, які прагнули запобігти потраплянню чи поширенню інфекції, але на практиці вдало й результативно його запровадити вдалося не всім.

Тому в Україні гостро постало питання виконання рішень щодо попередження потрапляння COVID-19 у країну. Зокрема, керівник пресслужби аеропорту «Київ» повідомила, що станом на 14 годину 25 лютого жодних розпоряджень щодо перевірки аеропорт не отримував, температурних сканерів і тепловізорів не було, а рішення про закупівлю обладнання температурного скринінгу для аеропорту «Бориспіль» було ухвалено КМУ лише 11 березня.

Отже, чи через недостатність запроваджених заходів, чи їх неорганізованість або невиконання відповідальними органами та особами, але запобіжні заходи виявилися неефективними: попередити проникнення хвороби в Україну не вдалося. 3 березня було виявлено перший випадок коронавірусної хвороби у чоловіка з Чернівців, а 12 березня - ще два випадки захворювання - у Чернівецькій та Житомирській областях. У житомирському райцентрі Радомишлі, де жінка пенсійного віку заразилася коронавірусною хворобою, за рішенням районної комісії запроваджено надзвичайну протиепідемічну ситуацію.

Згідно 3 пунктом 24 ч. 1 ст. 2 Кодексу цивільного захисту України (далі - КЦЗУ), надзвичайна ситуація - це обстановка на окремій території чи суб'єкті господарювання на ній або водному об'єкті, яка характеризується порушенням нормальних умов життєдіяльності населення, спричинена катастрофою, аварією, пожежею, стихійним лихом, епідемією, епізоотією, епіфітотією, застосуванням засобів ураження або іншою небезпечною подією, що призвела (може призвести) до виникнення загрози життю або здоров'ю населення, великої кількості загиблих і постраждалих, завдання значних матеріальних збитків, а також до неможливості проживання населення на такій території чи об'єкті, провадження на ній господарської діяльності [2, ст. 2]. У ст. 14 КЦЗУ визначено, за рішенням відповідно Кабінету Міністрів України, Ради міністрів Автономної Республіки Крим, обласних, Київської чи Севастопольської міських державних адміністрацій для єдиної державної системи цивільного захисту у повному обсязі або частково для окремих ії територіальних підсистем тимчасово встановлюється режим надзвичайної ситуації [2, ст. 14].

Тому Радомишльська районна державна адміністрація прийняла рішення щодо запровадження певних обмежувальних заходів у межах своїх повноважень задля запобігання поширенню хвороби у місті. Зокрема, про призупинення діяльності в денному стаціонарі стоматологічного відділення, лабораторії та аптеки; ізолювання доступу до будинку хворої; встановлення блокпостів на в’їзді та виїзді з міста та запровадження скринінгу температури; обмеження в'їзду транспортних засобів на територію лікарні. Своєю чергою, районна державна адміністрація рекомендувала Радомишльській міській раді, сільським, селищним головам: припинити діяльність (на період надзвичайної ситуації) всіх розважальних закладів, закладів громадського харчування, міського ринку, закла- 
дів із масовим перебуванням людей; призупинити рух маршрутного транспорту по м. Радомишль, а також масові соціально значимі заходи перевести у режим здійснення Інтернет-стримінгу. Одночасно забезпечити проведення дезінфекційних робіт та інформаційно-роз'яснювальної роботи з населенням [4, с. 2-3].

11 березня 2020 року ВООЗ оголосила, що спалах набув характеру пандемії - епідемії світового масштабу, центром якого стала Європа [1]. Цього ж дня КМУ на своєму засіданні з урахуванням рішення Державної комісії 3 питань техногенно-екологічної безпеки та надзвичайних ситуацій вперше в історії незалежної України ухвалив рішення про запровадження загальнонаціонального карантину. Відповідною Постановою «Про запобігання поширенню на території України коронавірусу COVID-19» з 12 березня до 3 квітня 2020 р. на всій території України було заборонено відвідування закладів освіти її здобувачами, а також проведення масових заходів, у яких бере участь понад 200 осіб, окрім заходів, необхідних для забезпечення роботи органів державної влади та органів місцевого самоврядування [10].

КМУ роз'яснив, що обмеження стосуються усіх закладів освіти незалежно від форми власності та сфери управління. Докладні ж рекомендації для керівників закладів та управлінців були викладені у Листі Міністерства освіти і науки (далі - МОН) № 1/9-154 від 11 березня 2020 року. Зокрема, йшлося про заборону проведення різних освітніх, наукових, спортивних та інших масових заходів, направлення за кордон здобувачів освіти, обмеження проведення нарад, перевірок, організації інформування здобувачів освіти та співробітників закладів освіти, а також забезпечення дистанційного навчання та відпрацювання занять відповідно до програми. Окрім урегулювання навчального процесу, у Листі містилися рекомендації щодо забезпечення виконання профілактичних заходів, виділення у гуртожитках місць для ізоляції, виконання рішень тимчасових обласних протиепідемічних комісій [3, с. 1-2].

Отже, карантин у зв'язку з поширенням коронавірусу COVID-19 в Україні розпочався 12 березня 2020 року із тритижневої заборони відвідування закладів освіти iï здобувачами та обмеження масових заходів. Наступного ж дня в Україні зареєстрували перший летальний випадок від COVID-19.

Указом Президента України від 13 березня 2020 року № 87 було введено в дію Рішення Ради національної безпеки і оборони України (далі - РНБО) «Про невідкладні заходи щодо забезпечення національної безпеки в умовах спалаху гострої респіраторної хвороби COVID-19, спричиненої коронавірусом SARS-CoV-2». Розглянувши інформацію про епідемічну ситуацію у зв'язку з поширенням територією України та країн світу COVID-19, РНБО відзначила, що епідемічна ситуація в Україні набула надзвичайно загрозливого характеру. Відповідно до функцій, визначених Конституцією України та Законом «Про Раду національної безпеки та оборони», реалізуючи свої повноваження, РНБО вважала за необхідне запровадити низку нових заходів щодо забезпечення карантину для запобігання поширення вірусу [15]. Серед них - закриття з 0 год. 00 хв. 17 березня 2020 року пунктів пропуску через державний кордон України для здійснення регулярного пасажирського сполучення на два тижні, а також припинення на цей же термін з 0 год. 00 хв. 16 березня 2020 року в’їзду на територію України іноземців та осіб без громадянства за винятком осіб, які мають право на постійне або тимчасове проживання на території України, та за окремими рішеннями Міністерства закордонних справ України акредитованих працівників дипломатичних представництв, консульських установ, представництв міжнародних організацій тощо. Важливим складником такого рішення стало відновлення системи протиепідемічного захисту, зокрема призначення головних державних санітарних лікарів відповідних адміністративно-територіальних одиниць. Інші заходи стосувалися переважно медичного забезпечення, його організації та фінансування. Також у своєму рішенні РНБО рекомендувала громадянам України утриматися від виїзду за кордон у країни, на території яких зафіксовано випадки COVID-19 [13].

Відповідно до Рішення РНБО, КМУ видав Розпорядження від 14 березня 2020 року № 287-р про тимчасове обмеження перетинання державного кордону. А саме із 17 березня до 3 квітня 2020 року закривалися пункти пропуску (пункти контролю) через державний кордон для міжнародного пасажирського залізничного, повітряного, автомобільного (для автобусів) сполучення, крім здійснення перевезень осіб із метою забезпечення захисту національних інтересів або у зв'язку з виконанням міжнародних зобов'язань, а також представників дипломатичних установ та гуманітарних місій [16].

Епідемічна ситуація натомість лише погіршувалася, тож вимагала вжиття більш суворих обмежень, тому КМУ вніс зміни до Постанови від № 211 (якою було встановлено карантин) й Постановою від 16 березня 2020 року № 215 заборонив проведення масових заходів, у яких бере участь понад 10 осіб (попередня редакція дозволяла до 200 осіб), а також $з 00$ год. 01 хв. 17 березня 2020 року до 3 квітня 2020 року роботу суб'єктів господарювання, яка передбачала приймання відвідувачів, зокрема закладів громадського харчування (ресторанів, кафе тощо), торговельно-розважальних центрів, інших закладів розважальної діяльності, фітнес-центрів, закладів культури, торговельного і побутового обслуговування населення. Проте за умови забезпечення персоналу засобами індивідуального захисту дозволялося продовжувати роботу суб'єктам роздрібної торгівлі продуктами харчування, пальним, засобами гігієни, лікарськими засобами та виробами медичного призначення, засобами зв'язку, провадження банківської та страхової діяльності, а також торговельної діяльності і діяльності з надання послуг із громадського харчування із застосуванням адресної доставки замовлень. До того ж сталися суттєві обмеження щодо перевезень пасажирів. Зокрема, з 12 год. 00 хв. 18 березня 2020 року і до 3 квітня цього ж року заборонялися будьякі регулярні та нерегулярні перевезення пасажирів автомобільним транспортом у приміському, міжміському внутрішньообласному і міжобласному сполученні, а у міському електричному, автомобільному транспорті та автобусах можливе перевезення лише 10 осіб.

Окрім цього, на той самий термін було заборонено роботу метрополітенів Києва, Харкова і Дніпра, а також залізничного транспорту усіх видів внутрішнього сполучення (за окремими винятками, погодженими з Міністерством інфраструктури та Міністерством охорони здоров'я). КМУ також рекомендував центральним і місцевим органам виконавчої влади, іншим державним органам, органам місцевого самоврядування, підприємствам, установам, організаціям забезпечити організацію позмінної роботи працівників, а за технічної можливості - також роботи в режимі реального часу через Інтернет [6].

Ще одним кроком щодо запобігання поширенню COVID-19 в Україні стало встановлення 16 березня п. р. режиму надзвичайної ситуації в Житомирській та Чернівецькій областях [8], а 18 березня - у Київській області [9]. Такі розпорядження КМУ були видані з урахуванням рішень відповідних обласних комісій із питань техногенно-екологічної безпеки та надзвичайних ситуацій та відповідно до ст. 14 КЦЗУ.

Ураховуючи, що поширення гострої респіраторної хвороби COVID-19 створює загрозу особистій, громадській та державній безпеці, спричиняє тяжкі соціальноекономічні та демографічні наслідки, з метою посилення захисту населення, невідкладного здійснення заходів 
щодо протидії поширенню COVID-19 в Україні, відповідно до пункту 28 ч. 1 ст. 106 Конституції України, Президент України постановив утворити Координаційну раду 3 протидії поширенню COVID-19 як консультативно-дорадчий орган при Президентові України. Згідно 3 Указом Президента України від 16 березня 2020 року № 88/2020, основним iii завданням є моніторинг ситуації та напрацювання пропозицій щодо здійснення ефективних заходів, спрямованих на протидію поширенню COVID-19 в Україні. Зокрема, Координаційна рада має право: 1) одержувати в установленому порядку від державних органів та органів місцевого самоврядування, підприємств, установ, організацій інформацію, документи та матеріали; 2) запрошувати на засідання та заслуховувати інформацію представників міністерств, інших центральних і місцевих органів виконавчої влади, керівників державних підприємств, установ та організацій із питань, що належать до іiї компетенції.

У зв'язку із запровадженням карантину і відповідних обмежень в Україні з'явилася потреба адаптації національного законодавства до нових реалій, адже різні запобіжні та заходи реагування, запровадженні КМУ та місцевими органами влади, суттєво вплинули на життя українців. Права потребували нових гарантій, а різні обмеження - забезпечення їх виконання, у тому числі шляхом установлення відповідальності за їх недотримання. Так, Законом України «Про внесення змін до деяких законодавчих актів України, спрямованих на запобігання виникненню і поширенню коронавірусної хвороби (COVID-19)» від 17 березня 2020 року Кодекс України про адміністративні правопорушення (далі - КУПАП) було доповнено статтею 44-3 такого змісту: «Стаття 44-3. Порушення правил щодо карантину людей» - Порушення правил щодо карантину людей, санітарно-гігієнічних, санітарно-протиепідемічних правил і норм, передбачених Законом України «Про захист населення від інфекційних хвороб», іншими актами законодавства, а також рішень органів місцевого самоврядування 3 питань боротьби 3 інфекційними хворобами, - тягне за собою накладення штрафу на громадян від однієї до двох тисяч неоподатковуваних мінімумів доходів громадян і на посадових осіб від двох до десяти тисяч неоподатковуваних мінімумів доходів громадян» [5].

Така норма, як і більшість у КУпАП, є бланкетною: вона не визначає конкретних правил карантину, за порушення яких настає відповідальність, проте такі правила встановлюються відповідними актами законодавства. Зокрема, таким актом є Постанова КМУ № 211 (зі змінами та доповненнями), яка передбачає, що на всій території України діє карантин із 12 березня 2020 року. Також важливими $€$ рішення органів місцевого самоврядування, які уповноважені встановлювати додаткові заходи забезпечення карантину.

3 аналізу судової практики вбачається, що працівники поліції часто припускалися порушень під час складання протоколів за ст. 44-3 КУПАП, через що останні або поверталися на доопрацювання, або суд закривав справи. Інколи трапляються досить сміливі суддівські рішення, позиції яких могли б наслідуватися іншими суддями. Зокрема, одним із карантинних заходів $є$ запровадження «маскового» режиму: кожен повинен перебувати у громадському місці у захисній масці. Кельменецький районний суд Чернівецької області виніс рішення, яке стало популярним через неочікувану правову позицію. По справі протокол було складено через відсутність у особи, яка перебувала у громадському місці, захисної маски. Під час розгляду справи особа, яка притягалася до відповідальності, пояснила, що не мала змоги придбати маску через брак коштів, а виготовити пї самостійно вона не змогла. Зазвичай за таких обставин судді або закривають справу через малозначність діяння, або ж більш принципові - накладають штраф (у Зарічному районному суду м. Суми було оштрафовано студентів за прогулянку біля озера без масок).

У Чернівецький області суддя по-іншому оцінив умови введення карантину та існуючи заборони й звернув увагу на те, що на даний час відсутні будь-які докази того, що за законом особа за власні кошти зобов язана придбати чи виготовити захисну маску, адже кошти на її придбання не були виділені, що й призвело до таких наслідків. До речі, сьогодні в Україні не визначені відповідні медичні критеpiї та не прийняті нормативно правові акти щодо випадків та необхідності носіння засобів індивідуального захисту, у тому числі й виготовлених самостійно громадянами.

20 березня в Україні було зафіксовано 41 випадок захворювання та три летальні випадки. Області продовжували запроваджувати режим надзвичайної ситуації, встановлюючи власні обмеження. Наприклад, із 23 березня проїзд у київському громадському транспорті дозволили тільки за перепустками. До таких самих заходів вдалися й інші міста: місцева влада намагалася мінімізувати кількість пересувань городян по місту, залишивши таку можливість лише працівникам необхідних для життєдіяльності міста підприємств. Проте на практиці це призвело до створення ще більших ризиків: через невдалу організацію видачі перепусток під стінами місцевих рад збиралися величезні натовпи осіб, бажаючих отримати можливість пересуватися громадським транспортом.

Розпорядженням від 25 березня 2020 року № 338-р КМУ 3 урахуванням поширення на території України гострої респіраторної хвороби COVID-19, висновків BOO3 щодо визнання розповсюдження COVID-19 пандемією 3 метою ліквідації наслідків медико-біологічної надзвичайної ситуації природного характеру державного рівня, забезпечення санітарного та епідемічного благополуччя населення та відповідно до ст. 14 та ч. 2 ст. 78 Кодексу цивільного захисту України встановив для єдиної державної системи цивільного захисту на всій території України режим надзвичайної ситуації до 24 квітня 2020 року [14].

У подальшому епідемічна ситуація в країні продовжувала погіршуватися, а тому було прийнято рішення про продовження карантину і запровадження більш жорстоких обмежень. Постановою КМУ від 2 квітня 2020 року № 255 «Про внесення змін до постанови Кабінету Міністрів України від 11 березня 2020 р. № 211» 36 квітня було заборонено: перебування в громадських місцях без вдягнутих засобів індивідуального захисту, зокрема респіратора або захисної маски, у тому числі й виготовлених самостійно; переміщення групою осіб у кількості більше ніж дві особи, крім випадків службової необхідності та супроводження осіб, які не досягли 14 років, батьками, усиновлювачами, опікунами, піклувальниками, прийомними батьками, батьками-вихователями, іншими особами відповідно до закону або повнолітніми родичами дитини; перебування в громадських місцях осіб, які не досягли 14 років, без супроводу батьків, усиновлювачів, опікунів, піклувальників, прийомних батьків, батьків-вихователів, інших осіб відповідно до закону або повнолітніх родичів дитини; відвідування закладів освіти іiі здобувачами; відвідування парків, скверів, зон відпочинку, лісопаркових та прибережних зон, окрім вигулу домашніх тварин однією особою та в разі службової необхідності; відвідування спортивних та дитячих майданчиків; роботу суб'єктів господарювання, яка передбачає приймання відвідувачів, зокрема закладів громадського харчування (ресторанів, кафе тощо), торговельно-розважальних центрів, інших закладів розважальної діяльності, фітнес-центрів, закладів культури, торговельного і побутового обслуговування населення; перебувати на вулицях без документів, що посвідчують особу, підтверджують громадянство чи її спеціальний статус, та деякі інші. Особам старшим 60 років рекомендували залишатися вдома. 
Такі радикальні заборони обурили громадян, до суду було спрямовано декілька позовів щодо протиправності рішення уряду. Основна претензія - необгрунтоване і незаконне обмеження свободи пересування, адже це можливо лише в умовах запровадження режиму надзвичайного стану, а не надзвичайної ситуації. Проте статистика захворюваності не тішила: 2 квітня кількість інфікованих зросла до 804 осіб, серед яких 57 - діти, а 3 квітня вже було зафіксовано 1072 випадки. Така ситуація змінила думку українців щодо обмежень: нормалізація епідемічної ситуації в країні стала мрією кожного.

При цьому уряд уже тричі продовжував загальнонаціональний карантин, який мав тривати до 3 квітня включно: його було продовжено на 21 день - до 24 квітня включно, потім до 11 травня, далі - до 22 травня. Проте з початку травня вже почали відбуватися його послаблення. Незважаючи на те що в Україні щодня виявляли близько 500 випадків захворювання, статистика щодо кількості вилікуваних усе ж тішила, тому уряд почав поступово пом'якшувати карантинні заходи.

4 травня в Україні зафіксували рекордно низький відсоток людей, які захворіли на COVID-19 відносно загальної кількості активних хворих $-3,5 \%$. Водночас МО3 попереджала про збільшення кількості випадків безсимптомного перебігу хвороби, що підвищує загрозу її поширення.

Послаблення карантину розпочалися на початку травня - уряд ухвалив відповідне рішення. Так, з 11 травня відкривали парки, сквери, зони відпочинку, було дозволено роботу салонів краси, закладів громадського харчування на виніс, літніх майданчиків кафе та ресторанів просто неба, музеїв, бібліотек, оптову і роздрібну торгівлю непродовольчими товарами, окрім зон розваг та харчування, дитячих зон у ТРЦ, тренування в командних видах спорту для професійних команд на закритих базах; відновлювали роботу стоматологи, аудитори, адвокати, нотаріуси тощо. Зокрема, основною умовою цих пом'якшень було дотримання маскового режиму, відповідних санітарних та протиепідемічних заходів та соціальної дистанції, а прийом відвідувачів ставав можливий лише разі забезпечення персоналу засобами індивідуального захисту (зокрема, захист обличчя, очей, рук). Водночас решту обмежень було продовжено до 22 травня.

Водночас КМУ Постановою від 14 травня 2020 року знову пом'якшив карантинні обмеження, дозволивши громадянам збиратися групами до восьми осіб за умови дотримання маскового режиму, а у ресторанах та кафе розміщувати на літніх майданчиках за одним столиком уже чотирьох осіб (окрім дітей до 14 років), а не двох, як раніше. При цьому крісла все ж повинні знаходитися як мінімум в 1,5 м одне від одного [7].

Уряд анонсує, що 22 травня карантин планують продовжувати, але на українців чекає другий етап послаблення карантину. МО3 планує дозволити роботу громадського транспорту, навчальних закладів - дитячих садочків, проведення спортивних змагань без глядачів, проведення зовнішнього незалежного тестування (ЗНО), відкриття готелів, окрім хостелів, без функціонування ресторанів та спортивних залів.
Тим часом ВООЗ продовжила режим пандемії і всесвітнього карантину на два місяці й попереджає про ризики повернення обмежувальних заходів, якщо країни, що виходять із карантину, робитимуть це занадто швидко [1]. Тим часом фахівці Сінгапурського університету технологій та дизайну на основі аналізу статистичних даних спрогнозували закінчення епідемії коронавірусної інфекції в Україні та інших країнах. Згідно з їхнім звітом, до 18 травня ситуація з поширенням вірусу в Україні поліпшиться на 97\% порівняно з піком, до 28 травня - на 99\%, а остаточно пандемія завершиться 7 липня. Водночас переломний момент, на думку фахівців із Сінгапуру, в Україні вже настав - це сталося 21 квітня.

Висновок. Отже, в умовах світової пандемії 2020 року в Україні вперше було встановлено загальнонаціональний режим карантину. Для запобігання спочатку занесенню, а згодом і поширенню коронавірусної інфекції COVID-19 центральною і місцевою владою було вжито різні заходи: превентивні і щодо ліквідації наслідків, організаційні та інформаційні, медико-санітарні тощо. Деякі 3 них передбачали нові обов'язки, наприклад дотримання соціальної дистанції та носіння захисної маски, інші - встановлювали заборони, зокрема щодо роботи навчальних закладів або закладів громадського харчування, а деякі вводили обмеження - пересування по вулиці не більше ніж удвох. До того ж одні заходи забезпечення карантину мали обов'язковий характер (щодо закриття скверів, парків, спортивних майданчиків), а інші - рекомендаційний (дотримання самоізоляції людей старших за 60 років). Залежно від динаміки захворюваності заходи посилювалися або послаблювалися. У цілому вони були досить своєчасні та вдалі, проте щодо їх організації часто виникали питання.

Також велике значення в боротьбі 3 поширенням вірусу мали заходи, встановлені місцевою владою. Маючи відповідні повноваження, місцеві органи виконавчої влади та місцевого самоврядування встановлювали власні обмеження, спираючись на епідемічну ситуацію в регіоні. Більшість із них були рекомендацією уряду або спеціальних комісій, деякі - власною ініціативою. Це дало змогу на місцях вирішити питання щодо організації роботи необхідних для нормального функціонування міст підприємств та стабілізувати ситуацію.

Загалом основним принципом забезпечення карантину стало максимальне обмеження масових зібрань, тобто закриття усіх закладів, установ, які були осередками скупчень людей. До того ж закриття кордонів мінімізувало контакти як між Україною та іншими державами, так і внутрішньодержавну міграцію населення. I, звичайно, важливим кроком стало введення адміністративної відповідальності за недотримання карантину, проте, як виявилося на практиці, застосування такої норми викликало неабиякі складнощі та протиріччя.

Саме дотримання усіх заходів забезпечення карантину $\epsilon$ головною умовою поліпшення епідемічної ситуації, тому відповідальність за боротьбу з пандемією покладена не лише на уряд та інші органи влади, а й на самих громадян, які мають бути свідомими.

\section{ЛITEPATYPA}

1. Всесвітня організація охорони здоров'я : офіційний сайт. URL : https://www.who.int.

2. Кодекс цивільного захисту України : Закон України від 02.10.2012 р. № 5403-VI. Відомості Верховної Ради (ВВР). 2013. № 34-35. Ст. 458. URL : https://zakon.rada.gov.ua/laws/show/5403-17.

3. Лист MOH № 1/9-154 від 11 березня 2020 p. URL : https://mon.gov.ua/storage/app/media/news/2020/03/11/1_9-154.

4. Про виявлення коронавірусу в Радомишльському районі та запобігання його розповсюдженню : Протокол № 3 позачергового засідання районної комісії з питань техногенно-екологічної безпеки та надзвичайних ситуацій м. Радомишль від 12 березня 2020 p. URL : http://radrda.gov.ua/?p=23892.

5. Про внесення змін до деяких законодавчих актів України, спрямованих на запобігання виникненню і поширенню коронавірусної хвороби (COVID-19) : Закон України від 17.03.2020. Відомості Верховної Ради України (BBP). 2020. № 16. Ст. 100. URL : https://zakon.rada.gov.ua/laws/show/530-20.

6. Про внесення змін до постанови Кабінету Міністрів України від 11 березня 2020 р. № 211 : Постанова КМУ від 16 березня 2020 р. № 215. URL : https://zakon.rada.gov.ua/laws/show/215-2020-п. 
7. Про внесення змін до пункту 2 постанови Кабінету Міністрів України від 11 березня 2020 р. № 211 : Постанова КМУ від 14 травня 2020 p. № 377 . URL : https://zakon.rada.gov.ua/laws/show/377-2020-п.

8. Про встановлення режиму надзвичайної ситуації в Житомирській та Чернівецькій областях : Розпорядження КМУ від 16 березня 2020 p. № 320-p. URL : https://zakon.rada.gov.ua/laws/show/320-2020-p.

9. Про встановлення режиму надзвичайної ситуації в Київській області : Розпорядження від 18 березня 2020 p. № 321-p. URL https://zakon.rada.gov.ua/laws/show/321-2020-p.

10. Про запобігання поширенню на території України коронавірусу COVID-19 : Постанова KMУ від 11 березня 2020 р. № 211. URL : https://zakon.rada.gov.ua/laws/show/211-2020-п.

11. Про заходи щодо запобігання занесенню і поширенню на території України гострої респіраторної хвороби COVID-19, cпричиненої коронавірусом SARS-CoV-2 : Розпорядженням KMУ від 3 лютого 2020 р. № 93-p. URL : https://zakon.rada.gov.ua/laws/show/93-2020-p.

12. Про евакуацію громадян України та членів їх сімей із зони поширення коронавірусу 2019-nCoV у Китайській Народній Республіці : Розпорядження КМУ від 3 лютого 2020 р. № 129-p. URL : https://zakon.rada.gov.ua/laws/show/129-2020-p.

13. Про невідкладні заходи щодо забезпечення національної безпеки в умовах спалаху гострої респіраторної хвороби COVID-19, спричиненої коронавірусом SARS-CoV-2 : Рішення РHБО від 13 березня 2020 р., введено в дію Указом Президента України від 13 березня 2020 p. № 87/2020. URL : https://zakon.rada.gov.ua/laws/show/n0002525-20.

14. Про переведення єдиної державної системи цивільного захисту у режим надзвичайної ситуації : Розпорядження КМУ від 25 березня 2020 р. № 338-p. URL : https://www.kmu.gov.ua/npas/pro-perevedennya-yedinoyi-derzhavnoyi-sistemi-civilnogo-zahistu-u-rezhimnadzvichajnoyi-situaciyi-338250320.

15. Про Раду національної безпеки і оборони України: Закон України від 05.03.1998 № № 183/98-ВР. Відомості Верховної Ради (ВВР). 2013. № 35. Ст. 237. URL : https://zakon.rada.gov.ua/laws/show/183/98-вр.

16. Про тимчасове обмеження перетинання державного кордону, спрямоване на запобігання поширенню на території України гострої респіраторної хвороби COVID-19, спричиненої коронавірусом SARS-CoV-2 : Розпорядження KMУ від 14 березня 2020 p. № 287-p. URL : https://zakon.rada.gov.ua/laws/show/287-2020-p. 


\title{
ДЕЦЕНТРАЛІЗАЦІЯ ВЛАДИ В УКРАЇНІ ЯК ШЛЯХ ДО ПОДОЛАННЯ КОРУПЦІї: АДМІНІСТРАТИВНО-ПРАВОВІ АСПЕКТИ
}

\section{DECENTRALIZATION OF POWER IN UKRAINE AS WAYS TO OVERCOME CORRUPTION: ADMINISTRATIVE AND LEGAL ASPECTS}

\author{
доцент кафедри кримінально-правових дисциплін та судочинства
}

Сумський державний університет

Статтю присвячено дослідженню реформування національного законодавства у сфері децентралізації органів державної влади в Україні. Децентралізація розглядається як один із дієвих засобів боротьби з корупцією в органах державної влади та місцевого самоврядування. Визначені можливі ризики впровадження децентралізації.

Згідно з міжнародними рейтингами в більшості економічно розвинених країн корупція має значно нижчий рівень, ніж у країнах з менш розвиненою економікою. Як зазначають міжнародні партнери, це досягається не тільки завдяки імперативним нормам та каральному апарату, а також завдяки застосуванню превентивних засобів у боротьбі з корупцією, а саме створенням умов, що унеможливлюють розвиток корупційних схем в органах державної влади та місцевого самоврядування. Україна стоїть на шляху реформ, направлених насамперед на боротьбу з корупцією, яка вже стала системним явищем у державі. За час існування незалежної України корупція набула безпрецедентних масштабів. I це попри те, що прийнято велику кількість антикорупційних нормативно-правових актів, створено спеціальні потужні правоохоронні та судові органи, такі як НАБУ, САП, антикорупційний суд, основним завданням яких є боротьба з корупцією.

Відсутність політичної волі в осіб, що займають особливо відповідальне становище в державі, прагнення до незаконного збагачення представників усіх гілок влади зводить нанівець боротьбу з корупцією та негативно впливає на зовнішньополітичний імідж України та ї̈ інвестиційний рейтинг.

Децентралізація органів влади в Україні є одним із дієвих засобів боротьби з корупцією та визнана міжнародними партнерами України однією з найпопулярніших та успішніших реформ в Україні. Децентралізація дає змогу громадськості здійснювати більш дієвий контроль над використанням фінансів на місцях та впливати на прийняття рішень, що значно ускладнює створення та функціонування корупційних схем. Органи місцевого самоврядування отримали повноваження, які раніше належали центральним органам влади, та мають можливість розвивати свої регіони самостійно.

Ключові слова: децентралізація, влада, органи місцевого самоврядування, об'єднані територіальні громади, корупція, реформа, громадянське суспільство.

The article deals with the study of reforming national legislation in the field of decentralization of public authorities in Ukraine. Decentralization is viewed as one of the effective means of combating corruption in public authorities and local self-government. Possible risks of decentralization implementation have been identified.

According to international rankings, most economically developed countries have significantly lower levels of corruption than countries with less developed economies. As noted by international partners, this is achieved not only due to imperative norms and the punitive apparatus but also due to the use of preventive measures in the fight against corruption, namely, the creation of conditions that exclude the development of corruption schemes in public authorities and local self-government. Ukraine is on the path of reforms aimed primarily at combating corruption, which has already become a systemic phenomenon in the state. During the existence of Ukraine as an independent state, corruption has acquired an unprecedented scale. This occurs despite the fact that a large number of anti-corruption regulatory legal acts have been adopted, special powerful law enforcement and judicial agencies have been created such as National Anti-Corruption Bureau of Ukraine, Specialized AntiCorruption Prosecutor's Office, anti-corruption court, the main task of which is to fight corruption.

The lack of political will among persons holding a particularly responsible position in the state, the desire for illegal enrichment of representatives of all branches of government negates the fight against corruption, and negatively affects the foreign policy image of Ukraine and its investment rating.

Decentralization of government in Ukraine is one of the effective means of combating corruption and is recognized by Ukraine's international partners as one of the most popular and successful reforms in Ukraine. Decentralization allows the public to exercise more effective control over the use of finances at the local level and to influence decision-making, which greatly complicates the establishment and operation of corruption schemes. Local governments have been given powers that previously belonged to the central government and have the opportunity to develop their regions independently.

Key words: decentralization, local governments, united territorial communities, corruption, reform, civil society.

Впродовж довгого часу корупція залишається однією 3 найбільших проблем України та $є$ темою для постійних дебатів як для української, так і для міжнародної спільноти. В Індексі сприйняття корупції (ICK), що укладається глобальною антикорупційною організацією Transparency International i базується на оцінках підприємців та аналітиків, за підсумками 2019 року наша країна посіла 126-ту сходинку в переліку зі 180 країн світу. Уперше з 2014 року Україна погіршила свої показники у світовому «Індексі сприйняття корупції» [1].

Саме корупція, за даними численних аналітичних звітів та опитувань, $є$ найбільшою проблемою як для іноземного, так і для вітчизняного бізнесу. Очевидні проблеми, викликані високим рівнем хабарництва та зловживання, - руйнація системи цінностей суспільства, тотальна недовіра до органів державної влади, що врешті-решт призводить до негативних економічних наслідків, збільшуючи нерівність та уповільнюючи зростання доходів населення [2].
Відсутність політичної волі у політичних та бізнесових еліт держави, прагнення до незаконного збагачення представників середньої та нижчої ланки органів виконавчої влади зводить нанівець боротьбу з корупцією та негативно впливає на зовнішньополітичний імідж України та іiї інвестиційний рейтинг.

Метою статті $є$ визначення децентралізації влади як дієвого способу боротьби з корупцією в органах виконавчої влади та місцевого самоврядування України, а також визначення ймовірних ризиків ії впровадження.

Питання, пов'язані з впровадженням антикорупційних заходів, були предметом наукових досліджень багатьох науковців, зокрема: С.О. Кравченка, С.С. Серьогіна, С.М. Алфьорова, І.А. Артеменка, І.С. Бачинської, В.О. Бєліка, В.Д. Гвоздецького, Н.В. Грицяк, Є.В. Невмержицького, М.І. Хавронюка та ін.

Однак, незважаючи на досить велику кількість наукових праць у сфері протидії корупції, прийняття вели- 
кої кількості антикорупційних нормативно-правових актів, створення потужних спеціальних правоохоронних та судових органів, таких як НАБУ, САП, антикорупційний суд, питання корупції в Україні, на жаль, не стало менш актуальним.

Як зазначає А. Волошенко, системну корупцію неможливо знищити лише каральними засобами, не менш важливою $є$ законодавчо-превентивна діяльність. На жаль, новостворені спеціалізовані антикорупційні органи не борються 3 першопричинами цього явища, а в кращому випадку протидіють наслідкам корупційного розгулу в країні. Тому органічне поєднання систем запобігання та ефективної протидії системній корупції на основі утвердження в країні антикорупційних регуляторів і технологій врешті-решт змусить діяти не за тіньовими схемами i корупційними пріоритетами, а насамперед i за законодавчо визначеними правилами [3].

Регуляторні антикорупційні імперативи ефективні лише тоді, коли вони враховують наявні об'єктивності, базуються на політичній волі глави держави та викликають довіру широкого загалу, тобто відображають базов державні й суспільні інтереси та пріоритети i, що найважливіше, спрацьовують на випередження. У цьому сенсі слід сприймати категорії «запобігання» і «протидія». Очевидно, що впродовж існування України як незалежної держави корупція набула безпрецедентних масштабів і натепер є системною. І це попри прийняття цілої низки різних нормативно-правових актів вищої юридичної сили (законів) антикорупційного напряму, а також президентських антикорупційних указів та офіційних постанов виконавчої влади, які фактично не виконувалися [3].

На думку В. Дубровського та Джона Лаф, поки що успіху вдалося досягти радше в обмеженні можливостей для корупції, аніж у притягненні корумпованих посадовців до відповідальності. За фактом, на нинішньому етапі системного розвитку України набагато простішим та ефективнішим способом боротьби з корупцією є обмеження можливостей для втілення в життя шахрайських схем, аніж покарання корупціонерів.

Українські реформатори та міжнародні партнери повинні зосередитися радше на запобіганні корупції, аніж на покаранні корумпованих чиновників. Запобігання і покарання слід розглядати як засіб системних перетворень, що мають на меті зміну соціального порядку, причому, на нашу думку, покарання є важливим, однак другорядним елементом, спрямованим здебільшого на запобігання зловживанням у майбутньому [4].

Надзвичайно важливо, щоб громадянське суспільство та міжнародні партнери й надалі пильно стежили за звуженням кола можливостей для існування давніх корупційних схем, що впродовж двадцяти років підривали розвиток України.

Зниження рівня корупції навряд чи вдасться досягти за допомогою самих лише каральних заходів хоча б тому, що запровадження жорсткіших антикорупційних норм може бути зведене нанівець через їхнє вибіркове дотримання [4].

Одним із дієвих превентивних засобів боротьби 3 корупцією є децентралізація органів державної влади, яка значно звужує можливості розвитку та функціонування корупційних схем.

Протягом тривалого часу постає питання, як подолати корупцію - це важливо для європейських підприємств, які готові інвестувати в Україну. Децентралізація дає можливість контролювати і впливати на прийняття рішення Важливо, що такі рішення приймаються на місцях. Органи місцевого самоврядування здобули можливість розвивати території. Тому реформу децентралізації європейські партнери оцінюють як найуспішнішу в Україні [5].

Децентралізація - це процес передачі частини функцій та повноважень центральних органів влади органам місцевого самоврядування, тобто процес розширення та зміцнення прав і повноважень територіальних громад 3 одночасним звуженням прав і повноважень відповідного центру. Децентралізація може розглядатись як цілеспрямований процес розширення повноважень органів місцевого самоврядування 3 метою:

- оптимізації і підвищення ефективності управління суспільно важливими справами;

- своєчасного та якісного надання всіх необхідних послуг громадянам у повному обсязі;

- найповнішої реалізації місцевих інтересів;

- створення розгалуженої системи місцевого самоврядування, за якої питання місцевого значення вирішуються представниками не центрального уряду, а територіальної громади [6].

Якщо громадяни сплачують податки за надання місцевих послуг, то вони активніше наполягатимуть на їхній високій якості й вимагатимуть від чиновників регулярно звітувати про свої дії. Зі схожих позицій виступають прихильники неоліберальних економічних реформ, на думку яких децентралізація робить державне управління ефективнішим, мобілізує додаткові державні ресурси та покращує процес прийняття рішень у бюджетній сфері. Вона розглядається як важливий інструмент для ревізії старих стратегій розвитку, котрі призвели до низьких показників економічного зростання та високого рівня корупції у сфері надання державних послуг. Очевидно, що ефективна демократична держава конче потребує активної участі громадян у місцевому самоврядуванні. Якщо вони мають можливість такої участі, то змушують представників місцевої влади краще реагувати на їхні вимоги й ефективніше розв'язувати місцеві проблеми. Якщо останні не здатні впоратися з цими завданнями, то мешканці можуть висловити їм недовіру та домогтися відсторонення від ведення місцевих справ. Водночас такий вид участі $є$ ефективною школою демократії, позаяк дає можливість здобувати навички ведення дискусій та дотримання правил, які сприяють розв'язанню конфліктів у демократичних системах.

Більше того, державні службовці змушені орієнтувати свою поведінку на надання якісних послуг, побоюючись громадського невдоволення та скарг від незадоволених «клієнтів». Корупція також є більш видимою на місцевому рівні, й, відповідно, іiї легше контролювати. У результаті фіскальної децентралізації зростає ефективність надання послуг, бо вони фінансуватимуться вже за рахунок місцевих податків і зборів. Отже, завдання поліпшення управління полягає в посиленні інститутів місцевого самоврядування, забезпеченні чиновників місцевих органів влади більшими можливостями для виконання нових обов'язків і розвитку механізмів підвищення ефективності їхньої діяльності, посилення підзвітності [6].

Мета реформи децентралізації - формування ефективного місцевого самоврядування і територіальної організації влади для створення і підтримки повноцінного життєвого середовища для громадян, надання високоякісних та доступних публічних послуг, становлення інститутів прямого народовладдя, узгодження інтересів держави та територіальних громад.

Реформа передбачає відповідальність органів місцевого самоврядування перед виборцями - за ефективність своєї роботи, а перед державою - за ії̈ законність.

Тривала відсутність політичної волі для проведення повноцінної децентралізації в державному управлінні стала однією з причин посилення сепаратистських рухів на сході країни. Наслідками політики тотальної централізації влади в Україні стали:

- істотна залежність територій від центру;

- низький рівень інвестиційної привабливості територій;

- інфраструктурно, фінансово та кадрово слабкі громади; 
- деградація сільської місцевості;

- складна демографічна ситуація;

- низька якість надання публічних послуг;

- низький рівень довіри до влади;

- високий рівень корупції;

- низька ефективність управлінських рішень [7].

Як зазначає Георг Мільбрадт - спеціальний посол Німеччини з питань децентралізації, досвід багатьох країн показує, що урядування стає кращим, коли в країні децентралізуються функції, з якими можна впоратися на місцевому рівні. На його думку, варто організовувати на місцях систему охорони здоров'я, школи, зберігання відходів. Громадяни можуть на це впливати. Громади, які нині мають владу, які обрали нових мерів, працюють ефективніше, демократичніше, ніж стара система [8].

Якщо здійснюється децентралізація використання грошей, також децентралізується можливість корупції. Набагато легше знайти корупцію на місцевому рівні, аніж на національному, де треба мати справу з «великими хлопцями». Децентралізація не повністю знищить корупцію, але так краще контролювати і боротися з нею.

Міжнародний досвід доводить, що децентралізовані країни мають менше корупції на місцевому рівні, ніж на національному.

В України є чудовий інструмент для боротьби з корупцією, який називається Prozorro, тому що ця система дуже прозора і дає можливість бачити, як витрачаються гроші [8].

М. Бризіцький вважає, що ризиком, який може бути пов'язаний з децентралізацією, є корупція. Наближеність представників влади до локальних груп інтересів, неформальність відносин, залежність службовців від політиків, велика дискреція у прийнятті рішень, відсутність або слабкість місцевих засобів масової інформації можуть бути чинниками, що сприяють поширенню корупції на субнаціональному рівні. Хоча емпіричні дослідження стверджують про негативний зв'язок між децентралізацією та корупцією: зіставивши відповідні індекси 59 країн, дослідники встановили, що чим більша частка місцевих видатків у сукупному бюджеті, тим нижчим є рівень корупції. Для України такі висновки дуже обнадійливі.

Децентралізація влади та відповідна реформа не $\epsilon$ панацеєю від усіх хвороб, а за найгіршого сценарію може бути навіть шкідливою для економічного розвитку, соціальної справедливості, макроекономічної стабільності чи боротьби з корупцією. Однак усвідомлення властивих ій ризиків, створення запобіжників і належний контроль дозволять не тільки скористатися всіма перевагами нової організації публічної влади в державі, а й створити необхідний фундамент для реформ в інших сферах [9].

Отже, незважаючи на існуючі ризики, варто визнати, що децентралізація органів виконавчої влади в Україні $\epsilon$ одним із дієвих та успішних засобів боротьби з корупцією. Посилення інститутів місцевого самоврядування надасть чиновникам місцевих органів влади більше можливостей для здійснення контролю за використанням коштів на місцях, посприяє посиленню підзвітності, що позитивно вплине на запобігання корупції, адже на місцевому рівні вона є більш видимою, і тому ії легше контролювати. Надзвичайно важливим у боротьбі з корупцією $\epsilon$ здійснення контролю громадянського суспільства за діяльністю органів місцевого самоврядування, адже це зменшить коло можливостей для реалізації корупційних схем, що впродовж усього існування нашої держави підривали їі розвиток.

\section{ЛITEPATYPA}

1. Transparency International. Індекс сприйняття корупції. URL: https://ti-ukraine.org/research/indeks-spryjnyattya-koruptsiyi-2019/ (дата звернення: 15.07.2020).

2. Урядовий портал. Реформа децентралізації. URL: https://www.kmu.gov.ua/diyalnist/reformi/verhovenstvo-prava-ta-borotba-z korupciyeyu/borotba-z-korupciyeyu (дата звернення: 15.07.2020).

3. Волошенко А., Ковальчук Т. Системна корупція: основні різновиди та державні імперативи запобігання і протидії. Банківська справа. 2018. № 3. С. 49-59.

4. Дубровський В., Джон Лаф. Реанімаційний пакет реформ. Україна має зосередитися на запобіганні корупції, а не покаранні Великий антикорупційний аналіз. URL: https://rpr.org.ua/news/ukrajina-maje-zoseredytysya-na-zapobihanni-koruptsiji-a-ne-pokaranni-velykyjantykoruptsijnyj-analiz/ (дата звернення: 15.07.2020).

5. Децентралізація дає можливості. Подолання корупції, розподіл повноважень, приєднання до міст і майбутнє районів. URL: https://decentralization.gov.ua/news/9062?page=4 (дата звернення: 15.07.2020).

6. Кресіна І. Вплив децентралізації на ефективність публічної влади. Віче. 2015. № 12. С. 11-13

7. Урядовий портал. Реформа децентралізації. URL: https://www.kmu.gov.ua/diyalnist/reformi/efektivne-vryaduvannya/reformadecentralizaciyi (дата звернення: 15.07.2020).

8. Hromadske. Децентралізовані країни мають менше корупції на місцях - спецпосланець Меркель з ресоорм в Україні. URL: https://hromadske.ua/posts/decentralizovani-krayini-mayut-menshe-korupciyi-na-miscyah-specposlannik-merkel-z-reform-v-ukrayini (дата звернення: 15.07.2020).

9. Бризіцький Максим. Децентралізація дає можливості. Ризики децентралізації. URL: https://decentralization.gov.ua/news/ columns/11589 (дата звернення: 15.07.2020). 


\title{
ЮРИДИЧНА ВІДПОВІДАЛЬНІСТЬ ОРГАНІВ МІСЦЕВОГО САМОВРЯДУВАННЯ: БАГАТОАСПЕКТНІСТЬ ВИЗНАЧЕННЯ
}

\section{LEGAL RESPONSIBILITY OF LOCAL SELF-GOVERNMENT BODIES: MULTIPLICITY OF DEFINITION}

\author{
Кириченко Ю.М., Д.ю.н., доцент, \\ професор кафедри правового забезпечення господарської діяльності \\ факультету № 6
}

Харківський начіональний університет внутрішніх справ

У статті розглянуто поняття юридичної відповідальності як важливого елемента правового регулювання суспільних відносин, проаналізовано сутність юридичної відповідальності органів місцевого самоврядування як складника правового статусу муніципальних органів. Визначено, що правове регулювання відповідальності суб'єктів місцевого самоврядування залишається одним із проблематичних з точки зору його юридичного змісту. Це пояснюється тим, що юридична відповідальність, будучи комплексним державно-правовим охоронним інститутом, поєднує за предметною ознакою неоднакові за своєю природою правові норми різних галузей права (конституційні, адміністративні, муніципальні, цивільні, трудові, кримінальні тощо).

Встановлено, що сутність юридичної відповідальності органів місцевого самоврядування розкривається завдяки їі таким характерним ознакам, як: а) формальна визначеність правовими нормами та обов'язковість для органів місцевого самоврядування; б) настає за скоєння протиправного, винного діяння (дію або бездіяльність) органом чи посадовою особою місцевого самоврядування, яке спричинило або створило загрозу спричинення моральної та/або матеріальної шкоди суспільним відносинам у сфері місцевого самоврядування; в) її наслідками є застосування законодавчо визначених обмежень особистого, організаційного або майнового характеру по відношенню до владного суб'єкта.

У статті наголошено на тому, що відповідальність органів та посадових осіб місцевого самоврядування в загальному вигляді характеризується багатоаспектністю, оскільки виступає одночасно як: 1) основний принцип місцевого самоврядування; 2) структурний елемент правового статусу місцевого самоврядування; 3) одна зі спеціальних гарантій реальності місцевого самоврядування. Подвійна природа органів місцевого самоврядування (як елемента громадянського суспільства і як елемента механізму публічного управління) свідчить про дуалістичну природу відповідальності, оскільки органи та посадові особи місцевого самоврядування несуть її і перед жителями територіальної громади, і перед державою.

Ключові слова: відповідальність, юридична відповідальність, публічна влада, муніципальна органи влади, місцеве самоврядування, територіальна громада.

The article considers the concept of legal responsibility as an important element of legal regulation of public relations, analyzes the essence of legal responsibility of local governments as a component of the legal status of municipal bodies. It is determined that the administrative and legal regulation of the responsibility of local governments remains one of the most problematic in terms of its legal content. This is explained by the fact that legal liability, being a complex state and legal protection institution, combines on a substantive basis different in nature legal norms of different branches of law (constitutional, administrative, municipal, civil, labor, criminal, etc.).

It is established that the essence of legal responsibility of local self-government bodies is revealed due to its characteristic features: a) formal definition by legal norms and obligatory for local self-government bodies; $b$ ) an unlawful, culpable act (action or omission) by a body or official of local self-government that has caused or created a threat of causing moral and/or material damage to public relations in the field of local self-government occurs; c) its consequences are the application of legally defined restrictions of a personal, organizational or property nature in relation to the subject of power.

The article emphasizes that the responsibility of bodies and officials of local self-government in general is characterized by multifaceted nature, as it acts simultaneously as: 1) the basic principle of local self-government; 2) a structural element of the legal status of local self-government; 3 ) one of the special guarantees of the reality of local self-government. The dual nature of local self-government bodies (as an element of civil society and as an element of the mechanism of public administration) testifies to the dualistic nature of responsibility, as local self-government bodies and officials bear it both to residents of the territorial community and to the state.

Key words: responsibility, legal responsibility, public authority, municipal authorities, local self-government, territorial community.

Органи місцевого самоврядування, які виступають активною формою участі громадян в управлінні суспільними і державними справами, органічним елементом системи народовладдя, призначені для того щоб відображати інтереси відповідних територіальних громад і забезпечувати їх урахування під час вироблення та реалізації управлінських рішень, що тим самим зумовлює їхню відповідальність за свої рішення, дії, бездіяльність перед особою, територіальною громадою та державою [1, с. 3].

Безсумнівно, функціональне призначення державно-правового охоронного інституту юридичної відповідальності для системи місцевого самоврядування неможливо недооцінювати. Він слугує свого роду противагою компетенційним повноваженням, які надані органам місцевого самоврядування, їх посадовим особам, виступає гарантом дотримання режиму законності в процесі нормотворчої та правозастосовної діяльності названих органів та осіб, є запорукою недопущення зловживання публічною владою на локальному рівні й надійного забезпечення та ефективної реалізації прав, свобод та інтересів жителів територіальної громади.
У Конституції України передбачено загальні засади для існування та функціонування інституту юридичної відповідальності у вітчизняній правовій системі [2]. У розрізі цієї статті варто вказати, що відповідно до ст. 56 Конституції України кожен має право на відшкодування за рахунок органів місцевого самоврядування матеріальної та моральної шкоди, завданої незаконними рішеннями, діями чи бездіяльністю органів місцевого самоврядування, їх посадових і службових осіб під час здійснення ними своїх повноважень; ст. 144 Конституції України встановлює, що рішення органів місцевого самоврядування 3 мотивів їх невідповідності Конституції чи законам України зупиняються у встановленому законом порядку з одночасним зверненням до суду. Водночас зміст ст. 146 Основного Закону залишає простір для врегулювання інституту відповідальності органів місцевого самоврядування на законодавчому рівні відповідно до потреб суспільства і держави, оскільки містить правило, за яким інші питання організації місцевого самоврядування та відповідальність органів місцевого самоврядування 
визначається законом. Отже, значна кількість статей Конституції України так чи інакше пов'язана 3 правовими нормами загального, концептуального характеру, які стосуються інституту юридичної відповідальності місцевого самоврядування.

Спеціальні правові норми, які забезпечують правове регулювання механізму юридичної відповідальності того чи іншого іiї виду, визначають процедуру притягнення до юридичної відповідальності органів місцевого самоврядування, їх посадових осіб, деталізовано в галузевому законодавстві (Законах України «Про місцеве самоврядування в Україні», «Про службу в органах місцевого самоврядування», «Про статус депутатів місцевих рад»).

Так, профільний Закон України «Про місцеве самоврядування в Україні» відповідно до конституційних положень, наділяючи органи місцевого самоврядування повноваженнями щодо вирішення питань місцевого значення, одночасно передбачає відповідальність цих органів та їх посадових осіб за свою діяльність перед територіальною громадою, державою, юридичними і фізичними особами, про що свідчить зміст ст. ст. 75-77 названого Закону [3]. Такий нормативний припис чітко вказує на коло суб'єктів, перед якими органи і посадові особи місцевого самоврядування несуть відповідальність. Отже, подвійна природа органів місцевого самоврядування (як елемента громадянського суспільства і як елемента механізму публічного управління) свідчить про дуалістичну природу відповідальності, оскільки органи та посадові особи місцевого самоврядування іiї несуть і перед жителями територіальної громади, і перед державою. Більш того, окремими статтями профільного Закону визначено підстави, які тягнуть за собою юридичну відповідальність, хоча питання про правові санкції відповідальності і механізми їх реалізації (контролю, оцінки, застосування заходів) у цьому законодавчому акті не порушено.

Поряд із названими національними законодавчими нормами, міжнародно-правовими приписами також чітко закріплено, що органи та посадові особи місцевого самоврядування мають сумлінно здійснювати свої повноваження, беручи на себе відповідальність за їх реалізацію. Так, у ст. 3 Свропейської Хартії місцевого самоврядування зазначається, що місцевим самоврядуванням слід вважати право і реальну здатність органів місцевого самоврядування регламентувати значну частину місцевих справ i управляти ними, діючи в межах закону і беручи на себе всю відповідальність в інтересах місцевого населення [4].

Безперечно, юридична відповідальність $є$ важливим елементом правового регулювання суспільних відносин, сутність якого полягає в цілеспрямованому впливі на поведінку індивідів за допомогою юридичних засобів. Завдяки такому впливу стає можливим гідне впорядкування суспільних відносин, надання їм певної системності та стабільності, уникнення різких загострень соціальних конфліктів, максимально можливе втілення принципів соціальної справедливості [5, с. 42].

Традиційним i загальноприйнятим в юридичній літературі вважається підхід, за яким відповідальність (у ретроспективному значенні) визначається як покарання за скоєний проступок (правопорушення, злочин). Низка дослідників юридичну відповідальність визначають як правовідносини, в яких держава має право застосувати певні заходи примусу до суб'єктів, що скоїли правопорушення і зобов'язані зазнати втрат чи обмежень, передбачених санкціями норми права [6, с. 204].

Як одну із форм державно-примусового впливу на порушників норм права, яка полягає у застосуванні до них передбачених законом санкцій - мір відповідальності, що тягнуть за собою додаткові несприятливі наслідки, розуміє юридичну відповідальність І.П. Голосніченко [7, с. 26-28].

Більш інформативним виглядає позиція, якої дотримуються В.М. Корельський і В.Д. Перевалов. На думку вче- них, юридична відповідальність - це застосування до правопорушника передбачених санкцією юридичної норми заходів державного примусу, що мають вираз у формі «позбавлень» особистого, організаційного або майнового характеру [8, с. 418].

Т.Б. Грек, розглядаючи юридичну відповідальність як самостійний і необхідний елемент механізму правового регулювання, виділяє такі характерні ознаки, що йому притаманні: 1) являє собою вид державного примусу; 2) єдиною підставою до його застосування виступає правопорушення; 3) функціонує шляхом вжиття певних негативних заходів до осіб, що скоїли правопорушення [5, с. 42].

Слушною також видається точка зору П.М. Рабіновича, відповідно до якої юридична відповідальність виступає як закріплений у законодавстві і забезпечений державою обов'язок правопорушника зазнати примусового позбавлення певних цінностей, що йому належать [9, с. 56].

Досить схожу тезу висловлює Л. Наливайко, вкладаючи у зміст відповідальності обов'язок винної особи перетерплювати примусове позбавлення певних благ шляхом застосування до неї заходів державного примусу $[10$, c. 46$]$. Як бачимо, розуміння юридичної відповідальності пов'язане з протиправною оцінкою поведінки, правопорушенням, що тягне за собою державний примус у формі покарання.

Отже, для всіх вищезазначених визначень поняття юридичної відповідальності характерним $є$ те, що наголос робиться, по-перше, на «обов'язку» та «покаранні», й особливо - на суб'єктивному розумінні цього явища, тобто розглядається з точки зору правопорушника, відповідаючи на питання: у чому виражається відповідальність саме для нього, в яких наслідках? По-друге, вченими відмічається, що юридична відповідальність реалізується в межах особливих, охоронних правовідносин, які виникають між державою і правопорушником, унаслідок чого до останнього застосовуються санкції з негативними для нього наслідками. При цьому всіма без виключення дослідниками підкреслюється, що юридична відповідальність - складне, багатофункціональне явище, яке міцно пов'язане з численними правовими категоріями: «правовідносинами», «правовими нормами», «правовими санкціями», «правомірною поведінкою», «законністю», «правопорушенням», «правовою діяльністю», «правовою культурою» тощо.

Серед особливостей юридичної відповідальності виокремлюються: iï індивідуальний характер; яскраво виражене правове спрямування, що проявляється у застосуванні до правопорушника заходів державного примусу, внаслідок чого він зазнає негативних для себе наслідків; реалізується вона у визначеному законом порядку; застосовується за скоєний проступок (правопорушення або злочин).

В окремих випадках правознавці зауважують, що існує відповідальність, яка сполучена 3 активною правомірною діяльністю суб'єкта права, тобто «орієнтована не лише на минулу негативну поведінку, але й на сьогоднішню та майбутню правомірну поведінку суб'єкта правовідносин» [11, с. 191-216].

До речі, подібна ідея юридичної відповідальності, не пов'язаної з правопорушенням, була запропонована в юриспруденції ще на початку 60 -х років минулого століття (М.І. Матузовим, П.О. Недбайлом, Т.О. Слободніковим, В.С. Слободніковим, В.С. Марковим та ін.). В iï правову природу покладено правомірний характер відповідних дій та поведінки, тобто відповідальність за належне виконання обов'язків, правомірну юридично значущу поведінку і правову компетентність. Характерно, що прихильники цієї концепції, говорячи про відповідальність як про явище позитивне, що передбачає свідоме, відповідальне ставлення індивідів до своїх вчинків, способу життя, застосовують такі категорії, як: «добровільна від- 
повідальність», «позитивна відповідальність», «перспективна відповідальність» або «активна відповідальність».

М.В. Вітрук із цього приводу роз'яснює, що «визначення відповідальності, що існує ще до порушення будьякої правової норми, через правомірну поведінку суб' єктів права і категорію позитивної (перспективної) юридичної відповідальності збагачує зміст цього поняття, але не відкидає існування іiі негативного (ретроспективного) аспекту» [12, с. 186-204]. Таке судження допомагає чітко з'ясувати відносини відповідальності, які мають місце в діяльності того чи іншого суб'єкта права. Тобто буквально юридичну відповідальність не варто розглядати лише як результат правопорушення, що тягне за собою застосування державного примусу. Якщо в суспільстві зростатиме відповідальна правомірна поведінка учасників правовідносин, то зрозуміло, що необхідність у застосуванні покарання за скоєні правопорушення значно зменшуватиметься. Коротко кажучи, негативний аспект відповідальності наступає лише в тому разі, якщо не спрацював iї позитивний аспект.

Окремі науковці вказують на те, що позитивна відповідальність значною мірою знаходиться у площині морально-етичних норм, виникає за межами ретроспективної відповідальності. Позитивна відповідальність проявляється в тому, що уповноважена особа усвідомлює підвищені вимоги до виконання своїх повноважень, а ретроспективна відповідальність завжди пов'язана із застосуванням певної санкції [13, с. 11].

Таким чином, у позитивній формі правова відповідальність представлена у вигляді комплексу встановлених законодавчими та нормативно-правовими актами ознак, що характеризують діяння як правомірне та соціальнокорисне, яке не тягне застосування негативної форми реалізації відповідальності. Реалізовується позитивна форма відповідальності через юридичні обов'язки суб'єкта права, який у майбутньому добровільно, свідомо та відповідно до припису норми права їх виконує. Якщо ж цього не станеться, і суб'єкт права скоїть правопорушення, то виникне необхідність у застосуванні державного примусу для належного виконання цих суб'єктивних обов'язків. Отже, під час з'ясування сутності юридичної відповідальності важливо одночасно розглядати ii позитивний і негативний аспекти у взаємозв'язку та взаємозалежності, оскільки вивчення лише одного з них значно звужує смислове навантаження змісту цього правового явища.

Ведучи мову про органи місцевого самоврядування як суб'єкта відповідальності, передусім маємо на увазі представницькі органи місцевого самоврядування (сільські, селищні, міські, районні у містах ради); виконавчі органи рад; органи місцевого самоврядування, що представляють спільні інтереси жителів територіальних громад (районні, обласні ради); виборні посадові особи місцевого самоврядування (депутатів місцевих рад та сільських, селищних, міських голів, старост).

Досліджуючи питання відповідальності місцевого самоврядування, його органів та посадових осіб, окремі вчені-юристи розуміють іiі у вузькому значенні, а саме як реакцію спеціальних компетентних державних структур, що забезпечують юридичну відповідальність, на протиправні рішення органів місцевого самоврядування та неналежне виконання покладених на них обов'язків. Так, В.Ф. Опришко під відповідальністю місцевого самоврядування, його органів та посадових осіб пропонує розуміти несприятливі правові наслідки за прийняті ними протиправні рішення, неналежне здійснення своїх завдань та функцій [14, с. 352]. М.В. Постовий розглядає відповідальність органів місцевого самоврядування як настання несприятливих наслідків, що застосовуються до суб'єктів муніципальних правовідносин, які не виконують своїх обов'язків або виконують їх неналежним чином щодо інших учасників правовідносин [15, с. 299].
Практично дублює таку саму позицію А.А. Коваленко, розуміючи під відповідальністю органів та посадових осіб настання для них негативних правових наслідків за прийняті ними протиправні рішення та неналежне виконання покладених на них обов'язків [16, с. 570]. Співзвучна цьому визначенню й думка В.В. Кравченка та М.В. Пітцика, які під відповідальністю органів місцевого самоврядування мають на увазі настання негативних наслідків у разі невиконання або неналежного виконання покладених на них законом або договором обов'язків [17, с. 11]. При цьому незаконні діяння цих органів чи осіб можуть здійснюватись у формі як активних дій, так і бездіяльності (невиконання тих дій, які вони зобов'язані були виконати на підставі покладених на них обов'язків) [18, с. 717].

До поширених прикладів бездіяльності представників органів місцевого самоврядування можна віднести: відсутність звітування сільського, селищного чи міського голови, депутатів місцевих рад перед територіальною громадою; пропуск депутатами місцевих рад пленарних засідань ради або засідань постійних комісій. Законодавцем також визначено, що територіальна громада в будь-який час може достроково припинити повноваження органів та посадових осіб місцевого самоврядування, якщо вони порушують Конституцію або закони України, обмежують права і свободи громадян, не забезпечують здійснення наданих їм законом повноважень (ч. 2 ст. 75 Закону України «Про місцеве самоврядування в Україні») [3]. Отже, невиконання своїх повноважень органами місцевого самоврядування (хоча вони мали реальну можливість їх реалізації) варто розцінювати як бездіяльність.

Неналежна (протиправна) поведінка може виявлятися не лише у невиконанні обов'язків, а також у зловживанні правом, зловживанні владою або своїм службовим становищем, у тому числі й в їх перевищенні. У цьому сенсі варто нагадати, що зловживання правом означає використання своїх прав у недозволені способи, що суперечать призначенню права, внаслідок чого завдаються збитки (шкода) суспільству, державі, окремій особі [19, с. 428]; зловживання владою або службовим становищем зазвичай розуміється як умисне, 3 корисливих мотивів, іншої особистої заінтересованості або в інтересах третіх осіб використання службовою особою влади чи службового становища всупереч інтересам служби [20, с. 115]; а перевищення влади або службових повноважень розглядається як умисне вчинення службовою особою дій, які явно виходять за межі наданих їй законом прав і повноважень [20, с. 193].

Безвідповідальне ставлення органів місцевого самоврядування до покладених на них завдань може мати різноманітний прояв: порушення трудової дисципліни; вчинення корупційного правопорушення; заподіяння матеріальної шкоди фізичній особі; непроведення радою сесій без поважних причин у строки, встановлені законом; пропуск депутатом сесій ради тощо. Все це, так чи інакше, призводить до порушення норм законодавства, погіршення екологічного та економічного стану на певній адміністративно-територіальній одиниці, ставить під загрозу інтереси місцевого населення, сприяє дестабілізації суспільно-політичної ситуації, позначається на рівні довіри територіальної громади до органів публічної влади.

Окремі управлінські рішення органів місцевого самоврядування приймаються колегіально. Отже, персоніфікувати суб'єкта відповідальності в разі ухваленого колегіального рішення досить складно, оскільки його відповідальність нібито «розсіюється», що, очевидно, може також призводити до безвідповідальності органу місцевого самоврядування за наслідки своїх незаконних дій чи бездіяльності.

Як незаконні слід розглядати не лише рішення, дії чи бездіяльність органу місцевого самоврядування, що прямо заборонені в законі, а також і такі, що вчинені без відпо- 
відних повноважень або з їх перевищенням чи зловживанням. Таким чином, порушення прав та інтересів членів територіальної громади, окремих юридичних і фізичних осіб, держави чи завдання їм шкоди з боку органів місцевого самоврядування може відбуватися у такий спосіб: 1) через здійснення ними протиправних діянь (дій чи бездіяльності); 2) через прийняття ними неправомірних рішень.

Як уявляється, суспільна шкідливість діянь (дії чи бездіяльності) у сфері місцевого самоврядування полягає в тому, що вони посягають на основоположні засади конституційного ладу держави, на встановлений порядок сучасного демократичного локального управління. Протиправність виражається у порушенні органом чи посадовою особою місцевого самоврядування заборон, визначених у законах і підзаконних актах, невиконанні обов'язків, що виходять із нормативно-правового акта, акта застосування норм права або договору, укладеного на основі закону; у зловживанні своїми повноваженнями або службовим становищем, у тому числі їх перевищенні. Караність виражається у застосуванні спеціальних правових санкцій до органів та посадових осіб місцевого самоврядування за скоєні ними винні діяння (дію або бездіяльність).

Виходячи 3 наведеного, можна констатувати, що в основу розуміння поняття юридичної відповідальності органів та посадових осіб місцевого самоврядування більшістю сучасних науковців покладено передбачений нормами права обов'язок зазначених суб'єктів публічної влади зазнати певних негативних наслідків у разі невиконання або неналежного виконання своїх юридичних обов'язків, прийнятті незаконних та необгрунтованих рішень, вчиненні інших протиправних діянь (дій чи бездіяльності). Виявлятися юридична відповідальність може або в застосуванні до органів місцевого самоврядування каральних санкцій, або у примушенні до поновлення незаконно порушених прав, свобод та інтересів територіальної громади, фізичних і юридичних осіб, а також держави.

Сутність юридичної відповідальності органів місцевого самоврядування розкривається завдяки таким iіi характерним ознакам, як: а) формальна визначеність правовими нормами та обов'язковість для органів місцевого самоврядування; б) настає за скоєне протиправне, винне діяння (дію або бездіяльність) органом чи посадовою особою місцевого самоврядування, яке спричинило або створило загрозу спричинення моральної та/або матеріальної шкоди суспільним відносинам у сфері місцевого самоврядування; в) іiї наслідками є застосування законодавчо визначених обмежень особистого, організаційного або майнового характеру по відношенню до владного суб'єкта (органу чи посадової особи місцевого самоврядування).

Разом із тим на сторінках фахової літератури зустрічаються наукові підходи, в яких відповідальність органів місцевого самоврядування не завжди пов'язується або ототожнюється 3 державним примусом. Можна навести твердження Н.Б. Писаренка, який підкреслює, що відповідальність органів місцевого самоврядування варто розглядати як таку, що реалізується не стільки з метою покарання, скільки для того, щоб ці органи належно виконували свої обов'язки [21, с. 189]. Тобто метою відповідальності визначено не лише покарання у вигляді застосування примусових заходів, але й стимулювання активної правомірної поведінки під час виконання обов'язків органами місцевого самоврядування. Наприклад, завдяки передбаченому у ст. ст. 8, 13 Закону України «Про місцеве самоврядування в Україні» проведенню загальних зборів громадян та громадських слухань опосередковується позитивна відповідальність органів місцевого самоврядування перед територіальною громадою.

Отже, відповідальність органів місцевого самоврядування у загальному вигляді характеризується багатоаспектністю, оскільки виступає одночасно як: 1) основний принцип місцевого самоврядування; 2) структурний елемент правового статусу місцевого самоврядування; 3) одна з гарантій реальності місцевого самоврядування. 3 одного боку, відповідальність впливає на належну організацію та правомірний характер функціонування сільських, селищних, міських рад та їх виконавчих органів, районних та обласних рад, районних у містах рад (у випадку їх створення) як потенційних суб'єктів відповідальності (позитивний аспект); з іншого боку, простежується у вигляді негативних правових наслідків за прийняті ними протиправні рішення та неналежне виконання покладених на них обов'язків (ретроспективний аспект). Саме тому досить аргументованими виглядають наукові підходи щодо визначення поняття відповідальності органів та посадових осіб місцевого самоврядування, які допускають і визнають одночасно iï як позитивний, так і ретроспективний аспекти. Лише в такому вигляді інститут юридичної відповідальності по відношенню до органів та посадових осіб місцевого самоврядування зможе виконувати найголовніші свої функції: регулятивну, превентивну, каральну, правовідновлювальну та виховну.

\section{ЛITEPATYPA}

1. Яцук В.А. Організаційно-правові засади відповідальності органів місцевого самоврядування в Україні : автореф. дис. ... канд. наук з державного управління: 25.00.04 «Місцеве самоврядування». Київ : Національна академія державного управління при Президентові України, 2012. 22 с.

2. Конституція України від 28.06.1996 р. № 254к/96-BP / Верховна Рада України. База даних «Законодавство України». URL: http://zakon2.rada.gov.ua/laws/show/254\%D0\%BA/96-\%D0\%B2\%D1\%80

3. Про місцеве самоврядування в Україні : закон України від 21.05.1997 р. № 280/97-ВР / Верховна Рада України. База даних «Законодавство України». URL: http://zakon2.rada.gov.ua/laws/show/280/97-\%D0\%B2\%D1\%80

4. Європейська хартія місцевого самоврядування (м. Страсбург, 15 жовтня 1985 року). URL: http://zakon.rada.gov.ua/laws/ show/994_036

5. Грек Т.Б. Правова природа юридичної відповідальності: поняття, принципи та види. Адвокат. 2010 . № 10 (121). С. 41-45.

6. Загальна теорія держави і права: підручник для студентів юридичних вищих навчальних закладів / М.В. Цвік та ін. ; за заг. ред. М.В. Цвіка, О.В. Петришина. Харків : Право, 2009. 584 с.

7. Голосніченко І.П. Проблеми адміністративного процесу на сучасному етапі розвитку української держави. Актуальні проблеми держави і права. 2003. Вип. 19. С. 26-28.

8. Теория государства и права : учебник под ред. В.М. Корельского и В.Д. Перевалова. Изд. группа ИНФРА-М-НОРМА, 1997.570 с.

9. Рабінович А. Юридично значимі послуги: загальнотеоретичне поняття, класифікація. Право України. 2010. № 8. С. $142-147$.

10. Наливайко Л. Проблеми визначення поняття, специфічних ознак та функцій конституційної відповідальності в сучасній конституційній теорії. Право України. 1999. № 10. С. 45-50.

11. Матузов Н.И. Правовая система и личность : учебное пособие. Саратов : Издательство Саратовского института, 1987. 294 с.

12. Витрук Н.В. Общая теория юридической ответственности : учебное пособие. 2-е изд., испр. и доп. Москва : Норма, 2009. 259 с.

13. Армаш Н.О. Адміністративно-правовий статус керівників органів виконавчої влади : автореф. дис. ... канд. юрид. наук :

12.00.07 «Теорія управління; адміністративне право і процес; фінансове право; інформаційне право». Київ : Інститут держави і права ім. В.М. Корецького НАН України, 2005. 19 с.

14. Закон про місцеве самоврядування в Україні: Науково-практичний коментар / за ред. В.Ф. Опришка. Київ : Ін-т законодавства Верховної Ради України, 1999. 398 с. 
15. Постовой Н.В. Муниципальное право России : учебник. 2-е изд., испр. и доп. Москва : Юриспруденция, 2000.352 с.

16. Коваленко А.А. Деякі актуальні питання юридичної відповідальності органів та посадових осіб місцевого самоврядування в Україні. Правова держава. 2003. Вип. 14. С. 569-574.

17. Кравченко В.В. Конституційні засади місцевого самоврядування в Україні (основи муніципального права) : навч. посіб. В.В. Кравченко, М.В. Пітцик. Київ : Арарат-Центр, 2001. 176 с.

18. Цивільний кодекс України: науково-практичний коментар: у 2 ч. / за заг. ред. Я.М. Шевченко. Київ : Вид. Дім «Ін Юре», 2004. Ч. 2. 896 с.

19. Скакун О.Ф. Теорія держави і права : підручник. Пер. з рос. Харків : Консул, 2001. 656 с.

20. Юридичні терміни. Тлумачний словник / В.Г. Гончаренко та ін. ; за заг. ред. В.Г. Гончаренка. 2-ге вид., стереотипне. Київ : Либідь, 2004. 320 c.

21. Писаренко Н.Б. До питання про теоретичні засади юридичної відповідальності органів і посадових осіб місцевого самоврядування. Проблеми удосконалення правового регулювання місцевого самоврядування в Україні : матеріали міжнар. наук.-практ. конф., 25 травня 2004 р. ; за ред. проф. Ю.П. Битяка. Харків : Ін-т держ. будівництва та місцевого самоврядування АПрН України, 2004. С. 187-189. 


\title{
СПЕЦАЛЬНІ ЗАХОДИ ЩОДО ПРОТИДІЇ ДОМАШНЬОМУ НАСИЛЬСТВУ: СУЧАСНІ ВИКЛИКИ ТА НАПРЯМИ ЇХ ВИРІШЕННЯ
}

\author{
SPECIAL MEASURES TO COMBAT DOMESTIC VIOLENCE: \\ CHALLENGES AND DIRECTIONS OF THEIR SOLUTION
}

Ковальова О.В., к.ю.н., с.н.с., професор кафедри адміністративної діяльності поліції Одеський державний університет внутрішніх справ

$\begin{aligned} \text { Дубенко О.М., к.ю.н., } & \text { заб.о. заступника начальника управління логістики і матеріально-технічного забезпеченя }\end{aligned}$

Головне управління Національної поліції в Одеській області

Статтю присвячено висвітленню особливостей застосування спеціальних заходів щодо протидії домашньому насильству. Звернуто увагу на проблемні питання під час їх практичної реалізації та запропоновано можливі шляхи їх вирішення як на нормативно-правовому, так і організаційному рівнях.

Підкреслено, що тимчасові заходи обмеження кривдника у користуванні житлом відповідно до термінового заборонного припису, обмежувального припису або обмежувальних заходів не $є$ порушенням права власника кривдника, а є законним, суспільно необхідним та пропорційним втручанням держави, спрямованим на захист життя та здоров'я постраждалої особи. Запропоновано розробити та впровадити єдині стандарти підготовки всіх фахівців, які є представниками суб'єктів, уповноважених на здійснення діяльності у сфері запобігання та протидії домашньому насильству, що сприятиме уніфікованому розумінню фахівцями витоків та сутності проблеми домашнього насильства та уникненню розбіжностей у тлумаченні законодавства в даній сфері.

Рекомендовано внести доповнення до законодавства щодо: визначення терміну та форми повідомлення кривдником про місце свого тимчасового перебування; наділення поліцейських повноваженнями застосовувати заходи поліцейського примусу у випадку відмови кривдника від добровільного виконання заходів тимчасового обмеження, покладених на нього обмежувальним приписом; визначення кола суб'єктів спеціальної підготовки фахівців з виконання програм для кривдників.

Наголошено на важливості забезпечення кожного поліцейського, який реагує на випадки домашнього насильства, нагрудною відеокамерою, за допомогою якої він/вона може зафіксувати обставини, враховуючи, які було прийнято рішення про винесення термінового заборонного припису за відсутності заяви постраждалої особи. Запропоновано розробити методичні рекомендації щодо змісту профілактичних бесід та інших форм профілактичної роботи поліцейських із кривдниками, які перебувають на профрілактичному обліку, що сприятиме підвищенню ефективності профілактичної роботи та недопущенню повторних випадків домашнього насильства. Наголошено на важливості розроблення ефективних засобів контролю поліцейськими за дотриманням кривдником заходів тимчасового обмеження у разі винесення обмежувального припису. Запропоновано розглянути питання про можливість запровадження закордонного досвіду, зокрема використання електронних браслетів для кривдників та спеціальних електронних пристроїв для постраждалих осіб.

Ключові слова: домашнє насильство, спеціальні заходи щодо протидії домашньому насильству, терміновий заборонний припис, обмежувальний припис, профілактичний облік, направлення на програми для кривдників.

The article is devoted to highlighting the peculiarities of the application of special measures to combat domestic violence. Attention is paid to problematic issues during their practical implementation and suggested possible ways to solve them, both at the regulatory and organizational levels.

It is emphasized that temporary measures restricting the offender's use of housing in accordance with an urgent prohibition, restrictive order or restrictive measures are not a violation of the offender's right, but a lawful, socially necessary and proportionate state intervention to protect the life and health of the victim. It is proposed to develop and implement common training standards for all professionals who are representatives of entities authorized to carry out activities in the field of prevention and combating domestic violence, which will promote a unified understanding of the origins and nature of domestic violence and avoid differences in interpretation and prevention legislation, combating domestic violence.

It is recommended to make additions to the legislation on: determining the term and form of notification of the offender about the place of his temporary stay; empowering police officers to apply measures of police coercion in case the offender refuses to voluntarily perform the measures of temporary restriction imposed on him by a restrictive order; determining the range of subjects of special training of specialists in the implementation of programs for offenders.

The importance of providing every police officer who responds to cases of domestic violence with a chest video camera, with which he/she can record the circumstances, taking into account the decision to issue an urgent restraining order in the absence of a statement of the victim. It is proposed to develop methodological recommendations on the content of preventive talks and other forms of preventive work of police officers with offenders who are on preventive registration, which will help increase the effectiveness of preventive work and prevent recurrence of domestic violence. Emphasis was placed on the importance of developing effective means of police control over the offender's compliance with temporary restraint measures in the event of a restraining order. It is proposed to consider the possibility of introducing foreign experience, in particular the use of electronic bracelets for offenders and special electronic devices for victims.

Key words: domestic violence, special measures to combat domestic violence, urgent prohibition order, restrictive prescription, preventive accounting, referral to programs for abusers.

Проблема домашнього насильства потребує комплексного підходу до їі вирішення. Саме тому законодавство у сфері запобігання та протидії домашньому насильству передбачає комплекс заходів, серед яких важливе місце займають спеціальні заходи щодо протидії домашньому насильству. Питанням їх застосування присвячений окремий розділ Закону України «Про запобігання та протидію домашньому насильству» [1] (далі - Закон) та ряд підзаконних нормативно-правових актів. Ураховуючи те, що дані нормативно-правові акти були прийняті відносно нещодавно, виникають окремі проблемні питання під час їх практичного застосування.
Метою даної статті $є$ визначення на підставі аналізу нормативно-правового забезпечення та узагальнення практики його реалізації проблемних питань у сфері застосування спеціальних заходів щодо протидії домашньому насильству, а також вироблення пропозицій стосовно напрямів їх вирішення. Основою даного дослідження $є$ нормативно-правові акти, які регламентують підстави та порядок застосування спеціальних заходів щодо протидії домашньому насильству, результати моніторингу практики їх застосування, зокрема аналіз єдиного державного реєстру судових рішень, опитування поліцейських під час проходження ними курсів підвищення квалі- 
фікації, а також власний практичний досвід поліцейської діяльності авторів статті.

Відповідно до законодавства до спеціальних заходів щодо протидії домашньому насильству належать: терміновий заборонний припис стосовно кривдника; обмежувальний припис стосовно кривдника; взяття на профілактичний облік кривдника та проведення 3 ним профілактичної роботи; направлення кривдника на проходження програми для кривдників.

Порядок винесення термінового заборонного припису стосовно кривдника уповноваженими підрозділами органів Національної поліції України закріплено Наказом МВС України від 01 серпня 2018 року № 654 [2]. Терміновий заборонний припис стосовно кривдника (далі - припис) виноситься строком до 10 діб у разі існування безпосередньої загрози життю чи здоров’ю постраждалої особи 3 метою негайного припинення домашнього насильства, недопущення його продовження чи повторного вчинення. Припис може містити такі заходи: зобов'язання залишити місце проживання (перебування) постраждалої особи; заборону на вхід та перебування в місці проживання (перебування) постраждалої особи; заборону в будь-який спосіб контактувати 3 постраждалою особою. Ці заходи можуть бути застосовані всі разом або вибірково. Під час вирішення питання про винесення припису пріоритет надається безпеці постраждалої особи. Зазначена вимога поширюється також на місце спільного проживання (перебування) постраждалої особи та кривдника незалежно від їхніх майнових прав на відповідне житлове приміщення Важливо, що якщо припис передбачає зобов'язання залишити місце проживання (перебування) постраждалої особи, а кривдник відмовляється добровільно його залишити, поліцейські можуть в установленому чинним законодавством України порядку застосовувати поліцейські заходи примусу для виселення 3 житлового приміщення кривдника. При цьому доцільно прокоментувати поширену думку щодо можливого при цьому порушення права власності кривдника. Відповідно до Конституції України та норм міжнародного права право власності, зокрема й право кривдника на житло, не є абсолютним. Це означає, що за певних умов (законність, суспільна необхідність та пропорційність втручання) держава вправі обмежувати дане право. Слід підкреслити, що в даному випадку право власності кривдника не порушується, а тимчасово обмежується (пропорційність дотримана, адже обмежується право користування житлом, а не право власності на житло, обмеження встановлюється виключно на підставі оцінки ризиків, а встановлені заходи є тимчасовими) на передбачених законодавством підставах (тобто втручання держави $є$ законним) у зв'язку з тим, що він порушив чи ймовірно може порушити право на життя чи здоров'я постраждалої особи (наявна суспільна необхідність захист життя та здоров’я постраждалої особи).

Припис забезпечує для постраждалої особи час та можливість без зайвого тиску з боку кривдника звернутись до суду для отримання обмежувального припису, вирішити питання 3 працевлаштуванням, подальшим місцем проживання, можливим розлученням тощо. При цьому слід звернути увагу, що законодавство не передбачає умовою для винесення припису із зобов'язанням покинути місце спільного проживання (перебування) постраждалої особи наявність у кривдника іншого місця проживання. Поліцейські під час вирішення питання про винесення чи невинесення припису мають ставити в пріоритет саме безпеку постраждалої особи. Однак поліцейські мають побоювання, що в разі відсутності у кривдника іншого місця проживання його життя та здоров'я може піддатися небезпеці, що може викликати питання щодо обгрунтованості застосування поліцейськими припису. Деякі правоохоронці пропонують створити центри для тимчасового розміщення кривдників, що також сприятиме можливості контролю за їхньою поведінкою. При цьому кривдники мають здійснювати оплату свого проживання в таких спеціалізованих центрах. Ця пропозиція $є$ дискусійною та потребує подальшого дослідження з урахуванням закордонного досвіду та ретельної оцінки переваг та недоліків ії можливого впровадження.

Згідно з чинним законодавством кривдник, стосовно якого винесено припис, котрий вказує, що він повинен залишити місце спільного проживання (перебування) 3 постраждалою особою, зобов'язаний повідомити про місце свого тимчасового перебування уповноважений підрозділ поліції за місцем учинення домашнього насильства. Повідомлення кривдника фіксується в спеціальному журналі. Неповідомлення кривдником про місце свого тимчасового перебування тягне за собою настання адміністративної відповідальності за ст. 173-2 КУпАП [3]. При цьому слід звернути увагу, що строк повідомлення кривдником про місце свого тимчасового перебування не визначений, тому притягнення його до адміністративної відповідальності можливе лише після закінчення терміну дії припису. Невизначеність терміну та форми повідомлення кривдником про місце свого тимчасового перебування $є$ правовою прогалиною, яка потребує усунення шляхом внесення відповідних доповнень до законодавства. Існування даної прогалини може слугувати причиною уникнення відповідальності кривдником, а також унеможливлює здійснення контролю за його поведінкою поліцейськими, що підвищує ризики для постраждалої особи.

Слід звернути увагу, що дія термінового заборонного припису припиняється в разі застосування до кривдника судом адміністративного стягнення у вигляді адміністративного арешту або обрання щодо нього запобіжного заходу у вигляді тримання під вартою в кримінальному провадженні. Особа, стосовно якої винесено терміновий заборонний припис, може оскаржити його у суді в загальному порядку, передбаченому для оскарження рішень, дій або бездіяльності працівників уповноважених підрозділів органів Національної поліції України. При цьому не врегульованим залишається питання: чи продовжує діяти терміновий заборонний припис під час його оскарження, чи ні. Якщо так, то, враховуючи строк, на який він виноситься, даний підхід вбачається недоцільним.

Важливо, що терміновий заборонний припис виноситься як за заявою постраждалої особи, так і за власною ініціативою працівником уповноваженого підрозділу органів Національної поліції України за результатами оцінки ризиків. Оцінка ризиків - це оцінювання ймовірності продовження чи повторного вчинення домашнього насильства, настання тяжких або особливо тяжких наслідків його вчинення, а також смерті постраждалої особи. Порядок проведення оцінки ризиків учинення домашнього насильства та форма оцінки ризиків домашнього насильства визначені Наказом Міністерства соціальної політики України та Міністерства внутрішніх справ України від 13.03.2019 року № 369/180 [4]. Оцінка ризиків проводиться поліцейськими під час реагування на випадки домашнього насильства, після чого поліцейський долучає форму оцінки ризиків учинення домашнього насильства до матеріалів, зібраних за фактом такого насильства. Фактори небезпеки/ризику щодо вчинення домашнього насильства визначаються за результатами оцінки діянь кривдника і представлені у вигляді питань, на які відповідає поліцейський за результатами спілкування з постраждалою особою, та загальної оцінки ситуації вчинення домашнього насильства 3 метою виявлення ймовірності продовження чи повторного вчинення домашнього насильства, настання тяжких або особливо тяжких наслідків його вчинення, а також смерті такої особи.

У зв'язку з тим, що кожна окрема ситуація може мати унікальні чинники/обставини, не передбачені формою оцінки ризиків, які впливають на рівень небезпеки та ризик 
летального випадку, пов'язаного з насильством, поліцейський на власний розсуд може оцінити рівень небезпеки як високий, якщо вважає, що постраждала особа перебуває в потенційно небезпечній ситуації, або яка може спричинити смерть особи або інші тяжкі наслідки. Залежно від визначеного рівня небезпеки, яка загрожує постраждалій особі, поліцейський приймає рішення щодо необхідності винесення припису стосовно кривдника. Слід відмітити прогресивність норми щодо можливості винесення за результатами оцінки ризиків припису за власною ініціативою поліцейським. Ця норма спрямована на захист постраждалих осіб, які через побоювання не наважуються звернутися за захистом та подати заяву. Однак дана норма практично не застосовується на практиці, оскільки поліцейські побоюються звинувачень їх у перевищенні службових повноважень. При цьому єдиним документом, на якому грунтується рішення поліцейського про винесення припису, є оцінка ризиків, яка не містить жодного підпису, крім самого поліцейського. Такі повноваження поліцейських потребують їх належної підготовки щодо якісної оцінки наявних ризиків домашнього насильства та відпрацювання відповідних навиків. Крім того, важливо, щоб кожен поліцейський мав нагрудну відеокамеру, за допомогою якої може зафіксувати обставини (наприклад, сліди ударів або удушення на тілі постраждалої особи, розкидані або поламані меблі), враховуючи те, які він прийняв рішення про винесення припису за відсутності заяви постраждалої особи.

Винесення термінового заборонного припису стосовно кривдника $є$ підставою для поставлення кривдника на профілактичний облік. Порядок взяття на профілактичний облік, проведення профілактичної роботи та зняття 3 профілактичного обліку кривдника уповноваженим підрозділом органу Національної поліції України визначений Наказом МВС України від 25.02.2019 року № 124 [5]. Так, уповноважений підрозділ органу Національної поліції України бере на профілактичний облік кривдника 3 моменту виявлення факту вчинення ним домашнього насильства на встановлений законодавством строк і проводить 3 ним профілактичну роботу з метою недопущення скоєння повторних фактів домашнього насильства, забезпечує контроль за поведінкою кривдника за місцем проживання/перебування, а також контроль за дотриманням вимог заходів тимчасового обмеження прав кривдника або покладенням на нього обов'язків шляхом щотижневого спілкування 3 кривдником, а в разі необхідності 3 постраждалою особою за місцем проживання/перебування, навчання та/або місцем роботи, іншими місцями, які часто відвідують ці особи. Звертає на себе увагу той факт, що за наявності чіткого нормативного визначення підстав для постановки та зняття 3 профілактичного обліку, термінів перебування кривдників на ньому, при цьому відсутні методичні рекомендації щодо змісту профілактичних бесід та інших форм профілактичної роботи. На нашу думку, розроблення таких методичних рекомендацій сприятиме підвищенню ефективності профілактичної роботи 3 кривдниками та недопущенню повторних випадків домашнього насильства.

Таким чином, до повноважень поліції віднесено застосування двох із чотирьох спеціальних заходів щодо протидії домашньому насильству. Інші два - обмежувальний припис та направлення на програми для кривдників - це компетенція суду.

Особливості розгляду судом справ про видачу і продовження обмежувальних приписів визначені в Главі 13 Розділу IV Цивільного процесуального кодексу України [6]. Так, обмежувальним приписом визначаються один чи декілька таких заходів тимчасового обмеження прав кривдника або покладення на нього обов'язків: заборона перебувати в місці спільного проживання (перебування) 3 постраждалою особою; усунення перешкод у корис- туванні майном, що є об'єктом права спільної сумісної власності або особистою приватною власністю постраждалої особи; обмеження спілкування 3 постраждалою дитиною; заборона наближатися на визначену відстань до місця проживання (перебування), навчання, роботи, інших місць частого відвідування постраждалою особою; заборона особисто та через третіх осіб розшукувати постраждалу особу, якщо вона за власним бажанням перебуває в місці, невідомому кривднику, переслідувати іiі та в будьякий спосіб з нею спілкуватися; заборона вести листування, телефонні переговори з постраждалою особою або контактувати 3 нею через інші засоби зв'язку особисто та через третіх осіб. Відповідні обмежувальні приписи можуть бути винесені судом строком до 6 ти місяців. При цьому термін розгляду заяви про видачу обмежувального припису - 72 години.

Вбачається за доцільне здійснити узагальнений огляд судової практики щодо винесення обмежувального припису та розробити рекомендації для уніфікації судової практики з даного питання, оскільки причини відмови у видачі обмежувального припису доволі часто пов'язані 3 відсутністю належного розуміння суддями сутності та витоків проблеми домашнього насильства, наявних рішень Європейського Суду з прав людини з окреслених питань. Так, наприклад, таким, що суперечить ідеології сучасного законодавства 3 питань запобігання та протидії домашньому насильству, виглядає обгрунтування суддею відмови накладення на кривдника приписом такого тимчасового обмеження, як заборона перебувати в місці спільного проживання (перебування) 3 постраждалою особою: «У разі задоволення заяви ОСОБА_1 та заборони ОСОБА 2 перебувати в місці спільного проживання, як того просить заявник, ОСОБА_2 може залишитися без місця для проживання, що суд не може допустити» [7]. Це також свідчить про важливість відповідної підготовки суддів 3 питань запобігання та протидії домашньому насильству. На нашу думку, доцільно розробити та впровадити єдині стандарти підготовки всіх фахівців, які є представниками суб'єктів, уповноважених на здійснення діяльності у сфері запобігання та протидії домашньому насильству. Це сприятиме уніфікованому розумінню фахівцями витоків та сутності проблеми домашнього насильства та уникненню розбіжностей у тлумаченні законодавства у сфері запобігання та протидії домашньому насильству.

Наступний виклик пов'язаний з тим, що про видачу обмежувального припису кривднику суддя у встановлений законом строк (1 доба) має поінформувати по-перше, уповноважені підрозділи органів Національної поліції України для взяття кривдника на профілактичний облік, а, по-друге, районні, районні в містах Києві і Севастополі державні адміністрації та виконавчі органи сільських, селищних, міських, районних у містах (у разі їх створення) рад за місцем проживання (перебування) постраждалої особи. Враховуючи неукомплектованість судів та завантаженість суддів, такі повідомлення, за свідченнями поліцейських, надходять або із запізненням, або взагалі не надходять. Це зумовлює необізнаність поліцейських про факт винесення обмежувального припису та неможливість належного здійснення контролю за дотриманням кривдником заходів тимчасового обмеження. Адже відповідно до Закону саме поліція здійснює контроль за виконанням кривдниками всіх спеціальних заходів протидії домашньому насильству протягом строку їх дії. Тому постає питання про вироблення ефективних засобів такого контролю. Наприклад, у Румунії та Австрії для контролю за виконанням кривдником обмеження щодо наближення до постраждалої особи використовують електронні браслети для кривдників та спеціальні електронні пристрої для постраждалих осіб, які надсилають інформацію про наближення кривдника. Для притягнення кривдника до кримінальної відповідальності за порушення обмежувального при- 
пису (ст. 390-1 КК України [8]) поліцейським необхідно зібрати докази, а це доволі проблематично, якщо, наприклад, постраждала заявляє, що кривдник наблизився до неї ближче ніж на 100 метрів усупереч обмеженню відповідно до припису, а інших доказів, крім свідчень постраждалої, немає. Крім того, сучасним викликом є примусове виконання кривдником заходів тимчасового обмеження у випадку, якщо він відмовляється виконувати їх добровільно. Наприклад, якщо кривдник відмовляється виконувати обмеження щодо заборони перебувати в місці спільного проживання (перебування) з постраждалою особою, поліцейські можуть порушити кримінальне провадження за ст. 390-1 КК України, однак при цьому застосувати до кривдника заходи поліцейського примусу, як у випадку термінового заборонного припису, поліцейські не уповноважені. Виконання судових рішень - це компетенція виконавчої служби, в якої при цьому відсутні нормативно встановлені рекомендації щодо забезпечення виконання обмежувальних приписів. Порушення кримінального провадження в даному випадку також не є гарантією досягнення мети обмежувального припису - ізоляції кривдника від постраждалої особи для забезпечення її безпеки. Для подолання даного виклику вкрай необхідним $є$ внесення доповнень до законодавства та наділення або виконавчої служби додатковими повноваженнями, або поліцейських повноваженнями застосовувати заходи поліцейського примусу у випадку відмови кривдника від добровільного виконання заходів тимчасового обмеження, покладених на нього обмежувальним приписом.

Найбільш декларативним натепер залишається такий спеціальний захід щодо протидії домашньому насильству, як направлення на програму для кривдників. Відповідно до ст. 39-1 КУПАП, у разі вчинення домашнього насильства суд під час вирішення питання про накладання стягнення про адміністративне правопорушення має право одночасно вирішити питання про направлення особи, яка вчинила домашнє насильство, на проходження програми для кривдника [3]. Так само відповідно до ст. 91-1 КК України в інтересах потерпілого від злочину, пов'язаного 3 домашнім насильством, одночасно 3 призначенням покарання, не пов'язаного з позбавленням волі, або звільненням від кримінальної відповідальності чи покарання 3 підстав, передбачених КК України, суд може застосувати до особи, яка вчинила домашнє насильство, один або декілька обмежувальних заходів, відповідно до якого (яких) на засудженого може бути покладений обов'язок пройти програму для кривдника [8]. Крім того, рішення про направлення кривдника на проходження програми для кривдників може бути прийняте під час розгляду судом справи про видачу обмежувального припису. Кривдник, який умисно ухилятиметься від проходження програми для кривдників, несе кримінальну відповідальність за ст. 3901 КК України.

Натепер судді нечасто застосовують механізм направлення кривдників на програми через ряд причин: 1) необізнаність суддів про надані їм повноваження; 2) відсутність програм для кривдників; 3) відсутність фахівців для реалізації програм для кривдників. При цьому нам імпонує підхід суддів, які, незважаючи на відсутність програм для кривдників, все ж таки направляють кривдників на проходження таких програм і зазначають у своєму рішенні про обов'язок забезпечити можливість їх проходження органам місцевого самоврядування (наприклад, у рішенні Приморського районного суду м. Одеси від 31 липня 2018 року у справі № 522/13440/18 зазначено: «Напра- вити ОСОБА_2 на проходження програми для кривдників, забезпечивши виконання програми Одеській міській раді строком 1 рік» [9]). Такі рішення судів $є$ важливим поштовхом для місцевої влади виконати покладений на них Законом обов'язок щодо організації діяльності програм для кривдників. Так, відповідно до ч. 1 ст. 28 Закону суб'єктами, відповідальними за виконання програм для кривдників, є місцеві державні адміністрації та органи місцевого самоврядування [1]. Слід зазначити, що представники органів місцевої влади часто скаржаться на складність підбору фахівців, які реалізовуватимуть програми для кривдників. Так, відповідно до Наказу Мінсоцполітики України від 01 жовтня 2018 року № 1434 [10] такими фахівцями можуть бути виключно психолог, психотерапевт або психіатр, які представляють суб'єктів, що здійснюють заходи у сфері запобігання та протидії домашньому насильству. Слід зазначити, що коло таких суб'єктів суттєво розширене чинним законодавством і визначено в ст. 6 Закону. Враховуючи спеціалізацію суб'єктів, це можуть бути представники переважно або служб підтримки постраждалих осіб, або закладів освіти, або закладів охорони здоров'я. Як правило, органи місцевого самоврядування бажають створити дані програми при центрі соціальних служб для сім'ї, дітей та молоді, в яких не завжди серед співробітників є психологи. Однак при цьому слід урахувати, що до виконання таких програм можуть бути залучені фахівці за відповідним договором. Наприклад, у м. Арциз Одеської області за договором до реалізації програм для кривдників залучена врач-психіатр місцевої лікарні. Більш того, і сам кабінет для проходження програм для кривдників із відповідним дотриманням заходів безпеки (зокрема, обладнання «тривожною» кнопкою) розташований на базі цієї лікарні.

Додатковим викликом є те, що Закон (ч. 5 ст. 28) вимагає, щоб ці фахівці пройшли відповідне навчання, а наказ Мінсоцполітики України від 01 жовтня 2018 року № 1434 [10] деталізує: спеціальну підготовку, перепідготовку, курси підвищення кваліфікації. I тут думки експертів у сфері запобігання та протидії домашньому насильству розходяться. Одні вважають, що таким навчанням можна вважати тренінгові курси підготовки, які здійснюються за сприяння неурядових організацій, зокрема ОБСС. Інші наполягають на тому, що це мають бути виключно освітні програми, які передбачають отримання свідоцтва державного зразка. На нашу думку, дане питання має бути вирішення шляхом надання відповідних роз'яснень Мінсоцполітики України, яке є координатором реалізації законодавства у сфері запобігання та протидії домашньому насильству на загальнодержавному рівні.

Крім того, слід звернути увагу, що іноді представники органів місцевої влади зауважують на те, що у них відсутні направлення кривдників суддями на проходження програм, виправдовуючи цим відсутність таких програм. Однак у такому випадку важливо звернути увагу на ч. 7 ст. 28 Закону, відповідно до якої кривдник повинен мати можливість відвідувати програму для кривдників за власною ініціативою на добровільній основі [1]. Отже, ця думка $є$ такою, що суперечить чинному законодавству.

Звичайно, в даній статті розглянуті не всі сучасні виклики нормативно-правового забезпечення та практичної реалізації спеціальних заходів щодо протидії домашньому насильству. Дане питання потребує подальшого дослідження з метою забезпечення дієвості спеціальних засобів та ефективності державної політики у сфері запобігання та протидії домашньому насильству.

\section{ЛITEPATУPA}

1. Про запобігання та протидію домашньому насильству : Закон України від 07 грудня 2017 року № 2229-VIII / Верховна Рада України. URL: https://zakon.rada.gov.ua/laws/show/2229-19\#Text (дата звернення: 20.07.2020).

2. Про затвердження Порядку винесення уповноваженими підрозділами органів Національної поліції України термінового заборонного припису стосовно кривдника : Наказ Міністерства внутрішніх справ України від 01 серпня 2018 року № 654 . URL: https://zakon.rada.gov.ua/laws/show/z0965-18/\#Text (дата звернення: 20.07.2020). 
3. Кодекс України про адміністративні правопорушення від 07 грудня 1984 року. URL: https://zakon.rada.gov.ua/laws/ show/80731-10\#Теxt (дата звернення: 20.07.2020).

4. Про затвердження Порядку проведення оцінки ризиків вчинення домашнього насильства : Наказ Міністерства соціальної політики України та Міністерства внутрішніх справ України від 13 березня 2019 року № 369/180. URL: https://zakon.rada.gov.ua/laws/show/ z0333-19\#Text (дата звернення: 20.07.2020).

5. Про затвердження Порядку взяття на профрілактичний облік, проведення профілактичної роботи та зняття з профрілактичного обліку кривдника уповноваженим підрозділом органу Національної поліції України : Наказ Міністерства внутрішніх справ України від 25 лютого 2019 року № 124. URL: https://zakon.rada.gov.ua/laws/show/z0270-19/\#Text (дата звернення: 20.07.2020).

6. Цивільний процесуальний кодекс України від 18 березня 2004 року / Верховна Рада України. URL: https://zakon.rada.gov.ua/laws/ show/1618-15\#Text (дата звернення: 20.07.2020).

7. Рішення Приморського районного суду м. Одеси від 16 січня 2019 року у справі № 522/513/19 / Єдиний державний реєстр судових рішень. URL: http://www.reyestr.court.gov.ua/Review/79229900 (дата звернення: 20.07.2020).

8. Кримінальний кодекс України від 05 квітня 2001 року / Верховна Рада України. URL: https://zakon.rada.gov.ua/laws/show/2341-14\#Text (дата звернення: 20.07.2020).

9. Рішення Приморського районного суду м. Одеси від 31 липня 2018 року у справі № 522/13440/18 / Єдиний державний реєстр судових рішень. URL: http://reyestr.court.gov.ua/Review/75598605 (дата звернення: 20.07.2020).

10. Про затвердження Типової програми для кривдників: Наказ Міністерства соціальної політики України від 01 жовтня 2018 року № 1434. URL: https://zakon.rada.gov.ua/laws/show/z1222-18\#Text (дата звернення: 20.07.2020). 


\title{
ВІЙСЬКОВО-ПРАВОВА РЕФЛЕКСІЯ УКРАЇНИ НА ЗБРОЙНУ АГРЕСІЮ РОСІЙСЫКОЇ ФЕДЕРАЦІЇ
}

\author{
MILITARY AND LEGAL REFLECTION OF UKRAINE \\ ON THE ARMED AGGRESSION OF THE RUSSIAN FEDERATION
}

\author{
начальник науково-дослідного відділу проблем військового законодавства \\ Центру воснно-стратегічних досліджень \\ Національний університет оборони Украӥни імені Івана Черняховського
}

\begin{abstract}
У статті розглянуто основні нормативно-правові акти та військово-політичні рішення, які були прийняті в Україні протягом останніх шести років для належного реагування на збройну агресію Російської Федерації та стосуються зміцнення інституційних та функціональних спроможностей складників системи забезпечення національної безпеки і оборони України.

3'ясовано, що система забезпечення національної безпеки і оборони України на початку 2014 року виявилась неефективною і не забезпечила виконання покладених на сили безпеки і оборони Конституцією та іншими законами України завдань.

Важливим чинником підвищення обороноздатності держави та бойових спроможностей Збройних Сил України стало створення інструменту воєнно-силового стримування збройної агресії - Сил спеціальних операцій Збройних Сил України. Лише їм притаманні специфічні завдання і повноваження - здійснювати спеціальну розвідку і спеціальні операції.

У статті доведено, що в умовах «гібридної» війни відбувається динамічне оновлення правових вимог, оскільки швидкозмінний характер «гібридних» впливів стимулює відмову від попередніх та вироблення нових нормативно-правових стандартів ставлення соціальних суб'єктів до воєнно-політичних реалій.

Підсумовано, що правова система України поки що недостатньо пристосована до цілеспрямованої системної діяльності, орієнтованої на забезпечення цілей і завдань національної безпеки у воєнній сфері. Внаслідок цього система забезпечення національної безпеки і оборони реалізує військові пріоритети переважно в контексті реагування на вже існуючі загрози.

Наголошено на необхідності проведення ряду організаційно-правових заходів, спрямованих на удосконалення державної правової політики протидії російській збройній агресії, шляхом утворення координаційного органу протидії гібридній агресії правовими засобами.

Ключові слова: Збройні Сили України, інші військові формування, сектор безпеки і оборони, протидія збройній агресії, «гібридний» збройний конфлікт.
\end{abstract}

The article examines the main legal acts and military-political decisions taken in Ukraine over the past six years in order to respond adequately to the armed aggression of the Russian Federation and to strengthen the institutional and functional capabilities of the components of Ukraine's national security and defense system.

It was found that the national security and defense system of Ukraine in early 2014 was ineffective and did not ensure the implementation of the tasks assigned to the security and defense forces by the Constitution and other laws of Ukraine.

An important factor in increasing the state's defense and combat capabilities of the Armed Forces of Ukraine was the creation of a military deterrence instrument of armed aggression - the Special Operations Forces of the Armed Forces of Ukraine. Only these forces have specific tasks and powers - to carry out special intelligence and special operations.

The article proves that in the "hybrid" war conditions there is a dynamic renewal of legal requirements, as the rapidly changing nature of "hybrid" influences stimulates the abandonment of previous and the development of new legal standards for the attitude of social actors to military and political realities.

It is concluded that the legal system of Ukraine is not yet sufficiently adapted to purposeful systemic activities focused on ensuring the goals and objectives of national security in the military sphere. As a result, the national security and defense system implements military priorities mainly in the context of responding to existing threats.

It was stressed that it is necessary to carry out a number of organizational and legal measures aimed at improving the state legal policy to combat Russian armed aggression by establishing a coordinating body to combat hybrid aggression by legal means.

Key words: Armed Forces of Ukraine, other military formations, security and defense sector, armed aggression counteraction, "hybrid" armed conflict.

В умовах постійних змін безпекового середовища та триваючої збройної агресії Російської Федерації проти України держава повинна випереджувально і гнучко реагувати на зміни світового та національного «порядку денного».

Перехід до так званих «стратегій обмежених дій», гібридних способів вирішення конфлікту, зростання ролі національної стійкості держави зумовлює ландшафтні зміни у підходах до функціонування системи забезпечення національної безпеки і оборони держави, стимулює відмову від попередніх та вироблення нових нормативноправових стандартів у сфері оборони України. За таких обставин створення ефективної та гнучкої системи правових координат є одним із пріоритетів розвитку спроможностей Збройних Сил України (далі - ЗС України), інших утворених відповідно до законів України військових формувань (далі - сили безпеки і оборони).

Факт окупації Російською Федерацією (далі - РФ) частини території України - Автономної Республіки Крим i міста Севастополя, а також збройна агресія з боку Росії у східних регіонах України показали, що система забезпечення національної безпеки і оборони України на початку 2014 року виявилась неефективною і не забезпечила виконання покладених на сили безпеки і оборони Конституцією та іншими законами України завдань.

Протягом лютого 2014 року Росія за допомогою своїх збройних сил та створених і озброєних іррегулярних збройних формувань найманців, керованих офіцерами спецслужб, здійснила збройне захоплення і воєнну окупацію, тобто незаконну окупацію Автономної Республіки Крим та міста Севастополя. 1 березня 2014 року Рада Федерації Федеральних зборів РФ надала згоду на використання на території України Збройних Сил РФ. 17 березня 2014 року Верховна Рада Автономної Республіки Крим, розпущена постановою Верховної Ради України, проголосила Крим незалежною державою.

Через різке ускладнення внутрішньополітичної обстановки, втручання РФ у внутрішні справи України Президент України видав Указ від 17 березня 2014 року № 303 «Про часткову мобілізацію». На підставі цього 
Указу всі військові формування України та Оперативнорятувальна служба цивільного захисту були переведені на організацію та штати воєнного часу, а також на території визначених областей України розпочато проведення заходів часткової мобілізації з практичним призовом військовозобов'язаних та поставкою транспортних засобів.

Враховуючи інституційну слабкість сил оборони та реальність нових викликів безпеці України, Верховна Рада України 13 березня 2014 року прийняла Закон України «Про Національну гвардію України», який визначив, що Національна гвардія України $є$ військовим формуванням із правоохоронними функціями, що входить до системи Міністерства внутрішніх справ України. Національна гвардія України бере участь відповідно до закону у взаємодії зі ЗС України у відсічі збройній агресії проти України та ліквідації збройного конфлікту завдяки веденню воєнних (бойових) дій, а також у виконанні завдань територіальної оборони. Слід зазначити, що ухвалення цього Закону належить до першочергових заходів правової рефлексії на збройну агресію.

Окремі питання, пов'язані з окресленою проблематикою, розглядались у роботах таких вітчизняних учених О.С. Бакумова, Г.І. Вісича, С.М. Возняка, В.К. Горовенка, С.М. Мельника, В.Й. Пашинського, С.П. Пономарьова, А.М. Сиротенка, П.П. Скиби, О.І. Сухоноса, Д.В. Талалая, В.С. Чорного та інших. Водночас виклики сьогодення змушують глибше розглянути це питання 3 особливою акцентуацією уваги на 3'ясуванні перспектив створення координаційного органу протидії гібридній агресії правовими засобами.

В умовах різкого збільшення кількості злочинів проти основ національної безпеки України та через блокування руху колон військової техніки наша держава зазнала нового виду злочинної діяльності, яка істотно погіршувала рівень боєздатності підрозділів Збройних Сил України. Для створення механізму та правових підстав притягнення до кримінальної відповідальності осіб, які перешкоджають законній діяльності ЗС України та інших складових сил безпеки і оборони, Верховна Рада України 8 квітня 2014 року прийняла Закон України «Про внесення змін до Кримінального кодексу України», яким розділ I Особливої частини Кримінального кодексу України було доповнено статтею $114^{-1}$ «Перешкоджання законній діяльності Збройних Сил України та інших військових формувань». Таким чином, було встановлено кримінальну відповідальність за створення перешкод у виконанні покладених на ЗС України завдань в особливий період.

У квітні 2014 року розпочався другий етап збройної агресії Російської Федерації проти України, під час якого контрольовані, керовані й фінансовані спецслужбами Росії озброєні парамілітарні формування проголосили створення «Донецької народної республіки» (7 квітня 2014 року) та «Луганської народної республіки» (27 квітня 2014 року).

Враховуючи зазначене, Указом Президента України від 14 квітня 2014 року № 405 було уведене в дію рішення Ради національної безпеки і оборони України «Про невідкладні заходи щодо подолання терористичної загрози і збереження територіальної цілісності України» та розпочато проведення широкомасштабної антитерористичної операції на території Донецької та Луганської областей (далі - АТО) із залученням 3С України.

Початок ведення АТО на території України зумовив прийняття нових та внесення змін до діючих нормативноправових актів, адже як показали події 2014 року, чинні закони з питань безпеки й оборони мали істотну ваду вони не були розраховані на дії в умовах збройної агреciї. Саме тому з 2014 року розпочалася кропітка робота з удосконалення законодавства у сфері безпеки і оборони, в якій брали безпосередню участь представники Націо- нального університету оборони України імені Івана Черняховського (далі - Університет).

Варто зазначити, що 5 червня 2014 року був прийнятий Закон України «Про внесення змін до законів України щодо боротьби з тероризмом», який вніс певні зміни до Законів України «Про боротьбу з тероризмом», «Про Збройні Сили України» та інших. Цей закон удосконалив порядок залучення і використання сил та засобів Збройних Сил України, Державної прикордонної служби України, Державної служби спеціального зв'язку та захисту інформації України та Управління державної охорони України до антитерористичних операцій. Водночас цей закон розширив повноваження суб'єктів боротьби з тероризмом, зокрема Міністерства оборони України (далі - Міноборони), щодо припинення терористичної діяльності, а також уповноважив Збройні Сили України на застосування зброї та бойової техніки під час участі в антитерористичній операції.

Суспільно-політичні події в Україні, оголошення часткової мобілізації в державі, проведення АТО з квітня 2014 року дали привід для відновлення органів військової прокуратури. Діяльність спеціалізованих прокуратур з нагляду за додержанням законів у воєнній сфері, їх територіальна структура, принципи комплектування та організаційні засади діяльності не повною мірою відповідали ступеню загроз державі у воєнній сфері. Як результат, Верховною Радою України 14 серпня 2014 року прийнято Закон України «Про внесення змін до Закону України «Про прокуратуру» щодо утворення військових прокуратур». Значною мірою це було зумовлено збільшенням чисельності ЗС України майже вдвічі. Тобто, таке рішення було не випадковим кроком керівництва держави, а зумовлювалося об’єктивними причинами, пов'язаними із забезпеченням обороноздатності.

Виходячи 3 необхідності удосконалення правового регулювання діяльності Ради національної безпеки і оборони України (далі - РНБО), забезпечення виконання їі конституційних повноважень, Верховна Рада України 25 грудня 2014 року прийняла Закон України «Про внесення змін до Закону України «Про Раду національної безпеки і оборони України» щодо вдосконалення координації і контролю у сфері національної безпеки і оборони. Цей Закон суттєво розширив компетенцію РНБО, зокрема стосовно прийняття рішень щодо невідкладних заходів із розв'язання кризових ситуацій, що загрожують національній безпеці України, та коло повноважень Секретаря РНБО; удосконалив її структуру завдяки утворенню апарату тощо.

Крім того, для підвищення готовності до відвернення і нейтралізації загроз національній безпеці України Указом Президента України від 12 березня 2015 року № 139 уведено в дію відповідне рішення РНБО та утворено Воєнний кабінет Ради національної безпеки і оборони України, який $є$ ії робочим органом в особливий період.

Також на підставі рішення РНБО від 25 січня 2015 року, уведеного в дію Указом Президента України від 28 лютого 2015 року № 115, при РНБО був створений Головний ситуаційний центр України, як програмно-апаратний комплекс зі збору, накопичення і обробки інформації, необхідної для підготовки та прийняття рішень у сфері національної безпеки і оборони.

Згадані законодавчі зміни щодо удосконалення компетенції РНБО позитивно вплинули на оперативність схвалення документів стратегічного планування у сфері забезпечення національної безпеки і оборони, зокрема таких як: Стратегія національної безпеки України, Воєнна доктрина України, Концепція розвитку сектору безпеки і оборони України, Стратегічний оборонний бюлетень України, Державна програма розвитку Збройних Сил України на період до 2020 року, Стратегія кібербезпеки України та інших, які заклали правове підгрунтя для ефективного розвитку сектору безпеки і оборони в сучасних умовах. 
Слід констатувати, що «гібридний» збройний конфлікт в Україні фактично є симбіозом традиційних ознак міжнародного та внутрішнього збройного конфлікту. Фактично відбувається зовнішня інтервенція, замаскована під гуманітарну допомогу, захист прав російськомовного населення. Такі реалії засвідчили неготовність місцевих органів державної влади до управління власними територіями внаслідок їх фактичного самоусунення від виконання повноважень, що потребувало відповідної реакції законодавчого органу. Практичним втіленням такої реакції стало прийняття Верховною Радою України Закону України «Про військово-цивільні адміністрації», який започаткував появу військово-цивільних адміністрацій - унікальної форми взаємодії військового командування та цивільної адміністрації.

Для актуалізації законодавчого регулювання правового режиму воєнного стану з урахуванням особливостей сучасних збройних конфліктів і досвіду проведення АТО Верховна Рада України 12 травня 2015 року прийняла в новій редакції Закон України «Про правовий режим воєнного стану», проєкт якого був внесений Президентом України як невідкладний

Важливим чинником підвищення обороноздатності держави та бойових спроможностей Збройних Сил України було створення в розпал АТО (2016 рік) дієвого інструменту воєнно-силового стримування збройної агресії - Сил спеціальних операцій Збройних Сил України (далі - ССпО). Так, згідно із Законом України «Про внесення змін до деяких законів України щодо Сил спеціальних операцій Збройних Сил України» від 7 липня 2016 року № 1437-VIII в структурі Збройних Сил України утворено окремий рід сил - ССпО, з притаманними лише їм специфічними завданнями - здійснювати спеціальну розвідку і спеціальні операції, в тому числі на тимчасово окупованій (непідконтрольній) території України та за іiі межами. Важливу роль ССпО в забезпеченні обороноздатності підкреслює Указ Президента України «Про День Сил спеціальних операцій Збройних Сил України».

Наступний крок у правовому протистоянні Росії можна охарактеризувати прийняттям нормативно-правових актів, спрямованих на формування системи захисту інформаційного простору та системи кібербезпеки України. Передусім це Доктрина інформаційної безпеки України, Закон України «Про основні засади забезпечення кібербезпеки України», Положення про Національний координаційний центр кібербезпеки. Слід відмітити, що до складу цього центру входять, зокрема, перший заступник Міністра оборони України та заступник начальника Генерального штабу Збройних Сил України.

«Враховуючи стратегічне значення, якого набувають питання кібербезпеки в системі національної безпеки України й у світі, діяльність Національного координаційного центру кібербезпеки стає одним із ключових у роботі РНБО України, і його завдання значно розширені відповідно до вимог часу», - прокоментував підписання Указу Президента України від 28 січня 2020 року № 27 Секретар РНБО Олексій Данілов [1]. Згідно з цим Указом граничну чисельність працівників Апарату РНБО збільшено на 30 осіб, які здійснюватимуть інформаційно-аналітичне, експертне, організаційне, матеріально-технічне та інше забезпечення діяльності Національного координаційного центру кібербезпеки.

Відповідно до статті 8 Закону України «Про основні засади забезпечення кібербезпеки України» та з метою визначення і впровадження єдиних підходів шодо підготовки держави до відбиття воєнної агресії в кіберпросторі, підготовки та ведення кібероборони, Міноборони видало наказ «Про затвердження Основних напрямів підготовки до відбиття воєнної агресії в кіберпросторі (підготовки та ведення кібероборони) в системі Міністерства оборони України» від 1 квітня 2019 року № 10. Водночас у складі
ЗС України сформовано Командування військ зв'язку та кібербезпеки Збройних Сил України, підрозділи кіберзахисту та кібербезпеки.

У контексті правового реагування на прояви збройної агресії РФ найбільш знаковим вважаємо прийняття Закону України «Про національну безпеку України», який закріпив незворотність процесу трансформації ЗС України відповідно до стандартів НАТО. Побіжний аналіз тексту цього закону дає змогу переконатися, що він стосується фундаментальних засад системи забезпечення національної безпеки, а отже, докорінно змінює механізми управління у сфері національної безпеки і оборони, структуру, склад сектору безпеки і оборони, вперше законодавчо унормовує ряд понять, зокрема «воєнна безпека», «збройний конфлікт». Такі зміни концептуально відрізняються від раніше існуючих положень, закладають систему реформ усього сектору безпеки і оборони, й насамперед ЗС України.

Також у 2018 році був прийнятий Закон України «Про особливості державної політики із забезпечення державного суверенітету України на тимчасово окупованих територіях у Донецькій та Луганській областях», який змінив попередній формат АТО, порядок застосування ЗС України, інших складових сил безпеки і оборони. На підставі наказу Верховного Головнокомандувача Збройних Сил України «Про початок операції Об'єднаних сил із забезпечення національної безпеки і оборони, відсічі та стримування збройної агресії Російської Федерації на території Донецької та Луганської областей» від 30 квітня 2018 року № 3дск-оп з 30 квітня розпочалася операція Об'єднаних сил, проведення якої передбачено в умовах правового режиму мирного часу з можливістю введення правового режиму воєнного стану у разі розширення збройної агресії РФ

Відповідно до статті 6 цього закону постановою Кабінету Міністрів України від 12 грудня 2018 року № 1059 утворено «Міжвідомчу комісію $з$ питань узагальнення правової позиції держави щодо відсічі і стримування збройної агресії Російської Федерації та підготовки консолідованої претензії України до Російської Федерації щодо реалізації іiі міжнародно-правової відповідальності за збройну агресію проти України».

Далі варто згадати політико-правову подію істотної та історичної значимості, яка відбулася в Україні наприкінці 2018 року: після п’яти років фактичної війни на один місяць було запроваджено воєнний стан. Привід - агресія прикордонних кораблів Росії в Керченській протоці. Час показав, що військові та політичні наслідки цього кроку були досить позитивними. Водночас запровадження воєнного стану зумовило низку правових наслідків та виявило слабкі місця, серед яких і недосконалість окремих норм законодавства України. Зважаючи на все вищенаведене, Рада національної безпеки і оборони України прийняла рішення «Щодо підсумків введення воєнного стану в Україні», яке уведено в дію Указом Президента України від 25 січня 2019 року № 17. Оскільки згадане рішення РНБО має закритий характер, ми не можемо висвітлити його зміст. Однак маємо відмітити, що з огляду на динаміку розвитку сучасних загроз національній безпеці України питання, які стосуються особливостей функціонування держави в умовах воєнного стану та/або оголошення стану війни, залишаються надважливим.

3 огляду на розв'язану РФ довготривалу збройну агресію доречно згадати актуальну й нині думку колишнього військового прокурора Південного регіону генералмайора юстиції М.Г. Фещука, який зазначає, що «правова система держави повинна мати запас міцності, аби забезпечувати законність і правопорядок не лише в мирному житті суспільства, а й у важкі воєнні часи» [2]

Крім наведених вище організаційно-правових заходів, що відбулися в умовах триваючої збройної агресії РФ, варто також згадати ряд інших, зокрема: 
- утворено Десантно-штурмові війська Збройних Сил України, Комітет з питань розвідки при Президентові України, Командування об’єднаних сил Збройних Сил України, Командування Медичних сил Збройних Сил України;

оголошено та проведено шість черг часткової мобілізації та збільшено чисельність Збройних Сил України (до 250 тисяч), додатково сформовано більше 40 військових частин;

запроваджено військову службу та перетворено на військове формування Державну службу спеціального зв’язку та захисту інформації України [3];

збільшено чисельність Державної прикордонної служби України [4];

- запроваджено військовий збір (тимчасово, до завершення реформи Збройних Сил України) [5];

- Державну спеціальну службу транспорту передано до сфери управління Міноборони [6];

- унормовано питання щодо військових стандартів [7];

- започатковано розроблення нового документу стратегічного рівня - Плану оборони України [8] та затверджено його структуру [9];

- уповноважено Міноборони здійснювати оборонні закупівлі за імпортом [10];

прийнято Закони України «Про Єдиний державний реєстр військовозобов'язаних», «Про протимінну діяльність в Україні», «Про правовий статус осіб, зниклих безвісти»; відповідними постановами Кабінету Міністрів України затверджено: Воєнно-медичну доктрину України, Морську доктрину України на період до 2035 року (нова редакція), «Порядок логістичного забезпечення сил оборони під час виконання завдань 3 оборони держави, захисту її суверенітету, територіальної цілісності та недоторканності», «Порядок застосування зброї і бойової техніки з'єднаннями, військовими частинами і підрозділами Збройних Сил під час виконання ними завдань у районі проведення антитерористичної операції у мирний час», «Порядок застосування зброї і бойової техніки з'єднаннями, військовими частинами і підрозділами Збройних Сил під час виконання ними завдань щодо відсічі збройної агресії проти України» тощо.

Маємо відзначити, що два останні нормативно-правові акти були розроблені науковцями-юристами Центру воєнно-стратегічних досліджень Університету.

Потребує висвітлення й Указ Президента України від 8 листопада 2019 року № 837 «Про невідкладні заходи 3 проведення реформ та зміцнення держави», оскільки згідно з пунктом одинадцятим статті 1 цього Указу Кабінету Міністрів України доручено розробити ряд нормативно-правових актів у сфері обороноздатності. Найбільш знаковим у цьому переліку є завдання щодо кодифікації законодавства у сфері оборони, виконання якого доручено Міноборони. 3 метою його виконання, на підставі рішень керівництва Міноборони, Університету доручено розробити проєкт «Концепції кодифікації законодавства у сфері оборони».

Позитивно оцінюючи вказану динаміку вдосконалення правового регулювання у сфері оборони, вважаємо, що правотворчий процес у цій сфері є надто філігранним і потребує належного наукового супроводу. Маємо наголосити на важливості співіснування і взаємного збагачення наукової і нормотворчої діяльності. Саме тому, на нашу думку, назріла необхідність створення у складі Університету підрозділу наукового та експертно-аналітичного супроводу нормотворчої діяльності Міноборони - Центру військово-правових досліджень, удосконалення та розвитку законодавства у сфері оборони України.

Загалом, слід констатувати, що ситуація на Сході України ускладнюється й тим, що збройний конфлікт із Росією не отримав належної правової оцінки, не визначений як міжнародно-правовий конфлікт, що має статус війни. Головна особливість цього конфлікту полягає в тому, що «гібридний» противник заперечує свою присутність та намагається уникнути правових наслідків за свої дії, експлуатує прогалини в законі та юридичну складність, діє в «міжзаконні», експлуатує юридичні пороги, вчиняє суттєві порушення закону та створює правову «сіру зону», щоб приховати свої дії.

Так, наприклад, формально не порушує міжнародне право нинішне самообмеження участі РФ у механізмах міжнародного гуманітарного права. Це й відкликання підпису РФ із Римського статуту, й припинення визнання Росією повноважень Комісії з встановлення фактів за Женевськими конвенціями. Але очевидною $є$ мета таких дій - унеможливлення притягнення до відповідальності російських посадовців за міжнародні злочини, як воєнні, так і проти людства [11].

Відсутність координованої правової політики протидії російській збройній агресії за таких умов невідворотно призведене до непоправних та масштабних негативних юридичних наслідків. У такій ситуації держава поставлена перед необхідністю ухвалювати нестандартні державницькі рішення. У зв'язку з цим, на нашу думку, заслуговує на підтримку ідея щодо створення координаційного органу - Центру координації ведення правової війни, висловлена під час експертного обговорення в Комітеті Верховної Ради України з питань зовнішньої політики та міжпарламентського співробітництва на тему «Правова війна: українсько-російський контекст» [12].

Окремо слід відмітити задекларований намір про створення надзвичайно важливої й абсолютно нової інституції в протистоянні російській агресії. Так, згідно з Річною національною програмою під егідою Комісії Україна НАТО на 2020 рік передбачено пріоритетне завдання щодо утворення та забезпечення функціонування «Центру передового досвіду захисту цивільного населення під час збройного конфлікту та протидії гібридній агресії правовими засобами». Відповідальним за виконання визначено Міноборони 3 терміном виконання до кінця 2020 року. Вважаємо, що його запровадження сприятиме водночас посиленню і розвитку системи забезпечення національної безпеки України.

Підсумовуючи вищенаведене в нашому дослідженні, слід зробити такі висновки. Правова система України поки що недостатньо пристосована до цілеспрямованої системної діяльності, орієнтованої на забезпечення цілей і завдань національної безпеки у воєнній сфері. Внаслідок цього система забезпечення національної безпеки і оборони реалізує військові пріоритети переважно в контексті реагування на вже існуючі загрози, тобто постфактум.

Разом із тим швидкозмінний характер «гібридних» впливів стимулює відмову від попередніх та вироблення нових нормативно-правових стандартів. Адже наразі з'явилось розуміння, що основною метою майбутніх «гібридних» війн будуть дії нижче порогу реагування, а ключові цілі досягатимуться ще до того, як буде розгорнуто ефективний захист. Тому на сучасному етапі розвитку оборонних і безпекових спроможностей держави найбільш актуальним завданням $є$ створення гнучкої, спрямованої в майбутнє системи правових координат, яка би передбачала своєчасне реагування на всі види загроз національній безпеці у воєнній сфері.

Отже, цілком природно, що реалізація цілей і завдань протидії збройній агресії військово-правовими засобами спирається насамперед на достатність та цілісність правового поля, наявність чіткого військово-політичного рішення та інституційно-правові безпекові й оборонні спроможності України. 


\section{ЛITEPATYPA}

1. Данілов О.М. Указ Президента України дозволить суттєво посилити можливості Національного координаційного центру кібербезпеки, 28 січня 2020 року. URL: http://www.rnbo.gov.ua/news/3474.html

2. Фещук М.Г. Правова система держави повинна мати запас міцності. Віче. 2010. № 21 (листопад). URL: http://www.viche.info/ journal/2270/

3. Про внесення змін до Закону України «Про Державну службу спеціального зв'язку та захисту інсоормації України» : Закон України від 9 квітня 2014 року № 1194-VII. URL: http://zakon.rada.gov.ua/laws/show/1194-18

4. Про внесення зміни до статті 6 Закону України «Про Державну прикордонну службу України» : Закон України від 9 квітня 2015 року № 306-VIII. URL: http://zakon4.rada.gov.ua/laws/show/306-VIII

5. Про внесення змін до Податкового кодексу України та деяких інших законодавчих актів України : Закон України від 31 липня 2014 року № 1621-VII. URL: http://zakon.rada.gov.ua/laws/show/1621-18

6. Про внесення змін до Закону України «Про Державну спеціальну службу транспорту» щодо статусу Державної спеціальної служби транспорту : Закон України від 5 грудня 2017 року № 2225-VIII. URL: http://zakon2.rada.gov.ua/laws/show/2225-19

7. Про внесення змін до деяких законів України щодо військових стандартів : Закон України від 6 червня 2019 року № 2742-VIII. URL: https://zakon.rada.gov.ua/laws/show/2742-VIII

8. Про внесення змін до Закону України «Про оборону України» щодо організації оборони держави : Закон України від 20 вересня 2019 року № 133-IX. URL: https://zakon.rada.gov.ua/laws/show/133-IX

9. Про структуру плану оборони України : Указ Президента України від 3 березня 2020 року № 61. URL: https://zakon.rada.gov.ua/ laws/show/61/2020

10. Про внесення змін до деяких законодавчих актів України щодо здійснення закупівель продукції, робіт і послуг оборонного призначення за імпортом : Закон України від 17 січня 2019 року № 2672-VIII. URL: https://zakon.rada.gov.ua/laws/show/2672-VIII

11. Бабін Б.В. Юридичний механізм російської агресії проти України. 2019. 13 грудня URL: https://censor.net.ua/blogs/3165346/ yuridichniyi_mehanzm_rosyisko_agres_proti_ukrani

12. Свиридова Д.О. Дії України в юридичних спорах з РФ залишаються нескоординованими та неефективними. 2019.13 грудня URL: https://aspi.com.ua/news/politika/dii-ukraini-v-yuridichnikh-sporakh-z-rf-zalishayutsya-neskoordinovanimi-ta

13. Річна національна програма під егідою Комісії Україна - HATO на 2020 рік : затверджена Указом Президента України від 26 травня 2020 року № 203. URL: https://zakon.rada.gov.ua/laws/show/203/2020 


\title{
ТЕОРЕТИКО-ПРАВОВИЙ АНАЛІЗ КАТЕГОРІЇ СТАНДАРТУ ДОКАЗУВАННЯ ЯК ОДНОГО ЗІ СКЛАДНИКІВ ЗАБЕЗПЕЧЕННЯ ПРАВА НА СПРАВЕДЛИВИЙ СУД
}

\section{THEORETICAL AND LEGAL ANALYSIS OF THE CATEGORY OF STANDARD OF PROOF AS ONE OF THE COMPONENTS OF ENSURING THE RIGHTS TO A FAIR TRIAL}

\author{
Максименко Н.В., к.ю.н., доцент, \\ доцент кафедри права та правого регулювання авіаційної діяльності \\ Льотна академія \\ Наиіонального авіаиійного університету
}

\begin{abstract}
Статтю присвячено розкриттю особливостей застосування категорії «стандарт доказування» в юрисдикційних процесах різних галузей права. Прослідковано відображення у правовій системі та судовій практиці України вимоги міжнародних юрисдикційних органів, зокрема Європейського суду з прав людини та Європейської комісії з прав людини, практики доказування за допомогою використання категорії «стандарту доказування».

На підставі аналізу судової практики та точок зору вчених зазначено, що стандартом доказування є ступінь достовірності наданих стороною доказів, за допомогою яких судом установлюється рівень імовірності доведення фактів у справі. Спираючись на вказаний Верховним Судом перелік основних стандартів доказування, - «баланс імовірностей» (balance of probabilities) або «перевага доказів» (preponderance of the evidence); «наявність чітких та переконливих доказів» (clear and convincing evidence); «поза розумним сумнівом» (beyond reasonable doubt) - розкрито юрисдикційну практику застосування. У справах господарської юрисдикції суд у зв'язку із внесенням змін до чинного законодавства останнім часом застосовує стандарт доказування - «імовірності доказів» замість існуючого до цього стандарту «достатності доказів». Стандарт доказування «імовірності доказів», на відміну від «достатності доказів», зумовлює необхідність здійснювати зіставлення доказів, які надає позивач та відповідач. Стандарт «баланс імовірностей» має застосовуватися під час вирішення цивільної справи, на що вказує також судова практика. Останньою зазначено, що суд повинен вирішити: чи являється ймовірність того, що на підставі наданих доказів, а також правдивості тверджень заявника вимога цього заявника заслуговує довіри. На безпідставність застосування стандарту доведеності «поза розумним сумнівом» під час вирішення цивільних справ вказує рішення Європейського суду з прав людини щодо доведеності «поза розумним сумнівом» (рішення від 18 січня 1978 року «Ірландія проти Сполученого Королівства»), оскільки стосується критеріїв доведення вини у кримінальному провадженні щодо злочинів проти життя і здоров'я особи. Зазначено, що Кодекс адміністративного судочинства України не встановлює стандартів доказування під час вирішення справи, але в судовій практиці прослідковується використання судовими інстанціями двох підходів під час вибору стандарту доведення в адміністративних справах: «поза розумним сумнівом» і «встановлення об'єктивної істини».
\end{abstract}

Ключові слова: стандарт доказування, баланс імовірностей, поза розумним сумнівом, встановлення об'єктивної істини, доказування.

The article is devoted to the disclosure of the features of application of the "standard of proof" category in jurisdictional processes in various branches of law. It was tracked the reflection of the requirements of the international jurisdictional bodies in the legal system and judicial practice of Ukraine, particularly, the European Court of Human Rights and the European Convention on Human Rights, of the practice of proving by using the category of "standard of proof".

Based on the analysis of jurisprudence and the points of view of scientists, it is indicated that the standard of proof is the degree of reliability of the evidence submitted by the party, in which the court sets the level of probability of proving the facts in a case. Based on the list of basic standards of evidence specified by the Supreme Court - "balance of probabilities" or "preponderance of the evidence" "Clear and convincing evidence" "Beyond reasonable doubt" (beyond reasonable doubt) - the jurisdictional practice of application is disclosed. In cases of economic jurisdiction, the court to face the amendments of the name to the current legislation, has recently been applying the standard of proof - "reliability of evidence" instead of the existing "sufficiency of evidence". The standard of proof of "reliability of evidence", in contrast to "sufficiency of evidence", requires comparing of evidence provided by the plaintiff and the defendant. The "balance of probabilities" standard should be applied in solving a civil case, which is also indicated by judicial practice. The latter indicates that the court must decide: is the probability that on the basis of the evidence, as well as the veracity of the applicant's allegations, the applicant's requirement is credible. The decision of the European Court of Human Rights regarding proof of "beyond reasonable doubt" (judgment of 18 January 1978 "Case of Ireland against The United Kingdom") indicates on the baseless of the application of the standard of proof "beyond reasonable doubt" in the decision of civil cases. This is because it concerns the criteria of proof of guilt in criminal proceedings in relation to crimes against human life and health. It has been pointed out that the Code of Administrative Procedure of Ukraine does not establish any standards of proof when deciding a case, but in judicial practice, there are two approaches used by courts when choosing a standard of proof in administrative cases: "beyond reasonable doubt" and "establishing of objective truth".

Key words: standard of proof, balance of probabilities, beyond reasonable doubt, establishment of objective truth, proof.

Конституція проголошує Україну правовою державою, в якій права і свободи людини та їх гарантії визначають зміст і спрямованість діяльності держави. Відповідно до ст. 55 Конституції України права і свободи людини та громадянина захищаються судом [18]. Кожному гарантується право на оскарження в суді рішень, дій чи бездіяльності органів державної влади, органів місцевого самоврядування, посадових і службових осіб.

Цитоване конституційне положення $є$ фундаментом для формування правозастосовних уявлень щодо таких основоположних у національному судочинстві понять, як звернення до суду з позивними вимогами відносно предмета спору та їх обгрунтування, перегляд судових рішень в адміністративних справах в апеляційному, касаційному порядку, надання інформації щодо предмету доказування під час вирішення справи.
Останнім часом особливий інтерес становлять стандарти доказування, які, попри свою значимість, залишаються малодослідженими в науці та невизначеними в законодавстві. Хоча останнім часом категорія «стандарт доказування» знайшла своє відображення в національній доктрині та судовій практиці.

Дослідження питання стандарту доказування та стандарту доказування «поза розумним сумнівом» здійснювали такі вітчизняні науковці, як: В. Баранкова, В. Бігун, Л. Білецька, В. Вапнярчук, Д. Гетманцев, І. Гловюк, Н. Глинська, В. Гмирко, О. Дроздов, В. Зеленецький, В. Іщенко, В. Комаров, С. Ковальчук, О. Литвин, Т. Морщакова, Л. Ніколенко, К. Пільков, П. Прилуцький, Б. Ратушна, А. Степаненко та ін. Зарубіжні вчені у своїх працях розкривали особливості питань стандартів доказування «поза розумним сумнівом» (О. Александров, 
С. Будилін, Л. Зонгжі, К. Енгель, А. Кухта, І. Решетнікова, Д. Кей, Т. Сколнік, Е. Шервін тощо).

Мета статті - на основі аналізу судової практики різних юрисдикційних процесів з'ясувати правову природу категорії «стандарт доказування» у праві, виділити ії особливість та можливі критерії застосування.

Перед тим, як розкрити поставлену нами мету, звернімось до семантики терміна «стандарт доказування». Як зазначає К. Пілков, термін «стандарт доказування» (standard of proof) використовується для позначення рівня ймовірності, до якого обставина повинна бути підтверджена доказами, щоби вважатись дійсною. Даний термін бере витоки $з$ доктрини правових систем загального права, звідки він був запозичений у теорію та практику доказування в міжнародному комерційному арбітражі [19], інших міжнародних юрисдикційних органів, зокрема Європейського суду з прав людини (ЄСПЛ), звідки поступово впроваджується в країнах континентальної правової традиції, зокрема й в Україні [20].

Термін «поза розумним сумнівом» $\epsilon$ складником поняття «стандарт доказування», який за смисловим наповненням $є$ більш ширшим. На користь цієї думки виступає А. Степаненко, який зазначає, що даний феномен знайшов своє відображення у правових системах Англії, США, Канади, Японії та в діяльності ряду міжнародних судових установ, у тому числі й Європейського суду 3 прав людини (далі - ЄСПЛ). Європейський суд 3 прав людини та Європейська комісія з прав людини неодноразово однією з підстав відсутності порушень Конвенції про захист прав і основоположних свобод людини (стаття 3) Україною зазначали відсутність достатніх доказів, які би «поза розумним сумнівом» підтверджували обставини, зазначені у скаргах заявників [25].

Із прикладу судової практики ССПЛ, своїм рішенням у праві Справа «Кобець проти України» (Заява № 16437/04) Суд зазначив, що відповідно до його прецедентної практики під час оцінки доказів керується критерієм доведення «поза розумним сумнівом» (рішення у справі «Авшар проти Туреччини»). Таке доведення має випливати із сукупності ознак чи неспростовних презумпцій, досить вагомих, чітких і узгоджених між собою [23, п. 43].

Своєю Постановою Верховний Суд [5] практично надав визначення поняттю «стандарт доказування», зазначивши, що саме це виступає важливим елементом змагальності процесу. Відповідно, Судом зазначено, що стандарти доказування - спеціальні правила, якими суд має керуватися під час вирішення справи. Ці правила дозволяють оцінити, наскільки вдало сторони виконали вимоги щодо тягаря доказування і наскільки вони змогли переконати суд у своїй позиції, що робить оцінку доказів більш алгоритмізованою та обгрунтованою [5].

Також Верховним Судом вказано, що нині у праві існують такі основні стандарти доказування: «баланс імовірностей» (balance of probabilities) або «перевага доказів» (preponderance of the evidence); «наявність чітких та переконливих доказів» (clear and convincing evidence); «поза розумним сумнівом» (beyond reasonable doubt) [5].

Якщо звернемось до судової практики, то Верховний Суд у справах господарської юрисдикції останнім часом звертається до стандарту доказування. Суд у своїх постановах зазначає, що під час оцінки достатності доказів діють спеціальні правила - стандарти доказування, якими має керуватися суд під час вирішення справи. Суд наголошував, що стандарти доказування $\epsilon$ важливим елементом змагальності процесу. Якщо сторона не подала достатньо доказів для підтвердження певної обставини, то суд робить висновок про іiї недоведеність. Обов'язок (тягар) доказування обставин покладається на особу, яка посилається на ці обставини (справа № 922/1163/18 [8], справа № 909/105/15 [6], справа № 910/16092/18 [7] тощо).
Верховний Суд у складі колегії суддів Касаційного господарського суду, розглянувши касаційну скаргу Приватного підприємства на постанову Львівського апеляційного господарського суду від 10.09.2018 p. (справа № 914/2505/17), у своїй постанові зазначив, що суд вважає оцінку судами такого доказу, як «експрес-накладна № 100...» 3 висновком про його неналежність на підтвердження фактичної доставки вантажу відповідачу, здійсненою $з$ порушенням правил оцінки доказів відповідно до статті 86 ГПК України та порушенням принципу оцінки доказів «поза розумним сумнівом», про що зазначалося в Рішенні ССПЛ у справі Avsar vs. Turkey, суть якого полягає в тому, що розумним є сумнів, який грунтується на певних обставинах та здоровому глузді, випливає зі справедливого та зваженого розгляду всіх належних та допустимих відомостей, визнаних доказами, або з відсутності таких відомостей, і $€$ таким, який змусив би особу втриматися від прийняття рішення в питаннях, що мають для неї найбільш важливе значення [4].

В іншому рішенні Київський апеляційний господарський суд у справі № 911/3289/14 зазначив, що позовні вимоги повинні бути доведені «поза розумним сумнівом» [3]. У рішенні Суд вказав, що розумний сумнів не є сумнівом, що базується на чисто теоретичній можливості чи викликаний для уникнення негативних висновків. Суд повинен спиратися на всі елементи наданих йому доказів чи, в разі потреби, на ті, які він зможе офіційно отримати.

Із набуттям чинності Закону України «Про внесення змін до деяких законодавчих актів України щодо стимулювання інвестиційної діяльності в Україні» від 20.09.2019 p. [22] до чинного Господарського процесуального кодексу України [1] внесені зміни, а саме: змінено назву ст. 79 ГПК 3 «Достатність доказів» на нову - «Ймовірність доказів» та викладено в новій редакції, якою впроваджено в господарський процес такий стандарт доказування, як «імовірність доказів». На це вказує Постанова Верховного Суду у складі колегії суддів Касаційного господарського суду (справа № 924/233/18) [5]. Суд зазначив, що з введенням в дію нового стандарту доказування - «ймовірності доказів» необхідним $є$ не надати достатньо доказів для підтвердження певної обставини, а надати їх саме ту кількість, яка зможе переважити доводи протилежної сторони судового процесу [5]. Тобто стандарт доказування «ймовірності доказів», на відміну від «достатності доказів», зумовлює необхідність здійснювати зіставлення доказів, які надає позивач та відповідач. Також у Постанові Верховного суду вказано, що питання про ймовірність доказів для встановлення обставин, що мають значення для справи, суд вирішує відповідно до свого внутрішнього переконання [5].

Стандарт «баланс імовірностей» має застосовуватися під час вирішення цивільної справи. На це вказує Постанова Верховного суду (справа № 924/233/18), якою також зазначено, що суд повинен вирішити, чи являється ймовірність того, що на підставі наданих доказів, а також правдивості тверджень заявника вимога цього заявника заслуговує довіри [5].

Схожий стандарт під час оцінки доказів застосовано в рішенні ЄСПЛ від 15.11.2007 р. у справі «Бендерський проти України» (заява № 22750/02) [24], в якому суд, оцінюючи фактичні обставини справи, звертаючись до балансу ймовірностей і вирішуючи спір, виходив 3 того, що факти, встановлені в експертному висновку, є більш імовірними за інші докази.

На безпідставність застосування стандарту доведеності «поза розумним сумнівом» під час вирішення цивільних справ вказує Постанова Верховного Суду у складі колегії суддів Першої судової палати Касаційного цивільного суду (справа № 668/9918/13-ц) [2]. Суд вказав, що посилання на рішення Європейського суду з прав людини щодо доведеності «поза розумним сумнівом» 
(рішення від 18 січня 1978 року «Ірландія проти Сполученого Королівства») безпідставні, оскільки стосується критеріїв доведення вини у кримінальному провадженні щодо злочинів проти життя і здоров'я особи.

Судова практика Європейського суду з прав людини, рішення якого $є$ обов'язковими для виконання Україною в межах Закону України «Про виконання рішень та застосування практики Європейського суду з прав людини» від 23 лютого 2006 року [21], свідчить, що у кримінальних справах має застосовуватися стандарт доказування «поза розумним сумнівом». Так, зокрема, в рішенні від 23.08.2016 р. (заява № 59166/12) у справі «Дж. К. та Інші проти Швеції» (J.K. AND OTHERS v. SWEDEN) ЄСПЛ наголошується, що у країнах загального права в кримінальних справах діє стандарт доказування «поза розумним сумнівом» («beyond reasonable doubt») [5].

У Постанові від 21 лютого 2018 року (справа № 701/613/16-к) Верховний Суд наводить класичне визначення стандарту «поза розумним сумнівом»: «Обвинувальний вирок може бути постановлений судом лише в тому випадку, коли вина обвинуваченої особи доведена поза розумним сумнівом. Тобто, дотримуючись засади змагальності та виконуючи свій професійний обов'язок, передбачений ст. 92 КПК України, обвинувачення має довести перед судом за допомогою належних, допустимих та достовірних доказів, що існує єдина версія, якою розумна і безстороння людина може пояснити факти, встановлені в суді, а саме винуватість особи у вчиненні кримінального правопорушення, щодо якого їй пред'явлено обвинувачення. Стандарт доведення «поза розумним сумнівом» означає, що сукупність обставин справи, встановлена під час судового розгляду, виключає будь-яке інше розуміння пояснення події, яка $\epsilon$ предметом судового розгляду, крім того, що інкримінований злочин був учинений, і обвинувачений є винним у вчиненні цього злочину» [9].

Кодекс адміністративного судочинства України не встановлює стандартів доказування під час вирішення справи. Лише ч. 1 ст. 78 КАС України вказує на існування такої процесуальної категорії, як «обгрунтовані сумніви», сутність якої полягає в тому, що обставини, які визнаються учасниками справи, не підлягають доказуванню, якщо суд не має обгрунтованого сумніву щодо достовірності цих обставин або добровільності їх визнання [17].

Слід зазначити, що в судовій практиці прослідковується використання судовими інстанціями двох підходів у виборі стандарту доведення в адміністративних справах: «поза розумним сумнівом» і «встановлення об'єктивної істини». На користь вибору підходу під час вибору стандарту доведення «поза розумним сумнівом» свідчать ухвали від 03 червня 2019 р. (справа № 480/1920/19) [11], від 24 квітня 2020 р. (справа № 480/2506/20) [12], від 15 червня 2020 р. (справа № 818/2712/15) [16] тощо. Суд в ухвалі посилався на Рішення Європейського суду з прав людини від 08.04.2010 р. у справі «Фельдман проти України», відповідно до чого суд, оцінюючи докази, брав до уваги стандарт «поза розумного сумніву».

Щодо використання стандарту під час розгляду адміністративних спорів «встановлення об'єктивної істини», то даним критерієм керувався суд під час прийняття ухвали від 14 травня 2019 р. (справа № 200/2838/19-а) [10], від 19 лютого 2019 р. (справа № 813/3327/18) [14], від 12.03.2019 р. (справа № 520/115/19) [13], від 13 березня 2019 р. (справа № 817/1343/17) [15] тощо. У своїх ухвалах судові інстанції зазначали, що забезпечення доказів в адміністративному процесі $є$ своєрідним інститутом, який створений для запобігання втрати чи пошкодження фактичних даних, що відіграють важливу роль для встановлення об'єктивної істини в адміністративній справі.

Як бачимо, сьогодні постає необхідність закріплення стандартів доказування в Кодексі адміністративного судочинства України, оскільки це дасть змогу на законодавчому рівні закріпити дану категорію в адміністративному процесі.

Входячи з аналізу стандарту доказування, що використовується у праві, під ним слід розуміти ступінь достовірності наданих стороною доказів, за допомогою яких судом встановлюється рівень імовірності доведення фактів по справі.

Підсумовуючи результати дослідження, слід зазначити, що судова практика закріпила у практиці застосування стандарту доказування як важливий елемент змагальності процесу. Впровадження стандарту доказування в сучасному процесуальному процесі відповідає європейському рівню судової практики, зокрема Європейського суду $з$ прав людини.

Впровадження категорії стандарту доказування в юрисдикційні процеси права повинні включати правила, якими суд має керуватися під час вирішення справи, що дозволить оцінити, наскільки вдало сторони виконали вимоги щодо тягаря доказування, й наскільки вони змогли переконати суд у своїй позиції. Наслідком цієї вимоги може бути впровадження різних стандартів доказування у відповідних юрисдикційних процесах галузей права.

\section{ЛITEPATYPA}

1. Господарський процесуальний кодекс України від 06.11.1991 р. № 1798-XII. Дата оновлення 23.05.2020. URL: https://zakon.rada.gov.ua/laws/show/1798-12\#Text (дата звернення: 15.07.2020).

2. Категорія справи № 668/9918/13-ц від 11 липня 2018 року. URL: http://reyestr.court.gov.ua/Review/75690189 (дата звернення: 15.07.2020).

3. Категорія справи № 911/3289/14 від 31 жовтня 2017 року. URL: http://reyestr.court.gov.ua/Review/70025197 (дата звернення: 15.07.2020).

4. Категорія справи № 914/2505/17 від 27 листопада 2018 року. URL: http://reyestr.court.gov.ua/Review/78450568 (дата звернення: 15.07.2020).

5. Категорія справи № 924/233/18 від 25 червня 2020 року. URL: http://reyestr.court.gov.ua/Review/90205664. (дата звернення: 15.07.2020).

6. Категорія справи № 909/105/15 від 29 серпня 2018 року. URL: http://reyestr.court.gov.ua/Review/76237002 (дата звернення: 15.07.2020).

7. Категорія справи № 910/16092/18 від 21 серпня 2019 року. URL: http://reyestr.court.gov.ua/Review/83871339 (дата звернення: 15.07.2020).

8. Категорія справи № 922/1163/18 від 27 лютого 2019 року. URL: http://reyestr.court.gov.ua/Review/80181097 (дата звернення: 15.07.2020).

9. Категорія справи № 701/613/16-к від 21 лютого 2018 року. URL: https://verdictum.ligazakon.net/document/80147749? ?tm_ source=jurliga.ligazakon.ua\&utm_medium=news\&utm_campaign=Verdictum_text\&utm_content=jl01 (дата звернення: 15.07.2020).

10. Категорія справи № 200/2838/19-а від $14{ }^{-}$травня 2019 p. URL̈: http://reyestr.court.gov.ua/Review/81725676 (дата звернення: 25.07.2020).

11. Категорія справи № 480/1920/19 від 03 червня 2019 p. URL: http://reyestr.court.gov.ua/Review/82138511 (дата звернення: 25.07.2020).

12. Категорія справи № 480/2506/20 від 24 квітня 2020 p. URL: http://reyestr.court.gov.ua/Review/88907952 (дата звернення: 25.07.2020).

13. Категорія справи № 520/115/19 від 12.03.2019 p. URL: http://reyestr.court.gov.ua/Review/82138511 (дата звернення: 25.07.2020). 
14. Категорія справи № 813/3327/18 від 19 лютого 2019 року URL: http://reyestr.court.gov.ua/Review/79964683 (дата звернення: 25.07.2020).

15. Категорія справи № 817/1343/17 від 13 березня 2019 року. URL: http://reyestr.court.gov.ua/Review/80407276 (дата звернення: 25.07.2020).

16. Категорія справи № 818/2712/15 від 15 червня 2020 p. URL: http://reyestr.court.gov.ua/Review/82138511 (дата звернення: 25.07.2020).

17. Кодекс адміністративного судочинства України 06.07.2005 p. № 2747-IV. Дата оновлення 02.04.2020. URL: https://zakon.rada.gov.ua/ laws/show/2747-15\#Техt (дата звернення: 25.07.2020).

18. Конституція України від 28.06.1996 р. № 254к/96-BP. Дата оновлення 01.01.2020. URL: https://zakon.rada.gov.ua/laws/ show/254\%D0\%BA/96-\%D0\%B2\%D1\%80\#Text (дата звернення: 11.07.2020).

19. Пільков К.М. Теорія і практика доказування у міжнародному комерційному арбітражі : монографія. Київ : Освіта України, 2016.

20. Пільков К. Стандарт доказування як складова забезпечення права на справедливий суд. Юрліга. 2019. 4 листопада. URL: bit.ly/2NfsI5b (дата звернення: 12.07.2020).

21. Про виконання рішень та застосування практики Європейського суду з прав людини : Закон України від 23.02.2006 p. № $3477-\mathrm{IV}$. Дата оновлення 02.12.2012. URL: https://zakon.rada.gov.ua/laws/show/3477-15\#Text (дата звернення: 17.07.2020).

22. Про внесення змін до деяких законодавчих актів України щодо стимулювання інвестиційної діяльності в Україні : Закон України від 20.09.2019 р. № 132-IX. URL: https://zakon.rada.gov.ua/laws/show/132-20\#Text (дата звернення: 15.07.2020).

23. Справа «Кобець проти України» (Заява № 16437/04) : Рішення Європейського суду з прав людини від 14.02.2008 p. URL: https://zakon.rada.gov.ua/laws/show/974 320\#Теxt (дата звернення: 15.07.2020).

24. Справа «Бендерський проти України» (заява 22750/02). Страсбург, 15 листопада 2007 року : Європейський суд 3 прав людини. URL: https://zakon.rada.gov.ua/laws/show/974_313\#Text (дата звернення: 15.07.2020).

25. Степаненко А. Теорія та практика застосування стандарту доказування «поза розумним сумнівом» Європейським судом з прав людини. Вісник кримінального судочинства. 2015. № 4. С. 184-191. 


\title{
ФОРМУВАННЯ ІНСТИТУТУ КОНТРОЛЬНО-НАГЛЯДОВОЇ ДІЯЛЬНОСТІ У СФЕРІ НАДРОКОРИСТУВАННЯ В КИЇВСЬКІЙ РУСІ (IX-ХII СТ.): ІСТОРИКО-ПРАВОВИЙ АСПЕКТ
}

\author{
FORMATION OF THE INSTITUTE OF CONTROL AND SUPERVISION ACTIVITY \\ IN THE FIELD OF SUB-USE IN KIEVAN RUS (IX-XII CENTURY): \\ HISTORICAL AND LEGAL ASPECT
}

\author{
Мачуська І.Б., к.ю.н., \\ доцент кафедри цивільного та трудового права \\ Київський національний економічний університет імені Вадима Гетьмана
}

У статті досліджуються питання правового регулювання, управління, контролю і нагляду у сфері надрокористування в Київській Русі (IX - XII ст.). Досліджено, що Київська Русь у період IX - XIII ст. являла собою могутню східноєвропейську державу з розвиненою економікою та правовою системою. На основі археологічних досліджень встановлено, що гірнича промисловість займала одну з ключових позицій в економіці Київської Русі IX - XII ст. Зазначено, що в досліджуваний період у Київській Русі видобувалася значна кількість різноманітних видів корисних копалин, добувна промисловість мала системний характер.

Наголошено, що основним нормативно-правовим актом Київської Русі була «Руська Правда». 3 метою дослідження правовідносин у ссрері надрокористування досліджені норми «Руської Правди». Встановлено, що ці норми не містять положень щодо права власності на надра. Зроблено висновок, що відсутність окремих норм щодо права власності на надра вказує на той факт, що земельна ділянка розглядалась як єдиний природний об'єкт, що включав не тільки поверхню землі, а й підземний простір.

Встановлено, що досить розвинене в період Київської Русі гірничодобувне виробництво передбачало наявність системи державного управління та контрольно-наглядової діяльності у сфері надрокористування. У Київській Русі була сформована державна система, що мала всі ознаки автократичної феодальної монархії.

Досліджено, що інститут управлінської та контрольно-наглядової діяльності в Київській Русі формувався поступово, від десяткової до палацо-вотчинної системи управління. Палацо-вотчинна система формувалась на основі ідеї з'єднання управління великокнязівським палацом з державним управлінням.

Зроблено висновок, що управлінська та контрольно-наглядова діяльність у Київській Русі не розмежовувалась. Контроль і нагляд у сфері надрокористування здійснювався призначеними Київським князем представниками князівської адміністрації, що в центрі й на місцях здійснювали контрольно-наглядові та управлінські функції.

Ключові слова: надра, надрокористування, корисні копалини, гірничі відносини, охорона та використання надр, управління та контроль у сфері надрокористування.

The article examines the issues of legal regulation, management, control and supervision in the field of subsoil use in Kievan Rus (IX XII centuries). It is investigated that Kievan Rus in the period of IX - XIII centuries. was a powerful Eastern European state with a developed economy and legal system. Based on archaeological research, it is established that the mining industry occupied one of the key positions in the economy of Kievan Rus (IX - XII centuries). It is noted that in the studied period in Kievan Rus a significant number of different types of minerals were extracted, the mining industry was systemic.

It is emphasized that the main legal act of Kievan Rus was Ruska Pravda. In order to study the legal relations in the field of subsoil use, the norms of Russkaya Pravda were studied. It has been established that the norms of Russkaya Pravda do not contain provisions on subsoil ownership. It is concluded that the absence of separate norms on the right of ownership of subsoil indicates the fact that the land was considered as a single natural object, which included not only the land surface, but also the underground space.

It is established that the mining production, which was sufficiently developed in the period of Kievan Rus, provided for the existence of a system of public administration and control and supervision activities in the field of subsoil use. In Kievan Rus, a clear state system was formed, which had all the hallmarks of an autocratic feudal monarchy.

It is investigated that the institute of administrative and control-supervisory activity in Kievan Rus was formed gradually, from the decimal to the palace-patrimonial system of government. The palace-patrimonial system was formed on the basis of the idea of combining the management of the Grand Ducal Palace with the state administration.

It is concluded that management and control activities in Kievan Rus were not separated. Control and supervision in the field of subsoil use was carried out by representatives of the princely administration appointed by the Prince of Kyiv, who exercised control, supervisory and managerial functions in the center and in the field.

Key words: mineral resources, subsoil use, minerals, mining relations, protection and use of mineral resources, management and control in the field of subsoil use.

Постановка проблеми. Використання корисних копалин є однією 3 найдавніших сфер діяльності людини. Інститут надрокористування в Україні має багатовікову історію. Одним із визначальних історичних періодів, де закладались підвалини української державності, економіки, культури і права, є період Київської Русі (IX XII ст. ст.).

У сучасних умовах розвитку української держави, формування якісно нового економічного і соціального розвитку, долучення до євроінтеграційних процесів є необхідність створення умов для раціонального використання та охорони надр.

У цьому контексті особливого значення набуває дослідження історико-правових аспектів розвитку гірничої галузі стародавньої України періоду Київської Русі
(IX - XII ст.), а також її правове регулювання, управління, контроль і нагляд.

Аналіз останніх досліджень. Питання формування правового регулювання гірничих відносин, управлінської та контрольно-наглядової діяльності в період Київської Русі були предметом дослідження багатьох науковців: І.Й. Бойко, Б. Бачура, І.М. Булгакова, О.А Грицан, М.О. Максіменцевої, О.М. Олійника, Р.С. Кіріна, В.К. Філатової. Окремі аспекти правового забезпечення природних ресурсів досліджувались В.І. Курило, О.П. Світличним.

Дослідження гірничих відносин у період Київської Русі розглядались у працях вчених, а саме: Г. Гойко, В. Білецького, Г.О. Вознесенської, Д.В. Недопалко, С.В Панькова, А.В. Петраускас, С.А. Сагайдак, А. Сушко, П.А. Толочко, П.А. Тутковського, Б.П. Томенчука, В.В. Хвойко. 
Мета статті полягає в теоретичному дослідженні становлення та формування інституту контрольно-наглядової діяльності у сфері надрокористування в період Київської Pусі (IX - XII ст.).

Виклад основного матеріалу. Гірництво справило суттєвий вплив на історію суспільства, розвиток технічного прогресу, відкриття й освоєння нових земель [1, с. 135]. Доцільно погодитись із думкою В.І. Курило i О.П. Світличного в тому, що на кожному етапі конкретних історичних умов розвитку суспільних відносин формуються органи публічної влади, що одночасно зосереджують попередній досвід, який у залежності від динаміки розвитку відносин суспільства може доповнюватися новими, притаманними саме цій системі регулювання управлінськими відносинами [2, с. 150].

Київська Русь у період IX - XIII ст. являла собою могутню східноєвропейську державу, що займала територію 1,5 млн км ${ }^{2}$ [3, с. 217]. Присутність у Києві великокнязівського столу та державних інституцій, стратегічне розташування міста сприяли розвитку ремісництва і промислів [4, с. 266]

Існує усталена думка, що головну роль в економіці Київської Русі відігравало сільське господарство. Водночас доцільно зауважити, що нарівні зі сталим розвитком сільського господарства значного рівня дістав інститут надрокористування, що мав велике значення для формування економіки Київської Русі.

Становлення та розвиток інституту надрокористування, в тому числі й інституту контрольно-наглядової та управлінської діяльності в Київській Русі, доцільно дослідити на основі археологічних свідчень, що дозволить безпосередньо встановити розвиток гірничих відносин, а також правове регулювання, управління, контроль і нагляд у зазначеній сфері.

Археологія давньоруського Києва надала багато свідчень опанування його мешканцями високотехнологічних (як на той час) виробництв, пов’язаних 3 видобуванням корисних копалин $[5$, с. 40$]$.

Так, у Київській Русі IX - XIII ст. значного розвитку досягли промисли та ремесла, в тому числі: обробка заліза, чорно-металургійне виробництво (Київ X ст.) [6, с. 41]; обробка бурштину та іншого дорогоцінного каміння, золота, срібла, виготовлення прикрас (Київ X ст., вул. Ярославська) [7, с. 18]. Цей період характеризується також розвитком будівництва 3 використанням будівельного каміння [8, с. 112], у тому числі і профіліту [9, с. 25].

Отже, базуючись на дослідженнях учених-археологів, можна встановити наявність у Київській Русі (IX XII ст.) розвиненого ремісництва, основу якого становила потужна мінерально-сировинна база.

Дослідження гірничої галузі Київської Русі IX XIII ст. дозволяють безпосередньо встановити розвиток інституту надрокористування, його правове регулювання, управління та контрольно-наглядову діяльність. Доцільно зауважити, що на території Київської Русі видобували значну кількість корисних копалин.

Г.О. Вознесенська зазначає, що в Київській Русі відкритим способом здійснювався видобуток болотних, озерних, залізних руд $[10$, с. 78$]$; В.В. Хвойка звертає увагу на видобуток залізистого піщаника (для будівництва палацу на Андріївському узвозі) $[11$, с. 66]. В.А. Нестеровський зазначає, що одним із відомих промислів був видобуток бурштинової сировини з проявів Київського Придніпров'я [7, с. 19]. Також на території Південно-Західної Русі XI - XIII ст. ст. здійснювалась добича солі [12, с. 197]. Для потреб будівництва видобувався вапняк, пісковик, граніт, глина [13, с. 96].

Особливе місце у видобутку корисних копалин у Київській Русі належить найбільшому та єдиному в Східній Європі родовищу Словечансько-Овруцького кряжа, де розроблювали поклади пірофілітового сланцю «шиферу», що були вперше зафіксовані П.А. Тутковським на початку ХХ ст. [14, с. 69].

Промисловий видобуток пірофілітового сланцю, на нашу думку, є прикладом налагодженої індустрії (середина X - XI ст.) щодо видобутку корисних копалин, на основі дослідження якої можна прослідкувати формування в Київській Русі інституту контрольно-наглядової діяльності у сфері надрокористування.

Доцільно зауважити, що значного розвитку в Київській Русі IX - XIII ст. дістала не тільки видобувна промисловість, а й переробна, що разом утворювали єдиний, взаємопов'язаний гірничодобувний промисловий комплекс. Цей факт ще більше підтверджує значний масштаб гірничих робіт у Київській Русі. У цьому контексті П.П. Толочко зазначає, що видобуток корисних копалин носив тривалий, а не сезонний характер, про що вказує наявність спеціалізованих сезонних та постійних ремісницьких і промислових пунктів [15, с. 163].

Формування та розвиток української правової системи пов'язаний із прийняттям першого кодифікованого нормативно-правового акта Київської Русі - «Руської правди», норми якої охоплювали широке коло суспільних відносин, у тому числі й у сфері використання природних ресурсів (ст. ст. $1 ; 14 ; 65)$ [16, с. 147].

У Київській Русі земельна власність існувала у формах: князівського домену, боярської та монастирської вотчин, особистих вотчин церковних ієрархів, верховним власником яких виступав великий князь як глава держави $[17$, c. 392], способами набуття якої були володіння, давність володіння, успадкування та дарування [18, с. 10].

Доцільно зазначити, що, незважаючи на існування інституту власності на землю в Київській Русі, «Руська Правда» не містила безпосередньо поняття «права власності на землю». Виходячи зі змісту статей «Руської Правди», можна зазначити, що цей документ містив перелік штрафних санкцій, що передбачався за знищення межових знаків, а також пошкодження бортних та релейних меж. Тобто знищення межових знаків, що позначали кордон княжих земель, свідчило про посягання на право власності на землю. Таким чином, можна зробити висновок, що інститут права приватної власності в Київській Русі існував і сприймався суспільством як усталене явище, що не потребувало окремого законодавчого визначення. Захист права приватної власності на землю був зазначений як захист меж або кордонів земель. Законодавець лише зосереджував увагу на санкціях за неправомірне використання земель та порушення цілісності визначених земель. Водночас можна зробити висновок, що інститут права власності на землю тоді не мав належного законодавчого оформлення.

Доцільно зауважити, що норми «Руської правди» не містили посилання, що безпосередньо вказували на право власності на надра. Існують різні точки зору науковців щодо права власності на надра за законодавством Київської Русі. Так, на думку О. Олійник, «Руська правда» не містила правових норм щодо охорони надр у зв'язку з особливостями економіки Київської держави, яка мала натуральний характер [19, с. 17]. Н.О. Максіменцева зазначає, що аналіз норм «Руської правди» дозволяє стверджувати, що на той час надрам і видобуванню корисних копалин не приділялось настільки великої уваги, щоб запроваджувати окреме їх нормативне регулювання [20, с. 69].

Водночас ми не можемо погодитись із такою позицією вчених, оскільки археологічні свідчення доводять протилежну думку щодо використання корисних копалин у Київській Русі. Враховуючи наявність значного виду промислів, що використовували різноманітні види корисних копали як сировину, та залишки видобувних промислів, можна дійти висновку про широке використання в Київській Русі ресурсів надр, що нарівні із сільським господарством становили основу економіки держави. 
На наш погляд, відсутність окремих норм щодо права власності на надра вказує на той факт, що земельна ділянка розглядалась як єдиний природний об'єкт, що включав не тільки територію поверхні землі, а й підземний простір. Тієї ж думки дотримуються такі вчені, як В.К. Філатова [21, с. 12], Н.О. Максіменцева, [20, с. 69], С. Голубка [22].

Таким чином, у нормах Київської Русі спостерігається певна невідповідність щодо значно розвиненої (як на той час) гірничої галузі, що була основою економіки країни, та відсутності норм законодавства у сфері надрокористування.

На нашу думку, відсутність у законодавстві Київської Русі, в тому числі й у положеннях Руської Правди, згадки про право власності на надра можна пояснити тим фактом, що наявність права власності на надра розглядалось як право власності на територію земельної ділянки разом із простором під нею, в межах якої знаходились корисні копалини. Тобто можна говорити не про відсутність норм законодавства у сфері надрокористування, а про приналежність надр до території земельної ділянки.

Досить розвинене в Київській Русі гірничодобувне виробництво передбачало наявність системи державного управління та контрольно-наглядової діяльності у сфері надрокористування.

У Київській Русі була сформована чітка державна система, що мала всі ознаки автократичної феодальної монархії. Князівська адміністрація, як у центрі, так і на місцях, складалася з довірених урядників, відповідальних за певну галузь діяльності [23]. Разом із тим поєднання в ній військової, судової та адміністративної функцій свідчить про нерозвиненість цісї влади [24, с. 30-31].

Інститут управлінської та контрольно-наглядової діяльності в Київській Русі формувався поступово, від десяткової до палацо-вотчинної системи управління, на чолі якої стояв київський князь. Палацо-вотчинна система формувалась з ідеї з'єднання управління князівським палацом $з$ державним управлінням.

У другій пол. IX - першій пол. X ст. формується система посадництва [25, с. 33]. Управлінські та контрольнонаглядові функції на місцях здійснювали представники центральної влади - посадники і волостелі. Безпосередньо управлінські та контрольно-наглядові функції за князівським господарством здійснював тіун огнищний, до повноважень якого входили не тільки управління князівським палацом, а і землями князя [26].

Відповідно до норм Руської Правди (гл. 11) мірою у 80 гр. каралось вбивство княжого тіуна, а вбивство сільських та ротайних старост - 12 гр. [27, с. 154]. Тіун сільський або ратайний завідував землеробським господарством [28].

Враховуючи, що відповідно до норм давньоруського законодавства земля розглядалась як єдиний природний об'єкт, а право власності і право користування надрами не відокремлювалось від права власності на землю, можна припустити, що здійснення контрольно-наглядової діяльності у сфері надрокористування не відмежовувалось від здійснення контрольно-наглядової діяльності у сфері земельних відносин.
Цієї ж думки дотримується і Н.О. Максіменцева, яка зазначає, що здійснення публічного адміністрування в галузі використання та охорони надр за часів Київської Русі здійснювалось опосередковано (через управління земельними ресурсами) [29, с. 24].

Враховуючи, що видобування корисних копалин здійснювалось на територіях, приналежних до знаходження корисних копалин, контроль і нагляд за видобуванням корисних копалин здійснювались представниками київського князя, що виконували контрольно-наглядові функції, а саме тіуном огнищним, що підпорядковувався посаднику. У свою чергу тіуну підпорядковувалися сільські та ротайні старости.

Висновки. Гірництво справило суттєвий вплив на історію суспільства, розвиток технічного прогресу, відкриття й освоєння нових земель.

Одним із визначальних історичних періодів, де закладались підвалини української державності, економіки, культури і права, є період Київської Русі (IX - XII ст. ст.). Київська Русь у той період являла собою могутню східноєвропейську державу. Одним зі складників економіки Київської Русі була розвинена (як на той час) гірничодобувна галузь, основу якої становила потужна мінеральносировинна база.

Формування та розвиток української правової системи пов'язані 3 прийняттям першого кодифікованого нормативно-правового акта Київської Русі - «Руської правди», норми якої охоплювали широке коло суспільних відносин, у тому числі й у сфері використання природних ресурсів.

Водночас норми «Руської правди» не містили норми щодо права власності на надра. На нашу думку, відсутність окремих норм щодо права власності на надра вказує на той факт, що земельна ділянка розглядалась як єдиний природний об'єкт, що включав не тільки територію поверхні землі, а і підземний простір.

Таким чином, у правових нормах Київської Русі спостерігається певна невідповідність щодо значно розвиненої (як на той час) гірничої галузі, що була основою економіки країни, та відсутності норм законодавства у сфері надрокористування.

У період Київської Русі система управління, контролю і нагляду існувала у формі палацо-вотчинної системи, що формувалась на основі з'єднання управління великокнязівським палацом із державним управлінням. Управлінські функції здійснювали тіун огнищний, сільські та ротайні старости.

Управлінські та контрольно-наглядові функції в Київській Русі здійснювали представники князівської влади посадники і волостелі. Безпосередньо управління, контроль і нагляд за князівським господарством здійснював тіун огнищний, до повноважень якого входило не тільки управління князівським палацом, а управління князівськими землями та видобутком корисних копалин.

Однак подальшому розвитку гірничої справи та вдосконаленню інституту контрольно-наглядової діяльності у сфері надрокористування перешкодило монголо-татарське нашестя (XIII - XIV ст.).

\section{ЛІТЕРАТУРА}

1. Білецький В., Гайко Г. Історія гірництва як складова цивілізаційного поступу: актуальність, досягнення і перспективи. Україна: культурна спадщина, національна свідомість, державність. 2012. № 21. С. 131-143.

2. Курило В.І., Світличний О.П. Державний контроль у сфері земельних ресурсів. Науковий вісник НУБІП України: Серія «Право». 2011. Вип. 165. Ч. 1. С. 150-155.

3. Толочко П.П. Давня історія України : в 3 т. / ред. кол. П.П. Толочко та ін. ; НАН України, Ін-т археол. Київ : Наукова думка, 1997. Т. 3: Слов'яно- Руська доба / Ю.С. Асєєв та ін. ; ред. П.П. Толочко, 2000. 695 с.

4. Толочко П.П. Новое в археологии Киева / ред. кол. : П.П. Толочко (отв. ред.), С. А. Высоцкий, Я. Е. Боровский ; АН Украинской ССР. Институт археологии. Киев : Наукова думка, 1981. 457 с.

5. Паньков С.В., Вознесенська Г.О. Організація залізодобувного і залізообробного виробництва у давньоруському Києві (про витоки місцевої чорної металургії та металообробки). Археологія. 2008. № 3. С. 40-46.

6. Паньков С.В. Залізовидобувне і ковальське виробництво давньоруського Києва та його околиць. Дослід історико-технічної реконструкції і порівняльної характеристики. Київ : ІА НАН України, 2012. 240 с. 
7. Нестеровський В.А., Журухіна О.Ю. Коштовне каміння Київського Подолу XI-XIII століть. Повідомлення 1. Бурштин. Коштовне та декоративне каміння. 2015. № 1. С. 16-20.

8. Толочко П.П. Новое в археологии Киева / ред. кол. : П.П. Толочко (отв. ред.), С.А. Высоцкий, Я.Е. Боровский ; АН Украинской ССР. Институт археологии. Киев : Наукова думка, 1981. 457 с.

9. Петрашенко В.О. Слов'янські пряслиця VIII-X ст. з Правобережжя Середнього Подніпров'я. Археологія. 1988. № 62. С. $24-32$.

10. Вознесеньська Г.О., Недопалко Д.П., Паньков С.В. Чорна металургія та металообробка населення східноєвропейського лісостепу за доби ранніх слов'ян та Київської Русі. Київ, 1996. 186 с.

11. Хвойка В.В. Древние обитатели Среднего Приднепровья и их культура в доисторические времена (по раскопкам). Киев, 1913. C. $66-69$

12. Бондарчук В.Г. Геологія України. Київ : Видавництво Академії наук УССР, 1959. 832 с.

13. Сивий М., Паранько І., Іванов Є. Географія мінеральних ресурсів України : монографія. Львів : Простір М, 2013. 684 с.

14. Тутковский П.А. Побережье р. Норина в Овручском уезде Волынской губ. (геологическое и географическое описание). Труды общества исследователей Волыни. Житомир : Электр. типография насл. М. Дененмана, 1911. Т. 6. 340 с.

15. Толочко П.П. Киев и Киевская земля в эпоху феодальной раздробленности XII-XIII веков. Киев : Наукова думка, 1980. 224 с.

16. Донець О.В. Правове регулювання використання й охорони земель в Україні до 1917 року. Науковий вісник Ужгородського національного університету : Серія Право. 2015. Випуск 32. Том 2. С. 146-150.

17. Бойко І.Й. Правове регулювання майнових відносин у Київської Русі (IX - XII ст.). Актуальні проблеми держави $і$ права. 2013. Вип. 70. С. 391-396.

18. Бачур Б. Інститут земельних відносин у цивільному звичаєвому праві України в X - середині XIX ст. (історико-правовий аспект) : автореф. дис. ... канд. юрид. наук : 12.00 .01 ; Нац. ун-т внутр. справ. Харків, 2004. 20 с.

19. Олійник О.М. Правове регулювання охорони надр за законодавством України (окремі аспекти) : монографрія. Хмельницький : Поліграфіст, 2011. 140 c.

20. Максіменцева Н.О. Становлення системи державного управління у галузі надродобування у період Київської Русі, козацької доби та в українських землях у складі Російської імперії. Адміністративне право і процес. 2018. № 1. С. 68-79.

21. Філатова В.К. Правове регулювання геологічного вивчення надр : дис. ... канд. юрид. наук : 12.00.06. Харків, 2008. 113 с.

22. Голубка С. 3 історії фрінансів української державності від Київської Русі до Гетьманщини. URL: http://nauditor.com.ua/uk/component/ na archive/917?view=material

23. Чорна К.П. Традиції державного управління у Київській Pyci URL: http://www.dy.nayka.com.ua/?op=1\&z=1239

24. Шевчук В.П., Тараненко М.Г. Історія української державності. Київ : Либідь, 1999. 480 с.

25. Ухач В.3. Історія держави і права України : навчальний посібник (конспекти лекцій). Тернопіль : Вектор, 2011. 378 с.

26. Літопис руський / пер. з давньорус. Л.Є. Махновця ; відп. ред. О.В. Мишанич. Київ : Дніпро, 1989. URL: http://litopys.org.ua/litop/ lit.htm

27. Грекова Б.Д. Правда Русская. Москва-Ленинград : Изд-во Акад. наук СССР, 1947. Т. II / под ред. Б.Д. Грекова. 862 с.

28. Сергиевич В.И. Русские юридические древності. 2-е изд., с переменами и доп. Санкт-Петербург : Тип. М.М. Стасюлевича, 1902. T. 1: Территория и население. URL: http://dugward.ru/library/sergeevich/sergeevich drevnosti russkogo prava1.html

29. Максіменцева Н.О. Публічне адміністрування у галузі використання і охорони надр в Україні. : дис. ... докт. юрид. наук : 12.00 .07$. Дніпро, 2018. 541 c. 
удК 342

DOI https://doi.org/10.32782/2524-0374/2020-4/42

\title{
АДМІНІСТРАТИВНО-ПРАВОВИЙ СТАТУС ПРАВООХОРОННИХ ОРГАНІВ ЯК СУБ'СКТІВ СИСТЕМИ ЕКОНОМІЧНОЇ БЕЗПЕКИ УКРАЇНИ
}

\author{
ADMINISTRATIVE AND LEGAL STATUS OF LAW ENFORCEMENT AGENCIES \\ AS SUBJECTS OF THE ECONOMIC SECURITY SYSTEM OF UKRAINE
}

\author{
Мельник В.І., к.ю.н., \\ викладач кафедри адміністративного, господарського права \\ та фінансово-економічної безпеки \\ Сумський державний університет
}

\begin{abstract}
Статтю присвячено питанню характеристики адміністративно-правового статусу правоохоронних органів як суб'єктів системи економічної безпеки України. Зроблено спробу довести про безспірну важливість правоохоронної діяльності в аспекті сприяння забезпеченню належного функціонування вітчизняної економічної системи. Вказане, на переконання автора, насамперед мотивується багатогранністю і складністю національної економіки з позиції оцінки дійсних матеріальних можливостей та потреби всілякого забезпечення економічної стійкості останньої, особливо в нинішніх реальних ризикових фінансових умовах.

Оцінюється роль правоохоронної діяльності з позиції її значимості для сприяння забезпеченню належного функціонування системи економічної безпеки України. Зроблено спробу доведення її реальної ролі, враховуючи одержані показники від діяльності відповідних вітчизняних правоохоронних структур саме в цьому напрямі. Наголошується, що така діяльність сприяє не тільки послабленню поточної криміногенної ситуації в економічній сфері, а й слугує своєрідною профілактичною мірою для багатьох імовірних економічних правопорушень, демонструючи тим самим значимість суб'єктів національної правоохоронної системи.

Досліджуються ключові аспекти діяльності правоохоронних органів - суб'єктів національної правоохоронної системи. Враховуючи думки вітчизняних учених, науковців та фахівців, чинне нормативно-правове забезпечення та усвідомлюючи специфіку економічної сфери, пропонується своє бачення переліку ключових правоохоронних органів як суб'єктів системи економічної безпеки України.

Звертається увага на питаннях поняття і визначення структури адміністративно-правового статусу правоохоронних органів як суб'єктів системи економічної безпеки України. Визначається й характеризуються мета, завдання та функції останніх саме в цьому напрямі. Окреслюється компетенція вказаних структур, а також додатково виокремлюються основні їхні повноваження як суб'єктів вітчизняної системи економічної безпеки.

Враховуючи поточне адміністративно-правове становище вказаних суб'єктів, запропоновані кроки з його вдосконалення. Наголошується, що вказані новації мають позитивно відобразитися на роботі цих структур в окресленому напрямі в перспективі.
\end{abstract}

Ключові слова: адміністративно-правовий статус, безпека, правоохоронні органи, система, статус, суб'єкти.

The article is devoted to the issue of characterization of the administrative and legal status of law enforcement agencies as subjects of the economic security system of Ukraine. An attempt is made and an attempt is made to prove the indisputable importance of law enforcement activities in terms of promoting the proper functioning of the domestic economic system. This, in the author's opinion, is primarily motivated by the versatility and complexity of the national economy, from the standpoint of assessing the real material capabilities and the need to ensure the economic stability of the latter, especially in the current, without detriment, real risky financial conditions.

The role of law enforcement is assessed from the standpoint of its importance in promoting the proper functioning of the economic security system of Ukraine. An attempt is made to prove its real role, taking into account the indicators obtained from the activities of relevant domestic law enforcement agencies in this direction. It is emphasized that such activities not only contribute to the weakening of the current criminogenic situation in the economic sphere, but also serve as a kind of preventive measure for many possible economic offenses, thus demonstrating the importance of the national law enforcement system.

The key aspects of the activity of law enforcement bodies - subjects of the national law enforcement system are studied. Taking into account the views of domestic scientists, scientists and specialists, the current regulatory framework and understanding the specifics of the economic sphere offers its vision of the list of key law enforcement agencies as subjects of the economic security system of Ukraine.

Attention is paid to the issues of the concept, as well as to the definition of the structure of the administrative and legal status of law enforcement agencies as subjects of the economic security system of Ukraine. The purpose, tasks and functions of the latter in this direction are defined and characterized. The competence of these structures is outlined, and their main powers as subjects of the domestic system of economic security are additionally singled out.

Given the current administrative and legal status of these entities, steps are proposed to improve it. It is emphasized that these innovations should have a positive impact on the work of these structures in the outlined direction in the future.

Key words: administrative and legal status, security, law enforcement agencies, system, status, subjects.

Одним із надважливих завдань Української держави, визнаних та задекларованих на конституційному рівні, $\epsilon$ забезпечення економічної безпеки. Зважаючи на очевидну складність, багатогранність, помітну уразливість та значимість національної економіки, ії ефективний захист є завданням багатьох вітчизняних державних інституцій.

Серед числа таких, зважаючи на функції, компетенцію та роль у державному механізмі, певне місце відводиться правоохоронним органам. Досвід правоохоронної діяльності окремих таких суб'єктів за певними напрямами показує, що вона позначається й на економічному секторі. Вказане зумовлює потребу виокремлення основних суб'єктів правоохоронної роботи, а також ознайомлення зі специфікою діяльності останніх за цими напрямами.

Перш ніж вирішувати поставлені наукові завдання, слід сфокусувати увагу на загальновизнаній проблемі, що стосується визначення поняття «правоохоронні органи». У науковій літературі існує багато думок із цього приводу, а також ведуться активні наукові розробки вказаного питання в сучасних дослідженнях. Як відмічають M.I. Мельник та M.I. Хавронюк, такий стан свідчить не тільки про відсутність єдиного підходу в розумінні того, які органи $є$ правоохоронними, але й ускладнює вирішення теоретичних проблем у цій сфері, здійснює негативний вплив на діяльність вказаних органів, оскільки безпосереднім чином впливає на правове регулювання іхньої компетенції, правове і соціальне становище працівників таких органів тощо [1, с. 191]. Проте існує стійке переконання, що формулювання чіткого понятійного апарату та подальше його визнання на нормативному рівні допоможе усунути ряд дискусійних питань у майбутньому. Також це позитивно вплине на розроблення супутніх нормативно-правових актів, адже існуватиме базова 
термінологія та розроблятиметься логічна й послідовна система законодавства.

Щодо думок відносно цього терміна, то, наприклад, C.B. Россоха стверджує, що під правоохоронним органом слід розуміти такий державний орган, що Конституцією України [2] та законами України наділений певним обсягом прав і обов'язків щодо здійснення захисту прав та законних інтересів громадян, юридичних осіб, суспільства і держави, шляхом вчинення специфічних дій примусового характеру, які проводяться в певній процесуальній формі [3, с. 13]. А.М. Детюк та С.М. Кременчуцький сходяться на думці, що йдеться про існуючі в суспільстві та державі установи й організації, що здійснюють правозастосовчу і правоохоронну функції, основне завдання яких - забезпечувати законність, захищати права та законні інтереси громадян, юридичних осіб, боротися зі злочинністю, іншими правопорушеннями [4, с. 34-35; 5]. Зустрічається позиція, що під такими суб'єктами розуміють певним чином відособлену за ознакою професійної діяльності самостійну групу органів держави, що мають свої чітко визначені завдання (наприклад, відновлення порушеного права, притягнення винного до юридичної відповідальності, тощо) $[6$, с. $17 ; 7$, с. 14]. На переконання Т.О. Пікулі, до правоохоронних належать органи, які поряд із другорядними (допоміжними) виконують або кілька головних правоохоронних функцій, які є визначальними в їхній діяльності (профілактичну, захисну, ресоціалізаційну, оперативно-розшукову функції, функцію розслідування злочинів, судового розгляду справ, розгляду справ про адміністративні правопорушення, розгляду справ про фінансові та адміністративно-господарські правопорушення, виконання вироків, рішень, ухвал і постанов судів, постанов органів дізнання і досудового слідства та прокурорів) [8, с. 79]. У свою чергу А.М. Куліш вказує, що правоохоронні органи - це спеціально уповноважені державні органи, які забезпечують додержання та реалізацію прав і свобод громадян, законності та правопорядку із додержанням встановлених законом правил та процедур відповідно до своєї компетенції [9, с. 92]. А.Ю. Гулягін вважає, що правоохоронними є органи, на які законом покладено виконання правоохоронних функцій, спрямованих спеціально на боротьбу зі злочинністю: 1) охорона громадського порядку та безпеки; 2) дізнання у справах про злочини; 3) попереднє розслідування злочинів; 4) прокурорський нагляд за дотриманням законів у діяльност по боротьбі зі злочинністю [10, с. 42]. Безумовно, в зарубіжних та вітчизняних наукових джерелах зустрічаються і мотивуються й інші думки відносно видів діяльності цих суб'єктів. До прикладу, К.Ф. Гуценко, М.А. Ковальов і К.Л. Савюк називають такі: 1) правосуддя; 2) організаційне забезпечення діяльності судів; 3 ) надання юридичної допомоги $[11$, с. $11-12 ; 12$, с. 38]. Вважється, що під такими суб' єктами варто розуміти окрему групу державних органів, наділених спеціальними завданнями, функціями й компетенцією, які реалізуються в межах правоохоронної діяльності з метою забезпечення охорони прав і законних інтересів фізичних, юридичних осіб та держави, що здійснюються на умовах та в порядку, визначеному чинним законодавством, із застосуванням невластивих для інших установ санкціонованих способів і засобів.

3 приводу наукових завдань, вочевидь, проблематикою, яка вимагає особливої уваги та окремого змістовного аналізу в межах вибраної тематики дослідження, безумовно, є виділення 3-поміж наявних правоохоронних структур саме тих, від результатів діяльності яких суттєво залежить поточне та перспективне становище економічного безпекового складника. Саме вони, будучи суб'єктами системи економічної безпеки України, відграють вагому роль у питанні забезпечення стійкості національної економіки до широкого діапазону зовнішніх, а також внутрішніх загроз.
Слід погодитися із загальновідомою думкою, що більшість правоохоронних органів так чи інакше дотичні до процесу забезпечення належного функціонування системи економічної безпеки України. Проте, очевидно, що діяльність деяких 3 їх числа, порівняно 3 іншими, суттєво впливає на економічне безпекове становище в державі. Нормами чинного законодавства визначений перелік структур, уповноважених забезпечувати національну, в тому числі й економічну безпеку України, до яких віднесено й деякі вітчизняні правоохоронні органи, проте, на наше переконання, законодавець не виділив всіх суб'єктів правоохоронної діяльності. Це, зокрема, зумовлюється сферою впливу багатьох національних правоохоронних структур на охоронювані законом суспільні відносини, порушення яких може суттєво позначитися на економічному безпековому становищі держави. Виходячи 3 такого розуміння, до числа основних правоохоронних органів як суб'єктів системи економічної безпеки України варто віднести такі: 1) органи прокуратури; 2) Національну поліцію; 3) Службу безпеки України; 4) Національне антикорупційне бюро України; 5) підрозділи податкової міліції Державної фіскальної служби України (до завершення здійснення заходів з утворення центрального органу виконавчої влади, на який покладатиметься обов'язок забезпечення запобігання, виявлення, припинення, розслідування та розкриття кримінальних правопорушень, об'єктом яких $\epsilon$ фінансові інтереси держави та/або місцевого самоврядування, що будуть віднесені до його підслідності [13]); 6) Державне бюро розслідувань.

Проаналізуємо специфіку діяльності кожного з названих правоохоронних органів саме як суб'єктів системи економічної безпеки України.

1. Органи прокуратури. Серед правоохоронних органів як суб'єктів системи економічної безпеки України вагоме місце, враховуючи їхнє призначення та роль серед інших державних інституцій, відводиться органам прокуратури. 3 числа всіх правоохоронних установ указані суб'єкти наділені законодавцем особливими повноваженням, не характерними для інших. У відповідності до ст. $131^{1}$ Конституції України від 28.06.1996 р. № 254к/96-ВР [2] прокуратура здійснює: 1) підтримання публічного обвинувачення в суді; 2) організацію і процесуальне керівництво досудовим розслідуванням, вирішення відповідно до закону інших питань під час кримінального провадження, нагляд за негласними та іншими слідчими і розшуковими діями органів правопорядку; 3) представництво інтересів держави в суді у виключних випадках і в порядку, що визначені законом [2]. ЗУ «Про прокуратуру» від 14.10.2014 р. № 1697-VII [14] деталізує перелік функцій аналізованого суб'єкта. Зокрема, йдеться про такі: 1) підтримання державного обвинувачення в суді; 2) представництво інтересів громадянина або держави в суді у випадках, визначених відповідним законодавством; 3) нагляд за додержанням законів органами, що провадять оперативно-розшукову діяльність, дізнання, досудове слідство; 4) нагляд за додержанням законів під час виконання судових рішень у кримінальних справах, а також у разі застосування інших заходів примусового характеру, пов'язаних з обмеженням особистої свободи громадян [30]. Вочевидь, що діяльність за кожним із напрямів часто може стосуватися прямого та опосередкованого забезпечення належного функціонування системи економічної безпеки України. Це стосується питання ефективної роботи вказаної структури - одного з багатьох суб'єктів досліджуваної системи, що насамперед санкціоновано й обгрунтовано впливає на діяльність інших учасників шляхом здійснення нагляду, а також вживає інші заходи, передбачені чинним законодавством.

2. Національна поліція. Серед суб'єктів системи економічної безпеки України своя особлива роль відводиться органам Національної поліції. Вагоме місце в цьому 
аспекті відводиться Департаменту стратегічних розслідувань Національної поліції України. У відповідності до п. 1 Загальних засад Положення про Департамент стратегічних розслідувань Національної поліції України від 23.10 .2019 р. № 1077 [15] вказаний суб'єкт $€$ міжрегіональним територіальним органом у складі кримінальної поліції Національної поліції України, який бере участь у реалізації державної політики з питань боротьби з організованою злочинністю та згідно із законодавством України здійснює оперативно-розшукову діяльність [15]. До його основних завдань в аспекті забезпечення економічної безпеки України варто віднести: 1) виявлення, припинення і попередження незаконної діяльності суспільно небезпечних організованих груп і злочинних організацій, у тому числі в органах державної влади та місцевого самоврядування, які впливають на криміногенну ситуацію в державі та в окремих іiі регіонах; 2) здійснення заходів, спрямованих на координацію діяльності органів (підрозділів) поліції у сфері боротьби з тероризмом відповідно до компетенції, визначеної законодавством України; 3) протидія корупції серед посадових осіб, на яких поширюється дія ЗУ «Про запобігання корупції», від 14.10.2014 р. № 1700-VII [16], вжиття заходів з метою виявлення корупційних правопорушень і правопорушень, пов'язаних 3 корупцією, та їх припинення відповідно до законодавства України; 4) здійснення оперативно-розшукової діяльності, спрямованої на здобуття інформації про криміногенні процеси в злочинному середовищі, пов'язані з протиправною діяльністю окремих осіб та злочинних угруповань, схеми легалізації (відмивання) доходів, одержаних злочинним шляхом [16]. Щодо більшості статей, підслідних Національній поліції, об'єктом яких є економічні відносини, оперативно-розшукові заходи проводить саме вказаний підрозділ. Досудове слідство, дізнання, а також оперативно-розшукова діяльність відносно всієї решти відповідних правопорушень здійснюється іншими підрозділами досліджуваного правоохоронного органу.

3. Служба безпеки України. Важливе місце серед правоохоронних органів як суб'єктів системи економічної безпеки Української держави відведено цій структурі. П. 3 ч. 1 ст. 19 ЗУ «Про національну безпеку України» від 21.06.2018 р. № 2469-VIII [17] передбачається, що одним iз напрямів діяльності Служби безпеки України $є$ також контррозвідувальний захист державного суверенітету, конституційного ладу і територіальної цілісності, оборонного і науково-технічного потенціалу, кібербезпеки, економічної та інформаційної безпеки держави, об'єктів критичної інфраструктури [17]. Націленість на економічний складник державної безпеки вказаного суб'єкта прямо визначена законодавцем, що передбачає існування відповідної компетенції для досягнення намічених цілей. Ознайомлюючись зі структурою Служби безпеки України та досліджуючи повноваження підрозділів, можемо відмітити, що вагоме значення в досліджуваному нами аспекті виправдано відводиться Головному управлінню по боротьбі з корупцією та організованою злочинністю та Головному управлінню контррозвідувального захисту інтересів держави у сфері економічної безпеки.

До основних напрямів діяльності СБУ щодо забезпечення економічної безпеки держави слід віднести такі: здійснення досудового слідства, проведення оперативнорозшукових і вжиття допустимих контррозвідувальних заходів. Також до цього переліку доцільно віднести такий напрям роботи, як складання протоколів про адміністративні правопорушення внаслідок вчинення окремих протиправних діянь [18, с. 84; 19, с. 85]. Кожен із цих напрямів роботи відграє свою роль відносно аналізованої системи.

4. Національне антикорупційне бюро України. Зважаючи на широкий спектр реальних загроз для економічного складника державної безпеки, вбачається за доцільне в межах цього питання сфокусувати свою увагу на Наці- ональному антикорупційному бюро України. У відповідності до чинного законодавства Національне антикорупційне бюро України $є$ державним правоохоронним органом, який має попереджати, виявляти, припиняти, розслідувати та розкривати корупційні правопорушення, віднесені до його підслідності, а також запобігати вчиненню нових [20]. При цьому завданнями вказаного суб'єкта правоохоронної діяльності є протидія тільки кримінальним корупційним правопорушенням, які вчинені вищими посадовими особами, уповноваженими на виконання функцій держави або місцевого самоврядування, та становлять загрозу національній безпеці [20]. Також законодавством передбачені й декілька інших умов, за яких вказаний суб'єкт повинен здійснювати досудове розслідування відповідних злочинів [21, с. 67]. Успішно виконуючи власні завдання та реалізуючи функції, вказана структура сприяє послабленню деструктивного впливу на деякі сектори національної економіки.

5. Підрозділи податкової міліції Державної фіскальної служби України. Зважаючи на існуючу компетенцію аналізованого суб'єкта, вбачається недоцільним його не репрезентувати як суб'єкта системи економічної безпеки України. Основною ознакою, що визначає місце і роль податкової міліції в системі органів виконавчої влади, $€$ застосування санкціонованого державою правового примусу. Його значення зростає в разі ускладнення економічної та криміногенної ситуації [22], що об'єктивно дає підстави позиціонувати його як суб'єкта досліджуваної системи. Відповідно до законодавства ці суб'єкти здійснюють досудове слідство, проводять оперативно-розшукові заходи, а також можуть складати протоколи про адміністративні правопорушення.

6. Державне бюро розслідувань. Віднесення цього правоохоронного органу до числа суб'єктів системи економічної безпеки України зумовлено специфікою сфери його впливу. Так, згідно зі ст. 5 3У «Про Державне бюро розслідувань» від 12.11.2015 р. № 794-VIII [23] вказаний суб'єкт вирішує завдання із запобігання, виявлення, припинення, розкриття і розслідування: 1) злочинів, учинених службовими особами, які займають особливо відповідальне становище відповідно до ч. 1 ст. 9 ЗУ «Про державну службу» від 10.12 .2015 р. № 889-VIII [24], особами, посади яких віднесено до першої - третьої категорій посад державної служби, суддями та працівниками правоохоронних органів, крім випадків, коли ці злочини віднесено до підслідності детективів Національного антикорупційного бюро України; 2) злочинів, учинених службовими особами Національного антикорупційного бюро України, заступником Генерального прокурора - керівником Спеціалізованої антикорупційної прокуратури або іншими прокурорами Спеціалізованої антикорупційної прокуратури, крім випадків, коли досудове розслідування цих злочинів віднесено до підслідності детективів підрозділу внутрішнього контролю Національного антикорупційного бюро України; 3) злочинів проти встановленого порядку несення військової служби (військових злочинів), крім злочинів, передбачених ст. 422 Кримінального кодексу України від 05.04.2001 р. № 2341-III [23; 25]. Вочевидь, що і вказаний суб'єкт правоохоронної діяльності уповноважений сприяти забезпеченню належного функціонування вітчизняної системи економічної безпеки. Це зумовлено специфікою підслідності органу, адже за певних умов суб'єкт розслідує та проводить оперативно-розшукові заходи щодо багатьох правопорушень, наслідки від скоєння яких можуть нести загрозу економічній складовій частині державної безпеки.

Отже, за результатами наукового дослідження наголошено на залежності системи економічної безпеки України від роботи правоохоронних органів. 3 урахуванням існуючих наукових думок та виходячи з власного переко- 
нання, запропоновано авторське бачення поняття «правоохоронні органи».

Визначено коло суб'єктів правоохоронної діяльності, які потенційно можуть суттєво впливати на функціонування системи економічної безпеки України. Розглянуто й проаналізовано завдання та звернуто увагу на специфіку роботи кожного з них саме як суб'єктів вітчизняної системи економічної безпеки.
Вважаємо, що результати наукового дослідження можуть мати значення та становитимуть інтерес під час вивчення і дослідження широкого кола питань для вчених, науковців, фахівців 3 питань забезпечення функціонування системи економічної безпеки та ін. Зокрема, йдеться про такі аспекти, як поняття «правоохоронні органи», правоохоронні органи як суб'єкти системи економічної безпеки України, їх завдання в цій сфері тощо.

\section{ЛITEPATYPA}

1. Мельник М.І., Хавронюк М.І. Правоохоронні органи та правоохоронна діяльність : навч. посібник. Київ : Атіка, 2002.576 с.

2. Конституція України : Закон від 28.06.1996 р. № 254к/96-BP. Дата оновлення: 15.03.2016 p. URL: https://zakon.rada.gov.ua/laws/ show (дата звернення: 28.07.2020)

3. Россоха С.В. Правоохоронні органи держави в механізмі захисту прав і свобод людини і громадянина : автореф. дис. ... канд. юрид. наук : 12.00.02. Харків, 2016. 20 С.

4. Детюк А.М. Правоохоронні органи як суб'єкти системи забезпечення економічної безпеки України. Підприємництво, господарство і право, 2009. № 12 (168). С. 33-37.

5. Кременчуцький С.М. Діяльність правоохоронних органів України щодо адміністративно-правової протидії нелегальній імміграції : дис. ... канд. юрид. наук : 12.00.07. Львів, 2009. 219 с.

6. Божьев В.П. Правоохранительные органы Российской Федерации. Москва : Спарк, 1996. 414 с.

7. Гуценко К.Ф., Ковалев М.А. Правоохранительные органы. Москва : Зерцало, 1997. 367 с.

8. Пікуля Т.О. Правоохоронні органи в механізмі держави України (теоретико-правові питання фуункціонування) : авторефр. дис. ... канд. юрид. наук : 12.00.01. Київ, 2004. 20 с.

9. Куліш А.М. Щодо визначення поняття «правоохоронні органи». Право і Безпека. 2005. № 5. Т. 4. С. 90-93.

10. Гулягин А.Ю. Правоохранительная система: обусловленность законностью. Рос. Следователь. 2012. № 9. С. 41-43.

11. Гуценко К.Ф., Ковалев М.А. Правоохранительные органы : учеб. для юрид. вузов и фак. Москва : Зерцало, 2007. 440 с.

12. Савюк Л.К. Правоохранительные органы : учебник. 2-е изд., перераб. и доп. Москва : Норма, 2007. 704 с.

13. Про внесення змін до деяких актів Кабінету Міністрів України : Постанова від 25.09.2019 р. № 846. URL: https://zakon.rada.gov.ua/ laws/show/846-2019-\%D0\%BF (дата звернення: 29.07.2020).

14. Про прокуратуру : Закон від 14.10.2014 р. № 1697-VII. Дата оновлення: 03.07 .2018 p. URL: https://zakon.rada.gov.ua/laws/ show/1697-18 (дата звернення: 29.07.2020)

15. Положення про Департамент стратегічних розслідувань Національної поліції України : Положення від 23.10.2019 p. № 1077. URL: http://tranzit.ltd.ua/nakaz/ (дата звернення: 29.07.2020).

16. Про запобігання корупції : закон України від 14.10.2014 p. № 1700-VII. Дата оновлення: 30.03.2020 p. URL: https://zakon.rada.gov.ua/ laws/show/1700-18\#Text (дата звернення: 29.07.2020).

17. Про національну безпеку : Закон України від 21.06.2018 р. № 2469-VIII. URL: https://zakon.rada.gov.ua/laws/show/2469-19 (дата звернення: 29.07.2020).

18. Гаруст Ю.В., Мельник В.І. Правоохоронні органи на захисті економічної безпеки України: адміністративно-правовий аспект : монографрія. Суми : видавничо-виробниче підприємство «Мрія», 2019. 256 с.

19. Garust Y.V., Melnyk V.I. Law enforcement agencies on protection of economic security of Ukraine: administrative and legal aspect : monograph. 2019. 368 p.

20. Про Національне антикорупційне бюро України : Закон України, від 14.10.2014 р. № 1698-VII. Дата оновлення: 03.07.2018 p. URL: http://zakon5.rada.gov.ua/laws/show/1698-18 (дата звернення: 29.07.2020).

21. Мельник В.І. Адміністративно-правове забезпечення діяльності Національного антикорупційного бюро України як суб'єкта забезпечення функціонування системи економічної безпеки держави. Правові горизонти. 2020. Вип. 21 (34). С. 65-70.

22. Шестаков С.В. Адміністративно-правовий статус працівника міліції : дис. ... канд. юрид. наук : 12.00.07. Харків, 2003. 205 с.

23. Про Державне бюро розслідувань : Закон України від 12.11.2015 р. № 794-VIII. Дата оновлення: 16.05.2019 p. URL: https://zakon.rada.gov.ua/laws/show/794-19 (дата звернення: 30.07.2020).

24. Про державну службу : Закон від 10.12.2015 р. № 889-VIII. Дата оновлення: 23.11 .2018 p. URL: https://zakon.rada.gov.ua/laws/ show/889-19 (дата звернення: 30.07.2020)

25. Кримінальний кодекс України : Кодекс від 13.04.2012 р. № 4651-VI. Дата оновлення: 14.01.2020p. URL: https://zakon.rada.gov.ua/ laws/show/4651-17 (дата звернення: 30.07.2020). 
УДК 342.9

DOI https://doi.org/10.32782/2524-0374/2020-4/43

\title{
АДМІНІСТРАТИВНО-ПРАВОВІ ЗАСАДИ ОХОРОННОЇ ДІЯЛЬНОСТІ
}

\author{
ADMINISTRATIVE AND LEGAL BASIC SECURITY ACTIVITIES
}

\author{
Міщук І.В., к.ю.н., \\ доцент кафедри конституційного права та галузевих дисциплін \\ Навчально-науковий інститут права \\ Національного університету водного господарства та природокористування
}

Зазначимо, що охоронна діяльність - це далеко не сучасне явище. Вона існувала й в минулому. Це й не дивно, адже людина від народження має певні речі, які потребують охорони. Від народження нам потрібно охороняти власне життя, а надалі ми маємо охороняти й наше майно, яке ми змогли набути протягом свого життєвого шляху.

У ході нашого дослідження ми визначили для себе такий алгоритм роботи: спочатку, щоб повноцінно розкрити тему нашого дослідження, ми зупинилися на аналізі поняття охоронної діяльності, а також додатково дослідили суб'єктів та об'єктів охоронної діяльності. Об'єктом охоронної діяльності вважається фізична особа, ії майно; щодо суб'єкта - це суб'єкт, що здійснює охорону діяльність, але важливо, що б цей суб'єкт був зареєстрований на території України, а також обов'язково мав ліцензію на здійснення охоронної діяльності.

У ході дослідження на основі аналізу українського законодавства ми встановили, які саме бувають види охоронних послуг. Як вже зазначалося вище, це може бути охорона фізичної особи, ії майна, а також охоронятися може і юридична особа.

Було з'ясовано, що до суб'єктів охоронної діяльності в Україні відносяться: поліція охорони, приватні охоронні структури, а також Державна служба охорони при Міністерстві внутрішніх справ України. Також деякі науковці відносять до суб'єктів охоронної діяльності публічних юридичних осіб, їхні структурні підрозділи, відомчу воєнізовану охорону, відомчу охорону, спеціалізоване охоронне підприємство, спеціальні відомчі підрозділи охорони, служби морської безпеки тощо, правоохоронні органи, військові частини й підрозділи Збройних Сил України, органи охорони державного кордону, Національну гвардію України.

Детальніше ми зупинилися саме на охоронній діяльності поліції охорони, приватних охоронних структурі, а також Державної служби охорони при Міністерстві внутрішніх справ України.

У роботі було використано такі методи дослідження, як аналіз, теоретичне пізнання, узагальнення.

Ключові слова: охоронна діяльність, адміністративно-правові засади, правове регулювання, поліція охорони, державна служба охорони при МВС України, приватні охоронні структури.

Notice that, security activities it is not a modern phenomenon. It appeared in past and still exist, and it is not wondering. When we born we have our live, which must be protected, also later throughout our lives we get other things such as: flat/house, car or other property, which also must be protected.

During the research, we defined such an algorithm for work to begin with, to fully reveal the topic of our research, we focused on the analysis of the concept of security activities, as well as further explored the subjects and objects of security activities. So we identified that the object of security activities is a natural person, his property, as for the subject, it is the entity that carries out security activities, but it is important that this entity was registered in Ukraine, and must have license to carry out security activities.

In the course of the research, based on the analysis of Ukrainian legislation, we established what exactly are the types of security services. As mentioned above, this can be the protection of an individual, his property, as well as a legal entity can be protected as well.

We found out that the subjects of security activity in Ukraine include: security police, private security structures, as well as the State Security Service under the Ministry of Internal Affairs of Ukraine. Also, some scientists refer to the subjects of security activities of public legal entities, their structural units, departmental paramilitary security, departmental security, specialized security company, special departmental security units, maritime security services, etc., law enforcement agencies, military units and units of the Armed Forces of Ukraine, state border guards, the National Guard of Ukraine.

In our work, we focused more on the security activities of the security police, private security structures and the State Security Service under the Ministry of Internal Affairs of Ukraine.

In the work were used the following research methods as analysis, theoretical knowledge, generalization

Key words: security activity, administrative and legal bases, legal regulation, security police, state security service at the Ministry of Internal Affairs of Ukraine, private security structures.

Постановка проблеми. Охорона життя фізичних осіб, їхнього майна - одна з пріоритетних цілей держави. Це все вимагає чіткої роботи органів охорони й лаконічно вибудуваного правового регулювання цієї сфери діяльності. Тому дослідження поставленої теми актуальне, зокрема, як саме здійснюється охоронна діяльність, хто є суб' єктами, а хто є об'єктами охорони, на яких правових засадах вона грунтується.

Аналіз останніх досліджень та публікацій. У роботі ми використали праці таких науковців: О.М. Сщука, М.В. Завального, О.П. Угровецького, А.Г. Сачаво, а також ми зверталися до законодавчих актів, а саме Закону України «Про охоронну діяльність».

Постановка завдання. Дослідити теоретичні засади адміністративно-правової основи охоронної діяльності.

Результати дослідження. У Законі України № 4616VI від 22 березня 2012 року «Про охоронну діяльність» наводиться таке визначення: охоронна діяльність надання послуг з охорони власності й громадян; об'єкт охорони - фізична особа та/або майно; суб'єкт охоронної діяльності - суб'єкт господарювання будь-якої форми власності, створений і зареєстрований на території України, що здійснює охоронну діяльність на підставі отриманої у встановленому порядку ліцензії $[1$, ст. 1$]$.

М.В. Сийплокі у своїй праці зазначає, що охорону можна розглядати в декількох аспектах:

- як систему правових норм, які здійснюють охорону певних суспільних відносин;

- як діяльність фізичних або юридичних осіб зі створення належних умов реалізації своїх прав і законних інтересів [2, с. 62].

С.А. Шаронов на підставі дослідження історичних правових джерел під охороною розуміє дії держави й осіб, яким державою надаються відповідні повноваження, закріплені в актах права й спрямовані на забезпечення стану захищеності об'єктів, що охороняються від протиправних посягань, які здійснюються з використанням спеціальних засобів і без них [3, с. 139].

Отож, виходячи 3 наведених вище визначень, можемо підсумувати, що охоронна діяльність - діяльність, яка здійснюється задля захисту фізичних чи юридичних осіб, їхнього майна, державними й недержавними установами, 
які отримали ліцензію на здійснення охоронної діяльності й зареєстровані в Україні.

Предмет охоронної діяльності поділяється на ліцензування охоронної діяльності й контроль за дотриманням суб'єктами охоронної діяльності ліцензійних умов; накладення на охоронні структури адміністративних санкцій; організацію навчання працівників охоронних структур усіх форм власності; контроль за застосуванням фізичної сили, спеціальних засобів; участь у проведенні розслідувань про законність застосування фізичної сили, спеціальних засобів і вогнепальної зброї [4, с. 7].

Види охоронних послуг:

1) охорона майна громадян;

2) охорона майна юридичних осіб

$3)$ охорона фізичних осіб [1 ст. 5].

Забезпечення охоронної діяльності:

1) використання пунктів централізованого спостереження, технічних засобів охорони, транспорту реагування, службових собак;

2) контроль за станом майнової безпеки об'єкта охорони;

3) запобігання загрозам особистій безпеці фізичної особи, яка охороняється;

4) реагування в межах наданих законом повноважень на протиправні дії, пов'язані з посяганням на об'єкт охорони [1 ст. 6].

Органи виконавчої влади у сфері адміністративноправового регулювання охоронної діяльності - це органи публічного управління, які мають певну визначену законодавством компетенцію та структуру, територіальний масштаб діяльності, утворюються в порядку, встановленому законом, і реалізують свої повноваження у сфері регулювання охоронної діяльності $[4$, с. 9].

Найчастіше серед суб' єктів охоронної діяльності виділяють поліцію охорони й приватні охоронні структури, Це пов'язано з тим, що ці суб'єкти є безпосередніми учасниками ринку охоронних послуг.

Водночас низка суб'єктів охоронної діяльності забезпечує охорону окремих об'єктів через законодавче закріплення відповідних функцій, хоча й не є учасником ринку охоронних послуг. Це, зокрема, публічні юридичні особи, їхні структурні підрозділи, відомча воєнізована охорона, відомча охорона, спеціалізоване охоронне підприємство, спеціальні відомчі підрозділи охорони, служби морської безпеки тощо й правоохоронні органи, військові частини й підрозділи Збройних Сил України, органи охорони державного кордону, Національна гвардія України [6, с. 134].

Поліції охорони притаманні такі повноваження: здійснювати охорону об'єктів права державної власності у випадках і порядку, визначених законом та іншими нормативно-правовими актами, а також брати участь у виконанні державної охорони, реалізація на договірних засадах охорони фізичних осіб та об'єктів права приватної та комунальної власності [6, с. 134].

О.П. УГровецький у своїй праці зазначив, що охорона, а також пов'язана 3 нею діяльність відіграють дуже значну роль у житті й розвитку суспільства та його нормального функціонування щодо забезпечення правопорядку. Послуги 3 охорони власності й забезпечення особистої безпеки громадян - це вид адміністративноправових відносин, який за своїм суб' єктивним складом і змістом є зобов'язальними правовідносинами й здійснюється на підставі законодавчих та інших нормативно-правових актів.

Особливості адміністративних правовідносин полягають насамперед у тому, що в них завжди беруть участь органи виконавчої влади або їх представники, у сфері досліджуваної теми - працівники Державної служби охорони при Міністерстві внутрішніх справ (далі - МВС) України, яких наділено владними повноваженнями по здійсненню виконавчо-розпорядчих функцій. Крім цього, адміністративні правовідносини можуть виникнути з іні- ціативи будь-якої зі сторін, згоди іншої сторони не вимагається. Конфлікти, спори, які виникають між сторонами таких правовідносин, розв'язуються, як правило, в адміністративному й судовому порядку. Відповідальність за неналежне виконання сторонами обов'язків настає перед державою. Для регулювання адміністративно-правових відносин властиві відношення субординації або владні приписи, які походять від уповноваженого суб' єкта управління. Ці приписи мають односторонній характер, в них висловлюється воля суб'єкта управління, тому адміністративні правовідносини ще називають відносинами влади й підпорядкування. Саме такими владними суб'єктами є працівники Державної служби охорони при МВС України в правовідносинах, які виникають із приводу охорони всіх форм власності й забезпечення особистої безпеки громадян [5, с. 8].

Практичне здійснення охоронної діяльності Державною службою охорони (далі - ДСО) має конкретний зміст, оскільки виявляється та існує у визначених формах, які своєю чергою показують, яким чином представники міліції охорони виконують обов язки, що покладені на них, як вони реалізують свою компетенцію. Виділено такі форми адміністративної діяльності ДСО при МВС України: організаційні заходи; вчинення організаційно-технічних і матеріальних дій; видання індивідуальних актів.

Основними методами адміністративної діяльності Державної служби охорони стосовно надання охоронних послуг є примус і переконання [6, с. 11].

Запобігання правопорушенням приватними охоронними організаціями розглядається крізь призму залежності суб'єктів вказаної діяльності від договірних зобов'язань, що виникають у результаті цивільного договору. На думку А.Г Сачаво, приватні охоронні організації, що з'явилися в нашій країні, дозволили частково компенсувати недоліки державної правоохоронної системи щодо захисту життя, здоров'я та власності громадян, а також запобігання правопорушенням, хоча сам захист суспільного порядку не став оптимальним. Спостерігається повна залежність сучасних приватних охоронних підприємств від так званого «хазяїна, що платить», іншими словами - юридичної або фізичної особи, яка користується платними послугами такого роду організацій. Але не можна розглядати правоохоронну діяльність як залежну тільки від бажань окремих суб'єктів, як діяльність безправну, що керується тільки волею окремого власника [7, с. 11].

Розвиваючи приватну, іншими словами недержавну, охоронну діяльність, держава тим самим частково делегує свою правоохоронну функцію, а також розвиває ініціативу населення. Приватна охоронна діяльність нині єдиний різновид правоохоронної діяльності, що реально працює. Отже, населення в особі приватних підприємців може надати й надає відчутну допомогу в запобіганні правопорушенням. Держава повинна відстежувати можливості, за яких спиратиметься на населення в правоохоронній сфері, заохочувати й розвивати їх [7, с. 12].

Створення недержавних охоронних організацій іде шляхом офіційної політики МВС України, яке вважає, що реалії сьогодення змушують вести пошуки нових форм і методів роботи, побудови організаційної структури системи управління з метою вжиття додаткових заходів, спрямованих на ефективне забезпечення правопорядку, захисту конституційних прав громадян та активізації боротьби зі злочинністю [7, с. 12].

У чинних нормативних документах приватна охоронна діяльність визначена як надання на договірних засадах послуг фізичним та юридичним особам щодо здійснення заходів охорони нерухомих об'єктів та іншого майна, в тому числі вантажів, що перевозяться, а також забезпечення особистої безпеки громадян підприємствами, що мають спеціальну ліцензію (дозвіл) органів внутрішніх справ України [7, с. 13]. 
У сучасних умовах автор виділяє такі форми взаємодії підприємств, які здійснюють приватну охоронну діяльність, $з$ органами внутрішніх справ: спільна діяльність (проведення заходів) правоохоронної спрямованості; надання взаємодопомоги й підтримки один одному; обмін інформацією з питань попередження та припинення різних правопорушень; спільна розробка й планування заходів щодо вдосконалення охорони власності, а також запобігання правопорушенням [7, с. 14].

У процесі взаємодії органів внутрішніх справ і підприємств, які здійснюють приватну охоронну діяльність, спостерігається злиття характеру й змісту їхніх дій щодо охорони правопорядку в країні. Тому відсутність конкретних поставлених завдань, непідготовленість до процедури взаємодії, відсутність довіри, а також відсутність нормативної бази виключають можливість установлення реального співробітництва або роблять його значною мірою неефективним [7, с. 14].

Висновки. Отже, в нашій роботі ми досліджували адміністративно-правові засади охоронної діяльності. Охоронна діяльність здійснюється на засадах законності, адже в законодавстві України $є$ закон «Про охоронну діяльність», який чітко регламентує особливості ії здійснення, та договору, адже укладається договір, що має на меті регулювати відносини щодо охоронної діяльності.

Аналізуючи поняття охоронної діяльності, ми вказали суб'єктів та об'єктів охоронної діяльності. Об'єктами $\epsilon$ фізичні, юридичні особи та їх майно, щодо суб'єктів то це поліція охорони, ДСО при МВС України й струк- тури приватної охоронної діяльності, також можна віднести до суб'єктів охоронної діяльності відомчу воєнізовану охорону, відомчу охорону, спеціалізоване охоронне підприємство, спеціальні відомчі підрозділи охорони, служби морської безпеки тощо, правоохоронні органи, військові частини й підрозділи Збройних Сил України, органи охорони державного кордону, Національну гвардію України.

Ми визначили види охоронних послуг та як саме здійснюється охоронна діяльність і можемо зазначити, що вид охоронних послуг залежить від того, над чим ця охоронна діяльність буде проводитися, тобто розрізняють такі види: охорона фізичної особи, охорона юридичної особи, охорона майна.

Варто зазначити, що до суб'єктів охоронної діяльності насамперед належать такі установи, як поліція охорони, ДСО при МВС України й структури приватної охоронної діяльності. Коротко проаналізувавши кожну 3 вищезазначених організацій, можемо зауважити, щодо форм адміністративної діяльності ДСО при МВС України можна віднести організаційні заходи, вчинення організаційно-технічних і матеріальних дій і видання індивідуальних актів. Поліція охорони проводить охорону об'єктів права державної власності у випадках і порядку, визначених законом та іншими нормативно-правовими актами, а також здійснює охорону фізичних осіб та об'єктів права приватної та комунальної власності на договірних засадах; щодо приватних охоронних установ, то вони здійснюють охоронну діяльність лише на договірних засадах.

\section{ЛITEPATYPA}

1. Про охоронну діяльність : Закон України від 03 липня 2020 р. № 4616-VI / Верховна Рада України. URL: https://zakon.rada.gov.ua/ laws/show/4616-17\#Text (дата звернення: 08.07.2020).

2. Сийплокі М.В. Охоронна діяльність в Україні (поняття, ознаки, кримінально-правовий захист). Вісник кримінологічної асоціації України. 2019. № 2 (21). С. 61-67.

3. Шаронов С.А. Правовая сущность категории «охрана» как основание возникновения охранной деятельности: историкосравнительный аспект. Вестник Саратовской государственной юридической академии. 2013. № 6 (95). С. 134-139.

4. Єщук О.М. Адміністративно-правове регулювання охоронної діяльності в Україні : автореф. дис. ... канд. юрид. наук :12.00.07. Запоріжжя, 2011. $16 \mathrm{c.}$

5. Завальний М.В. Правовий статус державних та недержавних суб'єктів охоронної діяльності в Україні. Форум права. 2016. № 4. С. 133-139.

6. Угровецький О.П Організаційно-правові засади охоронної діяльності державної служби охорони при МВС України : : автореф. дис. ... канд. юрид. наук :12.00.07. Харків, 2004. 20 с.

7. Сачаво А.Г. Адміністративно-правові основи діяльності приватних охоронних структур та їх взаємодія з ОВС України : автореф. дис. ... канд. юрид. наук :12.00.07. Київ, 2004. 18 с. 


\title{
АДМІНІСТРАТИВНО-ПРАВОВИЙ СТАТУС ПІДРОЗДІЛІВ ЮВЕНАЛЬНОЇ ПРЕВЕНЦЇ̈ НАЦІОНАЛЬНОӤ ПОЛІЦЇ̈ ЯК СУБ'ЄКТІВ ПРОФІЛАКТИКИ ПРАВОПОРУШЕНЬ
}

\author{
ADMINISTRATIVE AND LEGAL STATUS OF JUVENILE PREVENTION UNITS \\ OF THE NATIONAL POLICE AS SUBJECTS OF CRIME PREVENTION
}

\author{
Назар Т.Я., к.ю.н., \\ викладач кафедри адміністративно-правових дисциплін \\ Львівський державний університет внутрішніх справ
}

У науковій статті досліджено й розкрито зміст адміністративно-правового статусу підрозділів ювенальної превенції Національної поліції України як суб'єктів профілактики правопорушень.

Зазначено, що для здійснення якісного аналізу адміністративно-правового статусу підрозділів ювенальної превенції Національної поліції України як суб'єктів профрілактики правопорушень доцільно схарактеризувати їхній елементний склад. 3 цією метою автором взято за основу класифікацію елементів, відповідно до якої адміністративно-правовий статус державного органу складається з трьох блоків:

1) цільового, який визначає норми про цілі (мету), завдання та функції діяльності;

2) організаційно-структурного, який утворюють правові приписи, що регламентують порядок утворення, реорганізації, ліквідації органу, його структуру, лінійну й функціональну підпорядкованість;

3) компетенції як сукупності владних повноважень і підвідомчості.

Запропоновано під адміністративно-правовим статусом підрозділів ювенальної превенції Національної поліції України як суб'єктів профілактики правопорушень розуміти сукупність закріплених адміністративно-правовими нормами взаємопов'язаних елементів, завдяки яким підрозділи ювенальної превенції Національної поліції України реалізують свої повноваження щодо виявлення та усунення причин, які призводять до вчинення дітьми правопорушень, здійснюють інші профілактичні заходи як самостійно, так і взаємодіючи з іншими суб'єктами профілактики. Вказано на доцільність закріплення на нормативно-правовому рівні повноважень підрозділів ювенальної превенції Національної поліції України організовувати й координувати проведення узгоджених заходів з іншими підрозділами Національної поліції України щодо профрілактики правопорушень серед дітей.

Ключові слова: адміністративно-правовий статус, підрозділи ювенальної превенції Національної поліції України, правопорушення, суб'єкти профрілактики правопорушень.

The scientific article examines and reveals the content of the administrative and legal status of juvenile prevention units of the National Police of Ukraine as subjects of crime prevention.

It is noted that in order to analyze the administrative and legal status of juvenile prevention units of the National Police of Ukraine as subjects of crime prevention qualitatively, it is advisable to characterize their elemental composition. For this purpose, the author takes as a basis the classification of elements, according to which the administrative and legal status of a state body consists of three blocks:

1) target, which determines the rules of purpose (goal), objectives and functions of the activity;

2) organizational and structural, which is formed by legal regulations governing the formation, reorganization, liquidation of the body, its structure, linear and functional subordination;

3) competence as a complex of powers and jurisdiction.

It is proposed to understand the administrative and legal status of juvenile prevention units of the National Police of Ukraine as subjects of crime prevention as a set of interrelated and interdependent elements fixed in administrative and legal norms, due to which juvenile prevention units of the National Police of Ukraine exercise their powers to identify and eliminate causes that lead to the offenses commission by children, carry out other preventive measures both independently and interacting with other subjects of prevention. The expediency of consolidating at the legal level the powers of juvenile prevention units of the National Police of Ukraine to organize and coordinate the implementation of agreed activities with other units of the National Police of Ukraine on crime prevention among children has been proved.

Key words: administrative and legal status, juvenile prevention units of the National Police of Ukraine, offense, subjects of crime prevention.

Актуальність теми. Процес реформування правоохоронної системи України, зокрема створення підрозділів ювенальної превенції Національної поліції України, зумовлює вивчення та аналіз їхнього адміністративноправового статусу як суб'єктів профілактики правопорушень серед дітей. Непрості реалії сучасного економічного, соціально-демографічного й культурного становища в нашій країні об'єктивно довели те, що нині діти часто незахищені й намагаються розв'язувати свої проблеми методами й шляхами, які вони обирають самостійно. Результатом цього є збільшення кількості дітей, чия поведінка виходить за межі моральних і правових норм та які стають об'єктом нагляду правоохоронних органів. Серед основних завдань підрозділів ювенальної превенції Національної поліції України $є$ спрямовані на запобігання вчинення дітьми правопорушень.

Аналіз останніх публікацій. Поняттю правового статусу й адміністративно-правового статусу органів державної влади присвячено праці науковців усіх галузей права. Так, особливості адміністративно-правового статусу різних органів державної влади розглядали такі вчені, як Г. Балика, С. Банах, Д. Бахрах, В. Глуховеря, В. Гуцул, М. Золотарьова, І. Коротич, В. Комзюк, О. Костилєв, О. Лавренова, Т. Мінка, А. Мельник, С. Попова, О. Сікорський, О. Стасюк та інші.
Дослідження поняття та змісту адміністративно-правового статусу підрозділів Національної поліції України були предметом вивчення I. Волокітенко, В. Грітчіна, С. Діденко, Д. Ластович, С. Лелет, Д. Катрич, О. Кожухар, Т. Плугатар, А. Сердюк, А. Стеблянко, В. Фелик. Однак особливості адміністративно-правового статусу підрозділів ювенальної превенції Національної поліції України як суб'єктів профілактики правопорушень серед дітей у працях науковців викладено недостатньо.

Метою статті є здійснення аналізу адміністративноправового статусу підрозділів ювенальної превенції Національної поліції України як суб'єктів профілактики правопорушень серед дітей шляхом дослідження законодавства й праць вчених, які розглядали таку тематику.

Правовий статус суб'єкта складний за своєю структурою, що підтверджується значною кількістю наукових досліджень. Водночас натепер у правовій науці відсутній єдиний підхід серед науковців у визначенні поняття «правовий статус», «адміністративно-правовий статус» та елементного складу адміністративно-правового статусу органів публічної адміністрації, зокрема підрозділів ювенальної превенції Національної поліції України.

Поняття «правовий статус» загальне щодо статусів, визначених галузевими нормами, й вважається змістов- 
нішим, оскільки містить поняття адміністративно-правового статусу. Це, на думку М.М. Алексійчука, пояснюється тим, що правовий статус визначає загальне правове становище будь-якого органу Міністерства внутрішніх справ шляхом наділення його комплексом прав та обов'язків [1, с. 7]. Так, у розділі II «Основні завдання та повноваження підрозділів ЮП» Інструкції з організації роботи підрозділів ювенальної превенції Національної поліції України [2] вказано, що серед основних завдань підрозділів ювенальної превенції є профілактична діяльність, спрямована на запобігання вчиненню дітьми кримінальних та адміністративних правопорушень, виявлення причин та умов, які цьому сприяють, вжиття в межах своєї компетенції заходів для їхнього усунення.

Д.М. Ластович розуміє адміністративно-правовий статус Національної поліції як визначене нормами адміністративного права юридичне становище такого органу влади в механізмі держави й системі суспільних відносин і вважає, що сутнісний зміст правового становища Національної поліції проявляється в цілях, завданнях і принципах діяльності такого органу, в тих можливостях, якими він користується, реалізуючи своє функціональне призначення, та обов'язках, які на нього покладаються [3, с. 71]. Під час визначення адміністративно-правового статусу Національної поліції в окремих сферах діяльності чи окремих поліцейських підрозділів науковці беруть до уваги загальні елементи адміністративно-правового статусу поліції та вказують на певні особливості.

Для дослідження змісту адміністративно-правового статусу підрозділів ювенальної превенції Національної поліції України як суб'єкта профілактики правопорушень серед дітей доцільно розглянути структурні елементи цього статусу. У науковій літературі більшість учених аналізують адміністративно-правовий статус органу публічної адміністрації, беручи за основу класифікацію елементів, запропоновану Д.М. Бахрахом, відповідно до якої адміністративно-правовий статус державного органу складається з трьох блоків:

1) цільового, який визначає норми про цілі (мету), завдання та функції діяльності;

2) організаційно-структурного, який утворюють правові приписи, що регламентують порядок утворення, реорганізації, ліквідації органу, його структуру, лінійну й функціональну підпорядкованість;

3) компетенції як сукупності владних повноважень і підвідомчості [4, с. 85$]$.

Отже, для здійснення якісного аналізу адміністративно-правового статусу підрозділів ювенальної превенції Національної поліції України як суб'єкта профілактики правопорушень серед дітей доцільно схарактеризувати елементний склад відповідно до вищенаведеної класифікації елементів адміністративно-правового статусу органу публічної адміністрації.

Структурні елементи адміністративно-правового статусу тією чи іншою мірою закріплюються в адміністративно-правових нормах. Правові основи адміністративно-правового статусу підрозділів ювенальної превенції Національної поліції України як суб'єкта профілактики правопорушень серед дітей визначаються Конституцією України й наказом Міністерства внутрішніх справ України «Про затвердження Інструкції з організації роботи підрозділів ювенальної превенції Національної поліції України» від 19 грудня 2017 р. № 1044 [2]. Зокрема, саме Інструкція з організації роботи підрозділів ювенальної превенції Національної поліції України на нормативно-правовому рівні закріплює поняття профілактики адміністративних і кримінальних правопорушень серед дітей як діяльності підрозділів Національної поліції України, спрямованої на виявлення та усунення причин та умов, що призводять до вчинення дітьми адміністративних і кримінальних правопорушень (п. 5 р. 1 Інструкції з організації роботи підрозділів ювенальної превенції Національної поліції України).
До цільового блоку включають такі елементи, як «мета» («ціль»), «завдання», «функції». Мету в такому випадку можна розуміти як вказівку в нормативно-правових актах на забезпечення певної соціальної потреби, що в положеннях та інших установчих документах конкретизується в переліку завдань і функцій, що виконуються. Профілактична мета як складова частина адміністративно-правового статусу підрозділів ювенальної превенції Національної поліції України хоча й не виокремлена в Інструкції з організації роботи підрозділів ювенальної превенції Національної поліції України, однак вона конкретизується та розкривається через поставлені перед ними завдання. Так, відповідно до Інструкції, основними завданнями підрозділів ювенальної превенції як суб’єктів профілактики правопорушень серед дітей є:

профілактична діяльність, спрямована на запобігання вчиненню дітьми кримінальних та адміністративних правопорушень, виявлення причин та умов, які цьому сприяють, вжиття в межах своєї компетенції заходів для їхнього усунення;

ведення профілактичного обліку дітей, схильних до вчинення правопорушень, і проведення з ними заходів індивідуальної профілактики;

участь в установленні місцеперебування дитини в разі iї безвісного зникнення чи отриманні даних для цього в межах кримінального провадження, відкритого за фактом її безвісного зникнення;

вжиття заходів щодо запобігання та протидії домашньому насильству, вчиненому дітьми й щодо них, а також жорстокому поводженню $з$ дітьми;

вжиття заходів щодо запобігання дитячій бездоглядності, в тому числі здійснення поліцейського піклування щодо неповнолітніх осіб;

провадження діяльності, пов'язаної із захистом права дитини на здобуття загальної середньої освіти.

Всі ці завдання підрозділів ювенальної превенції спрямовані на запобігання вчиненню правопорушень дітьми.

Наступним елементом адміністративно-правового статусу підрозділів ювенальної превенції Національної поліції України як суб'єкта профілактики правопорушень серед дітей є структурно-організаційний блок, що містить нормативне регулювання порядку створення, реорганізації, ліквідації підрозділів поліції; встановлення та зміни організаційних структур, процедур діяльності; звітність і підконтрольність, право на власну символіку тощо.

На рівні апарату центрального органу управління поліції для виконання основних завдань щодо профілактики правопорушень, у тому числі й правопорушень серед дітей, створено Департамент превентивної діяльності Національної поліції України, який слід вважати спеціалізованим суб'єктом профілактики. У структурі Департаменту превентивної діяльності Національної поліції України діє, зокрема, управління ювенальної превенції. Крім цього управління, згідно з Інструкцією з організації роботи підрозділів ювенальної превенції Національної поліції України, до підрозділів ювенальної превенції входять підрозділи ювенальної превенції головних управлінь Національної поліції в Автономній Республіці Крим та м. Севастополі, областях і м. Києві, а також підрозділи ювенальної превенції територіальних (відокремлених) підрозділів головних управлінь Національної поліції.

На регіональному й місцевому рівні діють підрозділи ювенальної превенції як структурні одиниці управлінь (секторів) превентивної діяльності Головного управління Національної поліції (далі - ГУ НП) (відділів поліції). Наприклад, відповідно до Положення про Управління превентивної діяльності Національної поліції України у Львівській області [5], управління очолює начальник, який організовує роботу Управління, забезпечує ефективне виконання покладених на нього завдань, а також несе особисту відповідальність за виконання підлеглими своїх функціональних обов'язків і стан службової дисци- 
пліни. Контроль за діяльністю Управління здійснюється начальником ГУ НП у Львівській області. Управління виконує завдання на основі поєднання єдиноначальності й колегіальності в розв'язанні питань, пов'язаних з оперативно-службовою діяльністю, з урахуванням персональної відповідальності керівництва й кожного з працівників за стан справ на закріплених напрямках роботи, своєчасне та якісне виконання запланованих заходів та окремих доручень. Отже, підрозділи ювенальної превенції мають чітку структурну побудову, що сприяє ефективному виконанню завдань із профілактики правопорушень серед дітей.

Наступний блок елементів адміністративно-правового статусу розкриває компетенцію підрозділів ювенальної превенції Національної поліції України як суб’єкта профілактики правопорушень серед дітей. Компетенція вважається головним елементом у структурі адміністративно-правового статусу будь-якого органу публічної адміністрації. На думку Ю.П. Битяка, компетенція становить певний обсяг державної діяльності, що покладений на конкретний орган, або коло питань, передбачених законодавством, іншими нормативно-правовими актами, які орган має право розв'язувати в процесі практичної діяльності [6, с. 59]. А.М. Сердюк стверджує, що адміністративноправовий статус патрульної поліції України визначає компетенцію, тобто окреслює коло іiі прав та обов'язків, необхідних для реалізації мети, завдань і функцій [7, с. 79], Компетенція розкривається через з'ясування повноважень (прав та обов'язків) і підвідомчості (предмету відання) підрозділів ювенальної превенції як суб'єктів профілактики правопорушень серед дітей. Підвідомчість передбачає наявність певного поля діяльності й кола суспільних відносин, на які підрозділи поліції впливають, виходячи зі своєі мети й завдань. На відміну від мети, завдань і функцій, компетенція підрозділів ювенальної превенції як суб'єктів профілактики правопорушень серед дітей закріплена на рівні нормативно-правових актів досить детально. Так, відповідно до п. 2 р. II Інструкції з організації роботи підрозділів ювенальної превенції Національної поліції України, основними повноваженнями підрозділів ювенальної превенції, що мають профілактичне значення, є:

1) планування та реалізація профілактичних заходів у дитячому середовищі щодо попередження негативних явищ серед дітей;

2) контроль за дотриманням суб'єктами підприємницької діяльності вимог законодавства щодо заборони продажу неповнолітнім особам алкогольних, слабоалкогольних напоїв і тютюнових виробів, а також щодо дотримання обмежень перебування дітей у нічний час у закладах, в яких провадиться діяльність у сфері розваг, і закладах громадського харчування;

3) вжиття заходів для запобігання та припинення стосовно дитини будь-яких протиправних діянь;

4) притягнення до адміністративної відповідальності дітей віком від 16 до 18 років, які вчинили адміністративні правопорушення, а також батьків або осіб, що їх замінюють, які не виконують передбачених законодавством обов'язків щодо забезпечення необхідних умов життя, навчання та виховання неповнолітніх дітей;

5) участь у профілактичних заходах щодо запобігання дитячій бездоглядності й правопорушенням серед дітей;
6) відвідування дітей, які опинилися в складних життєвих обставинах, за місцем їх проживання разом зі службою в справах дітей для з'ясування умов проживання;

7) залучення дітей до участі в просвітницько-профілактичних чи корекційних програмах;

8) інформування відповідних місцевих органів державної влади щодо батьків, інших законних представників, які не виконують обов'язки щодо виховання дітей, жорстоко з ними поводяться чи вчиняють стосовно дітей домашнє насильство;

9) ініціювання перед службами в справах дітей, відділами охорони здоров'я місцевих органів виконавчої влади й органів місцевого самоврядування питання про направлення дитини до відповідного закладу для надання необхідної медичної, психологічної допомоги;

10) вжиття заходів індивідуальної профілактики 3 дітьми, схильними до вчинення правопорушень.

Проводячи такі профілактичні заходи, поліцейським підрозділам ювенальної превенції доцільно взаємодіяти 3 іншими суб'єктами профілактики правопорушень.

Поліцейські підрозділи ювенальної превенції здійснюють такі заходи індивідуальної профілактики з дітьми, які перебувають на профілактичному обліку в поліції: проводять ознайомлювальні, попереджувальні й виховні бесіди 3 дитиною за місцем проживання, навчання або роботи не рідше одного разу на місяць; проводять ознайомлювальні, попереджувальні бесіди з батьками дитини, іiі законними представниками, членами сім'ї з метою усунення причин та умов, які спонукали до вчинення адміністративного чи кримінального правопорушення; складають план заходів з індивідуальної профілактики на основі вивчення матеріалів характеристик, індивідуально-психологічних особливостей дитини; відвідують за місцем проживання дитину для 3'ясування умов проживання, а також чинників, які можуть негативно впливати на неї та спонукати до вчинення адміністративних і кримінальних правопорушень; вживають інших профілактичних заходів, передбачених законодавством.

Таким чином, визначаючи мету, завдання, структурну побудову, компетенцію підрозділів ювенальної превенції Національної поліції України, в нормативно-правових актах виокремлено й профілактику правопорушень серед дітей як невіддільну складову частину поліцейської діяльності.

Висновки. Отже, адміністративно-правовий статус підрозділів ювенальної превенції Національної поліції України як суб'єктів профілактики правопорушень серед дітей доцільно розглядати як сукупність закріплених адміністративно-правовими нормами взаємопов'язаних і взаємозумовлених елементів, завдяки яким підрозділи ювенальної превенції реалізують свої повноваження щодо виявлення та усунення причин та умов, що призводять до вчинення дітьми правопорушень, здійснюють інші профілактичні заходи як самостійно, так і у взаємодії з іншими суб'єктами профілактики. Також, на нашу думку, необхідно на нормативно-правовому рівні закріпити повноваження підрозділів ювенальної превенції Національної поліції України організовувати й координувати проведення узгоджених заходів з іншими підрозділами Національної поліції України щодо профілактики правопорушень серед дітей.

\section{ЛITEPATYPA}

1. Алексійчук М.М. Адміністративно-правовий статус міського, районного органу внутрішніх справ : автореф. дис. ... канд. юрид. наук : 12.00.07. Київ, 2009. 18 с.

2. Про затвердження Інструкції з організації роботи підрозділів ювенальної превенції Національної поліції України : наказ Міністерства внутрішніх справ України від 19 грудня 2017 р. № 1044 / Верховна Рада України. URL: https://zakon.rada.gov.ua/laws/show/z0686-18.

3. Ластович Д.М. Поняття адміністративно-правового статусу поліції як суб’єкта надання поліцейських послуг. Наше право. № 6. 2015. C. 71-75.

4. Бахрах Д.Н. Административное право : учебник для вузов. Москва : БЕК, 1996. 368 с.

5. Положення про Управління превентивної діяльності Національної поліції у Львівській області від 17 березня 2016 р.

6. Адміністративне право України. / за ред. Ю.П. Битяка. Харків : Право, 2001. 528 с

7. Сердюк А.М. Поняття й елементи адміністративно-правового статусу патрульної поліції України. Науковий вісник Херсонського державного університету. Серія «Юридичні науки». Випуск 1. Том 3. 2016. С. 76-80. URL: http://li.kherson.ua/2016/pravo01/part_3/22.pdf. 


\title{
СУТНІСТЬ ТА ЗНАЧЕННЯ АДМІНІСТРАТИВНО-ПРАВОВОГО РЕЖИМУ ЦИВІЛЬНО-ВІЙСЬКОВОГО СПІВРОБІТНИЦТВА
}

\author{
THE ESSENCE AND IMPORTANCE OF THE ADMINISTRATIVE LAW REGIME \\ OF CIVIL-MILITARY COOPERATION
}

\begin{abstract}
Настюк В.Я., д.ю.н., професор, заслужений діяч науки і техніки України, член кореспондент Національної академії правових наук України, завідувач кафедри адміністративного права та адміністративної діяльності Національний юридичний університет імені Ярослава Мудрого
\end{abstract}

Коропатнік І.М., д.ю.н., доцент, полковник, начальник кафедри правового забезпечення

Військовий інститут Київського національного університету імені Тараса Шевченка

Карелін В.В., д.ю.н., капітан, науковий співробітник науково-дослідного відділу проблем педагогіки у військовій сфері науково-дослідного управління військово-гуманітарних досліджень науково-дослідного центру Військовий інститут

Киівського начіонального університету імені Тараса Шевченка

Встановлено, що питання здійснення правового режиму цивільно-військового співробітництва в умовах проведення операції об'єднаних сил в окремих районах Донецької та Луганської областей актуальне натепер, оскільки саме воно багато в чому визначає ефективність діяльності Збройних Сил України і як наслідок - мир і порядок у державі.

Доведено, що дослідження проблеми правового режиму цивільно-військового співробітництва в умовах проведення операціі об'єднаних сил в окремих районах Донецької та Луганської областей є однією із малодосліджених проблем у науці адміністративного права. Питання цивільно-військового співробітництва торкалась низка наукових правників і військових, зокрема Б.В. Бернадський, Н.В. Васюкова, С.І. Денисенко, Р.О. Додонов, В.В. Коваленко, І.М. Коропатнік, В.О. Кушнір, В.Я. Настюк, О.О. Оліфіров, С.В. Пєтков, І.П. Рущенко, С.М. Салкуцан, О.Ф. Сальнікова, В.М. Тарасов, В.М. Телелим, Р.В. Шаповал, І.М. Шопіна й інші.

Визначено, що незважаючи на певні відмінності у визначеннях, вчені сходяться на думці, що будь-який правовий режим - це певний порядок регулювання, що має у своєму змісті комплекс правових засобів, за допомогою яких і забезпечується необхідне соціально-правове становище суб'єктів або об'єктів права. Водночас і сам по собі правовий режим виступає інструментом правового регулювання, з огляду на що правові режими взагалі й галузеві правові режими зокрема - це проблемні утворення, доцільність і потреба вивчення яких не викликає сумнівів.

Доведено, що під адміністративно-правовим режимом цивільно-військового співробітництва розуміється самостійний, законодавчо визначений, комплексний правовий інститут, який складається з комплексу заходів діяльності центрів цивільно-військового співробітництва Збройних Сил України, інших військових формувань, державних і правоохоронних органів, утворених відповідно до законів України по координації та взаємодії з органами виконавчої влади, органами місцевого самоврядування, громадськими об'єднаннями, організаціями й громадянами в районах дислокації військових частин і підрозділів Збройних Сил України з метою формування позитивної громадської думки й забезпечення сприятливих умов для виконання Збройними Силами України покладених на них завдань і функцій шляхом надання допомоги цивільному населенню в розв'язанні проблемних питань життєдіяльності з використанням військових і невійськових сил і засобів.

Ключові слова: операція об'єднаних сил, цивільно-військове співробітництво, адміністративно-правовий режим, Збройні сили України, окупація.

It is established that the issue of conducting the legal regime of civil-military cooperation in the conditions of the joint forces operation in certain districts of Donetsk and Luhansk regions is relevant today, because it largely determines the effectiveness of the Armed Forces of Ukraine and as a result - peace and order in the country.

It is proven that researching the problem of the legal regime of civil-military cooperation in the conditions of joint forces operation in certain districts of Donetsk and Luhansk regions is one of the little-studied problems of the administrative law. It is also proven that that the issue of civil-military cooperation was addressed by a number of military and research staff, notably: B.V. Bernadsky, N.V. Vasyukova, S.I. Denisenko, R.O. Dodonov, V.V. Kovalenko, I.M. Koropatnik, V.O. Kushnir, V.Y. Nastyuk, O.O. Olifirov, S.V. Petkov, I.P. Rushchenko, S.M. Salkutsan, O.F. Salnikova, V.M. Tarasov, V.M. Telelym, R.V. Shapoval, I.M. Shopina and others.

It is determined that despite some differences in definitions, scholars agree that any legal regime is a certain regulatory procedure, which contains a set of legal means by which the necessary socio-legal status of the subjects or objects of law is ensured. At the same time, the legal regime itself is an instrument of legal regulation. Given that legal regimes in general and sectoral legal regimes in particular are problematic entities, the expediency and need to study them is undoubtable.

It is proved that the administrative law regime of civil-military cooperation is interpreted as an independent, legally defined, complex legal institution, which consists of a set of measures of the centers of civil-military cooperation of the Armed Forces of Ukraine, other military formations, state and law enforcement agencies, that were created according to the jurisdiction of Ukraine regarding coordination and cooperation with executive authorities, local governments, public associations, organizations and citizens in the areas of deployment of military units and subdivisions of the Armed Forces of Ukraine in order to form positive public opinion and provide favorable conditions for the Armed Forces of Ukraine to execute their duties and functions by providing help to the civilian population in resolving issues with the use of military and nonmilitary forces and means.

Key words: joint force operation, civil-military cooperation, administrative law regime, Armed Forces of Ukraine, occupation.

Вступ. Питання здійснення правового режиму цивільно-військового співробітництва в умовах проведення операції об’єднаних сил в окремих районах Доне- цької та Луганської областей актуальні нині, оскільки саме вони багато в чому визначають ефективність діяльності Збройних Сил України та як наслідок - мир і поря- 
док у державі. Це, на нашу думку, зумовлює необхідність розгляду питання глибше.

Дослідження проблеми правового режиму цивільновійськового співробітництва в умовах проведення операції об'єднаних сил в окремих районах Донецької та Луганської областей $є$ однією з малодосліджених проблем у науці адміністративного права. Розуміння проблематики цього питання, а також недосконалість законодавства й правозастосовної практики, необхідність приведення їх у відповідність до міжнародних стандартів, підвищення ефективності дії вже наявних правових норм і правових інститутів держави; формування позитивної правової свідомості й правомірної поведінки як військовослужбовців, так і цивільного населення прифронтових територій Донецької та Луганської областей вказують на своєчасність дослідження питання.

Аналіз останніх досліджень і публікацій. До питання цивільно-військового співробітництва зверталась низка науковців правників i військових, зокрема: Б.В. Бернадський, Н.В. Васюкова, С.І. Денисенко, Р.О. Додонов, В.В. Коваленко, І.М. Коропатнік, В.О. Кушнір, В.Я. Настюк, О.О. Оліфіров, С.В. Пєтков, І.П. Рущенко, С.М. Салкуцан, О.Ф. Сальнікова, В.М. Тарасов, В.М. Телелим, Р.В. Шаповал, I.M. Шопіна й інші.

Постановка завдання. Метою статті є характеристика сутності й значення правового режиму цивільно-військового співробітництва як ефективного засобу забезпечення операції об'єднаних сил в Україні.

Як видається, досліджуючи поняття «адміністративноправий режим цивільно-військового співробітництва», необхідно розпочати з розкриття підходів до розуміння таких базових понять, як «режим», «правовий режим» та «адміністративно-правовий режим».

Термін «режим» $\epsilon$ первинним для визначення всіх інших понять і категорій, оскільки саме він зумовлює зміст і значення всіх інших категорій режимів. А тому насамперед потрібно визначити, що означає зазначена вище категорія. Термін «режим» має своїм корінням французьке слово «regime» й латинське «regimen» у значенні:

1) державний устрій, форма правління;

2) точно встановлений розпорядок життя, праці, відпочинку;

3) система заходів, правил, запроваджуваних для досягнення певної мети;

4) певні умови, необхідні для забезпечення роботи, функціонування, існування чого-небудь [1, с. 576].

Як справедливо зазначає В.В. Конопльов, режим виникає лише в зонах так званого інтенсивного правового регулювання, коли законодавець приділяє особливу увагу конкретному об'єкту правовідносин [2, с. 170]. Це зумовлює ситуацію, коли правовий режим усе частіше стверджується як важлива категорія адміністративно-правової науки. Такої думки, до речі, дотримуються як вітчизняні, так і зарубіжні вчені.

Поняття «правовий режим» законодавчо не закріплено, тому натепер науковці тлумачать його по-різному, пропонують різноманітні терміни для його називання У науковій літературі загальноправового характеру поширений погляд, за яким галузям права властив свої особливі правові режими регулювання («правові режими» чи «режими правового регулювання»). Для обгрунтування цього підходу зазвичай наводиться позиція С.С. Алексєєва, що й став першопрохідцем у питаннях розробки поняття, структури й видів правових режимів регулювання.

Запропонована С.С. Алексєєвим ідея «галузевих» режимів зводилася насамперед до того, що правовий режим регулювання:

1) забезпечується галузями права 3 огляду на особливий вид суспільних відносин, і в цьому полягає основна функція галузей у правовій системі;
2) це особлива система правового впливу, що складається переважно зі спеціальних прийомів (методів) регулювання, а також його механізму;

3) характеризується багатьма рисами, але його грані окреслюють метод і механізм правового регулювання;

4) характеризується відомою замкнутістю, що полягає в неможливості застосування до відносин, що регулюються цією галуззю, норм, розміщених за ії межами [3, c. $162-189]$.

Пізніше С.С. Алексєєв спробував подивитися на правовий режим з іншого боку, зокрема, в динаміці. Він наголошує, що це поняття під таким кутом зору набуває нових відтінків, висвітлюється новими правовими гранями й дозволяє вести мову про багатоплановість цього явища. Окрім того, динамічний підхід може дозволити чіткіше окреслити порядок правового регулювання режиму, таких його сторін, як механізм, способи, методи, типи регулювання та, нарешті, правові режими» [4, с. 184]. 3 того часу позиція вченого з питань правового режиму є такою:

1) правовий режим «у найзагальнішому виді слід визначати як певну процедуру, порядок регулювання, що відбитий у системі конкретних правових засобів, що полягають у певних типах заборон, зв'язків, дозволів і моделей поведінки. Саме все це в сукупності й утворює специфічний напрям правового регулювання;

2) коли ми говоримо саме про правовий режим, то він зумовлює існування різних способів і методів правового регулювання, водночас один із цих способів чи методів набуває домінівного характеру й здійснює ключовий вплив на зміст відповідного режиму;

3) правовий режим - це не просто набір способів і методів регулювання, це система, правова конструкція, що містить у собі комплекс таких заходів впливу на правовідносини;

4) правовий режим відбиває міцний зв'язок між змістом відносин та їх правовою формою;

5) правовий режим є відбиттям ступеня жорсткості відповідного правового регулювання, наявних у цьому процесі обмежень і можливостей, вимог до дій чи бездіяльності, міри самостійності учасників таких відносин, санкцій за порушення;

6) правові режими не тотожні, мають вплив один на іншого й можуть бути первинними й вторинними; первинні - це, як правило, такі правові засоби, що відбивають загальні й вихідні форми правового регулювання відносин у певній сфері соціального життя, вторинні - вносять або додаткові переваги й пільги, або особливі обмеження [4, с. $185-205 ; 5$, с. 333-337; 6, c. 372-375].

Ряд вчених (зокрема, Т.П. Мінка) визначають правовий режим через його розуміння як певного зовнішнього вияву чи правової форми відповідного регулювання відносин у тій або іншій сфері життєдіяльності держави й суспільства. Фактично, йдеться про відбиття правовим режимом правовідносин в їх динаміці, що забезпечується через зміну й перетворення всіх наявних елементів, які входять до змісту правового регулювання: це й норми права й акти, що мають забезпечити їхню практичну реалізацію, і наявний стан правосвідомості, правової культури, наявних у правовідносинах принципів тощо. Саме ці елементи й повинні забезпечити досягнення цілей і завдань, що постають перед регулюванням відповідних відносин [7, с. 123-127].

Інші вчені (М.I. Матузов та О.М. Малько) виходять із пропозицією визначати правовий режим як специфічний порядок, за яким відбувається правове регулювання. Вони вбачають специфіку правового режиму також і в тому, що він проявляється в поєднанні чітких юридичних засобів, за допомогою яких забезпечується необхідне соціальне становище в державі, належна сприятлива обставина для існування певного типу правовідносин або несприятливі наслідки, що мають на меті забезпечення задоволення 
інтересів учасників відносин. Фахівці звертають увагу на наближеність поняття «правовий режим» у структурі правових категорій до поняття «правовий стан», «правове становище», «правовий статус». М.І. Матузов та O.M. Малько наголошують, що правовий режим повинен упорядковувати соціальні процеси й дії, що відбуваються в суспільстві; до того ж він по суті сам є певним соціальним станом [8, с. 16-17].

Досліджуючи значення та сутність правового режиму, Д.Д. Коссе визначає кілька важливих його характеристик: по-перше, режим установлюється законодавством і залежить від забезпечення зі сторони держави; по-друге, його метою є регламентація специфічним чином конкретних сфер суспільних відносин, обмежена часом або простором тих чи інших суб'єктів та об'єктів права; по-третє, режим передбачає особливий порядок правового регулювання, що здійснюється безперервно (правового впливу), й містить сукупність юридичних засобів, що займають чітко визначене місце в їхній ієрархії; по-четверте, забезпечує необхідне соціальне становище в державі, належну сприятливу обставу для існування певного типу правовідносин або несприятливі наслідки, що мають на меті забезпечення задоволення інтересів учасників відносин; по-п’яте, встановлює додаткові можливості для застосування до порушників встановлених обмежень та обов'язків юридичної відповідальності конкретного розміру й виду (фактично - за порушення норм і вимог відповідних правових режимів) [9, с. 28].

Говорячи про структуру правових режимів, зазначений автор наголошує, що вона складається 3 певного числа базових і допоміжних елементів. Базовими є сам механізм правового регулювання (норми права, юридичні факти, форми реалізації правових приписів, акти реалізації прав та обов'язків), суб'єкти й об'єкти права, методи, за допомогою яких відбувається взаємодія цих суб'єктів з об'єктами, встановлені й забезпечені гарантії дотримання цього статусу, що містить також і можливість застосування до порушників юридичної відповідальності [9, с. 28-29].

На думку Е.Ф. Шамсумової, поняття «правовий режим» $є$ особливим порядком законодавчого врегулювання діяльності, дій, поведінки фізичних та юридичних осіб у різних сферах суспільних відносин або певних об'єктів. Цей порядок повинен встановлювати механізм забезпечення фактичної реалізації стимулювання, нормативів, гарантій, заборон, зобов'язань, обмежень. Водночас увага має приділятися компетентному виконанню всіх норм, які визначають перелічені елементи правового режиму, застосування заходів примусу й притягнення винних до відповідальності [10, с. 72].

Заслуговує на увагу думка, за якою під терміном «правовий режим» розуміється певна сукупність правових актів та організаційно-технічних заходів, що у своїй єдності утворюють специфічний правовий інститут, який характеризується наявністю організаційних та юридичних складових частин і належить до відповідної сфери безпеки [11, с. 84].

Крім того, нині в науковій літературі прослідковується існування двох основних думок щодо тлумачення змісту поняття «правовий режим», які отримали умовні найменування: управлінський та управлінський і сутнісно-правовий напрями [12, с. 120-121].

Таким чином, підбиваючи проміжний підсумок аналізу наявних нині наукових підходів щодо розуміння правових режимів, можемо стверджувати, що, незважаючи на певні відмінності у визначеннях, вчені сходяться на думці, що будь-який правовий режим - це певний порядок регулювання, що містить комплекс правових засобів, за допомогою яких і забезпечується необхідне соціальноправове становище суб'єктів або об'єктів права. Водночас і сам по собі правовий режим виступає інструментом правового регулювання, з огляду на що правові режими взагалі й галузеві правові режими зокрема - це проблемні утворення, доцільність і потреба вивчення яких не викликає сумнівів.

До числа основних елементів змісту адміністративноправового режиму належать правові засоби, що виявляються заходами захисту й гарантують дотримання цього режиму в заданих параметрах. До їх числа належать: правозастосовна діяльність суб'єктів реалізації виконавчої влади, в тому числі тих, хто безпосередньо застосовує державний примус, адміністративно-юрисдикційні повноваження, судовий контроль за діяльністю апарату управління [13, с. 76$]$.

Для глибшого розуміння та виокремлення елементів адміністративно-правового режиму цивільно-військового співробітництва необхідно з'ясувати поняття та елементи адміністративно-правового режиму, що є базовими категоріями в цьому блоці знання.

На думку O.I. Миколенка, адміністративному праву як елементу системи права України притаманний свій правовий режим, який, як уже зазначалося, розуміється нами як специфічний порядок правового регулювання. Він охоплює: цілі, принципи, предмет і метод адміністративноправового регулювання; статус суб'єктів, установлений адміністративним правом; адміністративно-правові гарантії та адміністративно-правовий стан [14, с. 254-277].

У науковій літературі поширена позиція, що адміністративне право, як і будь-яка інша галузь права, характеризується особливими режимами регулювання, та саме останні визначаються специфічними рисами цієї галузі права, тією роллю, а також завданнями й функціями $[15$, с. 189$]$

О.О. Крестьянінов наголошує, що адміністративноправовий режим - це певна сукупність адміністративно-правових засобів регулювання, встановлених за централізованою процедурою, що характеризуються імперативним методом правового впливу, який проявляється в тому, що завжди в адміністративно-правових відносинах присутній владний суб'єкт і підлегла особа. Тобто суб'єкти правовідносин перебувають в юридично нерівних позиціях [16, с. 91].

Інколи адміністративно-правовий режим розуміють (В.В. Ласточкін) не лише як сукупність певних норм чи процедур, а як систему правових установ і доцільних заходів управлінського характеру, шляхом яких і створюються передумови для реалізації громадянами наданих їм прав і можливостей, а також такий порядок роботи державних і громадських інституцій, за якого забезпечуються найкращі умови для забезпечення безпеки й правової охорони громадського порядку на визначеній і чітко окресленій ділянці (напрямі) державного управління [17, с. 55-56].

За визначенням I.C. Розанова, адміністративно-правовий режим - це визначений на рівні закону комплекс правил діяльності, дій або поведінки громадян та юридичних осіб, що визначає порядок реалізації ними своїх прав в умовах відповідних життєвих ситуацій, пов'язаних iз забезпеченням підтримки суверенітету й оборони держави, інтересів безпеки й охорони громадського порядку спеціально створеними із цією метою службами державного управління [18, с. 85$]$.

У підручнику з адміністративного права наголошується, що адміністративно-правовий режим є відокремленим і самостійним правовим інститутом, який характеризується наявністю організаційно-забезпечувальних елементів і спрямовується на встановлення оптимальних iз боку держави відносин у конкретній, доволі вузькій, проте вельми важливій сфері - забезпеченні безпеки особи, держави й суспільства [19, с. 195].

Як справедливо відзначає Д.М. Бахрах, адміністративно-правовий режим полягає в поєднанні адміністративно-правових засобів регулювання, закріплених центра- 
лізовано на рівні закону, що застосовуються у визначеному порядку й базуються на імперативному методі юридичної дії. Останній же полягає в тому, що суб'єкти правовідносин за своїм правовим статусом перебувають на юридично нерівних позиціях [20, с. 202]. У структурі адміністративно-правових режимів учений виділяє два взаємопов'язані складники - змістовий і формальний. До змісту змістовного елемента він включає мету й причини виникнення та існування режиму, економічні й управлінські (організаційні) його елементи, а також дії, що 3 них витікають. Юридичний складник визначає суб'єкта встановлення режиму, строк його дії, межі території запровадження режиму, порядок його введення, скасування, зміни, а також систему «режимних» обов'язків і прав [20, с. 203].

Такий підхід підтримує Ю.П. Битяк, який доводить, що розглядуваний режим містить визначене об'єднання адміністративно-правових засобів, якими регулюються правовідносини, й базується на централізованому порядку й використанні імперативного методу правового впливу з існуванням певної асиметрії суб'єктів правовідносин [21, с. 276].

О.В. Зіборов, проаналізувавши наукові праці С.С. Алексєєва, розглядає елементи адміністративно-правового режиму у вигляді сукупності низки компонентів:

- організаиійний компонент, в якому вивчають поняття адміністративно-правового режиму, мету й часові межі його дії;

- нормативний компонент, тобто правова основа адміністративно-правового режиму;

- причинний компонент (підстави застосування того чи іншого адміністративно-правового режиму). I тільки детальна регламентація причинного компонента може гарантувати дотримання прав і свобод об'єктів режимного регулювання та обмежить використання державою примусових режимних заходів у випадках, коли такі заходи не необхідні;

- процесуальний компонент, який містить комплекс питань щодо правозастосовної діяльності органів державної влади;

- забезпечувальний компонент як сукупність економічних, політичних, адміністративних, воєнних заходів, націлених на запровадження вихідних передумов для реалізації цілей і завдань відповідного адміністративного режиму;

- змістовний компонент, у рамках якого передбачається вичерпний перелік режимних заходів, а також гарантії реалізації наданих прав і свобод об'єктів режимного впливу;

- компетентний компонент. У процесі реалізації певного адміністративно-правового режиму відбувається перерозподіл повноважень органів державної влади. 3 урахуванням цієї обставини важливу роль відіграє завчасне формування компетентного компонента, який би містив нове коло повноважень органів державної влади на визначений період, а також визначав особливості функціонування в період дії адміністративно-правового режиму;

- статусний компонент, адресатами якого є особи (фізичні та юридичні), пов'язані з носієм режиму. Статусний компонент адміністративно-правового режиму містить перелік обов'язків, що покладаються на громадян в умовах дії певного адміністративно-правового режиму, а також відповідальність за недотримання режимних правил [22, с. 97-99; 23, с. 208-209].

В.Б. Рушайло зазначає, що в змісті адміністративноправового режиму необхідно виділяти: його цільову спрямованість, базові принципи, об'єкти, на які спрямовується адміністративно-правове регулювання, юридичний стан суб'єктів та адміністративно-правовий інструментарій [24, с. 33].

У навчальній літературі з адміністративного права виділяються такі базові елементи адміністративно- правового режиму: принципи існування та розвитку розглядуваного режиму; метод, за допомогою якого відбувається нормативне регулювання відносин; специфічні адміністративно-правові засоби, за допомогою яких відбувається виникнення визначених форм прав та обов'язків; положення адміністративного законодавства, які належать до питань регулювання значного обсягу різноманітних соціальних відносин, пов'язаних із державним управлінням; установлення поряд із загальногалузевим правовим режимом внутрішньогалузевих правових режимів [25, с. 324$]$.

Базовим, безперечно, слід визнати підхід В.В. Бєлєвцевої та В.Я. Настюка, які до елементів адміністративноправового режиму відносять типові елементи, що є тотожними для змісту всіх адміністративно-правових режимів і мають ознаки заходів режимної спрямованості. До типових елементів науковці відносять цільове призначення, правові принципи, об'єкт адміністративно-правового регулювання, юридичний стан суб'єктів та адміністративно-правовий механізм [26, с. 74]

Інші фахівці серед ознак адміністративно-правових режимів називають такі:

специфічна сфера їх існування - вони забезпечують певний порядок у сфері інтересів і впливу публічної влади й у зв'язку з реалізацією державними владними органами своїх обов'язків у напрямі забезпечення безпеки, необхідної охорони, захисту;

накази, режимні вимоги, зазвичай, містять заборонні й такі, що зобов'язують, адміністративно-правові норми, що певною мірою обмежують загальну правосуб'єктність фізичних та юридичних осіб;

адміністративно-правовий режим також характеризується і позитивним аспектом, на чому наголошується й у юридичній літературі. Йдеться про зобов'язання державних органів, посадовців, організацій, установ, підприємства й громадян поводитися певним чином для досягнення тієї або іншої мети в напрямі забезпечення безпеки суспільства й держави. Таке зобов'язання може мати загальний характер правової орієнтації, чіткої вимоги, вказівки, доручення на виконання тієї або іншої юридично значущої дії;

- обов'язковими суб'єктами правових режимів $\epsilon$ компетентні органи влади публічного рівня;

- більшість адміністративно-правових норм, що лежать у підгрунті таких режимів, можуть бути впроваджені виключно через відповідне правозастосування та, відповідно, видання актів правозастосування індивідуального характеру;

- під час регулювання правовідносин, що утворюються між невладними суб'єктами й владою публічного характеру $з$ приводу виконання режимних правил, застосовується адміністративно-правовий метод впливу;

порушення правил та обмежень режиму спричиняє вжиття заходів примусу адміністративного характеру $[15$, c. 192$]$.

Грунтуючись на власному баченні підходів до визначення поняття та сутності адміністративно-правового режиму, О.В. Адабаш висловлюється щодо доцільності виділення таких його ключових ознак:

правовий режим запроваджується для забезпечення безпеки держави в будь-якій сфері діяльності країни;

- перед установленням адміністративно-правового режиму, в більшості випадків, розробляється та схвалюється правозастосовний акт індивідуальної дії;

- правила й норми режиму містять в собі конкретні обмеження та звуження правового статусу;

обов'язково повинна бути окреслена мета введення відповідного правового режиму, яка повинна передбачати й відповідати всім діям, спрямованим на їі досягнення; необхідно передбачити нагляд компетентних суб'єктів за дотриманням режимних правил; 
- застосування імперативного методу регулювання відносин;

- передбачення застосування до порушників певних заходів примусу за порушення режимних правил [27, с. 39].

Наголошуючи на мультидисциплінарному характері адміністративно-правових режимів, Н.М. Бірюкова підтримує вищевказану позицію [28, с. 220].

Висновки. Отже, під адміністративно-правовим режимом цивільно-військового співробітництва розуміється самостійний, законодавчо визначений, комплексний правовий інститут, який складається 3 комплексу заходів діяльності центрів цивільно-військового співробітництва
Збройних Сил України, інших військових формувань, державних і правоохоронних органів, утворених відповідно до законів України по координації та взаємодії 3 органами виконавчої влади, органами місцевого самоврядування, громадськими об'єднаннями, організаціями й громадянами в районах дислокації військових частин і підрозділів Збройних Сил України з метою формування позитивної громадської думки й забезпечення сприятливих умов для виконання Збройними Силами України покладених на них завдань і функцій шляхом надання допомоги цивільному населенню в розв'язанні проблемних питань життєдіяльності з використанням військових і невійськових сил і засобів.

\section{ЛITEPATYPA}

1. Словник іншомовних слів / за ред. О.С. Мельничука. Київ : Гол. ред. УРЕ, 1974. 776 с.

2. Конопльов В.В. Категорія «адміністративно-правовий режим» в юридичній науці та законодавстві України. Форум права. 2010. № 1. C. $170-174$.

3. Алексеев С.С. Структура советского права. Москва : Юрид. лит., 1975. 264 с.

4. Алексеев С.С. Общие дозволения и общие запреты в советском праве. Москва : Юрид. лит., 1989. 288 с.

5. Алексеев С.С. Восхождение к праву. Поиски и решения. Москва : НОРМА, 2001. 376 с.

6. Алексеев С.С. Право: азбука - теория - философия: Опыт комплексного исследования. Москва : Статут, 1999.710 с.

7. Мінка Т.П. Онтологічна характеристика правового режиму. Право і суспільство. 2012. № 3. С. 123-127.

8. Матузов Н.И., Малько А.В. Правовые режимы: вопросы теории и практики. Правоведение. 1996. № 1. С. 16-29.

9. Коссе Д.Д. Значення та сутність правового режиму в правовій системі України. Часопис Київського університету права. 2010. № 2. C. $25-29$.

10. Шамсумова Э.Ф. Правовые режимы (теоретический аспект) : дис. ... канд. юрид. наук : 12.00 .01 ; Урал. юрид. ин-т МВД России. Екатеринбург, 2001. 213 с.

11. Розанов И.С. Административно-правовые режимы по законодательству РФ, их назначение и структура. Государство и право. 1996. № 9. C. 84-91.

12. Шарабурина О.О. Поняття адміністративно-правового режиму інсрормації з обмеженим доступом (основні підходи). Часопис Київського університету права. 2011. № 2. С. 120-123.

13. Снігур В.М. Правова природа адміністративно-правових режимів в Україні. Право і суспільство. 2007. № 4. С. 73-77.

14. Миколенко О.І. Теорія адміністративного процедурного права : монографрія. Харків : Бурун Книга, 2010. 336 с.

15. Бєлєвцева В.В. Сутність та особливості адміністративно-правових режимів у сфері державно безпеки України. Вісник Національної академії правових наук України. 2012. № 3 (70). С. 185-194.

16. Крестьянинов А.А. Место таможенных режимов в системе административно-правовых режимов. Проблеми законності : Республіканський міжвідомчий науковий збірник / відп. ред. В.Я. Тацій. Харків : НЮАУ. 1999. Вип. 37. С. 90-96.

17. Ласточкин В.В. Административно-правовые режимы и охрана государственной границы. Москва : Факт-М, 1999. 98 с.

18. Розанов И.С. Административно-правовые режимы по законодательству РФ, их назначение и структура. Государство и право. 1996. № 9. C. 84-91.

19. Адміністративне право в Україні / за ред. С.В. Ківалова. Одеса : Юрид. лит., 2003. 321 с.

20. Бахрах Д.Н. Административное право : учебник. Москва : БЕК, 1996. 368 с.

21. Административное право Украины / Ю.П. Битяк, В.В. Богуцкий, В.Н. Гаращук и др. ; под ред. Ю.П. Битяка. Харьков : Право, 2003. $576 \mathrm{c}$.

22. Зиборов О.В. Компонентное исследование военного положения. Среднерусский вестник общественных наук. 2015. № 1 (37). C. 95-99.

23. Проблемы теории государства и права : учебник / под ред. С.С. Алексеева. Москва : Юрид. лит., 1987. 448 с.

24. Рушайло В.Б. Административно-правовые режимы : монография. Москва : Щит-М, 2000. 263 с.

25. Адміністративне право : навчальний посібник / 3.Р. Кисіль, Р.В. Кисіль. 3-тє вид. Київ : Алерта; ЦУЛ, 2011. 696 с.

26. Настюк В.Я., Бєлєвцева В.В. Адміністративно-правові режими в Україні : монографрія. Харків : Право, 2009. 128 с.

27. Адабаш О.В. Поняття, сутність та ознаки адміністративно-правових режимів. Європейські перспективи. 2013. № 12 . С. 36-40.

28. Бірюкова Н.М. Щодо підходів до інтерпретації категорії «адміністративно-правовий режим». Південноукраїнський правничий часопис. 2011. № 4. С. 219-221. 


\title{
ПРОБЛЕМИ АДМІНІСТРАТИВНО-ПРАВОВОГО ЗАБЕЗПЕЧЕННЯ ЕЛЕКТРОННОГО СУДУ В УКРАЇНІ В УМОВАХ ПАНДЕМІЇ СОVID-19
}

\section{PROBLEMS OF ADMINISTRATIVE AND LEGAL SUPPORT OF ELECTRONIC COURT IN UKRAINE UNDER THE CONDITIONS OF THE COVID-19 PANDEMIC}

\author{
Обрусна С.Ю., д.ю.н., доцент, \\ професор кафедри державно-правових дисциплін \\ Черкаський національний університет імені Богдана Хмельницького \\ Іванова І.В., к.пед.н., доцент, \\ доцент кафедри економіки, підприсмництва і маркетингу \\ Черкаський державний бізнес-коледж \\ Чубань В.С., к.е.н., доцент, \\ доцент кафедри управління у сфері цивільного захисту \\ Черкаський інститут пожежної безпеки імені Героїв Чорнобиля \\ Начіонального університету цивільного захисту України
}

У статті розглянуто окремі аспекти адміністративно-правового забезпечення електронного суду в Україні в умовах пандемії COVID-19, визначено проблемні питання його впровадження та подальші перспективні напрямки функціонування в майбутньому.

Адміністративно-правове забезпечення впровадження електронного суду визначено як теоретичну, правотворчу, правореалізаційну діяльність щодо впорядкування, закріплення та розвитку надання адміністративних послуг через електронний ресурс і здійснення в цій системі виконавчо-розпорядчої діяльності з метою якісного підвищення функціонування судової системи й здійснення правосуддя.

Проаналізовано проблемні питання правотворчої, правореалізаційної та виконавчо-розпорядчої діяльності щодо впровадження електронного суду у вказаних умовах. Відзначено, що пандемія коронавірусної інфекції COVID-19 стала викликом юридичній спільноті й судовій системі, які замислилися над необхідністю удосконалення електронного судочинства, оскільки варто чітко розуміти, як реалізувати право кожного громадянина на отримання правничої допомоги навіть в умовах карантину.

Визначено коло проблемних питань подальшого впровадження електронного суду: відсутність налагодженої взаємодії та дублювання функцій між органами, що забезпечують роботу електронного суду, недосконале програмне забезпечення, технічні й матеріальні можливості судів, корупційні скандали, недостатній досвід впровадження електронного суду на рівні судових адміністрацій, суддів, учасників процесу, необізнаність учасників процесу щодо переваг і можливостей електронного судочинства.

У висновках відзначено, що ефективне адміністративно-правове забезпечення електронного суду в Україні в час таких серйозних викликів передбачає системні дії щодо вдосконалення законодавства; технічно-інформаційного забезпечення судів; розроблення заходів і систем забезпечення захисту інформації; правового регулювання питань відповідальності осіб за порушення в цій сфері; вжиття заходів попередження кіберзлочинності в цій ссері; проведення навчальних семінарів серед працівників апарату суду й інших користувачів системи; широкої просвітницької роботи серед населення, систематичного моніторингу ефективності роботи системи та її постійної модернізації.

Ключові слова: судова система, суд, електронний суд, адміністративно-правове забезпечення електронного суду, особливий режим роботи судів, єдина судова інформаційно-телекомунікаційна система.

The article touches upon some aspects of administrative and legal support of e-court in Ukraine in the context of the COVID-19 pandemic, identifies problematic issues of its implementation and highlights important areas for its functioning in the future.

Administrative and legal support for the introduction of e-court is defined as theoretical, law-making, law enforcement activities to streamline, consolidate and develop the provision of administrative services through electronic resources and implementation of executive and administrative activities aimed at improving the functioning of the judiciary and the efficiency of justice.

The problematic issues of law-making, law-enforcement and executive-administrative activity in terms of electronic court introduction under the specified conditions are analyzed. It is noted that the pandemic of coronavirus disease COVID-19 has become a challenge to the legal community and the judiciary, which has led to the need to improve e-justice, as it is necessary to understand how to exercise the right of every citizen to legal aid even in quarantine.

The range of problematic issues of e-court further implementation is outlined. They are lack of interaction and duplication of functions between bodies providing e-court, imperfect software, technical and material capacities of courts, corruption scandals, and insufficient experience of e-court implementation at different levels including court administrations, judges, and parties to proceedings, ignorance of the litigants about the benefits and opportunities of electronic litigation.

The authors come to the conclusion that the effective administrative and legal support of e-court in Ukraine during serious challenges requires a number of systematic actions to improve legislation. They include technical and information support of courts; development of measures and systems to ensure information security; legal regulation of liability issues for breaches; prevention of cybercrime in this area; provision of training seminars among court staff and other users of the system; extensive educational campaign for the population, systematic monitoring of the system effectiveness and its constant modernization.

Key words: judicial system, court, electronic court, administrative and legal support of electronic court, special mode of operation of courts, unified judicial information and telecommunication system.

Постановка проблеми. Вагомою гарантією справедливого й ефективного правосуддя є досконало організована система судів та органів, що забезпечують їі функціонування. Не менш важливе значення має ефективне судове адміністрування, що передбачає розв'язання теоретичних i практичних проблем, напрацювання нових методологічних підходів до судового управління, провадження нових форм і методів роботи суду. Нині нагальною потребою $€$ реалізація можливості використання інформаційних, комунікаційних та інших технологій під час розгляду справ у судах, організації роботи суду, що може забезпечити електронний суд - порівняно нове явище в Україні, що розвивається як частина загальновизнаної в сучасному інформаційному суспільстві моделі електронного врядування, покликаної надавати швидкі та якісні державні послуги населенню.

Пандемія короновірусної інфекції COVID-19 нині стала викликом для юридичної спільноти, судової влади, 
які замислилися над необхідністю побудови досконалої системи електронного судочинства, оскільки ні судова система, ні гарантії громадян на судовий захист не можуть знаходитися на «карантині», а головною функцією держави навіть у таких умовах є забезпечення ефективного захисту прав і свобод людини й громадянина. Безумовно, вказана проблематика актуальна як для адміністративноправової науки, так і для галузі адміністративного права, зважаючи на його сучасну природу, в основу якої покладено людино орієнтовану ідеологію [1, с. 9].

Аналіз останніх досліджень і публікацій. Проблемам електронного судочинства у вітчизняній юридичній науці на рівні наукових публікацій приділяють увагу М. Кравчик, Н. Кушакова-Костицька, А. Коршун, I. Камінська, Н. Логінова, І. Каланча, Л. Сердюк, М. Бондаренко, С. Пограничний, В. Білоус, О. Фонова, А. Паскар, I. Ізарова, О. Головченко, Р. Кирилюк, І. Боголюбський, О. Присяжнюк, О. Євсєєв, І. Булгакова й інші.

Перший досвід і перспективи подальшого впровадження електронного суду узагальнено в монографії О. Бринцева [2]. Позитивно, що з'являються публікації, присвячені проблемам адміністативно-правового забезпечення електронного суду, зокрема В. Куценком досліджено поняття «адміністративно-правове забезпечення електронного суду» й визначено його зміст [3]. Окремі питання електронного судочинства в ракурсі дослідження адміністративно-правового аспекту розглянуто в дисертаційній роботі О. Іваненка [4]. Аналізуючи проблеми й сучасні тенденції судового реформування, досліджує електронний суд і Р. Крусян [5]. Разом із тим спостерігається незначна кількість монографій чи дисертаційних робіт, присвячених вище вказаній проблематиці.

Наявна також низка публікацій, в яких аналізуються окремі процесуальні аспекти електронного судочинства. Крім того, питання запровадження електронного судочинства, роботи електронного суду в умовах COVID-19 останнім часом досить часто викладається в засобах масової інформації, вебсайтах судів тощо. Але більшість публікацій мають науково-популярний, прикладний, публіцистичний характер. Звичайно, це можна пояснити новизною самого проєкту й ситуації, що склалася, але важливо, щоб науковці також активно долучилися до обговорення та дослідження вказаної проблеми, оскільки без належного наукового обгрунтування впровадження електронного суду може бути не досить ефективним.

Мета статті полягає у викладенні окремих аспектів адміністративно-правового забезпечення електронного суду в Україні в умовах пандемії COVID-19, визначенні проблемних питань його впровадження та подальших перспективних напрямків функціонування в майбутньому.

Виклад основного матеріалу. У науковій літературі поняття «адміністративно-правове забезпечення впровадження електронного суду», визначають як теоретичну, правотворчу, правореалізаційну діяльність щодо впорядкування, закріплення та розвитку надання адміністративних послуг через електронний ресурс і здійснення в цій системі виконавчо-розпорядчої діяльності з метою якісного підвищення функціонування судової системи й здійснення правосуддя [3].

Повністю погоджуючись із запропонованим змістом вказаного поняття, відзначаємо, що для успішного впровадження проєкту «Електронний суд» вагоме значення мають усі його складові частини. В адміністративно-правовому регулюванні цих напрямів в умовах, що склалися, маємо як низку успішних кроків, так і розв'язаних проблем. У публікації нами сконцентровано увагу на аналізі окремих аспектів правотворчої, правореалізаційної та виконавчо-розпорядчої діяльності щодо впровадження електронного суду.

Загальновідомо, що ідея інформатизації всіх сфер суспільного життя, в тому числі й судочинства, в Україні була закладена ще Законом України «Про основні засади розвитку інформаційного суспільства в Україні на 20072015 роки» [6], а одна 3 перших концепцій «Електронного суду» в Україні розроблена у 2012 році Державним підприємством «Інформаційні судові системи» на розвиток положень низки законів, Концепції галузевої програми інформатизації судів загальної юрисдикції, інших органів та установ судової системи й Стратегічного плану розвитку судової влади в Україні на 2013-2015 роки.

Реалізацію пілотного проєкту щодо обміну електронними документами між судом та учасниками судового процесу було розпочато у Святошинському районному суді міста Києва й апеляційному суді Дніпропетровської області з 15 жовтня 2012 р. [2, с. 18]. 32015 р. пілотний проєкт «Електронний суд» запрацював у трьох судах Одеської області [7]. У липні 2016 р. організаторами проєкту презентовано його позитивні результати й наголошено на неможливості повного завантаження такої практики в судову систему внаслідок недосконалості чинного законодавства [8], чим і були зумовлені подальші зміни нормативного поля, зокрема прийняття Закону України «Про внесення змін до Господарського процесуального кодексу України, Цивільного процесуального кодексу України, Кодексу адміністративного судочинства України та інших законодавчих актів» [9]. Відповідно до ст. 151 і п. 8 ч. 1 ст. 152 Закону України «Про судоустрій і статус суддів» було розроблено й затверджено Концепцію побудови Єдиної судової інформаційної-телекомунікаційної системи.

34 червня 2018 р. у 18 пілотних судах України розпочалося тестування підсистеми Єдиної судової інформаційно-телекомунікаційної системи (далі - ССITC) «Електронний суд» [10], а з 22 грудня 2018 у всіх місцевих та апеляційних судах розпочалась експлуатація підсистеми «Електронний суд» в тестовому режимі [11].

Єдина судова інформаційно-телекомунікаційна система мала запрацювати 31 березня 2019 р., але Державна судова адміністрація (далі - ДСА) України відтермінувала запуск ЄСІТС відповідно до рішення Вищої ради правосуддя та враховуючи результати обговорення питання з судами, іншими органами й установами системи правосуддя. 07 листопада 2019 р. ДСА затверджено Концепцію в новій редакції, якою змінено підходи до побудови Єдиної судової інформаційно-телекомунікаційної системи, iii структури й визначено етапи й терміни впровадження, кінцевий $з$ яких датовано 2023 р. [12], що можна було б розцінювати як системний, виважений підхід до впровадження електронного суду.

Але 3 початком карантину перед українською судовою системою постали виклики як процесуального (процесуальні строки, гласність і відкритість судового процесу, порядок розгляду справ онлайн), так і адміністративноправового характеру: необхідність швидкого внесення змін до процесуального законодавства, відсутність чітких механізмів роботи судів в умовах карантину й ефективної системи електронного судочинства, взаємодії між органами, що відповідають за впровадження електронного суду. Не менш критичними стали проблеми технологій i технічних можливостей судів, матеріального й фінансового характеру.

Як із початку карантину, так і нині в організації роботи судів основний акцент робиться на дотриманні балансу між забезпеченням права на доступ до правосуддя та убезпеченням учасників судового провадження, відвідувачів суду і працівників суду від поширення гострих респіраторних захворювань і COVID-19.

16 березня 2020 р. Радою Суддів України було прийняте рішення № 9 рс-186/20, відповідно до якого на період із 16 березня 2020 р. до 03 квітня 2020 р. встановлено особливий режим роботи судів України з можливістю відкладення розгляду справ у зв'язку з карантинними заходами. 
Суди змінили формат роботи, що передбачало мінімізацію контактів працівників суду з громадянами, в перший місяць карантину розгляд справ за участю сторін переносився, розглядали справи в письмовому провадженн (без участі сторін), обмежували допуск у судові засідання осіб, що не є учасниками справи (вільних слухачів, журналістів), подання процесуальних документів відбувалося в обмеженому режимі - через скриньку й поштою, ознайомлення 3 матеріалами справи відбувалося в дистанційному режимі, припинявся та обмежувався особистий прийом громадян керівництвом судів.

На початку карантину суди намагалися уникати розгляду справ дистанційно, що можна пояснити відсутністю досконалого програмного забезпечення, чіткого порядку розгляду справ, передбаченого законодавством. Тому досить слушним стало прийняття Верховною Радою України Закону України «Про внесення змін до деяких законодавчих актів, спрямованих на забезпечення додаткових соціальних та економічних гарантій у зв'язку з поширенням коронавірусної хвороби (COVID-2019)», відповідно до якого внесені зміни до процесуальних кодексів, у тому числі про те, що у судовому засіданні учасники справи можуть брати участь в режимі відеоконференції поза межами приміщення суду з використанням власних технічних засобів. Відповідно до зазначених положень Закону, підтвердження особи учасника справи здійснюється із застосуванням електронного підпису, а якщо особа не має такого підпису, то в порядку, визначеному Законом України «Про Єдиний державний демографічний реєстр i документи, що підтверджують громадянство України, посвідчують особу чи її спеціальний статус» або Державною судовою адміністрацією України» [13].

Разом із тим виникла необхідність удосконалення процедури ідентифікації особи, учасника справи й можливості повноцінної участі зазначеної особи як сторони судового провадження, подання сторонами заяв, клопотань і доказів у судовому засіданні в режимі відеоконференції без участі з боку учасників судового процесу (сторін) відповідального секретаря судового засідання.

08 квітня 2020 р. Державною судовою адміністрацією України було затверджено «Порядок роботи 3 технічними засобами відеоконференцзв'язку під час судового засідання в адміністративному, цивільному й господарському процесах за участі сторін поза межами приміщення суду» [14], а 23 квітня 2020 р. прийнято вищевказаний порядок у новій редакції, який визначає процедурні етапи проведення відеоконференцій судового засідання: основні терміни, порядок проведення, створення робочої та архівної копій, зберігання архівних копій, подання заяви про участь у судовому засіданні, проведення судового засідання, фіксацію ходу й результатів процесуальних дій, зберігання робочих копій. Також Порядком визначені технічні вимоги для доступу до Системи, наводяться примірники заяви про участь у судовому засіданні в режимі відеоконференції поза межами приміщення суду й акту про несправність (неналежне функціонування) системи відеоконференцзв'язку. Відповідно до оновленого Порядку, суди зможуть використовувати не лише систему відеоконференцзв'язку Easycon, а й інші доступні суду й учасниками судового процесу засоби, що забезпечують проведення судових засідань у режим відеоконференцзв'язку й відповідають вимогам законодавства [15].

Можливість здійснення «безконтактного» судочинства 3 використанням сучасних технічних засобів - одне 3 головних завдань Єдиної судової інформаційно-телекомунікаційної системи (далі - ССITC), яка має забезпечити ведення судами електронного діловодства, захищене зберігання, автоматизоване аналітичне й статистичне опрацювання інформації, визначення суддів для розгляду конкретних справ, добір присяжних, ведення Єдиного державного реєстру судових рішень тощо. Принцип побудови ССITC - хмарні технології, що забезпечують віддалене опрацювання та зберігання даних і надають користувачам Інтернету доступ до обчислювальних ресурсів i програмного забезпечення. Але поки що вона повноцінно не працює.

Пандемія прискорила процес судової діджиталізації. Протягом карантину суди у своїй роботі застосовували Zoom, Skype, Google Meet. Але проблемами цих програм $€$ незахищеність від зовнішнього втручання, часові обмеження, ідентифікація учасників тощо.

Як звітує державне підприємство «Інформаційні судові системи», на замовлення вітчизняних судів із початку року проведено майже 54 тисячі сеансів відеоконференцзв'язку [16]. Це стало можливим також завдяки використанню спеціального програмного комплексу EasyCon, запровадженого з 13 квітня 2020 р., який дозволяє спілкування у великих і малих групах людей, що перебувають на відстані одне від одного. За допомогою цієї системи учасники відеоконференцій діляться інформацією, документацією, цілими базами даних, навчаються, а головне - можуть колегіально ухвалювати рішення. Для участі в режимі відеоконференції від учасника вимагається: реєстрація на порталі EasyCon через електронну пошту й прив'язка до облікового запису електронного цифрового підпису для підтвердження особи; заява в суд про бажання прийняти участь у судовому засіданні в режимі відеоконференції не пізніше, ніж за 5 днів до дати засідання. Програма належним чином ідентифікує учасника, що безумовно $є$ позитивом порівняно з іншими програмами й не порушує процесуальне право.

Нині проводиться робота над розробкою законопроєкту щодо організації дистанційного електронного правосуддя, що активно обговорюється в суддівській спільноті, ЗМI, соцмережах. Основними його пропозиціями є доступ до суду в режимі відеоконференції з офісу адвоката; використання будь-яких месенджерів для зв'язку із судом; робота через електронний кабінет - обов'язково; подача документів до суду виключно в електронній формі; скасування вимоги про «очне» судове засідання; дистанційний доступ до діловодства суду всіх працівників; електронний підпис замінює власноручний (фізичний) - можливість підписання тексту рішення без особистої присутності в суді; авторозподіл справ між усіма суддями України відповідної спеціалізації (де-факто скасування територіальної підсудності) [17].

Щодо змісту вказаних пропозицій можна дискутувати, але деякі видаються досить прийнятними. Це, наприклад, стосується скасування територіальної підсудності, що значно зменшує ризики корупції. Адже наявний нині авторозподіл справ мало заважає місцевим юристам вступати в неправомірні домовленості із суддями, оскільки в межах одного регіону такі зв'язки вже здебільшого налагоджені. Крім того, це значно зекономить державні кошти, може зменшити кількість відкладених справ через неявку на засідання, зекономить час учасників процесу, сприятиме забезпеченню відкритості судового процесу тощо.

Аналіз думок експертів щодо проблемних питань подальшого впровадження електронного суду дав змогу ïx звести до таких: відсутність налагодженої взаємодії та дублювання функцій між органами, що забезпечують роботу електронного суду, недосконале програмне забезпечення, технічні й матеріальні можливості судів, корупційні скандали, недостатній досвід впровадження електронного суду на рівні судових адміністрацій, суддів, учасників процесу, необізнаність учасників процесу щодо переваг і можливостей електронного судочинства. Зрозуміло, що запровадження карантинних заходів стало певним каталізатором, що дав поштовх для активізації роботи щодо розбудови електронного суду. Разом із тим цей процес може гальмуватися через як об'єктивні, 
так і суб'єктивні причини. В ситуації, що склалася саме в суддівській спільноті, Вища рада правосуддя має взяти на себе функції з контролю за впровадженням ЕCITC, створивши відповідний координаційний центр, оскільки лише спільна робота представників судової влади разом iз розробниками програмного забезпечення можуть дати позитивний ефект щодо створення ефективної системи електронного суду в Україні, яка буде зручною у використанні й сприятиме швидшому й надійному захисту прав фізичних та юридичних осіб.

Ефективне адміністративно-правове забезпечення електронного суду в Україні в час таких серйозних викликів передбачає системні дії щодо удосконалення законодавства; технічно-інформаційного забезпечення судів; розроблення заходів і систем забезпечення захисту інфор- мації; правове регулювання питань відповідальності осіб за порушення в цій сфері; вжиття заходів попередження кіберзлочинності в цій сфері; проведення навчальних семінарів серед працівників апарату суду й інших користувачів системи; широку просвітницьку роботу серед населення, систематичний моніторинг ефективності роботи системи та їі постійну модернізацію.

Висновки. Ситуація, що нині склалася в країні, потребує нестандартних рішень та ідей для того, щоб налагодити доступ до суду. Виклики, які постали перед судовою системою на шляху до запровадження електронного судочинства, мають розв'язуватися рішуче й без зволікань, надмірний формалізм за таких обставин шкодить авторитету судової влади, яка повинна захищати інтереси громадян у будь-яких умовах.

\section{ЛITEPATУРA}

1. Авер'янов В.Б. Оновлена українська адміністративно-правова доктрина на основі принципу верховенства права. Часопис Київського університету права. 2008. № 3. C. 9-14/ URL: http://kul.kiev.ua/ images/chasop/2008 3/2008 3.pdf (дата звернення: 10.07.2020).

2. Бринцев О.В. «Електронний суд» в Україні. Досвід та перспективи : монографрія. Харків : Право, 2016. 72 с.

3. Куценко В.Д. Поняття та зміст адміністративно-правового забезпечення електронного суду. Науковий вісник публічного і приватного права : в 6 т. T. 2. 2017. C 3-9. URL: http://www.nvppp.in.ua/vip/2017/6/tom_2/3.pdf (дата звернення: 10.07.2020).

4. Іваненко О.Ю. Адміністративно-правовий аспект надання судових послуг в Україні : автореф. дис. ... канд. юрид. наук : 12.00 .07$. Запоріжжя, 2018. 18 c.

5. Крусян Р.А. Реформування судоустрою в Україні: досвід, сучасність, тенденції : дис. ... канд. юрид. наук : 12.00.10. Одеса, 2018. $255 \mathrm{c}$.

6. Про основні засади розвитку інформаційного суспільства в Україні на 2007-2015 р. : Закон України від 9 січня 2007 р. № 537-V I Верховна Рада України. URL: https://zakon.rada.gov.ua/laws/show/537-16\#Text (дата звернення: 11.07.2020).

7. Про визначення модельних судів щодо поетапного запровадження інструментів «електронного правосуддя» в діяльності судів України : Рішення Ради суддів України від 22 липня 2015 р. № 74. URL: http://consultant.parus.ua/?doc=09NSXADB16.

8. В Одесі презентовано результати пілотного проєкту «Електронний суд». URL: http://rsu.gov.ua/ua/news/v-odesi-prezentovanorezultati-pilotnogo.

9. Про внесення змін до Господарського процесуального кодексу України, Цивільного процесуального кодексу України, Кодексу адміністративного судочинства України та інших законодавчих актів : Закон України від 3 жовтня 2017 р. № 2147-VIII / Bepховна Рада України. URL: https://zakon.rada.gov.ua/laws/show/2147-19.

10. Про внесення змін до наказу ДСА України від 23 березня 2017 р. № 367 : Наказ ДСА України від 31 травня 2018 р. № 269. URL: https://dsa.court.gov.ua/dsa/inshe/14/N_269.

11. Про проведення тестування підсистеми «Електронний суд» у місцевих та апеляційних судах : Наказ ДСА України від 22 грудня 2018 p. № 628. URL: https://dsa.court.gov.ua/userfiles/media/628_18.pdf.

12. Про забезпечення створення і функціонування Єдиної судової інформаційно-телекомунікаційної системи : Наказ ДСА від 07 листопада 2019 р. № 1056. URL: https://dsa.court.gov.ua/userfiles/media/media/ECITC_Koncepcia.pdf.

13. Про внесення змін до деяких законодавчих актів, спрямованих на забезпечення додаткових соціальних та економічних гарантій у зв'язку з поширенням коронавірусної хвороби (COVID-2019) : Закон України від 30 березня 2020 р. № 540-IX / Верховна Рада України. URL: https://zakon.rada.gov.ua/laws/show/540-20\#Text.

14. Порядок роботи з технічними засобами відеоконференцзв'язку під час судового засідання в адміністративному, цивільному та господарському процесах за участі сторін поза межами приміщення суду : Наказ ДСА України від 08 квітня 2020 р. № 169 . URL: https://dsa.court.gov.ua/dsa/inshe/14/N 16920.

15. Порядок роботи з технічними засобами відеоконференцзв'язку під час судового засідання в адміністративному, цивільному та господарському процесах за участі сторін поза межами приміщення суду : Наказ ДСА України від 23 квітня 2020 р. № 196. URL: https://dsa.court.gov.ua/userfiles/media/dsa_pres_slujba_2019/dsa_pres_slujba_2020/N19620.

16. Відеоконференцзв'язок як один з елементів «електронного правосуддя». URL: https:/ics.gov.ua/ics/news/novyny/931606/.

17. Суддя Верховного Суду заявив про підготовку законопроєкту про дистанційне правосуддя. URL: https://sud.ua/ru/news/ publication/164561-suddya-verkhovnogo-sudu-zayaviv-pro-pidgotovku-zakonoproektu-pro-distantsiyne-pravosuddya. 


\title{
ПРАВОВЕ РЕГУЛЮВАННЯ ВІРТУАЛЬНИХ АКТИВІВ ТА КРИПТОВАЛЮТ В УКРАЇНІ: СУЧАСНИЙ СТАН І ПЕРСПЕКТИВИ
}

\author{
VIRTUAL ASSETS AND CRYPTOCURRENCY IN UKRAINE: \\ CURRENT STATE AND PROSPECTS
}

\author{
Овчаренко А.С., к.ю.н., \\ асистент кафедри фінансового права \\ Наиіональний юридичний університет імені Ярослава Мудрого
}

\begin{abstract}
Стаття присвячена питанням визначення змісту, правової сутності віртуальних активів і криптовалют, їх співвідношенню. Автором надається визначення як віртуальних активів, так і криптовалют, визначаються їхні суттєві характеристики й види. Автор наголошує, що терміни «віртуальні активи» й «криптовалюти» не можна вважати синонімами, адже криптовалюти $є$ одним з видів «децентралізованих віртуальних валют», тобто значно вужче поняття «віртуальних активів». Криптовалюта як один із видів віртуальних активів за своєю природою має автономний, децентралізований, транскордонний характер, не має юрисдикційної прив'язки й визначеного емітента. Невизначеність правового статусу віртуальних активів призводить до того, що фізичні та юридичні особи, які мають у своїй власності віртуальні активи, фактично позбавлені ефективного способу захисту свого права власності на такі активи. Крім того, через відсутність законодавчого визначення використання віртуальних активів представляє такі ризики, як загроза й вразливість віртуальних активів у відмивання грошей, а також неналежна комп'ютерна безпека під час їхнього обміну. Автор звертає увагу на новели законодавства з фінансового моніторингу, а саме окремі норми Закону України «Про запобігання та протидії легалізації (відмиванню) доходів, одержаних злочинним шляхом, фінансуванню тероризму й фінансуванню розповсюдження зброї масового знищення» в редакції від 06 грудня 2019 р. щодо моніторингу операцій з віртуальними активами. Автор доходить висновку, що віртуальний актив можна визначити як актив в електронній формі, створений із використанням криптографічних засобів, що існує у вигляді цифрового програмного коду й не має фізичної форми, право власності на яке засвідчується шляхом внесення цифрових записів до реєстру цифрових транзакцій, і має економічну цінність. Реальних дієвих механізмів державного контролю натепер в Україні не запроваджено, а зміни в законодавстві спрямовані в основному на встановлення вимог до ідентифікації учасників такого ринку.
\end{abstract}

Ключові слова: віртуальні активи, фінансовий моніторинг, криптовалюта, валюта, гроші, блокчейн.

The interest of the author is connected with law enforcement problems, which take their origin in unique technologies making it possible to use crypto currency. The article considers the problem of determining the characteristic features of the virtual assets and crypto currency for the purposes of its legal regulation in Ukraine. The author emphasizes that the terms "virtual assets" and "cryptocurrencies" cannot be considered synonymous, because cryptocurrencies are one of the types of "decentralized virtual currencies", that is much narrower concept of "virtual assets". Nature and legal uncertainty does not allow it to be identified with any of the related concepts (money, currency, currency value, means of payment, electronic money, securities, money surrogate, etc.). That is, cryptocurrencies are currently in Ukraine outside the scope of legal regulation. The author states there is an urgent need for legal regulation of relations which arise from transactions with virtual assets. In addition, due to the lack of a legal definition, the use of virtual assets poses risks such as the threat and vulnerability of virtual assets to money laundering, as well as inadequate computer security during their exchange. The article is devoted to the analysis of the legal nature of virtual assets, consequences of their usage. The article analyzes international experience of virtual assets legal regulation. Purpose is to study the legal nature, types of virtual assets, in particular crypto currency based on the analysis of foreign legal regulation experience, to reveal the most common problems linked with the usage of virtual assets. The study is based on the methods of comparison, analysis, synthesis, generalization, and formal-logical method. The article provides the analysis of the legal nature of virtual assets. The author draws attention to the novelties of the legislation on financial monitoring, namely certain provisions of the Law of Ukraine "On Prevention and Counteraction to Legalization (Laundering) of Proceeds from Crime, Financing of Terrorism and Financing of Weapons of Mass Destruction Proliferation". Operations with crypto currency do not refer to currency operations, it is reasonable to take into consideration the specificity of crypto currency as "virtual assets", which combine a number of features common for services and means of payment, determining the specifics of their accounting in comparison with real goods and services.

Key words: virtual assets, financial monitoring, cryptocurrency, currency, money, blockchain.

Вступ. Найважливішою складовою частиною четвертої промислової революції продовжує залишатися безперервне оновлення інформаційно-комунікаційних технологій $[1$, с. 5]. Нові технології, продукти й пов'язані з ними послуги мають потенціал для стимулювання інновацій у фінансовій сфері, розвиток цифрових технологій зумовило появу нового поняття - «цифровий (віртуальний) актив».

Криптовалюта як один, проте не єдиний, з віртуальних активів $є$ складною системою інформаційно-технологічних процедур, що заснована на децентралізованому механізмі емісії та обігу. У законодавстві більшості країн світу, в тому числі України, не визначено статус криптовалюти, водночас виробництво й обіг криптовалюти в країні не заборонено. Нещодавно ситуація 3 правовим визначенням категорії «віртуальні активи» кардинально змінилася, та було законодавчо визначено поняття віртуальних активів. Незважаючи на появу законодавчо визначеного терміну «віртуальний актив», ситуація з правовим статусом таких активі та їх видів і досі залишається неоднозначною та належним чином неврегульованою нормами права. Усе зазначене вище й зумовило актуальність і новизну теми статті.
Питання визначення змісту й правової сутності віртуальних активів віртуальних валют - криптовалют натепер не знайшли достатнього відбиття в науці фінансового права. Комплексних праць, присвячених аналізу фінансової сутності віртуального актива як сучасного явища й обліку операцій із ними, в Україні немає. Крім того, на теоретичному рівні відсутній єдиний підхід до використання понятійного апарату із зазначеного питання.

Аналіз сучасних наукових публікацій і досліджень із питань цифрового активу свідчить, що нині не існує чіткого визначення та розуміння таких понять. Окремими питаннями запровадження та розвитку криптовалюти займалися такі вітчизняні й зарубіжні вчені: М. Кучерявенко, А. Кудь, Є. Смичок, В. Костюченко, Д. Нікколаї, I. Гусєва, Т. Петрова, Р. Прайс, Л. Фрідкін, Т. Дмитренко й інші. 3 огляду на новизну явища й невизначеність його правового статусу у вітчизняній науці актуальність дослідження не викликає сумнівів.

Постановка завдання. Метою статті $€$ визначення змісту, правової сутності, видів віртуальних активів, зокрема криптовалют, їх співвідношення з грошима, аналіз міжнародного досвіду щодо визначення зазначених категорій. 
Сучасні цифрові технології змусили переоцінити матеріальні активи, поставивши їх в один ряд 3 нематеріальними - цифровими активами, наявними виключно в електронній формі. Однією з базових технологій, що дозволяє говорити про існування цифрових активів в розподіленому реєстрі, виступив blockchain (блокчейн). Скріплення ланцюжка послідовних транзакцій блоками дозволило стверджувати про створення віртуального активу. Блоки прив'язані за часом між собою, скріплюючи попередні блоки-операції, що забезпечує високу надійність. Дані про здійснені угоди розподіляються та підтверджуються всіма резидентами розподіленого реєстру. Розподілений реєстр цифрових транзакцій або «розподілена база даних» (distributed database) - систематизована база цифрових транзакцій, які зберігаються, одночасно створюються та оновлюються на всіх носіях у всіх учасників реєстру на основі заданих алгоритмів, що забезпечує ії тотожність у всіх користувачів реєстру.

Натепер серед науковців єдиного підходу до змісту поняття ані «віртуальний актив», ані «цифровий актив», ані «віртуальні валюти», ані «криптовалюта» не має. Часто віртуальний актив або цифровий актив ототожнюють із поняттям «криптовалюта», проте цифровий (віртуальний) актив, за справедливим зауваженням, як ширше поняття через закладену в нього суть, є інформаційним ресурсом, похідним від права на цінність і таким, що обертається в розподіленому реєстрі у вигляді унікального ідентифікатора, що дозволяє говорити про новий об'єкт цивільних правовідносин - право на користування інформацією, похідною від права на цінність [2, с. 175, 194]. Автори використовують термін «віртуальна валюта» як цифрове вираження вартості, яке можна використовувати в цифровій формі й котре функціонально прагне виступати як засіб обміну, одиниці обліку й зберігання вартості [2, с. 107].

Натепер поняття «віртуальний актив» не має єдиного комплексного визначення, яке повністю розкривало б його суть та ознаки. У зв'язку із чим актуальним є визначення поняття «віртуальний актив», його істотних ознак, характеристик, а також визначення співвідношення понять «віртуальний актив» і «криптвалюта». Складність правового статусу криптовалюти як широковживаного віртуального активу в Україні нні полягає в тому, що криптовалюта не підпадає під визначення електронних грошових коштів, яке надано в ст. 15 Закону України «Про платіжні системи й переказ коштів в Україні», а також не підпадає під визначення платіжної системи, яке міститься в п. 29 ст. 1 зазначеного Закону [3]. Криптовалюта також не $є$ іноземною валютою у світлі вимог Закону України «Про валюту й валютні операції», не входить до переліку іноземних валюти згідно з Класифікатором іноземних валют і не підпадає під визначення об'єктів цивільних прав, що перераховані в Цивільному кодексі, не будучи річчю (товаром), готівкою або безготівковими грошима, бездокументарними цінними паперами й майновими правами. Крім того, в криптовалют відсутні ознаки документа, у зв'язку із чим криптовалюта не може бути визнана грошовим сурогатом згідно з його визначенням в Законі України «Про Національний банк України». Складна природа й правова невизначеність криптовалют не дозволяє ототожнити ії з будьяким із суміжних понять (грошові кошти, валюта, валютна цінність, платіжний засіб, електронні гроші, цінні папери, грошовий сурогат тощо) $[4$, с. 51$]$.

Суттєві ознаки криптовалюти можна зобразити в такому визначенні. Криптовалюта є децентралізованою системою зі специфічною фінансово-правовою природою, яка характеризується високим ступенем ліквідності, $€$ подільною, проте ії стабільність не забезпечена державою, на відміну від фіатних грошей, і відсутній емітент (монети генеруються окремою групою користувачів майнерів). Головне, що відрізняє криптовалюту від інших електронних грошових коштів (електронних грошей або безготівкових розрахунків) - автономний, приватний характер емісії, а також технологічні особливості їх виготовлення та випуску в обіг $[5 ; 6]$.

28 квітня 2020 р. набрав чинності Закон України «Про запобігання та протидію легалізації (відмиванню) доходів, одержаних злочинним шляхом, фінансуванню тероризму й фінансуванню розповсюдження зброї масового знищення» від 6 грудня 2019 р. (далі - Закон 361-IX). Відповідно до П. 13 ч. 1. ст. 1 Закону 361-IX, віртуальним активом $€$ цифрове вираження вартості, яким можна торгувати в цифровому форматі або переказувати та яке може використовуватися для платіжних або інвестиційних цілей [7].

3 цього випливає, що для того, щоб об’єкт вважався віртуальним активом і став об'єктом фінмоніторинга, він має відповідати трьом критеріям: наявності вартості, можливості до обігу в цифровому форматі й можливості до його обміну на інші об'єкти цивільного права. В законі визначено термін «постачальник послуг, пов'язаних з обігом віртуальних активів», визначено перелік операцій із такими активами. Проте жодного іншого нормативного акту щодо зазначеного терміну не з'явилося, та питання правового визначення видів таких активів, механізму контролю за їх обігом та обліку наразі залишаються відкритими. У зв'язку із чим актуальною є розробка регулятора ринку віртуальних активів Міністерством цифрової трансформації умов ліцензування для постачальників сервісів віртуальних активів.

Важливою особливістю віртуальних активів виступає їх існування виключно в електронній формі у відриві від матеріального світу, по суті, у вигляді криптографічного цифрового коду, який розкриває їх зміст. Умовою поширення цифрових активів стала базова технологія блокчейн.

3 огляду на те, що віртуальні активи є інформацією в електронному вигляді, можна спостерігати певну правову невизначеність їх статусу як об'єкта права, зокрема 3 позиції їх охороноздатності. Ще кілька років тому цифрові активи розглядалися виключно як набір цифрових даних і були лише зібраним математичним алгоритмом цифр. Наразі цифрові активи стали самостійними об'єктами угод, у тому числі інвестування (наприклад, криптовалюта), споживання (електронні твори мистецтва, артефакти) тощо.

Ключовий аспект технології розподіленого реєстру відсутність посередників - став спочатку привабливим для інвестування в криптовалюту. Довіра між учасниками ринку заснована на технологічному захисту транзакцій блоками, який не потребує правової регламентації. По суті, натепер регулювання віртуальних активів знаходиться скоріше в технологічній, ніж правовій площині.

Оскільки до віртуальних активів відносять нематеріальні об'єкти, які мають економічну цінність, корисні або можуть бути використані виключно у віртуальному просторі, то в їх структурі можна виділити такі види активів:

1. Віртуальні валюти (криптовалюти).

Ще у 2012 р. Європейський центральний банк опублікував доповідь «Схеми віртуальних валют». У ньому наголошується, що в деяких випадках віртуальні спільноти створюють і поширюють свою власну цифрову валюту для обміну товарами (послугами) й одиниці обліку. У доповіді Віртуальна валюта визначається як один із видів нерегульованих державою цифрових грошей, які створюються та контролюються зазвичай розробниками, й прийняті серед членів певного віртуального співтовариства. Проте у 2015 р. у звіті Європейського центрального банку віртуальна валюта визначається вже ширше, як цифрове вираження вартості, яка не емітована центральним банком або фінансовою установою, уповноваженою видавати електронні гроші [8].

2. Віртуальні товари - нематеріальні об'єкти, які купуються користувачами соціальних мереж та онлайн- 
ігор. Віртуальні товари можуть використовуватися тільки в специфічному віртуальному середовищі, відповідно, не мають матеріальної цінності й не забезпечуються реальними активами. До них відносять гральні активи - активи гравців віртуальних ігор: зброя, спорядження, артефакти, внутрішньоігрові гроші й інше «майно», включаючи «зовнішність» і додаткові можливості аватара (персонажа) гравця в багатокористувацькій онлайн-грі. До таких товарів можна віднести й віртуальні активи в соціальних мережах. Це також самі облікові записи користувачів і придбані ними стікери й картинки-подарунки. Такі активи неконвертовані, адже використовуються в обмежених мережевих доменах.

3. Віртуальні токени - записи в розподіленому реєстрі.

4. Доменні імена як ідентифікатор юридичних або приватних осіб в Інтернеті.

Висновки. «Віртуальний актив» можна визначити як актив в електронній формі, створений із використанням криптографічних засобів, що існує у вигляді цифрового програмного коду й не має фізичної форми, право власності на яке засвідчується шляхом внесення цифрових записів до реєстру цифрових транзакцій, і має економічну цінність.

Тому зазначені терміни «віртуальні активи» й «криптовалюти» не можна вважати синонімами, адже криптовалюти є одним із видів «децентралізованих віртуальних валют», тобто значно вужчі поняття «віртуальних активів».

Криптовалюта як один із видів віртуальних активів за своєю природою має автономний, децентралізований, транскордонний характер, не має юрисдикційної прив'язки й визначеного емітента, що передбачає регулювання таких відносин нормами як приватного, так і публіч- ного права. Нині віртуальні активи - це об'єктивне економічне явище, яке потребує якнайшвидшого створення оптимальних правових умов для свого розвитку. Невизначеність правового статусу віртуальних активів призводить до того, що фізичні та юридичні особи, які мають у своїй власності віртуальні активи, фактично позбавлені ефективного способу захисту свого права власності на такі активи. Проведений аналіз показав, що єдиного підходу до визначення криптовалют та інших віртуальних активів наразі немає. Натепер криптовалютам не властиві всі функції грошей повною мірою (як одиниця розрахунку, засіб збереження вартості), вони не забезпечуються державою, тому можна лише вести мову про використання криптовалют як засобу обігу.

Як бачимо, віртуальні активи, в тому числі такий їх вид, як криптовалюти, надалі все ширше застосовуються в господарських відносинах. Проте через відсутність законодавчого визначення, використання віртуальних активів має такі ризики, як загроза й вразливість віртуальних активів у відмиванні грошей, а також неналежна комп'ютерна безпека під час їх обміну. Разом із тим, залишається відкритим питання про правові наслідки втрати паролів від цифрового гаманця, успадкування таких активів, юридичних гарантій учасників ринку віртуальних активів і ролі держави. Реальних дієвих механізмів державного контролю нині в Україні не запроваджено, а зміни в законодавстві спрямовані в основному на встановлення вимог до ідентифікації учасників такого ринку. У зв'язку із чим перспективним здається подальше дослідження правовою сутності віртуальних активів, їх класифікація, а також питання обліку операцій із такими активами й державного фінансового контролю у цій сфері.

\section{ЛITEPATYPA}

1. Industry 4.0. Changes and solutions for the digital transformation and use of exponential technologies. Zurich : Deloitte AG0, 2015. 32 p.

2. Кудь О.О., Кучерявенко М.П., Смичок Є.М. Цифрові активи та їх правове регулювання у світі розвитку технології блокчейн : монографія. Харків : Право, 2019. 216 с.

3. Про платіжні системи та переказ коштів в України : Закон України від 03 липня 2020 р. № 2346-ІІІІ / Верховна Рад України. Відомості Верховної Ради України. 2001. № 29. Ст. 137.

4. Овчаренко А.С. Облік операцій з криптовалютами в Україні: сучасний стан і перспективи. Науковий вісник Ужгородського національного університету. Серія «Право». Випуск 58. Том 2. С. 50-53.

5. Овчаренко А.С., Полатай В.Ю. Криптовалюта в системі міжнародного приватного валютного права. Щодо окремих питань оподаткування віртуальних активів в Україні. Recht der Osteuropäischen Staaten (ReOS) (Право країн Східної Європи). 2018. № 4. C. 155-162.

6. Polatay V., Ovcharenko A., Bondarenko I., Gavkalova N. Cryptocurrencies in the system of international private monetary law. Some issues of virtual assets taxation and accounting in Ukraine. Revista Espasios. 2020. Vol. 41 (Issue 08). P. 22.

7. Про запобігання та протидію легалізації (відмиванню) доходів, одержаних злочинним шляхом, фінансуванню тероризму та фрінансуванню розповсюдження зброї масового знищення : Закон України від 6 грудня 2019 р. № 361-IX / Верховна Рада України. Відомості Верховної Ради України. 2020. № 25. Ст. 171.

8. Virtual currency schemes - a futher analysis. European Central Bank. February 2015 URL: https:www.ecb.europa.eu/pub/pdf/other/ virtualcurrencyschemesen.pdf. 
УДК 342.951

DOI https://doi.org/10.32782/2524-0374/2020-4/48

\section{ОСОБЛИВОСТІ ЗДІЙСНЕННЯ МИТНИХ ФОРМАЛЬНОСТЕЙ НА ПОВІТРЯНОМУ ТРАНСПОРТІ В УКРАЇНІ}

\section{SPECIAL FEATURES OF IMPLEMENTING CUSTOMS FORMALITIES IN AIR TRANSPORT IN UKRAINE}

Плетньова А.С., к.ю.н.,
асистент кафедри адміністративного права та адміністративної діяльності Національний юридичний університет імені Ярослава Мудрого

Стаття присвячена викладенню одного з актуальних питань у сфері митної діяльності - здійсненню митних формальностей на повітряному транспорті в Україні.

Кожен з наявних у сучасному світі видів транспорту - водний, наземний і повітряний - має свої особливості, які зумовлені кількістю митних фрормальностей і дій, які виконуються під час митного контролю та митного оформлення, а саме засобом і способом переміщення тощо.

Повітряний вид транспорту займає важливе місце не тільки в процесах внутрішньої економіки України, але й на світовій арені. В науковій літературі поряд із поняттям «повітряний транспорт» застосовується поняття «авіаційний транспорт». Законодавчого закріплення в Україні цих понять немає. Вбачається необхідним чітке розмежування цих категорій на законодавчому рівні для усунення суперечностей, що виникають у зв'язку з оформленням необхідного пакету документів у процесі організації перевезень у межах повітряного простору, а також під час тлумачення понять у разі впровадження міжнародних норм і правил у національне законодавство України.

Митний контроль повітряного судна на прибуття або вибуття складається з декількох митних формальностей і низки дій:

а) повідомлення посадових осіб митниці й отримання відповідних документів;

б) огляд повітряного судна (надання дозволу на висадку пасажирів і вивантаження товарів із борту повітряного судна (у випадку прибуття);

в) безпосереднє проведення огляду повітряного судна;

г) проставлення відмітки на генеральній декларації;

д) надання дозволу на посадку пасажирів (у випадку вибуття).

Митна формальність декларування повітряного судна (на прибуття/вибуття) складається з таких дій: подання командиром повітряного судна необхідних документів; реєстрація поданих документів і проставлення посадовою особою відповідного підрозділу митниці особистого митного забезпечення; внесення інформації до відповідного програмного модуля; формування літакової справи.

Митні фоормальності стосовно товарів, що перевозяться пасажирами на борту повітряного судна, залежать від обрання «зеленого» або «червоного» коридору для проходження митного контролю.

Ключові слова: митна формальність, митне оформлення, митний контроль, повітряний транспорт, повітряне судно, орган доходів і зборів.

The article deals with coverage one of the topical issues in the field of customs activity - implementing customs formalities in air transport in Ukraine.

Nowadays transport modes are divided into waterborne (marine, river), land (rail, road, pipeline) and air transport. Each of them has its own nature, that is determined by the means and method of transportation, the number of customs formalities and actions performed during the customs control and customs clearance.

Air transport plays an important role not only in domestic processes, but also worldwide. In scientific literature, along with the concept of "air transport", the concept of "airlift" is used. There is no legislative consolidation of these concepts in Ukraine. We think that it's necessary to clearly differentiate between these categories at the legislative level to eliminate contradictions that emerge in practice while performing appropriate paperwork in organizing transportation within the sovereign airspace and beyond, as well as in interpreting terms in the context of implementing international rules and standards into the national legislation of Ukraine.

Customs control of an aircraft arrival or departure consists of several customs formalities and a number of actions:

a) notifying customs officials and obtaining relevant documents;

b) an aircraft security search (granting permission to disembark passengers and unload goods from the aircraft (in case of arrival);

c) direct inspection of the aircraft;

d) affixing a mark on the general declaration, granting permission to embark passengers (in case of departure)

The customs formality of declaring an aircraft (arrival/departure) consists of the following actions: submission of necessary documents by the aircraft commander; registration of submitted documents and affixing by an official of the corresponding division of the customs of personal customs support; entering data into the corresponding software module; forming an aircraft record.

Customs formalities for goods carried by passengers on board depend on the choice of a "green" or "red" channel for customs control.

Key words: customs formalities, customs clearance, customs control, air transport, aircraft, revenue and duties authority.

Сучасний стан інтеграції економіки України у світовий економічний простір потребує приведення національного законодавства у відповідність до загальноприйнятих у міжнародній практиці норм, правил та стандартів. Повною мірою це стосується і митної діяльності, яка здійснюється у зв'язку з переміщенням товарів, транспортних засобів, громадян різними видами транспорту через митний кордон України [1]. Зовнішньоекономічна діяльність держави також тісно пов'язана $з$ транспортним забезпеченням, яке являється одною з важливих складових процесу організації доставки товарів від місця їх виготовлення до місця споживання.

Сучасний світовий ринок транспортних послуг $\epsilon$ складним структурованим комплексом, який охоплює транспортні перевезення абсолютно всіх країн світу та забезпечує безперервне функціонування міжнародного товарообороту та перевезень. Країни-лідери 3 найбільш розвиненим транспортним комплексом володіють більшою частиною такого ринку та здатні здійснювати власні перетворення на свою користь та встановлювати нові умови та принципи світових перевезень та комплексу послуг, пов'язаних з ними [2, с. 50].

Транспорт займає особливе місце в міжнародному товарообігу. По-перше, він є необхідною умовою здійснення міжнародного розподілу праці та зовнішньоекономічних зв'язків. По-друге, транспортна промисловість виступає на світових ринках експортером своєї продукції, зокрема, транспортних послуг. Транспортні послуги, що 
здійснюються в сфері зовнішньоекономічної діяльності, піддаються впливу всіх факторів, що характеризують розвиток ринкової економіки.

Кожен 3 існуючих в сучасному світі видів транспорту - водний, наземний та повітряний - має свої особливості, які обумовлені кількістю митних формальностей та дій, які виконуються під час митного контролю та митного оформлення, саме засобом та способом переміщення, тощо.

Митні процедури та митні формальності в цілому та на транспорті зокрема були предметом досліджень дисертаційного та монографічного рівня, виконаних С.А. Трофімовим («Організаційно-правові засади здійснення митних процедур на морському транспорті», 2008 р.), 3.Ю. Кунєвою («Митні формальності: основи адміністративноправової моделі», 2017 р.), О.О. Германом («Митні формальності щодо автомобільних транспортних засобів», 2018 р.), тощо [1].

Поняття «митні формальності» є одним із системоутворювальних у правовому регулюванні митних відносин, але наразі відсутня єдність поглядів щодо його змісту та обсягу [3]. Відповідно до Загального додатку Кіотської конвенції 1973 р., митні формальності - це сукупність дій, що підлягають виконанню відповідними особами і митною службою з метою дотримання вимог митного законодавства [4]. В Україні поняття «митні формальності» вперше було закріплено у Митному кодексі України лише у редакції 2012 р. Відповідно до пункту 29 статті 4 митні формальності визначаються як сукупність дій, що підлягають виконанню відповідними особами і органами доходів і зборів з метою дотримання вимог законодавства України з питань державної митної справи [5]. У глосарії міжнародних митних термінів, опублікованому Всесвітньою митною організацією, під митними формальностями розуміють усі операції, що мають здійснюватися особами, яких це стосується, і митною службою з метою дотримання митного законодавства [6].

У рамках роботи зупинимося на характеристиці специфіки митних формальностей на повітряному транспорті. Повітряний транспорт відіграє важливу роль не тільки у внутрішньодержавних процесах, але й на світовому рівні. Порівняно за невеликий відрізок часу перевезення повітряними шляхами отримали велику популярність. Зростання вантажопідйомності повітряного транспорту, розвиток міжнародної торгівлі, оптимізація логістичних схем, зниження витрат на перевезення - все це зробило переміщення товарів повітряним шляхом доступними для великої кількості замовників.

Слід відзначити, що діюче законодавство України, що регулює переміщення товарів повітряним шляхом одночасно використовує два поняття - «авіаційний транспорт» i «повітряний транспорт» [9].

Згідно статті 32 Закону України «Про транспорт» зазначається, що до складу авіаційного транспорту входять підприємства повітряного транспорту, що здійснюють перевезення пасажирів, вантажів, багажу, пошти, аерофотозйомки, сільськогосподарські роботи, а також аеропорти, аеродроми, аероклуби, транспортні засоби, системи управління повітряним рухом, навчальні заклади, ремонтні заводи цивільної авіації та інші підприємства, установи та організації незалежно від форм власності, що забезпечують роботу авіаційного транспорту [8].

Відповідно до п. 79. ч.1. ст.1 Повітряного кодексу України, повітряне судно - це апарат, що підтримується в атмосфері у результаті його взаємодії з повітрям, відмінної від взаємодії з повітрям, відбитим від земної поверхні [7].

Визначення понять «авіаційного транспорту» й «повітряного транспорту» вищевказаний Кодекс не містить.

Треба зауважити, що науковці неодноразово наголошували про необхідність врахування того факту, що IКАО (Міжнародна організація цивільної авіації) при перевиданні у 2004 р. важливого для всіх користувачів повітряного простору нормативно-правового документа «Керівництво по регулюванню міжнародного повітряного транспорту» у передмові підкреслила, що питання польотів «виходять за межі Керівництва», оскільки термін «авіація» часто некоректно використовується замість терміна «повітряний транспорт». При цьому робився висновок, що «повітряний транспорт» $є$ більш конкретним терміном, що стосується аспектів перевезення повітрям (зазвичай комерційним повітряним транспортом), а «авіація» є загальним терміном, який включає значно більше аспектів, таких як польоти військових, державних та приватних повітряних суден, виробництво повітряних суден, аеронавігацію, некомерційні повітряні перевезення й спеціальні авіаційні послуги [10].

Таким чином, вбачається необхідним чітке розмежування цих категорій, для усунення протиріч, що виникають у зв'язку з оформленням необхідного пакету документів у процесі організації перевезень у межах повітряного простору, а також при тлумаченні понять при впровадженні міжнародних норм та правил у національне законодавство України. Переміщення товарів через митний кордон України повітряним шляхом здійснюється через міжнародні аеропорти, в яких розташовано митні органи. Міжнародний аеропорт - визначений державою на її території аеропорт для приймання і відправлення повітряних суден, що виконують міжнародні повітряні перевезення, у якому здійснюються митні, імміграційні, санітарні, карантинні (стосовно тварин і рослин) та інші процедури, передбачені законодавством [7]. Винятком є випадки вимушеної посадки повітряного судна або з дозволу Кабінету Міністрів України, що надається на кожний окремий випадок митного оформлення поза міжнародним аеропортом. Згідно Типової технологічної схеми здійснення митного контролю повітряних транспортних засобів перевізників і товарів, що переміщуються ними, у пунктах пропуску через державний кордон митний контроль повітряних суден і товарів здійснюється виключно митним органом відповідно до законодавства, вибірково, у формах та обсязі, що визначені на підставі результатів системи управління ризиками. Митний контроль повітряних суден i товарів здійснюється виключно в зонах митного контролю і завершується митним оформленням відповідно до вимог законодавства [11].

Митний контроль повітряних суден, що виконують міжнародні рейси, і товарів здійснюються:

1) таких, що прибувають на митну територію України - після проведення прикордонного контролю;

2) таких, що вибувають з митної території України - до початку прикордонного контролю.

У разі нетривалої стоянки повітряного судна відповідно до затвердженого розкладу руху митний контроль такого судна здійснюється одночасно 3 прикордонним контролем.

Адміністрація міжнародного аеропорту щодня інформує орган доходів і зборів у строки та за формою, погодженою $з$ ним, про план польотів повітряних суден на добу та протягом доби (про його поточне виконання і внесення змін до нього). Водночас повідомляються номер рейсу, маршрут руху, тип повітряного судна, кількість пасажирів, термінал, в якому пасажири проходитимуть контроль, номер стоянки повітряного судна і уточнюється порядок доставки посадових осіб контрольних служб на стоянку повітряного судна чи зі стоянки. Час початку митного контролю повітряного судна, що прибуває на митну територію України чи вибуває з митної території України, встановлюється з урахуванням розкладу руху [12].

Для здійснення митного контролю командир повітряного судна подає посадовій особі органу доходів і зборів документи, передбачені ст. 335 Митного кодексу України, які можна поділити на основні та додаткові [5]. 
У випадках, встановлених законодавством, командир повітряного судна разом 3 документами, передбаченими статтею 335 Кодексу, подає органу доходів і зборів зобов'язання командира судна про реекспорт/реімпорт повітряного судна.

Зобов'язання командира судна про реекспорт/реімпорт повітряного судна не подається митному органу у разі: здійснення міжнародних регулярних польотів на підставі міжнародних договорів України про повітряне сполучення; делегацій;

перевезення вищих посадових осіб і офіційних

- переміщення через державний кордон повітряних суден з метою забезпечення ліквідації наслідків стихійного лиха, аварії, катастрофи, епідемії;

переміщення через державний кордон повітряних суден у зв'язку з проведенням Збройними Силами та іншими військовими формуваннями України за ії межами або військовими формуваннями іноземних держав на території України заходів у рамках міжнародних договорів України, що передбачають відповідний механізм державного контролю за переміщенням таких повітряних суден.

Вибуття повітряного судна за межі митної території України можливе тільки після завершення всіх передбачених законодавством України видів контролю та 3 дозволу адміністрації міжнародного аеропорту, органу доходів і зборів та органу охорони державного кордону. Інформація про оформлення повітряного судна вноситься до програмного модуля «Журнал пункту пропуску» Автоматизованої системи митного оформлення «Інспектор» [12].

Свої особливості має митний контроль товарів, що ввозяться на митну територію України. Товари, що ввозяться повітряним судном на митну територію України, розміщуються на складі. Вивантаження товарів 3 борту проводять уповноважені представники міжнародного аеропорту або перевізника після закінчення прикордонного контролю та 3 дозволу і під контролем органу доходів і зборів. Для отримання дозволу на вивантаження товарів 3 повітряного судна командир також подає посадовій особі органу доходів і зборів документи, передбачені ст. 335 Митного кодексу України [12]. Відомості про вивантаження з борту повітряного судна товарів, що надійшли без документів, про кількість місць із пошкодженою упаковкою та про перевезення їх на склад вносить уповноважений представник міжнародного аеропорту або перевізника до каргоманіфесту.

Каргоманіфест - це зведена відомість, що містить інформацію про номери авіаційних вантажних накладних, кількість вантажних місць, вагу, найменування товарів та інших предметів, які навантажуються на борт (вивантажуються з борту) повітряного судна під митним контролем.

Товари, що надійшли без документів, розміщуються на складі окремо від інших товарів. Документи, що надійшли без товарів, повертаються уповноваженому представникові перевізника [12].

Вивезення товарів за межі складу дозволяється, якщо ці товари:

- оформлені відповідно до заявленого митного режиму; направляються під митним контролем в інший орган доходів і зборів ДФС (інший підрозділ органу доходів і зборів) для їх подальшого митного оформлення;

вивозяться за межі митної території України у разі наявності заборони на їх увезення або відмови інших контролюючих органів у пропуску цих товарів на митну територію України;

в інших випадках, передбачених законодавством України, з письмового дозволу керівництва органу доходів і зборів.

При митному контролі товарів, що вивозяться за межі митної території України, товари розміщуються на складі на підставі авіаційної вантажної накладної, товаросупровідних (товаротранспортних) документів 3 дозволу органу доходів і зборів та під його контролем. Підставою для вивезення товарів із складу для подальшого їх завантаження на борт повітряного судна та вивезення за межі України $€$ каргоманіфест, авіаційні вантажні накладні, товаросупровідні (товаротранспортні) документи та документи, що свідчать про завершення митного оформлення. 3 метою контролю процесів вивантаження товарів зі складу та перевезення їх до повітряного судна посадова особа органу доходів і зборів має право на каргоманіфесті (авіаційних вантажних накладних) робити написи із застереженнями, які є обов'язковими для виконання всіма особами, які беруть участь у цих процесах.

Таким чином, митне оформлення на повітряному транспорті складається 3 низки митних формальностей, а саме - попередніх операцій, тимчасового зберігання та декларування. До попередніх операцій віднесені: попереднє повідомлення органів доходів і зборів про намір ввезти товари на митну територію України; подання документів та відомостей органам доходів і зборів у пунктах пропуску через державний кордон України та доставка товарів та документів у місце, визначене органом доходів і зборів.

Товари (у тому числі особисті речі), що переміщуються у супроводжуваному багажі та ручній поклажі пасажирів повітряного судна, підлягають декларуванню органу доходів і зборів у встановленому законодавством України порядку. Митний контроль товарів, що перевозяться пасажирами, здійснюється з використанням двоканальної системи.

Згідно Митного кодексу України, двоканальна система - це спрощена система митного контролю, яка дає громадянам змогу здійснювати декларування, обираючи один 3 двох каналів проходу (проїзду транспортними засобами особистого користування) через митний кордон України («зелений коридор»/«червоний коридор») [5]. Безпосередньо перед двоканальною системою створюється інформаційна зона, яка надає можливість громадянину зробити свідомий вибір відповідного каналу, для проходження митного контролю. За результатами застосування системи управління ризиками, в тому числі із використанням інформаційних технологій і врахуванням попередньої інформації, та/або якщо є підстави вважати, що у багажі громадянина переміщуються товари 3 порушенням встановленого порядку, орган доходів і зборів має право провести огляд, а в разі необхідності - переогляд багажу з його розпакуванням. На вимогу посадової особи органу доходів і зборів громадянин зобов'язаний пред'явити вміст багажу.

Багаж громадян перебуває під митним контролем 3 моменту переміщення його у зону митного контролю. Митний контроль багажу громадян закінчується:

- у разі ввезення/вивезення на/з митну/митної територію/території України і обрання громадянином «зеленого коридору» - 3 моменту його переміщення за межі зони митного контролю;

у разі ввезення/вивезення на/з митну/митної територію/території України і обрання громадянином «червоного коридору» - після здійснення його митного оформлення в повному обсязі, за винятком митних режимів, які передбачають перебування під митним контролем протягом усього часу дії митного режиму [12].

Слід зазначити, що на повітряному транспорті двоканальна система митного контролю передбачена виключно для пасажирів цих транспортних засобів, в той час коли на автомобільному транспорті передбачена двоканальна система митного контролю щодо транспортних засобів комерційного призначення [1].

Посадка пасажирів на борт повітряного судна проводиться $з$ дозволу органу доходів і зборів й органу охорони 
державного кордону за погодженням з командиром повітряного судна або уповноваженим представником авіаперевізника [12].

Підсумовуючи вищевикладене, можна зробити такі висновки.

Транспорт займає одне з головних місць у економічних відносинах кожної держави сучасності. Використання повітряного транспорту найбільшого поширення набуло в українському законодавстві в умовах розвитку міжнародної торгівлі та зниження витрат на перевезення Але, треба наголосити, що, не дивлячись на європейські спрямування розвитку української економіки, повітряний транспорт розвивається повільно, матеріально-технічна база цієї галузі є застарілою та не відповідає світовим нормам, що негативно впливає на якість послуг у цій сфері та взагалі гальмує розвиток головних соціально-економічних процесів у нашій державі.

В науковій літературі поряд 3 поняттям «повітряний транспорт» широко використовується поняття «авіаційний транспорт». Законодавчого закріплення в Україні цих понять не має. Вбачаємо необхідним чітке розмежування цих категорій на законодавчому рівні для усунення протиріч, що виникають у зв'язку з оформленням необхідного пакету документів у процесі організації перевезень у межах повітряного простору, а також при тлумаченні понять при впровадженні міжнародних норм та правил у національне законодавство України.
Митний контроль повітряного судна (на прибуття/ вибуття) складається 3 декількох митних формальностей та низки дій: а) повідомлення посадових осіб митниці та отримання відповідних документів б) огляд повітряного судна (надання дозволу на висадку пасажирів та вивантаження товарів з борту повітряного судна (у випадку прибуття); безпосереднє проведення огляду повітряного судна; проставлення відмітки на генеральній декларації; надання дозволу на посадку пасажирів (у випадку вибуття). Митна формальність декларування повітряного судна (на прибуття/вибуття) складається з таких дій: подання командиром повітряного судна необхідної документації; реєстрація наданих документів та проставлення посадовою особою органу доходів і зборів відбитку особистої номерної печатки (митного забезпечення); внесення даних до відповідного програмного модулю; складання літакової справи.

Митні формальності стосовно товарів, що перевозяться пасажирами на борту повітряного судна, залежить від обрання «зеленого» або «червоного» коридору для проходження митного контролю.

Також актуальною залишається необхідність відповідності міжнародним митним нормам, принципам і стандартам Європейського Союзу шляхом внесення відповідних змін у національне законодавство України щодо використання єдиної термінології, а саме - в Митний кодекс України, Повітряний кодекс України та інші акти з питань митної справи.

\section{ЛITEPATУРA}

1. Прокопенко В.В. Митні формальності на транспорті в Україні та їх адаптація до міжнародних митних норма, правил та стандартів : автореф. дис. ... д-ра юрид. наук : 12.00.07. Запорожжя, 2018, 32 с.

2. Кухарчик В.Г. Міжнародна торгівля транспортними послугами: сучасний стан. Экономические инновации. 2009. № 39. С. 50-56.

3. Плетньова А.Є. Митні формальності: міжнародний та національний досвід. Актуальні проблеми вітчизняної юриспруденції. 2019. № 4. C. $166-169$.

4. Міжнародна конвенція про спрощення та гармонізацію митних процедур (Кіотська конвенція) від 18 травня 1973 р. Офріційний Вісник України. 2011. № 71. Ст. 2711.

5. Митний кодекс України : Закон України від 19 червня 2020 р. № 4495-VI / Верховна Рада України. URL: https://zakon.rada.gov.ua/ laws/show/4495-17\#Text.

6. Glossary of international customs terms. Організація об'єднаних націй : офіційний вебсайт. URL: http://www.wcoomd.org/media/ wco/public/global/pdf/topics/facilitation/instruments-and-tools/tools/glossary-of-international-customs-terms/glossary-of-international-customsterms.pdf.

7. Повітряний кодекс України : Закон України від 07 серпня 2020 р. № 3393-VI / Верховна Рада України. URL: https://zakon.rada.gov.ua/ laws/show/3393-17/ed20200801\#Техt (дата звернення: 20.07.2020).

8. Про транспорт : Закон України від 10 листопада 1994 р. № № 232/94-BP / Верховна Рада України. URL: https://zakon.rada.gov.ua/ laws/show/232/94-\%D0\%B2\%D1\%80/card2\#Card (дата звернення: 20.07.2020).

9. Демченко Д.О. Державна політика в сфері повітряного транспорту в Україні: особливості та основні напрями розвитку. Економіка і держава. 2012. № 9. С. 115-118.

10. Шереметьєва Є.Т. Теоретичні та методологічні основи дослідження повітряного права України. Юридичний вісник. Серія «Повітряне і космічне право». 2009. № 1. С. 7-11.

11. Типова технологічна схема здійснення митного контролю повітряних транспортних засобів перевізників і товарів, що переміщуються ними, у пунктах пропуску через державний кордон : Постанова Кабінету Міністрів України від 21 травня 2012 р. № 451 / Верховна Pада України. URL: https://zakon.rada.gov.ua/laws/show/451-2012-\%D0\%BF\#n305 (дата звернення: 20.07.2020).

12. Про затвердження Порядку виконання митних формальностей на повітряному транспорті : Наказ Міністерства фінансів України від 03 серпня 2018 р. № 671 / Верховна Рада України. URL: https://zakon.rada.gov.ua/laws/show/z1036-18\#n21 (дата звернення: 21.07.2020). 


\title{
МЕХАНІЗМ ПРИТЯГНЕННЯ ДО АДМІНІСТРАТИВНОЇ ВІДПОВІДАЛЬНОСТІ ІНОЗЕМЦІВ ТА ОСІБ БЕЗ ГРОМАДЯНСТВА
}

\author{
MECHANISM FOR BRINGING TO ADMINISTRATIVE RESPONSIBILITY \\ FOREIGNERS AND STATELESS PERSONS
}

\author{
доцент кафедри адміністративного, господарського права \\ та фінансово-економічної безпеки \\ Сумський державний університет
}

\begin{abstract}
У статті досліджено механізм притягнення до адміністративної відповідальності іноземців та осіб без громадянства. На підставі проведеного аналізу розроблено пропозиції щодо удосконалення такого механізму. Вказано на доцільність конкретизації у законодавстві підстав примусового видворення іноземців та осіб без громадянства, удосконалення самої процедури примусового видворення. Аргументовано доцільність приведення у відповідність положень Кодексу України про адміністративні правопорушення та Закону України «Про правовий статус іноземців та осіб без громадянства» у частині застосування до іноземців та осіб без громадянства примусового видворення та повернення іноземців та осіб без громадянства. Визначено проблемні питання механізму притягнення до адміністративної відповідальності таких осіб. Майновий характер адміністративних стягнень, що накладаються за більшість правопорушень, що вчиняються іноземцями на території України, та відсутність дієвого механізму примусу щодо виконання рішень компетентних органів у таких справах. Наявність у Законі України «Про виконавче провадження» положення про те, що у разі відсутності у боржника-іноземця майна, на яке може бути звернене стягнення, державний виконавець може ініціювати процедуру примусового видворення таких осіб за межі України або заборони для них в'їзду в Україну, яка, по суті, дозволяє іноземцю уникнути відповідальності. Прогалини у митному та адміністративному законодавстві дозволяють іноземцю уникнути виконання накладення стягнення у формі штрафу. Запропоновано два напрями вирішення окреслених проблем: удосконалення національного адміністративно-деліктного законодавства та укладення міжнародних договорів про взаємодопомогу. У частині удосконалення адміністративно-деліктного законодавства запропоновано створення системи фіксації та електронного реєстру транспортних засобів, за допомогою яких було скоєно адміністративні правопорушення; зменшення строків сплати адміністративних штрафів. Запропоновано замінити частини стягнень, що накладають за вчинення адміністративних правопорушень у формі штрафу незначного розміру, на громадські роботи, які відповідно до ст. $30^{1}$ КУпАП полягають у виконанні особою, яка вчинила адміністративне правопорушення, у вільний від роботи чи навчання час безоплатних суспільно корисних робіт, вид яких визначають органи місцевого самоврядування.

Ключові слова: іноземець, особа без громадянства, адміністративна відповідальність, адміністративне стягнення, примусове видворення, примусове повернення, штраф.
\end{abstract}

The article examines the mechanism of bringing foreigners and stateless persons to administrative responsibility. Based on the analysis, proposals for improving such a mechanism have been developed. The expediency of specifying in the legislation the grounds for expulsion of foreigners and stateless persons, improvement of the expulsion procedure itself is indicated. The expediency of bringing the provisions of the Code of Ukraine on Administrative Offenses and the Law of Ukraine "On the Legal Status of Foreigners and Stateless Persons" in terms of applying to foreigners and stateless persons forced expulsion and return of foreigners and stateless persons is argued. Problematic issues of the mechanism of bringing such persons to administrative responsibility have been identified. Property nature of administrative penalties imposed for most offenses committed by foreigners on the territory of Ukraine and the lack of an effective enforcement mechanism for the execution of decisions of competent authorities in such cases. The Law of Ukraine "On Enforcement Proceedings" stipulates that if a foreign debtor does not have property that can be levied, the state executor may initiate a procedure to expel such persons from Ukraine or prohibit them from entering Ukraine, which, in fact, allows a foreigner to avoid liability. Gaps in customs and administrative legislation that allow a foreigner to avoid enforcing a fine. Two directions of solving the outlined problems are offered: improvement of the national administrative-tort legislation and the conclusion of international agreements on mutual assistance. In terms of improving the administrative-tort legislation, it is proposed to create a system of fixation and electronic register of vehicles with which administrative offenses were committed; reduction of terms of payment of administrative fines. It is proposed to replace parts of the fines imposed for committing administrative offenses in the form of a fine of insignificant size, for public works, which in accordance with Art. $30^{1} \mathrm{КУПАП} \mathrm{consist} \mathrm{in} \mathrm{performance} \mathrm{by} \mathrm{the} \mathrm{person} \mathrm{who} \mathrm{has} \mathrm{committed} \mathrm{an} \mathrm{administrative} \mathrm{offense,} \mathrm{in} \mathrm{free} \mathrm{time}$ from work or study of free socially useful works which kind is defined by local governments.

Key words: foreigner, stateless person, administrative liability, administrative penalty, forced expulsion, forced return, fine.

Постановка проблеми. Перехід України від пострадянської моделі адміністративно-деліктного законодавства до європейської потребує удосконалення механізму притягнення до адміністративної відповідальності іноземців та осіб без громадянства. У національному законодавстві задекларовано однакову правосуб'єктність як іноземців, осіб без громадянства, так і громадян України (ст. 23 Конституції України [1], ст. 3 Закону України «Про правовий статус іноземців та осіб без громадянства» [2]). У ст. 16 Кодексу України про адміністративні правопорушення (надалі - КУпАП) зазначено, що іноземці та особи без громадянства підлягають адміністративній відповідальності на загальних підставах [3]. Проте зазначені норми не підкріплено дієвим механізмом притягнення до адміністративної відповідальності таких осіб.

У адміністративному законодавстві передбачено порядок реалізації адміністративного примусу у вигляді видворення за межі України та заборону подальшого в'їзду в Україну за порушення іноземцями та особами без громадянства порядку перетину державного кордону; порушення правил перебування в Україні недотримання порядку реєстрації, проживання за недійсними документами; недотримання порядку пересування і вибору місця проживання. Проте практична реалізація примусового видворення іноземців є проблематичною. Протягом 2018 першого півріччя 2019 років до адміністративної відповідальності за порушення правил перебування в Україні притягнуто 38607 іноземців, прийнято рішення про примусове видворення (повернення) 16514 осіб, виконано рішення тільки щодо 10898 осіб [4]. Притягнення іноземців та осіб без громадянства до адміністративної відповідальності у вигляді майнових санкцій за порушення громадського порядку, митного та податкового законодавства також є неефективним. У цій частині адміністративне законодавство є застарілим. Про відсутність належного механізму притягнення до адміністративної відповідальності іноземців та осіб без громадянства неодноразово звітували Державна міграційна служба, Департамент державної виконавчої служби, Рахункова палата. Залишається невирішеним питання 3 ідентифікації (встановлення) 
особи та документування виявлених нелегальних мігрантів для забезпечення їх примусового видворення за межі України. 31405 осіб, яких звільнено з пунктів тимчасового перебування іноземців, лише $816(58,1 \%)$ покинули Україну, а 589 (майже 40\%) звільнені у зв'язку із закінченням терміну утримання, або на підставі рішень суду знову переходили на нелегальне становище [4].

Стан наукової розробки теми. Теоретичні засади адміністративної відповідальності є грунтовно розробленими у вітчизняній правничій науці. Питання адміністративної відповідальності іноземців та осіб без громадянства досліджувалися О.В. Аніною [5], І.О. Гавриловою [6], Є.В. Кобко [7], Я.П. Павлович-Сенетою [8]. Проте механізм притягнення до адміністративної відповідальності іноземців та осіб без громадянства досліджений фрагментарно. Аналіз наукової літератури вказує на два проблемні складники: доцільність упорядкування системи адміністративних стягнень та порядку їх застосування до іноземців та осіб без громадянства; реформування процесуальних норм, які визначають порядок притягнення до адміністративної відповідальності таких категорій осіб.

Основною метою статті $є$ розробка пропозицій щодо удосконалення механізму притягнення до адміністративної відповідальності іноземців та осіб без громадянства.

Виклад основного матеріалу. Порядок притягнення до адміністративної відповідальності іноземців та осіб без громадянства визначається ст.ст. 16, 24, 33-40 КУпАП, ст.ст. 23, 24, 26, 30, 32 Закону України «Про правовий статус іноземців та осіб без громадянства». На підзаконному рівні порядок реалізації ст.ст. 26, 30 Закону України «Про правовий статус іноземців та осіб без громадянства» визначається Інструкцією про примусове повернення і примусове видворення з України іноземців та осіб без громадянства, затвердженою спільним наказом Міністерства внутрішніх справ України, Адміністрації Державної прикордонної служби, Служби безпеки України від 23 квітня 2012 року № 353/271/150. Опосередковано порядок притягнення до відповідальності іноземців та осіб без громадянства визначається також Законами України «Про громадянство України», «Про імміграцію», «Про свободу пересування та вільний вибір місця проживання в Україні», «Про біженців та осіб, які потребують додаткового або тимчасового захисту».

3 огляду положень ст. 16 КУПАП жоден іноземний громадянин не може уникнути відповідальності в разі порушення норм адміністративного законодавства Ст. 24 КУПАП разом 3 переліком видів адміністративних стягнень зазначено спеціальний вид адміністративного стягнення щодо іноземців та осіб без громадянства видворення за межі України. Порівняльний аналіз положень КУПАП та Закону України «Про правовий статус іноземців та осіб без громадянства» вказує на такі обов'язкові умови застосування видворення за межі України: необхідність наявності спеціальної норми, яка передбачає адміністративне видворення; вчинення іноземцем або особою без громадянства адміністративного правопорушення, яке грубо порушує порядок.

Ст. 26 Закону України «Про правовий статус іноземців та осіб без громадянства» передбачено такий вид адміністративного примусу, як примусове повернення іноземців та осіб без громадянства. Зазначений вид примусу взагалі не передбачено у ст. 24 КУПАП. Зазначене вказує на потребу приведення у відповідність положень Закону України «Про правовий статус іноземців та осіб без громадянства» та КУпАП. Механізм, підстави застосування примусового повернення вказують на його конкретизацію саме як адміністративного стягнення. Такого ж погляду додержується Є.В. Кобко та пропонує доповнити КУПАП ст. $32^{2}$ «Адміністративне видворення іноземців та осіб без громадянства», ст. $32^{3}$ «Примусове повернення іноземців та осіб без громадянства» $[7$, с. 33$]$.
Погоджуючись 3 автором, слід вказати на доцільність конкретизації у законодавстві підстав видворення іноземців та осіб без громадянства та удосконалення самої процедури видворення. Зокрема, Законом «Про перебування іноземців на території Чеської Республіки та внесення змін до деяких законів» встановлено перелік правопорушень, які $€$ підставою для видворення з зазначенням періоду, протягом якого іноземець не може в 'їжджати на територію держав - членів ЄС. Відповідно до § 19 Закону «Завершення тимчасового перебування на території, для якого не потрібна віза, і закінчення цього перебування» перебування іноземця на території, для якої не потрібна віза, припиняється поліцією, якщо іноземець, серед іншого, умисно грубо порушує громадський порядок, порушує обов'язки, встановлені чинним законом, на вимогу поліції не підтвердить законними засобами підстави для перебування на території.

Поліція припиняє перебування відповідно до ст. 1 Закону шляхом видачі виїзного наказу. Іноземець зобов'язаний виїхати з території в термін, встановлений виїзним наказом, якщо не було почато провадження щодо видворення іноземця з території згідно з законом [9]. Таким чином, чеським органам поліції надано повноваження щодо видворення іноземців за порушення чинного законодавства без залучення до цього процесу суду.

Окрім приведення у відповідність положень КУпАП та Закону України «Про правовий статус іноземців та осіб без громадянства», потребують доопрацювання норми підзаконних нормативно-правових актів. Однією з основних проблем є несвоєчасна ідентифікація іноземців, які за рішенням суду підлягають примусовому видворенню. Основними причинами несвоєчасної ідентифікації є відсутність в Україні акредитованого дипломатичного представництва або консульської установи країни походження іноземця, тривалі терміни очікування відповідей від компетентних органів країни походження іноземця або консульської служби Міністерства закордонних справ, неузгодженість дій територіальних органів Державної міграційної служби, пов'язаних з примусовим видворенням нелегальних мігрантів (направлення індивідуальних запитів до країни походження іноземця, отримання додаткової інформації про нього, встановлення зв'язків із Міністерством внутрішніх справ або консульськими закладами в інших країнах) [4, с. 18].

Наприклад, 25 червня 2018 року Дзержинський районний суд м. Харкова у справі № 743/255/19 прийняв рішення про примусове видворення громадянина Бангладеш Раселя, 1991 року народження, з поміщенням у Чернігівський пункт тимчасового перебування іноземців на строк до 6 місяців. Рішенням Ріпкинського районного суду Чернігівської області від 30 листопада 2018 року строк затримання іноземця продовжено до 28 лютого 2019 року. За 9 місяців утримання іноземця в пункті тимчасового перебування іноземців його особу не ідентифіковано та не видано свідоцтва про належність до громадянства, що унеможливило видворення за межі України. У матеріалах судової справи зазначено: ГУ Державної міграційної служби в Харківській області 4 липня 2018 року звернулося до Департаменту, але відповіді не отримало. Державна міграційна служба 1 серпня 2018 року звернулася до Міністерства закордонних справ 3 проханням ідентифікувати вісьмох громадян Бангладеш, оскільки в Україні відсутне дипломатичне представництво або консульська установа Бангладеш. Шосткінський апеляційний адміністративний суд рішенням від 12 березня 2019 року відмінив рішення Ріпкинського районного суду від 18 лютого 2019 року про продовження строку затримання зазначеного громадянина ще на три місяці, мотивуючи це тим, що «в матеріалах справи відсутні докази здійснення ГУ Державної міграційної служби в Харківській області дій щодо забезпечення виконання рішення про примусове видво- 
рення з моменту продовження строку утримання, а саме з 20 грудня 2018 року». У результаті іноземця звільнено 3 пункту тимчасового перебування іноземців та залишено в Україні. Інформацією про його подальше перебування в країні Державна міграційна служба не володіє [4, с. 19].

Системні невирішені проблеми та прогалини має механізм притягнення до адміністративної відповідальності у формі майнових стягнень (штрафів). Окрім КУпАП, адміністративні штрафи передбачено Митним та Податковим кодексами України. При цьому відповідно до положень кодексів іноземці та особи без громадянства мають таку ж правосуб'єктість, як і фізичні особи - громадяни України, а отже, несуть відповідальність на загальних підставах. Проте примусове виконання рішень про стягнення адміністративних штрафів 3 іноземців та осіб без громадянства має ускладнений компонент, зумовлений тимчасовим перебуванням таких осіб на території України.

Законом України «Про виконавче провадження» державному виконавцю надано можливість застосовувати до боржників, в тому числі іноземців, осіб без громадянства та іноземних юридичних осіб усі визначені цим законом заходи примусового виконання, які встановлені ст. 10 Закону. Проте не всі ці заходи можна застосувати до іноземця.

Також державний виконавець 3 метою ефективного виконання рішення має право у разі ухилення боржника від виконання зобов'язань, покладених на нього рішенням, звертатись до суду за встановленням тимчасового обмеження у праві виїзду боржника за межі України (ст. 18 Закону). У зв'язку із цим суди розглядали подання державних виконавців про тимчасове обмеження у праві виїзду за межі України боржників у виконавчому провадженні.

Особливості виконання рішень щодо іноземців, осіб без громадянства та іноземних юридичних осіб визначені ст. 77 Закону України «Про виконавче провадження». Відповідно до ч. 1 цієї статті під час виконання рішень стосовно іноземців, осіб без громадянства та іноземних юридичних осіб, які, відповідно, проживають (перебувають) чи зареєстровані на території України або мають на території України власне майно, яким володіють самостійно або разом з іншими особами, застосовуються положення Закону. У разі невиконання іноземцями, особами без громадянства та іноземними юридичними особами таких рішень виконавець звертається до центрального органу виконавчої влади, що забезпечує реалізацію державної політики у сфері міграції, органів охорони державного кордону з поданням про заборону в 'їзду в Україну чи видворення за межі України таких осіб відповідно до Закону [10].

Питання про тимчасове обмеження у праві виїзду за межі України вирішується судом за правилами цивільного судочинства в порядку, передбаченому ст. 441 Цивільного процесуального кодексу України [11]. За змістом цієї статті вирішення питання про тимчасове обмеження у праві виїзду за межі України вирішується в порядку цивільного процесу щодо боржників у виконавчому провадженні, за будь-якими виконавчими документами, передбаченими ст. 3 Закону України «Про виконавче провадження», примусове виконання яких здійснюється Державною виконавчою службою.

Крім того, Розділом XIII Інструкції з організації примусового виконання рішень [12] передбачено, що у разі невиконання іноземцем, особою без громадянства чи іноземною юридичною особою рішення про накладення штрафів за правопорушення, розгляд справ за якими законом віднесено до компетенції Державної прикордонної служби України або Державної міграційної служби України, державний виконавець у тридцятиденний строк 3 моменту відкриття виконавчого провадження звертається до відповідного органу охорони державного кордону чи Державної міграційної служби з поданням про заборону в’їзду в Україну таких осіб відповідно до Закону України «Про правовий статус іноземців та осіб без громадянства».

Аналіз зазначених положень законодавства України свідчить, що іноземець, який тимчасового перебуває на території України на законних підставах у разі вчинення адміністративного правопорушення, у разі відсутності у нього майна, на яке може бути звернене стягнення, може уникнути адміністративної відповідальності. За умови, якщо візит іноземця до України і планувався як короткотерміновий та без повторного в'їзду, механізм притягнення його до відповідальності за порушення митних правил, правил дорожнього руху, інших адміністративних правопорушень, за які законодавством передбачене стягнення у формі штрафу, є абсолютно недієвим.

Зокрема, здебільшого іноземні громадяни покидають територію України за час, який відведений для сплати штрафу за порушення митних правил. Майна та відкритих рахунків в банках на території України вони зазвичай також не мають. За таких обставин державні виконавці органів Державної виконавчої служби не можуть реалізувати виконання постанов про накладення штрафів і стягнути кошти з осіб, які порушили митні правила.

Реалізація виконання рішення щодо іноземців, які порушили митні правила та не сплатили штрафи, можлива лише в порядку, передбаченому ч. 2 ст. 77 Закону України «Про виконавче провадження», а саме - звернення з поданням про заборону в'їзду в Україну чи видворення за межі України таких осіб відповідно до Закону.

Отже, вітчизняні механізми притягнення іноземців до адміністративної відповідальності у вигляді штрафу $\epsilon$ недосконалими та містять суттєві прогалини. Серед таких недоліків доцільно зазначити:

майновий характер адміністративних стягнень, що накладаються за більшість правопорушень, що вчиняються іноземцями на території України, та відсутність дієвого механізму примусу щодо виконання рішень компетентних органів у таких справах;

наявність у Законі України «Про виконавче провадження» положення про те, що у разі відсутності у боржника-іноземця майна, на яке може бути звернене стягнення, державний виконавець може ініціювати процедуру видворення таких осіб за межі України або заборони для них в'їзду в Україну, яка, по суті, дозволяє іноземцю уникнути відповідальності;

прогалини у митному та адміністративному законодавстві, які дозволяють іноземцю уникнути виконання накладення стягнення у формі штрафу.

Висновки. Проведений аналіз вказує на два напрями вирішення окреслених проблем: удосконалення національного адміністративно-деліктного законодавства та укладення міжнародних договорів про взаємодопомогу.

У частині удосконалення адміністративно-деліктного законодавства представляється доцільним створення системи фіксації та електронного реєстру транспортних засобів, за допомогою яких було скоєно адміністративні правопорушення; зменшення строків сплати адміністративних штрафів.

Іншим шляхом вирішення проблеми може бути заміна частини стягнень, що накладають за вчинення адміністративних правопорушень у формі штрафу незначного розміру на громадські роботи, які відповідно до ст. $30^{1}$ КУПАП полягають у виконанні особою, яка вчинила адміністративне правопорушення, у вільний від роботи чи навчання час безоплатних суспільно корисних робіт, вид яких визначають органи місцевого самоврядування. За таких умов навіть іноземці, які не мають майна, зможуть «відпрацювати» вчинене адміністративне правопорушення. Звісно, впровадження таких змін потребує також створення компетентних органів та фінансування їх діяльності. 


\section{ЛITEPATYPA}

1. Конституція України від 28 червня 1996 року № 254K/96-BP. URL: https://zakon.rada.gov.ua/laws/show/254\%D0\%BA/96$\% \mathrm{D} \% \mathrm{~B} 2 \% \mathrm{D} 1 \% 80$.

2. Про правовий статус іноземців та осіб без громадянства: Закон України від 22 вересня 2011 року № 3773-VI. Офріційний вісник України. 2011 р. № 83. С. 7.

3. Кодекс України про адміністративні правопорушення: Закон УРСР від 18 грудня 1984 року № 8073-Х. Відомості Верховної Ради УPCP. 1984 p. № 51. С. 1122.

4. Звіт про результати аудиту ефективності використання бюджетних коштів, виділених Державній міграційній службі України на забезпечення виконання завдань у сферах міграції, громадянства, реєстрації фізичних осіб, біженців та інших визначених законодавством категорій мігрантів: затверджено рішенням Рахункової палати від 8 жовтня 2019 року № 28-7. URL: https://rp.gov.ua/upload-files/ Activity/Collegium/2019/28-7 2019/Zvit 28-7 2019.pdf.

5. Аніна О.В. Іноземці та особи без громадянства в адміністративно-деліктному процесі України : автореф. дис. ... канд. юрид. наук : 12.00.07. Держ. НДІ МВС України. Київ, 2012, 19 с.

6. Гаврилова І.О. Особливості адміністративної відповідальності іноземців та осіб без громадянства. Науковий вісник Херсонського державного університету. Серія «Юридичні науки». 2015. Вип. 5. Т. 2. С. 99-102.

7. Кобко Є.В. Щодо застосування норм адміністративно-деліктного законодавства України до іноземців. Право $і$ безпека. 2017. № 2 (65). С. 30-34.

8. Павлович-Сенета Я.П. Основні напрями вдосконалення адміністративної відповідальності іноземців та осіб без громадянства в Україні: сучасний стан та досвід зарубіжних країн. Науковий вісник Львівського державного університету внутрішніх справ. 2016. № 1. С. 206-217.

9. Про перебування іноземців на території Чеської Республіки та внесення змін до деяких законів: Закон Чеської Республіки № 326/1999. URL: http://www.czechlegistation/com/ru/326-1999-sb.

10. Про виконавче провадження: Закон України від 2 червня 2016 року № 1404-VIII. Відомості Верховної Ради України. 2016 р. № 30. C. 5.

11. Цивільний процесуальний кодекс України: Закон України в редакції Закону від 3 жовтня 2017 року № 2147-VIII. URL: https://zakon.rada.gov.ua/laws/show/1618-15\#n9192.

12. Про затвердження Інструкції з організації примусового виконання рішень: наказ Міністерства юстиції України від 02.04.2012 № 512/5 Ооріційний вісник України. 2012 р. № 27. С. 23. 


\title{
ПРАВО НА БЕЗОПЛАТНУ ПРАВОВУ ДОПОМОГУ ЯК ОБ'ЄКТ АДМІНІСТРАТИВНО-ПРАВОВОГО ЗАБЕЗПЕЧЕННЯ
}

\author{
THE RIGHT TO FREE LEGAL AID \\ AS AN OBJECT OF ADMINISTRATIVE AND LEGAL SUPPORT
}

\author{
Сахнюк В.В., здобувач вищої освіти третього рівня \\ Навчально-науковий інститут права \\ Національного університету водного господарства та природокористування
}

У статті проаналізовано дефініції, запропоновані теоретиками адміністративного права на поняття «адміністративно-правове забезпечення». Виокремлено чотири основних наукових підходи: по-перше, адміністративно-правове забезпечення розглядається як цілеспрямована дія на поведінку людей і суспільні відносин або ж вплив на них за допомогою передбачених у законодавстві адміністративноправових засобів; по-друге, як діяльність уповноважених державою органів щодо здійснення своїх функцій; по-третє, як упорядкування суспільних відносин, їх юридичне закріплення, охорона, реалізація та розвиток; по-четверте, як створення та підтримка умов для всебічної реалізації прав, свобод та інтересів людини, громадянського суспільства, а також інших суб'єктів адміністративно-правових відносин.

Проведено розмежування між поняттям «адміністративно-правове забезпечення» та «адміністративно-правове регулювання». Запропоновано під адміністративно-правовим забезпеченням права на безоплатну правову допомогу розглядати діяльність органів державної влади та місцевого самоврядування, суб'єктів надання безоплатної правової допомоги, зміст якої становить створення та підтримка необхідних правових, інституційних, кадрових, інформаційно-аналітичних та матеріально-технічних умов належної реалізації, охорони та захисту права громадян, які опинилися в важких життєвих обставинах, на безоплатну професійну правову допомогу.

Розкрито складники адміністративно-правового забезпечення права на безоплатну правову допомогу, до яких включено нормативноправовий, інституційний, кадровий, інформаційно-аналітичний, фінансовий та матеріально-технічний складники.

Описано ознаки адміністративно-правового забезпечення права на безоплатну правову допомогу, серед яких: 1) це діяльність уповноважених суб'єктів, що володіють загальною та спеціальною компетенцією у сфері надання безоплатної правової допомоги; 2) така діяльність знаходить юридичне закріплення в нормах права, зокрема законах та підзаконних нормативно-правових актах; 3) метою адміністративно-правового забезпечення $є$ захист та охорона права на безоплатну правову допомогу; 4) адміністративно-правового забезпечення здійснюється шляхом створення правових, інституційних, кадрових, інформаційно-аналітичних та матеріально-технічних умов.

Ключові слова: адміністративно-правове забезпечення, адміністративно-правове регулювання, право на безоплатну правову допомогу.

The article analyzes the definitions proposed by theorists of administrative law for the concept of "administrative and legal support". There are four main scientific approaches and they are as follows: firstly, administrative and legal support is considered as a purposeful action aimed on the behavior of people and social relations or the impact on them through the administrative legal means provided by law; secondly, as the activity of the bodies authorized by the state to perform their functions; thirdly, as the regulation of social relations, their legal consolidation, protection, implementation and development; fourthly, as the creation and maintenance of conditions for the full realization of human rights, freedoms and interests, civil society and other subjects of administrative and legal relations.

A distinction is made between the concept of "administrative and legal support" and "administrative and legal regulation". It is proposed to consider the activities of public authorities and local governments, subjects of free legal aid under the administrative and legal support of the right to free legal aid, the content of which is to create and maintain the necessary legal, institutional, personnel, information-analytical and logistical conditions for the proper realization, protection and defense of the right of citizens who find themselves in difficult life circumstances to free professional legal assistance. It is proposed to consider the activities of public authorities and local governments, subjects of free legal aid under the administrative and legal support of the right to free legal aid. Their content is to create and maintain the necessary legal, institutional, personnel, information-analytical and logistical conditions for the proper implementation, protection and defense of the right to free professional legal assistance of citizens who find themselves in difficult life circumstances.

The components of administrative and legal support of the right to free legal aid are revealed, which include normative-legal, institutional, personnel, information-analytical, financial and material-and-technical parts.

The features of administrative and legal support of the right to free legal aid are described, among which are the follows, 1) the activity of authorized entities with general and special competence in the field of free legal aid; 2) such activity is legally enshrined in the law, in particular, laws and bylaws; 3 ) the purpose of administrative and legal support is to protect and safeguard the right to free legal aid; 4) administrative and legal support is provided by creating legal, institutional, personnel, information-analytical and material-and-technical conditions.

Key words: administrative and legal support, administrative and legal regulation, the right to free legal aid.

У своїй щорічній доповіді Уповноважений Верховної Ради України з прав людини констатував порушення права людини на професійну правничу допомогу. Серед основних проблемних питань було відмічено необізнаність про можливість отримання правничої допомоги у більшості відвіданих закладів соціального захисту населення, освіти, охорони здоров'я; низький рівень інформування громадян про їх права; неналагоджена співпраця центрів вторинної безоплатної правової допомоги з соціальними установами; порушення адвокатами стандартів якості надання безоплатної вторинної правової допомоги; недотримання органами поліції обов'язку забезпечити право затриманої особи на адвоката з самого початку кримінального переслідування та деякі інші [18]. Як бачимо, більшість 3 названих порушень знаходяться у площині саме адміністративно-правового забезпечення права на без- оплатну правову допомогу, а тому обрана проблематика $\epsilon$ актуальним предметом наукового пошуку.

Адміністративно-правове забезпечення як одна 3 основних категорій адміністративного права вивчалася В.П. Бойко, К.В. Бурсуковим, О.М. Гуміним, I.О. Ієрусалімовою, Є.Є. Колесниковим, О.О. Кривко, О.В. Климнко, К.В. Степаненко, І.М. Шопіною, М.В. Цвік та інші. Своєю чергою окремі адміністративно-правові аспекти права на безоплатну правову допомогу були предметом дослідження С.Ю. Бови, С.В. Вилкова, А.В. Іванцова, М.В. Стаматіної, К.О. Струкової та інших.

Мета статті - охарактеризувати право на безоплатну правову допомогу як об'єкт адміністративно-правового забезпечення.

Поняття адміністративно-правового забезпечення у теорії адміністративного права не знайшло однознач- 
ного вирішення. Аналіз наукових публікацій, присвячених окресленій проблематиці, дозволяє сформувати чотири основні підходи.

Так, по-перше, адміністративно-правове забезпечення розглядається як цілеспрямована дія на поведінку людей і суспільні відносини [16, с. 327], або ж вплив на них за допомогою адміністративно-правових засобів [8, с. 83; 6, с. 127]. Прикладом такого підходу є визначення, запропоноване I.О. Ієрусалімовою, яка вважає, що адміністративно-правове забезпечення передбачає насамперед регулювання за допомогою норм адміністративного права суспільних відносин, що виникають у процесі реалізації прав і свобод людини та громадянина, вплив на них за допомогою передбачених у законодавстві елементів [8, с. 83].

Представником другого підходу є К.В. Бурсуков, який розглядає поняття «забезпечення» у двох значеннях По-перше, як діяльність уповноважених державою органів щодо здійснення своїх функцій. По-друге, як результат цієї діяльності, що виражається у фактичній реалізації правових приписів, прав і свобод громадян [1, с. 7] Діяльність органів державної влади знаходиться в основі визначення адміністративно-правового забезпечення функціонування органів судової влади, запропонованого В. Бойком [2, с. 98$]$.

Іншого погляду дотримується група авторів, до якої входять О.М. Гумін [5, с. 49], О.В. Клименко [9, с. 12], Є.Є. Колесников [10, с. 434], М.В. Фролков [15, с. 550]. Названі автори розглядають адміністративно-правове забезпечення як упорядкування суспільних відносин, їх юридичне закріплення, охорона, реалізація та розвиток.

Наступну групу авторів представляють О.О. Кривко [11], К.В. Степаненко [14, с. 14], I.М. Шопіна [17, с. 460]. Адміністративно-правове забезпечення в межах підходу, запропонованого названими авторами, розглядається як створення та підтримка умов для всебічної реалізації прав, свобод та інтересів людини, громадянського суспільства а також інших суб'єктів адміністративно-правових відносин.

Водночас поряд 3 поняттям «адміністративно-правове забезпечення» вживається також поняття «адміністративно-правове регулювання». Для їх розмежування звернемося до Великого тлумачного словника української мови. У останньому міститься таке тлумачення дієслова забезпечувати - «створювати надійні умови для здійснення чого-небудь, гарантувати щось», i таке визначення дієслова регулювати - «впорядковувати що-небудь, керувати чимось, підкоряючи його відповідним правилам, певній системі» [3]. Відштовхуючись від таких значень, вважаємо, що під адміністративно-правовим забезпеченням необхідно розглядати діяльність органів державної влади та місцевого самоврядування, зміст якої становить створення та підтримка необхідних правових та організаційних умов для належної реалізації, охорони та захисту прав і свобод громадян. Тоді як адміністративно-правове регулювання - це діяльність органів державної влади та місцевого самоврядування, зміст якої становить цілеспрямований вплив на суспільні відносини з метою їх упорядкування, юридичного закріплення, охорони та реалізації.

У цьому контексті хочемо підтримати позицію I.M. Шопіної, яка зазначає, що збільшення впливу людиноцентристських тенденцій у розвитку адміністративного права зумовлює поступову втрату провідної ролі адміністративно-правового регулювання як більш жорсткої правової конструкції, якій не притаманна полісуб'єктність та врахування індивідуальних відмінностей. Натомість протягом останніх років спостерігається підвищення ролі категорії «адміністративно-правове забезпечення», особливістю якої $є$ зміщення акценту у системі прийняття рішень 3 волі держави на інтенції людини та громадян- ського суспільства. Інакше кажучи, спрямованість адміністративно-правового регулювання передбачає формування мети такого регулювання органами держави за провідної ролі імперативного методу. Натомість адміністративно-правове забезпечення передбачає формування мети прийняття тієї чи іншої правової норми передусім за системою публічного адміністрування, така мета формується суб'єктами громадянського суспільства, суб'єктами господарювання, для розвитку яких є необхідним ті чи інші зміни у структурі та змісті суспільних відносин. Завданням держави за таких умов є зміна або створення за допомогою правових засобів умов, за яких мета таких суб'єктів може найбільш ефективно досягатися $[17$, с. 459$]$.

Для характеристики права на безоплатну правову допомогу необхідно використовувати саме поняття «адміністративно-правове забезпечення», адже завданням держави $є$ створення належних умов для реалізації цього права, а не його підпорядкування державній системі. Так, А.В. Іванцова пише: «Теза про те, що «кожен має право на професійну правничу допомогу» $є$ конституційною декларацією, яка передбачає створення в державі умов, за яких кожен міг би задовольнити своє право на отримання необхідної правової допомоги в будь-якому місці й у будь-який час. Це означає, що така допомога за Основним Законом має бути доступною, нічим не обмеженою й реальною» [7, с. 40]. С.В. Вилков своєю чергою відзначає, що особливість права на отримання безоплатної правової допомоги полягає в тому, що воно опосередковує суспільні відносини і взаємозв'язки громадян не лише між собою, але й 3 державою загалом [4, с. 26].

Держава як гарант забезпечення прав і свобод людини і громадянина повинна створити належні реальні, а не формальні умови для реалізації і використання права на безоплатну правову допомогу категорією осіб, яка має на нього право. На наш погляд, адміністративно-правове забезпечення права на безоплатну правову допомогу повинно включати такі складники:

1) нормативно-правовий складник, під яким ми розглядаємо систему національних та міжнародних стандартів, дотримання яких обов'язкове під час надання безоплатної правової допомоги. На цей час право на безоплатну правову допомогу гарантоване низкою міжнародних актів, серед яких Загальна декларація прав людини, прийнята 10 грудня 1948 р. Генеральною Асамблеєю $\mathrm{OOH}$, Міжнародний пакт про громадянські і політичні права, прийнятий 6 грудня 1966 р. Генеральною Асамблеєю ООН, Конвенція про захист прав людини і основоположних свобод, прийнята 11 квітня 1950 р. Радою Європи, та інші міжнародно-правові акти.

2) Національні стандарти щодо забезпечення конституційного права особи на правову допомогу закріплені у Конституції України від 28.06.1996 № 254к/96-ВР, галузевих процесуальних кодексах, Законі України «Про безоплатну правову допомогу» від 02.06.2011 № 3460-VI, Законі України «Про адвокатуру та адвокатську діяльність» від 05.07.2012 № 5076-VI та інших нормативноправових актах.

3) інституційний складник як сукупність уповноважених суб'єктів, що володіють загальною або спеціальною компетенцією у сфері надання безоплатної правової допомоги та мають на меті ефективне забезпечення належного практичного втілення в життя основ захисту прав людини, забезпечення доступу до правосуддя, установлених нормами права, через спеціально створені організації та інші уповноважені суб'єкти з метою надання правових послуг. Суб'єктів, що беруть участь в організації діяльності системи надання безоплатної правової допомоги, можна розділити на тих, що володіють загальною компетенцією (Кабінет Міністрів України, Міністерство юстиції України), та тих, що володіють спеціальною компетенцією 
(Координаційний центр 3 надання правової допомоги, суб'єкти надання безоплатної первинної правової допомоги та суб'єкти надання безоплатної вторинної правової допомоги);

4) кадровий складник, який включає наявність професійних кадрів, які здійснюють надання безоплатної правової допомоги. Кадровий потенціал відіграє надзвичайно важливу роль і визначається професійним рівнем працівників системи надання безоплатної правової допомоги, здатністю відповідних працівників за наявності необхідних знань та умінь виконувати покладені на них функції 3 надання правових послуг.

5) інформаційно-аналітичний складник. Це передусім наявність та належне функціонування комплексної інформаційно-аналітичної системи забезпечення надання безоплатної правової допомоги, яка покликана полегшити роботу та управління системою безоплатної правової допомоги, слугувати основою для всіх ключових процесів і процедур, у тому числі спрямування запитів на надання безоплатної вторинної правової допомоги від уповноважених органів, управління людськими ресурсами (у тому числі укладання контрактів 3 адвокатами), моніторингу та розподілу справ і робочого навантаження між адвокатами та компенсації їхніх витрат тощо [12]. На сучасному етапі описана інформаційно-аналітична система функціонує, однак невирішеними залишаються ряд питань, серед яких, наприклад, взаємодія між центрами з надання безоплатної вторинної правової допомоги в частині перенаправлення звернень клієнтів, у тому числі по цивільних та адміністративних справах, до тих центрів, де знаходиться суд, що має розглядати справу, та можливі механізми врегулювання таких питань, фіксація першої зустрічі адвоката / працівника місцевого центру з клієнтом та ін.

6) матеріально-технічне та фінансове забезпечення. У Законі України «Про безоплатну правову допомогу» ст. 29 визначено, що фінансування безоплатної вторинної правової допомоги здійснюється за кошти видатків Державного бюджету України [13].

3 урахуванням всього зазначеного вище пропонуємо під адміністративно-правовим забезпеченням права на безоплатну правову допомогу розглядати діяльність уповноважених суб'єктів, що володіють загальною та спеціальною компетенцією у сфері надання безоплатної правової допомоги, зміст якої становить створення та підтримка необхідних правових, інституційних, кадрових, інформаційно-аналітичних та матеріально-технічних умов для належної реалізації, охорони та захисту права громадян, які опинилися в важких життєвих обставинах та потребують безоплатної професійної правової допомоги.

Також хочемо виділити характерні ознаки адміністративно-правового забезпечення права на безоплатну правову допомогу:

1) це діяльність уповноважених суб'єктів, що володіють загальною та спеціальною компетенцією у сфері надання безоплатної правової допомоги;

2) така діяльність знаходить юридичне закріплення в нормах права, зокрема, законах та підзаконних нормативно-правових актах;

3) метою адміністративно-правового забезпечення є захист та охорона права на безоплатну правову допомогу;

4) адміністративно-правове забезпечення здійснюється шляхом створення правових, інституційних, кадрових, інформаційно-аналітичних та матеріально-технічних умов.

Отже, аналіз дефініцій, запропонованих теоретиками адміністративного права для позначення поняття «адміністративно-правове забезпечення», дозволяє виділити декілька підходів: по-перше, адміністративно-правове забезпечення розглядається як цілеспрямована дія на поведінку людей і суспільні відносин, або ж вплив на них за допомогою передбачених у законодавстві адміністративно-правових засобів; по-друге, як діяльність уповноважених державою органів щодо здійснення своїх функцій; по-третє, як упорядкування суспільних відносин, їх юридичне закріплення, охорона, реалізація та розвиток; по-четверте, як створення та підтримка умов для всебічної реалізації прав, свобод та інтересів людини, громадянського суспільства, а також інших суб'єктів адміністративно-правових відносин.

Запропоновано під адміністративно-правовим забезпеченням права на безоплатну правову допомогу розглядати діяльність органів державної влади та місцевого самоврядування, суб'єктів надання безоплатної правової допомоги, зміст якої становить створення та підтримка необхідних правових, інституційних, кадрових, інформаційно-аналітичних та матеріально-технічних умов належної реалізації, охорони та захисту права громадян, які опинилися у важких життєвих обставинах, на безоплатну професійну правову допомогу.

\section{ЛІТЕРАТУРА}

1. Барсуков К.В. Адміністративно-правове забезпечення проходження служби працівниками органів внутрішніх справ у складі міжнародних миротворчих підрозділів : автореф. дис. ... канд. юрид. наук : 12.00.07. Київ, 2010. 20 с.

2. Бойко В.П. Адміністративно-правове забезпечення ефективності функціонування судової влади України. Підприємництво, господарство і право. 2020. № 1. С. 96-100.

3. Великий тлумачний словник сучасної української мови : 250000 / уклад. та голов. ред. В.Т. Бусел. Київ; Ірпінь : Перун, 2005. VIII, $1728 \mathrm{c}$

4. Вилков С.В. Адміністративно-правові засади організації надання адвокатами безоплатної правової допомоги : автореф. дис. на здобуття наук. ступеня канд. юрид. наук за спец. 12.00.07. Київ, 2019. 26 с.

5. Гумін О.М., Пряхін Є.В. Адміністративно-правове забезпечення: поняття та структура. Наше право. 2014. № 4. С. 46-50.

6. Дручек О.М. Поняття адміністративно-правового забезпечення прав, свобод та інтересів дитини органами внутрішніх справ України. Форум права. 2013. № 2. С. 123-128.

7. Іванцова А.В. Поняття безоплатної правової допомоги в Україні та за кордоном. Часопис Академії адвокатури України. 2015. № 3 (28). C. $40-45$.

8. Іерусалімова І.О. Механізм адміністративно-правового забезпечення прав і свобод людини та громадянина : дис. ... канд. юрид. наук : 12.00.07. Київ, 2006. 205 с.

9. Клименко О.В. Адміністративно-правове забезпечення державної регуляторної політики у сфері господарювання : авторефр. дис. ... канд. юрид. наук: 12.00.07. Київ, 2015. 21 с.

10. Колесников Є.Є. Поняття та особливості адміністративно-правового забезпечення захисту прав споживачів. Форум права. 2011. № 2. C. 432-438.

11. Кривко О.О. Адміністративно-правове забезпечення діяльності юридичних відділів в Україні : автореф. дис. .... канд. юрид. наук : 12.00.07. Суми, 2020. 219 с.

12. Огляд системи надання безоплатної правової допомоги. URL: http://qala.org.ua/wp-content/uploads/2016/04/BAR_FINAL_23_10.pdf.

13. Про безоплатну правову допомогу: Закон України № 3460-VI від 02.06.2011 року. Офіційний сайт Верховної Ради України. URL: https://zakon.rada.gov.ua/laws/show/3460-17\#Text.

14. Степаненко К.В. Адміністративно-правове забезпечення прав і свобод громадян України за кордоном : автореф. дис... канд. юрид. наук : 12.00.07. Дніпропетровськ, 2009. 19 с. 
15. Фролков М.В. Поняття та особливості адміністративно-правового забезпечення захисту прав споживачів. Актуальні проблеми права: теорія і практика. 2013. № 26. С. 547-555.

16. Цвік М.В. Загальна теорія держави і права: підруч / М.В. Цвік, В.Д. Ткаченко, Л.Л. Рогачова, О.В. Петришин, С.М. Олейников; М.В. Цвік (ред.). Харків : Право, 2002. 432 с.

17. Шопіна І.М. Поняття адміністративно-правового забезпечення базових категорій адміністративного права. Правові засади організації та здійснення публічної влади : збірник тез III Міжнародної науково-практичної інтернет-конференції, присвяченої світлій пам'яті Леоніда Петровича Юзькова (м. Хмельницький, 28 лютого - 2 березня 2020 року). Хмельницький : Хмельницький університет управління та права імені Леоніда Юзькова, 2020. С. 458-461.

18. Щорічна доповідь Уповноваженого Верховної Ради України з прав людини про стан додержання та захисту прав і свобод людини і громадянина в Україні у 2019 році. Офріційний сайт Міністерства юстиції України. URL: https://www.minregion.gov.ua/press/news/ shhorichna-dopovid-upovnovazhenogo-verhovnoyi-rady-ukrayiny-z-prav-lyudyny/. 


\title{
МЕТОДИ ДІЯЛЬНОСТІ СЕРВІСНИХ ЦЕНТРІВ МВС УКРАЇНИ: СУТНІСТЬ, ПОНЯТТЯ ТА ВИДИ
}

\author{
OPERATING METHODS OF THE SERVICE CENTERS OF THE MINISTRY \\ OF INTERNAL AFFAIRS OF UKRAINE: ESSENCE, CONCEPT AND TYPES
}

\author{
Слободенюк І.В., к.ю.н., \\ докторант кафедри поліцейського права \\ Національна академія внутрішніх справ
}

\begin{abstract}
У статті на основі аналізу чинного законодавства України та поглядыв вчених з'ясовано та визначено методи діяльності сервісних центрів МВС України та проведено їх систематизацію. Розкрито сутність правової конструкції «методи діяльності сервісних центрів Міністерства внутрішніх справ України» та окреслено розподіл їх на види. Обґрунтовано, що методи діяльності сервісних центрів Міністерства внутрішніх справ України - це сукупність засобів та прийомів, за допомогою яких досягається мета та завдання, функції органів системи сервісних центрів МВС України, реалізуються повноваження та компетенція. Акцентовано увагу на тому, що система сервісних центрів Міністерства внутрішніх справ України утворена як юридична особа публічного права. Розкрито, що система сервісних центрів МВС України складається із Головного сервісного центру МВС України, регіональних та територіальних органів.

Встановлено, що до методів діяльності сервісних центрів МВС України належать: (1) переконання; (2) примус; а також (3) методи: (а) прямого впливу (адміністративні); (б) непрямого впливу (економічні); (в) соціально-психологічні. Акцентовано увагу на тому, що метод переконання в діяльності сервісних центрів МВС України полягає у додержанні встановлених правил, яких мають дотримуватися посадові особи системи сервісних центрів МВС України під час виконання своїх функцій, завдань та повноважень. Обґрунтовано, що метод заохочення в діяльності сервісних центрів МВС України належить до форм методу переконання. Розкрито, що в діяльності сервісних центрів MBC України доцільно виділити такі групи заходів адміністративного примусу, а саме: (1) заходи адміністративного попередження; (2) заходи адміністративного припинення; (3) заходи адміністративного стягнення; (4) заходи адміністративно-процесуального забезпечення. Зроблено висновок, що методи діяльності сервісних центрів МВС України становлять собою систему, тобто цілісну, внутрішньо узгоджену сукупність, а тому мають застосовуватися комплексно.
\end{abstract}

Ключові слова: методи, переконання, адміністративний примус, система сервісних центрів МВС України, адміністративно-правове регулювання.

Based on the analysis of the current legislation of Ukraine and the points of view of scientists, the article establishes and defines the methods of activity of the service centers of the Ministry of Internal Affairs of Ukraine and their systematization. The essence of the legal structure "methods of activity of the service centers of the Ministry of Internal Affairs of Ukraine" is revealed and their distribution into types is outlined. It is substantiated that the methods of activity of the service centers of the Ministry of Internal Affairs of Ukraine are a set of means and techniques with the help of which the goal, tasks and functions of the bodies of the system of service centers of the Ministry of Internal Affairs of Ukraine are achieved, powers and competence are realized. Attention is focused on the fact that the system of service centers of the Ministry of Internal Affairs of Ukraine was created as a legal entity of public law. It is revealed that the system of service centers of the Ministry of Internal Affairs of Ukraine consists of the Main Service Center of the Ministry of Internal Affairs of Ukraine, regional and territorial bodies.

It has been established that the methods of activity of the service centers of the Ministry of Internal Affairs of Ukraine include: (1) persuasion; (2) coercion; and also (3) methods: (a) direct influence (administrative), (b) indirect influence (economic), (4) socio-psychological method. Attention is focused on the fact that the method of persuasion in the activities of the service centers of the Ministry of Internal Affairs of Ukraine is to comply with the established rules that officials of the system of service centers of the Ministry of Internal Affairs of Ukraine must adhere to in the performance of their functions, tasks and powers. It is substantiated that the method of encouragement in the activities of the service centers of the Ministry of Internal Affairs of Ukraine belongs to the forms of the method of persuasion. It is revealed that in the activities of the service centers of the Ministry of Internal Affairs of Ukraine, it is advisable to distinguish the following groups of measures of administrative coercion, namely: (1) measures of administrative prevention; (2) measures of administrative restraint; (3) measures of administrative penalty; (4) measures of administrative and procedural support. It is concluded that the methods of activity of the service centers of the Ministry of Internal Affairs of Ukraine constitute a system, that is, an integral, internally coordinated set, and therefore should be applied in a comprehensive manner.

Key words: methods, beliefs, administrative coercion, the system of service centers of the Ministry of Internal Affairs of Ukraine, administrative and legal regulation.

Постановка проблеми. Проблему методів будь-якої діяльності можна розглядати з погляду співвідношення більш загальних понять - мети цієї діяльності та засобів iii досягнення [1, с. 32]. Усі методи, що використовуються в управлінні, пов'язані між собою, доповнюють один одного, використовуються в органічній єдності [2, с. 244]. Діяльність правоохоронних органів проявляється у відповідних методах. Такі методи мають застосовуватись відповідно до закону. В сучасних умовах реформування органів внутрішніх справ і створення «публічно-сервісної держави» вивчення методів діяльності сервісних центрів МBC України має теоретичне та практичне значення. Крім того, такі методи діяльності є недостатньо дослідженими науковцями-адміністравістами, що і вказує на актуальність вибраної теми цієї роботи.

Аналіз останніх досліджень і публікацій. У юридичній науці окремим питанням визначення видів методів управління приділяли увагу такі українські й зарубіжні вчені, як В.Б. Авер'янов, О.Ф. Андрійко, Д.М. Бахрах, Ю.П. Битяк, В.М. Гаращук, Т.О. Коломоєць,
М.М. Тищенко, О.М. Шевчук та інші. Так, І.В. Зозуля провів аналіз сутності поняття «нові форми і методи діяльності органів внутрішніх справ» та їх трактовки в новітніх програмних документах 3 питань реформування МВC України, якими наразі є Концепція першочергових заходів реформування системи Міністерства внутрішніх справ і розвитку органів внутрішніх справ України [3]. М.П. Гурковський та С.С. Єсимов досліджували основні форми і методи діяльності поліції щодо забезпечення конституційних прав і свобод людини і громадянина в Україні [4]. П.О. Комірчий окреслив специфіку методів діяльності органів публічної служби у правоохоронній сфері України [5]. О.М. Клюєв звернув увагу на форми та методи профілактичної діяльності органів внутрішніх справ на місцевому рівні [6]. Ф.Ф. Краснояров вивчив форми і методи управління органами внутрішніх справ у забезпеченні законності та правопорядку [7] тощо. Однак питання критеріїв класифікації методів діяльності органів внутрішніх справ в наукових джерелах донині залишаються дискусійними, а в сфері надання сервісних 
послуг - взагалі опинилися поза увагою науковців і тому потребують вивчення.

Мета статті - аналіз методів діяльності сервісних центрів МВС України, а також надання пропозицій щодо їх систематизації.

Виклад основного матеріалу. У 2015 році було створено Головний сервісний центр МВС та його регіональні підрозділи як юридичні особи публічного права [8]. Головний сервісний центр МВС України у своїй діяльності керується Конституцією та законами України, актами Президента України, Верховної Ради України та Кабінету Міністрів України, прийнятими відповідно до Конституції та законів України, наказами Міністерства внутрішніх справ України, іншими нормативно-правовими актами та цим Положенням. Головний сервісний центр МВС підпорядковується Міністерству внутрішніх справ України та $€$ міжрегіональним територіальним органом 3 надання сервісних послуг МВС України [9]. Тобто система надання сервісних послуг МВС України складається із Головного сервісного центру МВС України, регіональних та територіальних органів.

Так, Головний сервісний центр МВС України: (1) надає платні та безкоштовні послуги; (2) здійснює комплекс заходів з організації та забезпечення діяльності системи сервісних центрів МВС України; (3) удосконалює процедури надання адміністративних послуг; (4) узагальнює практику застосування законодавства 3 питань діяльності системи сервісних центрів МВС України; (5) розробляє та вносить Міністру внутрішніх справ України пропозиції щодо поліпшення діяльності системи сервісних центрів МВС України [9].

Дефініція «методи діяльності сервісних центрів МВС України» у чинному законодавстві не визначена. На думку М.В. Цвіка та О.В. Петришина, під час здійснення юридичної діяльності державні органи використовують також різноманітні методи - прийоми, засоби і способи, за допомогою яких справляється вплив на суспільні відносини [10, с. 397]. Надалі для визначення «методів діяльності сервісних центрів МВС України» розглянемо категоріальні дефініції у співвідношенні з правовими конструкціями, а саме «методи управління», «методи державного управління», «методи діяльності» державного органу.

Однак спочатку зупинимося на розумінні змісту терміну «метод». Поняття «метод» походить від грецького "methodos" і означає шлях дослідження чи пізнання, теорія, вчення. В етимологічному розумінні «метод» - це сукупність прийомів або операцій практичного чи теоретичного освоєння дійсності, підпорядкованих вирішенню конкретної задачі $[11$, с. 162$]$. Е юридичному словнику «метод» трактується як прийом, спосіб чи образ дії [12, с. 339]. О.М. Шевчук дефініцію «метод» визначає як спосіб, прийом, досягнення поставленої мети [13, с. 74]. О.Д. Єршов вважає, що метод - це сукупність прийомів i способів впливу на керований об'єкт для досягнення поставлених організацією цілей [14, с. 85]. Т.О. Коломоєць термін «метод» у загальноприйнятому розумінні визначає як спосіб чи прийом здійснення чого-небудь, засіб досягнення поставленої мети [15, с. 193]. Таким чином, метод це сукупність прийомів або операцій впливу на керований об'єкт для досягнення поставлених цілей.

3 наукової позиції Ю.П. Битяка, під методами управління слід розуміти науково-обгрунтовані, дозволені законом способи впливу на керовані об'єкти в цілях найбільш правильного оперативного рішення управлінських завдань та досягнення максимальної ефективності управління [16, с. 157]. С.Г. Стеценко вказує, що методи державного управління - це способи і засоби впливу органів державного управління чи посадових осіб на керовані об'єкти $[17$, с. 175$]$. Т.О. Коломоєць методи державного управління визначає як способи і засоби впливу органів державного управління чи посадових осіб на керовані об'єкти
[18, с. 121]. Д.М. Бахрах наголошує, що методи діяльності $\epsilon$ засобами здійснення цілей, а методи управління - засобами, способами, прийомами цілеспрямованого впливу на керовану соціальну систему. Автор також зазначає, що розуміння методу перш за все пов'язане $з$ діяльністю, 3 процесом. Однак не з будь-якою діяльністю, а 3 цілеспрямованою [19, с. 74, 75]. Отже, методи діяльності сервісних центрів МВС України є засобами здійснення цілей та завдань у сфері сервісних послуг

Визначимо сутність методів діяльності органів внутрішніх справ. Так, П. Комірчий розуміс під методами діяльності органів публічної служби у правоохоронній сфері нашої держави сукупність передбачених законодавством прийомів, засобів й способів досягнення мети в правоохоронній сфері - вирішення поставлених у ній завдань (приміром, охорона конституційного ладу, суверенітету та територіальної цілісності держави, захист громадян; запобігання та протидія протиправній діяльності; забезпечення та розвиток системи правоохорони), у разі застосування яких найбільш оптимальним чином досягається бажаний результат діяльності у відповідній сфері органу та його кадрового складу (чи частини цього кадрового складу) [5, с. 97]. Так, І.П. Голосніченко та Я.Ю. Кондратьева під методами адміністративної діяльності поліції розуміють передбачені адміністративно-правовими нормами різноманітні засоби, прийоми і способи, за допомогою яких міліція здійснює вплив на суспільні відносини з метою реалізації своїх правоохоронних завдань та функцій $[20$, с. 30]. Під методом адміністративної діяльності Національної поліції, на думку О. Карась, слід розуміти цілеспрямований спосіб поведінки, набір дій та засобів, які повторюються і ведуть до: (а) вирішення завдань із забезпечення публічної безпеки і порядку; (б) охорони прав і свобод людини, а також інтересів суспільства і держави; (в) протидії злочинності; (г) надання в межах, визначених законом, послуг з допомоги особам, які з особистих, економічних, соціальних причин або внаслідок надзвичайних ситуацій потребують такої допомоги [21, с. 115]. Д.О. Карбовський указує, що методи адміністративно-правового регулювання діяльності територіальних органів Національної поліції України - це інструменти адміністративноправового регулювання, які за своєю суттю є способами та прийомами впливу територіальних органів Національної поліції України на окремих осіб, суспільство та органів влади 3 метою виконання поставлених перед ними законних завдань, функцій та повноважень [22, с. 164]. А.Т. Комзюк методи адміністративної діяльності органів внутрішніх справ визначає як різноманітні засоби, прийоми та способи, за допомогою яких останні здійснюють вплив на суспільні відносини з метою реалізації своїх правоохоронних завдань і функцій [23, с. 19]. На нашу думку, під методами діяльності сервісних центрів МВС України слід розуміти сукупність засобів та прийомів, за допомогою яких досягається мета, завдання та функції органів системи сервісних центрів МВС України, реалізуються повноваження та компетенція.

Методи діяльності державного органу мають різноманітні критерії класифікації. О.І. Безпалова указує, що ключовими методами реалізації правоохоронної функції держави є адміністративні, економічні та соціально-психологічні. У рамках адміністративних методів реалізації правоохоронної функції держави окремі суб'єкти можуть застосовувати методи переконання та примусу, прогнозування та планування, координації, субординації, методи перевірки, заслуховування й аналізу інформації, узагальнення матеріалів тощо. Крім того, застосування відповідних адміністративних методів під час реалізації правоохоронної функції держави залежить від суб'єкта, на який покладено обов'язок щодо реалізації цієї функції, його завдань і повноважень [24, с. 142]. Інші вчені відносять до методів управлінської діяльності організаційні, 
адміністративні, економічні, соціально-психологічні та інші методи [2, с. 244]. С.Г. Стеценко залежно від міри використання владних повноважень поділяє методи на: (1) переконання; (2) заохочення; (3) примус; а залежно від характеру впливу суб'єкта на об'єкт управління на методи (а) прямого впливу (адміністративні) та (б) непрямого впливу (економічні) [17, с. 176]. А.Т. Комзюк вважає, що основними методами в правоохоронній діяльності є переконання та примус [23, с. 19]. О.М. Бандурка залежно від характеру (змісту) впливу розрізняє адміністративні (організаційно-розпорядчі) й економічні методи управління [25, с. 347]. В.М. Плішкін та Ю.Ф. Кравченко доповнюють ці методи соціально-психологічним методом [26, с. 345]. На наш погляд, до методів діяльності сервісних центрів МВС України слід віднести: (1) переконання; (2) примус; (3) методи (а) прямого впливу (адміністративні) та (б) непрямого впливу (економічні); (4) соціально-психологічні тощо. Розглянемо окремі із них.

Метод переконання використовується поліцією не тільки під час вирішення завдань правового виховання громадян, а й як основний метод ефективної організації своєї діяльності, що стимулює особовий вплив на високопродуктивну працю, дисциплінованість, творчу активність і відповідальне ставлення до справи за допомогою застосування різних заходів переконання (виховних, заохочувальних та інше) [4, с. 180]. Як зазначає С.Г. Стеценко, переконання як метод державного управління полягає в застосуванні способів впливу на свідомість та поведінку людей і проявляється у використанні роз'яснювальних і виховних заходів із метою дотримання вимог чинного законодавства $[17$, с. 97]. Метод переконання реалізується в різних формах, які доцільно звести у такі групи: (a) правове виховання; (б) постійне інформування населення про стан правопорядку і боротьби із злочинністю; (в) агітаційно-роз'яснювальна робота серед населення; (г) критика антигромадських проявів; (д) застосування заходів заохочення; (е) робота 3 правопорушниками, особами з так званих груп ризику; (є) поширення та популяризація передового досвіду боротьби 3 порушеннями громадського порядку тощо [6, с. 101]. 3 огляду на вищенаведене метод переконання в діяльності сервісних центрів МВС України полягає у дотриманні встановлених правил, яких мають дотримуватися посадові особи системи сервісних центрів МВС України під час виконання своїх функцій, завдань та повноважень.

На окрему увагу заслуговує метод заохочення (стимулювання), який поряд із методами переконання та примусу може бути засобом впливу через інтереси та свідомість на сумлінне, якісне та добросовісне виконання обов'язків у сфері надання сервісних послуг. Так, С.В. Ківалов та Л.Р. Біла вказують, що заохочення є таким способом впливу, який через інтереси й свідомість спрямовує волю людей на здійснення корисних з погляду суб'єкта публічного адміністрування дій $[27$, с. 156]. В.Б. Авер'янов наголошує, що заохочення - це публічне визнання заслуг юридичної і фізичної особи у виконанні адміністративноправових або громадських обов'язків [28, с. 87]. Ми погоджуємося 3 цією думкою. 3 нашого погляду, метод заохочення в діяльності сервісних центрів МВС України належить до форм методу переконання.

Коли методи переконання в діяльності сервісних центрів МВС України не мають впливу на об'єкт управління, то тільки в цьому разі можна застосовувати метод «примусу», частіше йдеться про адміністративний примус. У положеннях Закону України «Про національну поліцію» визначено поняття поліцейський захід як дія або комплекс дій превентивного або примусового характеру, що обмежує певні права і свободи людини та застосовується поліцейськими відповідно до закону для забезпечення виконання покладених на поліцію повноважень (ст. 29). До таких заходів віднесено: (1) превентивні поліцейські заходи (ст. 31) та (2) поліцейські заходи примусу [29].

На думку А.Т. Комзюка, державний примус $є$ методом впливу держави на свідомість і поведінку осіб, що допускають протиправні вчинки. Вказаний інститут виявляється у застосуванні встановлених правовими нормами заходів впливу морального, майнового, фізичного та іншого характеру, які мають на меті попередження правопорушень, покарання та виховання правопорушників і застосовуються незалежно від волі та бажання правозобов'язаних суб'єктів [23, с. 30, 31]. Слід погодитися 3 поглядом Ю.П. Битяка, який указує, що примус слід розуміти як «систему засобів психологічної або фізичної дії на свідомість та поведінку людей з метою досягнення чіткого виконання встановлених обов'язків, розвитку громадських відносин у рамках закону, забезпечення правопорядку та законності». Також автор розрізняе такі групи заходів адміністративного примусу: (1) заходи адміністративного попередження; (2) заходи адміністративного припинення; (3) заходи адміністративного стягнення; (4) заходи адміністративно-процесуального забезпечення [16, с. 109]. $\mathrm{У}$ цій роботі має значення адміністративний примус. Враховуючи вищенаведене, на нашу думку, в діяльності сервісних центрів МВС України доцільно виділити такігрупи заходів адміністративного примусу, а саме: (1) заходи адміністративного попередження; (2) заходи адміністративного припинення; (3) заходи адміністративного стягнення; (4) заходи адміністративно-процесуального забезпечення. Наведені вище методи діяльності сервісних центрів МВС України не є вичерпними i, звичайно ж, можуть бути доповнені іншими.

Висновки. Під методами діяльності сервісних центрів МВC України слід розуміти сукупність засобів та прийомів, за допомогою яких досягається мета, завдання та функції органів системи сервісних центрів МВС України, реалізуються повноваження та компетенція. До методів діяльності сервісних центрів МВС України слід віднести: (1) переконання; (2) примус; а також (3) методи (a) прямого впливу (адміністративні) та (б) непрямого впливу (економічні); (4) соціально-психологічні та інші. Методи діяльності сервісних центрів МВС України становлять собою систему, цілісну, внутрішньо узгоджену сукупність, а тому мають застосовуватися комплексно.

\section{ЛITEPATУPA}

1. Адміністративна діяльність поліції у питаннях та відповідях : навч. посібн. за ред Бандурка О.М., Безпалова О.І., Джафрарова О.В. та інших. МВС України, Харків. нац. ун-т внутр. справ. Харків : ХНУВС, 2017. 242 с

2. Осовська Г.В. Основи менеджменту : навч. посіб. Київ : Кондор, 2003. 556 с.

3. Зозуля І.В. Нові форми і методи діяльності органів внутрішніх справ: практика проголошення та запровадження. Форум права. 2015. № 2. C. 58-63. URL. http://nbuv.gov.ua/jpdf/FP_index.htm_2015_2_11.pdf. (дата звернення: 29.07.2020).

4. Гурковський М.П., Єсимов С.С. Основні форми і методи діяльності поліції щодо забезпечення конституційних прав і свобод людини і громадянина в Україні. Науковий вісник Львівського державного університету внутрішніх справ.2016. № 4. С. 171-186.

5. Комірчий П.О. Методи діяльності органів публічної служби у правоохоронній сфері України. Підприємство, господарство і право. 2019. № 10. C. 95-100.

6. Клюєв О.М. Форми та методи профілактичної діяльності органів внутрішніх справ на місцевому рівні. Форум права. 2007. № 1. C. 99-103. URL: http://www.nbuv.gov.ua/e-journals/FP/2007-1/07komsmr.pdf (дата звернення: 25.07.2020).

7. Краснояров Ф.Ф. Форми і методи управління органами внутрішніх справ у забезпеченні законності та правопорядку. Наука і правоохорона. 2014. №. 2. С. 90-94. 
8. Про утворення територіальних органів з надання сервісних послуг Міністерства внутрішніх справ: постанова Кабінету Міністрів України від 28.10.2015 № 889. Офіційний вісник України. 2015. № 90. Ст. 3024.

9. Про затвердження Положення про Головний сервісний центр МBC (у редакції наказу Міністерства внутрішніх справ України від 26.11.2018 р. № 955) від 07.11.2015 № 1393.URL. https://hsc.gov.ua/wp-content/uploads/2019/02/Polozhennya-GSTS. ( дата звернення: 29.07.2020).

10. Загальна теорія держави і права: підручн. за ред. М.В. Цвіка, О.В. Петришина. Харків : Вид-во «Право», 2009. 584 с.

11. Большая Советская Энциклопедия (В 30 томах). Гл. ред. А.М. Прохоров. Изд-е 3-е. Москва, «Советская Энциклопедия», 1974. T. 16. 616 c.

12. Юридический словарь. Под. ред. А.Н. Азрилияна. Москва : Институт новой экономики, 2007. 1152 с.

13. Шевчук О.М. Методи державного контролю у сфері обігу наркотичних засобів: поняття та види. Вісник Харківського нац. ун.-ту імені В. Н. Каразіна. Серія «Право». 2014. № 1. С. 74-77.

14. Ершов А.Д. Основы управленій и организации в таможенном деле: учеб. пособ. Санкт-Петербург : Изд-во ПГУ, 1999. 415 с.

15. Коломоєць Т.О. Адміністративне право України. Академічний курс : підручн. Київ : Юрінком Інтер, 2011. 576 с

16. Адміністративне право України : підручн. За ред. Ю.П. Битяка. Харків : Право, 2012. 654 с.

17. Стеценко С.Г. Адміністративне право України : навч. посіб. Київ : Атіка, 2011. 640 с.

18. Адміністративне право України. Академічний курс : підручник / за заг. ред. Т.О. Коломоєць. Київ : Істина, 2010. 480 с.

19. Бахрах Д.Н. Основные понятия теории социального управления. Пермь : Изд-во Перм. ун-та, 1978. С. 74-75.

20. Адміністративна діяльність органів внутрішніх справ. Загальна частина : підручн. за ред. І.П. Голосніченка, Я.Ю. Кондратьева. Київ : КМУЦА, 1999. 178 с.

21. Карась О.В. Особливості закріплення методів адміністративної діяльності Національної поліції в Законі України «Про Національну поліцію». Вісник Чернівецького фракультету Національного університету «Одеська юридична академія». 2017. Вип. 2. С. 114-121.

22. Карбовський Д.О. Методи адміністративно-правового регулювання діяльності територіальних органів національної поліції України. Прикарпатський юридичний вісник. 2018. Вип.2 (23). Т.3 С. 164-167.

23. Комзюк А.Т. Заходи адміністративного примусу в правоохоронній діяльності міліції: поняття, види та організаційно-правові питання реалізації: моногр. Харків : НУВС, 2002. 336 с.

24. Безпалова О.І. Адміністративно-правовий механізм реалізації правоохоронної функції держави : монографія. Харків : НікаНова, 2014. 544 c.

25. Адміністративне право України. Загальна частина. Академічний курс : підручн. за ред. О.М. Бандурки. Харків : Золота миля, 2011.584 c.

26. Теорія управління органами внутрішніх справ : підручн. В.М. Плішкін; за ред. Ю.Ф. Кравченка. Київ : НАВС, 1999.720 с.

27. Ківалов С.В. Біла Л.Р. Адміністративне право України: навч.-метод. посіб. Одеса : Фенікс, 2008. 388 с.

28. Виконавча влада і адміністративне право. За заг. ред. В.Б. Аверьянова. Київ : Ін-юре. 2002. 668 с.

29. Про Національну поліцію: Закон України від 02.07.2015 № 580-VIII. Відомості Верховної Ради. 2015. № 40-41. Ст.379. 


\title{
АДМІНІСТРАТИВНО-ПРАВОВІ ЗАСАДИ ЗАБЕЗПЕЧЕННЯ ЕНЕРГЕТИЧНОЇ ГАЛУЗІ В УКРАЇНІ
}

\author{
ADMINISTRATIVE AND LEGAL FRAMEWORKS OF ENERGY SUPPLY IN UKRAINE
}

\author{
професор кафедри адміністративного, фінансового та інформаційного права \\ Київський начіональний торговельно-економічний університет
}

Стаття присвячена аналізу адміністративно-правових засад фрункціонування ринку енергетичної галузі в Україні. Досліджено нормативно-правову базу, що регламентує діяльність цього важливого сектору економіки. Виокремлено проблемні питання, наявні в адміністративно-правовому механізмі регулювання енергетичної галузі. За результатами аналізу сформульовано низку висновків та пропозицій, спрямованих на вдосконалення адміністративно-правового регулювання енергетичного ринку.

У статті також досліджено форми державного управління в енергетичній сфері, що використовуються в інших країнах і певною мірою залежать від умов функціонування, ступеня вертикальної та горизонтальної інтегрованості, повноти запровадження ринкових відносин. Проаналізовано роль держави в регулюванні ринку енергетики. Досліджено міжнародне законодавство та законодавство певних країн в аспекті адміністративно-правового регулювання ринку енергетичної енергії. Підсумовано основні адміністративно-правові заходи країн - членів $€ С$ щодо енергетичного ринку, які потрібні для вступу в $Є С$ та подальшого перебування в $Є С$. Визначено, що застосування адміністративно-правових засобів щодо регулювання діяльності монополій в деяких країнах відбувалося під впливом історичних процесів формування та розвитку економік різних країн. Тому великій відсоток країн Європи мають схожі вектори розвитку під час застосування різних механізмів регулювання ринків електричної енергї̈. Аналіз досвіду таких країн свідчить про те, що $є$ необхідність створення державного незалежного органу, що буде адмініструвати ринок природних монополій, в тому числі і ринок електроенергії.

Зазначено, що інтеграція України в європейський енергетичний ринок вимагає виконання умов Угоди про асоціацію між Україною та ЄС в частині змін до законодавства щодо природних монополій, в тому числі електроенергії.

Досвід Європейського Союзу у сфері регулювання ринку електроенергії має використовуватися для забезпечення максимальної конкурентоспроможності між суб'єктами природних монополій і державою та оптимізації адміністративно-правового механізму управління енергетичною галуззю.

На основі дослідження сформульовано пропозиції та способи вирішення найбільш актуальних питань щодо вдосконалення правового регулювання в енергетичній сфері.

Ключові слова: ринок енергії, природна монополія, механізм державного управління в енергетичній сфері, адміністративне-правове регулювання, європейський енергетичний ринок.

The article is devoted to the analysis of administrative and legal bases of functioning of the energy market in Ukraine. The normative-legal base, which regulates the activity of the energy energy market, has been studied. The problematic issues that are present in the administrative and legal mechanism of energy regulation are highlighted. Based on the analysis, it formulated a number of conclusions and proposals aimed at improving the administrative and legal regulation of the energy market.

The paper examines the forms of public administration in the energy sector used in countries around the world and which to some extent depend on the operating conditions, the degree of vertical and horizontal integration, the degree of market relations. The main role of the state in regulating the energy market is analyzed. International legislation and the legislation of individual countries on the administrative and legal regulation of the energy market have been studied. The main administrative and legal measures of the EU member states regarding the energy market before joining the EU and subsequent stay in the EU are summarized. It is determined that the use of administrative and legal means to regulate the activities of monopolies in foreign countries is due to the historical development of economic relations. The vast majority of European countries have common approaches, but use different means to regulate electricity and utilities markets. The experience of these countries shows that for the optimal and effective implementation of antitrust law, including legislation governing the activities of natural monopolies, it is necessary to create a special regulatory body or system of bodies.

It is stated that the integration of Ukraine into the European energy market and the implementation of the Association Agreement between Ukraine and the EU necessitates regulatory changes in the areas of natural monopolies that directly affect the welfare of the population and ensure the public interest. The EU experience can be used to identify opportunities to reform the administrative and legal regulation of markets that are in a state of natural monopolies, by stimulating competition in their individual segments and ensuring transparency in relations between natural monopolies and the state.

Based on the researched materials, proposals and ways to address the most pressing issues of improving legal regulation in the energy sector were formulated.

Key words: energy market, natural monopoly, mechanism of public administration in energy spheres, administrative and legal regulation, European energy market.

Постановка проблеми. Природні монополії є однією із найважливіших ресурсів держави, які за умови ефективної політики держави можуть забезпечувати ріст економіки та підвищувати добробут населення. На цей час одним із гострих питань в Україні залишається цінова політика тарифів на електричну енергію. Вбачаючи, що енергетична галузь регулюється державою, отже, до іiі пріоритетних завдань можна віднести боротьбу та протидію корупції в цій галузі, створення привабливого клімату для ринку електроенергії, формування ефективного адміністративно-правового механізму регулювання ринку електроенергії через підтримання балансу між приватним підприємницьким інтересом суб'єктів природних монополій та інтересу суспільства.

На цьому етапі законодавча база в Україні не $є$ до кінця сформованою, частина законів суперечать один іншому, а деякі статті і зовсім визнані неконституційними. Не до кінця сформованим також залишається ряд регуляторних органів, які повинні забезпечувати діяльність суб'єктів природних монополій. Вдосконалити та оптимізувати необхідно і засоби адміністративно-правового регулювання суб'єктів природних монополій. Для уникнення колізій та адаптації вітчизняного законодавства до норм Європейського Союзу слід прийняти ряд нормативно-правових актів, що органічно повинні гармонізувати українське законодавство у сфері регулювання природних монополій та положень Угоди про асоціацію між Україною і ЄС. Ці проблеми зумовлюють актуальність та вибір дослідження.

Аналіз останніх досліджень і публікацій. Фундаментальною базою дослідження стали праці таких вітчизняних i зарубіжних вчених, як В.Б. Авер'янов, 
О.Ф. Андрійко, О.В. Безух, А.І. Берлач, Ю.П. Битяк, А.Г. Бобкова, Т.В. Бондар, В.В. Галунько, Б.В. Дерев'янко, В.А. Дерець, О.М. Єщук, І.О. Ієрусалімов, Т.О. Коломоєць, А.Я. Курбатов, В.П. Нагребельний, П.М. Павлик, О.П. Поцерковний, А.А. Пухтецька та інші.

Метою і завданням статті $\epsilon$ аналіз адміністративноправового регулювання енергетичної сфери в Україні та на основі зроблених висновків, формування пропозицій щодо іiї оптимізації та адаптації до вимог ЄС.

Виклад основного матеріалу. За останні декілька років у сфері ринку світової енергетики проходять масштабні та кардинальні зміни. Ці зміни пов'язані із швидким розвитком прогресу та розвитку технологій, винайденням альтернативних видів енергії, що своєю чергою призводить до відмови від архаїчних моделей великих виробників, неефективних енергомереж, домінування несправедливої конкуренції на енергетичних ринках та переходу до нових моделей, які включають в себе такі елементи, як сприятливе та об'єктивне конкурентне поле, рівність розвитку всіх видів виробництва енергії, створення нових маршрутів постачання паливно-енергетичних ресурсів Поштовхом до цього послужили і реалізації положень Паризьких угод у контексті адаптації до зміни клімату, що призвело до використання низьковуглецевих джерел у поєднанні із застосуванням технічних засобів із найвищими коефіцієнтами перетворення енергії та автоматизації виробництва енергії шляхом запровадження інтелектуальних систем (smart energy).

Погоджуємося із думкою Г.Л. Рябцева який наголошує, що для того щоб гідно відповісти на зумовлені цими змінами виклики, національна енергетика має бути трансформована 3 дотаційного й проблемного в економічно прибутковий, конкурентний i гнучкий сектор економіки, що дозволить реалізувати нові можливості для пошуку та впровадження інноваційних розробок у галузі видобутку, переробки, виробництва, трансформації, постачання і споживання паливно-енергетичних ресурсів [1]

Як влучно зазначає P.I. Раімов, правовий статус органів, які здійснюють адміністративно-правове регулювання функціонування цих ринків, механізми їхньої взаємодії, адміністративно-правові засоби впливу та питання співвідношення публічного і приватних інтересів під час їх застосування до діяльності суб'єктів природних монополій не здобули належного теоретичного визначення i обгрунтування. Невирішеність зазначених питань не в останню чергу зумовлюється недосконалістю правового регулювання, нестабільністю та неефективністю системи органів, які забезпечують державне регулювання в цій сфері, створює умови для зловживань і не сприяє належному задоволенню потреб споживачів у товарах та послугах, що виробляються (надаються) суб'єктами природних монополій [2, с. 1].

Всі країни з розвиненою економікою займалися державним регулюванням природних монополій, шляхом створення ефективної нормативної бази та ряду регуляторних органів. Енергетична галузь вимагає специфічно державної регуляторної політики, з урахуванням особливостей виробництва та розподілу енергоресурсів.

Як зазначив I.А. Франчук, «діяльність держави з регулювання енергетики має бути спрямована не на боротьбу 3 природною монополією, а на усунення неефективної конкуренції на ринках певного типу, оскільки транспортування енергії є сферою винятковою, і з погляду економіки винятковість означає виведення окремих сфер господарювання 3-під впливу суто ринкових конкурентних механізмів саморегулювання» [3, с. 97].

Енциклопедія державного управління визначає різні форми державного управління енергетичної галузі залежно від виду економіки (планова або ринкова), виду власності (державна або приватна), моделей ринкових від- носин (монополія чи конкуренція на оптовому або на роздрібних ринках) [4, с. 498].

Погоджуємося 3 думкою Б.В. Слупського та Б.А. Малюська, які виділяють наступні основні форми державного управління у сфері енергетики:

1) пряме державне управління. Ця форма управління передбачає максимальне управління державою певної галузі через наявність відповідного міністерства або відомства. До відання такого органу належать створення нормативно-правової бази, прогнозування фінансових показників, вироблення програми залучення інвестицій та розподіл доходів від галузі;

2) державне управління через державну корпорацію. Така форма передбачає створення державної компанії, у віданні якої знаходяться питання ефективного управління ресурсами з відносною самостійністю, але основні питання залишаються за самою державою;

3) державне регулювання і нагляд за функціонуванням електроенергетики. Найбільш ліберальна форма управління, яка застосовується, тоді, коли всі або частина підприємств у цій галузі є приватною власністю. За такої форми управління приватним підприємствам надана максимальна самостійність в ухваленні рішень. Держава здійснює нагляд за безпековим складником та наглядом за додержанням закону суб'єктами монополій. Така форма часто використовується на ринках електроенергії Європейського Союзу [5].

Аналіз країн Свропейського Союзу показує, що на національному рівні було створене нормативно-правове забезпечення, що стало фундаментом для подальшого реформування й розвитку енергосистеми.

Європейська Комісія прийняла ряд рішень задля розв'язання проблем транскордонної мережі та інтеграції країн - членів ЄС до ринку електроенергії. Однак пріоритетним залишаються права країн - членів СС щодо створення національного законодавства за умові, що воно не буде суперечити транскордонній торгівлі енергетичними ресурсами.

У країнах Західної Європи є багаторічна практика створення та застосування національних правил функціонування й планування розвитку енергосистем, розроблення та прийняття національних мережевих кодексів і правил [6, с. 154].

Б.В. Слупський виділяє такі форми впливу державного нагляду та регулювання ринків електроенергетики:

1) забезпечення нормативної та правової бази функціонування ринків;

2) заходи із захисту і заохочення конкуренції, податки і субсидії;

3) регулювання цін (тарифів);

4) ліцензування суб'єктів господарювання;

5) регулювання кількості товару (квотування) на ринку;

6) встановлення загальнообов'язкових правил з виробництва, передачі, розподілу і споживання електричної енергії тощо [7, с. 279].

Так, у Великобританії енергетична сфера регулюється Системним кодексом (Grid Code), який складається із: Кодексу планування; Умов технологічного приєднання; Кодексу оперативного управління; Кодексу балансування; Кодексу реєстрації даних; Загальних умов [8]

Такі кодекси прийняті й у ряді інших країн. Ці кодекси різних країн відрізняються, серед іншого, співвідношенням технічних і комерційних правил. Кодекси Великобританії та Румунії мають спрямованість на технічні аспекти енергетичної сфери, а мережеві кодекси Казахстану, Росії спрямовані на економічний складник, наприклад, торгівлю електроенергією [6].

Поділяємо думку Я.І. Олійника, який дослідив досвід зарубіжних країн та встановив, що в розділах мережевих кодексів повинні бути врегульовані такі питання, як належний рівень та умови підключення нових спожива- 
чів до електромереж різних рівнів напруги, оптимальне розв'язання основних проблемних питань споживача, а саме розмір плати за потужність та мінімізація кількості процедур і часу, необхідних для підключення [9, с. 13].

В Україні правову основу функціонування ринку електричної енергії становлять Закони України «Про ринок електричної енергіï», «Про альтернативні джерела енергії», «Про комбіноване виробництво теплової та електричної енергії (когенерацію) та використання скидного енергопотенціалу», «Про Національну комісію, що здійснює державне регулювання у сферах енергетики та комунальних послуг», «Про природні монополії», «Про захист економічної конкуренції», «Про охорону навколишнього природного середовища», міжнародні договори України, згода на обов'язковість яких надана Верховною Радою України, Концепція вдосконалення державного регулювання природних монополій від 27 вересня 2007 р. № 921/2007, Енергетична стратегія України на період до 2035 року «Безпека, енергоефективність, конкурентоспроможність» від 18 серпня 2017 р. № 605-р та інші нормативно-правові акти України.

Енергетична галузь $є$ однією із найпріорітетніших напрямів розвитку для подальшого розвитку економіки України. Вектор розвитку було надано із прийняттям та схваленням Урядом у 2017 р. Енергетичної стратегії України до 2035 року [10]. Ця стратегія стала поштовхом до переходу від старої моделі розвитку на європейську модель, яка включає в себе рівні можливості для розвитку всіх видів виробництва енергії.
Висновки. Налагодження співробітництва на ринку енергетики з $С \mathrm{C} є$ одним із основних напрямів діяльності України в міжнародному просторі. Таке співробітництво може бути досягнуто шляхом активної участі України у міжнародних заходах для розв'язання спільних проблем шляхом прийняття узгоджених рішень, стабільності енергетичної взаємодії, налагодження партнерських стосунків в енергетичній сфері для подальшої мінімізації ризику енергетичної кризи та створення міжнародної системи енергетичної безпеки.

Основними напрямами державної політики в енергетичній сфері мають стати:

- захист національних інтересів у енергетичній сфері 3 урахуванням дотримання міжнародних договорів, згоду на обов'язковість яких дала Україна;

- вироблення стратегії для максимального збереження енергетичної самодостатності, а саме вдосконалення та модернізація вітчизняної енергетичної галузі 3 акцентом на використанні низьковуглецевих джерел i технологій із найвищими коефіцієнтами перетворення енергіï;

- диверсифікація енергетичної галузі шляхом створення партнерських відносин $з$ країнами $Є C$;

- приведення національного законодавства у енергетичній сфері до стандартів ЄС;

- посилення контролю та відповідальності органів державної влади, які здійснюють адміністрування в енергетичній сфері.

\section{ЛITEPATYPA}

1. Рябцев Г.Л. Актуальні виклики та загрози енергетичній безпеці України. URL: http://old2.niss.gov.ua/content/articles/files/111Zagrozi--AZ-(fin)-40cb6.pdf.

2. Раімов Р.І. Адміністративно-правове регулювання діяльності суб'єктів природних монополій у сферах енергетики та комунальних послуг. автореф. дис. ... канд. юрид. наук : 12.00.07. Суми. 2019 р. 20 c. URL: https://essuir.sumdu.edu.ua/bitstreamdownload/123456789/77751/1/avtoref_Raimov.pdf.

3. Франчук І.А. Особливості державного регулювання енергетики в ринкових умовах. Вісн. НАДУ. 2008. № 4. С. 91-98.

4. Энциклопедия государственного управления в России : в 2 т. / под общ. ред. В. К. Егорова ; отв. ред. И.Н. Барцин. Москва : Изд-во РАГС. 2008. Т. 1. $552 \mathrm{c}$.

5. Слупський Б.В., Малюська В.А. Форми та методи державного управління електроенергетичною галуззю. URL: http://academy.gov.ua/ ej/ej15/txts/12SBVUEG.pdf.

6. Грудницька С.М., Руденко Л.Д. Правове регулювання ринків електричної енергії в Україні та інших країнах: порівняльно-правовий аналіз. Електронне наукове видання «Порівняльно-аналітичне право». № 5. Ужгород. 2018 p. C. 153-157. URL: http://www.pap.in.ua/5_2018/42.pdf.

7. Слупський Б. $\bar{B}$. Сучасні форми та методи державного регулювання ринків електроенергї. Розвиток публічного адміністрування на засадах менеджменту : європейський контекст : матеріали наук.практ. конф., Дніпропетровськ, 15-16 трав. 2009 р. / за заг. ред. С.М. Серьогіна. Дніпропетровськ : ДРІДУ НАДУ, 2009. С. 278-280.

8. Синюгин В. Ю. Международный опыт рефрормирования электроэнергетики. PAO «EЭС России». 2003. 16 c. URL: http://www.rao-ees.ru/ ru/reforming/foreign/mo/England.pdf.

9. Олійник Я.І. Економічне регулювання ринку електроенергії України : автореферат дис. ... канд. екон. наук : 08.00.03. Львів, 2013. 20 с.

10. Загрози у сфері енергетичної безпеки та їхній вплив на стан національної безпеки: моніторинг реалізації Стратегії національної безпеки України : аналіт. записка. URL: http://old2.niss.gov.ua/content/articles/files/111Eco-Threats-Ivaniuta-2019-3040a.pdf. 


\title{
ADMINISTRATIVE AND LEGAL QUALIFICATIONS IN DOMESTIC THEORY OF ADMINISTRATIVE LAW
}

\author{
АДМІНІСТРАТИВНО-ПРАВОВА КВАЛІФІКАЦІЯ \\ У ВІТЧИЗНЯНІЙ ТЕОРІЇ АДМІНІСТРАТИВНОГО ПРАВА
}

\author{
Timashov V.O., Doctor of Law, \\ Professor at the Department of Administrative, Financial and Information Law \\ Kyiv National University of Trade and Economics
}

Oliinyk O.V., Doctor of Law,
Professor at the Department of Legal Security of Business Kyiv National University of Trade and Economics

Through some recent years the problems on defining the concept of "administrative and legal qualifications" have not been studied almost at all. Basically, the above-mentioned topic has been investigated within the aspect of criminal law qualification, and from the standpoint of the theory of law; so, it needs further scientific research and development. With regards to the theory of administrative law, the uncertainty of administrative and legal qualification being juridical institution is the main problem for scholars up to date. Nowadays it can be argued that there is no legitimately justified definition of the "administrative and legal qualifications", and there is no single scientific approach to this concept.

The concept of administrative and legal qualification is used in literature, but it is not defined specifically. The main attention of leading domestic lawyers is traditionally focused on the criminal law aspect of juridical qualification.

The importance of thorough study in the field of such an extraordinary legal reality phenomenon, taking into account administrative and legal qualification (qualification of administrative offense) investigation in juristical literature, is quite obvious. Also, this does not seem to be accidental; evidently, it goes without saying, that there can be no argument or discussion on systematic and error-free application of administrative delict rules taking up no development for perfect doctrinal and legal principles assessing qualifications as the concept under study.

The qualification of administrative offense is quite complex cognitive process. To qualify illegal act of an authorized person often faces a number of problems like the differentiation of peculiar misconducting activity from other kinds of misdemeanor or offense (crimes, civil delicts, etc.), the distinguishing of inter-related administrative offenses; the presence of competition between several administratively delict norms; the presence of administratively delict immunity (i. e., circumstances that exclude liability for administrative misconduct), etc.

The solution of the outlined tasks depends on many factors, that are as follows: the level of professional training of the subjects of administrative jurisdiction, the perfection of equipment used when developing drafts on administratively delict legislation, the existence of clear and accurate practical recommendations. It is significant to notice that none of these factors is possible without scientific solution on current issues of administrative and legal qualifications.

General theoretical aspects of qualification are essential attribute of modern juridical education. The doctrinal provisions of the administrative and legal qualification must be obligatory taken into account when developing administratively delict norms. Designing effective practical recommendations always requires from the author (authors) clear understanding of the legal and psychological nature of the qualification, its content, structure and objective grounds. Therefore, from the point of view of studying regularity, law enforcement and rule-making, the significance of the theory of qualification is just impossible to overestimate.

Key words: administrative-legal qualification, qualification, administrative responsibility, administrative misdemeanor, qualification of administrative misdemeanors, subject of administrative offense.

Проблеми визначення поняття «адміністративно-правової кваліфікації» останнім часом майже не досліджуються. В основному вищевказана тематика досліджується в аспекті кримінально-правової кваліфікації та з позицій теорії права, але потребує подальшого розвитку. У теорії адміністративного права основною проблемою залишається невизначеність адміністративно-правової кваліфрікації як правового інституту. Сьогодні можна стверджувати, що немає законодавчого визначення «адміністративно-правової кваліфрікації», а також щодо цього поняття відсутній єдиний науковий підхід.

Поняття адміністративно-правової кваліфікації у літературі використовується, але спеціально не визначається. Основна увага провідних вітчизняних правників традиційно прикута до кримінально-правового аспекту юридичної кваліфбікації.

У статті зазначається про важливість ґрунтовного вивчення такого непересічного феномену правової дійсності у юридичній літературі, як адміністративно-правова кваліфікація (кваліфікація адміністративного проступку). І це не випадково, адже без вироблення досконалих доктринальних і правових засад кваліфрікації не може бути й мови про системне та безпомилкове застосування адміністративно-деліктних норм.

Кваліфікація адміністративного проступку - достатньо складний пізнавальний процес. Кваліфікація протиправного діяння уповноваженої особи часто-густо стикається з низкою проблем, як-то: відмежування діяння від інших правопорушень (злочинів, цивільних деліктів); розмежування суміжних складів адміністративних проступків; наявність конкуренції декількох адміністративно-деліктних норм; наявність адміністративно-деліктних імунітетів (тобто обставин, що виключають відповідальність за адміністративні проступки) тощо.

Вирішення окреслених задач залежить від багатьох чинників: рівня професійної підготовки суб'єктів адміністративної юрисдикції, досконалості техніки, використаної під час розробки актів адміністративно-деліктного законодавства, існування чітких практичних рекомендацій. Показово, що жоден з цих чинників неможливий без наукового вирішення актуальних питань адміністративно-правової кваліфікації.

Загальнотеоретичні аспекти кваліфікації є неодмінним атрибутом сучасної юридичної освіти. Доктринальні положення адміністративно-правової кваліфікації обов'язково враховуються під час розробки адміністративно-деліктних норм. Конструювання ефрективних практичних рекомендацій завжди потребує від автора (авторів) чіткого розуміння юридичної і психологічної природи кваліфікації, її змісту, структури та об'єктивних підстав. Відтак з погляду науки, що вивчає закономірності, правозастосування та нормотворення, значущість теорії кваліфікації переоцінити просто неможливо.

Ключові слова: адміністративно-правова кваліфікація, кваліфікація, адміністративна відповідальність, адміністративний проступок, кваліфікація адміністративних проступків, суб'єкт адміністративного проступку.

Presentation of the main material. Issues concerning definitions of the concept of "administrative and legal qualifications" have not been studied thoroughly of late. Basically, the above-mentioned topics are having been investigated through the aspect of criminal law qualification, and from the standpoint of the theory of law, which needs further 
research and development. As for the theory of administrative law, the main problem that still remains indistinct, is the uncertainty of administrative and legal qualification as the legal institution. Today it can be argued that there is no legislative definition for the "administrative and legal qualifications", and there is no single scientific approach to this concept.

The concept of administrative and legal qualification is used in literature, but it is not defined specifically. The main attention of leading domestic lawyers is traditionally focused on the criminal law aspect of juridical qualification. The qualification of crimes has been and still remains the subject of active scientific investigations, heated by immense discussion and debate. Its content is revealed in dozens of monographs, doctoral and candidate dissertations, text-books and scientific articles. The meaningful content in the field of criminal law being the "golden mean" of the issue on criminal liability cannot be thought over other way than within unbreakable connection to the qualification of crimes.

Thus, on the contrary to the criminal law sphere, which focuses purely on the regulation of delict relationships, administrative law has much wider range of assignments, they are: the provision of administrative services, public administration, administrative justice, and others. Therefore, liability for administrative misconduct is not a central axis in the field of administrative law, and the related issues (including issues of administrative and legal qualification) are not considered as preferable ones.

Basing on the mentioned above, we may affirm that the reason for the permanent lack of attention to the relevant issues is the hyperbolizing idea of the comparatively insignificant qualification of some administrative misdemeanor, that is their obviousness and simplicity of juridical content. Sometimes there can be payed attention onto the issue of administrative and legal qualifications which are not worthy for fundamental study because the administrative misconduct is quite primitive in its nature, and its juridical assessment does not make any significant complications.

In our opinion, it is difficult to agree with this point of view. In fact, social danger of some particular administrative misdemeanor is always less than social threat of a particular offense (crime). When comparing quantitative parameters of some crimes and administrative delicts, the picture is sometimes diametrically opposed.

For example, in present day Ukraine there are more than six thousand cases annually recorded on violations established by the Article \# 41, part 1 of the Code of Ukraine on Administrative Offenses, like payments concerning pensions, scholarships, salaries and wages deadlines, and also underpayment, meaning their not full volumes given [1], and only a few crimes are consolidated in the Criminal Code of Ukraine and provided by the Article \# 175 of the Criminal Code of Ukraine as for unjustified and intentional non-payment of wages, scholarships, pensions or other statutory payments. Which of these two phenomena (administrative or criminal delict on labor protection) more relevant for society in the whole is a debatable question.

The other important and debatable issue is the question on the simplicity of juridical qualification of administrative misdemeanors consolidated in the Article \# 121 and \# 122 of the Code of Ukraine on Administrative Offenses in comparison with the offenses (crimes) specified in the Article \# 286 of the Criminal Code of Ukraine. Obviously, the vast majority of features of legal composition of administrative and criminal violations of traffic rules (in particular, the object, the subject, the subjective side, the nature of the illegal act) are absolutely identical.

The main difference between mentioned administrative offenses is stated above, and the nature of misdemeanors and crimes is characterized by the upcoming harmful material consequences to society. Thus, from the point of view of legal complexity, the qualification of both types of delicts is of little difference. Moreover, some administrative offenses significantly outweigh the majority of crimes in terms of their complexity of the legal content. For example, the administrative and legal qualification in abuses of monopoly position on the market (Article 166-1 of the Code of Ukraine on Administrative Offenses) requires from the authorized entity not just applying to a number of legal acts and documents (like the Commercial Code to the Decisions of the Antimonopoly Committee of Ukraine), but also to conduct complex economic and mathematical calculations (in particular, when determining the share of some particular business entity/entities on the market).

Therefore, comparative insignificance of some administrative misdemeanors does not diminish the importance of the phenomenon of administrative and legal qualifications and should not be reflected beneath the depth of its scientific development.

The fact remains as it is that through the period of 1996-2010 in Ukrainian jurisprudence literature appeared insignificantly small number of scientific papers on the theory of administrative and legal qualifications. In 1996 O.I. Ostapenko's Doctor's Degree dissertation "Administrative Delict" was published [2]. In this work (or rather, in one of its chapters) the author pays attention to such important issues like defining the concept of administrative and legal qualifications, clarifying its content and structure, also defining its prerequisites and basic determinants. In the middle of 2000-th professor T. Gurzhii, defined the concept of administrative and legal qualification, also clarified its content and structure, as well as its prerequisites and basic determinants [3-7]. Subsequently, the main provisions of T. Gurzhii's works found practical implementation within the development of draft laws of Ukraine, draft decisions of the National Security and Defense Council of Ukraine, drafts of Orders of the Ministry of Infrastructure of Ukraine, the Ministry of Internal Affairs of Ukraine and other central executive bodies. In addition, they are widely used through educational process in a number of Establishments of Higher Education of Ukraine.

Confirming the importance of provisions, formulated by Professor O.I. Ostapenko, the theoretical statements on administrative and legal qualifications can be acknowledged as follows:

First, both from psychological and legal point of view, the qualification of administrative offense is a dualistic phenomenon. In psychological aspect, the dual essence of qualification is manifested in the fact that it is simultaneously: a) the process of comprehension to legal essence of an illegal act committed in real life; b) the final judgment (inference) resulting the process of cognition. As a legal phenomenon, qualification it is also an inseparable unity of two points: a) the process of comparison between the signs of actual encroachment and the juridical norm; b) juridical conclusion consolidated in procedural documents [2, p. 208-210].

Second, based on the previous provision, O.I. Ostapenko defines the concept of administrative and legal qualification as "the establishment and procedural consolidation of exact correspondence of signs concerning illegal actions or inaction committed by the person featuring structure of the delict, provided by the administrative legislation" [2, p. 40].

It should be noted that this definition has repeatedly been criticized from the side of scientific researchers in this sphere.

However, T.O. Gurzhii questioned the thesis of consolidation the content of the delict into administrative law, which clearly follows from the above-given definition. According to the opinion of this scholar, administrative law provides for the misdemeanor itself, but not its content (composition) being an abstract model, which compares the signs of actual encroachment and signs of misconduct, consolidated within the administratively delict norm/norms. According to the author's opinion, the content of administrative offense is just a theoretical construction, meaning, that "...the law does 
not know, and which any author understands and interprets in his own way" $[3$, p. 29]. Therefore, when talking about qualification, it should be borne in mind that it is necessary to establish firm correspondence between the actual features of the act and the normative features of an administrative offense (and not of its content or composition), on which the author insists [5, p. 219; 6, p. 13; 7, p. 29].

Another administrative law researcher - O.M. Storozhenko - emphasizes on the inexpediency of using the term "compliance" in the definition of the term "administrative and legal qualification". In her reasoning, the author based on the experience of the Humanities and the Natural Sciences (Chemistry, Mathematics, Biology, Physics), where compliance is understood as functional connection of conditions, parties, objects [8, p. 11-16]. At the same time the author also argues that in relation to compliance there are all the signs of the factual action and the signs of misdemeanor consolidated in the administratively delict code of regulations. For example, both the purpose of the misdemeanor and its harmful consequences functionally correspond to certain forms of guilt. The goal always indicates the presence of direct intention; and the commission of administrative delicts with formal contents (without harmful consequences occurrences) is possible only in the form of direct intent or unlawful negligence. With this understanding of the compliance, as O. M. Storozhenko states, the reference to it when defining the concept of qualification seems not quite appropriate, because "qualification is not a statement of all the multifaceted and multidirectional functional links between the actual encroachment and the legal formula of the delict, but also it is the establishment of identity of each feature of the factual action to the corresponding feature of the administrative offense (the real subject - to the normative features of the subject of the offense, the real guilt - to the legislative formula of guilt, etc.) [9, p. 274]". Therefore, in the context of administrative and legal qualifications, we should not talk just about the compliance, but also about the identity of factual and legal signs of the encroachment, as O.M. Storozhenko actually sums up [9, p. 275].

It goes without saying, that the expressed remark has certain scientific value, but, in our opinion, its practical significance is quite conditional. Much more practical significance has another O.M. Storozhenko's detailed specification, which regards to the thesis of comparing the process of qualification of the signs of administratively delict norms and signs of actual actions or inactions. As the author rightly notes, the use of the semantic construction of "actions or inactions" may incorrectly direct the authorized person onto the fact that in the course of qualification the signs of actual encroachment should be "tried" only on for the signs of the objective party of administrative delict $[9$, p. 276]. It seems that in this case it is actually more correct to talk about encroachment in general, but not on the action or inaction.

Paying the tribute to the fact that all the above remarks bear exclusively clarifying nature, they diminish in no way the role of the definition of the concept "administrative and legal qualifications", built by O.I. Ostapenko. This is acknowledged by the critics themselves, who unanimously support the definition of Professor O.I. Ostapenko: "...the most reasonable of those are available in domestic administrative and legal literature" $[2$, p. 44$]$ and "dominating in the theory of administrative law in the whole" [2, p. 31].

It is quite easy to notice, that Professor O.I. Ostapenko considers the procedural consolidation signs of the action compliance to the signs of the misdemeanor as an integral ele- ment of the qualification of an administrative offense, reflected in the content of administratively delict norms. According to the formal-logical rules of division of concepts into classes (types), all features inherent in the general concept and are necessarily included into the content of all its varieties [2, p. 32; 36]. Therefore, if taking the above definition as the basic one, then according to all logical criteria, the procedural consolidation should be equally inherent in both official and doctrinal qualifications. In fact, this is not the case at all. It is obvious that the procedural legalization of qualification results contradicts the idea of its informality (doctrinaire). Doctrinal qualification is therefore called informal, which is not expressed in official documents. Conversely, the procedural consolidation of qualification directly indicates its official nature.

Despite some logical flaws, the general theoretical significance of the analyzed classification is difficult to overestimate. The fact cannot be refuted, that this classification set the general direction to all further research on the scope of the concept on administrative and legal qualifications.

Third, Professor O.I. Ostapenko also is one of the first scholars who attempts to determine the prerequisites for administrative and legal qualifications. All in all O.I. Ostapenko identifies three prerequisites: 1) comprehensive, complete and objective establishment of all factual circumstances of the case; 2) accurate and reliable determination of the legal significance among all factual circumstances of the committed illegal actions and the identity of the violator; 3 ) the correct choice of administrative law and clarification of its content and meaning [2, p. 210]. Subsequently, the concept under consideration has been repeatedly clarified (to be discussed below), that has not also prevented its general recognition. A vivid evidence of which is the reflection of O.I. Ostapenko's key ideas on to the scientific achievements of the leading scientists of domestic jurisprudence, let's say V.K. Kolpakov and O.I. Kuzmenko [10, p. 8-10].

Fourth, O.I. Ostapenko in his works pays special attention to questions of administrative and legal qualification structure. "Since the qualification of administrative delict is a logical process that takes place over a period of time, it is necessary to determine certain terms that reflect qualitative originality of a particular part of the qualification process" as he emphasizes $[2$, p. 210,211$]$. In author's reasoning, the scholar takes into account differences in understanding the structure of qualifications in administrative and criminal law. If in criminal law the stages of qualification are usually identified with the stages of application to the juridical norm, then administrative law connects them with the stages of the proceedings on the case [2, p. 43].

As it has been already mentioned, the qualification is cognitive process. It is extremely complex, multi-vectoral and being at the same time non-schematic. Within the consciousness of any individual there is no formulation and no way to form an inviolable algorithm for drawing inferences. Some cognitive processes of consciousness occur simultaneously, some are constantly repeated, etc. Thus, the awareness of the general administrative delict of encroachment occurs simultaneously with the statement of the presence of signs of a specific administrative offense in it. During the qualification, the subject may be re-applied to the analysis of the generic features of the delict and then some.

As for the practical aspect of the issue under consideration, often an experienced subject of jurisdiction immediately qualifies the encroachment onto a particular administratively delict norm, bypassing the procedure of its preliminary assessment.

\section{REFERENCES}

1. Кодекс України про адміністративні правопорушення. Відомості Верховної Ради Української РСР. 1984. Дод. до № 51. Ст. 1122.

2. Остапенко О.І. Адміністративна деліктологія : Іис... д-ра юрид. наук : 12.00.07. Київ : УАВС, 1996. 401 с.

3. Гуржій Т.О. Актуальні проблеми державного прогнозування у сфері безпеки дорожнього руху. Проблеми правознавства та правоохоронної діяльності. 2009. № 3. С. 68-73.

4. Гуржій Т.О. Керування автотраспортними засобами : адміністративно-деліктний аспект : монографія. Кіровоград : Полімед-сервіс, 2007. 255 c. 
5. Гуржій Т.О. Логіко-методологічні засади визначення поняття адміністративно-правової кваліфікації. Вісник Української Академії державного управління при Президентові України. 2002. № 4. С. 218-223.

6. Гуржій Т.О. Логіко-філософські категорії і класифрікація об’єктів адміністративного делікту. Право України. 2003. № 1. С. 13-17.

7. Гуржій Т.О. Місце кваліфікації у процесі правозастосування. Право України. 2006. № 4. С. 29-31.

8. Стороженко О.М. Адміністративно-правова кваліфікація зловживань монопольним (домінуючим) становищем на ринку : Дисертація на здобуття наукового ступеня кандидата юридичних наук : 12.00.07. Київ : ВМУРЛ «Україна», 2008. 183 с.

9. Стороженко О.М. Теоретичні проблеми визначення поняття кваліфікації адміністративного складу / держави та права. Збірник наукових праць. Випуск № 35. 2007. с. р. 270-276.

10. Колпаков В.К., Кузьменко О.В. Адміністративні правопорушення в системі корупційних деліктів. Боротьба з організованою злочинністю та корупцією (теорія та практика). 2002. № 5. с. р. 7-12. 


\title{
ЗНАЧЕННЯ СПРАВОЧИНСТВА У РЕАЛІЗАЦІЇ ПРАВОСУБ'ЄКТНОСТІ ЮРИДИЧНОЇ КЛІНІКИ ЯК СУБ'ЄКТА АДМІНІСТРАТИВНО-ПРАВОВИХ ВІДНОСИН
}

\author{
THE IMPORTANCE OF REPRESENTATION IN THE IMPLEMENTATION \\ OF LEGAL ENTITY OF THE LEGAL CLINIC AS A SUBJECT \\ OF ADMINISTRATIVE AND LEGAL RELATIONS
}

\author{
Удод М.В., к.ю.н., доцент, \\ доцент кафедри теорії та історії держави і права та адміністративного права \\ Донецький національний університет імені Василя Стуса
}

У статті наводиться аналіз правових основ діяльності юридичних клінік закладів вищої освіти, а також погляди як вітчизняних, так і зарубіжних вчених щодо становлення юридичної клінічної освіти. Автором досліджується інститут справочинства як дієвий інструмент впливу під час реалізації суб'єктивних юридичних прав та суб'єктивних юридичних обов'язків юридичною клінікою в адміністративноправових відносинах.

У роботі Юридична клініка подається як осередок для проходження навчальної та виробничої практики, а також як науково-дослідницький майданчик. Акцентується увага на необхідності нормативного вирішення питання щодо положення про справочинство для запровадження і використання всіма юридичними клініками України. Важливим тут є пошук оптимальної моделі справочинства у діяльності юридичних клінік закладів вищої освіти. У процесі дослідження з'ясовані форми справочинства юридичної клініки правозахисного і правопросвітницького напряму; ознаки, відповідно до яких документи класифікуються. Встановлено, що для діяльності юридичної клініки з практичного права ключовим документом є договір про співпрацю із закладами освіти, школами, коледжами, училищами, інтернатами тощо. Згідно з укладеними домовленостями складається графік занять у місцях їх проведення, що надає змогу організувати роботу як самої юридичної клініки, так і у відповідному навчальному закладі, установі, організації.

Визначена необхідність впровадження в діяльність юридичної клініки «номенклатури справ», що покликана встановити єдиний порядок формування справ, забезпечення їхнього обліку, оперативного пошуку документів за їх змістом і видом та визначення строків зберігання. Запропоновано визначення поняття справочинства в юридичній клініці, а також виділено основні види документації. За результатом дослідження виділено основні види документів для використання закладом вищої освіти під час організації діяльності юридичної клініки.

Ключові слова: юридична клініка, справочинство, документообіг, адміністративно-правові відносини, правозахисна діяльність правопросвітницька діяльність, практичне право.

The article provides an analysis of the legal basis of legal clinics of higher education institutions, as well as the views of both domestic and foreign scholars on the formation of legal clinical education. The author examines the institution of office work as an effective tool of influence in the implementation of subjective legal rights and subjective legal obligations of a legal clinic in administrative and legal relations.

In the work, the Legal Clinic is presented as a center for training and production practice, as well as a research site. Emphasis is placed on the need for a normative solution to the issue of regulations on the introduction and use of all legal clinics in Ukraine. It is important here to find the optimal model of reference in the activities of legal clinics of higher education institutions. In the course of the research the forms of reference of the legal clinic of human rights and legal education are clarified; features according to which documents are classified. It is important here to find the optimal model of reference in the activities of legal clinics of higher education institutions. In the course of the research the forms of reference of the legal clinic of human rights and legal education are clarified; features according to which documents are classified. It is established that a key document for the activity of a legal clinic on practical law is a cooperation agreement with educational institutions, schools, colleges, schools, boarding schools, etc. According to the concluded agreements the schedule of employment in places of their carrying out is made that gives the chance to organize work both of the legal clinic, and in the corresponding educational institution, establishment, the organization.

The need to introduce a "nomenclature of cases" into the activities of the legal clinic is designed to establish a single procedure for the formation of cases, ensure their accounting, rapid search for documents by their content and type and determine the retention period. The definition of the concept of office work in a legal clinic is offered, and also the basic types of documentation are allocated. According to the results of the research, the main types of documents for use by a higher education institution in organizing the activities of a legal clinic are identified.

Key words: legal clinic, document management, document circulation, administrative and legal relations, human rights activities, legal education activities, practical law.

Постановка проблеми. Важливим складником успішної діяльності будь-якої організації є правильно налагоджене відповідно до нормативно-правових актів справочинство. Не винятком у цьому є і Юридична клініка закладу вищої освіти, оскільки для легалізації своєї діяльності і набуття суб'єктивних юридичних прав і обов'язків справочинство відіграє одну із ключових засад. Сьогодні наукові дослідження щодо справочинства в юридичній клінічній освіті та його впливу на правосуб'єктність юридичної клініки проводилися фрагментарно.

Аналіз останніх досліджень і пуб̆лікацій. Питання, присвячені юридичній клінічній освіті, характеристиці юридичної клініки як суб'єкта адміністративно-правових відносин та організаційно-правові аспекти створення i діяльності, були предметом наукових пошуків таких українських і зарубіжних дослідників, як Л.А Воскобітова, А.О. Галай, А.В. Гутніков, І.В. Дмитриченко, Н.С. Дубчак, М.В. Дулеба, В.А. Єлов, В.В. Король, М.Т. Лоджук Д.І. Мейєр, М.Б. Поляков, В.В. Самолюк, В.В. Стаднік, Н.В. Сухицька, А.М. Удод, А.О. Філіп’єв та інші.
Виділення не вирішених раніше частин загальної проблеми. Наразі у юридичній науці недостатньо уваги приділяється дослідженню юридичної клінічної освіти і юридичної клініки як навчального, науково-дослідницького та практичного майданчика для якісної фахової підготовки правників та впливу на її правосуб' єктність такого важливого інституту, як справочинство.

Мета статті. Визначення основних проблем та напрямів вдосконалення інституту справочинства як дієвого інструменту реалізації суб'єктивних юридичних прав і суб'єктивних юридичних обов'язків юридичної клініки закладу вищої освіти.

Виклад основного матеріалу. Будь-яка інформація, яка надходить до юридичної клініки або створюється нею, може бути використана за умови фіксування іiі відповідним способом та інструментарієм, що у подальшому надає можливість зберігати та відтворювати іiі. Найпоширеніший спосіб фіксації інформації - створення документу на папері, але за наявності сучасного матеріальнотехнічного забезпечення юридичних клінік інформація 
може фіксуватись і на електронних носіях. В окремих випадках під час проведення ділових ігор з інтерв'ювання та консультування, навчальних судових процесів може застосовуватись також і відеозапис. Всі ці інструменти надають можливість використати отриману інформацію надалі, для аналізу, вдосконалення і розвитку юридичної клінічної освіти і діяльності Юридичної клініки загалом.

Слід враховувати, що система справочинства в юридичній клініці повинна підпорядковуватись загальним вимогам, які висуваються до будь-якої системи справочинства, а саме бути:

оперативною щодо обігу інформації та документів всередині юридичної клініки та за її межами;

простою за змістом і формою, щоби кожен працівник юридичної клініки міг самостійно забезпечити дієвість такої системи;

функціональною щодо наявності необхідних елементів, які сприяють повній фіксації необхідної інформації та скороченню зайвих елементів, що ускладнюють іiі опрацювання.

Таким чином, щоб зберегти і використати максимально корисно весь обсяг отриманої інформації, слід організувати ефективну іiі фіксацію. Для зручності користування інформацією та уникнення складнощів в іiї пошуку рекомендується складати Реєстр справ і документів, а також розробити і затвердити Положення «Про справочинство юридичної клініки».

Слід підкреслити, що робота 3 документами не може виконуватись епізодично та не систематизовано. Від іï якісного виконання залежить успіх програмної діяльності юридичної клініки. Саме тому від визначення кожного документа як окремого носія певної потрібної інформації необхідно розглянути поняття «справочинство» як вид систематизованої діяльності. В галузях знань, присвячених внутрішній практиці реєстрації та обігу нормативних актів і документів, можна знайти різне визначення такого поняття. Дослідниками у сфері менеджменту переважно вживається визначення поняття справочинства як систематизованої фіксації, обробки, обігу та зберігання у вигляді документів інформації, пов'язаної з програмною діяльністю установи, організації, підприємства. Напевно, можна погодитись 3 таким визначенням, оскільки йдеться про зберігання наявної та систематизованої інформації на відповідних носіях: паперових, електронних, фото-відеоаудіо. За визначенням юридичної енциклопедії, справочинство - це ведення канцелярських справ, сукупність робіт 3 документування діяльності організацій i здійснення документообігу [1, с. 534]. Таке визначення можна застосовувати і до характеристики справочинства в юридичній клініці.

Належна організація справочинства в будь-якій установі $є$ необхідним складником іiї ефективної діяльності. Документування ключових етапів роботи юридичної клініки та подальша його систематизація зробить ефективнішим пошук необхідних матеріалів, спростить процес узагальнення та статистичну обробку отриманої інформації, що значно полегшує повсякденну роботу з управління Клінікою та забезпечує ії сталість та ефективність.

Як зазначалось вище, справочинству в юридичній клініці приділяється вагоме значення, оскільки від правильної побудови документообігу та фіксації отриманої інформації (документування) здебільшого залежить ритмічна і злагоджена робота офісу Клініки. Якщо розглядати справочинство в юридичній клініці як систему, то слід визначити іiі три взаємопов'язані складові частини: підготовка документів, систематизація документів, організація їх архівного зберігання. Під час вирішення кожного з названих елементів «клініцисти» повинні керуватись чинними законами, підзаконними нормативно-правовими актами та локальними нормативними актами (накази, статути, положення, стандарти, інструкції тощо), що регламенту- ють процедури справочинства взагалі та в юридичних клініках зокрема. Під час підготовки чи розробки документів слід враховувати, що створювані в юридичній клініці документи повинні відповідати ii організаційно-правовому статусу. Водночас право на створення, підписання, погодження та затвердження документів визначається відповідним Положенням про юридичну клініку, Положенням про справочинство в Клініці та посадовими інструкціями їі працівників.

Для систематизації справ опрацьовується логічна блок-схема, яка безпосередньо закріплюється в номенклатурі та використовується під час розробки картотеки виконання документів. Необхідність впровадження в діяльність юридичної клініки «номенклатури справ» покликана для встановлення єдиного порядку формування справ, забезпечення їх обліку, оперативного пошуку документів за їх змістом і видом та визначення строків зберігання. 3 моменту створення чи надходження документів i до їх направлення на архівне зберігання вони знаходяться за місцем формування справ у осіб, які за посадовою інструкцією несуть відповідальність за цей етап документообігу та зберігання відповідно до номенклатури справ. Такими особами можуть бути як керівник юридичної клініки, так і координатор програм чи лаборант.

Відповідно до наказу Міністерства юстиції України від № 1000/5 18 червня 2015 року «Про затвердження Правил організації справочинства та архівного зберігання документів у державних органах, органах місцевого самоврядування, на підприємствах, в установах і організаціях» (далі за текстом - Наказ Мінюста) функції організації справочинства в установі або ведення іiї архіву покладено на відповідальну особу, у посадовій інструкції якої зазначаються ці обов'язки, а також ії права та відповідальність. Оскільки юридична клініка зазвичай є структурним підрозділом факультету або університету, то, відповідно, відповідальність за справочинство в юридичній клініці та ведення архіву покладається на керівника юридичної клініки або методиста чи координатора 3 обов'язковою умовою, що цей обов'язок буде зазначений в його посадовій інструкції. Таким чином, справочинство юридичної клініки - це обіг документів з моменту їх отримання або створення до завершення виконання та їхнє архівування.

Розрізняють три основні потоки (види) документації: документи, які надходять до юридичної клініки (зовнішні), документи, які надсилаються до інших організацій (вихідні), документи, які створюються і використовуються в юридичній клініці (внутрішні). Документи, які надходять до юридичної клініки, підлягають попередньому опрацюванню відповідальною за справочинство особою щодо перевірки правильності доставки кореспонденції та ії цілісності. Документи, надіслані не за адресою, повертаються відправникові без розгляду. Відповідно до Наказу Мінюсту документи підлягають попередньому розгляду у день їх надходження або в перший наступний день у разі надходження їх після закінчення робочого дня або у вихідні та святкові дні. Всі документи, що надійшли до юридичної клініки або створені нею, у тому числі для внутрішнього користування, вважаються внесеними до документаційного фонду з моменту їх реєстрації 3 подальшою їх передачею до виконавця, що дозволяє визначити від кого і коли надійшла інформація, і чи вчасно надана відповідь адресату. Такий облік може здійснюватись у журналі вхідної кореспонденції із зазначенням відправника та його реквізитів, найменування кореспонденції, дати іiі надходження та реєстраційного номеру.

Попри те, що у документообігу юридичної клініки їхня кількість $є$ зазвичай незначною, необхідність здійснення реєстрації документів сприяє забезпеченню їх обліку, оперативному використанню наявної в документах інформації та контролю за виконанням і полягає у веденні запису облікових даних про документ за встановленою юридич- 
ною клінікою реєстраційною формою. Необхідно зауважити, що така процедура (порядок) залежить від виду та об'єму діяльності юридичної клініки. У разі захисту клінікою публічних інтересів кількість вхідних документів буде значною.

У документообігу юридичної клініки «вихідні документи» представлені в більшому обсязі, ніж «вхідні», оскільки, крім переписки з клієнтами, партнерами, державними та громадськими організаціями, $є$ необхідність у надсиланні відповідних запитів, заяв, звернень, клопотань та скарг. 3 цією метою юридичною клінікою здійснюється облік вихідної кореспонденції в однойменному журналі, де зазначається відправник, отримувач та їхні адреси, найменування документу, дата відправки та реєстраційний номер. Вихідні документи опрацьовуються і надсилаються в день їх надходження від безпосередніх виконавців, але не пізніше наступного робочого дня. При цьому забороняється передача або надсилання без їх попередньої реєстрації особою, яка є відповідальною за справочинство в юридичній клініці.

Левову частку документообігу юридичної клініки становлять внутрішні документи. Організація системи внутрішнього документообігу не є самоціллю. Цей інструмент дозволяє не втратити корисну інформацію. Головною метою роботи 3 нею $є$ отримання позитивного результату, а також доведення такої інформації до суб'єкта, якому вона необхідна для прийняття рішення. Отже, кожен працівник юридичної клініки повинен знати, що він має робити 3 отриманою і створеною ним інформацією, куди та у якій формі ця інформація повинна бути передана. Такі питання можуть бути вирішені у Положенні «Про справочинство юридичної клініки» або ж безпосередньо в Положенні (Статуті) юридичної клініки, а саме: кому з працівників юридичної клініки повинна надходити та чи інша інформація; для вирішення яких питань надсилається така інформація; хто уповноважений встановлювати строки ухвалення рішення щодо отриманої інформації тощо.

Особливості сучасного справочинства полягають насамперед у здійсненні його державною мовою, широкому застосуванні комп'ютерних систем обробки та друкування документів, необхідності дотримання вимог чинних державних стандартів, а також стандартів юридичної клініки [2, с. 135].

Необхідно підкреслити, що використання електронного документообігу в діяльності юридичної клініки являє собою сукупність технологій, які оптимізують та істотно змінюють якість та ефективність роботи персоналу Клініки. Застосовування сучасних IT-технологій дає можливість організувати злагоджену взаємодію між учасниками юридичної клініки та забезпечує ефективну обробку документів, систематизує документообіг і сприяє контролю за виконанням першочергових завдань персоналом юридичної клініки. До таких технологій, що необхідно застосовувати в діяльності юридичної клініки, можуть належати: засоби збереження електронної інформації, засоби передачі електронних даних, трансформування паперових документів в електронну (цифрову) форму. Учасники електронного документообігу самостійно визначають режим доступу до електронних документів, їх використання та встановлюють для них систему захисту.

Нормативно-правовою базою, яка врегульовує відносини, що виникають у зв'язку з функціонуванням юридичних клінік у закладах вищої освіти України, є Закон України «Про вищу освіту» [3], в якому передбачається створення юридичної клініки як структурного підрозділу ЗВО. Крім того, таким нормативним актом $є$ «Типове положення про юридичну клініку в вищих навчальних закладах України» [4], яке визначає мету та завдання юридичних клінік, принципи їх діяльності, організацію роботи, права та обов'язки студентів, матеріально-технічну базу та фінансування юридичної клініки. Водночас діяльність юридичних клінік регламентується окремим Положенням про юридичну клініку конкретного ЗВО, яке розробляється на основі «Типового положення про юридичну клініку в вищих навчальних закладах України», а також на основі «Стандартів діяльності юридичних клінік України», що були схвалені Всеукраїнським з'їздом Асоціації юридичних клінік України [5]. Відповідно до такого Положення кожна юридична клініка здійснює свою діяльність на підставі засновницьких документів, у яких повинна бути визначена організаційно-правова форма юридичної клініки, іiі структура і органи управління, мета та завдання діяльності юридичної клініки, характер та обсяг правової допомоги, яка надається юридичною клінікою. [5] Таким чином, Положення «Про юридичну клініку» $\epsilon$ основним локальним нормативним актом, що визначає мету та завдання діяльності юридичної клініки, іiі організаційну структуру, управління та організацію роботи юридичної клініки, облік результатів роботи студентів і викладачів, матеріально-технічне забезпечення і фінансування та питання припинення діяльності юридичної клініки. Такий Акт (документ) підлягає обов'язковому затвердженню керівництвом закладу вищої освіти, оскільки регламентує діяльність юридичної клініки як складника навчального процесу та як окремий структурний підрозділ університету або факультету. Положення про юридичну клініку має бути доступним для ознайомлення широкому колу осіб, але тільки у вигляді копії. Також копії Положення надсилаються на запити державних органів та органів місцевого самоврядування. Оригінал Положення має зберігатись в окремому місці і не може переміщатись за межі приміщення Клініки без дозволу ії керівника [4]. До локальних нормативних актів Клініки слід віднести також «Примірний етичний кодекс юридичної клініки», затверджений 3'їздом Асоціації юридичних клінік України.

Первинним організаційним документом, що визначає фактичний початок діяльності Клініки, є «Заява про відкриття юридичної клініки» та комплект «Навчальнометодичних матеріалів» клінічної освіти, в якому передбачаються обов'язкові для викладання курси, а також матеріали, присвячені програмній спеціалізації Клініки. Ці документи підлягають розгляду на засіданні ради факультету або відповідного структурного підрозділу і затверджуються Протоколом.

Зауважимо, що як свідчить зарубіжний досвід, обов'язковою умовою для започаткування спеціалізованої юридичної клініки, наприклад, у Пітсбургському університеті (США), є фінансова підтримка ії діяльності з боку донорських організацій

У юридичній клініці також ведеться облік заяв студентів, які виявили бажання працювати в ній. Коли кількість поданих заяв перевищує наявну кількість місць (зазвичай 8-12 осіб) можливе оголошення конкурсу на зайняття посад консультантів. Зарахування студентів здійснюється Розпорядженням керівника відповідного структурного підрозділу (факультету, ЗВО) на підставі результатів проведеного конкурсу або Подання керівника юридичної клініки, на які також розповсюджуються загальні вимоги справочинства. Наприклад, в Юридичній клініці Національної академії внутрішніх справ розроблено Положення «Про підбір кадрів персоналу юридичної клініки», в якому зазначаються загальні положення такого добору та регламентується процедура добору студентів-клініцистів [6, с. 124]. Важливими організаційними документами $\epsilon$ «Анкети студентів», які виявили бажання працювати в юридичній клініці і зараховані до ії складу, а також Список працівників юридичної клініки. Практика діяльності Клінік свідчить, що зібрані відомості щодо всіх членів юридичної клініки стають у пригоді впродовж всього часу iii роботи. Розташування усіх прізвищ персоналу Клініки за абеткою надає змогу швидко віднайти необхідну інфор- 
мацію про ту чи іншу особу. Цей документ загального користування рекомендується розмістити на відкритому і доступному місці у приміщенні Клініки [7, с. 103].

Подальший розвиток юридичної клініки неможливий без чітко сформульованих завдань, які повинні знайти своє відображення у Річному плані діяльності юридичної клініки, в якому розглядаються питання кадрового забезпечення, навчально-методична робота, фінансові аспекти, грантова робота, наукова діяльність тощо.

Важливим документом, який встановлює порядок ведення прийому громадян в юридичній клініці, є Регламент або Порядок прийому громадян. Необхідність створення такого документу є обов'язковою умовою під час ведення прийому громадян, оскільки він містить необхідну інформацію про час, порядок та умови надання безоплатної правової допомоги та усуває певні непорозуміння, які $є$ наслідком необізнаності широких верств населення щодо такого виду допомоги. Цей документ $\epsilon$ винятково внутрішнім, а закріпленні в ньому приписи регулюють відносини, які виникають в процесі функціонування юридичної клініки [7, с. 103].

За умови, коли у складі однієї Юридичної Клініки функціонують декілька спеціалізованих Програм ( спеціалізованих юридичних клінік), доцільно вести «Журнал обліку роботи спеціалізованих юридичних клінік», у якому містяться відомості щодо таких спеціалізацій (напрямів), їх керівників-кураторів та студентів-консультантів, а також часу і місця їх роботи. У цей Журнал доречно вносити інформацію про відвідування студентами занять (тренінгів, лекцій, семінарів) в юридичній клініці.

Одним із важливих організаційних документів юридичної клініки є «Договір (меморандум) про співпрацю», що певною мірою забезпечує окремі сторони ії діяльності. Предметом укладання такого Договору є співпраця щодо обміну інформацією і досвідом в межах відповідних функцій і повноважень кожної із сторін. У рамках цих домовленостей здійснюється науково-дослідницька та організаційна діяльність, забезпечується всебічна підтримка активних ініціатив студентів юридичної клініки, підвищення рівня їх професійної підготовки в певній галузі права, а також допомога у здобутті якісної, грунтовної та конкурентоспроможної юридичної освіти.

Для забезпечення ефективності та належної якості роботи юридичної клініки координатор клініки складає графік чергувань іiї працівників / персоналу. Цей документ доводиться до відома всіх працівників юридичної клініки 3 урахуванням їх побажань щодо днів та годин чергування. Керівник юридичної клініки відповідно до графіку чергувань може подавати керівнику факультету або ЗВО службову записку щодо звільнення студента від навчальних занять у день чергування.

Під час першого прийому клієнта / відвідувача у зазначені Регламентом (Порядком прийому громадян) дні і години координатор заповнює «Реєстраційну картку клієнта юридичної клініки» або ж Анкету, яка складається під час його першого опитування. Вона містить номер справи, галузь права / законодавства, відомості про особу, iii соціальний статус, подається короткий опис проблеми / питання, $з$ якою звертається клієнт, дати зустрічей 3 консультантом, а також умови надання юридичної допомоги, a саме: допомогу надають студенти-юристи під контролем викладачів, копії документів справи можуть бути використані у навчальному процесі з дотриманням вимог конфіденційності, копії документів справи не повертаються клієнту.

Згода клієнта на такі умови надання правової допомоги засвідчується його підписом. Окремі юридичні клініки поряд з Реєстраційною карткою (Анкетою) практикують укладати «Договір про надання правової допомоги» 3 цих питань, в якому визначаються сторони, їхні права та обов'язки під час надання безоплатної правової допо- моги. Значення цього Договору полягає у тому, що сторони домовляються про використання наданої клієнтом інформації та документів у навчальному процесі юридичної клініки із збереженням конфіденційності. У разі його підписання студент заповнює вищезазначену картку і проводить інтерв'ювання.

Для уникнення непорозумінь щодо наступних зустрічей 3 консультантом юридичної клініки клієнту видається Запрошення на консультацію, де зазначається дата, час і місце наступної консультації, П.І.Б. консультанта, а також дата і підпис консультанта про проведену чи перенесену консультацію.

Одним із найважливіших документів юридичної клініки є «Журнал обліку справ», взятих до розгляду Клінікою. За загальними правилами документообігу цей Журнал повинен бути прошитий, а його сторінки пронумеровані. Цей документ містить хронологічний перелік справ та відповідних клієнтів. Його зміст має відображати основні відомості щодо руху справи згідно з галузевою приналежністю юридичної клініки, інформацію щодо закріплення справи за студентом-консультантом. Ведення такого Журналу є обов'язковим, що надає можливість вести аналіз вирішення справ за відповідною галуззю права / правових відносин, відображати кількісні показники опрацювання справи та соціальний статус клієнтів. Можна рекомендувати щойно створеним юридичним клінікам вести такий Журнал протягом навчального року. Водночас, як свідчить практика, значна кількість юридичних клінік ведуть такий Журнал 3 моменту створення (початку роботи) самої Клініки. Зауважимо, що альтернативною формою обліку справ може слугувати Електронна база даних, яка надає можливість оперативно одержати необхідну статистичну та змістовну інформацію.

За завершенням навчального семестру керівник юридичної клініки за результатами їі роботи складає Звіт викладача-куратора про роботу в юридичній клініці, який містить інформацію про кількість відпрацьованого часу та використані форми роботи. Такий Звіт є необхідним документом у разі оплати праці в юридичній клініці викладачу закладом вищої освіти. У разі діяльності юридичної клініки за грантовим фінансуванням така форма не $\epsilon$ обов'язковою, оскільки донорські організації такої звітності зазвичай не вимагають.

Підсумовуючи результати діяльності студентів-консультантів в юридичній клініці, викладач може подати до деканату або іншого структурного підрозділу, відповідального за юридичну клінічну освіту, клопотання про нарахування встановлених рейтингових балів за участь студента в роботі юридичної клініки, яке складається у довільній формі. Робота студента-консультанта в юридичній клініці передбачає ведення справи, зустрічі з клієнтами (інтерв'ю, консультування), складання відповідних процесуальних документів і підготовку Звіту про надану правову допомогу, де відображатиметься інформація про номер справи (відповідно до Журналу обліку справ), галузь права / сфера правових відносин, П.І.Б. клієнта і консультанта, дата відкриття і закриття справи, зміст консультації, правові дії студента-консультанта, результат і кількість зустрічей. Деякі юридичні клініки до цього Звіту долучають реєстрацію відзиву клієнта щодо роботи студента. Можливим альтернативним варіантом реєстрації «відзиву клієнта на роботу студента» може бути окремий «Журнал відзивів клієнтів» або Анкета, яка долучатиметься до справи. В окремих ЗВО практикується ведення Журналу скарг, подяк та пропозицій. Необхідність таких записів у звітах (журналах, анкетах) продиктована можливістю та необхідністю керівника юридичної клініки оцінити якість правової допомоги і виявити проблеми в діяльності Клініки.

Документи в юридичній клініці повинні передаватися виконавцям (студентам-консультантам, викладачам-кура- 
торам, керівникам спеціалізованих юридичних клінік) під розписку в Журналі обліку справ.

Необхідно також звернути увагу на такі види документів, як Відомості про оголошення конкурсів на отримання грантів та Відомості про семінари, тренінги, круглі столи, школи та конференції, оскільки подібна інформація $є$ необхідною для обміну досвідом між різними юридичними клініками України.

Фінальним документом, який підсумовує роботу юридичної клініки протягом навчального року, є «Звіт про виконання річного плану діяльності юридичної клініки». Необхідність складання такого документу продиктована тим, що він надає можливість проаналізувати виконання запланованих заходів, виявити недоліки, відмітити досягнення та намітити подальші шляхи розвитку юридичної клінічної освіти.

Документування правопросвітницької діяльності здійснюється зазвичай у межах реалізації Програми «Практичного права» і мало чим відрізняється від документування діяльності класичної юридичної клініки. Одним iз найважливіших документів юридичної клініки «Практичного права» $є$ Навчальна програма, яка визначає зміст і обсяг знань, умінь та навичок, які підлягають засвоєнню, а також зміст розділів і тем з розподілом їх за роками навчання [8, с. 184]. Для діяльності юридичної клініки 3 «Практичного права» ключовим документом є Договір про співпрацю із закладами освіти - школами, коледжами, училищами, інтернатами тощо. Згідно 3 укладеними домовленостями складається графік занять у місцях їх проведення, що надає змогу організувати роботу як самої юридичної клініки, так і у відповідному навчальному чи іншому закладі (установі, організації).

За результатами роботи юридичної клініки з «Практичного права», як і юридичної клініки з надання безоплатної правової допомоги, складаються звіти студента і викладача. Вдалою практикою в окремих юридичних клініках $є$ оцінювання результатів проведених студентами занять, що дає можливість вдосконалити застосування інтерактивних методик та підвищити їх ефективність. Крім того, таке оцінювання враховує якість змісту і форми викладеного матеріалу студентами певній аудиторії слухачів.

Висновки і пропозиції. Наведений у цій статті перелік документів не можна вважати вичерпним у справочинстві юридичної клініки, оскільки в Україні триває становлення юридичної клінічної освіти, і тому зразки документів постійно вдосконалюватимуться у процесі діяльності юридичних клінік, щоби відповідати основним вимогам будь-якої системи справочинства, а саме бути простими, оперативними і функціональними. Своєю чергою наявність досконалого справочинства $\epsilon$ важливим інструментом у реалізації суб'єктивних юридичних прав та обов'язків в адміністративно-правових відносинах юридичною клінікою закладу вищої освіти.

3 метою впровадження кращих практик діяльності юридичних клінік закладів вищої освіти Міністерству освіти і науки України слід завершити підготовку та прийняття нормативно-правових актів, які сприятимуть удосконаленню справочинства в юридичній клініці і юридичної клінічної освіти загалом.

\section{ЛITEPATУРA}

1. Юридична енциклопедія. Т. 5. Київ : Видання «Юридична енциклопедія» ім. М.П. Бажана, 2003. 734 с.

2. Охотнікова О.М., Удод М.В., Шевчук С.С. Правові основи справочинства в державному управлінні : навчальний посібник для студентів денної, вечірньої та заочної форми навчання вищих навчальних закладів / За заг. ред. О.М. Охотнікової. Донецьк, 2010. 336 с.

3. Про вищу освіту: Закон України від 01 липня 2014 р. № 1556-II. URL: https://zakon.rada.gov.ua/laws/show/1556-18.

4. Про затвердження Типового положення про юридичну клініку вищого навчального закладу України: затверджене наказом Міністерства освіти і науки України № 592 від 3 серпня 2006 p. URL: https://zakon.rada.gov.ua/laws/show/z0956-06\#Text.

5. Стандарти діяльності юридичних клінік України: прийняті за З'їзді юридичних клінік України від 19.06.2012. Київ : АЮКУ, 2012. 12 c.

6. Галай. А.О., Стадник В.В. Організаційна та управлінська модель юридичної клініки в Україні: забезпечення якісного функціонування; Навчальний посібник. Київ : Атіка, 2005. 280 с.

7. Юридична клініка. Навчальний посібник. В.А. Єлов, С.І. Молібог, Д.Г. Павленко. Київ : «Школяр», 2004. 315 с.

8. Гончаренко С.У. Український педагогічний словник. Київ : Либідь, 1997. 386 с. 


\title{
ПУБЛІЧНИЙ ІНТЕРЕС У ВИЗНАЧЕННІ ЮРИСДИКЦЙНОЇ НАЛЕЖНОСТІ ЗЕМЕЛЬНИХ СПОРІВ
}

\section{PUBLIC INTEREST IN DETERMINING THE JURISDICTION OF LAND DISPUTES}

\author{
Удод М.В., к.ю.н., доцент,
доцент кафедри теорії та історії держави і права та адміністративного права \\ Донецький національний університет імені Василя Стуса
}

\author{
Пирогов В.С., консультант \\ Касаиійний адміністративний суд у складі Верховного Суду
}

\begin{abstract}
Стаття присвячена дослідженню впливу суспільних інтересів на визначення юрисдикції земельних спорів. Характерні риси суспільних інтересів у сфері земельних відносин визначені як ключовий критерій публічно-правового спору. Обґрунтовано необхідність урахування інтересів суспільства під час створення суду, який має право розглядати земельні спори за участю суб'єктів державної адміністрації. Встановлено, що суспільний інтерес у земельному спорі представлений об’єктивно наявними життєвими та найважливішими потребами усього суспільства або значної частини його частини у володінні, користуванні та розпорядженні землею як суспільною власністю, а також для збереження та захисту його природного стану від впливу негативних природних та штучних факторів, які визнаються державою та закріплені нормами закону, обов'язок із забезпечення та захисту яких покладається на компетентний орган державного управління. 3 огляду на вищесказане під «громадською власністю» слід розуміти ті об'єкти матеріального світу (включаючи природні ресурси), які є майновими правами українського народу, держави та територіальної громади, якими користується державна адміністрація суб'єкта захисту прав, свобод та законних інтересів фрізичних та юридичних осіб і для якого державна адміністрація здійснює права власника від імені та в інтересах українського народу, держави та територіальної громади. Подальше дослідження категорії «суспільний інтерес» та її вплив на визначення юрисдикційного характеру спорів, що виникають із земельних відносин, допоможе чітко визначити юрисдикцію певної категорії спорів. Подальші наукові дослідження також повинні розглядати поєднання державних та приватних інтересів, щоб мати уявлення про ступінь, у якому суспільний інтерес $€$ відносно приватним. Визначення пріоритетів у цьому разі буде особливим процесом, який повинен регулюватися адміністративно-правовими нормами.

Ключові слова: юрисдикція адміністративних судів, суб'єкт публічної адміністрації, земельні спори, публічний інтерес, публічноправовий спір.

The article focuses on the study of the influence of the public interest in determining the jurisdiction of land disputes. The characteristic features of public interest in the field of land relations are identified as a key criterion for a public legal dispute. The necessity of taking into account public interest during the establishment of a court competent to hear land disputes involving public administration subjects is substantiated. It is established that the public interest in the land dispute is represented by the objectively available vital and essential needs of the whole society or a large part of it for the possession, use and disposal of the land as public property, as well as for the preservation and protection of its natural state from the influence of negative natural and artificial factors that are recognized by the state and are enshrined in the rules of law and the duty of providing and protection of which rests with the competent public administration entity. In view of the above, "public property" should be understood to mean those objects of the material world (including natural resources) that are the property rights of the Ukrainian people, the state and the territorial community, which are used by a public administration entity to protect rights, the freedoms and legal interests of individuals and legal entities and for which the public administration exercises the rights of the owner on behalf and in the interests of the Ukrainian people, the state and the territorial community. Further research into the category of "public interest" and its impact in determining the jurisdictional nature of disputes arising from land relations will help to clearly determine the jurisdiction of a particular category of disputes. Further scientific research should also look at the combination of public and private interests in order to have an idea of the extent to which public interest is relatively private. Setting priorities in this case will be a special process that must be regulated by administrative and legal rules.
\end{abstract}

Key words: jurisdiction of administrative courts, subject of public administration, land disputes, public interest, public law dispute.

Постановка проблеми. Земельні спори в Україні можна віднести до особливої категорії справ, які розглядаються адміністративними судами. Це насамперед пов'язано з тим, що в законодавстві, яке регулює земельні правовідносини, мають місце окремі прогалини та правові колізії, а також проблеми щодо визначення юрисдикційної належності спорів, що виникають із земельних правовідносин, та впливу на них категорії «публічний інтерес».

Аналіз останніх досліджень і публікацій. Питання юридичного змісту цієї категорії, вивчення його характерних рис були предметом наукових пошуків таких українських та закордонних дослідників, як В.В. Галунько, Р.А. Калюжний, Р.С. Мельник, С.В. Пєтков, Ю.О. Тихомиров, К.Ю. Тотьєв та інші.

Виділення не вирішених раніше частин загальної проблеми. Наразі у юридичній науці недостатньо уваги приділяється саме комплексному дослідженню змісту цієї категорії. Також фрагментарно розробленою залишається проблема впливу публічного інтересу у визначенні судової юрисдикції, зокрема в контексті юрисдикційних суперечок щодо того, який саме суд наділений компетенцією розглядати земельні спори за участю носіїв публічної влади, що і зумовлює актуальність теми цього дослідження.
Мета статті - визначення впливу публічного інтересу через його ознаки, формулювання власної дефініції цієї категорії з урахуванням її сутності та характерних особливостей, обгрунтування значення публічного інтересу для правильної ідентифікації суду, до компетенції якого належить розгляд земельних спорів за участю органів державної влади та органів місцевого самоврядування.

Виклад основного матеріалу. На думку окремих вчених-юристів під час визначення правової природи спору публічно-правовий це чи приватно-правовий - необхідно передусім виходити 3 природи самих правовідносин. Публічно-правовим спір є тоді, коли позовна вимога (наприклад, надання дозволу чи скасування заборони) пов'язана $з$ положеннями публічного права. Якщо до приватного права належать законодавчі норми, які грунтуються на принципі рівності прав суб'єктів правовідносин, то до публічного права належать законодавчі норми, які визначають привілейоване право держави чи іншого представника державної влади.

Як справедливо зауважує Т. Коломоєць, кожен вид судочинства, незалежно від того, чи пов'язаний він із радянською правовою традицією, чи виник в Україні за нових політико-правових реалій, своїм предметом має 
спори, що виникають або із певного типу приватних, або із певного типу публічних правовідносин [1, с. 75].

Отже, позиція науковців щодо юридичної природи будь-яких правовідносин грунтується на концепції дуалізму системи права, тобто розмежування права на дві окремі підсистеми - публічне та приватне. Основою для поділу права на дві галузі- публічне та приватне, є дві категорії - предмет правового регулювання та метод правового регулювання [2, с. 177-178]. Водночас основу термінологічно-понятійного апарату галузей публічного та приватного права становлять такі категорії, як «приватний інтерес» і «публічний інтерес» відповідно [3, с. 474], а також «публічне майно»[4, с. 145]. Тому під час визначення правової природи певного спору та його юрисдикційної належності слід виходити передусім із юридичного змісту (сутності) інтересу учасника правовідносин та об'єкта, щодо якого такий інтерес існує.

3 метою визначення змісту публічного інтересу в земельних правовідносинах слід розглянути його характерні риси.

На думку Р. Мельника, публічний інтерес становить категорію, яка виходить за межі особистості, перебуваючи на рівні суспільного інтересу. Основою публічного інтересу є об'єктивний інтерес усього суспільства [4, с. 34]. Поряд із цим К. Тотьєв підкреслює, що публічність інтересу означає, що його суб'єктом (носієм) є суспільство як органічне ціле [5, с. 25]. Тому можна стверджувати, що публічний інтерес $\epsilon$ невідокремленим, або ж самостійним. Він виражається у єдності інтересів соціуму, які мають єдине бачення щодо кола своїх потреб, а також прав і свобод. Саме тому необхідною ознакою публічного інтересу має вважатися суспільна узгодженість, тобто відсутність жодних сумнівів та суперечок стосовно його значущості та виняткової ролі в людській життєдіяльності.

Між тим, В. Галунько, проаналізувавши доктринальні позиції науковців-адміністративістів, під публічним інтересом розуміє важливі для значної кількості фізичних і юридичних осіб потреби, які відповідно до законодавчо встановленої компетенції забезпечуються суб'єктами публічної адміністрації [6, с. 65]. Тобто обов'язковими ознаками цього інтересу мають бути важливі потреби, які повинні забезпечуватися у суспільстві. Слід погодитися із цією позицією, адже такі потреби мають бути значущими не лише для окремого індивіда, а й для сукупності зацікавлених суб'єктів (великої соціальної групи), що вважають його життєво необхідним для себе.

Як слушно зауважують Р. Калюжний та С. Пєтков, від приватних суб'єктивні права публічного характеру відрізняє те, що у відносинах, у яких вони формуються і реалізуються, зобов'язальною стороною, крім самого носія цих прав, зазвичай виступає носій публічної влади - суб'єкт владних повноважень [7, с. 4]. У цьому і полягає визначальна особливість публічно-правових відносин, у яких публічному інтересу завжди кореспондує обов'язок компетентного суб'єкта публічної адміністрації всіляко захищати його та вживати заходів щодо дотримання прав та свобод особи. А неодмінною умовою виконання таких обов'язків є компетенція суб'єкта публічної адміністрації, що встановлена законом. Саме тому конкретний обов'язок публічно-владного характеру має бути елементом управлінської діяльності лише уповноваженого на те суб'єкта що відповідає основоположному принципу поділу влади у демократичній державі, який закріплений ч. 2 ст. 6 Конституції України.

Крім того, слід зазначити, що навіть попри природний характер публічного інтересу і об'єктивну наявність потреб, які становлять його зміст, неодмінно забезпечуватиме його дотримання лише закріплення такого інтересу в нормах права, що регламентують певну групу публічноправових відносин. Адже сама наявність відповідної норми права $є$ передумовою для виникнення відносин у сфері його охорони та забезпечення. На цьому акцентує увагу і Ю. Тихомиров, оскільки, на думку вченого, публічним інтересом $є$ визнаний державою та забезпечений правом інтерес соціальної спільності, задоволення якого $\epsilon$ гарантією її існування та розвитку [8, с. 55].

У зв'язку з наведеним виняткову роль у нормативному закріпленні публічного інтересу відіграє Конституція України як суспільний договір, що встановлює найважливіші потреби суспільства, які беззаперечно визнаються державою і які держава у будь-якому разі має захистити та створити належні умови для їх реалізації. Тому під час 3'ясування правової природи інтересу передусім слід керуватися положеннями Основного Закону України, які з огляду на зміст ст. 8 мають застосовуватися до суспільних відносин, що врегульовані ними, безпосередньо та обов'язково.

На підставі проведеного аналізу можна дійти висновку, що публічний інтерес як ключовий критерій визначення належності земельних спорів до адміністративної юрисдикції характеризується тим, що:

1) він об'єктивно наявний у суспільстві, тобто передумовою для його існування $є$ природні потреби суспільства, які для нього найбільш важливі, значущі, життєво необхідні, зокрема, необхідність володіння, користування та розпорядження землею;

2) він невідокремлений, або ж самостійний, а грунтується на волі усього суспільства, тобто він стосується суспільства як сукупності (широкого кола) суб'єктів, для яких він однаково важливий та цінний;

3) визнається державою та закріплюється у нормах публічного права, насамперед у положеннях Конституції як Основного Закону;

4) полягає в існуванні зобов'язань держави перед суспільством, яка прагне їхнього належного виконання, і публічна адміністрація - той єдиний суб'єкт, який має компетенцію щодо забезпечення їх виконання.

Публічний інтерес у земельному спорі становлять об'єктивно наявні життєво необхідні та найважливіші прагнення усього суспільства чи його значної частини щодо володіння, користування та розпорядження землею як загальнонаціональним благом, а також щодо збереження та захисту ii природного стану від впливу негативних природних та штучних факторів, які визнаються державою та закріплюються в нормах публічного права, й обов'язок стосовно забезпечення та захисту яких покладається на компетентного суб'єкта публічної адміністрації.

Крім того, із системного аналізу положень статей 13 та 14 Основного Закону України випливає, що земля основне національне багатство, а отже, вона вважається надбанням Українського народу, яке він може використовувати для задоволення своїх потреб та здійснення прав, свобод і законних інтересів, що гарантовані Конституцією та законами України. Про публічний характер такого майна свідчить можливість кожного громадянина користуватися земельними об'єктами, а також взяття державою на себе зобов'язань щодо охорони такого майна. Тобто призначення такого майна - сприяння повсякденній реалізації суспільного інтересу.

Висновки і пропозиції. Отже, важливе значення для визначення спору як такого, що має публічно-правовий характер, має поняття «публічний інтерес». Під публічним інтересом треба розуміти прагнення суспільства чи окремої його частини до добропорядного та відповідального виконання належною публічною адміністрацією обов'язків, закріплених нормативно-правовими актами, передусім Конституцією України - суспільним договором, який містить зобов'язання держави щодо створення належних умов для реалізації гарантованих Конституцією і законами України прав, свобод та інтересів громадян. 
На основі зазначеного можна дійти висновку про те, що публічний інтерес в земельному спорі становлять об'єктивно наявні життєво необхідні та найважливіші потреби усього суспільства чи його значної частини щодо володіння, користування та розпорядження землею як публічним майном, а також щодо збереження та захисту iii природного стану від впливу негативних природних та штучних факторів, які визнаються державою та закріплюються в нормах права й обов'язок щодо забезпечення та захисту яких покладається на компетентного суб'єкта публічної адміністрації.

3 наведеного випливає, що обгрунтованим буде виокремлення земельних спорів щодо публічного майна об'єктами права власності Українського народу, держави та територіальної громади в окрему групу публічно-правових спорів та їі закріплення на нормативному рівні.
Тому, на нашу думку, частину першу статті 17 Кодексу адміністративного судочинства України слід доповнити пунктом 14 такого змісту:

«9) спори щодо володіння, користування та розпорядження публічним майном органами державної влади та органами місцевого самоврядування, у яких превалює публічний інтерес.

Для мети застосування цього пункту під «публічним майном» слід розуміти ті об'єкти матеріального світу (зокрема, природні ресурси), що є об'єктами права власності Українського народу, держави та територіальної громади, які використовуються суб' єктом публічної адміністрації для захисту прав, свобод та законних інтересів фізичних і юридичних осіб, і щодо яких публічна адміністрація здійснює права власника від імені та в інтересах Українського народу, держави та територіальної громади».

\section{ЛITЕРАТУРА}

1. Коломоєць Т.О. Розмежування юрисдикційних повноважень між адміністративними та господарськими судами: окремі проблемні питання сьогодення. Вісник Запорізького національного університету. 2009. № 1. С. 69-78.

2. Козюбра М.І., Погребняк С.П., Цельєв О.В., Матвєєва Ю.І. Загальна теорія права : підручник; за заг. ред. М. І. Козюбри. Київ : Ваіте, 2015. $392 \mathrm{c.}$

3. Гриценко І.С., Мельник Р.С., Пухтецька А.А. та інші. Загальне адміністративне право : підручник / за заг. ред. І.С. Гриценка. Київ : Юрінком Інтер, 2017. 568 с.

4. Мельник Р.С., Бевзенко В.М. Загальне адміністративне право: Навчальний посібник / За заг. ред. Р.С. Мельника. Київ : Ваіте, 2014. $376 \mathrm{c}$.

5. Тотьев К.Ю. Публичный интерес в правовой доктрине и законодательстве. Государство и право. 2002. № 9. С. 23-29.

6. Галунько В.В. Публічний інтерес в адміністративному праві. Форум права. 2010. № 4. С. 178-182.

7. Адміністративне право України: законодавчі визначення: словник-довідник / укладачі Р.А. Калюжний, С.В. Пєтков. Запоріжжя : КПУ, 2009. 220 с.

8. Тихомиров Ю.А. Публичное право. Москва, 1995. 467 с. 


\title{
СИСТЕМА ЗДЙСНЕННЯ НОРМАТИВНО-ПРАВОВОГО РЕГУЛЮВАННЯ КІБЕРБЕЗПЕКИ У США
}

\section{SYSTEM OF LEGISLATIVE REGULATION OF CYBER SECURITY IN THE USA}

\author{
Хом'яков Д.О., к.ю.н, \\ начальник науково-дослідної лабораторії проблем права воснної сфери \\ науково-дослідного центру \\ Військовий інститут \\ Київського начіонального університету імені Тараса Шевченка \\ Коропатнік I.М., д.ю.н., професор, \\ начальник кафедри правового забезпечення \\ Військовий інститут \\ Київького національного університету імені Тараса Шевченка
}

\begin{abstract}
Сучасна ера є ерою інформаційного суспільства. Виробництво товарів і послуг, розподіл продукції, науково-технічні відкриття - все це відбувається за використання сучасних технологій оброблення й передавання інформації. Інформаційно-телекомунікаційні технології надають небачені раніше можливості в обміні інформацією: змінилися швидкість і якість передавання інформації, збільшилася кількість людей, що можуть одночасно дізнатися й передати інформацію, значно збільшилася кількість користувачів мережі Інтернет, спростився доступ до джерел інформації. Водночас кіберпростір від звичайного способу передавання інформації трансформується у новітній простір здійснення правовідносин і навіть розв'язання конфліктів. Ставлення до кіберпростору в сучасному світі зумовлює появлення нових думок, поглядів і концепцій як серед користувачів мережі, так і серед науковців. Українська держава лише починає формувати правове поле регулювання кіберпростору й правовідносин, які з ним пов'язані. Водночас у світі це питання почали досліджувати ще на початку 1980-х років XX сторіччя. Особлива увага приділяється питанням безпеки в кіберпросторі та кіберзахисту інформаційних ресурсів держав. Також важливим за останнє десятиріччя є питання здійснення кібероборони держав у кіберпросторі. У статті пропонується розглянути досвід здійснення правового регулювання кібербезпекових питань в одній з найбільш розвинених країн світу - Сполучених Штатах Америки. Адже саме Сполучені Штати Америки є найбільш інформаційно розвиненою державою світу, і мережа Інтернет починалася в цій державі. У статті досліджено підходи й порядок здійснення кіберзахисту у Сполучених Штатах Америки, практичне підґрунтя кібероборони, напрям політики держави щодо загроз у кіберпросторі та проаналізовано основні нормативно-правові акти, які регулюють різні
\end{abstract} аспекти забезпечення кібербезпеки як на рівні всієї держави, так і для захисту окремих громадян.

Ключові слова: кіберпростір, кіберзахист, правове регулювання кіберпростору, кібербезпека, Сполучені Штати Америки.

The modern era is the era of the information society. Production of goods and services, distribution of products, scientific and technical discoveries - all this is done using modern technologies for processing and transmission of information. Information and telecommunication technologies provide unprecedented opportunities in information exchange: the speed and quality of information transmission has changed, the number of people who can simultaneously learn and transmit information has increased, the number of Internet users has significantly increased, people's access to information sources has been simplified. At the same time, cyberspace, from the usual way of transmitting information, is transformed into the latest space for legal relations and even conflict resolution. The attitude to cyberspace in the modern world acquires new thoughts, views and concepts, both among network users and among scientists. The Ukrainian state is just beginning to form a legal framework for regulating cyberspace and related legal relations. At the same time, the world began to study this issue in the early $1980 \mathrm{~s}$ of the twentieth century. Particular attention is paid to issues of security in cyberspace and the implementation of cyber protection of information resources of states. Also important in the last decade is the issue of cyber defense of states in cyberspace. This article proposes to consider the experience of legal regulation of cybersecurity issues in one of the most developed countries in the world - the United States. After all, the United States of America is the most information-developed country in the world, and the emergence of the Internet itself originates in this country. The article examines the approaches and procedures for cyber defense in the United States, the practical basis for cyber defense, the direction of state policy on threats in cyberspace and analyzes the basic regulations governing various aspects of cybersecurity, both at the state level and on the level of protection individual citizens.

Key words: cyberspace, cyberdefence, legal regulation of cyberspace, cybersecurity, United States.

Питання правового регулювання кібербезпекових аспектів функціонування держави стає дедалі актуальнішим й обговорюваним у всіх країнах світу. Причина такої зацікавленості - розвиток інформаційних технологій і швидка популяризація мережі Інтернет, що викликало необхідність здійснення правового регулювання цієї сфери; крім того, практика показала, що мережа Інтернет використовується не лише для задоволення потреб людей у спілкуванні й обміні інформацією, а також може використовуватися зловмисниками для спричинення шкоди як приватним особам, так і корпораціям, так і державам. 3 огляду на це гостро постає питання вживання саме кібербезпекових заходів для захисту інформаційних мереж держави та її громадян.

Тому перед правниками постає питання, яким чином та у яких обсягах необхідно здійснювати нормативно-правове регулювання у кіберпросторі.

Для України ця сфера є відносно новою. Лише у 2017 p було прийнято закон України «Про основні засади забезпечення кібербезпеки України». Хоча цей закон і встанов- лює деякі основоположні засади щодо регулювання кібербезпеки та процесів, які відбуваються в кіберпросторі, водночас він отримав багато негативних відгуків у науковій спільноті через свою недосконалість і невизначеність термінологічного апарату. Таким чином, можна говорити про те, що в Україні процес розвитку нормативно-правової бази для регулювання процесів і відносин у кіберпросторі перебуває на початковій стадії. Можна також стверджувати, що розходяться й точки зору науковців у сфері інформаційного права щодо того, чи є кіберпростір окремим простором, який потребує регулювання, чи це просто ще один спосіб здійснення вже врегульованих взаємовідносин, як, наприклад, телефонія (тобто як ще один засіб обміну інформацією).

Метою цієї статті $є$ проведення аналізу нормативноправового регулювання відносин у кіберпросторі в одній із найбільш розвинених країн світу - Сполучених Штатах Америки.

Здійснення аналізу допоможе встановити, які саме сфери кіберпростору підлягають регулюванню та в який 
спосіб. Також у статті здійснено огляд органів, до компетенції яких належить забезпечення кібербезпеки у Сполучених Штатах Америки. Аналіз допоможе визначити, на які аспекти кібербезпекових питань варто звернути увагу під час здійснення національного нормативно-правового регулювання кібербезпекових питань.

Сполучені Штати Америки (далі - США) є однією 3 найбільш розвинутих країн світу як в економічному аспекті, так і у сфері розвитку збройних сил. Тому вважаємо за необхідне розглянути систему нормативно-правового регулювання здійснення кіберзахисту саме в цій державі.

Розробки науковців показують, що першість у забезпеченні інформаційної безпеки у світі належить США. Так, навіть Японія, яка вважається Меккою виробництва цифрової техніки та використання найсучасніших IT-технологій, відстає від США більше ніж на п'ять років у сфері розповсюдження персональних комп'ютерів, кабельного телебачення, цифрової телефонії та в інших аспектах інформаційної політики [1, с. 34].

Спершу розглянемо, що $\epsilon$ кібербезпекою в розумінні законодавства США. Кодекс Сполучених Штатів Америки, що є зведеною кодифікацією законодавства Сполучених Штатів Америки, у розділі 6 «Внутрішня безпека» визначає цілі забезпечення кіберзахисту: «Термін „мета кібербезпеки“ означає мету захисту інформаційної системи або інформації, яка зберігається, обробляється в цій системі або переходить через неї від кібербезпекових загроз або порушень безпеки» [2].

Тобто, можливо зробити висновок, що кібербезпека мереж означає їхню захищеність і захищеність інформації, що проходить або зберігається в цих мережах від порушень, таких як втручання в мережу й незаконний доступ до інформації, яка є в цій мережі. Цікавим та вартим уваги в цьому акті є термін «контроль безпеки», що визначений як «управління, експлуатаційний і технічний контроль, що використовуються для захисту від несанкціонованих втручань 3 метою негативного впливу на конфіденційність, цілісність і доступність інформаційної системи або iii інформації» [2].

Говорячи саме про інформаційну безпеку, складовою частиною якої $є$ кібербезпека, ми можемо стверджувати, що сьогодні законодавство США у сфері забезпечення інформаційної безпеки складається з федеральних законів і законів штатів, які створили правову основу для формування єдиної державної політики в галузі захисту інформації для забезпечення інтересів національної безпеки. Це насамперед такі закони: «Про інформаційну безпеку», «Про удосконалення інформаційної безпеки» (1997р.), «Про комп'ютерне шахрайство та зловживання» (1986р.), «Про свободу інформації» (1967р.), «Про висвітлення діяльності уряду», «Про охорону особистих таємниць», «Про таємницю» (1974 р.), «Про право на фінансову таємницю» (1978 р.), «Про доступ до інформації про діяльність ЦРУ» (1984 р.), «Про безпеку комп’ютерних систем» (1987 p.) [3].

Якщо розглядати практичний аспект здійснення кіберзахисту у США, то донедавна головним виконавчим суб' єктом кіберзахисту США був створений у червн 2003 р. на базі Агенції національної безпеки (National Security Agency, NSA) (далі - АНБ), але підпорядкований Міністерству внутрішньої безпеки (далі - МВБ) Центр комп'ютерної безпеки (National Computer Security Center, NCSC). Нині його реорганізовано в Національний центр кібербезпеки й інтеграції зв'язку (National Cybersecurity and Communication Integration Center, NCCIC) (далі NCCIC). До складу NCCIC входять Група екстреного реагування на комп'ютерні події в США (U. S. Computer Emergency Response Team, US-CERT) (далі - US-CERT), Група екстреного реагування на надзвичайні події в системах керування промисловістю (Industrial Control Systems
Cyber Emergency Response Team, ICS-CERT) (далі - ICSCERT) i Національний координаційний центр зв'язку (National Coordinating Center for Communications, NCC). US-CERT виявляє кібератаки на ITC цивільних федеральних органів влади США, попереджає про них адміністраторів безпеки ITC і координує дії 3 відновлення федеральних ITC після кіберінцидентів. Відповідно ICSCERT виявляє і запобігає здійсненню кібератаки на ITC критично-важливих об'єктів промисловості США. 16 листопада 2018 р. указом президента США Д. Трампа NCCIC передано до нового Агентства 3 кібербезпеки й безпеки інфраструктури МВБ США $[4,9]$.

Тобто у 2018 р. створено новий орган - CISA (Cybersecurity and Infrastructure Security Agency), який на сьогодні є основним, центральним органом, що координує питання здійснення кіберзахисту інформаційно-телекомунікаційної мережі у США. CISA розбудовує національний потенціал для захисту від кібератак і працює з федеральним урядом для надання інструментів кібербезпеки, служб реагування на інциденти й можливостей оцінки для захисту мереж “.gov”, які підтримують необхідні операції партнерських відомств й агентств.

CISA координує зусилля щодо безпеки та стійкості, використовуючи надійні партнерські відносини в приватному й державному секторах, i надає технічну допомогу й оцінку федеральним зацікавленим сторонам, а також власникам інфраструктури й операторам по всій країні [5].

Розглядаючи далі питання законодавчого забезпечення кібербезпеки, необхідно зазначити, що законодавство США у сфері зовнішньої інформаційної безпеки складається із сукупності федеральних законів, законів штатів і нормативних актів, які разом створюють правову основу для створення й здійснення державної політики у сфері інформаційної безпеки. Основні з них такі: «Національна стратегія захисту кіберпростору» (2003 р.), «Огляд з кібербезпеки» (Cyber Security Review, 2009 р.), «Ініціатива зі всеосяжної національної кібербезпеки» (2010р.), Стратегія кібербезпеки США (2011 р.), Закон CISPA (2012р.) (Cyber Intelliggence Sharring and Protection Act) [6].

У вересні 2018 р. у США була ухвалена Національна кіберстратегія (далі - Кіберстратегія). Основними завданнями цієї Кіберстратегії визначено:

- «захищати Батьківщину, захищаючи мережі, системи, функції та дані;

- сприяти процвітанню Америки шляхом розвитку безпечної, розвинутої цифрової економіки й сильних вітчизняних інновацій;

- зберегти мир і безпеку шляхом зміцнення спроможності США - узгоджено зі союзниками та партнерами для стримування та, за необхідності, покарання тих, хто використовує кіберінструменти в шкідливих цілях;

- розширити американський вплив за кордоном, щоб розширити основні принципи відкритої, сумісної роботи, надійний і безпечний Інтернет».

Також ця Кіберстратегія визначає, що: «Адміністрація (президента США - Д. Х.) визнає, що США беруть участь у постійній конкуренції проти стратегічних супротивників, шахрайських держав і терористичних і злочинних мереж. Росія, Китай, Іран і Північна Корея використовують кіберпростір як засіб кинути виклик США, їхнім союзникам і партнерам, часто з необачністю, яку вони не проявляють в інших областях (просторах). Ці противники використовують кіберінструменти, щоб підірвати нашу економіку й демократію, красти нашу інтелектуальну власність і сіяти розбрат у наших демократичних процесах» [7].

Також в огляді цієї Стратегії хотілося б звернути увагу на розділ «Визначення та встановлення неприйнятної поведінки в кіберпросторі». У цьому розділі зазначається: «Як США продовжують просувати консенсус щодо того, що становить відповідальну державну поведінку в кіберп- 
росторі, ми також повинні працювати щодо гарантування наявності наслідків для безвідповідальної поведінки, яка завдає шкоди США й нашим партнерам. Усі інструменти національної влади доступні для запобігання, реагування та стримування зловмисної кібердіяльності проти США. Сюди входять дипломатичні, інформаційні, військові (як кінетична, так і кібер), фінансова, розвідувальна, публічна атрибуція та правоохоронні можливості. Сполучені Штати офіційно оформлять і здійснюватимуть співпрацю з однодумцями для визначення та стримування шкідливої кібердіяльності з інтегрованими наслідками, які дають швидкі, дорогі й прозорі наслідки, коли зловмисники шкодять США чи нашим партнерам [7].

Таким чином, можливо зробити висновок, що у Сполучених Штатах Америки значна увага приділяється викликам, які виникають у кіберпросторі, та розгляду кіберпростору як нової та значущої площини ведення протистояння.

Водночас, говорячи про кіберпростір, ми можемо говорити про декілька видів порушень, які можуть у ньому відбуватися. Тобто кіберпросторові порушення передбачають не лише порушення інтересів держави у кіберпросторі, але й ряд інших порушень, які також завдають чималої шкоди.

У США $є$ окремі регулювання, що стосуються різних видів правопорушень у кіберпросторі. Федеральний акт 3 комп’ютерних крадіжок і зловживань № 1030 - це основний акт, що закріплює механізм розслідування кіберзлочинів і встановлює за них як кримінальні, так і цивільні покарання. Акт забороняє:

- неавторизований доступ до комп'ютерів й отримання національної секретної інформації;

- неавторизований доступ до комп'ютерів, які використовуються в торгівлі між штатами або з іншими країнами, та заволодіння інформацією з них;

- неавторизований доступ до непублічних комп'ютерів, які використовуються урядом Сполучених Штатів;

- зумисний доступ до захищених комп'ютерів без авторизації з наміром обману або отримання інформації, що на них міститься;

- знищення комп'ютера (з наміром або випадково);

- викрадення паролів;

- розповсюдження загроз вторгнення, а особливо загроз отримання інформації чи компрометування конфіденційності цієї інформації;

- кібервторгнення, пов'язане з бажанням заволодіти грошима чи власністю.

Залежно від специфіки конкретного вчиненого правопорушення покарання можуть варіюватися від одного до двадцяти років ув'язнення [8].

Іншим пов'язаним законом $є$ Акт щодо захисту електронних комунікацій (Elecronic Communications Protection Act), який захищає інформацію у сховищах та в разі іiї передавання. Відповідно до цього акту й розділу 17 Кодексу Сполучених Штатів параграф $20702 €$ кримінальним порушенням навмисний доступ без авторизації чи в обхід авторизаційного доступу до потужностей, які надають сервіс електронної комунікації, що можуть включати, крім іншого, провайдерів імейл-сервісів чи навіть роботодавців, які надають імейл-адресу своїм робітникам. Водночас персональні комп'ютери не належать до потужностей, які надають сервіс електронної комунікації. Ці порушення є предметом покарань, які варіюються від одного року за вперше здійснене таке порушення без невиправданої (злочинної) цілі (також порушення, які вчиняються не 3 комерційною метою або щоб спричинити знищення інформації) і до 10 років за повторне порушення або здійснення 3 невиправданою (злочинною) метою [8].

Також необхідно зазначити, що законодавство США має окремі нормативні акти, що регулюють такі правопорушення, як хакерство (мається на увазі неавторизований доступ). Відповідно до цих актів покарання можуть бути до десяти років за доступ до національної секретної інформації або, наприклад, лише до одного року ув'язнення за просте отримання інформації, або до п’яти років, якщо є обтяжувальні фактори.

Наступним видом правопорушення $€$ здійснення DOS-атаки, тобто атаки з метою відмови роботи сервісів. В залежності від того, які настають наслідки та яка нанесена шкода, термін ув'язнення може бути аж до десяти років. Ще одним видом правопорушення $є$ фішинг. За різними законодавчими актами потенційний вирок може бути до двадцяти років ув'язнення.

Правопорушенням також $є$ зараження комп'ютерної системи шкідливим програмним забезпеченням, наприклад таким, як шпигунські програми - так звані Троянпрограми й віруси. Такі дії також (відповідно до нормативно-правових актів США) можуть бути віднесені до злочину, але з урахуванням того, що порушення має бути здійснено навмисно й заподіяно шкоду. Покарання може бути до десяти років ув'язнення.

Ще одним видом порушення є використання програмного забезпечення чи інших інструментів для вчинення кіберзлочинів. Але необхідно зазначити, що виявлення таких злочинів $є$ достатньо складним і їх важко розслідувати, але якщо буде встановлено саме злочинний намір, таке порушення також може бути віднесено до кримінального злочину.[8]

Наступним злочином є викрадення особистості або обман особистості. Але такий злочин має бути пов'язаним із доступом до пристроїв. Такий злочин може підпадати під дію федерального законодавства, а також і під велику кількість законів різних штатів і теж буде вважатися кримінальним злочином.

Також необхідно звернути увагу на злочин, який в Україні не $\epsilon$ достатньо розповсюдженим. Це електронна крадіжка, тобто порушення безпеки чинного або колишнього працівника або кримінальне порушення прав інтелектуальної власності, тобто прав копірайту. Відповідно до деяких умов і законодавчих актів це правопорушення може також містити складові частини крадіжки інтелектуальної власності та комерційних секретів відповідно до законодавства США. Правопорушення буде вважатися злочином якщо, по-перше, доступ до мережі було здійснено без відповідної авторизації, а по-друге, торгові секрети були надані 3 користю для іноземного уряду, а також якщо така крадіжка може спричинити економічні вигоди для інших або вона несе шкоду ринку, на якому здійснено крадіжку [8].

Таким чином, із проведеного аналізу ми можемо зробити висновок, що законодавство сполучених Штатів Америки є достатньо розгалуженим й об'ємним у питаннях здійснення кіберзахисту й забезпечення кібербезпеки.

Загальним рівнем $є$ федеральний рівень законодавства й політика США у цьому питанні. Тут ми можемо зробити висновок, що на федеральному рівні закладено важливість питання забезпечення кібербезпеки як усієї держави, так і їі установ і громадян та виражено позицію нетерпимості щодо порушення кібернетичної незалежності США та їхніх партнерів і рішучість щодо здійснення протистоянні у цьому полі. До цього питання належить і здійснення кібероборони держави. I, як ми можемо пересвідчитися 3 проведеного аналізу, у США створено потужну систему державних органів, що забезпечують кібербезпеку держави й протистоять викликам у кіберпросторі.

Наступним $є$ рівень регулювання діяльності в кіберпросторі на федеральному рівні та рівні штатів. У цьому випадку окремі правопорушення віднесено до злочинів на рівні всієї держави, що врегульовано Кодексом США та відповідними Актами, як діють по всій території США. Третім рівнем $\epsilon$ регулювання на рівні кожного окремого 
штату. Але проведений аналіз норм показав, що майже неможливо знайти правопорушення, які віднесені до злочинів лише у певних штатах.

Таким чином, ми можемо зробити висновок, що законодавство Сполучених Штатів Америки $є$ розвиненим і врегульовує значну кількість правопорушень, які можуть виникати в кіберпросторі. Основне регулювання здійснено на рівні всієї держави. Також чітко вбачається розмежування різних видів правопорушень, які стосуються забезпечення кібербезпеки всієї держави, і великої кількості правопорушень, які стосуються безпеки громадян у кіберпросторі.

\section{ЛITEPATУРA}

1. Брижко В. До питання сучасної інформаційної політики. Вісник Академії управління Міністерства внутрішніх справ. 2009. № 2. C. $32-36$.

2. Кодекс Сполучених Штатів Америки (U. S. Code) URL: https://www.law.cornell.edu/uscode/text/6/1501.

3. Бусол О. Інформаційна безпека США: законодавче регулювання та перспективи співпраці для України / вебсайт Центру досліджень соціальних комунікацій НБУВ. URL: http://nbuviap.gov.ua/index.php?option=com_content\&view=article\&id=2988:informatsijnabezpeka-ssha-zakonodavche-regulyuvannya-ta-perspektivi-spivpratsi-dlya-ukrajini\&catid=8\&ltemid $=350$.

4. Корченко О., Логінов І., Скворцов С. Стаціонарні системи виявлення і

попередження кібератак в інтересах кіберзахисту та кіберконтррозвідки (на прикладі США). Безпека інфоормації. 2019, Т. 25. Вип. 1, С. 5-12. URL: http://jrnl.nau.edu.ua/index.php/Infosecurity.

5. Official website of the Department of Homeland Security URL:https://www.cisa.gov/about-cisa.

6. Ничипорчук Н., Вознюк Є. Секрет успіху США у сфері інформаційної безпеки. Міжнародні відносини, суспільні комунікації та регіональні студіï. 2018. № 1. С. 66-71. URL: http://nbuv.gov.ua/UJRN/mvckrc_2018_1_13.

7. National Cyber Strategy of the United States of America / офріційний вебсайт Білого дому Сполучених Штатів Америки. URL: https://www.whitehouse.gov/wp-content/uploads/2018/09/National-Cyber-Strategy.pdf.

8. The International comparative Legal Guides and the International Bussiness reports / вебсайт Global Legal Group URL: https:/iclg.com/ practice-areas/cybersecurity-laws-and-regulations/usa. 


\title{
ПУБЛІЧНА БЕЗПЕКА Й ПОРЯДОК В УМОВАХ КАРАНТИНУ
}

\section{PUBLIC SECURITY AND PROCEDURE UNDER QUARANTINE}

\author{
Швець О.М., к.ю.н., \\ старший викладач кафедри правових природоохоронних дисциплін \\ Національний університет водного господарства та природокористування
}

Стаття присвячена визначенню місця порушення вимог карантину в системі правопорушень, що пов'язані з публічною безпекою й охороною порядку.

Підкреслено, що особливо гостро потреба охорони публічного порядку виникає в особливих умовах, зокрема в умовах карантину, запровадження якого зумовлене поширенням небезпечної інфекції під назвою COVID-19.

На основі аналізу вивченості проблеми забезпечення публічної безпеки та порядку було зроблено висновок, що зазначена проблема $€$ малодослідженою та недостатньо науково обґрунтованою, що підкреслило актуальність проведених досліджень. Наукові дослідження проблеми забезпечення публічної безпеки та порядку в умовах карантину свідчать про наявність проблем у цій сфері.

Установлено, що охорона здоров'я громадян є пріоритетним напрямом діяльності суспільства й держави, одним із головних чинни ків виживання й розвитку народу України. Відтак запровадження карантину є вимушеним заходом уряду, спрямованим на збереження здоров'я громадян країни. Визначено фактори, що обумовлюють стан здоров'я людини.

Розглянуто вимоги карантину, що введений з метою запобігання поширенню небезпечної інфекції COVID-19. Доведено, що обмеження прав громадян в умовах карантину є необхідним для забезпечення стану захищеності життєво важливих як для окремих громадян, так і для всього суспільства інтересів від впливу небезпечної загрози, отже карантинні заходи не можна вважати такими, що порушують конституційні права громадян.

Визначено фрактори соціального незадоволення, які можуть стати передумовами порушення публічної безпеки в умовах карантину.

Установлено основні ознаки стану «публічна безпека та порядок». Доведено, що порушення правил карантину, які встановлені нормативно-правовими актами, можна вважати порушеннями публічної безпеки та порядку.

Визначено основні причини порушення публічної безпеки та порядку в умовах карантину й розроблено рекомендації щодо посилення дії правових вимог, які врегульовують дотримання громадянами умов карантину.

Ключові слова: публічна безпека, публічний порядок, карантин, здоров'я громадян, порушення.

The article is devoted to determining the place of violation of quarantine requirements in the system of offenses related to public safety and law enforcement. It is emphasized that the need for protection of public order arises especially in special conditions, in particular the conditions of quarantine, the introduction of which is due to the spread of a dangerous infection called COVID-19.

Based on the analysis of the study of the problem of public safety and order, it was concluded that this problem is poorly studied and insufficiently scientifically substantiated, which emphasized the relevance of the research. Scientific research on the problem of ensuring public safety and order in quarantine conditions indicates the presence of problems with its provision.

It is established that public health is a priority of society and the state, one of the main factors of survival and development of the people of Ukraine. Therefore, the introduction of quarantine is a forced measure of the Government of the country, aimed at maintaining the health of citizens in society. The factors that determine the state of human health have been identified.

The requirements of quarantine imposed to prevent dangerous infection with COVID-19 are considered. It has been proved that restricting the rights of citizens in quarantine is a necessary measure to ensure the protection of vital interests for both individuals and society as a whole from the impact of a dangerous threat, and they can not be considered violating the constitutional rights of citizens.

Factors of social dissatisfaction which can become preconditions of infringement of public safety in the conditions of quarantine are defined. The main features of the state of "public safety and order" have been established. It is proved that violations of quarantine rules, which are established by regulations, can be considered violations of public safety and order.

The main reasons for the violation of public safety and order in the conditions of quarantine are determined and recommendations for strengthening the legal requirements governing the observance of quarantine conditions by citizens are developed.

Key words: public safety, public order, quarantine, public health, violations.

Якість життя громадянина в суспільстві значною мірою обумовлена відчуттям захищеності, яке передбачає безпечність життя та здоров'я, гарантію права власності, можливість реалізації своїх громадянських прав й особистих інтересів. Як відомо, суспільне життя впорядковується сукупністю нормативно-правових актів, які врегульовують усі його сфери. Проте в окремих випадках трапляється так, що встановлені законами норми певними особами (групами осіб) порушуються, що часто призводить до порушення прав і свобод інших осіб або й ставить під загрозу публічну безпеку частини суспільства. Відповідно основою забезпечення публічного порядку $\epsilon$ врегулювання поведінки громадян в соціумі та роботи правоохоронних органів щодо запобігання й припинення порушень установлених нормами права правил. Своєю чергою ефективність забезпечення публічного порядку, на нашу думку, напряму залежить від наявності чітких і дієвих нормативно-правових актів.

Найбільш гостро потреба охорони публічного порядку виникає в особливих умовах, коли звичне життя суспільства порушується внаслідок виникнення складних природних чи техногенних обставин. До таких обставин, зокрема, можна віднести поширення небезпечної інфекції під назвою COVID-19. Таке поширення інфекційної хвороби, яка значною мірою впливає на життя громадян, у тому числі й на їхню публічну безпеку, є для нашого суспільства відносно новим явищем. Отже, можна припустити, що воно є мало дослідженим і слабо врегульованим законодавчими актами й потребує додаткового обгрунтування правил публічної поведінки.

Той факт, що наукові дослідження явища публічної безпеки й порядку в умовах карантину мали й мають місце в наукових колах, не викликає сумніву. Проте, враховуючи відносно невелику тривалість карантину, опублікованих результатів таких досліджень $є$ небагато. Зокрема, варто відзначити, що науково-педагогічним колективом Дніпропетровського державного університету внутрішніх справ у складі А. Фоменка, К. Бахчева, О. Бочкового, В. Покайчука та В. Поливанюка було досліджено роботу правоохоронців щодо забезпечення публічної безпеки та порядку, виявлено іiі недоліки, які в основному були пов'язані 3 недотриманням процедури оформлення протоколів про адміністративні правопорушення, і розроблено детальні пам'ятки курсанту й поліцейському «із забезпечення 
публічної безпеки й охорони правопорядку під час карантину» [1], що значно полегшило роботу правоохоронців в умовах карантину.

Науковці Харківського національного університету внутрішніх справ (О. Сердюк, В. Марков, О. Рвачов та інші) провели дослідження «Публічна безпека та довіра до правоохоронних органів», результатом якого стало виявлення тих проблем у сфері захисту правопорядку, які турбують населення найбільше, а також визначення небезпек, які можуть загрожувати громадянам в умовах карантину. Особливу увагу згадані науковці приділили ряду проблем, пов'язаних з інтернет-простором, недоторканністю приватного життя в кіберпросторі, а також розповсюдженню неправдивої інформації та шахрайству [2].

Правові, інформаційні та психологічні аспекти карантинних заходів обговорили також науковці Сумського державного університету (М. Назаров, Н. Теслик та інші) за участі Регіонального центру 3 надання безоплатної вторинної правової допомоги (БВПД) у Сумській області (директор В. Волобуєва). У ході дискусії науковцями було наголошено, що обмеження конституційних прав громадян в умовах карантину є вимушеним кроком, який спрямований на охорону здорового життя громадян. Також було приділено увагу питанням державної інформаційної політики, комунікації влади та громадськості й психологічній адаптації в умовах карантину [3].

Варто також зазначити, що в наукових і правових колах відбувається дискусія стосовно того, що встановлені підзаконними нормативними актами правила життя в карантині порушують конституційні права та свободи громадян $[4,5,6,7,8$ та інші].

У результаті аналізу розглянутих вище та інших публікацій можна зробити висновок: проблема забезпечення публічної безпеки й порядку має місце в сучасних реаліях суспільного життя, є мало дослідженою та недостатньо науково обгрунтованою. У зв'язку з цим актуальність дослідження зазначеної проблеми є беззаперечною. Таким чином, ми ставимо перед собою завдання дослідити передумови порушення публічної безпеки й порядку, визначити місце порушення вимог карантину в системі правопорушень, що пов'язані з публічною безпекою та охороною порядку, і встановити основні причини їх вчинення з метою розроблення пропозицій щодо вдосконалення системи забезпечення публічної безпеки та порядку.

Виходячи 3 аналізу конституційних прав громадян та їхніх державних гарантій, можна стверджувати, що кожен громадянин має право на безпечні для життя та здоров'я умови проживання, які повинні забезпечуватися на державному рівні. Зокрема, відповідно до ст. 49 Конституції України кожен громадянин має право на охорону здоров'я [9]. Держава своєю чергою в ст. 4 Закону України «Основи законодавства України про охорону здоров' я» від 19 листопада 1992 р. № 2801-XII визнає охорону здоров’я громадян пріоритетним напрямом діяльності суспільства й держави, одним із головних чинників виживання й розвитку народу України [10]. У ст. 3 цього Закону надається поняття «здоров'я», яке законодавець визначає як «стан повного фізичного, психічного й соціального благополуччя, а не лише відсутність хвороб і фізичних вад» [10] Стан здоров'я людини обумовлюється значною кількістю факторів, до яких можна віднести:

- спадковість;

соціальну свідомість;

- здоровий спосіб життя;

- соціальний рівень життя;

- безпечність навколишнього середовища, в якому проживає особа;

- рівень охорони здоров'я в державі та доступність медичних послуг тощо.
Значною мірою, на нашу думку, збереження здоров'я громадян у суспільстві обумовлюється дотриманням гарантованих державою заходів щодо захисту здоров'я громадян і забезпеченням їхнього соціального благополуччя, а відтак і підтриманням публічної безпеки та порядку.

Велику загрозу здоров'ю громадян і розвитку суспільства несе поширення гострої респіраторної хвороби COVID-19, спричиненої коронавірусом SARS-CoV-2, яка ст. 1 Закону України «Про захист населення від інфекційних хвороб» від 6 квітня 2004 р. № 1645-III віднесена до особливо небезпечних інфекційних хвороб, «що характеризуються важкими та (або) стійкими розладами здоров'я в значної кількості хворих, високим рівнем смертності, швидким поширенням цих хвороб серед населення» [11]. Як відомо, випадки появи на території України коронавіpycy SARS-CoV-2 офіційно зареєстровані в березні 2020 p. Враховуючи світовий досвід поширення зазначеної інфекції та досвід боротьби 3 нею, уряд України 11 березня 2020 р. прийняв Постанову № 211 «Про запобігання поширенню на території України гострої респіраторної хвороби COVID-19, спричиненої коронавірусом SARSCoV-2», яка, перш за все, стала нормативною засадою введення на всій території України карантину й визначила обов'язки органів державної влади й місцевого самоврядування щодо забезпечення карантинних вимог. Зокрема на Міністерство внутрішніх справ і Національну поліцію зазначеною Постановою було покладено обов'язок вжити заходів, спрямованих на іії виконання [12]. Перша редакція згаданої Постанови уряду передбачала введення карантину до 3 квітня 2020 р., проте у зв'язку зі значним поширенням COVID-19 карантин було продовжено й посилено.

3 уведенням карантину права та свободи громадян в Україні вимушено були значно обмежені. Відтак під забороною опинилося відвідування закладів освіти її здобувачами, проведення всіх масових (культурних, розважальних, спортивних, соціальних, релігійних, рекламних та інших) заходів, у яких бере участь понад 10 осіб, робота закладів громадського харчування (ресторанів, кафе тощо), торговельно-розважальних центрів, фітнес-центрів, закладів культури, торговельного й побутового обслуговування населення, регулярні та нерегулярні перевезення пасажирів автомобільним і залізничним транспортом, метрополітенами міст Києва, Харкова й Дніпра. Окрім того, значно обмежився доступ населення до медичних закладів для отримання консультацій і лікування, крім невідкладних станів. Також було обмежено перебування людей в громадських місцях, введено соціальне дистанціювання й обов'язкове носіння захисних медичних масок. Пізніше посиленням карантинних заходів влада заборонила відвідувати парки й лісові зони, користуватися спортивними та дитячими майданчиками. Наприкінці травня, коли стало зрозуміло, що небезпечна інфекція в Україні ще триватиме довго, уряд продовжив карантин, проте передбачив деякі моменти його послаблення (Постанова Кабінету Міністрів України від 20 травня 2020 р. № 392 «Про встановлення карантину з метою запобігання поширенню на теритоpiї України гострої респіраторної хвороби COVID-19, спричиненої коронавірусом SARS-CoV-2, та етапів послаблення протиепідемічних заходів») [13].

На перший погляд, перераховані обмеження видаються такими, що порушують конституційні права громадянина. Це, зокрема, право вільного пересування, право на освіту, право мирно збиратися для проведення мітингів, право на працю тощо. Проте, варто зазначити, що розглянуті обмеження визначені офіційними постановами уряду. Тому відповідно до Загальної декларації прав людини (ст. 29) їх можна трактувати як «встановлені законом виключно 3 метою забезпечення громадського порядку й загального добробуту в демократичному суспільстві» [14]. Адже, запобігання розвитку небезпечної хвороби передбачає 
збереження таких цінностей, як життя та здоров'я громадян, а також створення сприятливіших умов для лікування хворих на COVID-19 шляхом уповільнення росту захворюваності, що своєю чергою зменшує навантаження на медичну систему. Важливо розуміти, що дотримання встановлених урядом карантинних правил $є$ необхідним заходом забезпечення стану захищеності як окремих громадян, так і всього суспільства від впливу загроз (у цьому випадку - від загрози інфікування коронавірусом), що відповідно до Закону України «Про національну безпеку України» від 21 червня 2018 р. №.2469-VIII визначається як громадська безпека й порядок [15]. Проте накладені карантином обмеження все-таки зумовили виникнення ряду факторів соціального незадоволення, які можуть стати передумовами порушення публічної безпеки:

1) вимушена зупинка робочих процесів великої кількості закладів зумовила скорочення доходів громадян, їхні вимушені відпустки тощо;

2) зупинення навчального процесу в закладах середньої освіти викликала потребу забезпечення батьками можливості дистанційного навчання дітей і більшої затрати часу по догляду за ними;

3) закриття закладів дошкільної освіти призвело до постійного перебування дітей молодшого віку вдома, що викликало потребу в батьків відмовитися від роботи або значно ускладнило їхню дистанційну працю;

4) необхідність соціального дистанціювання та відсутність транспортного сполучення внеможливила догляд за немічними родичами, які проживають окремо;

5) відсутність можливості відпочинку, розваг і спілкування викликала погіршення душевного стану.

Розвиток розглянутих факторів призвів до емоційної напруги в суспільстві, внаслідок чого почастішали випадки порушення правил карантину, що, на нашу думку, ставить під загрозу публічну безпеку суспільства. Отже, виникає запитання: чи відносить законодавство України порушення карантинного режиму до переліку порушень публічної безпеки та порядку?

Аналіз гл. 14 Кодексу України про адміністративні правопорушення (далі - КУпАП), яка визначає адміністративні правопорушення, що посягають на громадський порядок і громадську безпеку, свідчить про те, що порушення вимог карантину безпосередньо не належить до порушень публічної безпеки та порядку. Лише ст. $173^{1}$ КУПАП, яка передбачає адміністративну відповідальність за поширення неправдивих чуток, що можуть спричинити паніку серед населення, можна віднести до законодавчого означення одного 3 порушень публічної безпеки й порядку, що $є$ досить поширеним в умовах карантину. Водночас КУпАП у березні 2020 р. було доповнено ст. $44^{3}$, яка визначає покарання за порушення карантину людей, санітарно-гігієнічних і санітарно-епідеміологічних правил і норм. Загалом же можна відзначити, що відповідно до ст. 9 КУпАП «адміністративним правопорушенням визнається протиправна, винна (умисна або необережна) дія чи бездіяльність, яка посягає на громадський порядок, права й свободи громадян, i за яку законом передбачено адміністративну відповідальність» [16].

Для розуміння ситуації, яку можна вважати порушенням публічної безпеки та порядку, варто визначитися зі змістом поняття «публічна безпека та порядок». Варто зазначити, що розглянуте поняття є відносно новим у правовому полі Україні. Його чітке трактування нормативноправовими актами відсутнє. Забезпечення публічної безпеки та порядку, відповідно до ст. ст. 1 та 2 Закону України «Про Національну поліцію» від 2 липня 2015 р. № 580VIII є основним завданням Національної поліції в Україні. Доцільно зазначити, що стосовно поняття «публічна безпека та порядок» у зазначеному законі вживається термін «громадська безпека й порядок» як його складова частина (ч. 27 ст. 23, ч. 1 ст. 40) [17]. Згаданий нами КУПАП теж не містить поняття «публічна безпека та порядок», натомість у ньому та в Кримінальному кодексі України, інших нормативно-правових актах вживається термін «громадська безпека і порядок». Якщо вважати, що розглянуті поняття $€$ ідентичними за своїм змістом, то останнє 3 них можна визначити із Закону України «Про національну безпеку України» від 21 червня 2018 р. № 2469-VIII як «захищеність життєво важливих для суспільства та особи інтересів, прав і свобод людини й громадянина, забезпечення яких є пріоритетним завданням діяльності сил безпеки, інших державних органів, органів місцевого самоврядування, їхніх посадових осіб і громадськості, які здійснюють узгоджені заходи щодо реалізації й захисту національних інтересів від впливу загроз» [15].

Дослідженням понять «публічна безпека та порядок», а також «громадська безпека й порядок» у наукових колах займалося досить багато вчених. Окремі їхні аспекти вивчали В. Авер'янов, О. Бандурка, О. Батраченко, І. Голосніченко, О. Довгань, Є. Додін, М. Ковалів, В. Колпаков, А. Комзюк, В. Маліков, Р. Мельник, Ю. Небеський, О. Остапенко, М. Панов, А. Подоляка, С. Пономарьов, Ю. Римаренко, С. Сьомін, В. Тихий, В. Фатхутдінов та інші.

Загалом дослідження значення поняття «публічна безпека та порядок» вітчизняними науковцями зводиться до аналізу етимології термінів «безпека», «порядок», «публічність».

Наприклад, С. Пономарьов вважає, що «публічна безпека характеризується термінами «громадська безпека» й «громадський порядок» Усі вони «позначають сферу суспільних відносин, які виникають у процесі забезпечення правопорядку, але публічна безпека має більш широкий зміст, ніж громадська безпека чи громадський порядок» [18]. М. Панов і В. Тихий у своїй праці зазначають, що «суспільна безпека, відбиваючись у суспільній свідомості, створює певний суспільний настрій і формує масові й індивідуальні стереотипи, що характеризуються відчуттям захищеності інтересів, охоронюваних правом, наявністю почуття безпеки щодо різного роду загроз, а також відсутністю страху перед ними» [19]. Зазначені вчені стверджують, що «суспільна безпека створює атмосферу суспільного спокою, обстановку, в якій людина може не боятися загроз» [19].

Підсумовуючи аналіз іноземного досвіду концептуальних підходів щодо забезпечення громадської безпеки, С. Сьомін розглядає громадську безпеку «як наявний в державі рівень протидії загрозам різноманітного характеру нормальному стану життєдіяльності останньої, а також ступінь захищеності людини й суспільства» [20]. С. Сьомін також зазначає, що до загроз громадській безпеці в розвинених правових системах європейських країн «відносять не лише протиправні посягання, але й інші загрози, зокрема природні, техногенні, соціокультурн тощо». При цьому «заходи з забезпечення громадської безпеки повинні мати насамперед упереджувальний характер з метою недопущення протиправних дій, соціальних збурень і катастроф природного й техногенного характеру» [20]. Варто також відзначити, що в більшості європейських правових систем, судячи 3 дослідження С. Сьоміна, поняття публічної безпеки законодавством не визначається 3 метою недопущення обмеженості дій правоохоронних органів у кожній конкретній ситуації. Отже, на основі аналізу нормативно-правових актів і наукових досліджень вважаємо необхідним визначити основні ознаки стану «публічна безпека та порядок»:

1) захищеність життєво важливих для суспільства й особи інтересів (зокрема здоров'я);

2) наявність почуття безпеки й суспільного спокою щодо різного роду загроз (в тому числі й природного, у нашому випадку вірусного, характеру), а також відсутність страху перед ними; 
3) державний характер забезпечення запобігання порушенням публічної безпеки та порядку.

Таким чином, дії, які створюють небезпеку для інших осіб, особливо вчинені в публічних місцях, можна вважати порушенням публічної безпеки та порядку. Наприклад, відсутність захисної маски (носіння якої вимагають норми карантину) в потенційно хворої на COVID-19 людини (якою можна вважати кожного громадянина в умовах епідемії цієї хвороби) створює небезпеку для здоров'я інших людей, тим самим порушуючи їхні права. Особливо небезпечний прояв така дія має в публічному місці за умови присутності значної кількості людей, оскільки в цьому випадку, окрім масового поширення хвороби, може мати місце масове занепокоєння громадян, що своєю чергою може призвести до виникнення хуліганських та інших протиправних дій. Значно підсилити прояв порушення публічної безпеки та порядку можуть фактори соціального незадоволення, які розглядалися нами раніше.

Отже, виходячи 3 нормативного й наукового трактування поняття «публічна безпека та порядок», на нашу думку, порушення правил карантину, що встановлені нормативно-правовими актами, можна вважати порушеннями публічної безпеки й порядку. До основних причин порушення публічної безпеки й порядку в умовах карантину, на нашу думку, можна віднести:

- відсутність чіткого нормативно-правового визначення умов карантину;
- відсутність детально визначених видів порушень карантинних вимог і відповідної відповідальності;

- недостатність інформаційно-просвітницької роботи з громадянами;

- недостатнє застосування покарань за вчинення протиправних дій, що пов'язані з порушенням умов карантину;

- низька правова обізнаність, соціальна відповідальність і моральний рівень громадян;

- соціальне незадоволення громадян умовами життя в карантині.

3 метою посилення дії правових вимог щодо дотримання громадянами умов карантину, на нашу думку, необхідно:

1) у Конституції України передбачити законність обмеження певних прав і свобод громадян в умовах карантину;

2) детально прописати нормативно-правовими актами сутність карантину та в кожному конкретному випадку детально визначати правила поведінки громадян;

3) посилити роботу органів публічної влади, в тому числі правоохоронних, щодо підвищення рівня юридичної обізнаності, суспільної свідомості та морального стану суспільства;

4) оптимізувати роботу системи охорони здоров'я, покращити іiі матеріально-технічне забезпечення й доступність для громадян, що сприятиме суспільному спокою.

\section{ЛITEPATYPA}

1. Пам'ятка поліцейському із забезпечення публічної безпеки під час карантину. URL: https://dduvs.in.ua/pamyatka/.

2. Безпека та кібербезпека під час карантину. URL: http://univd.edu.ua/uk/news/6946.

3. У СумДУ обговорили правові, інформаційні та психологічні аспекти карантинних заходів. URL: https://news.sumdu.edu.ua/uk/ news/11437-u-sumdu-obgovorili-pravovi-informatsijni-ta-psikhologichni-aspekti-karantinnikh-zakhodiv.html.

4. Карантин в Україні: чи суперечать нові заборони Конституції. URL: https://www.bbc.com/ukrainian/features-52186556.

5. Коваленко С. Карантин: межі дозволеного. URL: https://pravo.ua/karantin-mezhi-dozvolenogo/.

6. Н. Токар Чи порушує карантин права людей? Пояснення юриста. URL: https://tokar.ua/read/41185.

7. Карантинні обмеження суперечать Конституції- ЦППР. URL: https://lexinform.com.ua/v-ukraini/karantynni-obmezhennya-superechatkonstytutsiyi-tsppr/.

8. Covid-19: роз'яснення Омбудсмена щодо свободи пересування в умовах карантину. URL: http://www.visnuk.com.ua/uk/ news/100017252-covid-19-rozyasnennya-ombudsmana-schodo-svobodi-peresuvannya-v-umovakh-karantinu.

9. Конституція України : Закон України від 28 червня 1996 р. № 254к/96- / Верховна Рада. URL: https://zakon.rada.gov.ua/laws/ show/254\%D0\%BA/96-\%D0\%B2\%D1\%80\#Text.

10. Основи законодавства України про охорону здоров'я : Закон України від 19 листопада 1992 р. № 2801-XII. URL: https://zakon.rada. gov.ua/laws/show/2801-12\#Text.

11. Про захист населення від інфекційних хвороб : Закон України від 6 квітня 2004 р. № 1645-III. URL: https://zakon.rada.gov.ua/laws/ show/1645-14\#Text.

12. Про запобігання поширенню на території України гострої респіраторної хвороби COVID-19, спричиненої коронавірусом SARS-CoV-2 : Постанова Кабінету Міністрів України від 11 березня 2020 р. № 211. URL: https://zakon.rada.gov.ua/laws/show/215-2020$\% \mathrm{D} 0 \% \mathrm{BFHn} 9$

13. Про встановлення карантину з метою запобігання поширенню на території України гострої респіраторної Xвороби COVID-19, спричиненої коронавірусом SARS-CoV-2, та етапів послаблення протиепідемічних заходів : Постанова Кабінету Міністрів України від 20 травня 2020 р. № 392. URL: https://www.kmu.gov.ua/npas/pro-vstanovlennya-karantinu-z-metoyu-zapobigannya-poshirennyu-na-teritoriyiukrayini-gostroyi-respiratornoyi-hvorobi-covid-19-sprichinenoyi-koronavirusom-sars-cov-i200520-392.

14. Загальна декларація прав людини : прийнята і проголошена резолюцією 217 A (III) Генеральної Асамблеї ООН від 10 грудня 1948 p. URL: https://zakon.rada.gov.ua/laws/show/995_015\#Text.

15. Про національну безпеку України : Закон України від 21 червня 2018 р. №.2469-VIII. URL: https://zakon.rada.gov.ua/laws/ show/2469-19\#Text.

16. Кодекс України про адміністративні правопорушення : Закон України від 7 грудня 1984 р. № 8073-X. URL: https://zakon.rada.gov.ua/ laws/show/80732-10\#Text.

17. Про Національну поліцію : Закон України від 2 липня 2015 р. № 580-VIII. URL: https://zakon.rada.gov.ua/laws/show/580-19?find=1\& text=\%D0\%B3\%D1\%80\%D0\%BE\%D0\%BC\%D0\%B0\%D0\%B4\%D1\%81\%D1\%8C\%D0\%BA\%D0\%BE\%D1\%97\#w1_1.

18. Пономарьов C.В. Поняття та зміст публічної безпеки в системі сектору безпеки і оборони. Право.иа. 2017. № 2. C. 112.

19. Панов М.І., Тихий В.П. Безпека як фундаментальна категорія в методології правознавства (до постановки проблеми). Вісник Академії правових наук. 2000. № 3 (22). C. 13. URL: http://dspace.nlu.edu.ua/handle/123456789/4814.

20. Концептуальні підходи щодо забезпечення громадської безпеки: іноземний досвід, висновки для України. URL: http://old2.niss.gov.ua/content/articles/files/1_Siomin-8f832.pdf. 


\title{
CONTEMPORARY TREND TO E-ADMINISTRATION AND MODERNIZATION OF UKRAINIAN DRAFT LAW ON ADMINISTRATIVE PROCEDURE
}

\section{СУЧАСНА ТЕНДЕНЦІЯ ДО ЕЛЕКТРОННОГО АДМІНІСТРУВАННЯ ТА МОДЕРНІЗАЦІЯ УКРАЇНСЬКОГО ЗАКОНОПРОЕКТУ ПРО АДМІНІСТРАТИВНУ ПРОЦЕДУРУ}

\author{
Shkolyk A.M., Docent at the Department of Administrative and Financial Law \\ Ivan Franko National University of Lviv
}

The paper highlights the current global trend of transformation of classical public administration into e-administration, as well as the influence of this tendency on the legal regulation of administrative procedure. The purpose of the article is to define provisions of general acts on administrative procedure, which are expedient to revise, amend or supplement for the full implementation of the idea of e-administration in administrative legislation and relevant practice.

The study outlines the criteria for assessing the level of the transition of administrative bodies to e-administration, as well as the principles that should be followed when implementing them into administrative practice. Besides, several updated provisions of the Spanish general act on administrative procedures are analyzed which maximize the use of electronic means in public administration.

The overview of the current Ukrainian laws regulating public administration as well the latest version of the draft law on administrative procedure (2020) confirms the existence of the tendency to e-administration in the newest acts of national legislation. At the same time, work on updating of the Ukrainian draft law on administrative procedure shall be continued, taking into consideration modern standards in e-administration. Specific articles in the mentioned draft law that should be supplemented by administrative procedural norms, which will further bring its content closer to modern requirements of e-administration, are named in the study.

The purpose of this update is to increase the efficiency of public administration through the priority implementation of information and communication technologies and to simplify administrative procedures for individuals, primarily in terms of reducing the resources needed and the time spent interacting with administrative bodies. A final version of Ukrainian law (code) "On administrative procedure" will hopefully be more updated in the context and subsequently in less need for further amendments.

Key words: general act on administrative procedure, public administration, information and communication technologies, digitalization, electronic means, improvement of the draft law.

Висвітлено сучасну глобальну тенденцію трансформації класичного публічного адміністрування в електронне адміністрування, а також вплив цієї тенденції на правове регулювання адміністративної процедури. Метою статті є визначення положень загальних актів про адміністративну процедуру, які доцільно переглянути, змінити або доповнити за повноцінної реалізації ідеї електронного адміністрування в адміністративному законодавстві та відповідної практики

Названо критерії, за якими оцінюється рівень переходу адміністративних органів до електронного адміністрування, а також принципи, якими необхідно керуватися під час його впровадження в адміністративну практику. Проаналізовано ряд оновлених положень іспанського законодавства, спрямованих на максимальне застосування електронних засобів комунікації.

Огляд чинних законів України, що регулюють публічне адміністрування, а також останнього варіанту проєкту Закону «Про адміністративну процедуру» підтверджує наявність тенденції до електронного адміністрування в найновіших актах національного законодавства. Поряд із цим роботу над удосконаленням українського законопроєкту про адміністративну процедуру повинно бути продовжено з урахуванням сучасних стандартів в електронному адмініструванні. У дослідженні названо конкретні статті в українському законопроєкті, які варто доповнити відповідними адміністративно-процедурними нормами, що додатково наблизять його зміст до сучасних вимог електронного адміністрування.

Метою цього оновлення повинні стати як підвищення ефективності публічного адміністрування через пріоритетне впровадження інформаційних і комунікаційних технологій, так і спрощення для приватних осіб адміністративного провадження, передусім у частині зменшення необхідних ресурсів і витраченого часу на взаємодію з адміністративними органами. Остаточна версія українського закону (кодексу) «Про адміністративну процедуру» повинна стати оновленою в цьому контексті та відповідно потребувати меншої кількості подальших доповнень.

Ключові слова: загальний акт про адміністративну процедуру, публічне адміністрування, інформаційні й комунікаційні технології, цифризація, електронні засоби, удосконалення законопроєкту.

A nearly twenty-year history of elaboration and adoption of the Ukrainian general act (initially code, later - law) on administrative procedure has a chance to be finished this year. In May 2020 another version of the draft law "On administrative procedure" was submitted by the Cabinet of Ministers of Ukraine and registered in the Verkhovna Rada of Ukraine [1]. The latest version includes new provisions that reflect global tendency of using contemporary information and communication technologies in public administration. However, these amendments are hardly known to administrative law specialists of our country and shall be analyzed regarding their full compliance with modern trends of e-administration.

In the context of our lawmaking story we have to remind that all former drafts of Ukrainian general act on administrative procedure have been mostly based on German example, Verwaltungsverfahrensgesetz that was adopted in 1976 and significantly influenced corresponding legislation in many European and other jurisdictions. Meanwhile, in the new millennium classic public administration gradually transforms into e-administration (as a constituent element of a much broader concept of e-governance). In new circumstances, legal regulation of public administration and especially legislation on general administrative procedure should not be an obstacle to such a transformation. On the contrary, this legislation should use additional possibilities of information and communication technologies to make public administration more effective and friendly for private persons.

Our research will start with an overall review of current legislation that regulates relations between public administration and private persons in Ukraine, including electronic forms of communication and procedural issues. Lack of general act on administrative procedure in our country does not mean a complete absence of legal regulation of public administration's activities. Current rules and procedures for Ukrainian administrative authorities are mostly scattered across different sector-specific laws and regulations

Though, a few exceptions exist and administrative procedural norms can be found in a few legislative acts of general 
nature. First, the Law of Ukraine "On citizen's appeals" [2] consists of some elements of the administrative procedure (time-limits for administrative decisions, procedural rights of individuals in the relations with public bodies, procedural obligations of public administration). Second, the paragraph 2 of the article 2 of the Code of Administrative Justice [3] foresees ten criteria, by which administrative courts shall examine appealed decisions or actions of administrative authorities. These criteria to a considerable extent correspond to the principles of administrative procedure that are envisaged in the aforementioned draft law. Third, the Law of Ukraine "On administrative services" [4] which introduced regulation of one-stop shops in public administration, also includes some procedural norms and undoubtedly reflects the tendency to e-administration. According to article 9 of this law, administrative services can be provided electronically through the Unified state portal of administrative services, including through the integrated information systems of state and local self-government bodies.

Despite these few exceptions of general nature, special legislation (both laws and by-laws) continues to play a decisive role in the legal support of public administration. Moreover, in some sector-specific legislation, one can find broader use of information and communication technologies in the formulation and implementation of corresponding legal norms. For example, the Tax Code of Ukraine [5] that combines substantial and procedural norms, at the end of 2014 was amended by the article 200-1 that foresees electronic administration of the value-added tax.

Regarding aforementioned transformation of Ukrainian public authorities to e-administration, it is also necessary to note at least two legislative acts: Law of Ukraine "On electronic documents and electronic workflow" [6] and especially Law of Ukraine "On electronic trust services" [7] that substituted previous act on electronic digital signature as well as added some contemporary legislative solutions. In particular, this comparatively new law provided:

- a possibility to use contemporary means of electronic identification, including Mobile ID;

- the digital approach in the fixation of the real-time signing of electronic documents;

- increasing confidentiality and better protection of personal data of electronic users.

In short, the Law of Ukraine "On electronic trust services" might be seen as another step to digitalization, both in interactions between private persons and with public administration. Subsequently, its legal norms of general nature are also used in administrative procedure; more specifically, they allow individuals and public officials to communicate by electronic means.

This short overview of relevant Ukrainian legislation undoubtedly shows that it is developing but hardly systematically. On one hand, it must be acknowledged that the legislature and the government are trying to introduce modern methods of electronic communication in public administration. On the other hand, lack of general act on administrative procedure objectively causes differences in legal regulation in specific areas of public administration and in using specific instruments. As one of the consequences, the level of transition to electronic administration in certain administrative bodies and certain spheres of administration differs.

Taking into account Ukraine's obligations to adapt its national legislation to acquis communutaire, it is worth showing criteria that are used by the European Union's bodies in the evaluation of e-administration. In particular, the European Commission proposes a five-degree scale in advancing electronic public services:

1. Information on-line. It is possible to search for information on a given public authority and its activities on the authority's website.
2. One-way interaction. It is not only possible to search for information, but also to download official forms from the public authority's website.

3. Two-ways interaction. In addition to searching for information and downloading official forms, it is also possible to return them via the Internet after completing them.

4. Transaction. It is possible to settle the matter via the Internet - obtain information, download and return appropriate forms, along with authentication (identity confirmation), payment of required fees, until receipt of a decision or certificate in an electronic version.

5. Personalization. In addition to the ability to perform all activities for the fourth degree, public services provided by the public authority are organized according to the needs and preferences of specific users [8, p. 774].

In certain areas of Ukrainian public administration, the fourth degree of this scale has been reached. Former State agency on e-governance and nowadays Ministry of digital transformation reports about the gradual increase of public services which can be obtained through the Internet. This process has its failures, for example, some public authorities demand from private persons besides paper versions of documents to complete a procedure. But in any case, the quantity of electronic public services is much higher than a few years ago. Public services that have been added to electronic way, include not only classic administrative services (i.e. registration of business or electronic driver licenses) but also e-services in health and education areas that to a considerable extent are provided in public sector.

Coming back to contemporary standards of e-administration, it is worth mentioning the E-government benchmark report (2018) that was prepared by Dutch and Italian experts for the European Commission [9]. This report foresees a list of principles that will be promoted in the electronic modernization of administration within the European Union. Most of these principles also might and should be used in Ukraine's efforts to transform its public administration to e-administration:

1. Digital by Default. Public administrations should deliver services digitally (including machine-readable information) as the preferred option (while still keeping other channels open for those who are disconnected by choice or necessity). Besides, public services should be delivered through a single contact point or a one-stop-shop and via different channels.

2. Once only principle. Public administrations should ensure that citizens and businesses supply the same information only once to a relevant public body. Public administration offices take action if permitted to internally re-use this data, in due respect of data protection rules, so that no additional burden falls on citizens and businesses.

3. Inclusiveness and accessibility. Public administrations should design digital public services that are inclusive by default and cater to different needs such as those of the elderly and people with disabilities.

4. Openness and transparency. Public administrations should share information and data between themselves and enable citizens and businesses to access control and correct their data; enable users to monitor administrative processes that involve them; engage with and open up to stakeholders (such as businesses, researchers and non-profit organizations) in the design and delivery of services.

5. Trustworthiness and security. All initiatives should go beyond mere compliance with the legal framework on personal data protection and privacy, and information technology security, by integrating those elements in the design phase.

Besides these five principles, another two ones of crossborder and interoperability by default are proposed, but they are designed for the internal relations between administrators within the European Union. So, going back to the mentioned five principles of electronic modernization of administration, our task will be to find out how these principles will influence 
the legal framework of public administration and, in particular, administrative procedure.

First, digital by default principle means that the electronic way of receiving e-services will become the main one. In the context of administrative procedure, it leads to a legal norm that simple administrative proceeding in electronic form will become the principal way of interactions between private persons and public administrations. Exceptions will exist, if necessary, for example, if an individual reasonably insists to be heard before a public authority in person. Or as well in more complicated administrative proceedings, where hearing or even cross-examination is needed.

The principle of "digital by default" was introduced in the latest version of the Ukrainian draft law "On Administrative Procedure". According to its paragraph 2 of the article 66 "written administrative act is issued in electronic form unless otherwise specified" [1].

Second, "once the only" principle is directed to public administration that will be obliged to re-use already given to another authority personal data. It will simplify the initiation of the procedure for an individuals or businesses - a list of necessary information and documents will be shortened. Such a norm might be added to the draft law "On administrative procedure" or to the existing Law of Ukraine "On administrative services".

Third, principles of inclusiveness and accessibility by default are strictly connected with the aforementioned fifth level of personalization of e-services. In the context of administrative procedure, it might be included in legal norms that regulate ways of initiating administrative proceedings and hearings with the participation of senior persons and people with disabilities.

Fourth, the mentioned principles of openness and transparency of public administration are not new ones for general acts on administrative procedure. However, nowadays they are enriched by the possibility of private persons to access control and correct their data. These actions may be done not only in some starting proceedings but also beforehand. Thus, a relevant norm can hardly be seen in the general act on administrative procedure, but definitely in related pieces of legislation

Fifth principles of trustworthiness and security are also directed to public administration, so they are not supposed to be included to procedural legislation that regulates external relations with private persons.

To sum up, most of the abovementioned principles of electronic modernization of administration shall be additionally considered in the future Ukrainian legal framework of public administration. Both substantial and procedural norms should be added in this context to relevant acts of legislation.

Described tendencies and ideas for transforming public administration to e-administration have been differently realized in certain jurisdictions, even within the European Union and not to mention other countries. To our opinion, some legislators are more conservative and not inclined to modify established rules promptly. At the same time, legislation on the administrative procedure (as well as other laws in related areas) has no other choice but to react to a steady trend to e-administration. Relevant legal provisions to varying degrees have been already modified in some jurisdictions of the European Union's member states.

We shall concentrate our analysis on the Spanish example - European country that tried to codify its legislation on administrative procedure already at the end of the nineteenth century. In the mid-twentieth century the first complete codification of Spanish administrative procedure was succeeded, later amended many times and finally, a substantially updated version of the Law "On the Common Administrative Procedure of the Public Administration" was passed in 2015 [10]. In the preamble of the latter law, one can find the assertion that it deepens the streamlining of procedures with the fully electronic operation.
So let us clarify which norms of the current Spanish law reflect the analyzed tendency to e-administration:

1) rules for representation by proxy that can be also made by electronic appearance in the corresponding electronic headquarters;

2) possibility of electronic identification of those interested in the procedure;

3 ) the obligation of public officials to assist in the use of electronic means to the interested parties;

4) additional rights of private person's rights in their relations with public administrations: to electronic communication, to be assisted in the use of electronic means, to obtain and use the means of identification and electronic signature;

5) the obligation of private persons to interact electronically with the public administrations, if it is enshrined in a special law;

6) the obligation of public administration to provide and save electronic documents with regard to completed procedures;

7) the issuance of electronic documents by the public administrations:

8) the validity of the electronic copies made by the public administrations

9) the priority of writing electronic forms of administrative acts and the electronic notification about issued acts.

Partly summarizing, numeral rules of Spanish general law on administrative procedure were reformulated in 2015 , thus implementing digitalization tendency in public administration. It does not mean that all provisions of the previous legislation have been changed - many norms, especially regulating separate stages of the administrative proceeding, for example about hearing, remained unchanged.

In many other European jurisdictions, the level of detail of general acts on the administrative procedure is visibly lower. For example, the Swedish Administrative Procedure Act belongs to so-called framework regulation, consists of only 33 sections and has not been changed significantly (including e-administration issues) since its entry into force more than thirty years ago [11].

It means that different legislative approaches can be successful in countries with different political and legal cultures, but in any case the movement to e-administration is visible in any jurisdiction. The overview of relevant rules in Spanish general law showed us an example of very detailed regulation of electronic means in the general act on administrative procedure itself. As a result, much less procedural issues are regulated in the other related legislative acts, not to mention by-laws.

We dare to affirm that because of post-Soviet administrative traditions, Ukraine also needs more detailed regulation of administrative procedure in the general act, including the analyzed context of digitalization of public administration. As noted earlier, the draft law on administrative procedure of Ukraine was being revised once again. Its final legislative version is naturally unknown yet, so for our study, we shall use the already mentioned last official version [1].

It should be noted that this version of the draft consists much more procedural norms reflecting the analyzed tendency to e-administration. For example, paragraph 6 of the article 32 one can find "revolutionary" norm for Ukrainian legislation: "If the time of receipt of the invitation sent by mail or e-mail is not recorded, it is considered received by the person on the fifth day of sending, unless the invitation was not received or received later" [1] Besides, the following provisions of the draft law on administrative procedure have been amended in line with the trend to e-administration, at least partly:

- registration of an application in an administrative body (paragraph 3 of the article 39);

- rules of evidence in administrative proceeding (paragraph 2 of the article 50); 
- forms of an administrative act and securing the electronic form as preferred in administrative proceedings (paragraph 2 of the article 66);

- notification on an issued administrative act (paragraph 4 of the article 72);

- validation of signatures and copying of documents by administrative bodies (paragraph 4 of the article 100).

However, taking into account previous overview of relevant legal norms in current Spanish general act on administrative procedure, the following provisions of the Ukrainian draft law shall be additionally reconsidered, amended or changed:

- the preamble of the draft that sounds very formally and does not heed modern ideas of good administration and e-administration;

- rights and duties of private persons in the administrative proceeding (article 29);

- representation of private persons (article 30);

- ways of carrying out administrative proceedings (articles 57-59) concerning fixing the priority of simplified proceedings by electronic means.

To sum up, the process of finalizing the Ukrainian draft law on administrative procedure should be consid- ered as an additional opportunity to adopt a truly modern act, which will fully reflects global trend to e-administration. The analysis of the current legislative acts regulating public administration in Ukraine as well the latest version of the draft law on the administrative procedure (2020) confirms the existence of the trend. At the same time, coverage of relevant provisions of the updated version of Spanish general act on administrative procedure demonstrates the feasibility of additional procedural rules which prioritize and maximize the ease of electronic communications between individuals and the public administration. This is especially true for simplified administrative proceedings, which account for over ninety percent in the administrative practice of any country. However, the prioritization of information and communication technologies is also appropriate at the initial and final stages of the administrative procedure in more complex proceedings.

Hopefully, the abovementioned mentioned proposals will allow to improve a final version of Ukrainian law "On Administrative Procedure" and its updated version will be in less need for further amendments.

\section{REFERENCES}

1. Про адміністративну процедуру : Проєкт Закону України № 3745 від 14 травня 2020 p. URL: http://w1.c1.rada.gov.ua/pls/zweb2/ webproc4_1?pf3511=68834.

2. «Про звернення громадян» : Закон України від 2 жовтня 1996 p. URL: https://zakon.rada.gov.ua/laws/show/393/96-\%D0\%B2\%D1\%80.

3. Кодекс адміністративного судочинства України в редакції від 3 жовтня 2017 року URL: https://zakon.rada.gov.ua/laws/show/2747-15.

4. Про адміністративні послуги : Закон України від 6 вересня 2012 p. URL: https://zakon.rada.gov.ua/laws/show/5203-17.

5. Податковий кодекс України в редакції від 29 грудня 2019 р. URL: https://zakon.rada.gov.ua/laws/show/2755-17.

6. Про електронні документи та електронний документообіг : Закон України в редакції від 7 листопада 2018 p. URL: https://zakon.rada.gov.ua/laws/show/851-15.

7. Про електронні довірчі послуги : Закон України від 5 жовтня 2017 р. URL: https://zakon.rada.gov.ua/laws/show/2155-19.

8. Wierzbowski M. Postępowanie administracyjne i sądowoadministracyjne. Warszawa, Wydawnictwo C.H. Beck, 2019.

9. E-government benchmark report (2018). URL: https://ec.europa.eu/information_society/newsroom/image/document/2018-47/egovernment_benchmark_2018_background_report_F21FA84B-0254-F4DB-7B2FC4567D4AA925_55487.pdf.

10. Law 39/2015 of the Kingdom of Spain, on October 1, of the Common Administrative Procedure of the Public Administrations. URL: http://afyonluoglu.org/PublicWebFiles/Reports/PDP/2015\%20Spain-Law\%2039-2015\%20Common\%20Administrative\%20Procedure\%20 of\%20PA.pdf.

11. The 1986 Administrative Procedure Act of the Kingdom of Sweden URL: https://www.kriminalvarden.se/globalassets/om_oss/lagar/forvaltningslagen-engelska.pdf. 


\title{
РОЗДІЛ 8 \\ КРИМІНАЛЬНЕ ПРАВО ТА КРИМІНОЛОГІЯ; КРИМІНАЛЬНО-ВИКОНАВЧЕ ПРАВО
}

УДК 343.85

DOI https://doi.org/10.32782/2524-0374/2020-4/59

\section{ЗАПОБІГАННЯ ЗЛОЧИННОСТІ У СФЕРІ ІНФОРМАЦІЙНИХ ТЕХНОЛОГІЙ: МІЖНАРОДНО-ПРАВОВИЙ АСПЕКТ}

\author{
CRIME PREVENTION IN THE FIELD OF INFORMATION TECHNOLOGIES: \\ INTERNATIONAL AND LEGAL ASPECT
}

\author{
Бодунова О.М., к.ю.н., \\ доцент кафедри кримінального права та кримінології \\ Університет державної фіскальної служби України
}

\begin{abstract}
У статті розглядається досвід зарубіжних країн, зокрема США, Канади, Франції, щодо запобігання злочинності у сфері інформаційних технологій.

Зауважено, що поширення інформаційних технологій має негативні наслідки, адже відкриває шлях до злочинної поведінки. Комп'ютерні системи надають нові, дуже досконалі можливості для вчинення невідомих раніше правопорушень, а також для вчинення традиційних злочинів, але нетрадиційними засобами. Саме тому зробити дієвими чи вдосконалити реалізацію національних стратегічних підходів із розглядуваного питання можливо, лише спираючись на досвід позитивної діяльності урядових і поза державних організацій інших країн, а також міждержавних інституцій та враховуючи їх зрушення у запобіганні загрозам інформаційній безпеці.

Зазначено, що злочинність у сфері інформаційних технологій характеризується високим рівнем латентності. Це зумовлено складністю виявлення осіб, що вчиняють кримінальні правопорушення у сфері інформаційних технологій, відсутністю єдиної методики розслідування та сформованої системи запобігання даному виду злочинності.

Порівняльно-правовий аналіз законодавства зазначених вище країн і України дав змогу стверджувати, що там створена цілісна і розгалужена система державних органів та неурядових організацій, діяльність яких спрямована на запобігання злочинності у сфері інформаційних технологій. Такі органи наділені власними повноваженнями щодо запобігання злочинності у сфері інформаційних технологій, у результаті діяльності яких повністю реалізується система заходів запобігання даному виду злочинності. Зокрема, детально проаналізовано досвід Франції, у системі державних органів якої створено: відділ кіберзлочинів технічного обслуговування судових досліджень та документації; комп'ютерний і електронний відділ Інституту кримінального розслідування Національної жандармерії; відомчі бригади інформації та судових розслідувань (BDRIJ) тощо.

Звернено увагу на те, що актуальним для України є досвід Франції щодо запобігання злочинності у сфері інформаційних технологій, а саме забезпечення діяльності різних державних органів, кожен з яких має власні завдання (розслідування, запобігання, облік осіб, що вчинили дані кримінальні правопорушення, тощо).
\end{abstract}

Ключові слова: злочинність, кримінальні правопорушення, зарубіжний досвід, кримінальні правопорушення, запобігання, розкриття.

The article examines the experience of foreign countries, in particular, the United States, Canada, France, in the prevention of crime in the field of information technology.

It is noted that the spread of information technology has negative consequences, because it opens the way to criminal behavior. Computer systems provide new, very advanced opportunities to commit previously unknown offenses, as well as to commit traditional crimes, but by unconventional means. That is why it is possible to make effective or improve the implementation of national strategic approaches to this issue only based on the experience of positive activities of governmental and non-governmental organizations of other countries and intergovernmental institutions and taking into account their progress in preventing information security threats.

It is noted that crime in the field of information technology is characterized by a high level of latency. This is due to the difficulty of identifying persons committing criminal offenses in the field of information technology, the lack of a unified methodology of investigation and the established system of prevention of this type of crime.

A comparative legal analysis of the legislation of the above countries and Ukraine allowed us to state that there is a holistic and extensive system of government agencies and non-governmental organizations whose activities are aimed at preventing crime in the field of information technology. Such bodies are endowed with their own powers to prevent crime in the field of information technology, as a result of which the system of measures to prevent this type of crime is fully implemented. In particular, the experience of France is analyzed in detail, in the system of state bodies of which the following has been created: the Department of Cybercrime, Maintenance of Judicial Research and Documentation; computer and electronic department of the Institute of Criminal Investigation of the National Gendarmerie; departmental information and judicial investigation teams (BDRIJ), etc.

Attention is drawn to the fact that the experience of France in preventing crime in the field of information technology is relevant for Ukraine, namely ensuring the activities of various government agencies, each of which has its own tasks (investigation, prevention, registration of perpetrators, etc.).

Key words: crime, criminal offenses, foreign experience, criminal offenses, prevention, disclosure.

Сьогодні суспільство переживає стрімкий розвиток автоматизації, інформатизації та комп'ютеризації кожної зі сфер діяльності. Ці процеси надають нові можливості для розвитку культури, освіти, науки й економіки кожної держави, а також дають змогу оперативно взаємодіяти 3 іншими державами та міжнародними організаціями. Проте поширення інформаційних технологій має й негативні наслідки, адже відкриває шлях до злочинної пове- дінки. Комп’ютерні системи надають нові, дуже досконалі можливості для вчинення невідомих раніше правопорушень, а також для вчинення традиційних злочинів, але нетрадиційними засобами.

Iз цього приводу науковці М.В. Карчевський і В.В. Невгад правильно зазначають, що «кіберзлочинність», «кібершахраї», «хакери», «комп’ютерний злом», «крадіжка машинного часу» - це терміни, які перестали 
бути «чимось недосяжним». Сьогодні злочинність у сфері інформаційних технологій - одна 3 найдинамічніших груп суспільно небезпечних посягань. Беззаперечним $\epsilon$ те, що швидке збільшення рівня поширеності такої злочинності, а також постійне зростання іiі суспільної небезпеки стало зворотним, негативним явищем такого суспільно важливого процесу, як інформатизація.

Окрім того, злочинність у сфері інформаційних технологій характеризується високим рівнем латентності. За різними оцінками, правоохоронним органам стає відомо лише про 10-20\% таких кримінальних правопорушень [1]. Усе це зумовлено складністю виявлення осіб, що вчиняють кримінальні правопорушення у сфері інформаційних технологій, відсутністю єдиної методики розслідування та сформованої системи запобігання даному виду злочинності.

Повністю погоджуючись із думкою О.В. Таволжанського, зазначимо, що зробити дієвими чи вдосконалити реалізацію національних стратегічних підходів із розглядуваного нами питання можливо, лише спираючись на досвід позитивної діяльності урядових і поза державних організацій інших країн, а також міждержавних інституцій та враховуючи їх зрушення у запобіганні загрозам інформаційній безпеці. У сучасних умовах складно уявити захищену державу, яка б не займалася власним секторами зовнішньої безпеки, змінюючи їх відповідно до викликів сучасності. Жодна війна, відкрита чи прихована, не відбувається без використання кіберзброї, потенціалу використання мережі Інтернет як кіберресурсу у військових цілях поза конкуренцією. Повсякденно в політиці провідних держав розробляються новітні заходи протидії загрозам у кіберпросторі, здійснюється коригування внутрішньої інформаційної політики, а також удосконалюються методи кібербезпеки [2, с. 155]. Саме це й зумовило актуальність дослідження злочинності у сфері інформаційних технологій та необхідності запобігання цьому негативному явищу.

Кримінологічні дослідження зарубіжного досвіду запобігання злочинності у сфері інформаційних технологій проводилися такими вченими, як П.Д. Біленчук, Л.Д. Варунц, М.І. Малій, В.В. Марков, О.В. Таволжанський та ін.

Досліджуючи дане питання, ми звернулися до досвіду найбільш розвинутих країн світу. Порівняльноправовий аналіз законодавства цих країн і України дає змогу стверджувати, що за кордоном у більшості держав створено цілісну систему органів щодо забезпечення кібербезпеки. Так, у США, до таких органів можна віднести Управління національної безпеки (Department of Homeland Security), при якому здійснює свою діяльність спеціальний кібербезпекововий департамент, що займається виключно безпекою високотехнологічних систем США. Кіберкомандування очолює підрозділи спеціального призначення, які мають на меті: ведення розвідувальної роботи в мережах, захист власних мереж, блокування i «обвал» структур супротивника 3 використанням можливостей кіберпростору.

У Канаді запобіганням комп'ютерним і телекомунікаційним кримінальним правопорушенням займається підрозділ Королівської канадської кінної поліції (далі - КККП). Діяльність підрозділу спрямована на розслідування та розкриття кримінальних правопорушень, пов'язаних із комп'ютерною діяльністю і телекомунікаціями. Секція захисту інформаційних технологій забезпечує захист федеральних державних комп'ютерних центрів, приватного сектору, надає консультації, готує персонал для роботи зі здійснення комп'ютерного захисту. Співробітники підрозділу допомагають поліцейським у проведенні розслідувань кримінальних правопорушень, пов'язаних із комп'ютерними системами. Ураховуючи, що інформаційна система дає змогу передавати повідомлення від одного терміналу до іншого майже негайно, у Канаді діє близько 2500 точок доступу, до яких входять близько 1285 федеральних і провінційних поліцейських відділень. 1180 підрозділів спеціалізованих відділівКККП підключені до ліній системи [3, с. 127].

Безперечно, цей напрям діяльності поліції є важливим, оскільки економічні втрати вже досягли великих масштабів, деякі злочинці діють на міжнародному рівні у складі організованих груп. Одному державному органу складно запобігати злочинності у сфері інформаційних технологій.

У зв'язку із цим кримінологи стверджують, що канадське законодавство щодо визначення злочинності у сфері інформаційних технологій $є$ суперечливим і потребує вдосконалення. Ураховуючи, що завдання, які стоять перед підрозділами поліції з боротьби зі злочинністю у сфері інформаційних технологій, носять міжнародний характер і не є специфічними для Канади, вони активно співпрацюють з іншими країнами та Інтерполом із метою вдосконалення законодавства у цьому напрямі. Розкриття комп'ютерних кримінальних правопорушень $\epsilon$ складним завданням передусім через фактор часу. Оскільки передача даних може бути виконана майже миттєво, часто буває даремно шукати будь-які докази, що підтверджують порушення міжнародного законодавства. За даними КККП, сьогодні безліч комп'ютерних кримінальних правопорушень здійснюється дітьми, які не досягли дванадцятирічного віку. Згідно з Кримінальним кодексом Канади, для встановлення кримінальної відповідальності необхідно довести несанкціоноване використання комп'ютерної системи та намір особи заподіяти своїми діями шкоду. Такий підхід потребує чіткого встановлення параметрів доступу до комп'ютерної техніки з метою попередження порушень. Необхідно враховувати дані про осіб, параметри доступу з урахуванням обмежень, можливість службовців «експериментувати» 3 програмами. Кваліфіковану консультацію щодо можливої неправомірної поведінки у цьому напрямі може надати міністерство юстиції чи відповідний підрозділ КККП [4, с. 110].

Слід зазначити, що методика розслідування випадків несанкціонованого дистанційного доступу до комп'ютерних мереж технічно складна, цим займаються спеціалізовані поліцейські підрозділи. 3 огляду на небезпеку комп'ютерної злочинності, тенденцію ії розвитку та впливу на світове співтовариство, у межах $\mathrm{OOH}$ регулярно проводяться симпозіуми 3 профілактики i припинення комп'ютерної злочинності. Як один із напрямів фахівці відзначають програмні методи захисту інформації в комп'ютерних системах колективного користування шляхом удосконалення системи автоматичного контролю. На попередження та зменшення злочинів щодо незаконного використання телекомунікаційних систем на міжпровінційному, державному i міжнародному рівних спрямовані дії та управління боротьби з економічними злочинами. Допомагає поліцейським підрозділам Інформаційний центр [4, с. 110].

Аналізуючи досвід європейських країн, можемо зазначити, що як і в США, тут створено єдину систему державних органів, кожен з яких наділений окремими блоками повноважень щодо запобігання злочинності у сфері інформаційних технологій.

Так, у Франції створено низку державних інституцій та неурядових установ, що займаються запобіганням кіберзлочинності. Відомою $є$ така структура, як Національна комісія з обчислювальної техніки та свобод (CNIL). Ціль діяльності CNIL - захисті персональних даних. У цифровому світі CNIL $€$ регулятором персональних даних, підтримує фахівців у кіберпросторі в їхній діяльності і допомагає людям контролювати свої особисті дані та здійснювати свої права. 32004 р. має право накладення санкцій на підприємства, що порушують Закон про інформатику, картотеки і свободи 1978 р. [5]. 
Окремим напрямом запобігання кіберзлочинності $\epsilon$ діяльність так званого Верховного органу поширення творів і охорони прав в Інтернеті (HADOPI). Здійснена спроба визначити, що таке незаконне скачування інформації та регламентувати таку діяльність. Вищий конституційний суд країни схвалив другий варіант Закону про так звану триступеневу заборону доступу до мережі Інтернет [5].

У правоохоронній системі Франції також діють відповідні суб'єкти з боротьби зі злочинністю у сфері інформаційних технологій. Починаючи 31998 р. Національна жандармерія визначила пріоритетною діяльність щодо вирішення проблем, пов'язану з інноваційними технологіями, шляхом створення відповідних структур і навчальних закладів, зокрема:

1. Відділ кіберзлочинів технічного обслуговування судових досліджень та документації (STRJD). Він здійснює моніторинг Інтернет-мережі шляхом пошуку злочинів проти людей та майна, пов'язаних із передачею нелегальних даних в Інтернеті (сайти, Інтернет-ресурси, групи новин, мережі обміну, соціальні мережі тощо)

2. Комп'ютерний і електронний відділ Інституту кримінального розслідування Національної жандармерії (IRCGN). Він розробляє методи, засоби та програмне забезпечення для автоматичного виявлення педофілів тощо.

3. Відомчі бригади інформації та судових розслідувань (BDRIJ) тощо.

Іншим суб' єктом запобігання кіберзлочинності у Франції є Національне агентство безпеки інформаційних систем (ANSII), французьке агентство з кібербезпеки, яке працює 3 державними спецслужбами. Діяльність органу спрямована на реалізацію Французької національної стратегії цифрової безпеки, оголошеної 16 жовтня 2015 р. Ця стратегія, що впроваджується ANSSI, є результатом скоординованих міжвідомчих зусиль, спрямованих на реагування на виникаючі проблеми цифрового століття. Було задекларовано, що цифровий перехід сприяє не лише інноваціям та економічному зростанню, а й одночасно несе ризики для держави, господарюючих суб'єктів та громадян. Кіберзлочинність, шпіонаж, пропаганда, саботаж та надмірне використання персональних даних загрожують цифровій довірі та безпеці. Визначено основні пріоритети в діяльності ANSSI: захист та безпека державних інформаційних систем та критично важливих інфраструктур, важливих операторів економіки та суспільства; цифрова довіра, конфіденційність, особисті дані, кібернасильство; підвищення обізнаності, початкове навчання, безперервна освіта; навколишнє середовище бізнесу цифрових технологій, промислова політика, експорт та інтернаціоналізація; цифрова стратегічна автономія, стійкість кіберпростору.

Доволі розповсюдженими сучасними заходами запобігання кіберзлочинності є проведення спільних навчань. У ході навчань виявляють недоліки, інфраструктури, формуються варіанти атак, інцидентів і пропонуються найбільш ефективні варіанти реагування та координації.

Cyber Europe-навчання передбачає симуляцію великих інцидентів із кібербезпеки, які загострюються, щоб стати кібернетичними кризами. Вправи пропонують можливості для аналізу передових технічних інцидентів кібербезпеки, а також для вирішення складних ситуацій безперервності бізнесу і кризових ситуацій. Навчання Cyber Europe показують сценарії з урахуванням реальних подій, розроблені європейськими експертами з кібербезпеки [6].

Отже, виходячи 3 вищесказаного, зазначимо, що у зарубіжних державах створено цілісну і розгалужену систему державних органів і неурядових організацій, діяльність яких спрямована на запобігання злочинності у сфері інформаційних технологій. Такі органи наділені власними повноваженнями щодо запобігання злочинності у сфері інформаційних технологій, у результаті діяльності яких повністю реалізується система заходів запобігання даному виду злочинності.

Уважаємо, що актуальним для України є досвід Франції щодо запобігання злочинності у сфері інформаційних технологій, а саме забезпечення діяльності різних державних органів, кожен 3 яких має власні завдання (розслідування, запобігання, облік осіб, що вчинили дані кримінальні правопорушення, тощо).

\section{ЛITEPATУРA}

1. Малій М., Біленчук П. Кіберсвіт у новому тисячолітті. Хто вони: кіберзлочинці, кібершахраї, кібертерористи? Юридичний вісник. URL : https://lexinform.com.ua/dumka-eksperta/kibersvit-u-novomu-tysyacholitti-hto-vony-kiberzlochyntsi-kibershahrayi-kiberterorysty/ (дата звернення: 20.07.2020)

2. Таволжанський О.В. Особливості забезпечення кібербезпеки у сучасному світі: огляд суб'єктів запобігання кіберзлочинності. Науково-інфоормаційний вісник Івано-Франківського університету права імені Короля Данила Галицького. Серія «Право». 2018. № 6(18). С. 154-163.

3. Варунц Л.Д. Досвід організації діяльності Королівської канадської кінної поліції та шляхи його використання в Україні : дис. ... канд. юрид. наук : 12.00.07. Дніпропетровськ, 2012. 203 с.

4. Марков В.В. До питання щодо зарубіжного досвіду протидії кіберзлочинності. Право і безпека. 2015. № 2(57). С. 107-113.

5. Loi favorisant la diffusion et la protection de la création sur Internet URL : http://www.senat.fr/dossier-legislatif/pjl07-405.html (дата звернення: 13.07.20120).

6. Loi 78-17 du 6 janvier 1978 modifiée. URL : https://www.cnil.fr/fr/loi-78-17-du-6-janvier-1978- modifiee (дата звернення: 13.07.2020). 


\title{
ДЕЯКІ АСПЕКТИ ІМПЛЕМЕНТАЦІЇ ПОЛОЖЕНЬ СТАМБУЛЬСЬКОЇ КОНВЕНЦІЇ В КК УКРАЇНИ ТА ПРОБЛЕМИ КРИМІНАЛЬНОЇ ВІДПОВІДАЛЬНОСТІ ЗА ДОМАШНЕ НАСИЛЬСТВО
}

\author{
SOME ASPECTS OF INTEGRATION OF ISTANBUL CONVENTION PROVISIONS \\ INTO PENAL CODE OF UKRAINE AND PROBLEMS OF CRIMINAL LIABILITY \\ FOR DOMESTIC VIOLENCE
}

Гальцова В.В., к.ю.н., доцент кафедри кримінального права № 2

\author{
Наиіональний юридичний університет імені Ярослава Мудрого
}

\begin{abstract}
У статті вказується, що національне законодавство не завжди відповідає міжнародним стандартам і з цією метою здійснюється імплементація. Досліджуються деякі аспекти імплементації норм міжнародного права у вітчизняне законодавство та наголошується, що немає єдиного підходу до її здійснення. Звертається увага на низку складнощів, які виникають унаслідок імплементації та зумовлені низкою чинників як внутрішнього, так і зовнішнього характеру. Акцентується, що в Україні відсутня чітка правова база, яка необхідна для врегулювання процесу імплементації та подальшої реалізації імплементованих норм. Зазначається, що внаслідок цього нерідко виникають правові колізії під час імплементації положень міжнародного права у національне законодавство. Наводяться думки вчених міжнародного та кримінального права на вказану проблему та пропонуються шляхи вирішення.

Досліджується імплементація положень Конвенції Ради Європи про запобігання насильству стосовно жінок і домашньому насильству та боротьбу із цими явищами (Стамбульська конвенція) у чинне кримінальне законодавство. Автором схвалюється рішення законодавця щодо криміналізації домашнього насильства.

Зазначається, що імплементація норм міжнародного права у національне законодавство здійснюється такими способами, як відсилання, рецепція, адаптація, трансформація чи інкорпорація. Уважається, що найбільш прийнятним способом імплементації міжнародного права у кримінальне законодавство є трансформація. Констатується, що імплементація норм Стамбульської конвенції у кримінальне законодавство України була здійснена шляхом інкорпорації, яка у цілому не схвалюється вченими-криміналістами. На підставі аналізу норми «домашнє насильство» (ст. $126^{1}$ КК), якою доповнено чинне кримінальне законодавство, указується, що має місце порушення правил законодавчої техніки під час формулювання ії диспозиції, оскільки у ній текстуально відтворено положення Стамбульської конвенції без урахування особливостей вітчизняного кримінального законодавства, що фактично призводить до складнощів у правозастосовній діяльності.

Звертається увага на проблеми, які можуть виникнути під час кваліфікації домашнього насильства. Зокрема, наводяться переконливі аргументи, що у такому формулюванні диспозиції статті застосування кримінального закону призведе до розширеного трактування норм кримінального права, що може тягти за собою порушення прав і свобод людини і, відповідно, є порушенням чинного кримінального законодавства. Зазначається, що окремі поняття, які відтворені зі Стамбульської конвенції та знайшли своє текстуальне закріплення у Кримінальному кодексі України, можуть призвести до безпідставної криміналізації певних діянь. Указується, що дані поняття є широкими за обсягом на рівні родових (а не видових) понять, чим порушуються правила законодавчої техніки, отже, постійно викликатимуть складнощі у практиці застосування. Робиться висновок про те, що абсолютне механічне перенесення норм міжнародного права у кримінальне законодавство України без урахування особливостей $є$ порушенням принципів законності та економії кримінально-правової репресії. Автором пропонуються шляхи вирішення цієї проблеми шляхом удосконалення чинного кримінального законодавства та внесення до нього змін.
\end{abstract}

Ключові слова: міжнародне право, законодавство, імплементація, домашнє насильство, Стамбульська конвенція, порушення законодавчої техніки, правозастосування.

The article says that the national legislation doesn't always comply with international standards for which the integration is being provided. The article studies some aspects of integration of international law into the national legislation and points out that it has no uniform approach. The article highlights multiple challenges arising as a result of integration and caused by a number of internal and external factors. It is emphasised on the absence of clearly defined legal framework in Ukraine required to resolve integration process and further incorporate integrated provisions. It is noted that this often results in judicial contradictions when international law is incorporated into the national legislation. The article provides views of international and criminal law scientists on the above problem and offers solution.

The article studies integration of provisions of the European Council Convention on Preventing and Combating Domestic Violence Against Women (Istanbul Convention) into existing criminal law. The author supports lawmaker's decision on criminalisation of domestic violence.

It is noted that the integration of international law into the national legislation is done by the following methods: reference, reception, adaptation, transformation, or incorporation. It is believed that the most acceptable method of integration of international law into criminal legislation is transformation The author says that the integration of provisions of Istanbul Convention into criminal law of Ukraine was made by method of incorporation which is frowned upon by criminalists. Based on analysis of "domestic violence" term, (Penal Code, Article. 1261) which supplements existing criminal law it was noted that this violates law-making technology regulations when wording its provisions as its text reproduces provisions of Istanbul Convention with no regard to the features of national criminal law which complicates law-enforcement activities.

The article highlights issues that can evolve at defining domestic violence. It provides strong arguments that this wording may result in extensive interpretation in criminal law enforcement which may follow violation of human rights and freedoms and respectively violates existing criminal law. It is noted that some concepts that are reflected in Istanbul Convention and found their way into the Criminal Code of Ukraine may result in unreasonable criminalisation of certain actions, The article maintains that these concepts are broad in volume on generic level (not specific) which infringes law technology rules правила and will subsequently cause enforcement problems. The author concludes that mechanical transfer of provisions of international law into the criminal law of Ukraine with no regard to its features violates the principles of law та economy of criminal repression. The author suggests to resolve the problem by enhancing and modifying existing legislation.

Key words: International law, legislation, introduction, domestic violence, Istanbul Convention, violation of law technology, law enforcement.

Постановка проблеми. Україна впевнено взяла курс приєднання до Європейського Союзу, тому одним із важливих завдань, які ставить євроінтеграційна стратегія, є наближення та приведення національного законо- давства у відповідність із нормами міжнародного права. Тому справедливо указують учені, що від рівня зближення національного законодавства з міжнародним, його узгодженості з відповідними стандартами та вимогами 
значною мірою залежить не тільки ефективність співпраці України з іншими державами та міжнародними організаціями, а й розвиток нашої держави як демократичної, соціально орієнтованої та правової. Автори вважають, що вирішувати це складне завдання необхідно планомірно, системно й на постійній основі 3 чітким додержанням норм міжнародних договорів і національного законодавства України [1, с. 129].

Аналіз останніх досліджень. Аспекти імплементації міжнародно-правових норм досліджували такі вчені-правознавці, як М. Баймуратов, М. Буроменський, А. Гавердовський, А. Вишенський, В. Денисов, В. Забігайло, Д. Левін, І. Лукашук, Ю. Медведєв, М. Раскалєй, М. Янишин та багато інших, а проблеми кримінальної відповідальності за домашне насильство вивчали такі науковці кримінального права, як А. Байда, А. Вознюк, О. Дудоров, А. Запорожець, М. Хавронюк, О. Харитонова та багато інших.

Метою статті $є$ дослідження проблем кримінальної відповідальності за домашнє насильство, які виникли внаслідок імплементації положень Конвенції Ради Європи про запобігання насильству стосовно жінок і домашньому насильству та боротьбу із цими явищами у чинне кримінальне законодавство.

Виклад основного матеріалу. Одним із питань національної політики України є входження до європейського простору, тому перед вітчизняним законодавцем постало важливе завдання - привести національне законодавство (у тому числі й кримінальне, яке його невід'ємною частиною) у відповідність із нормами міжнародного права. У зв'язку із цим особливого значення набуває дослідження імплементації, за допомогою якої відбувається втілення норм міжнародного права в національне законодавство, а також виявлення і вирішення проблем, що виникають унаслідок цього. В Україні із цією метою було ратифіковано Конвениію Ради Свропи про запобігання насильству стосовно жінок $і$ домашньому насильству та боротьбу із иими явищами (англ. Council of Europe Convention on preventing and combating violence against women and domestic violence; Istanbul Convention) (далі - Стамбульська конвенція). Стаття 3 цієї Конвенції зазначає, що «держава має здійснити не тільки низку заходів стосовно комплексної та негайної допомоги жертвам домашнього насильства, а й притягнути винних у вчиненні сімейного насильства до відповідальності, у тому числі й кримінальної: «Домашнє насильство має бути кримінально караним, тобто усі дії, що охоплюють акти фізичного, сексуального, психологічного або економічного насильства, які відбуваються в лоні сім'ї чи в межах місця проживання або між колишніми чи теперішніми подружжями або партнерами, незалежно від того, чи проживає правопорушник у тому самому місці, що й жертва, чи ні, або незалежно від того, чи проживав правопорушник у тому самому місці, що й жертва, чи ні».

Зазначимо, що до ратифікації Україною Стамбульської конвенції у раніше чинному кримінальному законодавстві не передбачалася кримінальна відповідальність за насильство у сім'ї (його називають ще сімейне, домашне чи побутове та ін.). Проте у подальшому, згідно 3 одним із принципів міжнародного права, що міститься у ст. 26 Віденської конвенції про право міжнародних договорів від 23.05.1969 Pacta sunt servanda - договори повинні виконуватися, 6 грудня 2017 р. Верховна Рада України ухвалила Закон «Про внесення змін до деяких законів України у зв'язку з ратифікацією Конвенції Ради Європи про запобігання насильству стосовно жінок і домашньому насильству та боротьбу з цими явищами». Згідно із цим Законом, Кримінальний кодекс України (далі - КК) доповнено новою статтею під номером $126^{1}$ «Домашне насильство»:

"умисне систематичне вчинення фізичного, психологічного або економічного насильства щодо подружжя чи колишнього подружжя або іншої особи, з якою винний перебуває (перебував) у сімейних або близьких відносинах, що призводить до фізичних або психологічних страждань, розладів здоров'я, втрати прачездатності, емоиійної залежності або погіршення якості життя потерпілої особи, -

карається громадськими роботами на строк від ста n'ятдесяти до двохсот сорока годин або арештом на строк до шести місяиів, або обмеженням волі на строк до n'яти років, або позбавленням волі на строк до двох років».

Отже, імплементація Стамбульської конвенції у чинне кримінальне законодавство $є$ однією 3 необхідних умов для досягнення відповідності правової системи України критеріям, що висуваються Європейським Союзом до держав, які мають намір вступити до нього. Тому у цілому заслуговує позитивної оцінки рішення законодавця щодо криміналізації домашнього насильства, оскільки держава повинна приділяти особливу увагу захисту сім'ї та ії̈ членів від суспільно небезпечних посягань, у тому числі й від проявів насильства, що виникає внаслідок внутрішніх конфліктів між членами родини та $\epsilon$ достатньо розповсюдженим негативним явищем в Україні й нерідко перетворюється на тривалий та систематичний процес. Безперечно, сім'я та ії̈ члени мають право на особливий захист із боку держави, у тому числі й від проявів насильства, за допомогою кримінально-правових норм, які встановлюють кримінальну відповідальність за посягання на суспільні відносини, що забезпечують нормальний розвиток і функціонування сім'ї та виховання неповнолітніх.

Дана норма має виконувати важливу роль у боротьбі 3 насильством у сім'ї та сприяти збереженню родини, яка $\epsilon$ надзвичайно важливим соціально-правовим інститутом суспільства та держави. Тому криміналізація домашнього насильства $є$ необхідною для захисту сімейних відносин та її членів, оскільки дане діяння заподіює істотну шкоду не лише одному об'єкту кримінально-правової охорони суспільним відносинам у сфері сім’і, а й страждає додатковий обов'язковий об'єкт - тілесна недоторканість, здоров'я, та навіть, життя ії членів.

Необхідно зазначити, що в Україні, на жаль, немає єдиного підходу до здійснення процесу імплементаціі та не закріплено на законодавчому рівні, незважаючи на низку складнощів, які виникають унаслідок цього. Складність процесу імплементації зумовлена низкою чинників як внутрішнього, так і зовнішнього характеру. До них науковці відносять: відсутність чіткої правової бази, необхідної для врегулювання процесу імплементації та реалізації імплементованих норм; невідповідність значної кількості стандартів, закріплених у національному законодавстві, міжнародним стандартам, що зумовлює виникнення колізій; недостатньо чітка визначеність моменту, з якого міжнародний акт стає частиною національного законодавства. Усе це призводить до помилок у правозастосуванні [2, с. 86].

Зазвичай імплементація норм міжнародного права в національне законодавство розуміється науковцями як складний процес, що являє собою цілеспрямовану організаційно-правову діяльність держав, яка здійснюється індивідуально, колективно або в рамках міжнародних організацій із метою своєчасної, всебічної і повної реалізації прийнятих ними, відповідно до міжнародного права, зобов'язань [3, с. 62]. Отже, імплементацією є фактична реалізація міжнародних зобов'язань на внутрішньодержавному рівні, що здійснюється шляхом трансформації міжнародно-правових норм у національні законодавчі та підзаконні акти. При цьому норма міжнародного права зберігає свій статус, але іiї змісту надається статус норми національного права. Це зазначено у ст. 9 Конституції України, яка проголошує, що чинні міжнародні договори, згода на обов'язковість яких надана Верховною Радою, $€$ частиною національного законодавства України [4, с. 73]. 
Імплементація норм міжнародного права, вказують учені, може здійснюватися способами відсилань, рецепщії, адаптації, трансформації чи інкорпорації [4, с. 73]. Інкорпорація передбачає точне відтворення міжнародно-правових норм без будь-яких змін у законодавстві імплементуючої держави. Проте такий спосіб можна застосовувати тоді, коли формулювання міжнародної норми у національному законодавстві відповідає принципам національної правової системи держави, є зрозумілою для суб'єкта правозастосування або міжнародним договором прямо передбачено створення національних правових норм, що співпадають за формою з відповідними міжнародно-правовими нормами [5, с. 73].

Проте Н.Ф. Кузнєцова вважає, що, здійснюючи імплементацію деяких положень міжнародно-правових актів, вітчизняний законодавець не завжди враховує специфіку вітчизняного закону про кримінальну відповідальність. Унаслідок того, що норми міжнародно-правових актів, як правило, не відповідають національному законодавству, імплементація міжнародного права до вітчизняного кримінального законодавства відбувається шляхом інкорпорації, трансформації або відсилки. Але найбільш правильним і поширеним способом імплементації, вважає авторка, є трансформація. А буквальне повторення міжнародних норм у тексті національного кримінального закону за допомогою інкорпорації у цілому є неприйнятним [6, с. 43].

Проаналізувавши ст. $126^{1}$ КК «Домашне насильство», якою було доповнено чинний КК України, зазначимо, що імплементація норм Стамбульської конвенції була здійснена шляхом інкорпорації. Унаслідок цього має місце порушення правил законодавчої техніки під час формулювання диспозиції цієї статті, оскільки у ній текстуально відтворено положення цієї Конвенції. Також при цьому не можна погодитися з низкою інших рішень і підходів, які знайшли відображення і визначення у тексті новели ст. $126^{1}$ КК. Тут необхідно вказати такі зауваження.

По-перше, формулювання у тексті диспозиції «систематичне вчинення насильства» суперечить поняттю злочину, яке закріплене у ч. 1 ст. 11 КК, згідно з яким, 3 одного боку, злочином визнається суспільно небезпечне, протиправне, винне діяння, тобто злочином визнається й один акт поведінки суб'єкта злочину. Проте можуть бути випадки вчинення одного акту насильства і за відсутності систематичного вчинення дій, але які потягли такі наслідки, як утрата працездатності чи розлад здоров'я та навіть смерть. Тому у цьому сенсі термін «систематичне вчинення насильства», що має багаторазовий (три i більше епізоди) характер, необгрунтовано обмежує кримінальну відповідальність за домашнє насильство лише систематичністю дій. Коли таке насильство може заподіяти, наприклад, тілесне ушкодження середньої тяжкості і внаслідок одиничного акту (діяння), тому заслуговує на необхідність кримінальної відповідальності за вчинення насильства у сім'ї, навіть якщо воно вчинене одним актом діяння суб' єкта злочину.

По-друге, звертає увагу невизначеність у законі понять та відповідних термінів, що включені до диспозиції ст. $126^{1}$ КК, зокрема «фізичне і психічне насильство», «психологічне насильство» чи «економічне насильство». Вони є надто широкими за обсягом, їх зміст (система ознак) не визначений у законі, тому отримують неоднозначне тлумачення.

Так, до психологічного насильства, на думку психологів, можна віднести: критику недоліків дружини, чоловіка, дітей; контроль учинків, дій, думок; образи; заборона зустрічатися з родичами, друзями; зневага в присутності інших людей, дітей; висміювання тощо [7, с. 67]. Нечітким та розмитим $\epsilon$ також поняття «економічне насильство», під яким фахівці розуміють: заборону працювати, обмеження розпоряджатися грішми; обмеження у хар- чуванні чи прийняття душу та інших форм забезпечення життєдіяльності людини [7, с. 65]; прийняття грошових і фінансових рішень без відома членів сім'ї; витрачання грошей виключно на себе, відмова в наданні грошей на оплату рахунків, їжі, речі для дітей; блокування доступу до фінансів чи матеріальних цінностей; вимога детальних звітів, як і на що витрачаються гроші; видача маленьких сум на утримання, які ніяк не можуть окупити навіть мінімальних витрат на себе і сім'ю; примус до підписання паперів, які обмежують доступ до фінансів або ресурсів, та ін. (економічне насильство).

Отже, неможливо перерахувати усі види психологічного та економічного насильства. До того ж за деякі види економічного або психологічного насильства вже встановлено кримінальну відповідальність в окремих нормах Особливої частини. Зокрема, доведення до самогубства (ст. 120 КК); погроза вбивством (ст. 129 КК); ухилення від сплати аліментів на утримання дітей (ст. 164 КК); ухилення від сплати коштів на утримання непрацездатних батьків (ст. 165 КК); використання малолітньої дитини для заняття жебрацтвом (ст. $150^{1}$ КК) або втягнення неповнолітніх дітей у злочинну діяльність (ст. 304 КК) та ін. Тому їх застосування у кримінальному законі призведе до розширеного трактування норм кримінального права, що, безумовно, може тягти за собою порушення прав і свобод людини i, відповідно, є порушенням чинного кримінального законодавства.

По-третє, невизначеними у ст. $126^{1}$ ККє й такі поняття, як «психологічні страждання», «емоційна залежність» або «погіршення якості життя потерпілої особи». Вони будуть тягнути за собою різні підходи до їх тлумачення, тобто здійснюватися на власний розсуд слідчого, прокурора, судді у правозастосовній діяльності, які можуть грунтуватися виключно на оцінці відповідно до особистих чи власних уявлень. Це може призвести у подальшому до безпідставної криміналізації певних діянь, порушення принципів законності та економії кримінально-правової репресії. До того ж дані поняття $\epsilon$ широкими за обсягом на рівні родових (а не видових) понять, чим порушуються правила законодавчої техніки, отже, постійно викликатимуть складнощі у практиці застосування.

По-четверте, викликає сумнів рішення законодавця, що домашнє насильство може вчинятися й стосовно колишнього подружжя або іншої особи, з якою винний перебував у сімейних або близьких відносинах. Уважаємо, що це мають бути винятково дійсні члени сім'ї: подружжя, батьки та діти, усиновлювачі (удочерителі) та усиновлені (удочерінені), баба, дід, прабаба, прадід, внуки, правнуки, рідні брати та сестри, мачуха, вітчим, падчерка, пасинок, які проживають разом та ведуть спільне господарство. Саме на цих осіб указує Сімейний кодекс України та регулює сімейні особисті немайнові та майнові відносини між ними (ч. 1, 2 ст. 2). Колишнє подружжя не є членом сім'ї.

Згідно 3 нормами сімейного законодавства, сім'я створюється на підставі шлюбу, кровного споріднення, усиновлення (удочеріння), а також на інших підставах, не заборонених законом і таких, що не суперечать моральним засадам суспільства, тому потерпілим від домашнього (сімейного) насильства вважаємо за необхідне визнати лише теперішнього (дійсного) члена сім’ї. Тільки тоді шкода заподіюється кільком об'єктам кримінально-правової охорони - суспільним відносинам, які забезпечують нормальне функціонування та розвиток сімейних відносин (обов'язковий об'єкт), а також здоров'ю або тілесній недоторканості людини (додатковий обов'язковий об'єкт). Учинення насильства стосовно колишнього подружжя або іншої особи, з якою винний раніше перебував у сімейних чи близьких відносинах, необхідно кваліфікувати за загальною нормою як злочини проти здоров'я та тілесної недоторканості особи, оскільки при цьому шкода сімейним відносинам (обов'язковому об'єкту) не заподіюється 
внаслідок того, що ні de jure, ні de facto сімейних зв'язків не існує.

По-n'яте, покарання за сімейне насильство має бути узгоджене зі злочинами проти тілесної недоторканості та здоров'я. Зокрема, за умисне легке тілесне ушкодження (ст. 125 КК), середньої тяжкості (ст. 122 КК), побої та мордування (ст. 126 КК), інше рішення призводить до штучної конкуренції кримінально-правових норм: загальної (злочини проти здоров'я) та спеціальної (сімейне насильство), а також до штучної сукупності злочинів та означає порушення принципу верховенства права, принципу законності, що неодмінно буде викликати складнощі у правозастосуванні.

Тому санкція статті спеціальної кримінально-правової норми за сімейне насильство (ст. $126^{1}$ КК) має відповідати суспільній небезпеці даного злочинного діяння, оскільки під час його вчинення спричиняється шкода кільком об'єктам кримінально-правової охорони: суспільним відносинам у сфері сім'ї та відносинам, що охороняють життя та здоров'я іії членів і має бути узгодженою із санкціями за вчинення інших, близьких за видом і характером злочинів і бути не меншою, ніж санкція таких злочинів проти здоров'я, як умисне легке тілесне ушкодження (ст. 125 КК), тілесне ушкодження середньої тяжкості (ст. 122 КК), побо та мордування (ст. 126 КК), які є загальними нормами відносно певних видів сімейного насильства.

Висновки. На нашу думку, необхідно розробити та на законодавчому рівні закріпити механізм імплементації у національне законодавство, оскільки, як справедливо вказують науковці, юридичні помилки та прогалини, що виникають унаслідок цього, можуть суттєво ускладнити досягнення цілей, закладених у нормах міжнародного права. На підтримку цього свідчать думки й інших науковців, що відсутність належної чіткості та визначеності призводить до небажаних наслідків, зокрема правової інфляції [8, с. 39-40].

Тому необхідно розробити та закріпити у вітчизняному законодавстві чіткий механізм реалізації імплементації норм міжнародного права та визначити їх межі, обов'язково враховувати особливості національного законодавства під час імплементації положень міжнародного права у кримінальне законодавство. Це дасть змогу: сформулювати норму закону про кримінальну відповідальність належним чином, не допускаючи механічного перенесення міжнародних норм; уникнути колізій і складнощів у правозастовній діяльності; не порушувати принципи законності та економії кримінально-правової репресії та сприятиме належній кримінально-правовій охороні від злочинних посягань.

Також аналіз новели КК «Домашне насильство», яка була імплементована шляхом інкорпорації, дає підстави висловити зауваження, що для оптимального втілення у чинний КК положень Стамбульської конвенції щодо кримінальної відповідальності за домашнє (сімейне) фізичне насильство вважаємо за можливе викласти так:

\section{ст. 126 $^{\mathbf{1}}$ КК Сімейне насильство}

1. Умисне нанесення члену сім'ї удару, побоїв або вчинення інших насильницьких дій, щзо завдають фізичного болю або заподіяли легке тілесне ушкодження, яке спричинило не короткочасний розлад здоров'я без утрати прачездатності, -

карається.......

2. Ті самі дії, що мають характер мордування, катування чи спричинили легке тілесне ушкодження, яке спричинило короткочасний розлад здоров'я або незначну втрату працездатності чи середньої тяжкості тілесне ушкодження,

- карається.......

3. Дії, передбачені ч. 1 або ч. 2 иієї статті, вчинені щодо неповнолітнього члена сім' $і$ або стосовно інших членів сім' $i$, які перебувають у безпорадному стані чи є особами похилого віку, -

карається.......

Також уважаємо за доцільне для оптимальної реалізації положень Стамбульської конвенції встановити кримінальну відповідальність за психічне насильство стосовно членів сім’ї у спеціальній нормі під назвою «жорстоке поводження у сім'ї».

\section{ЛІТЕРАТУРА}

1. Медведєв Ю. Імплементація норм міжнародного права у право України: зміст і способи реалізації. Публічне право. 2014. № 1(13). С. 129-135.

2. Янишин М.Б. Проблема імплементації норм міжнародного права у національне законодавство України та шляхи її вирішення. Міжнародні читання з міжнародного права пам'яті професора П.Є. Казанського : матер. третьої міжнар. наук. конф., м. Одеса, 2-3 листопада 2012 р. ; НУ «ОЮА». Одеса : Фенікс, 2012. С. 85-88.

3. Гавердовський А.С. Имплементация норм международного права. Киев : Вища школа, 1980. 318 с.

4. Капустин А.Я. Международное гуманитарное право : учебное пособие. Москва : Университет дружбы народов, 1991. 80 с.

5. Раскалей М. Особливості імплементації міжнародних договорів у внутрішній правопорядок у галузі повітряного права України. Віче. 2007. № 5-6. С. 72-74.

6. Кузнецова Н.Ф. О законодательной технике в уголовном праве. Вестник Московского университета. 2004. Сер. 11. № 4. С. 41-53.

7. Лях Д.Д. Насильство над жінками в сімейних стосунках. Практична психологія та соціальна робота. 2014. № 2. С. 65-69.

8. Забігайло В.К. Панування права чи інфляцція законодавства? Вісник Київського університету. Суспільно-політичні науки. 1992. № 6. С. $36-40$. 
УДК 343.2

DOI https://doi.org/10.32782/2524-0374/2020-4/61

\title{
НОРМАТИВНІ ПЕРЕДУМОВИ АНАЛІЗУ ПРОБЛЕМИ НАСИЛЬСТВА ЩОДО ДІТЕЙ REGULATORY PREREQUISITES FOR ANALYSIS OF THE PROBLEM OF VIOLENCE AGAINST CHILDREN
}

\author{
Данільченко І.Р., асистент кафедри кримінального права \\ Національний університет «Одеська юридична академія»
}

Пункт 1 ст. 19 Конвенції про права дитини від 20 листопада 1989 року говорить: «Держави-учасниці вживають усіх необхідних законодавчих, адміністративних, соціальних і просвітніх заходів із метою захисту дитини від усіх форм фізичного та психологічного насильства, образи чи зловживань, відсутності піклування чи недбалого і брутального поводження та експлуатації, включаючи сексуальні зловживання, з боку батьків, законних опікунів чи будь-якої іншої особи, яка турбується про дитину» [1].

Необхідним складовим елементом у системі захисту дітей від жорстокого поводження і зневажливого ставлення до їхніх потреб та інтересів у сучасному суспільстві $є$ законодавчі норми. Вони гарантують забезпечення прав дитини та передбачають покарання осіб, винних у скоєнні дій, що представляють небезпека для життя і здоров'я дітей та порушують або обмежують їхні права і свободи.

Державна політика в інтересах дітей завжди була пріоритетною сферою діяльності органів державної влади в багатьох країнах, будучи заснованою на таких провідних принципах, як законодавче забезпечення прав дитини; державна підтримка сім'ї з метою забезпечення повноцінного виховання дітей, захисту їхніх прав, підготовки їх до повноцінного життя в суспільстві; відповідальність посадових осіб, громадян за порушення прав і законних інтересів дитини, заподіяння їй шкоди. Як зазначалося вище, держава вкрай зацікавлена у виробленні комплексної системи заходів для ефективного захисту неповнолітнього від злочинних посягань та викоріненні економічної та соціально-політичної основи різних суспільно небезпечних явищ. Система заходів включає як свій неодмінний компонент групу правових норм, орієнтованих на захист найслабших і вразливих членів суспільства - неповнолітніх. Захист прав неповнолітніх з урахуванням властивих їм вікових і соціально-психологічних особливостей здійснюється за допомогою специфрічних норм, що містяться в адміністративному, кримінальному, кримінально-процесуальному та кримінально-виконавчому законодавстві.

Усе частіше в Україні фіксуються випадки жорстокого поводження з дітьми з боку не тільки дорослих, і тому ситуація з безпритульністю, бездоглядністю, неблагополуччям дітей досі залишається дуже важкою. Сьогодні важливо переглянути чинні норми законодавства і посилити відповідальність за вчинення протиправних діянь відносно неповнолітніх.

Ключові слова: насильство, насильство по відношенню до дітей, фізичне та психічне насильство, попередження насильства, домашнє насильство, насильство у сім'ї, Кримінальний кодекс, об'єкти насильства, корекційна програма.

Paragraph 1 of Art. 19 of the Convention on the Rights of the Child of 20 November 1989 states: "States Parties shall take all appropriate legislative, administrative, social and educational measures to protect the child from all forms of physical and psychological violence, abuse or abuse, neglect or neglect and ill-treatment. and exploitation, including sexual abuse, by parents, legal guardians or any other person caring for the child" [1].

Legislation is a necessary component of the system of protection of children from abuse and contempt for their needs and interests in modern society. They guarantee the rights of the child and provide for the punishment of those guilty of acts that endanger the life and health of children and violate or restrict their rights and freedoms.

Public policy for children has always been a priority for public authorities in many countries, based on guiding principles such as the legislative protection of children's rights; state support of the family in order to ensure the full upbringing of children, protection of their rights, preparing them for a full life in society; responsibility of officials, citizens for violation of the rights and legitimate interests of the child, causing him harm. As noted above, the State is extremely interested in developing a comprehensive system of measures for the effective protection of minors from criminal encroachment and the eradication of the economic and socio-political basis of various socially dangerous phenomena. The system of measures should include as its essential component a set of legal norms aimed at protecting the weakest and most vulnerable members of society - minors. The protection of the rights of minors, taking into account their inherent age and socio-psychological characteristics, is carried out with the help of specific norms contained in administrative, criminal, criminal procedure and criminal executive legislation.

Cases of child abuse by more than adults are increasingly recorded in Ukraine, and therefore the situation with homelessness, neglect, and child unhappiness still remains very difficult. At present, it is important to review the existing legislation and increase the responsibility for committing illegal acts against minors.

Key words: violence, violence against children, physical and mental violence, violence prevention, domestic violence, domestic violence, criminal code, objects of violence, correctional program.

Протягом усієї історії людства насильство завжди привертало увагу в першу чергу 3 тієї причини, що люди постійно вдавалися до нього для вирішення найрізноманітніших проблем - від духовних до політичних. Учинення злочинів проти неповнолітніх - це підвищена небезпека для суспільства. Це пов'язано не тільки з тим, що розширюється коло правопорушень, а й із тим, що порушуються основи конституційно-правового статусу особистості. Тому особливе місце серед злочинних посягань проти особистості займають злочини проти неповнолітніх. Ці злочини характеризуються особливим цинізмом та жорстокістю і свідчать про моральну деградацію залучених у ці діяння осіб. Вивчення сукупності злочинів проти неповнолітніх показує, що ця група злочинів виросла в самостійну кримінальну проблему.

Предметом дослідження виступають: соціальноправове явище жорстокого поводження 3 дітьми; його кримінологічні параметри і детермінанти; заходи його спеціально-кримінологічної профілактики; система кри- мінально-правових норм, спрямованих на протидію жорстокому поводженню з дітьми, і практика їх застосування.

Метою статті $\epsilon$ аналіз законодавства, що спрямоване на вдосконалення системи заходів попередження жорстокого поводження $з$ дітьми.

Ступінь наукової розробленості теми дослідження статті. Кримінально-правові проблеми протидії жорстокому поводженню 3 неповнолітніми були предметом наукових досліджень, виконаних такими вченими, як С.Н. Абельцев, Ю.М. Антонян, А.Е. Волкова, Н.В. Довголюк, О.Н. Івасюк, А.Н. Красиков, В.Н. Кудрявцев, Н.В. Машинська, Г.Г. Мошак, А.А. Нікітіна, Ю.В. Миколаєва, А.Е. Побегайло, О.В. Пристанська, Г.А. Панфілов, Ю.С. Пудовочкін, Е.Ф. Побігайло, Д.В. Рівман, І.М. Туктарова, Д.А. Шестаков та ін.

Визнаючи безперечну значимість досліджень кожного із зазначених авторів, слід разом із тим відзначити, що не всі $з$ наявних проблем попередження жорстокого поводження 3 дитиною науково розроблені достатньою 
мірою, а окремі питання і зовсім залишилися за рамками теоретичного аналізу. Це зумовлено, з одного боку, безперервною зміною законодавства, судово-слідчої практики i, в більш загальному плані, соціальної парадигми, а $з$ іншого - трансформацією і без того досить різноманітних форм і проявів жорстокого поводження з дітьми.

Одним із найбільш пріоритетних напрямів внутрішньої політики України є захист неповнолітніх від різних злочинних посягань та залучення їх у протиправну діяльність На думку Г.М. Мелкова, «світове співтовариство неодноразово зверталося до вирішення проблем, пов'язаних із захистом прав та законних інтересів дітей» [2]. У ст. 3 Конвенції про права дитини підкреслюється: «У всіх діях щодо дітей, незалежно від того, здійснюються вони державними чи приватними установами, що займаються питаннями соціального забезпечення, судами, адміністративними чи законодавчими органами, першочергова увага приділяється якнайкращому забезпеченню інтересів дитини» [1].

Окремої уваги вимагає аргумент професора O.I. Плужніка, який уважає, що «органи державної влади усіх кран світу та міжнародна спільнота прикладають чимало зусиль для становлення своєї країни на міжнародній арені як держави самостійної, незалежної, демократичної та правової. Важливою характеристикою, що визначає авторитет будь-якої держави на міжнародній арені, певною мірою $\epsilon$ політика щодо захисту прав та свобод своїх громадян, насамперед до наймолодших» [3, с. 141].

Так, 27 лютого 1991 р. Постановою Верховної Ради України № 789XII (78912) ратифіковано Конвенцію Ради Свропи про права дитини, яка набула чинності для України 27 вересня 1991 р. Згодом Україна прийняла Закон України «Про охорону дитинства» (№ 2402-III від 26.04.2001).

Згідно зі Світовою декларацією про забезпечення виживання, захисту і розвитку дітей, «усім дітям повинна бути забезпечена можливість визначити себе як особистість і реалізувати свої можливості в безпечних і сприятливих умовах, у середовищі сім'ї або опікунів, що забезпечують їх благополуччя» [9].

Згідно зі ст. 52 Конституції України, будь-яке насильство над дитиною та ii експлуатація переслідуються за законом [4]. Відповідно до ст. ст. 141, 155 Сімейного кодексу України, «мати, батько мають рівні права та обов'язки щодо дитини незалежно від того, чи перебували вони у шлюбі між собою, розірвання шлюбу між ними, проживання їх окремо від дитини не впливає на обсяг їхніх прав і не звільняє від обов'язків щодо дитини. Ухилення батьків від виконання батьківських обов'язків $€$ підставою для покладення на них відповідальності, встановленої законом» [5].

Відповідно до Закону України «Про охорону дитинства», «жорстоке поводження 3 дитиною - це будь-які форми фізичного, психологічного, сексуального або економічного насильства над дитиною, зокрема домашнього насильства, а також будь-які незаконні угоди стосовно дитини, зокрема вербування, переміщення, переховування, передача або одержання дитини, вчинені з метою експлуатації, з використанням обману, шантажу чи уразливого стану дитини» [6].

Висока суспільна небезпека розглянутих посягань вимагає не тільки їх своєчасного виявлення і розкриття, а й передусім недопущення самих фактів. Злочини проти неповнолітніх являють собою невід'ємну частину соціального управління і передбачають здійснення комплексу різнопланових і разом із тим взаємопов'язаних заходів соціально-економічного, правового, організаційного, виховного, медичного характеру, спрямованих на корекцію особистості правопорушників і нейтралізацію дій, які зумовлюють учинення злочинів.

Успішне попередження злочинів передбачає вирішення соціальних проблем, а саме створення умов для забезпечення: прав і свобод громадян; гідного життя і вільного розвитку людини; державної підтримки сім'ї; соціального забезпечення за віком; правового захисту життєво важливих інтересів неповнолітніх.

В останні роки в країні намітилося стабільне зростання злочинів, скоєних щодо неповнолітніх. Особливо неблагополучно складається становище дітей і підлітків у сім'ї. Саме в родині проявляються найбільш витончені форми жорстокості і насильства щодо неповнолітніх. Це й образи, приниження, побої, грубий примус до протиправних дій, так само виганяють із дому, позбавляють їжі та ін.

Некоректні форми виховання дітей, приниження їхньої людської гідності, психічне і фізичне насильство все частіше простежуються як у сім'ях, так і в дошкільних установах, навчальних закладах, дитячих будинках і інтернатах, спеціальних навчальних виховних установах. У результаті щорічно, рятуючись від жорстокого поводження, кінчають життя самогубством, багато хто йде із сімей, дитячих будинків та шкіл-інтернатів.

Особливу групу насильницьких посягань щодо неповнолітніх становить сексуальне насильство. Усе більше відбувається згвалтувань неповнолітніх, злочинів, пов'язаних 3 убивством або загрозою вбивства, важкими тілесними ушкодженнями, катуванням, викраденням дітей, із різними діяннями іншого сексуального характеру. Основний тягар таких злочинів усе більше переноситися у сферу сімейних, побутових відносин, частіше зазнають насильства діти у віці від 8 до 12 років.

Однією $з$ найбільш яскравих тенденцій у злочинності проти неповнолітніх $€$ велика кількість злочинів, скоєних дорослими по відношенню до неповнолітніх, у тому числі:

«неналежне виконання професійних обов'язків медичним працівником або 306 Правовий вплив на неправомірну поведінку: актуальні грані фармацевтичним працівником, якщо це спричинило тяжкі наслідки для хворого (ч. 2 ст. 140 КК);

зараження неповнолітнього венеричною хворобою (ч. 2 ст. 133 КК); залишення матір'ю у небезпеці новонародженої дитини (ч. 2 ст. 135 КК);

умисне вбивство матір'ю своєї новонародженої дитини (ст. 117 KK);

незаконне позбавлення волі або викрадення людини (ч. 2 ст. 146 КК);

зараження неповнолітнього вірусом імунодефіциту

(ч. 3 ст. 130 КК);

згвалтування (ч. ч. 2-4 ст. 152 КК);

незаконне проведення дослідів над людиною (ч. 2.

ст. 142 КК);

неналежне виконання обов'язків щодо охорони життя та здоров'я дітей (ст. 137 КК);

захоплення заручників (ч. 2. ст. 147 КК); торгівля людьми (ч. 2 ст. 149 КК);

експлуатація дітей (ст. 150 КК);

насильницьке задоволення статевої пристрасті неприродним способом (ч. ч. 2, 3 ст. 153 КК);

використання малолітньої дитини для заняття жебрацтвом (ст. 150-1 КК);

розбещення неповнолітніх (ст. 156 КК);

статеві зносини з особою, яка не досягла статевої зрілості (ст. 155 КК);

ввезення, виготовлення, збут і розповсюдження порнографічних предметів (ч. 2 ст. 301 КК);

жорстоке поводження 3 тваринами (ч. 2 ст. 299 КК); схиляння до вживання наркотичних засобів, психотропних речовин або їхніх аналогів (ч. 2 ст. 315 КК);

сутенерство або втягнення особи у заняття проституцією (ч. ч. 3, 4 ст. 303 КК);

втягнення неповнолітнього у злочинну діяльність (ст. 304 KK);

незаконне виробництво, виготовлення, придбання, зберігання, перевезення наркотичних засобів, психотропних речовин або їхніх аналогів (ч. ч. 2, 3 ст. 307 КК); 
створення або утримання міст розпусти і звідництва (ч. 3 ст. 302 КК);

незаконне введення в організм наркотичних засобів, психотропних речовин або їхніх аналогів (ч. 3 ст. 314 КК); організація або утримання місць для незаконного вживання, виробництва чи виготовлення наркотичних засобів, психотропних речовин або їхніх аналогів (ч. 2 ст. 317 КК)» [7].

3 огляду на перелік злочинів проти неповнолітніх, необхідно зазначити про нагальну необхідність у класифікації злочинів проти неповнолітніх.

Кримінальний кодекс України 1960 р. має звужений характер відносно захисту інтересів та прав неповнолітніх, проте чинний Кримінальний кодекс України 2001 р. значно ширше охороняє інтереси неповнолітніх.

Так, Л. Кривачук зазначає, що «держава $є$ найактивнішим суб'єктом державної політики у сфері охорони дитинства, вона сьогодні шукає найефективнішу модель політики для захисту прав неповнолітніх, яка повинна базуватися на принципах державної політики у сфері охорони дитинства в Україні: дитиноцентризму, забезпечення і захисту прав, гарантій та законних інтересів дітей, найкращого забезпечення інтересів дітей, пріоритету, гуман- ності, участі, міжгалузевості, партнерства. Переконані, що від того, наскільки продуманою та виваженою буде державна політика у сфері охорони дитинства, залежить забезпечення гідного життя майбутніх поколінь юних громадян України» [8].

Висновки. Якість і межі кримінально-правової охорони неповнолітніх від злочинних посягань визначаються поряд $з$ іншими соціально-економічними та політичними чинниками специфікою взаємин між державою і сім'єю. Встановлені сучасним законодавством межі «закритості» сім'ї, її свободи від державного і громадського контролю вимагають уточнення. Держава має право втручатися у внутрішнє життя сім'ї і брати на себе функцію захисту неповнолітніх, коли сім'я перетворюється на джерело їх експлуатації і зловживань. Кримінально-правові засоби регулювання сімейних і ювенальних відносин «вступають у дію» в ситуації, коли відсутність такого втручання здатна створити загрозу життю та здоров'ю членів сім'ї (особливо неповнолітніх); їх фізичному, моральному, емоційному благополуччю; вільному і розумному здійсненню членами сім'ї своїх прав. При цьому в ситуації, коли інтереси дитини й інтереси сім'ї у цілому або її дорослих членів суперечать один одному, пріоритет повинен належати інтересам дітей.

\section{תITEPATYPA}

1. Конвенція про права дитини (OOH, 1989 р.) URL : https://zakon.rada.gov.ua/laws/show/995_021\#Text.

2. Мелков Г.М. Международная защита прав и свобод человека. Сборник документов. Москва, 1990. URL : https://books.google.com.ua.

3. Плужнік О.І., Корнієнко М.В. Актуальні питання захисту прав дітей кримінально-правовими заходами. Прикарпатський юридичний вісник. 2018. Вип. 3(24). С. 140-144.

4. Конституція України. Відомості Верховної Ради України (ВВР). 1996. № 30. C. 141. URL : http://zakon5.rada.gov.ua/laws/show/ $254 \% \mathrm{D} 0 \% \mathrm{BA} / 96-\% \mathrm{D} 0 \% \mathrm{~B} 2 \% \mathrm{D} 1 \% 80$.

5. Сімейний кодекс України від 10.01.2002 № 2947-III. URL : http://zakon5.rada.gov.ua/laws/show/2947-14

6. Про охорону дитинства : Закон України № 2402-III від 26.04.2001. URL : http://zakon2.rada.gov.ua/laws/show/2402-14.

7. Кримінальний кодекс України від 05.04.2001 № 2341-ІІІ. Відомості Верховної Ради України. 2001. № 25-26. Ст. 131.

8. Кривачук Л. Принципи державної політики у сфері охорони дитинства в Україні. Ефективність державного управління. 2015. Вип. 43. URL : http://Desktop/efdu 2015 43 7.pdf.

9. Всемирная декларация об обеспечении выживания, защиты и развития детей, принятая на Всемирной встрече на высшем уровне в интересах детей. Нью-Йорк, 30.09.2000. URL : http://www.un.org/ru/documents/decl_conv/declarations/decl_child90.shtml. 


\title{
МОДЕЛІ ЗАЛЕЖНОЇ ПОВЕДІНКИ ТА ПОВ'ЯЗАНІ 3 НИМИ ФАКТОРИ КРИМІНОЛОГІЧНОГО РИЗИКУ
}

\section{DEPENDENT BEHAVIOR MODELS AND RELATED CRIMINAL RISK FACTORS}

\author{
Ларченко М.О., к.ю.н. \\ доцент кафедри політології, права та філософії \\ Ніжинський держсавний університет імені Миколи Гоголя
}

Статтю присвячено аналізу закономірностей залежної поведінки та її зв'язку з факторами кримінологічного ризику. Проаналізовано традиційні для нашої країни погляди на причини розвитку адикцій, а також і злочинної поведінки, проведено аналіз передової зарубіжної літератури з проблем причинності злочинів, віднайдено паралелі існуючих концепцій щодо втрати самоконтролю з моделями адиктивної поведінки та простежено їх зв'язок із факторами кримінологічного ризику. Проведено паралелі між різними видами залежностей та злочинною поведінкою особи з точки зору науки кримінології. Окреслено природу адиктивної поведінки та її наслідків із встановленням спільних рис для різних видів залежностей. Окремо розглядається вплив на поведінку особи ігрової та алкогольної залежності, в тому числі й в зарубіжній кримінологічній літературі. На основі проведеного аналізу виявлено необхідні закономірності причинно-наслідкового впливу адикцій на злочинну поведінку особи. Класифіковано напрями адиктивного впливу на рішення вчинити злочин.

3 метою диференціації запобіжного впливу виділено та проведено кримінологічний аналіз чотирьох типів осіб з антисоціальною спрямованістю діяльності, яким притаманні різні моделі адиктивної поведінки. Зокрема, це: 1) адикт, що вчиняє корисливі ненасильницькі злочини проти власності з метою задоволення адиктивних потреб; 2) адикт, що вчиняє насильницькі або корисливо-насильницькі злочини та, як правило, має суттєві деформації психічного стану, сформовані під впливом адикції; 3) адикт, що є представником субкультури, де ризикована поведінка та вчинення дрібних корисливих або корисливо-насильницьких злочинів є нормою; 4) адикт, який поки що не має фінансових проблем, але завдяки втраті самоконтролю внаслідок дії адиктивного агента, з корисливих спонукань стає частиною системи поширення певного способу адиктивного проведення часу іншими особами. Виділено основні шляхи запобігання злочинності залежних осіб, а також форми можливої корекції їхньої злочинної поведінки з урахуванням різних ступенів адиктивного впливу.

Ключові слова: залежна поведінка, адикт, адиктивний вплив, моделі адиктивної поведінки, ігрова залежність, алкогольна залежність, запобіжний вплив.

The article is devoted to the analysis of the patterns of addictive behavior and its connection with criminological risk factors. The traditional views of our country on the causes of addictions and criminal behavior are analyzed, the analysis of the advanced foreign literature on the problems of causality of crimes is analyzed and parallels of existing concepts on loss of self-control with models of addictive behavior are found and their connection with criminological risk factors. On the basis of the conducted analysis, the necessary regularities of causal influence of addictions on criminal behavior of the person are revealed. The directions of addictive influence on the decision to commit a crime are classified.

In order to differentiate the preventive effect, a criminological analysis of four types of persons with antisocial orientation, which are characterized by different models of addictive behavior, was identified and conducted. In particular, it is: 1) an addict who commits mercenary nonviolent crimes against property in order to satisfy addictive needs; 2 ) an addict who commits violent or mercenary-violent crimes and, as a rule, has significant deformations of the mental state, formed under the influence of addiction; 3) an addict who is a representative of a subculture, where risky behavior and the commission of petty selfish or selfish-violent crimes is the norm; 4) an addict who does not yet have financial problems, but due to the loss of self-control due to the action of an addictive agent, out of selfish motives becomes part of the system of disseminating a certain way of addictive pastime to others. The article also highlights the main ways to prevent the crime of addicts, as well as forms of possible correction of their criminal behavior, taking into account the different degrees of addictive influence.

Key words: addictive behavior, addict, addictive influence, models of addictive behavior, game addiction, alcohol dependence, preventive influence.

Залежна поведінка є предметом наукового дослідження окремої науки - адиктології. Втім, натепер відсутня єдина феноменологічна та термінологічна база, загально прийнятий категоріальний апарат. Поняття «залежна поведінка» розглядається фахівцями різних наук по-різному: з медичної точки зору, це - хвороба (переважно вивчаються хімічні форми залежностей); з точки зору соціології, це - соціальне явище, що має свої соціальні чинники; з точки зору психології, це - спосіб адаптації особистості до несприятливих життєвих обставин; а кримінологи розглядають залежну поведінку переважно як кримінально провокуючий фактор.

Ми вважаємо, що з кримінологічної точки зору вплив залежної поведінки на злочинність має бути досліджено більш грунтовно та із застосуванням методу моделювання. Метою даного дослідження є аналіз закономірностей залежної поведінки та іiі зв'язок із факторами кримінологічного ризику. Завданнями дослідження є: 1) окреслення природи адиктивної поведінки із встановленням спільних рис для різних видів залежностей; 2) виявлення закономірностей причинно-наслідкового впливу адикцій на злочинну поведінку особи; 3) класифікація напрямів адиктивного впливу на рішення вчинити злочин; 4) виділення та кримінологічний аналіз чотирьох типів осіб з антисоціальною поведінкою, яким притаманні різні моделі адиктивного впливу.

Деякі дослідники стверджують, що і сама злочинна поведінка за певних ознак може бути об'єктом залежності
[1]. Прикладні критерії медичного визначення адиктивної поведінки наведено в Міжнародній класифікації хвороб десятого перегляду (MКX-10) [2]. Термін «адиктивна поведінка» зручний через його інтернаціональну транскрипцію.

Слово addictus - це юридичний термін, яким позначають людину, яка підкоряється, засудженого: «addicere liberum corpus in servitutem» означає «засуджувати вільну людину до рабства за борги»; «адикіус» - той, хто пов'язаний боргами [3, с. 56]. Таким чином, адиктивна (залежна) поведінка є однією з форм девіантної поведінки 3 формуванням прагнення до відходу від реальності за допомогою вживання деяких речовин або 3 постійною фіксацією уваги на певних видах діяльності з метою розвитку і підтримки інтенсивних емоцій $[4$, с. $5 ; 5$, с. 8].

Дослідники переважно поділяють залежності на два види: хімічні (алкогольна, наркотична) та поведінкові (ігрова, технологічна, харчова, любовна тощо).

Між усіма видами залежностей простежується багато спільних рис. Зокрема, значну роль під час формування залежної поведінки відіграє певна стресова подія в житті індивіда. Вона виступає так званим тригером. Це може бути особиста трагедія, звільнення з роботи, смерть близької людини тощо. Переживаючи важкий період життя, людина може спробувати відволіктись від проблем шляхом вживання хімічних речовин або через нові поведінкові форми. При цьому за певних обставин вона може 
відчути значне полегшення, відхід болісних емоцій на другий план. Це відчуття закарбовується в пам'яті людини і створює суб'єктивну ілюзію можливості управління своїми емоціями, швидкої зміни свого внутрішнього стану, тобто ілюзію контролю. Насправді вчинення емоційно змінюючих поведінкових епізодів або вживання специфічних хімічних речовин (адиктивна реалізація) веде до втрати контролю над психоемоційним станом.

Процес розвитку інтенсивних емоцій настільки захоплює людину, що починає управляти ії життям. Людина стає безпорадною перед своїми пристрастями. Вольові зусилля слабшають і не дають можливості протистояти адикції [5].

Фахівці зазначають, що адиктивний агент стає незмінним супутником людини, яка поступово звикає до нього i не здогадується про можливість потрапити в залежність. Починається шлях до формування іншого життя адиктивного: хімічні або інформаційні задоволення, які людина вибрала, з часом потребують все більшої дози адиктивного агента, що за механізмом зворотного зв'язку призводить до того, що розірвати ланцюги залежності сама людина вже не в змозі [6].

Вважається, що є два основні способи виживання особи: боротьба та адаптація. Втім, адиктивна особистість шукає і знаходить свій універсальний і надто однобокий спосіб виживання - відхід від проблем. Можна справедливо сказати, що природні адаптаційні можливості адикта порушені саме на психологічному рівні. Такі люди мають низьку переносимість фрустрацій. Як спосіб відновлення психологічного комфорту вони вибирають адикцію, прагнучи штучної зміни психологічного стану, отримання суб'єктивно приємних емоцій. Таким чином, створюється ілюзія вирішення проблеми. Подібний спосіб боротьби з реальністю закріплюється в поведінці людини і стає стійкою стратегією взаємодії з оточуючим середовищем [7, с. 21-23; 8].

Традиційними для нашої країни є такі погляди на причини розвитку адикцій, а також і злочинної поведінки.

У розгляді шкідливих етіологічних факторів, що мають значення під час формування адикцій, вважається, що більшість 3 них є екзогенними, що безпосередньо відносяться до впливу зовнішнього середовища. Наявний лише один фактор - спадковість, який прийнято вважати ендогенним (у вузькому сенсі слова) на тій підставі, що спадкові якості організму притаманні йому як успадковані від пращурів. Однак у сутності і спадкові якості можуть вважатись ендогенними лише умовно. Ймовірно, що ці якості були набуті пращурами екзогенним шляхом, тобто під впливом зовнішнього середовища, та можуть вважатися ендогенними лише по відношенню до даного організму. Крім того, спадковим шляхом передаються не залежності, а сама схильність до адикцій, аналогічно - щодо схильності до злочинної поведінки. Людина може потрапити під вплив сприятливих зовнішніх умов і реалізуватись як адикт (злочинець), але може й уникнути такого розвитку подій. Для реалізації спадкової схильності необхідним $\epsilon$ додатковий вплив зовнішніх шкідливих факторів, що ще більше підсилює роль екзогенних факторів у розвитку адикції (злочинної поведінки) [9, с. 24].

Вважається, що такі фактори, як: інфекції, інтоксикації, травматичні ураження мозку, перевтома та виснаження, аутоінтоксикації та хвороби внутрішніх органів, психічні фактори, соціальні фактори, фактори кліматичні, метеорологічні, ушкодження зародку і плоду, вікові та статеві особливості впливають на формування сталих розладів поведінки.

Вказаними вище факторами визначається так звана особиста схильність до адикцій та/або до злочинної поведінки, яка складається 3 морфологічної структури, соматичних особливостей, характеру, інтелекту, превалюючих реакцій на оточуюче.

Кримінологічне моделювання як метод наукового пізнання має широке застосування переважно в закордонних дослідженнях, вітчизняна наука кримінологія має багато невирішених проблем, тому масштабні грунтовні дослідження із застосуванням сучасних комп'ютерних технологій $\epsilon$ вкрай рідкісним явищем.

Ряд кримінологічних та міждисциплінарних досліджень у США присвячені проблемам взаємовпливу хімічних адикцій та антисоціальної поведінки. Грунтовність та об'єктивність таких досліджень пов'язані насамперед із комплексом методів, що застосовуються для отримання емпіричних результатів. Так, варто звернути увагу на колективне дослідження фахівців 3 університетів штатів Мінесоти та Флориди, опубліковане у 2018 році, яке присвячене інтеграції кримінологічних та психопатологічних результатів аналізу поведінки за низького самоконтролю, що викликаний вживанням маріхуани, інших наркотиків або алкоголю. Застосовувались: метод самоаналізу, аналізу поведінки за спеціальною шкалою, нейрофізіологічне дослідження (відповіді мозку на різні когнітивні завдання, нейровізуалізація), міждисциплінарне дослідження за спеціальною шкалою. Результати показали сильний негативний зв'язок антисуспільної поведінки з вживанням зазначених психоактивних речовин. Доведено, що: 1) низький рівень самоконтролю та розгальмованість сильно корелює 3 конкретними актами імпульсивно-поведінкової девіації; 2) низький рівень самоконтролю, викликаний вживанням психоактивних речовин, $є$ надійним показником міждисциплінарної моделі антисуспільної поведінки [10].

В іншому дослідженні (Moffitt та ін. - 2010), що представляє інтерес 3 точки зору кримінологічного моделювання та прогнозування злочинної поведінки залежних осіб, автори виявили принципову можливість прогнозування різних форм правопорушень у доповнення до інших наслідків для здоров'я у зв'язку з високим або низьким рівнем самоконтролю. Так, особи (як дорослі, так і діти) з низьким рівнем самоконтролю мали значні проблеми 3 алкоголем та наркотиками (табак, канабіс, інші вуличні та рецептурні препарати). Згідно з висновками авторів описуваного дослідження, рівень самоконтролю, оцінений ще в ранньому дитинстві (3-5 років), у подальшому надійно корелював зі злочинною поведінкою, вживанням психоактивних речовин у віці 32-х років. Однак низький самоконтроль також передбачав більш широкий спектр негативних результатів, що включали зниження рівня освіти та професійних навиків, фінансові складнощі та фізичні недуги, зокрема порушення обміну речовин, запальні захворювання та венеричні хвороби. При цьому дослідники підтверджують, що прогностична здатність самоконтролю не залежить від загального інтелекту та соціально-економічного статусу. Прогнози ж антисоціальної поведінки та вживання психоактивних речовин щодо зазначених осіб з низьким самоконтролем показали також і нейронаукові дослідження [11].

Gottfredson M. та Hirschi Т. (1990) висунули свою власну теорію злочинів, яка стверджує, що суттєвим елементом злочинності є знову ж таки відсутність самоконтролю, а соціологічні, біологічні, психологічні та економічні концепції насправді суперечать характеру злочину. Так, особи $з$ високим рівнем самоконтролю враховують довгострокові наслідки своєї поведінки, а ті, що мають низький рівень самоконтролю, цього не роблять. Такий контроль засвоюється, як правило, на ранніх етапах життя, а після навчання досить стійкий до змін [12].

Виходячи 3 аналізу результатів цих та деяких інших сучасних закордонних досліджень, є підстави говорити про фактори адикцій та злочинної поведінки як такі, що мають спільні предиктори, які полягають у низькому самоконтролі. Тобто можна говорити про вплив спільних чинників на формування схильності до адикцій та до злочинної поведінки, а також і про взаємовплив моделей залежної поведінки та факторів кримінологічного ризику.

Водночас злочинність та азартні ігри теж можуть по-різному перетинатись: 1) самі ігри можуть відбуватись 
незаконно; 2) вони можуть сприяти утворенню та функціонуванню кримінальних організацій; 3) сама гра може провокувати злочинну діяльність (наприклад, здобуття грошей); 4) проблеми з азартними іграми значно поширені серед тюремного населення.

Недавні дослідження передбачають зв'язок між проблемою азартних ігор та злочинністю, але як і у випадку 3 хімічними адикціями, важко інтерпретувати напрям причинності. Зокрема, деякі нейробіологічні дослідження показали, що з проблемою азартних ігор пов'язана не сама злочинність, а імпульсивність особи. І дійсно, азартні ігри та кримінальна діяльність можуть бути частиною екстремального ризикованого способу життя, тому важко встановити причинно-наслідковий зв'язок між цими двома видами занять [13].

Необхідним завданням залишається визначення ролі адикцій під час різних злочинних проявів, а також виокремлення спільних рис залежних осіб, що схильні до антисоціальної поведінки.

3 метою визначення характеру зв'язку між адикціями та злочинними проявами варто класифікувати напрями адиктивного впливу на рішення вчинити злочин:

1) вплив хімічних або поведінкових адикцій на рішення вчинити злочин конкретною особою 3 метою реалізації потреб, безпосередньо зумовлених залежністю (результат слугує задоволенню адиктивної потреби);

2) опосередкований вплив хімічних або поведінкових адикцій на рішення вчинити злочин особою, ядро особистості якої зазнало значної деформації під впливом залежності (рівень психічного захворювання);

3) вплив переважно поведінкових адикцій на рішення вчинити злочин у випадку, коли сам процес його вчинення є безпосереднім об'єктом залежності (адиктивне задоволення від процесу злочинної діяльності);

4) вплив переважно хімічних адикцій на рішення вчинити злочин у зв'язку з порушенням гальмівних механізмів особистості та вмиканням сценарію миттєвого задоволення будь-яких потреб будь-яким способом (результат злочинного акту слугує задоволенню безпосередньо не пов'язаних з адикцією потреб).

Важливо, що адикції самі по собі безпосередньо не призводять до злочину на відміну від фінансових та особистих проблем, які утворюються завдяки їм. Залежні особи зазвичай постійно потребують коштів. Втім, кошти, отримані в результаті злочинних актів, лише активізують та посилюють адиктивні прояви. Тому вони не слугують ні для вирішення фінансових проблем, ні для підтримки бажаного способу життя. Цей хибний шлях продовжується доти, доки залишається можливість учинення злочину, тобто поки злочинець не буде затриманий.

Серед злочинів, пов'язаних з адикціями, варто назвати передусім корисливі злочини, вчинені залежними особами за місцем їхньої трудової діяльності або проживання, а також «насильницькі спалахи», фізичні та/або емоційні, що з'являються під впливом адиктивного агента або неможливості його миттєвого отримання. Цей же механізм може також призвести до віктимізації самого адикта, коли, наприклад, насильство в колі близьких осіб супроводжується звинуваченнями в згубній залежності. Ще один вид злочинної активності адиктів пов'язаний із крадіжками особистих даних інших осіб, фінансовими або кредитними махінаціями, шахрайством. Як свідчить аналіз судової практики в Україні, більшість злочинів, що вчиняють адикти, - це ненасильницькі злочини проти власності. Цей висновок узгоджується і з закордонними дослідженнями $[14 ; 15]$.

Часто суб'єкти прикладають значні зусилля, щоб приховати свої антисоціальні дії, втім, лише незначний відсоток погоджується на лікування від згубної залежності. Варто зауважити, що циклічне повторення адиктивних проявів може призводити до циклічного характеру кримі- нальних інцидентів, і це $є$ ще однією рисою, що характеризує злочинність залежних осіб. Як правило, єдиною метою злочину в таких випадках $є$ продовження адиктивної активності, а гроші дуже швидко закінчуються. Проблема ж насильницької злочинної поведінки адиктів насамперед спричиняється результатами соціального тиску, що пов'язаний 3 фінансовими проблемами. Тобто звинувачення у згубній залежності у відповідь можуть викликати застосування фізичного насильства. Однак досить часто родичі всіляко приховують проблему адикта, що у свою чергу дає тому можливість зловживати довірою інших осіб, які не в курсі «проблеми», з метою отримання коштів.

Якщо говорити про особливості особистості глибоко залежного злочинця, що вчиняє корисливі злочини проти власності, то для нього характерним є стрімке та хаотичне «азартне» ставлення до життя в цілому. Йдеться про майже повну відсутність самоконтролю та неспроможність належним чином передбачити наслідки своїх дій. Іноді злочинці-адикти вже є представниками кримінальної субкультури, де ризикована поведінка і злочинна діяльність $є$ нормою. Важливою складовою частиною цього механізму $є$ компанії, що дають так звані «швидкі гроші» (досить часто онлайн) під великі відсотки, але без суттєвих гарантій повернення.

Окремо слід сказати про ризики криміналізації особи, узалежненої від алкоголю. Ряд вітчизняних та закордонних дослідників приділяли цьому факту окрему увагу. Крім загальноприйнятих у кримінології уявлень та ідей протидії цьому явищу, вважаємо за потрібне звернути увагу на такий аспект. Реальну небезпеку представляють перш за все особи, узалежнені від алкоголю, 3 маренням ревнощів на різних етапах його розвитку. Серйозні злочини (вбивство, нанесення тяжких тілесних ушкоджень, згвалтування тощо), за свідченням В.М. Банщикова та Ц.П. Короленка, мали місце лише у хворих на алкоголізм, що страждали через марення ревнощів без явищ алкогольного галюцинозу або алкогольного делірію (біла гарячка). Важливо, що для розвитку алкогольного марення ревнощів необхідним $є$ зниження вищих психічних функцій, зменшення контролю над вчинками, звільнення автоматизмів, а також зміна самих статевих функцій $[16$, с. 218,221$]$. Агресія таких осіб найчастіше виникає за вживання середніх (для такої особи) доз алкоголю і спрямована насамперед на дружину (чоловіка), співмешканку (співмешканця), сексуальну партнерку (партнера) тощо.

На основі аналізу поліцейської статистики та судової практики в Україні є можливим виділити кілька типів осіб 3 антисоціальною поведінкою, що мають хімічні або поведінкові залежності. Класифікація здійснюється 3 метою диференціації запобіжних заходів. Це, зокрема:

1) адикт, що вчиняє корисливі ненасильницькі злочини проти власності з метою задоволення адиктивних потреб;

2) адикт, що вчиняє насильницькі або корисливонасильницькі злочини та, як правило, має суттєві деформації психічного стану, сформовані під впливом адикції;

3) адикт, що є представником субкультури, де ризикована поведінка та вчинення дрібних корисливих або корисливо-насильницьких злочинів є нормою;

4) адикт, який поки що не має фінансових проблем, але завдяки втраті самоконтролю внаслідок дії адиктивного агента, $з$ корисливих спонукань стає частиною системи поширення певного способу адиктивного проведення часу іншими особами.

Кожному 3 цих типів притаманна окрема модель залежної поведінки.

Так, для першого типу характерними є дрібні правопорушення. До нього можна віднести чоловіків і жінок переважно середнього віку. Ці особи вже встигли втратити сім'ю та адекватні соціальні зв'язки; у них відсутня постійна робота, але можуть бути випадкові заробітки; рівень освіти може бути як високим, так і низьким. Втім, 
навіть високий інтелект не допомагає їм піднятись над залежністю. Цих осіб оточення вважає такими, які через свою згубну залежність втратили все. Вони розуміють неадекватність свого способу життя й іноді, за певних умов, можуть погодитись на лікування. Злочинна мотивація таких осіб зводиться до того, що їм вже немає чого втрачати. Вони характеризуються байдужістю до власної долі, але іноді мають певні таланти та позитивні риси, які можуть лягти в основу концепції виправлення злочинної поведінки таких осіб.

Для другого типу осіб характерною є деформація особистості під впливом адикції, а крім цього, може спостерігатися поєднання адикцій з іншими психічними відхиленнями. Ці особи (чоловіки і жінки) з досить юного віку вважались проблемними, часто походять із неблагополучних родин, неодноразово притягуються до кримінальної відповідальності, сім'ю не створюють, іноді мають більшменш тривалі статеві взаємини з особами, в яких також присутні значні особистісні деформації, часто спільне проведення часу полягає саме в досягненні адиктивного задоволення. Це може бути спільне вживання спиртного, наркотиків, азартні ігри. Мотивами вчинення злочинів такими особами є їхня неконтрольована агресивність, часто під впливом психоактивних речовин або через синдром скасування. На відміну від першого типу, ці особи мають демонстративні риси характеру, що значно ускладнює їх виправлення та лікування.

Для третього типу адиктів (переважно чоловіки) характерним є середній рівень інтелектуального розвитку, їхнє психічне здоров'я майже відповідає нормі. Серед них багато осіб з демонстративними рисами особистості, вони досить адекватно комунікують із представниками свого соціального прошарку, іноді створюють власні сім'ї, презирливо ставляться до заборон та контролю, тому за першої нагоди порушують закон. Стежать за своїм зовнішнім виглядом та намагаються підтримувати певний авторитет у середовищі адиктів своєї соціальної групи. Дрібні злочини вчиняють переважно 3 корисливих та хуліганських мотивів. Вважають, що їхня адиктивна поведінка є цілком нормальною: «усі навколо шукають кайф». Втрачають антисоціальні якості лише з віком, практично не піддаються виправленню кримінально-правовими засобами через свою комунікативність та гарну пристосовуваність і адаптованість до середовища.
Четвертий тип адиктів не є сталим. Поступово ці особи зазнають незворотньої деградації особистості та переходять до першого типу адиктів. Вони мають досить високий інтелектуальний розвиток і вважають себе здатними зрозуміти: «алгоритм азартної гри», «мудрість пляшки», «широту горизонтів свідомості під дією наркотичних речовин» тощо. Вони мають свою філософію залежності, характерний середній рівень адаптації в суспільстві, часто мають сім'ю, яку потім втрачають через постійну дію адиктивного агента. Ці особи йдуть на злочин, бо вважають себе кращими за інших адиктів, такими, що «пізнали життя»; їхня злочинна діяльність завжди кружляє навколо згубної пристрасті, їм певний час вдається отримувати від цього і гроші, і задоволення, вони організують нелегальні місця проведення азартних ігор, вживання спиртних напоїв, вирощують наркотичні речовини 3 метою збуту і т.п. Саме ці особи є найбільш небезпечними серед адиктів, бо вони постійно пропагують свій спосіб життя, долучаючи до нього інших осіб. Врештірешт вони або переходять до першого типу внаслідок швидкої деградації особистості під впливом адиктивного агента, або можуть бути зупинені зовнішніми обставинами, до яких відноситься і притягнення до кримінальної відповідальності.

Очевидно, що запобігання злочинній поведінці особи, що має хімічну або поведінкову залежність, полягає в цілісній підтримці з боку держави, в якій важливу роль відіграє фінансовий контроль. Більш сувора ідентифікація клієнтів у банківських онлайн-сервісах та законодавчі обмеження роботи постачальників миттєвих кредитів реально можуть зменшити кількість корисливих злочинів проти власності. Що ж стосується насильницьких проявів, агресії, спрямованої на близьких осіб, то особи з числа адиктів, які мають до них схильність, також повинні мати змогу отримувати необхідне юридичне та психологічне консультування і користуватись підтримкою відповідних державних служб. Ще одним завданням є недопущення віктимізації самого адикта.

Таким чином, нами було окреслено чотири кримінологічно значущі моделі залежної поведінки та простежено їх зв'язок із факторами кримінологічного ризику. Окреслено також основні шляхи запобігання злочинності залежних осіб та форми можливої корекції їхньої поведінки з урахуванням різних ступенів адиктивного впливу.

\section{ЛІТЕРАТУРА}

1. Антонян Ю.М., Леонова О.В., Шостакович Б.В. Феномен зависимого преступника ; под ред. Ю.М. Антоняна. Москва : Аспект Пресс, 2007. 192 c.

2. Про затвердження таблиці співставлення кодів діагностично споріднених груп з кодами Міжнародної статистичної класифрікації хвороб Десятого перегляду (МКХ-10) : Наказ МОЗ України від 29.03.2019 р. № 703. URL: https://moz.gov.ua/article/ministry-mandates/ nakaz-moz-ukraini-vid-29032019--703-pro-zatverdzhennja-tablici-spivstavlennja-kodiv-diagnostichno-sporidnenih-grup-z-kodami-mizhnarodnoistatistichnoi-klasifikacii-hvorob-desjatogo-peregljadu-mkh-10 (дата звернення: 29.07.2020).

3. Психология и лечение зависимого поведения / под ред. С. Даулинга ; пер. с англ. Р.Р. Муртазина. Москва : Независимая фрирма «Класс», 2000. 240 c.

4. Сорокіна О.А. Психологія залежності : навчальний посібник. Кам'янець-Подільський : ПП Буйницький О.А., 2014. 180 с.

5. Железнякова Ю.В. Основні характеристики адиктивної поведінки. Теорія і практика сучасної психології. 2016. № 2. С. 4-8.

6. Короленко Ц.П., Донских Т.А. Семь путей к катастрофе. Новосибирск : Наука, 1990. 224 с.

7. Девиантное поведение подростков: причины, тенденции и формы социальной защиты / под ред. Ю. Клейберга. Москва : Тверь, 1998. $110 \mathrm{c}$.

8. Практикум по психологии состояний : учебное пособие / под ред. А. Прохорова. Санкт-Петербург : Речь, 2004. 480 с.

9. Гуревич М.О. Психиатрия : учебник для медицинских институтов. Москва : Медгиз, 1949. 503 с.

10. Integrating Criminological and Mental Health Perspectives on Low Self-Control: A Multi-Domain Analysis / Noah C. Venables et al. Journal of Criminal Justice. 2018. May-June. Volume 56. Pages 2-10.

11. A gradient of childhood self-control predicts health, wealth, and public safety / Moffitt TE et al. Proceedings of the National Academy of Sciences. 2011. 108 (7). P. 2693-2698.

12. Gottfredson M, Hirschi T. A General Theory of Crime. Palo Alto, CA : Stanford Univ Press, 1990.

13. Kalle Lind, Juha Kääriäinen, Sanna-Mari Kuoppamäki. From problem gambling to crime? Findings from the Finnish National Police Information System. Journal of Gambling Issues. Centre for Addiction and Mental Health, 2015. DOI: 10.4309/jgi.2015.30.10

14. Brown R.I.F. Pathological gambling and associated patterns of crime: Comparisons with alcohol and other drug addictions. Journal of Gambling Behavior 1987. № 3. P. 98-114. DOI: 10.1007/BF01043449

15. Crofts P. Problem gambling and property offences: An analysis of court files. International Gambling Studies. 2003. № 3. P. $183-197$. DOI: $10.1080 / 1356347032000142289$

16. Банщиков В.М., Короленко Ц.П. Алкоголизм и алкогольные психозы. Всесоюзное научное медицинское общество невропатологов и психиатров. Москва, 1968. 257 с. 


\title{
КОМУНІКАТИВНА ПОЗИЦІЯ ПОТЕРПІЛОГО У КРИМІНАЛЬНОМУ ПРОВАДЖЕННІ НА ПІДСТАВІ УГОД
}

\section{COMMUNICATIVE POSITION OF THE VICTIM IN CRIMINAL PROCEEDINGS ON THE BASIS OF THE AGREEMENTS}

\author{
Мудрак І.В., к.ю.н., доцент, \\ доцент кафедри кримінального процесу \\ Національний університет «Одеська юридична академія»
}

\begin{abstract}
У статті досліджується проблематика забезпечення реалізації права потерпілого на процесуальну комунікацію у кримінальному про-
\end{abstract} вадженні на підставі угод.

Висловлюється думка про те, що досить актуальною проблематикою є обов'язкова участь представника потерпілого в кримінальному провадженні з моменту ініціювання укладення угоди між потерпілим та підозрюваним чи обвинуваченим про примирення. Підкреслюється, що очевидною видається обов'язкова участь у кримінальному провадженні представника потерпілого, якщо потерпілим $€$ неповнолітня особа.

Вказується на те, що слід забезпечити обов'язкову участь представника потерпілого в кримінальному провадженні не тільки у разі укладення угоди про примирення (з моменту ініціювання угоди), але й у разі невиконання угоди про примирення - 3 моменту звернення потерпілого з клопотанням про скасування вироку.

Робиться висновок про необхідність введення елементів змісту угоди про примирення в угоду про визнання винуватості, зокрема, у частині розміру шкоди, завданої кримінальним правопорушенням, строку її відшкодування чи переліку дій, не пов'язаних з відшкодуванням шкоди, які підозрюваний чи обвинувачений зобов'язані вчинити на користь потерпілого, строку їх вчинення, оскільки зміст угоди про визнання винуватості мав би захищати й інтереси потерпілого в світлі оновлення галузевого законодавства. Зокрема, зазначається, що ч. 1 ст. 472 КПК слід викласти у такій редакції:

«1. В угоді про визнання винуватості зазначаються ії сторони, формулювання підозри чи обвинувачення та його правова кваліфікація з зазначенням статті (частини статті) закону України про кримінальну відповідальність, істотні для відповідного кримінального провадження обставини, беззастережне визнання підозрюваним чи обвинуваченим своєї винуватості у вчиненні кримінального правопорушення, обов'язки підозрюваного чи обвинуваченого щодо співпраці у викритті кримінального правопорушення, вчиненого іншою особою (якщо відповідні домовленості мали місце), умови часткового звільнення підозрюваного, обвинуваченого від цивільної відповідальності у вигляді відшкодування державі збитків внаслідок вчинення ним кримінального правопорушення, узгоджене покарання та згода підозрюваного, обвинуваченого на його призначення або на призначення покарання та звільнення від його відбування з випробуванням, наслідки укладення та затвердження угоди, передбачені статтею 473 цього Кодексу, наслідки невиконання угоди.

В угоді про визнання винуватості, письмову згоду на укладення якої дає потерпілий, також зазначаються розмір шкоди, завданої кримінальним правопорушенням, строк її відшкодування чи перелік дій, не пов'язаних з відшкодуванням шкоди, які підозрюваний чи обвинувачений зобов'язані вчинити на користь потерпілого, строк їх вчинення».

Ключові слова: кримінальне провадження, угода про примирення, угода про визнання винуватості, потерпілий, кримінально-процесуальна комунікація.

The article explores the problem of ensuring the exercise of the victim's right to procedural communication in criminal proceedings on the basis of agreements.

It is argued that the mandatory involvement of the victim's representative in criminal proceedings since the initiation of the agreement between the victim and the suspect or accused of reconciliation is an urgent issue. It is emphasized that compulsory involvement in the criminal proceedings of a victim's representative appears to be obvious if the victim is a minor.

It is stated that the obligatory representation of the victim's representative in the criminal proceedings should be ensured not only in the case of conciliation agreement (from the moment of initiation of the agreement), but also in case of failure to comply with the conciliation agreement from the request of the victim to request the cancellation of the sentence.

It is concluded that the elements of the content of the conciliation agreement should be included in the plea agreement, in particular as regards the amount of the damage caused by the criminal offense, the term of its compensation or the list of actions not related to the compensation of damage, which the suspect or accused is obliged to commit. for the benefit of the victim, the term of their commission, because the content of the plea agreement should also protect the victim's interests in the light of the sectoral legislation update. In particular, it is noted that Part 1 of Art. 472 of the CPC should be outlined in the following wording:

"1. The plea agreement specifies the parties to it, the formulation of the suspicion or charge and its legal qualification, specifying the article (part of the article) of the Criminal Code of Ukraine, essential to appropriate criminal proceedings circumstances, unreserved recognition of the suspect or the accused's guilt of a criminal offense, the suspect or accused obligations to cooperate in exposing the criminal offense committed by another person (if appropriate arrangements have taken place), conditions for partial release of a suspect accused of civil liability in the form of compensation to the state for the damage caused by the commission of a criminal offense, agreed punishment and consent of the suspect, accused of his or her appointment, punishment and release from serving his sentence, 473 of this Code, the consequences of non-compliance with the agreement.

The plea agreement, the written consent of which is given by the victim, also specifies the amount of the damage caused by the criminal offense, the term of its compensation or the list of actions not connected with compensation of the harm which the suspect or accused is obliged to do in favor of, the term of their commission".

Key words: criminal proceedings, conciliation agreement, plea agreement, victim, criminal procedure communication.

Вступ. Здійснення кримінального провадження на підставі угод як особливого порядку кримінального провадження має на меті насамперед розв'язання наявного кримінальноправового конфлікту між його учасниками, спрощення та скорочення загальної процедури кримінального провадження, забезпечення процесуальної економії, зменшення навантаження на суди, надання самостійності сторонам угоди щодо вирішення питання про призначення узгодженого ними покарання або призначення покарання та звільнення від його відбування 3 випробуванням. Шляхом удосконалення кримінального процесуального законодавства України, що регламентує процедуру укладення угоди про примирення та угоди про визнання винуватості в кримінальному провадженні, може бути вирішена низка теоретичних і практичних проблем, які систематично виникають після запровадження цього інституту до національного законодавства. 
Постановка завдання. 3 огляду на ці міркування мета статті полягає у напрацюванні окремих змін до чинної редакції КПК України в частині забезпечення реалізації кримінально-процесуальної комунікації потерпілого у кримінальному провадженні на підставі угод.

Результати дослідження. Згідно із Законом України «Про внесення змін до деяких законодавчих актів України щодо забезпечення діяльності Національного антикорупційного бюро України та Національного агентства 3 питань запобігання корупції» від 12.02.2015 р. [1] були справедливо внесені зміни та доповнено ч. 2 ст. 52 КПК пунктом 9, та визначено, що у разі укладення угоди між прокурором та підозрюваним чи обвинуваченим про визнання винуватості обов'язкова участь захисника забезпечується у кримінальному провадженні з моменту ініціювання укладення такої угоди. Відповідно до Закону України «Про внесення змін до Кримінального та Кримінального процесуального кодексів України з метою реалізації положень Конвенції Ради Свропи про запобігання насильству стосовно жінок і домашньому насильству та боротьбу з цими явищами» від 6.12.2017 р. [2] угода про примирення у кримінальних провадженнях щодо злочинів, пов'язаних 3 домашнім насильством, може бути укладена лише за ініціативою потерпілого, його представника або законного представника.

Принагідно зазначимо, що згідно з ч. 4 ст. 394 КПК серед підстав, які уможливлюють оскарження вироку суду першої інстанції на підставі угоди між прокурором та підозрюваним, обвинуваченим про визнання винуватості законодавець не вказує на відсутність захисника, участь якого $є$ обов'язковою, як на одну з таких підстав, що не узгоджується 3 п. 9 ч. 2 ст. 52, п. 4 ч. 2 ст. 412 КПК. А вказівка у п. 1 ч. 7 ст. 474 КПК на те, що суд відмовляє в затвердженні угоди, якщо умови угоди суперечать вимогам КПК та/або закону, вважаємо, вказує передусім на зміст угоди згідно зі ст. 472 КПК, що, на превеликий жаль, підтверджує й судова практика (наприклад, вироком Вижницького районного суду Чернівецької області від 02.10 .2015 р. затверджено угоду від 14 вересня 2015 року про визнання винуватості між ОСОБА 2 та старшим прокурором прокуратури Вижницького району Чернівецької області ОСОБА 3 у кримінальному провадженні, внесеному в Єдиний реєстр досудових розслідувань за № 12015260060000446 від 29.08.2015 року; зазначається, що підстав для відмови в затвердженні угоди про визнання винуватості, передбачених ч. 7 ст. 474 КПК України, не встановлено; проте захисник обвинуваченого участі у судовому засіданні не брав, а вказівка на п. 9 ч. 2 ст. 52 КПК в судовому рішенні відсутня) [3].

Слід звернути увагу також на таке: досить актуальною проблематикою $є$ обов'язкова участь представника потерпілого в кримінальному провадженні з моменту ініціювання укладення угоди між потерпілим та підозрюваним чи обвинуваченим про примирення. На нашу думку, потерпілий - жертва кримінального правопорушення під час ініціювання та укладення угоди про примирення в кримінальному провадженні неспроможний на належному рівні комунікувати 3 метою захисту своїх законних інтересів в силу незначної юридичної обізнаності та домогтися суб'єктивно бажаного результату, який повинен настати після укладення та затвердження такої угоди про примирення. До таких висновків приходимо, зокрема, аналізуючи матеріали судової практики (Узагальнення ВССУ судової практики здійснення кримінального провадження на підставі угод від 22.01.2014р.) [4], які свідчать про те, що неналежне врахування сторонами угоди про примирення вимог процесуального закону в практичній діяльності трапляється досить часто. Причому здебільшого йдеться саме про неврахування вимог процесуального закону в бік порушення прав та законних інтересів потерпілого в кримінальному провадженні.
Так, вироком Кіровоградського районного суду затверджено угоду про примирення. На вказаний вирок прокурором було подано апеляцію, в якій він просив судове рішення скасувати через неправильне застосування закону України про кримінальну відповідальність, істотне порушення вимог кримінального процесуального закону та направити кримінальне провадження за обвинуваченням О. до районного суду для проведення нового судового провадження в загальному порядку. Прокурор мотивував свої доводи тим, що суд, не забезпечивши присутність потерпілої особи у судовому засіданні, не пересвідчився у добровільності укладеної угоди з іiї боку та не роз'яснив потерпілій наслідки укладення такої угоди, таким чином поверхнево перевірив обставини укладення угоди, чим припустився істотного порушення вимог кримінального процесуального закону [5].

Непоодинокими $€$ випадки, коли угоди не містили відомостей про розмір шкоди, завданої кримінальним правопорушенням, строк ії відшкодування чи перелік дій, не пов'язаних з відшкодуванням шкоди, які підозрюваний чи обвинувачений зобов'язаний вчинити на користь потерпілого, а також строк їх вчинення. Так, 3 цих підстав Хмельницький міськрайонний суд ухвалою від 5 червня 2013 р. відмовив у затвердженні угоди між обвинуваченим за ч. 1 ст. 296 КК К. В. М. та потерпілою Г. Г. О., оскільки в угоді було зазначено лише про те, що обвинувачений зобов'язується відшкодувати шкоду, без зазначення іï розміру і строку відшкодування. Крім того, угодою було передбачено звільнення від відбування покарання, але без посилання на норму закону як підставу такого звільнення, також сторони в угоді вказали на відсутність обтяжуючих покарання обставин, тоді як обвинувачений вчинив злочин у стані алкогольного сп'яніння [6].

В угоді про примирення між потерпілим П. О. та підозрюваним М. Р., затвердженій вироком Мелітопольського міськрайонного суду Запорізької області, не визначено строки відшкодування шкоди потерпілому, у якого було викрадено майно. За змістом угоди, яку було надано до суду 3 обвинувальним актом, вбачається, що підозрюваний М. Р. під час розслідування визнав себе винуватим і зобов'язується у найкоротші строки відшкодувати збитки потерпілому. При цьому які саме збитки та про які строки йшлося в угоді, встановити з ії змісту неможливо. Інші дані щодо поновлення прав потерпілого у матеріалах провадження відсутні.

А тому доходимо висновку про те, що досить часто потерпілі з огляду на свою правову неосвіченість залишаються пасивними учасниками укладення угоди, при цьому їхні права внаслідок затвердження судом такої угоди не поновлюються. Не завжди, як свідчить судова практика, належним чином реагує на такі порушення й суд, який зобов'язаний перевірити умови угоди на відповідність кримінальному та кримінальному процесуальному закону й у разі встановлення такої невідповідності прийняти рішення щодо відмови в затвердженні угоди.

Ухвалою Голопристанського районного суду Херсонської області від 21 березня 2013 р. було відмовлено в затвердженні угоди між обвинуваченим К. С., дії якого кваліфіковано за ч. 1 ст. 125 КК, та потерпілим К. Ю. у зв'язку з тим, що попри констатацію в угоді про примирення обов'язку обвинуваченого відшкодувати потерпілому матеріальні та моральні збитки, заподіяна шкода, як засвідчила перевірка в судовому засіданні умов угоди, потерпілому ані на момент укладення угоди, ані на час підготовчого судового провадження відшкодована не була. 3 підстав незазначення в угоді відомостей про відшкодування чи невідшкодування шкоди, факт завдання якої в судовому засіданні підтвердили потерпілі, Хмельницький міськрайонний суд ухвалою від 30 квітня 2013 р. цілком правильно прийняв рішення про відмову у затвердженні угоди між обвинуваченим за ч. 1 ст. 185 КК Ч. О. і потерпілою Р. Н. [7]. 
Крім того, угода про примирення також може укладатися, якщо іiі сторонами чи стороною $є$ неповнолітні. У такому разі угода укладається за участю законних представників і захисників неповнолітніх. При цьому якщо неповнолітній досяг шістнадцятирічного віку, він має право укладати угоду про примирення самостійно, але за наявності згоди його законного представника. Якщо ж неповнолітній не досяг 16 років, угоду про примирення за його згодою укладає законний представник неповнолітнього. Тому очевидною видається обов'язкова участь у кримінальному провадженні представника потерпілого, якщо потерпілим є неповнолітня особа.

Загалом слід погодитись, що проблема забезпечення права потерпілого мати свого представника у кожному кримінальному провадженні загострилася у зв'язку з прийняттям КПК України 2012 р. і появою в ньому нових, раніше не відомих кримінальному процесу України інститутів (інституту укладення угоди про примирення між потерпілим та підозрюваним чи обвинуваченим), нових процесуальних дій (особливо негласних слідчих (розшукових) дій), нових положень щодо збирання та оцінювання доказів під час досудового розслідування і в судовому провадженні (щодо допустимості доказів, оцінювання показань з чужих слів тощо) [8]. Тому, на наше переконання, обов'язкова участь представника потерпілого в кримінальному провадженні має забезпечуватись у разі укладення угоди між потерпілим та підозрюваним чи обвинуваченим про примирення 3 моменту ініціювання укладення такої угоди.

Крім того, вважаємо, що слід забезпечити обов'язкову участь представника потерпілого в кримінальному провадженні не тільки у разі укладення угоди про примирення (з моменту ініціювання угоди), але й у разі невиконання угоди про примирення - 3 моменту звернення потерпілого $з$ клопотанням про скасування вироку. Адже потерпілому потрібна допомога представника-адвоката, щоб довести невиконання засудженим умов угоди, за необхідності оскаржити відмову у задоволенні клопотання про скасування вироку, а у разі якщо угода була ініційована, наприклад, на стадії досудового розслідування - для представництва інтересів потерпілого під час подальшого досудового та судового провадження.

Актуальним $€$ також питання надання потерпілому права збирати докази невиконання засудженим умов угоди про примирення / визнання винуватості для належного правового обгрунтування подання ним до суду клопотання про скасування вироку, ухваленого на підставі угоди про примирення.

На нашу думку, на обов'язковість участі представника потерпілого під час укладення угоди про примирення вказують і зміни до ст. 469 КПК, згідно з якими угода про примирення у кримінальних провадженнях щодо злочинів, пов'язаних $з$ домашнім насильством, може бути укладена лише за ініціативою потерпілого, його представника або законного представника.

Також зазначимо, ЗУ «Про внесення змін до Кримінального процесуального кодексу України щодо удосконалення механізмів забезпечення завдань кримінального провадження» від 16.03.2017 р. [9] були внесені істотні зміни до ст. 469 КПК щодо умов укладення угод про визнання винуватості. Таким чином, зазначені умови не відповідають вимогам юридичної визначеності як складнику верховенства права та мають бути уточнені з метою забезпечення інтересів потерпілих. Цю проблематику дослідила I.В. Гловюк $[10$, с. $40-42]$ та слушно звернула увагу на те, що зміст угоди про визнання винуватості аж ніяк не захищає інтереси потерпілих, зокрема, щодо відшкодування шкоди, завданої кримінальним правопорушенням. Погоджуємось, що така умовна «участь» потерпілого в укладенні угоди про визнання винуватості не дає відповіді на питання, на що саме потерпілий дає згоду: на факт укла- дення угоди про визнання винуватості, чи то він погоджується з формулюванням підозри чи обвинувачення та його правовою кваліфікацією, узгодженим покаранням, а також на питання, які правові наслідки заяви потерпілого у судовому засіданні, що він не згоден з угодою про визнання винуватості (адже зміни до ч. 4 та ч. 7 КПК ст. 474 КПК щодо встановлення та врахування у судовому засіданні волевиявлення потерпілого не внесені); чи можливе укладення угоди про визнання винуватості у провадженнях щодо кримінальних правопорушень, внаслідок яких шкода правам та інтересам окремих осіб, у яких беруть участь потерпілий або потерпілі, без укладення угоди про примирення (у тих провадженнях, де це можливо з урахуванням положень ч. 3 ст. 469 КПК). Тому щодо вирішення цієї проблеми підтримуємо ініціативу ввести елементи змісту угоди про примирення в угоду про визнання винуватості, зокрема, у частині розміру шкоди, завданої кримінальним правопорушенням, строку іiі відшкодування чи переліку дій, не пов'язаних з відшкодуванням шкоди, які підозрюваний чи обвинувачений зобов'язані вчинити на користь потерпілого, строку їх вчинення, і тоді, відповідно, визнавати ініціатором скасування угоди про визнання винуватості також потерпілого, про що вносити зміни до ст. 476 КПК. Крім того, необхідно вносити зміни й до ч. 4 ст. 394 КПК щодо можливості оскарження вироку суду першої інстанції на підставі угоди між прокурором та підозрюваним, обвинуваченим про визнання винуватості, вказавши на підстави оскарження вироку потерпілим, його представником, законним представником.

Загалом же слід, на нашу думку, підтримати законодавчу ініціативу щодо надання потерпілим / потерпілими письмової згоди на укладення угоди про визнання винуватості відповідно до ч. 4 ст. 469 КПК, оскільки аналіз судової практики попередніх років свідчить про те, що було виявлено численні випадки, коли слідчий / прокурор, нехтуючи забороною щодо укладення угоди про визнання винуватості у провадженнях, де є потерпілий, такі угоди укладав, а судді, не звертаючи на таке порушення належної уваги або навіть посилаючись на потерпілих у мотивувальній частині вироку, такі угоди затверджують. Так, вироком Ізяславського районного суду Хмельницької області від 19 березня 2013 р. у справі № 675/523/13-к затверджено угоду про визнання винуватості, укладену між прокурором та $Є$. В., обвинуваченим у вчиненні злочинів, передбачених ч. 1 ст. 191 , ч. 1 ст. 358 , ч. 3 ст. 358 КК [11]. Аналогічні порушення закону допускали й інші суди, затверджуючи всупереч вимогам ч. 4 ст. 469 КПК угоди про визнання винуватості, хоч у кримінальному провадженні фактично були потерпілі, тобто шкоди було завдано не лише публічним чи суспільним інтересам, а й приватним (вирок Хмельницького міськрайонного суду у кримінальному провадженні за обвинуваченням К. А. у вчиненні злочину, передбаченого ч. 2 ст. 190, ч. 1 ст. 364 КК, вирок Новоушицького районного суду Хмельницької області у кримінальному провадженні за обвинуваченням К. В. за ч. 2 ст. 191, ч. 1 ст. 366 КК, вироки Старосинявського районного суду Хмельницької області у кримінальних провадженнях за обвинуваченням П. Л. за ч. 1 ст. 191 КК та за обвинуваченням Щ. В. за ч. 1 ст. 191 КК, вирок Сватівського районного суду Луганської області у кримінальному провадженні за обвинуваченням В. О. за ч. 2 ст. 185 КК, вирок Ровеньківського міського суду Луганської області у кримінальному провадженні за обвинуваченням Б. С. за ч. 1 ст. 125 КК).

Навіть більше доречно було б із врахуванням усіх вищезазначених проблем, пов'язаних з правозастосуванням, та вимог КПК України розробити та запропонувати єдиний проєкт угоди про примирення в кримінальному провадженні та проєкт угоди про визнання винуватості в кримінальному провадженні, передбачивши конкретний зміст відповідних угод (конкретні формулювання), 
що сприятиме як захисту прав та законних інтересів потерпілого, так і слугуватиме єдності судової практики загалом. Це питання проблемного характеру є надзвичайно актуальним, на наше переконання, особливо якщо вести мову про необхідність введення елементів змісту угоди про примирення в угоду про визнання винуватості, зокрема, у частині розміру шкоди, завданої кримінальним правопорушенням, строку іiі відшкодування чи переліку дій, не пов'язаних з відшкодуванням шкоди, які підозрюваний чи обвинувачений зобов'язані вчинити на користь потерпілого, строку їх вчинення, оскільки, вкотре підкреслимо, зміст угоди про визнання винуватості мав би захищати й інтереси потерпілого в світлі оновлення галузевого законодавства.

Отже, враховуючи вищевикладене, вважаємо за необхідне внесення системних змін та доповнень до ч. 3, 4 ст. 394 КПК, ч. 2 ст. 473 КПК, ч. 4, 7 ст. 474 КПК, ч. 1 ст. 476 КПК, ч. 3 ст. 424 КПК, ч. 2 ст. 412 КПК, ч. 1 ст. 472 КПК.

Так, зокрема, ч. 1 ст. 472 КПК слід викласти, на нашу думку, у такій редакції:

«1. В угоді про визнання винуватості зазначаються іiї сторони, формулювання підозри чи обвинувачення та його правова кваліфікація з зазначенням статті (частини статті) закону України про кримінальну відповідальність, істотні для відповідного кримінального провадження обставини, беззастережне визнання підозрюваним чи обвинуваченим своєї винуватості у вчиненні кримінального правопору- шення, обов'язки підозрюваного чи обвинуваченого щодо співпраці у викритті кримінального правопорушення, вчиненого іншою особою (якщо відповідні домовленості мали місце), умови часткового звільнення підозрюваного, обвинуваченого від цивільної відповідальності у вигляді відшкодування державі збитків внаслідок вчинення ним кримінального правопорушення, узгоджене покарання та згода підозрюваного, обвинуваченого на його призначення або на призначення покарання та звільнення від його відбування 3 випробуванням, наслідки укладення та затвердження угоди, передбачені статтею 473 цього Кодексу, наслідки невиконання угоди.

В угоді про визнання винуватості, письмову згоду на укладення якої дає потерпілий, також зазначаються розмір шкоди, завданої кримінальним правопорушенням, строк іiі відшкодування чи перелік дій, не пов'язаних з відшкодуванням шкоди, які підозрюваний чи обвинувачений зобов'язані вчинити на користь потерпілого, строк їх вчинення».

Висновки. Отже, необхідністю $є$ введення елементів змісту угоди про примирення в угоду про визнання винуватості, зокрема, у частині розміру шкоди, завданої кримінальним правопорушенням, строку іiї відшкодування чи переліку дій, не пов'язаних 3 відшкодуванням шкоди, які підозрюваний чи обвинувачений зобов'язані вчинити на користь потерпілого, строку їх вчинення, оскільки зміст угоди про визнання винуватості мав би захищати й інтереси потерпілого в світлі оновлення галузевого законодавства.

\section{ЛITEPATУРA}

1. Про внесення змін до деяких законодавчих актів України щодо забезпечення діяльності Національного антикорупційного бюро України та Національного агентства з питань запобігання корупції: Закон України від 12.02.2015 p. URL: https://zakon.rada.gov.ua/laws/ show/198-19.

2. Про внесення змін до Кримінального та Кримінального процесуального кодексів України з метою реалізації положень Конвенції Ради Європи про запобігання насильству стосовно жінок і домашньому насильству та боротьбу з цими явищами: Закон України від 6.12.2017 p. URL: https://zakon.rada.gov.ua/laws/show/2227-19.

3. Вирок Вижницького районного суду Чернівецької області від 02.10.2015 p. URL: http://reyestr.court.gov.ua/.

4. Узагальнення ВССУ судової практики здійснення кримінального провадження на підставі угод від 22.01.2014 p. URL: https://zib.com.ua/ua/print/92557-uzagalnennya vssu sudovoi praktiki zdiysnennya kriminalnogo .html.

5. Вирок Кіровоградського районного суду від 05.07.2013 p. URL: http://reyestr.court.gov.ual.

6. Ухвала Хмельницького міськрайонного суду від 05.06.2013 p. URL: http://reyestr.court.gov.ua/.

7. Ухвала Голопристанського районного суду Херсонської області від 21.03.2013 p. URL: http://reyestr.court.gov.ua/.

8. Шибіко В.П. Проблема забезпечення прав потерпілого за новим КПК України 2012 p. URL: http://www.pravnuk.info/ 2013-12-27-15-13-14/382-problema-zabezpechennya-prav-poterpilogo-za-novim-kpk-ukra\%D1\%97ni-2012-roku.html.

9. Про внесення змін до Кримінального процесуального кодексу Україну щодо удосконалення механізмів забезпечення завдань кримінального провадження: Закон України від 16.03.2017 p. URL: https://zakon.rada.gov.ua/laws/show/1950-19.

10. Гловюк І.В. Укладення угод про визнання винуватості: окремі питання у контексті оновлення законодавства. Теорія та практика протидії злочинності у сучасних умовах: збірник тез Міжнародної науково-практичної конфреренції (10 листопада 2017 року) / упор. О.В. Авраменко, С.С. Гнатюк, І.В. Красницький. Львів: ЛьвДУВС. 316 с. С. 40-42.

11. Вирок Ізяславського районного суду Хмельницької області від 19.03. 2013 p. URL: http://reyestr.court.gov.ua/. 


\title{
ДО ПИТАННЯ КРИМІНАЛЬНОГО ПРОТИПРАВНОГО НЕВІГЛАСТВА (НА ПРИКЛАДІ СТАТТІ 140 КРИМІНАЛЬНОГО КОДЕКСУ УКРАЇНИ «НЕНАЛЕЖНЕ ВИКОНАННЯ ПРОФЕСІЙНИХ ОБОВ'ЯЗКІВ МЕДИЧНИМ АБО ФАРМАЦЕВТИЧНИМ ПРАЦІВНИКОМ»)
}

\author{
TO THE QUESTION OF CRIMINAL UNLAWFUL IGNORANCE \\ (ON EXAMPLE OF THE ARTICLE 140 OF THE CRIMINAL CODE OF UKRAINE \\ "IMPROPER PERFORMANCE OF PROFESSIONAL DUTY \\ BY A MEMBER OF MEDICAL OR PHARMACEUTICAL PROFESSION")
}

\author{
Парамонова О.С., к.ю.н., \\ старший викладач кафедри державно-правових дисциплін \\ Черкаський національний університет імені Богдана Хмельницького
}

\begin{abstract}
Статтю присвячено розгляду кримінального протиправного (злочинного) невігластва як правової категорії через призму неналежного виконання професійних обов'язків медичним або фрармацевтичним працівником, передбаченого ст. 140 Кримінального кодексу України. Приділено особливу увагу вивченню наукового доробку щодо сутності злочинного невігластва. Відзначено, що поряд із цим існує високий ступінь невизначеності досліджуваного питання.

У зв'язку з тим, що суб'єктивна сторона злочину за ст. 140 Кримінального кодексу України характеризується необережною формою вини, автор аналізує невігластво в контексті необережності з використанням матеріалів судової практики.

У статті розглянуто співвідношення встановлених кримінальним законом різних видів необережної форми вини з кримінальним протиправним невіглаством, визначено їхні схожі й відмінні ознаки. Зазначено, що подібність невігластва з кримінальною протиправною самовпевненістю полягає в тому, що суб'єкт кримінального правопорушення легковажно виконує роботу, яка вимагає спеціального знання або навичок, усвідомлює, як правило, загальну небезпеку такого роду діяльності, хоча конкретного характеру цієї небезпеки він може й не уявляти. Схожість із кримінальною протиправною недбалістю виявляється в тому, що особа не передбачає можливості настання суспільно небезпечних наслідків свого діяння.

Встановлено, що на відміну від самовпевненості в разі прояву невігластва суб'єкт не передбачає можливості настання конкретних суспільно небезпечних наслідків і не розраховує на будь-які конкретні обставини, які цим наслідкам допоможуть запобігти. Розбіжність невігластва з кримінальною караною недбалістю характеризується тим, що особа в разі вчинення некваліфрікованих, непрофесійних діянь не могла передбачити суспільно небезпечні наслідки, хоча була зобов'язана це зробити.

Висловлена пропозиція вважати необережність кримінальним протиправним невіглаством у разі, якщо особа легковажно ставилась до виконання покладених на неї професійних обов'язків, не передбачала й не могла передбачити можливості настання суспільно небезпечних наслідків свого діяння (дії або бездіяльності), хоча повинна була їх передбачити з урахуванням презумпції опанування нею спеціальними знаннями й вміннями.

Ключові слова: медичний або фрармацевтичний працівник, медична або фармацевтична діяльність, професійна некомпетентність,
\end{abstract} необережність, кримінальна правова недбалість, кримінальна правова самовпевненість, кримінальне правове невігластво.

The article is devoted to criminal unlawful ignorance as a legal category through the prism of improper performance of professional duties by a medical or pharmaceutical worker under Article 140 of the Criminal Code of Ukraine. Special attention is paid to the study of important scientific heritage on the criminal ignorance. Despite this, a high level of research uncertainty on the analyzed issue is noted. Due to the fact, that the subjective side of a criminal offence under Article 140 of the Criminal code of Ukraine is characterized by the recklessness form of guilt, the author characterizes ignorance in the context of recklessness, using materials of a court practice.

The article examines the interrelation between the various types of recklessness form of guilt under the criminal law and criminal unlawful ignorance, identifies their similarities and differences. It is mentioned, the similarity of ignorance with criminal unlawful presumption is that the subject of the criminal offense recklessly does his job that requires special knowledge or skills, usually aware of the general danger of this type of activity, although the specific nature of this danger he may not imagine. The similarity with criminal unlawful negligence is reflected in the fact that a person does not anticipate that his/her act may have socially injurious consequences. However, unlike presumption, in the case of ignorance, the subject does not anticipate socially injurious consequences and does not count on any specific circumstances that will help prevent these consequences. The difference between ignorance and criminal negligence is characterized by the fact that a person could not anticipate socially injurious consequences when committing unskilled, unprofessional acts, although he was obliged to do so.

The author suggests to consider negligence as criminal unlawful ignorance if a person was negligent in the performance of his professional duties, did not anticipate and could not anticipate socially injurious consequences of his acts (actions or omissions), although he should have foreseen them taking into account presumption of possession of special knowledge and skills.

Key words: medical or pharmaceutical worker, medical or pharmaceutical activity, professional incompetence, recklessness, criminal legal negligence, criminal legal presumption, criminal legal ignorance.

Сучасна кримінально-правова наука України характеризується активним пошуком моделі протидії злочинам у сфері професійної діяльності. Це пов'язано, зокрема, зі зростанням випадків, «коли за розв'язання тих чи інших питань, виконання завдань беруться люди, які не мають для цього належної підготовки, кваліфікації, знань, умінь i навичок» [1, с. 37], що призводить до заподіяння чи створення загрози заподіяння істотної шкоди правоохоронювальним інтересам. Таке явище в доктрині кримінального права отримало назву «злочинне невігластво», а у світлі останніх змін у кримінальному законодавстві його можна визначити як «кримінальне протиправне невігластво».
Значної актуальності вищезазначене набуває під час дослідження кримінального правопорушення, передбаченого ст. 140 Кримінального кодексу України (далі - КК) «Неналежне виконання професійних обов'язків медичним або фармацевтичним працівником». До речі, відповідно до положень ст. 12 КК це кримінальне правопорушення $€$ нетяжким злочином, адже санкцією ст. 140 КК, крім інших альтернативних покарань, передбачено покарання у вигляді позбавлення волі [2]. Суб'єкти діяння, виявляючи професійну некомпетентність під час виконання своїх службових або функціональних обов'язків, фактично діючи в межах професійного невігластва, здатні заподіяти тяжкі наслідки потерпілому. 
Звернення до вивчення невігластва як кримінальноправової категорії не $є$ новим для теорії кримінального права. Дослідження його змісту грунтується на загальнотеоретичних положеннях вчення про вину, сформульованих у працях багатьох вітчизняних і зарубіжних вчених, зокрема Р.В. Вереші, С.В. Гончаренка, М.С. Грінберга, П.С. Дагеля, О.О. Дудорова, В.О. Навроцького, С.І. Нежурбіди, А.І. Рарога, М.І. Хавронюка, М.Д. Шаргородського й інших, а також на наукових підходах тих дослідників, які викладали проблеми суб'єктивної сторони злочинів, вчинених у сфері медичної діяльності, а саме Ф.Ю. Бердичевського, І.Г. Вермеля, В.О. Глушкова, М.І. Ковальова, Г.В. Чеботарьової тощо. Водночас погляди на природу явища різні, неоднозначні: від міркувань про осудність невігласа до визначення місця невігластва серед форм вини під час проявів некомпетентної поведінки суб'єкта кримінального правопорушення.

Мета статті полягає у викладенні як основних наукових позицій щодо розуміння кримінального протиправного невігластва в цілому, так і проблемних питань щодо визначення його змісту, ознак і співвідношення з іншими видами вини в контексті неналежного виконання професійних обов'язків медичним або фармацевтичним працівником.

Аналіз теоретичних оцінок природи кримінального протиправного невігластва дозволяє виділити такі тенденції щодо його розуміння. Так, у новітніх дослідженнях зазначене явище розглядається «під кутом зору встановлення осудності». Відомий вчений В.О. Навроцький відзначає, що «суть проблеми кримінально-правової оцінки злочинного невігластва полягає у визначенні того, чи $\epsilon$ осудною особа, що вчинила діяння, передбачене Кримінальним кодексом України внаслідок невігластва, а якщо так, то чи діє вона за наявності ознак, що відповідають певній формі (умисел чи необережність) і виду (прямий чи непрямий умисел, злочинна самовпевненість чи злочинна недбалість) вини» [1, с. 43]. Водночас автор розуміє, що кримінально-правові особливості злочинного невігластва належать до суб'єктивних ознак посягання, в тому числі йому притаманні риси всіх форм і видів вини, передбачених КК. Думка, що невігластво, «припускаючи незнання певного питання та діяльність в рамках цього незнання, <..> іноді межує з казусом, необережністю, самовпевненістю або непрямим умислом», притаманна й М.С. Грінбергу [3, с. 225]. Вчений пропонує в кримінальному законі виокремити норму про злочинне невігластво такого змісту: «Незнання спеціалістом правил своєї професії, що спричинило нещасні випадки з людьми або інші тяжкі наслідки» [3, с. 229]. I хоч така позиція має право на життя, незрозуміле місце норми в законі.

Втім, панівним залишається погляд на невігластво через призму необережної форми вини. Щоправда, деякі вчені відносять такі дії до злочинної недбалості [4, с. 90]; інші переконують, що є підстави вважати некомпетентну діяльність злочинною самовпевненістю [5, с. 184 ; 6, с. 204]; треті підкреслюють, що невігластво має схожі ознаки й 3 недбалістю, і $з$ самовпевненістю, але не $\epsilon$ окремим видом необережності [7, с. 259; 8, с. 56]; четверті зазначають, що ця категорія $є$ самостійним видом необережності $[9$, с. $115 ; 10$, с. $99 ; 11$. с. 97$]$.

Так, різновидом злочинної недбалості називає невігластво С.В. Гончаренко й пише, що у випадках прояву завідомої некомпетентності, навіть діючи в ситуації, обтяженій факторами ризику, особа могла й повинна була передбачати настання шкідливих наслідків [4, с. 90].

Проте О.О. Дудоров і М.I. Хавронюк позначену проблему пропонують «розв'язувати не шляхом вдосконалення законодавчого визначення необережності як форми вини й тим більш відмови від принципу суб'єктивного ставлення у вину, а шляхом відповідної інтерпретації (тлумачення) легальної дефініції самовпевненості як виду необережності» [6, с. 204]. За судженням науковців, «<..> відповідна особа (невіглас), беручись за виконання певної роботи, не може не передбачати можливість настання суспільно небезпечних наслідків, хай навіть i не зовсім конкретних. <..> особа передбачає абстрактну можливість настання таких наслідків, усвідомлюючи, що взагалі (в аналогічних випадках) схожі діяння можуть призвести до суспільно небезпечних наслідків, але виключає їх настання в конкретному випадку. Так, професійно непідготовлений медичний працівник може розраховувати на те, що раніше в подібних випадках в його практиці все закінчувалось добре, що в разі необхідності на допомогу прийдуть його кваліфіковані колеги, організм пацієнта витримає медичне втручання тощо. $<\ldots>$ діючи самовпевнено, «невіглас» не бажає настання шкідливих наслідків і свідомо не допускає їх настання» [6, с. 203].

Підтримуючи погляди, що невігластво не є окремим видом необережної форми вини, Р.В. Вереша погоджується, що таке явище існує, та вказує: «У загальному розумінні сутності злочинного невігластва можна зазначити, що наявність вини в діяннях суб'єкта злочину визначається наявною в особи можливістю порівняти вимоги, які ставляться до відповідного виду діяльності, з власними знаннями й досвідом. Відсутність же можливості передбачити наслідки своїх дій (бездіяльності) компенсується усвідомленням або можливістю усвідомлювати загальну суспільну небезпечність вчинюваних дій (бездіяльності) й власну непідготовленість до їх вчинення» [7, с. 259-260].

Вважаючи, що злочинне невігластво є своєрідним видом необережності, П.С. Дагель має на увазі випадки, коли людина, яка самовпевнено здійснює діяльність, що вимагає спеціального знання, професійних навичок або особистісних якостей, заподіює суспільно небезпечні наслідки, які вона не могла передбачити внаслідок професійної некомпетентності [9, с. 115]. 3 цим положенням солідарний В.О. Глушков [10, с. 99]. Український вчений C.I. Нежурбіда також стверджує, що «злочинна необізнаність» (так автор переклав із російської термін «преступное невежество»-O.П.) є різновидом необережності. Він зазначає: «Під час «злочинної необізнаності» особа не усвідомлює, але має можливість усвідомлювати суспільну небезпеку своєї поведінки, зобов'язана утриматись від вчинення діяння та має можливість усвідомити свою непідготовленість до цієї дії. Тому суб'єктивний критерій необережності тут є. На відміну від самонадійності, особа не передбачає суспільно небезпечних наслідків своїх дій, а на відміну від недбалості, й не може їх передбачати (саме в силу своєї необізнаності). Проте на відміну від випадку, ця можливість викликана причинами, за які особа не має права на вибачення» [11, с. 97].

Свого часу М.Д. Шаргородський писав: «Людина в сучасному суспільстві повинна відповідати за те, що вона приймає на себе відповідальність за діяння, з наслідками яких вона не може впоратися. Так, повинен відповідати хірург, який неграмотно провів операцію (в результаті чого помер хворий), але який цю операцію краще провести не міг тому, що він погано навчався, хоча закінчив медичний інститут, краще оперувати не вміс, однак повинен, якщо він береться за таку діяльність» [12, с. 550]. Таким чином, опанування певною сумою професійних знань (компетентність - О.П.) - «не лише право будь-якого фахівця, що дозволяє йому займатися відповідною діяльністю, але й його обов'язок» [13, с. 15].

Зауважимо, що, притягуючи до кримінальної відповідальності медичного або фармацевтичного працівника за неналежне виконання професійних обов'язків (у більшості розглянутих нами вироків до кримінальної відповідальності притягуються саме медичні працівники - О.П.), суди встановлюють факти некомпетентності й вказують про це у своїх рішеннях. Наприклад, один $з$ апеляційних судів відмітив, що обвинувачена лікар-хірург, перебува- 
ючи за сумісництвом на посаді лікаря-онколога й не маючи достатньої освіти й кваліфікаційного рівня, несумлінно поставилась до виконання своїх професійних обов'язків і неналежно їх виконала [14]. Неосвіченість, недостатність знань і вмінь у медичного працівника характеризують останнього як некомпетентного спеціаліста й не дозволяють йому займати посади, до яких він неготовий.

Розмірковуючи над природою компетентності, М.С. Грінберг вважає, що «компетентність будь-якого фахівця обмежена певними межами, які умовно можна диференціювати на «горизонтальні» й «вертикальні»» [3, с. 225] Дійсно, наприклад, у горизонтальному зрізі лікар-хірург зобов'язаний знати певний розділ хірургії (кардіохірургія, нейрохірургія та таке інше), суміжні 3 нею розділи медицини (травматологія, анестезіологія, дитяча хірургія та таке інше). У вертикальному - межі компетентності неоднакові, тому що можливості початківця лікаря та лікаря вищої кваліфікації, лікаря та фельдшера або медсестри різні. Таким чином, «коли особа не засвоїла знання, які вона повинна була й мала можливість засвоїти, вона несе відповідальність за свої незнання (невігластво)» [3, с. 229].

З урахуванням того, що суб'єктивна сторона злочину за ст. 140 КК характеризується необережною формою вини, ми розглянемо невігластво саме в контексті необережності. Термін «недбалість», який використано в ст. 140 КК найімовірніше характеризує об'єктивну сторону такого злочину, а тому не $є$ вказівкою на вид необережності. Тому вина в разі неналежного виконання професійних обов'язків медичним або фармацевтичним працівником може бути як у вигляді кримінальної протиправної недбалості, так і кримінальної протиправної самовпевненості, а також у вигляді особливого виду необережності - кримінального протиправного невігластва.

Кримінальне протиправне невігластво повністю не вкладається в визначення самовпевненості й недбалості, хоча має з ними спільні риси. Відповідно до ч. 2 ст. 25 КК, «необережність $є$ кримінальною протиправною самовпевненістю, якщо особа передбачала можливість настання суспільно небезпечних наслідків свого діяння (дії або бездіяльності), але легковажно розраховувала на їх відвернення» [2]. Згідно із ч. 3 ст. 25 КК, «необережність $€$ кримінальною протиправною недбалістю, якщо особа не передбачала можливості настання суспільно небезпечних наслідків свого діяння (дії або бездіяльності), хоча повинна була й могла їх передбачити» [2].

Схожість невігластва із самовпевненістю полягає в тому, що суб'єкт діяння - в нашому випадку медичний або фармацевтичний працівник - легковажно виконує роботу, яка вимагає спеціального знання або навичок, усвідомлює, як правило, загальну небезпеку такого роду діяльності, хоча конкретного характеру цієї небезпеки він може й не уявляти. Легковажне ставлення до професійних обов'язків виявляється в тому, що особаспеціаліст не вважає за потрібне мати якісний рівень фахової компетентності. Це є прямим порушенням припису ст. 78 Основ законодавства про охорону здоров'я про те, що медичний або фармацевтичний працівник зобов'язаний «постійно підвищувати рівень професійних знань і майстерності» [15].

Момент самовпевненості тут належить до самого факту вчинення діяння, для успішного виконання якого в особи немає ні знань, ні досвіду. Однак на відміну від самовпевненого ставлення до діяння, суб'єкт не передбачає можливості настання конкретних суспільно небезпечних наслідків (саме через своє невігластво) й не розраховує на будь-які конкретні обставини, які цим наслідкам допоможуть запобігти. Він розраховує лише на те, що «впорається» зі своїми обов'язками.

Подібність невігластва 3 недбалістю полягає в тому, що особа не передбачає можливості настання суспільно небезпечних наслідків свого діяння, а розбіжність - у тому, що особа у зв'язку зі своїм невіглаством і не могла їх передбачити, хоча й була зобов'язана це зробити. Водночас на відміну від суб'єктивного випадку ця неможливість передбачення сталася в результаті невігластва, викликаного причинами, які не можна пробачити. Саме за характером (повнотою) інтелектуальної ознаки й розмежовуються ці види вини. Зауважимо, що не передбачення можливої шкоди або легковажний розрахунок на іiї запобігання не вичерпують суспільно небезпечні форми невігластва, яке іноді поєднується зі злочинно байдужим ставленням до наслідків.

Так, лікар або фармацевт, що проявляє невігластво, некомпетентність, легковажно береться за незнайому йому справу, однак не передбачає можливості настання суспільно небезпечних наслідків, не розраховує на обставини, за допомогою яких їм можна запобігти. Або не передбачає через невігластво настання суспільно небезпечних наслідків, проте не має можливості усвідомлювати суспільну небезпеку свого втручання під час здійснення професійних обов'язків внаслідок незнання та невміння.

Критикуючи такі підходи до розуміння необережної вини, О.I. Рарог відзначає, що «відсутність можливості передбачити наслідки містить кримінально-правову вину незалежно від причин нездатності суб'єкта передбачити ці наслідки» [16, с. 76]. 3 цим можна було б погодитися, якщо суб'єктом злочину була б звичайна особа, не наділена спеціальними ознаками, які характеризують іiі як фахівця. Йдеться про наявність спеціальної підготовки, яка складає основу професії та дає можливість працівнику успішно виконувати свої обов'язки, що, звичайно, визначає професійну придатність такої особи. Звідси ми можемо вивести певну формулу: медичний працівник не може не знати, тому що знати зобов'язаний. В основі цього твердження лежить презумпція опанування особою спеціальними знаннями й вміннями й усвідомлення медичним або фармацевтичним працівником як професіоналом суспільної небезпеки свого незнання, невігластва.

«На відміну від недбалості й самовпевненості, які носять ситуативний характер, - зауважує М.С. Грінберг, невігластво - стійке явище, що свідчить про очевидні антигромадські установки особи. Конкретно йдеться про небажання особою засвоїти той обсяг знань, який вона зобов'язана мати для належного виконання своїх професійних, службових, виробничих та інших функцій <...> Ця обставина дозволяє відмежувати злочинне невігластво від вимушеного чи «невинного невігластва», коли особа не отримує належну інформацію через брак інформації <..> неодмінною умовою поставлення особі професійно неграмотного діяння у вину є встановлення факту підготовки його до певної діяльності: отримання освіти в навчальному закладі, разового ознайомлення 3 певним документом тощо» [3, с. 228]. Тобто, якщо незнання медичним працівником тих чи інших положень медичної науки $€$ результатом об'єктивних причин (наприклад, відсутність відповідного навчального курсу у вищому навчальному закладі), таке незнання не може вважатися підставою для притягнення його до кримінальної відповідальності $[17$, с. 440$]$. Неможливість встановлення суб'єкта злочину в справах такого роду ставить питання про відповідальність особи, яка допустила неграмотного працівника до виконання професійних та інших обов'язків.

Невігластво «серед причин неправильних діянь медичних працівників дослідники ставлять на перше місце» $[10$, c. 99]. Проведений нами аналіз судових вироків щодо притягнення осіб до кримінальної відповідальності за ст. 140 КК підтверджує це твердження. Водночас суди під час кваліфікації такого діяння не відступають від ознак, наведених у диспозиції ст. 140 КК. У судових рішеннях констатується, що доказане винне діяння характеризується недбалістю, хоча встановлені об'єктивні ознаки свідчать про те, що обвинувачений проявив невігластво. 
Наведемо такий приклад. Під час розгляду кримінальної справи встановлено, що лікар-хірург, маючи відповідну освіту, кваліфікацію, досвід роботи, науковий ступінь із відповідної спеціалізації, «< ..> не провів кваліфіковане обстеження хворого, встановив невірний діагноз $<\ldots>$ », а «<..> проведене лікування на догоспітальному й госпітальному етапах не відповідало чинному уніфікованому клінічному протоколу надання медичної допомоги Міністерства охорони здоров'я України». У вироку було зазначено, що «некваліфіковані дії лікаря під час надання медичної допомоги пацієнту стоять у прямому причинному зв'язку з негативними наслідками у вигляді смерті» й кваліфікуються за ч. 1 ст. 140 КК України як «неналежне виконання професійних обов'язків медичним працівником внаслідок недбалого й несумлінного до них ставлення, що спричинило тяжкі наслідки для хворого» [18].

Інша справа. Судом встановлено, що неналежне та недбале виконання своїх професійних обов 'язків завідувачем відділення судинної хірургії центру трансплантації органів та інших анатомічних матеріалів Львівської обласної клінічної лікарні виявилось у тому, що «<..> під час діагностичного обстеження та оперативного втручання лікар своєчасно не прийняв рішення про лікування потерпілої <..> та провів оперативне втручання. < ..> Після проведення першого 3 двох оперативних втручань не обрав правильної тактики, що спричинило виникнення ятрогенного ускладнення, через що було проведено друге оперативне втручання, в ході якого було $<\ldots>$ проведено заміну артерії $<\ldots>$, що стало наслідком ускладнення, <..> та виникла необхідність проведення третього термінового оперативного втручання, через яке $<\ldots>$ наступив тромбоз стегнової артерії через іiї травму або травму ії гілок, < ..> що є тяжким ушкодженням, яке знаходиться в причиновому зв язку» [19] з проведеним обвинуваченим медичним втручанням. Далі суд визначив, що «кваліфікація дій обвинуваченого за ч. 1 ст. 140 КК України є правильною, оскільки, бувшии медичним працівником, неналежно виконав свої професійні обов язки внаслідок недбалого до них ставлення, що спричинило тяжкі наслідки для хворого».

На наш погляд, такі рішення $є$ відвертою «абракадаброю». У них ознаки об'єктивної (характер діяння) та суб'єктивної сторони (вид необережності) встановлюються немов би відірвано одне від одного, їх взаємозв'язок алогічний. Також не зрозумілий зміст внутрішнього відношення суб'єкта злочинного діяння до суспільно небезпечних наслідків. У результаті висновки щодо виду вини $\epsilon$ необгрунтованими.

Вважаємо, що у першому і другому випадках наведених кримінальних справ необережна вина медичних працівників не є проявом ні самовпевненості, ні недбалості, а характеризується як кримінальне протиправне невігластво. Маючи належну освіту, кваліфікацію, спеціалізацію, досвід практичної роботи, займаючи відповідні посади, які обвинувачені не могли посісти без проходження професійної атестації, будучи ознайомленими 3 нормативними документами, які регламентують їх діяльність, що підтверджено матеріалами кримінальних справ, медичні працівники фактично проявили професійне невігластво, яке $є$ наслідком незасвоєння ними необхідного комплексу знань та вмінь.
Для правильної кваліфікації кримінально-караних необережних діянь професіоналів у сфері охорони здоров'я, вірного встановлення виду (або форми) вини судам «необхідно враховувати, що ознаки суб' єктивної сторони складу злочину відображають зв'язок свідомості та волі суб'єкта iз ознаками об'єкта та об'єктивної сторони. Тому в аналізі конкретних складів злочинів необхідно точно встановлювати, з якою саме об'єктивною ознакою злочину пов'язана та чи інша ознака його суб'єктивної сторони» [20, с. 54].

Також вважаємо, що при кваліфікації таких діянь варто уточнювати, зокрема: чи мав суб'єкт злочину фактичних достатніх знань, відповідну професійну кваліфікацію для постановлення діагнозу, чи були в його практиці такі випадки, чи розумів він, що має недостатню компетентність внаслідок браку знань та вмінь, яке $є$ проявом кримінального протиправного невігластва. Також при кваліфікації неналежного виконання професійних обов'язків медичним або фармацевтичним працівником «потрібно враховувати вплив на діяння винуватої особи характеру порушення правил, яке було допущене» [20, с. 59]. При цьому важливим $€$ таке. Якщо професійна підготовка медичного або фармацевтичного працівника відсутня 3 причин незалежних від самого суб' єкта або він за своїми психофізіологічними особливостями $є$ професійно непридатним, то він не може бути притягнутий до кримінальної відповідальності. Якщо медичний або фармацевтичний працівник унаслідок некомпетентності, яка обумовлена неналежною освітою, браком отриманих знань, недостатнім практичним досвідом, має сумніви або розуміє свою некомпетентність під час встановлення діагнозу чи вибору методу лікування, він повинен звернутися до досвідченішого спеціаліста. Він зобов'язаний утриматися від лікування у зв'язку зі своїм професійним невіглаством.

Крім того, проблема кваліфікації за ст. 140 КК полягає у неточності викладених у диспозиції норми ознак об'єктивної і суб'єктивної сторони складу цього злочину та неповному розумінні правозастосовувачем що ж собою являють прояви невігластва і як останне співвіднести із словосполученням «внаслідок недбалого чи несумлінного до них ставлення». На нашу думку, у диспозиції ст. 140 КК варто було б чітко визначити суб'єктивну сторону аналізованого злочину з прямою вказівкою на форму та/або вид вини, що дозволило б уникнути помилкового їх визначення.

На підставі викладеного робимо висновок, що кримінальне протиправне невігластво є видом необережності, яке у розумінні ст. 140 КК характеризується недостатністю професійних знань і навичок медичних або фармацевтичних працівників при можливості та необхідності ix отримання. Для подолання законодавчих прогалин пропонуємо власне визначення невігластва: «Необережність $€$ кримінальним протиправним невіглаством, якщо особа легковажно ставилась до виконання покладених на неї професійних обов'язків, не передбачала й не могла передбачити можливості настання суспільно небезпечних наслідків свого діяння (дії або бездіяльності), хоча повинна була їх передбачити 3 урахуванням презумпції володіння нею спеціальними знаннями та вміннями». Втім, питання щодо місця невігластва серед передбачених ст. ст. 23-25 КК форм та видів вини на сьогодні залишається відкритим, потребує спеціального вивчення, адже вичерпати його в одній публікації неможливо.

\section{ЛITEPATУРA}

1. Навроцький В.О. Злочинне невігластво та його правова оцінка. Криминалистъ первопечатный. 2019. № 19. C. 37-73. URL: https://crimcongress.com/wp-content/uploads/2020/03/criminalist 19 anons.pdf (дата звернення : 12.07.2020).

2. Кримінальний кодекс України : Закон України від 05 квітня 2001 року № 2341-III / Верховна Рада України. URL: https://zakon.rada.gov.ua/laws/ show/2341-14 (дата звернення : 12.07.2020).

3. Гринберг М.С. Преступное невежество как форма преступной неосторожности. Вестник Омского университета. 2009. № 3. C. 224-229. URL: https://cyberleninka.ru/article/n/prestupnoe-nevezhestvo-kak-forma-prestupnoy-neostorozhnosti/viewer (дата звернення: 13.07 .2020$)$

4. Преступная неосторожность (уголовно-правовое и криминологическое исследование) / И.П. Лановенко, Ф.А. Лопушанський, А.Н. Костенко и др. ; отв. ред. И.П. Лановенко, Ф.А. Лопушанский. Киев : Наукова думка, 1992. 220 с. 
5. Савицкая А.Н. Возмещение ущерба, причиненного ненадлежащим врачеванием. Львов : Вища школа, 1982. 195 с.

6. Дудоров О.О., Хавронюк М.І. Кримінальне право : навчальний посібник / за заг. ред. М.І. Хавронюка. Київ : Ваіте, 2014. 944 с.

7. Вереша Р.В. Проблеми суб'єктивної сторони складу злочину : дис. ... док. юрид. наук : 12.00.08. Київ, 2017. 583 с.

8. Вермель И.Г., Ковалев М.И. Критерии уголовной ответственности медицинских работников за ненадлежащее лечение. Социалистическая законность. 1987. № 4. С. 51-58.

9. Дагель П.С. Неосторожность. Уголовно-правовые и криминологические проблемы. Москва : Юридическая литература, 1977. 144 с.

10. Глушков В.А. Ответственность за преступления в области здравоохранения. Киев : Вища школа, 1987. 200 с.

11. Нежурбіда С.І. Проблеми вдосконалення законодавчого визначення злочинної необережності. Науковий вісник Чернівецького університету : збірник наукових праць. Вип. 105. Серія «Правознавство». 2001. С. 96-98.

12. Шаргородский М.Д. Научный прогресс и уголовное право. Избранные труды / сост. предисл. Б.В. Волженкина. Санкт-Петербург : Юридический центр Пресс, 2004. С. 543-558.

13. Бердичевский Ф.Ю. Уголовная ответственность медицинского персонала за нарушение профессиональных обязанностей. Москва : Юридическая литература, 1970. 128 с.

14. Ухвала Апеляційного суду Кіровоградської області від 29 травня 2014 року. Справа № 11/781/127/14 / Єдиний державний реєстр судових рішень. URL: http://www.reyestr.court.gov.ua/Review/39033709 (дата звернення: 05.06.2014).

15. Основи законодавства України про охорону здоров'я : Закон України від 19 листопада 1992 року № 2801-XII / Верховна Рада України. URL : https://zakon.rada.gov.ua/laws/show/2801-12\#Text (дата звернення: 12.07.2020).

16. Рарог А.И. Вина в советском уголовном праве : монография. Саратов : Изд-во Саратовского университета, 1987. 186 с.

17. Чеботарьова Г.В. Кримінально-правова охорона правопорядку у сфері медичної діяльності : монографія. Київ : КНТ, 2011. 616 с.

18. Вирок Вінницького районного суду Вінницької області від 21 січня 2019 року. Справа № 128/998/18 / Єдиний державний реєстр судових рішень. URL: http://www.reyestr.court.gov.ua/Review/79281813 (дата звернення: 05.07.2020).

19. Вирок Личаківського районного суду м. Львова від 12 червня 2019 року. Справа № 463/4211/17 / Єдиний державний реєстр судових рішень. URL: http://www.reyestr.court.gov.ua/Review/82352587 (дата звернення: 05.07.2020).

20. Вереша Р.В. Визначення ознак суб’єктивної сторони складу злочину в Особливій частині КК України. Вісник Академії адвокатури України. Т. 13. Ч. 2 (36). 2016. С. 53-61. 


\title{
ЗАСТОСУВАННЯ ЗАСТАВИ У КРИМІНАЛЬНОМУ ПРОВАДЖЕННІ: ТЕОРЕТИЧНІ ТА ПРАКТИЧНІ ПИТАННЯ
}

\author{
APPLICATION OF BAIL IN CRIMINAL PROCEEDINGS: \\ THEORETICAL AND PRACTICAL ISSUES
}

Ситайло О.І., аспірант кафедри кримінального процесу та криміналістики Академія адвокатури України

У статті проаналізовані теоретичні та практичні питання застосування застави у кримінальному провадженні. Зосереджено увагу на тому, що чинний Кримінальний процесуальний кодекс України (далі - КПК України) не містить у собі формулювання чітких цілей, порядку та підстав застосування застави. Також відсутня детальна регламентація процесуального порядку застосування цього запобіжного заходу і вимоги до процесуального оформлення документів, що складаються під час його застосування. Крім цього, немає чіткого визначення предмета застави та порядку його внесення на депозит суду, остаточно не вирішено питання про подальшу долю застави. Застосування застави у кримінальному провадженні викликає багато питань теоретичного та практичного характеру. Зокрема, у законодавстві відсутній єдиний перелік підстав та умов застосування застави як запобіжного заходу. Правозастосовна практика також не містить єдиного підходу до вирішення цього питання. Проведений аналіз дає підстави стверджувати, що фактичними підставами для застосування запобіжних заходів загалом та застави зокрема є наявність обґрунтованої підозри у вчиненні особою кримінального правопорушення; наявність ризиків, які дають підстави слідчому судді, суду вважати, що підозрюваний, обвинувачений, засуджений може здійснити дії, передбачені ч. 1 ст. 177 КПК України. Юридичною підставою для застосування застави як запобіжного заходу є ухвала слідчого судді, суду про: застосування запобіжного заходу у вигляді застави; застосування запобіжного заходу у вигляді тримання під вартою з визначенням розміру застави як альтернативи тримання під вартою; зміна запобіжного заходу з особистого зобов'язання, особистої поруки, домашнього арешту або тримання під вартою на заставу як наслідок невиконання умов застосування більш м'якого або жорсткого запобіжного заходу. Під час обрання застави як запобіжного заходу доцільно разом з підставами враховувати і умови, наявність яких має враховуватися під час обрання цього запобіжного заходу. Так, умови застосування застави фрормують сукупність обставин, визначених нормами КПК України, а їхня фактична наявність надає можливість застосування застави як запобіжного заходу та гарантує права власника (законного володільця) майна.

Ключові слова: застава, кримінальне провадження, підозрюваний, обвинувачений, слідчий суддя, суд, підстави, умови, ухвала, ризики.

The article analyses the theoretical and practical issues of bail in criminal proceedings. It is noted that the current Criminal Procedural Code of Ukraine (hereinafter referred to as "the CPC of Ukraine") does not state clear objectives, procedures and grounds for the use of bail. There is also no detailed regulation of the procedure for the application of this preventive measure and the requirements for the procedural preparation of documents drawn up in case of applying bail. Besides, there is no clear definition of the subject of the bail and the procedure for depositing it to the court, the issue of the further fate of the bail has not been finally resolved. The use of bail in criminal proceedings raises many questions of a theoretical and practical nature. In particular, the legislation does not contain a single list of grounds and conditions for the use of bail as a preventive measure. Law enforcement practice also does not contain a single approach to addressing this issue. The conducted analysis allows asserting that the actual grounds for the application of preventive measures in general and bail in particular is the existence of reasonable suspicion that a person has committed a criminal offense; the risks that give grounds to the investigating judge, the court to believe that the suspect, accused, or convicted person may perform the actions provided for in Part 1 of Art. 177 of the CPC of Ukraine. The legal ground for the use of bail as a preventive measure is the decision of the investigating judge, the court on: the application of a preventive measure in the form of bail; application of a preventive measure in the form of detention to determine the amount of bail as an alternative to detention; change of a preventive measure from personal obligation, personal surety, home arrest or detention for bail as a result of the failure to comply with the conditions of application of a milder or more severe preventive measure. When choosing a bail as a preventive measure, it is advisable to take into account, together with the grounds, the conditions that must be taken into account. Thus, the conditions for application of bail form a set of circumstances enshrined in the CPC of Ukraine, and their actual occurrence provides the opportunity to apply bail as a preventive measure and guarantees the rights of the owner (legal owner) of the property.

Key words: bail, criminal proceedings, suspect, accused, investigating judge, court, grounds, conditions, decision, risks.

Чинний Кримінальний процесуальний кодекс України (далі - КПК України) не містить у собі формулювання чітких цілей, порядку та підстав застосування застави. Також відсутня детальна регламентація процесуального порядку застосування цього запобіжного заходу і вимоги до процесуального оформлення документів, що складаються під час його застосування. Крім цього, немає чіткого визначення предмета застави та порядку його внесення на депозит суду, остаточно не вирішено питання про подальшу долю застави. Поряд 3 цим останнім часом в юридичній літературі вітчизняними процесуалістами все більше уваги приділяється саме заставі як запобіжному заходу, багаторічне ігнорування якої було припинено на початку дев'яностих років XX століття.

Мабуть, головним поштовхом у процесі вивчення питання застосування застави стало прийняття чинного КПК України у 2012 р., у якому приділено значну увагу забезпеченню прав та законних інтересів громадян, зроблено акцент на загальнолюдських цінностях і пріоритеті прав особи. 3'явилася необхідність у забезпеченні розум- ної достатності і реальної результативності від застосування запобіжних заходів. У положенні ст. 176 КПК України визначено перелік запобіжних заходів для застосування припинення кримінального правопорушення чи як форма запобігання протиправній поведінці обвинуваченого, підозрюваного, серед яких названо і запобіжний захід у вигляді застави [1].

На думку Ю.В. Лисюка, питання застосування застави у кримінальному провадженні є дуже актуальним, і немає однозначного трактування законодавчих положень. Автор обмірковує як саме слідчий, прокурор буде доводити ті чи інші обставини справи, які саме переконання будуть вагомими для того, щоб слідчий суддя прийняв сторону слідчого або прокурора, оскільки все залежить від обставин справи, від затриманої особи, від доказової бази тощо. Науковець підкреслює, що на практиці норми ст. 176 КПК України виконуються і здебільшого судом виносяться рішення на користь затриманих осіб, але неможливо, щоб майже всі випадки попереднього кримінального провадження закінчувались внесенням застави [2, с. 216]. 
У країнах Європи ця норма діє аналогічно нашим вітчизняним правовим реаліям, і таким чином має загальну актуальність. Також у світлі економічних реформ, що проводяться у нашій державі, необхідно акцентувати увагу саме на економічних, майнових заходах кримінального процесуального примусу, а саме застави. Однак жвавий інтерес вчених-правознавців до питання застави в кримінальному процесі не знайшов адекватного відгуку у практиків юридично-правової сфери, які здійснюють кримінальну процесуальну діяльність, обирають і застосовують запобіжні заходи [3, с. 128].

Слід зауважити, що вся історія розвитку застави в кримінальному судочинстві свідчить, що цей інститут має цивільно-правове походження, і перенесена 3 цивільного права застава видозмінилася і набула рис самостійного кримінального процесуального інституту або стала складником інституту запобіжних заходів у кримінальному провадженні. Однак зауважимо, що застава як запобіжний захід у кримінальному провадженні істотно відрізняється від цивільно-правової застави: за характером виникаючих правових відносин, за цілями, за підставами застосування, за наслідками невиконання основного зобов'язання.

Водночас сутність застави як запобіжного заходу частково визначається іiі цивільно-правовою природою, і це повинно враховуватися під час вирішення питань, що виникають у процесі ії обрання.

Особливе місце застава в системі запобіжних заходів зумовлено тим, що цей запобіжний захід є єдиною мірою, яка використовує методи майнового примусу, обмеження прав і свобод особистості та психологічного впливу на обвинуваченого, підозрюваного.

За даними нашого дослідження, частка запобіжного заходу у вигляді застави в загальній кількості всіх запобіжних заходів в 2019 р. в середньому становить лише $0,83 \%$, тоді як тримання під вартою застосовується в 70,23\% випадках (за даними Державної судової адміністрації України) [4].

Наведені статистичні дані привертають увагу науковців. Так, під час аналітичного огляду практичного застосування положень застави як запобіжного заходу O.M. Коріняк виявила низькі статистичні показники призначення застави у кримінальному процесі, але навіть за умови недосягнення бажаного результату «імперативність вимоги» ч. 3 ст. 183 КПК України сприяє посиленню ролі застосування застави на практиці та виявляє гуманність і демократичність положень КПК України. Автор зазначає, що це «зумовлено можливістю внести заставу і виконувати процесуальні обов'язки, які будуть визначені слідчим суддею, судом в ухвалі про застосування запобіжного заходу та сприймається більш позитивно, ніж перебування у місцях попереднього ув'язнення» [5, с. 52]

Враховуючи, що основна маса усіх розслідуваних кримінальних справ зосереджена в провадженні слідчих органів Національної поліції, важливу роль у зміні негативної ситуації відіграють питання розсуду слідчого під час обрання та застосування застави як запобіжного заходу. Попри те, що заставу вправі застосувати тільки слідчий суддя та суд, у досудовому провадженні основним ініціатором обрання цього запобіжного заходу залишається слідчий. Саме він порушує перед судом відповідне клопотання. Законодавець, вважаємо, виправдано залишив ініціативу обрання запобіжних заходів у досудовому провадженні за органами публічного кримінального переслідування. Таке положення відповідає виконуваним ними кримінальним процесуальним функціям, зокрема, функції обвинувачення У судових стадіях зазначений запобіжний захід застосовується судом як за клопотанням сторони обвинувачення так і за власною ініціативою. Застава має розглядатися не тільки як засіб забезпечення явки обвинувачуваного, підозрюваного за викликом, та як попередження вчинення ним нових злочинів, але і як спосіб попередження інших видів його неналежної поведінки. Цей запобіжний захід застосовується слідчим і судом (мається на увазі слідчим суддею на стадії досудового розслідування і судом на стадії судового розгляду) у суворо встановленому кримінальним процесуальним законом порядку заходів державного примусу, що складаються в обмеженні особистих прав і свобод обвинуваченого, у встановленні за ним спостереження (нагляду) або загрозі майнових втрат з метою забезпечення належної поведінки обвинуваченого (підозрюваного) і запобігання вчинення ним перешкод провадження по справі. 3 огляду на належність застави до групи запобіжних заходів, внесення застави не означає, що підозрюваний, обвинувачений таким чином, буде позбавлений від покарання і вважатиметься не винуватим чи позбудеться статусу підозрюваного, обвинуваченого [6, с. 32].

Г.М. Куцкір аргументує, що застава може застосовуватися лише за наявності фактичної та юридичної підстав, визначених ч. 2 ст. 177 і ст. 196 КПК України. Відповідно до норм ч. 3 ст. 183 , ст. 196 , ч. 4 ст. 201 і ч. 4 ст. 202 КПК України юридичною підставою для застосування застави як запобіжного заходу є ухвала слідчого судді, суду про: застосування запобіжного заходу у вигляді застави; застосування запобіжного заходу у вигляді тримання під вартою $з$ визначенням розміру застави як альтернативи тримання під вартою; зміна запобіжного заходу з особистого зобов'язання, особистої поруки, домашнього арешту або тримання під вартою на заставу як наслідок невиконання умов застосування більш м'якого або жорсткого запобіжного заходу [7, с. 150].

Фактичними підставами для застосування запобіжних заходів загалом та застави зокрема $є$ наявність обгрунтованої підозри у вчиненні особою кримінального правопорушення; наявність ризиків, які дають підстави слідчому судді, суду вважати, що підозрюваний, обвинувачений, засуджений може здійснити дії, передбачені ч. 1 ст. 177 КПК України [1]. Цитовані положення чинного кримінального процесуального закону здаються оцінними поняттями. Тому задля їх роз'яснення необхідно звернутися до наукових визначень. Як зазначає М.Є. Громова, обгрунтованою $є$ підозра за наявності наступних принципових обставин: врученого письмового повідомлення про підозру з обов'язковим посиланням на докази вчинення особою кримінального правопорушення; наявність у матеріалах кримінального провадження доказів, що підтверджують вчинення особою кримінального правопорушення; доведення перед судом вагомості та достатності наявних доказів про вчинення особою кримінального правопорушення; оцінення судом доказів вчинення особою кримінального правопорушення [8, с. 43].

В аспекті досліджуваної проблематики Т.В. Данченко зазначає, що у разі обрання застави як запобіжного заходу доцільно разом з підставами враховувати і умови, наявність яких має враховуватися під час обрання цього запобіжного заходу. На думку науковця, умови застосування застави формують сукупність обставин, визначених нормами КПК України, а їхня фактична наявність надає можливість застосування застави як запобіжного заходу та гарантує права власника (законного володільця) майна [9, с. 106].

У продовження цього питання Г.М. Куцкір, грунтуючись на дослідженнях норм кримінального процесуального закону, до умов застосування застави пропонує віднести: обов'язковість внесення відомостей про вчинення кримінального правопорушення до СРДР; перебування особи, відносно якої вирішуватиметься питання про застосування застави як запобіжного заходу у процесуальному статусі підозрюваного, обвинуваченого; неефективність застосування більш м'яких запобіжних заходів для досягнення мети, відповідно, норм ч. 1 ст. 177 і ч. 1 ст. 182 КПК України або можливість досягнення мети шляхом застосування застави до підозрюваного, обвинуваченого, до якого 
було застосовано запобіжний захід у вигляді тримання під вартою згідно з ч. 1 ст. 182 та ч. ч. 3 і 4 ст. 183 КПК України [7, с. 152]. Погоджуючись із наведеними вище положеннями, додамо, що, на нашу думку, обов'язковою умовою застосування застави $\epsilon$ також урахування майнового стану підозрюваного, обвинуваченого і визначення такого розміру застави, який, з одного боку, забезпечить ефективність застосування такого запобіжного заходу, з іншого буде помірним, тобто реальним для внесення підозрюваним, обвинуваченим.

Необхідно зазначити, що відповідно до ст. 178 КПК України обставини майнового та сімейного стану підозрюваного розглядаються під час обрання всіх запобіжних заходів, але під час визначення підстав застосування застави законодавець акцентує на необхідності їнього окремого та ретельного з'ясування. На думку Л.М. Бабіч, застосування такого прийому юридичної техніки $є$ невипадковим, якщо враховувати виняткову мету застави як запобіжного заходу - попередження можливої протиправної поведінки особи або перешкоджання ії виникненню за допомогою загрози застосування фінансової санкції. Як зазначає науковець, у межах вирішення питання про обрання застави як запобіжного заходу такі обставини повинні більш ретельно досліджуватися [10, с. 46].

Однак норми чинного КПК і відсутність єдиної практики його застосування свідчать про відсутність такої конкретики в положеннях ч. 4 ст. 182 КПК України. Аналіз правозастосовної практики наочно демонструє, що 3'ясування особливостей майнового або сімейного стану особи під час застосування застави зводиться до часткового та формального. Але є випадки, коли детальний перелік коштовного майна не надає переконливості слідчому судді для призначення застави в більших обсягах. Однак зауважимо, що в цьому разі існує апеляційна інстанція для перегляду законності рішення слідчого судді й вона навіть може скасувати відповідне рішення про розмір застави на підставі того, що слідчий суддя поверхнево врахував усі майнові та сімейні обставини підозрюваного, обвинуваченого в кримінальному правопорушенні.

Для оцінювання вартості майна підозрюваного, обвинуваченого використовується положення Закону України «Про оцінку майна, майнових прав та професійну оціночну діяльність в Україні». В статті 3 цього закону визначено, що оцінюваним майном $є$ об'єкти в матеріальній формі, будівлі та споруди з включенням їхніх невіддільних частин, машини, обладнання, транспортні засоби тощо; паї, цінні папери; нематеріальні активи, в тому числі об'єкти права інтелектуальної власності; цілісні майнові комплекси всіх форм власності, а майновими правами визначено будь-які права, пов'язані з майном, відмінні від права власності, у тому числі права, які є складовими частинами права власності (права володіння, розпорядження, користування), а також інші специфічні права (права на провадження діяльності, використання природних ресурсів) та права вимоги [11, с. 277$].$

Необхідно зазначити, що інколи прокурори під час розгляду клопотання про призначення застави взагалі не надавали слідчому судді та суду будь-якої доказової бази про наявність у особи нерухомого чи рухомого майна, що ускладнювало встановлення суттєвих обставин по справі, i, як наслідок, апеляційним судом зменшувався розмір застави. На думку В.А. Завтура, «поверхневе встановлення обставин, які характеризують майновий стан підозрюваного, обвинуваченого, зумовлено тим, що у ч. 1 ст. 182 КПК України передбачене внесення застави лише у вигляді коштів у грошовій одиниці України, а про можливість ії внесення у формі іншого майна в законі не йдеться, що $є$ істотним недоліком». Автор зазначає, що під час застосування застави як запобіжного заходу саму заставу можна забезпечити певним майном без попередньої примусової реалізації [12, с. 87].
Своєю чергою О.Г. Шило зазначає, що «складність доказування необхідності застосування запобіжного заходу зумовлена його прогностичним характером, адже йдеться про доведення необхідності перешкоджання можливій негативній поведінці підозрюваного, обвинуваченого». Науковець підкреслює, що доведення існування наведених підстав у сукупності з обставинами ст. 178 КПК обгрунтовує можливість прогнозування негативної поведінки підозрюваного, обвинуваченого, що аргументовано «доводить необхідність застосування запобіжного заходу і неможливість забезпечити здійснення кримінального провадження іншими заходами». Автор також зазначає, що обгрунтована ймовірність, що формує докази для надання до суду, забезпечує необхідні стандарти доказування, які визнаються достатніми для застосування запобіжного заходу і обмеження у зв'язку із цим конституційного права людини. Імовірність може бути абсолютно припустимою для процесуальних рішень, якщо вона базується на достовірних фактах, що «надає прийнятому рішенню якості обгрунтованості» [13, с. 269].

Відповідно до норм ч. 2 ст. 182 КПК можливість внесення застави іншими фізичними та юридичними особами не конкретизує їхнє коло, але вказує, що заставодавцем може бути юридична особа державної або комунальної власності, або яка фінансується з місцевого, державного бюджету, бюджету АР Крим, або у статутному капіталі якої є частка державної, комунальної власності, або яка належить до суб'єкту господарювання, що є у державній або комунальній власності. Враховуючи, що поняття та види юридичних осіб досить детально визначені нормами ЦК України, науковці такий підхід вважають обгрунтованим. Отже, слушною є пропозиція Г.М. Куцкір, що для визначення можливості конкретної фізичної або юридичної особи бути заставодавцем необхідно враховувати наступні критерії: повна дієздатність для фізичних осіб; правоздатність для юридичних осіб; для фізичних та юридичних осіб - їхня згода та згода підозрюваного, обвинуваченого на залучення їх у якості заставодавця (за винятком випадків, коли фізичні особи вносять кошти від імені підозрюваного, обвинуваченого) [7, с. 153].

Як зазначає Ю.В. Дрозд, закон формулює сукупність обставин та критеріїв, якими слід керуватися під час визначення розміру застави в кожному конкретному випадку. Такими обставинами є всі обставини вчиненого кримінального правопорушення, майновий та сімейний стан підозрюваного, обвинуваченого, характер ризиків, передбачених у ст. 177 КПК. Автор зауважує, що межі розміру застави залежать від установленого КК України тяжкості злочину згідно зі ст. 12, у вчиненні якого особа підозрюється, обвинувачується [13, с. 72].

Висновки. Застосування застави у кримінальному провадженні викликає багато питань теоретичного та практичного характеру. Зокрема, у законодавстві відсутній єдиний перелік підстав та умов застосування застави як запобіжного заходу. Правозастосовна практика також не містить єдиного підходу до вирішення цього питання. Проведений аналіз дає підстави стверджувати, що фактичними підставами для застосування запобіжних заходів загалом та застави зокрема є наявність обгрунтованої підозри у вчиненні особою кримінального правопорушення; наявність ризиків, які дають підстави слідчому судді, суду вважати, що підозрюваний, обвинувачений, засуджений може здійснити дії, передбачені ч. 1 ст. 177 КПК України. Юридичною підставою $є$ відповідне судове рішення. Під час обрання застави як запобіжного заходу доцільно разом 3 підставами враховувати і умови, наявність яких має враховуватися під час обрання цього запобіжного заходу. Так, умови застосування застави формують сукупність обставин, визначених нормами КПК України, а їхня фактична наявність надає можливість застосування застави як запобіжного заходу та гарантує права власника (законного володільця) майна. 


\section{ЛITEPATУРA:}

1. Кримінальний процесуальний кодекс України від 13.04.2012 р. № 4651-УІ. Відомості Верховної Ради України. 2013, № 9-10, № 11-12, № 13, ст. 88 .

2. Лисюк Ю.В. Окремі аспекти застосування запобіжного заходу у вигляді застави. Науковий вісник Міжнародного гуманітарного університету. Серія «Юриспруденція». 2014. № 7. С. 216-219.

3. Лобойко Л.М.. Кримінально-процесуальне право: курс лекцій : навч. посібник. Киії : Істина, 2005. 456 с.

4. Державна судова адміністрація України. URL: https://dsa.court.gov.ua/dsa/pokazniki-diyalnosti/efekt_roboti_sudiv1/ (дата звернення 15.06.2020)

5. Коріняк О.М. Практика застосування запобіжних заходів за новим КПК України. Перші здобутки. Кримінальний процесуальний кодекс України: перші проблеми та здобутки: матеріали круглого столу, 20 листоп. 2013 р. Запоріжжя : Класич. приват. ун-т. 2013. С. 52-55.

6. Кримінальне право України. (Загальна частина) : підручник / Кол. авторів Бабенко А.М., Вапсва Ю.А., Грищук В.К. та ін. ; за заг. ред. О.М. Бандурки. Харків : Вид-во ХНУВС, 2010. С. 30-57.

7. Куцкір Г.М. Підстави і процесуальний порядок застосування застави як способу обмеження права власності під час кримінального провадження. Науковий вісник Херсонського державного університету. Серія: Юридичні науки. Випуск 3, Том 3. С. 150-155.

8. Громова М.Є. Обґрунтована підозра як підстава застосування запобіжних заходів. Часопис Академії адвокатури України. 2015. № 2 (27). Том 8. С. 40-43.

9. Данченко Т.В. Застава: історія розвитку та проблеми застосування. Підприємниитво, господарство і право. 2004. №1. С. $106-108$.

10. Бабіч Л.М. Застава як вид запобіжного заходу у кримінальному судочинстві України : дис. ... канд. юр. наук : 12.00.09. М-во освіти і науки України, Луган. держ. ун-т внутр. справ ім. Е.О. Дідоренка. Луганськ, 2014. 250 с.

11. Баулін Ю. Кримінальна відповідальність: сутність, зміст та правова форма. Вісник Академії правових наук України. 2003. № 2-3. С. 626-627.

12. Завтур В.А. Обґрунтування ухвал слідчого судді про застосування запобіжного заходу у вигляді застави: аналіз проблем та шляхи вдосконалення. Вісник Прокуратури. № 12 (174). 2015. С. 87-95.

13.Шило О.Г. Особливості обґрунтування обрання запобіжних заходів у кримінальному провадженні. Науковий вісник Ужгородського національного університету. 2014. С. 269-273.

14. Дрозд В.Ю. Проблемні аспекти застосування застави як одного з видів запобіжних заходів, не пов'язаних з обмеженням волі особи. Вісник Луганського держ. ун-ту внутр. справ ім. Е.О. Дідоренка. 2016. Вип. 1. С. 72-80. 


\title{
ОСОБЛИВОСТІ КІЛЬКІСНО-ЯКІСНИХ ВИМІРІВ УМИСНИХ ВБИВСТВ В УКРАЇНІ ЗА ПЕРІОД 1992-2019 РР.
}

\section{PECULIARITIES OF QUANTITATIVE-QUALITATIVE MEASUREMENTS OF WILLFUL MURDERS IN UKRAINE FOR THE PERIOD 1992-2019}

\author{
Старко О.Л., к.ю.н., доцент, \\ доцент кафедри кримінального права і процесу \\ Східноєвропейський національний університет імені Лесі Украйнки
}

Статтю присвячено проблемі особливостей кримінологічної характеристики умисних вбивств в Україні, а саме питанню щодо їх кількісно-якісних вимірів. У статті проведено аналіз кількісно-якісних вимірів стосовно умисних вбивств (ст.ст. 115-118 Кримінального кодексу (далі - КК) України) за період з 1992 р. по 2019 р. Інформаційним підґрунтям дослідження є статистична інформація, надана Департаментом Інформаційних Технологій (Департаментом інформаційно-аналітичного забезпечення) Міністерства внутрішніх справ України, а також оприлюднені статистичні дані Офісу Генерального прокурора (Єдиний звіт про кримінальні правопорушення за 2013-2019 рр., Єдиний звіт про осіб, які вчинили кримінальні правопорушення за 2016-2019рр.), Верховного Суду України (аналітичні огляди Верховного Суду про здійснення правосуддя).

Виділено декілька періодів, які характеризуються відповідними показниками рівня умисних вбивств за останні 29 років. Показники рівня умисних вбивств та їх питомої ваги у структурі злочинності, у тому числі щорічно, наведено у таблиці 1. Визначено, що питома вага умисних вбивств у структурі злочинності за досліджуваний період становить у середньому близько 1\%. Зауважується, що у 2013 p. питома вага умисних вбивств перевищила $1 \%$, а у 2014 р. зросла до $2,2 \%$.

У статті наводяться дані щодо рівня кожного з видів умисних вбивств та осіб, які їх вчинили, а також засуджених осіб. Наведено окремі дані щодо коефріцієнтів, які характеризують інтенсивність злочинів / кримінальних правопорушень, географії. Проведено аналіз структури умисних вбивств, передбачених ст.ст. 115-118 КК України. Встановлено, що 85\% з них становлять умисні вбивства, передбачені ч. 1 ст. 115 КК України. У структурі умисних вбивств, вчинених за обтяжуючих обставин (ч. 2 ст. 115 КК України), переважають умисні вбивства з корисливих мотивів, двох і більше осіб, за попередньою змовою групою осіб. Серед умисних вбивств, вчинених при пом'якшуючих обставинах, четверту частину становлять умисні вбивства, вчинені за перевищення меж необхідної оборони або у разі перевищення заходів, необхідних для затримання злочинця (ст. 118 КК України).

Ключові слова: умисні вбивства, офіційні статистичні дані, рівень, коефіцієнти інтенсивності злочинності, динаміка, структура, питома вага, географія, умисне вбивство, вчинене без обтяжуючих та пом'якшуючих обставин, умисне вбивство, вчинене за обтяжуючих обставин, умисне вбивство, вчинене за пом'якшуючих обставин.

The article is devoted to the problem of criminological characteristics of willful murders in Ukraine namely the question of quantitative and qualitative measurements. The quantitative and qualitative measurements analysis as to willful murder (Art. 115-118 of the Criminal Code of Ukraine) for the period $1992-2019$ has been carried out. The background information of the investigation is statistical information provided by the Department of Information Technology (Department of Information and Analytical Support) of the Ministry of Internal Affairs of Ukraine as well as published statistics of the Office of the Prosecutor General (Unified Report on Criminal Offenses for the period 2013-2019, Unified report on persons who have committed criminal offenses for the period 2016-2019), the Supreme Court of Ukraine (analytical Supreme Court reviews on administration of justice).

There are several periods that are characterized by relevant indicators of willful murders level over the last 29 years. Indicators of willful murders level and their specific weight in the crime structure including annually are given in Table 1. It is determined that specific weight of willful murders in the crime structure for the period of investigation is on average about $1 \%$. It is noted that in 2013 the specific weight of willful murders are exceeded to $1 \%$, and in 2014 are increased to $2.2 \%$. The article provides data on the level of each type of willful murders and the perpetrators as well as convicted persons. Some data on the coefficients that characterize the intensity of crimes / criminal offenses, geography are highlighted. The analysis of the structure of willful murders provided by Art. 115-118 of the Criminal Code of Ukraine has been done. It is established that $88 \%$ are willful murders provided by p. 2 . Art. 115 of the Criminal Code of Ukraine. The structure of willful murders committed under aggravating circumstances (p.2. Art. 115 of the Criminal Code of Ukraine) is dominated by willful murders for selfish motives, two or more persons by prior conspiracy of a group of persons. Among the willful murders committed under mitigating circumstances a quarter are willful murders committed in excess of the limits of necessary defense or in case of exceeding the measures necessary to detain the offender (Art.118 of the Criminal Code of Ukraine).

Key words: willful murders, official statistics, level, crime rates, dynamics, structure, specific weight, geography, willful murder committed without aggravating and mitigating circumstances, willful murder committed under aggravating circumstances, willful murder committed mitigating circumstances.

Постановка проблеми. Особлива соціальна цінність життя людини, поширеність умисних вбивств, зростання їх кількості впродовж останніх років, несприятливі структурні показники, зумовлюють потребу у приверненні постійної уваги до проблеми запобігання цим небезпечним посяганням. Дослідження стану злочинності на основі оновлених статистичних даних виступає інформаційним підгрунтям запровадження та удосконалення системи заходів протидії умисним вбивствам.

Стан опрацювання. Проблеми кримінологічної характеристики та запобігання тяжкій насильницькій злочинності проти особи вивчались у працях багатьох вчених-кримінологів - Г.А. Аванесова, Ю.М. Антоняна, В.В. Голіни, Б.М. Головкіна, І.М. Даньшина, О. М. Джужи, А.І. Долгової, Л.В. Дорош А.П. Закалюка, А.Ф. Зелінського, О.М. Ігнатова, В.М. Кудрявцева, К.Д. Кулик,
О.М. Литвака, Р.І. Мельника, І.К. Туркевич, О.Ю. Юрченко, В.I. Шакуна та інших.

Метою статті є дослідження особливостей кількісноякісних вимірів умисних вбивств, передбачених ст.ст. 115118 КК України, за період з 1992 р. по 2019 р. (на основі офіційних статистичних даних Міністерства внутрішніх справ України, Офісу Генерального прокурора, Верховного Суду України).

Викладення основного матеріалу. Загострення криміногенної ситуації в Україні неодноразово супроводжувалось зростанням числа тяжких насильницьких злочинів проти особи, передусім умисних вбивств. За період з 1992 р. по 2019 р. стан насильницької злочинності не відзначався стабільними показниками. Враховуючи зафіксовані за останні 29 років «показники спадів та зростань» щодо умисних вбивств (ст.ст. 115-118 КК України) (див. 
таблицю 1), виділимо декілька періодів, які характеризуються відповідними кількісно-якісними вимірами:

- 1992-2002 рр. Рівень умисних вбивств не перевищував 5 тисяч. За ці одинадцять років, найбільшу кількість умисних вбивств було зареєстровано у 2000 році-4 806 [1]. Питома вага умисних вбивств у структурі злочинності не перевищувала $1 \%$;

- 2003-2006 рр. Рівень умисних вбивств знизився та не перевищував 4000 (у 2003 р. - 3 875, у 2004 р. 3 788, у 2005 р. - 3 315, у 2006 р. - 3 220) [2]. Слід відзначити те, що кількість виявлених осіб перевищила кількість зареєстрованих умисних вбивств. Так, за 2004 2006 рр. було виявлено 10486 осіб, які вчинили умисні вбивства (у 2004 р. - 3819 осіб, у 2005 р. - 3322 особи, у 2006 р. - 3345 осіб) [2]. Умисних вбивств за цей період (2004-2006 рр.) було зареєстровано дещо менше - 10323. Зазвичай показники рівня зареєстрованих злочинів перевищують, інколи у декілька разів, кількість виявлених осіб.

Коефіцієнт інтенсивності умисних вбивств (ст.ст. 115118 КК України) на 100 тис. населення у 2004 р. становив 8 злочинів, у 2005 р. - 7, у 2006 р. - 6,8. Динаміка (до попереднього періоду) була від'ємною та відображалась у таких показниках: 2004 р. - мінус 6,3\%, 2005 р. - мінус $12,5 \%, 2006$ р. - мінус 2,9\% [2];

- 2007-2012 рр. За цей період рівень умисних вбивств не перевищував 3000 . У 2007 р. їх рівень скоротився на 9,8\% у порівнянні з попереднім роком, у 2008 р. - на $6,8 \%$. Так, у 2007 р. було зареєстровано 2790 умисних вбивств, передбачених ст.ст. 115-118 КК України, у 2008 р. - 2 707, у 2009 p. - 2478 , у 2010 p. - 2 356, у 2011 p. - 2 506, у 2012 р. за ст.115 КК України - 2 048). Кількість виявлених осіб, які вчинили умисні вбивства, на відміну від 2004-2006 рр., перевищила кількість зареєстрованих злочинів ( у 2007 р. - 2947 осіб, у 2008 р. - 2792 виявлені особи) [2]. Коефіцієнт інтенсивності злочинності у 2007 р. становив 6,2 умисні вбивства на 100 тисяч населення, у 2008 р. $-5,8$.

- 2013-2019 рр. - період ескалації кількісно-якісних вимірів умисних вбивств. Абсолютна кількість обліко- ваних умисних вбивств у порівнянні з 2000-ми та 90-ми роками зросла у 2,5 рази. Так, за ст.ст. $115-118$ КК України у 2013 р. було обліковано 5923 , у 2014 р. - 11532 , y 2015 p. -8280 , у 2016 p. -6051 , у 2017 p. - 5180 , у 2018 р. - 5 600, у 2019 р. - 5508 [3]. Кількість засуджених за ст.ст. 115-118 КК України становила за останні три роки (2017-2019 pp.) - 1463 осіб [4; 5].

Питома вага умисних вбивств у структурі злочинності загалом за досліджуваний період (1992-2019 рр.) становила у середньому близько 1\%. I лише з 2014 р. їх питома вага перевищила 1\% і становила 2,2\%. (див. таблицю 1).

Характерним є те, що питома вага умисних вбивств була незмінною (на рівні 0,7\%) як при скороченні кількості всіх облікованих злочинів у 2006-2009 рр. до 410 тисяч, так і у 90-ті роки (у 1993-1998р.), коли кількість зареєстрованих злочинів перевищувала 600 тисяч.

Використовуючи дані Департаменту Інформаційних технологій Міністерства внутрішніх справ України (далі ДІТ МВС), Офісу Генерального прокурора, охарактеризуємо кількісно-якісні виміри щодо кожного з видів умисних вбивств за досліджуваний період.

Умисне вбивство (ст. 115 КК Украӥни). За 2004-2008 pp. було зареєстровано 15318 злочинів (у 2004 р. зареєстровано 3 632, у 2005 p. 3 194, у 2006 р. - 3 093, у 2007 p. 2 790, у 2008 р. - 2609 [2]), що становить 0,7\% у структурі злочинності за цей період. Питома вага цих умисних вбивств у структурі умисних вбивств, передбачених ст.ст. 115118 КК України, за вказаний період становила 96\%.

Щодо географії умисних вбивств, передбачених ст. 115 КК України, відзначимо наступне. Найбільшу їх кількість за період 2004-2008 pp. зареєстровано було у Донецькій (2 543), Одеській (1 031), Луганській (1 005), Харківській (1 001) областях та Автономній Республіці Крим (842). Найнижчий рівень умисних вбивств зафіксовано за 2004-2008 рр. у Тернопільській (126), Рівненській (155), Закарпатській (168), Волинській (243) областях [2]. Однак коефіцієнт інтенсивності умисних вбивств як у Донецькій, так і у Тернопільській областях однаковий та становить 1,1 на 100 тисяч населення.

Таблиця 1

\begin{tabular}{|c|c|c|c|c|c|c|c|c|c|c|}
\hline роки & 1992 & 1993 & 1994 & 1995 & 1996 & 1997 & 1998 & 1999 & 2000 & 2001 \\
\hline $\begin{array}{l}\text { кількість всіх зареєстро- } \\
\text { ваних злочинів / кримі- } \\
\text { нальних правопорушень }\end{array}$ & 480478 & 539299 & 571891 & 641860 & 617262 & 589208 & 575982 & 558716 & 553594 & 503676 \\
\hline $\begin{array}{l}\text { Кількість зареєстрова- } \\
\text { них умисних вбивств }\end{array}$ & 3679 & 4008 & 4571 & 4783 & 4896 & 4529 & 4563 & 4623 & 4806 & 4571 \\
\hline $\begin{array}{l}\text { питома вага умисних } \\
\text { вбивств у структурі зло- } \\
\text { чинності, \% }\end{array}$ & 0,8 & 0,7 & 0,8 & 0,7 & 0,8 & 0,8 & 0,8 & 0,8 & 0,9 & 0,9 \\
\hline роки & 2002 & 2003 & 2004 & 2005 & 2006 & 2007 & 2008 & 2009 & 2010 & 2011 \\
\hline $\begin{array}{l}\text { кількість всіх зареєстро- } \\
\text { ваних злочинів / кримі- } \\
\text { нальних правопорушень }\end{array}$ & 450661 & 556351 & 520105 & 485725 & 420900 & 401293 & 384424 & 434678 & 500902 & 515833 \\
\hline $\begin{array}{l}\text { Кількість зареєстрова- } \\
\text { них умисних вбивств }\end{array}$ & 4296 & 3875 & 3788 & 3315 & 3220 & 2906 & 2707 & 2478 & 2356 & 2506 \\
\hline $\begin{array}{l}\text { питома вага умисних } \\
\text { вбивств у структурі зло- } \\
\text { чинності, \% }\end{array}$ & 0,9 & 0,7 & 0,7 & 0,7 & 0,8 & 0,7 & 0,7 & 0,6 & 0,5 & 0,5 \\
\hline роки & 2012 & 2013 & 2014 & 2015 & 2016 & 2017 & 2018 & 2019 & & \\
\hline $\begin{array}{l}\text { кількість всіх зареєстро- } \\
\text { ваних злочинів / кримі- } \\
\text { нальних правопорушень }\end{array}$ & 443665 & 563560 & 529139 & 565182 & 592604 & 523911 & 487133 & 444130 & & \\
\hline $\begin{array}{l}\text { Кількість зареєстрова- } \\
\text { них умисних вбивств }\end{array}$ & $\begin{array}{c}2048 \\
\text { (лише за } \\
\text { ст. 115) }\end{array}$ & 5923 & 11532 & 8280 & 6051 & 5180 & 5600 & 5508 & & \\
\hline $\begin{array}{l}\text { питома вага умисних } \\
\text { вбивств у структурі зло- } \\
\text { чинності, \% }\end{array}$ & 0,5 & 1 & 2,2 & 1,5 & 1 & 1 & 1,1 & 1,2 & & \\
\hline
\end{tabular}


За період 2013-2019 рр. було обліковано 47710 умисних вбивств, передбачених ст. 115 КК України (2013 p. - 5861 умисних вбивств, за 2014 р. - 11 466, за 2015 p. -8224 , за 2016 p. - 5992 , за 2017 p. - 5145 , за 2018 р. - 5 557, у 2019 р. - 5465 [3]. Питома вага умисних вбивств (ст. 115 КК України) у структурі умисних вбивств, передбачених ст.ст. 115-118 КК України, за вказаний період становила 99,2\%. За даними Верховного Суду України за 2017-2019 рр. було засуджено за ст. 115 України 1337 осіб [4; 5].

Умисне вбивство без обтяжуючих та пом'якщуючих обставин (ч. $1 \mathrm{~cm} .115$ КК Украӥни). У 2002 р. було зареєстровано 3458 (питома вага у структурі умисних вбивств - 80,5\%). За період 2004-2008 рр. було зареєстровано 11927 умисних вбивств (у середньому щороку 2385 ) [2]. Питома вага у структурі всіх умисних вбивств $75 \%$, у структурі злочинів, передбачених ст. 115 КК України, $-78 \%$.

За період 2013-2019 рр. було обліковано 42199 простих умисних вбивств (2013 р. - 5317 , за 2014 р. - 9919 , за 2015 p. - 7046 , за 2016 p. - 5 356, за 2017 p. - 4 579, за 2018 p. - 5 014, у 2019 p. - 4968 [3]. Питома вага у структурі умисних вбивств - $88 \%$, у структурі умисного вбивства, передбаченого ст. 115 КК, України - також 88\%.

Оприлюднені сучасні статистичні дані не містять інформації щодо мотивів вчинення простих умисних вбивств. О. Литвак зазначає, що у звіті МВС за 1995 р. було вказано про такі спонукання вбивств, як побутові $36,3 \%$; хуліганські - $1,2 \%$; корисливі під час розбійних нападів $-2,1 \%$; сексуальні та поєднані із згвалтуванням $1,0 \%$; інші $-56,6 \%$ [6, с. 52].

За даними ДІТ МВС України за 1997-2000 р. третина від усіх умисних вбивств (ст.ст. 115-118 КК України) вчиняється на грунті ревнощів, сварки та інших побутових причин. Так, у 1997 р. було зареєстровано за вказаними мотивами 1363 вбивства, що становить 30,1\% від усіх зареєстрованих умисних вбивств, у 1998 р. - $1546(33,9 \%)$, у 1999 p. - 1601 (34,6\%), у 2000 p. - $1646(34,2 \%)$ [2].

На грунті помсти вчинено було у середньому $4 \%$ від усіх зареєстрованих умисних вбивств (ст.ст. 115118 КК України). Зокрема, у 1997 р. було зареєстровано 208 простих умисних вбивств, вчинених з мотиву помсти (питома вага у структурі всіх умисних вбивств $-4,6 \%$, y 1998 p. $-180(3,9 \%)$, y 1999 p. $-200(4,3 \%)$, y 2000 p. $185(3,8 \%)[2]$.

Умисне вбивство, вчинене за обтяжсуючих обставин (ч. 2 cm. 115 КK України). Наведемо дані щодо тих кваліфікованих вбивств, рівень та питома вага яких $€$ порівняно вищими, ніж інших вбивств цього виду. Так, за період 1997-2001 рр. було зареєстровано:

1421 умисне вбивство 3 корисливих мотивів, що становить $6,1 \%$ у структурі умисних вбивств. Зокрема, у 1997 р. зареєстровано 232 злочини, питома вага яких у структурі умисних вбивств за цей рік становить $5,1 \%$, у 1998 p. - $284(6,2 \%), 1999$ p. - $285(6,2 \%)$, у 2000 p. $384(8 \%)$; y 2001 p. $-236(5,2 \%)[2]$;

- 664 умисні вбивства двох і більше осіб злочини, що становить 2,9\% у структурі всіх зареєстрованих умисних вбивств. Зокрема, у 1997 р. - 123 злочини, питома вага яких у структурі умисних вбивств за цей рік становить 2,7\%, у 1998 р. - 125 (2,7\%), 1999 р. - 115 (2,5\%), y 2000 p. $-110(2,3 \%)$, y 2001 p. - $191(4,2 \%)$ [2];

504 умисні вбивства за попередньою змовою групою осіб або організованими злочинними групами, питома вага яких у структурі умисних вбивств становить 2,2\%. Зокрема, у 1997 р. - 63 злочини, питома вага яких у структурі умисних вбивств за цей рік становить $1,4 \%$, у 1998 p. - $109(2,4 \%), 1999$ p. - $102(2,2 \%)$, у 2000 p. $112(2,3 \%)$; у 2001 p. $-118(2,6 \%)[2]$;

- 251 умисне вбивство з особливою жорстокістю, що у структурі умисних вбивств за цей період становить
1,1\%. У 1997 р. було зареєстровано 68 вбивств, питома вага яких у структурі умисних вбивств за цей період становить $1,5 \%$, у 1998 р. - 55 (1,5\%), у 1999 р. - $45(1 \%)$, у 2000 p. $-33(0,7 \%)$, у 2001 p. $-50(1,1 \%)$ [2];

126 вбивств на замовлення, питома вага яких у структурі умисних вбивств становить 0,5\%. Зокрема, у 1997 р. - 28 злочинів, питома вага яких у структурі умисних вбивств за цей рік становить $0,6 \%$, у 1998 p. - $30(0,7 \%), 1999$ p. - $28(0,6 \%)$, у 2000 p. $28(0,6 \%)$; у 2001 р. - 12 (0,3\%) [2]. У порівнянні з 1995 р. (зареєстровано 202 вбивства) та 1996 р. (157) їх кількість скоротилась у середньому у 8 разів;

133 умисних вбивства, поєднані зі згвалтуванням, що становить $0,6 \%$ у структурі умисних вбивств. Зокрема, у 1997 р. зареєстровано 28 злочинів, питома вага яких у структурі умисних вбивств за цей рік становить $0,6 \%$, у 1998 p. - $40(0,9 \%), 1999$ p. - $20(0,4 \%)$, у 2000 p. $33(0,7 \%)$; y 2001 p. $-12(0,3 \%)$ [2].

У 2002 р. було зареєстровано 79 кваліфікованих умисних вбивств [2], питома вага яких у структурі умисних вбивств, передбачених ст.ст. 115 - 118 КК України, становить $1,8 \%$, у структурі умисного вбивства, передбаченого ст. 115 КК України, $-2,2 \%$.

Таким чином, найбільшу питому вагу у структурі умисних вбивств за період з 1997 по 2001 р. становили такі умисні вбивства: 3 корисливих мотивів $(6,1 \%)$, двох і більше осіб (2,9\%), вчинене за попередньою змовою групою осіб - 2,2\%, вчинене з особливою жорстокістю $(1,1 \%)$.

За даними ДІТ МВС України за 2004-2008 рр. було зареєстровано 3391 кваліфіковане умисне вбивство (2004 p. - 760, 2005 p. - 648, 2006 p. - 674, 2007 p. - 662, 2008 р. - 647) [2]. Зокрема, найвищий рівень було зафіксовано щодо таких кваліфікованих видів умисних вбивств:

945 умисних вбивств 3 корисливих мотивів. Зокрема, у 2004 р. було зареєстровано 230 вбивств, у 2005 p. - 190, у 2006 p. - 184, у 2007 p. - 170, у 2008 p. 171 [2]. Питома вага у структурі умисних вбивств - 5,9\%, у структурі умисних вбивств, передбачених ст. 115 КК України $-6,2 \%$;

625 умисних вбивств двох і більше осіб. Зокрема, у 2004 р. було зареєстровано 151 вбивство, у 2005 р. - 128, у 2006 p. -114 , у 2007 p. - 124, у 2008 p. - 108 [2]. Питома вага у структурі умисних вбивств - 3,9\%, у структурі умисних вбивств, передбачених ст. 115 КК України - 4\%;

554 умисних вбивства за попередньою змовою групою осіб. Зокрема, у 2004 р. було зареєстровано 109 вбивств, у 2005 р. - 110, у 2006 р. - 106, у 2007 р. 104, у 2008 p. - 125 [2]. Питома вага у структурі умисних вбивств - 3,5\%, у структурі умисних вбивств, передбачених ст. 115 КК України - 3,6\% ;

271 умисне вбивство, вчинене особою, яка раніше вчинила умисне вбивство. Зокрема, у 2004 р. було зареєстровано 53 вбивства, у 2005 р. - 50, у 2006 р. - 57, у 2007 p. -53 , у 2008 p. - 58 [2]. Питома вага у структурі умисних вбивств - 1,7\%, у структурі умисних вбивств, передбачених ст. 115 КК України, - 1,8\%);

218 умисних вбивств 3 особливою жорстокістю. Зокрема, у 2004 р. було зареєстровано 43 вбивства, y 2005 p. - 33, у 2006 p. - 45, y 2007 p. - 47, y 2008 p. 50 [2]. Питома вага у структурі умисних вбивств $-1,4 \%$, у структурі умисних вбивств, передбачених ст. 115 КК України, $-1,4 \%$.

Упродовж 2013-2019 рр. за ч. 2 ст. 115 КК України рівень облікованих умисних вбивств, вчинених за обтяжуючих обставин, зріс до 5511 злочинів (у 2013 р. 544, y 2014 p. - 1547 , у 2015 p. - 1178 , y 2016 p. - 636, у 2017 p. - 566, у 2018 р. - 543, у 2019 р. - 497 [3]). Питома вага у структурі умисних вбивств, передбачених ст.ст. 115118 , складає $11,5 \%$, у структурі умисних вбивств, передбачених ст. 115 КК України, - 11,5\%. 
У структурі кваліфікованих умисних вбивств за цей період найбільшу питому вагу мали такі вбивства: двох і більше осіб (25\%), вчинені за попередньою змовою групою осіб (16,4\%), з корисливих мотивів (14,6\%), вчинені особою, яка раніше вчинила умисне вбивство, за винятком вбивства, передбаченого статтями 116-118 КК України $(10,2 \%)$, малолітньої дитини або жінки, яка завідомо для винного перебувала у стані вагітності $(8,7 \%)$, вчинені 3 особливою жорстокістю (3,1\%). Практично відсутні у структурі кваліфікованих умисних вбивств вбивства заручника або викраденої людини $(0,3 \%)$ та умисні вбивства 3 мотивів расової, національної чи релігійної нетерпимості (лише 2 обліковані злочини).

Умисне вбивство, вчинене у стані сильного душевного хвилювання (cm. 116 КК України). За 2004-2008 pp. було зареєстровано 143 вбивства, що у структурі умисних вбивств за цей період становить 0,9\%. Зокрема, у 2004 p. - 34, у 2005 p. - 17, у 2006 p. - 37, у 2007 p. - 25, у 2008 р. - 30. За вказаний період найбільшу кількість цих вбивств було зареєстровано у Донецькій області 37 , у Запорізькій області - 15 . У Тернопільській області жодного злочину [2].

За період 2013-2019 pр. було зареєстровано 46 вбивств, що у структурі умисних вбивств за цей період становить $0,1 \%$, у структурі привілейованих умисних вбивств - 12,6\%. Зокрема, у 2013 р. - 13, у 2014 р. - 4, y 2015 p. -7 , y 2016 p. -7 , y 2017 p. -5 , y 2018 p. -6 , у 2019 р. - 4 [3]. За 2017-2019 pp. за умисне вбивство, вчинене у стані сильного душевного хвилювання, було засуджено 21 особу [4;5].

Умисне вбивство матір'ю своєї новонародженої дитини (cm. 117 КК Украӥни). Впродовж останніх 27 років (1993-2019 рр.) відбувалось поступове скорочення рівня дітовбивств. 31993 р. по 2003 р. число зареєстрованих дітовбивств (за ст. 96 КК) України 1960 р. та ст. 117 КК України 2001 р.) у середньому за рік становило 30 випадків (у 1993 р. - 33 зареєстровані злочини, у 1994 р. - 28 y 1995 p. -32 , y 1996 p. - 33, y 1997 p. - 48, y 1998 p. - 32, y 1999 p. -26, y 2000 p. $-29,2001$ p. -20 , y 2002 p. -20 , у 2003 p. - 29) [2].

Починаючи 32004 р. відбувалось чергове зниження рівня дітовбивств. За період з 2004 р. по 2010 р., число зареєстрованих за ст. 117 КК України злочинів скоротилось майже вдвічі та у середньому становило вже 18 злочинів. Так, за даними ДІТ МВС України у 2006 р. було зареєстровано 18 злочинів, у 2007 р. - 21, у 2008 - 16, у 2009 р. -17 , у 2010 р. - 14 злочинів [2].

32013 р. по 2019 р. відмічається подальше скорочення рівня дітовбивств. Разом було зареєстровано 93 вбивства, тобто у середньому щорічно обліковано всього 13 кримінальних правопорушень (питома вага у структурі умисних вбивств за цей період становить $0,2 \%$, у структурі привілейованих умисних вбивств - 25,5\%). За даними Oфicy Генерального прокурора, у 2013 р. було обліковано 12 кримінальних правопорушень, у 2014 р. - 14, у 2015 p. - 11, у 2016 p. - 14, у 2017 p. - 11, у 2018 p. 12, у 2019 р. -19 [3]. Кількість засуджених за ст. 117 КК України за 2017-2019 рр. - 22 особи [4; 5]. Зазначимо, що питома вага дітовбивств у структурі жіночої злочин- ності на тлі їі стрімкого зниження є незмінною та становить $0,1 \%$. Питома вага дітовбивств у структурі умисних вбивств, вчинених жінками, за останні три роки становить $8 \%$.

Умисне вбивство при перевищенні меж необхідної оборони або у разі перевишення заходів, необхідних для затримання злочиния (cm. 118 КК України). За 2004 2008 рр. було зареєстровано 380 вбивств (питома вага у структурі умисних вбивств - $2,4 \%$, у структурі злочинності - 0,02 \%). Зокрема, у 2004 р. - 99, у 2005 р. - 87, у 2006 р. - 72, у 2007 р. - 70, у 2008 р. - 52 [2]. За вказаний період найбільшу кількість цих вбивств було зареєстровано у Донецькій області - 51, у Дніпропетровській області - 47, Луганській - 33, АРК - 23. У Хмельницькій області - жодного злочину [2]. Коефіцієнт інтенсивності злочинності (на 10 тисяч населення) у Донецькій області у 2004 р. становив 210 вбивств, у Івано-Франківській 7 вбивств.

За період 2013-2019 рр. було зареєстровано 225 цих вбивств, що у структурі умисних вбивств за цей період становить $0,5 \%$, у структурі привілейованих умисних вбивств - 61,8\%. Зокрема, у 2013 р. - 37, у 2014 р. - 48, у 2015 p. -38 , у 2016 p. -38 , у 2017 p. -19 , у 2018 p. -25 , у 2019 р. - 20 [3]. Кількість засуджених за умисне вбивство при перевищенні меж необхідної оборони або у разі перевищення заходів, необхідних для затримання злочинця (ст. 118 КК України), за 2017-2019 рр. - 83 особи [4; 5].

Висновки. Впродовж 1992-2019 рр. динаміка умисних убивств (ст.ст. 115-118 КК України) мала суперечливий характер, адже періоди спаду неодноразово змінювались періодами зростання їх рівня. Відносно сприятлива у 2000-2012 рр. динаміка умисних вбивств, змінилась стрімким зростанням абсолютних вимірів у 2013-2014 pp. За останні 29 років найвищий рівень умисних вбивств зафіксовано у 2013-2019 рр. Враховуючи відсутність офіційних статистичних даних 3 тимчасово окупованих територій Донецької, Луганської областей, Автономної Республіки Крим, а також латентність вбивств, пов'язану iз військовими діями, можна припустити що їх кількість є значно вищою. Найвищий рівень облікованих умисних вбивств було зафіксовано у 2014 р. (11 532), а найнижчий у 2010 (2 356)

Питома вага умисних вбивств (у середньому) у структурі злочинності у 90 -ті роки становила $0,8 \%$, у 2000 -ні роки $-0,7 \%$, з 2013 р. - 1,3\%. У структурі умисних вбивств близько $85 \%$ складають прості умисні вбивства, третина яких вчиняється на грунті ревнощів, помсти, сварки та 3 інших побутових причин. У структурі кваліфікованих умисних вбивств переважають умисні вбивства з корисливих мотивів та двох і більше осіб, вчинені за попередньою змовою групою осіб. Практично відсутні у структурі кваліфікованих умисних вбивств вбивства заручника або викраденої людини (частка - 0,3 \%) та умисні вбивства 3 мотивів расової, національної чи релігійної нетерпимості. Серед привілейованих умисних вбивств більшу половину становлять вбивства, передбачені ст. 118 КК України. Рівень дітовбивств поступово знижується. Якщо у 90-ті роки реєструвалось у середньому щорічно 33 таких вбивства, то останні сім років лише 13.

\section{ЛITEPATУРA}

1. Стан та структура злочинності в Україні. Департамент інформаційно-аналітичного забезпечення MBC України. URL: http://mvs. gov.ua/mvs/control/main/uk/publish/article/717134.

2. Довідка Департаменту інформаційно-аналітичного забезпечення МВС України за 1992-2008 рр. Рукопис.

3. Офіс Генерального прокурора. Статистична інформація. Про зареєстровані кримінальні правопорушення та результати їх досудового розслідування (2013-2019 pp.). URL: http://www.gp.gov.ua/ua/stst2011.html?dir id=111482\&libid=100820\&c=edit\& c=fo

4. Стан здійснення судочинства в Україні судами кримінальної юрисдикції у $201 \overline{8}$ p. URL: https://supreme.court.gov.ua/userfiles/media/ Analiz_kramin_sud_2018.pdf

5. Стан здійснення правосуддя у кримінальних провадженнях та справах про адміністративні правопорушення судами загальної юрисдикції у 2019 p. URL: https://supreme.court.gov.ua/userfiles/media/Zbirka_analit_tablic_2019.pdf.

6. Литвак О.М. Держава і злочинність. Київ : Атіка, 2004. 303 с. 
УДК 343.9

DOI https://doi.org/10.32782/2524-0374/2020-4/67

\section{СУЧАСНИЙ ПОГЛЯД У КРИМІНОЛОГІЇ НА ПОНЯТТЯ ТА ОЗНАКИ ЕКОНОМІЧНОЇ ЗЛОЧИННОСТІ}

\section{MODERN VIEW IN CRIMINOLOGY ON THE CONCEPTS AND SIGNS OF ECONOMIC CRIME}

Толкач А.М., старший викладач кафедри кримінального права та правосуддя юридичного факультету

Навчально-науковий інститут права і соичіальних технологій Національного університету "Чернігівська політехніка»

Стаття присвячена дослідженню поняття та ознак «економічної злочинності» на сучасному етапі. Автор звертає увагу, що недосконалість економічної системи України спричинила глобальну кризу в усіх сферах життєдіяльності. Одним з найбільш небезпечних проявів такої кризи стала економічна злочинність. У статті наголошується, що економічна злочинність характерна для будь-якої держави і має свою специфіку прояву та поширення.

На цей час поняття «економічна злочинність» у кримінальному праві та кримінології офіційно не закріплене. Чинний Кримінальний кодекс України не містить окремого розділу, який би мав назву «Економічні злочини».

З'ясовано, що перші кримінологічні дослідження економічної злочинності були проведені американським кримінологом Е. Сатерлендом у 1939 р., який ввів поняття «білокомірцевої» злочинності.

Проаналізовано та узагальнено сучасні підходи у кримінології до визначення сутності економічної злочинності.

Автор звертає увагу на складність визначення сутності економічної злочинності, попри те, що поняття економічних злочинів уже давно увійшло в широкий науковий обіг. Проведено аналіз термінології понять, близьких до економічної злочинності, та встановлено, що вони не є тотожними.

Ґрунтуючись на даних офріційної статистики Генеральної прокуратури, визначена кількість економічних злочинів на підприємствах, установах організаціях за перше півріччя 2020 р. Окреслені основні ознаки економічної злочинності, на які звертають увагу вітчизняні науковці.

Сформовано авторське бачення поняття «економічна злочинність». Наголошено, що українські науковці не виробили єдиної позиції, які злочини та за якими критеріями слід відносити економічної злочинності.

Автор дійшов висновку, що поняття «економічної злочинності» на сучасному етапі потребує системного і комплексного дослідження. Сформульоване поняття економічної злочинності $є$ негативно-правовим явищем, що властиве будь-якій державі та виникає у результаті високоінтелектуальної злочинної діяльності осіб з метою незаконного спрямування частини економічних ресурсів на свою користь.

Ключові слова: злочинність, економічна злочинність, економічні злочини, злочини у сфері економіки, «білокомірцева» злочинність, ознаки економічної злочинності.

The article is devoted to the study of the concept and signs of "economic crime" at the present stage. The author draws attention to the fact that the imperfection of Ukraine's economic system has caused a global crisis in all spheres of life. One of the most dangerous manifestations of such a crisis has been economic crime. The article emphasizes that economic crime is characteristic of any state and has its own specifics of manifestation and distribution.

To date, the concept of "economic crime" in criminal law and criminology is not officially enshrined. The current Criminal Code of Ukraine does not contain a separate section entitled "Economic crimes".

It was found that the first criminological research on economic crime was conducted by the American criminologist E. Sutherland in 1939 , who introduced the concept of "white-collar" crime.

Modern approaches in criminology to the definition of the essence of economic crime are analyzed and generalized.

The author draws attention to the difficulty of defining the essence of economic crime, despite the fact that the concept of economic crime has long been in wide scientific circulation. An analysis of the terminology of concepts close to "economic crime" and found that they are not identical.

Based on the official statistics of the Prosecutor General's Office, the number of economic crimes at enterprises, institutions and organizations for the first half of 2020 is determined. The main features of economic crime to which domestic scientists pay attention are outlined.

The author's vision of the concept of "economic crime" is formed. Thus, Ukrainian scholars have not developed a single position on what crimes and by what criteria should be considered components of economic crime.

The author came to the conclusion that the concept of "economic crime" at the present stage requires a systematic and comprehensive study. The concept of economic crime as a negative legal phenomenon that is inherent in any state and arises as a result of highly intellectual criminal activity of individuals in order to illegally direct part of economic resources in their favor.

Key words: criminality, economic criminality, economic crime, crimes in the field of economics, "white-collar" crime, signs of economic criminality.

Постановка проблеми. Недосконалість економічної системи України спричинила глобальну кризу в усіх сферах життєдіяльності. Одним із найбільш небезпечних проявів такої кризи є економічна злочинність, яка стала підгрунтям для організованої злочинності. Саме це негативне правове явище внаслідок сприятливих умов збільшує рівень корумпованості державного апарату та правоохоронних органів.

Тривалий час вважалося, що економічна злочинність це злочинність без фізичних жертв, оскільки вона не має насильницького характеру, але сучасні дослідження показали, що одним із масових видів економічної злочинності $\epsilon$ свідоме порушення техніки безпеки та законів про охорону здоров'я й довкілля, а наслідки таких порушень у кілька разів перевищують смертність від насильницької

злочинності. Отже, крім матеріальної, економічною злочинністю завдається значна фізична шкода, визначити яку зараз важко [1, с. 224].

В Україні, за офіційними даними Генеральної прокуратури, у 2020 р. набули поширення такі види економічних злочинів: незаконне використання бюджетних коштів; зловживання у сфері приватизації; зловживання, пов'язані 3 земельними відносинами; злочини у сфері зовнішньоекономічної діяльності [2].

Аналіз останніх досліджень і публікацій. Велика когорта науковців у всьому світі присвятила чимало наукових досліджень вивченню поняття «економічна злочинність», іiі ознак та методів боротьби з цим негативним явищем. Цій темі присвячені наукові доробки українських та зарубіжних дослідників, таких як I.M. Базярук, 
І.Г. Богатирьов, А.М. Бойко, А.П. Закалюк, О.Г. Кальман, С.Й. Кравчук, О.М. Литвак, Г.А. Матусовський, Є.Х. Сатерленд, Л.П. Скалозуб, Бу Свенсон, О.О. Титаренко та інші.

Мета статті - здійснити аналіз поняття та характерних ознак «економічної злочинності» та сформулювати авторське визначення цього поняття.

Виклад основного матеріалу. Коли йдеться про поняття «економічна злочинність», потрібно розуміти, що це явище властиве будь-якій державі, яка використовує всі ресурси для боротьби з цим негативним явищем.

Використовуючи офіційні дані звітів про кримінальні правопорушення, вчинені на підприємствах, установах організаціях за видами господарської діяльності за січень - червень 2020 р., ми отримали такі результати [3] (рис. 1).

Як бачимо з даних діаграми, кількість економічних злочинів, вчинених на підприємствах, установах, організаціях за перше півріччя 2020 р., має значну тенденцію до зростання. Тільки за шість місяців поточного року їх кількість зросла у 5 разів. На нашу думку - це тривожна статистика, яка свідчить про те, що економічна злочинність в країні протягом проаналізованого часу - 3 січня 2020 р. по червень 2020 р. - не падає, а постійно зростає і держава повинна звернути увагу та прийняти заходи у боротьбі 3 цим негативним явищем.

Загальноприйнятого кримінально-правового та кримінологічного поняття «економічна злочинність», попри його широке використання у науковому обігу, досі не існує. Така ситуація не дозволяє уніфікувати законодавство про боротьбу з цим економіко-правовим явищем.

Варто відмітити, що чинний Кримінальний кодекс України не містить окремого розділу, який би мав назву «Економічні злочини» чи «Злочини у сфері економічної діяльності». Статті, якими передбачено кримінальну відповідальність за економічні злочини, містяться у Розділі VII «Злочини у сфері господарської діяльності».

Однак з метою визначення найбільш суттєвих ознак, які властиві економічним злочинам, ми розглянемо сучасні наукові підходи до його визначення.
Перші кримінологічні дослідження економічної злочинності були проведені американським кримінологом Е. Сатерлендом ще у 1939 р. Саме він ввів поняття «білокомірцевої» злочинності. Найважливішими ознаками цього явища кримінолог назвав обман та зловживання довірою. Він досконало дослідив особистість злочинця у сфері економіки, іiі службове становище та соціальний статус.

Враховуючи ці критерії, Є. Сатерленд запропонував таке визначення білокомірцевої злочинності: «це антисуспільна, спрямована на збагачення поведінка осіб, які займають соціально престижне місце в суспільстві та в рамках своєї професійної діяльності діють таким чином, що за одночасної законослухняної поведінки решти осіб зловживають суспільною довірою, якою користується їхня група» [4, с. 286].

Послідовники цієї теорії також вказували на те, що білокомірцеві злочинці завжди намагаються працювати в межах законності чи, принаймні, уявної законності. Такі злочини вони віднесли до групи непрямих абстрактних інтелігентних злочинів у сфері економіки.

Серед зарубіжних авторів також слід згадати Головного директора Ради $з$ попередження злочинності при Департаменті юстиції Швеції Свенсона Бу, який назвав подібні злочинні дії не білокомірцевою, а економічною злочинністю і вказував, що до ії складу необхідно відносити передусім злочини, «які мають в якості прямого мотиву економічну вигоду». Крім того, до ознак економічної злочинності він відніс систематичність, триваючий характер та здійснення в межах легальної господарської діяльності, на підставі якої виникають злочинні діяння [5, с. 4].

Саме праці цього вченого, на думку науковців I.М. Базярука, В.І. Василинчука, С.Й. Кравчука, Л.П. Скалозуба, заклали підгрунтя для дослідження економічної злочинності у нашій країні. 3 того часу ця проблема є предметом наукового дослідження багатьох дослідників у різних країнах світу, в тому числі і в Україні.

Аналізуючи сучасний стан наукової думки і враховуючи практичні потреби сьогодення у виробленні ефективних засобів протидії кримінальним явищам економічного

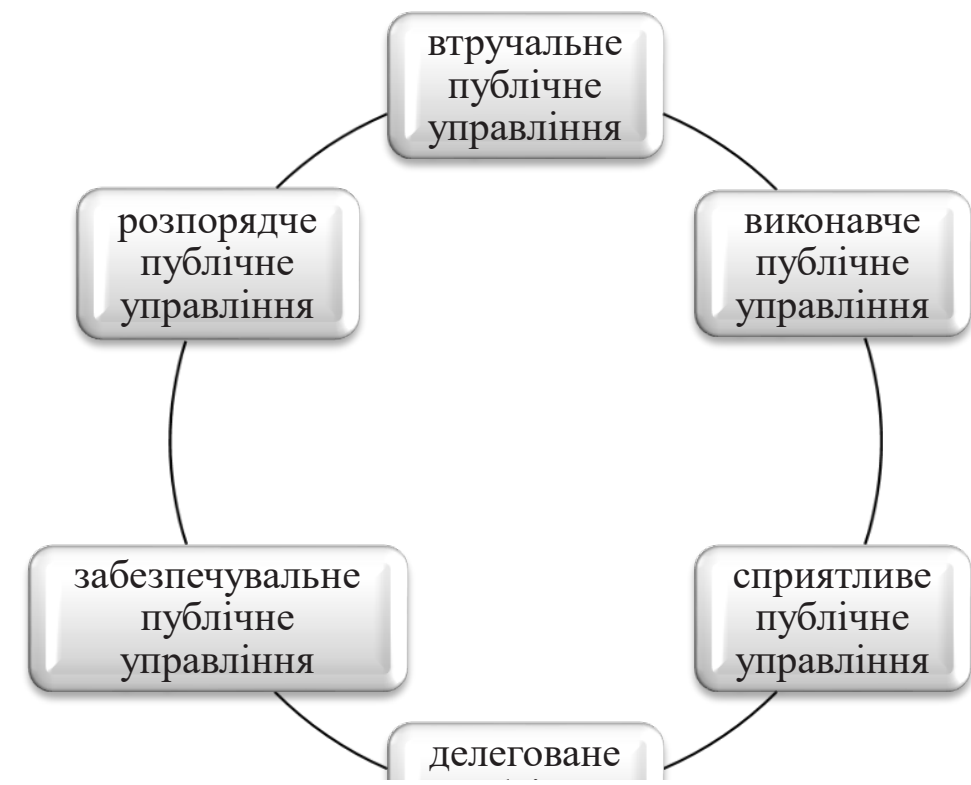

Рис. 1. Кількість злочинів, вчинених на підприємствах, установах, організаціях за різними видами господарської діяльності за січень-червень 2020 р.

Джерело: розроблено автором за даними [3] 
характеру, вважаємо за необхідне навести деякі підходи щодо співвідношення категорій «злочини у сфері економіки» та «економічні злочини» в кримінології.

Економічна злочинність зазвичай розглядається як кваліфіковані та окремі злочини, що вчиняються у значних розмірах. Її об'єктами є значні державні чи колективні цінності. Такі злочини, як показує судова практика, важко розкриваються в рамках кримінальних справ. Як приклади економічної злочинності можна привести приховування від сплати податків до державного бюджету, валютні злочини, розкрадання у значних розмірах державного майна [6, с. 55].

Використовуючи вислів М. Мамардашвілі, економічну злочинність можна розглядати «як явище, зміст якого не виявлений до кінця, не може бути виявлений до кінця, але пізнання якого є важливим стимулом для безперервного пошуку нового змісту» [7, с. 32].

Професор Г.А. Матусовський влучно зазначив, що фактор умовності розгляду складних проблем не може бути перешкодою для визначення складових елементів понять, необхідних для наукового пізнання. Він вважає, що одна з головних ознак економічних злочинів полягає в тому, що їх більша частина - це корисливі діяння, які вчиняються особами, які виконують певні функції у сфері виробництва і послуг [8, с. 27].

Деякі з учених вважають, що розширення меж економічної злочинності є невиправданим, а тому слід розрізняти: злочини у сфері економіки (переважно господарські злочини, вчинювані в різних сферах); економічну злочинність (господарські злочини та розкрадання); злочини економічного характеру (інші діяння, що пов'язані із спричиненням матеріальної шкоди чи отриманням матеріальної вигоди) [9, с. 3]. Проте нерідко поняття «економічні злочини» $\mathrm{i}$ «злочини в сфері економіки» розглядаються як тотожні.

Проведений аналіз літературних джерел, у яких дається визначення поняття «економічна злочинність», дозволив зробити висновок, що цей термін вживається в трьох видах: у широкому розумінні, серединному і вузькому.

На думку О.Г. Кальмана, найбільша кількість науковців дотримується широкого визначення поняття «економічна злочинність».

У широкому значенні розуміють усі види злочинів, які зазіхають на економіку, права, свободи, потреби учасників економічних відносин, що порушують нормальне функціонування економічного механізму, спричиняють цим шкоду соціальним цінностям і благам. У середньому значенні до злочинності у сфері економіки відносять злочини проти власності, господарські та корисливі службові злочини. У вузькому - злочини проти власності та господарські злочини [10, с. 36].

3'ясуємо сутність поняття «економічні злочини». Відомий кримінолог А. Долгова серед ознак економічної злочинності називає високу латентність, тісний зв'язок iз організованою злочинністю, корисливу мотивацію та стійкі негативні тенденції [11, с. 628].

Щодо українських кримінологів, то О. Горбань i I. Карпець визначають злочинність в сфері економіки як злочини, що спричиняють шкоду суспільним відносинам у виробничій, кредитно-фінансовій та торговій сферах. Ці науковці розробили визначену структуру економічних злочинів, включивши до неї розкрадання державного або колективного майна шляхом привласнення, розтрати або заволодіння ним шляхом зловживання службовим становищем, крадіжки такого майна, обман покупців та замовників, спекуляцію, порушення правил про валютні операції $[12$, с. 18$]$.

Науковець О. Литвак у своїй праці «Злочинність, іiі причини та профілактика» зазначає, що, наприклад, такі склади злочинів, як крадіжки, грабежі, розбійні напади і вимагання, варто розглядати як економічні, якщо вони мають на меті усунення або послаблення конкурента на ринку. Він запропонував визначення «економічної злочинності як сукупність навмисних корисливих злочинів, що вчинюються службовими особами, іншими працівниками підприємств і установ, незалежно від їх форм власності, шляхом використання власного становища і місця роботи» $[13$, с. 86$]$.

Професор О.Г. Кальман під злочинами у сфері економіки розуміє соціально-економічне деструктивне для економіки держави явище, що проявляється у вчиненні особами навмисних корисливих злочинів у сфері легальної і нелегальної господарської діяльності, основним безпосереднім об'єктом яких виступають відносини власності та відносини у сфері виробництва, обміну, розподілу і споживання товарів і послуг з метою отримання доходу.

Основні риси злочинності у сфері економіки, на думку О.Г. Кальмана, полягають у тому, що: 1) вони вчинюються у сфері легальної і нелегальної господарської діяльності; 2) суб'єктами цих злочинів можуть бути як підприємці, так і інші особи, які сприяють виконанню господарської діяльності; 3) вони завдають економічної, політичної, моральної шкоди суспільству і державі; 4) спрямовані на одержання економічної вигоди; 5) вчинюються тільки навмисно; 6) можуть здійснюватися різноманітними засобами, передбаченими чинним кримінальним законодавством $[10$, с. 36$]$.

А.П. Закалюк наголошував на методологічній коректності використання терміна «злочинність у сфері економіки», оскільки у такий спосіб визначається місце вчинень злочинів та підкреслюється його предметна сутність порушення інтересів і цілей легальних учасників економічних відносин, а саме отримання у правомірний спосіб прибутку, доданої вартості [14, с. 97].

На думку Є.Л. Стрельцова, економічні злочини включають протиправні діяння, спрямовані на порушення відносин власності та існуючого порядку здійснення господарської діяльності [15, с. 121].

В.М. Попович під економічною злочинністю розуміє сукупність економічних злочинів, вчинених у сфері цивільного обігу речей, прав, дій за певний період часу, 3 протиправним використанням легітимних технологічно-облікових операцій, фінансово-господарських і цивільно-господарських інструментів, організаційнорегулятивних та контрольно-управлінських прав і повноважень [16, с. 32].

У своєму дисертаційному дослідженні А.М. Бойко пропонує вважати економічну злочинність таким видом злочинності, що становить спричинену закономірностями розвитку суспільства кримінологічно-однорідну сукупність суспільно небезпечних і кримінально-караних проявів господарської діяльності, які посягають на механізм організації національної економіки і які вчиняють зазвичай суб'єкти господарської діяльності - фізичні особи або службові особи юридичних осіб - суб'єктів господарської діяльності у процесі здійснення ними фактичної чи фіктивної господарської діяльності через порушення порядку іiі здійснення 3 метою отримання економічної вигоди $[17$, с. 70$]$. Вважаємо запропоновану дефініцію правильною по суті, але змістовно перевантаженою.

На думку, професора Б.М. Головкіна, злочинність у сфері економіки - це корислива злочинна діяльність службових осіб та інших учасників економічних відносин, спрямована на заподіяння матеріальної шкоди підприємствам, установам, організаціям різних форм власності або суб' єктам господарювання [18, с. 30].

O.O. Титаренко пропонує під економічними злочинами розуміти умисні корисливі злочини, що вчиняються у сфері економіки службовими та іншими особами, які включені в систему економічних відносин і посягають на ці відносини, а також на порядок управління економікою 
в різних галузях господарства, заподіюючи при цьому шкоду економічним інтересам громадян, суб'єктів господарювання та держави [19, с. 16]. На нашу думку, наведене визначення $є$ досить вдалим і повністю розкриває правовий зміст економічних злочинів.

Отже, українські кримінологи не виробили єдиної класичної позиції щодо дефініції «економічна злочинність», відтак вивчення та дослідження цього явища триває.

Перші спроби закріпити визначення «економічної злочинності» на законодавчому рівні були закладені в законопроєкті України «Про боротьбу з економічною злочинністю», де під економічною злочинністю розумілася сукупність різних видів навмисних посягань на економічні відносини, що охороняються державою, незалежно від форм власності та видів діяльності суб'єктів, які виконують певні функції у сфері виробництва, обміну, обслуговування, а також осіб, пов'язаних із регулюванням цієї діяльності [20].

3 метою забезпечення єдиного порядку обліку злочинів у сфері економіки, достовірності та об'єктивності статистичних даних у 2004 році було розроблено спільну вказівку Генеральної прокуратури, МВС, СБ та ДПА України від 02.06.2004 № 12-157 «Щодо єдиного порядку обліку злочинів у сфері економіки», у якій зазначено, що під поняттям «злочин у сфері економіки» слід розуміти передбачене Кримінальним кодексом України суспільно небезпечне діяння, яке посягає на відносини власності у сфері господарської чи службової діяльності.

Крім того, цією вказівкою цей перелік обов'язкових ознак злочинів, наявність яких $є$ підставою для їх обліку як економічних: 1) спеціальний об'єкт посягання; 2) спеціальний суб'єкт; 3) склад злочину, передбачений відповідною статтею КК України; 4) спричинення шкоди економічним інтересам держави та суб'єктам господарської діяльності [1, с. 231].

І.Г. Богатирьов надає таке визначення економічної злочинності - це сукупність кримінально караних діянь, які вчиняються в економічній сфері з використанням легітимних, техніко-облікових та контрольно-управлінських прав і повноважень, здійснюється систематично і мають довготривалий характер [21, с. 256].

Таким чином, узагальнюючи викладені положення, пропонуємо таке визначення економічної злочинності - це сукупність протиправних діянь, вчинених спеціальними суб'єктами, шляхом використання власного становища i місця роботи, які спрямовані на порушення відносин власності та існуючого порядку здійснення господарської діяльності.

Науковці, крім визначення поняття економічної злочинності, розкривають основні ознаки цього явища.
На думку С.Й. Кравчук, економічній злочинності притаманні такі ознаки:

- складається із кримінально караних діянь суб'єктів господарювання; посягає на порядок управління економікою;

- спричиняє значні збитки державі, суспільству чи окремим громадянам;

- має триваючий характер;

- вчиняється фізичними особами, оскільки за кримінальним законодавством України суб'єктом злочину може бути лише фізична особа;

- характеризується високою латентністю;

- характеризується тісним зв'язком 3 організованою злочинністю, корупцією та тіньовою економічною діяльністю;

- формує напівкримінальний менталітет у громадян держави [22, с. 42].

Про те, що економічна злочинність здатна формувати спосіб життя певної частини населення, формуючи напівкримінальний менталітет, зазначала також К. Гуцалова $[23$, c. 115].

На переконання I.М. Базярука, основні риси злочинності у сфері економіки полягають у тому, що: по-перше, вони вчиняються у сфері легальної і нелегальної господарської діяльності; по-друге, суб'єктами цих злочинів можуть бути як підприємці, так і інші особи, які сприяють виконанню господарської діяльності; по-третє, вони завдають економічної, політичної, моральної шкоди суспільству і державі; по-четверте, спрямовані на одержання економічної вигоди; по-п'яте, вчиняються тільки навмисно; по-шосте, можуть здійснюватися різноманітними засобами, передбаченими чинним кримінальним законодавством $[9$, с. 6$]$

Висновки. Таким чином, підсумовуючи вищенаведене, можна зазначити. що українські автори ще й досі не виробили єдиної позиції, які злочини та за якими критеріями слід вважати складниками економічної злочинності, що, безумовно, заважає подальшому вивченню цього явища та виробленню рекомендацій з його попередження та зменшення негативних наслідків.

Запропонована автором дефініція ««економічної злочинності» не претендує на вичерпність та повноту розкриття змісту, враховуючи той факт, що кожне дослідження економічної злочинності є новим та актуальним, оскільки враховує нові сучасні тенденції попередження та боротьби з економічною злочинністю.

Отже, сформульоване поняття економічної злочинності $є$ негативно-правовим явищем, що властиве будь-якій державі та виникає у результаті високоінтелектуальної злочинної діяльності осіб з метою незаконного спрямування частини економічних ресурсів на свою користь.

\section{ЛITEPATУPA}

1. Скалозуб Л.П., Василинчук В.І. Проблеми визначення поняття економічної злочинності. Науковий вісник Львівського державного університету внутрішніх справ. 2011. № 1 (2). С. 223-233.

2. Офіційний сайт Генеральної Прокуратури України URL: https:/old.gp.gov.ua/ua/stst2011.html?dir id=114142\&libid=100820 (дата звернення: 01.06.2020).

3. Звіт про кримінальні правопорушення, вчинені на підприємствах, установах організаціях за видами господарської діяльності за січень - червень 2020 p. URL: https://old.gp.gov.ua/ua/stst2011.html?dir id=113897 (дата звернення: 11.06.2020).

4. Сатерленд Эдвин X. Являются ли преступления людей в белых воротничках преступлениями? Социология преступности. Современные буржуазные теории : сб. статей. Москва : Прогресс, 1966. 368 с.

5. Свенсон Бу. Экономическая преступность : Пер. со швед. Москва : Прогресе, 1987. 305 с.

6. Кравчук С. Основні причини поглиблення економічної злочинності в Україні. Право України. 2002. № 11. С. 54-56.

7. Мамардашвили М Картезианские размышления. Москва : Издательская группа «Прогресе», «Культура», 1993. 352 с.

8. Матусовский Г.А. Экономическая преступность: криминалистический анализ. Харьков : Консум, 1999. 480 с.

9. Базярук І.М. Економічна злочинність та її ознаки. Науковий вісник Львівського державного університету внутрішніх справ. 2008. № 2. С. 1-7.

10. Кальман О.Г. Злочинність у сфері економіки України: теоретичні та прикладні проблеми попередження : дис. ... д-ра юрид. наук : 12.00.08. Харків, 2004. 431с.

11. Криминология : Учебник для вузов/Под общ. ред. д. ю. н., проф. А. И. Долговой. 3-е изд., перераб. и доп. Москва : Норма, 2005. 912 c

12. Горбань О. Злочини у сфері економіки. Юридичний вісник України. 2007. 156 с.

13. Литвак О.М. Злочинність, її причини та профілактика. Київ, 1997.168 с. 
14. Закалюк А.П. Курс сучасної української кримінології: теорія і практика : у 3 кн. Кн. 2: Кримінологічна характеристика та запобігання вчиненню окремих видів злочинів / Київ : Ін Юре, 2007. 712 с.

15. Стрельцов Е.Л. Экономическая преступность в Украине : курс лекций / Одесса : АО БАХВА, 1997. 572 с.

16. Попович В.М., Трачук П.А., Андрушко А.В., Логін С.В. Актуальні проблеми кримінального права : навчальний посібник. Київ : Юрінком Інтер, 2009. 256 с.

17. Бойко А.М. Теорія детермінації економічної злочинності в Україні в умовах переходу до ринкової економіки : дис. ... д-ра юрид. наук : 12.00 .08 / Львів, 2009. 492 с.

18. Головкін Б.М. Поняття злочинності у сфері економіки. Форум права. 2013. № 3. C. 128-133. URL: http://nbuv.gov.ua/j pdf/FP index. htm_2013_3_24.pdf. (дата звернення: 21.05.2020).

19. Титаренко О.О. Кримінологічна характеристика та протидія економічним злочинам у вугільній промисловості : монографія. Дніпропетровськ. 2008. 196 с.

20. Про боротьбу з економічною злочинністю: Проект Закону України (вих. № 269/5/26-1640 від 02.04.2002 ДПAУ). URL: www.rada.gov.uа (дата звернення: 14.05.2020).

21. Богатирьов І.Г. Кримінологія: підручник / заг. ред. І.Г. Богатирьова, В. В. Топчія. Київ : ВД Дакор, 2018. 352 с.

22. Кравчук С.Й. Економічна злочинність в Україні : навчальний посібник. Київ : Кондор, 2009. 282 с.

23. Гуцалова К. Кримінологічне визначення поняття та ознак економічної злочинності: проблемні питання. Юридичний журнал. 2004. № 11. C. 113-115. 


\title{
ПРОБЛЕМИ ВИЗНАЧЕННЯ ЗМІСТУ ОЗНАК СУБ' СКТА ВИМАГАННЯ НЕПРАВОМІРНОЇ ВИГОДИ
}

\author{
PROBLEMS OF DETERMINATION OF MAINTENANCE OF SIGNS \\ OF SUBJECT OF SHAKEDOWN OF ILLEGAL BENEFIT
}

\author{
Хмиз М.В., аспірант кафедри кримінального права та кримінології \\ Львівський національний університет імені Івана Франка
}

Стаття присвячена висвітленню питань визначення різних спеціальних суб'єктів вимагання неправомірної вигоди: працівника підприємства, установи чи організації, службової особи, службової особи юридичної особи приватного права, особи, яка надає публічні послуги. Відзначається, що чинний КК України містить логічну помилку щодо класифікації службових осіб на службових осіб державних чи комунальних підприємств, установи чи організацій та службових осіб юридичних осіб приватного права. Пропонується вирішення цієї проблеми. У статті піддається критиці спосіб законодавчого визначення особи, яка надає публічні послуги. Стверджується, що кращим $€$ визначення відповідного поняття шляхом використання родових ознак. У підсумку дослідження пропонується визначення кожного з видів спеціальних суб'єктів вимагання неправомірної вигоди.

Так, наприклад, особа, яка надає публічні послуги, це особа, яка не є службовою, однак на професійних засадах здійснює делеговані їй функції держави чи місцевого самоврядування за публічні кошти. Працівник підприємства, установи чи організації, який не є службовою особою - фізична особа, яка безпосередньо власною працею виконує трудову функцію згідно з укладеним з роботодавцем трудовим договором (контрактом) відповідно до закону і не є представником влади, представником місцевого самоврядування, не обіймає посаду, пов'язану із виконанням організаційно-розпорядчих або адміністративно-господарських функцій. Службова особа юридичної особи приватного права незалежно від організаційно-правової форми - особа, яка обіймає постійно чи тимчасово на не державних та не комунальних підприємствах, в установах чи організаціях посади, пов'язані з виконанням організаційно-розпорядчих чи адміністративно-господарських функцій, або виконує такі функції за спеціальним повноваженням, яким особа наділяється повноважним органом чи повноважною особою підприємства, установи, організації, судом або законом.

Ключові слова: вимагання, спеціальний суб'єкт, неправомірна вигода, службова особа, особа, яка надає публічні послуги, працівник.

The article is sanctified to illumination of questions of determination of the different special subjects of shakedown of illegal benefit: worker of enterprise, establishment or organization, official person, official face of legal entity of private right, person that renders public services. Marked, that operating criminal code of Ukraine contains a logical error during classification of official persons on the official persons of state or communal enterprises, establishment or organizations and official persons of legal entities of private right. Solution of this error is offered.

The method of legislative determination of person that renders public services yields in the article to criticism. It becomes firmly established that the best is determination of corresponding concept by the use of generic features. In a result research is offered determination each of types of the special subjects of shakedown of illegal benefit.

For example, a person who provides public services is a person who is not an official, but on a professional basis performs the delegated functions of the state or local government at public expense. An employee of an enterprise, institution or organization who is not an official a natural person who directly performs a labor function by his own work in accordance with the employment agreement (contract) concluded with the employer in accordance with the law and is not a government official, does not hold a position, associated with the implementation of organizational and administrative or administrative and economic functions. Official of a legal entity of private law, regardless of organizational and legal form - a person who holds permanently or temporarily at non-state and non-communal enterprises, institutions or organizations positions related to the implementation of organizational or administrative or economic functions, or performs such functions by special authority, which a person is endowed with an authorized body or authorized person of an enterprise, institution, organization, court or law.

Key words: shakedown, special subject, illegal benefit, official person, person that renders public services, worker.

Постановка проблеми. На перший погляд, проблем із визначенням змісту суб'єкта вимагання неправомірної вигоди не повинно виникати, адже суб'єкт кваліфікованого складу злочину зазвичай не відрізняється від суб'єкта основного складу злочину. Законодавець встановлює кримінальну відповідальність за вимагання неправомірної вигоди як кваліфікований склад щодо пасивного підкупу таких спеціальних суб'єктів:

- працівник підприємства, установи чи організації, який не є службовою особою (ст. 354 КК України);

- особа, яка працює на користь підприємства, установи чи організації (ст. 354 КК України);

- службова особа (ст. 368 КК України);

- службова особа юридичної особи приватного права незалежно від організаційно-правової форми (ст. 368-3 КК України);

- особа, яка надає публічні послуги (ст. 368-4 КК України)

Однак, як показує аналіз чинного кримінального законодавства та практики його застосування, зі змістом відповідних ознак складів аналізованих злочинів не все однозначно.

Метою статті $є$ розкриття ознак спеціальних суб'єктів складів злочинів, які полягають у вимаганні неправомірної вигоди.
Стан дослідження проблеми. Окремі питання визначення змісту ознак спеціального суб' єкта у злочинах у сфері службової діяльності розглядалися у працях Р.Л. Максимовича, М.I. Хавронюка, О.О. Дудорова, В.М. Киричка, Ю.О. Чернеги, В.І. Тютюгіна, К.П. Задої. Однак спеціального дослідження, яке б присвячувалося проблемам визначення суб'єкта вимагання неправомірної вигоди, у теорії кримінального права нам віднайти не вдалося.

Виклад основного матеріалу. Визначення ознак відповідних спеціальних суб'єктів ми знаходимо як у чинному кримінальному законодавстві, так і у спеціальній кримінально-правовій літературі.

Так, щодо двох видів цих спеціальних суб'єктів вимагання неправомірної вигоди ми знаходимо визначення відповідних понять у примітках до статей Особливої частини КК.

У примітці 1 до ст. 354 КК України визначено, що під особою, яка працює на користь підприємства, установи, організації, слід розуміти особу, яка виконує роботу або надає послугу відповідно до договору з таким підприємством, установою, організацією.

У примітці 1 до ст. 364 КК України визначається поняття службової особи, що застосовується у ст. 368 КК України так: службовими особами у статтях $364,368,368^{-2}$, 369 цього Кодексу є особи, які постійно, тимчасово чи за 
спеціальним повноваженням здійснюють функції представників влади чи місцевого самоврядування, а також обіймають постійно чи тимчасово в органах державної влади, органах місцевого самоврядування, на державних чи комунальних підприємствах, в установах чи організаціях посади, пов'язані з виконанням організаційно-розпорядчих чи адміністративно-господарських функцій, або виконують такі функції за спеціальним повноваженням, яким особа наділяється повноважним органом державної влади, органом місцевого самоврядування, центральним органом державного управління із спеціальним статусом, повноважним органом чи повноважною особою підприємства, установи, організації, судом або законом. Водночас службовими особами також визнаються посадові особи іноземних держав (особи, які обіймають посади в законодавчому, виконавчому або судовому органі іноземної держави, у тому числі присяжні засідателі, інші особи, які здійснюють функції держави для іноземної держави, зокрема для державного органу або державного підприємства), а також іноземні третейські судді, особи, уповноважені вирішувати цивільні, комерційні або трудові спори в іноземних державах у порядку, альтернативному судовому, посадові особи міжнародних організацій (працівники міжнародної організації чи будь-які інші особи, уповноважені такою організацією діяти від іï імені), члени міжнародних парламентських асамблей, учасником яких $\epsilon$ Україна, та судді і посадові особи міжнародних судів.

У цьому наведене визначення службової особи задовольняє як теорію кримінального права, так і судову практику. Зміст цього поняття досить детально проаналізовано у роботі Р.Л. Максимовича, основні висновки та результати якої на момент іiі опублікування заслуговували на підтримку. Та й зараз у частині, яка не суперечить нині чинному законодавству, такі висновки можуть бути використані [6].

Інша ситуація із «новими» спеціальними суб'єктами, визначення яких не апробовані ні в теорії, ні в практиці правозастосування та викликають певні застереження. Так, щодо такого виду спеціального суб'єкта вимагання неправомірної вигоди, як особа, яка надає публічні послуги, то його поняття можна спробувати відшукати безпосередньо у диспозиції ст. 368-4 КК України. Аналіз диспозиції ч. 1 цієї статті дає можливість зробити висновок про те, що особами, які надають публічні послуги, є: аудитор;

- нотаріус;

- приватний виконавець;

- експерт;

- оцінювач;

- третейський суддя;

інша особа, яка провадить професійну діяльність, пов'язану з наданням публічних послуг;

незалежний посередник;

арбітр під час розгляду колективних трудових спорів.

Використання законодавцем такого прийому визначення поняття, як перерахування видів суб'єктів, які $\epsilon$ особами, що надають публічні послуги, видається невиправданим і помилковим. Справа у тому, що переліки осіб, які надають публічні послуги, у різних статтях КК істотно відрізняються. Вони відрізняються навіть у різних частинах однієї статті КК - 368-4 «Підкуп особи, яка надає публічні послуги». Виникає абсолютно неприпустима ситуація, коли активний підкуп здійснюється щодо одного кола спеціальних суб' єктів, а пасивний підкуп у цій самій статті - щодо іншого. На перший погляд виправленням ситуації могло б стати приведення переліків у відповідність один 3 одним. Однак, ураховуючи динамічність діяльності українського парламенту із внесення змін до КК України, такого погодження, очевидно не буде достатньо. Вихід з ситуації, яка склалася iз поняттям особи, яка надає публічні послуги, як спеці- ального суб'єкта вимагання неправомірної вигоди, необхідно шукати у площині визначення родових ознак цього поняття та пропонування загального його визначення у примітці до ст. 365-2 КК України.

Тим більше, що такі пропозиції вже висловлювалися у літературі. Зокрема, Г.М. Зеленов запропонував власну редакцію примітки до ст. $365^{2}$ КК України, щоправда враховуючи її обсяг, вона навряд чи стане предметом серйозного розгляду законодавцем. Тим не менш автор пропонує примітку до ст. $365^{2}$ КК України викласти у такій редакції: «Під публічними послугами у статтях $365^{2}$ та $368^{4}$ цього Кодексу розуміють послуги, які надаються: 1) органами державної влади (в основному виконавчої) та державними підприємствами, установами, організаціями, а також органами місцевого самоврядування в порядку виконання делегованих державою повноважень за рахунок коштів державного бюджету (державні послуги); 2) органами місцевого самоврядування, а також органами виконавчої влади та підприємствами, установами, організаціями в порядку виконання делегованих органами місцевого самоврядування повноважень за рахунок коштів місцевого бюджету (муніципальні послуги); 3) уповноваженими суб' єктами, що відповідно до закону забезпечують юридичне оформлення умов реалізації фізичними та юридичними особами прав, свобод та законних інтересів за їх заявою (видача дозволів, ліцензій, сертифікатів, посвідчень, проведення реєстрації, аудиторська, експертна, нотаріальна діяльність тощо) (адміністративні послуги). Перелік і порядок надання таких послуг визначається законодавством. Під особами, які здійснюють професійну діяльність, пов'язану із наданням публічних послуг, у статтях $365^{2}$ та $368^{4}$ цього Кодексу слід розуміти осіб, які на професійній основі як самозайняті особи чи наймані працівники надають публічні послуги, зазначені у цій примітці» [3, с. 195].

Кардинально інше формулювання примітки пропонує В. Киричко, пропонуючи доповнити ст. 365-2 приміткою наступного змісту: «Під іншими особами, які здійснюють професійну діяльність пов'язану із наданням публічних послуг, у статтях 365-2 та 368-4 цього Кодексу слід розуміти тих осіб, під час визначення повноважень яких у відповідному законі України прямо зазначено про їх належність до цієї категорії осіб». Останній варіант, на думку вченого, зберігає стабільність кримінально-правової норми, але потребуватиме внесення законодавцем відповідних доповнень до вже чинних законів України та врахування цих положень під час прийняття нових законів України [5, с. 59].

Так які ж родові ознаки можуть позначати поняття «особи, які надають публічні послуги» і як їх закріпити у тексті закону? Розв'язуючи цю проблему, варто навести міркування О.О. Дудорова, який відзначив, що слід мати на увазі, що в ч. 3 ст. 368-4 КК спочатку наводиться приблизний (незакритий), але конкретизований (казуїстичний) перелік осіб, які є суб'єктами одержання неправомірної вигоди, прийняття іiї пропозиції, обіцянки, а потім вказується на те, що до цих суб'єктів належать і інші особи, здійснення професійної діяльності яких пов'язане із наданням публічних послуг. У разі визнання суб'єктом злочину, передбаченого ч. 3 (4) ст. 368-4 КК, особи, прямо не віднесеної законодавцем до числа тих, хто надає публічні послуги, таке рішення правозастосовувача має аргументуватись у процесуальних документах. Разом з тим законодавчий зворот «іншою особою, яка провадить професійну діяльність, пов'язану з наданням публічних послуг», повинен підлягати обмежувальному тлумаченню, оскільки: по-перше, усі сумніви мають тлумачитись на користь особи, діяння якої кваліфікуються, а чинне законодавство не містить чітко визначеного поняття «публічні послуги» (фактично воно є оціночним); по-друге, згідно з п. 2 ч. 1 ст. 3 Закону України від 14.10.2014 р. «Про запо- 
бігання корупції» віднесення інших осіб (крім аудиторів, нотаріусів, оцінювачів, оцінювачів, арбітражних керуючих, незалежних посередників, членів трудового арбітражу, третейських суддів під час виконання ними цих функцій) до тих, хто надає публічні послуги, має бути визначено законом. Із викладеного випливає негативна відповідь на питання про віднесення до числі осіб, які здійснюють професійну діяльність, пов’язану із наданням публічних послуг, наприклад, лікарів під час оформлення ними листків тимчасової непрацездатності і викладачів при прийнятті ними заліків та екзаменів (при тому, що відповідні результати професійної діяльності таких осіб фіксуються в офіційних документах і набувають обов'язкового значення для інших учасників правовідносин). За наявності підстав вказані професіонали за свою корупційну поведінку можуть нести відповідальність за ст. 354 КК [2]. Ці міркування складно заперечити. На підтвердження наведеному, вкажемо на те, що законодавець, маючи потребу віднести до кола осіб, які надають публічні послуги, наприклад, приватних виконавців та реєстраторів, вніс безпосередньо у КК України зміни, включивши цих осіб до кола відповідних спеціальних суб'єктів.

Водночас таке розв'язання - пропозиція вносити зміни до КК - не $\epsilon$ повноцінним вирішенням проблеми визначення поняття, яке досліджується.

Особами, що здійснюють професійну діяльність, пов'язану з наданням публічних послуг (ст. ст. 358, 365-2, 368-4 КК), є адвокати, нотаріуси, аудитори, експерти, оцінювачі, арбітражні керуючі, незалежні посередники, члени трудового арбітражу, третейські судді, а також інші особи, що займаються діяльністю (надають послуги), умовою здійснення яких $є$ проходження після здобуття вищої освіти спеціальної підготовки та одержання за ii результатами сертифікату (свідоцтва), що видається уповноваженим органом державної влади або уповноваженою державою самоврядною організацією [8, с. 11]. Варто погодитися із думкою про те, що відправною точкою у розв'язанні питання про конкретний зміст цього формулювання має бути аналіз правового статусу тих категорій осіб, яких законодавець прямо називає у тексті КК особами, що здійснюють професійну діяльність, пов'язану з наданням публічних послуг. Абсолютна більшість із них займається діяльністю (надає послуг), умовами здійснення якої є: а) наявність вищої освіти; б) проходження після здобуття вищої освіти спеціальної підготовки; в) одержання за результатами підготовки сертифікату (свідоцтва), що видається уповноваженим органом державної влади або уповноваженою державою самоврядною організацією [9, с. 11]. Тобто всі такі особи займаються діяльністю, яка вимагає додаткових компетентностей, які не забезпечуються тільки вищою освітою.

У літературі є спроби виділити загальні ознаки, які характеризують осіб, які надають публічні послуги. Так, вже згаданий нами В. Киричко відзначив, що до загальних ознак, які характеризують зазначених осіб, можна віднести такі:

1) їх повноваження передбачені відповідними законами України;

2) їх функції належать публічній сфері суспільних відносин і пов'язані із виконанням функцій держави чи місцевого самоврядування;

3) публічна послуга виражається у здійсненні певних повноважень, передбачених законом, на засадах об'єктивності та неупередженості;

4) здійснення повноважень не $є$ реалізацією приватного інтересу особи, яка надає публічні послуги, хоча може здійснюватися на умовах оплати;

5) фактичні результати здійснення особами своїх повноважень зазвичай відображаються в офіційному документі і набувають обов'язкового юридичного значення для всіх суб' єктів правовідносин або лише для визначених законом суб' єктів (наприклад, для сторін спору);

6) прийняті такими особами рішення спричиняють чи здатні спричинити наслідки правового характеру у сфері виконання функцій держави чи місцевого самоврядування (регулювання суспільних відносин загалом, забезпечення умов для реалізації прав та законних інтересів фізичних чи юридичних осіб, захисту таких прав та інтересів, вирішення спорів (конфліктів) тощо).

Ці ознаки можна брати до уваги під час вирішення розглядуваного питання лише в їх сукупності із урахуванням того, що вони є лише теоретичним орієнтиром, який може мати певне практичне значення для законодавчого вирішення цього питання [5, с. 50-51].

Загалом сприймаючи ці ознаки, відзначимо, що використання у визначенні для позначення ознаки поняття звороту зазвичай ставить під сумнів обов'язковість цієї ознаки.

У спеціальних джерелах містяться й пропозиції авторських визначень відповідного поняття, які, очевидно, так само містять його ознаки. Так, В. Киричко у іншій своїй праці визначив досліджуване поняття так: під особами, які здійснюють професійну діяльність, пов'язану 3 наданням публічних послуг (особами, які здійснюють публічні послуги), у статтях 3652 та 3684 КК слід розуміти слід розуміти осіб, які не є службовими (у кримінально-правовому значенні), державними службовцями чи посадовими особами органів місцевого самоврядування, але на законних підставах надають публічні послуги, що функціонально входять до сфери суспільних відносин і полягають у виконанні певних визначених законом повноважень на засадах об'єктивності та неупередженості, фактичні результати яких зазвичай відображаються в офіційному документі і набувають обов'язкового юридичного значення для всіх або для визначених законом суб'єктів правовідносин та спричинюють чи здатні спричинити наслідки правового характеру у сфері виконання функцій держави чи місцевого самоврядування (регулювання суспільних відносин загалом, забезпечення умов для реалізації прав та законних інтересів фізичних чи юридичних осіб, захисту таких прав та інтересів, вирішення спорів (конфліктів) тощо) $[4$, c. 296]. Як бачимо, визначення не сильно відрізняється від попередніх висновків цього ж автора.

B.I. Тютюгін зазначив, що в основу вирішення цього питання можуть бути покладені різні критерії, а публічними можуть визнаватися послуги, виходячи 3 того: а) що вони $є$ загальнодоступними і тому надаються на звернення будь-якої особи; б) що правом надання таких послуг осіб, які здійснюють певну професійну діяльність, наділяють органи держави чи місцевого самоврядування; в) що такі послуги, на відміну від суто професійних, мають юридично значущий характер, оскільки підтверджують чи посвідчують певні події, явища або факти, які породжують чи здатні породити наслідки правового характеру; г) що при наданні таких послуг зазначені особи також здійснюють організаційно-розпорядчі чи адміністративно-господарські функції, але не належать при цьому до службових осіб чи найманих працівників юридичних осіб публічного чи приватного права [10].

Науковці Національної академії прокуратури України визначають публічні послуги як послуги: 1) що безпосередньо породжують наслідки правового характеру, спрямовані на реалізацію прав та законних інтересів фізичних або юридичних осіб; 2) порядок та форма надання яких визначається державою чи органами місцевого самоврядування у відповідних нормативно-правових актах або угодах; 3) що надаються особами, які не є державними службовцями, посадовими особами місцевого самоврядування. До публічних послуг за умови, що вони безпосередньо тягнуть за собою правові наслідки, належать 
такі види послуг: адміністративні, соціальні, $з$ надання правової допомоги, житлово-комунальні, інформаційні, медичні, послуги з оздоровлення і відпочинку, освітні, послуги 3 протипожежного захисту та рятування, транспортні і послуги зв'язку, послуги з фізичної культури і спорту тощо [7, с. 16, 36].

М.I. Хавронюк визначає публічні послуги як послуги, що надаються публічним сектором (тобто органами державної влади, органами місцевого самоврядування, підприємствами, установами та організаціями державної та комунальної форм власності), а в окремих випадках приватним сектором під відповідальність публічного сектору (публічної влади) і за рахунок публічних коштів (тобто коштів державного і місцевого бюджетів). Науковець зазначає, що крім адміністративних, за критерієм їхнього змісту виділяється такі види публічних послуг, як соціальні, житлово-комунальні, медичні послуги та послуги з оздоровлення та відпочинку, освітні послуги, послуги 3 протипожежного захисту та рятування, транспортні послуги та послуги зв'язку, послуги з фізичної культури і спорту тощо [11, с. 76].

Таким чином, можемо підсумувати. Загальним ознаками поняття «особа, яка надає публічні послуги» є:

1) особа, яка не є службовою у розумінні ч. 3 ст. 18 КК України;

2) сфера діяльності такої особи належать до публічної сфери суспільних відносин і пов'язані із виконанням функцій держави чи місцевого самоврядування і не є реалізацією приватного інтересу;

3) така діяльність здійснюється за публічний кошт;

4) така діяльність особи здійснюється на професійних засадах, що передбачає наявність спеціальної освіти та додаткових вимог як для професіонала, виражається у здійсненні певних повноважень, передбачених законом, на засадах об'єктивності та неупередженості.

Таким чином, особу, яка надає публічні послуги, варто визначити як особу, яка не є службовою, однак на професійних засадах здійснює делеговані їй функцій держави чи місцевого самоврядування за публічні кошти.

Визначення інших спеціальних суб'єктів вимагання неправомірної вигоди також потребує певного аналізу, оскільки не міститься безпосередньо у КК України.

Так, поняття «працівник», як складник такого спеціального суб'єкта, як «працівник підприємства, установи чи організації, який не є службовою особою», визначено у ст. 14.1.195 Податкового кодексу України - працівник - фізична особа, яка безпосередньо власною працею виконує трудову функцію згідно 3 укладеним 3 роботодавцем трудовим договором (контрактом) відповідно до закону. Використання цієї позитивної ознаки, а також наявної у диспозиції статті 354 КК України негативної ознаки - «який не є службовою особою», зміст якої визначено у ч. 3 ст. 18 КК, дає нам можливість запропонувати таке визначення цього спеціального суб'єкта: «працівник підприємства, установи чи організації, який не є службовою особою - фізична особа, яка безпосередньо власною працею виконує трудову функцію згідно з укладеним 3 роботодавцем трудовим договором (контрактом) відповідно до закону і не є представником влади, представником місцевого самоврядування, не обіймає посаду, пов'язану із виконанням організаційно-розпорядчих або адміністративно-господарських функцій».

Варто погодитись із тезою про те, що однією з вад перманентно оновлюваного антикорупційного законодавства $є$ відсутність у ньому визначення поняття «службова особа юридичної особи приватного права» і відсутність посилань на таку особу у загальному визначенні поняття «службова особа» (ст. 18 КК) [1, с. 81-98].

При цьому погоджуватись із наступними висновками автор, як видається, підстав не має. О. Дудоров відзначає, що присвячені службовим особам положення, які наразі містяться у ст. 18 КК, як такі, що стосуються лише одного виду спеціального суб'єкта і тому безпідставно включені до Загальної частини КК, мають бути перенесені до розділу XVII Особливої частини КК. У вдосконаленому визначенні «публічної» службової особи повинні фігурувати не будь-які державні підприємства, а лише казенні підприємства, у зв'язку із чим в ч. 1 примітки до ст. 364 КК замість слів «на державних чи комунальних підприємствах» слід зазначити «на казенних чи комунальних підприємствах». Законодавче визначення суб'єкта злочину, передбаченого ч. 3 (4) ст. 368-3 КК, доцільно удосконалити, беручи до уваги те, що: 1) термінологічний зворот «службова особа юридичної особи приватного права» не охоплює осіб, які, не займаючи посад в юридичних особах приватного права, виконують в інтересах цих юридичних осіб організаційно-розпорядчі та адміністративно-господарські функції за спеціальним повноваженням; 2) поділ юридичних осіб на два види (публічного і приватного права) в сучасній українській цивілістиці не вважається безспірним; 3) коло суб'єктів кримінально караного підкупу в приватному секторі слід розширити за рахунок осіб, які, працюючи у фізичної особи - підприємця на підставі трудового договору, виконують відповідні функції. Зважаючи на викладене, в ч.3 ст. 368-3 КК суб'єкта злочину, передбаченого цією нормою, пропонуємо позначити як «службову особу крім тієї, що вказана в ч. 1 і ч. 2 примітки ст. 364 КК України». Реалізація викладеної пропозиції, означаючи відмову від дискусійного у цивілістиці поділу юридичних осіб на осіб публічного та приватного права, дозволить точніше визначити коло осіб, спроможних нести кримінальну відповідальність у приватному секторі [1, с. 81-98].

Така низка висновків, як видається, навіть за умови ïx законодавчої реалізації істотно не вплинуть на упорядкованість нормативних положень у цій сфері. Ми ж вважаємо, що на увагу заслуговуватимуть такі міркування. Щодо поняття службової особи юридичної особи приватного права незалежно від організаційно-правової форми, то його визначення на перший погляд має стати результатом логічної операції порівняння ознак загального поняття службової особи, яке міститься у ст. 18 КК України, та ознак поняття службової особи, яке міститься у примітці до ст. 364 КК України.

Так, ч. 3 ст. 18 КК України містить наступне визначення загального поняття службової особи: службовими особами є особи, які постійно, тимчасово чи за спеціальним повноваженням здійснюють функції представників влади чи місцевого самоврядування, а також постійно чи тимчасово обіймають в органах державної влади, органах місцевого самоврядування, на підприємствах, в установах чи організаціях посади, пов'язані з виконанням організаційно-розпорядчих чи адміністративно-господарських функцій, або виконують такі функції за спеціальним повноваженням, яким особа наділяється повноважним органом державної влади, органом місцевого самоврядування, центральним органом державного управління із спеціальним статусом, повноважним органом чи повноважною службовою особою підприємства, установи, організації, судом або законом.

Співставлення цього визначення із визначенням, зазначеним у примітці до ст. 364 КК, дає можливість виключити із поняття службової особи юридичної особи приватного права незалежно від організаційно-правової форми ті ознаки, які характерні лише для службових осіб, визначених у примітці до ст. 364 КК. Ці ознаки, що залишаться, стануть істотними необхідними ознаками поняття службової особи юридичної особи приватного права незалежно від організаційно-правової форми. Таким чином, досліджуване поняття можна визначити так:

«службова особа юридичної особи приватного права незалежно від організаційно-правової форми - особа, яка 
обіймає постійно чи тимчасово на недержавних та некомунальних підприємствах, в установах чи організаціях посади, пов'язані 3 виконанням організаційно-розпорядчих чи адміністративно-господарських функцій, або виконує такі функції за спеціальним повноваженням, яким особа наділяється повноважним органом чи повноважною особою підприємства, установи, організації, судом або законом».

Певна логічна невідповідність відразу кидається в очі. Законодавець, диференціюючи відповідальність залежно від виду службової особи, використав для дихотомічного поділу не один критерій, як цього вимагають правила формальної логіки, а відразу два: вид юридичної особи - юридична особа приватного права та вид власності: державне чи комунальне. У абз. 2 примітки 1 до ст. 364 зазначено, що для цілей статей $364,368,368^{-2}, 369$ цього Кодексу до державних та комунальних підприємств прирівнюються юридичні особи, у статутному фонді яких державна чи комунальна частка перевищує 50 відсотків або становить величину, що забезпечує державі чи територіальній громаді право вирішального впливу на господарську діяльність такого підприємства. Таким чином, ми можемо стверджувати, що юридичними особами приватного права $\epsilon$ юридичні особи у статутному фонді, державна чи комунальна частка яких не перевищує 50 відсотків або становить величину, що не забезпечує державі чи територіальній громаді право вирішального впливу на господарську діяльність такого підприємства. Такий підхід, м'яко кажучи, не відповідає цивільно-правовому розумінню юридичної особи приватного права, що визначено у ст. 81 ЦК України. Це може призвести до випадків, коли службова особа обійматиме посаду у такій юридичній особі, яка одночасно не є юридичною особою приватного права у розумінні ст. 81 ЦК України і не буде державним чи комунальним підприємством у розумінні абз. 2 прим. 1 до ст. 364 КК України, що створить штучну прогалину у кримінально-правовому регулюванні.

Висновок. Виходом 3 цієї ситуації може стати внесення до КК змін, спрямованих на усунення цієї логічної помилки: приведення класифікації у відповідність до вимог формальної логіки - проведення іiї за одним критерієм.

Таким чином, попри наявність у тексті КК України визначень більшості понять суб'єктів вимагання неправомірної вигоди, вважати питання із змістом цієї ознаки складу злочину вичерпаним підстав немає.

Вказані визначення містять істотні недоліки, виправлення яких дасть можливість підвищити ефективність протидії службовій злочинності загалом та вимаганням неправомірної вигоди зокрема.

\section{ЛІТЕРАТУРА}

1. Дудоров О.О. Суб'єкт «пасивного» підкупу службової особи юридичної особи приватного права: сучасний ста і перспективи. Вісник Луганського державного університету внутрішніх справ імені Е.О. Дідоренка. 2015. Вип. 3. С. 81-98.

2. Дудоров О.О. Проблеми кваліфікації злочину, передбаченого статтею 368 Кримінального кодексу України. Вісник Луганського державного університету внутрішніх справ імені Е.О. Дідоренка. 2016. Вип. 1. С. 80-98.

3. Зеленов Г.М. Щодо визначення змісту поняття «публічні послуги». Теоретичні та прикладні проблеми сучасного кримінального права: матеріали II міжнародної науково-практичної конфреренції, м. Луганськ, 19-20 квітня 2012 р. / Упорядники: Є.О. Письменський, Ю.Г. Старовойтова; МВС України, Луганський державний університет внутрішніх справ імені Е.О. Дідоренка. Луганськ : РВВ ЛДУВС ім. Е.О. Дідоренка, 2012. С. 190-195.

4. Киричко В.М. Поняття осіб, які здійснюють професійну діяльність, пов'язану із наданням публічних послуг (статті $365^{2}$ та $368^{4}$ КК України). Основні напрями розвитку кримінального права та шляхи вдосконалення законодавства України про кримінальну відповідальність: матеріали міжнародної науково-практичної конфреренції, 11-12 жовтня 2012 року / редколегія В.Я. Тацій (головний редактор), В.І. Борисов (заступник головного редактора) та інші. Харків : Право, 2012. С. 294-298.

5. Киричко В.М. Кримінальна відповідальність за корупцію. Харків : Право, 2013. 424 с.

6. Максимович Р.Л. Поняття службової особи у кримінальному праві України: Монографія. Львів : Львівський державний університет внутрішніх справ, 2008. 304 с.

7. Методичні рекомендації з питань кваліфікації корупційних злочинів, передбачених ст. ст. $364^{1}, 365^{1}, 365^{2}, 368^{2}, 368^{3}, 368^{4}, 369^{2}$ КК України / О.Г. Кальман, В.М. Куц, Я.О. Триньова, Н.М. Ярмиш. Київ : Національна академія прокуратури України, 2012. С. 16, 36.

8. Проект постанови Пленуму Вищого спеціалізованого суду України з розгляду цивільних і кримінальних справ «Про судову практику в справах про злочини у сфері службової діяльності та професійної діяльності, пов'язаної з наданням публічних послуг». В кн.: Судова практика в справах про злочини в сфері службової діяльності та професійної діяльності, пов'язаної з наданням публічних послуг: окремі тенденції, проблеми та перспективи вдосконалення / К.П. Задоя, М.О. Захаренко та ін / Науковий редактор К.П. Задоя. Київ, 2014. 136 с.

9. Судова практика в справах про злочини в сфері службової діяльності та професійної діяльності, пов'язаної з наданням публічних послуг: окремі тенденції, проблеми та перспективи вдосконалення / К.П. Задоя, М.О. Захаренко та ін. / Науковий редактор К.П. Задоя. Київ, 2014. 136 с.

10. Тютюгін В. Новели кримінального законодавства щодо посилення відповідальності за корупційні злочини: вирішення проблеми чи проблеми для вирішення. Юридичний вісник України. 30 січня-5 лютого 2010 р. № 5.

11. Хавронюк М.І. Науково-практичний коментар до Закону України «Про засади запобігання і протидії корупції». Київ : Атіка, 2011. 


\title{
НАПРЯМИ СУЧАСНИХ ДОСЛІДЖЕНЬ ПРОБЛЕМ ВІДПОВІДАЛЬНОСТІ ЗА ПРОВОКАЦІЮ ПІДКУПУ В ТЕОРІЇ КРИМІНАЛЬНОГО ПРАВА
}

\author{
MODERN AREAS OF RESEARCH ON THE ISSUES OF RESPONSIBILITY \\ FOR THE PROVOCATION OF BRIBERY IN THE THEORY OF CRIMINAL LAW
}

\author{
Шепотько М.А., аспірантка кафедри кримінального права \\ Національний університет «Одеська юридична академія»
}

Стаття присвячена аналізу сучасних напрямів досліджень проблем відповідальності за провокацію підкупу в теорії кримінального права. Динаміка законодавчих змін, які стосуються кримінальної відповідальності за провокацію підкупу, викликає підвищений інтерес у науковців. Проведений аналіз сучасних досліджень, присвячених проблемам кримінальної відповідальності за провокацію підкупу, дає можливість зазначити, що більшою мірою злочин, передбачений ст. 370 Кримінального кодексу України, досліджується під час розгляду кримінально-правових категорій «провокація» та «підкуп». У таких дослідженнях, враховуючи їхній предмет, провокація підкупу розглядається як один із видів провокації або - опосередковано за кримінально-правового аналізу - підкупу. Комплексні дослідження вказаного складу злочину були проведені до внесення чинних змін до Кримінального кодексу України. Водночас ті наукові праці, де предметом дослідження є питання кримінальної відповідальності за провокацію підкупу, мають здебільшого фрагментарний характер і присвячені окремим аспектам (проблемам кваліфікації, розмежуванню із суміжними складами злочинів, питанням добровільної відмови провокатора й особливостей притягнення в такому разі його до кримінальної відповідальності, дослідженню зарубіжного досвіду та практики Європейського суду з прав людини тощо). Інколи провокацію підкупу розглядають в розрізі інституту співучасті, визначаючи провокацію спеціальним видом співучасті, або ж розглядають аналізований злочин крізь призму поняття необхідної співучасті. Також $є$ дослідження, у яких провокація підкупу розглядається як обставина, що виключає склад злочину, або як крайня потреба.

Враховуючи зазначене, а також рефрорму кримінального законодавства, зроблено висновок, що назріла потреба проведення комплексного дослідження кримінальної відповідальності за провокацію підкупу відповідно до чинного законодавства України, причому з акцентом на аналізі зарубіжного законодавства й практики Європейського суду з прав людини.

Ключові слова: провокація підкупу, провокація, підкуп, провокація злочину.

The article analyses modern areas of scientific research on the issues of responsibility for the provocation of bribery within the theory of criminal law. The dynamics of legislative changes relating to the responsibility of bribery led to a rise in sparked heightened interest of researchers. Analysis of contemporary studies of issues of the responsibility for provocation of bribery suggests that analyzed criminal offence provided for by Article 370 of Criminal Code of Ukraine is examined, mostly, in relation to criminal law categories of "provocation" and "bribery". Considering the subject of these studies, the provocation of bribery is deemed as one of the types of bribery, or indirectly in criminal law analysis of bribery. Comprehensive studies of the mentioned criminal offence had been carried out before the amendments were made to the Criminal Code of Ukraine. Notwithstanding, academic works that had the issues of the responsibility for provocation of bribery as their subject are, in general, fragmented and deal with certain aspects (issues of qualification, separation from related criminal offences, issues of voluntary refusal of provocateur and specificities of their criminal prosecution in that case, analysis of international experience and case-law of European Court of Human Rights (ECtHR)). Provocation of bribery is occasionally viewed from the perspective of complicity institute, whereas provocation is regarded as a special form of complicity or examine the analyzed crime in terms of the notion of necessary complicity. There are also researches where provocation of bribery is examined as either a precluding circumstance or state of necessity.

Taking the abovementioned considerations into account as well as the ongoing reform of criminal legislation it is concluded that there is a need to conduct holistic research of criminal responsibility for the provocation of bribery under the current law of Ukraine while making an emphasis on both international legislation and case-law of ECtHR.

Key words: provocation of bribery, provocation, bribery, entrapment.

Вступ. Ст. 370 Кримінального кодексу України (далі КК України) передбачає кримінальну відповідальність за провокацію підкупу. 3 моменту прийняття КК України й до сьогодні вказана норма кардинально змінилася. Перші зміни в диспозицію статті були внесенні Законом № 3207VI від 7 квітня 2011 р., відповідно до якого передбачалася кримінальна відповідальність за провокацію хабаря або комерційного підкупу, тобто свідоме створення службовою особою обставин і умов, що спричинюють пропонування або одержання хабаря чи неправомірної вигоди, щоб потім викрити того, хто дав або отримав хабар або неправомірну вигоду. Однак уже згодом Законом № 221-VII від 18 квітня 2013 р. було суттєво змінено редакцію аналізованої статті на таку: «Провокація підкупу, тобто свідоме створення службовою особою обставин і умов, що зумовлюють пропонування, обіцянку чи надання неправомірної вигоди або прийняття пропозиції, обіцянки чи одержання такої вигоди, щоб потім викрити того, хто пропонував, обіцяв, надав неправомірну вигоду або прийняв пропозицію, обіцянку чи одержав таку вигоду». Проте й ця редакція, на думку законодавця, потребувала коректив, і менш як за 2 роки Законом № 198-VIII від 12 лютого 2015 р. в диспозицію ст. 370 КК України були знову внесені зміни, і сьогодні вказана стаття викладена так: «Провокація підкупу, тобто дії службової особи з підбурення особи на пропонування, обіцянку чи надання неправомірної вигоди або прийняття пропозиції, обіцянки чи одержання такої вигоди, щоб потім викрити того, хто пропонував, обіцяв, надав неправомірну вигоду або прийняв пропозицію, обіцянку чи одержав таку вигоду».

Безумовно, така динаміка законодавчих змін, які стосуються кримінальної відповідальності за провокацію підкупу, викликала підвищений інтерес у науковців. Водночас, враховуючи, що реформування кримінального законодавства триває, виникла нагальна потреба в систематизації всіх напрацювань учених з указаного питання.

Постановка завдання. Метою статті є встановлення напрямів сучасних досліджень проблеми відповідальності за провокацію підкупу в теорії кримінального права.

Результати дослідження. Різним аспектам кримінальної відповідальності за провокацію підкупу у вітчизняній кримінально-правовій науці приділено велику увагу. Враховуючи назву вказаної норми й правову природу цього діяння, всі дослідження з аналізованої теми умовно можна поділити на декілька груп. Так, до першої групи можна віднести наукові праці, присвячені дослідженню провокації в кримінальному праві, в яких провокація підкупу розглядалася як один із проявів провокації. Одним із перших фундаментальних кримінально-правових досліджень провокації злочину $є$ дисертаційна робота O.I. Альо- 
шина «Провокація злочину (кримінально-правове дослідження)» (2007р.) [1]. Пізніше провокація злочину стала предметом ще ряду наукових досліджень [2; 3]. Варто виокремити статтю К.Ю. Карелова «Спеціальні правила кваліфікації провокації злочинів, вчинених у співучасті: відмежування провокації від суміжних кримінально-правових понять» [4], яка цікава саме своїм порівняльно-правовим аспектом.

У наступну групу можна виділити дослідження, які присвячені кримінальній відповідальності за підкуп. Так, ті чи інші питання, пов'язані з кримінальною відповідальністю за підкуп, висвітлені в дисертаційних дослідженнях О.Д. Ярошенко («Кримінальна відповідальність за пропозицію та надання неправомірної вигоди службовій особі») [5], Я.В. Ризак («Кримінальна відповідальність за підкуп службової особи юридичної особи приватного права») [6], К.К. Овод («Кримінально-правова характеристика підкупу працівника підприємства, установи чи організації») [7], О.С. Перешивко («Кримінальна відповідальність за підкуп особи, яка надає публічні послуги») [8]. Питання притягнення до кримінальної відповідальності за підкуп особи, яка надає публічні послуги, висвітлювали О.В. Шемякін [9] та В.П. Кушпіт [10]. Кримінально-правову характеристику підкупу працівника підприємства, установи чи організації досліджували Ю.А. Комисарчук [11], С.В. Якимова [12]. Види підкупу як кримінально караного корупційного правопорушення в Україні висвітлюють у своїй публікації В.С. Боровікова та С.В. Якимова [13].

3 останніх робіт слід виокремити дисертаційне дослідження В.В. Комар «Поняття та види підкупу за кримінальним законодавством України» (2020р.), яке є комплексним аналізом кримінально-правового поняття «підкуп» [14].

До наступної групи можна віднести дослідження, які присвячені різним аспектам кримінальної відповідальності за провокацію підкупу. Так, на дисертаційному рівні аналізований злочин досліджувався О.М. Грудзур («Кримінально-правова характеристика провокації хабаря», 2011 р.) [15]. Доцільність існування вказаної норми стала предметом ряду досліджень вітчизняних науковців, таких як В.В. Веретянніков [16], О.I. Романова [17], О.О. Дудоров [18]. Питанням кваліфікації провокації підкупу й аналізу судової практики присвятили наукові дослідження такі вчені, як О.В. Ус [19], Р.В. Перелигіна, Б.М. Мирко [20], О.О. Колотило [21], О.О. Дудоров [22], А.В. Штерн [23], О.В. Баганець [24].

Досить часто вчені аналізують провокацію підкупу в розрізі інституту співучасті [25], визначаючи провока- цію спеціальним видом співучасті [26]. О.О. Кваша розглядає аналізований злочин крізь призму поняття необхідної співучасті [27].

Ряд досліджень присвячено питанням розмежування провокації підкупу з суміжними злочинами. Так, П.П. Андрушко аналізує відмежування провокації хабаря від вимагання [28]. Досить цікавими є дослідження, присвячені добровільній відмові провокатора й особливостям притягнення в такому разі його до кримінальної відповідальності [29].

Також варто виокремити дослідження, у яких провокація підкупу розглядається як обставина, що виключає склад злочину [30], або як крайня необхідність [31].

В окрему групу вважаємо за доцільне виокремити публікації вчених, присвячені міжнародно-правовому досвіду кримінальної відповідальності за провокації підкупу й дослідженням практики Європейського суду з прав людини (далі - ССПЛ).

До праць, у яких досліджено досвід зарубіжних країн в аспекті кримінальної відповідальності за провокацію підкупу, можна віднести роботи Є.О. Турова [32], Т.С. Батраченко [33], Д.В. Каменського [34], П.Д. Гуйван [35].

Вивчення практики ЄСПЛ є надзвичайно важливим у дослідженні провокації підкупу. Зазначений аспект став предметом уваги таких вітчизняних науковців, як О.М. Дроздов [36], В.В. Березнер [37], К.Ю. Алданова [38].

Висновки. Проведений аналіз сучасних наукових праць, присвячених проблемам кримінальної відповідальності за провокацію підкупу, дає можливість зазначити, що більшою мірою аналізований злочин досліджується під час розгляду кримінально-правових категорій «провокація» та «підкуп». У таких дослідженнях, враховуючи їхній предмет, провокація підкупу розглядається як один із видів провокації або, опосередковано за кримінальноправового аналізу, підкупу. Комплексні дослідження вказаного складу злочину були проведені до внесення чинних змін до КК України. Водночас ті наукові праці, де предметом вивчення $є$ питання кримінальної відповідальності за провокацію підкупу, мають здебільшого фрагментарний характер і присвячені окремим аспектам (проблемам кваліфікації, розмежуванню з суміжними складами злочинів, дослідженню зарубіжного досвіду та практики ЄСПЛ тощо). Враховуючи зазначене й реформу кримінального законодавства, вважаємо, що назріла потреба в проведенні комплексного дослідження кримінальної відповідальності за провокацію підкупу відповідно до чинного законодавства України з акцентом на аналізі зарубіжного законодавства та практики ЄСПЛ.

\section{ЛITEPATУРА}

1. Альошина О.І. Провокація злочину (кримінально-правове дослідження) : автореф. дис... канд. юрид. наук : 12.00.08; Дніпропетровський державний університет внутрішніх справ. Дніпропетровськ, 2007. 19 с.

2. Саакян М.Б. Провокація: кримінально-правовий аспект. Роль та місие правоохоронних органів у розбудові демократичної правової держави : матеріали VIII Міжнар. наук.-практ. конф., м. Одеса, 25 березня 2016 р. Одеса : ОДУВС, 2016. С. 326-327.

3. Чуприна 3. Провокація чи боротьба зі злочинністю? Вісник Національної асоціації адвокатів України: Офріційний бюлетень Національної асоціації адвокатів України. 2016. № 3. С. 27-31.

4. Карелов К.Ю. Спеціальні правила кваліфікації провокації злочинів, вчинених у співучасті: відмежування провокації від суміжних кримінально-правових понять. Прикарпатський юридичний вісник. 2019. Вип. 3(28). Т. 2. С. 143-146.

5. Ярошенко О.Д. Кримінальна відповідальність за пропозицію та надання неправомірної вигоди службовій особі (ст. 369 КК України) : автореф. дис. ... канд. юрид. наук : 12.00.08; Національний університет імені Тараса Шевченка, Київ. 2014. 20 с.

6. Ризак Я.В. Кримінальна відповідальність за підкуп службової особи, юридичної особи приватного права : автореф. дис. ... канд. юрид. наук : 12.00.08. Київ : Національна академія прокуратури України, 2014. 20 с.

7. Овод К.К. Кримінально-правова характеристика підкупу працівника підприємства, установи чи організації (ст. 354 КК України) : автореф. дис. ... канд. юрид. наук : 12.00.08; Харківський національний університет внутрішніх справ. Харків, 2017. 18 с.

8. Перешивко О.С. Кримінальна відповідальність за підкуп особи, яка надає публічні послуги : автореф. дис. .... канд. юрид. наук : 12.00.08 ; Академія адвокатури України, Київ, 2018. 20 с.

9. Шемякін О.В. Деякі питання притягнення до кримінальної відповідальності за підкуп особи, яка надає публічні послуги. Вісник Луганського державного університету внутрішніх справ імені Е.О. Дідоренка. 2012. № 2. С. 268-275.

10. Кушпіт В.П. Кримінально-правова характеристика підкупу особи, яка надає публічні послуги. Вісник Національного університету «Львівська політехніка». Серія «Юридичні науки». 2014. № 801. С. 202-211.

11. Комісарчук Ю.А., Якимова С.В. Підкуп за кримінальним законодавством України. Науковий вісник Львівського державного університету внутрішніх справ. Серія «Юридична». 2014. № 4. С. 230-240.

12. Якимова С. Про коректність використання терміна «підкуп» при конструюванні диспозицій кримінально-правових норм. Проблеми української термінології: збірник наукових праць. 2014. С. 85-89. 
13. Боровікова В.С., Якимова С.В. Види підкупу як кримінально караного корупційного правопорушення в Україні. Науковий вісник Львівського державного університету внутрішніх справ. 2015. № 3. С. 222-233.

14. Комар В.В. Поняття та види підкупу за кримінальним законодавством України: автореф. дис. ... канд. юрид. наук : 12.00.08; Національний університет «Одеська юридична академія», Одеса. 2020. 23 с.

15. Грудзур О.М. Кримінально-правова характеристика провокації хабаря: автореф. дис. ... канд. юрид. наук: 12.00.08; Академія адвокатури України. Київ, 2011. 20 с.

16. Веретянніков В.В. Деякі аспекти доцільності існування кримінальної відповідальності за провокацію хабаря або комерційного підкупу. Вісник Луганського державного університету внутрішніх справ ім. Е.О. Дідоренка. 2013. Вип. № 1. С. 95-102.

17. Романова О.І. Місце та значення кримінально-правової протидії провокації у боротьбі з корупцією та хабарництвом в межах державної політики. Право і Безпека. 2011. № 3 (40).

18. Дудоров О.О. Кримінально-правова заборона провокації підкупу, або Правоохоронець як ініціатор злочину. Юридичний вісник України. 2015. № 15. С. 12-13.

19. УС О.В. Провокація підкупу: аналіз складу злочину й питання кваліфікації. Науковий вісник Міжнародного гуманітарного університету. Серія «Юриспруденція». 2015. Вип. 16 (2). С. 66-70.

20. Перелигіна Р.В., Мирко Б.М. Щодо окремих аспектів кримінальної відповідальності за провокацію підкупу. Часопис Київського університету права. 2018. № 2. С. 289-292.

21. Колотило О. Провокація вчинення корупційного злочину: актуальні аспекти та судова практика. Вісник прокуратури. 2017. № 10. C. $22-27$.

22. Дудоров О.О. Кримінально-правові аспекти провокації підкупу. Юридичний науковий електронний журнал. 2016. № 1. С. 76-82.

23. Штерн А. Провокаційна діяльність правоохоронних органів та ії відмінність від правомірних заходів контролю за вчиненням злочину. Публічне право : науково-практичний юридичний журнал. 2018. № 3. С. 100-106.

24. Баганець О. Провокування підкупу: справи, про які мовчать. Юридичний вісник України. 2018. № 5. С. 6-7.

25. Ярмиш Н. Провокація підкупу та співучасть у корупційних злочинах: парадокси кримінально-правового регулювання. Вісник Національної академії прокуратури України. 2017. № 4/2. С. 111-116.

26. Бантишев О.Ф. Провокація хабаря як спеціальний вид співучасті у злочині. Боротьба з організованою злочинністю і корупцією (теорія і практика). 2008. Вип. 19. С. 105-112.

27. Кваша О.О. Розгляд окремих корупційних злочинів крізь призму поняття необхідної співучасті. Історико-правовий часопис. 2014. № 1 (3). С. $97-101$

28. Андрушко П.П. Провокація хабаря: кримінально-правова характеристика та відмежування від вимагання. Судова апеляція. 2006. № 1.

29. Гродецький Ю.В. Добровільна відмова провокатора злочину. Вісник Асоціації кримінального права України. 2015. № 2 (5). C. $122-134$.

30. Буняк В. Провокація хабаря як обставина, що виключає склад злочину. Юридична газета. Юридичні питання: практика. 2015. № 29/30. C. 32.

31. Попов І.М. Провокація хабаря або крайня (службова) необхідність?! Право і безпека : науковий журнал. 2002. № 4. С. $134-137$.

32. Турова Є.О. Міжнародний досвід відповідальності за злочини, вчинені внаслідок провокації. Правові реформи в Україні: реалії сьогодення : тези доповідей VII Всеукр. наук.-теорет. конф., присвяч. Дню юриста України, 29 жовтня 2015 р., Київ. 2015. С. 319-320.

33. Батраченко Т.С. Порівняльно-правовий аналіз кримінальної відповідальності за провокацію підкупу законодавства України та зарубіжних країн. Правова позиція. 2016. № 1. С. 96-101.

34. Каменський Д.В. Agent provocateur: провокація злочину чи законна правоохоронна діяльність? Правові горизонти. 2018. Вип. 11 (24). С. 54-61.

35. Гуйван П.Д. До питання про кваліфікацію провокації підкупу: європейський досвід. Вчені записки Таврійського національного університету імені В.І. Вернадського. Серія «Юридичні науки». 2019. № 1. С. 87-92.

36. Дроздов О.М. Актуальні питання здійснення захисту від провокації (підбурювання) особи на вчинення злочину у світлі практики Європейського суду з прав людини. Вісник Кримінального судочинства. 2016. № 2. С. 31-44.

37. Березнер В. Провокація підкупу у світлі практики Європейського суду з прав людини. Jurnalul juridic național: teorie și practică (Национальный юридический журнал: теория и практика). 2016. № 2/1. С. 103-107.

38. Алданова К.Ю. Провокація злочину: практика Європейського суду з прав людини. URL: https://sud.ua/ru/news/blog/112137provokatsiya-zlochinupraktika-yevropeyskogo-sudu-z-prav-lyudini. 


\section{РОЗДІЛ 9 \\ КРИМІНАЛЬНИЙ ПРОЦЕС ТА КРИМІНАЛІСТИКА; СУДОВА ЕКСПЕРТИЗА; ОПЕРАТИВНО-РОЗШУКОВА ДІЯЛЬНІСТЬ}

УДК 343.14

DOI https://doi.org/10.32782/2524-0374/2020-4/70

НЕДОПУСТИМІСТЬ ДОКАЗІВ, ОТРИМАНИХ ІЗ ПОРУШЕННЯМ ПІДСЛІДНОСТІ

INADMISSIBILITY OF EVIDENCE OBTAINED IN VIOLATION OF JURISDICTION

Благодир А.А., к.ю.н., доцент,

доцент кафедри відновного правосуддя та приватної детективної діяльності

Національний університет водного господарства та природокористування

Благодир В.С., к.ю.н., адвокат

Благодир С.М., к.ю.н., доцент, доцент кафедри відновного правосуддя та приватної детективної діяльності

Національний університет водного господарства та природокористування

Статтю присвячено розгляду питань, пов'язаних із дослідженням та оцінкою доказів під час досудового слідства та судового розгляду кримінальних проваджень, які отримані з порушенням правил підслідності.

Проаналізовано підходи різних учених до визначення категорії «підслідність». Звернено увагу на те, що підслідність дає можливість розподілити кримінальні провадження як між окремими органами досудового розслідування, так і між окремими підрозділами в одному органі досудового розслідування. Однак, як свідчить практика, органи досудового розслідування по-різному тлумачать норми кримінального процесуального законодавства, якими встановлено правила підслідності, що перешкоджає виконанню завдань кримінального судочинства. Автори звернули увагу на те, що важлива роль у правильному тлумаченні кримінальних процесуальних норм належить Конституційному Суду України та Верховному Суду. У рішеннях зазначених судових інстанцій неодноразово зверталася увага на те, що обвинувачення у вчиненні злочину не може бути обґрунтоване фактичними даними, одержаними в незаконний спосіб, а саме: з порушенням конституційних прав і свобод людини і громадянина; з порушенням установлених законом порядку, засобів, джерел отримання фактичних даних; не уповноваженою на те особою тощо. Судді касаційного кримінального суду у складі Верховного Суду висловили правову позицію, в якій зазначено, що підслідність кримінальних проваджень визначається виключно кримінальним процесуальним законом. Генеральний прокурор, керівник регіональної прокуратури, їхні перші заступники та заступники своєю вмотивованою постановою мають право доручити здійснення досудового розслідування будь-якого кримінального правопорушення, окрім того, що віднесено до підслідності Національного антикорупційного бюро України, іншому органу досудового розслідування, у тому числі слідчому підрозділу вищого рівня в межах одного органу, лише у разі здійснення органом, визначеним у ст. 216 КПК, досудового розслідування у розпочатому кримінальному провадженні та встановлення за наслідками такого розслідування його неефективності.

Ключові слова: доказування, допустимі докази, кримінальне провадження, слідчий, прокурор, підслідність.

The article is devoted to the issues related to the examination and evaluation of evidence during the pre-trial investigation and trial of criminal proceedings obtained in violation of the rules of jurisdiction.

The approaches of different scientists to the definition of the category «investigation» are analyzed. Attention is drawn to the fact that jurisdiction makes it possible to distribute criminal proceedings both between separate bodies of pre-trial investigation and between separate subdivisions in one body of pre-trial investigation. However, as practice shows, the pre-trial investigation bodies differently interpret the norms of the criminal procedural legislation establishing rules of jurisdiction that hinder the performance of the tasks of criminal proceedings. The authors drew attention to the fact that an important role in the correct interpretation of criminal procedural norms belongs to the Constitutional Court of Ukraine and the Supreme Court. The decisions of these courts have repeatedly drawn attention to the fact that the accusation of a crime cannot be substantiated by factual data obtained illegally, namely: in violation of the constitutional rights and freedoms of man and citizen; violation of statutory procedure, sources, means, obtaining factual data; unauthorized person, etc. Judges of the Criminal Court of Cassation of the Supreme Court expressed a legal position stating that the jurisdiction of criminal proceedings is determined exclusively by the criminal procedure law. The Prosecutor General, the head of the regional prosecutor's office, their first deputies and deputies have the right to entrust the pre-trial investigation of any criminal offense, except for those under the jurisdiction of the National Anti-Corruption Bureau of Ukraine, to another pre-trial investigation body, including the investigative unit of the highest level within one body, only in the case of implementation by the body specified in Art. 216 of the CPC of pre-trial investigation in the initiated criminal proceedings and the establishment of the ineffectiveness of such an investigation.

Key words: evidence, admissible evidence, criminal proceedings, investigator, prosecutor, investigative jurisdiction

Постановка проблеми. Після прийняття нового Кримінального процесуального кодексу України значно змінилися підходи до критеріїв оцінки допустимості доказів. Незважаючи на достатньо чіткі положення нового кримінального процесуального законодавства, якими врегульовані питання допустимості доказів, органи досудового розслідування та суди по-різному тлумачать окремі положення. Як свідчить практика, у судах апеляційної та касаційної інстанцій докази, покладені судом першої інстанції в основу обвинувального висновку, нерідко визнають недопустимими. Такий стан зумовлений різним тлумаченням суб'єктами кримінальної процесуальної діяльності суті правових норм, що стосуються даного питання.
Аналіз досліджень і публікацій. Проблеми доказування у кримінальному процесі та інститут підслідності кримінального провадження постійно знаходяться у полі зору науковців. До цієї проблеми зверталися у своїх роботах багато відомих українських та зарубіжних учених-юристів: Ю.І. Азаров, Ю.П. Аленін, О.В. Баулін, В.Г. Гончаренко, Ю.М. Грошевий, А.Я. Дубинський, 3.3. Зінатуллін, Л.М. Лобойко, А.О. Ляш, М.М. Михеєнко, В.Т. Нор, С.М. Сівочек, С.М. Стахівський, В.М. Тертишник, Л.Д. Удалова, В.П. Шибіко, М.Є. Шумило та ін. Однак проблеми, пов'язані із застосуванням норм, які регулюють це питання, 3 урахуванням нового Кримінального процесуального кодексу України (далі - КПК) 
та практики Європейського суду з прав людини, досліджено недостатньо.

Постановка завдання. Метою статті є дослідження наукових поглядів i практики застосування питань, пов'язаних із проблемами оцінки доказів під час кримінального судочинства, та формулювання авторської позиції щодо усунення наявних теоретичних і практичних проблем.

Виклад основного матеріалу дослідження. У КПК законодавець не встановлює дефініції підслідності кримінального провадження, однак серед юристів відсутні істотні відмінності у визначенні цього поняття.

В Юридичній енциклопедії зазначено, що підслідність - це сукупність установлених законом ознак кримінальних справ (проваджень), відповідно до яких установлюється конкретний слідчий орган, компетентний провадити досудове слідство [1, с. 551].

Автори підручника «Кримінальний процес» указують, що підслідність кримінальних проваджень - це встановлена законом сукупність ознак кримінального провадження, відповідно до яких воно належить до віддання того чи іншого органу досудового розслідування. Підслідність зумовлює правильний розподіл кримінальних проваджень між різними органами досудового розслідування [2, с. 215].

На думку В.М. Тертишника, підслідність - це сукупність установлених законом ознак кримінальних справ, відповідно до яких установлюється конкретний слідчий орган, компетентний проваджувати досудове слідство $[3$, c. 9]. Висловлювалася думка, що підслідність - розподілення кримінальних проваджень згідно з кримінальним процесуальним законодавством України між органами, які мають право розслідувати кримінальні правопорушення [4].

Правила про підслідність зумовлюють правильний розподіл кримінальних проваджень як між окремими органами досудового розслідування, так і між окремими підрозділами в одному органі досудового розслідування.

Деякі процесуалісти зауважували, що правильне визначення підслідності вимагає від правозастосовника встановлення низки юридичних і фактичних підстав, сукупність яких, своєю чергою, дасть можливість визначити орган, який у даній конкретній ситуації уповноважений здійснювати досудове розслідування. До переліку такого роду чинників слід віднести: (а) кваліфікацію діяння; (б) правовий статус особи, яка причетна (може бути причетна) до вчинення кримінального правопорушення або щодо якої вчинено кримінальне правопорушення; (в) розмір предмета кримінального правопорушення або завданої ним шкоди; (г) місце вчинення кримінального правопорушення; (г) факт початку кримінального провадження іншим органом досудового розслідування. При цьому невстановлення зазначених обставин може суттєво вплинути на правильність визначення підслідності та, як наслідок, знівелювати всі зусилля органу досудового розслідування у процесі збирання, перевірки та оцінки доказів у зв'язку з визнанням таких доказів недопустимими [5, с. 103].

У кримінальному процесуальному законодавстві України підслідність кримінальних правопорушень визначається за територією вчинення кримінального правопорушення органами, уповноваженими на розслідування цих кримінальних правопорушень.

Слід погодитися з авторами, які стверджують, що на практиці досить поширеними є випадки виникнення спірних ситуацій у разі порушення стороною обвинувачення правил предметної підслідності [6, с. 75].

Відповідно до Рішення Конституційного Суду України від 20 жовтня 2011 р. у справі № 1-31/2011, обвинувачення у вчиненні злочину не може бути обгрунтоване фактичними даними, одержаними в незаконний спосіб, а саме:
3 порушенням конституційних прав та свобод людини i громадянина; 3 порушенням установлених законом порядку, засобів, джерел отримання фактичних даних; не уповноваженою на те особою тощо [7].

Згідно зі ст. 86 КПК, доказ визнається допустимим, якщо він отриманий у порядку, встановленому КПК (ч. 1). Недопустимий доказ не може бути використаний під час прийняття процесуальних рішень, на нього не може посилатися суд під час ухвалення судового рішення (ч. 2).

Відповідно до ч. 1 ст. 87 КПК, недопустимими є докази, отримані внаслідок істотного порушення прав та свобод людини, гарантованих Конституцією та законами України, міжнародними договорами, згода на обов'язковість яких надана Верховною Радою України, а також будь-які інші докази, здобуті завдяки інформації, отриманій унаслідок істотного порушення прав та свобод людини.

Частиною 2 та 3 цієї статті встановлено, що суд зобов'язаний визнати істотними порушеннями прав людини і основоположних свобод, зокрема, такі діяння, як здійснення процесуальних дій, які потребують попереднього дозволу суду, без такого дозволу або з порушенням його суттєвих умов. Недопустимими є також докази, що були отримані після початку кримінального провадження шляхом реалізації органами досудового розслідування чи прокуратури своїх повноважень, не передбачених цим Кодексом, для забезпечення досудового розслідування кримінальних правопорушень.

Відповідно до ст. 216 КПК, слідчі органів Національної поліції здійснюють досудове розслідування кримінальних правопорушень, передбачених законом України про кримінальну відповідальність, окрім тих, які віднесені до підслідності інших органів досудового розслідування. Цією ж статтею чітко визначено підслідність інших органів досудового розслідування (слідчих органів безпеки, слідчих органів, що здійснюють контроль над додержанням податкового законодавства, слідчих органів Державного бюро розслідувань та детективів Національного антикорупційного бюро України).

Питання щодо процесуальних наслідків порушення правил підслідності під час досудового розслідування після прийняття нового КПК було предметом розгляду на рівні касаційної судової інстанції в 2016 р. Так, судді Судової палати у кримінальних справах Вищого спеціалізованого суду України з розгляду цивільних і кримінальних справ за підсумками розгляду цього питання направили до судів загальної юрисдикції Лист за № 9-2388/0/4-16 від 13.09.2016.

У цьому Листі судді вищої на той час касаційної інстанції зазначили, що, на їхню думку, проведення досудового розслідування кримінального провадження, зокрема проведення окремих слідчих (розшукових) дій, заходів забезпечення кримінального провадження органом, до компетенції якого, згідно із процесуальним законодавством, не віднесено його здійснення, порушує загальні засади законності здійснення кримінального провадження, закріплені у ст. 9 КПК, та унеможливлює виконання завдань кримінального провадження, визначених у ст. 2 КПК України. Згідно з вимогами ч. 1 ст. 9 КПК, під час кримінального провадження суд, слідчий суддя, прокурор, керівник органу досудового розслідування, слідчий, інші службові особи органів державної влади зобов'язані неухильно додержуватися вимог Конституції України, КПК, міжнародних договорів, згода на обов'язковість яких надана Верховною Радою України, вимог інших актів законодавства. У ст. 216 КПК визначено підслідність органів досудового розслідування. Законодавче розмежування підслідності між різними органами досудового розслідування визначає розподіл наданих кримінальним процесуальним законом повноважень таким органам. 3 огляду на наведене, відповідно до положень п. 2 ч. 3 ст. 87 КПК, недопустимими визнаються докази, що були отримані 
після початку кримінального провадження шляхом реалізації органами досудового розслідування чи прокуратури своїх повноважень, не передбачених цим Кодексом, для забезпечення досудового розслідування кримінальних правопорушень. Водночас судді зазначили, що питання допустимості тих чи інших доказів вирішується під час судового розгляду судом, який здійснює розгляд кримінального провадження [8].

Відповідно до вимог кримінального процесуального законодавства, зазначений Лист суддів касаційно інстанції мав лише рекомендаційний характер. Висловлена думка суддів не була обов'язковою для застосування судами першої та апеляційної інстанцій.

Практика свідчить про те, що на протязі 2012-2020 pp. непоодинокими були випадки, коли вимоги КПК стосовно підслідності порушувалися слідчими та прокурорами і залишалися поза належного реагування судової інстанції.

Так, слідчий і прокурор прокуратури Тернопільської області вийшли за рамки наданих їм повноважень і самовільно безпідставно визначили підслідність кримінального провадження по підозрі начальника реєстраційної служби Н. у вчиненні кримінального правопорушення, передбаченого ч. 3 ст. 368 КК України. 3 метою створення ілюзії законності самовільного визначення підслідності слідчий прокуратури вказав в офіційних документах завідомо неправдиві дані про те, що Н. є працівником правоохоронного органу. Однак, як слідує з матеріалів провадження, на час подачі заяви і початку проведення слідчих дій, задовго до затримання Н. та оголошення йому про підозру, слідчому та прокурорам було достовірно відомо, що він не є працівником правоохоронного органу, i, згідно 3 КПК, кримінальне провадження порушене стосовно нього підслідне слідчим органів внутрішніх справ [9].

Слідчий та прокурор військової прокуратури Західного регіону в порушення вимог закону провели досудове розслідування кримінального провадження по підозрі сільського голови Б. у вчиненні кримінального правопорушення, передбаченого ст. 369-2 КК України [10]

У зазначених та інших кримінальних провадженнях сторона захисту звертала увагу органів досудового слідства та судів щодо порушення правил підслідності.

Згідно з ч. 1 розділу XI «Перехідні положення», КПК було передбачено, що до дня введення в дію положень частини першої (у частині положень щодо повноважень здійснення досудового розслідування злочинів, передбачених статтями 402-421, 423-435 Кримінального кодексу Украіни) та частини четвертої статті 216 цього Кодексу повноваження щодо досудового розслідування передбачених ними кримінальних правопорушень здійснюють слідчі органів прокуратури, які користуються повноваженнями слідчих, визначених цим Кодексом.

Саме тому слідчі прокуратури, у тому числі й військової, приймали до свого провадження матеріали про вчинення службовими особами різних кримінальних правопорушень. Особливою популярністю користувалися провадження про вчинення корупційних правопорушень.

Серед основних аргументів, якими сторона захисту обгрунтовувала незаконність дій органів прокуратури щодо визначення підслідності (на час прийняття відповідного рішення), було те, що ч. 4 ст. 216 КПК встановлено коло осіб, щодо яких досудове розслідування проводять слідчі органів Державного бюро розслідувань. Тобто розслідування кримінальних правопорушень, передбачених ст. 368 КК України, якщо вони вчинені не особами, вказаними в ч. 4 ст. 216 КПК, віднесені до компетенції слідчих органів внутрішніх справ (слідчих поліції). Чинний КПК не надає прокурорам будь-якого рівня визначати підслідність на свій розсуд, оскільки підслідність чітко визначена у ст. 216 КПК.

Спростовуючи аргументи сторони захисту, прокурори та судді у своїх рішеннях, як правило, зазначали, що, згідно 3 ч. 5 ст. 36 КПК, Генеральний прокурор України, його заступники, прокурори Автономної Республіки Крим, областей, міст Києва та Севастополя і прирівняні до них прокурори своєю вмотивованою постановою мають право доручити здійснення досудового розслідування будь-якого кримінального правопорушення іншому органу досудового розслідування, у тому числі слідчому підрозділу вищого рівня в межах одного органу.

Однак при цьому ігнорувалася вимога ч. 5 ст. 36 КПК, якою було встановлено, що прокурор має право доручити проведення досудового розслідування іншому органу в разі неефективного досудового розслідування. Таким правом можуть скористатися лише визначені законом службові особи прокуратури.

Верховний Суд у квітні 2020 р. висловив свою правову позицію щодо питання порушення підслідності кримінальних проваджень.

Зокрема, у Постанові від 14 квітня 2020 р. (справа № 761/34909/17) суд касаційної інстанції зазначив: «Відповідно до вимог ст. 86 КПК, докази визнаються допустимими, якщо їх отримано у порядку, встановленому цим Кодексом

Докази мають бути отримані тільки уповноваженими на це особами (органами); способами і засобами, які призначені для одержання певних доказів; у процесі отримання доказів мають бути дотримані вимоги закону, що визначають порядок проведення конкретних дій, їх послідовність, склад учасників; докази мають бути закріплені належним чином.

Недодержання вказаних вимог має наслідком визнання доказів недопустимими, вони не можуть бути використані під час прийняття процесуальних рішень, на них не може послатися суд під час ухвалення судового рішення.

Згідно 3 приписами ст. 87 КПК, недопустимими $€$ докази, отримані внаслідок істотного порушення прав та свобод людини, гарантованих Конституцією та законами України, у тому числі внаслідок порушення права особи на захист та шляхом реалізації органами досудового розслідування чи прокуратури своїх повноважень, не передбачених КПК, для забезпечення досудового розслідування кримінальних правопорушень.

Тобто здійснення досудового розслідування невповноваженими на те особами (органами) визнається істотним порушенням прав людини і основоположних свобод та має наслідком визнання отриманих доказів недопустимими.

Як убачається з матеріалів справи, під час здійснення досудового розслідування у кримінальному провадженні щодо ОСОБА_2 та ОСОБА 3 органи прокуратури діяли поза межами визначених КПК повноважень.

Так, кримінальне провадження було розпочате прокурором за заявою потерпілого ОСОБА_1, внесеною до Єдиного реєстру досудових розслідувань 19 серпня 2016 р. за ознаками кримінального правопорушення, передбаченого ч. 3 ст. 15 , ч. 4 ст. 190 КК.

Згідно зі ст. 216 КПК, дане кримінальне правопорушення віднесено до підслідності слідчих органів Національної поліції. Тому, розпочавши кримінальне провадження, прокурор на підставі ч. 7 ст. 214 КПК зобов 'язаний був невідкладно, але не пізніше наступного дня, 3 дотриманням правил підслідності передати наявні у нього матеріали до слідчих органів Національної поліції та доручити проведення досудового розслідування.

Проте всупереч приписам процесуального закону органи прокуратури з 19 серпня до 30 вересня 2016 р., тобто протягом одного місяця і десяти днів, здійснювали досудове розслідування з порушенням визначеної ст. 216 КПК підслідності, у ході чого провели низку слідчих дій, спрямованих на отримання доказів, у тому числі й негласні слідчі (розшукові) дії, результати яких було покладено в основу обвинувачення. 
Окрім того, вказані порушення процесуального закону не було усунуто й у результаті винесення Генеральним прокурором України постанови від 30 вересня 2016 р. про визначення підслідності та доручення здійснення досудового розслідування слідчим органам Генеральної прокуратури України».

Таким чином, правова позиція Верховного Суду полягає у тому, що підслідність кримінальних проваджень визначається виключно кримінальним процесуальним законом, а саме ст. 216 КПК. На підставі ч. 5 ст. 36 КПК Генеральний прокурор, керівник регіональної прокуратури, їхні перші заступники та заступники своєю вмотивованою постановою мають право доручити здійснення досудового розслідування будь-якого кримінального правопорушення, окрім того, що віднесене до підслідності Національного антикорупційного бюро України, іншому органу досудового розслідування, у тому числі слідчому підрозділу вищого рівня в межах одного органу, лише у разі здійснення органом, визначеним у ст. 216 КПК, досудового розслідування у розпочатому кримінальному провадженні та встановлення за наслідками такого розслідування його неефективності.

Висновки. Уважаємо, що до ч. 5 ст. 36 КПК необхідно добавити пункт, яким установити, що порушення правил підслідності є істотним порушенням вимог кримінального процесуального законодавства.

У разі встановлення порушень правил підслідності суд повинен керуватися вимогами ч. 2 ст. 89 КПК, якими передбачено, що у разі встановлення очевидної недопустимості доказу під час судового розгляду суд визнає цей доказ недопустимим, що тягне за собою неможливість дослідження такого доказу або припинення його дослідження в судовому засіданні, якщо таке дослідження було розпочате.

\section{ЛITEPATУРA}

1. Юридична енциклопедія : у 6 т. / редкол. Ю.С. Шемшученко (гол. редкол.) та ін. Київ : Українська енциклопедія імені М.П. Бажана, 2002. T. $5.720 \mathrm{c}$.

2. Кримінальний процес : підручник / Л.Д. Удалова та ін. ; за ред. В.В. Коваленка, Л.Д. Удалової, Д.П. Письменного. Київ : Центр учбової літератури, 2013. 544 с.

3. Тертишник В.М. Кримінальний процес України. Особлива частина : підручник. Київ : Алерта, 2014. 420 с.

4. Підслідність. URL : https:/luk.wikipedia.org/wiki/\%D0\%9F\%D1\%96\%D0\%B4\%D1\%81\%D0\%BB\%D1\%96\%D0\%B4\%D0\%BD\%D1\%96 \%D1\%81\%D1\%82\%D1\%8C (дата звернення: 08.07.2020).

5. Омаров А.А. Інститут підслідності в кримінальному провадженні : дис. ... канд. юрид. наук : 12.00.09. Харків, 2017. 214 с.

6. Погорецький М.А., Волкотруб С.Г. Удосконалення кримінального процесуального законодавства щодо підслідності органів досудового розслідування. Вісник кримінального судочинства. 2017. № 1. С. 71-80.

7. Рішення Конституційного Суду України у справі за конституційним поданням Служби безпеки України щодо офріційного тлумачення положення частини третьої статті 62 Конституції України. Офріційний вісник України. 2011. № 84. С. 136-141.

8. Лист Вищого Спеціалізованого Суду України з розгляду цивільних і кримінальних справ від 13.09.2016. URL : http:// search.ligazakon.ua/l_doc2.nsf/link1/VRR00209.html (дата звернення: 08.07.2020).

9. Матеріали кримінального провадження № 593/987/15-к. Тернопільський міськрайонний суд Тернопільської області. 2020.

10. Матеріали кримінального провадження № 344/8491/17. Івано-Франківський міський суд Івано-Франківської області. 2020.

11. Постанова Верховного Суду від 14 квітня 2020 р. у справі № 761/34909/17. URL : http://www.reyestr.court.gov.ua/Review/88904111 (дата звернення: 08.07.2020). 


\title{
ТИМЧАСОВИЙ ТА ЕКСТРАДИЦЙНИЙ АРЕШТ У КРИМІНАЛЬНОМУ ПРОВАДЖЕННІ: ОКРЕМІ ПРОБЛЕМИ ПРАВОЗАСТОСУВАННЯ
}

\author{
TEMPORARY AND EXTRADITIONAL ARREST IN CRIMINAL PROCEEDINGS: \\ INDIVIDUAL PROBLEMS OF LAW ENFORCEMENT
}

\author{
Давиденко С.В., к.ю.н., \\ доцент кафедри кримінального процесу та оперативно-розшукової діяльності \\ Національний юридичний університет імені Ярослава Мудрого
}

У статті досліджено окремі проблеми правового регулювання процедур застосування та припинення дії таких запобіжних заходів, як тимчасовий та екстрадиційний арешт, спрямованих на забезпечення видачі осіб (екстрадиції), у контексті гармонізації чинного національного кримінального процесуального законодавства з міжнародними стандартами у сфері захисту прав і свобод людини, що свідчить про актуальність даного наукового дослідження.

У представленій роботі здійснено ґрунтовний аналіз положень указаного правового інституту, присвячених особливостям регламентації підстав, умов і порядку застосування тимчасового та екстрадиційного арешту. Виокремлено нормативні конструкції, що використовуються законодавцем під час вирішення питань тематичного спрямування, а також види судових рішень, які можуть бути ухвалені за результатами розгляду відповідного клопотання прокурора.

У ході наукового дослідження звернуто увагу на специфіку закріплених процесуальних гарантій прав осіб, стосовно яких вирішується питання про застосування названих запобіжних заходів, зокрема права визначених у законі учасників кримінального судочинства на оскарження прийнятих судових рішень. У зв'язку із цим наведено аргументацію щодо важливості забезпечення реалізації однойменної засади в такій категорії кримінальних проваджень.

Логічною частиною цієї роботи є характеристика загальної процедури припинення дії тимчасового арешту та запобіжного заходу у вигляді тримання під вартою для забезпечення видачі особи (екстрадиційного арешту) компетентним органам іноземної держави. Проаналізовано загальновизнані норми та принципи міжнародного права з означеної теми, сучасну практику національних судів та необхідні правові позиції Верховного Суду.

Сформульовані у статті пропозиції спрямовані на вдосконалення окреслених положень чинного кримінального процесуального законодавства України в частині правового регулювання процедури застосування тимчасового й екстрадиційного арешту. Надано обґрунтовані рекомендації щодо реалізації окремих нормативних приписів вітчизняного законодавства, які свідчать про практичне значення результатів проведеного дослідження.

Ключові слова: запобіжні заходи, тимчасовий арешт, екстрадиційний арешт, видача особи (екстрадиція).

The article examines some problems of legal regulation of procedures for application and termination of such precautionary measures as temporary and extradition arrest, aimed at ensuring the extradition of persons (extradition), in the context of harmonization of existing national criminal procedure legislation with international standards in the field of human rights and freedoms. indicates the relevance of this research.

In the presented work the thorough analysis of the provisions of the specified legal institute devoted to features of regulation of the bases, conditions and the order of application of temporary and extradition arrest is carried out. The normative constructions used by the legislator in resolving issues of thematic orientation are singled out, as well as the types of court decisions that can be made based on the results of consideration of the relevant petition of the prosecutor.

In the course of the research, attention was paid to the specifics of the established procedural guarantees of the rights of persons in respect of whom the issue of application of these precautionary measures is resolved, and in particular the right of participants in criminal proceedings to appeal against court decisions. In this regard, the argument is given about the importance of ensuring the implementation of the principle of the same name in this category of criminal proceedings.

The logical part of this work is the description of the general procedure for termination of temporary arrest and pre-trial detention in order to ensure the extradition of a person (extradition arrest) to the competent authorities of a foreign state. The generally recognized norms and principles of international law on this topic, the current practice of national courts and the necessary legal positions of the Supreme Court are analyzed.

The proposals formulated in the article are aimed at improving the outlined provisions of the current criminal procedure legislation of Ukraine in terms of legal regulation of the procedure for applying temporary and extradition arrest. Substantiated recommendations for the implementation of certain regulations of domestic legislation, which indicate the practical significance of the results of the study.

Key words: precautionary measures, temporary arrest, extradition arrest, extradition (extradition).

Сьогодні надзвичайної актуальності набувають проблемні питання вдосконалення правового регулювання процедури застосування до певної категорії осіб таких специфічних запобіжних заходів, як тимчасовий та екстрадиційний арешт, із метою забезпечення успішного співробітництва органів правопорядку, інших уповноважених органів державної влади України з компетентними органами іноземних держав та міжнародними організаціями у сфері боротьби зі злочинністю транснаціонального характеру, що, беззаперечно, свідчить про подальшу інтеграцію України до загальновизнаної системи європейських та світових стандартів гарантування прав і свобод людини.

Так, відповідно до статті 583 КПК, тимчасовий арешт як «спеціальний» запобіжний захід застосовується: до затриманої особи, яка вчинила злочин за межами теритоpiї України; до моменту надходження запиту про ії видачу; строком до 40 діб або на інший, встановлений відповідним міжнародним договором України термін (ч. 1). Разом i3 тим якщо максимальний строк тимчасового арешту, передбачений частиною 1 цієї статті, закінчився, а запит про видачу такої особи не надійшов, затримана уповноваженими суб'єктами особа підлягає негайному звільненню 3-під арешту [1]

За процедурою, визначеною статтею 583 КПК, прокурор звертається до слідчого судді місцевого суду, у межах територіальної юрисдикції якого було здійснено затримання, із клопотанням про застосування тимчасового арешту, що за своєю правовою природою має превентивний характер (наприклад, є наявною реальна загроза зникнення затриманої особи у разі її звільнення з місця постійного проживання чи тимчасового перебування на території запитуваної держави, що, безумовно, може ускладнити або взагалі унеможливити процедуру майбутньої екстрадиції). До названого документу додаються: 1) складений у визначеній законом формі протокол затримання особи 3 обов'язковою відміткою про роз'яснення їй у тому числі права: а) надати згоду на видачу (екстрадицію) для забез- 
печення можливості застосувати процедуру видачі (екстрадиції) особи у спрощеному порядку; б) відмовитися від застосування спеціально встановленого правила щодо меж кримінальної відповідальності у разі надання згоди на іiї видачу (екстрадицію); 2) документи (матеріали), що містять достатні дані (відомості) про вчинення затриманою особою злочину на території іноземної держави (чи держав) та вибору щодо неї певного запобіжного заходу компетентним органом іноземної держави; 3) документи, що 3 достовірністю підтверджують особу затриманого. Крім того, додатком до клопотання прокурора визнається подана у письмовій формі заява затриманої особи про згоду на її видачу (екстрадицію), в якій вона може зазначити про свою відмову від реалізації спеціального правила щодо меж кримінальної відповідальності (за наявності такої письмової заяви). Подане представником сторони обвинувачення клопотання розглядається слідчим суддею у найкоротший строк, але у будь-якому разі не пізніше 72 годин із моменту фактичного затримання даної особи (ч. ч. 3-5 указаної статті).

За алгоритмом процесуальних дій, окреслених у ч. 6 ст. 583 КПК, під час розгляду клопотання слідчий суддя: встановлює дані про особу затриманого; пропонує їй зробити заяву (зміст останньої зазвичай обмежується питаннями стосовно екстрадиційного процесу, правомірності здійсненого затримання, законності й обгрунтованості вибору такого заходу, як тимчасовий арешт); роз'яснює особі як право надати згоду на видачу (екстрадицію) для забезпечення можливості застосувати процедуру видачі (екстрадиціï) особи у спрощеному порядку, так і належне їй право на відмову від застосування спеціально встановленого правила стосовно меж кримінальної відповідальності у разі надання згоди на ii видачу (екстрадицію); з'ясовує дійсне бажання особи скористатися цими правами; перевіряе істинність i добровільність надання особою не лише згоди на їі видачу (екстрадицію), а й відображеної у письмовому вигляді відмови від застосування спеціального правила щодо меж кримінальної відповідальності, та реальність усвідомлення нею всіх правових наслідків вираження такої згоди (чи відмови); ретельно перевіряє наявність документів (матеріалів), передбачених п. 2 ч. 4 цієї статті; вислуховує думку прокурора та інших учасників (особи, стосовно якої вирішується дане питання, ііі захисника, ін.). У зв'язку із цим нагадаємо: якщо затримана особа надала згоду на її видачу (екстрадицію) або надала згоду на видачу та відмовилася від реалізації спеціально встановленого законом правила щодо меж кримінальної відповідальності, суд затверджує згоду особи на видачу (екстрадицію) та застосовує екстрадиційний арешт або відмовляє у затвердженні згоди особи на її видачу (екстрадицію) та застосовує тимчасовий арешт.

За результатами розгляду клопотання прокурора слідчий суддя має постановити один із таких видів ухвал, а саме про: 1) застосування тимчасового арешту; 2) відмову у застосуванні тимчасового арешту, якщо для його вибору відсутні підстави; 3) відмову у затвердженні згоди особи на іï видачу та застосування тимчасового арешту. Під час прийняття судом рішень про затвердження згоди особи на іiі видачу (екстрадицію) та застосування екстрадиційного арешту, а також про затвердження згоди особи на їі видачу (екстрадицію), одночасної відмови від реалізації спеціального правила стосовно меж кримінальної відповідальності та застосування екстрадиційного арешту копія ухвали, винесеної в результаті розгляду питання щодо затвердження згоди особи на ії видачу, невідкладно направляється уповноваженому (центральному) органу України (Офісу Генерального прокурора чи Міністерству юстиції України) через відповідну регіональну прокуратуру разом із копією письмової заяви такої особи про згоду на іiі видачу (екстрадицію) [1].
Наприклад, відмовляючи у задоволенні клопотання прокурора про застосування тимчасового арешту щодо затриманого громадянина Республіки Кіпр ОСОБА_1, слідчий суддя Солом'янського районного суду м. Києва у мотивувальній частині рішення від 23 вересня 2017 р. навів такі аргументи: «До матеріалів клопотання був доданий протокол затримання особи ... та документ, що підтверджує особу затриманого. Разом із тим до клопотання не додано документів, що містять дані про вчинення особою злочину на території іноземної держави. Зазначене грунтується лише на письмовому повідомленні Інтерполу, яке носить інформаційний характер. Також відсутні документи щодо вибору стосовно особи запобіжного заходу компетентним органом іноземної держави. Про наявність такого процесуального документу не зазначено навіть у повідомленні Інтерполу. Таким чином, до клопотання не додано належних процесуальних документів, передбачених п. 2 ч. 4 ст. 583 КПК України. Крім того, у клопотанні зазначено, що особа розшукується компетентними органами Грецької Республіки для притягнення до кримінальної відповідальності за вчинення злочину, який $€$ екстрадиційним, оскільки визначає покарання на строк більше року позбавлення волі. Разом із тим будь-якого доказу чи документу на підтвердження таких обставин до клопотання не додано, зокрема витягу з КК іноземної держави стосовно статей 26, 27, 187 КК Греції, перекладеного та посвідченого належним чином ... Убачається, що під час розгляду клопотання не встановлено, що особа переслідується або розшукується компетентними органами Грецької Республіки з метою виконання вироку або постанови про утримання під вартою» [2].

Контекстно відзначимо: особа, до якої застосовано тимчасовий арешт, iї захисник чи законний представник, прокурор вправі оскаржити відповідну ухвалу слідчого судді в апеляційному порядку. Разом із тим не підлягають оскарженню ухвали слідчого судді, якими він: затверджує згоду особи на ії видачу (екстрадицію) та застосовує екстрадиційний арешт; затверджує згоду особи на ії видачу (екстрадицію), відмову особи від застосування спеціально встановленого законом правила щодо меж кримінальної відповідальності та застосовує екстрадиційний арешт (ч. 7 ст. 583 КПК).

Окрім того, з'ясування особливостей процесуального статусу особи, до якої застосовано запобіжний захід тимчасовий арешт, дає змогу констатувати, що вона має право до моменту надходження запиту компетентного органу іноземної держави про іiі видачу (екстрадицію) подати на розгляд слідчого судді суду, у межах територіальної юрисдикції якого ця особа перебуває під вартою, заяву у письмовій формі про згоду на ії видачу (екстрадицію), у котрій може зазначити про своє рішення відмовитися від реалізації спеціального правила стосовно меж кримінальної відповідальності. Представлена заява підлягає невідкладному розгляду слідчим суддею у порядку, передбаченому ч. 6 цієї статті, за обов'язкової участі прокурора, особи, яка подала заяву, іiї захисника та за необхідності перекладача (ч. 8 ст. 583 КПК). За нормативними вимогами ч. 10 ст. 583 КПК факт надходження запиту про видачу особи (екстрадицію) до закінчення строку тимчасового арешту має наслідком утрату юридичної сили ухвалою слідчого судді про застосування тимчасового арешту лише 3 моменту винесення слідчим суддею ухвали про застосування екстрадиційного арешту щодо цієї особи. Водночас, якщо особа звільняється з-під тимчасового арешту через несвоєчасне надходження до центрального органу України запиту про видачу, це не перешкоджає застосуванню до неї екстрадиційного арешту в разі отримання в подальшому потрібного запиту (ч. 9 ст. 583 КПК).

У представленому ракурсі дослідження відзначимо, що статтею 16 Європейської конвенції про видачу правопорушників від 13 грудня 1957 р. також унормовано порядок 
застосування тимчасового арешту, а саме: у термінових випадках компетентні органи запитуючої сторони (іноземної держави) можуть звертатися із запитом про тимчасовий арешт розшукуваної особи. Своєю чергою, компетентні органи запитуваної сторони вирішують це питання відповідно до національного законодавства. У запиті про тимчасовий арешт повідомляється про існування одного 3 документів, зазначених у п. 2а ст. 12 («оригіналу або завіреної копії обвинувального вироку та постанови суду або постанови про негайне затримання чи ордера на арешт або іншого розпорядження, яке має таку ж силу і видане відповідно до процедури, передбаченої законодавством запитуючої сторони»), та намір надіслати запит про видачу правопорушника. Окрім того, у цьому документі вказується, за яке правопорушення буде запитуватися видача, де і коли таке правопорушення було вчинене, а також, за можливості, опис зовнішності розшукуваної особи. Запит про тимчасовий арешт надсилається компетентним органам запитуваної сторони дипломатичними каналами, безпосередньо поштою, телеграфом, через Міжнародну організацію кримінальної поліції (Інтерпол) або у будь-який інший спосіб, який дає змогу мати письмове підтвердження чи який визнається запитуваною стороною. При цьому запитуючий орган без зволікань інформується про результати розгляду його запиту. Особливо підкреслимо - тимчасовий арешт може бути припинено, якщо впродовж 18 днів після такого арешту запитувана сторона не отримує запиту про видачу правопорушника і документи, зазначені у статті 12 (у будь-якому разі цей період не може перевищувати 40 днів від дати здійснення арешту). Разом із тим можливість тимчасового звільнення у будь-який час не виключається, однак запитувана сторона вживає заходів, які, на їі думку, необхідні для запобігання втечі розшукуваної особи. Факт звільнення не перешкоджає повторному арешту та видачі правопорушника у разі отримання в подальшому запиту про видачу [3].

Що стосується певних відмінностей у визначенні тривалості вказаних вище строків, то, згідно з положеннями ч. 1 ст. 62 Конвенції про правову допомогу і правові відносини у цивільних, сімейних і кримінальних справах від 22 січня 1993 р., «особа, узята під варту ... повинна бути звільнена, якщо вимога про її видачу не надійде протягом одного місяця зі дня взяття під варту» [4], що, безсумнівно, не сприяє правовій визначеності у цьому питанні та має знайти правильне вирішення саме на законодавчому рівні.

На врегулювання наведених неузгодженостей спрямовані й приписи п. 7.5 Наказу Генеральної прокуратури України «Про організацію роботи органів прокуратури України у галузі міжнародного співробітництва» від 18 вересня 2015 р. № 223 (зі змінами, внесеними наказами Генеральної прокуратури України від 16.01.2017 № 6, від 09.10.2017 № 287, від 21.12.2018 № 261, від 20.08.2019 № 164), в якому закріплено, що у разі надходження звернення іноземного компетентного органу, зазначеного у п. 7.3 цього Наказу, прокурор відповідного рівня зобов'язаний звертатися до слідчого судді $з$ клопотанням про застосування тимчасового арешту такої особи на строк, передбачений кримінальним процесуальним законодавством або відповідним міжнародним договором України, до надходження запиту про iii видачу [5].

Процедура застосування запобіжного заходу у вигляді тримання під вартою з метою забезпечення видачі особи (тобто екстрадиційного арешту) детально регламентована статтею 584 КПК [1].

Так, після надходження запиту компетентного органу іноземної держави про видачу особи виключно прокурор вправі звернутися з клопотанням про іiї екстрадиційний арешт до слідчого судді за місцем тримання особи під вартою. Ініціація вказаних процесуальних дій відбувається за дорученням (або зверненням) центрального органу України. Разом із названим клопотанням на розгляд слідчого судді, зокрема, подаються: 1) копія запиту компетентного органу іноземної держави про видачу особи (екстрадицію), належним чином засвідчена центральним органом України; 2) документи про громадянство такої особи; 3) наявні матеріали екстрадиційної перевірки, а також інші документи, якими обгрунтовується клопотання про застосування запобіжного заходу - тримання під вартою для забезпечення видачі особи (екстрадиційного арешту).

Зважаючи на це, чинний кримінальний процесуальний закон установлює імперативне правило про те, що матеріали, перелік яких подається слідчому судді, мають бути перекладені державною або іншою (якою вільно володіє особа) мовою, передбаченою міжнародним договором, згода на обов'язковість якого надана Верховною Радою України (ч. ч. 1-3 статті 584 КПК). Окрім того, вітчизняний законодавець наголошує: під час вирішення питання про застосування екстрадиційного арешту слідчий суддя керується як положеннями КПК, так і відповідних міжнародних договорів, згода на обов'язковість яких надана Верховною Радою України. Якщо особа, стосовно якої вирішується питання про тримання під вартою, не володіє у достатньому обсязі державною мовою, їй забезпечується участь перекладача (ч. ч. 4, 5 статті 584 КПК), що повною мірою корелює з вимогою підп. «е» п. 3 ст. 6 Конвенції про захист прав людини і основоположних свобод: кожний обвинувачений у вчиненні кримінального правопорушення має право, якщо він не розуміє мови, яка використовується в суді, або не розмовляє нею, одержувати безоплатну допомогу перекладача [6].

Під час розгляду поданого клопотання слідчий суддя зобов'язаний учинити низку обов'язкових процесуальних дій, а саме: встановити особу; роз'яснити належне їй право надати власну згоду на видачу (екстрадицію) для гарантування можливості застосувати процедуру видачі особи у спрощеному порядку, а також право відмовитися від застосування спеціального правила стосовно меж кримінальної відповідальності у разі надання згоди на видачу (екстрадицію); з'ясувати справжність висловленого особою бажання скористатися цими правами; перевірити істинність і добровільність надання особою не тільки згоди на іï̈ видачу (екстрадицію), а й викладеної у письмовому виді відмови від застосування спеціально встановленого правила щодо меж кримінальної відповідальності та дійсність усвідомлення особою правових наслідків такої згоди (чи відмови); грунтовно перевірити представлений запит про видачу та наявні матеріали екстрадиційної перевірки; вислухати думку прокурора та інших учасників процесу, присутніх у залі судового засідання.

За результатами розгляду клопотання слідчий суддя постановляє одну з ухвал про: 1) застосування екстрадиційного арешту; 2) відмову у затвердженні згоди особи на iii видачу (екстрадицію) та застосування екстрадиційного арешту; 3) відмову у застосуванні екстрадиційного арешту, якщо для вибору цього запобіжного заходу немає підстав. Під час прийняття судом рішень про затвердження згоди особи на ії видачу (екстрадицію) та застосування екстрадиційного арешту, а також про затвердження згоди особи на іiї видачу (екстрадицію), відмови особи від застосування спеціального правила стосовно меж кримінальної відповідальності та застосування екстрадиційного арешту, копія ухвали слідчого судді, винесеної в результаті розгляду та вирішення питання щодо затвердження згоди особи на видачу (екстрадицію), невідкладно направляється уповноваженому (центральному) органу України, визначеному статтею 574 КПК, через відповідну регіональну прокуратуру разом із копією письмової заяви особи про згоду на їі видачу (екстрадицію) (ч. 7 ст. 584 КПК).

Необхідно зауважити, що під час розгляду в судовому засіданні клопотання слідчий суддя не досліджує питання про винуватість певної особи у вчиненні кримінального правопорушення та не перевіряє законність процесуаль- 
них рішень, прийнятих компетентними органами іноземної держави у справі стосовно особи, щодо якої надійшов запит про видачу (ч. 8 ст. 584 КПК).

За нормативними приписами досліджуваної статті постановлена ухвала слідчого судді місцевого суду може бути оскаржена в апеляційному порядку тією особою, щодо якої застосовано запобіжний захід (екстрадиційний арешт), а також іії захисником чи законним представником, прокурором. Разом із тим оскарженню не підлягають такі ухвали слідчого судді, якими: затверджується згода особи на їі видачу (екстрадицію) та застосовується екстрадиційний арешт; затверджується згода особи на іiї видачу (екстрадицію), заявлена відмова цієї особи від застосування спеціального правила стосовно меж кримінальної відповідальності та застосовується екстрадиційний арешт (ч. 9 ст. 584 КПК).

Із цього приводу вбачається доцільним акцентувати увагу на правовій позиції Касаційного кримінального суду Верховного Суду, що сформульована у Постанові від 20 березня 2018 р. Так, задовольняючи скаргу захисника, суд відзначив: «ОСОБА_2 12 травня 2017 р. отримав судове рішення українською мовою, а переклад судового рішення італійською мовою Чернігівський слідчий ізолятор отримав лише 29 червня 2017 р. Тобто у той час, коли захисник ... 20 червня 2017 р. вже направив апеляційну скаргу (штамп на конверті - 20 червня 2017 р.). Однак матеріали провадження не містять даних про те, що переклад рішення взагалі було вручено ОСОБА 2. Тоді як судове рішення, викладене державною мовою, отримано захисником ... від ОСОБА 2 під час їх зустрічі 16 червня 2017 р. Отже, у колегії суддів немає в розпорядженні даних, які б спростовували викладені у касаційній скарзі захисником обставини, що об'єктивно перешкодили вчасно оскаржити судове рішення. Вказане вище підтверджує доводи захисника стосовно незабезпечення права особи, щодо якої застосовано екстрадиційний арешт, на оскарження ухвали слідчого судді, що гарантовано ст. 24 та ч. 9 ст. 584 КПК, оскільки ОСОБА 2 не був забезпечений перекладом перебігу судового засідання та був позбавлений можливості на будь-яку комунікацію iз захисником у визначений кримінальним процесуальним законом період апеляційного оскарження судового рішення» [7].

Під час реалізації аналізованих положень чинного кримінального процесуального закону слід неухильно дотримуватися імперативної вимоги про те, що екстрадиційний арешт застосовується до остаточного вирішення питання про видачу особи (екстрадицію) та її фактичної передачі, але у будь-якому разі не може тривати більше 12 місяців. У межах цього строку слідчий суддя суду, у межах територіальної юрисдикції якого особа перебуває під вартою, зобов'язаний перевіряти наявність підстав: 1) для подальшого тримання особи під вартою або ії̈ звільнення за клопотанням прокурора не рідше одного разу на два місяці; 2) для звільнення особи з-під варти за скаргою особи, до якої застосовано екстрадиційний арешт, або ії захисника чи законного представника не частіше одного разу на місяць. Утім, звільнення особи з-під екстрадиційного арешту не $є$ перешкодою для повторного його застосування 3 метою фактичної передачі особи іноземній державі на виконання рішення про видачу, якщо інше не передбачено міжнародним договором України (ч. ч. 10-13 ст. 584 КПК).

Чинний КПК надає особі, до якої застосовано екстрадиційний арешт, гарантоване право до моменту прийняття уповноваженими суб'єктами рішення про іiї видачу (екстрадицію) подати на розгляд слідчого судді суду, у межах територіальної юрисдикції якого особа перебуває під вартою, письмову заяву про згоду на ії видачу (екстрадицію), безпосередньо у змісті якої може зазначити про свою відмову від застосування спеціального правила щодо меж кримінальної відповідальності. Така заява має бути невід- кладно розглянута слідчим суддею у порядку, передбаченому ч. ч. 7 і 8 ст. 584 КПК, за участю прокурора, особи, яка подала заяву, її захисника та за потреби перекладача.

Окрім того, ст. 586 КПК регламентовано процедуру припинення тимчасового арешту або запобіжного заходу екстрадиційного арешту.

Так, тимчасовий арешт або вказаний запобіжний захід автоматично припиняється у визначених законом випадках, а саме якщо: 1) центральний орган України не отримав запит про видачу особи (екстрадицію) у строки, передбачені міжнародним договором України (йдеться як про багатосторонні, так і про двосторонні міжнародні договори України); 2) під час екстрадиційної перевірки, проведеної в порядку ст. 587 КПК, встановлено обставини, за наявності яких екстрадиція особи взагалі не здійснюється; 3) компетентний орган іноземної держави резонно відмовляється (відмовився) вимагати видачу особи; 4) центральним органом України прийнято рішення про відмову у видачі особи (екстрадиціi). За змістом положень ч. 1 ст. 589 КПК у видачі особи іноземній державі категорично відмовляється, якщо: 1) особа, стосовно якої надійшов запит про видачу, відповідно до чинних законів України на час прийняття рішення про ії видачу (екстрадицію) є громадянином України (з огляду на наведену норму, не можна оминути увагою правові приписи Основного Закону, що регулюють питання екстрадиції у процесі: громадянин України не може бути виданий іншій державі (ч. 2 ст. 25 Конституції України) [8], а також ст. 10 Кримінального кодексу України: громадянин України, який учинив злочин поза межами України, не може бути виданий іноземній державі для притягнення до кримінальної відповідальності та віддання до суду. Утім, іноземці та особи без громадянства, які вчинили злочини за межами України і перебувають на iï території, можуть бути видані іноземній державі для притягнення їх до кримінальної відповідальності та віддання до суду (ч. ч. 1 і 2) [9]); 2) злочин, за вчинення якого запитано екстрадицію, не передбачає за законом України покарання у виді позбавлення волі; 3) закінчилися строки давності притягнення особи до кримінальної відповідальності або виконання вироку, встановлені законом України за той злочин, за який запитано видачу; 4) компетентний орган іноземної держави не представив на вимогу центрального органу України додаткові матеріали або дані, без яких $є$ неможливим прийняття рішення за запитом про видачу (екстрадицію); 5) видача особи суперечить узятим на себе Україною зобов'язанням за міжнародними договорами нашої держави; $\left.5^{1}\right) \in$ обгрунтовані підстави вважати, що видача (екстрадиція) конкретної особи суперечить інтересам національної безпеки України; 6) наявні інші підстави (обставини), передбачені міжнародним договором України.

Окрім того, категорії осіб, яким надано статус біженця, статус особи, яка потребує додаткового захисту, тимчасовий захист в Україні, не можуть бути видані державі, біженцями $з$ якої вони визнані, а також іноземній державі, в якій їх здоров’ ю, життю чи свободі загрожує небезпека за такими ознаками, як раса, віросповідання (релігія), національність, громадянство (підданство), приналежність до певної соціальної групи або політичних переконань, окрім випадків, передбачених міжнародним договором України (ч. 2 ст. 589 КПК).

Згідно 3 ординарним порядком, окресленим у ч. 2 ст. 586 КПК, суб'єктом, уповноваженим на скасування тимчасового арешту чи запобіжного заходу, є: керівник відповідної регіональної прокуратури, його перший заступник або заступник (лише за дорученням (зверненням) центрального органу України), а у випадку, передбаченому п. 2 ч. 1 цієї статті, за погодженням з відповідним центральним органом України (а саме, з Офісом Генерального прокурора чи Міністерством юстиції України). Копія 
постанови про скасування тимчасового арешту чи запобіжного заходу у вигляді тримання під вартою для забезпечення видачі особи (екстрадиційного арешту) надсилається уповноваженій службовій особі місця ув'язнення та слідчому судді, який приймав рішення про застосування тимчасового арешту або цього запобіжного заходу.

Системний аналіз наведених положень чинних нормативно-правових актів дає підстави стверджувати: законодавство України передбачає доволі ефективні заходи процесуального примусу - тимчасовий та екстрадиційний арешти, які можуть бути застосовані до осіб для забезпечення у подальшому їх видачі (екстрадиції) компетентним органам іноземних держав. Ураховуючи сучасний стан і загальні тенденції розвитку національного законодавства, а також міжнародний досвід реалізації відповідних нормативних приписів, перспективною вбачається гармонізація кримінального процесуального права України та деяких зарубіжних держав у цій сфері, у зв'язку з чим органам досудового розслідування, прокуратурі та судам різних інстанцій у кожному випадку слід більш ретельно підходити до вибору конкретного запобіжного заходу з метою неухильного дотримання прав, свобод і законних інтересів кожного з учасників кримінального провадження, що, своєю чергою, сприятиме підвищенню ефективності застосування будь-якого із цих запобіжних заходів.

\section{תITEPATYPA}

1. Кримінальний процесуальний кодекс України від 13.04.2012 № 4651-VI. URL : https://zakon.rada.gov.ua/laws/show/4651-17.

2. Ухвала Солом'янського районного суду м. Києва від 23 вересня 2017 р., справа № 1-м/760/43/17, категорія справи № 760/19212/17. URL : http://www.reyestr.court.gov.ua/Review/69323095.

3. Європейська конвенція про видачу правопорушників від 13 грудня 1957 p. URL : https://zakon.rada.gov.ua/laws/ show/995 033?find=1\&text\#Text.

4. Конвенція про правову допомогу і правові відносини у цивільних, сімейних і кримінальних справах від 22 січня 1993 p. URL : https://zakon.rada.gov.ua/laws/show/997_009?find=1\&text\#Text.

5. Наказ Генеральної прокуратури України «Про організацію роботи органів прокуратури України у галузі міжнародного співробітництва» від 18 вересня 2015 р. № 223 (зі змінами, внесеними наказами Генеральної прокуратури України від 16.01.2017 № 6, від 09.10.2017 № 287, від 21.12.2018 № 261, від 20.08.2019 № 164). URL : https://old.gp.gov.ua/ua/gl.html? m=publications\& $t=r e c \& i d=94102$.

6. Конвенція про захист прав людини і основоположних свобод від 04.11.1950. URL : https://www.echr.coe.int/Documents/ Convention_UKR.pdf.

7. Постанова Касаційного кримінального суду Верховного Суду від 20 березня 2018 р., справа № 751/2604/17, провадження № 51-2886км18. URL : http://reyestr.court.gov.ua/Review/72970296.

8. Конституція України від 28.06.1996. URL : https://zakon.rada.gov.ua/laws/show/254\%D0\%BA/96-\%D0\%B2\%D1\%80\#Text.

9. Кримінальний кодекс України від 05.04.2001 № 2341-III. URL : https://zakon.rada.gov.ua/laws/show/2341-14\#Text. 


\title{
ПІДСТАВИ ДЛЯ ВІДКРИТТЯ КРИМІНАЛЬНОГО ПРОВАДЖЕННЯ ЗА ФАКТОМ ДОВЕДЕННЯ ДО БАНКРУТСТВА: ОЗНАКИ ТА ДЖЕРЕЛА ІНФОРМАЦІї

\author{
GROUNDS FOR THE OPENING OF CRIMINAL PROCEEDINGS \\ ON THE FACT OF BRINGING TO BANKRUPTCY: SIGNS AND SOURCES OF INFORMATION
}

\author{
Давченко Т.М., суддя \\ Господарський суд Миколаївської області
}

Злочинам у сфері господарювання притаманна ознака латентності, оскільки внутрішня правова та економічна діяльність здійснюється в рамках правочинів, які погоджуються сторонами домовленостей. За наявності попереднього кримінального умислу учасниками таких угод інформація про вчинення злочину не є доступною для правоохоронних органів. Наслідки злочинів стають очевидними пізніше, що зумовлено свідомим ускладненням злочинцями схем доведення до банкрутства. Відкриття кримінальних проваджень за ознаками доведення до банкрутства відбувається зачасти віддалено у часі від моменту початку таких дій зацікавленими особами. Указана обставина ускладнює проведення розслідування, обмежені строки зберігання бухгалтерських документів унеможливлюють проведення судових експертиз. Слідча та судова практика свідчить про те, що підприємства, які належать територіальній громаді, потрапляють до складних фрінансових умов за сприяння злочинних структур із метою їх рейдерського захоплення. Інформація про це надходить від самої територіальної громади (через представників). Зацікавленими у відкритті такого провадження є також інші кредитори, які в результаті злочинного захоплення підприємства не можуть задовольнити свої законні господарські вимоги від підприємства-банкрута. Найчастіше такими суб'єктами, від яких надходить повідомлення про вчинення доведення до банкрутства, є власники підприємств, органи, уповноважені управляти майном, або особи, які заінтересовані в отриманні інформації щодо діяльності підприємства (державний орган із питань банкрутства, арбітражний керуючий, органи податкової служби, керівництво). Якщо підприємство звертається до суду для визнання його банкрутом, то господарські суди, оцінивши ситуацію, також надають правоохоронним органам відповідну інфрормацію щодо наявності ознаки умисного доведення до банкрутства. Розглядаючи справи про адміністративні правопорушення щодо банкрутства, місцеві суди також є суб'єктом, який може стати джерелом інформації про вчинення даного злочину. У рамках розслідування корупційних злочинів існує можливість правоохоронними органами виявити ознаки вчинення злочину, відповідальність за який передбачена ст. 219 КК України.

Ключові слова: доведення до банкрутства, підстави для відкриття кримінального провадження, фрінансова неспроможність, кредитори, джерела інформації.

Economic crimes are characterized by a sign of latency, as domestic legal and economic activities are carried out within the framework of transactions agreed by the parties to the agreements. In the presence of prior criminal intent by the parties to such agreements, information about the commission of a crime is not available to law enforcement agencies. The consequences of crimes become apparent later, due to the deliberate complication by criminals of bankruptcy schemes. The opening of criminal proceedings on the grounds of bankruptcy is often remote in time from the beginning of such actions by the persons concerned. This circumstance complicates the investigation, the limited period of storage of accounting documents makes it impossible to conduct forensic examinations. Investigative and judicial practice shows that enterprises belonging to the territorial community find themselves in difficult financial conditions with the assistance of criminal structures in order to seize them. Information about this comes from the territorial community itself (through representatives). Other creditors who are unable to satisfy their legal economic claims against the bankrupt enterprise as a result of the criminal seizure of the enterprise are also interested in initiating such proceedings. Most often, such entities from which the notification of bankruptcy is the owners, bodies authorized to manage the property, or persons interested in obtaining information about the activities of the enterprise (state bankruptcy body, arbitration manager, tax authorities, management ). If the company applies to the court to declare it bankrupt, the commercial courts, after assessing the situation, also apply to law enforcement agencies with appropriate notifications that there is a sign of intentional bankruptcy. When considering cases of administrative bankruptcy offenses, local courts are also an entity that can be a source of information about the commission of this crime. As part of the investigation of corruption crimes, it is also possible for law enforcement agencies to identify signs of a crime, the responsibility for which is provided by Art. 219 of the Criminal Code of Ukraine.

Key words: bringing to bankruptcy, grounds for opening criminal proceedings, financial insolvency, creditors, sources of information.

С.Н. Чурилов, досліджуючи проблемні питання формування окремих методик розслідування, наголошував, що питання змісту закономірностей, які керують процесом формування окремих методик, усе ще є недостатньо вивченим. Водночас вирішення проблеми підвищення ефективності криміналістичних методик на основі розвитку наукових положень криміналістичної методики та створення науково-емпіричної бази розслідування злочинів потребує його подальшого дослідження [1, с. 287]. Поява нових видів злочинів, включення нових суб'єктів відповідальності, зміна законів, якими регулюються відносини у сфері господарської діяльності, потребують розроблення конкретних рекомендацій, які мають стати, як зазначав Р.С. Бєлкін, «інструментом практичної діяльності» [2, с. 127].

Відповідно до положень Кримінального процесуального кодексу, кримінальне провадження щодо вчинення злочину, передбаченого ст. 219 КК України, здійснюється у формі приватного обвинувачення і може бути розпочато лише на підставі заяви потерпілого. У разі заподіяння шкоди виключно інтересам юридичної особи незалежно від організаційно-правової форми порушення криміналь- ного провадження здійснюється за заявою керівника або іншого уповноваженого представника цієї юридичної особи. По таких провадженнях за певними винятками допускається укладання угоди про примирення, яка після iї укладання має бути затверджена вироком суду [3].

Отже, по-перше, повідомлення до правоохоронних органів щодо доведення до банкрутства можуть надходити від керівників підприємств, власників, а також кредиторів чи інших зацікавлених осіб. Згідно з Методичними рекомендаціями щодо виявлення ознак неплатоспроможності підприємства та ознак дій із приховування банкрутства, фіктивного банкрутства чи доведення до банкрутства від 19.01.2006, такими суб'єктами є власники, органи, уповноважені управляти майном, або особи, які заінтересовані в отриманні інформації щодо діяльності підприємства (державний орган із питань банкрутства, арбітражний керуючий, органи податкової служби, керівництво) (п. 3) [4].

Так, слідчим в особливо важливих справах першого слідчого відділу управління з розслідування кримінальних проваджень слідчими органів прокуратури та процесуального керівництва прокуратури м. Києва на підставі 
заяви представника громади м. Києва 03.07.2019 внесено відомості до Єдиного реєстру досудових розслідувань за ознаками кримінальних правопорушень, передбачених ч. 5 ст. 191 , ч. 3 ст. 28 ч. 2 ст. $364-1$, ч. 2 ст. 15 ч. 2 ст. 233 , ч. 2 ст. 15 ч. 2 ст. 219 КК України за повідомленням представника громади м. Києва. Відповідно до ч. 2 ст. 9 КПК України, прокурор, керівник органу досудового розслідування, слідчий зобов'язані всебічно, повно і неупереджено дослідити обставини кримінального провадження, виявити як ті обставини, що викривають, так і ті, що виправдовують підозрюваного, обвинуваченого, а також обставини, що пом'якшують чи обтяжують його покарання, надати їм належну правову оцінку та забезпечити прийняття законних i неупереджених процесуальних рішень.

Слідчим було проведено досудове розслідування в повному обсязі, встановлено та допитано в повному обсязі осіб, які можуть бути причетними до вчинення вказаних кримінальних правопорушень, встановлено неможливість проведення судових експертиз у зв'язку із закінченням строків зберігання документів, ужито всіх інших дій, передбачених КПК України для встановлення дійсних обставин кримінального провадження, у результаті чого встановлено, що зміна виду акціонерного товариства та форми існування не вплинули та не могли вплинути на кількість акцій, що належала територіальній громаді міста Києва в статутному капіталі ВАТ «Хліб Києва», оскільки як станом на момент створення, так і станом на поточний час Головне управління комунальної власності міста Києва виконавчого органу Київської міської ради (Київської міської державної адміністрації) є власником 75997940 шт. акцій ВАТ «Хліб Києва», що становить 51\% статутного капіталу [5].

У такій категорії проваджень правоохоронні органи на стадії досудового розслідування мають установити та перевірити таке:

1) Чи відноситься об'єкт продажу (юридична особа) до переліку об'єктів, що належать територіальній громаді та підлягають продажу? Необхідно встановити наявність цього факту, закріпленого у відповідному рішенні.

2) Чи існує програма приватизації об'єктів права комунальної власності територіальної громади та чи включені відповідні об'єкти до неї? Чи визначено спосіб продажу (аукціон)?

У даній категорії проваджень необхідно перевірити повноваження органу, який приймає відповідні рішення (щодо укладання угод, надання дозволу на приватизацію тощо). Варто зазначити, що, згідно з Рішенням Конституційного Суду України від 12 січня 2010 р. по справі № 1-2/2010 [6], Пленуму Верховного Суду України від 24 жовтня 2008 р. № 13 «Про практику розгляду судами корпоративних спорів» повноваження посадових осіб товариства припиняються їх переобранням [7]. Згідно 3 п. 18. ст. 33 Закону України «Про акціонерні товариства», до виключної компетенції загальних зборів акціонерного товариства належить прийняття рішення про припинення повноважень членів наглядової ради за винятком випадків, установлених цим Законом [8].

Абзацом 2 ч. 1 ст. 57 Закону України «Про акціонерні товариства» встановлено перелік підстав припинення повноважень члена наглядової ради без рішення загальних зборів акціонерів: за його бажанням за умови письмового повідомлення про це товариства за два тижні; у раз неможливості виконання обов'язків члена наглядової ради за станом здоров'я; у разі набрання законної сили вироком чи рішенням суду, яким його засуджено до покарання, що виключає можливість виконання обов'язків члена наглядової ради; у разі смерті, визнання його недієздатним, обмежено дієздатним, безвісно відсутнім, померлим Статутом товариства можуть бути передбачені додаткові підстави для припинення повноважень члена наглядової ради, що визначено абзацом 3 ч. 1 ст. 57 Закону України «Про акціонерні товариства».

Окрім того, відповідно до роз'яснень, наданих у п. 41 Постанови Пленуму Верховного Суду України від 24.10.2008 № 13 «Про практику розгляду судами корпоративних спорів», під час розгляду справ за позовами про визнання повноважень членів (члена) виконавчого органу, наглядової ради та інших органів товариства припиненими у зв'язку зі спливом строку, на який вони були обрані (призначені), судам необхідно враховувати, що такого способу захисту прав та законних інтересів чинним законодавством не передбачено. Повноваження посадових осіб товариства припиняються їх переобранням, і вирішення цього питання не належить до компетенції судів. На підставі цього слід визнати, що повноваження посадових осіб товариства припиняються їх переобранням. Якщо досудовим розслідуванням буде встановлено, що члени наглядової ради підприємства не переобиралися, тому їхні повноваження, відповідно, не припинялися. Отже, станом на момент призначення особи тимчасово виконуючим обов'язки генерального директора, відповідно, склад наглядової ради товариства $є$ чинним.

Правоохоронні органи мають перевіряти факт проведення загальних зборів юридичної особи (підприємства). В окремих кримінальних провадженнях було встановлено, що коли порушується провадження у справі про банкрутство і фактично керівництво підприємством переходить до арбітражного керуючого, то внаслідок цього унеможливлюється здійснення керівництва підприємством повною мірою.

Так, у кримінальному провадженні «у зв'язку з колізією в законодавстві щодо скликання загальних зборів акціонерів, складання реєстру акціонерів та втратою реєстру акціонерів ВАТ «Хліб Києва», який було передано до Центрального депозитарію та знищено в результаті пожежі в офісі Центрального депозитарію, що розміщувався в Будинку профспілок під час подій у лютому 2014 року, загальні збори акціонерів ВАТ «Хліб Києва» не скликалися протягом тривалого часу».

У ході розслідування доцільно встановлювати позитивні дії уповноважених органів, скеровані на проведення загальних зборів акціонерів, зокрема: чи повідомляли посадові особи підприємства головне управління комунальної власності громади, яке $\epsilon$ акціонером, щодо скликання та проведення загальних зборів акціонерів? Чи були останнім учинено відповідні дії, якщо ні, то 3 яких причин? Наприклад, у справі доведення до банкрутства ВАТ «Хліб Києва» такі дії стали неможливими у зв'язку з відсутністю механізмів відновити реєстр акціонерів, що був утрачений Центральним депозитарієм у 2014 році. При цьому посадовими особами ВАТ «Хліб Києва» вчинялися дії, спрямовані на отримання реєстру та проведення загальних зборів акціонерів.

Наявність таких перешкод, що мінімізують управлінські важелі, встановлює відсутність у діях посадових осіб складу злочину, передбаченого ст. 364-1 КК України.

Ретельному дослідженню підлягають правочини, зобов'язання за якими утворюють підстави для банкрутства підприємства (наприклад, укладення договору купівлі-продажу цінних паперів між ПрАТ «Київмлин» та ВАТ «Хліб Києва», внаслідок чого останній придбав інвестиційні сертифікати, випущені ТОВ «КУА «КредитПром-Капітал» у кількості 470 шт., номінальною вартістю 470000 грн. за ціною 4455500 грн.).

Досить часто підприємства, які не виконують зобов'язання за угодами, укладають договори про відступлення права вимоги іншим підприємствам із метою відстрочення звернення кредитора до суду із заявою про визнання банкрутом. Свідки в таких випадках пояснюють, що до таких заходів вони вдаються для одержання часу, необхідного для продажу цінних паперів, які були у власності, вартості яких було достатньо для задоволення 
вимог кредиторів. Проте спроби знайти покупця не дали позитивного результату.

Зволікання з відкриттям кримінального провадження, що зумовлюється тим, що спочатку провадження здійснюється в рамках господарського судочинства, призводить до того, що на стадії досудового розслідування неможливо провести низку важливих судових експертиз у зв'язку із закінченням установлених законодавством строків зберігання документів на підприємстві. Відповідно до ч. 3 ст. 8 Закону України «Про бухгалтерський облік та фінансову звітність в Україні», відповідальність за організацію бухгалтерського обліку та забезпечення фіксування фактів здійснення всіх господарських операцій у первинних документах, збереження оброблених документів, регістрів і звітності протягом встановленого терміну, але не менше трьох років, несе уповноважений орган (посадова особа), який здійснює керівництво підприємством, або власник відповідно до законодавства та установчих документів [9].

По-друге, повідомлення про ознаки доведення до банкрутства надходить до правоохоронних органів від господарського суду, який розглядає справу про банкрутство. Так, під час досудового розслідування встановлено, що 05.03.2013 Господарський суд Вінницької області порушив провадження у справі № 902/273/13-г про банкрутство ЗАТ «Гефест Плюс», визнав указане товариство банкрутом, відкрив ліквідаційну процедуру та призначив ліквідатором Д

17.11.2016 ухвалою Господарського суду Вінницької області провадження у справі про банкрутство ЗАТ «Гефест Плюс» припинене, указане підприємство як юридична особа ліквідоване, через відсутність коштів та майна заборгованість кредиторам не відшкодована.

У повідомленні Господарського суду Вінницької області, яке стало підставою для початку досудового розслідування, зазначено, що 25.10.2016 до суду надійшло клопотання 3., яким вона просила суд повідомити прокурора та органи досудового розслідування про факти, виявленні в ході розгляду справи про банкрутство ЗАТ «Гефест Плюс» щодо доведення підприємства до банкрутства.

У зв'язку з отриманням клопотання 3. Господарський суд Вінницької області проаналізував обставини, викладені у клопотанні, і встановив, що у звіті про аналіз щодо виявлення ознак дій із приховування банкрутства, фіктивного банкрутства чи доведення до банкрутства ЗАТ «Гефест Плюс» станом на 05.03.2013 3-поміж іншого зазначається, що дослідження проведено лише на підставі фінансової звітності, поданої ЗАТ «Гефест Плюс» до органів статистики за 2010-2012 рр., причому первинні документи банкрута, які б підтверджували достовірність відображеної у фінансовій звітності інформації, у ліквідатора відсутні, а показники фінансової звітності не перевірені. Ураховуючи також наявну у справі про банкрутство інформацію про об'єкти нерухомості у власності ЗАТ «Гефест Плюс», достовірність та правильність складення фінансової звітності викликає обгрунтовані сумніви. Після чого Господарський суд дійшов висновку про те, що мають місце факти, які можуть свідчити про наявність ознак злочину, передбаченого ст. 219 КК України [10].

В Україні сьогодні досить грунтовно досліджуються питання нормативних джерел адміністративно-правового механізму протидії правопорушенням у сфері підприємницької діяльності [11, с. 50-53]. Кодекс України про адміністративну відповідальність містить три статті, які передбачають відповідальність за правопорушення, пов'язані 3 банкрутством. Стаття 164-15 «Приховування стійкої фінансової неспроможності» містить санкцію за умисне приховування громадянином - засновником (учасником) або службовою особою суб'єкта господарської діяльності своєї стійкої фінансової неспроможності шляхом подання недостовірних відомостей або неподання в установлений строк до господарського суду заяви про порушення справи про банкрутство юридичної особи у випадках, передбачених законом, якщо це завдало великої матеріальної шкоди кредиторові.

Статтею 166-16 КУПАП «Незаконні дії у разі банкрутства» передбачається адміністративна відповідальність за умисне приховування майна, відомостей про майно, передачу майна в інше володіння або його відчуження чи знищення, а також фальсифікацію, приховування або знищення документів, які відображають господарську чи фінансову діяльність, у тому числі планів санації чи мирових угод, якщо ці дії вчинені громадянином - засновником (учасником) або службовою особою суб'єкта господарської діяльності в період провадження у справі про банкрутство і завдали великої матеріальної шкоди. Кваліфікуючою ознакою цієї статті є вчинення адміністративного правопорушення розпорядником майна, керуючим санацією, ліквідатором.

Стаття 166-17 «Фіктивне банкрутство» тягне відповідальність за завідомо неправдиву офіційну заяву громадянина - засновника (учасника) або службової особи суб'єкта господарської діяльності, а так само громадянина - суб'єкта підприємницької діяльності про фінансову неспроможність виконання вимог із боку кредиторів і зобов'язань перед бюджетом, якщо такі дії завдали великої матеріальної шкоди кредиторам або державі.

Згідно зі ст. 255 КУпАП, у справах про адміністративні правопорушення протоколи про вказані правопорушення мають право складати уповноважені на те посадові особи органів внутрішніх справ (Національної поліції). А згідно зі ст. 221 КУПАП, розглядають справи про адміністративні правопорушення, передбачені вказаними статтями, судді районних, районних у місті, міських чи міськрайонних судів

Якщо під час розгляду справи орган (посадова особа) дійде висновку, що в порушенні є ознаки кримінального правопорушення, він передає матеріали прокурору або органу досудового розслідування (ст. 253 КУПАП) [12].

Таким чином, очевидно, що інформація до правоохоронних органів може надходити від місцевих судів, які розглядали справи про адміністративне правопорушення за ст. ст. 164-15, 166-16, 166-17 КУПАП.

Ознаки кримінального правопорушення можуть бути встановленні правоохоронними органами під час розслідування іншого злочину (підробка документів, незаконне збагачення, декларування недостовірної інформації тощо). Однак, як свідчить практика, така інформація жодного разу за останні п’ять років не надходила.

Відповідно до ч. 3 ст. 216 КПК України, досудове розслідування злочинів, передбачених ст. 219 КК України, здійснюють слідчі органів, що здійснюють контроль над додержанням податкового законодавства.

На тлі низького рівня розкриття злочинів 22 листопада 2018 р. прийнято Закон України «Про внесення змін до деяких законодавчих актів України щодо спрощення досудового розслідування окремих категорій кримінальних правопорушень» [13] (у редакції від 03.12.2019 набрав чинності 31 липня 2020 р.), яким уводиться поняття кримінальних проступків, розслідування яких відбуватиметься у формі дізнання. Указана новела спрямована на зменшення статистичної кількості кримінальних справ, які перебувають у провадженні слідчих, задля того щоб вони були зосереджені на розслідуванні тяжких злочинів.

Відповідно до ст. 12 Кримінального кодексу України, кримінальні правопорушення поділяються на кримінальні проступки і злочини (ч. 1). Кримінальним проступком $є$ діяння (дія чи бездіяльність), за вчинення якого передбачене основне покарання у виді штрафу в розмірі не більше трьох тисяч неоподатковуваних мінімумів доходів громадян або інше покарання, не пов'язане 3 позбавленням волі (ч. 2). Розслідування кримінальних проступків здійснюватиметься у формі дізнання, покладається на дізнавача - 
службову особу підрозділу дізнання органу Національної поліції, органу безпеки, органу, що здійснює контроль над додержанням податкового законодавства, органу Державного бюро розслідувань. Чи буде сприяти такий підхід підвищенню якості зібраних доказів?

По-перше, проведення розслідування кримінальних правопорушень здійснюється слідчим після внесення відомостей до Єдиного реєстру досудових розслідувань (СРДР). На відміну від цього органами дізнання до внесення відомостей до ЄРДР для з'ясування обставин вчинення кримінального проступку може бути: 1) відібрано пояснення; 2) проведено медичне освідування; 3) отримано висновок спеціаліста і знято показання технічних приладів та технічних засобів, що мають функції фотоі кінозйомки, відеозапису, чи засобів фото- і кінозйомки, відеозапису; 4) вилучено знаряддя і засоби вчинення кримінального проступку, речі і документи, що є безпосереднім предметом кримінального проступку, або які виявлені під час затримання особи, особистого огляду або огляду речей.

По-друге, доцільно погодитися з думкою Н.М. Ахтирської щодо перегляду санкції статей, якими передбачається склад кримінальних правопорушень, що віднесені нині до категорії проступків. Негативний прогноз даної новели проілюструємо одним прикладом. Так, особливу небезпеку становлять економічні злочини (злочини у сфері господарської діяльності). Відповідно до Угоди про асоціацію між Україною, з однієї сторони, та Європейським Союзом, Свропейським співтовариством з атомної енергії і їхніми державами-членами, з іншої сторони, Україна взяла зобов'язання вжити заходи, спрямовані на процес широкомасштабної адаптації законодавства задля сприяння економічній інтеграції до внутрішнього ринку Європейського Союзу. Ключовим чинником для розвитку інвестицій і заохочення конкуренції є відповідний рівень економічної надійності та безпеки, що досягається завдяки запобіганню вчиненню злочинів у сфері господарювання та ефективності їх розслідування. Особлива загроза для економічного співробітництва полягає в умисному, з корисливих мотивів, іншої особистої заінтересованості або в інтересах третіх осіб вчинення громадянином - засновником (учасником) або службовою особою суб'єкта господарської діяльності дій, що призвели до стійкої фінансової неспроможності суб'єкта господарської діяльності, що завдало великої матеріальної шкоди державі чи кредитору.

Однак методика розслідування кримінальних правопорушень, з огляду на складність економічних відносин та взаємодії суб'єктів господарювання, нестабільності регулювання функцій контролю над господарською діяльністю, у тому числі у сфері міжнародного економічного співробітництва, не відповідає потребам сьогодення; наявні методичні рекомендації не враховують нових економічних викликів та загроз; електронні мережі розрахунків ускладнюють виявлення ознак злочину; наявність розвиненої мережі міжнародного економічного співробітництва обмежує юрисдикцію держави щодо збору доказів тощо $[14$, с. 326$]$.

Організація економічного розвитку та співробітництва наполегливо рекомендує Україні посилити ефективність у цій сфері. Очевидно, що відсутність методики «нового покоління» розслідування доведення до банкрутства негативно впливає на результативність діяльності правоохоронних органів та суду. За 2019 рік зареєстровано 31 кримінальне правопорушення 3 ознаками доведення до банкрутства, жодній особі не повідомлено про підозру. Низький рівень розкриття доведення до банкрутства зумовлює доцільність на підставі аналізу слідчої та судової практики розробити рекомендації щодо вдосконалення розслідування доведення до банкрутства в сучасних умовах, посилити санкції.

3 урахуванням новел такий злочин, як доведення до банкрутства, тепер віднесений до кримінальних проступків, розслідування здійснюватиме орган дізнання. Невнесення відомостей до ЄРДР гальмуватиме оперативне реагування на виявлені факти, не сприятиме вчасному проведенню слідчих (розшукових) дій. Наведені статистичні дані свідчать про відсутність результативності діяльності слідчих, передача таких повноважень дізнавачам є сумнівним рішенням. Формує невтішний прогноз щодо підвищення якості розслідування те, що до категорії проступків, зокрема, відносяться доведення до банкрутства, фальсифікація фінансових документів та звітності фінансової організації, приховування неплатоспроможності фінансової установи або підстав для відкликання (анулювання) ліцензії фінансової установи, умисне введення в обіг на ринку України (випуск на ринок України) небезпечної продукції, розголошення комерційної або банківської таємниці тощо.

\section{ЛITEPATУРA}

1. Чурилов С.Н. Криминалистическая методика: история и современность. Москва : Маркетинг, 2002.370 с.

2. Белкин Р.С. Криминалистика: проблемы сегодняшнего дня. Злободневные вопросы российской криминалистики. Москва: НОРМА-ИНФРА-М, 2001. 237 с.

3. Ришелюк А.М. Коментар до ст. 219 КК України. Науково-практичний коментар Кримінального кодексу України / за заг. ред. М.І. Мельника, М.І. Хавронюка ; 10-е вид., перероб. та доп. Київ : Дакор, 2018. 456 с.

4. Методичні рекомендації щодо виявлення ознак неплатоспроможності підприємства та ознак дій 3 приховування банкрутства, затверджені Наказом Міністерства економіки України 19.01.2006 № 14 (у редакції Наказу Міністерства економіки України 26.10.2010 № 1361). URL : https://zakon.rada.gov.ua/rada/show/v0014665-06\#Text.

5. Ухвала Голосіївського районного суду міста Києва від 26.12.2019 Судове провадження: 1-кс/752/9331/19. Кримінальне провадження в ЄРДР: 42019100000000418. URL : //http://reyestr.court.gov.ua/Review/86642721.

6. Рішення Конституційного Суду у справі у справі за конституційним зверненням товариства з обмеженою відповідальністю «Міжнародний фінансово-правовий консалтинг» про офріційне тлумачення частини третьої статті 99 Цивільного кодексу України від 12 січня 2010 р. Справа № 1-2/2010. Вісник Конституційного Суду України. 2010. № 2

7. Постанова Пленуму Верховного Суду України «Про практику розгляду судами корпоративних спорів» від 24.10.2008 № 13. Вісник Верховного суду України. 2008. № 11.

8. Закон України «Про акціонерні товариства» від 17.09.2008 (у редакції від 13.05.2020). URL : // https://zakon.rada.gov.ua/laws/ show/514-17\#Text

9. Закон України «Про бухгалтерський облік та фрінансову звітність в Україні» від 16.07.1999 (у редакції від 30.03.2020). URL : https:// zakon rada.gov.ua/laws/show/996-14\#Text.

10. Справа № 127/19588/17 Провадження № 1-кс/127/8252/17. URL : http://reyestr.court.gov.ua/Review/69106586.

11. Васильєв В.М. Щодо нормативних джерел адміністративно-правового механізму протидії правопорушенням у сфері підприємницької діяльності. Науковий вісник Херсонського державного університету. Серія «Юридичні науки». Вип. $1 / 2019$.

12. Кодекс України про адміністративні правопорушення від 07.12.1984 (у редакції від 05.06.2020). URL : https://zakon.rada.gov.ua/ laws/show/80731-10\#Text.

13. Закон України «Про внесення змін до деяких законодавчих актів України щодо спрощення досудового розслідування окремих категорій кримінальних правопорушень» від 22.11.2018. URL : https://zakon.rada.gov.ua/laws/show/2617-19\#Text.

14. Ахтирська Н.М. Міжнародне співробітництво під час кримінального провадження: теоретичні та практичні аспекти : монографія. Київ : Логос, 2019. 576 с. 


\title{
ВСТАНОВЛЕННЯ ПОДІЇ ВБИВСТВА ЯК ОБСТАВИНА, ЩО ПІДЛЯГАЕ ВСТАНОВЛЕННЮ НА ПОЧАТКОВОМУ ЕТАПІ РОЗСЛІДУВАННЯ ВБИВСТВ, УЧИНЕНИХ ІНОЗЕМЦЯМИ НА ТЕРИТОРІЇ УКРАЇНИ
}

\author{
ESTABLISHING THE EVENT OF A KILLING AS THE CIRCUMSTANCES \\ TO BE INSTALLED AT THE INITIAL STAGE OF THE INVESTIGATION \\ OF THE KILLING ATTENDED BY ALIENS IN THE UKRAINE
}

Замула Б.А., здобувач кафедри криміналістики та судової медицини Національна академія внутрішніх справ

\begin{abstract}
Встановлено, що в ході реалізації завдань розслідування працівники правоохоронних органів у результаті вчинення кримінального правопорушення на початковому етапі розслідування повинні зібрати дані про основні обставини розслідуваної події. Тому статтю присвячено висвітленню однієї з актуальних теоретико-практичних проблем криміналістики щодо питання обставин, що підлягає встановленню на початковому етапі розслідування вбивств, учинених іноземцями на території України. Зокрема, детально розкрито встановлення події вбивства (що саме відбулося - насильницьке заподіяння смерті чи настання смерті з інших причин), яка виступає невід'ємною обставиною розслідування вбивств.

Наголошується, що в ході розслідування слідчому необхідно довести наявність події злочину, в даному випадку - вбивства. Привернуто увагу на те, що в Кримінальному процесуальному кодексі України (далі - КПК України) не досить конкретно вказується, що означає довести подію кримінального правопорушення. Тому зміст даної обставини має визначатися в залежності від конкретного виду кримінального правопорушення. Нами доведено, що у провадженнях про вбивства, зокрема вчинених іноземцями, має бути доведено подію вбивства. Однак, на наш погляд, такий стан вимагає подальшого розкриття, тобто в межах розглянутої обставини повинні бути доведені більш окремі обставини, які у своїй сукупності і становитимуть зміст події вбивства.

Тому підлягає встановленню перша обставина - чи настала смерть потерпілого. Привернуто увагу, що в судово-слідчій практиці мали місце помилки, які полягають у засудженні особи за вбивство «без трупа», тоді як «потерпілий» опинявся живий. Такі помилки $€$ результатом того, що слідство і суд не завжди приділяють увагу доведенню фракту настання смерті. Друга обставина - чи є смерть потерпілого насильницькою. Встановлюється це шляхом дослідження трупа на предмет причини смерті. Третя обставина - чи є смерть, можливо, наслідком самогубства, нещасного випадку або перевищення меж необхідної оборони? У таких ситуаціях важливе значення мають матеріальні сліди, залишені на місці події і які не «збігаються» з припущенням про нещасний випадок або самогубство (негативні

Ключові слова: вбивство, обставини, що підлягають встановленню, подія вбивства, іноземець, розслідування.
\end{abstract} обставини).

It is established that in the course of realization of tasks of investigation law enforcement officers as a result of commission of a criminal offense at the initial stage of investigation should collect data on the main circumstances of the investigated event. Therefore, the article is devoted to the coverage of one of the current theoretical and practical problems of criminology on the issue of circumstances to be established at the initial stage of the investigation of murders committed by foreigners in Ukraine. In particular, the establishment of the event of the murder (what exactly happened - violent death or other causes of death), which is an integral part of the murder investigation, is revealed in detail.

It is emphasized that during the investigation the investigator must prove the existence of a crime, in this case - murder. Attention is drawn to the fact that the Criminal Procedure Code of Ukraine (hereinafter - the CPC of Ukraine) does not specify enough what it means to prove the event of a criminal offense. Therefore, the content of this circumstance should be determined depending on the specific type of criminal offense. We have proved that in murder proceedings, including those committed by foreigners, the event of the murder must be proved. However, in our opinion, such a state requires further disclosure, in within the framework of the considered circumstance more separate circumstances must be proved, which together will constitute the content of the murder event.

Therefore, it is necessary to establish the first circumstance - whether the death of the victim. Such errors are the result of the fact that the investigation and the court do not always pay attention to proving the fact of death. The second circumstance is whether the death of the victim is violent. This is established by examining the corpse for the cause of death. Third circumstance - is death, perhaps, the result of suicide, accident or exceeding the limits of self-defense? In such situations, material traces left at the scene and which do not "coincide" with the assumption of an accident or suicide (negative circumstances) are important.

Key words: murder, circumstances to be established, event of the murder, foreigner, investigation.

Завданнями кримінального провадження, які зазначені в ст. 2 КПК України, є захист особи, суспільства та держави від кримінальних правопорушень, охорона прав, свобод і законних інтересів учасників кримінального провадження, а також забезпечення швидкого, повного та неупередженого розслідування і судового розгляду з тим, щоб кожний, хто вчинив кримінальне правопорушення, був притягнутий до відповідальності в міру своєї вини, жоден невинуватий не був обвинувачений або засуджений, жодна особа не була піддана необгрунтованому процесуальному примусу, і щоб до кожного учасника кримінального провадження була застосована належна правова процедура [1].

У ході реалізації даних завдань працівники правоохоронних органів у результаті вчинення кримінального правопорушення на початковому етапі розслідування повинні зібрати дані про основні обставини розслідуваної події. Особливого значення під час розслідування вбивств, учинених іноземцями, набуває можливість установлення особи, яка вчинила кримінальне правопорушення, та іiі вину- ватості у вчиненому. На цій стадії досить часто зустрічаються складні ситуації, які характеризуються недостатньою інформацією про обставини, що підлягають установленню.

Початок досудового розслідування має важливе значення в кримінальному провадженні. Саме від вирішення питання щодо реєстрації заяви чи повідомлення про вчинене кримінальне правопорушення в СРДР залежить подальша доля ефективності досудового розслідування. Слідчий, прокурор здійснюють свої повноваження, починаючи 3 моменту надходження інформації про злочин від заявника до правоохоронного органу, що є підставою для початку досудового розслідування, шляхом внесення відомостей до ЄРДР [2, с. 177]. При цьому необхідно відмітити, що внесення відомостей про кримінальне правопорушення до ЄРДР не зводиться лише до єдиного акту. Дана дія включає в себе подальший ланцюжок дій і рішень, направлених на з'ясування дійсної події і встановлення в ній ознак конкретного складу кримінального правопорушення, а також закріплення отриманих відомостей. 
Ми не будемо зупинятися на обставинах, які підлягають доказуванню і які закріплені в ст. 91 КПК України, адже під час розслідувань кримінальних правопорушень слід встановлювати такі обставини, які правового значення не мають, але вони необхідні в криміналістичному відношенні для успішного та якісного розслідування. Іншими словами, існують факти й обставини, які мають важливе криміналістичне значення і тим самим підлягають установленню, але не входять у предмет доказування в кримінальному провадженні.

Необхідно відзначити, що декларовані в законодавстві обставини мають для сторони обвинувачення орієнтуючий характер, стосуються розслідування всіх кримінальних правопорушень і недостатньо конкретизовані щодо певних категорій кримінальних правопорушень. Водночас слід відмітити, що переліки таких обставин для окремих видів кримінальних проваджень $є$ специфічними й залежать від ознак конкретного складу кримінального правопорушення. Саме тому дослідження обставин, що підлягають установленню та доказуванню в разі вбивств, учинених іноземцями на території України, слід визнати невід'ємним елементом методики розслідування.

Обставини, що підлягають встановленню під час розслідування вбивств, досліджували та формулювали чимало вчених, зокрема 3 огляду на вид убивства, що вивчався. Наприклад, на думку Р.О. Чеботарьова, обставинами, що підлягають встановленню під час доказування події вбивства, є: смерть потерпілого, насильницький характер смерті, факт заподіяння смерті іншою людиною [3, с. 180].

Більш узагальнений перелік обставин, що підлягають з'ясуванню під час розслідування вбивств, наводять M.I. Панов і B.О. Коновалова: безпосередня причина смерті; що саме відбулося - насильницьке заподіяння смерті чи настання смерті $з$ інших причин (нещасний випадок, хвороба); яким способом, за допомогою яких знарядь учинено вбивство; час настання смерті; місце вчинення вбивства; обставини, за яких вчинено вбивство; особа жертви; співучасники вбивства та роль кожного 3 них у вчиненні злочину; особа вбивці; мотиви вбивства; обставини, що сприяли вбивству (умисному чи необережному); заходи, яких слід вжити для попередження таких злочинів [4, с. 195]. Перелічені обставини $є$ основними питаннями під час розслідування вбивств, але не вичерпують їх

До елементів, які найважче доказувати в кримінальних правопорушеннях, пов'язаних із вбивством, вчиненим іноземцем, опитані слідчі віднесли: особу злочинця, винність у вчиненні вбивства, форму вини, мотив і мету вчинення, враховуючи статус іноземця (34\%); встановлення події вбивства (відбулося насильницьке заподіяння смерті чи настання смерті з інших причин) - 28\%; яким способом, за допомогою яких засобів чи знарядь учинено вбивство - 22\%; час настання смерті та місце вчинення вбивства - $12 \%$; ; інше - $(4 \%)$.

Так, на основі узагальнення практики нами виокремлені особливості обставин, що підлягають встановленню у провадженнях, пов'язаних із вбивствами, вчиненими іноземцями на території України, враховуючи обставини, які підлягають доказуванню у кримінальному провадженні.

Враховуючи те, що встановлення події вбивства часто деякі автори упускають, розглянемо дану обставину більш детально.

На наш погляд, законодавець у ст. 91 КПК України визначив черговість розташування обставин згідно з важливістю і черговістю їх встановлення. Якщо не з'ясовувати обставини, які стоять насамперед, то встановлення наступних взагалі не має сенсу. Наприклад, якщо не встановлено достовірно обставин, що характеризують подію злочину, то питання про винність особи не ставиться, так само як і всі наступні.
У зв'язку з цим насамперед слідчому необхідно довести наявність події злочину, в даному випадку - вбивства. Водночас закон недостатньо конкретно вказує, що означає довести подію кримінального правопорушення. Тому зміст даної обставини має визначатися в залежності від конкретного виду і різновиду кримінального правопорушення. Таким чином, у провадженнях про вбивства, зокрема і вчинених іноземцями, має бути доведено подію вбивства. Однак, на наш погляд, такий стан вимагає подальшого розкриття, тобто в межах розглянутої обставини повинні бути доведені більш окремі обставини, які у своїй сукупності і становитимуть зміст події вбивства.

На наш погляд, встановлення події вбивства передбачає 3'ясування таких окремих обставин:

1. Передусім необхідно встановити, чи настала смерть потерпілого. Найчастіше в літературі ця обставина не береться (мабуть, через іiі очевидність) до уваги, й автори говорять про те, що необхідно встановити, чи вбитий потерпілий. Однак не встановлення факту настання смерті потерпілого виключає подальше провадження про закінчений злочин - вбивство.

У судово-слідчій практиці мали місце помилки, які полягають у засудженні особи за вбивство «без трупа», тоді як «потерпілий» опинявся живий. Такі помилки $\epsilon$ результатом того, що слідство і суд не завжди приділяють увагу доведенню факту настання смерті.

Так, С.В. Бородін наводить приклад засудження В. за вбивство тещі, труп якої виявлений не був. Звинувачення спиралося на свідчення сусідки, яка бачила, як напередодні ввечері В. бив тещу, в результаті чого вона впала і більше не піднімалася. В. не заперечував побиття, але стверджував, що теща незабаром піднялася, зібрала свої речі й поїхала. Суд не взяв до уваги свідчення В. Однак після засудження з'ясувалося, що жінка після побиття дійсно зібрала свої речі i, намагаючись не привертати уваги, поїхала до родичів у віддалене село [6, с. 56].

Наявність подібних помилок, однак, не означає, що факт настання смерті не може бути доведений за відсутності трупа. Так, натепер 3 метою уникнення покарання злочинці застосовують найвитонченіші способи приховування та знищення трупів потерпілих, що створює значні труднощі в доведенні слідчими органами таких кримінальних правопорушень. Однак узагальнення практики показало, що невиявлення трупа потерпілого не $є$ перешкодою для притягнення до кримінальної відповідальності винних осіб.

Так, згідно з Вироком Києво-Святошинського районного суду Київської області по справі № 369/420/17 засудили ОСОБУ 3 за сукупністю Вироків, шляхом поглинення менш суворих покарань довічним позбавленням волі, остаточне покарання у виді довічного позбавлення волі з конфіскацією всього належного йому майна. Згідно 3 матеріалами даної справи місцезнаходження трупу потерпілого - ОСОБИ_5 у ході розслідування не встановлено [7]. У цьому випадку отримані в ході розслідування докази дозволили дійти обгрунтованого висновку про вчинене вбивство за відсутності трупа.

Крім показань підозрюваного, даних на початковій стадії розслідування, які були підтверджені в ході слідчих експериментів, велике значення у встановленні факту смерті мають матеріальні сліди злочину. Як показує аналіз практики, матеріальними носіями інформації і того, що смерть потерпілого настала (за відсутності трупа), виступають зазвичай сліди крові й інші сліди біологічного походження (мозкова речовина тощо). Такі сліди можуть бути виявлені на місці скоєння злочину, в транспортних засобах, використаних для транспортування трупа 3 метою подальшого приховування, на предметах, використаних для тимчасової упаковки трупа, в каналізаційних системах (наприклад, у разі розчленування трупа, відмивання знаряддя злочину, запирання предметів одягу, білизни і т. д.), 
на знаряддях вбивства, одязі та інших предметах, що належать злочинцю, в місцях приховування або знищення трупа. Дані сліди можуть бути слабо видимі або невидимі, можуть перебувати у важкодоступних місцях. Найчастіше злочинець намагається знищити дані сліди. Слідчий же повинен використовувати весь арсенал науково-технічних засобів для їх виявлення.

Виявлені сліди повинні бути ретельно досліджені як на предмет їх походження від конкретної особи, так і на предмет механізму їх утворення. Оскільки труп потерпілого в розглянутих випадках відсутній, то особливого значення набувають молекулярно-генетичні дослідження, при цьому використовують зразки крові близьких родичів потерпілого

Особливу роль у таких ситуаціях буде відігравати здійснення обліку слідової інформації щодо об'єктів, вилучених у ході проведення слідчих (розшукових) дій (далі - С(Р)Д), в єдиному інформаційному просторі 3 використанням сучасних інформаційних технологій, комп'ютерного та телекомунікаційного обладнання. Тим паче, що це вже стає вимогою сьогодення. Так, відповідно до Наказу № 257 від 16.03.2020 року «Про затвердження Інструкції з формування та ведення інформаційної підсистеми «СЛІД» інформаційно-телекомунікаційної системи «Інформаційний портал Національної поліції України», яка покликана на забезпечення обробки інформації про об'єкти, що були вилучені під час проведення слідчих (розшукових) дій, відбувається наповнення та підтримка в актуальному стані інформаційних ресурсів баз (банків) даних, що входять до ІПНП [8].

Так, під час розслідування кримінального провадження по факту безвісного зникнення гр. П. (Львівська область) в автомобілі марки «Audi-A6» під час огляду виявлені такі сліди: на ремені безпеки переднього правого пасажирського сидіння містилась речовина бурого кольору; між водійським сидінням та переднім правим пасажирським сидінням - підлокітник, знизу якого зроблено змив речовини бурого кольору; на килимку біля заднього правого пасажирського сидіння - сліди бурого кольору; на водійському сидінні виявлено три наскрізні отвори на задньому сидінні, були виявлені плями бурого кольору, які зазнали затирання. Згідно з даними з протоколу отримання зразків для експертизи від 12.05.2016 р. у батьків гр. П було відібрано букальний епітелій для проведення судової молекулярно-генетичної експертизи. Згідно з висновком експерта особа, генетичні ознаки (ДНК-профіль) якої встановлено у змиві РБК із підлокітника (об'єкт № 1 у висновку експерта № 6-01/417 від 11.05.2016 р.), на частині ременя безпеки (об’єкти №№ 4-7 у висновку експерта № 6-01/411 від 12.05.2016 р.) та у змиві з килимка біля заднього правого пасажирського сидіння (об'єкт № 1 у висновку експерта № 6-01/431 від 12.05.2016р.), може бути біологічним сином гр. П. Ймовірність даної події становить 99,99\% [9]

Іноді кількість крові або механізм утворення слідів свідчать про масивність кровотечі, несумісної із життям.

Крім цього, в слідчій практиці зустрічаються випадки, коли свідчення підозрюваних підтверджуються слідами застосування на місці злочину того чи іншого знаряддя злочину, про який розповідає підозрюваний. А також механізм заподіяння смерті підтверджується іншими слідчими (розшуковими) діями. Так, із провадження, яке ми розкривали раніше, враховуючи дані слідчого експерименту, в людини 3 антропометричними даними, схожими 3 даними статиста, в положенні сидячи на водійському сидінні автомобіля «Audi А6», під час пострілу, здійсненого в напрямку № 1 (згідно з додатком до протоколу слідчого експерименту), ймовірно, могло утворитись наскрізне вогнепальне поранення правого стегна і тазу; під час пострілу, здійсненого в напрямку № 2, ймовірно, могло утворитись наскрізне вогнепальне проникаюче поранення живота і тазу з ушкодженням внутрішніх орга- нів; під час пострілу, здійсненого в напрямку № 3, могло утворитись наскрізне вогнепальне проникаюче поранення грудей $з$ ушкодженням внутрішніх органів [7]. Зазначені докази слідчим були визнані достатніми, і він обгрунтовано прийняв рішення про направлення кримінального провадження до суду з обвинувальним актом.

Крім того, про настання смерті можуть свідчити предмети, що належали потерпілому, виявлені в місцях знищення або приховування трупа (наприклад, у печах, у водоймах тощо) або на прилеглій до них території.

Натепер нерідкі випадки інсценування власної смерті 3 метою ухилення від відповідальності за скоєні злочини або розправи з боку інших осіб. Проте нині в розпорядженні слідчого є великий арсенал засобів ідентифікації особи загиблого, крім пред'явлення трупа для впізнання. За наявності трупа з метою ідентифікації можуть використовуватися прижиттєві фотографії та інші об'єктивні відображення особи.

У таких випадках слід призначити портретну експертизу. Дана експертиза особливо ефективна у випадках, коли труп зазнав значних змін. Якщо в розпорядженні слідчого є зразки папілярних візерунків зниклої особи, ідентифікація особистості трупа може бути проведена за допомогою дактилоскопічної експертизи. За наявності зразків крові чи інших біологічних об'єктів і за відсутності сумнівів в їх походженні від зниклої особи, для ідентифікації трупа може бути призначена судово-медична і біологічна експертизи. У разі відсутності подібних зразків можливе проведення судових молекулярно-генетичних досліджень 3 використанням зразків крові близьких родичів зниклої особи.

2. Встановлення насильницького характеру смерті. Він встановлюється шляхом дослідження трупа на предмет причини смерті, адже згідно з ч. 2, п. 1. ст. 242 КПК України слідчий або прокурор зобов'язані забезпечити проведення експертизи щодо встановлення причин смерті [1].

Так, згідно 3 висновком експерта № 42/2447/2 від 03 лютого 2014 року «Під час судово-медичного дослідження трупа гр. О виявлено такі тілесні ушкодження: сліпе кульове проникаюче вогнепальне поранення голови (вхідна вогнепальна рана розташована на нижній повіці правого ока, на фоні синця та множинних дрібних саден - рана видовженої форми, з відносно рівними краями, дефектом «мінус-тканина», від якої відходить рановий канал, по ходу якого ушкоджується шкіра та слизова оболонка нижньої повіки лівого ока, очне яблуко, нижня стінки очниці (вилична кістка та кістка верхньої щелепи), решітчаста кістка та тіло основної кістки, проникає в порожнину черепа і закінчується стороннім тілом кулею сіруватого металу); сліпе кульове проникаюче вогнепальне поранення голови (вхідна вогнепальна рана розташована в потиличній ділянці ліворуч, з краями, які не зіставляються, та наявністю дефекту «мінус-тканини», від якої відходить рановий канал, по ходу якого ушкоджується шкіра, апоневроз, потилична кістка, у вигляді конусоподібного наскрізного перелому, тверда та м'яка мозкові оболонки головного мозку, ліва доля мозочок, закінчується між тім'яною та скроневою долями стороннім тілом під м'якою мозковою оболонкою - кулею сіруватого металу).

Смерть гр. О настала від вогнепальних проникаючих кульових поранень голови 3 ушкодженням оболонок та речовини головного мозку.

Виявлені тілесні ушкодження є прижиттєвими і утворились незадовго до настання смерті, мають ознаки тяжких тілесних ушкоджень, небезпечних для життя. Враховуючи наявність навколо вхідної вогнепальної рани на нижній повіці лівого ока саден, що виникли від дії вторинних снарядів, слід вважати, що постріл відбувся через перешкоду (окуляри). Дані вогнепальні поранення голови утворились від дії вогнепального снаряду в результаті пострілу з вогнепальної зброї [10]. 
3. Чи є смерть, можливо, наслідком самогубства, нещасного випадку або перевищення меж необхідної оборони. Насильницький характер смерті, проте, ще не свідчить про подію вбивства, оскільки смерть може наступити в результаті самогубства або нещасного випадку. Таким чином, для того щоб довести наявність убивства, необхідно виключити можливість настання смерті від нещасного випадку або самогубства. Дана інформація, як правило, виходить у процесі судово-медичного дослідження трупа на предмет можливості нанесення відповідних ушкоджень власною рукою.

У результаті вивчення слідчо-судової практики встановлені випадки і вчинення умисних вбивств у разі перевищення меж необхідної оборони або перевищення заходів, необхідних для затримання злочинця (ст. 118 КК України).

Так, згідно з Вироком Дніпровського районного суду м. Києва по справі № 1-150/2011 від 17 травня 20121 року встановлено, що 14.05.2010 року, приблизно о 13 год. 15 хв. між громадянином США ОСОБА 4, який знаходився за адресою: АДРЕСА_2, на грунті особистих неприязних стосунків виникла суперечка з ОСОБА 8 , в ході якої останній здійснив з пістолету два постріли в бїк ОСОБА 4, від чого останній отримав вогнепальні поранення голови та обличчя. У зв'язку з цим у ОСОБА_4, який був збентежений раптовістю нападу на нього та усвідомлюючи реальність небезпеки власному життю, винник умисел, спрямований на умисне позбавлення життя ОСОБА_8, 3 метою захисту свого життя. ОСОБА 4 тим часом став наносити удари по різних частинах тіла ОСОБА_8. При цьому ОСОБА 4, отримавши перевагу над потерпілим ОСОБА_8, заволодів вогнепальною зброєю - револьвером системи «Наган». Реалізуючи свій злочинний умисел, ОСОБА_4 в процесі боротьби з ОСОБА_8, усвідомлюючи при цьому суспільно небезпечний характер свого діяння, розуміючи, що заподіює ОСОБА_8 тяжкої шкоди, яка не відповідає небезпечності посягання, маючи можливість припинити бійку без застосування зброї, проте, перевищуючи межі самооборони, вчинив постріл через перешкоду журнальний стіл в область голови потерпілого ОСОБА_8, спричинивши смертельне вогнепальне поранення, від чого останній помер [11].

У таких ситуаціях важливе значення відіграють матеріальні сліди, залишені на місці події, які не «збігаються» 3 припущенням про нещасний випадок або самогубство (негативні обставини).

Таким чином, встановлюючи подію вбивства, слідчий повинен вирішити такі питання: 1) чи настала смерть потерпілого; 2) чи є смерть потерпілого насильницькою; 3) чи є смерть, можливо, наслідком самогубства, нещасного випадку або перевищення меж необхідної оборони? Встановлення таких обставин однозначно позитивно вплине на прийняття процесуально обгрунтованих рішень.

\section{ЛITEРАТУРА}

1. Кримінальний процесуальний кодекс України : Закон України від 13 квіт. 2012 р. № 4651-VI. URL: http://zakon2.rada.gov.ua/laws/ show/4651-17 (дата звернення: 12.05.2020)

2. Столітній А.В. Особливості початку досудового розслідування за ухилення від сплати аліментів на підставі подань (повідомлень) державної виконавчої служби. Актуальні проблеми держави і права. 2015. Вип. 75. С. 175-181.

3. Іщенко А.В., Ієрусалімов І.О., Удовенко Ж.В. Теорія і практика криміналістичного забезпечення процесу доказування в розслідуванні злочинів : навч. посібник. Київ : Центр учбової літератури, 2007. 160 с.

4. Чеботарев Р.А. Обстоятельства, подлежащие установлению при доказывании события убийства. Известия Российского государственного педагогического университета им. А.И. Герцена. 2011. № 127. С. 179-184.

5. Розслідування вбивств на замовлення. Настільна книга слідчого / М.І. Панов та ін. 3-тє вид., переробл. і доповн. Київ, 2011. C. $192-198$

6. Бородин С.В. Рассмотрение судом уголовных дел об убийствах. Москва : «Юридическая литература», 1964. 211 с.

7. Єдиний державний реєстр судових рішень. URL: http://reyestr.court.gov.ua/Review/82545260 (дата звернення: 12.04.20202).

8. Про затвердження Інструкції з формування та ведення інформаційної підсистеми «СЛІД» інформаційно-телекомунікаційної системи «Інформаційний портал Національної поліції України» : Наказ № 257 від 16.03.2020 p. URL: https://zakon.rada.gov.ua/laws/show/ z0319-20 (дата звернення: 12.04.20202).

9. Кримінальне провадження № 12016140080000997 від 04.04.2016 року.

10. Єдиний державний реєстр судових рішень. URL: http://reyestr.court.gov.ua/Review/39636652 (дата звернення: 12.04.20202).

11. Єдиний державний реєстр судових рішень. URL: http://reyestr.court.gov.ua/Review/26229172 (дата звернення: 12.04.20202). 


\title{
КОНСУЛЬТАЦІЯ ЯК ОДНА 3 ФОРМ ВИКОРИСТАННЯ СПЕЦАЛЬНИХ ЗНАНЬ У КРИМІНАЛЬНОМУ ПРОВАДЖЕННІ
}

\author{
CONSULTATION AS ONE OF THE FORMS OF USE OF SPECIAL KNOWLEDGE \\ IN CRIMINAL PROCEEDINGS
}

\author{
Марушев А.Д., к.ю.н., \\ доцент кафедри криміналістики \\ Національний юридичний університет імені Ярослава Мудрого
}

\begin{abstract}
У статті висвітлюються основні консультаційні форми використання спеціальних знань під час розслідування злочинів. Автором основну увагу зосереджено на характеристиці консультаційних форм, а саме усній і письмовій формах, що застосовуються в процесі розслідування злочинів. У ході проведеного аналізу визначено мету консультативної діяльності спеціалістів та основні вимоги до них у разі залучення до розслідування кримінального провадження. Відзначено, що консультативна діяльність спеціаліста складається не тільки з усного роз'яснення особливостей використання технічних засобів, але й попереднього дослідження окремих об'єктів, надання письмових довідкових даних, складання письмових висновків спеціаліста, які є джерелом орієнтуючої інформації для слідчого (оперативного працівника) в пошуку знаряддя злочину, злочинця, предметів його одягу та взуття, транспортного засобу. Автор відзначає, що для вирішення окремих оперативно-тактичних завдань необхідно проводити попередні дослідження в ході проведення слідчої (розшукової) дії (наприклад, огляду місця події) або відразу після ії закінчення. Попередні дослідження є важливим елементом пізнавальної діяльності спеціаліста, спрямованої на з'ясування обставин вчиненого злочину, пошук і встановлення винного. Але отримані висновки в результаті попереднього дослідження не є процесуально регламентованою дією, а отримані результати (висновки) не є джерелами доказів. Крім того, в проведенні попередніх досліджень зі слідами та об'єктами необхідно вживати заходів, що забезпечують цілісність та незмінність досліджуваних об'єктів (слідів). У процесі попереднього дослідження не повинні застосовуватися методи, що змінюють властивості речових доказів (форму, кількість, розміри, склад, колір тощо) і можуть вплинути на результати наступних експертних досліджень. У підсумку встановлено, що використання таких форм консультаційної діяльності спеціаліста забезпечить об'єктивність, повноту та всебічність досудового розслідування і сприятиме оперативному та ефективному розкриттю злочинів.

Ключові слова: досудове слідство, консультативна діяльність, кримінальне судочинство, слідчі (розшукові) дії, спеціальні знання,
\end{abstract} спеціаліст, форми.

The article highlights the main consultative forms of using special knowledge in the investigation of crimes. The author focuses on the characteristics of consultation forms, namely oral and written forms used in the investigation of crimes. In the course of the analysis, the purpose of the consultative activity of specialists and the main requirements to them in case of involvement in the investigation of criminal proceedings were determined. It is noted that the consultative activity of the specialist consists not only of oral explanation of the peculiarities of the use of technical means, but also preliminary research of individual objects, provision of written reference data, written conclusions of the specialist, which are a source of indicative information for investigators. instruments of the crime, the offender, his clothing and footwear, vehicle. The author notes that, to solve certain operational and tactical tasks, it is necessary to conduct preliminary research during the investigative (search) action (for example, inspection of the scene) or immediately after its completion. Preliminary research is an important element of the cognitive activity of the specialist, aimed at clarifying the circumstances of the crime, finding and identifying the culprit. But the conclusions obtained as a result of the preliminary study are not a procedurally regulated action, and the results obtained (conclusions) are not sources of evidence. In addition, in previous studies with traces and objects, it is necessary to take measures to ensure the integrity and immutability of the studied objects (traces). In the process of preliminary research, methods that change the properties of physical evidence (shape, quantity, size, composition, color, etc.) and that may affect the results of subsequent expert research should not be used. As a result, it was established that the use of such forms of consulting activities of the specialist will ensure the objectivity, completeness and comprehensiveness of the pre-trial investigation and will facilitate the prompt and effective detection of crimes. forms.

Key words: pre-trial investigation, consultative activity, criminal proceedings, investigative (search) actions, special knowledge, specialist,

Актуальність теми. Удосконалення інституту спеціальних знань на досудовому слідстві є важливою складовою частиною судово-правової реформи в Україні. Зростаючі можливості впровадження новітніх досягнень науки і техніки в процес розслідування кримінальних правопорушень, необхідність більш раціонально організувати процес доказування зумовлюють значну увагу вчених до проблем використання спеціальних знань на досудовому слідстві. Однак питання правового забезпечення використання спеціальних знань на досудовому слідстві не тільки не вичерпані, але й потребують подальшого вдосконалення і розроблення. Зокрема, теоретичного аналізу потребують питання правової регламентації спеціальних знань, принципи застосування спеціальних знань у кримінальному судочинстві. Немає єдиної думки з приводу процесуальної регламентації, змісту та класифікації форм спеціальних знань тощо. Актуальність вибраної проблематики визначається тим, що питання впливу результатів використання консультаційної форми спеціальних знань на процесуальні рішення в такому дослідницькому зрізі ще не ставились у сучасній юридичній літературі та у спеціальній монографічній літературі окремо не розглядалися.
Ступінь наукової розробки. Загальні організаційнотактичні аспекти застосування спеціальних знань у кримінальному провадженні розглядались у наукових працях із кримінального процесу, криміналістики i теорії судової експертизи такими українськими вченими, як Л.Ю. Ароцкер, О.О. Бондаренко, А.Ф. Волобуєв, В.Г. Гончаренко, І.В. Гора, Г.Л. Грановський, Ю.М. Грошевий, М.В. Даньшин, А.В. Журавель, А.В. Іщенко, Н.С. Карпов, Н.І. Клименко, I.І. Когутич, В.А. Колесник, В.П. Колмаков, В.О. Коновалова, В.К. Лисиченко, О.М. Моїсєєв, Г.М. Надгорний, І.В. Постіка, М.В. Салтевський, Е.Б. СімаковаЄфремян, Р.Л. Степанюк, І.Я. Фрідман, В.В. Циркаль, К.О. Чаплинський, В.Ю. Шепітько, В.М. Шерстюк та ін.

Окремі проблеми використання спеціальних знань під час розслідування кримінальних правопорушень були предметом дисертаційних досліджень Є.С. Демидової (Тактика допиту обізнаних осіб. - Харків, 2013), B.I. Дячука (Використання спеціальних знань при розслідуванні дорожньо-транспортних пригод. - Київ, 2010), А.В. Мировської (Використання спеціальних знань при розслідуванні фальшивомонетництва. - Ірпінь, 2012), П.Ю. Кравчука (Використання спеціальних знань під час 
розслідування грабежів і розбоїв. - Ірпінь, 2015), К.А. Садчикова (Використання спеціальних знань на стадії досудового розслідування (процесуальний аспект). - Одеса, 2017), В.О. Яремчук (Залучення спеціаліста до проведення слідчих дій (організація і тактика). - Харків, 2014) та інших.

Метою статті є визначення й дослідження консультаційних форм використання спеціальних знань та їх ролі в розкритті й розслідуванні злочинів. Як свідчить слідча та судова практика, несвоєчасне застосування спеціальних знань породжує численні правові, організаційні й інші проблеми залучення спеціалістів на стадії досудового слідства, використання результатів їхньої роботи в доказуванні. Саме це й зумовило необхідність розгляду деяких загальних положень використання спеціальних знань у даній роботі.

Виклад основного матеріалу. У кримінально-процесуальному законодавстві визначені загальні засади використання спеціальних знань у кримінальному судочинстві, але всі проблеми інституту використання спеціальних знань так и не були усунені. Треба зазначити, що в кримінально-процесуальному законодавстві зазначаються й нові види джерел доказів, основаних на спеціальних знаннях. До них відносяться висновки або думки свідка, підозрюваного, обвинуваченого, потерпілого, які дають показання, що грунтуються на спеціальних знаннях (ч. 6 ст. 95 КПК України). Ми згодні, що специфіка показань таких осіб полягає в тому, що їхній зміст становлять не тільки «голі» факти, але i їх тлумачення на основі спеціальних знань. Ще одним новим джерелом доказів визнаються показання експерта, отримані під час допиту на досудовому слідстві (ст. 95 КПК України) або в суді (ст. 356 КПК України) [4, с. 23-24].

У сучасній науці кримінально-процесуального права та криміналістики приділяється значна увага класифікації форм використання спеціальних знань, але й досі немає єдиної думки 3 приводу процесуальної регламентації, змісту та класифікації форм спеціальних знань у процесі розслідування злочинів. Це пояснюється тим, що форми використання спеціальних знань належним чином не врегульовані кримінальним процесуальним законодавством. Науковці наводять різні переліки форм спеціальних знань.

На наш погляд, найбільш повний перелік форм спеціальних знань визначив B.I. Шиканов: а) безпосереднє використання спеціальних знань слідчим, прокурором i складом суду, тобто тими особами, на яких у процесуальному порядку покладений обов'язок щодо збирання та оцінювання судових доказів; б) використання спеціальних знань обізнаних осіб без залучення їх до участі в слідчих діях (консультації, отримання різного роду довідок зі спеціальних питань); в) використання результатів позасудових (відомчих, адміністративних) розслідувань, а також результатів досліджень окремих об'єктів, що проводяться під час зазначених розслідувань або за інших умов; г) використання спеціальних знань обізнаних осіб, залучених до виконання процесуальних функцій спеціаліста; г) використання спеціальних знань обізнаних осіб, притягнутих до виконання процесуальних функцій судового експерта; д) використання спеціальних знань перекладачів і осіб, що розуміють знаки німого або глухого; е) призначення ревізій у порядку, передбаченому законом є) проведення по завданню слідчого або суду технічних та інших обстежень [8, с. 7].

Згідно з ч. 1. ст. 71 КПК України спеціаліст, який залучається до кримінального провадження, може надавати консультації під час досудового розслідування і судового розгляду з питань, що потребують відповідних спеціальних знань і навичок. Спеціаліст як консультант - фігура в судочинстві відносно нова, і ця сторона діяльності обізнаної особи задіяна далеко не повною мірою [2, с. 211]. «Консультація» в тлумачному словнику розглядається як порада фахівця з якого-небудь питання, а «надання пояснення» автори словника розуміють як роз'яснення про що-небудь, для того щоб зробити його ясним і зрозумілим; з'ясовування ситуації, розкриття причин дії, явища; розкриття особливостей речі, явища, вказуючи на їхні певні ознаки $[1$, с. 451$]$

У криміналістичній і процесуальній літературі науковці виокремлюють процесуальну i непроцесуальну форми використання спеціальних знань. До непроцесуальної форми і відноситься консультативна діяльність спеціаліста на досудовому слідстві. Безумовно, така консультація може надаватись як в усній, так і в письмовій формах. Д.В. Куриленко зазначає: під час досудового розслідування спеціаліст, який брав участь у проведенні слідчої (розшукової) дії, дає письмові пояснення, що приєднуються до протоколу як додатки (ч. 2 ст. 105 КПК України). Якщо в протоколі фіксуються наочні, очевидні дані, що сприймали всі учасники слідчої (розшукової) дії, то в поясненнях, на наш погляд, можуть вказуватися не тільки особливості використання технічних засобів, але й довідкові дані, консультації спеціаліста, які є джерелом орієнтуючої інформації для слідчого (оперативного працівника) в пошуку знаряддя злочину, злочинця, предметів його одягу та взуття, транспортного засобу та ін. [4, с. 24].

Аналіз слідчої та судової практики дозволяє визначити, що усна консультація спеціаліста надається для:

- роз'яснення цільового призначення й методики застосування технічних засобів у процесі фіксації слідів злочину;

- роз'яснення особливостей вилучення, пакування, транспортування і зберігання виявлених об'єктів та слідів злочину;

- роз'яснення особливостей правильного опису в протоколі виявлених об'єктів та слідів злочину;

- роз'яснення механізму і часу утворення слідів на місці злочину, роз'яснення фізичних особливостей особи, що, можливо, вчинила правопорушення. Наприклад, лікар по характеру нанесених колото-різаних ран визначає, що це була особа, яка добре знайома 3 анатомією, крім того, він чи вона лівша тощо;

- проведення попереднього дослідження слідів і речових доказів;

- роз'яснення можливості вилучених об'єктів для подальшого дослідження та проведення судових експертиз. Наприклад, виявлення ознак підробки грошових коштів та інших документів або проведення експрес-аналізів виявлених порошків для встановлення наявності наркотичних засобів тощо;

- роз'яснення можливості і необхідності вилучення експериментальних зразків для проведення в подальшому судової експертизи;

- роз'яснення необхідності обов'язкового призначення експертизи по вилучених речових доказах у цьому випадку. Як правило, спеціаліст надає консультативну допомогу у визначені класу, роду та виду судової експертизи, яку необхідно призначити. Консультативну допомогу спеціаліста слідчій може отримати й у випадках, коли виникає запитання: чи достатньо для проведення конкретного експертного дослідження знань експерта однієї спеціальності, або ж є необхідність призначення комплексної. Треба надати консультативну допомогу в правильному формулюванні питань, які підлягають постановці перед експертом.

Окремо треба зупинитись на попередньому дослідженні спеціалістом слідів та речових доказів на місці вчинення злочину. Більшість науковців згодні, що попереднє дослідження є невід'ємною частиною застосування спеціальних знань у процесі проведення окремих слідчих (розшукових) дій. Спричиняє заперечення думка B.M. Реваки, що дослідницька діяльність характерна тільки для експертизи й відсутня у всіх інших формах 
застосування спеціальних знань у кримінальному судочинстві [6, с. 23]. Метою попередніх досліджень матеріальних слідів злочину $є$ :

- негайне одержання орієнтуючої інформації, що використовується для висування слідчих версій стосовно осіб, що причетні до вчинення злочину;

- визначення напрямку пошуку злочинця по гарячих слідах;

- визначення напрямку пошуку об'єктів, що залишили сліди на місці події;

- визначення напрямку пошуку очевидців, свідків та іншої розшукової інформації;

- визначення виду та класу виявлених предметів, речовин, матеріалів, 3'ясування механізму й обставин вчиненого злочину й т. ін.

Зазвичай для вирішення цих оперативно-тактичних завдань попередні дослідження необхідно проводити одночасно в ході проведення слідчої (розшукової) дії (наприклад, огляду місця події) або відразу після іiі закінчення. Попередні дослідження є важливим елементом пізнавальної діяльності спеціаліста, спрямованої на з'ясування обставин вчиненого злочину, пошук і встановлення винного. Але отримані висновки в результаті попереднього дослідження не $є$ процесуально регламентованою дією, а отримані результати (висновки) не $\epsilon$ джерелами доказів. Крім того, в проведенні попередніх досліджень зі слідами та об'єктами необхідно вживати заходів, що забезпечують цілісність та незмінність досліджуваних об'єктів (слідів). У процесі попереднього дослідження не повинні застосовуватися методи, що змінюють властивості речових доказів (форму, кількість, розміри, склад, колір тощо) і можуть вплинути на результати наступних експертних досліджень. На нашу думку, помилковим є твердження I.I. Когутича, що під час проведення слідчих (розшукових) дій спеціальні знання можуть використовуватися лише в процесуальних формах [5, с. 114]. Попередні дослідження є важливим елементом пізнавальної діяльності спеціаліста, спрямованої на 3'ясування обставин вчиненого злочину, пошук і встановлення винних осіб тощо.

У слідчий та судовій практиці, окрім усних консультацій і пояснень, використовуються й письмові. Згідно зі ст. 84 КПК України доказами у кримінальному провадженні є будь-які фактичні дані, отримані в передбаченому законом порядку. Слідчому надано право витребувати документи, в тому числі й ті, що складаються спеціалістами поза кримінальним провадженням. Значення для слідства таких документів часом важко переоцінити. Їх підготовка здійснюється хоча за межами кримінальної процесуальної діяльності, але в установленому законодавством порядку. Це дає підстави віднести їх до процесуальних форм використання знань спеціалістів, змістом яких є підготовка особами, що володіють спеціальними знаннями, або за їхньою участю в порядку, встановленому відомчими (або міжвідомчими) правилами й інструкціями, документів довідкового характеру. Підготовку цих документів здійснюють спеціалісти за межами кримінального процесу в адміністративному порядку. До них можна віднести:

1. Документи, що містять довідкові та інші відомості й стосуються кримінального провадження, підготовлені з використанням знань спеціалістів. У цих довідках відображаються елементи досліджень, що проводяться обізнаними особами під час перевірки за криміналістичним обліком, є довідковою інформацією про об'єкти, що перевіряються (людина, зброя, транспортний засіб та ін.), які раніше могли потрапити в орбіту кримінального судочинства і підлягали кримінальній реєстрації.
Використання цих інформаційних обліків дозволяє виявити належність конкретної особи або предмета до розслідуваного злочину, визначити, чи вчинені кілька злочинів тією самою особою, чи застосовувалася при цьому та ж сама зброя, встановити особистість живих осіб чи невпізнаних трупів тощо.

2. Документи, що не містять відомостей про кримінальне правопорушення. Здебільшого це довідки разового характеру, що містять відповіді на запити слідчого. Вони можуть, наприклад, засвідчувати або роз'яснювати положення відомчих наказів та інструкцій, аналіз яких вимагає спеціальних знань, характеризувати особу з місця роботи, довідкові дані про перенесені хвороби тощо;

3. Документи, що мають дослідницький характер та прямо стосуються події злочину. До них відносяться висновки досліджень, які складають психологи на досудовому розслідуванні. Зазвичай спеціалісти-психологи за зверненням слідчого та за матеріалами кримінального провадження проводять дослідження та надають висновок про психологічний профіль злочинця, на підставі якого здійснюється розшук осіб, які вчинили злочин. Зокрема, А.М. Старушкевич пропонує використовувати допомогу психолога на початковому етапі розслідування для складання психологічних профілів для виявлення осіб, які вчинили злочин [7, с. 65]. Аналогічних поглядів дотримуються російські вчені Л.Н. Іванов і С.А. Полунін, які пропонують залучати психолога для огляду місця пригоди, приміщення, в якому проживає підозрюваний, документів, текстів, малюнків, трупа на місці його знаходження для виявлення додаткових джерел інформації про вчинений злочин [3, с. 27].

До письмової форми використання відносяться й висновки спеціалістів, які проводили спеціальні психофізіологічні дослідження з використанням поліграфа. Діагностування людини 3 використанням поліграфа можливе лише за згодою особи, а отримані висновки не мають статусу доказів та носять орієнтуючий характер.

На відміну від усних форм використання спеціальних знань письмові форми можуть бути застосовані тільки після початку досудового розслідування. Письмові форми, пов'язані $з$ витребуванням слідчим документів, що містять довідкові та інші відомості, стосуються провадження та підготовлені з використанням знань спеціалістів, але не заміняють висновків експертів та інших документів, які складаються у встановленому порядку. У деяких випадках у довідках немає відомостей про кримінальне правопорушення. Здебільшого це довідки разового характеру, що містять відповіді на запити слідчого. Вони можуть, наприклад, засвідчувати або роз'яснювати положення відомчих наказів та інструкцій, аналіз яких вимагає спеціальних знань. Документи цієї групи можна поділити на ті, які складаються спеціально за запитом слідчого, й ті, які були складені раніше.

Висновки. Узагальнюючи вищевикладене, можемо зробити висновок, що консультації спеціалістів належать до основних форм використання спеціальних знань у розслідуванні злочинів. Консультативна діяльність спеціаліста складається не тільки з усного роз'яснення особливостей використання технічних засобів, але й $з$ попереднього дослідження окремих об'єктів, надання письмових довідкових даних, складання письмових висновків спеціаліста, які є джерелом орієнтуючої інформації для слідчого (оперативного працівника) в пошуку знаряддя злочину, злочинця, предметів його одягу та взуття, транспортного засобу та ін. Комплексне використання таких форм забезпечить об'єктивність, повноту і всебічність досудового розслідування та сприятиме оперативному розкриттю злочинів. 


\section{ЛITEPATУРA}

1. Великий тлумачний словник сучасної української мови / гол. ред. В.Т. Бусел. Київ : ВТФ «Перун», 2005.1728 с.

2. Гора І.В. Проблеми використання спеціальних знань у кримінальному судочинстві України. Юридичний часопис Національної академії внутрішніх справ. 2013. № 1. С. 208-214.

3. Иванов Л.Н., Полунин С.А. Процессуальные основы использования специальных знаний и проблемы полисистемного анализа личности в следственном осмотре. Вестник криминалистики. Москва : Спарк, 2004. № 1 (9). С. $26-29$.

4. Куриленко Д.В. Інститут обізнаних осіб у змагальному кримінальному провадженні : дис. ... канд. юрид. наук : 12.00 .09 ; Харківський нац. ун-т внутр. справ. Харків, 2017. 258 с.

5. Когутич I.І. Окремі питання сутності та фрорм використання спеціальних знань у кримінальному провадженні. Вісник Академії адвокатури України. 2015 № 2 (33). T. 12. С. 112-123. URL: http://nbuv.gov.ua/UJRN/vaau_2015_12_2_16

6. Ревака В.М. Форми використання спеціальних пізнань в досудовому провадженні : дис. … канд. юрид. наук : 12.00 .09 ; Нац. юрид акад. імені Ярослава Мудрого. Харків, 2006. 198 с.

7. Старушкевич А.М. Криміналістичне профілювання: наукове обґрунтування та проблеми використання у розслідуванні злочинів. Право України. 2004. № 8. С. 64-68.

8. Шиканов В.И. Использование специальных познаний при расследовании убийств : учебное пособие. Иркутск : из-во Иркут. гос. ун-та, 1976. 90 с. 
удК 343.148

DOI https://doi.org/10.32782/2524-0374/2020-4/75

\title{
ОСОБЛИВОСТІ ОТРИМАННЯ ДЕЗОКСИРИБОНУКЛЕЇНОВОЇ КИСЛОТИ 3 БІОЛОГІЧНИХ ОБ' ЄКТІВ, ФІКСОВАНИХ У ПАРАФІНІ
}

\author{
FEATURES OF DNA OBTAINING FROM FIXED \\ AND PARAFFIN-EMBEDDED BIOLOGICAL OBJECTS
}

\author{
Мещанінова Г.П., судовий експерт сектору молекулярно-генетичних досліджень \\ відділу біологічних досліджень та обліку \\ Харківський науково-дослідний експертно-криміналістичний иентр \\ Міністерства внутрішніх справ Украӥни
}

Дослідження нуклеїнових кислот, отриманих із зафіксованих формаліном і занурених у парафінові блоки тканин, методом аналізу на основі полімеразної ланцюгової реакції стало часто використовуватися в судовій експертизі. Водночас відсутні загальновизнані рекомендації щодо особливостей вибору методів вилучення нуклеїнових кислот. У зв'язку із цим, метою роботи є проведення порівняльної характеристики наявних методів виділення дезоксирибонуклеїнової кислоти із зафіксованих фрормаліном і занурених у парафінові блоки тканин.

Загальні етапи процедур екстрагування нуклеїнової кислоти із зафіксованих формаліном і занурених у параффінові блоки тканин пов'язані з депарафінізацією та протеолітичним розщепленням протеїназою К. Водночас у різних методиках вказані різні концентрації та час/температура інкубації.

Більшість комерційних методів і внутрішніх методик різних лабораторій рекомендують проводити протеолітичну стадію при температурі $55-60^{\circ} \mathrm{C}$, проте час значно відрізняється в різних методиках - від години до 12-48 год.

Екстракція нуклеїнової кислоти із зафіксованих формаліном і занурених у парафінові блоки тканин є технічно вимогливою та лабораторно інтенсивною процедурою, тому автоматизація може значно підвищити ефективність процесу. Натепер комерціалізовано кілька напівавтоматів. Проте єдиною повністю автоматизованою системою вилучення дезоксирибонуклеїнової та рибонуклеїнової кислот $€$ інструмент Siemens, який виділяє загальні нуклеїнові кислоти із заффіксованих формаліном і занурених у парафінові блоки тканин за допомогою пластин заліза оксиду, що покриті наношаром кремнезему з модифікованою молекулярною системою VERSANT kPCR.

Важливим завданням для дослідження дезоксирибонуклеїнової кислоти є не тільки її виділення, але й подальше визначення вмісту нуклеїнових кислот в екстракті методом полімеразної ланцюгової реакції. На якість проведення полімеразної ланцюгової реакції впливає велика кількість факторів, зокрема наявність інгібіторів, деградованих матриць дезоксирибонуклеїнової кислоти, а також низький/високий вміст матриць. У цих випадках моніторинг гальмування може здійснюватися за допомогою полімеразної ланцюгової реакції в реальному часі або кількісному застосуванні з використанням внутрішнього позитивного контролю. Повторне тестування гальмування дозволяє оптимізувати комбінації фрасилітаторів полімеразної ланцюгової реакції та розведення зразків таким чином, щоб кількість вилученої дезоксирибонуклеїнової кислоти та/або кількісна точність були максимальними в наступних циклах полімеразної ланцюгової реакції.

Роботи в напрямку стандартизації кількісних методів визначення нуклеїнових кислот продовжуються. Це важливо, оскільки контроль і забезпечення якості є запорукою будь-якого аналізу, а молекулярні аналізи вимагають складніших і жорсткіших заходів для забезпечення надійних результатів.

Ключові слова: нуклеїнові кислоти, дезоксирибонуклеїнова кислота, зафіксовані формаліном та занурені в парафрінові блоки тканини, полімеразна ланцюгова реакція, екстракція, кількісне визначення, стандартизація.

Nucleic acid studies, derived from formalin-fixed paraffin-embedded tissue blocks (FFPE), have been widely used in forensic examination using the polymerase chain reaction assay. At the same time there are no generally recognized recommendations on the peculiarities of the choice of nucleic acids extraction method. In this regard, the purpose of the work is to perform a comparative characterization of the existing deoxyribonucleic acid (DNA) extraction methods from formalin-fixed and paraffin-embedded tissue blocks.

The general steps of nucleic acid extraction procedures from FFPE were related to dewaxing and proteolytic cleavage by proteinase K. Different incubation times and temperatures were indicated in different methods.

Most commercial methods and internal techniques from different laboratories recommend a proteolytic step at a temperature of $55-60{ }^{\circ} \mathrm{C}$, but the time varies greatly from one hour to 12-48 hours.

Nucleic acid extraction from FFPE is a technically demanding and laboratory-intensive procedure, so automation can greatly increase the efficiency of the process. Currently, several semi-automatic machines are commercialized. However, the only fully automated system for DNA and RNA extraction is the Siemens tool, which isolates total nucleic acids from FFPE tissues by using iron oxide plates coated with a silica nanoclay with a modified VERSANT kPCR molecular system.

An important task for DNA research is not only its isolation but also the subsequent determination of the nucleic acid content in the extract by the polymerase chain reaction (PCR) method. The quality of PCR is influenced by a number of factors, including the presence of inhibitors, degraded DNA matrices, and low/high content of the matrices. In these cases, the braking can be monitored by real-time PCR or quantified using internal positive control. Re-testing the inhibition allows optimization of PCR facilitators and dilution of the samples combinations so that the amount of DNA extracted and/or quantitative accuracy is maximized in subsequent PCR cycles.

Work towards standardizing quantitative methods for nucleic acid determination is continuing. This is important because quality control and quality assurance is the key to any analysis, and molecular analyzes require more sophisticated and rigorous measures to ensure reliable results.

Key words: nucleic acids, deoxyribonucleic acid, formalin-fixed and paraffin-embedded tissue blocks, polymerase chain reaction, extraction, quantification, standardization.

Підвищення ефективності розслідування злочинів проти життя та здоров'я громадян $є$ перманентним завданням правоохоронної діяльності. Важливе значення в розслідуванні злочинів, об'єктивізації доказування в кримінальних справах мають об'єкти біологічного походження, які є предметом дослідження судово-медичної експертизи. Для цього використовуються різні методи: серологічний, цитологічний, гістологічний, біохімічний, хіміко-токсикологічний, фізико-технічний тощо.
Проте натепер найточнішими методами, що є альтернативою медико-криміналістичним і серологічним методам дослідження, є молекулярно-генетичні. Для проведення такої експертизи як біологічні об’єкти застосовують зуби, кісткову й м'язову тканини, волосся, плідний матеріал тощо. У випадках поховання трупа й відсутності вищеперерахованих біологічних об'єктів єдиним біологічним матеріалом є парафінові блоки, оскільки вони зберігаються в архіві гістологічного відділення до 3 років [1, с. 40]. 
Однак під час дослідження нуклеїнових кислот, отриманих із зафіксованих формаліном і занурених в парафінові блоки тканин (далі - ЗФЗП), методом аналізу на основі полімеразної ланцюгової реакції (далі - ПЛР) виникає низка труднощів, зумовлених тим, що виділені із ЗФЗП нуклеїнові кислоти є деградованими. Водночас із метою стандартизації досліджень відсутні стандарти для контролю якості. Незважаючи на те, що зростає кількість публікацій про методи проведення молекулярних аналізів нуклеїнових кислот, отриманих із ЗФЗП [21, с. 416], та особливостей їх виконання, не існує загальновизнаних рекомендацій щодо особливостей вибору методів вилучення нуклеїнових кислот [16, с. 812]. Це й зумовлює актуальність дослідження.

У зв'язку із цим, метою роботи є проведення порівняльної характеристики наявних методів виділення дезоксирибонуклеїнової кислоти (далі - ДНК) із зафіксованих формаліном і занурених в парафінові блоки тканин.

Формалін є золотим стандартним фіксатором для гістопатологічної діагностики, оскільки він чудово зберігає морфологію структури тканини, створюючи зшивання між білками [11, с. 375]. Хоча зшивання білок-білок $є$ найчастішою реакцією, відбувається також значне міжмолекулярне зшивання білків із нуклеїновими кислотами. Формальдегід реагує з основами нуклеїнових кислот з утворенням N-гідроксиметильної (метилової) групи (-CH2OH) 3 подальшою повільною електрофільною атакою цієї $\mathrm{N}$-метилової групи на амінокислотні основи з утворенням метиленових містків між двома аміногрупами [3, с. 762] Ця реакція дозволяє тверднути тканинам для подальшого мікроскопічного й імуногістохімічного аналізу, але метиленові мостики між білками й нуклеїновими кислотами як додавання $\mathrm{CH} 3 \mathrm{OH}$ до основ нуклеїнових кислот є критичними для вилучення неушкоджених нуклеїнових кислот із ЗФЗП [13, с. 28].

Робочий процес вилучення нуклеїнової кислоти із ЗФЗП полягає в такому. Загальні етапи процедур екстрагування пов'язані з депарафінізацією та протеолітичним розщепленням протеїназою К. Найпоширеніша методика видалення парафіну заснована на його солюбілізації в ксилолі чи інших органічних розчинниках, таких, як лимонен і гексан [14, с. 280], а потім промиванні етанолом [14, с. 281].

Відомо, що за здатністю розчиняти парафін у разі порівняння ксилолу, гексану й лимонену переважає ароматичний ксилол, який розчиняє парафін краще, ніж інші розчинники $[19$, с. 20]. Існують також альтернативні методи, такі, як його видалення або пряме плавлення за допомогою мікрохвильових печей $[21$, с. 416], мінеральної олії та інкубації при температурі $90{ }^{\circ} \mathrm{C}$ [20, с. 495] або використання специфічних екстракційних реагентів, таких, як Q-розчин (TrimGen'sWax Free ${ }^{\mathrm{TM}}$ Набір для підготовки рибонуклеїнової кислоти з парафінових зразків, TrimGen, MA, США) [2, с. 151]. Більшість авторів сходяться на думці, що етап депарафінізації не надає конкретного ефекту в разі використання таких процедур [9, с. 9], можливо, через його видалення під час фаз екстрагування. Однак невелика кількість вчених продемонструвала, що відновлення нуклеїнових кислот із ЗФЗП тісно пов'язане з процесом депарафінізації [6, с. 585].

Екстракція нуклеїнових кислот із тканин ЗФЗФ вимагає спеціальних методик, які грунтуються на вичерпному протеолітичному видаленні зшивання білка, що зшитий із нуклеїновими кислотами. Це дозволить проекстрагувати нуклеїнові кислоти в повному об'ємі.

У більшості випадків протеоліз досягається протеїназою К. Водночас в різних методиках вказані різні концентрації та час/температура інкубації. Проте саме час і температура інкубації суттєво впливають на процедуру вилучення, оскільки вони безпосередньо пов'язані з введенням теплової енергії для видалення зшивок.
Низка вчених наполегливо підтверджують, що кількість фрагментів ядерної ДНК значно збільшується внаслідок збільшення часу гідролізу [5, с. 693]. Щодо введення теплової енергії, температура інкубації також впливає на видалення поперечних зв'язків. Однак, коли температура вище $65{ }^{\circ} \mathrm{C}$, може відбутися деградація ДНК [4, с. 19]. Відомо, що вихід ДНК, які ампліфіковані ПЛР, збільшується з часом інкубації з протеїназою К у результаті того, що під час введення теплової енергії в систему зшивання формальдегід-білок є оборотним [19, с. 495]. Під час виділення ДНК із ЗФЗП відбувається ії деградація. Проте ступінь деградації не така критична, як для рибонуклеїнової кислоти (далі - РНК) із того ж джерела.

Для екстрагування ДНК із ЗФЗП може використовуватися декілька методів, таких, як засолювання, вилучення фенолом/хлороформом і фільтрація на основі кремнезему [19, с. 18]. Більшість комерційних методів і внутрішніх методик різних лабораторій містять протеолітичну стадію, що, як правило, проводиться при температурі $55-60{ }^{\circ} \mathrm{C}$, проте час значно відрізняється в різних методиках - від години до 12-48 год.

Протеоліз $є$ досить мінливим процесом, оскільки можуть бути використані різні буфери й різні концентрації протеїнази К. Зазвичай буфери для гідролізу складаються 3 трис(гідроксиметил)амінометан-хлоридної кислоти, етилендіамінтетраоцтової кислоти, натрію хлориду, детергенту й протеїнази К. Згідно з думкою вчених С. Viertler, D. Groelz, S. Gündisch [22, с. 460], також у склад буферу може входити й натрію гідроксид.

Так, у багатоцентровому дослідженні з одних і тих же тканин ЗФЗП екстрагували ДНК, використовуючи різні методи, 3 кінцевою концентрацією протеїнази К в межах від 0,2 до 3,3 мкг/мкл при температурі від 37 до $56{ }^{\circ} \mathrm{C}$ без особливої різниці в тривалості ампліфікованості ДНК [13, с. 30].

Хоча гідроліз протеїназою К не достатній для видалення речовин, що інгібують ПЛР, вона відіграє важливу роль у гідролізі довших фрагментів секвенування ДНК (> 200 основ), можливо, шляхом доступності ДНК для ампліфікації. Имовірно, це відбувається шляхом розриву зв'язків кислот із протеїном [10, с. 112].

Застосування діагностики під час молекулярної патології в основному базується на використанні комерційних наборів, оскільки вони можуть підвищити відтворюваність, зменшивши також мінливість препаратів реагентів [9, с. 9]. У такому контексті використання комерційного набору $є$ якоюсь мірою гармонізацією під час підготовки зразків, а не вдосконаленням або стандартизацією процедур вилучення ДНК. Немає доказів того, що комерційні набори підвищують кількість та/або якість вилученої ДНК. Останні звіти показали, що використання внутрішніх методів, заснованих на екстракції фенолом/хлороформом, може забезпечити екстрагування більшої кількості ДНК, але не обов'язково вищу ампліфікованість [12, с. 48].

3 боку ампліфікованості ПЛР різні методи екстракції ДНК досить схожі між собою. Якщо довжина амплікона обмежена приблизно 200 bp, ефективність різних методів вилучення ДНК буде досить схожою [15, с. 262]. Відомо, що рівень деградації ДНК у ЗФЗП залежить також від інших факторів, таких, як склад тканини, умови префіксації, а також час фіксації та період зберігання [15, с. 264].

У лабораторній практиці широко використовуються такі комерційні засоби: QIAmp ${ }^{\circledR}$ DNA FFPE (Qiagen, Valnecia, Каліфорнія, США), AmbionRecoverAll ${ }^{\circledR}$ (Ambion, TX, CШA), Wax Free ${ }^{\circledR}$ TrimGenDNA, NucliSenseEasyMAG $^{\circledR}$ (Biomerieux, NC, CШA) або GentraDNA (Qiagen, Каліфорнія, США). Вибір конкретних продуктів також залежить від напрямку подальшого дослідження отриманого екстракту з ДНК. Нещодавно опубліковані повідомлення про можливість спільної екстракції ДНК i РНК [20, с. 497], а також про інноваційний і швидкий 
метод отримання ДНК із ЗФЗП методом на основі готування під тиском [12, с. 50].

Враховуючи всі вищезазначені дані, серед вчених немає загальної думки щодо переваги одного набору або одного конкретного методу, оскільки більшість із них працює добре. Тканини ЗФЗП неоднорідні за обробкою та типом тканини, і навіть невелике коригування в інструкціях до комплекту може показати відмінності в продуктивності $[8$, с. 106].

Екстракція нуклеїнової кислоти із ЗФЗП є технічно вимогливою та лабораторно інтенсивною процедурою. Підготовка зразків вручну вимагає багато практичного часу, і на неї впливають особливості роботи оператора, що може спричинити менш відтворювані й надійні результати [23, с. 6385]. Оскільки кількість молекулярних аналізів збільшується в зразках ЗФЗП під час проведення молекулярно-генетичних досліджень, автоматизація може стати складним завданням для підвищення ефективності й стандартизації.

Існують різні рівні автоматизації молекулярних досліджень: від методів вилучення, що потребують значної кількості ручних маніпуляцій, до майже повністю автоматизованих методологій. Найважливішими процедурами в процесі автоматизації є мікродисекція, видалення парафіну зі зразків і стандартизація умов лізису, які враховують різні умови, що виникали під час фіксації та в процесі зшивання, а також коливання розміру зразка тканини та його неоднорідний морфологічний склад [18, с. 322]. Після лізису протягом ночі оператори зазвичай можуть проводити візуальний огляд для встановлення необхідності подальшої інкубації зі свіжою протеїназою К. Цю процедуру за участю оператора досить важко перевести в автоматизований режим.

Натепер комерціалізовано кілька напівавтоматів. Дослідники оцінювали два автоматизовані екстрактори й порівнювали їхню продуктивність із ручним екстрагуванням, використовуючи різні мішені нуклеїнової кислоти, отримані з різних типів зразків, які зазвичай зустрічаються в педіатричній лабораторії мікробіології. Потім вони порівнювали як вартість, так і продуктивність аналізованих напівавтоматів [17, с. 706$]$. Встановлено, що значних відмінностей не знайдено.

Інші автори випробували напівавтоматичне отримання нуклеїнових кислот зі зразків ЗФЗП [11, с. Е376] і продемонстрували, що для такого типу тканини можна застосовувати роботизовані процедури. Водночас у деяких випадках кількість нуклеїнової кислоти під час проведення ручного вилучення нуклеїнових кислот була вище ніж у напівавтоматизованій процедурі. Однак результати були порівняні за якістю ДНК [23, с. 6384].

Єдиною повністю автоматизованою системою вилучення ДНК і РНК є інструмент Siemens (Siemens Enterprise Communications GmbH\&Co, KG, Мюнхен, Німеччина), який виділяє загальні нуклеїнові кислоти з тканин ЗФЗП за допомогою пластин заліза оксиду, які покриті наношаром кремнезему 3 модифікованою молекулярною системою VERSANT kPCR. Цей автомат також оснащений модулем нагрівача/шейкера й носіями зразків. Вищезазначена конфігурація дозволяє здійснювати повну автоматизацію, включаючи видалення парафіну, оскільки він плавиться під час вилучення [23, с. 6383].

Після першого звіту про цю автоматизовану систему для вилучення нуклеїнових кислот були проведені інші дослідження 3 метою вивчення можливості екстрагування обох нуклеїнових кислот з однієї ділянки або тканинних ядер у поєднанні із соматичним мутаційним аналізом KRAS і BRAF, і найскладнішим виявилося рутинне тестування мутації KRAS без попередньої мікродисекції [7, с. 14]. Вчені визнають, що кількість опублікованих даних щодо автоматизації вилучення в тканини ЗФЗП досить мало. Однак, можливість використання напів- або повністю автоматизованих процедур у молекулярному аналізі тканини ЗФЗП є важливим кроком для молекулярних лабораторій, що проводять велику кількість досліджень.

Як відомо, кількість та якість є незалежними параметрами під час вилучення нуклеїнових кислот із ЗФЗП $[3$, c. 766]. Щодо екстрактів ДНК, то це очевидно для сирих екстрактів, які не піддаються очищенню ні екстракцією фенолу, ні фільтруванням кремнеземом. У цих випадках кількість ДНК завищена й наявність інгібіторів ПЛР може впливати на якість проведення ПЛР [18, с. 322]. У таких випадках вимірювання спектрофотометра точне лише для співвідношення А260:А280, що $є$ показником чистоти екстрактів. Однак навіть після етапів очищення екстракти ДНК можуть містити інгібітори ПЛР, які також можна було б ідентифікувати як невеликі фрагменти копрофільованих нуклеїнових кислот [19, с. 19]. Якщо ПЛР не вдається провести, специфічне виявлення інгібіторів може бути корисним.

Інгібування особливо проблематично $з$ деградованими матрицями ДНК або в разі наявності низької кількості матриць, неможливості розведення екстракту [21, с. 418]. В таких випадках моніторинг гальмування може здійснюватися за допомогою ПЛР у реальному часі або кількісного застосування з використанням внутрішнього позитивного контролю. Повторне тестування гальмування дозволяє оптимізувати комбінації фасилітаторів ПЛР і розведення зразків таким чином, щоб кількість вилученої ДНК та/ або кількісна точність були максимальними в наступних циклах ПЛР [13, с. 30].

Як правило, розподіл за розміром ДНК, отриманої із ЗФЗП, є адекватним предиктором для успішності більшості тестів. Проте деякі вчені повідомляють про відсутність збіжності під час порівняння результатів дослідження геномних гібридизаційних структур. Водночас під час дослідження максимальної довжини кислот отримано подібні результати.

Під час проведення аналізу на встановлення клональних властивостей у результаті фіксації та обробки тканин ДНК фрагментується, тому клональні мішені не можуть бути ефективно ампліфіковані через можливість отримання потенційно хибнонегативних результатів. Це зумовлює те, що тестування на клональність не рекомендується у випадках із сильно фрагментованою ДНК (ампліфікація лише 100-nt продукту контрольного гена ПЛР BIOMED-2) [6, с. 590]. Аналогічні висновки можна зробити для більшості аналізів на основі ПЛР. Тому використання можливої комплементарної ПЛР для визначення максимальної довжини продукту ампліфікації може бути кроком до стандартизації аналізів.

Таким чином, натепер застосування молекулярних тестів на ДНК-екстрактах із ЗФЗП стало досить частим, по-перше, тому, що ДНК краще зберігається у ЗФЗП, а по-друге, тому, що більшість тестів якісні, а не кількісні. У найближчі кілька років застосування автоматизованих систем вилучення нуклеїнових кислот може стати досить популярним інструментом у судовій молекулярно-генетичній експертизі. Це може стати реальністю лише за умови отримання точної стандартизації на всіх етапах обробки тканин. Контроль і забезпечення якості є запорукою будь-якої експертизи, а молекулярні аналізи вимагають складніших і жорсткіших заходів для забезпечення надійних результатів. Ці вимоги потребують економічних та організаційних зусиль, що сильно залежать від надання фінансової підтримки з боку держави. Незважаючи на всі труднощі, вважаємо, що можливість використання складніших молекулярних тестів під час проведення молекулярногенетичних досліджень дозволить спростити роботу працівників правоохоронних органів у разі проведення оперативно-слідчих дій. 


\section{ЛITEPATYPA}

1. Федин И.В., Чикун В.И., Горбунов Н.С. Проблема идентификации человека. Вестник судебной медицины. 2017. Т. 6. № 4. С. 40-43.

2. Alvarez-Aldana A., Martinez J.W., Sepulveda-Arias J.C. Comparison of five protocols to extract DNA from paraffin-embedded tissues for the detection of human papillomavirus. Pathol. Res. Pract. 2015. Vol. 211. P. 150-155.

3. de Abreu F.B., Peterson J.D., Amos C.I. Effective quality management practices in routine clinical next-sequencing. Clin. Chem. Lab. Med. 2016. Vol. 54. P. 761-771.

4. Einaga N., Yoshida A., Noda H. Assessment of the quality of DNA from various formalin-fixed paraffin embedded (FFPE) tissues and the use of this DNA for next generation sequencing (NGS) with no artifactual mutation. PLoS One. 2017. Vol. 12. P. 18-23.

5. Flury B.B., Weisser M., Prince S.S. Performances of two different panfungal PCRs to detect mould DNA in formalin fixed paraffinembedded tissue: What are the limiting factors? BMC Infect. Dis. 2014. Vol. 14. P. 692-698.

6. Funabashi K.S., Barcelos D., Visoná I. DNA extraction and molecular analysis of non-tumoral liver, spleen, and brain from autopsy samples: the effect of formalin fixation and paraffin embedding. Pathol. Res. Pract. 2012. Vol. 208 (10). P. 584-591.

7. Haile S., Pandoh P., McDonald H. Automated high throughput nucleic acid purification from formalin-fixed paraffin-embedded tissue samples for next generation sequence analysis. PLoS One. 2017. Vol. 12. P 12-22.

8. Hamblin A., Wordsworth S., Fermont J.M. Clinical applicability and cost of a 46-gene panel for genomic analysis of solid tumours: Retrospective validation and prospective audit in the UK National Health Service. PLoS Med. 2017. Vol. 14. P. 102-111.

9. Janecka A., Adamczyk A., Gasinska A. Comparison of eight commercially available kits for DNA extraction from formalin fixed paraffinembedded tissues. Anal. Biochem. 2015. Vol. 476. P. 8-10.

10. Kapp J.R., Diss T., Spicer J. Variation in pre-PCR processing of FFPE samples leads to discrepancies in BRAF and EGFR mutation detection: A diagnostic RING trial. J. Clin. Pathol. 2015. Vol. 68. P. 111-118.

11. Kikuchi A., Sawamura T., Daimaru O. Improved protocol for extraction of genomic DNA from formalin fixed paraffin-embedded tissue samples without the use of xylene. Clin. Chem. Lab. Med. 2016. Vol. 54. P. E375-E377.

12. Kocjan B.J., Hosnjak L., Poljak M. Commercially available kits for manual and automatic extraction of nucleic acids from formalin-fixed, paraffin-embedded (FFPE) tissues. Acta Dermatovenerol. Alp. Pannonica Adriat. 2015. Vol. 24. P. 47-53.

13. Mathieson W., Marcon N., Antunes L. A critical evaluation of the PAX gene tissue fixation system: Morphology, immunohistochemistry, molecular biology, and proteomics. Am. J. Clin. Pathol. 2016. Vol. 146. P 25-40.

14. Milcheva R., Janega P., Celec P., Russev R., Babál P. Alcohol based fixatives provide excellent tissue morphology, protein immunoreactivity and RNA integrity in paraffin embedded tissue specimens. Acta Histochem. 2012. Vol. 115(3). P. 279-289.

15. Nietner T., Jarutat T., Mertens A. Systematic comparison of tissue fixation with alternative fixatives to conventional tissue fixation with buffered formalin in a xenograft-based model. Virchows. Arch. 2012. Vol. 461 (3). P. 259-269.

16. Oktay M.H., Hui P. Molecular pathology as the driving force for personalized oncology. Expert Rev. Mol. Diagn. 2012. Vol. 12 (8). P. $811-813$.

17. Sam S.S., Lebel K.A., Bissaillon C.L., Tafe L.J., Tsongalis G.J., Lefferts J.A. Automation of genomic DNA isolation from formalin-fixed, paraffin-embedded tissues. Pathol. Res. Pract. 2012. Vol. 208 (12). P. 705-707.

18. Sanchez I., Remm M., Frasquilho S. How severely is DNA quantification hampered by RNA co-extraction? Biopreserv. Biobank. 2015. Vol. 13. P. 320-324.

19. Seiler C., Sharpe A., Barrett J.C. Nucleic acid extraction from formalin-fixed paraffin-embedded cancer cell line samples: A trade off between quantity and quality? BMC Clin. Pathol. 2016. Vol. 16. P. 17-22.

20. Senguven B., Baris E., Oygur T. Comparison of methods for the extraction of DNA from formalin-fixed, paraffin embedded archival tissues. Int. J. Med. Sci. 2014. Vol. 11. P. 494-499.

21. Serizawa M., Yokota T., Hosokawa A. The efficacy of uracil DNA glycosylase pretreatment in amplicon-based massively parallel sequencing with DNA extracted from archived formalin-fixed paraffin-embedded esophageal cancer tissues. Cancer Genet. 2015. Vol. 208. P. 415-427.

22. Viertler C., Groelz D., Gündisch S. A new technology for stabilization of biomolecules in tissues for combined histological and molecular analyses. J. Mol. Diagn. 2012. Vol. 14 (5). P. 458-466.

23. Wallinger C., Staudacher K., Sint D. Evaluation of an automated protocol for efficient and reliable DNA extraction of dietary samples. Ecol. Evol. 2017. Vol. 7. P. 6382-6389. 


\title{
ЗАРУБІЖНИЙ ДОСВІД ОПЕРАТИВНО-РОЗШУКОВОЇ ДІЯЛЬНОСТІ МИТНИХ ОРГАНІВ: УРОКИ ДЛЯ УКРАЇНИ
}

\section{FOREIGN EXPERIENCE OF OPERATIONAL AND INVESTIGATIVE ACTIVITIES OF CUSTOMS AUTHORITIES}

\author{
Молдован Е.С., к.держ.упр., \\ старший науковий співробітник відділу удосконалення \\ протидії митним правопорушенням \\ Науково-дослідного центру митної справи \\ Науково-дослідний інститут фіскальної політики \\ Університету державної фіскальної служби Украӥни \\ Жданова В.П., молодший науковий співробітник відділу удосконалення \\ протидії митним правопорушенням \\ Науково-дослідного центру митної справи \\ Науково-дослідний інститут фіскальної політики \\ Університету державної фіскальної служби Украӥни
}

Стаття присвячена викладенню зарубіжного досвіду оперативно-розшукової діяльності митних органів. Досліджено й проаналізовано реалізацію оперативно-розшукових повноважень митними органами таких країн, як Федеративна Республіка Німеччина, Республіка Польща, США, Канада й Республіка Білорусь. За результатами аналізу сформульовано найхарактерніші особливості здійснення оперативно-розшукової діяльності митними органами кожної з названих вище країн. Встановлено, що у Федеративній Республіці Німеччина оперативно-розшукова діяльність митних органів $є$ чітко регламентованою законодавством і здійснюється окремими структурними підрозділами, які наділені повним спектром відповідних повноважень. Характерними рисами реалізації оперативно-розшукових повноважень митними органами Республіки Польща є інтегрованість і сепаратність, цілковита кореляція з правовими нормами Європейського Союзу й охоплення усієї митної логістики. Оперативно-розшукові повноваження відповідні підрозділи Митної служби США здійснюють як одноосібно, так і у міжвідомчій і міжнародній співпраці, охоплюючи широкий спектр легальних оперативно-розшукових дій. Канадський досвід реалізації оперативно-розшукових повноважень митними органами характеризується комплексністю, що спрощує процесуальну складову частину діяльності й роботу з інформацією та підвищує ефективність захисту державних кордонів. Митні органи Республіки Білорусь наділені досить широким, але типовим і валентним законодавству Євразійського економічного союзу й законодавству європейських країн колом оперативно-розшукових повноважень. Однак білоруське законодавство позиціює оперативно-розшукову діяльність як право митних органів, що означає свободу вибору їхніх посадових осіб. Наголошено, що зображений у статті зарубіжний досвід оперативно-розшукової діяльності митних органів, мабуть, повинен стати для України орієнтиром у разі подальших трансформацій у сфері запобігання та протидії митним правопорушенням.

Ключові слова: митні органи, оперативно-розшукова діяльність, оперативно-розшукова діяльність митних органів, Федеративна Республіка Німеччина, Республіка Польща, США, Канада, Республіка Білорусь.

The paper is dedicated to issues on foreign experience of operative and investigative activities of Customs Authorities. Implementing of operative and search powers by Customs Authorities of such states as the Federal Republic of Germany, the Republic of Poland, the United States, Canada and the Republic of Belarus is researched and analyzed. The most characteristic features of implementation of operative and search activities of Customs Authorities of each of states mentioned above are formulated on the basis of the analysis. There is indicated, that the operative and search activities of Customs Authorities of the Federal Republic of Germany is clearly regulated by law and is carried out by separate structural units endowed with a full range of relevant powers. Characteristic features of the implementation of operational and investigative powers by the Customs Authorities of the Republic of Poland are integration and separation, full correlation with EU legal norms and coverage of all Customs logistics. Relevant units of the US Customs Service exercise operational and investigative powers both individually and in interagency and international cooperation, covering a wide range of legal operational and investigative actions. The Canadian experience in the implementation of operational and investigative powers by Customs Authorities is characterized by complexity, which simplifies the procedural component of activities, information processing and increases the effectiveness of protection of state borders. The Customs Authorities of the Republic of Belarus are endowed with a fairly broad, but typical and valence legislation of the Eurasian Economic Union and the legislation of European states with a range of operational and investigative powers. However, Belarusian law positions operational and investigative activities as the right of Customs Authorities, which means the freedom of choice of their officials. There is emphasized that the foreign experience of operative and investigative activity of Customs Authorities reflected in the paper can and should become a reference point for Ukraine in further transformations in the field of prevention and counteraction to Customs offenses.

Key words: Customs Authorities, operative and investigative activities, operative and investigative activities of Customs Authorities, Federal Republic of Germany, Republic of Poland, United States, Canada, Republic of Belarus.

Постановка проблеми. У сучасних умовах зростання транскордонних потоків товарів особливої актуальності набуває захист національних економічних інтересів, а тому виникає потреба в удосконаленні, а подекуди й розширенні, повноважень митних органів (далі - МО) щодо боротьби з контрабандою та незаконним переміщенням товарів через митний кордон країн. Для України питання валідності повноважень МО сучасним реаліям злочинності на митному кордоні постає особливо гостро, оскільки «врізані» в частині оперативно-розшукових функцій їхні повноваження створюють чималі перешкоди не лише для здійснення каральних заходів, але й превентивних. Водночас і в більшості розвинутих країн світу, й у частині країн постсоціалістичного простору МО наділені оперативно-розшуковими повноваженнями, що забезпечує їм можливість у рази скоротити відсоток злочинів і правопорушень на митному кордоні. Отже, виникає необхідність дослідження зарубіжного досвіду функціонування МО, уповноважених на застосування заходів оперативно-розшукової діяльності (далі - ОРД) у системі активностей протидії контрабанді й незаконному переміщенню товарів через митний кордон.

Аналіз останніх досліджень. Питання реалізації оперативно-розшукових функцій досліджували в різних контекстах вітчизняні науковці. Наприклад, К.В. Антонов і В.В. Варава зосередили свою увагу на викладенні 
сучасного стану, проблем, причин, тенденцій необхідності збільшення повноважень МО в наданні їм права здійснювати ОРД [1]. До висновку про необхідність повернення МО України повноважень щодо здійснення ОРД доходить і О.О. Разумова [2]. Доводить доцільність та обгрунтованість офіційного визнання МО правоохоронними Л.М. Дорофєєва [3]. А. Г. Уліцький сформував обгрунтовані пропозиції щодо удосконалення правоохоронної діяльності [4].

Мета статті - дослідити зарубіжний досвід ОРД МО задля формування шляхів удосконалення вітчизняної практики в такій сфері.

Виклад основного матеріалу. 3 урахуванням проєвропейського вибору України, вважаємо за доцільне дослідити насамперед досвід країн-членів Європейського Союзу (далі - СС). На союзному рівні право МО організовувати й реалізувати ОРД регулюється Митним кодексом ЄС. Зокрема, в ньому визначено, що МО країн-членів можуть здійснювати ОРД, пов'язану з отриманням, нагромадженням, обробкою та перевіркою інформації щодо зовнішньоторговельного товарообігу; можливістю секретного спостереження; використанням допомоги осіб, не залучених у митній службі, а також правом на застосування засобів безпосереднього примусу у формі застосування фізичної сили й індивідуальних технічних і хімічних засобів або засобів, призначених для обеззброєння та конвоювання осіб [5].

Серед країн-членів СС заледве не еталонним у сенсі здійснення МО оперативно-розшукових повноважень можна вважати досвід Федеративної Республіки Німеччина (далі - ФРН). Основним законодавчим актом, котрим регулюють суспільно-правові відносини в досліджуваній сфері у ФРН, є Закон про Управління митної кримінальної поліції та органи митного розслідування від 16 серпня 2002 р., відоміший як Закон про Службу митного розслідування $(\mathrm{ZFdG})$ (далі - Закон ZFdG) [6]

Відповідно до § 1 цього Закону, Служба митного розслідування складається з Управління митної кримінальної поліції та Генерального управління митних розслідувань, у підпорядкуванні якого знаходяться оперативно-розшукові митниці [6]. Управління митної кримінальної поліції $€$ центральним органом Служби митного розслідування та водночас одним із Центральних управлінь інформаційно-комунікаційної системи митної адміністрації. Посадові особи цього структурного підрозділу Служби митного розслідування наділені повноваженнями слідчих органів і є слідчими Прокуратури ( $(16)$. Усі завдання, на виконання яких спрямована діяльність Управління митної кримінальної поліції, можна об'єднати в три групи:

1) завдання центрального органу влади;

2) власні завдання;

3) завдання у сфері безпеки й захисту.

Для виконання завдань першої групи Управління митної кримінальної поліції наділене рядом повноважень, пов'язаних здебільшого зі збором, обробкою та управлінням інформацією та персональними даними $(\S 7, \S 8, \S 10$, $\S 11, \S 23 \mathrm{~d}$ Закону ZFdG) [6].

Для виконання групи власних завдань Управління митної кримінальної поліції уповноважене на внутрішньовідомчу нормотворчість, збір та обробку персональних даних у визначених випадках, здійснення превентивного телекомунікаційного й поштового нагляду в разі підозр на переміщення (пересилання) певних видів товарів $(\S 6, \S 9, \S 15)[6]$.

Виконання третьої групи завдань - завдань у сфері безпеки й захисту - передбачає набір повноважень, пов'язаних з обробкою персональних даних у кримінальному провадженні, збором даних різними способами, характерними для ОРД, використанням спеціальних технічних засобів у процесі ОРД, агентурною роботою, захистом свідків (§§ 17-22, § $22 \mathrm{a}, \S 23)[6]$.
Перелік як загальних, так і спеціальних завдань, що покладаються на органи митного розслідування ФРН, за змістом співзвучні із завданнями Управління митної кримінальної поліції. Зрештою, як свідчить аналіз $\S \S 26-36$, повноваження, якими наділені органи митного розслідування для виконання вищезазначених завдань, практично повністю корелюються 3 повноваженнями Управління митної кримінальної поліції. До повноважень органів митного розслідування, які не зазначені в Главах 1-2 Закону ZFdG, належать, наприклад, обробка (знеособлення) та передавання персональних даних для наукових досліджень (§ 37) або стягнення штрафу в розмірі до двадцяти тисяч євро за вчинене адміністративне правопорушення (§ 46) [6].

Особливий інтерес у контексті дослідження становить досвід реалізації оперативно-розшукових повноважень МО Республіки Польща. Митна Служба Республіки Польща (Służba Celna Rzeczypospolitej Polskiej) в системі органів державної влади виконує ролі контролера міжнародної торгівлі, фіскала, до повноважень котрого входить нарахування та стягнення податку на додану вартість та акцизу, а також головного бория 3 контрабандою та митним шахрайством.

Найменшим за обсягом є блок фіскальних функцій Митної Служби Республіки Польща, а найоб'ємнішим - захисних. Водночас необхідно наголосити на мультиоб'єктності останніх: з їхнього змісту випливає, що під час реалізації такого функціоналу Митна Служба Республіки Польща спрямовує свою діяльність на захист і державних інтересів, і суспільних, і довкілля, і індивідуальних. Вочевидь, такий значний обсяг захисних функцій потребує застосування потужного інструментарію, одним 3 елементів якого виступає ОРД МО. Завдяки оперативно-розшуковим повноваженням МО Республіки Польща мають можливість запобігати й протидіяти злочинам і правопорушенням, предметом яких є ввезення на територію Республіки Польща та вивезення з іiі території товарів, що можуть загрожувати національній безпеці й завдати шкоди громадському здоров'ю [7]. Митна Служба має процесуальні права поліції за потреби запобігання та протидії правопорушенням і злочинам, що створюють загрозу здоров'ю громадян (ст. 2). У разі, якщо Митна Служба Республіки Польща розкриває такі злочини, то до іiі повноважень також входить притягнення до кримінальної відповідальності осіб, винних у вчиненні злочинів (пп. f п. 6 ст. 2) [7].

Необхідно зазначити, що оперативно-розшукові повноваження Митної служби Республіки Польща трансформуються в практичні дії посадовими особами відповідних структурних одиниць. Наприклад, одним із завдань директора Митної палати є виявлення, запобігання та боротьба 3 фіскальними правопорушеннями й злочинами й притягнення до кримінальної відповідальності осіб, що їх вчинили, в межах, визначених Фіскальним кримінальним кодексом Республіки Польща (п. 1 ст. 19), а керівник Митної Служби покликаний до аналогічних активностей у податковій сфері (п. 1 ст. 20) [7]. Коло повноважень посадових осіб Митної служби Республіки Польща, які здійснюють митний контроль, також охоплює право здійснювати обшук приміщень із використанням технічних пристроїв і службових собак, опитувати свідків, здійснювати в обгрунтованих випадках слідчий експеримент, збирати докази, здійснювати відео-, аудіо- й фотофіксацію, а також вести пряме переслідування підозрюваного (п. 1, п. 4 ст. 32). Посадові особи так званих «плавучих одиниць» Митної Служби також мають право здійснювати переслідування суден на воді й зупиняти їх у разі виникнення підозри у вчиненні злочину членами екіпажу або пасажирами (ст. 47) [7].

Значний обсяг оперативно-розшукових повноважень реалізується Митною Службою в співпраці з поліцією, Прикордонною службою, Національним центром кримі- 
нальної інформації (п. 11 ст. 2), податковими органами, митними й слідчими службами інших країн і міжнародними організаціями (п. 12 ст. 2) [7], комерційними організаціями, науково-дослідними й науковими інститутами, університетами тощо [8]. Посадові особи Митної служби Республіки Польща в співпраці з поліцією, Прикордонною службою, повітряними службами й Службою охорони залізничного транспорту також мають право здійснювати зупинку транспортних засобів, що перебувають у русі, за умови, що вони (митні офіцери) екіпіровані в уніформу й пересуваються на службовому маркованому авто (п. 2, п. 3 ст. 46) [7]. Переслідування судна судном «плавучої одиниці» може здійснюватися як самостійно відповідним підрозділом Митної служби, так і спільно 3 аналогічним підрозділом Прикордонної служби Республіки Польща (ст. 47) [7].

Окрім досвіду європейських країн, на наше переконання, необхідно проаналізувати й досвід Сполучених Штатів Америки (далі - США). Хоча основним завданням Митної служби США є захист кордонів і забезпечення дотримання законів під час ввезення товарів до США й вивезенні їх за межі країни, МО США наділені широким спектром додаткових завдань: забезпечувати дотримання митного законодавства, контролювати стягнення мит, здійснювати контроль за виконанням всіх федеральних законів на лінії митного кордону США, вести боротьбу 3 кіберзлочинністю та злочинами, вчиненими через інші електронні засоби [9].

Митна служба США як головний державний орган, що має право на затримання злочинців на кордоні, працює над розв'язанням проблеми в таких напрямках: розвідувальному, оперативному, дослідному. Нині Митна служба США $є$ єдиним державним органом, офіцери якого вповноважені здійснювати огляд людей, вантажів i транспортних засобів, що перетинають американські кордони, без ордера на обшук (огляд). Крім цього, співробітники Митної служби США використовують у своїй діяльності спеціальні комп'ютерні системи для розпізнавання певних невідповідностей під час переміщення вантажу й перевезення пасажирів через міжнародний кордон. У випадках виявлення співробітниками Митної служби США порушень митного законодавства, вони мають право проводити розслідування за цим фактом, а також накладати арешт на товари, що підлягають вивезенню за межі країни. Крім цього, МО США мають право конфісковувати без судового ордера будь-які товари, які планувалось нелегально вивезти 3 країни, а також транспортні засоби, які передбачалося використовувати для цих цілей. Подібних широких повноважень у сфері контролю над експортом у США, крім Митної служби, більше не має жодне інше федеральне правоохоронне відомство.

Зазначимо, що в разі виявлення Митною службою США інших правопорушень поза митною сферою, подальше розслідування, як правило, здійснюється митницею спільно з іншим слідчим органом [10]. У разі провезення наркотиків контрабандним шляхом, МО США здійснюють необхідні оперативні заходи, а під час розслідування порушень митного законодавства - типові заходи, що застосовуються правоохоронними органами.

Найпоширенішим і найдієвішим у практиці МО США $\epsilon$ спосіб отримання інформації від громадян шляхом повідомлення на анонімний номер «гарячої лінії» та за адекватну премію, розмір якої залежить від вартості захопленої контрабанди [9]. Іноді агенти Митної служби США виступають у ролі «покупців» або «продавців» контрабандного товару. Найважливішою процедурою в США, яка допомагає в розслідуванні й кримінальному переслідуванні (доказуванні) стосовно порушень митного законодавства, $\epsilon$ використання різних підроблених супровідних адміністративних документів, що посвідчують пасажирів та ідентифікують товари, які ввозяться або вивозяться ними. Ефективним превентивним заходом вважається широке використання помітних, розбірливих і зрозумілих інформаційних повідомлень щодо незаконності певних видів діяльності.

Варто зауважити, що такий структурний підрозділ Митної служби США, як Правоохоронна служба, також співпрацює з поліцейськими підрозділами Федерального бюро розслідувань США в питаннях здійснення стратегічної (отримання, накопичення, систематизація та аналіз відомостей про осіб, підозрюваних у причетності до організованих кримінальних структур) і тактичної (встановлення джерел отримання доказів, які б дозволили провести арешт підозрюваного й довести його вину) поліцейської розвідки [9]. Правоохоронна служба, крім іншого, відповідає за управління правоохоронними програмами, провадження слідства, надання допомоги розвідувальним службам шляхом збирання, аналізу розвідувальної інформації, формує політику, плани й програми щодо боротьби 3 контрабандою та нелегальною торгівлею, виявлення митних і супутніх правопорушень.

Ще одним структурним підрозділом Митної служби США, уповноваженим на здійснення ОРД, є Служба інспекції та контролю. Ї̈ї повноваження охоплюють контроль за пасажирами й вантажем, що прибувають до США, транспортними засобами, що перетинають кордони США, експортними товаропотоками, а також розробку й реалізацію програм розвитку за названими вище пунктами. У справі розвитку й управління правоохоронними програмами Служба інспекції та контролю тісно співпрацює 3 Правоохоронною службою. Зазначена служба встановлює нормативи для захисту вантажів, ефективності обладнання, визначає порт увезення, координує питання регіональних штрафів, покарань і конфіскації. Служба також бере участь у розвитку зв'язків між правоохоронними й фінансовими органами, в процедурах інспекції та навчання, проводить експертизу, надає підтримку іншим міністерствам і службам, а також таким міжнародним структурам, як Всесвітня митна організація, Міждержавна консультативна організація та Міжнародна організація цивільної авіації.

Зауважимо, що в питаннях протидії контрабанді Митна служба США співпрацює з підрозділами Прикордонного патруля США. Для виконання спільних завдань Митної служби США й Прикордонної служби США було розроблено Стратегічний план прикордонного патрулювання на 2020 рік, яким передбачається розміщення спільних патрулів там, де вони можуть найефективніше протидіяти правопорушникам і контрабандистам з урахуванням часового й просторового факторів незаконної діяльності [11].

Однією $з$ найуспішніших у сенсі реалізації оперативно-розшукових повноважень у митній сфері є Канада. Митна служба Канади, як і Прикордонна служба Канади, $\epsilon$ складовою частиною Агентства прикордонних служб Канади (далі - Агентство) - основного органу державної влади, що забезпечує прикордонну безпеку федеративної держави шляхом організації та проведення ефективного контролю по всій лінії кордону Канади [12]. Правове становище Агентства закріплено в Біллі К26, де визначені його повноваження: контрольні, нормотворчі, ідентифікація потенційно небезпечних осіб, проведення оперативних заходів із перевірки осіб, що в'іжджають у Канаду, а також спільна робота 3 правоохоронними органами з передачі даних про осіб, підозрюваних у вчиненні злочинів; проведення слідчих дій стосовно осіб, які незаконно знаходяться в країні, їхній арешт і випровадження; проведення відповідних перевірок і розслідувань щодо демпінгу й субсидій; боротьба 3 «відмиванням грошей» [13], тобто оперативно-розшукові повноваження. Нині Митна служба Канади свою місію виконує шляхом реалізації низки повноважень, визначених Митним Актом [14], які можна об'єднати в декілька груп: контрольні, фіскальні, 
технологічно-креативні, фасилітативні, захисні й оперативно-розшукові. Зважаючи на контекст нашого дослідження, акцентуємо увагу на оперативно-розшукових повноваженнях.

Оперативно-розшукові повноваження Митної служби Канади охоплюють певну частину повноважень, спільних для обох складників Агентства прикордонних служб Канади: проведення кримінального розслідування слідчими Агентства за підозрою в ухиленні від дотримання законів у сфері охорони й захисту кордону; збір та опрацювання інформації щодо підозр і фактичних випадків митного, міграційного або іншого виду шахрайства від громадян у підрозділ кримінального розслідування; здійснення внутрішньодержавної та міжнародної співпраці з питань стратегічної розвідки, реалізації концепції «інтелектуального кордону» [15], обміну даними щодо митного шахрайства, вивчення правових та оперативних питань, пов'язаних зі створенням міжнародних зон і спільних об'єктів та озброєння співробітників правоохоронних органів у таких зонах та об'єктах [13].

Окрім досвіду країн-членів СС та інших розвинутих країн світу, цікавим у контексті нашого дослідження також $\epsilon$ досвід держав пострадянського простору. Зокрема, увагу привертає реалізація оперативно-розшукових повноважень МO Республіки Білорусь. Оскільки Білорусь є частиною Євразійського Митного Союзу (далі - САЕС), то основоположні норми, якими регулюють здійснення оперативно-розшукових повноважень МО, містяться в Митному кодексі Євразійського Митного Союзу від 11 квітня 2017 р. (далі - МК СAEC) [16]. Такий міжнародний нормативно-правовий акт визначає ОРД МО як складову частину їхньої правоохоронної діяльності й визначає в цьому сенсі правовий статус МО як органів дізнання та / або слідства в справах щодо злочинів або кримінальних правопорушень, провадження по якім належить до юрисдикції МО (ст. 354). У цій же статті МК САЕС зазначається, що «МО здійснюють ОРД із метою виявлення осіб, які готують, вчиняють чи вчинили протиправне діяння, що визнається відповідно до законодавства країн-членів злочином, виконання запитів міжнародних організацій, митних або інших компетентних органів держав, що не $\epsilon$ членами Союзу <...> ОРД здійснюється МО відповідно до законодавства країн-членів» [16]. Крім того, МК САЕС дає «мандат» країнам-членам на надання правової допомоги й взаємодію МО як всередині СAEC, так і за його межами в питаннях кримінальних справ і справ про адміністративні правопорушення відповідно до міжнародних угод і договорів (п. 5 ст. 354) [16]

Спираючись на положення МК САЕС, білоруський законодавець у Законі «Про митне регулювання в Республіці Білорусь» від 10 січня 2014 р. № 129-3 закріпив перелік функцій МО (ст. 12), серед яких функціями у сфері ОРД є: боротьба з контрабандою або іншими злочинами, провадження в справах, що належать до компетенції МO, адміністративними правопорушеннями, за якими ведення адміністративного процесу належить до компетенції МО; припинення незаконного переміщення через митний кордон САЕС або Республіки Білорусь наркотичних засобів, психотропних речовин, їхніх прекурсорів та аналогів, зброї, культурних цінностей, радіоактивних речовин, рідкісних або тих, що охороняються, тварин і рослин, а також сприяння боротьбі 3 міжнародним тероризмом i припинення в аеропортах Республіки Білорусь незаконного втручання в діяльність міжнародної цивільної авіації; здійснення співпраці з митними й іншими компетентними органами іноземних держав, міжнародними організаціями у сфері митної справи, в тому числі - 3 питань ОРД [17].

За статусом ОРД відповідно до законодавства Білорусі $€$ правом МО, яке реалізується $з$ метою попередження, виявлення та припинення злочинів, дізнання в справах, що належать до компетенції МО, виявлення та ідентифі- кації осіб, які готують ці злочини, вчиняють або уже вчинили їх, а також із метою забезпечення власної безпеки (ст. 13) [17]. У межах цього права МО Республіки Білорусь уповноважені на: здійснення дізнання в межах своєї компетенції в порядку, встановленому кримінально-процесуальним законодавством Республіки Білорусь; ведення адміністративного процесу в справах про адміністративні правопорушення та притягнення осіб до відповідальності за їх вчинення; безперешкодний вхід на територію та в приміщення юридичних осіб із метою здійснення митного контролю; використання у виняткових обставинах засобів зв'язку або транспортних засобів, що належать організаціям (окрім дипломатичних представництв, консульських установ, інших офіційних представництв іноземних держав і міжнародних організацій) задля запобігання злочинів, дізнання в справах, які належать до компетенції МО, переслідування та затримання осіб, що вчинили такі злочини, або підозрюваних у вчиненні таких злочинів; затримання осіб, що підозрювані у вчиненні злочинів, вчинили або вчиняють злочин чи адміністративне правопорушення, провадження в справах, які належать до повноважень МО; здійснення документування, відео- й аудіозапису, кіной фотозйомки фактів і подій, пов'язаних із переміщенням товарів через митний кордон САЕС у Республіці Білорусь; отримання інформації або матеріалів, необхідних для виконання обов'язків, покладених на МО Республіки Білорусь, а також отримання доступу до інформаційних систем і баз даних у встановленому законодавчо порядку (ст. 13); застосування посадовими особами фізичної сили, спеціальних засобів, зброї в разі очевидної загрози для життя особи або інших тяжких наслідків (ст. 24) або 3 метою примусової зупинки транспортного засобу, відбиття нападу на посадових осіб МО, споруди або транспортні засоби чи звільнення цих об'єктів у разі їхнього захоплення, затримання правопорушників і доправлення ï у службові приміщення МО чи органи внутрішніх справ (ст. 26), відбиття групового або озброєного нападу на споруди, транспортні засоби або інші об'єкти МО або в разі їхного захоплення, затримання особи, що вчиняє збройний опір (ст. 27); застосування окремими категоріями посадових осіб бойових прийомів рукопашного бою у випадках, коли ненасильницькі способи не можуть забезпечити виконання МО їхніх обов'язків: запобігання правопорушенням, затримання правопорушника, подолання протидії законним вимогам посадових осіб МО, отримання доступу до приміщень і транспортних засобів, що знаходяться під митним контролем (ст. 25); застосування службових собак із метою пошуку й виявлення наркотичних засобів, психотропних речовин, прекурсорів, вибухівки, зброї, боєприпасів та інших заборонених товарів, а також пошуку людини (ст. 28) [17].

Висновки та перспективи подальших досліджень. Таким чином, усе вищевикладене дає змогу визначити особливості реалізації МО аналізованих країн оперативно-розшукових повноважень. До таких особливостей у ФРН належать:

1) створення окремої структурної одиниці МО, уповноваженої на здійснення ОРД;

2) чітка законодавча регламентація завдань і повноважень спеціальних МО, уповноважених на здійснення ОРД;

3) повноцінний спектр оперативно-розшукових повноважень МО й оперативно-розшукового інструментарію.

Характерними рисами реалізації оперативно-розшукових повноважень МО Республіки Польща є:

1) інтегрованість (тобто, в «комплекті» 3 іншими повноваженнями) й сепаратність (окремим блоком спеціальними «цільовими» структурними підрозділами);

2) цілковита кореляція з правовими нормами $\mathrm{CC}$;

3) охоплення всієї митної логістики.

Реалізація оперативно-розшукових повноважень Митної служби США має такі типові характеристики: 
1) здійснення як одноосібно, так і в міжвідомчій і міжнародній співпраці;

2) виокремлення підрозділів, що здійснюють ОРД;

3) охоплення широкого спектра легальних оперативнорозшукових дій.

Щодо канадського досвіду реалізації оперативно-розшукових повноважень МО, наголосимо на такій характеристиці, як комплексність, яка:

1) дозволяє уникнути необхідності долати бюрократичні бар'єри в процесі міжвідомчої співпраці, а отже суттєво спрощує ії̈ процесуальну складову частину;

2) у рази підвищує ефективність превентивних і захисних заходів на кордоні, оскільки перебування в межах та юрисдикції одного державного органу дає можливість Митній службі Канади й Прикордонній службі Канади об’єднувати в разі необхідності потрібні ресурси або оптимізувати їхнє використання;

3) спрощує роботу з інформаційними потоками.

МО Республіки Білорусь наділені досить широким, але типовим і валентним законодавству САЕС і законодавству європейських країн колом оперативно-розшукових повноважень. Однак саме білоруське законодавство позиціює ОРД як право МO, що - під кутом теорії права - означає свободу вибору посадових осіб МО в процесі реалізації їхніх повноважень.

Зображений у статті зарубіжний досвід оперативнорозшукової діяльності митних органів може й повинен стати для України орієнтиром у разі подальшого формування завдань і повноважень вітчизняних митних органів.

\section{ЛITEPATУPA}

1. Антонов К.В., Варава В.В. Збільшення правоохоронних повноважень митних органів у контексті розвитку митного та оперативно-розшукового законодавства. Вісник Академії митної справи України. 2010. № 1 (4). URL: http://nbuv.gov.ua/j-pdf/vamsup 2010 $1 \% 284 \% 29 \_29$.pdf.

2. Разумова О.О. Забезпечення митної безпеки України з урахуванням зарубіжного досвіду. Підприємництво, господарство і право. 2019. № 5. С. 166-169.

3. Дорофєєва Л.М. Окремі аспекти реалізації захисної функції митних органів України. Науковий вісник публічного та приватного права. 2017. Вип. 2. С. 124-129.

4. Уліцький А.Г. Шляхи удосконалення правоохоронного напряму діяльності ДФС для ефективної протидії контрабанді та порушенням митних правил. Держава та регіони. Серія «Державне управління». 2018. № 2 (62). С. 90-95.

5. Про встановлення Митного кодексу Союзу : Регламент Європейського Парламенту і Ради (ЄС) від 9 жовтня 2013 року № 952/2013 / Європейський Парламент і Рада (ЄC). URL: https://zakon.rada.gov.ua/laws/show/ru/984_009-13/print.

6. Gesetz über das Zollkriminalamt und die Zollfahndungsämter (Zollfahndungsdienstgesetz - ZFdG). Ausfertigungsdatum: 16.08.2002. URL: https://www.gesetze-im-internet.de/zfdg/ZFdG.pdf.

7. Ustawa o Slużbie Celnej z dnia 27 sierpnia 2009 r. URL: https://www.ilo.org/dyn/natlex/natlex4.detail?p_isn=82768\&p_lang=en.

8. Roles and responsibilities. Customs Service of Republic of Poland. URL: http://mf-arch.mf.gov.pl/en/customs-service/customs-service/ roles-and-responsibilities.

9. Офіційний сайт митної служби Сполучених Штатів Америки. URL: www.usrteas.org/sustoms.

10. Бережнюк І.Г. Митне регулювання України: національні та міжнародні аспекти : монографрія. Дніпропетровськ : Академія митної служби України, 2009. 543 с.

11. U.S. Border Patrol Strategy of August 2019, No. 0928-0819. 2020. URL: https://www.cbp.gov/sites/default/files/assets/documents/2019Sep/2020-USBP-Strategy.pdf.

12. Canada Border Services Agency. URL: https://www.cbsa-asfc.gc.ca/menu-eng.html

13. Про Агентство прикордонних служб Канади : Закон від 11 березня 2005 року. URL: https://laws-lois.justice.gc.ca/eng/acts/c-1.4/ page-1.html

14. Customs Act (R.S.C., 1985, c. 1 (2nd Supp.)). URL: https://laws-lois.justice.gc.ca/eng/acts/c-52.6/FullText.html.

15. Декларация об интеллектуальной границе США и Канады от 12 декабря 2001 г. URL: https://www.legislationline.org/documents/ id/7543.

16. Таможенный кодекс Евразийского Таможенного Союза от 11 апреля 2017 г. URL: http://www.consultant.ru/document/cons_doc_LAW 215315/5d2860bd5c083e77fa4abc506b47f34ded5b01a6/.

17. О таможенном регулировании в Республике Беларусь : Закон Республики Беларусь от 10 января 2014 г. № 129-3. URL : http://www.pravo.by/document/?guid=3871\&p0=H11400129. 


\title{
ПОКАЗАННЯ ІЗ ЧУЖИХ СЛІВ ЯК ПРОЦЕСУАЛЬНЕ ДЖЕРЕЛО ДОКАЗІВ
}

\section{HEARSAY EVIDENCE AS A PROCEDURAL SOURCES OF EVIDENCE}

\author{
Омельчук Л.В., к.ю.н., доцент, \\ доцент кафедри кримінального процесу та криміналістики \\ Університет державної фіскальної служби Украӥни \\ Бичок Т.П., здобувач вищої освіти другого (магістерського) рівня \\ Навчально-науковий інститут права \\ Університету державної фіскальної служби Украӥни
}

У статті з'ясовано зміст поняття показань із чужих слів і запропоновано власне визначення цього поняття. Викладено погляди науковців щодо інституту показань із чужих слів. На підставі аналізу наукових праць установлено, що інститут показання із чужих слів $€$ досить суперечливим інститутом, оскільки в науці кримінального процесу не існує єдиної думки щодо доцільності його закріплення в Кримінальному процесуальному кодексі України й можливості існування в цілому.

Розглянуто умови допустимості показань із чужих слів як процесуального джерела доказів, що закріплені кримінальним процесуальним законодавством. Зазначено, що використання таких показань як доказів у кримінальному провадженні $є$ винятком із загального правила щодо особистого сприйняття фактів особою, яка дає показання.

Здійснено аналіз практики Європейського суду з прав людини й національних судів щодо використання показань із чужих слів як процесуального джерела доказів. Зазначено, що показання із чужих слів як доказ все-таки враховується такими судами під час прийняття рішення. Однак Європейський суд із прав людини неодноразово звертав увагу на те, що показання із чужих слів не можуть бути вирішальними і єдиними під час винесення судового рішення, а мають бути підтверджені іншими допустимими доказами. Щодо практики національних судів, то вона не єдина.

Викладено проблеми правого регулювання показань із чужих слів як процесуального джерела доказів. Звернено увагу на необхідність вдосконалення законодавчого регулювання показань із чужих слів, яке певною мірою нівелюватиме негатив, пов'язаний із порушенням засади безпосередності дослідження доказів, та яке дійсно сприятиме належному використанню таких показань і виконанню завдань кримінального провадження. Запропоновано шляхи вдосконалення недоліків кримінального процесуального законодавства України в такій сфрері.

Ключові слова: показання із чужих слів, умови допустимості, судова практика, проблеми правового регулювання.

The article clarifies the meaning of the concept of hearsay evidence and offers its own definition of this concept.

The views of scientists on the institute of hearsay evidence are highlighted. Based on the analysis of scientific works, it is established that the institution of hearsay evidence is a rather controversial institution, because in the science of criminal procedure there is no consensus on the feasibility of its enshrinement in the Criminal Procedure Code of Ukraine and the possibility of existence in general.

The conditions of admissibility of hearsay evidence as a procedural source of evidence, which are enshrined in the criminal procedure legislation, are highlighted. It is noted that the use of such testimony as evidence in criminal proceedings is an exception to the general rule of personal perception of the facts by the person giving the testimony.

An analysis of the case law of the European Court of Human Rights and national courts on the use of hearsay evidence as a procedural source of evidence. It is noted that hearsay evidence as evidence is still taken into account by these courts when making a decision. However, the European Court of Human Rights has repeatedly pointed out that hearsay evidence cannot be decisive and unique in reaching a court decision, but must be corroborated by other admissible evidence. As for the practice of national courts, it is not the only one.

The problems of legal regulation of hearsay evidence as a procedural source of evidence are highlighted. Attention is drawn to the need to improve the legal regulation of hearsay evidence, which to some extent will eliminate the negative associated with the violation of the principle of immediacy of evidence and which will really contribute to the proper use of such testimony and criminal proceedings. Ways to improve the shortcomings of the criminal procedure legislation of Ukraine in this area are proposed.

Key words: hearsay evidence, conditions of admissibility, court practice, problems of legal regulation

Постановка проблеми. Останнім часом кримінальне процесуальне законодавство України зазнало суттєвого реформування. Ця тенденція стосується і процесу доказування. Водночас одним із найпоширеніших джерел доказів у кримінальному судочинстві $є$ показання. 3 введенням у дію Кримінального процесуального кодексу України (далі - КПК України) одним із джерел доказів також визнаються показання із чужих слів. А отже, показання із чужих слів є відносно «новим» процесуальним джерелом доказів. Проте норми ст. 97 КПК України, які належать до показань із чужих слів, неоднозначні й такі, що потребують суттєвого аналізу. Це підтверджується насамперед відсутністю єдності судової практики щодо використання показань із чужих слів як процесуального джерела доказів. Крім того, залишається не досить розкритим питання щодо виокремлення умов допустимості показань із чужих слів і розкриття їх змісту.

Аналіз останніх досліджень і публікацій. Питаннями використання показань із чужих слів як процесуального джерела доказів у кримінальному провадженні займалися такі вчені: С.Ю. Задерейко, А.В. Панова, Н.В. Скідан, О.П. Острійчук, А.О. Ляш, Г.Р. Крет, В.В. Король,
Т.В. Садова, І.Л. Чернега, В.В. Вапнярчук та інші. Однак варто зазначити, що поки що в Україні відчувається недостатність монографій, присвячених дослідженню показань із чужих слів.

Метою статті $є$ дослідження інституту показань із чужих слів як процесуального джерела доказів, аналіз правового регулювання такого інституту й вироблення пропозицій щодо його вдосконалення.

Виклад основного матеріалу. Показання із чужих слів $\epsilon$ досить суперечливим інститутом кримінального провадження, оскільки донедавна українському кримінальному процесуальному праву він був невідомий. Він прийшов до нас із кримінального процесуального права США, в якому розроблено цілу теорію допустимості показань із чужих слів як доказів [1, с. 51].

Однак такий інститут був відомий ще за часів Київської Русі. Так, із погляду кримінального процесу «Руська Правда» виділяла два роди свідків: свідки, які знали фактичні обставини по справі («видоки», «послухи»); свідки з боку відповідача - «очістнікі» (тільки «послухи»). Водночас «видоки» - це свідки, які були очевидцями факту (які в сучасному кримінальному процесі розглядаються як 
свідки), а «послухи» - ті, хто щось чув про те, що стався факт, може дати показання із чужих слів. Послухами могли бути й ті, хто просто давав характеристику репутації особи.

I в наступні роки показання свідків як самостійний вид доказів (тобто, «відоцтво» - свідчення очевидців, i «послухство» - показання із чужих слів або показання, що характеризують позивачів чи відповідачів) згадувалися в інших джерелах права, що регламентували кримінально-процесуальну діяльність, у державах, які виникли після поділу Київської Русі (в Новгороді, Пскові, Володимирі, Москві й інших, а також у Великому князівстві Литовському) [2, с. 267].

Водночас п. 15 ч. 2 розділу 3 «Короткого викладу процесів або судових тяжб» (1715 р.), який регламентував статус свідків у кримінальному процесі Російської імпеpiï у XVIII ст., заборонялося надавати свідчення із чужих слів [2, с. 267].

Нині показання із чужих слів регулюються ст. 97 КПК України, відповідно до якої показаннями із чужих слів $\epsilon$ висловлювання, здійснене в усній, письмовій або іншій формі, щодо певного факту, яке грунтується на поясненні іншої особи [3].

Оскільки показання із чужих слів $є$ досить суперечливим інститутом кримінального провадження, в науці кримінального процесу можна виокремити декілька позицій щодо доцільності й можливості його існування.

Так, наприклад, О.П. Острійчук зазначає, що інститут показань із чужих слів може бути істотною перепоною для встановлення істини в справі, оскільки особа, яка даватиме показання із чужих слів, не може нести відповідальність за їх неправдивість. А використання чуток, якими за своєю суттю можуть бути показання із чужих слів, неприпустиме під час розслідування злочинів, оскільки обвинувачення повинно грунтуватися на доказах, достовірність яких можливо перевірити [4, с. 321]. А.О. Ляш взагалі вважає, що доцільно виключити ст. 97 із чинного Кримінального процесуального кодексу України [5, с. 135].

На противагу цій позиції, Г.Р. Крег вказує лише на необхідність уточнення окремих норм кримінального процесуального закону в частині врегулювання допустимості показань із чужих слів [6, с. 262].

В.В. Король і Т.В. Садова зазначають, що інститут показань із чужих слів $є$ надто суперечливим і потребує вдосконалення [7, с. 434]. Аналогічної думки дотримуються А.В. Панова й Н.В. Скідан [8, с. 200].

І.Л. Чернега підкреслює, що стаття, яка закріплює можливість використання показань із чужих слів як доказу, дуже спірна, оскільки суб'єктивність таких показань сумнівів майже не викликає. Зі статей Кримінального процесуального кодексу зрозуміло, що такі показання можуть використовуватися як докази, якщо неможливо допитати особу, яка давала первинні пояснення, у виняткових випадках, але це виглядає як остання соломинка, за яку повинна хапатися особа, яка відбирає пояснення чи проводить допит [9].

B.В. Вапнярчук вважає, що загалом регламентація цього інституту в кримінальному процесуальному законодавстві $\epsilon$ рішенням правильним. Аргументом на користь такого висновку, який, як вбачається, компенсує всі можливі його недоліки, є те, що саме показання із чужих слів інколи можуть бути найкращим із доступних доказів за неможливості отримати інформацію 3 першоджерела [10, с. 251].

Враховуючи таку зацікавленість науковців до інституту показань ііз чужих слів, варто зазначити, що не існує наразі наукового визначення поняття «показання із чужих слів». Тому вважаємо за необхідне навести власне визначення на підставі аналізу змісту поняття «показання».

Так, відповідно до ст. 95 КПК України, показання - це відомості, які надаються в усній або письмовій формі під час допиту підозрюваним, обвинуваченим, свідком, потерпілим, експертом щодо відомих їм обставин у кримінальному провадженні, що мають значення для цього кримінального провадження [3]. 3 боку науки кримінального процесу показання - це різновид процесуальних джерел доказів, що становлять відомості, надані в усній або письмовій формі визначеним КПК України колом суб'єктів щодо відомих їм обставин, що є предметом доказування в кримінальному провадженні.

Таким чином, узагальнюючи попередні визначення, пропонуємо під показаннями із чужих слів розуміти відомості, які надані в усній, письмовій або в іншій формі щодо певного факту, що грунтуються на поясненні іншої особи, мають значення для відповідного кримінального провадження та можуть бути визнані допустимим доказом у випадках, передбачених КПК України

Слід зазначити, що в КПК України законодавець окремо закріпив умови допустимості показань із чужих слів як джерела доказів у кримінальному провадженні. Це насамперед пов'язано з тим, що використання показань із чужих слів $\epsilon$ не загальним правилом, а винятком із нього. Відповідно до ч. 2 ст. 97 КПК України суд має право визнати допустимим доказом показання із чужих слів незалежно від можливості допитати особу, яка надала первинні пояснення, у виняткових випадках, якщо такі показання $є$ допустимим доказом згідно з іншими правилами допустимості доказів.

Під час прийняття цього рішення суд зобов'язаний враховувати:

1) значення пояснень і показань у випадку їх правдивості для з'ясування певної обставини та їх важливість для розуміння інших відомостей;

2) інші докази щодо питань, передбачених попереднім пунктом, які подавалися або можуть бути подані;

3) обставини надання первинних пояснень, які викликають довіру щодо їх достовірності;

4) переконливість відомостей щодо факту надання первинних пояснень;

5) складність спростування пояснень, показань із чужих слів для сторони, проти якої вони спрямовані;

6) співвідношення показань із чужих слів з інтересами особи, яка надала ці показання;

7) можливість допиту особи, яка надала первинні пояснення, або причини неможливості такого допиту [3].

Урахування вказаних положень кримінального процесуального законодавства в сукупності надає можливість суду дійти обгрунтованого висновку щодо визнання показань із чужих слів допустимими.

Водночас законодавець у ч. 3 ст. 97 КПК України закріпив чотири випадки, в яких первинні показання можуть бути замінені показаннями із чужих слів у зв'язку з тим, що суд визнає неможливість безпосереднього допиту особи в суді. Зокрема, суд має право визнати неможливим допит особи, якщо вона:

1) відсутня під час судового засідання внаслідок смерті або через тяжку фізичну чи психічну хворобу;

2) відмовляється давати показання в судовому засіданні, не підкоряючись вимозі суду дати показання;

3) не прибуває на виклик до суду, а їі місцезнаходження не було встановлено шляхом проведення необхідних заходів розшуку;

4) перебуває за кордоном і відмовляється давати показання.

Крім того, суд має право визнати допустимим доказом показання із чужих слів, якщо підозрюваний, обвинувачений створив або сприяв створенню обставин, за яких особа не може бути допитана.

У будь-якому разі не можуть бути визнані допустимим доказом показання із чужих слів, якщо вони даються слідчим, прокурором, співробітником оперативного підрозділу або іншою особою щодо пояснень осіб, наданих 
слідчому, прокурору або співробітнику оперативного підрозділу під час здійснення ними кримінального провадження. Така заборона пов'язана 3 тим, що вказані особи мають у провадженні процесуальний інтерес. Такі показання не можуть визнаватися доказами, оскільки отримані з неналежного процесуального джерела [3].

Крім того, показання із чужих слів не може бути допустимим доказом факту чи обставин, на доведення яких вони надані, якщо показання не підтверджується іншими доказами, визнаними допустимими згідно 3 правилами, відмінними від положень ч. 2 ст. 97 КПК України [3]. Тобто законність та обгрунтованість судового рішення має визначатися в такому разі підтвердженням показань із чужих слів системою належних, допустимих і достовірних доказів.

Щодо практики Європейського суду з прав людини щодо визнання показання із чужих слів допустим доказом, то неодноразово зазначений Суд звертав увагу на те, що показання із чужих слів не можуть бути вирішальними та єдиними під час винесення судового рішення, а мають бути підтверджені іншими допустимими доказами.

Так, у п. 55 рішення у справі «Корнєв і Карпенко проти України» (Заява № 17444/04) від 21 жовтня 2010 р. суд визнав, що «за певних обставин може виникнути потреба послатись на показання, отримані на стадії досудового слідства. Якщо підсудному було надано відповідні й належні можливості заперечити такі показання, чи то під час їх надання, чи на пізнішому етапі, прийняття їх як доказів не суперечитиме саме по собі вимогам пунктів 1 і 3 (d) статті 6 Конвенції. Але із цього випливає, що якщо засудження виключно або вирішальною мірою грунтується на показаннях особи, допитати яку чи домогтися допиту якої підсудний не мав можливості ані під час досудового слідства, ані під час судового розгляду, права захисту виявляються обмеженими тою мірою, що $є$ несумісною з гарантіями, передбаченими статтею 6 Конвенції» [11].

Проте варто взяти до уваги, що Європейський суд із прав людини у своїй практиці може й відступити від вищезазначеної позиції. Зокрема, в рішенні по справі «АльХавайа й Тахері проти Сполученого Королівства» (Заява № 26766/05-22228/06) від 15 грудня 2011 р. суд визначає таке: «засудження, яке грунтується винятково або вирішальною мірою на твердженнях свідка, відсутнього в суді, якого обвинувачений не мав можливості допитати під час слідства або судового розгляду, як правило, вважалося би несумісним із вимогами справедливості відповідно до ст. 6 («єдиного або вирішального правила»). Однак це правило не було абсолютним і не мало застосовуватися в спосіб, який не враховував обставин та ігнорував специфіку конкретної правової системи, оскільки це перетворило б правило на тупий і нерозбірливий інструмент, який суперечив би традиційному способу, з допомогою якого Суд підходив до розгляду питання загальної справедливості провадження, а саме зважування конкуруючих інтересів сторони захисту, потерпілого, свідків, публічного інтересу в ефективному здійсненні правосуддя. Відповідно, навіть якщо показання із чужих слів були єдиним чи вирішальним доказом проти підсудного, то їх прийняття як доказу не спричинило б автоматичного порушення п. 1 ст. 6. Водночас, якщо засудження грунтувалося виключно або вирі шальною мірою на показаннях свідків, які були відсутні в суді, Суд мав піддати провадження детальній перевірці. Через небезпеку, пов'язану з прийняттям таких доказів, дуже важливим фактором було зважування в загальному масштабі, який вимагав досить урівноважувальних факторів, включаючи наявність сильних процесуальних гарантій. Питання в кожній справі полягало в тому, чи відбувалися достатні урівноважувальні фактори, зокрема заходи, які дозволяли зробити справедливу й правильну оцінку наявності достовірних доказів» [8, с. 201].
У рішенні по справі «Костовський проти Нідерландів» (Заява № 11454/85) від 29 березня 1990 р. Свропейський суд із прав людини зазначив, що письмове показання свідка, яке він дає під присягою, щодо того, що йому повідомила інша особа (показання із чужих слів), може бути використане як доказ, але з надзвичайною обережністю.

У рішенні зазначений Суд посилається на рішення Верховного суду, згідно з яким показання із чужих слів можуть враховуватися навіть тоді, коли свідок не називає особу, яка повідомила йому відповідну інформацію (рішенням від 17 січня 1938 р. (NJ 1938, 709)) [12].

Щодо практики національних судів, то варто зазначити, що вона позбавлена такої ознаки, як єдність. Водночас Верховний Суд зазначив, що показання, які містять висловлювання іншої особи, надані з іншою метою, наприклад, для доведення того, що інша особа висловилася саме так за певних обставин, не можуть вважатися показаннями із чужих слів відповідно до ст. 97 КПК України, оскільки в такому разі вони є повідомленням про факт висловлювання, який свідок безпосередньо спостерігав [13].

Аналізуючи показання із чужих слів як процесуальне джерело доказів, особливу актуальність має звернення до проблем правового регулювання показань із чужих слів у кримінальному процесуальному праві Україні.

Так, ч. 3 ст. 97 КПК України встановлено право суду на визнання неможливим допиту особи за наявності визначених умов. Однак, на наш погляд, такою статтею передбачений занадто широкий перелік випадків, коли суд має право визнати неможливим допит особи, яка надала первинні пояснення. Для прикладу, п. 1 ч. 3 ст. 97 КПК України вказує на неможливість допиту особи, відсутньої під час судового засідання через тяжку психічну хворобу. Однак законом не визначено, про які психічні хвороби йдеться. Це можуть бути хронічні психічні хвороби (шизофренія, епілепсія, пресенільні психози, стареча недоумкуватість, прогресивний параліч тощо), тимчасовий розлад психічної діяльності, недоумство, інші хворобливі стани психіки. В разі хронічних психічних захворювань характерні глибокі й стійкі патологічні зміни психіки, які виражаються в глибокому розладі психологічного контакту з реальною дійсністю, виражених порушеннях мислення, свідомості, пам'яті, афекту, поведінки, критичних здібностей. Останні порушують судження та поведінку, здатність усвідомлювати чи оцінювати реальність. Тому цілком логічно виникає питання щодо правдивості й достовірності почутої від такої особи інформації, реальності ії сприйняття та відтворення. Тобто за таких умов може виникнути ситуація, коли суд визнає допустимим доказом показання зі слів особи, яка має тяжкі психічні розлади показання [5].

Крім того, суд має право визнати допустимим доказом показання із чужих слів, якщо підозрюваний, обвинувачений створив або сприяв створенню обставин, за яких особа не може бути допитана. Відповідно до КПК України, підставами неможливості допиту особи, на які міг вплинути обвинувачений, $є$ смерть, тяжка хвороба або небажання давати показання. Однак для того, щоби довести факт створення обвинуваченим обставин, що спричинили смерть, тяжку хворобу чи залякування свідка, потрібно визнати його винним у вчиненні злочину вироком суду згідно із засадою презумпції невинуватості. Але в ч. 5 ст. 97 КПК України йдеться про визнання особи винною ще до винесення вироку [7, с. 432].

Ще одним із недоліків правового регулювання є невизначення кола осіб, які можуть давати показання із чужих слів. Лише в ч. 7 ст. 97 КПК України уточняється, що в будь-якому разі не можуть бути визнані допустимим доказом показання із чужих слів, якщо вони даються слідчим, прокурором, співробітником оперативного підрозділу або іншою особою щодо пояснень осіб, наданих слідчому, прокурору, або співробітнику оперативного 
підрозділу під час здійснення ним кримінального провадження. Таким чином, якщо відсутня відповідна заборона, то можна зробити висновок, що малолітні й неповнолітні особи можуть давати показання із чужих слів.

Однак слушною із цього приводу є думка І.Л. Чернеги, яка вважає, що така позиція дуже спірна, оскільки сама по собі можливість легітимності показань із чужих слів уже викликала багато суперечок серед процесуалістів, а якщо окремо брати таку специфічну категорію, як малолітні й неповнолітні, то тут ще більше питань. По-перше, на малолітніх, неповнолітніх дуже легко впливати. Це можуть здійснювати як законні представники, педагоги, так і безпосередньо особа, яка надає первинні показання. По-друге, категорія осіб, яка розглядається, ще не пройшла всіх етапів соціальної формації та її світосприйняття може бути спотворене як власною уявою, так і зовнішніми страхами чи навпаки бажанням виділитись. У таких умовах неможливо передбачити, наскільки показання із чужих слів устами малолітньої чи неповнолітньої особи збережуть свій реальний зміст, чи не будуть такі показання піддані впливу власної фантазії допитуваного [14].

Спірне також положення щодо відмови особи від надання показань у судовому засіданні, адже відмовитися давати показання в судовому засіданні мають право лише свідки, які є членами сім'ї та близькими родичами обвинуваченого. Інші свідки зобов'язані давати правдиві показання про відомі їм обставини, що підлягають доказуванню. За надання завідомо неправдивих показань або за відмову від надання показань слідчому, прокурору, слідчому судді чи суду, крім випадків, передбачених КПК України, свідок несе кримінальну відповідальність за ст. 384,385 Кримінального кодексу України. А за злісне ухилення від явки до слідчого, прокурора, слідчого судді чи суду свідок несе відповідальність, встановлену законом.

Таким чином, результати проведеного дослідження вказують на необхідність уточнення окремих норм кримінального процесуального закону в частині врегулювання допустимості показань із чужих слів. Зокрема, вбачається за доцільне закріпити в КПК України положення про те, що показання із чужих слів можуть бути визнані судом допустимим доказом у виняткових випадках, які уне- можливлюють допит особи, яка надала первинні пояснення, якщо такі показання $є$ допустимим доказом згідно 3 іншими правилами допустимості доказів. Крім того, доцільне закріплення положення про те, що суд має право визнати допустимим доказом показання із чужих слів за наявності обставин, що можуть свідчити про створення підозрюваним, обвинуваченим або його сприяння обставин, за яких особа не може бути допитана. Також необхідно законодавчо закріпити коло суб'єктів, які можуть давати показання із чужих слів.

Висновки. У результаті проведеного дослідження, виконаного на основі аналізу чинного кримінального процесуального законодавства України, теоретичного осмислення низки наукових праць сформульовані висновки щодо використання показань із чужих слів як процесуального джерела доказів.

У результаті аналізу напрацювань науковців виявлено, що не досить обгрунтованими залишаються питання щодо розкриття сутності показань із чужих слів. Крім того, серед вчених немає одностайної думки щодо можливості використання показань із чужих слів як процесуального джерела доказів і взагалі доцільності закріплення такого інституту в КПК України. Не вдаючись до аналізу висловлених негативних моментів, вважаємо, що загалом закріплення показань із чужих слів у кримінальному процесуальному законодавстві $\epsilon$ вірним рішенням. Викладено недоліки правового регулювання показань із чужих слів у законодавстві Україні й запропоновано внести зміни до КПК України. Зокрема, вбачається за доцільне закріпити в КПК України положення про те, що показання із чужих слів можуть бути визнані судом допустимим доказом у виняткових випадках, які унеможливлюють допит особи, яка надала первинні пояснення, якщо такі показання є допустимим доказом згідно з іншими правилами допустимості доказів. Крім того, доцільне закріплення положення про те, що суд має право визнати допустимим доказом показання із чужих слів за наявності обставин, що можуть свідчити про створення підозрюваним, обвинуваченим або його сприяння обставин, за яких особа не може бути допитана. Також необхідно законодавчо закріпити коло суб'єктів, які можуть давати показання із чужих слів.

\section{ЛITEPATУРA}

1. Доказування у кримінальному провадженні : курс лекцій / О.О. Бондаренко, Г.І. Глобенко, В.В. Романюк та ін. ; за заг. ред. О.О. Юхна ; МВС України, Харків. нац. ун-т внутр. справ, Ф-т № 1, Каф. кримінал. процесу та організації досуд. слідства. Харків : ХНУВС, 2018. 156 c.

2. Задерейко С.Ю. Генеза показань свідка як джерело доказів у кримінальному процесі. Науковий вісник публічного та приватного права. Випуск 2. 2018. С. 265-271.

3. Кримінальний процесуальний кодекс України : Закон України від 13 квітня 2012 р. № 4651-VI / Верховна Paда України. URL: http://zakon2.rada.gov.ua/laws/card/4651-17 (дата звернення: 22.05.2020).

4. Острійчук О.П. Місце показань в системі процесуальних джерел доказів. Часопис Київського університету права. 2013. Вип. 3. С. 319-322.

5. Ляш А.О. Показання з чужих слів: норма, яка підлягає виключенню з КПК України. Правове регулювання суспільних відносин в умовах демократизаиії Української держави: матеріали V Міжн. наук.-практ. конф. / укладачі І.П. Голосніченко, Т.О. Чепульченко, В.Ю. Пряміцин. Київ : Національний технічний університет України «Київський політехнічний інститут», 2015. С. 134-135.

6. Крет Г.Р. Допустимість показань із чужих слів як процесуального джерела доказів у кримінальному провадженні. Прикарпатський юридичний вісник. Випуск 2 (5). 2014. С. 254-262.

7. Король В.В., Садова Т.В. Показання як джерело доказів у кримінальному провадженні. Науковий вісник Дніпропетровського державного університету внутрішніх справ. 2013. № 3. С. 428-434.

8. Панова А.В., Скідан Н.В. Окремі питання використання показань із чужих слів у кримінальному процесі України. Национальный юридический журнал: теория и практика. 2018. С. 199-203.

9. Чернега І.Л. Показання з чужих слів: новела чи регрес? URL: http://dspace.onua.edu.ua/bitstream/handle/11300/8525/\%D0\%A7\%D0 \%B5\%D1\%80\%D0\%BD\%D0\%B5\% (дата звернення: 22.05.2020).

10. Вапнярчук В.В. Теорія і практика кримінального процесуального доказування : монографія. Харків : Юрайт, 2017. 408 с.

11. Рішення ЄСПЛ у справі «Корнєв і Карпенко проти України» від 21 жовтня 2010 р. Заява № 17444/04 / База даних «Законодавство України». URL: https://zakon.rada.gov.ua/laws/show/974_637 (дата звернення: 23.05.2020).

12. Рішення ЄСПЛ у справі «Костовський проти Нідерландів» від 29 березня 1990 р. Заява № 11454/85. URL: https://zakon.rada.gov.ua/ laws/show/980_090 (дата звернення: 23.05.2020).

13. Рішення суду загальної юрисдикції : Постанова Верховного Суду від 19 листопада 2019 р. у справі № 441/845/17. Провадження № 51-8328км18. URL: http://reyestr.court.gov.ua/Review/85934761 (дата звернення: 23.05.2020).

14. Чернега І.Л. Показання із чужих слів устами малолітніх та неповнолітніх. Проблеми допустимості. URL:http://dspace.onua.edu. ua/bitstream/handle/11300/4540/Chernega\%20Pokazannja\%20z\%20chuzhih\%20sl\%D1\%96v\%20ustami\%20malol\%D1\%96tn\%D1\%96h. pdf?sequence=1\&isAllowed=y (дата звернення: 24.05.2020). 


\title{
TACTICS OF THE SUSPECT INTERROGATION IN THE INVESTIGATION OF FALSIFICATION AND TURNOVER OF FALSIFIED MEDICINES
}

\section{ТАКТИКА ДОПИТУ ПІДОЗРЮВАНОГО ПРИ РОЗСЛІДУВАННІ ФАЛЬСИФІКАЦІЇ ТА ОБІГУ ФАЛЬСИФІКОВАНИХ ЛІКАРСЬКИХ ЗАСОБІВ}

\author{
Parfylo I.V., Postgraduate Student at the Department of Criminalistics \\ Yaroslav Mudryi National Law University
}

The article is devoted to the research of actual problems of tactics of the suspect interrogation at investigation of falsification and turnover of falsified medicines. A detailed analysis of modern scientific views on the definition of interrogation as an investigation (search) action, its most significant features and peculiarity of carrying out, which are debatable in criminalistics science, was performed. Particular attention is paid to the problems of forming a system of tactical methods of interrogation in the investigation of falsification and turnover of falsified medicines. It is substantiated that during the interrogation of the suspect it is necessary to take into account: the procedural status of the interrogated person (suspect); categories of interrogated persons due to the peculiarities of the investigative situation that has developed at a certain stage of the pre-trial investigation of criminal proceedings; interrogation situation (conflict, conflict-free); the nature of the information to be clarified, i.e. the subject of the interrogation.

It is noted that during the investigation of falsification and turnover of falsified medicines can identify three main categories of interrogated persons who have the suspect status, in particular, these are: the head or other official of a legal pharmaceutical enterprise where the falsified medicines were carried out; an worker of an clandestine production specially equipped for falsification of medicines in artisanal conditions; the head or other official of the pharmacy where the falsified medicines were found. With regard to these categories of interrogated persons, the subject of the interrogation, the list of issues that need to be clarified and the system of tactical methods considering the interrogation situations, have been determined. It is substantiated the importance of taking into account the possibility of conflict situations of interrogation related to the refusal of suspects to testify or giving false testimony, for which a system of tactical methods is proposed to induce the suspect to testify, as well as exposing untruths in testimony with full and partial denial of his guilt. Proved that, based on the specifics of this category of criminal offenses, an important problem is the need for further research, which will greatly contribute to the effectiveness of interrogation as an investigation (search) action, saving time and effort at the beginning of pretrial investigation of falsification and turnover of falsified medicines.

Key words: interrogation of the suspect, subject of interrogation of the suspect, tactics of interrogation, situations of interrogation of the suspect, investigation of falsification and turnover of falsified medicines.

Стаття присвячена дослідженню актуальних проблем тактики допиту підозрюваного під час розслідування фальсифрікації та обігу фальсифрікованих лікарських засобів. Проведено детальний аналіз сучасних наукових поглядів щодо визначення допиту як слідчої (розшукової) дії, його найістотніших ознак та особливостей проведення, які $є$ дискусійними в криміналістиці. Особливу увагу приділено проблемам формування системи тактичних прийомів проведення допиту під час розслідування фальсифікації та обігу фальсифікованих лікарських засобів. Обґрунтовано, що під час допиту підозрюваного необхідно враховувати: процесуальний статус допитуваної особи (підозрюваного); категорії допитуваних осіб, зумовлених особливостями слідчої ситуації, яка склалася на певній стадії досудового розслідування кримінального провадження; ситуацію допиту (конфлліктну, безконфлліктну); характер відомостей, які підлягають з'ясуванню, тобто предмет допиту.

Зазначається, що під час розслідування фальсифікації та обігу фальсифікованих лікарських засобів можна визначити три основні категорії допитуваних осіб, які мають статус підозрюваного, зокрема: керівник або інша посадова особа легального фрармацевтичного підприємства, на якому здійснювалася фальсифікація лікарських засобів; робітник підпільного цеху, спеціально обладнаного для фальсифікації лікарських засобів у кустарних умовах; завідувач або інша посадова особа аптеки, в якій було виявлено фальсифріковані лікарські засоби. Стосовно зазначених категорій допитуваних осіб визначено предмет допиту, перелік питань, що потребують з'ясування, та систему тактичних прийомів з урахуванням ситуацій допиту. Обґрунтовано важливість урахування можливості виникнення конфлліктних ситуацій допиту, які пов'язані з відмовою підозрюваних від надання показів або надання неправдивих показів, щодо яких запропоновано систему тактичних прийомів спонукання підозрюваного до надання показів, а також викриття неправди в його показах у разі повного й часткового заперечення вини. Доводиться, що виходячи зі специфіки зазначеної категорії кримінальних правопорушень, важливою постає проблема в необхідності проведення подальших наукових розробок, що значною мірою сприятиме ефективності проведення допиту як слідчої (розшукової) дії, економії сил і часу на початку кримінального провадження, що $є$ необхідною передумовою успішного розслідування фральсифікації та обігу фальсифікованих лікарських засобів.

Ключові слова: допит підозрюваного, предмет допиту підозрюваного, тактичні прийоми допиту, ситуації допиту підозрюваного, розслідування фральсифікації та обігу фальсифікованих лікарських засобів.

Formulation of research problem. One of the most common investigative (search) actions in the investigation of falsification and turnover of falsified medicines is the interrogation of the suspect. The effectiveness of conducting and achieving the purpose of this type of interrogation largely depends on understanding the specifics of its subject, the categories of interrogated persons, the current situation and professional training of the investigator, the ability to properly apply tactics and recommendations. Ignoring these requirements negatively affects the quality of the investigation process, slows it down and leads to conflict situations, which ultimately leads to the loss of evidence. Given the above, it is important to note that a necessary prerequisite for an effective investigation of this type of criminal offense is to take into account tactical recommendations for interrogation of the suspect, their proper application, considering the specifics of investigating specific circumstances, tactical tasks (tactical combinations) in certain situations.
Before proceeding to the direct development of tactical recommendations for interrogation the suspect during the investigation of falsification and turnover of falsified medicines, in our opinion, it is necessary to study the theoretical foundations of this issue, generalize the views of scientists on the most important features and peculiarities of this investigative (search) action.

In criminalistics, the question of interrogation tactics is covered quite fully. Nevertheless, during the preparation and conduct of the interrogation there are problems due to the current state of development of science. In particular, in the special literature there are different approaches to the definition of criminalistics signs of interrogation as an investigative (search) action. According to R.S. Belkin interrogation is a procedural (investigative or judicial) action, which consists in obtaining testimony (information) about the event that became the subject of criminal proceedings, persons involved 
in the case, the reasons and conditions that contributed to the commission and concealment of the crime [2, p. 62]. In the opinion of O.P. Vashchuk interrogation can be defined as an investigative (search) action or a judicial action aimed at obtaining by the investigator, prosecutor or court in accordance with the rules of procedural law information from the interrogated about the facts known to him that are important for the proper resolution of criminal proceedings [3, p. 291]. V.Yu. Shepitko defines interrogation as a procedural investigative (search) or judicial action, which is regulated by criminal procedural rules, that is information and psychological process of communication of persons involved in it. The interrogation is aimed at obtaining information about the facts known to the interrogated, which are important for establishing the truth in criminal proceedings [7, p. 192].

Given these views, in our opinion, it is necessary to identify the features of interrogation as an investigative (search) action, which are decisive in the formation of its conduct tactics:

1) the interrogation is due to establish circumstances relevant to establishing the truth in criminal proceedings, that is, the subject of interrogation;

2) interrogation is not just the information transfer that the interrogees know, but the interaction between the interrogation participants (investigator, prosecutor and witness, suspect, victim), which necessitates the use of psychological techniques during its conduct.

According to V.O. Konovalova subject of interrogation covers the circumstances to be established during the investigation and is determined by two factors: a list of circumstances to be clarified in the proceedings, and data that must be known or known to persons involved in the crime. Thus, the subject of interrogation does not coincide in scope with the subject of witnesses and suspects testimony, as witnesses and suspects report only the circumstances known to them in connection with the crime, and the subject of interrogation is a wider range of circumstances to be established regardless of the knowledge of the interrogated about them [4, p. 6].

M.I. Porubov points out the importance of taking into account psychology during interrogation, emphasizing that knowledge in the field of psychology allows the investigator to understand the behavior of the suspect, or a false witness who hides the truth, to choose tactics that will help establish the goals and motives of the crime, to identify factors that prevent the interrogated person from telling the truth, determine the optimal line of behavior in relation to the interrogated person [5, p. 32]. As noted by V.Yu. Shepitko, the study of typical interrogation situations makes it possible to establish conflict-free and conflict situations. Conflict-free situations may include:

1) the interrogated person reports reliable testimony;

2 ) in the testimony of the interrogated there are distortions;

3 ) in the testimony of the interrogated there are contradictions;

4) the impossibility of communicating certain information due to forgetting certain moments. ations:

In turn, the conflict presupposes the existence of two situ-

1) refusal of the interrogated from the testimony;

2) reporting a lie in the testimony. In this case, the construction and use of tactical receptions of interrogation depends not only on the situational conditionality, but also on the purpose of the interrogation, its type, the procedural position of the interrogated and other factors [8, p. 340].

Therefore, it should be agreed that the use of tactics in interrogation can be effective only if they are targeted, selected according to specific circumstances, if the investigator concludes that the use of certain tactical methods in this situation may contribute to an interrogation positive outcome. The use of recommendations in the interrogation of witnesses or suspects, without taking into account the specifics of the testi- mony, the identity of the interrogated and other circumstances, is usually ineffective $[4, \mathrm{p} .11]$.

In this regard, in our opinion, when investigating the falsification and turnover of falsified medicines to form a system of tactical methods of interrogation must take into account:

1) the procedural status of the interrogated person (suspect);

2) categories of interrogated persons due to the peculiarities of the investigative situation that has developed at a certain stage of the pre-trial investigation of criminal proceedings;

3 ) interrogation situation (conflict, conflict-free);

4) the nature of the information to be clarified, i.e. the subject of the interrogation.

It is seen that the tactics of the suspect interrogation has a pronounced situational nature, because depending on the method, circumstances of the crime and the identity of the offender changes both the list of circumstances included in the subject of interrogation and the list and sequence of questions to interrogate.

The results of compilation of investigative and judicial practice materials of investigation of falsification and turnover of falsified medicines make it possible to distinguish three main categories of interrogated persons who have the status of suspects, in particular, they are:

1) the head or other official of a legal pharmaceutical enterprise where the falsified medicines were carried out;

2 ) a worker of a clandestine production specially equipped for falsification of medicines in artisanal conditions;

3 ) the head or other official of the pharmacy where the falsified medicines were found.

When interrogating suspects in the falsification and turnover of falsified medicines, it should be taken into account that they usually have technical education, are well-versed in the field of pharmaceuticals, know the peculiarities of the technological process of medical production, licensing conditions and instructions for quality control of medicines, often participated in inspections by regulatory authorities for the production of medicines, well aware of the circumstances of the event and the weight of the evidence possessed by the investigator. In addition, in view of the specifics of these pharmaceutical companies, it is difficult for the investigator to correctly and fully record the important circumstances due to lack of information about the interrogation subject and terminological features of the interrogated person testimony.

In addition, the interrogation of suspects in the falsification and turnover of falsified medicines is complicated by the possibility of distortion of information due to their knowledge of special terminology, the peculiarities of the production technological process and high level of mental abilities. This requires the investigator to prepare in more detail, indepth analysis of the existing evidence, as well as drawing up an interrogation plan, taking into account alternative ways in the event of a conflict situation of interrogation.

The process of preparation for interrogation in this case should include not only acquaintance with the materials of criminal proceedings, operational and investigative data and information about the identity of the interrogated, but also study the extensive system of licensing regulations of medicines production, wholesale and retail. The information obtained will help to predict the situation of interrogation, the reaction of the interrogated to a particular tactic, to choose the most effective way to establish psychological contact.

Given the need for rapid orientation of the investigator in a particular issue of pharmaceutical activity, the possibility of involving a specialist in the interrogation is considered relevant. At the same time, the position of scientists, who note that it is expedient to involve a specialist at all stages of the interrogation (preparatory, working, final) should be supported. Involvement of specialists helps to solve the main purpose of the interrogation - to obtain from the interrogated person the maximum amount of information necessary to establish the truth of the case [6, p. 381]. 
The interrogation of the head or other official of a legal pharmaceutical enterprise where the falsification of medicines was carried out, usually, takes place in the following circumstances, which are decisive in the formation of interrogation tactics:

1) inconsistency in accounting, which is that criminal activity is carried out by the means and resources of a legal enterprise, but is not reflected or incompletely reflected in the official accounting or reporting documents of the enterprise. Therefore, it is possible that there are contradictions in the testimony of the suspect in this regard, which should be used during interrogation;

2) the open nature of criminal activity, which is appeared in the fact that criminal activity is actually carried out with the participation of employees of a legal enterprise, who are either unaware of the illegal nature of certain activities or knowingly conceal their awareness of such nature. However, in any case, they are eyewitnesses of certain circumstances of the crime, and therefore their testimony is the basis for identifying inconsistencies with official accounting, reporting documents and the testimony of the suspect;

3 ) involvement of illegal workers, which is due to the need to formally exclude the official leadership from the structure of criminal activity (i.e., persons who manage criminal activity do not personally issue orders to commit illegal acts, do not appear in the manufacture). In addition to formal employment relationships, the enterprise may have an informal employment relationship or shadow management related to the production of falsified medicines. In this regard, it is important to find out the actual relationship in the enterprise.

Therefore, the subject of interrogation of head or other officials of the enterprise on which the falsification was carried out, the turnover of falsified medicines involves clarifying the following circumstances:

name, organizational and legal form, form of ownership, founders, basic registration data, types of activity of the business entity, availability of licenses, permits; management structure and distribution of powers of the business entity; what local and other documents (job description, employment contract, order, instruction, etc.) they are regulated; what managerial powers, not provided for in the documents, were actually exercised by these persons;

the position of the interrogated person, the direction of activity and the list of powers in accordance with official documents; work experience in this position, work experience in the specified specialty, education, training, advanced training in medicine, pharmacology, pharmacy;

powers that the interrogated person actually performed (except for those provided for officially), or which the person did not actually perform (despite the existence of such powers according to the official documentation); by whom, for what reason, for what period the person was entrusted with the actual performance of additional powers or the actual release from the powers entrusted to him;

where, when, under what circumstances, together with which persons, for what reasons there was an intention to commit criminal activity; when, where the previous conspiracy was reached, what is the distribution of roles (if there are signs of conspiracy);

how the criminal activity was combined with the official one, what conspiracy measures were taken, misleading employees, or other methods of masking criminal activity; what actions were actually taken during the production, storage, supply, packaging, accounting, wholesale of falsified medicines;

place, time and circumstances of all stages of criminal activity (in which manufacture, office, laboratory, warehouse, other industrial or domestic premises, in what period of the year, week, day);

what exactly falsified medicines were purchased, produced, sold, by whom, when, how, taking into account which criteria the choice of names of medicines which were subject to falsification was carried out;

who and in what form managed the technological process of production of falsified medicines, who developed the pharmaceutical composition and production technology, design of consumer packaging, labels, the text of the instructions for use;

- who, in what form, how carried out accounting and reporting activities and storage of falsified medicines;

- who, in what form, in what way carried out sale of falsified medicines, taking into account what criteria search of clients, the conclusion of agreements with them and sale of production was carried out;

- how the supply of falsified medicines to customers was carried out (self-pickup, delivery by transport of the enterprise, sending by courier delivery, etc.);

what is the total and detailed (for each name and each client) number of falsified medicines was sold; at what total and detailed cost.

The interrogation of persons who manufactured falsified medicines in a specially equipped clandestine production is characterized by the following circumstances, which are decisive in the formation of tactics:

1) the clandestine nature of criminal activity, the content of which is non-disclosure or partial concealment by criminals of signs of criminal activity by conspiracy measures (absence or incorrect state registration, violation of accounting or tax accounting, forgery of documents, etc.), which clearly contradicts factual information from the place of criminal activity;

2) special adaptation of the premises for the purposes of criminal activity, in particular, zoning of the territory (production area, office, warehouse), installation of equipment, supply of communications, etc.

These circumstances are important during the interrogation of a suspect in this situation, as it allows the investigator to make reasonable assumptions about the direction and specialization of criminal activity.

The subject of the suspect interrogation, who was engaged in the production of falsified medicines in the clandestine production, specially equipped for this purpose, has a slightly different direction. The key aspects to be clarified by the interrogated in the clandestine production of falsified medicines are: availability of higher or secondary professional education in the field of medicine, chemistry (pharmacology, pharmacy, etc.), as well as experience of professional activity in the field of health care and (or) production of medicines;

where, when, under what circumstances, together with which persons, for what reasons there was an intention to create an clandestine production;

where, when, under what circumstances the previous conspiracy was reached, what is the distribution of roles (in case of signs of conspiracy);

what measures were taken in preparation for the crime: recruitment of qualified participants; search for suppliers of medicinal raw materials, consumer packaging, labels, holograms, etc.; purchase and installation of equipment, development of methods and means of conspiracy; search for outlets, creation of criminal ties with authorized persons of medical and pharmacy institutions;

what exactly falsified medicines were produced, taking into account what criteria the choice of names of medicines to be manufactured in this clandestine production was made;

who, when, how, according to which criteria developed the chemical composition and technology of clandestine production of falsified medicines, which was the main active ingredient and excipient, what other components, consumables were used to manufacture the falsified medicines;

who, when, how carried out the process of manufacturing in the clandestine conditions of each name of falsified medicines, place, time and circumstances of all stages of production (in which place, office, laboratory, warehouse, other 
industrial or domestic premises, in what period of the year, week, day);

who, under what conditions supplied medicinal raw materials, as well as other components, consumables for the production of falsified medicines;

how many falsified medicines of each name were produced per work shift (per day) and in total for the period of criminal activity;

where and in what conditions the produced falsified medicines were stored, who was the person responsible for accounting and storage;

by whom, in what form, how the sale of falsified medicines was carried out, taking into account which criteria the search of clients, conclusion of agreements with them and sale of products was carried out;

by whom, in what form, how the delivery of falsified medicines to clients was carried out;

The formation of interrogation tactics of the head or other official of the pharmacy in which the falsified medicines were found is due to the purpose of criminal activity of the suspect in this case, which is to make a profit by wholesale purchase at discounted prices and subsequent retail sale at normal prices of known falsified medicines. This is usually accompanied by a violation of the quality control of medicines during wholesale and retail trade (for example, no request for a seller's license, a copy of which is stored in the pharmacy for three years, accompanying documents, certificates, lack of entry control). It is the presence of deliberate and intentional violations of these regulations can clearly indicate the criminal nature of the activity.

Therefore, the subject of the interrogation of the head or other official of the pharmacy in which the falsified medicines were found involves clarifying the following circumstances:

the name of the pharmacy as a business entity, its registration data, field of activity, availability of licenses and other permits, when and by whom they are issued, duration of activity in the field of health care or pharmaceutical market;

the position of the interrogated person, the duration of employment in the field of health care or the pharmaceutical market, the availability and content of managerial powers; how falsified medicines appeared in the supply chain of the pharmacy; when, where, by whom and under what conditions the agreement on the supply of these medicines was concluded, how long has the pharmacy been cooperating with the business entity that is the supplier of such medicines;

with which other business entities permanent economic cooperation was carried out;

how the pharmacy accounted for the receipt and subsequent movement of medicines; which of the employees was responsible for accounting and reporting, including medicines recognized as falsified;

whether the procedure for concluding the agreement established by the Order of the Ministry of Health of 29.09.2014 № 677 or other regulations on the batch of medicines that were falsified, were violated, by whom and for what reason;

whether the incoming quality control of medicines supplied to the pharmacy was carried out; if conducted, by whom, how (in what form), whether a violation was detected, if not conducted, for what reason;

how the payment for the delivered medicines recognized as falsified, was made: prepayment, partial prepayment, payment as sold, etc.; with the participation of which persons and with what frequency;

ways of further sale of medicines that turned out to be falsified: small wholesale or retail sales, centralized supply to medical institutions, etc.

The results of compilation of investigative and judicia practice materials show that in most cases the interrogation of the suspect is characterized by a conflict situation, which consists in the suspect refusal to testify or in telling the sus- pect false testimony. The choice of investigators of the types and forms of influence and specific methods of its implementation during interrogation depends on many factors. These include: the adequacy degree of awareness of the investigative situation; the quantity and quality of information available to the investigator on the interrogation subject and the identity of the interrogated person who is in conflict with the investigator; the sphere of the interrogated's psyche, rational or emotional, on which the influence is calculated (in other words, whether it is logical or emotional) [1, p. 247]. In this regard, it is advisable to use a system of tactical methods aimed at overcoming the suspects' reticence of facts important for the investigator, as well as exposing untruths in testimony with full and partial denial of his guilt $[9$, p. 313]

Refusal to testify or deliberate reticence of suspects of certain facts that are essential for the pre-trial investigation, usually occurs during the interrogation of workers of an clandestine production specially equipped for the production of falsified medicines, because for employees of legal pharmaceutical companies, pharmacies, in particular directors, heads of departments, managers, heads it is important to form a full picture of a completely legal activity. Complete or partial refusal to testify in this case draws unwanted attention to aspects that the interviewee wishes to conceal. At the same time, persons who were participants in the clandestine production, realizing, firstly, the obvious illegal nature of their activities, and secondly, the lack of the investigator's ability to establish other sources of information about the circumstances of the crime, often resort to the said method of counteracting the investigation.

The system of tactical methods for encouraging a suspect to testify in this case may be as follows:

1) explanation of the circumstances, which, according to criminal law, are recognized as mitigating liability;

2) appeal by the investigator to the available evidence and the circumstances of the crime established by the investigation;

3) demonstration of investigation capabilities; 4) appeal to the positive personal qualities of the interrogated person.

The implementation of the tactical method of "Explaining the circumstances that are recognized as mitigating" in practice usually consists of a thorough explanation to the suspect each of the circumstances listed in Article 66 of the Criminal Code of Ukraine, as well as which of them and under what conditions can be applied to it. It is also rational to acquaint the interrogated with copies of the verdicts, in which the court, when imposing a rather lenient sentence, referred to the existence of similar mitigating circumstances.

Quite common in practice is the tactical method of "Paying attention to the available evidence and established by the investigation circumstances of the crime". This tactic method is also designed to influence the intellectual psyche of the interrogated by convincing the suspect that the investigator has the evidence necessary and sufficient to prosecute him to responsibility. Evidence should be presented after the suspect has been questioned for all the circumstances surrounding that evidence. In so doing interrogation should be carried out in such a way that the interrogated further at could not compromise it because the last will lose probative force. That evidence may be seized during the inspection or search of physical evidence, documents and expert opinions.

The essence of the tactical method "Demonstration of investigative capabilities" is to explain to the interrogated person the objective possibility of the investigation to establish any hidden circumstances, regardless of his testimony, by conducting certain investigative actions (interrogations of certain persons, inspections, searches, appointment of forensic examinations, etc.). Possible tactical methods of demonstrating the possibilities of investigation may be a review of physical evidence with the participation of the suspect, as well as the withdrawal of samples of falsified medicines and other 
substances with the participation of the suspect with an explanation of the purposes and possibilities of their expert examination. Appeal to the positive personal qualities of the interrogated can take two forms:

1) evaluation-praise in order to evoke positive emotions in the interrogated person;

2) evaluation of the appeal, in order to encourage such feelings that stimulate the interrogated person to enter into communication during the interrogation [9, p. 299].

In our opinion, the tactics system of exposing untruths in the testimony of a suspect with full or partial denial of his guilt should include tactical methods aimed at detection of untruths in testimony, in particular: comparison of testimony with other information available to the investigator; articulation of detailed issues; asking control questions about the facts established during the investigation. In the future, when detecting and exposing a lie in the testimony of the suspect, it is necessary to use tactics aimed at encouraging the suspect to give the true testimony.

Comparison of testimony with other information available to the investigator, as a tactical method, may consist in such doings as: comparing the elements of the same name of the event, differently described by the interrogated during the interrogation; comparison of related and derived elements of the event covered during the interrogation; comparing the same and related circumstances according to the testimony of the interrogated at different interrogations; comparison of the same circumstances in the testimony of the interrogated person and other persons; comparison of individual circumstances of the event in the description of the interrogated with other data about the same events.

Without going into a detailed description of the possible elements of comparing the testimony with other information, we will pay attention only to some of them, which are most often hidden. Thus, it is possible to compare diverse data on:

a) the circumstances of the order for the production of falsified medicines within a legal pharmaceutical enterprise;

b) the circumstances of the purchase of falsified medicines in a pharmacy;

c) the circumstances of the organization and adaptation of the clandestine production for needs productions of falsified medicines.

An effective tactical method of interrogating a suspect in a situation where there is a likelihood of false testimony is to ask the interrogee so-called detailing and control questions aimed at clarifying the facts, circumstances, some of their details that can confirm or refute the objectivity of the testimony. Yes, quite a spread is the situation, when the suspects tell a lie about their being in a certain place at a certain time. The task of the interrogation is to link the detail questions or the control questions to give testimony to any other event, the time and place of existence of which are either known exactly or can be objectively confirmed by someone or something.

Summarizing the above, it should be noted that the effective interrogation of the suspect requires the knowledge of investigators of a different tactical methods, recommendations, as well as the ability to properly apply them in a particular investigative situation, taking into account the categories of interrogated persons and their behavior. Effective interrogation is the key to an objective and successful investigation into the falsification and turnover of falsified medicines, as it allows to form the most probable opinion of the circumstances and mechanism of the criminal event that are important for investigating and correctly determining the directions of investigation.

\section{REFERENCES}

1. Баев О.Я. Тактика следственных действий : учебное пособие. Москва : Юрлитинформ, 2013. 456 с.

2. Белкин Р.С. Криминалистическая энциклопедия. Москва, 2000. 334 с.

3. Ващук О.П. Невербальна інформація в кримінальному провадженні: теоретико-методологічні основи : монографрія. Одеса : Видавничий дім «Гельветика», 2017. 430 с.

4. Коновалова В.Е. Допрос: тактика и психология. Харьков : Консум, 2006. 176 с.

5. Порубов Н.И. Научные основы допроса на предварительном следствии. 3-е изд., перераб. Минск : Вышэйш. шк., 1978. 175 с.

6. Чорний Г.О. Особливості використання спеціальних знань при допиті. Реформування судових і правоохоронних органів України: проблеми та перспективи : матер. наук.-практ. конф., м. Харків, 14 травня 2010 р. Харків : Одіссей, 2010. С. 379-381.

7. Шепітько В.Ю. Велика юридична енциклопедія : у 20 т. Т.20 : Криміналістика, судова експертиза, юридична психологія ; Нац. акад. прав. наук України ; Нац. юрид. ун-т ім. Ярослава Мудрого. 2018. 952 с.

8. Шепітько В.Ю. Тактика допиту. Криміналістика : підручник : у 2 т. Т. 1. Харків : Право, 2019. 456 с.

9. Шепітько В.Ю. Криміналістична тактика (системно-структурний аналіз) : монографрія. Харків : Харків юридичний, 2007. 432 с. 


\title{
ПЕРСПЕКТИВНІСТЬ ПОБУДОВИ МЕТОДИКИ РОЗСЛІДУВАННЯ ДОМАШНЬОГО НАСИЛЬСТВА
}

\author{
PROSPECTIVENESS OF CONSTRUCTION OF METHODOLOGY OF INVESTIGATION \\ OF DOMESTIC VIOLENCE
}

\author{
Пчеліна О.В., д.ю.н., доцент, \\ доцент кафедри кримінального процесу та організації досудового слідства \\ факультету № 1 \\ Харківський наиіональний університет внутрішніх справ
}

\begin{abstract}
У статті відзначається, що з кожним роком домашнє насильство стає розповсюдженішим феноменом, у зв'язку із чим збільшується як кількість учинених правопорушень, пов'язаних із домашнім насильством, так і відкритих кримінальних проваджень. Проаналізовано стан нормативно-правового регулювання діяльності із запобігання та протидії домашньому насильству. Наведено статистичні дані Офісу Генерального прокурора про кількість і стан кримінальних проваджень, відкритих за фактом учинення домашнього насильства впродовж 2018 - першого півріччя 2020 року. Наголошено на необхідності розробити криміналістичні рекомендації 3 виявлення, розкриття та розслідування такого різновиду кримінального правопорушення, як домашнє насильство, й формування відповідної окремої криміналістичної методики. Зазначено, що побудова методики розслідування домашнього насильства зумовлена як науковими, так і практичними потребами, а значить є перспективним напрямком розвитку криміналістичної науки в цілому й криміналістичної методики зокрема, а також діяльності з виявлення, розкриття та розслідування домашнього насильства. Визначено завдання та принципи побудови методики розслідування домашнього насильства. Здійснено криміналістичну класифікацію домашнього насильства. Підкреслено, що розроблена методика розслідування домашнього насильства, щоб бути інформативною та придатною для використання в діяльності правоохоронних органів, повинна повною мірою зображувати як особливості механізму вчинення домашнього насильства, так і специфіку й фактичний стан діяльності з їхнього виявлення та досудового розслідування. Запропоновано структуру методики розслідування домашнього насильства: криміналістична класифікація та характеристика домашнього насильства; обставини, що підлягають з'ясуванню; відкриття кримінального провадження; початковий етап розслідування; наступний етап розслідування; взаємодія під час розслідування домашнього насильства; особливості тактики проведення окремих слідчих (розшукових) дій і заходів забезпечення кримінального провадження; використання можливостей судових експертиз. Водночас зазначено, що особливості відкриття кримінального провадження, початкового й наступного етапів розслідування домашнього насильства потрібно викладати у вигляді алгоритму дій з урахуванням тактичних завдань, типових слідчих версій і слідчих ситуацій.
\end{abstract}

Ключові слова: побудова методики розслідування кримінальних правопорушень, домашнє насильство, фрормування криміналістичної методики, криміналістична класифікація домашнього насильства, завдання, принципи, структура.

In the article it has been noted that domestic violence is becoming more common every year, which increases both the number of domestic violence offenses and open criminal proceedings. The state of normative-legal regulation of activity on prevention and counteraction to domestic violence has been analyzed. The statistics of the Office of the Prosecutor General on the number and status of criminal proceedings opened on the fact of domestic violence during 2018 - first half of 2020 have been presented. Emphasis has been placed on the need to develop forensic recommendations for the detection, detection and investigation of such a type of criminal offense as domestic violence and the formation of a separate forensic methodology. It has been noted that the construction of methods of investigation of domestic violence is determined by both scientific and practical needs, and therefore is a promising area of forensic science in general and forensic methodology in particular, as well as activities to detect and investigate domestic violence. The tasks and principles of building a methodology for investigating domestic violence have been defined. A forensic classification of domestic violence has been made. It has been emphasized that the developed methodology of domestic violence investigation, in order to be informative and suitable for use in law enforcement activities, should fully reflect both the features of the mechanism of domestic violence and the specifics and actual state of their detection and pre-trial investigation. It has been proposed the following structure of the methodology of domestic violence investigation: forensic classification and characteristics of domestic violence; circumstances to be clarified; opening criminal proceedings; the initial stage of the investigation; the next stage of the investigation; interaction during the investigation of domestic violence; features of tactics of carrying out separate investigative (search) actions and measures of maintenance of criminal proceedings; use of opportunities of forensic examinations. It has been noted that the peculiarities of the opening of criminal proceedings, the initial and subsequent stages of the investigation of domestic violence should be covered in the form of an algorithm of actions, taking into account tactical tasks, typical investigative versions and investigative situations

Key words: construction of methods of investigation of criminal offenses, domestic violence, formation of forensic methods, forensic classification of domestic violence, tasks, principles, structure.

Постановка проблеми. Як відзначає О.В. Александренко, останніми роками проблема домашнього насильства через його розповсюдженість і небезпеку привертає увагу світової спільноти; попередження та подолання насильства становлять значну проблему не лише для України, а й для світу в цілому. Потерпілими від злочинів, пов'язаних із домашнім насильством, стають найвразливіші й незахищені верстви населення: діти, підлітки, жінки, інваліди, люди похилого віку. Щороку від насильства в Україні страждає близько 100 тисяч осіб, 90\% з яких становлять жінки. Проте статистика відбиває лише найнебезпечніші форми домашнього насильства: вбивства, завдання шкоди здоров'ю різного ступеня тяжкості, мордування - ті, які не можна приховати від правоохоронних органів. Через свої особливості (вік жертв, їх родинна й інша залежність від насильників) цим злочинам притаманний досить високий ступінь латентності [1, с. 14].
У зв'язку із чим уважаємо актуальним питання про розроблення криміналістичних рекомендацій із виявлення, розкриття та розслідування такого різновиду кримінального правопорушення, як домашне насильство, й формування відповідної окремої криміналістичної методики.

Аналіз останніх досліджень і публікацій. Проблеми запобігання та протидії домашньому насильству досліджувалися в працях багатьох учених, зокрема таких, як Н.М. Ахтирська, А.Б. Блага, О.В. Бойко, Т.Р. Гуменникова, М.В. Євсюкова, М.О. Качинська, Н.В. Коломоєць, Т.П. Матюшкова, А.С. Метіль, С.О. Павлиш, Г.О. Христова, О.А. Шаповалова й інші. Проте більшість наукових напрацювань належать до характеристики домашнього насильства, в тому числі їхніх соціологічного й психологічного аспектів; питань адміністративно-правових засад боротьби з ним; кримінально-правової кваліфікації кримінальних правопорушень, пов'язаних із домашнім насиль- 
ством; тактики проведення окремих слідчих (розшукових) дій за участі жертв від насильницьких протиправних діянь; специфіки використання спеціальних знань під час досудового розслідування насильницьких кримінальних правопорушень. Однак не здійснювалися комплексні наукові дослідження засад та особливостей побудови й реалізації методики розслідування домашнього насильства 3 урахуванням вищезазначеного ставимо перед собою таке наукове завдання - обгрунтувати перспективність побудови методики розслідування домашнього насильства, визначити завдання, структуру й специфіку такої окремої криміналістичної методики.

Виклад основного матеріалу дослідження. Безсумнівно, насильство є однією 3 найрозповсюдженіших форм порушення прав людини. Зазвичай найбільше страждають від насильства жінки, діти й люди похилого віку. Найпоширенішим і найскладнішим для протидії $є$ домашнє насильство. Насильство в сім'ї або родині притаманне для багатьох держав, незважаючи на їхні позитивні здобутки в законодавчій, політичній і практичній сферах [2, с. 4]. Тому держава повинна використовувати всі наявні в її розпорядженні ресурси для того, щоб подолати такий негативний феномен суспільного життя, як «домашнє насильство».

Зокрема, Україна в кінці 2017 року прийняла закон України «Про запобігання та протидію домашньому насильству», який визначає організаційно-правові засади запобігання та протидії домашньому насильству, основні напрями реалізації державної політики у сфері запобігання та протидії домашньому насильству, спрямовані на захист прав та інтересів осіб, які постраждали від такого насильства [3]. Чим більше, з метою реалізації положень Конвенції Ради Європи про запобігання насильству стосовно жінок і домашньому насильству й боротьбу з цими явищами законодавець у цей же період вносить зміни до Кримінального й Кримінального процесуального кодексів України. Зокрема, Кримінальний кодекс України (далі КК України) було доповнено ст. 1261, яка передбачає склад нового кримінального правопорушення - домашнього насильства, а також розділом XIII1, який визначає перелік та особливості застосування обмежувальних заходів щодо осіб, які вчинили домашне насильство [4]. Прийняття названих законів і ратифікація Україною Конвенції Ради Європи про запобігання насильству стосовно жінок i домашньому насильству й боротьбу 3 цими явищами стало закономірним результатом боротьби нашої держави з домашнім насильством. Як зазначалося у 2017 році у відповідях Національної поліції та Міністерства соціальної політики на запити Центру інформації про права людини, більшість із заяв про домашнє насильство завершується адміністративними протоколами $\left(\begin{array}{llll}80 & 082 & \text { протоколи }\end{array}\right.$ складено у 2016 році). У випадках понад 5787 заяв про домашнє насильство ще рішення не прийнято, й тільки в понад 4\% від усіх заяв, які надійшли до Національної поліції, розпочате досудове розслідування випадків домашнього насильства. В цілому за 2016 рік у Міністерстві соціальної політики було зафіксовано 96143 звернень, з яких 821 звернення стосується дітей, 85037 звернень - від жінок, 10285 звернень про факти насильства скоєні над чоловіками [5]. Тому ратифікація названої вище Конвенції, а також криміналізація діянь, пов'язаних із домашнім насильством, $є$ одним 3 аспектів комплексного розв'язання проблеми домашнього насильства в Україні. Мало того, в такий спосіб демонструється підтримання державою домінівної позиції міжнародної спільноти щодо протидії такому явищу, яка полягає у визнанні насильства в сім'ї тяжким злочином проти особи й суспільства, що не можна вибачити або терпіти [6].

Разом із тим уважаємо, що ще одним кроком, який наблизить нашу державу до бажаного результату в боротьбі й протидії домашньому насильству, безперечно є розро- блення методики розслідування домашнього насильства. У цьому контексті зупинимося на теоретичних засадах формування таких методик, оскільки методичне забезпечення процесу розслідування та запобігання злочинів завжди було і $є$ одним із пріоритетних напрямків розвитку криміналістики. Це зумовлено тим, що саме в криміналістичній методиці як в особливому розділі цієї науки аналізується нагромаджений досвід виявлення, розслідування та запобігання злочинів, відшукуються найефективніші прийоми, методи ведення слідства в певних категоріях справ. Розроблені наукою криміналістичні рекомендації стають найважливішим інструментарієм слідчого, своєрідним алгоритмом дій у типових слідчих ситуаціях [7].

На необхідність і перспективність формування методики розслідування домашнього насильства вказують й статистичні дані про стан виявлення та розслідування кримінальних правопорушень, кваліфікованих за ст. 1261 КК України. Так, з моменту доповнення КК України статтею про домашнє насильство у 2018 році було відкрито 1029 кримінальних проваджень, за якими 783 особи визнані винними в здійсненні кримінального злочину, пов'язаного з домашнім насильством. Найбільше кримінальних злочинів, пов'язаних із домашнім насильством, було вчинено у 2018 році за такими категоріями: тяжкі й особливі тяжкі злочини - 179 випадків, навмисне вчинення легких тілесних ушкоджень -699 , навмисне вчинення тяжких тілесних ушкоджень -88 злочинів [8]. За статистичними даними офісу Генерального прокурора у 2019 році було відкрито 1068 кримінальних проваджень за фактом учинення домашнього насильства, водночас у 778 кримінальних провадженнях було повідомлено особі про підозру, а 755 - направлено до суду з обвинувальним актом. У січні - червні 2020 року відкрито 1286 кримінальних проваджень за фактом домашнього насильства, 3 яких у 1008 кримінальних провадженнях повідомлено про підозру, а 963 - направлено до суду з обвинувальним актом [9]. 3 наведеного помітно, що 3 кожним роком кількість виявлених та облікованих фактів учинення домашнього насильства збільшується. Однак кількість направлених до суду кримінальних проваджень з обвинувальним актом становить тільки близько 70-74\%, що вказує на те, що правоохоронні органи потребують рекомендацій щодо найефективніших засобів і методів виявлення та досудового розслідування досліджуваної категорії кримінальних правопорушень. Це вчергове вказує на те, що побудова методики розслідування домашнього насильства зумовлена як науковими, так і практичними потребами, а значить $€$ перспективним напрямком розвитку криміналістичної науки в цілому й криміналістичної методики зокрема, а також діяльності з виявлення, розкриття та розслідування домашнього насильства.

Формування криміналістичних методик взагалі й методики розслідування домашнього насильства зокрема $є$ важливим процесом, адже результатом такої діяльності є формулювання теоретичних основ і практичних рекомендацій щодо особливостей ефективного провадження досудового розслідування окремих злочинів. Тому розроблені методики розслідування злочинів повинні бути логічно побудованими, структурованими, лаконічними, однозначними й дієвими. 3 цією ціллю науковці, формуючи нову криміналістичну методику, у своїй діяльності повинні керуватися уніфікованими й усталеними началами [10, с. $218 ; 11$, с. 130]. Відповідно методика розслідування домашнього насильства повинна будуватися 3 урахуванням таких основних принципів формування окремої криміналістичної методики, як: наукова обгрунтованість; іiі зумовленість емпіричним матеріалом і криміналістичною класифікацією протиправних діянь, пов'язаних із домашнім насильством; залежність рекомендацій із виявлення, розкриття та розслідування правопорушень від механізму їхнього учинення; визначеність напрямку розслідування 
домашнього насильства стратегічними й проміжними тактичними завданнями, зумовленими обставинами, що підлягають 3'ясуванню, предметом доказування та складом кримінального правопорушення; типізація слідчих ситуацій розслідування та відповідних їм алгоритмів дій слідчого; етапізація досудового розслідування; програмування та алгоритмізація діяльності з виявлення, розкриття та розслідування домашнього насильства; пристосованість до потреб практики; орієнтованість на виконання поставлених перед нею завдань [10, с. 220].

Однією 3 передумов формування методики розслідування домашнього насильства $є$ формування криміналістичного визначення домашнього насильства, а також його криміналістичної характеристики шляхом здійснення криміналістичної класифікації таких кримінальних правопорушень та узагальнення відомостей про особливості, особливо закономірності, механізмів їхнього вчинення. Зокрема, пропонуємо за основу обрати тлумачення терміну «домашнє насильство», наведене в п. 3 ч. 1 ст. 1 закону України «Про запобігання та протидію домашньому насильству». Зокрема, під ним пропонується розуміти діяння (дії або бездіяльність) фізичного, сексуального, психологічного або економічного насильства, що вчиняються в сім’ї чи в межах місця проживання або між родичами, або між колишнім чи теперішнім подружжям, або між іншими особами, які спільно проживають (проживали) однією сім'єю, але не перебувають (не перебували) в родинних відносинах чи в шлюбі між собою, незалежно від того, чи проживає (проживала) особа, яка вчинила домашне насильство, в тому самому місці, що й постраждала особа, а також погрози вчинення таких діянь [3]. Зазначене трактування ширше за своїм обсягом і повніше відбиває сутність кримінальних правопорушень, пов'язаних із домашнім насильством, аніж те, що запропоноване в диспозиції ст. $126^{1}$ КК України, - навмисне систематичне вчинення фізичного, психологічного або економічного насильства щодо подружжя чи колишнього подружжя або іншої особи, з якою винний перебуває (перебував) у сімейних або близьких відносинах, що призводить до фізичних або психологічних страждань, розладів здоров'я, втрати працездатності, емоційної залежності або погіршення якості життя потерпілої особи [12].

Водночас під час здійснення криміналістичної класифікації з метою формування відповідної криміналістичної методики необхідно насамперед звернути увагу на розуміння домашнього насильства, а саме його форми й жертви (осіб, які страждають від насильства). Вказані характеристики домашнього насильства слід обрати як критерії його криміналістичної класифікації. Також під час класифікації кримінальних правопорушень, пов'язаних із домашнім насильством, варто враховувати той факт, що чимало статей КК України передбачають відповідальність за злочини, що часто вчинені стосовно членів сім'ї та є проявом різних видів сімейного насильства, через що Г.О. Христова запропонувала в КК України виділяти дві групи злочинів, що можуть бути вчинені в результаті насильницьких дій у сім'ї:

1) злочини, які можуть бути вчинені внаслідок сімейного насильства, але не враховують в основних чи кваліфікованих складах фактор насильства в сім’ї;

2) злочини, які цілеспрямовано передбачають кримінальну відповідальність за навмисні насильницькі дії з боку членів сім'ї [6, с. 52].

Відповідно, домашнє насильство можна класифікувати водночас за кримінально-правовими й криміналістичними ознаками, тобто за змішаним критерієм. Зокрема, в залежності від кримінально-правової кваліфікації слід розрізняти домашнє насильство й інші кримінальні правопорушення, пов'язані з домашнім насильством; у залежності від форми й способу вчинення домашнього насильства варто виокремлювати фізичне, сексуальне, психологічне й економічне насильство; за особистісними, в тому числі віктимологічними, характеристиками потерпілих від домашнього насильства осіб потрібно виділяти домашне насильство щодо жінок, чоловіків, дітей, осіб похилого віку, подружжя, іншого родича, осіб, які спільно проживають однією сім'єю, але не перебувають у родинних відносинах чи шлюбі тощо. 3 урахуванням наведеної криміналістичної класифікації домашнього насильства слід будувати відповідні криміналістичні методики. Як приклад насамперед, на нашу думку, необхідно сформувати міжвидову методику розслідування домашнього насильства, а вже потім видову й підвидові методики розслідування досліджуваної категорії кримінальних правопорушень. Міжвидова методика розслідування домашнього насильства насамперед буде виконувати роль наукового (теоретичного) підгрунтя побудови видових криміналістичних методик і мікрометодик. Останні ж у порівнянні $з$ першою будуть більше виконувати роль робочого інструменту розслідування вказаних протиправних діянь, до яких будуть звертатися працівники правоохоронних органів під час виявлення, планування, організації та здійснення досудового розслідування будь-яких кримінальних проявів домашнього насильства.

Щоб розроблена методика розслідування домашнього насильства була інформативною та придатною для використання в діяльності правоохоронних органів, вона повинна повною мірою відбивати як особливості механізму вчинення домашнього насильства, так і специфіку й фактичний стан діяльності з їхнього виявлення та досудового розслідування. Для цього необхідно сформувати криміналістичну характеристику таких правопорушень з урахуванням їхньої криміналістичної класифікації, а також виокремити типові слідчі ситуації для кожного $з$ етапів їхнього розслідування та відповідні їм алгоритми дій, визначити особливості планування розслідування задля встановлення всіх обставин, що підлягають з'ясуванню, та взаємодії як з правоохоронними, так і з іншими органами, установами, організаціями. Так, поряд із загальними обставинами, що підлягають з'ясуванню, слідчий повинен 3 моменту отримання інформації про вчинення домашнього насильства встановити обставини, які вказують на: кримінальний характер протиправних діянь і дозволяють правильно їх кваліфікувати, форму насильства, мотиви вчинення домашнього насильства щодо жертви, віктимологічні риси потерпілого, тривалість вчинення насильницьких дій та їхні наслідки тощо. Водночас варто пам'ятати, що за вчинення особою домашнього насильства, незважаючи на його форму, окрім властивих йому наслідків, також настають психологічні наслідки, особливість яких залежить від форми насильства та його тривалості [13, с. 13].

Поряд із цим, починаючи 3 виявлення факту вчинення домашнього насильства й упродовж його досудового розслідування, слідчий повинен застосовувати всі наявні в нього засоби й методи ге тільки для того, щоб зібрати достатню доказову базу, яка б підтверджувала причетність і вину злочинця до вчинених протиправних діянь, але й припинити його злочинну діяльність, а також забезпечити надання необхідної допомоги потерпілому. У цьому контексті особливу увагу під час формування методики розслідування домашнього насильства потрібно приділити визначенню видів, форм і порядку взаємодії. Зокрема, слід визначити алгоритм дій слідчого під час взаємодії з іншими підрозділами органів Національної поліції; закладами охорони здоров'я; департаментами соціального захисту населення; центрами соціальних служб для сім’ї, дітей і молоді; центрами соціально-психологічної допомоги; соціальними центрами матері й дитини; кризовими центрами; центрами медико-соціальної реабілітації жертв насильства в сім’ї; соціальними гуртожитками для дітей-сиріт і дітей, позбавлених батьківського піклу- 
вання; службами в справах дітей; закладами соціального захисту дітей (центрами соціально-психологічної реабілітації дітей і притулками для дітей); бюро судово-медичної експертизи управлінь охорони здоров'я; центрами/бюро 3 надання безоплатної вторинної правової допомоги; громадськими організаціями; мобільними бригадами соціально-психологічної допомоги [14, с. 34-41].

Підсумовуючи вищезазначене, вважаємо, що методика розслідування домашнього насильства повинна містити такі структурні елементи: криміналістична класифікація та характеристика домашнього насильства; обставини, що підлягають з'ясуванню; відкриття кримінального провадження; початковий етап розслідування; наступний етап розслідування; взаємодія під час розслідування домашнього насильства; особливості тактики проведення окремих слідчих (розшукових) дій і заходів забезпечення кримінального провадження; використання можливостей судових експертиз. Водночас особливості відкриття кримінального провадження, початкового й наступного етапів розслідування домашнього насильства потрібно викладати у вигляді алгоритму дій 3 урахуванням тактичних завдань, типових слідчих версій і слідчих ситуацій.
Висновки. Отже, формування методики розслідування домашнього насильства $є$ перспективним напрямком розвитку як криміналістичної методики, так і слідчої діяльності з виявлення, розкриття та розслідування вказаних правопорушень. Указану методику слід будувати 3 урахуванням таких основних принципів формування окремої криміналістичної методики, як: наукова обгрунтованість; ії зумовленість емпіричним матеріалом і криміналістичною класифікацією протиправних діянь, пов'язаних із домашнім насильством; залежність рекомендацій із виявлення, розкриття та розслідування правопорушень від механізму їх учинення; визначеність напрямку розслідування домашнього насильства стратегічними й проміжними тактичними завданнями, зумовленими обставинами, що підлягають 3'ясуванню, предметом доказування та складом кримінального правопорушення; типізація слідчих ситуацій розслідування та відповідних їм алгоритмів дій слідчого; етапізація досудового розслідування; програмування та алгоритмізація діяльності з виявлення, розкриття та розслідування домашнього насильства; пристосованість до потреб практики; орієнтованість на виконання поставлених перед нею завдань.

\section{ЛITEPATУРA}

1. Александренко О.В. Сучасні можпивості судових експертиз і напрями використання спеціальних знань при розслідуванні злочинів, пов'язаних з домашнім насильством. Теорія і практика судової експертизи і криміналістики : збірник матеріалів III-ої Всеукраїнської науково-практичної конференції, м. Київ, 27 лютого 2020 року. Київ-Маріуполь, 2020. С. 14-18.

2. Методичні рекомендації щодо запобігання та протидія насильству : лист Міністерства освіти і науки України від 18 травня 2018 p. № 1/11-5480. Київ, 2018. 86 с.

3. Про запобігання та протидію домашньому насильству : Закон України від 07 грудня 2017 р. № 2229-VIII / Верховна Рада України. Відомості Верховної Ради України. 2018. № 5. Стор. 32. Ст. 35.

4. Про внесення змін до Кримінального та Кримінального процесуального кодексів України з метою реалізації положень Конвенції Ради Європи про запобігання насильству стосовно жінок і домашньому насильству та боротьбу з цими явищами : Закон України від 06 грудня 2017 р. № 2227-VIII / Верховна Рада України. Відомості Верховної Ради України. 2018. № 5. Стор. 26. Ст. 34.

5. Нацполіція розслідує лише 4\% звернень про домашнє насильство. Закон і Бізнес. URL: https://zib.com.ua/ua/print/127387nacpoliciya rozslidue lishe 4 zvernen pro domashne nasilstvo.html (дата звернення: 07.07.2020).

6. Христова Г.О. Освітній курс «Розгляд судами справ, пов'язаних з насильством в сім'ї» : методичний посібник. Київ : ТОВ «Компанія «BAITE», 2011. 86 c.

7. Щур Б.В. Окремі криміналістичні методики: проблеми визначення та принципи формування. Радник : Український юридичний портал. URL: http://radnuk.info/statti/555-kruminalist/15015-2011-01-21-04-26-09.html (дата звернення: 07.07.2020).

8. За домашнє насильство - за ґрати: як в Україні та світі боряться зі знущанням у родині. ZIK. LIVE. URL: https://zik.ua/news/2019/11/22 za_domashnie_nasylstvo_za hraty_yak v ukraini ta sviti boriatsia zi znushchanniam_u rodyni 946146 (дата звернення: 07.07.2020)

9. Статистична інформація. Генеральна прокуратура України. URL ${ }^{2}$ https://old.gp.gov.ua/ua/statinfo.html (дата звернення: 07.07.2020).

10. Пчеліна О.В. Принципи та завдання побудови методики розслідування злочинів у сфері службової діяльності. Юридичний науковий електронний журнал. 2014. № 6. C. 217-220. URL: http://www.lsej.org.ua/6_2014/60.pdf (дата звернення: 07.07.2020).

11. Пчеліна О.В. Теоретичні засади формування та реалізації методики розслідування злочинів у сфері службової діяльності : дис. ... д-ра юрид. наук : 12.00.09. Харків, 2017. 568 с.

12. Кримінальний кодекс України : Закон України від 05 квітня 2001 р. № 2341-ІІІ / Верховна Рада України. Відомості Верховної Ради України. 2001. № 25. Ст. 131.

13. Гуменникова Т.Р., Метіль А.С. Характеристика домашнього насильства: відповідальність і наслідки. Науковий вісник Міжнародного гуманітарного університету. Серія: Юриспруденція. 2018. № 35. Том 2. С. 12-14.

14. Віллс Е., Калашник О.О. Протидія домашньому насильству : практичний посібник для поліцейських : Проєкт Ради Європи «Боротьба з насильством щодо жінок та дітей в Україні». 75 c. URL: https://rm.coe.int/cvavgu-jan2018-4-ua-web/16807874e0 (дата звернення: 08.07.2020) 
Удк 343.1

DOI https://doi.org/10.32782/2524-0374/2020-4/80

\title{
ОКРЕМІ ПИТАННЯ ІНСТИТУТУ СЛІДЧОГО СУДДІ У КРИМІНАЛЬНОМУ ПРОВАДЖЕННІ
}

\section{SEPARATE ISSUES OF THE INSTITUTE OF INVESTIGATIVE JUDGE IN CRIMINAL PROCEEDINGS}

\author{
Сіренко О.В., к.ю.н., \\ доцент кафедри кримінального процесу та криміналістики \\ Університет державної фіскальної служби Украӥни \\ Мурза I.B., студентка VI курсу магістратури \\ Навчально-науковий інститут права \\ Університету державної фіскальної служби Украӥни
}

Стаття присвячена дослідженню окремих питань функціонування інституту слідчого судді у кримінальному провадженні, який вважається однією з найактуальніших новел юридичної науки. Діяльність слідчого судді має досить суттєве значення в контексті додержання та гарантування захисту прав та законних інтересів учасників кримінального процесу.

У статті проаналізовано інститут слідчого судді, сформовано основні теоретичні підходи науковців щодо визначення поняття слідчого судді, його сутності та значення у кримінальному провадженні.

Мета статті - розглянути окремі питання інституту слідчого судді у кримінальному провадженні, визначивши повноваження і функції слідчого судді.

Особливу увагу приділено визначенню правового статусу слідчого судді та порядку його набуття. Схарактеризовано особливості правового регулювання діяльності слідчого судді як суб'єкта, що реалізує функцію судового контролю в кримінальному процесі. Проаналізовано наявні у кримінальній процесуальній доктрині позиції різних науковців щодо самої класифікації повноважень слідчого судді. Акцентовано увагу на важливості формування ефрективної та дієвої нормативно-правової бази щодо врегулювання здійснення слідчим суддею своїх повноважень.

На практиці слідчі судді стикаються з проблемою недосконалості кримінального процесуального законодавства, тому нормативноправове регулювання діяльності слідчого судді та здійснення ним контролю за додержанням прав, свобод та інтересів учасників кримінального провадження потребують вдосконалення та подальшого дослідження науковцями-процесуалістами. Висвітлено основні позиції науковців щодо шляхів удосконалення чинного кримінального процесуального законодавства. Висловлені власні пропозиції стосовно цього питання.

Ключові слова: кримінальне провадження, судовий контроль, досудове розслідування, слідчий суддя, повноваження слідчого судді.

The article is devoted to the study of certain issues of the functioning of the Institute of investigative judge in criminal proceedings, which is considered one of the most relevant novels of legal science. The activity of an investigating judge is very important in the context of observing and ensuring the protection of the rights and legitimate interests of participants in criminal proceedings.

The article analyzes the Institute of investigative judge, formed the main theoretical approaches of scientists regarding the definition of the concept of investigative judge, its essence and meaning in criminal proceedings.

The purpose of the article is to consider certain issues of the institution of an investigating judge in criminal proceedings, determining the powers and functions of an investigating judge.

Special attention is paid to determining the legal status of an investigative judge and the procedure for acquiring it. The article describes the features of legal regulation of the investigative judge as a subject that implements the function of judicial control in criminal proceedings. The article analyzes the positions of various scientists in the criminal procedural doctrine regarding the classification of the powers of an investigating judge. Attention is focused on the importance of forming an effective and efficient legal framework for regulating the exercise of investigative judge's powers.

In practice, investigating judges face the problem of imperfection of criminal procedure legislation, so the legal regulation of the investigative judge and his control over the observance of the rights, freedoms and interests of participants in criminal proceedings require improvement and further research by process scientists. The main positions of scientists on ways to improve the current criminal procedural legislation are highlighted. Expressed their own proposals on this issue.

Key words: criminal proceedings, judicial control, pre-trial investigation, investigating judge, powers of the investigating judge.

Основним призначенням слідчого судді є здійснення судового захисту прав і законних інтересів осіб, які беруть участь у кримінальному процесі, та забезпечення законності провадження на стадії досудового розслідування. Попри те, що інститут слідчого судді є одним 3 найбільш детально регламентованих інститутів у системі чинного законодавства, багато питань залишаються невирішеними, зокрема щодо визначення повноважень та функцій слідчого судді.

Дослідженню окремих проблем інституту слідчого судді присвячені роботи Ю.М. Грошевого, І.В. Іваненко, В.Т. Маляренка, В.Д. Бринцева, В.В. Руденко, Ю.П. Аленіна, С.П. Банах, Ю.В. Скрипіної, А.Р. Туманянц та інших.

Роль інституту слідчого судді багатоаспектна і складається головним чином із забезпечення законності кримінального провадження, захисту конституційних прав та свобод осіб, здійснення судового контролю за дотриманням прав людини, шляхом забезпечення змагальності в досудовому провадженні.
Слідчий суддя $є$ ключовою фігурою у кримінальному провадженні, оскільки його основна роль полягає у захисті прав та свобод осіб, які беруть участь у кримінальному провадженні, та у здійсненні судового контролю за законністю провадження.

На думку Ю.В. Скрипіної, слідчим суддею є суддя, що «забезпечує законність і обгрунтованість обмеження основоположних прав та свобод особи на досудовому розслідуванні у кримінальному провадженні, до повноважень якого належить прийняття рішень про застосування заходів процесуального примусу, а також проведення слідчих та інших кримінально-процесуальних дій, що обмежують права людини, розгляд скарг на дії (бездіяльність) та рішення слідчого або прокурора» $[1$, с. 7$]$.

Схожою є і думка А.P. Туманянца, який зазначає, що слідчий суддя, як новий суб'єкт кримінального судочинства України, є носієм судової влади. До його компетенції належить забезпечення недопущення протизаконного і необгрунтованого обмеження прав та свобод людини на 
досудовому провадженні шляхом превенції, тобто на їх відновлення у разі порушення [2, с. 294].

Як вважають науковці, «потенціал слідчого судді визначається такими чинниками: 1) організаційна, матеріальна та процесуальна самостійність від органів державної влади, від учасників кримінального провадження, відтак він не відповідає за стан боротьби зі злочинністю; 2) здійснення своїх повноважень постійно, оскільки може обиратися на тривалий строк (згідно з ч. 7 ст. 21 Закону України «Про судоустрій і статус суддів» - на строк не більше трьох років з можливістю повторного переобрання), що гарантує йому високу фаховість та значний досвід здійснення судового контролю; 3) здійснення ним повноважень із судового контролю враховується під час розподілу судових справ і має перевагу (ч. 8 ст. 21 Закону України «Про судоустрій і статус суддів»), а тому він також володіє і часовим ресурсом, що має позитивний вплив на якість судового контролю; 4) відповідно до ч. 1 ст. 76 КПК суддя, який брав участь у кримінальному провадженні під час досудового розслідування, не має права брати участі у цьому ж провадженні в суді першої, апеляційної і касаційної інстанцій, що робить його незалежним і дозволяє здійснювати свої повноваження якомога якісніше; 5) саме суд уповноважений вирішувати різноманітні правові спори, і тому остаточне його рішення, як нейтрального арбітра, має задовольнити як органи державної влади, так і суб'єктів кримінального провадження Наведені якості не притаманні ані відомчому контролю, ані прокурорському нагляду за законністю та обгрунтованістю рішень, дій та бездіяльності органів досудового розслідування [3, с. 517].

Відповідно до п. 18 ч. 1 ст. 3 КПК України слідчий суддя - це суддя суду першої інстанції, до повноважень якого належить здійснення у порядку, передбаченому цим Кодексом, судового контролю за дотриманням прав, свобод та інтересів осіб у кримінальному провадженні, та у випадку, передбаченому ст. 247 КПК, - голова чи за його визначенням інший суддя Апеляційного суду Автономної Республіки Крим, апеляційного суду області, міст Києва та Севастополя. Слідчий суддя (слідчі судді) у суді першої інстанції обирається зборами суддів зі складу суддів цього суду і у суді першої інстанції обирається зборами суддів зі складу суддів цього суду [4].

При цьому в законі жодних вимог чи обмежень до кандидата на виконання функцій слідчого судді не встановлюється мінімальної чи максимальної кількості слідчих суддів у певному суді залежно від загальної кількості суддів цього суду, не передбачається жодної залежності набуття особою цього статусу відносно спеціалізації цього судді у певній категорії справ. Також закон не встановлює і не регламентує порядок висунення претендентів на цей статус, порядок скликання і проведення зборів суддів, їх кворум, необхідну кількість голосів за обрання особи; щодо строку, на який обирається слідчий суддя, тощо [5].

На думку Я.О. Леон, особа, яка претендує на посаду слідчого судді, повинна мати принаймні два роки стажу роботи за спеціальністю із досвідом розгляду кримінальних справ, має бути ознайомлена 3 міжнародними стандартами прав та свобод людини і практикою Європейського суду з прав людини. Така особа повинна володіти моральними і діловими якостями, що відповідають таким критеріям, як оперативність, неупередженість, принциповість та професійність у прийнятті рішень у кримінальних справах.

Вищезазначені вимоги до слідчого судді мають бути встановлені на законодавчому рівні шляхом внесення змін та доповнень до Закону України «Про судоустрій і статус суддів». Водночас науковець пропонує розробити підзаконний акт - Положення про слідчого суддю, в якому порядок відбору кандидатів і обрання на посаду слідчого судді, вимоги до таких осіб та регламентована процедура реалізації повноважень слідчого судді на стадії досудового розслідування мають бути чітко визначені [6].

Крім того, як відмічають науковці, високий рівень довіри до слідчого судді як до гаранта прав та свобод людини повинен підтримуватися певними характеристиками судді, що мають важливе значення під час його обрання на посаду слідчого судді [7, с. 61].

Відповідно до ч. 7 ст. 21 Закону України «Про судоустрій і статус суддів», до обрання слідчого судді відповідного суду його повноваження здійснює найстарший за віком суддя цього суду [8].

На думку науковців та практиків, це положення не досить вдало урегульоване, адже 3 огляду на вказане можна сказати, що найстарший за віком суддя в окремому суді до певної міри $є$ заручником ситуації й буде змушений виконувати обов'язки слідчого судді у разі невирішення питання про обрання таких осіб незалежно від свого бажання виконувати ці функції, а також без урахування того, чи довірили б саме йому його колеги судді виконувати ці функції. Відмовитися в цій ситуації від виконання цих функцій найстарший за віком суддя не може, оскільки відсутність у суді слідчого судді з часу набрання чинності новим КПК України може паралізувати хід досудового розслідування по кримінальних провадженнях. Крім цього, така відмова може бути розцінена як ухилення від здійснення правосуддя, що може мати наслідком притягнення судді до дисциплінарної відповідальності [1, с. 12]. Тому слід взяти до уваги Положення про процедуру та умови призначення слідчих суддів [9] Республіки Молдови, одним із критеріїв відбору на посаду слідчого судді якого є згода судді.

Відповідно до законодавства кількість слідчих суддів визначається окремо для кожного суду зборами суддів цього суду. Наявність лише одного обраного зборами чи визначеного за віком слідчого судді є недоцільною. Таких осіб має бути щонайменше двоє 3 метою забезпечення безперервності відправлення правосуддя 3 питань, що належать до компетенції слідчого судді. Адже у разі хвороби слідчого судді, його відпустки, задоволення обгрунтованого відводу слідчому судді тощо жодний інший суддя цього суду без обрання його зборами суддів не зможе автоматично замінити відсутнього слідчого суддю [5, c. $100-101]$

Ми погоджуємось 3 тим, що чітке правове регулювання правового статусу слідчого судді, порядку обрання гарантуватиме незалежність і неупередженість його рішень, що забезпечить надійний захист прав та інтересів учасників кримінального провадження.

Значна увага в науковій літературі приділяється і повноваженням слідчого судді.

Зокрема, Н.3. Рогатинська виділяє три групи повноважень слідчого судді: 1) повноваження щодо застосування заходів процесуального примусу на досудовому розслідуванні; 2) повноваження слідчого судді під час розгляду скарг на дії і рішення особи, що здійснює дізнання, слідчого чи прокурора; 3) повноваження слідчого судді під час проведення слідчих дій, що обмежують конституційні права громадян [10, с. 286].

Натомість Н.П. Сиза розділила повноваження слідчого судді на п'ять груп залежно від змісту і характеру питань, вирішення яких віднесено законом до компетенції слідчого судді: 1) вирішення питань про застосування заходів забезпечення кримінального провадження; 2) вирішення питань проведення слідчих (розшукових) дій; 3) вирішення питань про проведення негласних слідчих (розшукових) дій; 4) розгляд скарг на рішення, дії чи бездіяльність слідчого або прокурора під час досудового розслідування; 5) вирішення інших процесуальних питань, що потребують неупередженого розгляду [11].

С.В. Нагачевський пропонує повноваження слідчого судді класифікувати за предметним критерієм на такі 
крупи: 1) дозвільні повноваження (пов'язані із вирішенням питань про проведення слідчих (розшукових) дій, які обмежують конституційні права особи (ч. 2 ст. 166, ч. 2 ст. 234 , ч. 2 ст. 237 , ч. 5 ст. 240 КПК та ін.); 2) повноваження із забезпечення законності та обгрунтованості застосування заходів кримінально-процесуального примусу; 3) повноваження зі здійснення судового контролю (у вузькому значенні); 4) повноваження із забезпечення доказів у кримінальному провадженні; 5) повноваження, пов'язані із міжнародним співробітництвом; 6) допоміжні повноваження [12].

Як бачимо, класифікації повноважень слідчого судді $\epsilon$ досить різноманітними, і кожна заслуговує на увагу. Слід також зазначити, що, реалізуючи свої повноваження, він приймає конкретні процесуальні рішення, яким притаманні ознаки владних актів.

Як зазначають науковці, владні повноваження слідчого судді поширюються на учасників кримінального провадження, щодо яких необхідно провести певні процесуальні дії, які передбачені законом. Кожний із таких учасників кримінального провадження має підкорятися вимогам слідчого судді, а його рішення мають обов'язковий характер для відповідних учасників [12].

Загалом питання функцій слідчого судді $є$ досить суперечливим. Але, як вже було зазначено вище, відповідно до п. 18 ч. 1 ст. 3 КПК України, його основоположною функцією є судовий контроль за збереженням прав, свобод, інтересів осіб у кримінальному провадженні. Ця функція складається 3 декількох окремих напрямів, які залежно від конкретних завдань відрізняються за суб'єктним складом осіб, що беруть участь у кримінальному провадженні, процесуальною формою, засобами доказування, а також рішенням слідчого судді [13, с. 214].

Норми, які визначають повноваження слідчого судді щодо здійснення судового контролю, розміщені по різних главах КПК, що ускладнює, на думку фахівців, яку i ми розділяємо, ознайомлення 3 ними. Закріплення порядку прийняття слідчим суддею процесуальних рішень та процедура їх оскарження у багатьох статтях КПК також викликає певні складнощі під час їх вивчення та не дає повного уявлення про процесуальний статус цього суб'єкта кримінального провадження [14, с. 119]. Саме тому це питання потребує чіткого законодавчого регулювання на рівні окремої глави Кримінального процесуального кодексу.

Здійснюючи аналіз наукових позицій, ми погоджуємось 3 думкою щодо необхідності доповнення Кримінального процесуального кодексу окремою главою, яка буде визначати повноваження слідчого судді у здійсненні ним судового контролю у кримінальному провадженні, чітко регламентувати статус слідчого судді з визначенням його службових прав та обов'язків, повноважень та функцій, а також порядку обрання на посаду слідчого судді і вимоги до нього.

\section{ЛITEPATУРA}

1. Скрипіна Ю.В. Слідчий суддя в системі кримінально-процесуальної діяльності (порівняльно-правове дослідження) : дис. ... канд. юрид. наук : 12.00.09 / Національна юридична академія України ім. Я. Мудрого. Харків, 2008. 219 с.

2. Туманянц А.Р. Інститут слідчого судді за новим Кримінальним процесуальним кодексом України. Університетські наукові записки. 2013. № 1(45). С. 293-299.

3. Кушпіт В.П., Цилюрик І.І. Про слідчого суддю як суб'єкта здійснення судового контролю. Вісник Національного університету «Львівська політехніка». Серія: Юридичні науки : збірник наук. праць. 2016. № 850. С. 513-520.

4. Кримінальний процесуальний кодекс України: Кодекс від 13.04.2012 р. № 4651-VI. Відомості Верховної Ради України. 2013. № 9-10, № 11-12, № 13. Ст. 88.

5. Омельчук Л.В., Клімковська Х.І. Процесуальний статус слідчого судді в кримінальному процесі України. Вісник Академії адвокатури України. 2014. Т. 11, № 3. С. 98-106.

6. Леон Я.О. Функції слідчого судді у кримінальному процесі. Право.иа. 2017. № 1. С. 159-163.

7. Бондюк А.Ф. Процесуальні основи статусу слідчого судді у кримінальному провадженні : дис. .... канд. юрид. наук : 12.00.09/ Національна академія внутрішніх справ. Київ, 2017. 241 с.

8. Про судоустрій і статус суддів: Закон України від 02.06.2016 № 1402-VIII. Дата оновлення: 11.03.2020. URL: https://zakon.rada.gov.ua/ laws/show/1402-19 (дата звернення: 01.06.2020).

9. Об утверждении Положения о процедуре и условиях назначения судей по уголовному преследованию. Выписка от 12.02 .2013 р. № 145/6. Monitorul Oficial. 2013. № 96. Ст. 516.

10. Рогатинська Н.3. Слідчий суддя: постановка та дослідження проблеми в Україні. Право і суспільство. 2014. № 1-2. С. $284-287$.

11. Сиза Н.П. Повноваження слідчого судді щодо здійснення судового контролю у кримінальному процесі України. Часопис Національного університету «Острозька академія». 2012. № 2(6).

12. Нагачевський С.В. Функції слідчого судді під час здійснення досудового розслідування. Науковий вісник Львівського державного університету внутрішніх справ. 2015. № 3. С. 301-310.

13. Скибіцький Б.А. Повноваження слідчого судді у кримінальному провадженні. Вісник Львівського торговельно-економічного університету. Серія: Юридичні науки. 2016. Вип. 3. С. 209-216.

14. Каткова Т.В. Проблемні аспекти викладання навчальної дисципліни «Кримінальний процес» за КПК України 2012 року. Актуальні проблеми застосування нового кримінального процесуального законодавства України та тенденції розвитку криміналістики на сучасному етапі: м-ли Всеукр. наук. - практ. конфр. (Харків, 5 жовт. 2012 р.). Харків : ХНУВС, 2012. С. 117-120. 


\title{
ОСОБЛИВОСТІ ВЗАСМОДІЇ СЛІДЧОГО З ОПЕРАТИВНИМИ ПРАЦВНИКАМИ НА ПОЧАТКОВОМУ ЕТАПІ ДОСУДОВОГО РОЗСЛІДУВАННЯ СЕКСУАЛЬНИХ УБИВСТВ
}

\author{
ORGANIZATION OF INTERACTION OF INVESTIGATOR AND OPERATUVE BODIES \\ DURING THE PRE-TRIAL INVESTIGATION OF SEXUAL MURDERS
}

\author{
Січковська І.В., к.ю.н., \\ доцент кафедри кримінального процесу та криміналістики \\ факультету № 1 \\ Інститут підготовки фахівиів для підрозділів Національної поліиії \\ Львівського державного університету внутрішніх справ
}

Наукову статтю присвячено висвітленню питань взаємодії слідчого з іншими органами та підрозділами під час досудового розслідування кримінального провадження про бандитизм. Проведеним аналізом встановлено, що поняття «взаємодія» розглядається з позиції науки кримінального процесу та криміналістики. Доведено, що взаємодією у широкому розумінні є спільна діяльність слідчого з іншими органами, спрямована на реалізацію завдань кримінального провадження. Встановлено, що найбільш ефективними для слідчого в процесі взаємодії виступають оперативні підрозділи. Проведено характеристику процесуальної та непроцесуальної фрорми взаємодії слідчого та оперативних працівників, що регламентуються нормами Кримінального процесуального Кодексу України (далі - КПК України) та підзаконними нормативно-правовими актами України. Зроблено акцент, що відповідна класифікація пов'язана із закріпленням або відсутністю закріплення у кримінально-процесуальному законі підстав та порядку певного виду взаємодії. Наголошено на умовах ефективності взаємодії слідчого з оперативними підрозділами. Визначено, що важливим підрозділом в процесі взаємодії з оперативними працівниками є нещодавно створене в системі Національної поліції України Управління стратегічних розслідувань. Наголошено на доцільності оперативно-розшукового забезпечення процесу розслідування злочинів, що є невіддільною частиною взаємодії слідчого та оперативних підрозділів під час розслідування бандитизму. Встановлена обов'язковість залучення до проведення огляду місця події за фрактами бандитизму спеціалістів, серед яких важливу роль відведено криміналісту, зброєзнавцю та судовому медику. Доведено, що неабияку роль в організації взаємодії відіграє громадськість. Окремі громадяни можуть залучатися до конфіденційного співробітництва та до проведення окремих слідчих (розшукових) дій шляхом залучення для засвідчення фракту їх проведення понятих як незаінтересованих осіб. Встановлено важливість взаємодії слідчого із засобами масової інформації (далі - ЗМІ) шляхом доведення до населення причин та умов, що сприяють вчиненню кримінальних правопорушень, а також публікацій суспільного резонансу в результаті бандитизму.

Ключові слова: взаємодія, слідчий, вбивство, досудове розслідування, кримінальне провадження.

The scientific article is devoted to covering the issues of the investigator's interaction with other bodies and subdivisions during the pretrial investigation of the criminal proceedings on banditry. The analysis shows that the concept of interaction is considered from the standpoint of the science of criminal procedure and criminology. It is proved that the interaction in a broad sense is the joint activities of the investigator with other bodies aimed at the implementation of the tasks of criminal proceedings. It is established that the most effective for the investigator in the course of interaction are operational units. A description of the procedural and non-procedural form of interaction between the investigator and operatives, which are regulated by the Criminal Procedure Code of Ukraine (hereinafter - the CPC of Ukraine) and bylaws of Ukraine. Emphasis is placed on the fact that the relevant classification is related to the enshrinement or lack of enshrinement in the criminal procedure law of the grounds and procedure for a particular type of interaction. Emphasis is placed on the conditions of effective interaction of the investigator with operational units. Identified as an important unit in the process of interaction with operational staff - the Office of Strategic Investigations, which is newly created in the system of the National Police of Ukraine. Emphasis is placed on the expediency of operative-investigative support of the criminal investigation process, which is an integral part of the interaction between the investigator and operative units during the investigation of banditry. It is obligatory to involve specialists in the inspection of the scene on the facts of banditry, among which an important role is given to a forensic scientist, a weapons expert and a forensic doctor. It is proved that the public plays an important role in the organization of interaction. Individual citizens may be involved in confidential cooperation and in the conduct of certain investigative (search) actions, by involving witnesses to certify the fact of their conduct, as disinterested persons - witnesses. The importance of the investigator's interaction with the mass media (hereinafter - the media), by bringing to the public the causes and conditions that contribute to the commission of criminal offenses, as well as the publication of public response as a result of banditry.

Key words: interaction, investigator, murder, pre-trial investigation, criminal proceedings.

Постановка проблеми. Реалізація завдань кримінального провадження, пов'язаних $з$ досудовим розслідуванням, зумовлює необхідність у злагодженій спільній роботі слідчого з іншими підрозділами під час вирішення конкретних практичних завдань, в тому числі під час розслідування сексуальних вбивств.

Розглядаючи питання взаємодії слідчого 3 оперативними підрозділами під час досудового розслідування, не можна оминути праці М.М. Багрія, В.П. Бахіна, Р.С. Бєлкіна, О.О. Волобуєвої, В.Г. Гончаренка, М.А. Погорецького, Н.С. Карпова, Б.С. Лукянчикова, В.М. Махова, М.А. Селіванова та інших, які в різні часи займались проблемними питаннями цього інституту кримінального процесу та криміналістики. Однак на цей час є необхідність у дослідженні питань, що стосуються взаємодії підрозділів досудового розслідування 3 оперативними підрозділами власне під час досудового розслідування такого виду кримінального правопорушення, як бандитизм сексуальних вбивств. Тому метою нашого дослідження є визначення кола суб'єктів та з'ясування їхньої ролі в процесі взаємодії зі слідчим під час досудового розслідування бандитизму.

Виклад основних положень. Поняття взаємодії досліджувалося багатьма вченими 3 позиції науки криміналістики, проте найбільш вдале визначення цього поняття, на нашу думку, наводить Р.С. Бєлкін, який вважає, що взаємодія - це одна із форм організації розслідування злочинів, що грунтується здебільшого на законі співробітництва слідчого з іншими підрозділами, погодженого щодо мети, місця та часу, спрямована на повне та швидке розкриття злочинів, всебічне розслідування кримінального провадження і розшуку злочинців, що переховуються, викрадених цінностей та інших об'єктів, істотних для розслідування [1, с. 31$]$.

Основними формами взаємодії слідчого й працівників оперативного підрозділу є: 1) створення й діяльність слідчо-оперативних груп; 2) розроблення спільного плану розкриття злочину; 3) обговорення процесу розслідування (доцільно запрошувати експертів, спеціалістів, досвідчених оперативних і слідчих працівників); 4) взаємний 
обмін інформацією; 5) доручення слідчого щодо проведення слідчих (розшукових) дій та негласних слідчих (розшукових) дій відповідним оперативним підрозділам (ст.ст. 40, 41 КПК України); 6) розкриття вбивств за гарячими слідами; 7) спільний аналіз причин і умов, що сприяють учиненню злочину, та обговорення профілактичних заходів; 8) спільне використання техніки, засобів зв'язку і транспорту, що мають у своєму розпорядженні оперативні підрозділи.

Загалом взаємодія має теоретичні та правові підстави. Теоретичними підставами взаємодії $є$ положення, які пояснюють іiі сенс і значення, їх усвідомлення слідчими i працівниками оперативних підрозділів. Це робить взаємодію більш осмисленою та цілеспрямованою, сприяючи iï законності й ефективності, дозволяє відповісти на питання, 3 якою метою здійснюється взаємодія; чому вона можлива; чим зумовлена ії необхідність?

Такими підставами є: а) спільність мети і завдань оперативних підрозділів та слідчого - лише об'єднуючи свої зусилля, органи досудового слідства і оперативні підрозділи зможуть ефективно їх вирішити; б) однакова юридична сила процесуальних актів працівників оперативних підрозділів та слідчого - протоколи слідчих дій, виконаних працівниками оперативних підрозділів за дорученням слідчого, мають таке ж доказове значення, як і протоколи, складені слідчим.

Правовими ж підставами взаємодії є: приписи законів (КПК, Законів України «Про оперативно-розшукову діяльність», «Про Національну поліцію», «Про Службу безпеки України», «Про організаційно-правові основи боротьби з організованою злочинністю» тощо) та підзаконних нормативних актів, зокрема актів обмеженого використання різного ступеня конфіденційності.

Науковцями описані блискучі приклади ефективного співробітництва слідчих і оперативних працівників, у результаті якого розкривалися вкрай складні сексуальні вбивства. Так, 29.09.1994 року злочинець I. у вестибюлі житлового будинку напав на неповнолітнього К. і вчинив щодо нього жорстокі й протиприродні сексуальні дії, видаливши в дитини близько 9 метрів кишечника. 3 місця події він зник і незабаром виїхав в інше місто. Однак у жовтні 1994 року до карного розшуку надійшла оперативна інформація про підозрюваного. 3 цією інформацією ознайомили слідчого, був розроблений план спільних слідчих (розшукових) дій. У результаті подальших спільних дій були отримані незаперечні докази вини I., який був затриманий, арештований, повністю викритий у злочинних діях стосовно К. і в низці інших тяжких злочинів [2, с. 137].

Здійснений нами аналіз практики розслідування сексуальних убивств дозволив виявити основні проблеми, які найчастіше виникають під час взаємодії суб'єктів розслідування.

Слідчо-оперативну групу часто очолює слідчий, який має незначний досвід слідчої роботи або раніше не розслідував злочини проти життя та статевої свободи. Це призводить до того, що слідчий перебуває в пасивному очікуванні появи особи, якій буде підстава повідомити про підозру.

Запорукою якнайшвидшого розкриття сексуального вбивства $€$ технічно оснащена слідчо-оперативна група, укомплектована кваліфікованими працівниками. Також вкрай необхідною умовою успішної роботи такої групи $\epsilon$ розслідування злочину з моменту початку кримінального провадження до передання його до суду.

Під час розслідування повинні спільно перевірятися всі слідчі і оперативні версії. Вивчена нами практика довела, що часто оперативні працівники не погоджуються 3 окремими слідчими версіями або вважають їх на певному проміжку розслідування відпрацьованими. Однак оперативна перевірка найчастіше результативна у разі кількаразових оперативних заходів у версіях, які відпра- цьовуються. Інколи навпаки, слідчий перевіряє на причетність особу, яка для карного розшуку інтерес не становить.

Найбільш цікавою формою взаємодії слідчого й оперативного підрозділу є спільна робота, спрямована на розшук та затримання злочинця за гарячими слідами [3, с. 492-493].

До розшуку злочинця за гарячими слідами найчастіше відносять: а) переслідування; б) оточення; в) організацію засідок і загороджувальних заходів [4, с. 132-136].

Нині поняття розкриття злочину за гарячими слідами значно розширилося. До нього входять організаційні заходи, використання криміналістичних обліків, громадськості, проведення невідкладних слідчих (розшукових) дій, експресдослідження тощо. Навряд чи можна погодитися з тим, що це, крім іншого, складання планів, а також уміння професійно орієнтуватися в складній слідчій ситуації [3, с. 496-500].

Автори підручників 3 криміналістики вважають, що під розкриттям злочину за гарячими слідами варто розуміти встановлення винного, його затримання в найкоротший термін, який не повинен перевищувати три доби. Це організаційний захід, комплекс слідчих дій і оперативнорозшукових заходів [5, с. 360-361].

На думку О.Л. Протопопова, можливі різні варіанти розкриття вбивства за гарячими слідами: 1) безпосереднє переслідування злочинця ще до прибуття слідчо-оперативної групи; 2) встановлення підозрюваного за оперативною інформацією; 3) одержання інформації про злочинця в результаті огляду місця події та експрес-досліджень; 4) інші слідчі дії й оперативно-розшукові заходи [2, с. 144].

Ми зробили висновок, що ефективна взаємодія слідчого та працівників оперативного підрозділу можлива лише за умови високого професіоналізму всіх учасників слідчо-оперативної групи, достатнього рівня інформаційного забезпечення та швидкості дій. Підсумком роботи за гарячими слідами повинні стати одержання й закріплення процесуальних доказів. Без цього встановлення злочинця та його затримання безрезультатно.

Проведене нами опитування слідчих і працівників кримінальної поліції підтвердило, що основними формами взаємодії слідчого й оперативного підрозділу на початковому етапі розслідування сексуальних убивств $\epsilon$ такі: створення й діяльність слідчо-оперативних груп $(100 \%)$; розроблення спільного плану розкриття злочину $(95 \%)$; обговорення процесу розслідування (доцільно запрошувати експертів, спеціалістів, досвідчених оперативних і слідчих працівників) (83\%); взаємний обмін інформацією (95\%); виконання оперативним підрозділом доручень слідчого в порядку ст.ст. 40, 41 КПК України $(87 \%)$; розкриття вбивств за «гарячими слідами» (12\%); спільний аналіз причин і умов, що сприяли вчиненню злочину, та обговорення профілактичних заходів (4\%).

А найбільш перспективними формами такої взаємодії є: участь у слідчо-оперативній групі (бригаді) (98\%); особисті контакти $(100 \%)$; спільне планування дій $(88 \%)$; спільне висунення версій та робота над їх перевіркою (87\%); спільні офіційні засідання у керівництва підрозділу (38\%); обмін інформацією (слідчою та оперативною) (94\%); спільне проведення слідчих дій (88\%).

Результативна взаємодія між слідчим і оперативним підрозділом зумовлена такими чинниками: слідчий і працівники кримінальної поліції повинні розуміти сутність сексуальних убивств, володіти знаннями в сфері судової медицини, сексопатології й судової психіатрії; суб'єкт розслідування повинен знати особливості проведення огляду місця події, інших слідчих (розшукових) дій, а також негласних слідчих (розшукових) дій, спрямованих на пошук і фіксацію відомостей про особу, яка вчинила сексуальне вбивство; перевірка всіма членами слідчооперативної групи спільно висунутих версій у вбивстві.

На нашу думку, особливості взаємодї̈ слідчого й оперативного підрозділу в прочесі розслідування сексуальних вбивств розкриваються під час: 
1. Планування та використання результатів негласних слідчих (розшукових) дій у прочесі розслідування сексуальних убивств. В основі розкриття злочинів лежить поєднання слідчих (розшукових) дій та негласних слідчих (розшукових) дій.

Неконкретні завдання, які часто даються слідчими оперативному підрозділу на встановлення особи, яка вчинила вбивство, навряд чи можуть бути ефективними, тому що карний розшук і без таких документів здійснює роботу в цьому напрямі. Завдання повинні грунтуватися на матеріалах кримінального провадження й спрямовувати оперативних працівників на досягнення певного результату. Вони повинні бути реальними й виконуваними. У іншому разі діяльність щодо них не виконуватиметься, а слідчий одержуватиме відповіді про те, що позитивні результати не досягнуті. Але якщо завдання мало конкретний характер, то слідчий повинен домогтися його виконання обов'язково.

Цілком правомірне завдання про перевірку конкретної особи на причетність до вчиненого вбивства. У поле зору слідчого іноді потрапляють особи, які з різних причин викликають підозру. Ліпшим способом перевірки такої особи є організація й проведення негласних слідчих (розшукових) дій або їх комплексу.

За допомогою негласних слідчих (розшукових) дій вивчаються особи потерпілих. Іноді це дає несподівану інформацію про людину, виявляє відомості, про які не знають і не підозрюють навіть найближчі люди.

У разі негативного результату такої перевірки слідчий має право вважати ту або іншу версію перевіреною. Однак таке питання доцільно вирішувати разом із оперативними працівниками. Крім того, повинно спільно вирішуватися питання про реалізацію оперативної перевірки та спосіб одержання процесуальних доказів.

Оперативна інформація повинна використовуватися слідчим під час проведення слідчих (розшукових) дій. Здебільшого така інформація може бути легалізована і стати джерелом процесуального доказу. В основному це залежить від кваліфікації слідчого й оперативного працівника. Практика довела, що розслідування сексуальних убивств повинно здійснюватися 3 постійним оперативним супроводом. Однак найчастіше після встановлення особи, яка вчинила злочин, інтерес працівників оперативного підрозділу до винного зникає, а оперативна діяльність стосовно нього припиняється.

Внаслідок замкнутості (прихованості) інтимного життя будь-якої людини, зокрема злочинця, тільки під час проведення комплексу слідчих (розшукових) дій та негласних слідчих (розшукових) дій, кількаразових і тривалих, вбивство може бути розкрите. При цьому варто зважати на те, що важливим резервом слідчо-оперативної діяльності $\epsilon$ використання оперативних обліків, оперативне спостереження за особами з нетрадиційною сексуальною орієнтацією, а також виявлення осіб, схильних до правопорушень у статевій сфері. Крім того, практика показала, що в результаті слідчо-оперативної діяльності можуть бути виявлені латентні сексуальні вбивства.

2. Створення слідчо-оперативних груп для розшуку ŭ затримання злочиниів у місиях $\ddot{x}$ можливої появи. Завданням цих груп є встановлення вбивці за ознаками його зовнішності й поведінки шляхом забезпечення постійного оперативного прикриття місць, де найбільш ймовірне вчинення чергового вбивства.

Діяльність таких груп здійснюється в громадських місцях і громадському транспорті. Цьому повинне передувати ретельне вивчення прийомів заманювання жертв i способів нападу на них, використовуваних злочинцем, обраних для цього часу й місць, шляхів ймовірного підходу й відходу, особливостей об'єкта статевого потягу й інших обставин злочину.

Наприклад, у разі кількаразового нападу на малолітніх дітей і підлітків необхідно організувати посилене спостереження за дитячими садками, школами, спортивними клубами, будинками або центрами дитячої і юнацької творчості, музичними училищами й іншими подібними установами. Доцільно направляти зазначені групи в ті місця, де неповнолітні перебувають тривалий час без належного контролю й спостерігання з боку дорослих (ковзанки, стадіони, дитячі парки тощо). Перекриваються дитячі майданчики, намети й павільйони з ігровими автоматами, торговельні майданчики 3 продажу морозива, води, магазини іграшок, куди діти можуть прийти самостійно, без відома батьків.

3. Утворення слідчо-оперативних груп для прихованого спостереження за місцем події або місием виявлення трупа. Завданням такої групи є організація засідки для затримання злочинця в той момент, коли він повернеться на місце злочину. Вивчення типових особистісних характеристик серійних убивць-гвалтівників доводить, що майже кожен п’ятий 3 них, вчинивши злочин, через певний час повертається до того місця, де був залишений труп.

Крім того, повернення на місце злочину було пов'язане 3 тим, що раніше убивця там уже вчиняв аналогічний злочин. Він повертається до знайомої йому місцевості (обстановки) з метою зменшити ступінь ризику свого викриття. Саме туди заманювалися чергові жертви.

Ознаками, які вказують на ймовірну появу сексуального вбивці на місці злочину, є такі: а) убивства вчинялися регулярно та на тому ж місці; б) сексуальне насильство здійснювалося після вбивства; в) жертва чинила запеклий опір; г) злочинець знущався 3 трупа.

Під час виявлення жертви сексуального насильства необхідно організувати роботу оперативно-пошукової групи 3 пошуку трупів інших жертв навколо місця події. У разі виявлення трупів інших жертв із ознаками сексуального насильства може бути висунута версія про психологічний профіль убивці з такими ознаками: а) сексуальний напад схильний учиняти у відомій для нього місцевості або обстановці; б) дуже ймовірно повторна поява сексуального вбивці на місці злочину.

У такій ситуації необхідно ухвалити рішення щодо створення оперативно-пошукової групи для прихованого спостереження за місцем події або місцем виявлення трупа. При цьому слід зазначити, що однією з особливостей діяльності цієї групи є цілодобовий графік роботи.

4. Діяльність групи з проведення подворових (поквартирних) обходів, відпрацьовування житлового масиву й підприємств, розташованих у районі вчинення злочину. Ïх завданням $€$ виявлення свідків злочину, а також живих потерпілих, які зазнали сексуального насильства та не заявили про це в органи розслідування, прокуратури і суду. Одночасно встановлюються особи, схильні до згвалтувань, статевих збочень, а також психічно хворі, які перебувають на піклуванні родичів або опікунів.

Подвірні обходи необхідно розпочати з вивчення особливостей району, де було вчинено злочин, і складання детальної схеми території з розбивкою іiї на мікрорайони (вулиці, будинки і підприємства). Під час інструктування необхідно вказати номери будинків (квартир), які повинен відвідати кожний учасник групи, визначити строки виконання та порядок документування результатів опитування.

Учасники обходу забезпечуються фотознімками потерпілих, аналогами викрадених у них предметів і цінностей та композиційним портретом злочинця. У низці випадків за допомогою подвірного обходу вдається виявити осіб, які вижили за збігом випадкових обставин, у результаті запеклого опору, внаслідок чого злочинцеві не вдалося реалізувати свій задум. Саме через них іноді вдається знайти розшукувану особу.

Крім установлення очевидців злочину й осіб, схильних до злочинної діяльності проти статевої свободи людини, необхідно прагнути за допомогою опитувань установити випадки згвалтувань, мужолозтва, вчинення розпусних 
і хуліганських дій на сексуальному грунті, про які потерпілі не заявляли в поліцію. Їх міг учинити розшукуваний злочинець. Практика доводить, що майже завжди вбивству на сексуальному грунті передують злочини проти статевої недоторканності та свободи особи без замаху на життя потерпілих.

Для виявлення таких випадків необхідно також провести опитування в жіночих консультаціях, вендиспансеpax, поліклініках, куди потерпілі могли звертатися по консультацію або за лікарську допомогу.

5. Створення слідчо-оперативної групи для розшуку злочиния за допомогою свідків або потерпілих. Завданням зазначеної групи є впізнання злочинця шляхом організації патрулювання в місцях ймовірної появи злочинця із залученням свідків або потерпілих, які вижили. 3 появою злочинця в місцях патрулювання членами оперативно-пошукової групи вживаються заходи щодо його затримання.

Доцільність створення такої групи визначається слідчою ситуацією. Одним із результативних оперативно-розшукових заходів щодо розшуку сексуального вбивці $є$ організація роботи оперативно-пошукової групи за участю свідків або потерпілих, які вижили. Діяльність щодо встановлення свідків може бути виконана членами групи 3 виявлення латентних сексуальних злочинів, а також групи з проведення обходів помешкань потенційних свідків. Робота такої групи повинна бути організована в місцях найбільш ймовірної появи злочинця. Такими місцями можуть бути громадські парки, сквери, місця відпочинку.

6. Утворення слідчо-оперативної групи для затримання злочиния на місиі злочину в прочесі проведення слідчого експерименту. 3 цією метою в місця, де злочинець може вистежувати чергову жертву, спрямовуються так звані «принади», роль яких виконують працівниці поліції або переодягнені в жіночий одяг чоловіки. Діють вони під прикриттям оперативної групи.

Отже, головним завданням цієї групи є затримання злочинця на місці злочину. Саме тому під час його захоплення члени слідчо-оперативної групи повинні діяти, 3 одного боку, швидко й злагоджено, щоб не дати злочинцеві змоги заподіяти тілесні ушкодження «принаді» і втекти 3 місця події, а з іншого боку - без зайвої поспішності, тобто не виявляти себе завчасно, оскільки цим підозрілу особу можна «злякати» і не отримати привід для затримання.

7. Створення слідчо-оперативної групи зі встановлення особи вбивиі, який використовував автотранспортний засіб. Завданням цієї групи є пошук злочинця за прикметами водія, автомобіля або інших ознак, установлених у ході слідства. Для більш ефективної роботи групи доцільно включити до її складу працівників патрульної поліції й експертної служби.

Завданнями зазначеної групи можуть бути такі:

а) провести вибірку автомашин відповідно до наявної інформації про автотранспорт злочинця;

б) скласти перелік власників відібраних автомашин, а також осіб, які отримали довіреність на право експлуатації, та перевірити їх за обліками Управління (відділу) інформаційно-аналітичного забезпечення ГУ (У) МВС України в областях, містах і залізницях;

в) організувати проведення техогляду, під час якого звертати особливу увагу на стан правих дверей, кріплень i ременів безпеки, на заміну водієм оббивки салону, чохлів, сидінь, на виявлення плям крові й інших біологічних виділень у салоні; г) з'ясувати, де були й чим займалися водії в період вчинення розслідуваних злочинів;

г) фотографувати автомашини, водії яких запідозрені у вчиненні сексуального нападу, для пред'явлення свідкам;

д) проаналізувати шляхові та реєстраційні документи автотранспортних господарств (підприємств), розташованих на території, яка становить інтерес для слідчо-оперативної групи;

е) опитати сторожів гаражних кооперативів й інших осіб для з'ясування, хто й коли виїжджав на авто та коли повернувся;

є) встановити водіїв, які надають транспортні послуги пасажирам 3 використанням державного автотранспорту, перевірити їх на причетність до вчинення убивств, а також водіїв, відряджених до транспортних підприємств міста в період учинення злочину;

ж) скласти список водіїв, які мають групу крові, аналогічну з груповою приналежністю виділень, виявлених на місці події, й перевірити їх за місцем проживання;

3) провести огляд гаражів індивідуальних власників автомашин з метою виявлення одягу, чохлів, забруднених кров'ю, речей і інших предметів, які належать потерпілим.

Крім того, за умови необхідності, доцільно організувати засідки й виставити пости на виїздах із населеного пункту з метою прихованого спостереження за автомототранспортом у місцях виявлення трупів і виявлення водіїв, які здійснюють перевезення.

Здійснений нами аналіз судової та слідчої практик розслідування сексуальних убивств виявив проблемні питання, пов'язані із взаємодією між слідчим і працівниками оперативного підрозділу, серед яких: а) нестабільність слідчо-оперативної групи, часта заміна їі учасників; б) недостатній кількісний склад і технічне оснащення; в) неузгодженість дій та взаємне неподання інформації у кримінальному провадженні.

Висновки. Таким чином, взаємодія слідчого й оперативного підрозділу під час діяльності слідчо-оперативних та оперативно-пошукових груп може бути організована таким чином: виявивши труп або фрагменти тіла жертви, слідчий в порядку ст. 41 КПК України доручає оперативному підрозділу організувати в місцях можливої появи злочинця розшук та затримання осіб, поведінка яких викликає підозру. У своєму дорученні він повинен вказати на особливості зовнішності, одягу злочинця, способи заманювання потерпілих, а також можливі поведінкові ознаки. Однак необхідно здійснити додатково пошук трупів інших жертв на навколишній території. Під час виявлення інших трупів з ознаками сексуального насильства може бути висунута версія про психологічний профіль убивці. У цій слідчій ситуації необхідно ухвалити рішення щодо створення слідчо-оперативної групи для прихованого спостереження за місцем події або місцем виявлення трупа. Однією з особливостей діяльності цієї групи є цілодобовий графік роботи. Потреба у залученні зазначеної групи може виникнути і в результаті інших підстав: а) сексуальне насильство вчинене після вбивства; б) злочинець знущався із трупа. Пошук початкової доказової бази, свідків і жертв латентних злочинів на сексуальному грунті має здійснювати група з проведення подвірних (поквартирних) обходів та інші тимчасові групи, під час діяльності яких можливо виявити людей, які систематично вчиняють злочини проти статевої свободи та недоторканності. Це встановлюється за ледь помітними поведінковими ознакам, які відображаються і у злочинній діяльності, і в побуті.

\section{ЛITEPATУРA}

1. Белкин Р.С. Криминалистическая энциклопедия. Москва : Изд-во БЭК. 1997. 342 с.

2. Протопопов А.Л. Расследование сексуальных убийств : монографрія. Санкт-Петербург : Юрид. центр Пресс, 2001. 226 с

3. Криминалистика : учеб. / отв. ред. Н.П. Яблоков. 2-е изд., перераб. и доп. Москва : Юристъ, 2001. 718 с.

4. Руководство по расследованию убийств / М.И. Авдеев, С.В. Бородин, Л.Г. Видонов, В.П. Власов и др.; отв. ред. : С.И. Гусев ; редкол. : А. И. Жуков, В.К. Звирбуль, А.Н. Игнатов, А.М. Ларин, Г.М. Миньковский. Москвав : Юрид. лит., 1977. 400 с.

5. Криминалистика : учеб. / А.Ф. Волынский, Т.В. Аверьянова, И.Л. Александрова и др. / под ред. А.Ф. Волынского. Москва : Закон и право, ЮНИТИ-ДАНА, 1999. 615 с. 
УДК 343.1

DOI https://doi.org/10.32782/2524-0374/2020-4/82

\title{
ВИЗНАЧЕННЯ РОЗМІРУ ЗАСТАВИ У КРИМІНАЛЬНОМУ ПРОЦЕСІ УКРАЇНИ: СТАТИСТИЧНИЙ АНАЛІЗ СУДОВОЇ ПРАКТИКИ
}

\section{DETERMINING THE AMOUNT OF BAIL IN THE CRIMINAL PROCESS OF UKRAINE: A STATISTICAL ANALYSIS OF JUDICIAL PRACTICE}

\author{
Торбас O.O., к.ю.н., \\ доцент кафедри кримінального процесу, детективної \\ та оперативно-розшукової діяльності \\ Національний університет «Одеська юридична академія»
}

Касьянова В.А., к.фіз-мат.н., доцент кафедри обліку і оподаткування

Одеський державний аграрний університет

Кримінальний процесуальний кодекс України визначає заставу як один із можливих запобіжних заходів, що застосовується до підозрюваного чи обвинуваченого. Проте український законодавець не надав чітких інструкцій щодо визначення розміру застави, визначаючи лише її межі.

Відсутність чітких орієнтирів може стати причиною того, що на рішення судді під час визначення розміру застави можуть впливати сторонні чинники, до яких відносять корупцію, дискримінацію, стереотипи суддів тощо. Проте наявність надто чітких орієнтирів може ставити під сумнів суддівську дискрецію.

Аналіз наукових робіт вказує, що проблема обрання до особи запобіжного заходу у вигляді застави як альтернатива тримання під вартою досить жваво обговорюється насамперед західними науковцями. Вчені аналізували як вірогідність прийняття рішення про обрання до особи застави, так і розмір застави, використовуючи різні фактори: соціальний вплив, расову приналежність, тип правової допомоги (платний чи безоплатний), стать, вік, попередні ув'язнення тощо. Проте українськими вченими така проблема досліджувалася слабо.

Відповідно, стаття присвячена аналізу обставин, які враховуються суддями в разі застосування застави, й вплив таких обставин на визначення розміру застави. Автори встановили, що в більшості випадків судді враховують розмір майнової шкоди, завданої кримінальним правопорушенням. Також було встановлено, що інші обставини майже не впливають на розмір застави. Такий висновок узгоджується з позицією інших науковців.

Як висновок автори зазначають, що інструменти для оцінки ризиків можуть бути досить вдалою альтернативою повній суддівській дискреції під час обрання до особи запобіжних заходів, у тому числі й застави. Водночас лишається серйозна проблема розробки вдалої моделі інструментального оцінювання рисків, яка може базуватися або на реальних статистичних показниках, тобто на судовій практиці, або може бути створена незалежно від судової практики, ввібравши в себе найпрогресивніші ідеї та позиції провідних науковців і практиків.

Ключові слова: застава, кримінальний процес, тримання під вартою, заходи забезпечення, матеріальна шкода.

The Criminal Procedural Code of Ukraine defines a cash bail as one of the possible measures of restrain that can be applied to a suspect or accused in criminal proceeding. But Ukrainian legislator didn't give clear instructions on setting bail amount, determining only limits for cash bail.

The lack of clear guidelines may be the reason that the judge's decision in determining the amount of bail may be influenced by external factors, such as corruption, discrimination, stereotypes of judges, etc. However, the existence of too clear guidelines may call into question judicial discretion

Analysis of scientific works indicates that the problem of choosing a measure of restraint in the form of bail as an alternative to detention received wide discussed primarily by western scholars. Researchers analysed both the probability of deciding on the choice of bail and the amount of bail, using various factors, such as social influence, race, type of legal aid (paid or free), gender, age, previous imprisonment, and so on. However, this problem has been poorly studied by Ukrainian scientists.

So, this article is devoted to the analysis of circumstances that are taken into account by judges when choosing a measure of restrain in the form of a bail, as well as the impact of these circumstances on cash bail amount. Authors found that judges have taken into consideration mostly the size of property loss as a result of criminal offence. Also, it was established that other circumstances had almost no effect on final bail amount. And such conclusions are consistent with the research of other scholars.

In conclusion, authors note that risk assessment tools can be a very good alternative to full judicial discretion in choosing a measures of restraint, including bail. This leaves a serious problem of developing a successful risk assessment model, which can be based either on real statistical indicators or can be created independently of case law, absorbing the most progressive ideas and positions of leading scientists and practitioners.

Key words: bail, criminal proceedings, keeping in custody, measures of restrain, property loss

Вступ. Галузі кримінального й кримінального процесуального права, на відміну від інших галузей, мають досить специфічні завдання та методи правового регулювання. Цілком логічно, що найбільших обмежень прав і свобод людина зазнає саме у зв'язку з розслідуванням, розглядом і розв'язанням кримінальних правопорушень. Одним із найсуттєвіших обмежень прав людини є застосування заходів забезпечення кримінального провадження, які покликані гарантувати ефективність досудового розслідування та судового розгляду. Враховуючи той факт, що тримання під вартою як запобіжний захід надто суворо обмежує права особи $[1 ; 2]$, яка ще навіть не була визнана судом винуватою [3], все більше держав схиляються до політики застосування інших, не пов'язаних
3 обмеженням волі, запобіжних заходів, наприклад застосування застави.

Проблема встановлення грошових застав у кримінальних провадженнях не нова для науковців і практиків різних країн. Водночас погляди на таку проблему досить сильно різняться між собою. Очевидно, що такий різний підхід насамперед пояснюється відмінностями правового регулювання вказаного питання. Наприклад, у США внесення грошової застави $є$ досить популярною гарантією того, що особа, наприклад, не втече від слідства чи не вчинить нове кримінальне правопорушення. До того ж достатньо велика кількість судів у США користується «таблицями застав», в яких надається перелік всіх кримінальних правопорушень і розмір застави, який відповідає 
кожному із зазначених злочинів [4; 5; 6]. Необхідно зауважити, що для суддів такі таблиці не обов'язкові [7], проте на практиці використання такого інструменту отримало відносну популярність [8]. Водночас система застави, яка натепер існує в США, постійно піддається критиці з боку науковців [1; 9; 10], суддів [11], урядовців [12;13], що вказує на суттєві недоліки в ії функціонуванні й на необхідність глибшого дослідження зазначеної проблеми.

Українське кримінальне процесуальне законодавство в частині визначення правової природи такого запобіжного заходу, як застава, досить подібне до процесуального законодавства інших пострадянських країн. Так, чинний Кримінальний процесуальний кодекс (далі - КПК) України містить декілька положень, які стосуються проблеми обрання та визначення розміру застави. Згідно зі ст. 182 КПК України, застава полягає у внесенні коштів у грошовій одиниці України на спеціальний рахунок, визначений у порядку, встановленому Кабінетом Міністрів України, з метою забезпечення виконання підозрюваним, обвинуваченим покладених на нього обов'язків, під умовою звернення внесених коштів у дохід держави в разі невиконання цих обов'язків. Згідно із ч. 5 ст. 182 КПК України, розмір застави визначається в таких межах:

1) щодо особи, підозрюваної чи обвинуваченої у вчиненні нетяжкого злочину, - від одного до двадцяти розмірів прожиткового мінімуму для працездатних осіб;

2) щодо особи, підозрюваної чи обвинуваченої у вчиненні тяжкого злочину, - від двадцяти до вісімдесяти розмірів прожиткового мінімуму для працездатних осіб;

3) щодо особи, підозрюваної чи обвинуваченої у вчиненні особливо тяжкого злочину, - від вісімдесяти до трьохсот розмірів прожиткового мінімуму для працездатних осіб.

У виключних випадках, якщо слідчий суддя, суд встановить, що застава в зазначених межах не здатна забезпечити виконання особою, що підозрюється, обвинувачується у вчиненні тяжкого або особливо тяжкого злочину, покладених на неї обов'язків, застава може бути призначена в розмірі, який перевищує вісімдесят чи триста розмірів прожиткового мінімуму для працездатних осіб відповідно.

Таким чином, у КПК України визначено лише певні межі розміру застави, яка залежить від тяжкості злочину, а також наданий перелік обставин, які повинен врахувати суд. Проте закон не зазначає, як саме ці обставини мають впливати на розмір застави.

Очевидно, ситуацію, що склалася, не можна вважати позитивною. Відсутність чітких орієнтирів може стати причиною того, що на рішення судді в разі визначення розміру застави можуть впливати сторонні чинники, до яких відносять корупцію [14], дискримінацію [15; 16], стереотипи суддів [16] тощо. Проте наявність надто чітких орієнтирів може ставити під сумнів суддівську дискрецію [17]. Однак вказані аргументи не можуть заперечувати необхідність внесення чіткості в саму методику визначення розміру застави, адже це питання підіймалося навіть на рівні Європейського суду з прав людини [18] й Верховного Суду США [19].

Аналіз наукових робіт вказує, що проблема обрання до особи запобіжного заходу у вигляді застави як альтернативи тримання під вартою досить жваво обговорюється насамперед західними науковцями. Вчені аналізували як вірогідність прийняття рішення про обрання до особи застави, так і розмір застави, використовуючи різні фактори: соціальний вплив [1], расову приналежність [20; 21], тип правової допомоги (платний чи безоплатний) [20;22], стать $[10 ; 20]$, вік $[10 ; 16 ; 20 ; 21]$, попередні ув'язнення $[10 ; 16 ; 21 ; 22]$ тощо.

Так, одна група вчених зосередилась на рівні впливу різних факторів на суддівські рішення. Науковці одночасно дослідили й вірогідність обрання до особи застави, й розмір обраної застави, й вірогідність внесення застави
[20]. Водночас використовувався такий фактор, як тип правової допомоги (безоплатний або приватний адвокат) як можливий індикатор матеріального положення підозрюваних. Мартін Вільямс (Martin R. Williams) своєю чергою дослідив вплив заповненості в'язниць на розмір застав, які обираються суддями [22].

Інша група вчених пропонували власні концепції щодо вдосконалення процедури прийняття рішення про обрання запобіжних заходів. Так, Кристал Янг (Crystal S. Yang) запропонувала під час прийняття рішення про обрання до особи застави враховувати також вартість тримання осіб під вартою [1].

Проте для України така проблема все ще залишається недослідженою. Тому існує необхідність провести грунтовніше дослідження тих обставин, які впливають на рішення суддів у разі визначенні розміру застави.

Методика дослідження. Для дослідження було проаналізовано 207 ухвал слідчих суддів про обрання запобіжного заходу у вигляді тримання під вартою з обранням як альтернативного запобіжного заходу застави. Вибір такого типу ухвал пояснюється значною популярністю тримання під вартою в порівнянні із заставою як самостійного запобіжного заходу. Всі ухвали були отримані з Сдиного державного реєстру судових рішень. 3 метою отримання найрепрезентативніших результатів із кожної області України була отримана майже однакова кількість ухвал за період із 2015 по 2018 роки. Ухвали обиралися випадково без виділення окремих критеріїв.

У зв'язку з початком дії інституту кримінальних проступків законодавцем була змінена класифікація кримінальних правопорушень. Ухвали слідчих суддів аналізувалися відповідно до законодавства, чинного на момент їх прийняття, тобто за існування злочинів невеликої та середньої тяжкості. Однак у зв'язку з аналізом лише ухвал про обрання запобіжного заходу у вигляді тримання під вартою з одночасним встановленням застави, злочини невеликої тяжкості не аналізувалися. Через те, що злочини середньої тяжкості в чинній редакції Кримінального кодексу України називаються нетяжкими, саме таке формулювання і буде використано в дослідженні, адже це не впливає на його кінцеві результати.

Таким чином, усі ухвали були поділені на 3 групи в залежності від тяжкості злочину:

- нетяжкі злочини (злочини середньої тяжкості) 31 ухвала;

- тяжкі злочини - 165 ухвал; особливо тяжкі злочини - 11 ухвал.

Такий розподіл ухвал пояснюється методикою відбору, яка була застосована.

Для аналізу обставин, які враховувалися суддями під час визначення розміру застави, була обрана номінальна шкала 3 виділенням трьох змінних: «не враховувалося», «погіршило», «покращило». Змінна «враховувалося» застосовувалась у тих випадках, коли суддя взагалі не брав до уваги ту чи іншу обставину. Змінна «покращило» застосовувалася тоді, коли суддя визначав обставину як таку, що позитивно характеризувала підозрюваного. Відповідно, змінна «погіршило» навпаки, на думку судді, негативно характеризувало особу підозрюваного.

Одиницею для обрахування розміру застави було обрано не грошову одиницю України (гривню - UAH), а прожитковий мінімум для працездатних осіб (далі ПМ) ${ }^{1}$. Такий вибір має одразу декілька пояснень. В КПК України межі розміру застави обраховуються в ПМ, а не у грошевих одиницях. ПМ щороку прогнозується урядом і зазначається в Законі України «Про Державний бюджет

${ }^{1}$ До 2016 року розмір застави обраховувався не в прожиткових мінімумах для працездатних осіб, а в мінімальній заробітній платі. Однак така зміна фактично не вплинула на вираження розміру застави в грошовому еквіваленті, тому в досліджені буде використано лише прожитковий мінімум. 
України», а тому ПМ адекватно відбиває реальні блага, які будуть покладені в основу застави (на відміну від грошових одиниць, які з роками в силу тих чи інших економічних факторів можуть суттєво змінюватись). Крім того, КПК України зобов'язує суддів визначати розмір застави в ПМ, а не у грошових одиницях, а тому саме ПМ має бути одиницею оцінки розміру застави (табл. 1).

Для аналізу сили зв'язку між числовими величинами було застосовано коефіцієнт кореляції Пірсона. Для аналізу впливу факторів на розмір застави було проаналізовано середнє значення розміру застави за кожною обставиною з виділенням стандартної помилки й 95\% довірчого інтервалу.

Виклад основного матеріалу. Відповідно до ст. 178 КПК України, судді під час обрання будь-якого запобіжного заходу повинні врахувати 11 обставин, які стосуються як події кримінального правопорушення, так і самої особи, яка вчинила кримінальне правопорушення. Проте під час аналізу ухвал було встановлено, що більшість із передбачених КПК України обставин суддями або не враховується взагалі, або лише зазначається в тексті ухвали у вигляді стандартних формулювань без реальних посилань на докази, які підтверджують або спростовують існування вказаних обставин. У зв'язку із цим було встановлено реальний перелік обставин, які судді дійсно враховували 3 визначенням частки випадків, коли такі обставини погіршували або покращували становище особи [23].

До таких обставин відносяться:

переховувався - факт того, що особа переховувалася від слідства. У випадках, які погіршували становище особи, підозрюваного було оголошено в розшук і насильно доставлено до суду. У випадках, які покращували становище особи, судді вказували, що підозрюваний самостійно з'явився до органу досудового розслідування; допомагав розслідуванню - чи допомагав підозрюваний досудовому розслідуванню. Якщо підозрюваний не заперечував своєї вини й активно сприяв досудовому розслідуванню, то судді враховували цю обставину як таку, що покращувала становище особи;

раніше судимий - чи вчинювались підозрюваним інші злочини на момент обрання запобіжного заходу. Варто зауважити, що судді враховували як факт вчинення особою вже доведених злочинів, за які особа відбула покарання, так і наявність інших кримінальних проваджень, за якими вироки ще не були винесені;

спосіб життя - в такому випадку судді аналізували спосіб життя підозрюваного: чи зловживає він алкоголь- ними напоями, чи вживає наркотичні речовини, як його в цілому оцінює громада, в якій він проживає тощо;

- сім'я - в такому випадку судді оцінювали міцність соціальних зв'язків підозрюваного: наявність чоловіка/ дружини, дітей, інших родичів, а також міцність зв'язків у середині родини;

робота (навчання) - судді враховували наявність або відсутність у підозрюваного постійного місця роботи (навчання), або наявність (чи відсутність) законних джерел доходу;

- житло - судді враховували, чи наявне в підозрюваного власне житло або житло, яке ним законно орендується. Також в такому випадку судді враховували факт проживання підозрюваного в місцевості, в якій ним було вчинено правопорушення, як одну з обставин, яка вказує на те, що підозрюваний не буде переховуватися від слідства;

особи на утриманні - судді оцінювали, чи є в підозрюваного на утримані непрацездатні особи або діти. Цікавий той факт, що досить часто відсутність таких осіб на утриманні підозрюваного згадувалося в судових рішеннях як обставина, яка не перешкоджає (іншими словами, дозволяє) застосовувати до підозрюваного відповідні запобіжні заходи;

- здоров'я - судді враховували стан здоров'я підозрюваного, наявність у нього хронічних хвороб тощо. В такому випадку судді також використовували відсутність у підозрюваного серйозних проблем зі здоров'ям як додаткове обгрунтування можливості застосування до особи запобіжного заходу, що знову таки суперечить загальним засадам кримінального процесу;

характеристика - судді в такому випадку враховували письмову характеристику особи, яка була надана уповноваженими на те особами за місцем проживання або роботи підозрюваного (табл. 2).

Власне аналіз таких обставин вже вказує на деякі цікаві висновки. Так, українські судді під час визначення розміру застави не враховують майновий стан підозрюваного, хоча КПК України зобов'язує їх це зробити. Очевидно, що це може пояснюватися складністю оцінки такої обставини. Натепер в Україні можна вільно ознайомитися лише 3 деклараціями про доходи державних службовців. В такому випадку оцінити матеріальне становище підозрюваного можна лише за показником «Робота (навчання)», однак цей показник лише вказує на сам факт існування постійного доходу, але не вказує на його обсяги.

Повертаючись до аналізу визначення розміру застави, насамперед слід проаналізувати, чи відповідає розмір

Вираження прожиткового мінімуму в грошових одиницях (UAH, EUR Ta USD)

Таблиця 1 відповідно до офіційного курсу НБУ за вказаний період часу

\begin{tabular}{|c|c|c|c|}
\hline Період & ПМ (в UAH) & ПМ (приблизно в EUR) & ПМ (приблизно в USD) \\
\hline \multicolumn{4}{|l|}{2015} \\
\hline 01 січня - 31 серпня & 1218 & 63 & 77 \\
\hline 01 вересня - 31 грудня & 1378 & 56 & 63 \\
\hline \multicolumn{4}{|l|}{2016} \\
\hline 01 січня - 30 квітня & 1378 & 53 & 57 \\
\hline 01 травня - 30 листопада & 1450 & 51 & 57 \\
\hline 01 грудня - 31 грудня & 1600 & 59 & 62 \\
\hline \multicolumn{4}{|l|}{2017} \\
\hline 01 січня - 30 квітня & 1600 & 56 & 58 \\
\hline 01 травня - 30 листопада & 1684 & 58 & 63 \\
\hline 01 грудня - 31 грудня & 1762 & 55 & 64 \\
\hline \multicolumn{4}{|l|}{2018} \\
\hline 01 січня - 30 червня & 1762 & 53 & 62 \\
\hline 01 липня - 30 листопада & 1841 & 60 & 70 \\
\hline 01 грудня - 31 грудня & 1921 & 59 & 67 \\
\hline
\end{tabular}


Юридичний науковий електронний журнал

Обставини, які враховували судді під час обрання запобіжного заходу

Таблиця 2

\begin{tabular}{|c|c|c|c|}
\hline Обставина & $\begin{array}{c}\text { Злочини середньої тяжкості } \\
\qquad N=31\end{array}$ & $\begin{array}{c}\text { Тяжкі злочини } \\
N=165 \\
\end{array}$ & $\begin{array}{c}\text { Особливо тяжкі злочини } \\
\qquad N=11\end{array}$ \\
\hline \multicolumn{4}{|l|}{ Переховувався } \\
\hline не враховувалось & $16(51,6 \%)$ & $125(75,8 \%)$ & $10(90,9 \%)$ \\
\hline погіршило & $15(48,4 \%)$ & $38(23 \%)$ & $1(9,1 \%)$ \\
\hline покращило & 0 & $2(1,2 \%)$ & 0 \\
\hline \multicolumn{4}{|c|}{ Допомагав розслідуванню } \\
\hline не враховувалось & $22(71 \%)$ & $96(58,2 \%)$ & $6(54,5 \%)$ \\
\hline погіршило & 0 & $5(3 \%)$ & $1(9,1 \%)$ \\
\hline покращило & $9(29 \%)$ & $64(38,8 \%)$ & $4(36,4 \%)$ \\
\hline \multicolumn{4}{|l|}{ Раніше судимий } \\
\hline не враховувалось & $3(9,7 \%)$ & $22(13,3 \%)$ & $7(63,6 \%)$ \\
\hline погіршило & $27(87,1 \%)$ & $136(82,4 \%)$ & $2(18,2 \%)$ \\
\hline покращило & $1(3,2 \%)$ & $7(4,2 \%)$ & $2(18,2 \%)$ \\
\hline \multicolumn{4}{|l|}{ Спосіб життя } \\
\hline не враховувалось & $31(100 \%)$ & $145(87,9 \%)$ & $11(100 \%)$ \\
\hline погіршило & 0 & $20(12,1 \%)$ & 0 \\
\hline покращило & 0 & 0 & 0 \\
\hline \multicolumn{4}{|l|}{ Сім'я } \\
\hline не враховувалось & $18(58,1 \%)$ & $77(46,7 \%)$ & $3(27,3 \%)$ \\
\hline погіршило & $12(38,7 \%)$ & $78(47,3 \%)$ & $7(63,6 \%)$ \\
\hline покращило & $1(3,2 \%)$ & $10(6,1 \%)$ & $1(9,1 \%)$ \\
\hline \multicolumn{4}{|l|}{ Робота (навчання) } \\
\hline не враховувалось & $5(16,1 \%)$ & $39(23,6 \%)$ & $2(18,2 \%)$ \\
\hline погіршило & $26(83,9 \%)$ & $116(70,3 \%)$ & $8(72,7 \%)$ \\
\hline покращило & 0 & $10(6,1 \%)$ & $1(9,1 \%)$ \\
\hline \multicolumn{4}{|l|}{ Житло } \\
\hline не враховувалось & $22(71 \%)$ & $96(58,2 \%)$ & $6(54,5 \%)$ \\
\hline погіршило & $7(22,6 \%)$ & $59(35,8 \%)$ & $5(45,5 \%)$ \\
\hline покращило & $2(6,5 \%)$ & $10(6,1 \%)$ & 0 \\
\hline \multicolumn{4}{|l|}{ Особи на утриманні } \\
\hline не враховувалось & $23(74,2 \%)$ & $129(78,2 \%)$ & $8(72,7 \%)$ \\
\hline погіршило & $5(16,1 \%)$ & $23(13,9 \%)$ & $1(9,1 \%)$ \\
\hline покращило & $3(9,7 \%)$ & $13(7,9 \%)$ & $2(18,2 \%)$ \\
\hline \multicolumn{4}{|l|}{ Здоров'я } \\
\hline не враховувалось & $30(96,8 \%)$ & $148(89,7 \%)$ & $11(100 \%)$ \\
\hline погіршило & $1(3,2 \%)$ & $14(8,5 \%)$ & 0 \\
\hline покращило & 0 & $3(1,8 \%)$ & 0 \\
\hline \multicolumn{4}{|l|}{ Характеристика } \\
\hline не враховувалось & $24(77,4 \%)$ & $126(76,4 \%)$ & $11(100 \%)$ \\
\hline погіршило & $6(19,4 \%)$ & $37(22,4 \%)$ & 0 \\
\hline покращило & $1(3,2 \%)$ & $2(1,2 \%)$ & 0 \\
\hline
\end{tabular}

застави нормальному розподілу. Як вже було зазначено, КПК України визначає межі застави в залежності від тяжкості злочинів:

- нетяжкі злочини - від 1 до 20 ПМ;

- тяжкі злочини - від 20 до 80 ПМ;

- особливо тяжкі злочини - від 80 до 300 ПМ.

Водночас судді під час розгляду тяжких та особливо тяжких злочинів мають право обирати застави більші, ніж максимально визначені межі (але не менші).

Аналіз показав, що розмір застави (в залежності від тяжкості злочину) розподіляється таким чином (див. рис. $1,2,3)$.

Як можна помітити, в жодному з трьох випадків не діє закон нормального розподілу. Поряд із цим можна вже зробити висновок, що в кожній групі діють свої певні спе- цифічні правила, які можуть впливати на визначення розміру застави.

Так, для нетяжких злочинів (злочинів середньої тяжкості) в більшості випадків судді обирали найбільший розмір застави - 20 ПМ. Водночас середній розмір застави складає 14,13 зі стандартним відхиленням 5,463. Тобто, приймаючи рішення про обрання запобіжного заходу, слідчі судді насамперед орієнтувалися на максимальний розмір застави.

Протилежною $є$ ситуація із заставами для тяжких злочинів. Переважна більшість суддів обрала мінімальну заставу (середнє значення - 34,15, стандартне відхилення - 19,07). Водночас можна помітити, що зі збільшенням розміру застави зменшувалася кількість проваджень, в яких такі застави були застосовані. 


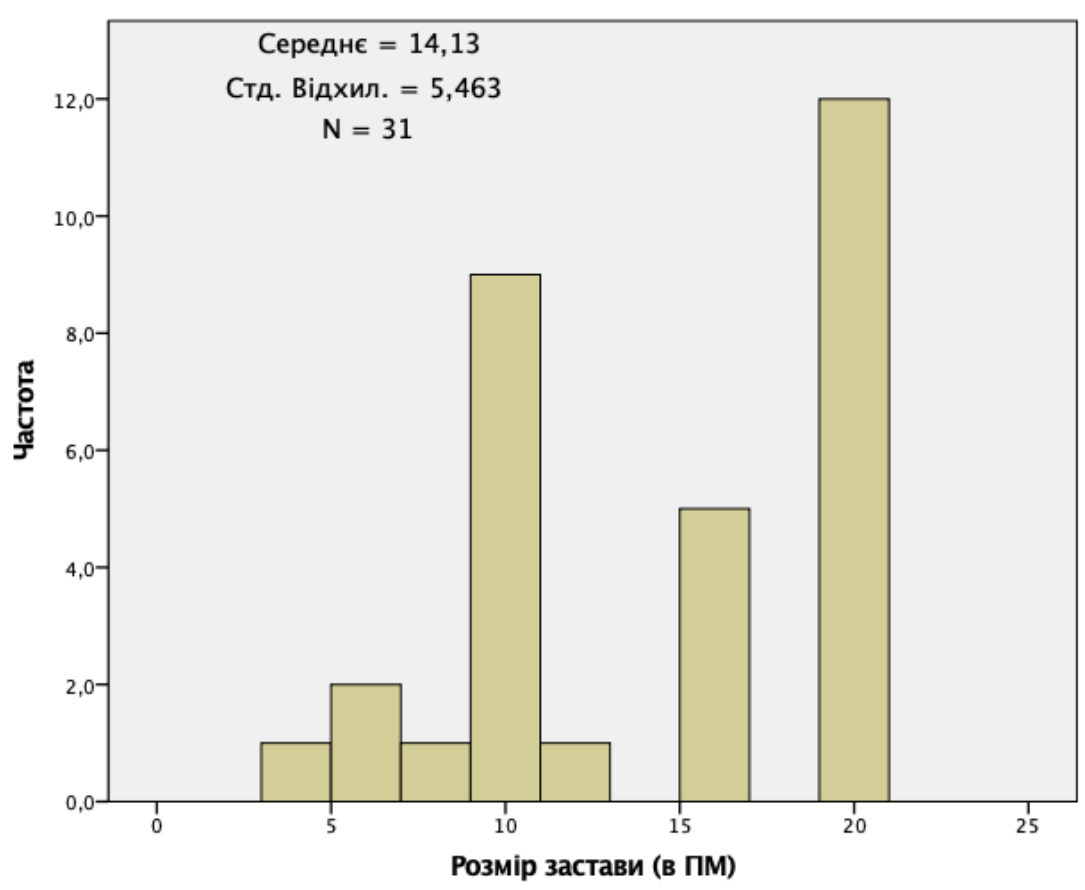

Рис. 1. Частота розміру застави (в ПМ) для нетяжких злочинів

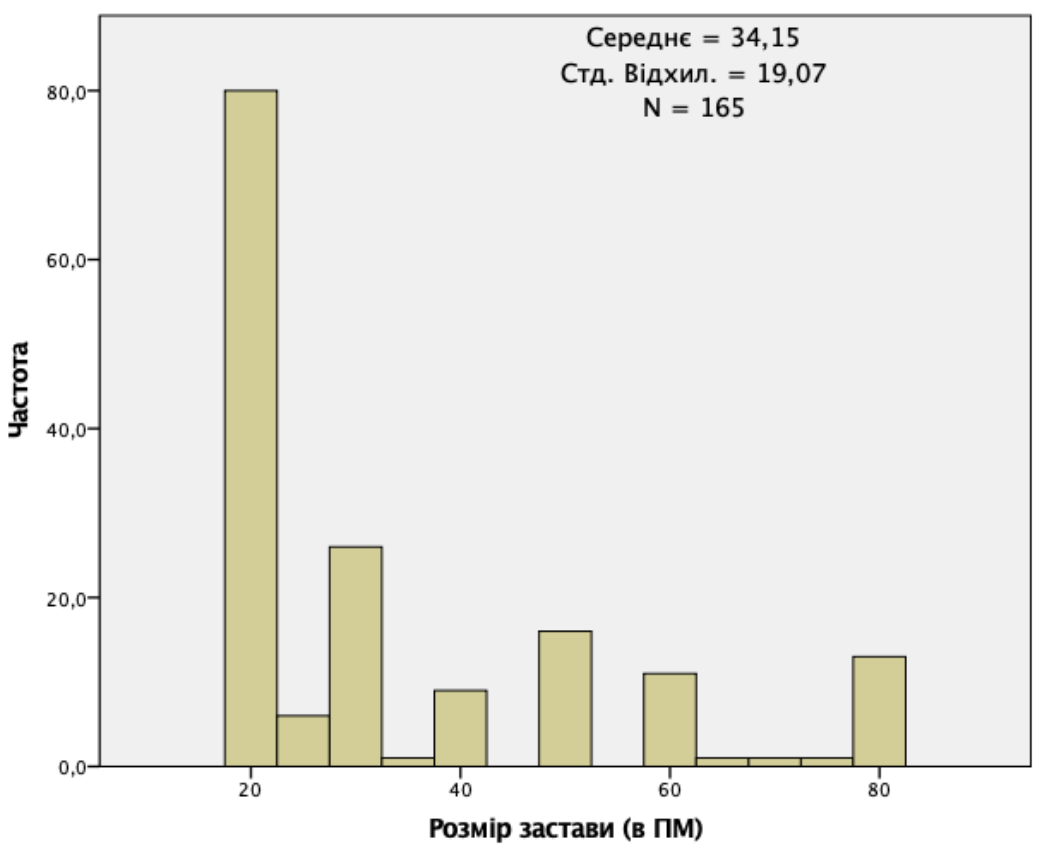

Рис. 2. Частота розміру застави (в ПМ) для тяжких злочинів

Дещо специфічною є ситуація із заставами для особливо тяжких злочинів. У такому випадку слідчі судді також за основу брали мінімальні межі застави, але значно охочіше встановлювали розмір застави, який набагато перевищує встановлений законом максимум (середнє 435,27 , стандартне відхилення - 608,96).

Отже, не можна стверджувати, що розмір застави може бути пояснений лише за допомогою стандартних статистичних моделей, а тому для кращого розуміння сутності такої проблеми необхідно вводити додаткові параметри й спостерігати відповідні зміни. I першим же параметром, якій необхідно взяти до уваги, повинен бути розмір завданої злочином матеріальної шкоди.
Одразу варто зробити ремарку, що далеко не у всіх злочинах можна встановити грошовий еквівалент завданої шкоди (злочини проти життя та здоров'я, злочини, якими було завданої моральної шкоди тощо). Поряд із цим категорія матеріальної шкоди видається цілком обгрунтованим показником, який мають враховувати судді. Однак за такої умови треба пам'ятати, що до особи обираються запобіжні заходи тоді, коли вина підозрюваного у вчиненні злочину (та, відповідно, в завданні шкоди) ще не доведена й не встановлена судом. Тому гіпотеза про виділення матеріальної шкоди як ключового фактора ще повинна знайти своє підтвердження. 


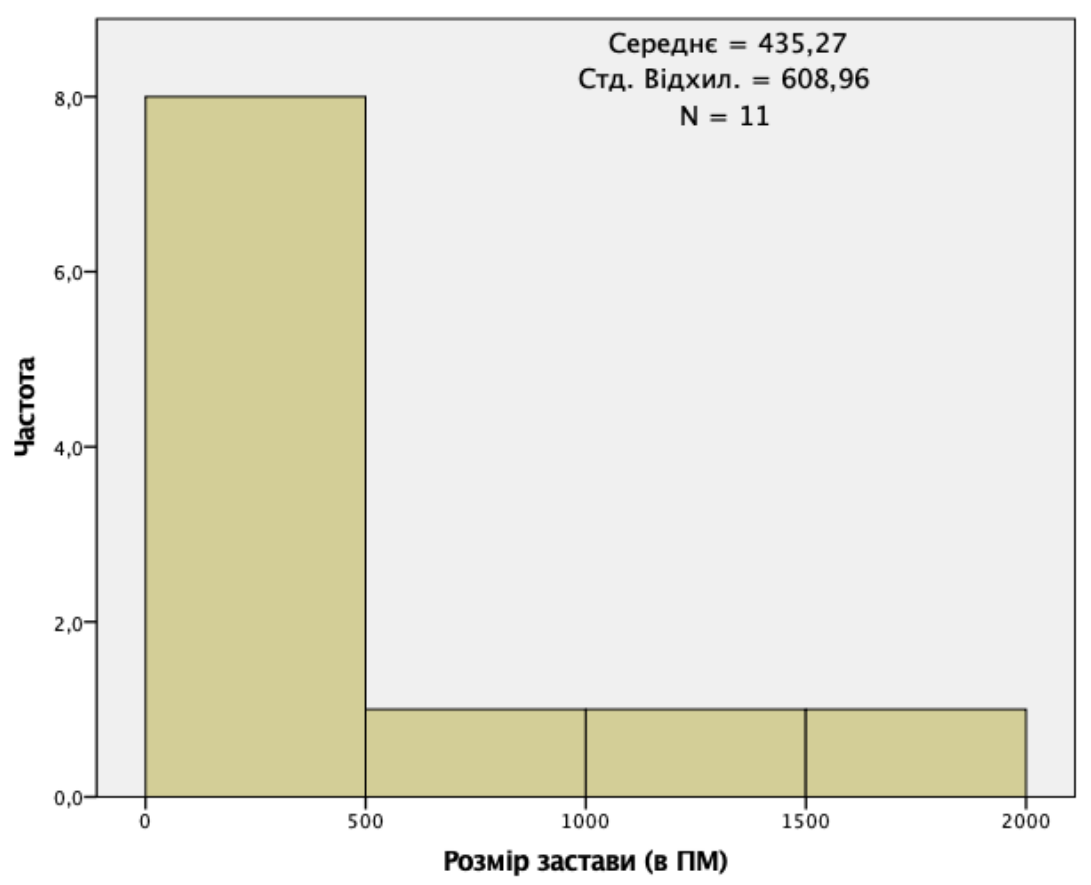

Рис. 3. Частота розміру застави (в ПМ) для особливо тяжких злочинів

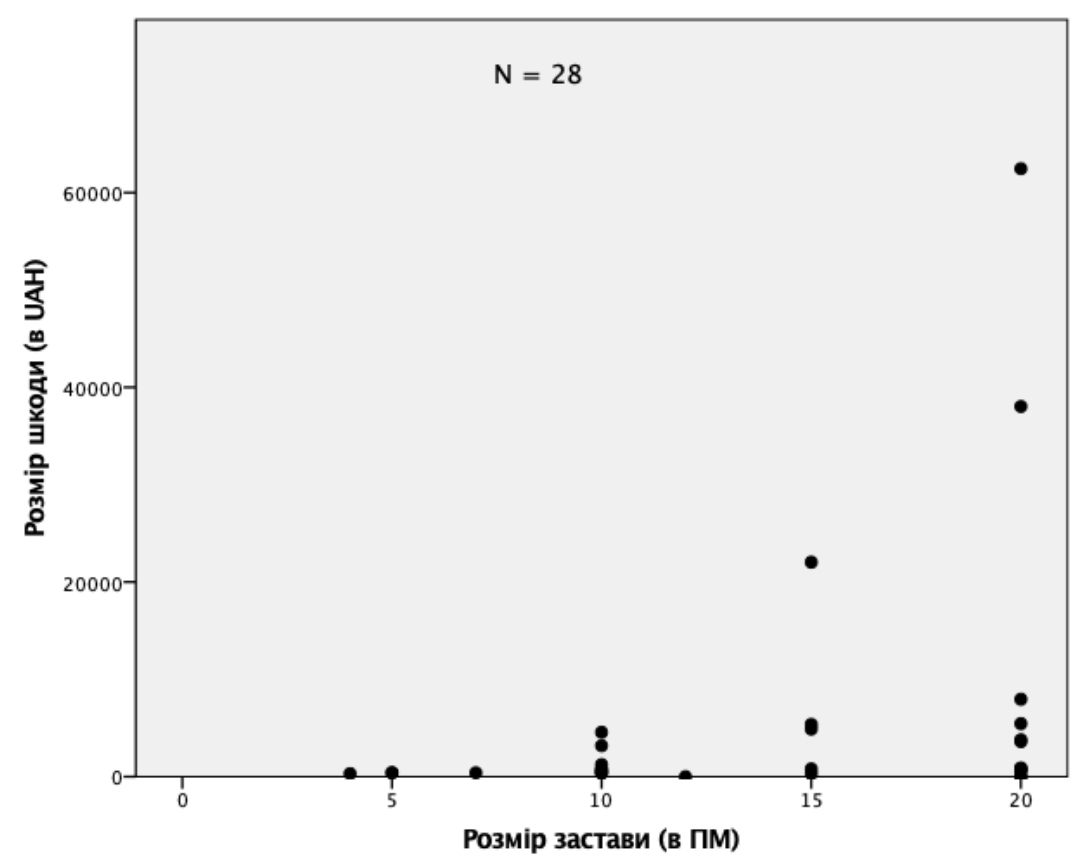

Рис. 4. Зв'язок між розміром застави й розміром майнової шкоди для нетяжких злочинів (злочинів середньої тяжкості)

В окремому дослідженні вже було проведено аналіз такого співвідношення [24], результатом якого було виділення таких графіків (рис. 4, 5, 6).

Таким чином, можна помітити, що дійсно існує певний взаємозв'язок між розміром матеріальної шкоди й розміром застави. Відповідно, задля оцінки сили зв'язку таких величин можна застосувати кореляцію Пірсона, за допомогою якої можна встановити коефіцієнт сили зв'язку (табл. 3).

Таким чином, можна помітити, що зв'язок між розміром майнової шкоди й розміром застави дійсно існує. За такої умови можна зробити висновок, що навіть рівень 0,373 вказує на достатньо сильний зв'язок, адже, по-перше, суд повинен враховувати низку інших обставин, а не лише розмір матеріальної шкоди, а по-друге, КПК України взагалі не встановлює розмір матеріальної шкоди як обставину, яка має враховуватися суддями під час визначення розміру застави.

Однак не можна не відзначити той факт, що сила кореляції збільшується зі збільшенням тяжкості кримінального правопорушення. Як було встановлено в іншому дослідженні [24], така обставина може мати таке пояснення. Щодо нетяжких злочинів, судді можуть обрати заставу лише в діапазоні 20 ПМ (від 1 до 20), щодо тяжких злочинів - 60 ПМ (від 20 до 80 ПМ), щодо особливо тяжких злочинів - 220 ПМ (від 80 до 300 ПМ). Тобто зі 
збільшенням тяжкості злочинів судді мають ширші можливості в частині відповідності розміру майнової шкоди й розміру застави.

Проте, як було неодноразово наголошено, під час визначення розміру застави судді також беруть до уваги низку інших обставин. Для того, щоб оцінити їхній вплив на числові показники розміру застави, було прийнято рішення за кожною обставиною порівняти середній розмір застави (в ПМ), в результаті чого були отримані такі результати (табл. 4-6).

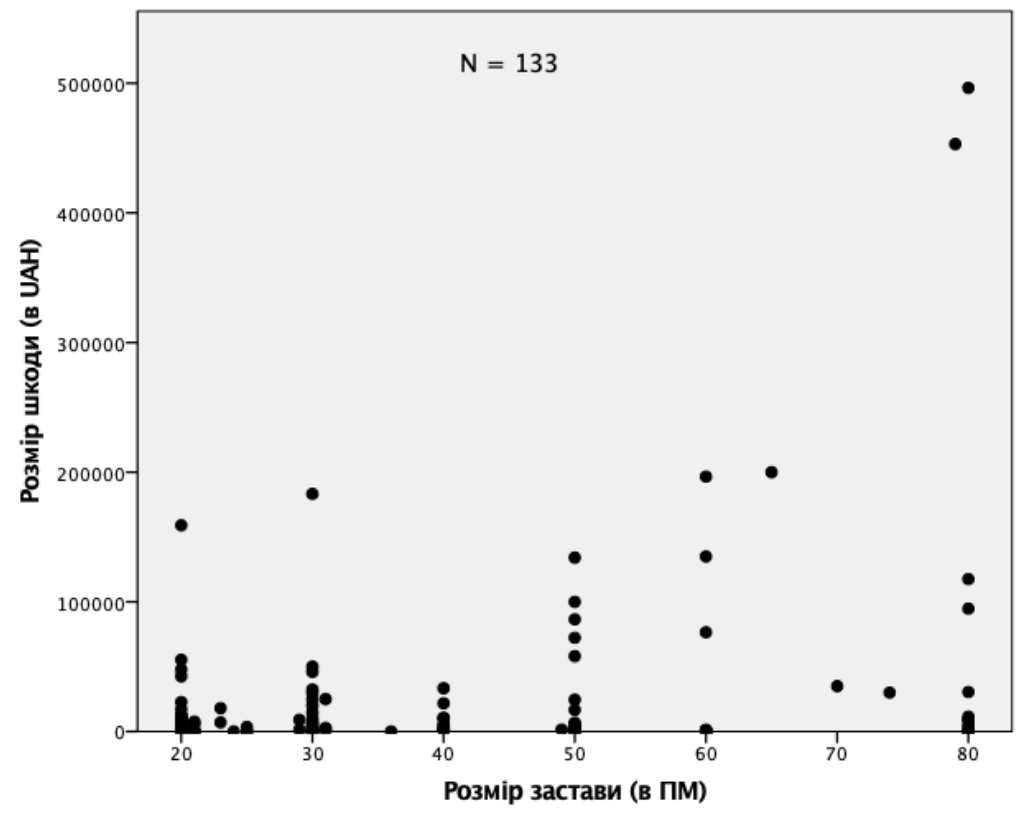

Рис. 5. Зв'язок між розміром застави й розміром майнової шкоди для тяжких злочинів

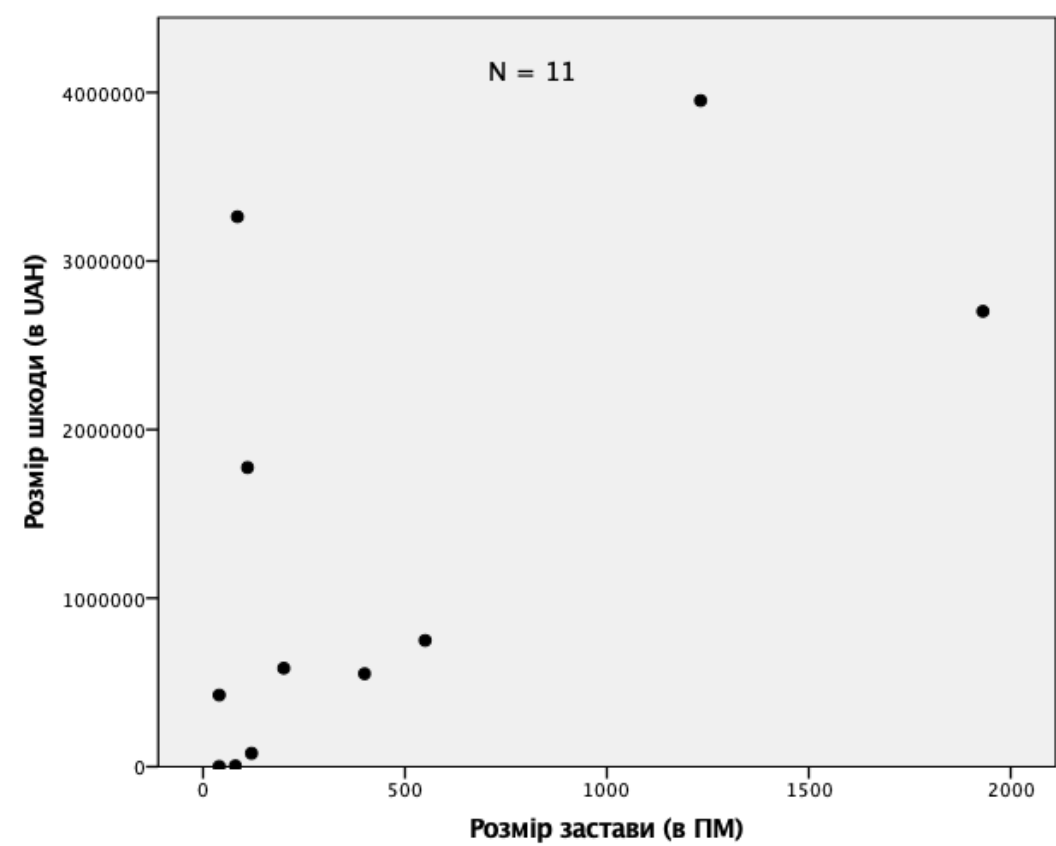

Рис. 6. Зв'язок між розміром застави й розміром майнової шкоди для особливо тяжких злочинів

Коефіцієнт кореляції між розміром матеріальної шкоди й розміром застави

Таблиця 3

\begin{tabular}{|l|c|c|c|}
\hline & Нетяжкі злочини & Тяжкі злочини & Особливо тяжкі злочини \\
\hline $\begin{array}{l}\text { Коефіціснт сили зв'язку між розміром } \\
\text { матеріальної шкоди й розміром застави }\end{array}$ & $0,373^{*}$ & $0,459 * *$ & $0,603^{*}$ \\
\hline $\begin{array}{l}* \mathrm{p}<0,05 \\
* * \mathrm{p}<0,01\end{array}$ &
\end{tabular}


Середній розмір застави для нетяжких злочинів (злочинів середньої тяжкості)

\begin{tabular}{|c|c|c|c|c|}
\hline \multirow[t]{2}{*}{ Обставина } & \multirow[t]{2}{*}{ Середнє } & \multirow[t]{2}{*}{ Стд. Помилка } & \multicolumn{2}{|c|}{ 95\% Довірчого інтервалу } \\
\hline & & & Нижня межа & Верхня межа \\
\hline \multicolumn{5}{|l|}{ Переховувався } \\
\hline не враховувалось & 14,813 & 1,377 & 11,996 & 17,629 \\
\hline погіршило & 13,400 & 1,422 & 10,491 & 16,309 \\
\hline покращило & - & - & - & - \\
\hline \multicolumn{5}{|c|}{ Допомагав розслідуванню } \\
\hline не враховувалось & 14,136 & 1,185 & 11,713 & 16,559 \\
\hline погіршило & 14,111 & 1,852 & 10,323 & 17,899 \\
\hline покращило & - & - & - & - \\
\hline \multicolumn{5}{|l|}{ Раніше судимий } \\
\hline не враховувалось & 13,333 & 3,096 & 6,991 & 19,676 \\
\hline погіршило & 14,556 & 1,032 & 12,441 & 16,670 \\
\hline покращило & 5,000 & 5,363 & $-5,986$ & 15,986 \\
\hline \multicolumn{5}{|l|}{ Спосіб життя } \\
\hline не враховувалось & 14,129 & 981 & 12,125 & 16,133 \\
\hline погіршило & - & - & - & - \\
\hline покращило & - & - & - & - \\
\hline \multicolumn{5}{|l|}{ Сім'я } \\
\hline не враховувалось & 14,389 & 1,299 & 11,728 & 17,050 \\
\hline погіршило & 13,250 & 1,591 & 9,991 & 16,509 \\
\hline покращило & 20,000 & 5,511 & 8,710 & 31,290 \\
\hline \multicolumn{5}{|l|}{ Робота (навчання) } \\
\hline не враховувалось & 13,800 & 2,484 & 8,719 & 18,881 \\
\hline погіршило & 14,192 & 1,089 & 11,064 & 16,420 \\
\hline покращило & - & - & - & - \\
\hline \multicolumn{5}{|l|}{ Житло } \\
\hline не враховувалось & 13,455 & 1,150 & 11,098 & 15,811 \\
\hline погіршило & 14,571 & 2,039 & 10,394 & 18,749 \\
\hline покращило & 20,000 & 3,815 & 12,185 & 27,815 \\
\hline \multicolumn{5}{|l|}{ Особи на утриманні } \\
\hline не враховувалось & 12,957 & 1,093 & 10,717 & 15,196 \\
\hline погіршило & 17,000 & 2,345 & 12,197 & 21,803 \\
\hline покращило & 18,333 & 3,027 & 12,133 & 24,534 \\
\hline \multicolumn{5}{|l|}{ Здоров'я } \\
\hline не враховувалось & 14,100 & 1,014 & 12,026 & 16,174 \\
\hline погіршило & 15,000 & 5,554 & 3,640 & 26,360 \\
\hline покращило & - & - & - & - \\
\hline \multicolumn{5}{|l|}{ Характеристика } \\
\hline не враховувалось & 14,000 & 1,131 & 11,684 & 16,316 \\
\hline погіршило & 13,667 & 2,262 & 9,034 & 18,299 \\
\hline покращило & 20,000 & 5,540 & 8,652 & 31,348 \\
\hline
\end{tabular}

Логічним було б припустити, що середній розмір застави у випадках, коли судді не враховували певні обставини, повинен бути вищим за випадки, коли ці обставини погіршують становище особи, й нижчим, ніж коли ці обставини покращують становище особи. Але проведене дослідження цю гіпотезу не підтверджує. Інколи середні розміри застави між собою майже рівні (Таблиця 4 - Переховувався; Таблиця 5 - Робота (навчання), Житло, Особи на утриманні тощо), а інколи в категорії «погіршує» розмір застави навіть менший, ніж у тих випадках, коли судді взагалі не брали до уваги відповідні обставини (Таблиця 5 - Раніше судимий, Спосіб життя, Характеристика; Таблиця 6 - Сім'я тощо). I навіть не можна брати до уваги випадки, коли розподіл заяв відповідає заявленій гіпотезі (Таблиця 6 - Допомагав роз- слідуванню), адже в порівнянні з іншими результатами, такі випадки більш схожі на статистичні помилки, ніж на підтвердження гіпотези.

Висновки. Таким чином можна зробити досить цікавий висновок: під час визначення розміру застави судді враховують розмір майнової шкоди (хоча КПК України цього не передбачає) й не враховують обставини, які вони зобов'язані враховувати відповідно до ст. 178 КПК України. Натепер у кримінальному процесі України досить складно спрогнозувати, який саме розмір застави буде обраний до особи, адже рішення про обрання застави не піддається логічному прогнозуванню 3 урахуванням передбачених КПК України факторів.

Водночас такий висновок не можна вважати несподіваним. Так, ще в 1995 році Голдкамп (Goldcamp) у резуль- 
Таблиця 5

Середній розмір застави для тяжких злочинів

\begin{tabular}{|c|c|c|c|c|}
\hline \multirow[t]{2}{*}{ Обставина } & \multirow{2}{*}{ Середнє } & \multirow[t]{2}{*}{ Стд. Помилка } & \multicolumn{2}{|c|}{ 95\% Довірчого інтервалу } \\
\hline & & & Нижня межа & Верхня межа \\
\hline \multicolumn{5}{|l|}{ Переховувався } \\
\hline не враховувалось & 34,648 & 1,710 & 31,272 & 38,024 \\
\hline погіршило & 33,237 & 3,101 & 27,114 & 39,360 \\
\hline покращило & 20,000 & 13,515 & $-6,688$ & 46,688 \\
\hline \multicolumn{5}{|c|}{ Допомагав розслідуванню } \\
\hline не враховувалось & 35,927 & 1,941 & 32,094 & 39,761 \\
\hline погіршило & 39,200 & 8,506 & 22,403 & 55,997 \\
\hline покращило & 31,078 & 2,378 & 26,383 & 35,773 \\
\hline \multicolumn{5}{|l|}{ Раніше судимий } \\
\hline не враховувалось & 37,773 & 4,076 & 29,724 & 45,822 \\
\hline погіршило & 33,772 & 1,639 & 30,535 & 37,009 \\
\hline покращило & 30,000 & 7,226 & 15,730 & 44,270 \\
\hline \multicolumn{5}{|l|}{ Спосіб життя } \\
\hline не враховувалось & 34,648 & 1,585 & 31,519 & 37,777 \\
\hline погіршило & 30,500 & 4,266 & 22,075 & 38,925 \\
\hline покращило & - & - & - & - \\
\hline \multicolumn{5}{|l|}{ Сім'я } \\
\hline не враховувалось & 35,870 & 2,174 & 31,577 & 40,164 \\
\hline погіршило & 33,231 & 2,160 & 28,965 & 37,497 \\
\hline покращило & 28,000 & 6,033 & 16,086 & 39,914 \\
\hline \multicolumn{5}{|l|}{ Робота (навчання) } \\
\hline не враховувалось & 34,949 & 3,017 & 28,991 & 40,906 \\
\hline погіршило & 33,974 & 1,749 & 30,520 & 37,429 \\
\hline покращило & 27,778 & 6,280 & 15,376 & 40,180 \\
\hline \multicolumn{5}{|l|}{ Житло } \\
\hline не враховувалось & 34,281 & 1,942 & 30,445 & 38,117 \\
\hline погіршило & 32,424 & 2,478 & 27,531 & 37,317 \\
\hline покращило & 43,000 & 6,019 & 31,115 & 54,885 \\
\hline \multicolumn{5}{|l|}{ Особи на утриманні } \\
\hline не враховувалось & 34,512 & 1,685 & 31,184 & 37,840 \\
\hline погіршило & 34,652 & 3,991 & 26,771 & 42,534 \\
\hline покращило & 29,615 & 5,309 & 19,132 & 40,099 \\
\hline \multicolumn{5}{|l|}{ Здоров’я } \\
\hline не враховувалось & 34,291 & 1,572 & 31,185 & 37,396 \\
\hline погіршило & 34,929 & 5,112 & 24,833 & 45,024 \\
\hline покращило & 23,333 & 11,044 & 1,524 & 45,143 \\
\hline \multicolumn{5}{|l|}{ Характеристика } \\
\hline не враховувалось & 35,302 & 1,681 & 31,983 & 38,620 \\
\hline погіршило & 29,081 & 3,101 & 22,957 & 35,206 \\
\hline покращило & 55,000 & 13,340 & 28,658 & 81,342 \\
\hline
\end{tabular}

таті змістовного дослідження факторів, які впливають на рішення суддів про обрання до особи запобіжного заходу у вигляді тримання під вартою, встановив, що «рішення про обрання запобіжних заходів рідко коли можуть бути адекватно поясненні вимірюваними факторами» [25, с. 147]. Відповідно, такий висновок дозволяє зробити низку досить важливих припущень. Наприклад, Куртіс Карнов (Curtis E. Karnow) зауважує, що розмір застави також не може обгрунтовуватися і таким фактором, як тяжкість злочину, в якому підозрюється особа [2, с. 16]. Однак у такому випадку цікавішим є інше питання: чи така ситуація прийнятна? Чи можна стверджувати, що неможливість прогнозування судового рішення $є$ прикладом високої довіри до суддівського розсуду?

Дійсно, судді повинні приймати всі процесуальні рішення виключно на підставі закону, орієнтуючись на цім на внутрішнє переконання. Проте відсутність чіткіших орієнтирів також може стати підставою для прийняття свідомо неправомірних рішень. Як вдало в такому випадку цитується рішення одного із суддів Верховного Суду Нью-Йорку, «Інколи, коли ти просто дивишся на підозрюваного, в тебе виникає відчуття, що ця особа точно буде переховуватися» [8, с. 326]. В такому випадку можна вести мову про певну правову крайність, коли суддівський розсуд фактично нічим не лімітований.

Очевидно, що введення, наприклад, обов'язкових таблиць застав $є$ іншою крайністю, яка також піддається суттєвій критиці. Представники Асоціації адвокатів США (American Bar Association) зазначили, що «таблиці застав не гнучкі: вони виключають дослідження інших обставин, які можуть мати більше значення для становлення того, що особа може переховуватись, ніж лише саме обвину- 
Юридичний науковий електронний журнал

Середній розмір застави для особливо тяжких злочинів

Таблиця 6

\begin{tabular}{|c|c|c|c|c|}
\hline \multirow[t]{2}{*}{ Обставина } & \multirow[t]{2}{*}{ Середнє } & \multirow[t]{2}{*}{ Стд. Помилка } & \multicolumn{2}{|c|}{ 95\% Довірчого інтервалу } \\
\hline & & & Нижня межа & Верхня межа \\
\hline \multicolumn{5}{|l|}{ Переховувався } \\
\hline не враховувалось & 423,800 & 202,590 & $-34,491$ & 882,091 \\
\hline погіршило & 550,000 & 640,646 & $-899,242$ & 1999,242 \\
\hline покращило & - & - & - & - \\
\hline \multicolumn{5}{|c|}{ Допомагав розслідуванню } \\
\hline не враховувалось & 377,833 & 152,758 & 25,573 & 730,093 \\
\hline погіршило & 1931,000 & 374,178 & 1068,143 & 2793,857 \\
\hline покращило & 147,500 & 187,089 & $-283,928$ & 578,928 \\
\hline \multicolumn{5}{|l|}{ Раніше судимий } \\
\hline не враховувалось & 302,429 & 228,047 & $-223,449$ & 828,306 \\
\hline погіршило & 1005,500 & 426,637 & 21,673 & 1989,327 \\
\hline покращило & 330,000 & 426,637 & $-653,827$ & 1313,827 \\
\hline \multicolumn{5}{|l|}{ Спосіб життя } \\
\hline не враховувалось & 435,273 & 183,608 & 26,168 & 844,378 \\
\hline погіршило & - & - & - & - \\
\hline покращило & - & - & - & - \\
\hline \multicolumn{5}{|l|}{ Сім'я } \\
\hline не враховувалось & 727,333 & 370,260 & $-126,488$ & 1581,155 \\
\hline погіршило & 360,143 & 242,392 & $-198,815$ & 919,100 \\
\hline покращило & 85,000 & 641,310 & $-1393,862$ & 1563,862 \\
\hline \multicolumn{5}{|l|}{ Робота (навчання) } \\
\hline не враховувалось & 160,000 & 456,389 & $-892,434$ & 1212,434 \\
\hline погіршило & 547,875 & 228,194 & 21,658 & 1074,092 \\
\hline покращило & 85,000 & 645,431 & $-1403,366$ & 1573,366 \\
\hline \multicolumn{5}{|l|}{ Житло } \\
\hline не враховувалось & 212,500 & 237,784 & $-325,406$ & 750,406 \\
\hline погіршило & 702,600 & 260,480 & 113,354 & 1291,846 \\
\hline покращило & - & - & - & - \\
\hline \multicolumn{5}{|l|}{ Особи на утриманні } \\
\hline не враховувалось & 569,125 & 222,927 & 55,055 & 1083,195 \\
\hline погіршило & 40,000 & 630,533 & $-1414,011$ & 1494,011 \\
\hline покращило & 97,500 & 445,854 & $-930,641$ & 1125,641 \\
\hline \multicolumn{5}{|l|}{ Здоров'я } \\
\hline не враховувалось & 435,273 & 183,608 & 26,168 & 844,378 \\
\hline погіршило & - & - & - & - \\
\hline покращило & - & - & - & - \\
\hline \multicolumn{5}{|l|}{ Характеристика } \\
\hline не враховувалось & 435,273 & 183,608 & 26,168 & 844,378 \\
\hline погіршило & - & - & - & - \\
\hline покращило & - & - & - & - \\
\hline
\end{tabular}

вачення» [26]. Ліндсі Карлсон (Lindsey Carlson) із цього приводу зазначає, що «регулярне використання таблиць застав часто стає причиною тримання під вартою осіб, які належать до незахищених верств населення та не можуть оплатити заставу. Такі затримання є коштовними й неефективними, адже відповідні особи втрачають роботу, соціальні зв'язки тощо» [17, с. 17].

Тому як проміжний результат можна спробувати запровадити інструмент для оцінки ризику (далі - IOP). В такому випадку йдеться про певну модель, яка дозволяє оцінити ризики в їхній сукупності й надати рекомендації щодо необхідності винесення того чи іншого рішення [27]. Поряд із цим також варто зауважити, що існують і супротивники введення та активного застосування IOP. Наприклад, серед аргументів проти застосування IOP можна почути думки про відсутність індивідуального підходу до кожного підозрюваного [28], про можливий дискримінаційний потенціал $[7$, с. 6] тощо. Водночас прибічники IOP надають власні контраргументи щодо можливості вдалого функціонування IOP у кримінальному процесі $[8$, с. 7].

Не вдаючись до подробиць суперечки, можна зробити один обережний висновок: IOP може бути досить вдалою альтернативою повній суддівській дискреції під час обрання до особи запобіжних заходів, у тому числі й застави. Водночас лишається серйозна проблема розробки вдалої моделі IOP, яка може базуватися або на реальних статистичних показниках, тобто на судовій практиці, або може бути створена незалежно від судової практики, ввібравши в себе найпрогресивніші ідеї та позиції провідних науковців і практиків. 


\section{תITEPATYPA}

1. Yang Crystal S. Toward an Optimal Bail System. New York University Law Review. 2017. No. 92 (5). P. 1399-1493.

2. Karnow E. Setting Bail for Public Safety. Berkeley J. Crim. L. 2008. No. 13 (1). P. 1-30. DOI: 10.15779/Z38W33C.

3. Myers N. Eroding the Presumption of Innocence: Pre-trial Detention and the Use of Conditional Release on Bail. The British Journal of Criminology. 2017. No. 57 (3). P. 664-683. https://doi.org/10.1093/bjc/azw002.

4. Felony bail schedule. Superior Court of California, county of Los Angeles. URL: https://www.lacourt.org/division/criminal/pdf/felony.pdf.

5. 2018 Felony bail schedule. Superior Court of California, county of Santa Barbara. URL: https://www.sbcourts.org/dv/bail/ FelonyBailSchedule.pdf

6. Bail schedule. Washington State Courts. URL: https://www.courts.wa.gov/newsinfo/content/pdf/Bail_Schedule.pdf.

7. Moving Beyond Money: A Primer on Bail Reform. Criminal justice policy program. Harvard Law School. URL: http://cjpp.law.harvard.edu/ assets/FINAL-Primer-on-Bail-Reform.pdf.

8. Glen J. Dalakian II. Open the Jail Cell Doors, HAL: A Guarded Embrace of Pretrial Risk Assessment Instruments. Fordham L. Rev. 2018. No. 87. P. 325-369.

9. Wiseman Samuel R. Fixing Bail. 2016. George Washington Law Review. 766 p. URL: https://ssrn.com/abstract=2642318.

10. Gupta A., Hansman C., Frenchman E. The Heavy Costs of High Bail: Evidence from Judge Randomization. The Journal of Legal Studies. 2016. No. 45 (2). P. 471-505. http://dx.doi.org/10.1086/688907.

11. Ex-New York Chief Judge: It's time to end cash bail. Fox News. URL: http://www.foxnews.com/opinion/2018/07/13/ex-new-york-chiefjudge-its-time-to-end-cash-bail.html.

12. Bernie Sanders' cash bail bill seeks to end "modern day debtors' prisons". The Guardian. URL: https://www.theguardian.com/ us-news/2018/jul/25/bernie-sanders-cash-bail-bill-seeks-to-end-modern-day-debtors-prisons.

13. California scraps cash bail system "because it discriminates against poor people". Independent. URL: https://www.independent.co.uk/ news/world/americas/california-cash-bail-end-state-courts-discrimination-poor-jerry-brown-a8512211.html.

14. Xiong M., Wei S. Unequal Treatment in Pretrial Detention in China. The British Journal of Criminology. 2017. No. 57 (6). P. $1398-1419$. DOI: 10.1093/bjc/azw060

15. Turner K.B., Johnson James B. A comparison of bail amounts for hispanics, whites, and african americans: A single county analysis. American Journal of Criminal Justice. 2005. No. 30 (1). P. 35-53. https://doi.org/10.1007/BF02885880.

16. Demuth S. Racial and ethnic differences in pretrial release decisions and outcomes: a comparison of hispanic, black, and white felony arrestees. Criminology. 2003. No. 41. P. 873-908. https://doi.org/10.1111/j.1745-9125.2003.tb01007.

17. Carlson Lindsey. Bail schedules: A Violation of Judicial Discretion? Criminal Justice; Chicago. 2011. No. 26 (1). P. 12-17.

18. CASE OF GAFÀ v. MALTA, European Court of Human Rights. URL: https://hudoc.echr.coe.int/eng\#\{,,itemid":[,001-183126"]\}.

19. United States v. Salerno, 481 U.S. 739., U.S. Supreme Court. URL: https://supreme.justia.com/cases/federal/us/481/739/.

20. Sacks M., Sainato V.A., Ackerman A.R. Sentenced to Pretrial Detention: A Study of Bail Decisions and Outcomes. American Journal of Criminal Justice. 2015. No. 40 (3). P. 661-681. DOI: 10.1007/S12103-014-9268-0.

21. Schlesinger T. Racial and ethnic disparity in pretrial criminal processing. Justice Quarterly. 2005. No. 22 (2). P. 170-192. https://doi.org/10.1080/07418820500088929.

22. Williams M.R. From Bail to Jail: The Effect of Jail Capacity on Bail Decisions. American Journal of Criminal Justice. 2016. No. 41 (3). P. 484-497. DOI: 10.1007/S12103-015-9305-7.

23. Торбас О.О., Касьянова В.А. Обставини, що враховуються слідчими суддями під час обрання запобіжного заходу у вигляді тримання під вартою. Південноукраїнський правничий часопис. 2018. № 3. С. 122-125.

24. Торбас О.О. Зв'язок між розміром майнової шкоди, завданої кримінальним правопорушенням, та розміром застави у кримінальному проваджені. Вісник Національного технічного університету України «Київський політехнічний інститут». Політологія. Соціологія. Право. 2018. № 3 (39). С. 157-161.

25. Goldkamp J. S., Gottfredson M. R., Jones P. R., Weiland D. Personal Liberty and Community Safety: Pretrial Release in the Criminal Court. Springer Science \& Business Media. New York, 1995. 147 p.

26. ABA Standards for Criminal Justice Third Edition Pretrial Release. American Bar Association. URL: https://www.americanbar.org/content/ dam/aba/publications/criminal justice standards/pretrial release.authcheckdam.pdf.

27. Торбас О.О. Застосування інструментів для оцінки ризиків (IOP) для обґрунтування необхідності обрання до особи запобіжних заходів: міжнародний досвід і перспективи запровадження в Україні. Юридичний бюлетень. 2018. № 8. С. 422-429.

28. Pfaff, J. F. Sentencing Law and Policy. Foundation Press. 2016. 140 p. 


\title{
ФОРМИ ВИКОРИСТАННЯ СПЕЦАЛЬНИХ ЗНАНЬ У РОЗСЛІДУВАННІ КРИМІНАЛЬНИХ ПРАВОПОРУШЕНЬ, ПОВ'ЯЗАНИХ ІЗ РЕЙДЕРСЬКИМИ ЗАХОПЛЕННЯМИ
}

\author{
FORMS OF USE OF SPECIAL KNOWLEDGE IN THE INVESTIGATION \\ OF CRIMINAL OFFENSES RELATED TO RIDER HOBBIES
}

\author{
Федорчук М.А., здобувач кафедри цивільного, господарського, \\ адміністративного права та правоохоронної діяльності \\ Відкритий міжнародний університет розвитку людини «Украйна»
}

Стаття присвячена аналізу використання спеціальних знань, тобто знань і навичок конкретно визначеної особи, які не є загальнодоступними й загальновідомими. Автор робить висновок про їх необхідність для виконання конкретно поставлених завдань, які є виключно компетенцією органів досудового розслідування чи суду для встановлення об'єктивної дійсності в кримінальному провадженні, а також застосування яких здебільшого потребує додаткових пристроїв, ресурсів і засобів.

Нами визначено, що важливою рисою спеціальних знань у кримінальному процесуальному значенні є мета їхнього використання. Вони застосовуються для доказу в установленому законом порядку, а також для непроцесуального застосування під час проведення оперативно-розшукових заходів. Метою застосування спеціальних знань також $є$ сприяння збиранню доказової орієнтувальної інформації для розслідування та запобігання скоєнню злочинів, а також розроблення тактичних і технічних засобів і методів ії збирання. Застосовувати спеціальні знання можуть не лише обізнані експерти й спеціалісти, але й особи, які проводять досудове розслідування, здійснюють оперативно-розшукову діяльність, хоча результати їхнього застосування матимуть різне процесуальне значення.

Проаналізовано матеріали слідчої практики, які дають підстави для висновку, що в кримінальних провадженнях, пов'язаних із рейдерськими захопленнями, письмові пояснення спеціаліста й експерта-криміналіста є додатковим способом підтвердження джерела формування такого доказу. В абсолютній більшості проваджень пояснення надають штатні працівники експертно-криміналістичних підрозділів, які $€$ фахівцями з виявлення та вилучення речових доказів і які в процесуальному статусі спеціаліста були залучені до проведення огляду місця події. У письмовому поясненні такий спеціаліст описує методи так званого експрес-аналізу (процес установлення фрактичних даних, що мають значення для конкретного фракту правопорушення), методи вилучення та збереження слідів злочину.

Ключові слова: спеціальні знання, рейдерське захоплення, кримінальне правопорушення, спеціаліст, експерт.

The article analyses the use of special knowledge, which means the knowledge and skills of a specific person, which are not publicly available and well-known, about their need to solve specific tasks, which are the exclusive competence of pre-trial investigation or court to establish effective reality in criminal proceedings, as well as the use of which mostly requires additional devices, resources and tools.

We have determined that an important feature of special knowledge in the criminal procedural sense is the purpose of their use. They are used for evidence, which is conducted in the manner prescribed by law, as well as for non-procedural use during operational and investigative measures. The purpose of the application of special knowledge is also to facilitate the collection of evidence-based information for the investigation and prevention of crimes, as well as the development of tactical and technical means and methods of its collection. Special knowledge can be applied not only by knowledgeable persons (experts, specialists), but also by persons conducting pre-trial investigation, carrying out operativeinvestigative activities, although the results of their application will have different procedural significance.

The materials of the investigative practice are analysed, which gives grounds to conclude that in criminal proceedings related to raids, written explanations of a specialist and forensic expert are an additional way to confirm the source of such evidence. In the vast majority of proceedings, explanations are provided by staff members of forensic units who are specialists in the detection and seizure of material evidence, and who were involved in the procedural status of the specialist during the inspection of the scene. In a written explanation, such a specialist describes the methods of so - called rapid analysis (the process of establishing factual data relevant to a particular fact of the offense); methods of removing and preserving traces of the crime.

Key words: special knowledge, raider capture, criminal offense, specialist, expert.

Застосування спеціальних знань під час розслідування кримінальних правопорушень взагалі та пов'язаних з рейдерськими захопленнями зокрема набуває все більшої актуальності.

Під спеціальними знаннями в наукознавстві й філософії розуміють системно упорядкований і перевірений суспільно-історичною практикою результат процесу пізнання дійсності у свідомості людини у вигляді уявлень, суджень, понять, теорій, сукупність відомостей з будь-якої галузі, набутих у процесі навчання, дослідження тощо [1].

Спеціальні знання - це знання, які вимагають більш чи менш довготривалої, серйозної підготовки, досвіду, можливо, навичок і талантів; які потрібні для вирішення питань, що входять у компетенцію органу досудового розслідування чи суду; які дають змогу особі, яка ними володіє, застосовувати суму відомостей, отриманих рекомендацій, досвіду на практиці, а нерідко їхнє використання неможливе без особливого спорядження, певних пристроїв тощо [2].

Спеціальні знання є одним із компонентів арсеналу організаційних, процесуальних, тактичних й інших засобів, що можуть використовуватися слідчим. Це зобов'язує до того, щоб їхній зміст відповідав завданням і меті кримінального судочинства.
Незаперечним є той факт, що неможливо досягти високої якості розслідування кримінальних правопорушень, пов'язаних із рейдерськими захопленнями, без застосування спеціальних знань із різних галузей науки й техніки [3].

Аналіз спеціальної літератури, слідчої й судової практики свідчить, що 3 приводу використання спеціальних знань слідчим немає єдиної думки, а наявні погляди такі суперечливі, що становлять труднощі в систематизації й виділенні будь-якої тенденції. Спільність поглядів виявляється лише в тому, що використання спеціальних знань слідчим належним чином не врегульовано кримінальним процесуальним законодавством [4].

Так, В.М. Ревака за способом реалізації спеціальних знань виокремлює п'ять форм: дослідження (передекспертне, зокрема ревізія, й експертне); техніко-прикладна форма (використання спеціальних знань під час провадження процесуальних дій); оперативно-розшукова форма; знаково-лінгвістична форма (переклад); консультаційна форма [5].

B.M. Тертишник виокремлює чотири форми застосування знань спеціалістом:

а) безпосередньо практична діяльність: 
- підготовка, організація й проведення слідчих (розшукових) дій;

- виявлення, закріплення, вилучення доказів, зразків об'єктів для експертного дослідження, а в разі необхідності - їх огляд і дослідження;

б) методична (3 питань науково-практичних прийомів і методів організації й проведення слідчих (розшукових) дій, роботи з доказами);

в) технічна (використання науково-технічних засобів під час проведення слідчих (розшукових) дій, необхідних для виявлення, закріплення, вилучення, огляду й дослідження речових доказів);

г) консультативна (полягає в усних роз'ясненнях, довідках зі спеціальних питань, що можуть виникнути або виникають під час підготовки, проведення гласних і негласних слідчих (розшукових) дій, роботи 3 доказами та процесуального оформлення їхніх результатів) [6].

A.M. Лазебний, використовуючи категорію «мета використання спеціальних знань», характеризує в методиці розслідування кримінальних правопорушень проти громадської безпеки дві інші форми: пошук і фіксація та призначення й проведення експертиз [7]. На думку вченого, кожна $з$ них передбачає використання знань спеціалістів під час здійснення окремих слідчих (розшукових) дій.

Вивчення спеціальної криміналістичної літератури й сучасної слідчої практики дає підстави стверджувати, що нині неможливо проводити досудове розслідування, під час якого не було б використано спеціальні знання хоча б в одній, прямо передбаченій Кримінальним процесуальним кодексом України (далі - КПК України), формі iii реалізації. У теорії кримінального процесу або криміналістики вони мають різні умовні назви, однак спосіб їх реалізації, передбачений процесуальним законодавством, від цього не змінюється.

Отже, враховуючи положення КПК України, вважаємо, що можна відокремити три процесуальні форми використання спеціальних знань під час досудового розслідування: залучення спеціаліста для надання письмової консультації; залучення спеціаліста для надання безпосередньої технічної допомоги під час процесуальних дій; залучення експерта для проведення судової експертизи й виконання обов'язків судового експерта [8].

Повсякденна практика розслідування злочинів, пов'язаних із рейдерськими захопленнями, засвідчує наявність безлічі організаційних і тактичних питань використання таких форм спеціальних знань.

Залучення спеціаліста для надання письмової консультації відбувається згідно зі ст. 71 КПК України. Консультації традиційно можуть бути письмовими й усними, однак процесуальною є лише письмова форма консультації (ч. 2 ст. 105 КПК України регламентує процесуальний спосіб надавання консультації спеціаліста: це письмове пояснення спеціаліста, який брав участь у проведенні відповідної процесуальної дії, що є додатком до протоколу такої дії).

Залучення спеціаліста для надання безпосередньої технічної допомоги регламентується відповідно до статті 71 КПК України, коли спеціаліст залучається під час проведення процесуальної дії та фотографування, складення схем, планів, креслень, відбору зразків для проведення експертизи тощо. Специфіка цієї форми полягає в тому, що іiі реалізація слідчим фактично дає змогу оформити в процесуальне джерело доказів результат залучення в кримінальне провадження спеціаліста як суб'єкта спеціальних знань. Можливо, саме тому, визначаючи специфіку цієї форми використання спеціальних знань, експертипрактики називають цей формат роботи «взаємодією слідчого та спеціаліста в кримінальних провадженнях» [9].

У документі як джерелі доказів згідно зі ст. 99 КПК України спеціаліст утілює свої спеціальні знання, зокрема, через створення матеріалів фотозйомки, звукозапису, відеозапису й інших носіїв інформації (стосовно досліджуваної категорії злочинів під час огляду чи обшуку); постановку з дозволу слідчого питань, що відображаються в протоколах слідчих (розшукових) дій (актуально з позицій психолога, педагога, лікаря, спеціаліста відповідного фаху); подання зауважень щодо протоколів процесуальних дій, чим акцентує увагу учасників процесу на обставинах й особливостях речей і документів, що стосуються відповідної сфери спеціальних знань [10].

Досліджуючи зміст діяльності 3 проведення негласних слідчих (розшукових) дій, використання їхніх результатів у кримінальному провадженні, С.С. Кудінов виокремив такі напрями застосування фахівцями спеціальних знань у зв'язку з проведенням негласних слідчих (розшукових) дій:

а) для їх підготовки (пов'язано з обранням найсприятливіших умов для проведення негласних слідчих (розшукових) дій (час, місце), підготовкою або виготовленням технічних, імітаційних засобів, визначенням кола учасників, їх добором й інструктажем);

б) безпосередньо під час їх проведення (розглянуто як вчинення конкретних дій, застосування тактичних прийомів проведення; участь у здійсненні візуального спостереження);

в) для фіксації, оформлення отриманих результатів i ïx збереження (полягає в урахуванні й використанні рекомендацій щодо роботи з окремими предметами, речовинами, вилучення слідів, речових доказів, зокрема забезпечення належних умов їх зберігання до передання прокурору);

г) проведення досліджень отриманих матеріалів (полягає в їх використанні або врахуванні безпосередньо під час дії: наприклад, виявлення та фіксація позначок предметом контрольованої поставки; виявлення, фіксація та збереження негласно отриманих зразків хімічних речовин) [11].

Залучення спеціаліста для надання усної консультації набуло широкого розповсюдження. У процесуальному законі немає згадок про отримання усних консультацій спеціаліста під час досудового розслідування; усні консультації та роз'яснення спеціаліста законодавець регламентує лише стосовно стадії судового розгляду (У ст. 360 КПК України). Ефективність цієї непроцесуальної форми використання спеціальних знань 3 метою подальшого залучення експерта для проведення судової експертизи не викликає сумніву в жодного практика. Такі усні консультації проводять здебільшого з керівниками й експертами (за погодженням із керівником) лабораторій експертних служб, зокрема:

- лабораторій комп'ютерної техніки й телекомунікаційних досліджень; нологій;

- лабораторій досліджень у сфері інформаційних тех-

$$
\text { - лабораторій економічних досліджень; }
$$

- лабораторій криміналістичних досліджень.

Залучення спеціаліста відбувається під час перевірки оперативної інформації про злочини, що вчинені або готуються. Процесуальні підстави для залучення оперативних співробітників до участі в проведенні оперативно-розшукових заходів не виокремлено. Непроцесуальне використання спеціальних знань під час розслідування кримінальних правопорушень, пов'язаних 3 рейдерськими захопленнями, обмежується тільки умовою забезпечення можливості подальшого дослідження вихідних матеріалів спеціалістом або судовим експертом. Звичайно, у будьякому випадку використання спеціальних знань слідчим має відповідати меті та принципам кримінального судочинства. Слідчий, з урахуванням першої умови, має право робити будь-які дослідження на основі спеціальних знань для одержання тактичної, але не доказової інформації. Хід i результати подібного дослідження, як і сам факт його виконання, у протоколах слідчих дій не відображаються. 
Використання спеціальних знань слідчим щодо розслідування кримінальних правопорушень, пов'язаних 3 рейдерськими захопленнями, як окремий рівень їхнього застосування має такі риси:

- слідчий безпосередньо сам здійснює практичну діяльність, засновану на спеціальних знаннях. Дійсно, і в цих випадках може бути участь спеціаліста, але найчастіше тільки у вигляді консультативної й науково-технічної допомоги;

- попри те що необхідність застосування слідчим спеціальних знань обумовлена інтересами досягнення процесуальної мети, що відповідає його діяльності, має непроцесуальний характер;

- спеціальні знання слідчого тісно переплітаються 3 його звичайними, правовими знаннями й життєвим досвідом. Виділити їх із загальної системи знань слідчого складно й можливо тільки тоді, коли дії слідчого цілком базуються на таких знаннях. В інших випадках упродовж усього розслідування спеціальні знання слідчого використовуються поряд з іншими. Процес цей є безперервним і пронизує все розслідування, тому застосування слідчим своїх спеціальних знань у більшості випадків важко виокремити й формалізувати.

Належна організація використання спеціальних знань під час розслідування кримінальних правопорушень, пов'язаних з рейдерськими захопленнями, дає можливість одержати слідчому інформацію, що полегшує збирання доказів, зменшує обсяг роботи з викриття осіб, які вчинили злочинні дії.

В.В. Цикаль взагалі заперечує існування непроцесуальної форми використання спеціальних знань. Він вважає припустимим непроцесуальне використання спеціальних знань лише в оперативно-розшуковій діяльності під час розкриття злочинів. [12]. 3 цим твердженням важко погодитись, оскільки використання слідчим допомоги фахівця в непроцесуальній формі є не лише припустимим, але й необхідним через єдність тактичного й процесуального боку слідчих (розшукових) дій і розслідування злочину в цілому. Разом із тим П.В. Цимбал наполягає на правомірності й необхідності ширшого використання спеціальних знань у непроцесуальній формі [13]. На думку В.В. Лисенка, практика кримінального судочинства свідчить про широке використання спеціальних норм у непроцесуальній формі [14].

3 цього приводу В.П. Бахін і П.В. Цимбал зазначають, що «спеціальні знання й технічні засоби використовуються під час розслідування злочинів не лише в процесуальній формі, а в значно ширших масштабах» [15].

Використання спеціальних знань під час розслідування кримінальних правопорушень, пов'язаних 3 рейдерськими захопленнями, окрім того може відбуватись у вигляді консультацій, науково-технічної допомоги, попередніх експрес-досліджень тощо.

Консультативна діяльність $\epsilon$ найбільш розповсюдженим різновидом непроцесуальної допомоги фахівця в ході розслідування кримінальних правопорушень, пов'язаних 3 рейдерськими захопленнями. Виділяють три основні типові види консультацій фахівця: а) консультації загального характеру; б) консультації в процесі підготовки до проведення слідчих (розшукових) дій; в) консультації під час проведення слідчих (розшукових) дій.

Консультації загального характеру дають змогу особі, яка здійснює розслідування, зорієнтуватися в події злочину, його механізмі, масштабах злочинної діяльності, колі учасників злочину тощо - у тій частині цих питань, що пов'язана зі спеціальними знаннями.

Конкретні консультації фахівця зі спеціальних питань під час підготовки до проведення слідчих (розшукових) дій $є$ засобами підвищення ефективності слідчих (розшукових) дій, тому що знижують ентропію, підвищують цілеспрямованість. За допомогою й на основі таких кон- сультацій слідчий точніше визначає обсяг, напрям і межі з'ясування питань, що вимагають спеціальних знань.

Консультативна допомога може здійснюватись і під час проведення слідчої (розшукової) дії.

У першу чергу це стосується залучених спеціалістів у допитах.

В.О. Коновалова рекомендує в складних випадках допит проводити в присутності спеціаліста [15].

Допомога фахівця в непроцесуальній формі може мати науково-технічний характер. Але також можливі варіанти. Залежно від спрямованості подібної допомоги можна виділити дві ситуації.

У ході непроцесуальних стосунків із фахівцем слідчий може одержати інформацію, що є важливою для розслідування. Специфіка цієї форми допомоги полягає в тому, що й тут фахівець не лише ділиться знаннями й досвідом їхнього застосування, але й передає слідчому інформацію, уже зібрану з використанням своїх знань під час здійснення підготовки до участі в розслідуванні кримінального правопорушення.

Велике значення у розслідуванні кримінальних правопорушень, пов'язаних з рейдерськими захопленнями, має інформація, здобута шляхом проведення попередніх експертних досліджень об'єктів, виявлених і вилучених під час огляду місця події чи проведення інших слідчих (розшукових) дій.

Іноді під час виконання слідчої (розшукової) дії або після неї слідчому важливо оперативно одержати інформацію, яка допомагає зорієнтуватися, на основі проведеного експрес-дослідження будь-яких об'єктів.

Попереднє експрес-дослідження об'єктів не лише не конкурує з судовою експертизою, але й сприяє іiї забезпеченню та процесуальній підготовці. Зважаючи на те, що в більшості випадків результати судово-експертного дослідження доводиться чекати тривалий час, попередня інформація $є$ важливою з тактичної точки зору [16].

Не виникає жодного сумніву в тому, що експертне дослідження є більш точним, глибоким і всебічним. Висновок експерта має велике доказове значення. Процедура підготовки матеріалів, призначення й проведення експертизи відпрацьовані багаторічним досвідом і детально регламентовані. Але потрібно зазначити, що призначення експертизи - складний, трудомісткий, тривалий процес, тому що, крім досить значного часу, якого вимагає саме дослідження, великі його витрати також на пересилання матеріалів до експертної установи й подальше їхнє доповнення й оформлення результатів [17].

Чи не свідчить усе це про те, що судова експертиза - особливий винятковий засіб, вид процесуальної форми допомоги фахівця, і застосовувати його потрібно лише тоді, коли того чітко вимагає законодавець.

Незнання можливостей різних форм використання спеціальних знань під час розслідування кримінальних правопорушень, пов'язаних 3 рейдерськими захопленнями, на практиці найчастіше призводить до двох за своєю сутністю протилежних помилок. Іноді без особливої необхідності призначається певна судова експертиза тоді, коли можна було б обмежитися іншою, простішою формою, або, навпаки, трапляються спроби підміни обов'язкової в такому випадку судової експертизи іншою, спрощеною формою використання спеціальних знань.

Вивчення слідчої практики свідчить про недоліки використання спеціальних знань під час розслідування кримінальних правопорушень, пов'язаних з рейдерськими захопленнями. Причини цього негативного явища багатоаспектні.

До основних потрібно віднести законодавче, кадрове, технічне й науково-методичне забезпечення. Вирішення цих проблем дасть змогу на більш високому рівні забезпечити практику розслідування кримінальних правопорушень $з$ використанням спеціальних знань. 
Таким чином, можна стверджувати, що необхідність використання спеціальних знань під час розслідування кримінальних правопорушень, пов'язаних із рейдерським захопленням, обумовлена складністю та специфікою процесу доказування обставин у кримінальному провадженні. Особливо це характерно для сучасного періоду, коли для підготовки, вчинення кримінального правопорушення використовуються передові наукові технології, сучасні технічні засоби тощо.

\section{ЛITEPATУРA}

1. Новий тлумачний словник української мови : у 3 т. / уклад. В.В. Яременко, О.О. Сліпушко. Київ, 2003. Т. 1. 926 с.

2. Лазебний А.М. Використання спеціальних знань при розслідуванні кримінальних правопорушень проти громадського порядку : автореф. дис. ... канд. юрид. наук. Ірпінь. 2016. 20 с.

3. Закатов А.А., Оропай Ю.Н. Использование научно-технических средств и специальных знаний в расследовании преступлений. Киев : РИО МВД УССР, 1980. 104 с.

4. Мотусовський Г., Корж В., Бушан О., Багирський В. Проблеми розслідування кримінальних справ про злочини у сфері економіки. Право України. 1997. № 8. С. 90-93.

5. Ревака В.М. Форми використання спеціальних знань у досудовому провадженні : дис. ... канд. юрид. наук : 12.00.09. Харків, 2006.180 c.

6. Тертишник В.М. Кримінально-процесуальне право України : підручник, 4-те вид., допов. і переробл. Київ : А.С.К., 2003. С. 691.

7. Лисиченко В.К., Циркаль В.В. Использование специальных знаний в следственной и судебной практике : учебное пособие. Киев : КГУ, 1987. $100 \mathrm{c}$

8. Самойленко О.А. Основи методики розслідування злочинів, вчинених у кіберпросторі : монографія / за заг. ред. А.Д. Волобуєва. Одеса, 2020. 372 c

9. Теплицький Б.В., Шарай Л.Г., Ковальов К.М., Кузьмін С.А. Злочини у сфері використання електронно-обчислювальних машин (комп'ютерів), систем та комп'ютерних мереж і мереж електрозв'язку: науково-практичний посібник. Київ : Паливода А.В., 2019. С. 78.

10. Кудінов С.С. Використання спеціальних знань під час проведення негласних слідчих (розшукових) дій. Вісник Академії адвокатури України. 2014. № 3 (31). С. 154-161.

11. Циркаль В.В. Тактика производства следственных действий с участием специалистов : дис. ... канд. наук : 12.00.09. Киев, 1984. 197 C.

12. Цымбал П.В. Совершенствование использования научно-технических достижений в расследовании преступлений : авторефр. дис. ... канд. юрид. наук : 12.00.09. Киев, 1992. 25 с.

13. Лисенко В.В. Криміналістичне забезпечення діяльності податкової міліції: (теорія та практика) : монографрія / В.В. Лисенко. Київ : Лoroc, 2004. С. 324 c.

14. Бахін В.П., Цимбал П.В. Удосконалення форм використання науково-технічних досягнень у розслідуванні. Проблеми удосконалення кримінального та кримінально-процесуального законодавства : міжвузівський збірник наукових праць. Київ : НАВС, 1993. С. 112-122.

15. Коновалова В.О. Допит: тактика і психологія. Харків, 1999. 157 с.

16. Кириченко А.А. Основы криминалистической микрологии : авторефр. дис. ... д-ра юрид. наук : 12.00.09. Национальная юридическая академия Украины. Харьков, 1996. 31 с.

17. Бахин В.П. Криминалистика. Проблемы и мнения (1962-2002) : монография. Киев : Б.И., 2002. 268 с. 


\title{
ПРАВОВИЙ СТАТУС НЕПОВНОЛІТНІХ ПІДОЗРЮВАНИХ У КРИМІНАЛЬНОМУ ПРОЦЕСУАЛЬНОМУ ЗАКОНОДАВСТВІ УКРАЇНИ
}

\author{
THE LEGAL STATUS OF MINORS SUSPECTED \\ OF CRIMINAL PROCEDURAL LAW OF UKRAINE
}

\author{
Харченко С.В., к.ю.н., \\ старший викладач кафедри досудового розслідування \\ Навчально-науковий інститут № 1 \\ Національної академії внутрішніх справ
}

\begin{abstract}
У статті окреслено правовий статус неповнолітніх підозрюваних у кримінальному процесуальному законодавстві України й розглядаються його особливості. Проаналізовано поняття «неповнолітній», «підозрюваний» у різних галузях законодавства. Досліджено законодавство України, міжнародні документи щодо статусу неповнолітніх підозрюваних. Сформульовано авторський погляд стосовно переліку основних елементів структури правового статусу неповнолітніх підозрюваних, описано вікові особливості неповнолітніх підозрюваних.

Неповнолітні належать до особливої категорії в будь-якому суспільстві, оскільки через свою соціальну незрілість, особливості вікового та психічного розвитку не здатні повною мірою оцінювати характер і наслідки своїх вчинків. Разом із тим вони $є$ повноправними членами цього суспільства. Кожна особа нашої держави володіє загальноправовим статусом, що надає їй можливість реалізовувати конституційні права, свободи й обов'язки. Прагнення України стати повноправним учасником міжнародного співтовариства зумовило ратифікацію низки міжнародних договорів, що стосуються захисту прав неповнолітніх. На положення цих нормативних актів повинні спиратися як українські законодавці, так і органи, що здійснюють кримінальне провадження, однак аналіз і порівняння норм національного законодавства й міжнародно-правових документів свідчать про необхідність їх узгодження. Сьогодні актуальності знову набули питання такого змісту: визначення поняття «неповнолітній підозрюваний»; момент, з якого особа набуває статусу неповнолітнього підозрюваного; підстави, що дозволяють повідомити особі про підозру в кримінальному правопорушенні.

Правовий статус неповнолітніх підозрюваних у кримінальному процесуальному законодавстві України базується на міжнародно-правових актах, що ратифіковані Україною, та національному законодавстві України, починаючи з Конституції, законів й інших нормативноправових актів, дотримання яких є обов'язковою умовою здійснення кримінального провадження за участю неповнолітніх. Важливого значення набуває вдосконалення правового статусу неповнолітнього підозрюваного, що підвищить його активність у реалізації та захисті своїх процесуальних прав.
\end{abstract}

Ключові слова: кримінальне провадження, правовий статус, неповнолітні підозрювані, вікові особливості, гарантії, процесуальні права й обов'язки.

The article outlines the legal status of minors suspected of criminal procedural legislation of Ukraine and considered its features. Analyzed the concept of "minor", "suspect" in the various fields of law. Studied the legislation of Ukraine, international documents on the status of juvenile suspects. Author's opinion on the list of basic elements that are included in the structure of the legal status of the juvenile suspects, described age characteristics of juvenile suspects.

Minors are a special category in any society because through their social immaturity, especially the age and mental development is not able to fully assess the nature and consequences of their actions. At the same time - they are full members of society. Every person our country has a common law status, which gives her the opportunity to implement constitutional rights, freedoms and responsibilities. Ukraine's desire to become a full member of the international community led to the ratification of several international treaties relating to the protection of minors. The provisions of these regulations should be based as Ukrainian lawmakers and authorities engaged in criminal proceedings, but the analysis and comparison of national legislation and international instruments demonstrates the need for coordination. Today its relevance regained question as follows: the definition of a juvenile suspect; moment at which a person acquires the status of a minor suspect; base, allowing the person to report suspicion of a criminal offense.

One of the components of the legal status of the juvenile suspect - the procedural rights and obligations enshrined in paragraph 7 of Article 42 of the CPC of Ukraine. A juvenile suspect not only enjoys the rights provided by the Constitution of Ukraine, in particular Articles $28,29,55,56,59,62,63$, because the current Code of Ukraine significantly expanded the rights of the defense in criminal proceedings.

Increased attention by the legislator to protect the rights of persons under eighteen years of age and have committed a criminal offense, first revealed that the Criminal Procedure Act provides for them to "dual representation" of their interests, that involves simultaneously participate in the proceedings in the criminal proceedings defense counsel, legal representative, teacher or psychologist.

The legal status of minors suspected of criminal procedural law of Ukraine based on international instruments that are ratified by Ukraine, and Ukraine national legislation, starting with the Constitution, laws and other legal acts, compliance with which is a prerequisite for the implementation of criminal proceedings involving minors. Gaining importance to improve the legal status of the juvenile suspect, thus increasing its activity and protect their procedural rights.

Key words: criminal proceedings, legal status, underage suspects, age characteristics guarantee procedural rights and obligations.

Постановка проблеми. Правова реформа, що покликана гармонізувати кримінальне процесуальне законодавство відповідно до міжнародно-правових стандартів, обумовила перегляд низки положень різних галузей права, у тому числі й кримінального процесуального. Неповнолітні належать до особливої категорії в будь-якому суспільстві, оскільки через свою соціальну незрілість, особливості вікового та психічного розвитку не здатні повною мірою оцінювати характер і наслідки своїх вчинків. Разом iз тим вони є повноправними членами цього суспільства. Кожна особа нашої держави володіє загальноправовим статусом, що надає їй можливість реалізовувати конституційні права, свободи й обов'язки. Прагнення України стати повноправним учасником міжнародного співтовари- ства зумовило ратифікацію низки міжнародних договорів, що стосуються захисту прав неповнолітніх. На положення цих нормативних актів повинні спиратися як українські законодавці, так і органи, що здійснюють кримінальне провадження, однак аналіз і зіставлення норм національного законодавства й міжнародно-правових документів свідчать про необхідність їх узгодження.

Стан дослідження проблеми. Досліджуючи проблеми правового статусу неповнолітніх у кримінальному провадженні, враховувати необхідно те, що це питання розглядалося вітчизняними й зарубіжними вченими з різних галузей юриспруденції: конституційного права, кримінології, кримінального процесу, юридичної психології. Питання правового статусу (у тому числі неповноліт- 
ніх) були предметом наукових досліджень таких учених, як В.М. Бурдін, А.С. Голубов, Т.О. Гончар, М.В. Джига, М.О. Карпенко, С.П. Коталейчук, О.О. Левендаренко, О.Р. Михайленко, Ю.П. Янович та інших. Безумовно, значущість досліджень цих науковців дуже суттєва. Однак багато питань у цій сфері залишаються невирішеними й дискусійними. Незважаючи на багаторічні напрацювання вчених, слід зазначити, що неабиякої актуальності набуває питання процесуального статусу неповнолітнього підозрюваного в кримінальному провадженні в наш час.

Актуальність теми дослідження. Нове законодавство, зокрема чинний Кримінальний процесуальний кодекс України 2012 року (далі - КПК України), ратифікація Україною міжнародних договорів обумовлюють потребу розгляду процесуального статусу неповнолітнього в сучасних умовах. КПК України містить ряд нових положень, які потребують поглибленого наукового осмислення. Як убачається, законодавець у чинному КПК України процесуальні права підозрюваного урівняв з процесуальними правами обвинуваченого. Це, зокрема, стосується й положень, що розкривають сутність процесуального статусу неповнолітніх, які вчинили кримінальне правопорушення та є підозрюваними. Сьогодні своєї актуальності знову набули питання такого змісту: визначення поняття неповнолітнього підозрюваного; момент, з якого особа набуває статусу неповнолітнього підозрюваного; підстави, що дозволяють повідомити особі про підозру в кримінальному правопорушенні. 3'ясування цих питань обумовлюе актуальність зазначеної проблематики.

Метою й завданням статті є визначення правового статусу неповнолітніх підозрюваних у кримінальному процесуальному законодавстві України.

Виклад основного матеріалу. Права, гарантовані державою, незалежно від віку, статі й національності

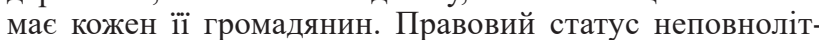
ніх в Україні включає правові положення стосовно прав людини, закріплені як у міжнародно-правових актах, так i в національному законодавстві (Конвенція ООН про права дитини [7], Закон України «Про охорону дитинства») [3].

Кримінальне провадження щодо неповнолітніх повинно здійснюватися з неухильним дотриманням Конвенції ООН про права дитини 1989 року, Міжнародного пакту про громадянські й політичні права 1966 року, Конвенції про захист прав людини й основоположних свобод 1950 року та інших міжнародно-правових актів щодо прав людини.

Стаття 1 Конвенції про права дитини, прийнятої Генеральною Асамблеєю ООН 20 листопада 1989 року i ратифікованої Постановою Верховної Ради України 27 лютого 1991 року [7], проголошує, що дитиною $\epsilon$ кожна людська істота до досягнення вісімнадцятирічного віку. 3 огляду на викладене, слід погодитися з тим, що вік як особливість особи є одним із чинників, від якого залежить формування й закріплення правового статусу неповнолітнього підозрюваного. 3 юридичної точки зору вік особи розглядається як показник можливості засвоєння та виконання нею правових вимог. Більше того, вік особи вказує на спроможність особи бути не пасивним об'єктом правового регулювання, а його активним суб'єктом. Досягнення певного віку передбачає здатність особи брати участь у широкому колі правовідносин, реалізуючи свої права, виконуючи обов'язки та відповідаючи за свої дії $[8$, с. 108].

Так, В.Б. Ісаков відзначав, що вік - це юридично значуща обставина (юридичний факт), яка обумовлює особливий тип правових зв'язків - загальних (загально регулятивних), а в подальшому існуванні вік особи стає юридичною умовою, що впливає на визначення правоздатності й громадянського стану суб'єктів права [4, с. 22]. Є.Г. Коваленко зазначає, що залежно від віку законода- вець поділяє осіб на декілька категорій і встановлює для них певні процесуальні гарантії для захисту їхніх прав [6, с. 658]. Фактичною основою такого стану, як наголошується в літературі та відзначається в нормативних актах (Конвенція ООН про права дитини), є недостатній рівень психофізіологічного розвитку особи, який певним чином унеможливлює здійснення нею юридично значущих дій $[5$, c. $4-11 ; 14$, с. $500-501 ; 1$, с. $38 ; 7]$.

Усі особи, що беруть участь у кримінально-процесуальних правовідносинах, постають як суб'єкти. Залежно від процесуального стану, а також кримінально-процесуальних функцій і завдань, що ними виконуються, у кримінально-процесуальній науці проводиться їхня класифікація [13, с. 88].

Відповідно до статті 431 КПК України 2012 року особа визнається підозрюваною з моменту повідомлення ій про підозру в стадії досудового розслідування згідно зі статтею 42 КПК. Повідомлення про підозру, зміст якого визначено в статті 277 КПК, обов'язково здійснюється у таких випадках: 1) затримання особи на місці вчинення кримінального правопорушення чи безпосередньо після його вчинення; 2) обрання щодо особи одного із запобіжних заходів; 3) наявності достатніх доказів для підозри особи у вчиненні кримінального правопорушення (ст. 276 КПК).

Отже, з огляду на викладене вище, можна погодитися 3 тим, що особа може набути правового статусу неповнолітнього підозрюваного лише відповідно до вимог чинного кримінального процесуального законодавства, а це має важливе значення для забезпечення правової визначеності в цьому питанні [11, с. 147].

Загалом статус неповнолітнього підозрюваного збігається 3 кримінально-процесуальним статусом повнолітнього підозрюваного (дорослої особи). Втім, неповнолітні в кримінальному процесі загалом і неповнолітні, які вчинили кримінальне правопорушення зокрема, у порівнянні 3 повнолітніми учасниками кримінально-процесуальної діяльності обмежені у власній правоздатності та дієздатності, тобто правосуб'єктності. Це відбувається через особливості загального впливу неповноліття як юридично-фактичного стану. Що стосується особливостей розслідування кримінальних проваджень щодо неповнолітніх осіб, то урівноваження наявних обмежень відбувається завдяки участі додаткових суб'єктів - захисника, законного представника й педагога чи психолога, а також завдяки впровадженню додаткових запорук охорони їхніх прав і законних інтересів з боку держави. Узяті разом вони, грунтуючись на принципах правового протекціонізму, позитивної дискримінації, соціальної насиченості, державної опіки відносно дитини, виступають як прояв охоронного режиму щодо неповнолітніх [10, с. 102] та доповнюють обмеженість їхнього кримінально-процесуального статусу.

3 огляду на те, що положення документів, в яких визначається міжнародно-правовий статус неповнолітніх, $€$ орієнтиром, то згідно з ним, як зазначено вище, розробляється законодавство нашої держави. Зокрема, стаття 40 Конвенції ООН про права дитини передбачає, що кожна дитина, яка, як вважається, порушила кримінальне законодавство чи звинувачується в його порушенні, повинна мати принаймні такі гарантії: а) презумпцію невинуватості, коли ії вина не буде доведена згідно з законом; б) негайне й безпосереднє інформування іiї про обвинувачення проти неї, а у випадку необхідності - через іï батьків чи законних опікунів та одержання правової й іншої необхідної допомоги під час підготовки та здійснення свого захисту; в) невідкладне прийняття рішення 3 розглядуваного питання, незалежним і безстороннім органом чи судовим органом у ході справедливого слухання згідно з законом у присутності адвоката чи іншої відповідної особи та, якщо це не вважається таким, що суперечить найкращим 
інтересам дитини, зокрема, з урахуванням її віку чи становища іiї батьків або законних опікунів; г) свободу від примусу щодо даваних свідчень чи визнання вини; вивчення показань свідків обвинувачення або самостійно, або за допомогою інших осіб та забезпечення рівноправної участі свідків захисту й вивчення їхніх свідчень; д) якщо вважається, що дитина порушила кримінальне законодавство, повторний розгляд вищим компетентним, незалежним і безстороннім органом чи судовим органом згідно з законом, відповідне рішення й будь-які вжиті у цьому зв'язку заходи; є) безоплатну допомогу перекладача, якщо дитина не розуміє використовуваної мови чи не розмовляє нею; ж) повну повагу до її особистого життя на всіх стадіях розгляду [7, с. 48$]$.

Правове положення неповнолітнього в кримінальному процесі ще отримало регламентацію в Мінімальних стандартних правилах, які стосуються відправлення правосуддя щодо неповнолітніх (Пекінські правила). У цих правилах закріплені права осіб, які не досягли вісімнадцяти років, на конфіденційність; на можливість вирішення справи без офіційного іiі слухання в судових органах; на провадження по справі без затримань тощо [12].

Права неповнолітніх закріплені в Декларації прав дитини від 20 листопада 1959 року. Згідно з ії принципом 2 дитині повинні належати всі зазначені в Декларації права. Ці права мають визнаватися за всіма дітьми без жодних винятків і без відмінностей чи дискримінації за ознакою раси, кольору шкіри, статі, мови, релігії, політичних або інших переконань, національного чи соціального походження, майнового стану, народження чи іншої обставини, що стосується самої дитини чи її сім'ї.

У Конвенції про права дитини, прийнятій 44-ю сесією Генеральної Асамблеї ООН у 1989 році й ратифікованій Верховною Радою України 27 лютого 1991 року, містяться рекомендації щодо застосування до неповнолітніх запобіжних заходів. Так, відповідно до статті 37 Конвенції арешт, затримання чи тюремне ув'язнення дитини здійснюється згідно з законом і застосовується лише як крайній захід і протягом найкоротшого відповідного періоду часу.

Україною підписано міжнародний договір від 29 листопада 1985 року, за яким вона взяла на себе зобов'язання виконувати Мінімальні стандартні правила $\mathrm{OOH}$, що стосуються здійснення правосуддя щодо неповнолітніх (Пекінські правила). Зокрема, Пекінські правила містять положенняпро початковий контакт неповнолітнього правопорушника 3 компетентними органами держави, який повинен відбуватися таким чином, щоб «поважати правовий статус неповнолітнього, сприяти його благополуччю й уникати спричинення шкоди 3 урахуванням обставин кримінального провадження».

24 травня 2011 року президентом України була схвалена Концепція розвитку кримінальної юстиції щодо неповнолітніх в Україні, метою якої є побудова в Україні повноцінної системи кримінальної юстиції щодо неповнолітніх, спроможної забезпечити законність, обгрунтованість й ефективність кожного рішення щодо дитини, яка потрапила в конфлікт із законом, пов'язаного з іiї перевихованням і подальшою соціальною підтримкою [15].

Підвищена увага з боку законодавця до охорони прав осіб, які не досягли вісімнадцяти років і вчинили кримінальне правопорушення, насамперед виявляється в тому, що кримінально-процесуальний закон передбачає для них можливість «подвійного представництва» їхніх інтересів, тобто допускає одночасну участь у кримінальних провадженнях захисника, законного представника, педагога або психолога.

Питання дотримання прав людини в разі притягнення iii до кримінальної відповідальності, а також прав підозрюваного й обвинуваченого на досудовому розслідуванні й судовому провадженні завжди були й залишаються акту- альними. Тому розглянемо один зі складників правового статусу неповнолітнього підозрюваного - процесуальні права й обов'язки, закріплені в частині 7 статті 42 КПК України. Зазначимо, що неповнолітній підозрюваний користується не лише правами, передбаченими Конституцією України, зокрема статтями $28,29,55,56,59,62$, 63 [9], адже чинний КПК України значно розширив права сторони захисту в кримінальному провадженні.

Розглянемо перелік процесуальних прав й обов'язків підозрюваного, закріплений у статті 42 КПК України. Зокрема, частина 3 статті 42 КПК України встановлює право підозрюваного: 1) знати, у вчиненні якого кримінального правопорушення його підозрюють; 2) бути чітко та своєчасно поінформованим про свої права, а також отримати роз'яснення щодо них у разі потреби; 3) на першу вимогу мати захисника й побачення 3 ним до першого та перед кожним наступним допитом 3 дотриманням умов, що забезпечують конфіденційність спілкування; на присутність захисника під час допиту й інших процесуальних дій; на відмову від послуг захисника в будь-який момент кримінального провадження; на отримання послуг захисника коштом держави у випадку браку коштів на оплату таких послуг; 4) не говорити нічого з приводу підозри проти нього або в будь-який момент відмовитися відповідати на запитання; 5) давати пояснення, показання 3 приводу підозри чи в будь-який момент відмовитися їх давати; 6) вимагати перевірки обгрунтованості затримання; 7) у разі затримання - на негайне повідомлення членів сім'ї, близьких родичів чи інших осіб про затриманняй місце свого перебування; 8) збирати й подавати докази слідчому, прокурору, слідчому судді; 9) брати участь у проведенні процесуальних дій; 10) під час проведення процесуальних дій ставити запитання, подавати свої зауваження та заперечення щодо порядку проведення дій, які заносяться до протоколу; 11) застосовувати з додержанням вимог КПК України технічні засоби під час проведення процесуальних дій, у яких він бере участь (слідчий, прокурор, слідчий суддя, суд мають право заборонити застосування технічних засобів під час окремої процесуальної дії чи на певній стадії кримінального провадження з метою нерозголошення відомостей, які містять таємницю, що охороняється законом, чи стосуються інтимного життя особи, про що виноситься вмотивована постанова (ухвала)); 12) заявляти клопотання про проведення процесуальних дій, про забезпечення безпеки щодо себе, членів своєі сім' $і$, близьких родичів, майна, житла тощо; 13) заявляти відводи; 14) ознайомлюватися 3 матеріалами досудового розслідування та вимагати відкриття матеріалів; 15) одержувати копії процесуальних документів і письмові повідомлення; 16) оскаржувати рішення, дії та бездіяльність слідчого, прокурора, слідчого судді; 17) вимагати відшкодування шкоди, завданої незаконними рішеннями, діями чи бездіяльністю органу, що здійснює оперативнорозшукову діяльність, досудове розслідування, прокуратури або суду, в порядку, визначеному законом, а також відновлення репутації, якщо підозра, обвинувачення не підтвердились; 18) користуватися рідною мовою, отримувати копії процесуальних документів рідною або іншою мовою, якою він володіє; в разі потреби користуватися послугами перекладача коштом держави.

Перейдемо до розгляду наступного складового елементу правового статусу неповнолітнього підозрюваного - обов'язків, визначених частиною 7 статті 42 КПК України, відповідно до положень якої підозрюваний зобов'язаний: 1) прибувати за викликом до слідчого, прокурора, слідчого судді, суду, а в разі неможливості прибути за викликом у призначений строк - заздалегідь повідомити про це зазначених осіб; 2) виконувати обов'язки, покладені на нього рішенням про застосування заходів забезпечення кримінального провадження; 3) підкорятися 
законним вимогам і розпорядженням слідчого, прокурора, слідчого судді, суду.

Доречно відзначити, що найважливішим чинником реального забезпечення прав і свобод неповнолітнього підозрюваного, поряд з їх визнанням, дотриманням і повагою, є гарантування, яке здійснюється за допомогою специфічних засобів - гарантій, що надають усім елементам правового статусу підозрюваного реального змісту, завдяки яким стає можливим безперешкодне здійснення прав і свобод, їх охорона від можливих протиправних посягань і захист від незаконних порушень.
Висновки. Правовий статус неповнолітніх підозрюваних у кримінальному процесуальному законодавстві України базується на міжнародно-правових актах, що ратифіковані Україною, та національному законодавстві України, починаючи з Конституції, законів та інших нормативно-правових актів, дотримання яких є обов'язковою умовою здійснення кримінального провадження за участю неповнолітніх. Важливого значення набуває вдосконалення правового статусу неповнолітнього підозрюваного, що підвищить його активність у реалізації та захисті своїх процесуальних прав.

\section{ЛІТЕРАТУРА}

1. Галимов О.Х. Малолетние лица в уголовном судопроизводстве. Санкт-Петербург : Питер, 2001. 224 с.

2. Закалюк А.П. Курс сучасної української кримінології: теорія і практика : у 3 кн. Кн. 2 : Кримінологічна характеристика та запобігання вчиненню окремих видів злочинів. Київ : Ін Юре, 2007. 712 с.

3. Про охорону дитинства : Закон України від 26 квітня 2001 р. № 2402-III. База даних «Законодавство України» / Верховна Рада України. URL: https://zakon.rada.gov.ua/laws/show/2402-14\#Text (дата звернення: 03.07.2020).

4. Исаков В.Б. Юридические факты в советском праве. Москва : Юридическая литература, 1984. 144 с.

5. Каневский Л.Л. Расследование и профилактика преступлений несовершеннолетних. Москва : Юридическая литература, 1982. $111 \mathrm{C}$.

6. Коваленко Є.Г., Маляренко В.Т. Кримінальний процес України. Київ : Юринком Інтер, 2004. 688 с.

7. Конвенція ООН про права дитини. Провадження у справах про злочини неповнолітніх як дифреренціація кримінально процесуальної форми /Г.М. Омельяненко. Київ : Атіка, 2002. с. 57-75.

8. Коновалова В.Е. Допрос: тактика и психология. Харьков : Консум, 1999. 157 с.

9. Конституція України : Закон від 28 червня 1996 р. № 254к/96-ВР. База даних «Законодавство України» / Верховна Рада України. URL: https://zakon.rada.gov.ua/laws/show/ 254\%D0\%BA/96-\%D0\%B2\%D1\%80\#Text (дата звернення: 03.07.2020).

10. Крестовська Н. Становлення ювенального права в Україні. Юридичний вісник, 2003. № 3. С. 100-104.

11. Кримінальний процесуальний кодекс України. Науково-практичний коментар : у 2 т. Т. 1. / О.М. Бандурка та ін. ; за заг. ред. В.Я. Тація та ін. Харків : Право, 2012. 768 с.

12. Минимальные стандартные правила Организации Объединенных Наций, касающиеся отправления правосудия в отношении несовершеннолетних (Пекинские правила). Збірник законодавчих актів і нормативних документів з питань соціально-правового захисту дітей. Київ : Столиця, 1998. С. 10-35.

13. Советский уголовный процесс / под ред. Н.С. Алексеева, В.З. Лукашевича. Ленинград : Изд-во Ленинградского университета, 1989. $472 \mathrm{c}$

14. Судебная власть / под ред. И.Л. Петрухина. Москва : ТК Велби, 2003. 720 с.

15. Про концепцію розвитку кримінальної юстиції щодо неповнолітніх в Україні : Указ Президента України від 24 травня 2011 р. № 597/2011. База даних «Законодавство України» / Верховна Рада України. URL: https://zakon.rada.gov.ua/laws/show/597/2011\#Text (дата звернення: 03.07.2020). 


\title{
СУЧАСНІ НАУКОВІ КОНЦЕПЦІЇ ФОРМУВАННЯ ТИПОВОЇ СТРУКТУРИ ОКРЕМОЇ КРИМІНАЛІСТИЧНОЇ МЕТОДИКИ
}

\author{
MODERN SCIENTIFIC CONCEPTS OF FORMATION OF A TYPICAL STRUCTURE \\ OF A SEPARATE CRIMINALISTIC METHODICS
}

\author{
Шевчук В.М., д.ю.н., професор, заслужений юрист України, \\ професор кафедри криміналістики \\ Наиіональний юридичний університет імені Ярослава Мудрого
}

\begin{abstract}
Стаття присвячена дослідженню актуальних проблем формування типової структури окремої криміналістичної методики. Проведено аналіз сучасних наукових концепцій дослідження структурної побудови окремих криміналістичних методик. Зазначається, що необхідність подальших наукових досліджень розглядуваних питань має бути пов'язана з розробленням загального підходу до структурної побудови окремих криміналістичних методик і формуванням типової структури таких методик. Відзначається, що процес розроблення типової окремої криміналістичної методики, її структури та змісту є таким, що об'єктивно триває, прогностично й ситуативно динамічним. Обґрунтовується, що такий процес залежить від низки обставин і чинників, серед яких особливого значення набувають такі: системне узагальнення слідчої, судової, прокурорської, адвокатської, детективної й експертної практики; результати вивчення стану, структури й динаміки сучасної злочинності, а також криміногенної ситуації в країні та в окремих областях і регіонах; результати вивчення злочинної діяльності й аналізу найбільш ефективних і дієвих криміналістичних засобів виявлення, розслідування, профілактики та судового розгляду окремих видів чи груп кримінальних правопорушень та інші.

Зазначається, що структуру окремої криміналістичної методики необхідно розглядати як інформаційно-пізнавальну модель, яка складається з певних елементів (блоків), що мають своє змістовне наповнення та внутрішню побудову, структурні елементи якої взаємопов'язані між собою. Запропоновано типову структуру окремих криміналістичних методик. Проведено аналіз і розглянуто концепцію блочно-модульної побудови структури криміналістичної методики. Обґрунтовується, що сучасні тенденції розвитку криміналістичної методики вимагають розширення ї̈ меж дослідження. Виходячи з цього, на сьогодні перспективним напрямом криміналістичних досліджень $є$ подальші наукові розробки структури для кожного з класифікаційних рівнів і різновидів криміналістичних методик, зокрема структури криміналістичної методики розслідування окремих видів кримінальних правопорушень; криміналістичної методики судового розгляду окремих категорій кримінальних проваджень (справ); криміналістичної методики професійного захисту; криміналістичної методики підтримання обвинувачення тощо. Обґрунтовано нові наукові підходи та пропозиції стосовно вирішення досліджуваних дискусійних
\end{abstract} проблем, визначено інноваційні напрями досліджень у галузі криміналістичних методик

Ключові слова: окрема криміналістична методика, типова структура криміналістичної методики, удосконалення окремих криміналістичних методик, оптимізація досудового розслідування та судового розгляду.

The article is devoted to the research of actual problems of formation of a typical structure of a separate criminalistic methodics. The analysis of modern scientific concepts of research of structural construction of separate criminalistic methodics is carried out. It's noted that the need for further research on these issues should be associated with the development of a general approach to the structural construction of separate criminalistic methodics and the formation of a typical structure of such methodics. It's substantiated that the process of development of a typical separate criminalistic methodics, its structure and content is objectively continuous, prognostic and situationally dynamic. It's determined that such a process depends on a number of circumstances and factors, among which the following are of particular importance: systematic generalization of investigative, judicial, prosecutorial, legal, detective and expert practice; the results of studying the state, structure and dynamics of modern crime, as well as the criminogenic situation in the country and in individual regions and regions; the results of the study of criminal activity and analysis of the most effective and efficient criminalistic means of detection, investigation, prevention and trial of certain types or groups of criminal offenses, etc.

It's noted that the structure of a separate criminalistic methodics should be considered as an information-cognitive model, which consists of certain elements (blocks) that have their own content and in more detail the internal structure, the structural elements of which are interconnected. A typical structure of some criminalistic methodics is proposed. The analysis is carried out and the concept of block-modular construction of the structure of criminalistic methodics is considered, its advantages and disadvantages are determined. It is substantiated that the current trends in the development of criminalistics and criminalistic methodics require the expansion of its research. Based on this, today a promising area of criminalistic research is further scientific development of the structure for each of the classification levels and types of criminalistic methodics, in particular the structure of criminalistic methodics of investigation of certain types of criminal offenses; criminalistic methodics of judicial review of certain categories of criminal proceedings (cases); criminalistic methodics of professional defense; criminalistic methodics of supporting the accusation, etc. New scientific approaches are substantiated and offers on the decision of researched discussion problems are given, innovative directions of researches in the field of criminalistic methodics are defined.

Key words: separate criminalistic methodics, typical structure of criminalistic methodics, improvement of separate criminalistic methodics, optimization of pre-trial investigation and trial.

Постановка проблеми. Для розроблення концептуальних основ формування окремої криміналістичної методики вагомого значення набуває потреба в з'ясуванні переліку елементів, що входять до ії̈ структури. У зв'язку з цим слід зазначити, що на сьогодні в криміналістиці немає одностайності розуміння типової структури окремих криміналістичних методик, що, звичайно, не сприяє підвищенню ефективності розслідування окремих видів (груп) злочинів У криміналістичній доктрині представлені різні наукові підходи щодо структури криміналістичної методики розслідування окремих видів (груп) кримінальних правопорушень. Одні науковці пропонують лаконічну структуру криміналістичної методики, включаючи тільки основні елементи, а інколи певні блоки таких елементів (наприклад, кримі- налістична характеристика, початковий і наступний етап розслідування), а інші обгрунтовують за необхідне використовувати більш громіздкі структури (наприклад, криміналістична характеристика; обставини, що підлягають установленню; особливості виявлення та планування початкового етапу розслідування; типові слідчі ситуації та версії під час розслідування; тактика слідчих (розшукових) дій, організаційних та інших заходів; застосування спеціальних знань під час розслідування цієї категорії злочинів; взаємодія слідчого з оперативними підрозділами в розслідуванні злочинів певного виду; профілактична діяльність слідчого в розслідуванні таких злочинів та інші). Однак однозначного підходу у вирішенні цього питання в криміналістиці не знайдено, що потребує спеціальних наукових розробок. 
В.Ю. Шепітько слушно акцентує на тому, що попри різноманіття окремих методик у них є типові елементи, тому система таких елементів утворює структуру окремих методик, до яких можуть належати: а) криміналістична характеристика злочинів певного виду; б) обставини, що підлягають з'ясуванню в кримінальному провадженні; в) особливості виявлення ознак того або іншого виду злочинів; г) дії на етапі відкриття кримінального провадження; г) тактика слідчих (розшукових) і негласних слідчих (розшукових) дій; д) профілактичні дії слідчого [12, с. 4-5]. Своє бачення проблеми висловив Р.Л. Степанюк, який вказує, що структура методики розслідування великої групи злочинів (міжвидової, позавидової) може бути варіативною, тоді як мікрометодики слід будувати за однією схемою: 1) криміналістична характеристика злочину; 2) відкриття кримінального провадження; 3) початковий етап розслідування; 4) подальший етап розслідування; 5) особливості тактики окремих слідчих дій і негласних слідчих (розшукових) дій [13, с. 241]. В.Г. Гончаренко зазначав, що типовими елементами окремої методики розслідування злочинів $є$ : криміналістична характеристика злочинів окремого виду; обставини, що підлягають доказуванню; типові слідчі ситуації, які виникають на різних етапах розслідування, версії та планування; особливості виявлення того чи іншого виду злочину (зокрема особливості порушення справи та дослідної перевірки); початковий етап розслідування, тактика проведення початкових слідчих дій й оперативно-розшукових заходів; наступний етап розслідування, тактика проведення окремих слідчих дій на цьому етапі розслідування; особливості взаємодії слідчого з органами, які проводять оперативно-розшукові дії; особливості використання слідчим спеціальних знань у розслідуванні; особливості запобігання вчиненню злочинів [10, с. 367].

Критично проаналізувавши ці та інші наукові підходи вчених-криміналістів до структури окремої криміналістичної методики, можна відзначити відразу, що кожен із них має своє право на існування, передбачає певне обгрунтування, приводяться аргументи доцільності існування тієї чи іншої структури, проте одностайності серед науковців і практиків досі не спостерігається. Розглядаючи окремі криміналістичні методики, автори у своїх дисертаційних дослідженнях, монографіях, навчальних посібниках, підручниках на власний розсуд обирають структуру досліджуваної ними методики, що, на нашу думку, негативно впливає на ефективність і результативність таких криміналістичних методик. Тому подальше дослідження означеної проблематики, пов'язане 3 розробленням загального підходу до структурної побудови окремих криміналістичних методик і формуванням типової структури, і нині залишається одним із пріоритетних завдань криміналістики, що свідчить про його актуальність і значущість у реаліях сьогодення.

У зв'язку з цим Р.Л. Степанюк вказує, що суперечливими нині $є$ підходи до структури окремої криміналістичної методики. У підручниках із криміналістики, не кажучи про посібники, монографії та дисертації, вони викладаються за різною структурою. Водночас висловлюється думка про недоцільність вироблення єдиної архітектоніки для будь-якої методики розслідування, зважаючи на специфічність певних груп злочинних діянь, що охоплюються конкретною методикою [13, с. 241]. Своєю чергою В.В. Тищенко, зазначає, що єдиної усталеної структури методики розслідування злочинів бути не може, оскільки з інформаційної точки зору методика $є$ певною сукупністю знань, а з позиції використання - певним алгоритмом дій; крім того, на структуру методики впливає їі функціональна спрямованість $[15$, с. 270]. Як бачимо, на теперішній час науковці й практики не дійшли єдиної позиції стосовно конфігурації елементного складу структури окремої криміналістичної методики, що потребує окремих грунтовних досліджень цієї проблематики.
Отже, на сьогодні в криміналістичній літературі простежується розмаїття пропозицій, конструкцій структурної побудови окремої криміналістичної методики, і очевидно, що за цих підходів побудувати єдину типову структуру такої методики є, звичайно, досить складним завданням. Разом із тим необхідно враховувати, що окрема криміналістична методика, як і будь-яка інша теоретична конструкція, що являє собою інформаційно-пізнавальну модель, яка розроблена для застосування спеціальними суб'єктами в процесі досудового розслідування та судового розгляду й спрямована на вирішення конкретних завдань кримінального судочинства, повинна бути чітко структурована, логічно викладена й досягати своїх цілей і розв'язувати покладені на неї завдання. Очевидно, що сьогодні досить актуальною $є$ проблема розроблення й уніфікації типової структури криміналістичної методики. Як і будь-яка система наукових і практичних положень, окрема криміналістична методика має бути чітко структурована. На наш погляд, це можливо й потрібно для створення ефективних криміналістичних методик окремих різновидів (груп) кримінальних правопорушень. Тому для побудови типової структури окремої криміналістичної методики, на нашу думку, необхідно враховувати наступні положення.

По-перше, структура криміналістичної методики передусім залежить від підходів до формування конфігурації системи криміналістичних методик. У зв'язку з цим слушними є пропозиції В.А. Журавля стосовно виокремлення таких різновидів вищеозначеної системи або рівнів формування розглядуваних криміналістичних методик, у якій основними іiї елементами у запропонованій інтерпретації $€: 1)$ базова методика як універсальна, уніфікована модель, за якою мають створюватися інші окремі криміналістичні методики; 2) видові криміналістичні методики розслідування (види злочинів, чітко визначені у відповідних розділах Особливої частини Кримінального кодексу України (далі - КК), причому такий рівень $є$ найбільш усталеним, традиційним, за яким традиційно формується система окремих криміналістичних методик розслідування й вона базується на кримінально-правовій класифікації злочинів); 3) підвидові криміналістичні методики розслідування, підвиди чи різновиди, виділені з-поміж злочинів одного виду за криміналістично значущими ознаками (приміром, до такого виду злочинів, як умисне вбивство, виділяють такі підвидові методики (мікрометодики), як методика розслідування вбивств із розчленуванням, на замовлення, на релігійному підгрунті та інші); 4) родові криміналістичні методики розслідування (групи злочинів, об'єднаних за ознакою родового об'єкта в одному розділі Особливої частини КК і на підставі криміналістично значущих ознак, притаманних декільком видам, наприклад методика розслідування злочинів: а) проти довкілля; б) проти статевої свободи та статевої недоторканності особи; в) в разі надання медичної допомоги тощо); 5) міжродові криміналістичні методики розслідування (групи злочинів, диференційованих відповідно до групування їх у різних розділах Особливої частини КК й на підставі криміналістично значущих ознак, притаманних декільком видам, наприклад методика розслідування злочинів, учинених неповнолітніми, організованими злочинними угрупованнями тощо, де об’єднувальною криміналістичною класифікаційною ознакою виступають особа злочинця, сфера реалізації його злочинного наміру тощо); 6) комплексні криміналістичні методики розслідування злочинів, у яких відображені рекомендації з розслідування комплексів взаємопов'язаних злочинних дій, об'єднаних на підставі одночасного врахування кримінально-правових і криміналістичних критеріїв класифікації злочинів. Як правило, такі злочинні прояви охоплюються єдиним умислом організаторів, підбурювачів, пособників і виконавців, спільною метою й мотивами, загальним механізмом реалізації злочинного задуму тощо [5, с. 196-197]. 
На наш погляд, пропонований науковцем концептуальний науковий підхід до формування конфігурації системи криміналістичних методик має велике теоретико-методологічне та практичне значення для подальших розроблень досліджуваної проблематики, що багато в чому визначає нове бачення структури й змісту виокремлених класифікаційних рівнів і системи розглядуваних криміналістичних методик. Більше того, вбачається, що на сьогодні важливим і необхідним є спеціальне вивчення та дослідження структурної побудови для кожного з названих класифікаційних рівнів вищеозначених різновидів криміналістичних методик. Мова може йти про необхідність врахування та побудови структури для базової криміналістичної методики, а також для видових криміналістичних методик, підвидових криміналістичних методик, родових криміналістичних методик, міжродових криміналістичних методик i комплексних криміналістичних методик. Такий підхід визначає нові можливості вдосконалення криміналістичних методик, у сучасних реаліях виступає інноваційним напрямом наукових досліджень у криміналістиці й потребує подальших наукових пошуків і перспективних розробок у цій царині знань.

По-друге, визначення структури й розроблення змісту окремих криміналістичних методик різних категорій кримінальних правопорушень залежить не від випадкових чинників або хаотичного розвитку процесу кримінального провадження. Як слушно зазначає Б.В. Щур, їх формування залежить у першу чергу від рівня узагальнення кримінальних правопорушень (роду, виду, підвиду, групи тощо), підходів до криміналістичної класифікації злочинних діянь, причому для методики розслідування окремих видів (різновидів) злочинів одним із головних завдань $\epsilon$ розроблення типових систем (і підсистем) дій слідчого, що відображають найбільш ефективні шляхи розкриття злочину та сприяють обранню оптимальної системи дій з конкретної кримінальної справи (провадження) $[20$, с. 89]. Тому, на наш погляд, структура окремої криміналістичної методики повинна враховувати не лише класифікаційний рівень розроблюваної методики, а й сферу iii застосування. Водночас необхідно виходити з того, що криміналістична методика в широкому розумінні складається 3 чотирьох підсистем: а) криміналістичної методики розслідування окремих видів кримінальних правопорушень; б) криміналістичної методики судового розгляду окремих категорій кримінальних проваджень (справ); в) криміналістичної методики професійного захисту; г) криміналістичної методики обвинувачення. Тому виникає необхідність виокремлення й дослідження структурної побудови для кожного з названих класифікаційних рівнів вищеозначених різновидів криміналістичних методик.

Більше того, в системі криміналістичних знань такі класифікаційні рівні розглядуваних методик є системноструктурним утворенням, яке відображається в певній інформаційно-пізнавальній моделі в їх переломленні до специфіки та умов розслідування й судового розгляду окремих видів (груп) кримінальних правопорушень. Виходячи з таких положень, необхідно говорити про структуру базової криміналістичної методики та структуру окремої криміналістичної методики певного виду кримінального правопорушення з урахуванням різних класифікаційних рівнів розглядуваних методик. Так, наприклад, мова може йти про: а) структуру базової криміналістичної методики; б) структуру окремої криміналістичної методики розслідування; в) структуру базової криміналістичної методики криміналістичної методики судового розгляду; г) структуру окремої криміналістичної методики судового розгляду певних видів кримінальних проваджень; г) структуру базової криміналістичної методики професійного захисту під час досудового розслідування; д) структуру окремої криміналістичної методики професійного захисту під час досудового розслідування та судового розгляду; е) структуру базової криміналістичної методики криміналістичної методики підтримання обвинувачення; є) структуру окремої криміналістичної методики підтримання обвинувачення. Звичайно, такий підхід є новаторським, перспективним та потребує поглибленого аналізу, детального вивчення та подальших наукових досліджень та обгрунтувань.

По-третє, традиційно побудова окремих криміналістичних методик здійснюється на узагальненій, універсальній основі, якою, на думку В.А. Журавля $[6$, с. 215$]$, є базова криміналістична методика, що має модельний елементний склад. Більшість учених, які займалися розробленням теоретичних аспектів побудови криміналістичних методик, пропонували власні погляди на такий універсальний елементний склад (О.I. Возгрін, А.Ф. Волобуєв, М.В. Салтевський, В.В. Тищенко, Б.В. Щур, В.Ю. Шепітько, О.В. Шмонін, М.П. Яблоков та інші). Вбачається, що процес розроблення типової окремої криміналістичної методики та її структури та змісту є таким, що об'єктивно триває, прогностично й ситуативно динамічним, залежить від низки обставин і чинників. Важливими чинниками цього процесу є: а) системне узагальнення слідчої, судової, прокурорської, адвокатської, детективної й експертної практики; б) результати вивчення стану, структури й динаміки сучасної злочинності, а також криміногенної ситуації в країні та в окремих областях і регіонах; в) результати вивчення злочинної діяльності й аналізу найбільш ефективних і дієвих криміналістичних засобів виявлення, розслідування, профілактики та судового розгляду окремих видів чи груп кримінальних правопорушень і низка інших чинників-детермінантів, які зумовлюють врахування класифікаційного рівня методики, специфіку й різновид кримінального правопорушення та сферу застосування такої криміналістичної методики.

На наш погляд, проблема визначення структури окремих криміналістичних методик має комплексний характер. Тому структура і зміст окремої криміналістичної методики має формуватися з урахуванням: 1) комплексного характеру тактичних і стратегічних завдань, що виконуються в процесі розслідування та судового розгляду; 2) необхідності розроблення специфіки комплексу слідчих (розшукових), негласних слідчих (розшукових) і судових дій для виконання цих завдань; 3) комплексної участі у виявленні, розкритті, розслідуванні, запобіганні кримінальним правопорушенням, судовому розгляді 3 урахуванням можливостей взаємодії в межах своєї компетенції слідчого, детектива, судді та інших учасників кримінального провадження 3 оперативними працівниками, експертними установами, іншими спеціалістами, представниками громадськості тощо; 4) реальних зв'язків і залежностей між рекомендаціями та структурними елементами криміналістичної методики [12, с. 7].

Досліджуючи проблеми криміналістичної методики, Р.Л. Степанюк ставить питання про необхідність створення загальної криміналістичної методики (родової, міжродової, міжвидової), яка має містити рекомендації меншого ступеня конкретності щодо застосування в слідчій практиці та $\epsilon$ підгрунтям для формування спеціальних (окремих) методик. На думку науковця, іï структура може бути представлена таким чином: а) криміналістична класифікація злочинів відповідної групи; б) зміст і загальний аналіз елементів криміналістичної характеристики злочинів; в) перспективи формування спеціальних криміналістичних методик щодо вужчих груп злочинів у межах злочинної діяльності, що розглядаються; г) проблемні питання стадії порушення кримінальної справи про відповідну категорію злочинних діянь; г) проблемні питання проведення розслідування на відповідних етапах; д) проблеми й загальні особливості організації та науковотехнічного забезпечення розслідування; е) проблеми 
й загальні особливості взаємодії й оперативно-розшукового забезпечення; є) проблеми й загальні особливості використання спеціальних знань; ж) проблеми й загальні особливості криміналістичної профілактики відповідних злочинів [14, с. 146]. На наш погляд, для загальної криміналістичної методики запропонована структура $є$ досить громіздкою й не всі представлені автором структурні елементи потребують такого детального виокремлення До того ж більш правильною є постановка проблеми розроблення загальної (базової) криміналістичної методики (В.А. Журавель) і формування ії типової структури.

3 огляду на викладене передусім виникає необхідність структурної побудови базової криміналістичної методики, оскільки формування конкретної криміналістичної методики передбачає наявність деякої загальної (базової) криміналістичної методики, яка має обгрунтовувати іiі типові параметри та структурні елементи, які пов'язані 3 етапністю, ситуаційною зумовленістю, функціональною й логічною структурою, цілеполяганням, виконанням стратегічних і тактичних завдань кримінального провадження, застосуванням слідчих (розшукових), негласних слідчих (розшукових) і судових дій, тактичних операцій досудового розслідування й судового розгляду тощо. Тому важливим завданням сьогодні є формування базової криміналістичної методики.

Вважаємо, що структура базової криміналістично методики в широкому розумінні, незалежно від іiї класифікаційного виду, межі застосування якої поширюються й на досудове розслідування й судовий розгляд, повинна містити такі структурні елементи: криміналістичну характеристику кримінального правопорушення певного виду чи групи (у тому числі й судового розгляду); типові слідчі й судові ситуації етапів розслідування й судового розгляду та відповідні комплекси слідчих (розшукових), судових дій і тактичних операцій; особливості тактики окремих слідчих (розшукових), негласних слідчих (розшукових), судових дій і тактичних операцій; криміналістичну профілактику розслідування кримінальних правопорушень i судового розгляду. Наведена структура елементів базової криміналістичної методики вбачається оптимальною, але не обов'язковою. Зазначені методики як інформаційно-пізнавальні моделі та результат науково-дослідних розробок, враховуючи специфіку видів (груп) кримінальних правопорушень і суттєві відмінності в підставах їх об'єднання (виокремлення, групування), що входять до об'єкта дослідження, можуть мати також і дещо іншу структурну побудову залежно від поставлених дослідником завдань, об'єктивних і суб'єктивних передумов i чинників-детермінантів, які зумовлюють особливост побудови (формування) досліджуваних окремих криміналістичних методик. Очевидно, що залежно від виду кримінального правопорушення той чи інший структурний елемент криміналістичної методики матиме більше або менше практичне значення й набуватиме певної ваги, проте це повинна бути найбільш доцільна система розроблених методико-криміналістичних рекомендацій, що забезпечують ефективність і результативність процесу кримінального провадження.

По-четверте, під час розроблення структури та змісту окремих криміналістичних методик різних категорій кримінальних правопорушень, на наш погляд, необхідно враховувати принципи побудови (формування) криміналістичної методики, серед яких визначальними, як зазначає А.С. Колодіна, можуть бути такі: принцип урахування кримінально-правової класифікації злочинів; принцип урахування криміналістичної класифікації злочинів; принцип охоплення всіх обставин, які підлягають установленню в процесі розслідування певного виду (групи) кримінальних правопорушень і судового розгляду; принцип ситуативності; принцип етапності (періодизація розслідування); принцип програмування; принцип урахування тактичних особливостей провадження залежно від виду кримінального правопорушення; принцип виконання тактичних завдань шляхом планування й здійснення комплексів слідчих (розшукових), негласних слідчих (розшукових) дій і тактичних операцій) [9, с. 13]. В.А. Журавель уточнює та доповнює перелік цих принципів такими положеннями: 1) відповідність технології створення (побудови) криміналістичних методик їхньому класифікаційному рівню; 2) відповідність методико-криміналістичних рекомендацій кінцевій меті формування певної методики; 3) відповідність типових криміналістичних моделей розслідування предмету доказування й диспозиції статті Кримінального кодексу; 4) відповідність структури окремої криміналістичної методики структурі базової моделі криміналістичної методики розслідування злочинів; 5) відповідність послідовності викладення методичних порад етапності процесу розслідування; 6) ситуаційна зумовленість побудови криміналістичних рекомендацій [7, с. 180]. Вбачається, що означені принципи побудови (формування) криміналістичної методики суттєво впливають на визначення структурної побудови базової криміналістичної методики та структури окремих криміналістичних методик.

На наш погляд, передусім структура та зміст окремої криміналістичної методики повинні мати такі ознаки: 1) мають бути розраховані на адаптацію до конкретних умов розслідування та судового розгляду матеріалів кримінальних проваджень, тобто розроблені з урахуванням класифікаційного рівня методики; 2) орієнтовані на врахування всіх виявлених криміналістичних особливостей окремих різновидів кримінальних правопорушень, тобто мають враховувати дані їхньої криміналістичної характеристики; 3) мають враховувати коло обставин, які підлягають установленню в процесі розслідування певного виду (групи) кримінальних правопорушень і судового розгляду; 4) повинні відображати ситуаційність й етапність цього процесу, ті завдання, які виконуються на кожному його етапі, особливості цих етапів; 5) мають враховувати алгоритмічність, програмування й системність специфіки тактики проведення слідчих (розшукових), негласних слідчих (розшукових) дій, зумовлених тактичними завданнями розслідування й судового розгляду; 6) під час розроблення положень криміналістичної методики вона має враховувати сферу іiі реалізації (досудове розслідування й судовий розгляд) і потребу в розробленні методикокриміналістичних рекомендацій не лише для суб'єктів досудового розслідування, а й для суду та судового розгляду кримінальних проваджень, тому така методика відповідно має складатися 3 двох підсистем: криміналістичної методики розслідування окремих видів кримінальних правопорушень і криміналістичної методики судового розгляду окремих категорій кримінальних проваджень (справ); 7) невід’ємною складовою окремих криміналістичних методик мають стати рекомендації щодо особливостей тактики негласних слідчих (розшукових) дій. Ця проблематика впродовж багатьох років розроблялася в науці оперативно-розшукової діяльності, тому сьогодні необхідно відповідні знання інтегрувати в криміналістику та надалі розвивати основні ії положення. У сучасних реаліях уже важко уявити криміналістичну методику складних категорій кримінальних правопорушень, наприклад корупційних, без висвітлення тактики негласних слідчих (розшукових) дій $[13$, с. 215]; 8) у структурі таких методик важливе місце посідає криміналістична профілактика злочинів, кримінальних правопорушень; розроблення відповідних методико-криміналістичних рекомендацій профілактичної спрямованості стосовно окремих видів і груп кримінальних правопорушень $€$ перспективним напрямом наукових пошуків у цій царині знань.

3 огляду на викладене можна дійти висновку, що структурно окрема криміналістична методика має складатись iз таких елементів (блоків): 1) криміналістична характе- 
ристика кримінального правопорушення; 2) обставини, що підлягають з'ясуванню; 3) особливості виявлення ознак кримінального правопорушення й початку кримінального провадження; 4) типові слідчі ситуації та слідчі версії початкового етапу розслідування й програма дій слідчого щодо їх вирішення та перевірки; 5) типові слідчі ситуації та слідчі версії наступного етапу розслідування й програма дій слідчого щодо їх вирішення; 6) організація й планування розслідування, взаємодія слідчого з іншими суб'єктами кримінального провадження; 7) особливості тактики провадження окремих слідчих (розшукових) дій, негласних слідчих (розшукових) дій і забезпечувальних заходів; 8) заходи криміналістичної профілактики окремих видів і груп кримінальних правопорушень.

Виокремлені структурні елементи окремої криміналістичної методики взаємопов'язані між собою. Взаємозв'язок і взаємовпливи таких структурних елементів можна представити як своєрідний ланцюжок пов'язаних етапів розвитку процесу виявлення, розслідування, профілактики кримінальних правопорушень, зміну інформаційно-пізнавальних моделей, що відображають такий процес як функціональну систему діяльнісного типу, що складається 3 певних блоків, кожен із яких має свою внутрішню будову та змістове наповнення. Можна виділити такі основні блоки: «слідча ситуація» - «типові слідчі версії» - «алгоритм слідчих (розшукових) та інших дій» - «формування тактичних завдань розслідування та планування» - «оптимальне поєднання слідчих (розшукових) та інших дій (тактичних комплексів), спрямованих на виконання завдань досудового розслідування» тощо. Інформаційною базою окремої криміналістичної методики є криміналістична характеристика кримінального правопорушення, дані якої слугують основою для висунення слідчих версій і визначення напрямів розслідування. Тому структура окремої криміналістичної методики в такому випадку може розглядатися як інформаційно-пізнавальна модель, яка складається з певних блоків (модулів), що мають своє змістове наповнення та детальнішу внутрішню побудову, елементи якої взаємопов'язані між собою.

Розвиваючи ідею комплексного розгляду криміналістичних особливостей діяльності слідчого та інших суб'єктів кримінального провадження, останнім часом у криміналістиці пропонується використовувати принцип блочно-модульної побудови криміналістичної методики як перспективний напрям наукових досліджень [1, c. 31-38]. Водночас поняття «модуль» розглядається як відокремлювана, відносно самостійна частина якої-небудь системи, організації $[11$, с. 361$]$. Стосовно досліджуваної проблематики використання блоків і модулів виступає як спосіб систематизації методико-криміналістичних рекомендацій, що на основі блочно-модульного уявлення про процес розслідування кримінальних правопорушень поєднуються в змістові структурні компоненти (блоки інформації), які являють собою певну систему інформаційнопізнавальних моделей діяльнісного типу, спрямованих на оптимізацію діяльності щодо розслідування окремих видів (груп) кримінальних правопорушень.

Отже, принции блочно-модульної побудови криміналістичної методики передбачає взаємообумовлене та взаємопов'язане функціонування декількох блокових одиниць - модулів, які тісно взаємопов'язані між собою й доповнюють один одного. Концепція блочно-модульної побудови криміналістичної методики є новаторською й досить оригінальною, потребує додаткового вивчення й поглибленого аналізу, на наш погляд, вона не претендує на абсолютну істинність і визначає певні можливі перспективи подальших наукових розробок і пошуків у цій царині знань. Як доречно зазначає Ю.П. Гармаєв, не може бути єдино правильної, уніфікованої методології створення криміналістичних методик, оскільки сценарії та технології формування криміналістичних методик можуть і повинні бути різними [4, с. 39], що зумовлює необхідність застосування в цьому напрямі творчого підходу, новаторських науково обгрунтованих пропозицій і конструктивних рішень.

На наш погляд, застосовуючи принцип блочномодульної побудови криміналістичної методики, можна запропонувати таку структуру окремої криміналістичної методики, яка міститиме такі модулі: 1) криміналістична характеристика кримінального правопорушення; 2) типові слідчі ситуації етапів розслідування (початкового, наступного й заключного) та відповідні комплекси слідчих (розшукових), негласних слідчих (розшукових) дій і тактичних операцій; 3) особливості тактики окремих слідчих (розшукових), негласних слідчих (розшукових) i судових дій; 4) заходи криміналістичної профілактики розслідування кримінальних правопорушень. Зрозуміло, що кожний із запропонованих модулів має свою деталізацію, внутрішню структуру та змістове наповнення. Крім цього, на нашу думку, важливо зауважити, що такий підхід і запропонований блочно-модульний принцип побудови окремої криміналістичної методики є новаторським i потребує додаткового аналізу й обговорень. Практична цінність такої технології формування криміналістичної методики, як на нашу думку, обов'язково передбачає перевірку й апробацію на практиці, що визначає перспективні напрями подальших наукових досліджень й інноваційних розробок у галузі криміналістичної методики.

Окремою проблемою в криміналістичній доктрині постають питання дослідження структури криміналістичної методики судового розгляду кримінальних проваджень, які в криміналістиці на сьогодні залишаються дискусійними й потребують свого вирішення. Вивчення й аналіз спеціальної літератури свідчить про те, що в криміналістиці, як раніше, так і в теперішній час, існують діаметрально протилежні точки зору щодо означеної проблематики. Одні науковці (Р.Л. Степанюк) обстоюють позицію, що немає необхідності створювати методики судового розгляду окремих категорій злочинів, оскільки їм не буде властива достатня специфіка. На його думку, в цьому випадку може йтися лише про деякі рекомендації для суду, що грунтуються на досягненнях криміналістики, тобто доцільно говорити не про новий різновид окремих криміналістичних методик, а про криміналістичне забезпечення судового розгляду [13, с. 242], з чим ми не можемо погодитися.

Інші науковці (М.В. Авак'ян, Т.С. Волчецька) пропонують новаторський підхід у дослідженні розглядуваної проблематики, пов'язаний зі створенням так званої модульної криміналістичної методики [3, с. 131-132]. Автори обгрунтовують необхідність формування нової категорії в криміналістиці - модульної методики розслідування й підтримання державного обвинувачення у справах про умисне заподіяння тяжкої шкоди здоров'ю. У цьому випадку, на думку науковців, категорія «модуль» виступає як спосіб систематизації методичних компонентів кримінального переслідування на основі блочномодульного уявлення про діяльність із розслідування злочинів, пов'язаних з умисним заподіянням тяжкої шкоди здоров'ю, і діяльності 3 підтримання державного обвинувачення по такій категорії справ. Блочно-модульна побудова пропонованої методики функціонує на послідовному розгляді двох блокових одиниць (методики розслідування злочинів, пов'язаних з умисним заподіянням тяжкої шкоди здоров'ю, і методики підтримання державного обвинувачення в суді), які, незважаючи на корінні відмінності за змістом і структурою, перебувають у тісному взаємозв'язку й доповнюють одна одну [2, с. 131-132; 3].

Ще одна група науковців (В.I. Алєксєйчук, В.А. Журавель, I.I. Когутич, В.Т. Нор та інші), позицію яких і ми підтримуємо й обгрунтовуємо, визначають проблеми формування методик судового розгляду кримінальних 
проваджень одним із пріоритетних напрямів сучасних криміналістичних досліджень, які в сучасних реаліях потребують активних подальших наукових пошуків. Так, I.I. Когутич і B.T. Нор зазначають, що типова структура окремої методики судового розгляду певної категорії кримінальних справ може набувати такого вигляду: криміналістична характеристика (злочинів відповідних видів чи груп) і характеристика процесу досудового розслідування у справі; предмет судового розгляду (обставини, що підлягають установленню судовим розглядом); судові ситуації; система судових і судово-слідчих дій щодо окремих категорій кримінальних справ; використання в суді спеціальних знань залежно від специфіки (категорії) кримінальної справи тощо [8, с. 304-305].

Досліджуючи криміналістичну методику судового розгляду за участю присяжних засідателів справ про вбивства, А.Є. Хорошева вказує, що теоретично структура такої методики може бути представлена таким чином: криміналістична характеристика вбивств; предмет судового слідства по справах про вбивства, що розглядаються в суді за участю присяжних засідателів; 3) механізм доказування по справах про вбивства, що розглядаються в суді за участю присяжних засідателів; 4) дослідження й оцінка суб'єктами доказування в суді за участю присяжних засідателів елементів, що становлять криміналістичну характеристику особи підсудного по справах про вбивства; 5) система тактичних прийомів із вирішення судових ситуацій, що виникають у процесі розгляду в суді за участю присяжних засідателів справ про вбивства [16, с. 50-51].

Щодо структури й змісту окремих криміналістичних методик захисту, як зазначають Т.В. Варфоломеєва та В.Г. Гончаренко, структурна побудова таких методик здебільшого залежить від виду кримінального правопорушення, стадії процесу й статусу особи, стосовно якої здійснюється кримінальне переслідування. У загальному вигляді структура окремої криміналістичної методики захисту має включати: 1) встановлення обставин предмета захисту, тобто обставин, які належить довести чи спростувати адвокату-захиснику для виконання завдань захисту на кожному з етапів провадження у справі для досягнення його кінцевих цілей; 2) аналіз криміналістичної характеристики цього виду злочину з позицій захисту; 3) вибір типової правової позиції з урахуванням конкретної процесуальної (слідчої чи судової) ситуації; 4) визначення оптимальної послідовності дій захисника й можливість їі корегування на кожній стадії кримінального судочинства чи його етапах; 5) виявлення особливостей застосування дозволених і не заборонених законом способів і засобів з урахуванням специфіки захисту у справах щодо окремих видів і родів злочинів [10, с. 372$]$.

Що стосується структури криміналістичної методики підтримання державного обвинувачення, як вбачається, досить цікавий й оригінальний підхід запропонував М.С. Авак'ян. На думку автора, така презентована науковцем криміналістична модульна методика має об'єднувати дві підсистеми (модулі): методику розслідування й методику підтримання державного обвинувачення й структурно може мати такий вигляд:

Криміналістична характеристика злочинів

Модуль № 1. Методика розслідування певної категорії злочинів:

1) криміналістичні особливості порушення кримінальної справи та криміналістичні особливості перевірки повідомлень про злочин;

2) особливості початкового етапу розслідування злочинів;

3) тактика проведення окремих слідчих дій;

4) організаційні й тактичні особливості використання спеціальних знань під час розслідування злочинів.

Модуль 2. Методика підтримання державного обвинувачення за відповідною категорією кримінальних справ:
1) ознайомлення державного обвинувача 3 матеріалами кримінальної справи;

2) формування загальної стратегії підтримки держобвинувачення;

3) тактика підтримання державного обвинувачення в суді [1, с. 35$]$.

На наш погляд, такий підхід $є$ інноваційним, становить певний науковий і практичний інтерес, має право на існування, однак залишається досить багато невирішених питань, які потребують додаткового вивчення, детального аналізу, проведення наукових досліджень і перевірки його ефективності на практиці.

Виходячи 3 викладеного, вбачається, що типова структура окремої криміналістичної методики судового розгляду певної категорії кримінальних проваджень може включати такі елементи, як: 1) криміналістична характеристика відповідних видів чи груп кримінальних правопорушень із позиції суду та специфіки судового розгляду; 2) предмет судового розгляду, тобто обставин, що підлягають установленню судом; 3) типові судові ситуації й відповідні комплекси судових і процесуальних дій, тактичних операцій судового розгляду щодо окремих категорій кримінальних проваджень; 4) організаційно-тактичні основи проведення окремих судових дій, криміналістичних комплексів, а також дослідження, перевірка й оцінка представлених суду матеріалів, пов'язаних із формуванням доказової бази; 5) особливості використання в суді спеціальних знань, залежно від специфіки окремих категорій кримінальних проваджень та інші.

Висновки. Сьогодні проблеми формування й удосконалення окремих криміналістичних методик $\epsilon$ пріоритетними завданнями й перспективними напрямами досліджень у сучасній криміналістиці. Водночас, як показують вивчення й аналіз спеціальної літератури, узагальнення практики криміналістичної методики розслідування окремих видів кримінальних правопорушень, потребують подальших наукових розроблень і розв'язання низка дискусійних і невирішених питань, які вимагають проведення наукових досліджень у цій царині знань. Сучасні реалії України вимагають від криміналістики вдосконалення, розроблення та впровадження в практику окремих криміналістичних методик розслідування кримінальних правопорушень, скоєних в умовах надзвичайних ситуацій; кримінальних правопорушень проти основ національної безпеки України у сфері охорони здоров'я; кримінальних правопорушень, пов'язаних із вивезенням (пересиланням) через митний кордон України товарів протиепідемічного призначення або методики розслідування контрабанди медичних масок та інших товарів протиепідемічного призначення та інші. Поширення інформаційних комп'ютерних технологій сприяє подальшому розробленню алгоритмізації самого процесу виявлення, розслідування та профілактики окремих видів кримінальних правопорушень.

Вбачається, що сучасні тенденції розвитку криміналістики й криміналістичної методики вимагають розширення ऑii меж дослідження. Зазначається, що криміналістична методика в широкому розумінні складається 3 чотирьох підсистем: криміналістичної методики розслідування окремих видів кримінальних правопорушень; криміналістичної методики судового розгляду окремих категорій кримінальних проваджень (справ); криміналістичної методики професійного захисту; криміналістичної методики підтримання обвинувачення. Тому перспективним напрямом криміналістичних досліджень постають подальші наукові розробки структурної побудови для кожного 3 названих класифікаційних рівнів вищеозначених різновидів криміналістичних методик. Дослідження цих проблем спрямовано на вдосконалення й подальший розвиток теоретико-методологічних засад криміналістичної методики та становить один із найбільш пріоритетних напрямів криміналістичної доктрини в сучасних умовах. 


\section{ЛITEPATУРA}

1. Авакьян М.В. Теоретические основы модульной методики расследования и поддержания государственного обвинения. Союз криминалистов и криминологов. 2019. № 2. С. 31-38.

2. Авакьян М.В. Методика расследования и поддержания государственного обвинения по делам об умышленном причинении тяжкого вреда здоровью : дис. ... канд. юрид. наук : 12.00.12. Балтийский федеральный университет имени Иммануила Канта. Калининград, 2017. $251 \mathrm{c}$.

3. Волчецкая Т.С., Авакьян М.В. Криминалистическая модульная методика расследования и поддержания государственного обвинения в суде (по делам об умышленном причинении тяжкого вреда здоровью) : монография. Москва : Юрлитинформ, 2019. 200 с.

4. Гармаев Ю.П. Криминалистические методики расследования и судебного разбирательства: состояние концепции и перспективы развития. Уголовное производство: процессуальная теория и криминалистическая практика: материалы V Межд. науч.-практ. конфр. 2017. C. $35-39$.

5. Журавель В.А. Окремі методики в системі криміналістичних знань. Науковий вісник Львівської комериійної академії. Серія «Юридична». 2015. Вип. 1. С. 187-200.

6. Журавель В.А. Проблема формування базової методики розслідування злочинів. Вісник Національної академії правових наук України. Харків : Право, 2008. № 1 (52). С. 231-242.

7. Журавель В.А. Принципи формування окремих криміналістичних методик розслідування злочинів. Питання боротьби зі злочинністю : збірник наукових праць. Харків : Право, 2011. Вип. 1. С. 173-183.

8. Когутич І.І., Нор В.Т. Використання криміналістичних знань у судовому розгляді кримінальних справ : науково-практичний посібник. Львів, Київ : Тріада плюс, Алерта, 2010. 428 с.

9. Колодіна А. С. Принципи криміналістичної методики у діяльності з розслідування злочинів : автореф. дис. ... канд. юрид. наук : 12.00.09 ; Національний університет «Одеська юридична академія». Одеса, 2016. 20 с.

10. Криміналістика. Академічний курс : підручник / Т.В. Варфоломєєва та ін. 2-ге вид., стереотип. Київ : Юрінком Iнтер, 2018. 504 с.

11. Ожегов С.И., Шведова Н.Ю. Толковый словарь русского языка. 4-е изд., доп. Москва : А ТЕМП, 2006. 944 с.

12. Розслідування злочинів у сфері господарської діяльності: окремі криміналістичні методики : монографрія / В.О. Коновалова та ін. ; за ред. В.Ю. Шепітька. Харків : Право, 2006. 624 с.

13. Степанюк Р.Л. Проблеми розвитку криміналістичної методики в умовах рефрормування кримінальної юстиції України. Вісник кримінологічної асоціації України. 2016. № 1 (12). С. 236-245.

14. Степанюк Р.Л. Структура окремих криміналістичних методик розслідування злочинів. Право і безпека. 2011. № 4 (41). С. $143-147$.

15. Тищенко В.В. Корыстно-насильственные преступления: криминалистический анализ. Одесса : Гельветика, 2002. 365 с.

16. Хорошева А.Е. Современные проблемы методико-криминалистического обеспечения разбирательства в суде присяжных дел об убийствах : монография / под ред. проф. В.К. Гавло. Москва : Юрлитинформ, 2012. 240 с.

17. Шевчук В.М. Проблеми формування та удосконалення окремих криміналістичних методик. Challenges in Science of Nowadays: Proceedings of the 5th International Scientific and Practical Conference (July 16-18, 2020). Washington, USA: EnDeavours Publisher, 2020. Pp. 117-127.

18. Shevchuk V. Modern problems of criminalistic methodics: tendencies, innovations, perspectives. Impatto dell'innovazione sulla scienza: aspetti fondamentali e applicati: Raccolta di articoli scientifici " $\Lambda$ 'ОГО $\Sigma$ ” con gli atti della Conferenza scientifica e pratica internazionale (26 giugno, 2020. Verona, Italia). T. 2. Verona: Piattaforma scientifica europe, 2020. Pp. 108-113.

19. Шевчук В.М. Тактичні операції у криміналістиці: теоретичні засади формування та практика реалізації : монограсрія. Харків : Апостиль, 2013. $440 \mathrm{c}$.

20. Шепітько В.Ю. Сутність методики розслідування злочинів. Криміналістика : підручник : у 2 т. Т. 1 / В.Ю. Шепітько та ін. ; за ред. В.Ю. Шепітька. Харків : Право, 2019. С. 3-5.

21. Щур Б.В. Функції окремих криміналістичних методик. Науковий вісник Чернівецького університету. Серія «Правознавство». 2011. Вип. 578. С. 89-92. 


\title{
НАПРЯМИ ВДОСКОНАЛЕННЯ ТА ГАРМОНІЗАЦІЇ ЧИННОГО ЗАКОНОДАВСТВА В РОБОТІ ОРГАНІВ СИСТЕМИ МВС ТА ПРАВОСУДДЯ В КОНТЕКСТІ СУЧАСНИХ РЕФОРМ
}

\author{
DIRECTIONS FOR IMPROVEMENT AND HARMONIZATION \\ OF CURRENT LEGISLATION IN THE WORK OF THE BODIES OF THE MINISTRY \\ OF INTERNAL AFFAIRS AND JUSTICE IN THE CONTEXT OF MODERN REFORMS
}

\author{
Богданевич T.C., доктор філософії (PhD) в галузі права, \\ провідний науковий співробітник відділу «Тестологічний центр» \\ Національна школа суддів України
} Федченко О.С., к.ю.н., старший викладач кафедри вогневої підготовки Національна академія внутрішніх справ

\begin{abstract}
Статтю присвячено висвітленню однієї з актуальних теоретичних та практичних проблем щодо законодавчого вдосконалення чинного законодавства у правоохоронній сфрері та органах правосуддя в контексті новітнього реформування. Актуальність наукового дослідження зумовлена сучасними реаліями суспільного життя, що вимагає формування та реалізації державної політики у сфері практичної реалізації принципу верховенства права, зміцнення довіри до органів системи МВС із боку суспільства, забезпечення функціонування судової влади, що відповідає суспільним очікуванням та європейським цінностям захисту прав людини. Сьогодні громадянські, політичні, економічні та інші права громадян України не є достатньою мірою захищені, про це свідчать, наприклад, перші місця України серед країн Ради Європи за кількістю звернень громадян до Європейського суду з прав людини та кількістю рішень цієї судової інституції, винесених не на користь Української держави.

Тому ефективна й якісна робота правоохоронних органів та судової влади у цілому повинна відбуватися з урахуванням необхідності реалізації конституційно-правових положень щодо пріоритету прав і свобод людини і громадянина в діяльності держави відповідно до потреб правової демократичної держави і громадянського суспільства. Важливим напрямом сьогодні є об'єктивний аналіз ситуації у сфері правосуддя та правоохоронних органів та вироблення за участі правозахисників, міжнародних експертів, вітчизняних та закордонних учених заходів з усунення нинішніх недоліків системи судочинства в Україні, підвищення авторитету правоохоронних органів та правосуддя, зміцнення довіри громадян та доступності правосуддя для всіх членів суспільства. Такі фундаментальні цінності, як безпека і справедливість, мають бути захищеними, що дасть можливість Україні успішно розвиватися, долучаючись до світової спільноти, зберігаючи свою самостійність, суверенітет та безпеку.
\end{abstract}

Ключові слова: верховенство права, поліція, правосуддя, права та свободи громадян, національна безпека, судова реформа

The article is devoted to highlighting one of the current theoretical and practical problems of legislative improvement of existing legislation in the field of law enforcement and justice in the context of the latest reform. The urgency of scientific research is due to modern realities of public life, which requires the formation and implementation of state policy in the field of practical implementation of the rule of law, strengthening public confidence in the Ministry of Internal Affairs, ensuring the functioning of the judiciary. Today, the civil, political, economic and other rights of Ukrainian citizens are not sufficiently protected - as evidenced, for example, the first places of Ukraine among the Council of Europe in the number of appeals to the European Court of Human Rights and the number of decisions of this judicial institution. benefit of the Ukrainian state.

Therefore, effective and high-quality work of law enforcement agencies and the judiciary, in general, should take into account the need to implement constitutional and legal provisions on the priority of human and civil rights and freedoms in the state in accordance with the needs of a democratic state and civil society. An important area today is an objective analysis of the situation in the field of justice and law enforcement, and the development with the participation of human rights defenders, international experts, domestic and international scientists - measures to address current shortcomings of the judiciary in Ukraine, increase the authority of law enforcement and justice. and access to justice for all members of society. Fundamental values such as security and justice must be protected, which will enable Ukraine to develop successfully, joining the world community, while maintaining its independence, sovereignty and security.

Key words: rule of law, justice, police, citizens' rights and freedoms, national security, judicial reform.

Метою дослідження є комплексний аналіз проблем та заходів щодо вдосконалення роботи органів системи МBC і правосуддя для захисту прав, свобод та законних інтересів людини і громадянина.

Дослідженню даного питання присвячено низку праць відомих українських та зарубіжних учених-юристів: С. Алексєєва, І. Арістової, О. Бандурки, О. Бодрука, Ю. Борко, В. Кампо, С. Кашкина, А. Колодія, В. Литвиненко, М. Хавронюка, С. Шевчука, Ю. Шемшученка, О. Ярмиша та ін.

Сьогодні в Україні спостерігається високий запит суспільства на боротьбу з корупцією. Серед першочергових реформ, які необхідно впровадити, особлива увага при- діляється судовій реформі та реформі правоохоронних органів для утвердження правопорядку, який грунтується на високому рівні правової культури в суспільстві, діяльності всіх суб'єктів суспільних відносин на засадах верховенства права та захисту прав і свобод людини, а в разі їх порушення - справедливого їх відновлення.

Реформування правоохоронних органів повинно передбачати розроблення сучасних нормативно-правових умов функціонування як кожного правоохоронного органу окремо, так і всієї правоохоронної системи України у цілому.

Будь-які кардинальні зміни щодо організації роботи органів у системі МВС України та органів правосуддя 
потребують концептуально нових підходів із застосуванням детального аналізу досвіду зарубіжних країн у сфері підвищення якості безпеки професійної діяльності суб'єктів підтримання порядку в державі та здійснення правосуддя.

Відповідно до Стратегії розвитку органів системи Міністерства внутрішніх справ на період до 2020 р., схваленої Розпорядженням Кабінету Міністрів України від 15 листопада 2017 р. № 1023-p, розвиток органів системи МВС як невід'ємної частини сектору національної безпеки забезпечується за такими пріоритетами: створення безпечного середовища; протидія злочинності; дотримання та забезпечення прав людини; ефективне інтегроване управління державним кордоном і збалансована міграційна політика, забезпечення якості та доступності адміністративних послуг, розвиток кадрового потенціалу й соціальний захист працівників [1].

У Річній національній програмі під егідою Комісії Україна - НАТО на 2020 р., затвердженій Указом Президента України від 26 травня 2020 р. № 203/2020, головний акцент зроблено на зусиллях держави, спрямованих на забезпечення безпеки й добробуту людини як ключового суб'єкта національної безпеки. Стратегічною метою програми $є$ діяльність судових, правоохоронних органів i кримінально-виконавчих установ на принципах верховенства права, які повинні бути вільними від будь-якого політичного впливу та відповідати європейським стандартам та цінностям.

Варто констатувати той факт, що більшість стратегічних документів реформаційного характеру сконцентровано на формах та методах перетворень, тоді як їх зміст та цілі залишаються поза увагою [2].

Проте необхідно розуміти, що будь-яка реформа в державі має три основні складники: організаційний - що ми хочемо отримати, яку організаційну структуру, систему управління нею; правовий - законодавче та інше підзаконодавче забезпечення організаційної структури та іiі управління; технологічний - які інноваційні технології та техніки використовуватиме структура та її персонал під час завершення реформування [3].

Позитивним є досвід європейських держав щодо цілісного бачення системних перетворень у правоохоронній системі, органах правосуддя та їх комплексної взаємодії 3 процесуальних питань.

Особливістю британської поліцейської системи є те що всі працівники поліції наділені відповідними правами в частині досудового розслідування кримінальних справ. Окремого органу або посадової особи, спеціально призначених для виконання цієї функції, у поліції Англії немає.

Окрім поліції, досудове розслідування мають право також вести по окремих категоріях справ співробітники королівської митної служби Великобританії.

Німеччина $€$ федеративною державою, що зумовлює відповідну побудову правоохоронних органів країни. Наприклад, органом розслідування є поліція, на яку покладено обов'язок проведення розшукових дій за отриманим сигналом про злочин і яка виконує функцію кримінального переслідування, тоді як органом попереднього провадження є місцевий суд, котрий здійснює контроль над діяльністю органів розслідування. Водночас суду надано право визнавати доказами подані поліцією матеріали, а остання, своєю чергою, збирає докази тільки за наказом судді.

Ключовою ознакою діяльності правоохоронних органів багатьох країн світу є надзвичайно висока соціальна, правова захищеність і матеріально-фінансова забезпеченість їхніх працівників, що спонукає до відповідального виконання обов'язків, професійного зростання і мотивації.

Вивчення досвіду правоохоронної діяльності європейських країн, спільної політики у сфері внутрішніх справ, юстиції та правосуддя має велике значення для організа- ції влади на всіх рівнях. У сфері європейського простору спільної безпеки і правосуддя дискусійними виявилися питання щодо того, які функції слід передати на міжнародний рівень, а які мають залишитися виключно на внутрішньодержавному рівні.

Дотримуємося позиції, що ключовими незмінними індикаторами у процесі реформування правоохоронних органів залишаються аполітичність правоохоронної діяльності, децентралізація, попередження і боротьба з корупцією, бюрократизацією, а також підвищення правової культури діяльності правоохоронців. Наголошується, що забезпечення належного виконання чинного законодавства у цій сфері, його гармонізація з існуючими європейськими стандартами сприятимуть успішному звершенню реформування правоохоронної, насамперед поліцейської, діяльності в інтересах населення, підтримуючи безпеку і порядок, територіальну цілісність держави.

Поряд із реформаційними процесами правоохоронних органів існують нагальні проблеми в системі правосуддя. Погоджуємося 3 висновками вчених та міжнародних експертів щодо низького рівня довіри громадськості до судової системи, неналежного рівня ефективних судових послуг, розширення ролі громадян у розвитку та контролі над ефективністю роботи та підзвітності судової системи.

Основною проблемою, яка залишається невирішеною, $є$ кадровий дефіцит судової системи, що призводить до порушення прав громадян на доступ до правосуддя. Останні законодавчі зміни зі зменшення розміру суддівської винагороди спровокували хвилю звільнень за власним бажанням суддів, які не досягли граничного віку перебування на посаді. Зокрема, за інформацією Ради суддів України, на початок червня 2020 р. близько 1546 суддів (першої та апеляційної інстанцій) мають право на відставку. Якщо найближчим часом ці судді скористаються своїм законним правом, це загрожуватиме колапсом усієі судової системи.

Проблеми кадрового дефіциту в системі правосуддя поглибилися у зв'язку з неспроможністю сформувати Вищу кваліфікаційну комісію суддів України та, як наслідок, запустити процес добору, кваліфікаційного оцінювання суддів та вирішувати інші питання суддівської освіти і кар'єри. Безумовно, така ситуація перешкоджає наповненню судів молодими фахівцями із сучасним сприйняттям сьогодення і права, сприяючи, таким чином, кадровому оновленню судової системи.

Окремої уваги заслуговує проблема відсутності єдності судової практики, яка нині є предметом обговорення широкого загалу суддів, юристів та науковців. Судове рішення $є$ основним індикатором якості послуг суду. Проаналізувавши судову практику Верховного Суду починаючи 3 кінця 2017 р., ми дійшли обгрунтованого висновку, що єдності та сталості можна досягнути завдяки передбаченим законом процесуальним механізмам, що сприятиме підвищенню довіри населення, прогнозованості судових рішень, оперативності і швидкості розгляду судових справ. Це, як наслідок, слугуватиме втіленню принципу правової визначеності (resjudicata) та реалізації доктрини сталості правосуддя (jurisprudence constante).

Ще один із можливих способів вирішення питання поліпшення доступу до правосуддя - повноцінна, ефективна робота електронного суду. Протягом тривалого часу відбуваються суттєві зрушення, пов'язані з електронним правосуддям. Проте у березні 2019 р. впровадження ССITC не відбулося, оскільки рішенням ВРП від 28 лютого 2019 р. проєкт положення повернуто до ДСА України на доопрацювання та запропоновано ДСА України відкликати оголошення про створення та забезпечення функціонування ЄCITC [4]. Один із чинників невдалого запровадження ЄCITC полягає у відсутності концепції, яка б ураховувала нормотворчу діяльність, правозастосування, фінансові, матеріальні, кадрові питання та можли- 
вості програмного забезпечення. Застосування електронних сервісів, особливо в умовах пандемії COVID-19, $\epsilon$ своєчасним, виправданим і таким, яке мінімізує ризики інфікування, при цьому даючи громадянам змогу реалізувати право на справедливий суд, гарантоване і Конституцією України, і міжнародними актами.

Уважаємо, що будь-які реформи варто оцінювати, уникаючи перфекціоністських оцінок, та не ігнорувати серйозних проблем та викликів, які постають на шляху їх реалізації [5].

Необхідними комплексними кроками поліпшення чинного процесуального законодавства, викликаного потребами суспільства в правоохоронній сфері та органах правосуддя, є: удосконалення організаційних механізмів взаємодії органів системи МВС із місцевими органами влади і самоврядування; закріплення принципу community policing, який полягає у діяльності системи MBC, орієнтованої на потреби громадян; застосування аналітичних індикаторів у протидії злочинності і прогнозуванні відповідних загроз; мінімізація корупційних явищ у сфері правосуддя; розвиток кадрового планування органів правосуддя; підвищення публічності сфери правосуддя та довіри до судової системи.

Отже, вважаємо необхідним критично осмислити недоліки сучасного стану правоохоронної діяльності та органів правосуддя в Україні. Здійснення реформаційних процесів потребує єдиного комплексного підходу в управлінській сфері шляхом фундаментальних досліджень стосовно законодавчого забезпечення подальших перетворень для утвердження принципу верховенства права в усіх сферах державного життя та подальшої розбудови демократії в Україні.

\section{ЛITEPATУPA}

1. Стратегія розвитку органів системи Міністерства внутрішніх справ на період до 2020 року : Розпорядження Кабінету Міністрів України від 15 листопада 2017 р. № 1023-р. Київ, 2017. URL : https://zakon.rada.gov.ua/laws/show/1023-2017-р\#Техt (дата звернення: 20.07.2020).

2. Річна національна програма під егідою Комісії Україна - НАТО на 2020 рік : Указ Президента України від 26 травня 2020 року № 203/2020. Київ, 2020. URL : https://zakon.rada.gov.ua/laws/show/203/2020\#Text.

3. Сидоренко С. Концепція розвитку охоронної діяльності. Створення резервної системи безпеки України. Українська федерація професіоналів безпеки. Всеукраїнське об'єднання організацій роботодавців охоронної галузі. URL : http:// ufpb.kiev.ua/index.php/allnews/68-kontseptsiji-rozvitku-okhoronnoji-diyalnostistvorennya-rezervnoji-sistemi-bezpeki.

4. Рішення Вищої Ради правосуддя № 624/0/15-19 від 28.02.2019 «Про повернення на доопрацювання проєкту положення про Єдину судову інформаційно-телекомунікаційну систему». Київ, 2019. URL : http://www.vru.gov.ua/act/17577.

5. Білас А.І. Взаємодія правоохоронних органів України та країн ЄС: уніфікація стандартів правоохоронної діяльності. Європейські перспективи. 2016. № 1. С. 104-114. 
удк 347.633

DOI https://doi.org/10.32782/2524-0374/2020-4/87

\title{
ПРАВОВЕ РЕГУЛЮВАННЯ УСИНОВЛЕННЯ 3 ІНОЗЕМНИМ ЕЛЕМЕНТОМ: СУДОВА ПРАКТИКА
}

\author{
LEGAL ADJUSTING OF ADOPTION IS WITH FOREIGN ELEMENT: \\ JUDICIAL PRACTICE
}

\author{
Вітренко Л.Р., студентка V курсу \\ юридичного факультету \\ Навчально-науковий інститут права \\ Університету державної фіскальної служби України
}

Дяченко С.В., к.ю.н., доцент, доцент кафедри цивільного права та процесу

Університет державної фіскальної служби Украӥни

У статті досліджуються питання, що стосуються правового регулювання усиновлення з іноземним елементом, яке здійснюється в порядку цивільного судочинства з дотриманням принципу верховенства права шляхом опрацювання судової практики з даної категорії справ.

Міжнародне усиновлення регулюється низкою нормативно-правових актів, які приймаються на національному та міжнародних рівнях. Серед основних можна виділити, насамперед, Конституцію України, Сімейний кодекс України, Цивільний процесуальний кодекс України, Закон України «Про міжнародне приватне право», Закон України «Про охорону дитинства», Конвенцію про права дитини, Конвенцію про захист дітей та співробітництво в галузі міждержавного усиновлення, Європейську конвенцією про усиновлення дітей.

Проаналізувавши дані інформаційної системи «Єдиний державний реєстр судових рішень», було встановлено, що сьогодні в Україні існує велика кількість справ за заявами про усиновлення дітей, які є громадянами України, іноземцями, а це вказує на те, що іноземне усиновлення в Україні $є$ досить поширеним явищем, незважаючи на досить тривалу та складну процедуру, яку усиновлювачі повинні пройти, щоб стати батьками усиновленої ними дитини.

Велика відповідальність під час міжнародного усиновлення покладається на органи державної влади, які повинні усі свої рішення приймати на користь та в інтересах усиновлених дітей, а також у подальшому здійснювати контроль дотримання прав таких дітей в усиновлених сім'ях.

Розглянувши судову практику з даної категорії справ, установлено, що суд здебільшого задовольняє заяви іноземців про усиновлення дітей - громадян України. У процесі аналізу судових рішень із даної категорії справ було встановлено, що суди під час ухвалення рішень дотримувалися вимог процесуального законодавства, а також повно та всебічно встановлювали усі обставини справи і приймали рішення в інтересах усиновлених дітей.

Ключові слова: усиновлення, іноземці, верховенство права, суд, судова практика, іноземний елемент.

The article deals with issues related to the legal regulation of adoption with a foreign element, which is carried out in the order of civil proceedings in observance of the principle of the rule of law by processing the case law of this category of cases.

International adoption is governed by a number of national and international regulations. First of all, the Constitution of Ukraine, the Family Code of Ukraine, the Civil Procedure Code of Ukraine, the Law of Ukraine "On International Private Law", the Law of Ukraine "On Child Protection", the Convention on the Rights of the Child, the Convention on the Protection of Children and Cooperation in the Field of Interstate the European Convention on the Adoption of Children.

Analyzing the information system of the Unified State Register of Judgments, it was found that today in Ukraine, there are a large number of cases of applications for adoption of children who are Ukrainian citizens - foreigners, and this indicates that foreign adoption in Ukraine is quite widespread phenomenon, despite the lengthy and complicated procedure that adopters must undergo in order to become parents of their adopted child.

The responsibility of the international adopter rests with the public authorities, who must make all their decisions for the benefit and in the interests of the adopted children, as well as continue to monitor the observance of the rights of such children in the adopted families.

Considering the case law of this category of cases, it was found that the court overwhelmingly, satisfies the statements of foreigners about the adoption of children - citizens of Ukraine. In the course of the analysis of court decisions in this category of cases, it was found that the courts, in making their decisions, adhered to the requirements of the procedural law, as well as fully and comprehensively established all the circumstances of the case and made decisions in the interests of the adopted children.

Key words: adoption, foreigners, rule of law, court, jurisprudence, foreign element.

Постановка проблеми. Відповідно до частини 3 статті 51 Конституції України, сім'я, дитинство, материнство і батьківство охороняються державою [1]. Сьогодні багато дітей залишаються без піклування з боку батьків, і тому держава в особі органів державної влади вживає усіх належних заходів для забезпечення прав таких дітей на сім'ю та на піклування з боку батьків. Серед форм улаштування дітей-сиріт та дітей, позбавлених батьківського піклування, $є$ інститут усиновлення. Відповідно до статті 207 Сімейного кодексу України, усиновленням $є$ прийняття усиновлювачем у свою сім’ю особи на правах дочки чи сина, що здійснене на підставі рішення суду, крім випадку усиновлення дитини, яка $\epsilon$ громадянином України, але проживає за межами України. Усиновлення здійснюється, насамперед, в інтересах дитини для забезпечення стабільних та гармонійних умов іï життя [2].
Більшого значення інститут усиновлення набуває у контексті міжнародного усиновлення.

Відповідно до даних, які були опубліковані Державною службою статистики України, кількість усиновлених дітей іноземними громадянами кожного року стрімко падає. Якщо в 2005 р. було усиновлено 2110 дітейсиріт і дітей, позбавлених батьківського піклування, то в 2018 р. - лише 372 дитини [3]. Тенденцію до зменшення кількості усиновлених дітей іноземними громадянами можна пояснити, перш за все, складністю та довготривалістю процедури усиновлення, яка передбачена українським законодавством.

Усиновлення іноземцями дітей, які $є$ громадянами України, є досить дискусійною темою, яка має як багато прихильників, так і багато противників.

Аналіз останніх досліджень і публікацій. Деякі питання правового регулювання усиновлення 3 інозем- 
ним елементом досліджувалися у працях I.О. Гожій [4], В.В. Заборовського [16], Ю. Деркаченко [17], А.О. Кухар [18] та ін.

Метою даної статті є дослідження питання усиновлення українських дітей іноземними громадянами на основі дотримання принципу верховенства права шляхом опрацювання судової практики з даної категорії справ.

Виклад основного матеріалу. Для вирішення питань, що стосуються міжнародного усиновлення на національному та міжнародному рівнях, існує велика кількість нормативно-правових актів.

У внутрішньому праві України усиновлення регламентується Конституцією України, Сімейним кодексом України, Цивільним процесуальним кодексом України, Законом України «Про міжнародне приватне право», Законом України «Про охорону дитинства», Постановою Кабінету Міністрів України від 8 жовтня 2008 р. № 905 «Про затвердження Порядку провадження діяльності з усиновлення та здійснення нагляду за дотриманням прав усиновлених дітей» та ін.

Окрім національних актів, усиновлення регулюється також міжнародними документами, згода на обов'язковість яких надана Верховною Радою України, серед основних: Декларація про соціальні та правові принципи, що стосуються захисту і благополуччя дітей, особливо у разі передачі дітей на виховання та їх усиновлення на національному та міжнародному рівнях, яка затверджена Резолюцією Генеральної Асамблеї ООН 3 грудня 1986 р., Конвенція про права дитини, що була прийнята у НьюЙорку 20 листопада 1989 р., Конвенція про захист дітей та співробітництво в галузі міждержавного усиновлення від 29 травня 1993 р. та іншими нормативно-правовими актами міжнародного характеру.

Міністерство закордонних справ України міждержавне усиновлення розуміє як самостійний інститут міжнародного приватного права, головним завданням якого $є$ влаштування до сімей дітей, що залишилися без батьківського піклування. Тобто міждержавне усиновлення $є$ підставою для виникнення сімейних відносин як юридичного акта за участю іноземного громадянина.

Погоджуючись із думкою I.О. Гожій, варто зазначити, що відносини міжнародного усиновлення - це приватноправові відносини, які ускладнені іноземним елементом [4]. Що ж слід розуміти під категорією «іноземний елемент»? Відповідно до п. 2 ч. 1 ст. 1 Закону України «Про міжнародне приватне право», іноземний елемент - ознака яка характеризує приватноправові відносини, що регулюються цим Законом, та виявляється в одній або кількох 3 таких форм: хоча б один учасник правовідносин $є$ громадянином України, який проживає за межами України, іноземцем, особою без громадянства або іноземною юридичною особою; об'єкт правовідносин знаходиться на території іноземної держави; юридичний факт, який створює, змінює або припиняє правовідносини, мав чи має місце на території іноземної держави [5].

Відносини усиновлення, які ускладнені іноземним елементом, мають юридичний зв'язок із правопорядками декількох країн, оскільки зачіпають інтереси осіб, які можуть бути громадянами різних держав або проживати на території різних країн. Тому виникає питання вибору права, яке має бути застосоване для врегулювання зазначених відносин [4].

Відповідно до статті 69 Закону України «Про міжнародне приватне право», усиновлення та його скасування регулюються особистим законом дитини та особистим законом усиновлювача. Якщо усиновлювач - подружжя, яке не має спільного особистого закону, то застосовується право, що визначає правові наслідки шлюбу. Здатність особи бути усиновлювачем та правові наслідки усиновлення визначаються відповідно до особистого закону усиновлювача, а нагляд та облік усиновлених дітей здійснюються відповідно до особистого закону дитини [5].

Так, Сімейним кодексом України (далі - СК України) у ч. 1 ст. 283 передбачено, що усиновлення іноземцями в Україні дитини, яка є громадянином України, здійснюється на загальних підставах, установлених главою 18 СК України. Однак відносини усиновлення з іноземним елементом мають свої певні особливості, які регламентовано розділом 6 СК України.

Статтею 283 СК України передбачено, що дитина, яка $\epsilon$ громадянином України, може бути усиновлена іноземцями, якщо:

вона перебуває не менше як один рік на обліку в центральному органі виконавчої влади, що реалізує державну політику у сфері усиновлення та захисту прав дітей. Облік іноземців, які бажають усиновити дитину, що проживає в Україні, здійснює Міністерство соціальної політики;

- дитина досягла п'яти років. Проте існують певні винятки, які регламентовані в ч. 2 ст. 283 СК України, коли усиновлення можливе до досягнення дитиною п'ятирічного віку. Зокрема, якщо усиновлювач $є$ родичем дитини або якщо дитина страждає на хворобу, що внесена до спеціального переліку хвороб, затвердженого центральним органом виконавчої влади, що забезпечує формування державної політики у сфері охорони здоров'я. Також такі винятки поширюються на випадки, коли здійснюється усиновлення усіх рідних братів і сестер в одну сім'ю, якщо один із них досяг п'ятирічного віку та перебуває на обліку не менше одного року, а також коли іноземці виявили бажання усиновити дитину, яка $є$ братом або сестрою раніше усиновленої ними дитини.

Слід звернути увагу й на те, що усиновлювачем дитини може бути дієздатна особа віком не молодше двадцяти одного року за винятком, коли усиновлювач є родичем дитини, а також особа, що старша за дитину, яку вона бажає усиновити, не менш як на п'ятнадцять років [2].

Законом України «Про охорону дитинства» встановлено, що усиновлення дитини, яка є громадянином України, іноземцями проводиться, якщо були вичерпані всі можливості щодо передачі під опіку, піклування, на усиновлення чи виховання в сім'ї громадян України [6]. Так, у Рішенні Тульчинського районного суду Вінницької області у справі № 148/2336/19 від 27.12.2019 подружжя 3 Італії усиновило малолітню дитину, оскільки, згідно з копією довідки про вжиття вичерпних заходів щодо влаштування дитини в сім ю громадян України, вбачається, що за період перебування на обліку дітей, які можуть бути усиновлені, службою у справах дітей Тиврівської районної державної адміністрації вживалися вичерпні заходи щодо влаштування дитини в сім`ю громадян України. Зокрема, з дитиною було ознайомлено сім подружніх пар кандидатів в усиновлювачі, чотирьох батьків-вихователів, однак отримано дев'ять відмов щодо влаштування дитини в сім ю через наявність у дитини інвалідності. Таким чином, судом було встановлено, що громадяни України не виявили бажання усиновити чи взяти під опіку малолітню дитину у зв язку зі станом іiї здоров я [7].

Важливо зазначити, що переважне право на усиновлення дитини - громадянина України мають іноземці, які $\epsilon$ родичами дитини, а також які є громадянами держав, 3 якими Україна уклала договір про надання правової допомоги [2]. Наприклад, «Договір між Україною та Латвійською Республікою про правову допомогу та правові відносини у цивільних, сімейних, трудових та кримінальних справах» від 22.11.1995.

Усиновлення дитини, яка є громадянином України, здійснюється іноземцями лише за згодою Міністерства соціальної політики. Іноземці, які бажають усиновити дитину - громадянина України, повинні подати нотаріально засвідчену заяву та пакет документів, які перед- 
бачені п. 33 Постанови Кабінету Міністрів України «Про затвердження Порядку провадження діяльності 3 усиновлення та здійснення нагляду за дотриманням прав усиновлення дітей» до Міністерства соціальної політики про взяття їх на облік кандидатів, які бажають усиновити дитину з України. Заява та подані документи розглядаються Міністерством соціальної політики та в разі відповідності їх вимогам законодавства долучаються до справи заявників.

Міністерство соціальної політики протягом десяти робочих днів зі дня прийняття справи направляє запит до Національної поліції щодо перевірки іноземців, які бажають усиновити дитину, на наявність або відсутність інформації, яка може негативно охарактеризувати їх, у правоохоронних органах іноземної держави, а також у Генеральному секретаріаті Інтерполу. І лише після цього Міністерство соціальної політики України повідомляють заявника про взяття його на облік у письмовій або електронній формі.

Іноземець, який був взятий на облік усиновлювачів в Україні, повинен пройти співбесіду, і після успішного іiі проходження особа вже може ознайомитися з інформацією про дітей та отримує можливість особисто познайомитися 3 конкретною дитиною. Установивши контакт із дитиною, кандидати в усиновлювачі звертаються із заявою про бажання усиновити дитину до служби у справах дітей за місцем проживання (перебування) дитини [8]. Згідно із законодавством України, питання усиновлення вирішується в суді, тому завершальним етапом цього процесу буде отримання рішення суду на усиновлення дитини.

Щодо судової процедури усиновлення в Україні, то вона здійснюється в порядку цивільного судочинства. Згідно з положеннями глави 1 розділу IV Цивільного процесуального кодексу України (далі - ЦПК України), розгляд справ про усиновлення проводиться судом у складі одного судді і двох народних засідателів (ч. 4 ст. 234 ЦПК) у порядку окремого провадження.

Заява про усиновлення дитини, яка була позбавлена батьківського піклування, подається до суду за місцем проживання такої дитини (ст. 310 ЦПК України) Разом із заявою до суду повинні бути подані документи, які передбачені ч. 2 ст. 311 ЦПК України. Усиновлення вважається дійсним зі дня набрання законної сили рішенням суду [9].

Своєю чергою, цивільне судочинство в Україні здійснюється 3 дотриманням принципів цивільного процесуального права, головне місце серед яких посідає принцип верховенства права.

С.В. Дяченко та В.О. Сидорчук під принципом верховенства права розуміють основоположний принцип, що полягає в об'єднанні двох вимог: підпорядкування державних інституцій потребам захисту прав людини і пріоритетність цих прав перед усіма іншими цінностями демократичної соціальної держави [10].

О. Крижова у статті «Принцип верховенства права у практиці Європейського суду з прав людини» зазначений принцип тлумачить через виділення його окремих складників: 1) доступність закону; 2) питання юридичних прав мають бути вирішені з дотриманням норм права; 3) рівність перед законом; 4) права людини повинні бути захищені; 5) суд має бути справедливим; 6) дотримання державою як ії міжнародно-правових зобов'язань, так і тих, що зумовлені національним правом [11].

Україна, подавши заявку на вступ до Ради Свропи і ратифікувавши Свропейську конвенцію з прав людини, взяла на себе обов'язок визнавати верховенство права, забезпечувати права і свободи людини, а також узгодити своє внутрішнє національне законодавство 3 європейським [10].

Отже, принцип верховенства права займає центральне місце у судовій практиці, зокрема і під час вирішення судами питання, що стосується усиновлення. Зокрема, приймаючи рішення про усиновлення дитини іноземними громадянами, суд передусім вирішує питання на основі законодавства України, а також міжнародних актів, згода на обов'язковість яких надана Верховною Радою України, шляхом дотримання прав та інтересів дитини.

Що стосується особливостей усиновлення дітей - громадян України іноземцями, то ст. 285 СК України передбачене обмеження прав іноземців на таємницю усиновлення дитини, яка є громадянином України. Таке обмеження поширюється на усиновлювачів, які є громадянами держав, з якими Україна не має договору про надання правової допомоги, або якщо у державі, в якій усиновлювач постійно проживає і в яку має переїхати дитина, усиновлення не $є$ таємним. Ще однією особливістю $є$ те, що за усиновленою дитиною зберігається громадянство України до досягнення нею 18 років [2].

Дуже важливим моментом під час усиновлення $є$ врахування інтересів дитини, яку усиновлюють. На підставі цього законодавством передбачено, що для усиновлення дитини, потрібна іiі згода, якщо вона досягла віку та такого рівня розвитку, що може ії висловити. Згідно 3 п. 72 Постанови Кабінету Міністрів України від 08 жовтня 2008 р. № 905 «Про затвердження Порядку провадження діяльності з усиновлення та здійснення нагляду за дотриманням прав усиновлених дітей», згода дитини на усиновлення надається письмово або усно залежно від віку та стану здоров`я дитини [7]. Так, у справі № 303/3132/19 Мукачівського міськрайоного суду Закарпатської області дитиною була надана усна згода на її усиновлення громадянами Італії [12].

Отже, проаналізувавши судову практику щодо усиновлення українських дітей іноземними громадянами, можна дійти висновку, що суд здебільшого задовольняє заяви іноземців про усиновлення дітей - громадян України. Так, наприклад, у Рішенні Суворовського районного суду м. Одеси від 7 серпня 2017 р. у справі № 523/10995/17 громадяни США, які перебувають у зареєстрованому шлюбі, звернулися до суду із заявою та просять дозволити їм усиновити малолітню громадянку України. В обгрунтування своїх вимог посилаються на те, що вони не мають власних дітей, тому вирішили усиновити дитину з України, позбавлену батьківського піклування, на що одержали згоду своєї країни. Представник Суворовської районної адміністрації Одеської міської ради в особі органу опіки та піклування вказав на доцільність усиновлення громадянами США громадянки України та зазначив, що усиновлення буде відповідати інтересам дівчинки. Від Міністерства соціальної політики України також надійшла згода на усиновлення. Суд, заслухавши заявників та представників заінтересованих осіб, установивши факти та відповідні до них правовідносини, дійшов висновку, що усиновлення малолітньої дитини громадянами США є доцільним та таким, що відповідатиме їі інтересам, та оголосив громадян США усиновителями громадянки України [13].

Однак у судовій практиці зустрічаються поодинокі випадки, коли іноземці звертаються до суду не з метою усиновити дитину - громадянина України, а скасувати раніше прийняте судове рішення про усиновлення. Так, у справі № 265/3859/19 від 12.12.2019 до Орджонікідзевського районного суду міста Маріуполя Донецької області, надійшла позовна заява від громадян Аргентини до органу опіки та піклування виконавчого комітету Маріупольської міської ради, Маріупольської загальноосвітньої школиінтернату I-II ступенів № 2 Донецької обласної ради про скасування усиновлення. В обгрунтування поданої заяви громадяни Аргентини посилалися на те, що під час знайомства $з$ усиновленим хлопчиком останній поводив себе спокійно та виховано, однак після прибуття до Аргентини поведінка хлопчика погіршилася, у його поведінці присутні прояви агресії та неконтрольованої поведінки. Психіатри визначили, що хлопчик страждає важким психіч- 
ним розладом, захворюванням, про яке їм не було відомо та не могло бути відомо на момент усиновлення, тому, враховуючи те, що між позивачами як батьками та дитиною склалися відносини, що роблять неможливим виконання їхніх батьківських обов язків, вони просять суд скасувати усиновлення.

Здійснивши аналіз наведених вище обставин та досліджених доказів, суд доходить висновку, що на момент усиновлення громадянами Аргентини дитини - громадянина України останній не страждав будь-яким психічним захворюванням, а усиновлювачі були ознайомлені повністю зі станом здоров'я та соціальним походженням дитини. Відповідно до законодавства, усиновлення може бути скасоване за рішенням суду, якщо: між усиновлювачем і дитиною склалися, незалежно від волі усиновлювача, стосунки, які роблять неможливими їх спільне проживання і виконання усиновлювачем своїх батьківських обов 'язків. Але, як убачається 3 доказів та пояснень сторін по справі, то між усиновлючами та усиновленою ними дитиною склалися неприязні та конфліктні відносини. А наданих письмових доказів, на переконання суду, недостатньо для встановлення між усиновлювачами та усиновленою дитиною характеру стосунків, які роблять неможливими їх спільне проживання і виконання усиновлювачами своїх батьківських обов язків. Таким чином, суд дійшов висновку, що підстав для скасування усиновлення немає [14].

Як свідчить практика, більшість іноземців усиновлює дітей, які мають психічні або інші види захворювань. Якщо провести паралелі з українськими усиновлювачами, то вони, навпаки, у переважній більшості не готові взяти до своєї родини та забезпечити догляд дитині, яка має проблеми зі здоров'ям. На нашу думку, це можна пояснити тим, що усиновлювачі, які є громадянами України, не мають достатньої кількості матеріальних благ, щоб лікувати та підтримувати життєдіяльність хворої дитини. Також у цьому разі гостро постає питання у медичному обслуговуванні. Ті хвороби, які в Україні можуть бути віднесені до категорії складних чи невиліковних, за кордоном же, навпаки, завдяки більш розвинутій медицині таких дітей можна буде повністю вилікувати або буде легше доглядати за їхнім станом здоров'я. Так, у справі № 523/621/18 від 30.01.2018 року Суворовський районний суд м. Одеси задовольнив заяву громадян США про усиновлення ними дитини, яка, згідно з медичним висновком, наданим дитячою міською поліклінікою № 2 від 02.08.2017, має діагнози: G 40.2 локалізована (фокальна) (парціальна) симптоматична епілепсія та епілептичні синдроми 3 комплексними парціальними судомними нападами; F 71 розумова відсталість помірного ступеня; Q 99.8 інші уточнені хромосомні аномалії. Про наявні у дитини захворювання заявники ознайомлені і вже консультувалися зі своїми лікарями про способи лікування, а також мають матеріальну можливість утримувати дитину та забезпечити їй усі необхідні умови для проживання [15].

Висновки. Отже, підсумовуючи вищезазначене, слід підкреслити, що процедура міждержавного усиновлення $є$ досить складною та потребує багато зусиль і часу, оскільки під час міждержавного усиновлення необхідно одночасно враховувати правопорядки обох країн. Але, незважаючи на це, судова практика свідчить то про те, що усиновлення з іноземним елементом в Україні $\epsilon$ досить поширеним явищем, і це $\epsilon$ позитивною практикою, оскільки діти, які були позбавлені батьківського піклування та не знайшли сім'ю в Україні, мають можливість бути усиновленими громадянами іноземної країни. Але для того щоб процедура усиновлення працювала на користь дітей, вона повинна бути прозорою. Для цього органи державної влади України повинні докласти максимальних зусиль, щоб міждержавне усиновлення було здійснене на користь усиновленої дитини 3 дотриманням усіх її прав, що закріпленні національним законодавством, а також міжнародними актами, згода на обов'язковість яких надана Верховною Радою України.

Тому серед усіх форм сімейного виховання дітей-сиріт та дітей, позбавлених батьківського піклування, пріоритетною є усиновлення, оскільки саме воно дає можливість дитині реалізувати своє право на сім'ю та піклування з боку батьків.

\section{ЛITEPATYPA}

1. Конституція України від 28.06.1996 (у редакції від 01.01.2020) / База даних «Законодавство України».

2. Сімейний кодекс України від 10.01.2002 (у редакції від 18.03.2020) / База даних «Законодавство України».

3. Кількість усиновлених дітей (2000-2017). URL : http://www.ukrstat.gov.ua/operativ/operativ2007/oz rik/oz u/vsunovlennia 06 u.html.

4. Гожій І.О. Деякі питання колізійного регулювання міждержавного усиновлення. Вісник НТУУ «КПї. Політологія. Соціологія. Право. 2016. Вип. 1/2(29/30).

5. Про міжнародне приватне право від 23.06.2005 (у редакції від 20.10.2019) / База даних «Законодавство України».

6. Про охорону дитинства від 26.04.2001 (у редакції від 09.08.2019) / База даних «Законодавство України».

7. Рішення Тульчинського районного суду Вінницької області від 27 грудня 2019 року № 148/2336/19. Єдиний державний реєстр судових рішень. URL : http://reyestr.court.gov.ua/Review/86778612.

8. Постанова Кабінету Міністрів України «Про затвердження Порядку провадження діяльності з усиновлення та здійснення нагляду за дотриманням прав усиновлення дітей» № 905 від 08.10.2008.

9. Цивільний процесуальний кодекс від 18.03.2004 (у редакції від 13.02.2020) / База даних «Законодавство України».

10. Дяченко С.В., Сидорчук В.О. Верховенство права: науковий погляд, нормативне закріплення, судова практика. Юридичний бюлетень. 2018. Вип. 6(6). С. 71-77.

11. Крижова О. Принцип верховенства права у практиці Європейського суду з прав людини. 2017. С. 544-549.

12. Рішення Мукачівського міськрайоного суду Закарпатської області від 24 червня 2019 року № 303/3132/19. Єдиний державний реєстр судових рішень. URL : http://reyestr.court.gov.ua/Review/82630170.

13. Рішення Суворовського районного суду м. Одеси від 7 серпня 2017 року № 523/10995/17. Єдиний державний реєстр судових рішень. URL : http://reyestr.court.gov.ua/Review/68217889.

14. Рішення Орджонікідзевського районного суду міста Маріуполя Донецької області від 12 грудня 2019 року № 265/3859/19. Єдиний державний реєстр судових рішень. URL : http://reyestr.court.gov.ua/Review/86477353.

15. Рішення Суворовського районного суду м. Одеси від 30 січня 2018 року № 523/621/18. Єдиний державний реєстр судових рішень. URL : http://reyestr.court.gov.ua/Review/71927519.

16. Заборовський В.В. Міжнародне усиновлення: проблемні аспекти. Порівняльно-аналітичне право. 2015. С. 66-69.

17. Деркаченко Ю. Міжнародне усиновлення: визначення поняття та актуальні питання правового регулювання. Університетські наукові записки. 2006. № 1(17). С. 108-112.

18. Кухар А.О. Актуальні питання удосконалення інституту міжнародного усиновлення. Держава і право. Юридичні і політичні науки. 2010. Вип. 48. С. 407-412. 
удК 347.963

DOI https://doi.org/10.32782/2524-0374/2020-4/88

\title{
МІЖНАРОДНІ (ЄВРОПЕЙСЬКІ) СТАНДАРТИ ОЦІНЮВАННЯ РОБОТИ ПРОКУРОРІВ
}

\author{
INTERNATIONAL (EUROPEAN) STANDARDS \\ FOR EVALUATING THE WORK OF PROSECUTORS
}

\author{
Подкопасв С.В., к.ю.н., доцент, заслужений юрист України, \\ старший науковий співробітник відділу дослідження проблем \\ кримінального процесу та судоустрою \\ Національної академії правових наук України
}

Науково-дослідний інститут вивчення проблем злочинності імені академіка В.В. Сташиса

У статті йдеться про основні принципи й підходи до функціонування системи оцінювання якості роботи прокурорів, які містяться в міжнародних, насамперед європейських, документах у сфері прокурорської діяльності й статусу прокурорів.

За результатами аналізу змісту положень Рекомендації R (2000р.) 19 Комітету Міністрів Ради Європи державам-членам «Щодо ролі прокуратури в системі кримінального правосуддя», висновків Консультативної ради європейських прокурорів, звітів GRECO, висновків Венеціанської комісії та інших документів автор звертає увагу на основні елементи системи оцінювання, які потребують особливої уваги в процесі формування дієвої системи оцінювання якості роботи прокурорів, виходячи зі змісту п. $7^{2}$ ч. 1 ст. 9 Закону України «Про прокуратуру». Такими елементами є: мета оцінювання; суб'єкти проведення оцінювання; типи (види) оцінювання; критерії оцінювання; процедурні аспекти оцінювання.

Розрізняється оцінювання загальної ефективності роботи прокуратури й оцінювання роботи конкретного прокурора. У першому випадку метою проведення оцінювання є забезпечення належного управління ресурсами й фінансами, допомога в розподілі бюджетних коштів, що знаходяться в розпорядженні прокуратури (або надаються їй). У другому - оцінювання роботи прокурорів проводиться для визначення потреб у підвищенні їхньої кваліфікації та вдосконалення навчального процесу, вивчення професійного рівня прокурорів для розв'язання питань, пов'язаних з їхніми кар'єрними переміщеннями тощо.

Звертається увага на колегіальний спосіб проведення оцінювання суб'єктом, який складається з прокурорів того самого чи інших органів прокуратури. Для забезпечення інституціональної незалежності прокуратури бажаним є уникнення проведення оцінювання прокурорів представниками будь-яких інших зовнішніх суб'єктів (органів), оскільки головну роль мають відігравати саме прокурори.

Так само бажаною визнається формалізована система правил оцінювання, яка за необхідності не виключає проведення неформального оцінювання. В будь-якому випадку вона потребує визначення чітких критеріїв, встановлення гарантій для недопущення використання механізму оцінювання з метою впливу на прокурорів, а так само чітких правових наслідків у випадку негативного результату проведеного оцінювання.

Ключові слова: прокуратура, прокурори, оцінювання роботи, міжнародні (європейські) стандарти.

The article discusses the basic principles and approaches to the functioning of the system of quality assessment of prosecutors, which are contained in international, primarily European documents in the field of prosecution and the status of prosecutors.

Based on the analysis of the content of Recommendation R (2000) 19 of the Committee of Ministers of the Council of Europe to member states "On the role of the prosecution in the criminal justice system", conclusions of the Advisory Council of European Prosecutors, GRECO reports, conclusions of the Venice Commission and other documents, the author draws attention to the main elements of the evaluation system, which require special attention in the process of forming an effective system for evaluating the quality of work of prosecutors based on the content of paragraph $7^{2}$ part 1 of Art. 9 of the Law of Ukraine "On the Prosecutor's Office". Such elements are: the purpose of the evaluation; subjects of evaluation; types (types) of evaluation; evaluation criteria; procedural aspects of evaluation.

There is a difference between assessing the overall effectiveness of the prosecutor's office and assessing the work of a particular prosecutor In the first case, the purpose of the evaluation is to ensure proper management of resources and finances, assistance in the distribution of budget funds available to the prosecutor's office (or provided to it). In the second, the evaluation of the work of prosecutors is carried out to determine the needs for training and improvement of the educational process, to study the professional level of prosecutors to address issues related to their career transfers, and so on.

Attention is paid to the collegial way of conducting an assessment by an entity consisting of prosecutors of the same or other prosecutor's offices. To ensure the institutional independence of the prosecutor's office, it is desirable to avoid the evaluation of prosecutors by representatives of any other external entities (bodies), as the main role should be played by prosecutors.

A formalized system of evaluation rules is also considered desirable, which, if necessary, does not preclude informal evaluation. In any case it requires the definition of clear criteria, the establishment of safeguards to prevent the use of the evaluation mechanism to influence prosecutors, as well as clear legal consequences in the event of a negative evaluation.

Key words: prosecutor's office, prosecutors, performance appraisal, international (European) standards

Торічними змінами до Закону України «Про прокуратуру» (далі - Закон) його ч. 1 ст. 9 доповнено п. $7^{2}$, згідно з яким до повноважень Генерального прокурора віднесено затвердження «положення про систему індивідуального оцінювання якості роботи прокурорів і систему оцінювання якості роботи прокурорів» [1]. I хоча саме формулювання може викликати зауваження, адже створюється враження про різні системи оцінювання, в той час, як логічно передбачити, що має йтися саме про одну, водночас такий крок законодавця зроблено в правильному напрямі, в тому сенсі, що така система слугуватиме підвищенню результативності й ефективності діяльності прокуратури, іiї підзвітності перед суспільством.

Вона також може розглядатися і як своєрідний інструмент визначення потреб у підвищенні кваліфікації конкретних прокурорів, збільшення продуктивності їхньої роботи, формування об'єктивної та прозорої процедури для службових переміщень і, відповідно, в підсумку, сприяти забезпеченню незалежності прокурорів. Так, у п. 67 пояснювальної записки до висновку № 9 (2014 рік) Консультативної ради європейських прокурорів (далі КРЄП) «Європейські норми й принципи щодо прокурорів» йдеться про те, що підвищення кваліфікації прокурорів повинно грунтуватися на об'єктивних факторах, зокрема на професійній кваліфікації, здібностях, сумлінності й досвіді й прийматися відповідно до справедливих і неупереджених процедур [2]. Водночас міститься посилання на п. 7 Керівних принципів щодо ролі осіб, які здійснюють судове переслідування, де так само йдеться про зазначені об'єктивні фактори, на яких має відбуватися підвищення в посаді прокурорів [3]. Крім того, про потребу «в розвиненіших інструментах управління ефективністю» йдеться 
в Стратегії реформування судоустрою, судочинства й суміжних правових інститутів на 2015-2020 роки [4].

Відповідно, звернення до питань, які знаходяться в площині формування системи оцінювання якості роботи прокурорів, набуває актуальності, тим більше, що воно, за деяким виключенням [5], все ще залишається поза увагою дослідників. Мало розкритим залишається зміст тих підходів, які знайшли своє відбиття в міжнародних (європейських) документах у сфері прокурорської діяльності й статусу прокурорів, тому їхнє викладення та розкриття корисне для побудови в Україні дієвої системи оцінювання якості роботи прокурорів, що й становить мету статті.

Зміст положень Рекомендації R (2000 рік) 19 Комітету Міністрів Ради Європи державам-членам «Щодо ролі прокуратури в системі кримінального правосуддя» (далі Рекомендація R (2000) 19 КМ РЕ) [6], висновків КРСП № 7 (2012 рік) [7], № 9 (2014 рік) [2], № 11 (2016 рік) [8], звіту GRECO за результатами оцінки запобіганню корупції серед народних депутатів, суддів й прокурорів в Україні (2017 рік) [9], висновків Венеціанської комісії та низки інших документів свідчить, зокрема, про таке.

1. Мета оцінювання. Розрізняється оцінювання загальної ефективності прокуратури й оцінювання роботи конкретного прокурора. У першому випадку йдеться про поліпшення управляння ресурсами й допомогу в розподілі бюджетних коштів. КРЄП у своєму висновку № 7 (2012 рік) пропонує систему управління за результатами $[7$, с. 52, 54-55]. Такий механізм спирається на модель ресурсного забезпечення, в якій їх розподіляють відповідно до того, наскільки досягнута загальна соціальна ціль (цілі) діяльності прокуратури. Мета такого оцінювання полягає в забезпеченні належного управління ресурсами й фінансами, що знаходяться (надаються) в розпорядженні прокуратури для забезпечення балансу між наявними ресурсами й результатами, яких необхідно досягти. Воно містить оцінку ефективності роботи, контроль якості й стан управління людськими ресурсами. Водночас у рамках статті далі ми зосередимо увагу на питаннях індивідуального оцінювання роботи конкретного прокурора.

Дещо повторимося, зазначивши, що оцінювання індивідуальної ефективності роботи може бути інструментом для визначення потреб у підвищенні кваліфікації прокурора, продуктивності його праці й загального професійного рівня. Воно надає зворотний зв'язок, і в цьому сенсі сприяє визначенню навчальних цілей і сфер, які потребують вдосконалення [8, с. 42]. Поряд 3 іншими критеріями, такими, як стаж роботи, доброчесність, а також психологічні особливості, приміром, лідерські навички, оцінювання може відігравати ключову роль у підвищенні й кар'єрному зростанні прокурорів [10, с. 214].

2. Суб'єкти проведення оцінювання. В контексті оцінювання індивідуальної ефективності Венеціанська комісія у свій час звертала увагу на необхідність визначення суб'єкта оцінювання професійних якостей та особистих досягнень прокурора, - i це питання не варто залишати на власний розсуд безпосереднього керівника або Генерального прокурора [11, с. 50; 12, с. 84]. Якщо Рада прокурорів залучена до оцінювання, то краще було б обмежити цю роль лише наглядом, а фактичну реалізацію процедури оцінювання покласти на технічний орган. Зазвичай такий орган $є$ комітетом чи комісією в межах Ради прокурорів. Водночас комісія з оцінювання повинна мати достатній рівень незалежності від Ради прокурорів, а до іiі складу повинні входити авторитетні юристи, оскільки інформація, отримана від осіб поза системи, може виступати додатковою гарантією неупередженості й незалежності, а також допомагати уникати непотизму й сприйняттю діяльності комісії як інструменту самозахисту системи, що могло б статися, якби оцінювання здійснювали лише прокурори [13, с. 83-84]. Інші фахівці також можуть брати участь у цьому процесі, проте за умови, що вони мають знання та досвід у судовій системі, достатні для того, щоб бути спроможними належним чином оцінювати роботу прокурорів. Також важливо, щоб їхня роль була дорадчою, а не вирішальною. У цьому сенсі аналогічні підходи сформовані щодо суддів [14, с. 38$]$.

Отже, оцінювання має проводитися в колегіальний спосіб, суб'єктом (колегією), що складається 3 прокурорів того самого чи інших органів прокуратури. Водночас керівник прокуратури або безпосередній керівник не повинні мати вирішальний одноособовий голос під час оцінки підпорядкованих чи підрядних прокурорів. Крім того, для забезпечення інституціональної незалежності прокуратури краще уникати проведення оцінювання прокурорів представниками будь-яких інших зовнішніх суб'єктів (органів), оскільки головну роль мають відігравати саме прокурори.

3. Типи (види) оиінювання. Результати анкетування членів асоціації КРЄП свідчать про використання двох типів оцінки: формальної та неформальної. Кожен із них має однакову мету - з'ясування навичок і працездатності прокурора. Крім того, в деяких країнах вони застосовуються під час розв'язання питання про заохочення: підвищення заробітної плати, нагородження чи відзнаки, або ж для запобігання професійним зловживанням чи помилкам i, таким чином, стримують від необхідності притягнення прокурора до дисциплінарної відповідальності [8, с. 43].

Формальний вид передбачає проведення оцінки за визначеною процедурою та 3 певною періодичністю (наприклад, через кожні три-п'ять років). Він заснований на спеціально розробленій і регламентованій законом або підзаконним актом процедурі оцінки конкретних навичок прокурорів. Іноді він може поєднуватися 3 рейтинговою системою, яка дозволяє порівнювати прокурора 3 колегами, сприяючи швидкому службовому просуванню. Формальні заходи з оцінки передбачають чітко визначені цілі оцінювання, критерії та статус суб'єкта оцінювання.

Неформальний вид оцінювання - це обговорення, спрямоване на отримання чи надання інформації про шляхи й засоби підвищення якості, ефективності роботи прокурора, який оцінюється (наприклад, це може бути зрозумілість обвинувального акту, здатність працювати в команді, не порушувати професійні стандарти тощо), або як частина стратегічнішого підходу, який має містити перевірку того, чи має прокурор належні навички для виконання своїх обов'язків. Також воно дозволяє прокурору проаналізувати проблемні питання, продемонструвати свої навички й узгодити кар'єрні цілі та, як правило, не має безпосереднього наслідку для прокурора, щодо якого воно проводиться.

У висновку КРСП № 11 (2016 рік) не міститься позиція щодо формального чи неформального оцінювання [8]. Натомість GRECO у своєму звіті зазначає, що введення формалізованіших процедур, які замінюють неформальні оцінки системою періодичного оцінювання (що грунтується на стандартизованих критеріях), створює додаткові елементи об'єктивного оцінювання для кар'єрного зростання прокурора на засадах справедливості й заслуг. Така система може надавати велику кількість переваг у контексті поточного конструктивного діалогу з різними рівнями вертикалі управління та керівництвом [15, с. 94].

Група експертів GRECO переконана, що створення формальних механізмів оцінки виконання службових обов'язків не тільки забезпечить можливість проведення належного моніторингу й оцінки роботи прокурорів, але й сприятиме створенню об'єктивнішого й прозорішого механізму просування по службі, вільного від будь-яких неналежних впливів. У контексті України це особливо важливе, зважаючи на часті звинувачення в політичному втручанні й низький рівень довіри громадян до органів прокуратури. Відповідно, критерії та порядок оціню- 
вання повинні бути визначені завчасно, закріплені на законодавчому рівні й оприлюднені для широкого загалу [9, с. 227-228].

4. Критерії очінювання. Відповідно до п. 46 висновку № 11 (2016 рік) КРЄП, оцінювання повинно проводитися на основі однакових критеріїв для одного того ж виду роботи в прокуратурі. Як і у випадку, коли оцінюється загальна ефективність прокуратури, КРЄП вважає, що для визначення якості роботи прокурора слід враховувати кількісні та якісні елементи, такі, як кількість відкритих і закритих справ, типи рішень і результатів, тривалість провадження, навички організації роботи, вміння чітко висловлювати думку усно й письмово, відкритість до сучасних технологій, знання декількох мов, організаторські навички, а також здатність співпрацювати 3 іншими людьми в прокуратурі чи поза ії межами [8]. Водночас акцентується на тому, що кількісні показники як такі (кількість справ, тривалість провадження тощо) не повинні бути єдиним критерієм для оцінки ефективності функціонування прокуратури та (або) конкретного прокурора [8, с. 38].

Раніше аналогічним чином Консультативна рада європейських суддів (далі - КРСС) у п. 42 висновку № 6 (2004 рік) «Про справедливий суд у розумні строки й роль судді в судових процесах 3 урахуванням альтернативних засобів вирішення спорів» звертала увагу, що «якість» правосуддя не повинна розглядатися як синонім простої «продуктивності» судової системи», зазначивши водночас, що якісний підхід повинен насамперед оцінювати спроможність системи задовольняти попит на правосуддя відповідно до загальних цілей правової системи, де швидкість проходження справою процесуальних стадій розгляду є лише одним з елементів [16].

Міжнародні експерти звертають увагу на те, що якісні показники, такі, як належне використання доказів, точне вибудовування обвинувачення, професійна поведінка в суді тощо повинні враховуватися на доповнення до кількісних критеріїв. Водночас і на те, що подання результатів оцінювання лише у вигляді балів, цифр, відсотків або чисел без додаткових пояснень може створити хибне уявлення про об'єктивність і переконливість. Оцінювання не потребує точних балів - важливо знати, чи відповідає прокурор критеріям, якими є його сильні й слабкі сторони та як підвищити його спроможності. Це можна зробити без присвоєння балів $[17$, с. 8$]$.

Саме тому для того, щоб доповнювати показники кількісного характеру, в П. 39 висновку КРСП № 11 (2016 рік) акцентовано на врахуванні певних якісних показників, таких, як ефективність і ретельність розслідувань (якщо це належить до компетенції прокурора), належне використання доказів, чітка лінія побудови підтримання обвинувачення прокурором, професійна поведінка в суді тощо [8]. Водночас, оцінюючи строки кримінального переслідування, необхідно також брати до уваги гарантії, передбачені ст. 6 Конвенції про захист прав людини й основоположних свобод, а саме ухвалення рішення в розумні строки, як про це також згадується у п. 26 висновку № 11 (2008 рік) КРСС [18].

У контексті оцінки діяльності (роботи) окремого прокурора звертається увага й на необхідність розробки й впровадження такої системи без прив'язки до показників розкриття злочинів чи виправдувальних вироків. Замість цього вона повинна орієнтуватися на навички прокурора, включаючи показники, які можуть бути професійними (знання права, вміння надавати докази в суді, вміння писати клопотання та інші процесуальні документи), особистісними (вміння справлятися 3 робочим навантаженням, вміння самостійно приймати рішення) та соціальними (вміння працювати з колегами, повага до суду й сторони захисту й потерпілого) [19, с. 138-139].

Отже, в національних правових системах повинна бути впроваджена система оцінки роботи прокурорів на основі кількісних та якісних показників, відповідних основним принципам справедливості, які втілено в Конвенції про захист прав людини й основоположних свобод та інших міжнародних документах [8, с. 40].

5. Процедурні аспекти очінювання. У п. 65 пояснювальної записки до висновку № 9 (2014 рік) КРЄП вказується, що оцінка роботи прокурорів повинна проводитися через регулярні проміжки часу, бути розумною, на основі адекватних, об'єктивних і встановлених критеріїв, у рамках належної та справедливої процедури [2]. На такі процедури звертається увага й у п. 5 a), b), f) Рекомендації $\mathrm{R}$ (2000 рік) 19 КМ РЕ [6].

Водночас вважається, що оцінювання роботи, яке проводиться, приміром, один раз у 5 років, може вважатися недостатнім. Тому звертається увага, що термін проведення заходів 3 оцінювання ефективності роботи може бути також пов'язаний із конкретними цілями, такими, як надання посади або призначення на вищу посаду [17].

Процедури оцінювання повинні бути справедливими й неупередженими [9, с. 222-223], не допускати будьякої дискримінації та передбачати право на оскарження $[2$ с с. XII]. Джерела відповідної інформації мають бути надійними, а справи, які знаходилися в провадженні прокурора, для їх оцінки можна визначати шляхом випадкового вибору. Крім того, слід запропонувати прокурору, щодо якого проводиться оцінювання, надати власні приклади якісно виконаної ним роботи. Це, як зазначається, особливо важливо у випадку, якщо інформація є підставою для негативної оцінки $[13$, с. 88$]$.

Прокурори повинні мати доступ до результатів щодо їхньої оцінки, а також мати право подавати зауваження та, за необхідності, право на компенсацію [2, с. 66].

Так само й у висновку № 11 (2016 рік) КРСП йдеться про те, що оцінка роботи прокурорів має бути прозорою, передбачуваною та здійснюватися на чітких критеріях, заздалегідь опублікованих і тих, що належать як до матеріальних правил, так і до процедурних. Для того, щоб вважатись прозорою та передбачуваною, будь-яка оцінка повинна передбачати право прокурора обговорювати їі результати або порівнювати результати самооцінки 3 оцінкою його керівника чи компетентної особи, якщо вони відрізняються, а також оскаржувати їх. Результати оцінки не повинні оприлюднюватися так, щоб підірвати особисту недоторканість і честь зацікавленої особи (прокурора) [8, с. 44-45].

Як бачимо, системі оцінки діяльності прокурорів у міжнародних документах приділяється належна увага. Водночас бажаною моделлю $є$ формалізована система правил оцінювання, що за необхідності не виключає проведення неформального оцінювання. Вона потребує визначення чітких критеріїв оцінювання, встановлення гарантій від використання механізму оцінювання для впливу на прокурорів, а так само чітких правових наслідків у випадку негативного результату.

\section{ЛITEPATYPA}

1. Про прокуратуру : Закон України від 14 жовтня 2014 року № 1697-VII / Верховна Рада України. URL: http://zakon1.rada.gov.ua/laws/ show/1697-18.

2. Opinion No 9 of the Consultative Council of European Prosecutors to the Committee of Ministers of the Council of Europe on European norms and principles concerning prosecutors. 2014. URL: https://rm.coe.int/168074738b\%C2\%A0.

3. Руководящие принципы, касающиеся роли лиц, осуществляющих судебное преследование : приняты восьмым Конгрессом Организации Объединенных Наций по предупреждению преступности и обращению с правонарушителями, Гавана, Куба, 27 августа 7 сентября 1990 года. База даних «Законодавство України». URL: https://zakon.rada.gov.ua/laws/show/995_859. 
4. Про стратегію реформування судоустрою, судочинства та суміжних правових інститутів на 2015-2020 роки : Указ Президента України від 20 травня 2015 року № 276/2015 / Президент України. URL: https://zakon.rada.gov.ua/laws/show/276/2015\#Text

5. Костенко С.К. Засади створення системи оцінювання прокурорів в Україні. Науковий часопис Національної академії прокуратури України. 2018. № 3. С. 31-41. URL: http://www.chasopysnapu.gp.gov.ua/chasopys/ua/pdf/3-2018/kostenko.pdf

6. On the role of public prosecution in the criminal justice system: Recommendation R (2000)19 adopted by the Committee of Ministers of the Council of Europe on 6 October 2000 and Explanatory Memorandum. URL: https://search.coe.int/cm/Pages/result_details. aspx?ObjectID=09000016804be55a.

7. Opinion No. 7 of the Consultative Council of European Prosecutors on the management of the means of prosecution services adopted by the CCPE at its $7^{\text {th }}$ plenary meeting, Strasbourg, 26-27 November 2012. URL: https://rm.coe.int/16807475b5.

8. Opinion No. 11 of the Consultative Council of European Prosecutors On the quality and efficiency of the work of prosecutors, including when fighting terrorism and serious and organised crime adopted by the CCPE at its 11th plenary meeting, Strasbourg, 17-18 November 2016. URL: https://rm.coe.int/16807474b9.

9. Звіт за результатами оцінки запобіганню корупції серед народних депутатів, суддів та прокурорів (четвертий раунд оцінювання, Україна), ухваленого на 76-му пленарному засіданні GRECO, Страсбург, 19-23 червня 2017 року. GrecoEval4Rep(2016)9-P3. URL: https://rm.coe.int/grecoeval4rep-2016-9-p3-76-greco-19-23-2017-/1680737206.

10. Evaluation report corruption prevention in respect of members of parliament, judges and prosecutors (fourth evaluation round Switzerland), adopted by GRECO at its 74th plenary meeting, Strasbourg, 28 November - 2 December 2016. URL: https://rm.coe.int/ coermpubliccommonsearchservices/displaydctmcontent?documentid=09000016806fceda.

11. Opinion on the draft law on the Public Prosecutors' service of Moldova adopted by the Venice Commission at its 75th Plenary Session, Venice, 13-14 June 2008. URL: https://www.venice.coe.int/webforms/documents/?pdf=CDL-AD(2008)019-e.

12. Opinion on the draft Law on the High Judicial and Prosecutorial Council of Bosnia and Herzegovina adopted by the Venice Commission at its 98th Plenary Session, Venice, 21-22 March 2014. URL: https://www.venice.coe.int/webforms/documents/?pdf=CDL-AD(2014)008-e.

13. Interim Opinion on the Draft Law on the State Prosecution Office of Montenegro, adopted by the Venice Commission at its 101st Plenary Session, Venice, 12-13 December 2014. URL: https://venice.coe.int/webforms/documents/?pdf=CDL-AD(2014)042-e.

14. Про оцінювання роботи суддів, якості правосуддя та поваги до незалежності судової влади: висновок Консультативної ради європейських суддів № 17. 2014. URL: https://rm.coe.int/-17-2014-/1680792012.

15. Evaluation report corruption prevention in respect of members of parliament, judges and prosecutors (fourth evaluation round, Austria) Adopted by GRECO at its 73rd Plenary Meeting, Strasbourg, 17-21 October 2016. URL: https://rm.coe.int/CoERMPublicCommonSearchServices/ DisplayDCTMContent?documentld=09000016806f2b42.

16. Про справедливий суд у розумні строки та роль судді в судових процесах з урахуванням альтернативних засобів вирішення спорів: висновок Консультативної ради європейських суддів № 6. 2004. URL: https://rm.coe.int/-6-2004-/16807477cd.

17. Печі І., Вісентін М. Стандарти Ради Європи щодо оцінювання ефективності роботи прокурорів. Рада Європи. 2018. 15 с.

18. Про якість судових рішень : висновок Консультативної ради європейських суддів № 11. 2008. URL: https://rm.coe.int/opinion-n11-2008-on-the-quality-of-judicial-decisions-/16806a1fbc.

19. Укрепление функциональной независимости прокуроров в восточноевропейских государствах-участниках : отчет об оценке потребностей. OSCE, ODIHR, 2020. URL: https://www.osce.org/ru/odihr/447865?download=true. 


\title{
РОЗДІЛ 11 \\ МІЖНАРОДНЕ ПРАВО
}

УДК 341.232 .7

DOI https://doi.org/10.32782/2524-0374/2020-4/89

\section{МІЖНАРОДНЕ СПОРТИВНЕ ПРАВО: ДОКТРИНАЛЬНЕ ОБГ РУНТУВАННЯ}

\author{
INTERNATIONAL SPORTS LAW: DOCTRINAL BASIS
}

\author{
Андрейченко С.С., д.ю.н., доцентка, \\ професорка кафедри міжнародного та свропейського права \\ Національний університет «Одеська юридична академія»
}

\begin{abstract}
У статті висвітлюються підходи до розуміння міжнародного спортивного права. Пропонується вузька та широка інтерпретація поняття «міжнародне спортивне право». Обґрунтовується, що міжнародне спортивне право у вузькому значенні $є$ системою міжнародно-правових норм, що регулюють міжнародне співробітництво суб'єктів міжнародного права у галузі спорту на універсальному та регіональному рівнях й застосовуються до певного кола відносин, як-то: боротьба з апартеїдом та іншими формами дискримінації у спорті; боротьба з допінгом у спорті; визнання «права на спорт» як права людини; підтримання миру під час Олімпійських ігор, запобігання й боротьба з насильством у зв'язку зі спортивними подіями. У цьому разі відносини мають традиційний для міжнародного публічного права горизонтальний характер, і міжнародне спортивне право можна розглядати як галузь міжнародного публічного права.

3'ясовано, що під час розгляду міжнародного спортивного права у широкому значенні слід передусім ураховувати, що міжнародна спортивна діяльність активно розвивається завдяки Олімпійському руху, що включає структури, які є не міждержавними, а неурядовими (зокрема, Міжнародний олімпійський комітет та міжнародні спортивні федерації). Для позначення усього широкого комплексу норм, спрямованих на регулювання міжнародних спортивних відносин, що виходять за рамки взаємодії між державами та міжнародними міжурядовими організаціями у сфері спорту та є транснаціональними за своїм характером, можна використовувати концепцію «транснаціонального спортивного права», ядро якого становить lex sportiva. Обґрунтовується, що основою lex sportiva є рішення Спортивного арбітражного суду, що є обов'язковими для сторін і підлягають виконанню відповідно до Нью-Йоркської конвенції про визнання і приведення у виконання іноземних арбітражних рішень і $є$ керівництвом для майбутніх справ, а також рішення Міжнародного олімпійського комітету та міжнародних спортивних федерацій, діяльність яких разом сприяє інтенсивному розвитку міжнародного спортивного співробітництва.

Ключові слова: спортивне право, міжнародне спортивне право, lex sportiva, Олімпійський рух, Спортивний арбітражний суд.
\end{abstract}

The article highlights the approaches to the understanding of international sports law. Strict and broad interpretations of the concept of "international sports law" are proposed. It is substantiated that international sports law in the "strict" sense is a system of international norms which regulate international cooperation of subjects of international law in the sports field at the universal and regional levels, and apply to a range of relations, such as the struggle against apartheid and other forms of discrimination in sport; fight against doping in sports; recognition of the "right to sport" as a human right; maintaining peace during the Olympic Games, preventing and combating violence in connection with sporting events. In this case, legal relations are horizontal, that is traditional for public international law, and international sports law can be considered as a branch of public international law.

Should be taken into account when considering the international sports law in a broad sense, that international sports activities are developing through the Olympic Movement, which includes structures that are not interstate but non-governmental (in particular, the International Olympic Committee and international sports federation). To denote a wide range of norms aimed at regulating international sports relations that go beyond the interaction between states and international intergovernmental organizations in the sports field, and are transnational in nature, the concept of "transnational sports law" the core of which is lex sportive, can be used. It is argued that the basis of the lex sportiva are the decisions of the Court of Arbitration for Sport, which are binding on the parties and enforceable under the New York Convention on the Recognition and Enforcement of Foreign Arbitral Awards, and guide for future cases, as well as the decisions of the International Olympic Committee and international sports federations, whose activities together contribute to the intensive development of international sports cooperation.

Key words: sports law, international sports law, lex sportiva, Olympic Movement, Court of Arbitration for Sport

Постановка проблеми. Спорт важливий і особливий із багатьох причин у всьому світі, і це вкладено в юридичну концепцію «специфіки спорту» та іiі застосування до найрізноманітніших практичних ситуацій на національному, європейському та світовому рівнях [1, с. 149]. Право, як і політика, супроводжувало спортивні змагання протягом усієї історії, і таке право часто мало унікальний статус. До прикладу, стародавні Олімпійські ігри покладалися на спеціальних чиновників - по суті, суддів, які були наділені спеціальними санкціями для виконання правил гри як у певному змаганні, так і організаційних правил Ігор у цілому. Оповіщення міст-держав, що приймали участь у змаганнях та спортсменів про їхні зобов'язання, набуло форми статутів, названих «зейн» (zanes), присвячених Зевсу, і розміщувалися як нагадування біля входу на стадіон [2, с. 157]. Очевидно, що зародження класичних спортивних відносин відбулося на міжнародному рівні, що зумовлено інтернаціональним характером такого явища, як спорт [3, с. 189].

Глобалізація спортивних змагань є ознакою нашого часу. Натхненний сучасними Олімпійськими іграми, підтримуваними комунікаційними технологіями, високопрофесійними спортсменами та комерційними інтересами, процес глобалізації триває безперервно. У цьому процесі міжнародне спортивне право поступово займає визначне місце [4, с. 109]. Особливий статус спортивної діяльності й, відповідно, спортивного права набув особливого визнання в міжнародному публічному праві. Процес розвитку міжнародного спортивного права має недавнє походження, чітко проявляючись лише в останній чверті XX століття. Міжнародне спортивне право - це, безумовно, ідея, чий час прийшов у відповідь на значні події: бурхливе зростання спортивної галузі під сильним впливом корпоративних інвестицій; широке ефірне віщання; відкриту конкуренцію між професіоналами та аматорами; допінг спортсменів; насильство на ігровому полі та глядачів; стійкі - хоча й значно зменшені - питання міжнародної політики та національності [2, с. 157].

Аналіз останніх досліджень і публікацій. Відзначимо наявність в українській науковій літературі значної кількості праць, присвяченої питанням розвитку спортивного права (Г.Ю. Бордюгова, Р.М. Кацуба, О.В. Кири- 
люк, О.А. Костюченко, О.В. Макогон, О.А. Моргунов, О.С. Облакова, А.Я. Палюх та ін.), в яких розглядаються певні міжнародно-правові аспекти співробітництва у спорті. Вагомий внесок у дослідження розвитку міжнародного спортивного права зробили С.В. Алексєєв, М. Белофф (M. Beloff), Я. Блекшо (I. Blackshaw), А. Ербсен (А. Erbsen), Л.I. Захарова, Дж. Нафзігер (J. Nafziger), P. Сікман (R. Siekmann), К. Феддер (C. Vedder), К. Фостер (K. Foster) та ін.

Водночас слід наголосити на неодностайності думок щодо місця міжнародного спортивного права у системі права та співвідношенні таких понять, як «міжнародне спортивне право», lex sportiva та деяких інших, а також на відсутності в Україні комплексних грунтовних досліджень проблематики міжнародного спортивного права.

Мета статті полягає у висвітленні доктринального розуміння поняття «міжнародне спортивне право», його вузької та широкої інтерпретації, визначенні місця міжнародного спортивного права у системі міжнародного права.

Виклад основного матеріалу. Із погляду теорії права в багатьох країнах світу «спортивне право» як окрема галузь національного права перебуває у стадії розроблення, оскільки воно знаходиться на стику багатьох галузей і включає у себе велику кількість елементів з інших галузей права, таких як арбітражне (бізнесове, господарське, конкурентне - залежно від країни), цивільне, трудове, фінансове, тоді як галузь міжнародного спортивного права вже давно є визнаною [5, с. 1] і продовжує невпинно розвиватися.

Термін «міжнародне спортивне право» отримав широке застосування у сучасній юриспруденції. Так, Дж. Нафзігер (J. Nafziger), що одним із перших почав займатися питаннями виникнення та розвитку міжнародного спортивного права ще у 80 -хх роках XX ст., визначає міжнародне спортивне право як процес, який включає «більш-менш відмітний звід правил, принципів, установ та процедур для регулювання важливих наслідків транснаціональної спортивної діяльності» [6, с. 1]. Водночас, за його висловлюванням, публічні аспекти міжнародного спортивного права, яке все ще розвивається, не повинні затінювати супровідну роль міжнародного приватного права у вирішенні питань, пов'язаних зі спортом. До них належать, наприклад, юрисдикція національних судів щодо рішень міжнародних спортивних федерацій, правила за замовчуванням, коли сторони спору не застосовують автономію вибору закону, а також роль увічливості у визнанні та виконанні іноземних судових рішень за відсутності більш формальних вимог [2, с. 157].

На думку К. Фостера (K. Foster), міжнародне спортивне право охоплює «принципи міжнародного права, які застосовуються до спорту» [7, с. 2]. 3 позиції О. Олатавура (O. Olatawura), міжнародне спортивне право є «спеціалізованою галуззю транснаціонального права, яка у глобальному масштабі регулює поведінку та претензії приватних та державних учасників у спорті» [8, с. 130].

С.В. Алексєєв під міжнародним спортивним правом розуміє систему обов'язкових взаємопов'язаних норм, що характеризуються спільністю і специфічністю предмета правового регулювання - міжнародною спортивною діяльністю, що має спеціальні методи, принципи і джерела, встановлює відповідальність за порушення цих норм, а також має певну автономність у системі загального міжнародного права за умови, що виділення такої групи зумовлено зацікавленістю міжнародного співтовариства в більш ефективному регулюванні відповідного комплексу міжнародних відносин. С.В. Алексєєв відзначає, що міжнародні спортивні відносини неоднорідні за своїм характером. Це можуть бути як внутрішньодержавні відносини, що включають міжнародний (іноземний) елемент у тому чи іншому вигляді (наприклад, продаж (трансферти) гравців закордонним спортклубам, тобто угоди між громадянами й організаціями різної державної приналежності), так і суто міждержавні відносини владного характеру (наприклад, міжнародне співробітництво в боротьбі зі злочинністю у сфері спорту) [9, с. 209].

Л.І. Захарова, розуміючи під міжнародним спортивним правом «сукупність саме міжнародно-правових норм, що регулюють співробітництво держав у галузі спорту», не погоджується 3 можливістю включення до складу міжнародного спортивного права норм національного права, оскільки вони належать правопорядку, принципово відмінному від міжнародного публічного права, так само як і норм міжнародного приватного права, тому що останне «всупереч своїй назві є національним правом», хоча і тісно пов'язаних з іноземним правом та міжнародним публічним правом [10, с. $17 ; 11]$.

Вищевикладене свідчить про відсутність одностайності щодо визначення поняття міжнародного спортивного права, вкладання науковцями різного змісту у цей термін та застосування різних підходів до його розуміння - від визнання як міжнародного спортивного права лише системи норм міжнародного публічного права, що регулюють відносини, пов'язані зі спортом, до включення у таку систему відповідних норм міжнародного приватного права, а також внутрішньодержавного права.

Узагальнюючи різні доктринальні погляди на розуміння міжнародного спортивного права, можна виділити його широку та вузьку інтерпретацію. Міжнародне спортивне право у вузькому значенні є системою міжнародно-правових норм, що регулюють міжнародне співробітництво суб'єктів міжнародного права у галузі спорту на універсальному та регіональному рівнях й застосовуються до певного кола відносин, як-то: боротьба з апартеїдом та іншими формами дискримінації у спорті; боротьба з допінгом у спорті; визнання «права на спорт» як права людини. Також можна віднести до цього переліку підтримання миру під час Олімпійських ігор та запобігання й боротьбу з насильством у зв'язку зі спортивними подіями, які хоча й не є стосуються занять спортом, але безпосередньо пов'язані з ним [12, с. 13]. У цьому разі відносини мають традиційний для міжнародного публічного права горизонтальний характер, і міжнародне спортивне право можна розглядати як галузь міжнародного публічного права, що постійно активно розвивається.

Розглядаючи міжнародне спортивне право у широкому значенні, слід передусім ураховувати, що в рамках міжнародного спортивного права домінуюча інституційна структура $\epsilon$ не міждержавною, а неурядовою. Олімпійський рух $є$ яскравим прикладом неурядової організаційної структури, яка наділена обмеженою міжнародною правосуб'єктністю, завдяки чому вона безпосередньо сприяє прогресивному розвитку міжнародного права. Відповідно до Олімпійської хартії, структура Олімпійського руху охоплює Міжнародний олімпійський комітет, міжнародні спортивні федерації, національні олімпійські комітети, оргкомітети Олімпійських ігор, «інші організації та установи, визнані МОК», такі як Міжнародний параолімпійський комітет та Всесвітне антидопінгове агентство; національні асоціації; місцеві клуби, команди та ліги; спортсменів, арбітрів, тренерів та інших спортивних чиновників [13, с. 7].

«Вищим органом влади» Олімпійського руху є Міжнародний олімпійський комітет, що є міжнародною неурядовою неприбутковою організацією, місія, роль й обов'язки якого визначено в Олімпійській хартії [14]. Олімпійська хартія кодифікує загальні принципи, звичаї та авторитетні рішення, застосовні до міжнародних спортивних змагань, і тим самим формує нормативну основу міжнародного спортивного права. Із поступовим процесом легітимізації дія Олімпійської хартії почала розширюватися від організації періодичних олімпійських змагань серед неоплачуваних «аматорів» до управління певною 
поведінкою та діяльністю як спортсменів, що не отримують винагороду, так і професійних спортсменів, а також спортивних чиновників у різноманітних міжнародних змаганнях. Хоча юридична сила Олімпійської хартії може бути під питанням, іiї основні принципи та правила дії у цілому відповідають вимогам міжнародного звичаю, що стосуються повторення, тривалості та універсальності практики, що визнається opinio juris. Відповідно до міжнародного публічного права, особливий статус Олімпійського руху та його установчих організацій, особливо МОК, добре визначений. Держави приймають рішення, керуючись Олімпійською хартією, та ведуть дипломатію 3 МОК [13, с. 7].

Отже, міжнародне спортивне право у широкому значенні є системою різнорідних за своєю юридичною природою норм, що мають на меті регулювання міжнародних спортивних відносин. Ядро такого розуміння становлять норми, що мають транснаціональний характер й отримали назву lex sportiva. Під lex sportiva у даному разі розуміється сукупність правил та принципів, що випливають, передусім, із рішень Спортивного арбітражного суду (CAC) та рішень міжнародних неурядових організацій Олімпійського руху (МОК та міжнародних спортивних федерацій). На підставі цього вважаємо доцільним уживати не термін «міжнародне спортивне право» (що одразу викликає асоціацію з галуззю міжнародного публічного права й питаннями про суб' єктів, джерела правового регулювання та їх юридичну силу), а «транснаціональне спортивне право». У сфері спорту «концепція транснаціонального права дає змогу включити у цей новий правопорядок норми приватного характеру, розроблені міжнародними спортивними федераціями та МОК». Ще одним складником транснаціонального спортивного права є так зване м'яке право [15, с. 116].

Слід окремо зупинитися на різних поглядах щодо трактування lex sportiva. Термін lex sportiva був уперше уведений у 90 -х роках $\mathrm{XX}$ ст. і з того часу набирає все більшого значення [16, с. 40]. Термін lex sportiva охоплює різні поняття з різним змістом. Одразу слід наголосити, що питання про те, чи $\epsilon$ lex sportiva сукупністю унікальних юридичних принципів, характерних для спортивного права, залишається відкритим [16, с. 45-46], так само як i немає одностайності щодо змісту lex sportiva.

За відсутності єдиного погляду щодо lex sportiva, можна виділити такі основні позиції, згідно з якими lex sportiva визнається як:

комплексна система приватного права, що формується завдяки численним угодам і підзаконним актам щодо спортсменів, національних олімпійських комітетів, національних керівних органів із конкретних видів спорту, міжнародних спортивних федерацій, а також державних і приватних антидопінгових агентств;

форма самоврядування, яку спортивні посадовці намагаються створити, i, як наслідок, виключити судові розгляди в національних судах;

неупереджені доктрини, на які посилаються арбітри САС під час винесення конкретних рішень, або сукупність прецедентів, або юриспруденція, які впливають на майбутні рішення САС, що $є$ незалежним судовим органом для вирішення міжнародних спорів, пов'язаних зі спортом [17, с. 444].

Отже, обсяг lex sportiva розуміється по-різному, іноді розширювально, щоб охопити більшість норм, якщо не все міжнародне спортивне право. Однак, як правило, термін lex sportiva обмежується його початковим визначенням як сукупність правил та принципів, що випливають iз рішень САС, насамперед, та інших офіційних рішень загальноприйнятої практики [13, с. 14-15]. За роки своєї діяльності САС розглянув значну кількість справ, що охоплювали широкий спектр юридичних питань, пов'язаних зі спортом. Хоча арбітри САС, як правило, не зобов'язані виконувати раніше прийняті рішення та підкорятися принципу stare decisis (домінування юридичного прецеденту), в інтересах добросовісності та правової визначеності, вони зазвичай це роблять. Унаслідок такої практики постійно формується важливий масив норм спортивного права [1, с. 142].

Всесвітній антидопінговий кодекс - це найяскравіший показник існування lex sportiva. Кодекс ВАДА був прийнятий численними міжнародними спортивними федераціями, міжнародними організаціями, національними олімпійськими комітетами та асоціаціями, національними комітетами Паралімпійських ігор, асоціаціями з ігор Співдружності, державними антидопінговими організаціями, що фінансуються державою, та низкою інших організацій. По суті, це загальновизнане зобов'язання, що регулює допінг у спорті. Значна частина судової практики САС була визнана основою цього кодексу, що ще більше підтверджує важливість рішень САC у формуванні lex sportiva [16, c. 61].

Зауважимо, що Міжнародна конвенція ЮНЕСКО про боротьбу з допінгом у спорті 2005 р. вимагає від державучасниць дотримуватися принципів Всесвітнього антидопінгового кодексу, підтримувати Всесвітнє антидопінгове агентство, яке керує цим Кодексом, та здійснювати освітні програми проти допінгу. Кодекс, однак, не є невід'ємною частиною Конвенції і не створює обов'язкових зобов'язань відповідно до міжнародного права для держав-учасниць за винятком випадків, передбачених умовами співпраці Конвенції [13, с. 12].

Lex sportiva не вирішує всі питання, пов'язані зі спортом. Так, рішення щодо ігрового поля, правил гри або інших технічних положень - так звані lex ludica зазвичай не підпадають під юрисдикцію арбітражу, що відповідає правилу невтручання [13, с. 16]. Спортивний арбітражний суд неодноразово підтверджував, що технічні правила, стандарти чи рішення щодо гри не підлягають арбітражному чи судовому контролю, поки вони не $\epsilon$ довільними, грубо помилковими або злочинними [2, с. 157]. Натомість арбітражі, як правило, заслуховують три види суперечок: дисциплінарні заходи щодо спортсменів, інші питання, пов'язані з придатністю спортсменів, та комерційні питання.

Висновки. Стрімке поширення спорту у світі відбулося завдяки сучасному олімпійському руху. Citius, Altius, Fortius - швидше, вище, сильніше. Значною мірою цей відомий девіз Олімпійського руху виражає прагнення, які надихають і міжнародне спортивне право [13, IX].

Існує чимало варіантів термінологічної та змістовної інтерпретації поняття «міжнародне спортивне право». Міжнародне спортивне право у вузькому значенні є системою міжнародно-правових норм, що регулюють міжнародне співробітництво суб'єктів міжнародного права у галузі спорту на універсальному та регіональному рівнях. Для позначення усього широкого комплексу норм, спрямованих на регулювання міжнародних спортивних відносин, що виходять за рамки суто міжнародно-правового регулювання відносин між державами та міжнародними міжурядовими організаціями у сфері спорту та $€$ транснаціональними за своїм характером, можна використовувати концепцію транснаціонального спортивного права, ядро якого становить lex sportiva. Основою lex sportiva $є$ рішення САC, що є обов'язковими для сторін і підлягають виконанню відповідно до НьюЙоркської конвенції про визнання і приведення у виконання іноземних арбітражних рішень і $є$ керівництвом для майбутніх справ, а також рішення МОК та міжнародних спортивних федерацій, діяльність яких разом сприяє інтенсивному розвитку міжнародного спортивного співробітництва. 


\section{תITEPATYPA}

1. Blackshaw lan S. International Sports Law: An Introductory Guide. T.M.C. Asser Press, 2017. 154 p.

2. Nafziger J. International Sports Law. Max Planck Encyclopedias of International Law. 2009 (January). P. 156-166.

3. Облакова О.С. Міжнародні спортивні відносини: правова природа й історико-правові особливості виникнення. Держава та регіони. Серія «Право». 2018. № 3. С. 188-195.

4. Nafziger J. The Future of International Sports Law. Lex Sportiva: What is Sports Law? Siekmann, R., Soek, J. (Eds.). The Hague: T.M.C. ASSER PRESS. 2012. P. 109-122.

5. Бордюгова Г.Ю. Міжнародне спортивне право як основа для формування національної галузі права «Спортивне право України» : автореф. дис. ... канд. юрид. наук : 12.00.11. Київ, 2009. 18 с.

6. Nafziger J. International Sports Law. 2d ed. Ardsley, New York: Transnational Publishers, 2004. 376 p.

7. Foster K. Is there a global sports law? Entertainment Law. 2003. № 2(1). P. 1-18.

8. Olatawura O.O. Fundamental Doctrines of International Sport Law. The International Sports Law Journal. 2008. № 3-4. P. 130-143.

9. Алексеев С.В. Международное спортивное право : учебник/ под. ред. П.В. Крашентнникова. Москва : ЮНИТИ-ДАНА, 2012. 895 с.

10. Захарова Л.И. Международное спортивное право : учебник. Москва : Проспект, 2017. 271 с.

11. Захарова Л.И. Lex mercatoria и lex sportiva: особенности, сходства и различия. Lex russica. 2019. 11. C. 70-78. URL : https://doi.org/ 10.17803/1729-5920.2019.156.11.070-078.

12. Siekmann R. Introduction to International and European Sports Law: Capita Selecta (ASSER International Sports Law Series). T.M.C. Asser Press, 2012. 444 p.

13. Nafziger J. International sports law. Handbook on International Sports Law / Edited by James A.R. Nafziger, Stephen F. Ross. Cheltenham, United Kingdom: Edward Elgar Pub, 2011. P. 3-31.

14. Олімпійська хартія. URL : http://noc-ukr.org/about/officialdocuments/olimpiyska-khartiya/.

15. Кирилюк O. Lex sportiva - концепция транснационального спортивного права. Закон и жизнь. 2013. № 8(3). C. 113-117.

16. McLaren R. The Court of Arbitration for Sport. Handbook on International Sports Law. Edited by James A.R. Nafziger, Stephen F. Ross. Cheltenham, United Kingdom: Edward Elgar Pub, 2011. P. 32-64.

17. Erbsen A. The Substance and Illusion of Lex Sportiva. The Court of Arbitration for Sport 1984-2004. Blackshaw I, Siekman R, Soek J (eds). T.M.C. Asser Press, The Hague, 2006. P. 441-454. 
УДК 341.01

DOI https://doi.org/10.32782/2524-0374/2020-4/90

\title{
ЗАГАЛЬНІ ПРИНЦИПИ В КЛАСИЧНОМУ МІЖНАРОДНОМУ ПРАВІ: ВІД ВЕСТФАЛЬСЬКОГО МИРУ ДО ООН
}

\author{
GENERAL PRINCIPLES IN CLASSICAL INTERNATIONAL LAW: \\ FROM THE PEACE OF WESTPHAL TO THE UN
}

\author{
Задорожна С.М., д.ю.н., \\ доцент кафедри європейського права та порівняльного правознавства \\ Чернівецький начіональний університет імені Юрія Федьковича \\ Кирилюк Н.В., к.ю.н.,
асистент кафедри свропейського права та порівняльного правознавства
Чернівецький національний університет імені Юрія Федьковича \\ Маник А.З., к.ю.н., \\ асистент кафедри європейського права та порівняльного правознавства \\ Чернівеиький начіональний університет імені Юрія Федьковича
}

Класичний період в історії міжнародного права пов'язують із закінченням Тридцятилітньої війни в Європі та першою масштабною спробою встановити європейський правопорядок та, як показала історія, ще закладенням підґрунтя для універсального правопорядку завдяки принципам, що були закладені Вестфальським конгресом 1648 року. Актом установлюються принципи як загального міжнародного права, так і галузеві принципи, які становили єдиний правопорядок для Європи та в майбутньому отримають своє подальше утвердження в міжнародно-правових документах універсального характеру.

Наступним кроком в утвердженні універсальних принципів міжнародного права стало прийняття європейськими країнами Головного акта Віденського конгресу 1814-1815 рр. як документа, що в єдиному міжнародно-правовому форматі встановлює точний зміст і чітко формулює вже чинні принципи міжнародного права, а також установлює нові принципи з урахуванням науково-технічного прогресу та актуальних проблем того часу. Загальна характеристика документа дозволяє нам визнати його фундаментальними принципами суверенітет та вільне волевиявлення учасників угоди, повагу прав та інтересів народів.

Перша світова війна підтвердила необхідність подальшого пошуку механізмів і засобів мирного співіснування, розвитку європейської та світової цивілізації загалом. Ліга Націй стала ще одним кроком у прогресивному розвитку міжнародного права між двома світовими війнами, в основу якого насамперед покладаються принципи мирного співіснування та безпеки, гарантування політичної незалежності й територіальної цілісності для всіх держав світу.

Завершальним у становленні універсального міжнародного права є створення та діяльність Організації Об'єднаних націй $(\mathrm{OOH})$, розширення міжнародного права, збільшення кількості міжнародних організацій регіонального та універсального характеру (їх правотворча та правозастосовна практика), поява більшої кількості міжнародних установ та їхньої практики застосування принципів міжнародного права, зростання ролі норм soft law i, як наслідок, глобалізація та фррагментація міжнародного права. Особливу роль у процесах щодо формування та закріплення принципів јus cogens та зобов'язань erga omnes, які ними закріплюються, належить універсальним міжнародним організаціям.

Ключові слова: принцип міжнародного права, Вестсральський мирний договір 1648 року, ООН, Ліга Націй, принцип сумлінного виконання зобов'язань, принцип заборони застосування сили, принцип суверенної рівності держав, принцип поваги прав людини.

The classical period in the history of international law is associated with the end of the Thirty Years' War in Europe and the first largescale attempt to establish the European legal order and, as history has shown, to lay the foundations for universal law through the principles of the Westphalian Congress of 1648. The act establishes the principles of both general international law and sectoral principles that constituted a single legal order for Europe and in the future will be further approved in international legal instruments of a universal nature.

The next step in establishing the universal principles of international law was the adoption by European countries of the Main Act of the Congress of Vienna in 1814-1815 as a document that in a single international legal format establishes the exact content and clearly formulates existing principles of international law and establishes new principles scientific and technological progress and current issues of the time. The general characteristics of the document allow us to recognize its fundamental principles - the sovereignty and free will of the parties to the agreement, respect for the rights and interests of the peoples.

The First World War confirmed the need for further search for mechanisms and means of peaceful coexistence, the development of European and world civilization in general. The League of Nations was another step in the progressive development of international law between the two world wars, which is based primarily on the principles of peaceful coexistence and security, guaranteeing political independence and territorial integrity for all countries.

The final formation of universal international law is the creation and operation of the United Nations (UN), the expansion of international law, increasing the number of international organizations of regional and universal nature (their lawmaking and law enforcement practice), the emergence of more international institutions and their practice of international principles. law, the growing role of soft law, and, as a consequence, the globalization and fragmentation of international law. Universal international organizations have a special role to play in the processes of forming and consolidating the principles of jus cogens and the erga omnes obligations they enshrine.

Key words: principle of international law, Treaty of Westphalia of 1648, UN, League of Nations, principle of conscientious fulfillment of obligations, principle of prohibition of use of force, principle of sovereign equality of states, principle of respect for human rights.

Вступ. Якісно нових рис принципи міжнародного права набувають у класичному періоді міжнародного права, який, як згадувалося вище, бере свій початок від закінчення Тридцятилітньої війни в Європі. Перша масштабна спроба встановити європейський правопорядок та зафіксувати підгрунтя для універсального правопорядку закладена Вестфальським конгресом 1648 року. Таку позицію, хоча й неодноголосно, підтримують багато вчених [1, с. 21]. Крім того, на думку А. Мовчана, «міжнародно-правові позиції європейських держав у XVII-XVIII ст. ст. та на початку XIX ст. залишили свій відбиток на сутності принципів і норм традиційного міжнародного права» [14, с. 29]. Переломним моментом для розвитку міжнародного права стало усвідомлення всіма учасниками війни безглуздості військового вирішення суперечок і можливості їх урегулювання мирним шляхом. Така ситуація характеризувалася відсутністю аналогів мирного розв'язання міжнародних спорів у масштабах цілого регіону в попередні історичні періоди. 
Наявність деяких спільних елементів у системі основних міжнародно-правових принципів різних епох не впливає на те, що кожна така система представляє нову єдність. Особливо це стосується сучасної епохи, де система основних міжнародно-правових принципів набуває якісно нових рис.

Незважаючи на актуальність теми дослідження, варто зазначити, що наука історії міжнародного права загалом $\epsilon$ досить молодою, а питання історії принципів також майже не досліджувалися, окремі аспекти проблеми висвітлені в працях учених України (О.В. Буткевич, В.Г. Буткевича, М.В. Буроменського, О.В. Задорожнього, В.Н. Денисова, А.І. Дмитрієва, Л.Д. Тимченка та ін.) та фахівців із країн СНД (Л.А. Алексідзе, Ю.А. Баскіна, Д.В. Кузнецова, І.І. Лукашука).

Постановка проблеми. Отже, історія становлення міжнародного права пройшла кілька етапів еволюції, кожен 3 яких базувався на певних, притаманних саме цьому етапові принципах та принципах, що пройшли всі чи ряд етапів й еволюціонували до наших часів. У даній статті спробуємо виявити та проаналізувати принципи, притаманні класичному міжнародному праву, закладені в період від Вестфальського мирного договору до заснування ООН.

Результати дослідження. Правління Наполеона та його військова компанія в Європі і розпад Священної Римської імперії стали причиною руйнування європейського правопорядку, заснованого Вестфальським миром. Наступним кроком в утвердженні універсальних принципів міжнародного права стало прийняття європейськими країнами Головного акта Віденського конгресу 1814-1815 рр. як документа, що в єдиному міжнародно-правовому форматі встановлює точний зміст та чітко формулює вже чинні принципи міжнародного права, а також установлює нові принципи з урахуванням науково-технічного прогресу та актуальних проблем того часу. Загальна характеристика документа дозволяє нам визнати його фундаментальними принципами - суверенітету та вільного волевиявлення учасників угоди, поваги прав та інтересів народів.

Більшість додатків до Головного акта 1815 року містили норми щодо врегулювання територіальних розбіжностей між європейськими країнами на основі принципів територіальної цілісності, непорушності кордонів, невтручання у внутрішні справи та мирного вирішення спорів, зокрема ст. LXXIV: «цілісність і недоторканість < .. > визнаються основою Гельветичного союзу» [17, с. 209-210]. Дані принципи отримують всезагальне європейське визнання, оскільки Головний акт 1815 року прийнято вважати універсальним договором того часу, посилаючись при цьому на ст. CXIX: «Усім Державам, уповноваженим бути присутніми на конгресі, в однаковій мірі і Князям, і вільним містам, які брали участь у вищезазначених постановах або Актах, цим Головним Трактатом затвердженим пропонується приєднатися до нього» $[17$, с. 210$]$.

Завдяки принципу мирного вирішення спорів був досягнутий компроміс між воюючими сторонами у вигляді надання постійного нейтралітету Швейцарії (LXXIV) [17, с. 209] та вільному місту Краків (ст. VI) [17, с. 209], вироблення нових принципів інституту нейтралітету в міжнародному праві на основі покровительства п'ятірки великих європейських держав.

Принцип свободи судноплавства закріплений у ст. ст. 108-116 Головного акта та в окремому додатку до нього - Постанові про свободу судноплавства по міжнародних річках від 27 січня 1815 року; останній, крім того, стає першою спробою міжнародного врегулювання судноплавства на міжнародних річках Рейн, Некар, Майн, Мозель, Маас, Шельда. Зокрема, завдяки проголошенню принципу стало можливо вперше чітко визначити поняття «міжнародна річка», закріпити права прибережних дер- жав, установити правила такого судноплавства, закріплювалася перевага міжнародної норми. Даний принцип уперше закріплений на універсальному рівні і став прогресивним регулюванням актуального на той час питання.

Додаткового наповнення змісту набуває принцип захисту прав людини. 27 січня 1815 року результатом роботи конгресу стала перша у світі Декларація держав про припинення торгівлі рабами [19, с. 89]. Свобода людини як природне ії право проголошується в документі як таке, що вимагає загальновизнаності та обов'язковості: «припинення (работоргівлі - вставка наша - C.3.) вимагає одноголосно визнання всіма освіченими народами $<\ldots>$ уповноважені представники, що зібралися на Конгресі $<\ldots>$, зобов'язані від імені своїх государів виявити наполегливе бажання, щоб було покладено кінець джерелу бід» $[17$, с. 211$]$. Важливим моментом для реалізації принципу заборони работоргівлі стало гарантування учасниками вжиття заходів для іiї припинення.

Важливим компонентом гарантування принципу мирного вирішення спорів стало Положення щодо дипломатичних агентів 7 березня 1815 року [19, с. 91]. Важливим для забезпечення принципу дипломатичної недоторканості був уперше здійснений поділ дипломатичних агентів на класи, визначення їхніх повноважень, важливість принципів дипломатії для захисту інтересів держав мирними засобами. Такі принципи, як показала історія, виявились життєздатними протягом 150 років, на зміну яким прийшла Віденська конвенція про дипломатичні зносини 1961 року.

Отже, в 1815 році принципи міжнародного права вперше були кодифіковані та визнані загальнообов'язковими на універсальному на той час рівні. Гарантія «їх дотримання та виконання була досягнена завдяки спеціальному механізму - пентархії (п'ятидержав'я - вставка наша - C.3.) та розвитку такого правопорядку на основі християнства» [5, с. 252, визначення петархії див. с. 248]. Важливе значення для підтвердження та гарантування принципів даного періоду було підписання трьома європейськими монархами (Росії, Австрії та Пруссії) Акта Священного Союзу 14 вересня 1815 року. Передусім в основу механізму забезпечення покладені принципи християнської моралі. По-друге, створений союз став прототипом сучасних європейських міжнародних організацій, створених на основі єдності європейської християнської культури. По-третє, в основі союзу була ідея вирішення міжнародних зборів чи проблем на основі мирних зібрань (конференцій, конгресів). Положення Акта Священного союзу можна вважати імперативами міжнародного права даного періоду історії.

Особливу роль у кодифікаційному процесі відіграли створювані конференції та конгреси міжнародного права, які за результатами Аахенського конгресу були визнані необхідною формою вирішення міжнародно-правових питань, мирного співробітництва та підтримання балансу сил в Європі на основі періодичності та необхідності скликання не тільки за ініціативою п'ятірки великих держав, а й будь-якої європейської держави. Варто відзначити Паризький конгрес 1856 року, коли Паризький протокол був підписаний уперше нехристиянською Туреччиною, що стало підтвердженням універсального характеру принципів європейського правопорядку; конференція в Лондоні 1831 року сприяла розвиткові принципів інституту постійного нейтралітету (надання Бельгії статусу постійного нейтралітету); Паризький мирний конгрес 1856 року розвиває принципи морського права завдяки Паризькій мирній декларації (принцип вільного моря, принцип заборони каперства, принцип нейтрального прапору та ін.) [143, с. 259, 290]; Лондонська конференція 1867 року розвинула принцип постійного нейтралітету зобов'язаннями із роззброєння, заборони споруджувати нові укріплення, обмеження кількості військ; спроби кодифікації законів і звичаїв війни у Женевській конвенції про поранених і хворих 1864 року; розвитку принципів міжнародного гуманітарного права на 
Петербурзькій конференції 1868 року, зокрема, закріплення принципу гуманності як критерію військових потреб; подальшого розвитку принципів міжнародного гуманітарного права на Брюссельській конференції 1874 року, які пізніше будуть покладені в основу двох мирних конференцій у Гаазі 1899 і 1907 років та ін. [5, с. 180-283].

Перша світова війна підтвердила необхідність подальшого пошуку механізмів і засобів мирного співіснування та розвитку європейської та світової цивілізації загалом. Ліга Націй стала наступним кроком у прогресивному розвитку міжнародного права між двома світовими війнами, в основу якого перш за все покладаються принципи мирного співіснування та безпеки, гарантування політичної незалежності та територіальної цілісності для всіх держав світу. Міжнародно-договірні положення колективної безпеки в рамках архітектури Ліги Націй базувалися на трьох принципах: по-перше, війна або загроза війни являє собою проблему, що зачіпає всіх членів Ліги Націй (ст. 11); по-друге, члени зобов'язались дотримуватись територіальної цілісності і політичної незалежності один одного (ст. 10); по-третє, для забезпечення принципу мирного співіснування передбачалися колективні репресивні заходи, в тому числі виключення із членства [509]. Пропозиція про створення всесвітньої Ліги Націй належала президенту США Вудро Вільсону, який запропонував «створення нового правопорядку на основі самовизначення націй, закріпленого в мирних договорах - Версальському, СенЖерменському, Тріанонському і Нейському, якими завершилась Перша світова війна» [5, с. 334], саме тому така система міжнародного світопорядку отримала назву Версальської. Для забезпечення безпеки та мирного вирішення спорів Статут Ліги (ст. 8 [15]) націй закріплював принцип роззброєння. Особливістю механізму реалізації даного принципу було те, що зобов'язання виконати негайно роззброєння не передбачалося, а лише частково поширювалося на країни, які зазнали поразки в Першій світовій війні (такі зобов'язання закріплювались у вищезгаданих мирних договорах). Механізм суцільного роззброєння був розроблений і в Женевському протоколі про мирне вирішення спорів 1924 року (не вступив в силу) [18, с. 67], Конвенції про контроль над міжнародною торгівлею озброєнням і засобами війни (не вступила у силу) і в рамках проекту Конвенції про роззброєння під егідою Ліги Націй (не була прийнята), однак так і не задіяний у практичне коло.

Значним недоліком Версальської системи була відсутність прямої заборони війни, а лише мінімізація ймовірності війни шляхом колективної гарантії. Проте важливим досягненням Версальського миру стало формування принципу заборони агресії, зокрема в Паризькому договорі про відмову від війни як засобу національної політики 1928 року, що відомий як Пакт Бріана-Келлога [18, с. 83]. Даний акт вступив у силу в 1929 році, в 1938 році його учасниками стали 63 держави, а для гарантій його забезпечення укладалися договори про ненапад.

Поява системи мандатних територій та управління ними дало поштовх для доктринальних розробок питання прав та обов'язків держав і суверенітету, що не можна не вважати прогресивним розвитком принципів суверенної рівності держав. На універсальному рівні важливу роль для розробки теорії даного принципу відіграла Міжамериканська конвенція про права і обов'язки держав 1933 року, досвід якої пізніше було запозичено під час розроблення Комісією ООН Декларації прав і обов’язків держав 1949 року.

У рамках Версальської системи розвивалися принципи міжнародного гуманітарного права. Так, 17 червня 1925 року була підписана Женевська конвенція, яка вперше на універсальному рівні проголошує принцип заборони застосування на війні удушливих, отруйних та інших подібних газів $[18$, с. 67]. Однак найменшого розвитку набув принцип захисту прав людини, такий термін права людини навіть не був використаний у тексті статуту Ліги Націй. Особливістю принципу захисту прав людини даного періоду стало більш посилене гарантування та захист прав людини відповідно до мандатних угод (сучасний аналог опіки $\mathrm{OOH})$. К. Колісніченко вважає парадоксом, що «ті права, які творці Статуту не змогли закріпити в універсальному міжнародно-правовому документі для так званих «цивілізованих народів», якими, без сумніву, вважали себе члени Ліги, < . .> знайшли міжнародно-правове підтвердження для населення «відсталих територій»»» [8, с. 392]. Так, Ст. 23 Статуту Ліги Націй закріплювала, що члени організації докладають зусилля до «забезпечення і збереження справедливих і гуманних умов праці $<\ldots>>$ справедливий режим для туземного населення на територіях, підданих їх управлінню» [18, с. 47], ст. 6 Британського мандату на Палестину і Трансіорданію: «забезпечувати права і положення інших частин населення без шкоди» $[18$, с. 48], заборона рабства та звільнення всіх рабів (ст. 4 Мандата Великобританії і Франції на Камерун $[18$, с. 50]) та ін. Особливої уваги в рамках Версальської системи набув захист прав дитини. У 1924 році Асамблея Ліги прийняла Женевську декларацію прав дитини, ознаменувавши сходження принципу захисту прав дитини на універсальний міжнародний рівень.

У межах міжнародного економічного права отримує визнання принцип найбільшого сприяння в рамках нового підходу в міжнародному регулюванні, за яким перевага надається модельним договорам (на противагу універсальним), які можуть використовуватися за взірець під час укладання двосторонніх договорів.

У 1931 році на засіданні Європейської комісії Ліги Радянським Союзом у Проекті протоколу про економічний ненапад було запропоновано принцип мирного співіснування держав із протилежними соціально-політичними та економічними системами, однак він так і не був втілений у життя.

Отже, Статут Ліги Націй завдячує закріпленню основних засад повоєнного періоду - основних принципів, що втілювали загальнолюдські цінності в міжнародному праві: відкритості дипломатії, територіальної цілісності держав, невтручання у внутрішні справи, роззброєння, колективної безпеки, мирного вирішення міжнародних спорів.

Одним із факторів, що розрушили міжнародний правопорядок Ліги Націй та стали передумовою початку Другої світової війни, вважають Пакт Молотова-Ріббентропа.

Четвертим, завершальним етапом у становленні універсального міжнародного права є створення та діяльність Організації Об'єднаних Націй $(\mathrm{OOH})$. На думку I. Лукашука, на даному етапі «на зміну балансу сил має прийти баланс інтересів < ..> співвідношення національних і спільних інтересів» [10]. Важливим моментом для даного дослідження $є$ те, що саме принципи міжнародного права стали тим системоутворюючим базисом формування загального міжнародного права. Воно отримало основні характерні риси та ідеї, закладені в основних принципах міжнародного права та загальних принципах права на основі принципу універсальності. I. Лукашук стверджує: «цілі та принципи є системоутворювальними факторами та перетворили міжнародне право в єдину структуровану систему» [9, с. 182]. Однак зауважимо, що єдності в доктрині щодо універсального та загального міжнародного права немає. Одні вчені (М. Ушаков $[16$, с. 49-53], А. Мовчан [13, с. 33, 35-36]) ототожнюють універсальне та загальне міжнародне право, інші (В. Буткевич [1, с. 852-853], О. Мережко [379]) його розрізняють. Ми дотримуємося другої думки і вважаємо, що універсальне міжнародне право діє щодо всіх суб'єктів міжнародного права, які існують сьогодні чи можуть виникнути в майбутньому, тоді як загальне міжнародне право є частиною універсального, яке являє собою системоутворюючі, базисні норми, що встановлюють єдність і взаємозв'язок 
усієї системи міжнародного права, передусім - це загальні принципи міжнародного права. I. Зубар називає загальне міжнародне право «невід'ємною імперативною частиною універсального міжнародного права» [7, с. 125] загальнообов'язкового характеру. Не вдаючись до дискуciï, проаналізуємо основні документи, що стали основою для становлення універсальної системи $\mathrm{OOH}$.

Передумовами руху з формування післявоєнного (після Другої світової війни) універсального правопорядку називають Атлантичну хартію 14 серпня 1941 року [19, с. 550] (США та Великобританія), яка містила такі принципи, як: заборона захоплення чужих територій, право народів на самовизначення, принцип суверенних прав, рівність у торгівлі. Погодження цих принципів знайшло закріплення в Декларації уряду СРСР [19, с. 548], яка проголошувала принцип поваги суверенних прав народів, територіальну недоторканність i незалежність. Таке взаємовизнання сприяло створенню антигітлерівської коаліції та стало кроком до формування майбутньої міжнародної організації ООН. Термін «об’єднані нації» запропоновано Ф. Рузвельтом у Вашингтонській «Декларації Об'єднаних Націй» 1 січня 1942 року [19, с. 549-550]. «Декларація чотирьох держав з питань всезагальної безпеки» 1943 року (п. 4) проголошує «необхідність <..> створення всезагальної Міжнародної організації для підтримання міжнародного миру і безпеки, заснованої на принципі суверенної рівності всіх миролюбних держав, членами якої можуть бути всі такі держави - великі й малі» [19, с. 566].

Статут ООН був прийнятий на Сан-Франциській конференції 26 червня 1945 року, який вступив у силу 24 жовтня 1945 року та діє дотепер, а цей день оголошено Днем Об'єднаних Націй. Ст. 1, 2 Статуту [21] проголосили такі основні принципи універсального міжнародного права: суверенної рівності (п. 1 ст. 2), добросовісного виконання зобов'язань (п. 2. ст. 2), мирного вирішення міжнародних спорів (п. 3 ст. 2), утримання від загрози силою або іїі застосування (п. 4 ст. 2), співробітництва (п. 5. ст. 2 та п. 3 ст. 1), невтручання у внутрішні справи (п. 7 ст. 2), рівноправності та самовизначення народів (п. 2 ст. 1). Ці сім принципів уточнено та підтверджено в Декларації про принципи міжнародного права, що стосуються дружніх відносин і співробітництва між державами згідно зі Статутом Об'єднаних Націй 24 жовтня 1970 року [4].

Цікавими щодо аналізу ст. ст. 1-2 Статуту ООН є два моменти. По-перше, п. 6 ст. 2 (ст. 2 присвячена принципам Статуту $\mathrm{OOH}$ ) закріплює, на нашу думку, принцип універсальності, або, як його формулює А. Дмітрієв, «принцип забезпечення дій відповідно до цих принципів» [5, с. 252 ; визначення петархії див. с. 474]: «Організація забезпечує, щоб усі держави, які не є іiі Членами, діяли згідно з цими Принципами, оскільки це може виявитись необхідним для підтримання миру та безпеки» [21]. Даний принцип не закріплений у Декларації про принципи міжнародного права, що стосуються дружніх відносин і співробітництва між державами згідно зі Статутом Об'єднаних Націй 24 жовтня 1970 року, однак, на нашу думку, втілений у згаданій декларації, про що може свідчити термінологія щодо суб'єктів: жодна, кожна, всі, будь-яка < .. > держава, що вказує на універсальність застосування принципів. По-друге, цікавою виявляється ситуація із принципом поваги прав людини. Статут ООН закріплює: «заохочення i розвиток поваги до прав людини і основних свобод для всіх незалежно від раси, статті, мови, релігії» п. 3 ст. 1 цілі [20]. Декларація 1970 року також не фіксує чітко принцип поваги прав людини, однак підтверджує його в нормах принципу рівноправності та самовизначення народів (п. b): «... заперечення основних прав протирічить Статуту ООН» [4]. Остаточне закріплення принцип поваги прав людини отримав у Декларації про принципи взаємовідносин між державами 1975 року. Заключний акт Наради з безпеки та співробітництва в Європі (Хельсінки, 1 серпня
1975 року), основою якої стала дана Декларація, має особливе значення також для підтвердження універсальності та загального характеру принципів Статуту ООН. Декларація не тільки підтверджує принципи Статуту, а й розвиває принципи декларації 1970 року, закріплюються принцип поваги прав людини і основних свобод, включаючи свободу думки, совісті, релігії та переконань, принцип непорушності кордонів та територіальної цілісності. Акт 3 високою мірою деталізації відтворив та конкретизував основні принципи міжнародного права, закріплені в Статуті ООН. Оновлена система основоположних принципів міжнародного права, як іiі назвав О. Задорожній, ««десять заповідей міжнародного прав», ключових для цієї (міжнародної - вставка наша - C.3) системи, без яких саме їі існування неможливе» [6, с. 67]. У даному дослідженні ми називаємо ці принципи основними принципами міжнародного права. Ці принципи отримали універсальне визнання, що підтверджується, зокрема, нормами статутів міжнародних регіональних організацій та їх ключовими міжнародно-правовими документами.

Важлива для забезпечення та гарантії принципів Статуту $\mathrm{OOH}$ ст. 6, яка передбачає, винятково як крайній захід, за рекомендацією Ради Безпеки, виключення будь-якого члена організації за систематичне порушення принципів Статуту. Історія ООН не знає таких випадків, однак, як аргументує О. Задорожній: «визнання міжнародною спільнотою загрози основним міжнародно-правовим принципам пов'язується саме 3 агресивною війною Росії проти України: приклади такого визнання протягом 2014-2015 pp. - зміст актів універсальних і регіональних міжнародних організацій, насамперед ООН, Ради Європи, ОБСЄ, а також Європейського Союзу, держав та груп держав, заяв світових лідерів, що стосуються конфлікту та ситуації в європейському регіоні та світі в цілому» $[8$, с. 558-559]. У своїх наукових дослідженнях автор аналізує кожен зі згаданих вище документів і доводить загальне визнання у світі порушень основних принципів міжнародного права Росією у відносинах з Україною.

Наступний розвиток принципів міжнародного права відбувається під загальним процесом нормативного розширення міжнародного права, збільшення кількості міжнародних організацій регіонального та універсального характеру (іх правотворча та правозастосовна практика), появи більшої кількості міжнародних установ та їхньої практики застосування принципів міжнародного права, зростання ролі норм soft law i, як наслідок, глобалізації та фрагментації міжнародного права. Особлива роль у даних процесах належить універсальним міжнародним організаціям щодо формування та закріплення принципів jus cogens та зобов'язань erga omnes, що ними закріплюються.

Аналіз установчих документів регіональних організацій (наприклад, СНД, НБСС, НАТО, СС, АС, ЛАД, ШОС) дозволяє зробити висновок про підтвердження і відданість цілей їхньої діяльності основним принципам міжнародного права, закріплених у Статуті ООН.

Фундаментальність і актуальність принципів Статуту ООН неодноразово підтверджувалися в різних міжнародно-правових документах, зокрема у преамбулі Віденської конвенції про право міжнародних договорів 1969 р. [3]; у Манільській декларації про мирне вирішення міжнародних спорів 1982 р. [11]; Віденській декларації та Програмі дій 1993 р. [2]; Декларації тисячоліття Організації Об'єднаних націй 2000 р. [5]. Варто погодитись із висновком, що «Статут ООН як установчий акт універсальної міжнародної організації закріпив основні принципи та цілі міжнародних відносин, на основі яких було збудовано систему міжнародно-правових норм, що у своїй сукупності склали універсальний міжнародний правопорядок XX століття, та на основі яких продовжує будуватись універсальний правопорядок XXI століття та його регіональні міжнародно-правові підсистеми» [7, с. 94]. 


\section{ЛITEPATУPA}

1. Буткевич В.Г. Міжнародне право XXI століття: пошук шляхів до універсальності. Антологія української юридичної думки : в 10 т. Київ : ВД «Юридична книга», 2005. С. 831-856.

2. Віденська декларація та Програма дій 1993 р. Офріційний веб-портал Верховної Ради України. URL: http://zakon2.rada.gov.ua/ laws/show/995_504 (дата звернення: 10.01.2020).

3. Віденська конвенція про право міжнародних договорів 1986 р. Офріційний веб-портал Верховної Ради України. URL: http://zakon2.rada.gov.ua/laws/show/995_118 (дата звернення: 03.02.2020).

4. Декларація про принципи міжнародного права, що стосуються дружніх відносин та співробітництва між державами відповідно до Статуту ООН від 24.10.1970 p. URL: http://zakon3.rada.gov.ua/laws/show/995_569 (дата звернення: 05.06.2018) ; Декларація тисячоліття Організації Об'єднаних націй 2000 p. URL: http://zakon5.rada.gov.ua/laws/show/995_621 (дата звернення: 04.01.2020).

5. Дмитриев А.И. История международного права : монография / под рёд. А.И. Дмитриева, У.Э. Батлера. Одесса : Фенікс, 2013. 574 c.

6. Задорожній О.В. Порушення агресивною війною Російської Федерації проти України основних принципів міжнародного права : монографія. Київ : К.І.С., 2015. 712 с.

7. Зубар І.В. Розвиток універсального міжнародного права та його регіональних підсистем на сучасному етапі : дис. ... канд. юрид. наук : 12.00 .11 ; Київський національний університет імені Тараса Шевченка. Київ, 2016. 225 с.

8. Колисниченко Е.С. Международно-правовые механизмы правопорядка Лиги Наций. История международного права : монография / под ред. А.И. Дмитриева, У.Э. Батлера. Одесса : Фенікс, 2013. С. 343-395.

9. Лукашук И.И. Глобализация, государство, право и XXI век. Москва : Спарк, 2000. 279 с.

10. Лукашук И.И. Международное право. Общая часть : учебник для студентов юридических факультетов и вузов. Изд. 3-е, перераб. и доп. Москва : Волтерс Клувер, 2005. 432 с.

11. Манільська декларація про мирне вирішення міжнародних спорів 1982 р. Офііційний веб-портал Верховної Paди України. URL: http://zakon5.rada.gov.ua/laws/show/995_568 (дата звернення: 21.03.2020).

12. Мережко О. Поняття та сутність сучасного міжнародного права. Юридичний журнал «ЮСтIHIAH». 2008. Вип. 7. URL: http://www.justinian.com.ua/article.php?id=2992 (дата звернення: 10.09.2020).

13. Мовчан А.П. Международный правопорядок. Москва, 1996. 102 с.

14. Нгуен Куок Динь, Дайе П., Пелле А. Международное публичное право : в 2-х т. Київ : Сфера, 2000. Т. 1: Кн. 1.: Формирование международного права. Кн. 2.: Международное сообщество. 440 с.

15. Статут Ліги Націй. Повний текст українською. URL: https://yurist-online.org/publ/istoricheskie_dokumenty_istorichni_dokumenti/ statut_ligi_nacij_ustav_ligi_nacij/2-1-0-1227 (дата звернення: 02.05.2020).

16. Ушаков Н.А. Международное право : учебник. Москва : Юристь, 2000. 169 с.

17. Хрестоматия по истории международных отношений / сост. Д.В. Кузнецов. В 5-ти книгах. Благовещенск, 2013. Кн. 3.: Новое время. $1007 \mathrm{c.}$

18. Хрестоматия по истории международных отношений / сост. Д.В. Кузнецов. В 5-ти книгах. Благовещенск, 2013. Кн.: 4.: Новейшее время. 2214 с.

19. Эйхельман О. Хрестоматия русского международного права : в 2 ч. Киев : В.И. Завадзкого, 1889. Ч. 2.582 с.

20. Лукашук И.И. Глобализация, государство, право и XXI век. Москва : Спарк, 2000. 279 с. 


\title{
UKRANIAN EFFORTS TO ELIMINATE DISCRIMINATION AGAINST WOMEN
}

\section{ЗУСИЛЛЯ УКРАЇНИ ЩОДО УСУНЕННЯ ДИСКРИМІНАЦІЇ ЖІНОК}

\author{
Kachynska M.O., Candidate of Law, Associate Professor, \\ Associate Professor at the Department of Police Activity and Public Administration \\ Kharkiv National University of Internal Affairs
}

The article considers the issue of Ukrainian efforts to eliminate discrimination against women. The author points out that equality, equal opportunities for self-realization for everyone without exception in society is the key to building a true democratic society, in which the main goal is justice, humanity and respect for the rights and freedoms of everyone.

The article states that, unfortunately, discrimination against women is present in some form in almost every country in the world. This violation of women's rights occurs in a woman's family, public life (for example, at work, in the exercise of her civil rights, namely in voting, choosing a profession, etc.). The causes and conditions that contribute to discrimination against women's rights may vary from country to country, but they all boil down to certain traditional approaches to the role of women in society.

The author analyzes international treaties in the field of preventing and combating discrimination against women's rights. The definition of "discrimination of women's rights" is given. Attention is drawn to the provisions of the UN Convention on the Elimination of All Forms of Discrimination against Women and the Optional Protocol to this Convention.

The author analyzes in detail the powers of the Committee on the Elimination of Discrimination against Women, namely: consideration of reports of discrimination against women's rights; making recommendations on certain provisions of the Convention on the Elimination of All Forms of Discrimination against Women; and provides comments on reports of the countries party to this agreement. Attention is drawn to the existence of conditions under which the Committee may not accept reports of discrimination against women.

The author analyzed some provisions of the Concluding Observations to the Eighth Periodic Report of Ukraine on Ukraine's Implementation of the UN Convention on the Elimination of All Forms of Discrimination against Women.

Key words: discrimination against women's rights, international conventions, Committee on the Elimination of Discrimination against Women, report on discrimination against women's rights, report on the implementation of the Convention, recommendations of the Committee on the Elimination of Discrimination against Women.

У статті розглянуто питання: Україна проти дискримінації щодо жінок. Автор вказує, що рівноправність, однакова можливість самореалізації для кожної без виключень особи в суспільстві $€$ запорукою побудови справжнього демократичного суспільства, в якому головною метою є справедливість, людяність та повага до прав і свобод кожного.

У статті вказано, що, на жаль, практично в кожній державі світу присутня в тій чи іншій мірі дискримінація жінок. Означене порушення прав жінок трапляється в родині, громадському житті жінки (наприклад, на роботі, в реалізації її громадянських прав, а саме під час голосування, в обранні професії тощо). Причини та умови, що сприяють дискримінації прав жінок, можуть відрізнятись від країни до країни, однак усі вони зводяться до певних традиційних підходів щодо ролі жінки в суспільстві.

Автор аналізує міжнародні договори у сфері запобігання та протидії дискримінації прав жінок. Наведено дефініцію поняття «дискримінація прав жінок». Звернуто увагу на положення Конвенції ООН про ліквідацію всіх форм дискримінації щодо жінок та Факультативного протоколу до цієї конвенції.

Автор детально аналізує повноваження Комітету з ліквідації дискримінації щодо жінок, а саме: розгляд повідомлень про дискримінацію прав жінок; надання рекомендації щодо окремих положень Конвенції про ліквідацію всіх форм дискримінації стосовно жінок; надання зауважень щодо доповідей країн-учасниць цього договору. Звернуто увагу на існування умов, за яких повідомлення про дискримінацію жінок Комітет може не прийняти

Автор проаналізував окремі положення Заключних зауважень до восьмої періодичної доповіді України щодо виконання Україною Конвенції ООН про ліквідацію всіх форм дискримінації щодо жінок.

Ключові слова: дискримінація прав жінок, міжнародні конвенції, Комітет з ліквідації дискримінації щодо жінок, повідомлення про дискримінацію прав жінок, звіт про виконання положень Конвенції, рекомендацій Комітету з ліквідації дискримінації щодо жінок.

Equality, equal opportunity for self-realization for every person without exception in society is the key to building a true democratic society, in which the main goal is justice, humanity and respect for the rights and freedoms of everyone. Unfortunately, in almost every country in the world there is to some extent discrimination against women. This violation of women's rights occurs in a woman's family, public life (for example, at work, in the exercise of her civil rights, namely in voting, choosing a profession, etc.). The causes and conditions that contribute to discrimination against women's rights may vary from country to country, but they all boil down to certain traditional approaches to the role of women in society. This role of a woman, as a rule, is recessive in relation to the role of a man [1, p. 42].

At the international level, discrimination against women's rights has been the subject of debate for the past 50 years. A number of international treaties have been adopted that provide for the principles of preventing and combating discrimination against women. Ukraine is an active participant in this process and, therefore, seeks to fulfill its commitments in this area.

The essence of the concept of discrimination against women is provided in the UN Convention on the Elimination of All Forms of Discrimination against Women of Decem- ber 18,1979 . The latter states that it is any distinction, exception or restriction on the grounds of sex aimed at weakening or nullifying the recognition, use or exercise of women, regardless of their marital status, on the basis of equality between men and women, human rights and fundamental freedoms in political life, economic, social, cultural, social or any other field [2]. The Convention provides the basis for realizing equality between women and men through ensuring women's equal access to, and equal opportunities in, political and public life - including the right to vote and to stand for election - as well as education, health and employment [3].

Ukraine, as a party to the above-mentioned Convention, takes the following measures to prevent and combat discrimination against the rights of women and girls in the social and political life of the state:

- provides representatives of both sexes with the right to elect and be elected during all elections and referendums to all publicly elected bodies;

- provides equal opportunities for women and men to participate in the formation and implementation of the policy of the Cabinet of Ministers of Ukraine, to hold public office, including to perform all public functions at all levels of government; 
- provides women and men with the right to participate in the activities of non-governmental organizations dealing with issues of civil and political life of the country [2].

In order to report on the work done every 4 years to implement the provisions of the UN Convention on the Elimination of All Forms of Discrimination against Women, Ukraine will submit a report. The structure of the latter provides for the submission of the General Comments on the previous report, as well as the report on the implementation of each article documents [2].

Pursuant to the provisions of Section 5 of the Convention on the Elimination of All Forms of Discrimination against Women, a Committee on the Elimination of Discrimination against Women (CEDAW) is envisaged [4]. The Committee's mandate and the administration of the treaty are defined in Articles 17 to 30 of the Convention. The Committee is composed of 23 experts nominated by their Governments and elected by State parties as individuals "of high moral standing and competence in the field covered by the Convention" [5].

It is important to remember that on November 6, 1999, the Optional Protocol to this Conference (hereinafter the Optional Protocol) was adopted to improve the proper implementation of the provisions of the UN Convention on the Elimination of All Forms of Discrimination against Women. This Protocol clarifies the competence and activities of the Committee on the Elimination of Discrimination against Women (hereinafter referred to as the Committee). In order to improve the situation regarding the elimination of discrimination against women, to counteract any forms of violation of women's rights, the powers of the said committee include consideration of the report on discrimination against women's rights. Such notifications may be made by or on behalf of persons or groups of persons falling under the jurisdiction of a State Party who claim to be victims of a violation by a State Party of any of the rights provided for in the UN Convention on the Elimination of All Forms of Discrimination against women. However, a person (or group of persons) who has exhausted all available domestic remedies has the right to apply to the Committee, except in cases where the use of such remedies is unduly delayed or unlikely to produce a positive result [6].

The Committee has the right not to accept a notification under Article 4 of the Optional Protocol if one of the following conditions is met:

- the same issue has already been considered by the designated body or has been or is being considered in accordance with another procedure of international review or settlement;

- the issue is incompatible with the provisions of the Convention on the Elimination of All Forms of Discrimination against Women;

- the issue is insufficiently substantiated or is clearly unfounded;

- the issue is an abuse of the right to send such a notice;

- the facts which are the subject of the communication took place before the entry into force of this Protocol for the State Party concerned, unless those facts took place after that date [6].

The importance of the Committee's recommendations on the elimination of discrimination against women should also be borne in mind. These recommendations are made on any issues concerning women, and to which the parties to the treaty should pay more attention. For example, at its 1989 session, the Committee discussed the high frequency of violence against women and, as a result, demanded reports from all members. In 1992, the Committee adopted general recommendation № 19, which requires the following to be included in the reports of participating countries:

- statistics on the level of violence against women;

- information on the provision of services to victims;

- on legislative and other measures taken to protect women from violence in everyday life, in particular, on sexual harassment at work, domestic violence, sexual violence [7].
It should be noted that the Committee on the Elimination of Discrimination against Women also makes recommendations on certain provisions of the Convention on the Elimination of All Forms of Discrimination against Women. For example, there is only one article in the Convention that draws the attention of States to the multiple discrimination against rural women.

In the General Recommendations, the said Committee expands the list of factors that may exacerbate discrimination. These factors included circumstances affecting women's lives, namely: ethnicity / race, indigenous or minority status, skin colour, socio-economic status and/or caste, language, religion or belief, political opinion, national origin, marital and/or maternal status, age, urban/rural residence, health status, disability, property, sexual orientation, gender identity and intersex characteristics, illiteracy, trafficking in women, armed conflict, asylum, refugee status, internal displacement, statelessness, migration, households, widowhood, living with HIV / AIDS, imprisonment, prostitution, geographical remoteness and stigmatization of women fighting for their rights, including human rights defenders [8].

The Committee on the Elimination of Discrimination against Women also comments on the reports of participating countries. For example, in its Concluding Observations to the Eighth Periodic Report of Ukraine on Ukraine's Implementation of the UN Convention on the Elimination of All Forms of Discrimination against Women (hereinafter: the Committee on the Elimination of Discrimination against Women), it expressed concern about the following.

In Ukraine, patriarchal views and discriminatory stereotypes about the role and responsibilities of women and men in the family are still deeply ingrained in political discourse, the media and society. These views perpetuate the subordinate position of women in the family and society. This is reflected in the choice of women in education and professional activities, expressed by their limited participation in political and social life, their unequal participation in the labour market and unequal position in family relations. It is noted that these discriminatory stereotypes are also key causes of violence against women. Concerns were expressed that to date, Ukraine has not taken permanent measures to change or eliminate discriminatory stereotypes and negative traditional approaches [9].

Analyzing the issue of education in Ukraine, the Committee on the Elimination of Discrimination against Women noted the high level of literacy among women, as well as the development of the Education Strategy 2020. However, there are negative and patriarchal stereotypes about women and girls in the school curriculum. In addition, special attention was paid to conducting "labour lessons" in schools. During such lessons, girls are taught to cook and sew, while boys are taught carpentry and joinery skills. It upholds traditional gender roles in society. Unequal access for women to higher education institutions of the Ministry of Internal Affairs and the Ministry of Defense was stated. The Committee is also concerned about the high drop-out rates among girls belonging to the Roma community. In the light of these comments, the Committee on the Elimination of Discrimination against Women recommends that Ukraine:

- intensify efforts to review school curricula and textbooks to eliminate negative stereotypes about women and girls;

- ensure the use of the same curriculum for boys and girls, in particular, it is proposed to introduce the same "work lessons" for boys and girls, including through the adoption of temporary special measures;

- provide women with equal access to the universities of the Ministry of Internal Affairs and the Ministry of Defense, including through the adoption of temporary special measures;

- Encourage Roma girls' access to education and ensure their continuing education at all levels of education by raising awareness of the importance of education as a human right and as a basis for women's empowerment, and strengthening 
the implementation of re-entry policies that allow Roma girls who left school to return to school [11].

In pursuance of the above recommendations and a number of other provisions set out in the Remarks, the Cabinet of Ministers of Ukraine by Order № 634-r of September 5, 2018 approved the National Action Plan to implement the recommendations set out in the concluding observations of the UN Committee on the Elimination of Discrimination against Women. Ukraine on the implementation of the Convention on the Elimination of All Forms of Discrimination against Women for the period up to 2021 [11].
Thus, the concept of equality between women and men can be achieved through an objective study of the causes and conditions that contribute to it, and the taking of all measures that promote it. It is this concept that has formed the basis of the Convention on the Elimination of All Forms of Discrimination against Women. The comments of the UN Committee on the Elimination of Discrimination against Women help Ukraine, as well as other countries, to pay more attention to improving the implementation of the commitments made in the field of preventing and combating discrimination against women.

\section{REFERENCES}

1. Kachynska M. Gender Equality in Ukraine: National and International Perspectives. 2018. № 3. P. 40-47.

2. Конвенція Організації Об’єднаних Націй про ліквідацію всіх форм дискримінації щодо жінок (укр/рос) : Міжнародний документ від 18.12.1979 p. URL: https://zakon.rada.gov.ua/laws/show/995_207

3. Convention on the Elimination of All Form of Discrimination against Woman. Official Web-page UN WOMEN. URL: https://www.un.org/ womenwatch/daw/cedaw/cedaw.htm

4. Конвенция о ликвидации всех форм дискриминации в отношении женщин. Офріційний Веб-сайт UN WOMEN. URL: https://www.un.org/womenwatch/daw/cedaw/text/0360795R.pdf

5. Convention on the Elimination of All Forms of Discrimination against Women. New York, 18 December 1979. Official Web-page United Nations Human Rights Officer of the Hight Commissioner. URL: https://www.ohchr.org/EN/Professionallnterest/Pages/CEDAW.aspx

6. Факультативний протокол до Конвенції про ліквідацію усіх форм дискримінації стосовно жінок : міжнародний договір від 06 жовтня 1999 року. URL: https://zakon.rada.gov.ua/laws/show/995_794

7. General recommendations: official web-page of United Nations Human Rights Offiser of the High Commissioner. URL: https://www.ohchr.org/EN/HRBodies/CEDAW/Pages/Recommendations.aspx

8. Загальні рекомендації ухвалені Комітетом ОOH з ліквідації дискримінації щодо жінок № 1-37. URL: https://land.gov.ua/wp-content/ uploads/2019/01/\%D0\%97\%D0\%B0\%D0\%B3\%D0\%B0\%D0\%BB\%D1\%8C\%D0\%BD\%D1\%96-\%D1\%80\%D0\%B5\%D0\%BA\%D0\%BE\%D0 \%BC\%D0\%B5\%D0\%BD\%D0\%B4\%D0\%B0\%D1\%86\%D1\%96\%D1\%97-\%D0\%9A\%D0\%BE\%D0\%BC\%D1\%96\%D1\%82\%D0\%B5\%D1\%82 \%D1\%83-\%D0\%9E\%D0\%9E\%D0\%9D.pdf

9. Заключні зауваження до восьмої періодичної доповіді України. Комітет з ліквідації дискримінації щодо жінок. 03.03.2017р. URL: http://mip.gov.ua/files/documents/Zakluchni_zauvazhennya_Komitetu_OON.pdf

10. Заключні зауваження до восьмої періодичної доповіді України. Комітет з ліквідації дискримінації щодо жінок. 03.03.2017р. URL: http://mip.gov.ua/files/documents/Zakluchni zauvazhennya_Komitetu_OON.pdf

11. Про затвердження Національного плану дій 3 виконання рекомендацій, викладених у заключних зауваженнях Комітету $\mathrm{OOH}$ з ліквідації дискримінації щодо жінок до восьмої періодичної доповіді України про виконання Конвенції про ліквідацію всіх форм дискримінації щодо жінок на період до 2021 року : Розпорядження Кабінету Міністрів України № 634-р від 05.09.2018 p. URL: https://zakon.rada.gov.ua/laws/show/634-2018-\%D1\%80 


\title{
РОЗДІЛ 12 \\ ФІЛОСОФІЯ ПРАВА
}

УДК 340.112; 349; 34.02

DOI https://doi.org/10.32782/2524-0374/2020-4/92

\section{АНТРОПОЛОГІЯ СОЦІАЛЬНОЇ БЕЗПЕКИ ЗА ЛОКАЛЬНОЮ ОЗНАКОЮ «МАСОВОЇ ОСІЛОСТІ» У ПРИЗМІ ПАРАДИГМИ УРБАНІСТИКИ}

\author{
ANTHROPOLOGY OF SOCIAL SECURITY BY THE LOCAL SIGN \\ OF "MASS ASSETS" IN THE PRISM OF THE PARADIGM OF URBANISM
}

\author{
Мельник Я.Я., д.ю.н., адвокат, \\ старший науковий співробітник (керівник наукової теми НДР № 20БФ042-01) \\ Інститут права \\ Киїського національного університету імені Тараса Шевченка
}

\begin{abstract}
У статті розглядається проблема забезпечення соціальної безпеки за локальною ознакою масової осілості у призмі урбаністики. Аналізуються проблеми буття людини в екологічно нестійкому середовищі, доводиться вплив природно-нестійких фракторів на соціальну стабільність та соціальний добробут людини в урбанізованому середовищі. Доводиться, що внаслідок прояву екологічних ризиків у навколишньому середовищі, що викликані техногенними та/або урбаністичними фракторами, виникають ризики соціальні. Також доводиться, що на цій підставі відбувається зміна ціннісного сенсу соціального буття людини, відбувається й потреба зміни/корекції екологічних прав та обов'язків людини в позитивістському сенсі, а також в аксіологічному сенсі до природно-правових прав та обов'язків. Відповідно, у статті піднімається питання взаємозалежності наведених факторів із впливом на соціальні права, а також із потребою зміни концепції правового регулювання соціальних прав у державі, забезпечення соціальних гарантій. На цій основі виникає потреба для вироблення нової моделі забезпечення соціальної безпеки. Під час дослідження автором розкривається питання антропологічних чинників зміни соціальних прав, аналізуються доктринальні віхи соціального законодавства. Проте констатується, що хоча екологічні та соціальні права, як і право на безпеку, є взаємозалежними, соціальне законодавство не виділяє в особливий критерій потреби інклюзивності їх забезпечення за масовою осілістю, що притаманна урбаністичним фракторам. Унаслідок цього людина, суспільство у великих містах або містах зі шкідливим виробництвом позбавлені рівності в соціальних правах, адже забезпечити соціальні стандарти соціальних прав, соціальну безпеку в такому разі на локальному рівні неможливо. Як наслідок, проявляється диссункція в забезпеченні права на здоров'я, в рівні та якості життя людини, адже превалюють складні життєві обставини, ускладнені масовою осілістю та урбанізмом. Автор доходить висновку, що внаслідок об'єктивних та суб'єктивних чинників такі обставини мають антропологічну природу, яка дає можливість розвивати принципово нову парадигму, ідеологію в забезпеченні соціальних та екологічних прав, розвитку права.

Ключові слова: соціальна безпека, екологічні права, соціальні права, антропологія права, урбанізм.
\end{abstract}

The article considers the problems of social security on the local basis of mass settlement in the prism of urban planning. The problems of human existence in an ecologically unstable environment are analyzed, the influence of naturally unstable factors on social stability and social well-being of a person in an urban environment is proved. It is proved that as a result of the manifestation of environmental risks in the environment caused by man-made and/or urban factors, social risks arise. It is also proved that on this basis, there is a change in the value of human social existence, there is a need to change/correct environmental rights and responsibilities in the positivist sense, as well as in the axiological sense of natural rights and responsibilities. Accordingly, the article raises the question of the interdependence of these factors with the impact on social rights, as well as the need to change the concept of legal regulation of social rights in the state, providing social guarantees. On this basis, there is a need to develop a new model of social security. During the research the author reveals the issues of anthropological factors of change of social rights, analyzes the doctrinal milestones of social legislation. However, it is stated that although environmental rights and social rights, as well as the right to security are interdependent, social legislation does not allocate in a special criterion the need for inclusiveness of their provision for mass settlement, which is inherent in urban factors. As a result, people, society in large cities or cities with harmful production, deprivation of equality in social rights, because the ability to ensure social standards of social rights, social security in this case at the local level is not possible. As a result, there is a dysfunction in ensuring the right to health, there is a dysfunction in the level and quality of human life, because the complex circumstances of life are complicated by mass settlement and urbanism. The author concludes that due to objective and subjective factors, such circumstances have an anthropological nature, which allows to develop a fundamentally new paradigm, ideology in ensuring social and environmental rights, the development of law.

Key words: social security, environmental rights, social rights, anthropology of law, urbanism.

Постановка проблеми. Слабкість дії права проявляється здебільшого там, де втрачається стійкий зв'язок з об’єктом та змістом правовідносин. Найкраще це спостерігається в масовості. Зазвичай це пов'язано з відсутністю адекватного та оперативного правового механізму, його особливою властивістю забезпечити охорону та захист конкретного блага кожної людини окремо посеред інших, навіть коли правопорядок воліє бути забезпеченим соціально згуртованим та стійким суспільством. Масовість $\epsilon$ індикатором втрати індивідуальності, а фактично - соціальної інклюзії. Це одна з основних проблем сучасного гіперболізованого світу, парадигми розвитку права в глобалізаційних процесах.

В умовах масового скупчення людей, зосереджених у великих містах, проблеми забезпечення екологічних та соціальних прав носять яскраво виражений взаємозалежний і проблемний характер, оскільки людина та екологія (навколишній світ) є залежними в силу перебування людини в природному середовищі. Обидва фактори $€$ об'єктивно взаємно не виключними. Водночас користування/споживацтво людиною природніми ресурсами, перебування іiі в зоні екологічно несприятливих для проживання сфер природи, навколишнього середовища, як і прямої залежності людини від благ природи, вказують на те, що за таких обставин людина проходить і процес соціалізації, і суспільного життя, яке повинно бути повноцінним та пропорційним. Будь-які правовідносини, що покликані врегульовувати соціальні потреби між людьми, окремою групою людей чи то суспільством i, власне, заради них, мають носити також характер оптимального 
балансу. Суспільство ж повинно вибудувати такі відносини між собою, аби їх діяльність чи то бездіяльність не були основним фактором погіршення стану довкілля, екології, адже такі впливатимуть на соціальні сфери буття людини, формувати цінність людини до тих чи інших природніх, соціальних, а вслід за цим і соціальних благ.

Сьогодні сприятливий клімат перебування людини в умовах соціальної безпеки різко змінився в бік прояву соціальних ризиків, критичних станів локації перебування людини за місцем проживання. Міста, як окремі локальні майданчики, в силу тривалого розвитку індустрії, технологій сучасних мегаполісів стали як благом для людини, так і одночасно зоною ризику. Ми можемо спостерігати не тільки зміну сприятливого соціального клімату на несприятливий, але й відстежити ряд додаткових факторів, які дають підстави вести дискусію про зміну фактично соціальних цінностей людини в урбаністичному суспільстві. У зв'язку з цим перед нами розгорається інша правова реальність, яка 3 юридично-доктринальної точки зору вказує на слабкі спроможності правового механізму виявляти, оцінювати та долати соціальні ризики, враховувати виклики та забезпечити соціальні стандарти для життя та здоров'я людини. Це і становить актуальність даного дослідження.

Аналіз останніх публікацій та досліджень. Аналізуючи проблематику забезпечення соціальних благ за ознакою осілості, висуваються на перший план саме ті проблеми благ людини, які пов'язані з урбанізацією суспільства. I причинами появи ризикових соціальних факторів $є$ творіння людини, без яких вона не може обійтись в урбанізованому суспільстві - це певні сфери економіки, соціальні інфраструктури міст, загально доступні блага урбанізованого суспільства, що й становить об'єкт даного дослідження

Це означає, що методологічно доцільним буде вдатися саме до їх аналізу, а також простежити позиції основних дослідників у цій сфері, як і проаналізувати стан законодавства, яке зосереджене на регулюванні соціальної стабільності урбанізованих сфер суспільства. Водночас варто ураховувати й те, що соціальна безпека як правовий феномен $є$ комплексною юридичною конструкцією, яка поліморфно відображає різні сфери соціального та трудового забезпечення правового регулювання, дістаючи поширення у сферах екологічного чи то земельного сектору, має тісний зв'язок з економічною сферою життєдіяльності людини на окремій території її проживання.

Чимало дослідників нині переймались проблемами i правовідносинами безпеки. Так, проблемами безпеки у праві або ж правової безпеки займались М.I. Панов та В.П. Тихий («Модель общества и национальная безопасность», 2010), Л.В. Радовецька («Суб'єкти забезпечення державної безпеки», автореферат, 2015), Г.В. Новицький («Теоретико-правові основи забезпечення національної безпеки України», монографія, 2008), В.А. Ліпкан («Основи права національної безпеки», 2009), М.М. Пендюра («Національна безпека України в контексті сучасних європейських геополітичних трансформацій», автореферат, 2006); деякі дослідження були проведені автором цього дослідження, але в контексті теорії юридичного процесу з галузевим напрямом цивільного процесу («Безпека цивільного процесу: теоретико-правовий концепт», монографія, 2018).

У межах галузевих правових дисциплін проблеми безпеки в екологічному праві були предметом досліджень А.С. Євстігнєєва («Проблеми правового забезпечення екологічної безпеки у сфері соціального природокористування в Україні», автореферат, 2019).

Окремо слід вказати на праці у сфері соціального права, а саме на комплексне дослідження авторського колективу кафедри трудового права та права соціального забезпечення юридичного факультету Київського національного університету імені Тараса Шевченка та фахівців Центру проблем імплементації європейського соціального права. Зокрема, вченими напрацьована колективна монографія, яка охопила проблеми правового регулювання соціальної безпеки щодо правовідносин, які витікають із трудового права та права соціального забезпечення («Розвиток трудового потенціалу як складова соціальної безпеки України», 2018). Під егідою Центру та кафедри факультету цього ЗВО було проведено ряд тематичних конференцій, які присвячені проблемам соціальної безпеки $(2017,2018$, 2019 рр.). У межах досліджень соціальної безпеки слід відмітити і праці В.А. Багрія («Социальная безопасность на рынке труда в Украине», 2017), О.П. Коваля («Соціальна безпека: сутність та вимір», 2016), С.В. Вишновецької («Основні фактори, що складають загрозу безпеці працівників під час трудової діяльності», 2017), Д.В. Зеркалова («Социальная безопасность», 2012); в адміністративному праві - О.М. Ільницького («Організаційно-правове забезпечення громадської безпеки в Україні», 2015); інші праці.

В економічних науках проблеми безпеки були поєднані в дослідженнях із соціальними факторами такими вченими, як-от: М.В. Вінічук («Соціальна компонента економічної безпеки України», 2016), Н.В. Забута («Зайнятість населення як фактор забезпечення економічної безпеки держави»); у сфері державного управління - Г.П. Ситник («Концептуальні засади забезпечення національної безпеки України», 2010); тощо.

Водночас класична правова доктрина України не акцентує особливої уваги на питаннях «безпеки права» чи то «правової безпеки» в парадигмі ії розвитку (виходячи із серії «Правова доктрина України», Томи 3, 4 - Я.М. (див. $[5 ; 6]))$, не виділяє ії в системі права як модель та фундаментальну знакову юридичну конструкцію у XXI столітті.

Ознайомлення із зазначеними працями вказує на те, що натепер, очевидно, напрацьованих досліджень, які б характеризували повноцінну сферу соціальної безпеки 3 позиції визначення проблемних ознак осілості, на жаль, немає. Нема й аналізу антропологічної парадигми за результатами доктринальної оцінки потреб змін права за таких умов. Отже, прогнозувати в нестійкому урбанізованому суспільстві забезпечення правопорядку та належного правового регулювання не видається можливим. У зв'язку із цим виникає ряд ключових завдань, які слід вирішити завдяки чітко поставленій меті в ході цього дослідження.

Мета дослідження полягає в тому, щоб осмислити феномен соціальної безпеки за локальною ознакою осілості в контексті урбанізованого суспільства. Це надасть можливість з'ясувати антропологічні особливості зміни соціального права, визначити більш грунтовно проблеми погребового суспільства, критерії забезпечення соціальної безпеки в урбанізованому суспільстві.

Виклад основного матеріалу. Ведучи дискусію про урбаністичний складник впливу на феномен права, варто звернутись до семантичного навантаження змісту поняття «урбанізація».

Термін «урбанізація» походить від латинського (urbus) $[17$, c. 1381]. A «urbanus» за латиною означає міський, той, що відноситься до внутрішніх справ, внутрішньополітичний, приміський, заміський, культурний, освічений, вишуканий, ерудований, нахабний [2, с. 1047]. У радянській енциклопедії «урбанізація» подається як певний процес, що скерований на підвищення ролі міст у розвитку суспільства, причому передумовами урбанізації виступають ріст у містах індустрії, розвиток їх культурних та політичних функцій, поглиблення територіального розподілу праці [17, с. 1381]

Ведучи мову про «урбаністику», доцільно звернути увагу на певний правовий феномен «глокалізації права», який, на нашу думку, характеризує урбанізацію з іншої точки зору. Зокрема, у філософії права цей термін позначається як суперечливий, об'єктивно-суб' єктивний про- 
цес поєднання глобальних $\mathrm{i}$ регіональних правових процесів, явищ, зв'язків, пристосування національних правових інтересів, норм до глобальних, зі збереженням національних рис і особливостей. Глокалізація як процес призводить до появи глокалізованих правових систем. Водночас глокалізація права є світовою тенденцією суспільного розвитку, зміст якої полягає в певній єдності глобальних і локальних економічних, правових, політичних, культурних, моральних, релігійних факторів. Зрештою, глокалізація права має місце лише за умови наявності національного, етнічного, аутентичного компонента в колі універсальних правових цінностей, норм, принципів, стандартів, інститутів, що діють у певній країні $[1$, c. 156,157$]$. Таким чином, не важко віднайти у процесах глокалізації права пов'язаність з урбаністикою в частині впливу, приєднання, пристосування цих процесів із процесами соціально-правовими та еколого-правовими. Адже соціальні та екологічні процеси урбанізації нерозривно пов'язані з процесами творення права, процесами, що відбуваються на ринку праці, в процесах масової організації суспільства, які, відповідно, потребують спеціального (локального) режиму управління екологією, правового регулювання. 3 іншого боку, глокалізація - це процес, пронизаний об'єктивно-суб'єктивними процесами правової культури соціального добробуту, правовою культурою забезпечення та дотримання екологічного добробуту.

Критерії формування права за ознакою осілості відомі історії права. Зокрема, це міста з особливим порядком, статусом, які називались містами-державами (в Стародавньому Римі міста ${ }^{1}$, Магдебурзькому праві міста²). Та навіть сьогодні, враховуючи юридичні конструкції офшорних зон, міст-держав (Ватикан, Гонконг тощо), ми можемо спостерігати окремий режим правового регулювання відносин у них - за ознакою не осілості, а мінімізації податків. Щоправда, соціальний фактор та еколого-економічний можуть теж гостро виражати проблему безпеки соціального змісту.

Термін «осілість» у доктрині міжнародного приватного права $є$ устояним, пов'язується 3 «доктриною осілості» та означає визначення національності юридичної особи, тобто так званий закон місцезнаходження адміністративного центру юридичної особи [11, с. 82]. Цей критерій є необхідним для з'ясування місцезнаходження особи, для визначення ії правосуб'єктності [20, с. 109]. За таких умов і утворюються обставини для запровадження певних правових режимів [11, с. 83]. I.О. Соколова вважає, що юридичний підхід до розуміння змісту правового режиму відображає специфіку регуляторного впливу на соціальні відносини, які підлягають правовій регламентації, передусім встановлюючи за допомогою різних юридичних засобів особливий порядок законодавчого регулювання [18, с. 128]. Натомість варто задатись питанням: чи $\epsilon$ прийнятним поєднувати «соціальну осілість» із правовим режимом та безпекою?

Проведені попередні дослідження в процесуальному праві свідчать, що режим безпеки з точки зору цивільного процесу є нічим іншим, як сукупністю належних станів юридичного процесу, які досягаються в ході забезпечення судом особливих умов під час здійснення $<\ldots>$ судочинства, шляхом сприяння, обмежень та заборон задля найбільш ефективного досягнення мети <..> процесу,

\footnotetext{
Для довідки: враховуючи історичні аспекти виникнення «Міжнародного приватного права», то воно виникло в епоху середньовіччя; в Західній Європі, його виникнення пов'язують із торгівлею, яку вели в XIII-XV ст. міста Болонья, Модена, Венеція, Генуя. Цікавим $є$ те, що кожне із цих міст мало власну кодифікацію місцевих звичаїв (статутів). Див.: [11, с. 21].

2 Для довідки: Магдебургське право виникло внаслідок інтенсивного зростання міст, воно характеризувалось тим, що його зміст визначався записами правових звичаїв, поширених у місті, а також збірників постанов шеффенів, що здійснювали впровадження на основі місцевого права, та актів органів місцевого самоврядування, тощо. Див.: [19, с. 542-543].
}

виконання його завдань та реалізації учасниками <..> своїх прав, свобод та інтересів, забезпечення належної дії <..> процесуальної форми [13, с. 611]. За такого підходу стає очевидним, що навіть у процесуальному сенсі режим безпеки $\epsilon$ певним процесом, що сфокусований на забезпечення певного стану і може включати в себе певні інструменти - заборони, обмеження тощо для досягнення необхідної мети в конкретних суспільних відносинах.

Термін «безпека» у відповідності до етимології цього слова означає «відсутність небезпеки», тобто будь-яких загроз для особи, суспільства чи держави. Безпека, - відмічають у теорії права, - це стан захищеності життєво важливих інтересів держави від внутрішніх та зовнішніх загроз [15, с. 473$]$

За своєю юридичною природою безпека $€$ правом. Право на безпеку та екологічні права («право на безпечне для життя і здоров'я людини довкілля», «право на об'єктивну екологічну інформацію») належать до колективних прав, віднесені до четвертого покоління в доктрині теорії права [4, с. 57]. У теорії права з цього приводу зазначається, що «як і у випадку із соціально-економічними правами, основне питання, на яке нині немає переконливої відповіді, - це питання про те, чи є «колективні» права (як і деякі екологічні) правами юридичними, чи вони становлять собою ідеали й цілі міжнародного співтовариства і виступають лише як «юридичні рефлекси об'єктивного права», тобто не є правами людини в класичному їх розумінні [4, с. 57]. На додаток до цього відмічається, що історія прав людини - це історія «олюднення» людей, тобто дедалі глибшого самоусвідомлення ними своєї людської сутності й людської гідності [4, с. 57]. Звісно, таке «олюднення» виступає в антропологічному сенсі екологічних прав зі зміною акцентів стосовно сутності права на безпеку. Одночасно сам по собі феномен «безпеки» без «прив' язки» до соціально-екологічних прав чи будьяких інших («негативних», «позитивних») не має сенсу, адже право на безпеку вибудовано як «супутник» до певних майнових та немайнових прав, тобто є квазіправом, «прив'язкою» до них [14].

Для забезпечення соиіальної безпеки слід виділити такі умови: (a) стабільні, захищенні правом кордони, що надійно охороняються; (б) стійкі, передбачувані, засновані на праві та звичаях відносини між основними суб' єктами держави; (в) стійкий, «нормальний» політичний процес, iз наявною високою ступеню легітимності та передбачуваності поведінки політичних суб'єктів, урегульованості політичних конфліктів у межах підтримуваних законом та звичаєм процедур; (2) відсутність або достатня слабкість незаконно існуючих сил, здатних непередбачувано втручатись у політичний процес [15, с. 473].

За умови відсутності стійких політичних, соціальних та правових процесів сталість правопорядку, очевидно, нівелюється. Адже стабільність права залежить насамперед від гнучкого характеру правового регулювання в силу того, аби право було спроможнім забезпечити правопорядок під час перманентних соціоекологічних змін та викликів. Саме такі реалії сьогодення, що дістають своє пояснення в антропологічних змінах осоціалізованого суспільства, осоціалізованої влади, соціальної політики держави, соціальних благах на противагу зникаючим клановим та централізованим порядкам соціального контролю, власне - зміни функції соціального менеджменту із закритих до транспорентних засад контролю.

Звісно, як соціокультурний феномен право постійно залежить від тих чинників, які продукує людина в ході еволюції. Адже такі чинники мають мінливий характер тому, що в них відсутня стабільність для забезпечення незмінного правового регулювання, в тому числі стосовно первинної ланки правової системи - норми права як правового феномену, внаслідок чого діяльність людини продукує постійне збалансування, корегування правової реальності 
до соціальної. У такому ключі прогресу людини змінюється й аксіологія людських благ. А еволюція прав та еволюція соціокультурних феноменів залишаються таким чином взаємозалежні, проте вони є не одними й тими ж феноменами. 3 одного боку, це пояснюється змінами відношення людини до сенсів тих чи інших благ внаслідок рефлексорної їх появи, втрати, чи навпаки, - удосконалення та модифікації в гносеологічному (пізнавальному) сенсі. 3 іншого - еволюційні зміни викликані причинами появи та впливу зовнішніх факторів на самі ж блага, що не залежить від правосвідомості та людської діяльності, оскільки такі мають суто локальне природне походження, зовнішній характер та природу.

Але й ті чи інші еволюціонують, змінюються, впливаючи на буття людини, а отже, об'єктивно впливають на здатності права виконувати свою забезпечувальну та регулятивну функції. Так, в юридичному сенсі такі фактори $\epsilon$ проявами юридичних фактів - діями (залежними від волі та поведінки людини та нею контрольованими) та подіями (незалежними від волі людини, або розпочатими нею діями, але без можливості контролювати наслідки від тих чи інших подій), сукупністю юридичних фактів тощо.

Водночас і ті, й інші феномени «прив'язані» до певної місцевості, в якій здійснює свій побут людина, тобто вони характеризуються за локальною ознакою, адже виникають там, де проживає людина, де вона соціалізується, власне, на території якої вона проводить більшу частину свого життя (робота, побут тощо). Саме локальний характер «прив'язки» людини до територіальної приналежності в суспільстві ставить під питання ряд проблем соціальної реальності, що пов'язані із соціальним ії благополуччям, соціальною рівністю, соціальним добробутом людини.

Цей критерій і перманентно спричиняє потребу змін права в силу урбанізованого суспільства за ознаками осілості, перевірки правового режиму на предмет здатності до забезпечення правопорядку заради збереження соціального добробуту. Адже в умовах техногенних викликів (ризиків, загроз), в умовах світової пандемії, викликаної COVID-19, чи то в умовах урбаністичного характеру «соціалізація» за масовою осілістю перетворюється на предмет не благ людини, а, скоріш, кризових факторів, що здатні вплинути на економіку, здоров'я людини та, загалом, нівелювати стан правопорядку, створивши некеровану ситуацію.

Для правопорядку критерії «осілості» вказують на ризики та прояв загроз для безперешкодної дії права, забезпечення належного та повноцінного механізму правового регулювання в урбаністичному суспільстві. Відповідно, перед правниками постають досить необнадійливі підстави для іншого сприйняття правової реальності, що вимагає насамперед не стільки перегляду основних доктринальних основ, принципів забезпечення соціальної безпеки в правовому регулюванні, скільки відшукання локальних ознак соціальних проблем, спричинених масовою осілістю, як критеріїв для вироблення ключових інструментів для узгодження долання проблем урбаністичного дисгармонізаційного впливу на стан соціально безпеки. Зрештою, дослідження феномену масової осілості в урбаністичному суспільстві дає змогу більш ширше зрозуміти причини зміни «людини до права», переглянути

\footnotetext{
Для довідки: яскравим сумним прикладом подібної «відв'язки» на теренах України є Чорнобильська катастрофа, зумовлена пожежею 3 i 4 енергоблоків атомно електростанції 26.04.1986 р. Наслідки для суспільства, природнього середовища, здоров’я людини на значній частині Європи та України, соціального права та бюджету України були катастрофічними. Так, був прийнятий Закон України «Про статус і соціальний захист громадян, які постраждали внаслідок Чорнобильсьюо гатастрофи який спрямований на захист громадян, що пострахдали внасідок 'Чрнобильської катастрофи, та розв'язання пов'язаних 3 нею проблем медичного і соціального характеру, що виникли внаслідок радіоактивного забруднення території; громадян, які постраждали внаслідок інших ядерних аварій та випробувань, військових навчань із застосуванням ядерної зброї, та розв'язання пов'язаних із цим проблем медичного і соціального характеру. Див.: [8]
}

сенс «права в людині», що $є$, безумовно, антропологічним проявом пізнання буття.

У загальній соціології відмічається, що суспільство занурено в природно-географічне середовище, яке водночас $є$ середовищем існування соціуму та спричиняє різноманітний вплив на соціум. На думку соціологів, про це свідчить зв'язок рівня життя, звичаїв, побуту корінних народів Півночі із суворими умовами їх проживання; зв'язок побуту, життєвого укладу, типу господарської діяльності народів Кавказу з географічними особливостями місцевості і т.д. Тому, на думку представників соціології, вплив географічного середовища є очевидним, але водночас відмічається, що суспільство повинно бути адаптованим до природно-кліматичних умов свого існування [16, с. 85]. У цьому ключі соціологи доходять думки стосовно того, що проблеми адаптування вже настільки багатогранні, що вони фактично виходять за рамки «географічне середовище - суспільство». Проте таке поєднання дає більш точніше побачити іншу фундаментальну проблему - зв'язок соціальної реальності та позасоціальних (природно-кліматичних, біологічних, технологічних) умов іії усування, соціальної реальності та фізико-біологічних, речово-предметних факторів [16, с. 85-86].

У зв'язку із цим предметним є те, що соціологи виділяють різні аспекти впливу природно-географічного середовища на життєдіяльність людини та форми організації соціального життя, а саме: (a) механізм примусового впливу, або ж (умовно) обмежувально-дозвільний механізм досить жорсткого (механічного) обумовлення географічного середовища (а це - мінімум певних умов для розвитку людини; межі, в яких може розвиватися соціальне життя; вплив природніх катаклізмів, стихійних лих - подекуди в силу цього гинуть цілі цивілізації з їхнім населенням, порядками, устоями, а деколи люди змушені залишати своє житло, здійснюючи пошук для переселення по всій Землі. Такого роду колективна «відв'язка» від території, конкретного природно-географічного середовища не призводить до загибелі соціуму, який продовжує існувати, але в іншому географічному середовищі $)^{3}$; (б) механізм формування впливу природно-географічного середовища, а також механізм адаптації до зовнішніх природно-географічних умов шляхом прямого прилаштування; та (в) механізм впливу природно-географічної, екологічної, кліматичної зони, сприятливої для соціального життя. Йдеться про те, що географічне середовище, навпаки, сприяє або ж перешкоджає ефективному соціальному розвитку $[16$, с. $86-88]$

Не було б зайвим додати позицію вченої Н.В. Колотової, яка, переймаючись дослідженням захисту соціально-екологічних прав у сучасному світі, враховуючи тенденції недотримання трудових норм та стандартів соціального захисту, що спричинені необхідністю економічного виживання підприємств у глобальному світовому господарстві та потреби мінімізувати збитки підприємств, внаслідок чого відбувається послаблення державного регулювання стосовно безконтрольних звільнень, обмеження функцій профспілок, встановлення в нормативних актах загальної дії виключень із принципу недопустимості погіршення становища робітників у трудовому договорі порівняно із законодавством, констатує таке (враховуючи думку I.C. Королева, «Мировая экономика: глобальные тенденции за 100 лет. М, 2003, С. 72». - Я.М.). Зокрема, вчена віднаходить тісний зв'язок у тому, що дійсно, саме за таких умов збільшується гнучкість правового регулювання, розширяються можливості застосування «господарського розсуду». Проте дослідниця справедливо віднаходить, що хоча такі тенденції об'єктивно пов'язані з потребами постіндустріальної економіки, підвищенням рентабельності та конкурентоспроможності, все ж таки саме вони знижують ступінь соціальної захищеності працівників, 
посилюють соціальні нерівності, збільшують безробіття та «випадання» окремих осіб або цілих соціальних груп із нового інформаційного суспільства [7, с. 82-83]. Таким чином, капітали переміщуються в ті країни, де контроль за підприємницькою діяльністю послаблений, a податкове навантаження мінімальне, кваліфікована робоча сила дешевша, i, як наслідок (що цікаво - Я.М.), екологічні стандарти нижчі [7, с. 83].

Звертаючись до підручника із загальної соціологіï, слід звернути увагу на те, що особливості біології людини - передумови соціального ii життя. Зокрема, біологічні особливості з позиції загальної соціології проявляються у тому, що (a) біологічні особливості людини забезпечують можливе соціальне життя; (б) біологічні особливості конкретної людини впливають на іiї індивідуальність [16, с. 91$]$

Правова антропологія за своєю суттю пояснюється у найзагальнішому вигляді як певний процес осмислення взаємовідносин людини і права; вчення про спосіб і структуру буття людини як суб'єкта права, або ж вчення про право як спосіб людського буття [1, с. 59].

Досліджуючи антропологію I. Канта, В. Козловський доходить висновку в тому, що якщо емпіричні чинники людського життя є рецептивними, то свобода постає як вияв інтелігібельної спонтанності, яка на рівні моральних приписів, а також ідей розуму, демонструє зовсім іншу, не «емпіричну природу», тобто не таку природу, до якої ми звикли, як до нашого «органічного тіла». Тут учений додає, що саме в такому тілі розгортаються ті залежності, які зрештою зв'язують нас із зовнішніми обставинами нашого буття як певними казуальними залежностями, що, на думку Канта, зрештою позбавляє нас свободи [10, с. 426].

Отже, очевидно, що під час дослідження проблеми соціально-екологічного змісту виникає питання (a) прав людини на екологічну та соціальну безпеку; (б) прав людини на користування природніми ресурсами; (в) необхідність/обов'язок людини забезпечити свої покоління ресурсами, тобто до певної міри про межі прав та обов'язків, про межі соціально-необхідного використання природніх ресурсів, протистоянням природі. I чи $\epsilon$ в цьому дійсно сенс буття людини, коли право фактично обслуговує правовідносини між людьми в соціумі? Природа ж не потребує очевидної людської корекції, не потребує втручання та особливої турботи. Тому яке ж право ми воліємо дістати внаслідок індустріального розвитку, технологічного «прориву», як дійсно людина зобов'язана себе поводити в екосистемі? I чи дійсно є в неї такі можливості, власне, до певної міри - права? Як вони змінилися в ретроспективі? I чи екологічні фактори змінюють відношення людини до права? А саме: змінюється сенс буття людини, змінюється свобода їі, змінюється сенс ряду прав, якими людина користується, внаслідок появи екологічних ризиків, кліматичних змін тощо? Як змінилося відношення людини до екології, що спричинило зміни до свого буття в екосистемі? Внутрішні фактори людини? Чи все ж таки зовнішні, продиктовані станом екосистеми? Достеменно можемо стверджувати одне - вслід за змінами, об'єктивно екологічними, зумовленими станом навколишнього середовища, Матінки природи, людина бажає відчувати себе в безпеці. У межах урбаністичного буття людини, перебуваючи в соціумі, вона й бажає бути забезпечена соціально? Отже, зміни екологічні - це насамперед необхідна причина змін соціальних, власне, правових?

Очевидно, що в основі антропологічного підходу зміни соціальних прав в урбаністичному суспільстві можливо побачити наслідки процесу глобалізації. Зокрема, як відмічається в енциклопедичній довідці, глобалізація як багатогранний, різнорівневий, диференційований, незворотний, суперечливий процес розширення, посилення й прискорення світової інтеграції державно-правових, економіко-фінансових і суспільно-політичних інститу- тів, ідей, принципів, цінностей, зв'язків має наслідком становлення ускладненого глобалізаційного мегасуспільства, істотні зміни в конкретних соціумах, характеризується об'єктивно-суб'єктивним характером, позитивними й негативними наслідками для людини, суспільства, держави, світової спільноти. Водночас посилення протистояння й боротьби між різними державами за природні ресурси, засоби їх транспортування, посилення геополітичного чи геоекономічного тиску на національні держави, засад міжнародної безпеки спричинили небувалу поляризацію багатства й бідності, загострення етнічних конфліктів тощо. На цьому тлі зміни торкнулись особистих прав, головним 3 яких є право на життя. Як додаткові способи його реалізації позитивні й негативні зміни торкнулись в умовах глобалізації і права на соціальне забезпечення, на охорону здоров'я, на сприятливе навколишнє середовище [1, с. 604-605]. Також відмічається, що реалізація принципів глобального ринку провокує й виникнення проблеми трудової міграції, так званого «соціального демпінгу». Трудова міграція в умовах глобалізації набуває все більших масштабів та активізує проблему трудових прав і соціального захисту мігрантів. На вирішення цієї проблеми держави мають розробити загальні соціальні стандарти, прийняти загальні соціальні зобов'язання, гарантувати кожному, незалежно від громадянства, володіння соціальним правами і їх ефективно здійснювати [1, с. 605-606].

Отже, в глобалізаційних умовах ми можемо спостерігати такі особливості: (a) невирішення трудо-соціальних проблем, що призводять до соціальної прірви та загострення конфлікту в суспільстві; (б) міграційні процеси сприяють посиленню масовості за ознакою осілості, що посилює характер кризи трудо-соціальних проблем; (в) зміна правових цінностей людини, суспільства до природи, екології.

До певної міри слід фрагментарно звернути увагу й на еволюцію соціального законодавства, з'ясувавши, яким чином змінювались потреби соціального забезпечення людини в державі, й чи вони були пов'язані з екологічними кризовими факторами.

Так, Л.Ю. Малюга, досліджуючи проблему адаптації соціального законодавства до законодавства Європейського Союзу, у висновках стосовно історичних аспектів формування соціального законодавства на теренах України доволі показово визначає особливості його формування. До прикладу, на думку дослідниці, в епоху Київської Русі (X - XII) соціальне законодавство приймалось у формі договорів, уставів і законів, мало форму благодійництва і здійснювалось не державою, а князем за посередництвом участі держави. Причому, як зазначає дослідниця, соціальним забезпеченням слід, на їі думку, вважати різноманітні форми допомоги нужденним - від звільнення з полону до допомоги жебракам та сиротам. А коли Україна перебувала у складі Великого Князівства Литовського, Російської імперії, Речі Посполитої, Австро-Угорщини та інших держав (XVI - початок XX століття), соціальне законодавство врегульовувалось усіма законодавчими актами цих держав. Коли Україна перебувала у складі Союзу Радянських Соціалістичних Республік (1917-1991рр.) соціальне законодавство характеризувалось централізацією ресурсів і повноважень, а також жорсткою регламентацією соціальної сфери. Аналізуючи радянську добу, дослідниця також доходить висновку, що держава звела до мінімуму особисту відповідальність людини за самозабезпечення та економічний захист [12, с. 348-349].

А.С. Євстігнєєв, розглядаючи питання екологічних ризиків у системі забезпечення екологічної безпеки спеціального природокористування, доводить, що екологічні ризики як імовірність порушення екологічної безпеки у сфері, яка ним досліджується, завжди мають місце через стан забруднення природніх ресурсів, які викорис- 
товуються, або через особливості діяльності з такого використання (технології, обладнання тощо). Також учений доходить висновку, що забезпечення екологічної безпеки в таких відносинах має на меті не допустити прояву таких екологічних ризиків або оперативно припинити цей прояв [3, с. 15].

Поєднуючи соціальні фактори та потреби забезпечити соціальне благополуччя суспільства 3 умовами екологічно нестійкими, варто звернути увагу на деякі особливості вирішення соціальних проблем у Законі України «Про соціальні послуги» від 17 січня 2019 року (далі Закон № 2671-VIII), який визначає основні організаційні та правові засади надання соціальних послуг, спрямованих на профілактику складних життєвих обставин, подолання або мінімізацію їх негативних наслідків, особам/ сім'ям, які перебувають у складних життєвих обставинах [9]. Натомість питання «складних життєвих обставин» із прив'язкою до причини екологічних у цьому новоприйнятому законі не розкривається. Відповідно, в цій частин соціальне законодавство не еволюціонувало, має прогалини, але, на нашу думку, наявність прогалин не виключає соціальної основи для тлумачення норм цього закону 3 іншими, законодавчо закріпленими нормами екологічного змісту, тобто тими, які закріплюють екологічні права. Адже під час тлумачення преамбули Закону № 2671-VIII та змісту деяких дефініцій і норм цього закону постає за очевидне те, що соціальні послуги за своєю природою та аксіологічним сенсом можуть надаватись у зв'язку 3 різними причинами виникнення складних життєвих обставин, у тому числі спричинених стихійними лихами, пандеміями, ендемічними недугами тощо, у тому числі тих, які об'єднані критерієм певного скупченням людей, масовості, їх осілості. Адже абзацом 2 п. 15 ст. 1 Закону № 2671-VIII визначено ряд чинників, які можуть зумовити складні життєві обставини, а саме: а) похилий вік; б) часткова або повна втрата рухової активності, пам'яті; в) невиліковні хвороби, хвороби, що потребують тривалого лікування; <...> г) інвалідність; д) бездомність; е) безробіття; є) малозабезпеченість особи; ж) поведінкові розлади у дітей через розлучення батьків; <..> и) втрата соціальних зв'язків, у тому числі під час перебування в місцях позбавлення волі; < ..> [9]. Тут, звісно, слід констатувати, що недоліком таких законодавчо встановлених критеріїв якраз $є$ прямі вказівки закону на «стихійні лиха», «екологічні лиха» тощо, однак, беручи до уваги не законодавчу норму як факт, а фактичний склад таких фактів (їх сукупність), та застосовуючи аналогію закону/права, стає ймовірним тлумачити «складні життєві обставини» як ті, що пов'язані із соціальними ризиками, завдяки фактам екологічних, які стались внаслідок певних подій.

Ще одним аргументом, на додаток до взаємозв'язку соціальних та екологічних проблем, є позиція стосовно того, що якраз Закон № 2671-VIII закріплює положення про те, що «вразливі групи населення - це насамперед особи/сім'і, які мають найвищий ризик потрапляння у складні життєві обставини через вплив несприятливих зовнішніх та/або внутрішніх чинників...». Тому, звісно, на тлі екологічних ризиків, які проявились у тій чи іншій місцевості, ми теж можемо вести мову про формування складних життєвих обставин через вплив несприятливих зовнішніх факторів на людину, певну соціальну групу чи то частину суспільства, які взаємопов'язані критерієм «масової осілості».

Переймаючись дослідженнями соціальної безпеки у призмі впливу та зміни екологічних та соціальних факторів на її стан, важливо мати на увазі й те, що екологічні права переважно визначаються як: права, що скеровані на задоволення потреб людини за рахунок ресурсів природи; права, направлені на охорону здоров'я від несприятливого впливу оточуючого середовища; права, які слугують засобами забезпечення та захисту прав на сприятливе оточу- юче середовище та охорону здоров'я від несприятливого впливу навколишнього середовища [7, с. 177].

Підсумовуючи викладене, можливо констатувати, що соціальна безпека в умовах урбаністики за ознакою масової осілості з точки зору правової антропології дає можливість корегувати взаємовідносини «людини» до «права», до «природи», до «навколишнього середовища». Така корекція повинна бути націлена на відкриття додаткового «належного» та «необхідного» для людини, відповідно, й додаткової зміни пріоритетів соціальної безпеки у правовому бутті людини в масовому урбанізованому суспільстві. Це означає більше розширення правової обізнаності та правосвідомості стосовно природніх обов'язків людини перед природою, навколишнім середовищем. Це означає і те, що, оскільки природне середовище буття людини змінилося за ознакою осілості, змінилися й необхідні чинники забезпечення права на безпечне довкілля, на здоровий спосіб життя, права на життя і здоров'я та інші немайнові права, що забезпечують як соціальне буття фізичної особи, так і особисті немайнові права, які забезпечують фізіологічне ii буття. У такому разі соціальне право за своєю функціональною покликаністю повинно забезпечувати здорове і безпечне існування людини в урбаністичному суспільстві. Однак наразі залишаються невирішеними такі ключові проблеми урбанізованого суспільства, як-от: забезпечення населення у великих містах чистою питною водою, чистим атмосферним повітрям (проблеми численних заторів, завантаженість великих міст транспортом, відсутність транспортних розв'язок), забезпечення соціальною інфраструктурою (доступ до дитячих садків, навчальних закладів, медичних установ), відсутність соціальної інклюзії стосовно осіб, які проживають у промислових зонах та інфраструктурах зі шкідливими викидами в атмосферне повітря, відсутність повноцінного контролю безпеки харчових продуктів; зрештою, відсутність належного трудового законодавства, яке б надавало можливість у період пандемій забезпечувати гарантії реалізації права на працю, права на відпочинок, права на гідні умови праці та винагороду. Усе це вказує, що у випадку непристосування людини до реалій урбанізованого суспільства настає епоха постмодерну права, власне, аби реконструювати непрацюючі правові механізми, переглянути модель соціально-екологічної безпеки.

Висновки. Отже, у висновках варто вказати на те, що «право» (у широкому розумінні), «урбанізм» і «безпека» нерозривно пов'язані, невіддільні, а також $є$ взаємодоповнюючими факторами забезпечення соціальної стабільності за ознакою масової осілості.

Унаслідок прояву екологічних ризиків у навколишньому середовищі, що викликані техногенними та/або урбаністичними факторами, виникають і ризики соціальні. Також на цій підставі відбувається зміна ціннісного сенсу соціального буття людини, відбувається й потреба зміни/корекції екологічних прав та обов'язків людини в позитивістському сенсі, а також в аксіологічному сенсі до природно-правових прав та обов'язків. Відповідно, слід констатувати й те, що за таких обставин відбувається потреба змінити концепцію правового регулювання соціальних прав у державі, потреба в забезпеченні якісно інших соціальних гарантій, що тягне за собою потребу вироблення нової моделі забезпечення соціальної безпеки. Проте, хоч екологічні та соціальні права, як і право на безпеку, є взаємозалежними, соціальне законодавство не виділяє в особливий критерій потреб інклюзивності їх забезпечення за масовою осілістю стосовно того населення, яке урбанізовано. А тому урбаністичні фактори не враховуються під час вироблення моделі соціальної безпеки. Унаслідок цього люди у великих містах або містах зі шкідливим виробництвом, забрудненим довкіллям, відсутністю належних та безпечних умов проживання 
позбавлені рівності в соціальних правах, в їх рівномірному розподілі. Тому можливості забезпечити соціальні стандарти соціальних прав у такому разі не реалізовані, адже не вироблені гнучкі стандарти, адаптовані до урбаністичного суспільства. Як наслідок, проявляється ніщо інше як дисбаланс у правовому регулюванні та дисфункція в забезпеченні права на здоров'я, проявляється дисфункція в рівні та якості життя людини, оскільки превалюють складні життєві обставини, обтяженні масовою осілістю (скупченістю) та урбанізмом за відсутності адаптованого законодавства. Інституцій, які б оперативно виявляли, усували та контролювали на локальному рівні соціальні та екологічні ризики, не вистачає. Це і є чи не головною загрозою в забезпеченні соціальної безпеки.

Прояв ознак «масової осілості» в урбаністичному суспільстві впливає насамперед на зміну понятійного апарату «соціальної безпеки», доповнюючи його особливими елементами. Це вказує й на те, що антропологічно зміст цього поняття з точки зору урбаністичного підходу трансформується за своїм сенсом, постає в міждисциплінарній призмі сприйняття моделі соціальної безпеки. Відповідно, це й надає можливість трансформувати сферу особливого предмету та об'єкту соціальної безпеки до прив'язки за критерієм «масової осілості». Це підтверджується про- явом та верифікацією факторів «соціальної масовості» та їх «осілості» за територіальною ознакою, спричинених рядом міждисциплінарних правових категорій і феноменів, як-от 3-поміж ризиків та загроз екологічного, економічного, медико-соціального та трудо-правового характеру. В аксіологічному сенсі все це й тягне за собою ніщо інше, як зміну сенсу в змісті правовідносин безпеки в державі, національної захищеності держави. Зрештою, це й вказує на потребу зміни чинного законодавства, яке локально повинно принципово по-іншому діяти в урбанізованому суспільстві, а саме завдяки доведенню регулювання правовідносин до особливого гнучкого режиму, здатного оперативно та ефективно регулювати правові відносини задля забезпечення соціальної безпеки в суспільстві у період регіональної нестабільності, викликаної екологічними проблемами.

Сам же антропологічний фактор виводить на перший план принципово іншу стратегію та соціальну політику забезпечення безпеки людини, суспільства, держави внаслідок зміни стану довкілля, його впливу на захищеність людини в урбанізмі. Зрештою, антропологічний метод дозволяє найбільш вдало відстежити сучасні орієнтири та прогнозувати зміни в соціальній безпеці, адже пояснює механізм впливу екологічних факторів на соціальні права.

1. Велика українська юридична енциклопедія : у 20 т. Харків : Право, 2016. Т. 2: Філософія права / редкол. : С.І. Максимов (голова) та ін. ; Нац. акад. прав. наук України ; Ін-т держави і права імені В.М. Корецького НАН України ; Нац. юрид. ун-т імені Ярослава Мудрого, 2017. 1128 c.

2. Дворецкий И.Х. Латинско-русский словарь. Около 50000 слов. Изд. 2-е, переработ. и доп. Москва, «Русский язык», 1976.1096 с.

3. Євстігнєє А.С. Проблеми правового забезпечення екологічної безпеки у сфері спеціального природокористування в Україні : автореф. дис. ... д-ра юрид. наук : 12.00 .06 ; НАН України, Ін-т держави і права ім. В.М. Корецького. Київ, 2019.32 с

4. Загальна теорія права : підручник / за заг. ред. М.І. Козюбри. Київ : Ваіте, 2015. 392 с.

5. Правова доктрина України : у 5 т. Харків : Право, 2013. Т. 4: Доктринальні проблеми екологічного, аграрного та господарського права / Ю.С. Шемшученко та ін. ; за заг. ред. Ю.С. Шемшученка. 848 с.

6. Правова доктрина України: у 5 т. Харків : Право, 2013. Т. 3: Доктрина приватного права України / Н.С. Кузнєцова та ін. ; за заг. ред. Н.С. Кузнєцової. 760 с.

7. Права человека и процессы глобализации современного мира / отв. ред. Е.А. Лукашева. Москва : Норма, 2007. 464 с.

8. Про статус і соціальний захист громадян, які постраждали внаслідок Чорнобильської катастрофи : Закон України від 28 лютого 1991 року № 796-XII / Верховна Рада України. URL: https://zakon.rada.gov.ua/laws/show/796-12\#Text

9. Про соціальні послуги : Закон України від 17 січня 2019 року № 2671-VIII / Верховна Pada України. URL: https://zakon.rada.gov.ua/ laws/show/2671-19\#n482

10. Козловський В. Кантова антропологія: джерела, констеляції, моделі : монографія. Київ : Вид. дім. «Києво-Могилянська академія», 2014. 595 c.

11. Міжнародне приватне право. Практикум / за ред. Р.А. Майданика та ін. Київ : Логос, 2010. 320 с.

12. Малюга Л.Ю. Теоретико-правові основи адаптації соціального законодавства України до законодавства Європейського Союзу : монографія / Л.Ю. Малюга. Херсон : Видавничий дім «Гельветика», 2019. 406 с.

13. Мельник Я.Я. Безпека цивільного процесу: теоретико-правовий концепт : монографія. Київ : Четверта хвиля, 2018.648 с.

14. Мельник Я.Я. Безпека цивільного процесу: теоретико-правове дослідження : автореф. дис. .... докт. юрид. наук : 12.00 .01 ; Інститут законодавства Верховної Ради України. Київ, 2019. 39 с.

15. Общая теория права и государства : учебник / под ред. В.В. Лазарева. 3-е изд., перераб. и доп. Москва : Юристь, 2000.520 с.

16. Общая социология : учеб. пособие / под общ. ред. проф. А.Г. Эфендиева. Москва : ИНФРА-М, 2008. 654 с.

17. Советский энциклопедический словарь / гл. ред. А.М. Прохоров. 2-е изд. Москва : Сов. энциклопедия, 1982.1600 с.

18. Соколова І.О. Правовий режим як категорія правової думки : монографія. Харків : Право, 2014. 152 с.

19. Юридична енциклопедія : в 6 т. / редкол. : Ю.С. Шемшученко (голова редкол.) та ін. Київ : «Укр. енцикл.», 2001. Т. 3: К-М. 792 с.

20. Феденяк Г.С. Феденяк Л.С. Міжнародне приватне право : підручник. 3-тє вид., доп. і перероб. Київ : Атіка, 2003. 544 с. 


\section{ПРОЦЕСУАЛЬНІ ПИТАННЯ ПРИЙНЯТТЯ МІСЬКИХ СТАТУТІВ: РЕЦЕПЦІЯ ЄВРОПЕЙСЬКОГО ДОСВІДУ}

\section{PROCEDURAL ISSUES OF THE APPROVAL OF MUNICIPAL STATUTES: THE RECEPTION OF THE EUROPEAN EXPERIENCE}

Ідесіс I.B., асистент кафедри міжнародного та європейського права,

Національний університет «Одеська юридична академія»

Виходячи з норм Закону «Про місцеве самоврядування в Україні, статут територіальної громади є факультативним, а не обов'язковим документом - у вищенаведеній цитаті вказано, що «представницький орган місцевого самоврядування може прийняти статут територіальної громади села, селища, міста». У зв'язку з чим виникає питання: чи має рацію законодавець, коли проголошує статут територіальної громади актом, прийняття якого $є$ не обов'язком, а правом представницького органу місцевого самоврядування?

Автор доводить, що аргументи на користь того, щоб зробити прийняття статуту територіальної громади обов'язковим, а не фракультативним, є більш переконливими, ніж аргументи проти цього. У зв'язку з цим, запропоновано ч. 1 ст. 19 Закону від 21 травня 1997 р. «Про місцеве самоврядування в Україні» викласти у такій редакції: «3 метою врахування історичних, національно-культурних, соціальноекономічних та інших особливостей здійснення місцевого самоврядування представницький орган місцевого самоврядування на основі Конституції України та в межах цього Закону приймає статут територіальної громади села, селища, міста».

Отже, у дослідженні запропоновано встановити обов'язковість прийняття свого статуту для кожної територіальної громади та покласти обов'язок прийняття статуту територіальної громади на відповідну місцеву раду як на представницький орган територіальної громади та скасувати державну реєстрацію для статутів територіальних громад. Така практика існує у більшості європейських країн.

Також ссормульовано, що на підставі європейського досвіду доцільно замість терміну «статут територіальної громади» використовувати термін «хартія територіальної громади» - здебільшого для уникнення аналогій, коли йдеться про статути територіальних громад та певних юридичних осіб приватного права. Перспективи подальших досліджень у цьому напрямку полягають у вирішенні питання щодо того, чи необхідно запровадити спеціальну процедуру прийняття статуту територіальної громади у місцевій раді, керуючись найкращими європейськими практиками.

Ключові слова: місто, місцеве самоврядування, міське самоврядування, законодавча регламентація місцевого самоврядування у містах, муніципальне управління, статут територіальної громади.

Based on the provisions of the Law 'On Local Self-Government in Ukraine', the charter of a territorial community is an optional rather than a mandatory document - the above quote states that «a representative body of local self-government may adopt the charter of a territorial community of village, town, city». This begs the question: is the legislator right when he declares the charter of a territorial community an act, the adoption of which is not an obligation but a right of a representative body of local self-government?

The author argues that the arguments in favor of making the adoption of the statute of a territorial community mandatory rather than optional are more convincing than the arguments against it. In this regard, Part 1 of Art. 19 of the Law of May 21, 1997 «On local self-government in Ukraine» to read as follows: «In order to take into account historical, national-cultural, socio-economic and other features of local self-government representative body of local self-government on the basis of the Constitution of Ukraine and within of this Law adopts the charter of the territorial community of the village, settlement, city».

Therefore, the study proposes to establish the obligation to adopt its own charter for each territorial community and to impose the obligation to adopt the charter of the territorial community on the relevant local council as a representative body of the territorial community and cancel state registration for territorial communities' charter. This practice exists in most European countries.

It is also stated that on the basis of European experience it is expedient to use the term «territorial community charter» instead of the term «territorial community statute» - mostly to avoid analogies when referring to the statutes of territorial communities and certain legal entities of private law. Prospects for further research in this area are to address the question of whether it is necessary to introduce a special procedure for the adoption of the territorial community's charter in the local council, guided by European best practices.

Key words: city, local self-government, city self-government, legislative regulation of local self-government in cities, municipal administration, charter of territorial community.

Постановка проблеми. Оголошена Президентом України концепція децентралізації публічної влади передбачає, у тому числі, збільшення повноважень органів місцевого самоврядування [1]. 3 метою оптимальної реалізації цих повноважень (а також тих, що вже належать до компетенції органів місцевого самоврядування) важливим вбачається залучення населення до співпраці 3 ними. На нашу думку, ця співпраця має грунтуватись на статуті територіальної громади.

Конституція України розглядає територіальну громаду як жителів села чи добровільного об'єднання у сільську громаду жителів кількох сіл, селища та міста [2].

Територіальна громада є основним суб'єктом місцевого самоврядування (відповідно до Закону «Про місцеве самоврядування в Україні»). У зв'язку з цим цілком вірно автори іменують статути територіальних громад «локальними конституціями» [3]. Наразі важливою практичною проблемою є оптимізація порядку прийняття та державної реєстрації статутів територіальних громад з тим, щоб статути з'явились у кожній територіальній громаді. Відповідно, науковою проблемою є формулювання пропозицій з вдосконалення порядку прийняття та державної реєстрації цих актів.

Аналіз досліджень. Проблеми статутів територіальних громад аналізувались такими вченими, як М. О. Баймуратов, О. В. Батанов, Н. В. Мішина, О. С. Орловський, О. Ф. Фрицький, ін. Однак, в їхніх працях увага питанням, проаналізованим у статті, або майже не приділялась, або приділялась відносно давно (наприкінці 1990-х - на початку 2000-х рр.). 
Метою статті $€$ формулювання пропозицій з вдосконалення порядку прийняття та державної реєстрації статутів територіальних громад.

Відповідно до ст. 19 Закону від 21 травня 1997 р. «Про місцеве самоврядування в Україні», «з метою врахування історичних, національно-культурних, соціально-економічних та інших особливостей здійснення місцевого самоврядування представницький орган місцевого самоврядування на основі Конституції України та в межах цього Закону може прийняти статут територіальної громади села, селища, міста» [4].

Виходячи з норм Закону «Про місцеве самоврядування в Україні, статут територіальної громади є факультативним, а не обов'язковим документом - у вищенаведеній цитаті вказано, що «представницький орган місцевого самоврядування може (курсив наш. - I.I.) прийняти статут територіальної громади села, селища, міста».

У зв'язку з чим виникає питання: чи має рацію законодавець, коли проголошує статут територіальної громади актом, прийняття якого $\epsilon$ не обов'язком, а правом представницького органу місцевого самоврядування?

Основним аргументом на користь факультативності статутів територіальних громад є відсутність необхідності вживати примус для того, щоб статути були прийняті, та відповідно - надання територіальній громаді свободи вибору рішення у цьому випадку.

I дійсно, наразі далеко не усі територіальні громади мають свої статути. На наш погляд, така ситуація склалась тому, що фактично є лише три групи питань, які вирішуються не на державному рівні, а на місцевому рівні - причому, лише у статутах територіальних громад. М. Кушнір охарактеризував їх як «проблеми, пов'язані із урегулюванням загальних зборів місцевої громади; проблеми, пов'язані із урегулюванням громадських слухань на рівні територіальної громади; проблеми, пов'язані із урегулюванням місцевих ініціатив територіальної громади» [5]. Він зробив це узагальнення на підставі аналізу норм Закону від 21 травня 1997 р. «Про місцеве самоврядування в Україні».

Г. В. Макаров дослідив проблему обов'язковості статутів для територіальних громад та зазначив: «ідея обов'язкового ухвалення територіальними громадами своїх статутів та підвищення їхнього статусу знайшла своє відображення у Стратегії державної політики сприяння розвитку громадянського суспільства в Україні, затвердженій відповідним Указом Президента України № 212/2012 від 24 березня 2012 р. Разом із тим у процесі вдосконалення інституту статутів територіальних громад мають бути враховані деякі особливі умови розвитку статутного права в Україні, відмінні від європейських... В Україні ... статутне право діяло в основному на тих територіях, які перебували у складі Речі Посполитої та Угорщини, з кінця 18 ст. - у складі Австро-Угорщини. Після інкорпорації більшої частини українських земель до складу Російської Імперії самоврядування у формі Магдебурзького права було ліквідоване, а разом із ним і статути міст. За радянських часів однопартійна система перетворила місцеві ради на вертикаль представницьких органів, причому без чіткого розподілу сфер компетенції органів місцевого самоврядування різного рівня» [6].

3 іншого боку, статут територіальної громади можна було б впровадити як обов'язковий акт для кожної територіальної громади. Це певною мірою порушувало б проголошений Законом «Про місцеве самоврядування в Україні» принцип правової, організаційної та матеріально-фінансової самостійності в межах повноважень, визначених законами, але з іншого боку, - сприяло б реалізації принципу рівності по відношенню до усіх членів територіальних громад. Адже наразі члени тих територіальних громад, які мають статут, знаходяться у більш привілейованому положенні з точки зору реалізації їхніх прав на участь у місцевому самоврядуванні у частині місцевих ініціатив, загальних зборів за місцем проживання та місцевих громадських слухань.

О.В.Батанов з цього приводу пише: «чи потрібний узагалі статут територіальної громади в умовах максимальної законодавчої уніфікації моделі місцевого самоврядування в Україні та детальної регламентації структури органів місцевого самоврядування, їхніх повноважень та форм роботи? Відповідь має бути однозначною: так, статут потрібний, насамперед, із огляду на те, що його прийняття дасть можливість ліквідувати існуючі прогалини у правовій регламентації питань організації місцевого самоврядування в Україні. Зокрема, статут певною мірою сприятиме процесу формування територіальної громади, тобто спільноти людей-мешканців населеного пункту, об'єднаних необхідністю вирішення спільних питань [7, с. 38].

Отже, аргументи на користь того, щоб зробити прийняття статуту територіальної громади обов'язковим, а не факультативним, є більш переконливими, ніж аргументи проти цього. У зв'язку з цим, пропонуємо ч. 1 ст. 19 Закону від 21 травня 1997 р. «Про місцеве самоврядування в Україні» викласти у такій редакції: «3 метою врахування історичних, національно-культурних, соціально-економічних та інших особливостей здійснення місцевого самоврядування представницький орган місцевого самоврядування на основі Конституції України та в межах цього Закону приймає статут територіальної громади села, селища, міста».

Відповідно до п.48 ст.26 Закону від 21 травня 1997 р. «Про місцеве самоврядування в Україні», питання затвердження статуту територіальної громади вирішуються виключно на пленарних засіданнях сільської, селищної, міської ради [4]. Таким чином, статут територіальної громади приймає сільська, селищна або міська рада. У зв'язку 3 цим виникає питання: можливо, доцільним було б прийняття статутів територіальних громад на референдумах?

О. В. Батанов у 2004 р. розмірковував: «з огляду на те, що основною вимогою до представницького органу місцевого самоврядування $\epsilon$ репрезентативність, він не має бути компетентнішим за територіальну громаду в конкретних галузях місцевого життя, позаяк його основна роль у системі місцевого самоврядування полягає у вираженні волі місцевих жителів. Тому вважаємо, що має бути передбачена можливість прийняття статуту територіальної громади безпосередньо населенням на місцевому референдумі» [7, с. 39].

Натомість, В. М. Шаповал (не по відношенню до статутів територіальних громад конкретно, а взагалі розмірковуючи про співвідношення між безпосередньою та представницькою демократією) зазначив, що навряд чи доцільно встановлювати у законодавстві дуже широкий перелік питань, що вирішуються на референдумі. На його думку, це виказує «своєрідну недовіру виборному політичному представництву, його нібито другорядність і навіть вторинність щодо безпосереднього здійснення влади іiї носієм - народом» [8, с. 11].

Але, крім теоретичних міркувань вчених, доцільно виходити i iз сучасного стану діючого законодавства. 3 приводу прийняття статутів територіальних громад на референдумах зазначимо таке.

При вирішенні цього питання наразі (у 2020 р.) треба виходити з того, що проведення місцевих референдумів взагалі не регламентується на державному рівні зі втратою чинності Законом від 3 липня 1991 р. «Про всеукраїнський та місцевий референдуми» [9], так само, як і Законом від 6 листопада 2012 р. «Про всеукраїнський референдум» [10] (тобто, не можна застосувати навіть аналогію закону).

Отже, пропозиція приймати статут територіальної громади на місцевому референдумі вимагає одночасного перегляду референдного законодавства України на державному рівні. Таким чином, іï швидка реалізація є неможливою. 
3 іншого боку, прийняття статутів територіальних громад місцевими радами не викликає процесуальних труднощів. Сільська, селищна, міська рада - це представницький орган місцевого самоврядування. Закон «Про місцеве самоврядування» (далі - Закон) визначає представницький орган місцевого самоврядування як виборний орган, який складається 3 депутатів і відповідно до закону наділяється правом представляти інтереси територіальної громади і приймати від іiі імені рішення (ст. 1 Закону). Сільська, селищна, міська рада проводить свою роботи сесійно (ч. 1 ст. 46 Закону). Сесія скликається в міру необхідності, але не менше одного разу на квартал (ч. 5 ст. 46 Закону). Пропозиції щодо питань на розгляд ради можуть вноситися сільським, селищним, міським головою, постійними комісіями, депутатами, виконавчим комітетом ради, головою місцевої державної адміністрації, головою районної, обласної ради, загальними зборами громадян (ч. 12 ст. 46 Закону).

Нормотворчий процес відбувається відповідно до регламенту місцевої ради. На відміну від актів про організацію та проведення місцевого референдуму, Регламент $\epsilon$ у кожної місцевої ради.

Після того, як статут територіальної громади прийнято, його необхідно зареєструвати. Наразі ч. 2 ст. 19 Закону встановлює, що «статут територіальної громади підлягає державній реєстрації в центральному органі виконавчої влади, що реалізує державну політику у сфері державної реєстрації (легалізації) об'єднань громадян, інших громадських формувань», а у ч. 3 зазначається, що у такій реєстрації може бути відмовлено: «підставою для відмови в державній реєстрації статуту територіальної громади може бути його невідповідність Конституції та законам України. Відмова в реєстрації статуту територіальної громади може бути оскаржена в судовому порядку» [4].

Норма про необхідність державної реєстрації статутів територіальних громад конкретизується у Положенні про державну реєстрацію статутів територіальних громад, затвердженому постановою Кабінету Міністрів України від 27 липня 1998 р. № 1150 .

Фахівці з конституційного права майже не приділяють уваги проблемам державної реєстрації статутів територіальних громад. Чи не єдине зауваження 3 цього приводу висловив О. В. Батанов, зазначивши, що «статут територіальної громади підлягає державній реєстрації в органах Міністерства юстиції України» [7, с. 39]. На нашу думку, статут територіальної громади взагалі не має підлягати державній реєстрації.

Стосовно державної реєстрації статутів територіальних громад, просліджуються дві паралелі.

Першу паралель можна провести, виходячи 3 назви акту, який реєструється - «статут». В Україні на підставі статутів діє низка юридичних осіб, здебільшого такі юридичні особи публічного права, як товариства Стаття 87 Цивільного кодексу України передбачає, що «установчим документом товариства $є$ затверджений учасниками статут або засновницький договір між учасниками, якщо інше не встановлено законом» [12].

Саме він підлягає державної реєстрації (до речі, також як і статут територіальної громади - для набуття чинності). Порядок державної реєстрації для цих статутів не передбачено окремо - їхня державна реєстрація здійснюється в рамках державної реєстрації юридичної особи. Відповідно до Закону України від 15 березня 2003 р. «Про державну реєстрацію юридичних осіб та фізичних осіб-підприємців», «державна реєстрація юридичних осіб та фізичних осіб - підприємців - засвідчення факту створення або припинення юридичної особи, засвідчення факту набуття або позбавлення статусу підприємця фізичною особою, а також вчинення інших реєстраційних дій, які передбачені цим Законом, шляхом внесення відповідних записів до Єдиного дер- жавного реєстру. Порядок проведення державної реєстрації юридичних осіб та фізичних осіб - підприємців включає, зокрема: перевірку комплектності документів, які подаються державному реєстратору, та повноти відомостей, що вказані в реєстраційній картці; перевірку документів, які подаються державному реєстратору, на відсутність підстав для відмови у проведенні державної реєстрації; внесення відомостей про юридичну особу або фізичну особу - підприємця до Єдиного державного реєстру; оформлення і видачу виписки з Сдиного державного реєстру» (ст. 4) [13].

Другу паралель можна провести, виходячи $з$ того, що статут територіальної громади - це нормативно-правовий акт підзаконного характеру. В Україні існує практика державної реєстрації підзаконних нормативно-правових актів. Перелік органів, акти яких набувають чинності після такої державної реєстрації, та вимоги до підзаконних актів, які підлягають державній реєстрації, наводяться в Указі Президента України від 3 жовтня 1992 р. «Про державну реєстрацію нормативно-правових актів міністерств та інших органів виконавчої влади» та у Положенні про державну реєстрацію нормативно-правових актів міністерств, інших органів виконавчої влади, затвердженому Постановою Кабінету Міністрів України від 28 грудня 1992 р. № 731 .

Але, аналіз змісту цих актів надає підстави стверджувати, що державна реєстрація статутів територіальних громад відбувається за процедурою, ближчою до державної реєстрації не нормативно-правових актів, а статутів юридичних осіб публічного права. До того ж, ніколи не реєструються акти органів місцевого самоврядування - тільки акти органів державної влади. Не підлягають реєстрації і акти представницьких органів (крім того, в Україні немає іншого, ніж статут територіальної громади, нормативно-правового акта 3 назвою «статут»).

Доцільним виявляється скасування вимоги про державну реєстрацію статутів територіальних громад. Адже вони є актами представницьких органів місцевого самоврядування, до яких завжди можна застосувати положення ч. 2 ст. 144 Конституції України щодо того, що «рішення органів місцевого самоврядування 3 мотивів їх невідповідності Конституції чи законам України зупиняються у встановленому законом порядку з одночасним зверненням до суду» [2].

Для усунення плутанини між статутами певних юридичних осіб публічного права та статутами територіальних громад сіл, селищ, міст, на нашу думку, термін «статут територіальної громади» слід замінити терміном «хартія територіальної громади». Більшість англомовних країн для найменування цих актів як раз і використовує термін «хартія» (charter, див. напр. [14]). Це буде відповідати сучасній європейській практиці у цій сфері.

Висновки з даного дослідження. У статті запропоновано встановити обов'язковість прийняття свого статуту для кожної територіальної громади та покласти обов'язок прийняття статуту територіальної громади на відповідну місцеву раду як на представницький орган територіальної громади та скасувати державну реєстрацію для статутів територіальних громад. Така практика існує у більшості європейських країн.

Також сформульовано, що на підставі європейського досвіду доцільно замість терміну «статут територіальної громади» використовувати термін «хартія територіальної громади» - здебільшого для уникнення аналогій, коли йдеться про статути територіальних громад та певних юридичних осіб приватного права. Перспективи подальших досліджень у цьому напрямку полягають у вирішенні питання щодо того, чи необхідно запровадити спеціальну процедуру прийняття статуту територіальної громади у місцевій раді. 


\section{ЛІТЕРАТУРА}

1. Мішина Н.В. Муніципальна реформа в Україні: стан і перспективи. Право України. 2018. № 4. С. 126-138.

2. Конституція України : Закон України від 28 червня 1996 р. Відомості Верховної Ради України. 1996. № 30. Ст. 142.

3. Закон України «Про органи самоорганізації населення»: науково-практичний коментар / за заг. ред. О.С. Орловського, А.С. Крупника, Н.В. Мішиної, К.В. Терзіанової. Одеса: ПП „євродрук”, 2012. 192 с.

4. Про місцеве самоврядування в Україні : Закон України від 21 травня 1997 р. Відомості Верховної Ради України. 1997. № 24. Ст. 170.

5. Кушнір М. Статут територіальної громади в законодавчому полі держави. URL : http://old.niss.gov.ua/monitor/november08/1.htm (дата звернення: 01.03.2020).

6. Макаров Г.В. Проблеми прийняття та функціонування статутів територіальних громад. Аналітична записка. URL : http://www.niss.gov.ua/articles/1028/ (дата звернення: 01.03.2020).

7. Батанов О. В. Питання розробки та прийняття статуту територіальної громади. Юридичний журнал. 2004. № 3. С. 38-40.

8. Шаповал В. М. Безпосередня демократія і представницька демократія у взаємозв'язках. Право України. 2004 . № 8. С. 8-12.

9. Про всеукраїнський та місцевий референдуми : Закон України від 3 липня 1991 р. Відомості Верховної Ради України. 1991. № 33. Ст. 443.

10. Про всеукраїнський референдум : Закон від 6 листопада 2012 р. Відомості Верховної Ради України. 2013. № 44-45. Ст. 634.

11. Положення про державну реєстрацію статутів територіальних громад : затверджене Постановою Кабінету Міністрів України від 27 липня 1998 р. № 1150. Офріційний вісник України. 1998. № 30. Ст. 1133.

12. Цивільний кодекс України. Відомості Верховної Ради України. 2003. № 40. Ст. 356.

13. Про державну реєстрацію юридичних осіб та фізичних осіб-підприємців : Закон України від 15 березня 2003 р. Відомості Верховної Ради України. 2003. № 31. Ст. 263.

14. Мішина Н. В. Органи самоорганізації населення в Україні: типологія та класифікація. Наукові праці Національного університету «Одеська юридична академія». Том XX VI. Одеса, 2020. С. 81-89. 


\title{
ОСОБЛИВОСТІ ВИЗНАЧЕННЯ СУСПІЛЬНОЇ НЕБЕЗПЕЧНОСТІ ЗЛОЧИНУ
}

\section{PECULIARITIES OF DETERMINING THE SOCIAL DANGER OF A CRIME}

\author{
Лахова О.В., к.ю.н. \\ доцент кафедри адміністративного і кримінального права \\ Дніпровський національний університет імені Олеся Гончара
}

Стаття присвячена дослідженню особливостей визначення суспільної небезпечності злочину та кримінальних проступків, як основної ознаки кримінального правопорушення.

Висвітлюються особливості відмежування та класифікація критеріїв визначення суспільно-небезпечних наслідків та загрози їх настання, досліджуються категорії (якісні та кількісні характеристики) діяння, що визнається суспільно небезпечним та має наслідком настання кримінальної відповідальності.

Проаналізовано співвідношення понять «шкідливість» та «небезпечність», визначено основні наукові та практичні підходи до єдиного правозастосування та пеналізації кримінальних правопорушень за ознакою суспільної небезпечності.

Основну увагу приділено проблемам визначення виду і розміру шкоди, завданої кримінальним правопорушенням, що $є$ обов'язковим елементом предмета доказування слідчим у кримінальному провадженні, оскільки дана обставина має важливе кримінально-правове та кримінальне процесуальне значення. Досліджено відповідні положення чинних Кримінального кодексу України та Кримінального процесуального кодексу України, взято до уваги перспективне законодавство та модель Кримінального кодексу, представленому робочою групою.

Зроблено акцент на особливості відмежування кримінальних правопорушень від адміністративних правопорушень за ознакою суспільної небезпечності, приділено увагу дискусійним питанням щодо протиставлення малозначних діянь адміністративним та кримінальним правопорушенням. Основними питаннями, що вирішує криміналізація окремих діянь є суспільна оцінка небезпеки настання негативних наслідків та загрози їх заподіяння від конкретного акта людської поведінки. Окрім того, буздумна пеналізація та необґрунтоване включення діяння в коло таких, за які настає саме кримінальна відповідальність відповідно до діючого закону про кримінальне відповідальність, призводить до занадтого переобтяження змісту особливої частини Кримінального кодексу України, формування таких складів кримінальних правопорушень, які (виходячи з їх змісту та, відповідно, конструкції складу кримінального правопорушення) не $€$ спроможними для кваліфікації в судовій та слідчій практиці. Проблемним також вбачається наявність суміжних за своїм змістом правопорушень в Кодексі України про адміністративні правопорушення та в Кримінальному кодексі України. Акцентовано саме значення адекватної оцінки суспільно небезпечного діяння та необхідність чіткого розділення кримінального правопорушення від адміністративного як суспільно небезпечного від суспільно шкідливого.

Зроблено висновок про необхідність удосконалення єдиного дефінітивного апарату чинного КК, КПК.

Ключові слова: кримінальне правопорушення, злочин, суспільна небезпечність, шкода, кримінальна відповідальність.

The article is devoted to the study of the peculiarities of determining the social danger of crime and criminal offenses as the main features of a criminal offense.

The peculiarities of delimitation and classification of criteria for determining socially dangerous consequences and the threat of their occurrence are highlighted, the categories (qualitative and quantitative characteristics) of an act that is recognized as socially dangerous and has the consequence of criminal liability are investigated.

The relationship between the concepts of "harmfulness" and "danger" is analyzed, the main scientific and practical approaches to a single law enforcement and penalization of criminal offenses on the basis of public danger are identified.

The main attention is paid to the problems of determining the type and amount of damage caused by a criminal offense, which is a mandatory element of the subject of evidence by investigators in criminal proceedings, as this circumstance has important criminal and criminal procedural significance. The relevant provisions of the current Criminal Code of Ukraine and the Criminal Procedure Code of Ukraine are studied, the perspective legislation and the model of the Criminal Code presented by the working group are taken into account.

Emphasis is placed on the peculiarities of distinguishing criminal offenses from administrative offenses on the grounds of public danger, attention is paid to debatable issues regarding the opposition of minor acts to administrative and criminal offenses. The main issues that solve the criminalization of certain acts is the public assessment of the danger of negative consequences and the threat of causing them from a particular act of human behavior. In addition, reckless penalty and unjustified inclusion of the act in the circle of those for whom criminal liability arises in accordance with the current law on criminal liability, leads to excessive overload of the content of a special part of the Criminal Code of Ukraine, the formation of such criminal offenses. and, accordingly, the constructions of the criminal offense) are not capable of qualification in judicial and investigative practice. The presence of related offenses in the Code of Ukraine on Administrative Offenses and in the Criminal Code of Ukraine is also considered problematic. The importance of an adequate assessment of a socially dangerous act and the need for a clear separation of a criminal offense from an administrative one as a socially dangerous from a socially harmful one are emphasized.

It is concluded that it is necessary to improve the single definitive apparatus of the current Criminal Code, the CPC

Key words: criminal offense, crime, public danger, damage, criminal liability.

Постановка проблеми. Аналіз чинного кримінального законодавства України засвідчує, що під час конструювання його положень законодавець часто використовує поняття, що не мають чітко визначеного змісту. Уявлення про необхідність заборони в кримінальному законі тих чи інших діянь не залишається раз і назавжди даним та незмінним. Критерії визнання відповідних діянь суспільно небезпечними є вирішальним при визначенні підстав педалізації та кримінальної караності правопорушення. Безсумнівно, суспільна небезпечність діяння - найбільш вагома ознака злочину, є його невід'ємною властивістю. Відсутність цієї ознаки означає відсутність кримінально-правових засад для притягнення особи до кримінальної відповідальності, оскільки лише суспільна небезпечність як об’єктивна ознака кримінального правопорушення розкриває його матеріальну та правову природу.
Метою статті $є$ визначення та уніфікація дефінітивного розуміння суспільної небезпечності злочину як виду кримінальних правопорушень, а також встановлення критеріїв за якими має здійснюватись розмежування зазначених діянь.

Аналіз дослідження проблеми. Вагомий теоретичний внесок у розв'язання цієї проблеми зробили відомі вчені: Л.В. Багрій-Шахматов, М.І. Бажанов, Ю.В. Баулін, О.Ф. Бантишев, Я.М. Брайнін, Ф.Г. Бурчак, П.А. Воробєй, А.Ф. Зелінський, М.І. Загородніков, М.Й. Коржанський, П.С. Матишевський, П.П. Михайленко, Г.М. Міньковський, М.I. Мельник, А.А. Музика, В.О. Навроцький, Г.В. Новицький, В.С. Прохоров, В.І. Осадчий, О.І. Санталов, Я. І. Соловій, В.В. Сташис, В.Я. Тацій, А.П. Тузов, М.I. Хавронюк, В.І. Шакун, М.Д. Шаргородський та інші 
науковці. Але в цілому у вітчизняному кримінальному законодавстві, як неодноразово підкреслювалось в юридичній літературі, питання соціально-правової сутності кримінальної відповідальності та її підстав далекі ще від повного і всебічного вирішення.

Виклад основного матеріалу. У визначенні поняття суспільної небезпечності необхідно, головним чином, вказати на їі суспільну сутність, спрямованість на найбільш цінні, головні суспільні відносини, що охороняються законом і заподіяння у їх сфері суспільно небезпечної шкоди. Суспільна небезпечність - головна, найбільш суттєва ознака злочину, його визначальна властивість, притаманна лише злочинові. Всі інші правопорушення можуть бути визнані лише суспільно шкідливими. Не можна погодитись 3 тим, що між суспільною небезпечністю і суспільною шкідливістю різниця лише у словах, бо ними викривається різна загроза. "Шкідливість” і “небезпечність” в українській мові визначають загрозу настання якісно різних наслідків. Палити цигарку, наприклад, лише шкідливо, а торкатися до електропроводу під високою напругою - не шкідливо, а небезпечно; фізичний біль для здоров'я шкідливий, а рана 3 проникненням у живіт чи грудну порожнину - небезпечна і таке інше [1, с. 64-65]. Небезпечними для певної системи є такі зміни у звичайному, природному функціонуванні, що порушують умови iii існування, утворюють загрозу іiї існуванню, здатні призвести до її загибелі. Шкідливі порушення такими наслідками не загрожують.

Головна суспільна властивість злочину полягає у руйнуванні суспільних відносин, що і $€$ злочинними наслідками у вигляді фізичної, моральної чи майнової суспільно-небезпечної шкоди. Ця особливість злочину і вимагає охорони суспільства від небезпечних для нього посягань та застосування найбільш суворих кримінальноправових засобів. В той же час і кримінально-правові засоби доцільно застосовувати лише у випадках вчинення правопорушення, яке є суспільно небезпечним.

Правовою наукою генезис суспільної небезпечності злочину вивчено достатньо глибоко. Кримінологи та правознавці висловлювали різні, а в багатьох випадках $\mathrm{i}$ тотожні думки щодо основної матеріальної ознаки злочину. При цьому, звичайно, основний зміст суспільної небезпечності діяння формулювався тією концепцією соціальної ролі і походження права, яку поділяв той чи інший автор, так би мовити, парадигмою права.

Платон, наприклад, зазначав, що злочин є породженням зла, жадібності та почуттів, що затьмарюють розум [2, с. 31]. Чезаре Беккаріа послідовно відстоював тезис про те, що єдиною та істинною мірою злочину є шкода, яку він завдає нації” [3, с. 34]. Отже, користуючись сучасною термінологією, Платон та Беккаріа зазначали, що є суспільна небезпечність діяння безпосередньо визначає об'єктивні межі кримінальної відповідальності та підстави криміналізації чи декриміналізації діянь.

Сучасна теорія кримінального права та практика нормотворення розвинули, удосконалили та законодавчо закріпили положення про суспільну небезпечність як головну ознаку злочину. В ч. 1 ст. 11 КК України визачено, що кримінальним правопорушенням є передбачене цим Кодексом суспільно небезпечне винне діяння (дія або бездіяльність), вчинене суб' єктом кримінального правопорушення. Втім, в ч. 2 ст. 11 КК України акцентовано, що не є кримінальним правопорушенням дія або бездіяльність, яка хоча формально і містить ознаки будь-якого діяння, передбаченого цим Кодексом, але через малозначність не становить суспільної небезпеки, тобто не заподіяла і не могла заподіяти істотної шкоди фізичній чи юридичній особі, суспільству або державі [4]. Так, ще П.О. Фефелов вказував на дві обставини: на суспільну небезпечність та можливість забезпечення невідворотності відповідальності як на найбільш важливі передумови криміналізації [5, с. 135-138].
I.M. Гальперін зазначав, що для криміналізації за ознакою суспільної небезпечності діяння, необхідно вирішити, принаймні, декілька завдань: а) вивчити поширеність відповідних діянь та оцінити їх типовість як форму протиправної поведінки; б) розкрити динаміку вказаних діянь з урахуванням причин і умов, що їх породжують; в) визначити ефективність некримінальних заходів боротьби із вказаними діяннями, що застосовувались раніше; г) визначити можливості системи кримінальної юстиції у боротьбі із цими діяннями тощо [6, с. 58].

За тих чи інших розбіжностей між окремими авторськими позиціями все ж таки здається, що в сьогоднішніх умовах наука кримінального права може сформулювати свої висновки у вигляді юридичних правил криміналізації - це достатньо висока ступінь суспільної небезпечності; відносна поширеність; їхня заборона відповідає моральному грунту кримінального закону та виключає настання серйозних побічних негативних наслідків соціального плану; діяння є процесуально доказуваними; кримінально-правові заборони не суперечать іншим галузям права та міжнародним конвенціям. Природно, що поряд 3 дотриманням таких правил будь-якому акту криміналізації повинно передувати чітке врахування не тільки можливих соціальних надбань, але й втрат морального, економічного та навіть демографічного характеру.

Визнання діяння суспільно небезпечним, тобто пеналізація даного діяння - надзвичайно відповідальний акт законодавчої влади. Подальше удосконалення закону та розробка науково-обгрунтованих методик криміналізації i, перш за все, питань про підстави визнання діяння кримінально караним за ознакою суспільної небезпечності має не тільки абстрактно-теоретичне, але й пряме практичне значення. Як свідчить практика, змінюючи кримінальне законодавство шляхом змін та доповнень нерідко обгрунтування змін чи доповнень задовольнялось вимогами «здорового глузду», «загальновідомості», «очевидності», необхідності заповнити прогалину, тощо. При цьому розуміється, що нерідко вжиті заходи виявлялися малоефективними, а іноді це породжувало небажані побічні наслідки. Правильно з цього приводу зазначав М.Й. Коржанський, констатуючи, що право як інструмент суспільної регламентації придатне лише для регулювання суспільних відносин. Ні для чого іншого право непридатне, і тому ніякі інші завдання ставити перед ним немає сенсу. Навіть у сфері регулювання суспільних відносин дія права має дуже значні обмеження [1, с. 15].

3 іншого боку, дуже важливою є можливість забезпечення реалізації певної кримінально-правової норми. Якщо норма не застосовується, «є мертвою» або малоефективною - вона не має права на існування. Встановлюючи ту чи іншу норму, забороняючи правило поведінки, сім раз відмірявши, законодавець повинен добре обміркувати питання і про можливість забезпечення їх виконання, дотримання громадянами. Переоцінювати можливості кримінального закону у сфері регулювання суто всіх суспільних відносин недоцільно. Кримінальний закон може не все, його обмеження випливають із самої сутності права, дія якого є суспільно корисною, доцільною і припустимою лише до певної межі. Причому і в такому випадку законодавець повинен порівняти ефективність різних правових засобів: цивільно-правових, адміністративних, кримінально-правових. При рівній ефективності різних норм повинно бути правилом використовувати менш репресивні засоби, тобто застосування більш репресивних засобів може бути виправдано лише суспільною крайньою необхідністю [1, с. 18].

При розгляді досліджуваного питання необхідно врахувати, що злочин і адміністративне правопорушення мають ряд спільних або схожих ознак (протиправність, винність, суб'єкт правопорушення, заподіяння шкоди та інші), які не можуть бути критерієм розмежування 
цих видів правопорушень. Ряд авторів, вказуючи на ступінь суспільної небезпеки як на критерій розмежування кримінальних та адміністративних правопорушень, пов'язують іiі підвищення з наявністю чи відсутністю тяжких наслідків, розміром реально заподіяної матеріальної шкоди, повторністю чи систематичністю, способом вчинення правопорушення, умисним характером його вчинення та іншим [8]. На нашу думку, ці обставини мають факультативний (необов'язковий) характер. Навіть будучи вчиненим за певних обтяжуючих обставин, адміністративний проступок не може кваліфікуватись як кримінальне правопорушення, якщо його якісне визначення і ступінь шкідливості не виходять за межі проступку. Якщо ж ступінь його суспільної шкідливості досягає рівня суспільної небезпечності злочину, то він повинен визнаватись таким без адміністративної преюдиції. Ми приєднуємось до позиції тих науковців, які слушно зазначають, що суспільна небезпечність, виступаючи в ролі критерію розмежування злочинів та адміністративних проступків, $\epsilon$ поняттям збірним, що складається 3 конкретних і різнорідних показників. Це положення (як зазначалося вище) також відображено у ч. 2 ст. 11 КК України щодо визначення малозначності. Отже, закон не встановлює меншої, невеликої чи незначної міри суспільної небезпеки, а прямо вказує на її відсутність.

Висновки. 3 огляду на проведений аналіз, підсумуємо. По-перше, на наш погляд не можна в об'єктивній стороні злочину вказувати на обов'язкову присутність в діях особи таких ознак, які не визначені законодавцем, а лише розроблені теорією, оскільки ця норма через абсолютну невизначеність буде або знаряддям розправи над невинними, або просто «мертвою» статтею, але в будь-якому разі вона не матиме позитивного ефекту. По-друге, для звуження кола проблемних питань кваліфікації злочинів, необхідно включити в КК України главу з роз'ясненням термінів, які використовує законодавець в кримінальноправових нормах, а саме тих, які вказують на суспільну небезпечність діяння. Цілком позитивним та слушним $\epsilon$ включення такого розділу до моделі Кримінального кодексу, розробленою робочою групою та представленому на обговорення $[8,9]$. По-третє, вживання терміну “суспільна небезпечність” для характеристики всіх видів правопорушень веде до того, що зникає відмінність злочинів від інших правопорушень. Тому наполягаємо на уніфікації поняття суспільної небезпечності саме в кримінальноправовому сенсі.

\section{ЛITEPATУРA}

1. Коржанський М. Й. Квапіфікація злочинів: монографія. Київ, 1998.416 с.

2. Коркунов Н. М. История философии права: монографрія. С-пб., 1915. 431 с.

3. Ч. Беккариа. О преступлениях и наказаниях. М., 1939. 463 с.

4. Кримінальний кодекс України: Закон України від 05.04.2001 р. № 2341 III. URL : https://zakon.rada.gov.ua/laws/show/2341-14 (дата звернення: 23.07.2020).

5. Фефелов П.А. Общественная опасность преступного деяния: наук.збірник Сов. гос. и право, 1977. № 5. С. 135-138.

6. Гальперин И.М. Основные направления борьбы с преступностью: монографія. М., 1975. 158 с .

7. Фріс П.Л. Актуальні проблеми боротьби та попередження злочинності //Матеріали теоретичного семінару. Івано-Франківськ, 2002. - C.7-8

8. Питання Комісії з питань правової реформи: Указ Президента України № 584/2019 від 7 серпня 2019 p. URL : https://www.president. gov.ua/documents/5842019-28949 (дата звернення: 23.07.2020).

9. Текст проєкту нового кримінального кодексу: текст. URL : https://newcriminalcode.org.ua/criminal-code (дата звернення: 19.09.2020). 


\section{ПРИНЦИПИ ПРАВОВОГО РЕГУЛЮВАННЯ РЕАЛІЗАЦЙНИХ ПРОЦЕДУР У ДІЯЛЬНОСТІ МИТНИХ ОРГАНІВ УКРАЇНИ}

\section{PRINCIPLES OF LEGAL REGULATION OF IMPLEMENTATION PROCEDURES IN THE ACTIVITIES OF THE CUSTOMS AUTHORITIES OF UKRAINE}

Князев В.С. кандидат юридичних наук

Стаття присвячена питанням принципів правового регулювання реалізаційних процедур у діяльності митних органів України. У статті наголошено, що здійснення заходів з створення сучасної концепції розпорядження майном, що перейшло у власність держави, яка б забезпечила ефективне розпорядження відповідними товарами та транспортними засобами як з позицій державного бюджету, так й з позицій митних органів може відбутися лише на основі чіткого визначення принципів правового регулювання реалізаційних процедур у діяльності митних органів України. Зазначені принципи повинні лягти в основу уніфікованого правового регулювання та удосконалення існуючої нормативно-правової бази.

Підкреслено, що такі принципи визначають та впливають на характер інших елементів системи правового регулювання реалізаційних процедур у діяльності митних органів: правових норм, управлінських заходів та правовому положенні уповноважених суб'єктах таких відносин.

Запропоновано виокремити наступні принципи правового регулювання реалізаційних процедур у діяльності митних органів: гуманізму; гласності; об'єктивності; верховенства права; поваги до прав, свобод, гідності людини; координації та співпраці між органами державної влади у частині реалізаційних процедур у діяльності митних органів України; публічного контролю за здійсненням реалізаційних процедур у діяльності митних органів України; заборони зловживання правом у процесі реалізаційних процедур у діяльності митних органів України; врахування балансу інтересів держави, суспільства та окремої особи (прийняття обґрунтованих рішень з точки зору економічної ефективності та соціальної відповідальності, обліку коротко- та довгострокових цілей і завдань); принцип паритетності держави та інших учасників реалізаційних процедур відносин із здійснення окремих операцій з майном, що переходить у власність держави.

Особливо важливою є гласність реалізаційних процедур у діяльності митних органів України, яка полягає в оприлюдненні результатів здійснення таких реалізаційних процедур, в їх публічному обговоренні, притягнення до них уваги державних органів, громадських організацій і окремих громадян. Також гласність полягає у забезпеченні відкритості та доступності інформації про суб'єктів та об'єктів управління, безперервності процесів управління і контролю, виявлення і облік даних про об'єкти управління.

Ключові слова: майно; митні органи; матеріальні цінності; реалізація, розпорядження, товари; контрафактні товари; контрабанда; митні аукціони, лот.

The article is devoted to the principles of legal regulation of implementation procedures in the activities of the customs authorities of Ukraine. The article emphasizes that the implementation of measures to create a modern concept of disposal of state-owned property, which would ensure the effective disposal of relevant goods and commercial vehicles, both from the standpoint of the state budget and from the standpoint of customs authorities can only clear definition of the system of principles of legal regulation of implementation procedures in the activity of customs bodies of Ukraine. It is emphasized that such principles determine and influence the nature of other elements of the system of legal regulation of implementation procedures in the activities of customs authorities: legal norms, management measures and authorized subjects of relations.

It is proposed to single out the system of principles of legal regulation of implementation procedures in the activities of customs authorities. This system includes the principles of humanism; publicity; objectivity; rule of law; respect for human rights, freedoms, dignity; coordination and cooperation between public authorities in terms of implementation procedures in the activities of customs authorities; public control over the implementation of implementation procedures in the activities of customs authorities; prohibition of abuse of rights in the process of implementation procedures in the activities of customs authorities; taking into account the balance of interests of the state, society and the individual (making informed decisions in terms of economic efficiency and social responsibility, accounting for short- and long-term goals and objectives); parity of the state and other participants in the implementation procedures of relations for the implementation of certain transactions with property that becomes the property of the state.

Particular attention is paid to the importance of adhering to the principle of transparency of implementation procedures in the activities of customs authorities, which is to publicize the results of such implementation procedures, in their public discussion, attracting the attention of government agencies, NGOs and individuals. Also, publicity is to ensure the openness and accessibility of information about the subjects and objects of management, the continuity of management and control processes, detection and accounting of data on objects of management.

Key words: property; Customs Authorities; tangibles; sale; ordering about; goods; counterfeit goods; smuggling; Customs Auctions; lot.

Актуальність теми дослідження. Реалізація майна, що переходить у власність держави є додатковим джерелом поповнення Державного бюджету України. Від ефективності роботи державних органів, які наділенні функціями пошуку, вилучення, конфіскації, подальшого розпорядження майном, яке може бути звернено в дохід держави, залежать показники поповнення доходної частини державного бюджету. Найбільш активно у цій сфері діють митні органи України.

Митні органи України відповідно до покладених на них завдань зобов'язані проводити облік, зберігання, оцінку вилученого, прийнятого на зберігання, розміщеного у митний режим відмови на користь держави майна, а також майна, виявленого в зоні митного контролю, власник якого невідомий та розпорядження ним. Також у випадках, передбачених законом, митні органи здійснюють провадження у справах про порушення митних правил та у справах про адміністративні правопорушення, що також може потягнути за собою надходження майна у розпорядження митних органів [1].
На сьогоднішній день, в Україні не сформована концепція розпорядження майном, що перейшло у власність держави, яка б забезпечила ефективне розпорядження відповідними товарами та транспортними засобами комерційного призначення як 3 позицій державного бюджету (наповнення державного бюджету), так й $з$ позицій митних органів (створення умов для реалізації майна в максимально короткий час за мінімальних витрат). Тому це залишається сьогодні винятково актуальним питанням. В основу такої концепції мають бути покладено вихідні засади (принципи) правового регулювання реалізаційних процедур у діяльності митних органів України.

Аналіз останніх досліджень. Питання щодо правового регулювання реалізаційних процедур у діяльності митних органів України, у тому числі діяльності учасників правових відносин щодо прийняття на зберігання, оцінку, та інші операції 3 майном, яке перейшло у власність держави частково висвітлювали у своїх роботах I. Бережнюк, О. Вакульчик, П. Пашко, С. Терещенко, Л. Пісьмаченко, 
Л. Прус, А. Берзан, О. Грачов, Н. Жанарбаєва, М. Каленський, С. Коляда, У. Романюк, Є. Корнієнко, М. Разумей, Л. Пісьмаченко, Н. Єсипчук, Т. Єдинак, В. Фоменко та інші. Деякі проблеми, пов'язані з державним майном, досліджували у своїх працях А. Гальчинський, I. Лукінов, О. Пасхавер, М. Чечетов. Аналіз останніх досліджень і публікацій, доводить недостатній рівень науково-теоретичного та практичного опрацювання проблематики правових засад регулювання реалізаційних процедур у діяльності митних органів України.

Можна констатувати той факт, що існуюча правова система, яка регулює питання розпорядження майном, що переходить у власність держави, потребує докорінних змін. Проблемою, яка потребує наукового вирішення $є$ нормативна недосконалість процедур, пов'язаних із поводженням 3 майном, що переходить у власність держави

Метою статті $\epsilon$ визначення змісту окремих принципів правового регулювання реалізаційних процедур у діяльності митних органів України. Результати дозволять отримати комплексне бачення проблеми та створить можливість до формування відповідних доктринальних та практичних пропозиції для його подальшого використання у практичній діяльності державних служб, посадових осіб митних органів та суб'єктів підприємницької діяльності, формування відповідної концепції.

Виклад основного матеріалу. Процедуру реалізації майна, що перейшло у власність держави справедливо можна віднести до однієї із ефективних форм розпорядження державним майном, оскільки продаж майна дозволяє поповнити державну казну. Водночас процедура реалізації майна $\epsilon$ складним процесом, в якому приймають участь як суб'єкти публічного адміністрування, так і суб'єкти господарювання. Дуже важливо в процесі розпорядження майном дотримуватись балансу публічно правових та приватних інтересів, що можливо забезпечити шляхом виокремлення та впровадження в реалізаційні процеси загальнотеоретичних та спеціальних принципів.

Враховуючи те, що термін повинен якнайповніше та найточніше передавати зміст поняття, яке він позначає, існує об'єктивна необхідність у визначені сутності понятійного апарату даного дослідження, так як неточний термін може бути джерелом непорозумінь між фахівцями.

Принцип - це основна підвалина функціонування будь-якої соціальної системи (у тому числі - правової), вплив якої поширюються на всі елементи цієї системи та детермінує їх характерні риси. Термін «принцип» у перекладі з латинської мови означає «початок», «першооснова», «первинність» [2, с.40-41]. Принципи не завжди мають нормативне закріплення, проте від того, на яких принципах заснований правовий порядок, можна визначити характер правових норм, заходів та діяльності органів, які реалізують ці норми та заходи.

Принципи правового регулювання несуть у собі інформацію щодо основоположних соціально-правових ідей, які панують у суспільстві у конкретно-історичний період, впливають на світогляд та спрямовують поведінку особистості. У межах адміністративного права питанням дослідження змісту принципів приділяли увагу Т. О.Коломоєць та В.К.Колпаков $[3,4]$.

Для нашого дослідження особливо цікавим $\epsilon$ те, що, визначаючи сутність принципів здійснення правового регулювання, науковці вказують на їх здатність впливати як на поведінку, так і на правозастосовну діяльність органів [5].

Для багатьох науковців характерно широке розуміння правового регулювання, намагання охопити зазначеним поняттям всі форми і засоби впливу права на суспільні відносини [6].

В юридичній літературі по-різному визначають поняття правового регулювання та механізму його здійснення. Найбільш важливою при цьому є вказівка на те що правове регулювання $\epsilon$ вплив держави на суспільн відносини, що такий вплив має на меті впорядкувати сус- пільні відносини у відповідності до суспільних потреб, а також те, що впорядкування суспільних відносин здійснюється $з$ допомогою певних юридичних засобів [7].

Серед науковців не має одностайного підходу щодо дефініції «правове регулювання». У юридичній енциклопедії правове регулювання (від лат. regulare - спрямовувати, впорядковувати) визначається як один із основних засобів державного впливу на суспільні відносини з метою їх упорядкування в інтересах людини, суспільства і держави.

Зауважимо, що в теорії права під означеним терміном розуміють здійснюване державою за допомогою права і сукупності правових засобів упорядкування суспільних відносин, їх юридичне закріплення, охорону та розвиток або здійснюваний за допомогою юридичних засобів процес упорядкування суспільних відносин з метою забезпечення певної сукупності соціальних інтересів, які вимагають правового гарантування.

У юридичному словнику правове регулювання визначається як державна форма впливу на суспільні відносини, що здійснюється за допомогою норм права та інших юридичних засобів. За допомогою правового регулювання встановлюються межі правомірної поведінки учасників суспільного життя, їх права та обов'язки, гарантії реалізації прав та обов'язків, визначаються заходи юридичної відповідальності за правопорушення, процесуальні основи їх застосування [8].

Грунтовний аналіз категорії правового регулювання здійснено В. Спасенко, який наголошує, що: «На наше переконання, найбільш точно віддзеркалює зв'язки між поняттями «правове регулювання» й «адміністративноправове регулювання» позиція науковців, які інтерпретують останнє як різновид правового регулювання» [9].

Це, в свою чергу, дає змогу припустити, що такі принципи впливають на характер інших елементів системи правового регулювання реалізаційних процедур у діяльності митних органів: правових нормах, управлінських заходах та уповноважених суб'єктах відносин.

У правовій системі України виділяють групи загальноправових принципів, огляд яких сприятиме кращим розумінню та систематизації принципів правового регулювання реалізаційних процедур у діяльності митних органів, оскільки перші є вихідними для формування других.

Найбільш значимими із групи спеціально-соціальних принципів $є$ загальні принципи, так як вони відображають загальнолюдські цінності. Це принципи свободи, справедливості, рівності, гуманізму, демократизму та законності $[10$, c. $222-224]$.

Також серед загальних принципів, які $є$ вагомими для сфери досягнення мети дослідження, варто виділити принципи: верховенства права, єдності прав і обов'язків суб' єктів суспільних відносин, превалювання прав і свобод людини над правами держави, гарантовані прав і свобод громадян, взаємної відповідальності держави й особи тощо.

Міжгалузевими принципами $є$ ті, що виражають особливості декількох споріднених галузей управління. У контексті цього дослідження міжгалузеві принципи становлять особливий інтерес, так як очевидно, що принципи правового регулювання реалізаційних процедур у діяльності митних органів визначаються на межі конституційного, цивільного, адміністративного, митного та господарського права.

Національне законодавство не визначає принципи правового регулювання реалізаційних процедур у діяльності митних органів. У зв'язку з чим, на підставі проведення аналізу законодавчих положень, якими декларуються існуючі правила регулювання реалізаційних процедур у діяльності митних та інших державних органів пропонуємо їх виокремити.

Фундаментальні засади, перш за все, містить Конституція України, яка проголошує, що кожен має право володіти, користуватися і розпоряджатися своєю власністю, 
результатами своєї інтелектуальної, творчої діяльності; право власності є непорушним; а також, що використання власності не може завдавати шкоди правам, свободам та гідності громадян, інтересам суспільства, погіршувати екологічну ситуацію і природні якості землі [11].

Дані постулати мають аксіоматичний характер для забезпечення системи принципів правового регулювання реалізаційних процедур у діяльності митних органів. Їх сутність полягає у тому, щоб визначити основоположні, вихідні позиції охорони та захисту: запобігти порушенню прав учасників митних відносин.

Окрім загальноправових, і водночас конституційних, принципів верховенства права, єдності прав і обов'язків суб'єктів суспільних відносин, превалювання прав і свобод людини над правами держави, гарантованості прав і свобод громадян, взаємної відповідальність держави й особи, пропонуємо виокремити ще й такі принципи правового регулювання реалізаційних процедур у діяльності митних органів, як принцип гуманізму; гласності; об'єктивності; верховенства права; поваги до прав, свобод, гідності людини; координації та співпраці між органами державної влади у частині реалізаційних процедур у діяльності митних органів України; публічного контролю за здійсненням реалізаційних процедур у діяльності митних органів України; заборони зловживання правом у процесі реалізаційних процедур у діяльності митних органів України; врахування балансу інтересів держави, суспільства та окремої особи (прийняття обгрунтованих рішень 3 точки зору економічної ефективності та соціальної відповідальності, обліку коротко- та довгострокових цілей і завдань); принцип паритетності держави та інших учасників реалізаційних процедур відносин із здійснення окремих операцій з майном, що переходить у власність держави.

При цьому, принцип паритетності держави та інших учасників реалізаційних процедур знаходить прояв у:

- рівноправності між державою в особі митних органів та іншими учасниками (на відповідних етапах) відносин зі здійснення окремих операцій $з$ майном, що переходить у власність держави;

- методі диспозитивного регулювання цивільно-правових (господарсько-правових) відносин щодо збереження, оцінювання та реалізації майна;

- чіткому закріпленні ролі та функцій митних органів у сфері здійснення окремих операцій з майном, що переходить у власність держави;

- дотриманні вимоги своєчасної та повної реалізації майна, що переходить у власність держави. Митні органи повинні своєчасно і у найбільш вигідний спосіб реалізувати майно, що перейшло у власність держави. Повнота також полягає у забезпеченні повного обліку, відображенні і моніторингу об'єктів майна, в тому числі шляхом формування перспективної єдиної системи обліку та управління майном, заснованої на єдиній методології обліку і процесному управлінні, необхідності досягнення найкращого результату і встановлених показників діяльності.
Гласність реалізаційних процедур у діяльності митних органів України полягає в оприлюдненні результатів здійснення таких реалізаційних процедур, в їх публічному обговоренні, притягнення до них уваги державних органів, громадських організацій і окремих громадян. Також гласність полягає у забезпеченні відкритості та доступності інформації про суб'єктів та об'єктів управління, безперервності процесів управління і контролю, виявлення і обліку даних про об'єкти управління.

Важливість принципу об'єктивності в механізмі правового регулювання реалізаційних процедур у діяльності митних органів України обумовлена тим фактом, що рішення, прийняті посадовими особами відповідних компетентних органів під час реалізаційних процедур, повинні мати гранично зважену оцінку всіх фактів і обставин.

Висновки 3 даного дослідження та перспективи подальших розвідок у даному напрямку.

Таким чином здійснення заходів із створення сучасної концепції розпорядження майном, що перейшло у власність держави, яка б забезпечила ефективне розпорядження відповідними товарами та транспортними засобами як з позицій державного бюджету, так й 3 позицій митних органів може відбутися лише на основі чіткого визначення принципів правового регулювання реалізаційних процедур у діяльності митних органів України.

Такі принципи визначають та впливають на характер інших елементів системи правового регулювання реалізаційних процедур у діяльності митних органів: правових норм, управлінських заходів та повноваженнях уповноважених суб' єктів відносин. Також, зазначені принципи повинні лягти в основу уніфікованого правового регулювання та удосконалення існуючої нормативно-правової бази.

Пропонуємо виокремити систему принципів правового регулювання реалізаційних процедур у діяльності митних органів, до якої слід віднести: принцип гуманізму; гласності; об'єктивності; верховенства права; поваги до прав, свобод, гідності людини; координації та співпраці між органами державної влади у частині реалізаційних процедур у діяльності митних органів України; публічного контролю за здійсненням реалізаційних процедур у діяльності митних органів України; заборони зловживання правом у процесі реалізаційних процедур у діяльності митних органів України; врахування балансу інтересів держави, суспільства та окремої особи (прийняття обгрунтованих рішень 3 точки зору економічної ефективності та соціальної відповідальності, обліку коротко- та довгострокових цілей і завдань); принцип паритетності держави та інших учасників реалізаційних процедур відносин із здійснення окремих операцій 3 майном, що переходить у власність держави.

В межах перспектив подальших досліджень наголосимо на можливості дослідження окремих аспектів здійснення реалізації товарів (майна) митними органами України.

\section{תITEPATYPA}

1. Митний кодекс: Закон України від 13 березня 2012 року № 4495-VI. Верховна Рада України. База «Законодавство України». URL: http://zakon2.rada.gov.ua/laws/show/4495-17 (дата звернення: 12.07. 2020).

2. Словник іншомовних слів. URL: http://www.jnsm.com.ua/cgi-bin/u/book/sis.pl?Article=14621\&action=show (дата звернення: 12.07. 2020).

3. Коломоєць Т. О. Принципи адміністративного права: монографрія. Запоріжжя : Copy Art, 2012. 203 с.

4. Колпаков В.К. Поняття i принципи адміністративно-деліктного провадження. Журнал Східноєвропейського права. 2013. №1. C. 18-23.

5. Солоненко О. М. Функціональний аспект принципів права у правозастосовній діяльності. Юридичний часопис НАВС. 2011 . № 1. URL: http://www.naiau.kiev.ua/chasopis/materials/13 (дата звернення: 12.07. 2020).

6. Кочевой М. М. Нормативно-правове регулювання зовнішньоекономічної безпеки України. Бізнес-Інформ. 2014. № 10. С. $38-42$.

7. Блащук Т. В. Джерела правового регулювання договірних відносин: теоретико-правовий аспект. Часопис Національного університету «Острозька академія». Серія «Право». 2013. № 1(7). URL: http://li.oa.edu.ua/articles/2013/n1/13btvtpa.pdf.

8. Юридичний словник. К: Гол. ред. Української Радянської енциклопедії, 1983. 871 с.

9. Спасенко В. О. Деякі питання адміністративно-правового регулювання діяльності державної реєстраційної служби України. Часопис Київського університету права. 2013. № 1. С. 153-157.

10. Скакун О.Ф. Теорія держави і права (Енциклопедичний курс) : підручник. Харків: Еспада, 2006. 776 с.

11. Конституція України : Закон України від 28 червня 1996 року № 254к/96-ВР. Верховна Рада України. База «Законодавство України». URL: http://zakon4.rada.gov.ua/laws/show/254\%D0\%BA/961 (дата звернення: 12.07. 2020). 
Кудін А.В. здобувач

\title{
НАДАННЯ АДМІНІСТРАТИВНИХ ПОСЛУГ ЯК ІНСТРУМЕНТ ПУБЛІЧНОГО АДМІНІСТРУВАННЯ ПАТЕНТНОЇ ДІЯЛЬНОСТІ В УКРАЇНІ
}

\author{
PROVISION OF ADMINISTRATIVE SERVICES AS AN TOOL OF PUBLIC \\ ADMINISTRATION OF PATENT ACTIVITY IN UKRAINE
}

Актуальність статті полягає в тому, що Конституція України гарантує громадянам свободу літературної, художньої та наукової творчості, а також захист інтелектуальної власності та авторських прав, яких набувають громадяни у зв'язку з різними видами інтелектуальної діяльності. На жаль, в Україні спостерігаються непоодинокі випадки порушення прав інтелектуальної власності. Проте варто зазначити, що велику кількість таких правопорушень можна було б уникнути або у разі їх скоєння притягнути до відповідальності винних осіб, якби власники інтелектуальних прав закріплювали свої права у встановленому законодавством України порядку. Саме цю та інші проблеми повинна вирішувати система надання адміністративних послуг у сфері інтелектуальної власності, зокрема, у сфері патентування, особливо з огляду на стрімкий розвиток інформаційного суспільства, яке в розвинених країнах світу передбачає застосування високих технологій, що є основним напрямом економічної стратегії. Мета статті полягає в тому, щоб на основі системного аналізу норм законодавства, позицій вчених-адміністративістів та науковців інтелектуального права, статистичної діяльності суб'єктів публічної адміністрації патентної діяльності, визначити надання адміністративних послуг як інструмент публічного адміністрування патентної діяльності в Україні. В статті розкрито особливості надання адміністративних послуг як інструменту публічного адміністрування патентної діяльності в Україні. Ссоормовано поняття адміністративних послуг у сфері патентної діяльності в Україні як публічно-правових, інструментальних та процедурних послуг суб'єктів публічної адміністрації патентної діяльності, що надаються заявникам в межах правовідносин охорони, забезпечення та реалізації патентних прав з можливістю їх подальшого безперешкодного використання відповідно до законодавства. Розкрито класифікацію адміністративних послуг у сфері патентної діяльності в Україні. В загальному розумінні, патентування $€$ специфічною адміністративною послугою, що надається уповноваженим суб'єктом публічної адміністрації у визначеному законодавством порядку, з метою реєстрації права на визначені об'єкти інтелектуальної власності. Процес патентування супроводжується наданням різних фракультативних адміністративних послуг, пов'язаних з патентною діяльністю. До таких: надання довідок та інших патентних документів; надання копій патентних документів; надання консультацій та практичних рекомендацій; послуги реєстрації; проведення експертизи; патентно-інформаційний пошук; розміщення патентної інформації та інші.

Ключові слова: адміністративно-правове забезпечення, електронне врядування, інструменти, механізм, патент, патентна діяльність, принципи, публічна адміністрація, статус, суб'єкт.

The relevance of the article is that the Constitution of Ukraine guarantees citizens freedom of literary, artistic and scientific creativity, as well as protection of intellectual property and copyrights acquired by citizens in connection with various types of intellectual activity. Unfortunately, there are many cases of infringement of intellectual property rights in Ukraine. However, it should be noted that a large number of such offenses could be avoided or, if committed, the perpetrators could be prosecuted if the owners of intellectual property rights enshrined their rights in the manner prescribed by the legislation of Ukraine. This and other problems should be solved by the system of administrative services in the field of intellectual property, in particular, in the field of patenting, especially given the rapid development of the information society, which in developed countries involves the use of high technology, which is the main economic strategy. The purpose of the article is to determine the provision of administrative services as a tool of public administration of patent activity in Ukraine on the basis of a systematic analysis of legislation, positions of administrative scientists and scholars of intellectual law, statistical activities of public administration of patent activities. The article reveals the peculiarities of providing administrative services as a tool for public administration of patent activity in Ukraine. The concept of administrative services in the field of patent activity in Ukraine as public law, instrumental and procedural services of public administration of patent activity, provided to applicants within the legal relationship of protection, security and implementation of patent rights with the possibility of their further unimpeded use in accordance with law. The classification of administrative services in the field of patent activity in Ukraine is revealed. In a general sense, patenting is a specific administrative service provided by an authorized subject of public administration in the manner prescribed by law, in order to register the right to certain intellectual property. The patenting process is accompanied by the provision of various optional administrative services related to patent activities. These include: provision of certificates and other patent documents; providing copies of patent documents; providing advice and practical recommendations; registration services; examination; patent information search; placement of patent information and others.

Key words: administrative and legal support, e-government, tools, mechanism, patent, patent activity, principles, public administration, status, subject.

Актуальність теми. 3 кожним днем ефективне та поступове реформування України все більше залежить від впровадження в господарську та соціальну сферу якомога більшої кількості об'єктів прав інтелектуальної власності, розвитку та захисту творчого потенціалу українсккого суспільства та його інтелектуального капіталу. Саме тому створення та функціонування якісної системи правової охорони об'єктів прав інтелектуальної власності та прав на їх подальше використання повинно стати одним із найголовніших завдань нашої країни на шляху до євроінтеграції та розвитку економічного потенціалу [3, с. 3].

Основою доктрини адміністративних послуг стала концепція служіння держави людині. Таким чином, на сучасному етапі формування публічних послуг в Україні будуються відносини, за яких громадянин стає споживачем послуг у відносинах із владою, а остання, у свою чергу, в особі публічних суб'єктів повинна орієнтуватися на потреби особи. На жаль, прийняття Закону України «Про адміністративні послуги» не поставило крапку у формуванні нового формату відносин, а недосконалість усієї системи законодавства України взагалі призвела до того, що певна частина позитивних нововведень вказаного Закону взагалі не може бути реалізована на практиці до сьогодні, у тому числі у процесі надання адміністративних послуг у сфері інтелектуальної власності [3, с. 3].

Конституція України гарантує громадянам свободу літературної, художньої та наукової творчості, а також захист інтелектуальної власності та авторських прав, яких набувають громадяни у зв'язку з різними видами інтелектуальної діяльності. На жаль, в Україні спостерігаються непоодинокі випадки порушення прав інтелектуальної власності. Проте варто зазначити, що велику кількість 
таких правопорушень можна було б уникнути або у разі їх скоєння притягнути до відповідальності винних осіб, якби власники інтелектуальних прав закріплювали свої права у встановленому законодавством України порядку. Саме цю та інші проблеми повинна вирішувати система надання адміністративних послуг у сфері інтелектуальної власності, зокрема, у сфері патентування, особливо 3 огляду на стрімкий розвиток інформаційного суспільства, яке в розвинених країнах світу передбачає застосування високих технологій, що є основним напрямом економічної стратегії [3, с. 3].

Огляд останніх досліджень. Проблемні питання патентної діяльності крізь призму адміністративного права досліджували такі вчені, як: Г. Андрощук, В. Бурячок, Є. Валькова, М. Галянтич, С. Головань, І. Запорожець, С. Золота, I. Каплун, О. Коротун, І. Кравченко, К. Куркова, А. Пишна, В. Понікаров, Г. Римарчук, О. Світличний, Д. Смерницький, О. Тандир, С. Юркова та інші. При цьому, комплексних досліджень патентування як об’єкту адміністративного регулювання в Україні, на жаль, замало, що комплексно обгрунтовує актуальність обраної теми статті.

Мета статті полягає в тому, щоб на основі системного аналізу норм законодавства, позицій вчених-адміністративістів та науковців інтелектуального права, статистичної діяльності суб'єктів публічної адміністрації патентної діяльності, визначити надання адміністративних послуг як інструмент публічного адміністрування патентної діяльності в Україні.

Виклад основних положень. Згідно із Законом України «Про адміністративні послуги» від 6 вересня 2012 року № 5203-VI адміністративна послуга - це результат здійснення владних повноважень суб'єктом надання адміністративних послуг за заявою фізичної або юридичної особи, спрямований на набуття, зміну чи припинення прав та/або обов'язків такої особи відповідно до закону [2].

Адміністративні послуги Ю. Камардіна, визначає, що це та частина публічних послуг, які надаються органами виконавчої влади та органами місцевого самоврядування i надання яких пов'язане 3 реалізацією владних повноважень. Цим і відрізняються публічні послуги від адміністративних. Адміністративні послуги також є неконкурентними, оскільки існує лише один орган, що має відповідні повноваження щодо їх надання [4, с. 73-82].

А. Саєнко сформульовано авторське визначення поняття адміністративних послуг у сфері інтелектуальної власності як результату здійснення владних повноважень суб'єктом надання адміністративних послуг за заявою фізичної або юридичної особи, спрямованого на набуття, зміну чи припинення прав та/або обов'язків такої особи відповідно до закону щодо створених нею об'єктів прав інтелектуальної власності та діяльності, пов'язаної з їх подальшим використанням [3, с. 4].

Отже, враховуючи вищенаведені позиції, на наш погляд, адміністративні послуги у сфері патентної діяльності в Україні - це публічно-правові, інструментальні та процедурні послуги суб'єктів публічної адміністрації патентної діяльності, що надаються заявникам в межах правовідносин охорони, забезпечення та реалізації патентних прав 3 можливістю їх подальшого безперешкодного використання відповідно до законодавства.

Відносно особливостей адміністративних послуг як інструментів публічного адміністрування патентної діяльності в Україні, тут варто поєднати і наукові та законодавчі положення. Ю. Камардіна сформувала такі ознаки адміністративної послуги: надається за заявою (зверненням) юридичної або фізичної особи; існує для реалізації суб'єктивних прав конкретної особи; надається адміністративними органами обов'язково через реалізацію владних повноважень; результатом процедури є адміністративний акт (рішення, дія адміністративного органу), який має конкретного адресата - споживача послуги; надається адміністративними органами шляхом реалізації їх владних повноважень; результатом розгляду звернення $\epsilon$ адміністративний акт, що має індивідуальний характер (паспорт, свідоцтво, ліцензія, дозвіл тощо); право на отримання особою конкретної послуги та відповідне повноваження адміністративного органу має визначатися лише чинним законом; послуга, що надається, має бути включена до Реєстру адміністративних послуг із зазначення розміру плати, якщо таку встановлено; контрольна (перевірки, ревізіі, інспектування тощо) та інша дозвільно-розпорядча діяльність адміністративного органу не $\epsilon$ адміністративними послугами [4, с. 73-82].

Адміністративними послугами у сфері інтелектуальної власності є результат здійснення владних повноважень суб'єктом надання адміністративних послуг за заявою фізичної або юридичної особи, спрямований на набуття, зміну чи припинення прав та/або обов'язків такої особи відповідно до закону щодо створених нею об'єктів прав інтелектуальної власності та діяльності, пов'язаної з їх подальшим використанням. Тому до адміністративних послуг у сфері інтелектуальної власності належить та частина діяльності, завдання та функції уповноважених державних органів влади, яка ініціюється суб'єктом звернення та здійснюється шляхом реалізації їхніх владних повноважень, що призводить до набуття, зміни або припинення прав та/або обов'язків, а саме: творця об'єкта інтелектуальної власності стосовно такого об'єкта; фізичних та юридичних осіб, у тому числі суб'єктів господарювання, у разі якщо їхня діяльність пов'язана з використанням певних об'єктів прав інтелектуальної власності або якщо вони представляють інтереси творців таких об'єктів, а також інших, передбачених законом дій, у результаті яких суб'єкту звернення, а також об'єкту, що перебуває в його власності, володінні чи користуванні, надається або підтверджується певний юридичний статус та/або факт [3, с. 11].

Порядок надання адміністративних послуг встановлюється положеннями Закону України «Про адміністративні послуги» від 6 вересня 2012 року № 5203-VI, згідно з яким адміністративні послуги надаються суб'єктами надання адміністративних послуг безпосередньо або через центри надання адміністративних послуг. Адміністративні послуги в електронній формі надаються через Сдиний державний портал адміністративних послуг, у тому числі через інтегровані з ним інформаційні системи державних органів та органів місцевого самоврядування. Порядок та вимоги інтеграції інформаційних систем державних органів та органів місцевого самоврядування з Сдиним державним порталом адміністративних послуг затверджуються центральним органом виконавчої влади, що забезпечує формування державної політики у сфері надання адміністративних послуг, спільно з центральним органом виконавчої влади, що забезпечує формування державної політики у сфері розвитку електронного урядування. Фізична особа, у тому числі фізична особа - підприємець, має право на отримання адміністративної послуги незалежно від реєстрації іiї місця проживання, крім випадків, установлених законом. Юридична особа має право на отримання адміністративної послуги за місцезнаходженням такої особи або у випадках, передбачених законом, за місцем провадження діяльності або місцезнаходженням відповідного об'єкта [2].

Порядок надання адміністративних послуг у сфері патентної діяльності в Україні регулюється не лише спеціалізованим Законом України «Про адміністративні послуги», що $\epsilon$ головною їх особливістю та формує наступні. Адміністративні послуги як інструмент публічного адміністрування патентної діяльності в Україні надаються згідно законодавчих та підзаконних актів адміністративно-правового забезпечення патентної діяльності, що визначають специфіку діяльності суб'єктів публічної адміністрації у цій сфері. 
Також варто зазначити, що за адміністративні послуги у сфері патентної діяльності в Україні обов'язково сплачується плата, що регулюється Порядком сплати зборів за дії, пов'язані з охороною прав на об'єкти інтелектуальної власності, який затверджено постановою Кабінету Міністрів України від 23 грудня 2004 р. № 1716 [1]. Порядок сплати зборів за дії, пов'язані з охороною прав на об'єкти інтелектуальної власності визначає строки і механізм сплати зборів за дії, пов'язані з охороною прав на об'єкти інтелектуальної власності, а також розміри зазначених зборів згідно 3 додатком. Фізичні особи, що постійно проживають за межами України та юридичні особи з місцезнаходженням за межами України можуть сплачувати збори у гривнях, євро чи доларах США за офіційним курсом Національного банку на день сплати збору. Збори сплачуються на поточні рахунки уповноважених Мінекономіки закладів, що входять до державної системи правової охорони інтелектуальної власності. Надходження від зборів мають цільове призначення i в установленому Мінекономіки порядку використовуються виключно для забезпечення розвитку та функціонування державної системи правової охорони інтелектуальної власності, в тому числі на фінансування заходів з легалізації комп'ютерних програм в органах виконавчої влади, наповнення фонду державного стимулювання створення і використання винаходів (корисних моделей), промислових зразків. Інформація про обсяг отриманих та використаних коштів, які надійшли на рахунки закладів як збори, оприлюднюється на офіційних веб-сайтах закладів через Інтернет у режимі реального часу та повинна містити: код збору, вид збору, розмір надходження від збору, розмір витрат за напрямами використання коштів [1].

Тобто, надання адміністративних послуг як інструмент публічного адміністрування патентної діяльності в Україні має платний характер, оскільки за оформлення патентів та подальших факультативних патентних проце- дур особа зобов'язана заплатити певну грошову суму, що стає фінансовою базою правової охорони прав на об'єкти інтелектуальної власності.

Якщо аналізувати класифікацію адміністративних послуг, то згідно 3 реєстром адміністративних послуг та чинних переліків адміністративних послуг, сформованих суб'єктами ix надання у сфері інтелектуальної власності, надається понад два десятка адміністративних послуг, пов'язаних із наданням правової охорони та подальшим використанням об'єктів інтелектуальної власності, котрі належать до промислової власності. А. Саєнко вказує, що більшість адміністративних послуг у сфері інтелектуальної власності, котрі надаються Державною службою інтелектуальної власності України, розподілені лише на дві сфери прав інтелектуальної власності, а саме: промислової власності та авторських і суміжних прав. Проте в рамках цих сфер надаються адміністративні послуги на об'єкти прав інтелектуальної власності, котрі належать до засобів індивідуалізації цивільного обороту, товарів, робіт, послуг та до інших, так званих нетрадиційних результатів інтелектуальної власності; зокрема, у сфері промислової власності надаються адміністративні послуги $з$ надання охоронних документів на знак для товарів і послуг, реєстрацію прав на використання [3, с. 7].

Висновки. В загальному розумінні, патентування $\epsilon$ специфічною адміністративною послугою, що надається уповноваженим суб'єктом публічної адміністрації у визначеному законодавством порядку, з метою реєстрації права на визначені об'єкти інтелектуальної власності. Процес патентування супроводжується наданням різних факультативних адміністративних послуг, пов'язаних з патентною діяльністю. До таких: надання довідок та інших патентних документів; надання копій патентних документів; надання консультацій та практичних рекомендацій; послуги реєстрації; проведення експертизи; патентно-інформаційний пошук; розміщення патентної інформації та інші.

\section{ЛITEPATYPA}

1. Порядок сплати зборів за дії, пов'язані з охороною прав на об'єкти інтелектуальної власності, затверджений постановою Кабінету Міністрів України від 23 грудня 2004 року № 1716. Верховна Рада України: офріційний веб-сайт. 2017. URL: https://zakon.rada.gov.ua/cgi-bin/ laws/main.cgi?nreg=1716\%2D2004\%2D\%EF\&p=1113302200186125\#Text

2. Про адміністративні послуги: Закон України від 06.09.2012 № 5203-VI. Відомості Верховної Ради України. 2013. № 32. Ст. 409.

3. Саєнко А. І. Адміністративні послуги у сфері інтелектуальної власності: автореф. дис. ... канд. юрид. наук : 12.00.07; Запоріз. нац. ун-т. Запоріжжя, 2017. 17 с.

4. Камардіна Ю. В., Ковальов С. В. Сучасні тенденції розвитку сфери адміністративних послуг в Україні. Вісник Маріупольського державного університету. Серія : Право. 2018. Вип. 15. С. 73-82. 


\title{
МЕХАНІЗМ РЕЦЕПЦІї В КОНСТИТУЦЙНОМУ ПРАВІ: ПРОБЛЕМИ КОНЦЕПТУАЛІЗАЦІї ТА ПРАКТИЧНОЇ РЕАЛІЗАЦІї
}

\author{
MECHANISM OF RECEPTION IN CONSTITUTIONAL LAW: \\ PROBLEMS OF CONCEPTUALIZATION AND PRACTICAL IMPLEMENTATION
}

\author{
Верлос Н.В., к.ю.н., доцентка, \\ доцентка кафедри конституційного та трудового права \\ Запорізький наџіональний університет
}

В статті досліджується механізм рецепції в конституційному праві, сформульовано доктринальне визначення поняття, а також здійснюється детальний аналіз та загальна характеристика базових елементів та блоків (компонент) його структури.

Пропонується механізм рецепції в конституційному праві розуміти як системно організоване конституційно-правове явище та процес, що складається із взаємоузгоджених та взаємопов'язаних базових елементів та блоків (компонент) в процесі взаємодії яких здійснюється сприйняття, впровадження та засвоєння зарубіжного конституційно-правового матеріалу (міжнародно-правової норми) переважно для модернізації, розвитку національної системи конституційного права та підвищення ефективності їі функціонування.

Акцентується увага на тому, що структуру механізму рецепції в конституційному праві слід розуміти як універсальну, багаторівневу, збалансовану, системно організовану доктринально-нормативну конструкцію, яка складається із сукупності взаємопов'язаних та взаємодіючих базових елементів та блоків (компонент), які з одного боку характеризуються внутрішньою цілісністю та взаємоузгодженістю, а з іншої диференціацією, відносною відокремленістю та автономністю.

В структурі механізму рецепції в конституційному праві пропонується виділити ряд базових елементів: об'єкти рецепції (доктринальні, нормативні); суб'єкти рецепції (суб'єкт-донор, суб'єкт-реципієнт або транснаціональний суб'єкт), форми рецепції (запозичення, експансія, консенсус) та методи рецепції (метод аксіоматичної інсталяція та метод критичної транссоормації). При цьому усі базові елементи механізму рецепції в конституційному праві можна групувати у такі блоки (компоненти): доктринально-правовий (теоретико-правовий); нормативно-правовий; культурно-правовий (ідеологічний); інституційно-правовий; організаційно-правовий та ін.

У висновку зроблено акцент на тому, що для ефективного функціонування необхідною $є$ взаємодія усіх базових елементів та блоків (компонент) структури механізму рецепції в конституційному праві.

Ключові слова: механізм рецепції в конституційному праві, структура механізму рецепції, об'єкт рецепції, суб'єкт рецепції, форма рецепції, метод рецепції.

The article studies the mechanism of reception constitutional law, formulates the doctrinal definition of the concept and carries out a detailed analysis and general characteristics of basic elements and blocks (components) of its structure.

The author proposes to understand the mechanism of reception in the context of constitutional law as a system-based constitutional legal phenomenon and process, which consists of mutually agreed and interdependent basic elements and blocks (components) during the interoperation of which it is performed perception, introduction and assimilation of foreign constitutional legal material (international legal rule) mainly for modernization, development of the national system of constitutional law and improvement of the effectiveness of its functioning.

The focus is on the fact that the structure of reception mechanism in constitutional law should be considered as a universal, multi-level, balanced, systemic, doctrinal-statutory construction comprising a set of interdependent and coordinated basic elements and blocks (components) which, on the one hand, are characterized by internal integrity and consistency and, on the other hand, by a relative apartness and autonomy.

It is recommended to distinguish a set of basic elements in the structure of reception mechanism: objects of reception (doctrinal, statutory); subjects of reception (donor subject, recipient donor or transnational subject), forms of reception (borrowing, expansion, consensus) and methods of reception (the axiomatic method of installation and the critical transformation method). At the same time, all basic elements of the mechanism of reception in constitutional law can be grouped into the following blocks (components): doctrinal-legal (theoretical legal); statutory legal (ideological); institutional legal, organizational legal etc.

In conclusion, it is emphasized the fact that effective functioning requires the engagement of all the basic elements and blocks (components) of the structure of the mechanism of reception in constitutional law.

Key words: mechanism of reception in constitutional law, structure of mechanism of reception, reception object, reception subject, form of reception, reception method.

Постановка проблеми. В умовах перманентного процесу міждержавної правової взаємодії, а також глобалізації та конвергенції правових систем сучасності концептуалізація розуміння рецепції як конституційно-правового феномену та процесу дедалі набуває актуальності і привертає увагу з боку вчених в усьому світі. Адже для ефективного функціонування будь-кого правового явища необхідною умовою є створення дієвого правового механізму реалізації.

Дослідження механізму рецепції в конституційному праві та розроблення його теоретичної моделі $є$ важливим завданням вітчизняної науки конституційного права особливо в умовах транснаціоналізації (інтернаціоналізації) конституційного права та офіційно визнаного зовнішньополітичного курсу України спрямованого на євроінтеграцію. Вирішення цієї проблеми має не тільки теоретичне, але й практичне значення, оскільки значною мірою саме від ефективної реалізації механізму рецепції залежить функціонування конституційного механізму публічної влади та розвиток конституціоналізму взагалі.
Метою статті $є$ дослідження механізму рецепції в конституційному праві через формулювання його доктринальної дефініції та визначення структури, а також здійснення загальної характеристики базових елементів та виділення окремих блоків (компонент).

Стан дослідження. В сучасній юридичній науці вивченню та концептуальному аналізу механізму рецепції права приділяється незначна увага з боку вчених, більшість 3 них фрагментарно торкались цього питання, а в конституційному праві окреслена проблема взагалі $€$ недослідженою. Проте спроби дослідити механізм рецепції права, визначити його структуру та проаналізувати системний взаємозв'язок структурних елементів здійснювались окремими науковцями, серед яких можна назвати: Г. М. Азнагулову, А. І. Дудко, А. В. Сгорова, 3. П. Мельник, Н. В. Паршкову, О. О. Прієшкіну, В. О. Рибакова, А. В. Скоробогатова, С. В. Ткаченко, Є. О. Харитонова, О. І. Харитонову та ін.

Виклад основного матеріалу. Для обгрунтування важливості та необхідності створення дієвого механізму 
рецепції в конституційному праві, насамперед варто звернутись до етимології та семантики терміну «механізм». У словнику іншомовних слів зазначається, що «механізм»

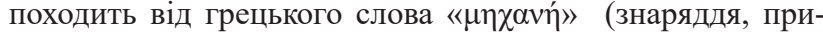
стрій) і має два значення: 1) пристрій (сукупність ланок або деталей), що передає чи перетворює рух; 2) сукупність проміжних станів або процесів будь-яких явищ [1, с. 498]. Більшість словників доповнюють розуміння цього терміну ще одним значенням і вважають, що він може означати також внутрішню будову, систему чогонебудь [2, с. $523 ; 3$, с. $671 ; 4$, с. 251$]$.

Будучи за сутністю технічним термін «механізм» вже давно увійшов до обігу та широко застосовується у гуманітарних науках, зокрема, семантичний аналіз надає змогу визначити, що природу будь-якого механізму складає єдність системи явищ, станів, процесів, яка має відповідну структуру, що визначає певний порядок та ефективність їх функціонування, тому цілком логічним $є$ його використання для дослідження рецепції як феномену та процесу в конституційному праві через визначення об'єктів, суб'єктів, форм та методів сприйняття, впровадження та засвоєння зарубіжного конституційно-правового матеріалу (міжнародно-правової норми) національною системою конституційного права.

Дійсно категорія «механізм» застосовується в різних галузях науки для позначення окремих явищ та процесів. Наприклад, сучасні дослідники в галузі теорії держави і права виділяють такі поняття як «державний механізм (механізм держави)» [5, с. 95-110], «механізм правового регулювання» [6, с. 341-342], «механізм правового впливу» [7, с. 434-438], «механізм державно-правового регулювання» [8, с. 307-310] та ін., а в конституційному праві «конституційний механізм державної влади» [9], «конституційно-правовий механізм забезпечення національної безпеки» [10], «механізм реалізації Конституції України» [11], «механізм забезпечення реалізації конституційних свобод людини і громадянина» [12] та ін.

При цьому в науковому дискурсі немає однозначної доктринальної інтерпретації сутності та змісту як загальнотеоретичного поняття «механізм», так і правової категорії «механізм рецепції права».

Зокрема, механізм рецепції права Є.Ю. Куришев пропонує визначати як систему юридичних засобів, за допомогою яких здійснюється вплив на правову систему держави, що включає об'єктно-суб'єктний, змістовний і методологічний компоненти [13, с. 98].

Інший дослідник А.В. Єгоров під механізмом правової рецепції пропонує розуміти теоретико-нормативну конструкцію за допомогою якої відбувається взаємодія правових систем у формі запозичення доктринальних та інших компонентів правової дійсності шляхом усвідомленого вольового перерозподілу нормативного і правового обсягу між правовими утвореннями різного рівня [14, с. 165$]$. Прієшкіна О.О. вважає механізм рецепції права важливим загальнотеоретичним поняттям, яке дозволяє узагальнити основні джерела і процеси рецепції, побачити їх цілісність і представити в працюючому, динамічному вигляді [15]. Тобто переважно дослідники розглядають механізм рецепції права 3 точки зору динамічної його складової процесу, але статична сторона є не менш важливою, адже відображає внутрішню будову цієї складної системи, окремі елементи якої в процесі взаємодії і утворюють єдине ціле.

Таким чином пропонується механізм рецепції в конституційному праві_розуміти як системно організоване конституційно-правове явище та процес, що складається iз взаємоузгоджених та взаємопов'язаних базових елементів та блоків (компонент) в процесі взаємодії яких здійснюється сприйняття, впровадження та засвоєння зарубіжного конституційно-правового матеріалу (міжнародно-правової норми) для модернізації, розвитку наці- ональної системи конституційного права та підвищення ефективності ії функціонування.

Враховуючи галузеву специфіку конституційного права, вважаємо, що структуру механізму рецепції варто розуміти як універсальну, багаторівневу, збалансовану, системно організовану доктринально-нормативну конституційну модель, яка складається із сукупності взаємопов'язаних та взаємодіючих базових елементів та блоків (компонент), які з одного боку характеризуються внутрішньою цілісністю та взаємоузгодженістю, а 3 іншої диференціацією, відносною відокремленістю та автономністю. Зокрема, пропонується в структурі механізму рецепції виділити ряд базових елементів: об'єкти, суб'єкти, форми та методи. При цьому об'єкти та суб'єкти характеризують статичну сторону, а форми та методи динамічну (процес функціонування).

Об'єкти рецепції в конституційному праві - це різноманітний зарубіжний конституційно-правовий матеріал (міжнародно-правова норма) щодо якого існує потенційна можливість чи необхідність сприйняття, впровадження та засвоєння системою конституційного права для іiї модернізації та розвитку. Тобто, об'єктом рецепції $\epsilon$ будь-який зарубіжний конституційно-правовий матеріал (міжнародно-правова норма) 3 приводу якого суб'єкти здійснюють свою діяльність. Пропонується здійснювати диференціацію об'єктів рецепції в конституційному праві поділяючи їх на дві групи: доктринальні та нормативні.

Доктринальні об'єкти рецепції в конституційному праві представлені різноманітними конституційно-правовими ідеями, аксіологічними засадами, принципами, доктринами, моделями, ученнями, теоріями, конституційно-правовим досвідом та ін., які вироблені у сучасну або історичну епохи зарубіжною наукою, науково-дослідними установами, окремими зарубіжними вченимидослідниками, авторитетними державними чи політичними діячами, інститутами громадянського суспільства. Особливістю доктринальних об'єктів є те, що вони мають необов'язковий характер і можуть застосовуватись для розвитку системи конституційного права лише за бажанням країни-реципієнта.

Вітчизняний процес конституційного будівництва 3 моменту здобуття Україною незалежності відбувався, в тому числі, в процесі рецепції різних доктрин та теорій, наприклад, відповідно до ст. 6 Конституції України «Державна влада в Україні здійснюється на засадах iі поділу на законодавчу, виконавчу та судову» [16], що фактично відповідає теорії поділу влади ідеологами якої, як традиційно вважається, виступають Дж. Локк та Ш. Монтекс'є. Також рецепція ідей зарубіжних мислителів наразі виявились органічно вбудованими в «тіло конституції» і продовжують розвиватись в процесі становлення конституціоналізму, наприклад, ствердження соціальної, правової держави (ст. 1), розвитку форм безпосереднього народовладдя (ст. 69), визнання місцевого самоврядування (ст. 7), забезпечення реалізації прав людини (ст. 3).

Сучасний розвиток конституційного права України відбувається під впливом принципів гуманізму, демократизму, верховенства права, універсальності, унітаризму, соціальної справедливості, децентралізації та ін. вироблених видатними зарубіжними вченими такими як Ж.-Ж. Руссо, Дж. Локк, Т. Гоббс, Ш. Монтекс'є, Т. Джеферсон, М. Вебер, О.Е. Лейст, Д. Гарінгтон, А. Дайсі та ін., рецепція яких в конституційне право також поступово відбувається до сьогоднішнього часу.

На відміну від доктринальних, до нормативних об'єктів рецепції в конституційному праві входять конституційно-правові акти або окремі конституційноправові норми, конституційно-правові інститути, нормативна термінологія, що мають ефективну практику функціонування в зарубіжних країнах, а також до них слід включити міжнародно-правові норми, що реципіюються 
в конституційне право і можуть міститись в деклараціях, резолюціях, рекомендаціях, стандартах, стратегіях тощо.

Специфічною особливістю групи нормативних об'єктів рецепції є те, що до них варто включати і міжнародно-правові норми, адже в умовах глобалізації та транснаціоналізації конституційного права розвиток національної системи конституційного права може відбуватись не тільки за бажанням країни-реципієнта, а й на вимогу, чи за рекомендацією, в тому числі, і міжнародної спільноти.

Наприклад, в процесі розробки Конституції норми основних міжнародних актів до яких приєдналась і Україна (Загальної декларації прав людини [17] Міжнародного пакту про економічні, соціальні і культурні права [18], Міжнародного пакту про громадянські і політичні права [19] та ін.) були взяті за основу та повною мірою увійшли до іiі тексту, а отже фактично відбулась рецепція міжнародних норм в конституційне право України.

Наступним елементом механізму рецепції в конституційному праві є суб'єкти, тобто учасники цього процесу.

Переважно вчені не приділяють належної уваги суб'єктному складу механізму рецепції, хоча це важливе питання, адже саме від нього і залежить ефективність і дієвість його функціонування. Проте, деякі дослідники все ж таки в своїх працях приділяли певну увагу цьому питанню. Зокрема, Є. Ю. Куришев вважає, що суб'єкти рецепції права - це наділені компетенцією рецепіювання на стадіях правотворчого процесу колегіальні органи та (або) фізичні особи, які здійснюють дії по запозиченню елементів іншої правової системи, а система суб'єктів рецепції права за своєю структурою збігається із встановленою в конституції системою правотворчості і правозастосування [13, с. 84, 87]. До цієї позиції приєднується i O.O. Прієшкіна [15].

Інша дослідниця Н. В. Паршкова пропонує виділяти два суб'єкта механізму рецепції права: правового донора (власника правового досвіду) і реципієнта (державу, яка запозичує досвід правового регулювання). При цьому вказує на те, що, на стороні правового донора може виникати множинність, оскільки одночасно може сприйматися досвід правового регулювання декількох держав. Дане положення, на іiі думку, має місце в тих випадках, коли перед реципієнтом виникає необхідність в правовому регулюванні відносин, і він для розробки національного нормативного акту здійснює узагальнення теорії і досвіду іноземних держав [20, с. 13-14].

На думку С.В. Ткаченка, в процесі рецепції приймають участь дві сторони, а суб'єктами, насамперед виступають держави, які він поділяє на країну-донора та країну-реципієнта [21, с. 24]

В конституційному праві А. І. Дудко вважає основними суб'єктами рецепції політичні інститути, серед яких виділяє: державу та громадянське суспільство, політичні партії, громадські організації, групи за інтересами, окремих громадян [22, с. 19].

Узагальнюючи позиції дослідників, можна зазначити, що по-перше, в літературі немає єдності думок щодо особливостей суб'єктного складу механізму рецепції; по-друге, відсутня системність у дослідженні окресленої проблеми; по-третє, з огляду на оновлене розуміння рецепції як конституційно-правового феномену та процесу існує певна специфіка і суб'єктного складу з орієнтацію на внутрішньополітичну та зовнішньополітичну діяльність.

Отже, пропонується суб'єктами рецепції в конституційному праві вважати потенційних учасників механізму рецепції які можуть виступати в якості суб'єкта-донора, суб'єкта-реципієнта конституційно-правового матеріалу (міжнародно-правової норми) або транснаціонального суб'єкта.

Суб'єктами-донорами зазвичай $\epsilon$ держави-донори або міжурядові організації (ООН, ОБСС, СС, НАТО,
ПАРЄ та ін). При цьому держави-донори можуть брати як активну участь у механізмі рецепції, тобто надавати рекомендації, ділитись досвідом або, навіть, наполягати на ії необхідності, так і бути індиферентними до цього процесу. А міжурядові організації завжди не тільки приймають активну участь в механізмі рецепції в якості донора, але можуть й наполягати на здійсненні рецепції та, навіть, контролювати процес її реалізації.

Суб'єктами-реципієнтами є держави-реципієнти, які прагнуть (або зобов’язані) розвивати (чи змінювати) національну систему конституційного права під впливом багатьох соціальних, економічних, політичних, ідеологічних, екологічних та ін. факторів.

Але, в процесі сприйняття, впровадження та засвоєння конституційно-правового матеріалу (міжнародноправової норми) державою-реципієнтом, тим чи іншим чином, можуть брати участь усі суб'єкти конституційних правовідносин. Тому їх пропонуємо визначати як «субдержавні (субнаціональні) суб'єкти рецепції в конституційному праві» та диференціювати за різними підставами: 1) за обсягом конституційної правосуб'єктності: офіційні (органи публічної влади, депутати, парламентські політичні партії та ін.) та неофіційні (народ, громадяни, непарламентські політичні партії, національні меншини, громадські об'єднання, науково-дослідні установи, заклади вищої освіти та ін); 2) за ступенем впливу на механізм рецепції: активні та пасивні та ін.

Окремо в механізмі рецепції у конституційному праві можуть брати участь транснаціональні суб'єкти, які $\epsilon$ відносно незалежними та незацікавленими установами, діяльність яких поширюється на досить велику кількість країн. Вони здійснюють консультативно-дорадчу допомогу в процесі сприйняття зарубіжного досвіду, здійснення конституційних реформ, розвитку демократії та ін., а саме проводять семінари, тренінги, конференції. Переважно вони представлені міжнародними неурядовими організаціями: бюро, фондами, фундаціями, організаціями т.д. (міжнародна фундація виборчих систем (IFES), Freedom House, Європейський фонд демократії (EED) та інші), міжнародними дослідницькими установами (Берлінський центр соціальних наук (WZB Berlin Social Science Center), Центр глобального конституціоналізму (Center for Global Constitutionalism), мережевими громадськими ініціативами (мережа екологічної взаємодії (CEE Bankwatch Network) та ін.

До структурних елементів механізму рецепції в конституційному праві належать також форми та методи. Зокрема, формою рецепції у конституційному праві $€$ зовнішній прояв іiї об'єктивації (існування) у конституційно-правовій дійсності. До основних форм рецепції можна віднести: запозичення, експансію та консенсус. Метод рецепції в конституційному праві - це сукупність способів (прийомів) та засобів сприйняття, впровадження та засвоєння зарубіжного конституційно-правового матеріалу (міжнародно-правової норми) національною системою конституційного права. До них пропонується відносити: метод аксіоматичної інсталяція та метод критичної трансформації.

Концептуалізація уявлення про механізму рецепції в конституційному праві визначає необхідність додаткового групування базових елементів структури у блоки (компоненти), які за своєю сутністю є відносно відокремленими механізмами, але у своїй сукупності утворюють цілісний конституційно-правовий механізм та сприяють підвищенню ефективності його функціонування. А саме пропонується виділяти наступні блоки (компоненти): доктринально-правовий (теоретико-правовий); нормативноправовий;культурно-правовий(ідеологічний);інституційноправовий; організаційно-правовий та інші.

Висновки. Підсумовуючи можна зазначити, що механізм рецепції в конституційному праві є складною багато- 
рівневою конструкцією, яка лише в процесі збалансованої і злагодженої взаємодії усіх частин, а саме базових елементів (об’єктів, суб'єктів, форм, методів) та блоків (доктринальноправового, нормативно-правового, культурно-правового (ідеологічного), інституційно-правового, організаційноправового та ін.) забезпечує ефективне сприйняття, впровадження та засвоєння зарубіжного конституційно-правового матеріалу чи міжнародно-правової норми.

\section{ЛITEPATУРA}

1. Словник іншомовних слів /За ред. О. С. Мельничука. К. : Головна редакція УРЕ, 1974.775 с.

2. Новейший словарь иностранных слов и выражений. Мн.: Современный литератор, 2007. 976 c.

3. Комлев Н.Г. Словарь иностранных слов. М.: ЭКСМО-Пресс, 2000. 1308 с.

4. Лопатин В.В., Лопатина Л.Е. Малый толковый словарь русского языка: М.: Рус. Яз., 1990. 704 с.

5. Матузов Н.И., Малько А.В. Теория государства и права: курс лекций. М.: Юристъ, 1997. 671 с.

6. Хропанюк В.Н. Теория государства и права. Изд. 2-е, доп. и исправ. / Под ред. В.Г. Стрекозова. М.: «Дабахов, Ткачев, Димов», 1995. 378 c.

7. Общая теория государства и права. Академический курс: в 2 т. / Учеб пособ. для вузов. / Отв. ред. М. Н. Марченко; МГУ им. Ломоносова. М.: Зерцало, 2000. Т.2.Теория права. 639 с.

8. Общая теория государства: учебник для юрид. вузов / В. С.Афанасьев, В.В.Лазарев (ред). М.: Юрист, 1994. 366 с.

9. Шатіло В.А. Теоретичні проблеми конституційного механізму державної влади: співвідношення організаційних структур та функцій (вітчизняний і світовий досвід): монографрія. К.: Юридична думка, 2017. 364 с.

10. Чуйко З.Д. Конституційно-правовий механізм забезпечення національної безпеки України. Бюлетень Міністерства юстиції України. 2006. № 8 (58). С. 81-89.

11. Морозюк С. М. Суть механізму реалізації конституції та його співвідношення із суміжними механізмами. Право $і$ суспільство. 2016. №6. C. 3-8.

12. Олійник А.Ю. Конституційно-правовий механізм забезпечення основних свобод людини і громадянина: монографія. К.: Алерта, КНТ, Центр навчальної літератури, 2008. 472 с.

13. Курышев Е.Ю. Рецепция в российском праве. дисс. канд. юрид. наук. 12.00 .01 - теория и история права и государства; история учений о праве и государстве. Саратов, 2005. 194 с.

14. Егоров А.В. Сравнительное правоведение и правовая рецепция. Вестник Полоцкого государственного университета. Серия D. Экономические и юридические науки. 2013. №6. С.164-167.

15. Приешкина Е.А. Категория рецепции в современной юридической литературе. Актуальные инновационные исследования: наука и практика: электронное научное издание. 2011. № 4. URL:http://www .actualresearch . ru/nn/2011_4/Article/index.htm

16. Конституція України від 28.06.1996 p. URL:https://zakon.rada.gov.ua/laws/show/254к/96-вp\#Text

17. Загальна декларація прав людини від 10.12.1948 p. URL:https://zakon.rada.gov.ua/laws/show/995 015\#Text

18. Міжнародний пакт про економічні, соціальні і культурні права 16.12.1966 p. URL:https://zakon.rada.gov.ua/laws/show/995_042\#Text

19. Міжнародний пакт про громадянські і політичні права від 16.12.1966 p. URL:https://zakon.rada.gov.ua/laws/show/995_043\#Text

20. Паршкова Н.В. Определение преемственности в рецепции права: общетеоретический аспект. Современная юриспруденция: тенденции развития»: материалы международной заочной научно-практической конфреренции. (10 января 2012 е.). Новосибирск: Изд. «ЭКОРкнига», 2012. С.11-14.

21. Ткаченко С.В. Идеологический компонент рецепции права. Юридические записки. 2014. №2. С.21-27.

22. Дудко А.И. Рецепция в конституционном праве России: автореф. дисс. канд. юрид. наук: спец. 12.00 .02 «конституционное право; муниципальное право». Челябинск, 2010. 26 с. 


\title{
СУЧАСНА ДОКТРИНА КАДРОВОГО ЗАБЕЗПЕЧЕННЯ НАЦІОНАЛЬНОЇ ПОЛЩІЇ УКРАЇНИ
}

\author{
MODERN DOCTRINE OF HUMAN RESOURCING \\ OF THE NATIONAL POLICE OF UKRAINE
}

\author{
кандидат юридичних наук, старший викладач кафедри адміністративного права
}

ПрАТ «ВНЗ «Міжрегіональна Академія управління персоналом»

\begin{abstract}
Стаття присвячена з'ясування змісту сучасної доктрини кадрового забезпечення Національної поліції. Звертається увага на те, що процес реформ, що відбуваються в органах поліції, інтеграція у Європейський Союз вимагає впровадження сучасної кадрової політики, нових методів та методик в сфері управління кадрами та роботи з ними. Сучасна кадрова політика потребує чіткого регулювання процесу відбору кадрів, їх навчання, оцінки, впровадження нового механізму кадрового забезпечення органів поліції, спрямованого на відбір до поліції високопрофесійного персоналу здатного ефективно виконувати поставлені перед органами поліції завдання. Тому гостро постає питання запровадження оновленої системи кадрового забезпечення органів поліції, яка повинна відповідати сучасним рефрормам, які відбуваються в правоохоронній сфері та потребам органів поліції у високопрофесійних кадрах, здатних працювати по-новому, в умовах реформ.

Обґрунтовується, що досягнення очікуваного результату потребує подолання таких викликів, як: руйнування професійного ядра, неукомплектованість персоналом органів системи МBC; відсутність ефективної та сучасної системи підготовки, відбору та управління персоналом, прозорих механізмів кар'єрного зростання; відсутність належної системи соціального захисту, професійного зростання та мотивації працівників органів системи МВС, низький рівень ініціативності працівників та їх вразливість до корупційних ризиків; відмінність категорій працівників різних органів системи MBC, що обумовлює необхідність вироблення спеціального підходу до управління персоналом, відсутність налагодженої системи внутрішніх комунікацій.

Робиться висновок, що на сучасному етапі реформ в Національній поліції питання організації їі кадрового забезпечення відіграє ключову роль з точки зору ефективності діяльності органів поліції, її дієвості як правоохоронного органу, який захищає суспільство шляхом охорони прав і свобод суспільства, протидії злочинності та підтримання публічної безпеки та порядку.

Ключові слова: поліція, політика, кадрова політика, реформи , доктрина, забезпечення.
\end{abstract}

The article is devoted to clarifying the content of the modern doctrine of staffing of the National Police. Attention is drawn to the fact that the process of reforms taking place in the police, integration into the European Union requires the introduction of modern personnel policy, new methods and techniques in the field of personnel management and work with them. Modern personnel policy requires clear regulation of the process of personnel selection, training, evaluation, implementation of a new mechanism for staffing the police, aimed at selecting highly professional staff capable of effectively performing the tasks assigned to the police. Therefore, the issue of introducing an updated system of staffing of police bodies is acute, which should meet modern reforms in law enforcement and the needs of police forces in highly professional staff capable of working in a new way, in the context of reforms.

It is substantiated that the achievement of the expected result requires overcoming such challenges as: destruction of the professional core, understaffing of the system of the Ministry of Internal Affairs; lack of an effective and modern system of training, selection and management of personnel, transparent mechanisms for career growth; lack of a proper system of social protection, professional growth and motivation of employees of the Ministry of Internal Affairs, low level of initiative of employees and their vulnerability to corruption risks; the difference between the categories of employees of different bodies of the system of the Ministry of Internal Affairs, which necessitates the development of a special approach to personnel management, the lack of an established system of internal communications.

It is concluded that at the current stage of reforms in the National Police the issue of its staffing plays a key role in terms of police efficiency, its effectiveness as a law enforcement agency that protects society by protecting the rights and freedoms of society, combating crime and maintaining public safety and order.

Key words: police, policy, personnel policy, reforms, doctrine, provision.

Актуальність теми. Процес реформ, що відбуваються в органах поліції, інтеграція у Європейський Союз вимагає впровадження сучасної кадрової політики, нових методів та методик в сфері управління кадрами та роботи 3 ними. Сучасна кадрова політика потребує чіткого регулювання процесу відбору кадрів, їх навчання, оцінки, впровадження нового механізму кадрового забезпечення органів поліції, спрямованого на відбір до поліції високопрофесійного персоналу здатного ефективно виконувати поставлені перед органами поліції завдання. Тому гостро постає питання запровадження оновленої системи кадрового забезпечення органів поліції, яка повинна відповідати сучасним реформам, які відбуваються в правоохоронній сфері та потребам органів поліції у високопрофесійних кадрах, здатних працювати по-новому, в умовах реформ.

Стан наукових досліджень. Питання кадрового забезпечення Національної поліції привертали увагу багатьох вчених. Серед останніх можна виділити праці таких науковців, як О.М. Бандурка, О.К. Безсмертний, В.М. Бурденюк, С.М. Гусаров, М.П. Гурковський, О.В. Ковальов, А.Т. Комзюк, С.Л. Курило, Р.С. Мельник, О.М. Музичук, О.С. Проневич, О.П. Рябченко, В.В. Сокуренко, B.В. Чумак, В.I. Шамрай та деякі інші. Наукові праці вка- заних дослідників безумовно мають теоретичне та практичне значення, однак, враховуючи умови сьогодення, необхідно переглянути концептуальні підходи до розуміння сутності сучасної доктрини кадрового забезпечення Національної поліції України.

Метою статті $\epsilon$ з'ясування змісту сучасної доктрини кадрового забезпечення Національної поліції.

Викладення основного матеріалу. Відповідно до пункту 5 статті 13 Закону України «Про Національну поліцію» загальна чисельність поліції, що утримується за рахунок коштів Державного бюджету України, до 01 січня 2018 року не може перевищувати 140 тисяч осіб. У відповіді Департаменту кадрового забезпечення Національної поліції на інформаційний запит Укрінформу зазначається, що Загальний некомплект поліцейських станом на 20 січня 2020 року $-17,1 \%$ осіб (станом на 1 червня 2019 року в Національній поліції налічувалося 19,4 тисячі вакансій - некомплект становив 15,3\%). Найвищий рівень некомплекту, згідно з повідомленням, у Черкаській області - 22,3\% і у Донецькій області - 20,6\%; найнижчий - в Івано-Франківській області - 9\% і у Чернівецькій області - 9,5\%. У свою чергу некомплект поліцейських у Києві - на рівні 16,8\%, у Київській області - 18\%; у Чер- 
нігівській і Одеській областях - на рівні 10,3\%; у Хмельницькій - 12,9\%; у Херсонській - 13,2\%, у Харківській, Вінницькій і Полтавській - на рівні 12,5\%. У Тернопільській області некомплект поліцейських становить 12,3\%; у Сумській області - 11,5\%; у Рівненській - 10,1\%; у кримській поліції - 15,9\% [1].

Загальний рівень некомплекту патрульних поліцейських по Україні становить 26,1\%. Найвищий рівень некомплекту патрульних - у Запорізькій області - 50,1 \%; найменший некомплект - у Харківській області - 13,7 \% [2].

Такий некомплект поліції гальмує не тільки реалізацію iii органами реформ, але й впливає на стан протидії злочинності та правопорушенням у країні.

Причинами проблем комплектування підрозділів Національної поліції можна назвати:

1) передчасний та неякісний відбір кандидатів на вакантні посади в підрозділах патрульної поліції у 2015 році спричинив відтік кадрів та некомплект підрозділів у 2017 році;

2) у тексті закону та інших нормативно-правових актів законодавцем недостатньо роз'яснено, в чому полягає комплектування підрозділів Національної поліції, та неоднозначно визначені поняття «добір на посаду», «призначення на посаду поліцейського», «штатний розпис (штат)», «штатна посада», «комплектування в порядку просування по службі»;

3) невизначеність напряму реформування вищих навчальних закладів зі специфічними умовами навчання, що здійснюють підготовку поліцейських, та їхньої ролі в комплектуванні підрозділів Національної поліції $[3$, c. 70$]$.

Наприклад, В. А. Ліпницький зазначає вважає, що проблеми набору поліцейських в умовах реформування МВС, полягають у такому :

1) передчасний та неякісний відбір кандидатів на вакантні посади в підрозділах патрульної служби МВС України;

2) непрозорість застосування системи відбору кадрів на службу до реформованих підрозділів ОВС;

3) у тексті закону та інших нормативно-правових актів законодавцем не роз'яснено, в чому полягає і в яких діях повинно проявлятися «партнерство» поліції і населення;

4) соціальна і правова незахищеність працівників поліцiї [4; с. 35-37].

Також в карай негативно впливає на стан розкриття та розслідування злочинів несвоєчасне заміщення вакантних посад керівників органів поліції. Дуже часто ці посади заміщуються працівниками, які не мають досвіду необхідного роботи як в органах поліції в цілому, так і на керівних посадах. Кожен другий має вік до 30-ти років, а кожен п’ятий - вислугу до 3 -х років.

3 цього приводу I.C. Кравченко вважає, що проблемними питаннями кадрових процедур в поліції $\epsilon$ те що послідовність етапів конкурсних випробувань та їх зміст може змінюватись залежно від посади, на яку оголошується конкурс. Крім того, передбачений конкурс $\epsilon$ обов'язковим лише для посад молодшого складу Національної поліції, а призначення на посади середнього та вищого складу й надалі відбуватиметься за «старою» схемою - на розсуд керівництва, тобто не є обов'язковим. Жодних конкурсних процедур та контролю громадськості не передбачено й щодо ротації кадрів. Не запланована учать поліцейських комісій і в процесі прийому на навчання до вищих навчальних закладів, які здійснюють підготовку поліцейських [3, с. 71].

Отже, сьогодні кадрове забезпечення органів поліції не $є$ задовільним, що має свій вияв у недостатньому професіоналізмі працівників поліції та високій плинності кадрів, зростанні кількості звільнених за негативними мотивами.

Поряд 3 цим, питанням кадрового забезпечення органів Національної поліції постійно приділяється значна увага з боку держави, що має всій вияв у відповідних стратегічних документах.

Зокрема, у Концепції першочергових заходів реформування системи Міністерства внутрішніх справ, затвердженої Постановою Кабінету Міністрів України від 22.10.2014 №1118-p, наголошується на необхідності сформованості стабільного та високопрофесійного кадрового складу органів Національної поліції, який здатний належно реагувати на виклики та загрози у сфері внутрішніх справ. Водночас відзначаються певні недоліки щодо кадрового забезпечення органів Національної поліції, серед яких: вимивання професійного ядра і некомплект персоналу органів поліції; відсутність ефективної та сучасної системи підготовки, відбору та управління персоналом, прозорих механізмів кар'єрного зростання; відсутність належної системи соціального захисту, професійного зростання та мотивації працівників системи МВС, низька ініціативність персоналу і його вразливість до корупційних ризиків; відмінність категорій працівників, що зумовлює необхідність вироблення спеціальних підходів в управлінні персоналом, відсутність налагодженої системи внутрішніх комунікації [5].

Крім того, цей програмний документ визначає напрями кадрового забезпечення Національної поліції, а саме:

1) Створення нових якісних критеріїв відбору кандидатів на службу. Це передбачає те, що поряд із фізичними якостями кандидата оцінюються його розумові здібності; вміння будувати та підтримувати робочі взаємовідносини; упевненість у власних силах, уміння спілкуватися; уміння працювати в групі.

2) Оновлення механізму процедур відбору кандидатів на службу. Усі вакансії підлягають оголошенню серед персоналу з одночасним створенням умов для безперешкодного доступу кандидатів до участі в конкурсному відборі, а етапи проходження іспитів фіксуються на відео носіях в присутності представників громадськості.

3) Удосконалення організаційно-функціональних аспектів діяльності кадрових і екзаменаційних комісій. До складу кадрових та екзаменаційних комісій, що оцінюють кандидатів на посади керівників регіонального та національного рівнів, в обов'язковому порядку входять представники місцевої громади, неурядових організацій, органів місцевого самоврядування.

4) Забезпечення високого рівня матеріального та соціального забезпечення працівників поліції. Це досягається за рахунок забезпечення персоналу системи Міністерства внутрішніх справ України високою заробітною платою та соціальними пільгами.

5) Створення корпоративної етики та утвердження морально-етичних цінностей. Міністерство внутрішніх справ України повинне створити систему корпоративної етики та протидії професійній деформації, надаючи обов'язкову та регулярну психологічну допомогу персоналу $з$ метою запобігання негативним явищам, а також безконфліктної реалізації особистих, корпоративних та державних інтересів. Основними етичними засадами правоохоронної діяльності виступають повага до особистості іншої людини, професіоналізм, дотримання принципів законності і верховенства права, відповідальність, чесність по відношенню до себе та інших, самовіддане служіння суспільству

6) Впровадження дієвої системи наставництва, коли за кожним працівником поліції, щойно призначеним на посаду,закріплюється наставник 3 числа досвідченнях працівників органів поліції. Т.В. Колісник зазначає наступне: досвід викладання кількох дисциплін в різних регіонах України загалом близько півтисячі слухачів в рамках навчання нової державної патрульної служби показує, що в аудиторії відчувається суттєва різниця у професійних навичках і досвіді між поліцейськими, які пройшли атестацію і підвищують свою кваліфікацію та новачками. 
Хоча, досвід, на відміну від теоретичних і практичних навичок, несила передати або набути за стислий термін навчання, тому після успішного закінчення теоретичних і практичних занять поліцейські не в змозі одразу впевнено нести службу. Вони повинні ужитися в новій роботі, колективі, субординації, незвичного робочого розпорядку, особливостей психології спілкування із потерпілими і правопорушниками.

7) Здійснення внутрішнього контролю за працівниками органу поліції, що включає відеоспостереження за персоналом протягом робочого часу, періодичні перевірки щодо професійної непідкупності.

8) Висока професійна підготовка поліцейських, яка передбачає: проходження первинної професійної підготовки; підготовку кадрів у вищих навчальних закладах із специфічними умовами навчання; отримання післядипломної освіти; проведення службової підготовки - системи заходів, спрямованих на закріплення та оновлення необхідних знань, умінь та навичок працівника поліції з урахуванням оперативної обстановки, специфіки та профілю його оперативно-службової діяльності (ч. 1 ст. 72 Закону України «Про Національну поліцію») [6, c. 48-49].

Наприклад, у Стратегії розвитку органів системи Міністерства внутрішніх справ до 2020 року питання кадрової політики також отримали своє відображення. Так, одним із стратегічних пріоритетів розвитку органів системи МВС визначено розвиток кадрового потенціалу та соціальний захист працівників.

Досягнення очікуваного результату потребує подолання таких викликів, як:

руйнування професійного ядра, неукомплектованість персоналом органів системи МВС;

відсутність ефективної та сучасної системи підготовки, відбору та управління персоналом, прозорих механізмів кар'єрного зростання;

відсутність належної системи соціального захисту, професійного зростання та мотивації працівників органів системи МВС, низький рівень ініціативності працівників та їх вразливість до корупційних ризиків;

відмінність категорій працівників різних органів системи МВС, що обумовлює необхідність вироблення спеціального підходу до управління персоналом, відсутність налагодженої системи внутрішніх комунікацій.
Так, у Стратегії державної кадрової політики на 2012-2020 роки, затвердженої указом Президента України, визначено, що метою державної кадрової політики $€$ забезпечення всіх сфер життєдіяльності держави висококваліфікованими кадрами, необхідними для реалізації інтересів у контексті розвитку України як демократичної, соціальної держави з розвиненою економікою [7].

В Стратегії також наголошується на необхідності: посилення вимог до моральних якостей осіб, які залучаються до управлінської діяльності, 3 метою уникнення можливих проявів корупції, запобігання виникненню конфлікту інтересів, удосконалення процедури дисциплінарного провадження; розроблення механізмів залучення до роботи у сферах державного управління висококваліфікованих фахівців, здібних випускників вищих навчальних закладів; відновлення технології добору кадрів для зайняття управлінських посад із числа працівників, що мають досвід роботи на посадах нижчого рівня у відповідній сфері діяльності; формування дієвого кадрового резерву на зайняття керівних посад у сферах державного управління тощо [8].

У Концепції розвитку сектору безпеки та оборони також вказується на необхідність реформування системи відбору на службу та професійної підготовки працівників Національної поліції України; запровадити нові стандарти фізичної та вогневої підготовки персоналу; запровадити нові критерії оцінки ефективності роботи Міністерства внутрішніх справ України; завершити основний перерозподіл та скорочення чисельності персоналу з урахуванням європейських практик [9].

Прийняття таких стратегічних документів говорить про те, що основа будь-яких реформ має базуватися на роботі з кадрами, їх підготовці, навчання, підвищення кваліфікації та професіоналізму, впровадження і розвитку нових вмінь та навичок. Це здійснюється для того, щоб працівники та їх кваліфікаційні здібності відповідали сучасним потребам, інформаціно-технічним особливостям розвитку суспільства.

Висновки. Отже, на сучасному етапі реформ в Національній поліції питання організації іiі кадрового забезпечення відіграє ключову роль з точки зору ефективності діяльності органів поліції, іiі дієвості як правоохоронного органу, який захищає суспільство шляхом охорони прав і свобод суспільства, протидії злочинності та підтримання публічної безпеки та порядку.

\section{ЛITEPATYPA}

1. Некомплект поліцейських. https://www.ukrinform.ua/rubric-society/2859088-nekomplekt-policejskih-v-ukraini-stanovit-171.html

2. Укрінфоорм. Патрульна поліція не укомплектована на $26 \%$ https://www.ukrinform.ua/rubric-society/2859659-patrulnapolicia-nedoukomlektovana-na-26.html

3. Кравченко І.С. Правові засади реалізації кадрової політики Національної поліції України. Підприємництво, господарство і право. № 1. 2018. с. 68-72.

4. Ліпницький В. А. Деякі правові проблеми підготовки поліцейських в умовах реформування системи МВС України / В. А. Ліпницький // Осо-бливості підготовки поліцейських в умовах ресор-мування системи МВС України : зб. матеріалів I міжнар. наук.-практ. конф., м. Харків, 20 трав. 2016 р. ; Харків. нац. ун-т внутр. справ. - Харків : ХНУВС, 2016. - 175 с.

5. Стратегія розвитку органів внутрішніх справ України : розпорядженням Кабінету Мініс-трів України від 22.10 .2014 p. No 1118-p. URL: https://www.google. com.ua/url?sa=t\&rct=j\&q=\&esrc=s\&source=web\&cd=1\&cad=rja\&u act=8\&ved=0ahUKEwjpmKvG073WAh WzZpoKHb7BDtMQFggmMA A\&url=http\%3A\%2F\%2Fwww.kmu.gov.ua\%2Fdocument\%2F2477 80692\%2FR01118-00.doc\&usg=AFQjCNFg7Xys52snHk04KTJHyL De7GZQ.

6. Іваниця А.В. Завдання, напрями та принципи кадрової політики в органах поліції України. Науковий вісник Дніпропетровського державного університету внутрішніх справ. №2.2010. с. 47-52

7. Про Стратегію державної кадрової політи-ки на 2012-2020 роки : Указ Президент України від 01.02.2012 № 45/2012 [Електронний ресурс]. - Ре-жим доступу : http ://zakon.rada.gov.ua/go/45/2012

8. Про Стратегію державної кадрової політи-ки на 2012-2020 роки : Указ Президент України від 01.02.2012 № 45/2012 [Електронний ресурс]. - Ре-жим доступу : http ://zakon.rada.gov.ua/go/45/2012

9. Про рішення ради національної безпеки і оборони України від 4 березня 2016 року "про концепцію розвитку сектору безпеки і оборони України". Указ Президента України від 14 березня 2016 року № 92/2016 https://zakon.rada.gov.ua/laws/show/92/2016\#Text 


\title{
ПРО ЗМІСТ ГЛОБАЛЬНИХ СТАНДАРТІВ АДМІНІСТРАТИВНИХ ПРОВАДЖЕНЬ
}

\section{ON THE ESSENCE OF GLOBAL STANDARDS OF ADMINISTRATIVE PROCEEDINGS}

\author{
Малетич М.М. \\ кандидат юридичних наук
}

У статті розглянуто актуальні проблеми формування, вивчення, застосування основних глобальних стандартів адміністративних проваджень, розглянуто специфіку їх формування на глобальному рівні та практику реалізації на національному рівні. Визначено, що вивчення змісту глобальних стандартів адміністративних проваджень має важливе значення для української науки та доктрини адміністративного права через значне відставання та не сформованість національного адміністративно-процедурного законодавства, невідповідність правозастосовної практики сучасним стандартам участі, прозорості, верховенства права, що необхідно для інтенсифікації торгівлі та руху послуг між країнами світу.

Розглянуто основний перелік глобальних стандартів адміністративних проваджень, охарактеризовано специфіку їх погодження та виконання державами з метою підтримання міжнародного авторитету впливових транснаціональних корпорацій, отримання додаткових можливостей в отриманні для національної держави прерогатив, що пов'язуються з розподілом ресурсів, продуктів, лікарських засобів на глобальному рівні.

Автором зроблено висновок про те, що поступове впровадження глобальних стандартів адміністративних проваджень має важливе значення не тільки для розвитку вітчизняної доктрини з урахуванням європейського досвіду, але й для інтенсифікації євроінтеграційних процесів, забезпечення доступності української публічної адміністрації функціонально та компетенційно для великої кількості європейських фізичних та юридичних осіб, які бажають увійти на український ринок, проте не довіряють національним стандартам ведення адміністративної діяльності.

Ключові слова: транснаціональна адміністрація, адміністративний орган, стандарт, глобальне адміністративне право, адміністративне право, адміністративні послуги, прозорість, участь, верховенство права.

In this article author's reviewed actual issues of development, lecturing and application of the main global standards of administrative proceedings, as well as considered specifics of it's development at global level and practice of their realization at national level. It was concluded, that research of the essence of global standards of administrative proceedings plays important role for Ukrainian science and doctrine of administrative law because of significant gap in development of the national administrative procedural legislation, misleading in realization of law-enforcement practice to modern standards of participation, transparency, rule of law, that is necessary for intensification of trade and services between countries of the world.

Author's explained the essence of the main global standards of administrative proceedings, characterized specific of their approval and enforcement by the states with the aim to contribute to international authority of influencing international corporations, providing additional possibilities for additional prerogatives for the state, connected with distribution of resources, products, medicines at global level.

Conclusions on further implementation of global standards of administrative proceedings have been made, that has significant value not only for development of the national doctrine with respect to European experience, but also for intensification of European integration process, providing accessibility of Ukrainian public administration both through functions and competence capacities to act for a huge number of European physical and legal persons.

Key words: transnational administration, administrative body, standard, global administrative law, administrative law, administrative services, participation, transparency, rule of law.

Актуальність вивчення змісту та характеристика глобальних стандартів адміністративних проваджень набуває особливого значення для української науки та доктрини адміністративного права через не сформованість власного адміністративно-процедурного законодавства, значне запізнення право-творчої практики у формуванні національних процесуальних стандартів 3 урахуванням сучасних глобальних стандартів - належної процедури, верхо-венства права, скасовності адміністративних актів, забезпечення принципу участі та прозорості.

Означений перелік глобальних стандартів для національних адміністративних проваджень не є зафіксованим на законодавчому рівні, а переважно їх дотримання забезпечується шляхом можливості оскарження через європейських конвенційний механізм захисту прав людини. На мій погляд, поступове впровадження означених стандартів має важливе значення не тільки для розвитку вітчизняної доктрини з урахуванням європейського досвіду, але й для інтенсифікації євроінтеграційних процесів, забезпечення доступності української публічної адміністрації функціонально та компетенційно для великої кількості європейських фізичних та юридичних осіб, які бажають увійти на український ринок, проте не довіряють національним стандартам ведення адміністративної діяльності.

Метою даної статті є розгляд змісту ключових стандартів глобального рівня, що застосовуються в європейському та міжнародному праві для регулювання різних видів адміністративної діяльності та стандартизовані у вигляді ключових вимог, що можуть застосовуватися до спірних та безспірних адміністративних проваджень. Завданнями даної статті є висвітлення змісту глобальних стандартів адміністративних проваджень та їх взаємозв'язку з європейськими та національними стандартами адміністративної діяльності, практикою Європейського суду з прав людини щодо перегляду рішень адміністративних органів.

Концептуальні засади формування сучасних європейських та глобальних стандартів в сфері реалізації компетенції адміністративних органів та позиції «людиноцентристської концепції» були обгрунтовані у працях В.Б. Авер'янова, Ю.П. Битяка, І.П. Голосніченка, І.А. Грицяка, Т.О. Губанової П.В. Діхтієвського, Р.А. Калюжного, М.I. Козюбри, Т.О. Коломоєць, В.К. Колпакова, Р.О. Куйбіди, Д.М. Лук'янця, В.П. Перепелюка, О.О. Соколенко, A.M. Школика та низки інших. Проте зміст та характеристика глобальних стандартів адміністративних проваджень залишилися по-за увагою вітчизняних вчених з огляду на відсутність доступних джерел українською мовою та відсутність монографічної літератури з даного питання.

Оскільки в європейських країнах адміністративне право вважається виключно державним правом, вимоги щодо здійснення адміністративної діяльності переважною мірою формуються урядом та парламентом, в залежності від розподілу функцій та повноважень в діючій формі державного правління. Проте, глобальні інструменти впливу на формування національних політик дедалі більшою мірою отримують підтримку національних урядів та пар- 
ламентів з огляду на важливість отримання цінностей першочергового порядку, розподіл яких, як і продовольчих ресурсів, вакцин та інших лікарських засобів, здійснюється на глобальному рівні.

Тому важливо забезпечити не тільки розуміння значення, змісту глобальних стандартів та їх правильного застосування в сучасній правотворчій та правозастосовній діяльності органів державної влади в Україні з метою поступового ведення основних процесуальних стандартів як невід'ємної складової конституційно- та законодавчо закріплених вимог щодо належного процесу, спільного регуляторного режиму, дотримання верховенства права, правил судового перегляду з метою забезпечення справедливого розгляду адміністративним справ та захисту порушених суб'єктивних прав людини.

«Формування глобального адміністративного права обумовило розвиток новітніх підходів до формування глобальних політик, виникнення нових суб'єктів глобального рівня, які мають вирішальний вплив на прийняття управлінських рішень на національному рівні, тому врахування вироблених суб'єктами глобального адміністративного права підходів до трансформації публічної адміністрації, правових форм їх діяльності, у т.ч. щодо взаємодії з приватними особами, потребує зваженого врахування з урахуванням збереження національних адміністративних традицій та удосконалення урядування» [1].

Вивчення змісту глобальних стандартів для національних проваджень здійснюється у вищих навчальних юридичних закладах України з метою набути знання про зміст, основні види, значення судових адміністративних проваджень, мінімальні стандарти захисту прав людини в адміністративному, кримінальному судочинстві, європейських адміністративних провадженнях; сприяння розвитку здатності студентів інтегрувати український та європейський досвід функціонування адміністративного судочинства, судового перегляду незаконних актів публічної адміністрації, застосування судової практики Європейського суду з прав людини; вміння формулювати, порівнювати істотні ознаки ключових дефініцій стосовно адміністративного процесу та його елементів, класифікувати європейські адміністративні провадження [2], брати безпосередню участь в спірних адміністративних провадженнях; формулювати пропозиції та рекомендації щодо захисту порушених прав людини в сфері виконавчої влади за допомогою національного, європейського конвенційного механізму. Вивченню глобальних стандартів адміністративної діяльності має перебувати роз'яснення доктринального розуміння природи і сутності адміністративного процесу, процесуальних прав та обов'язків сторін, видів судових рішень, порядку їх оскарження засобами адміністративного судочинства отримані в результаті вивчення дисципліни «Адміністративне судочинство»; володіння навичками сприйняття та аналізу положень про судові адміністративні провадження, судову реформу, діяльність адміністративних судів, Європейського суду з прав людини, а також навички перекладу, пояснення змісту ключових дефініцій англійською мовою в порівняльноправовому аспекті.

Глобальні стандарти адміністративних проваджень $\epsilon$ складовою вивчення навчальної дисципліни «Актуальні проблеми процесуального права» в магістратурі вищих навчальних юридичних закладів, при вивченні якої у порівняльно-правовому аспекті розкриваються: загальна характеристика адміністративного процесу, його елементів, змісту та видів судових адміністративних проваджень; мінімальні стандарти захисту прав людини в сфері виконавчої влади засобами адміністративного судочинства, ïx порівняння 3 цивільними та кримінальними провадженнями; процесуальні права, обов'язки сторін судових адміністративних проваджень, розвиток їх розуміння в процесуальному законодавстві; право на справедливий суд, доктрина належного процесу, електронне правосуддя [3]; особливості некримінальних проваджень; спрощені судові процедури.

Переходячи до розгляду змісту глобальних стандартів адміністративних проваджень, слід зазначити, що принцип верховенства права вже достатньо повною мірою охарактеризований у дослідженнях вітчизняних вчених і дослідників, його значення важно недооцінити для становлення сучасного правового механізму реалізації та захисту прав людини. У працях А.А. Пухтецької дістав обгрунтування «розвиток підходів щодо нормативного закріплення в актах законодавства країн Свропейського Союзу вимог щодо матеріальних та процедурних стандартів діяльності органів публічної адміністрації, вироблених європейською адміністративно-правовою доктриною. Розкрито розуміння змісту та співвідношення принципу верховенства права та принципу законності, обгрунтовано їх місце в правовій системі, системоутворююче, основоположне значення для фундаментальної галузі адміністративного права, специфіку тлумачення їх вимог з урахуванням судової практики Європейського суду з прав людини» [4].

На думку європейських дослідників глобальні стандарти адміністративних проваджень формуються централізовано, з урахуванням переважно інтересів міжнародних, транснаціональних корпорацій, їх бізнесових інтересів, які об'єднують континенти та підвищують могутність окремих країн в міжурядовій співпраці, тим самим надаючи їм додаткові можливості для розвитку та захисту населення від викликів тисячоліття.

У проаналізованих наукових працях зарубіжних вчених С. Батіні, Ф. Бігнамі, А. Богданді, С. Касіса, Н. Кірша, П. Піконе, М. Фромонта, Ю. Шварце та багатьох інших вчених встановлені важливі правила формування обов'язкових стандартів, що отримують імперативний вплив на вертикальну та горизонтальну взаємодію адміністративних органів національного, регіонального та наднаціонального рівнів. У їх працях описані приклади європейських вертикальних та горизонтальних адміністративних проваджень, специфічних за своїм змістом, спрямованістю та особливостями суб'єктного складу учасників аналізованих адміністративних проваджень [2].

Згадані правила формування глобальних стандартів адміністративних проваджень також обгрунтовані в працях С. Касіса, який зазначив, що національні адміністрації діють відповідно до конституції та законів країни, а стандарти глобального рівня виконуються ними завдяки високому авторитету міжнародних, європейських регіональних організацій, які, хоча і не є державними органами, проте завдяки досягнутим компромісам, домовленостям на глобальному рівні забезпечують можливість та доцільність виконання на всіх нижче підпорядкованих рівнях центральних, ключових по своїй суті вимог, критеріїв, стандартів адміністративної діяльності та, зокрема, адміністративних проваджень спірного та безспірного характеру [2].

Характеризуючи зміст глобальних стандартів адміністративних проваджень, слід звернути увагу і на вимоги щодо прозорості як самостійного інструменту глобального регуляторного режиму та стандарту, що застосовується до низки адміністративних проваджень в провідних країнах світу. Центральною вимогою даного стандарту $\epsilon$ зобов'язання адміністративних органів опубліковувати вимог до адміністративної діяльності та розгляду справ приватних осіб у такий спосіб, щоб вони були зрозумілі та відомі іншим учасникам адміністративних проваджень. Передбачається надання розумного строку перед вступом в законну силу нових вимог адміністративних органів щодо ведення бізнесу, розгляду індивідуальних справ, що було в пергу чергу спрямовано на те, щоб партнери-постачальники з різних країн могли забезпечити відповідність адміністративних документів новим вимогам адміністративних органів та мати час для внесення відповідних 
корективів у свою експортну діяльність. До означених вимог також додаються стандарти інформування та консультування громадян, завдяки чому доведення змісту та вимог глобальних стандартів до учасників адміністративних проваджень відбувається на постійній, централізованій основі, як і їх виконання.

Зміст стандарту гармонізації як самостійного інструменту глобального регуляторного режиму та стандарту, що застосовується для різних видів адміністративних проваджень, полягає у забезпеченні відповідності засобів впливу національних адміністративних органів міжнародним стандартам, рекомендаціям, що формуються на глобальному рівні. Хоча глобальні стандарти і не визнаються юридично обов'язковими, проте їх дотримання забезпечується завдяки високому авторитету міжнародних інституцій, а також тих додаткових можливостей, які надає участь на постійній основі в глобальних та міжнародних організаціях окремим національним державам.

Висновки. Зміст глобальних стандартів адміністративних проваджень сформувався в результаті підвищення міжнародного співробітництва країн світу як на Європейському континенті, так і в цілому в світовій торгівлі, що стало запорукою проникнення в національні правопорядки низки центральних стандартів - прозорості, участі, верховенства права, оскаржуваності адміністративних актів та рішень адміністративних органів. Для України вивчення змісту глобальних стандартів адміністративних проваджень набуває особливого значення 3 огляду на складність їх імплементації в національному законодавстві [5-7], що значно відстає від сучасних вимог європейського законодавства щодо взаємодії органів публічної адміністрації в умовах міжнародної взаємодії [8-9], співпраці в рамках Європейського адміністративного простору.

Зміст глобальних стандартів адміністративних проваджень сформований централізовано, з урахуванням інтересів міжнародних суб'єктів та транснаціональних корпорацій 3 метою впровадження спільних прозорих «правил гри» для обслуговування торгівельної взаємодії та адміністративної документації, необхідної для забезпечення іiї ведення. Тому залучення означених стандартів до внутрішніх національних має стати фактором залучення в Україну інвесторів, партнерів не тільки з Свропи, але й з усього світу, адже дотримання їх вимог значно підвищить міжнародні рейтинги країни.

\section{ЛITEPATYPA}

1. Cassese S. Administrative law in a supranational context: European administrative law/ URL: www.its.law.nyu.edu.

2. Chiti E. Administrative proceedings involving European agencies. URL: http:// law.duke.edu/journals/lcp.

3. European governance. A White paper. Commission of the European Communities. COM (2001) 428 final. Brussels, 25.07.2001. - P.8.

4. Пухтецька А.А. Європейські принципи адміністративного права та їх запровадження в законодавстві України: автореф. дис... канд. юрид. наук: 12.00.07; Ін-т держави і права ім. В.М.Корецького НАН України. К., 2009. 20 с.

5. Руденко А.В. Адміністративне судочинство: становлення та здійснення: Авторефр. дис... канд. юрид. наук: 12.00.07; Нац. юрид. акад. України ім. Я.Мудрого. Х., 2006. 20 с.

6. Рудой К.М. Адаптація адміністративного законодавства України у ссері охорони особистих прав громадян до норм Європейського Союзу: Автореф. дис... канд. юрид. наук: 12.00.07; Нац. ун-т внутр. справ. Х., 2004. 20 с.

7. Касараба Ю.Я. Адміністративно-правове забезпечення впровадження міжнародно-правових стандартів у діяльність органів міліції України: автореф. дис... канд. юрид. наук: 12.00.07; Нац. ун-т біоресурсів і природокористування України. К., 2009.18 с.

8. Barnes J. Towards a third generation of administrative procedures. 2016. Conference paper on Comparative administrative law. April 29-30,2016.

9. Franchini C. European principles governing national administrative proceedings. Law and contemporary problems. 2004. Vol. 68: 183. P.183-196 


\title{
СУЧАСНА ФІСКАЛЬНА ПОЛІТИКА ЯК ЕЛЕМЕНТ ЗОВНІШНЬОГО СЕРЕДОВИЩА ПУБЛІЧНОГО АДМІНІСТРУ ВАННЯ У СФЕРІ СЛУЖБОВО-БОЙОВОГО ЗАБЕЗПЕЧЕННЯ НАЦІОНАЛЬНОЇ БЕЗПЕКИ
}

\author{
MODERN FISCAL POLICY AS AN ELEMENT OF EXTERNAL ENVIRONMENT \\ OF PUBLIC ADMINISTRATION IN THE SECTOR OF SERVICE \\ AND COMBAT SUPPORT OF NATIONAL SECURITY
}

\author{
Павлютін Ю.М. \\ кандидат юридичних наук, докторант \\ Національна академія Служби безпеки України
}

У статті розглянуто особливості трансформації та системного удосконалення окремих організаційно-правових механізмів у сфері забезпечення національної безпеки держави за участю широкого кола суб'єктів виконавчої гілки влади, з урахуванням передового світового досвіду та країн Європейського Союзу.

Проведено історико-правовий аналіз економічних реформ у новоствореній незалежній державі, проблем переходу до ринкових відносин, зміни форм власності, фінансової системи та легалізації підприємницької діяльності, які закладені у сучасну фіскальну політику.

Виділено низку ризиків, що впливають на стан національної безпеки та протидія яким включатиме службово-бойові заходи: збереження високого рівня тінізації фінансових потоків; недостатня надійність вітчизняного фондового ринку та страхових інститутів; спотворення механізмів конкуренції; неформальна зайнятість та тінізація заробітних плат; маніпуляції з розміром офріційних доходів; тінізація земельних відносин.

Наголошено, що Державна фіскальна політика періоду становлення незалежності України характеризувалася достатньо значним тиском на платників податків, що суттєво вплинуло на розвиток тіньового сектору економіки. Зроблено висновок, що подолання негативної тенденції перерозподілу національного доходу на користь тіньової економіки вимагає проведення комплексу заходів забезпечення національної безпеки, спрямованих на контрольовану лібералізацію системи оподаткування, поліпшення інвестиційного клімату, поряд з цим, посилення кримінальної, адміністративної, фрінансової відповідальності за порушення законодавства в сфері оподаткування, введення суттєвого контролю за видатками фрізичних осіб, налагодження ефективної взаємодії між суб'єктами службово-бойового забезпечення національної безпеки, правоохоронними та контролюючими органами.

Особлива роль у проведенні цих та інших заходів забезпечення національної безпеки відведена заходам публічного адміністрування, що спрямовані на забезпечення сталого економічного зростання та створення сприятливих умов для розвитку бізнесу в Україні, реформі податкової системи та реформуванню Державної фіскальної служби України.

Ключові слова: фіскальна політика, національна безпека, фіскальна служба, адміністрування.

The article considers the features of transformation and systematic improvement of certain organizational and legal mechanisms in the field of national security of the state with the participation of a wide range of executive branch, taking into account best international experience and the European Union. economic reforms in the newly created independent state, the problems of transition to market relations, changes in ownership, financial system and legalization of entrepreneurial activity, which are embedded in modern fiscal policy.

A number of risks have been identified that affect the state of national security and counteraction to which will include service and combat measures: maintaining a high level of shadowing of financial flows; insufficient reliability of the domestic stock market and insurance institutions; distortion of competition mechanisms; informal employment and shadowing of wages; manipulation of the amount of official income;

It is emphasized that the State fiscal policy of the period of Ukraine's independence was characterized by considerable pressure on taxpayers, which significantly affected the development of the shadow sector of the economy. It is concluded that overcoming the negative trend of redistribution of national income in favor of the shadow economy requires a set of measures to ensure national security, aimed at controlled liberalization of the tax system, improving the investment climate, along with strengthening criminal, administrative, financial liability for violations of tax legislation, introduction of significant control over the expenditures of individuals, the establishment of effective interaction between the subjects of military support of national security, law enforcement and regulatory agencies.

A special role in these and other measures of national security is assigned to public administration measures aimed at ensuring sustainable economic growth and creating favorable conditions for business development in Ukraine, tax system reform and reform of the State Fiscal Service of Ukraine.

Key words: fiscal policy, national security, fiscal service, administration.

Постановка проблеми. В умовах недостатньої ефективності здійснення державного управління в різних сферах суспільних відносин протягом останніх років, необхідність провадження нових дієвих механізмів, створення ефективної, прозорої та гнучкої структури публічної адміністрації, що здатна виробляти і реалізовувати державну фіскальну політику, спрямовану на сталий розвиток суспільства і адекватне реагування на внутрішні та зовнішні виклики національній безпеці, стає очевидною.

Це вимагає трансформації та системного удосконалення окремих організаційно-правових механізмів у сфері забезпечення національної безпеки держави за участю широкого кола суб'єктів виконавчої гілки влади, з урахуванням передового світового досвіду та країн Європейського Союзу щодо покращення інвестиційного клімату в Україні, спрощення податкової системи, підвищення прозорості та якості адміністрування податків, ліквідації поширених схем ухилення від оподаткування, усунення неузгодженостей.

Для забезпечення економічного розвитку держави особливої актуальності набули питання вдосконалення фіскальної політики до сучасних реалій, оптимізації податкової системи та посиленні сервісних функцій Державної фіскальної служби України.

Аналіз останніх досліджень і публікацій. Дослідженню проблематики публічного адміністрування центральними органами виконавчої влади присвячені наукові праці таких вчених, як В.Б. Авер'янова, С.С. Алєксєєва, Г.В. Атаманчука, О.А. Банчука, Д.М. Бахраха, І.Л. Бачило, Ю.П. Битяка, В.О. Демиденко, Є.В. Доніна, Р.А. Калюжного, Т.О. Коломоєць, В.К. Колпакова, В.В. Копєйчикова, Р.С. Мельника, О.Ф. Скакуна, Ю.М. Старілова та ін. Однак, складність і комплексність зазначеної проблеми зумовлюють необхідність виявлення та дослідження 
історико-правових аспектів розвитку державної фіскальної політики, що стали підставами для ії реформування.

Матою статті $\epsilon$ отримання наукового результату у вигляді теоретичних положень щодо обумовленості розгляду державної фіскальної політики в контексті службово-бойового забезпечення національної безпеки України.

Викладення основного матеріалу. Історико-правовий аналіз низки джерел свідчить, що відправною точкою на шляху політичних, економічних та правових реформ для нашої держави стало прийняття Закону УРСР "Про економічну самостійність Української РСР” на основі Декларації про державний суверенітет України, котрим було визначено зміст, мету і основні принципи економічної самостійності України як суверенної держави $[1 ; 2]$.

Запроваджена економічна реформа в новоствореній незалежній державі передбачала перехід до ринкових відносин, що передбачало зміну форм власності, фінансової системи та легалізації підприємницької діяльності. Правову основу для забезпечення цього процесу склали закони "Про власність" [3], "Про підприємництво" [4], "Про господарські товариства" [5], "Про підприємства в Україні” [6] та ін. Закладена правова основа достатньо ефективно вплинула на швидкість розвитку підприємств недержавної форми власності. Економічним ефектом цього стало те, що поступово відбувалися зміни у виробництві валового внутрішнього продукту на користь підприємств недержавної форми власності.

Загальновідомо, що податки завжди були ефективним засобом державного регулювання розвитку економіки в умовах формування ринкових відносин, а реалізація цієі функції держави й складає в сучасних умовах фіскальну політику України, тобто систему заходів щодо регулювання сукупного попиту і реальних національних доходів за допомогою державних витрат, трансферних виплат і оподаткування. Ми вважаємо, що проблематика ефективності оподаткування сьогодні має надважливе значення.

У літературі відзначається слушна думку, що при аналізі податків варто виділяти два ії аспекти: 1) у широкому розумінні, потрібно мати на увазі, що податки впливають на економічне зростання, форми та методи фінансового контролю за сплатою податків, пропорції розподілу суспільного продукту, рівень зайнятості, сукупний попит рівень заощаджень, інвестицій, інфляцію та ін.; 2) у вузькому розумінні - методи податкової роботи: механізми визначення бази оподаткування, ставки оподаткування, порядок розрахунку податкового зобов'язання, порядок вирішення суперечок, принципи надання податкових пільг та ін. [7, с. 179-182].

Ретроспективний аналіз дає можливість зазначити, що вітчизняна система оподаткування формувалась на базі фінансової системи, котра діяла в умовах, коли ринкові відносини в економіці ще не були переважними, а більшість підприємств перебувала в державному секторі власності. Відповідно застосовувалися старі методи контролю за фінансово-господарською діяльністю підприємств та сплатою ними обов'язкових платежів.

Тож варто погодитися 3 думкою Т.В. Сараскіної про те, що податкова політика періоду становлення незалежної держави, відзначилась значним податковим тиском, нестабільністю [8, с. 12-13]. Показовим був Закон України "Про оподаткування доходів підприємств і організацій”, що діяв з 1 січня по 31 грудня 1992 року, а потім з 1 квітня 1993 року по 31 грудня 1994 року, норми якого передбачали стягнення податку на доходи підприємств за ставкою $18 \%$ з віднесенням до бази оподаткування фонду заробітної плати - суто собівартісної категорії [9]. Закон України "Про податок на добавлену вартість" від 20 грудня 1991 року слід також віднести до переліку невдалих прикладів впливу податкової системи на впровадження в Україні ринкових відносин [10].
Нажаль, як тоді, так і зараз податкова системи та фіскальна політика в цілому, піддається достатньо гострій критиці через її суто фіскальну спрямованість. Так, діючим Податковим кодексом України задекларовано, що вітчизняна податкова система має будуватися на принципах загальності оподаткування, рівності усіх платників перед законом, невідворотності настання визначеної законом відповідальності у разі порушення податкового законодавства, презумпції правомірності рішень платника податку в разі, якщо норма закону чи іншого нормативноправового акта, виданого на підставі закону, або якщо норми різних законів чи різних нормативно-правових актів припускають неоднозначне (множинне) трактування прав та обов'язків платників податків або контролюючих органів, внаслідок чого $є$ можливість прийняти рішення на користь як платника податків, так і контролюючого органу, фіскальної достатності, соціальної справедливості, нейтральності оподаткування, стабільності, рівномірності та зручності сплати, єдиного підходу до встановлення податків та зборів [11]. Хоча, якщо порівнювати 3 відповідними положеннями Закону України "Про систему оподаткування", який вже втратив чинність, на нашу думку, суттєвим недоліком діючого Податкового кодексу України $є$ не включення таких базових принципів як стимулювання підприємницької, виробничої та інвестиційної активності, економічної обгрунтованості [12], адже саме їх реалізація здатна забезпечити сталий економічний розвиток та покращення інвестиційного клімату.

Варто зазначити, що починаючи з травня 2015 року до цього часу Радою бізнес-омбудсмена як постійно діючим консультативно-дорадим органом Уряду отримано 1179 скарг, більшість 3 яких пов'язана 3 податковими питаннями [13]. Наразі ж Міністерством фінансів України опрацьовується пакет змін щодо удосконалення податкової системи з метою зменшення тиску на бізнес, створити умови для його розвитку [14] та перетворити Державну фіскальну службу з контролюючого органу на сервісну службу [15].

Нагадаємо, що Державну фіскальну службу України було утворено на базі Міністерства доходів і зборів України постановою Кабінету Міністрів України від 21 травня 2014 року № 160 "Про утворення Державної фіскальної служби"[16]. Згідно статті 1 "Положення про Державну фіскальну службу України” [17] іiї діяльність спрямовується і координується Кабінетом Міністрів України через Міністра фінансів.

І.П. Яковлев, здійснивши ретроспективний огляд реорганізаційних заходів, котрі призвели до виникнення фіскальної служби, цілком слушно підкреслив закономірність таких змін через невідповідність обсягу повноважень, більш характерних для інспекцій, агентств або служб, статусу Міністерства доходів і зборів України [18, с. 63-64]. Мова йде про те, що до завдань Міністерства доходів і зборів України було віднесено реалізацію єдиної державної податкової та митної політики, хоча забезпечення формування даної політики здійснювалося ним лише в частині адміністрування загальнообов'язкових платежів у той час, коли формування інших частин податкової і митної політики покладалося на Міністерство фінансів України $[18$, с. 64]. Цілком вірогідним вектором розвитку цього органу влади вбачалося відновлення діяльності податкової і митної служб як окремих центральних органів, діяльність яких мала спрямовуватися та координуватись Урядом через Міністра фінансів України [18, с. 64].

На нашу думку, створення Державної фіскальної служби України забезпечило приведення у відповідність ії статусу як центрального органу виконавчої влади до положень статті 16 Закону України "Про центральні органи виконавчої влади”, згідно якої центральні органи виконавчої влади утворюються для виконання окремих функцій з реалізації державної політики як служби, агентства, інспекції. 
Зазначимо, що саме в Конституції України закріплюється положення про те, що організація і діяльність органів виконавчої влади визначається виключно законами. Наразі ж діяльність Державної фіскальної служби України врегулювано постановою Уряду "Про Державну фіскальну службу", якою затверджено "Положення про Державну фіскальну службу України”. Отже, фактично 3 травня 2014 року до цього часу реалізація державної податкової політики, державної політики у сфері державної митної справи, державної політики з адміністрування єдиного внеску на загальнообов'язкове державне соціальне страхування, державної політики у сфері боротьби 3 правопорушеннями під час застосування податкового, митного законодавства, а також законодавства 3 питань сплати єдиного внеску здійснюється без базового законодавчого акту, яким би було врегулювано основи діяльності Державної фіскальної служби України.

Сьогодні, коли ще триває податкова реформа, питання визначення компетенції вказаного органу стоїть надзвичайно гостро та привертає увагу як науковців, так і практиків. На його вирішення, на наш погляд, суттєво впливає дослідження механізму правого регулювання ії діяльності зважаючи на те, що саме нормами права мають бути закріплені цілі утворення Державної фіскальної служби України, функції, завдання та встановлення певних повноважень по їх здійсненню. Переконані, що такі норми мають бути закріплені виключно в нормативних актах вищою юридичної сили - законах.

I. Якушник, дослідивши особливості розвитку податкової системи протягом дев'яностих років, цілком слушно виокремив, що головними її негативними чинниками були: 1) створення податкової системи відбулося без достатнього теоретико-методологічного обгрунтування шляхом некритичного перенесення зразка податкової системи країн з розвиненими ринковими відносинами; 2) невідповідність системи оподаткування реальному соціально-економічному стану країни; 3) постійне посилення фіскальної ролі податків [19, с. 148-150]. На нашу думку, сьогодні наведений перелік не втрачає актуальності.

Поділяємо думку багатьох авторів про те, що фіскальна політика держави може вважатися ефективною лише тоді, коли вона стимулює активну підприємницьку діяльність, накопичення інвестицій, відтворення і розвиток виробничого сектора економіки.

В той же час, системні прорахунки держави у податковій, фінансово-кредитній та інших сферах економіки, невиваженість в адмініструванні податків та недоліки в їх правовому регулюванні, розпад виробничих зв'язків тощо, призводять до поглиблення економічної кризи, втрати платоспроможності громадян, "вимивання" оборотних коштів підприємств, спаду виробництва, "тінізації” суспільно-економічних відносин.

За оцінками FATF реальні обсяги тіньової економіки у високо розвинутих країнах на рівні 17 відсотків ВВП, у країнах, що розвиваються, -40 , у країнах 3 перехідною економікою - понад 20 відсотків ВВП. За висновками зарубіжних експертів, Україна належить до країн 3 найбільш тінізованою економікою. Рівень тіi тінізації, за їх розрахунками, становить близько 50 відсотків. За матеріалами Держфінмоніторингу лише за січень-травень 2015 року, загальна сума фінансових операцій, які можуть бути пов'язані з легалізацією доходів, одержаних злочинним шляхом, становить 12,6 млрд. грн., а сума фінансових операцій, які можуть бути пов'язані з учиненням інших злочинів, становить 2,9 млрд. гривень [20]. 3 іншого боку, певні дослідження прихованих економічних процесів, здійснені зарубіжними та вітчизняними вченими, дозволили визначити, що достатньо великою складовою тіньової економіки є й “кримінальна економіка".

Для України легалізація (відмивання) доходів, одержаних злочинним шляхом, $є$ порівняно новим складом злочину. Статистичні данні переконують в неготовності української правоохоронної системи ефективно боротися $з$ цим кримінальним явищем. Так, за даними Генеральної прокуратури України, за період з 2013 по жовтень 2015 року правоохоронними органами обліковано 790 кримінальних проваджень, з яких у 277 вручено повідомлення про підозру, а спрямовано до суду з обвинувальним актом лише 224 кримінальних провадження [21].

На стан розслідування легалізації (відмивання) доходів, одержаних злочинним шляхом суттєво впливають висока латентність даного злочину, приховані механізми легалізації з відповідними фінансовими операціями, склад злочинних груп з диференційованим поділом ролей, відсутність дієвих механізмів відстеження «брудних» фінансових потоків за кордон, найгостріший дефіцит кваліфікованого кадрового апарату правоохоронних органів для боротьби $з$ легалізацією (відмиванням) доходів, одержаних злочинним, гостра нестача відповідного методичного забезпечення процесів їх виявлення та розслідування.

На думку О.П. Рябченко до основних причин тінізації економіки належать: кризовий стан української економіки; неефективність та деформація системи управління; відсутність стабільного законодавства, яке б чітко регламентувало економічну діяльність, сприяло б реалізації приватної ініціативи та подоланню правового нігілізму влади і населення країни; недосконалість системи обліку та звітності; надмірний податковий тиск, антагоністичний з інтересами та можливостями переважної кількості фізичних та юридичних осіб, які діють у межах законодавчого поля; відсутність інвестиційної альтернативи тіньовим капіталам; формування професійної організованої злочинності, інтеграція організованої злочинності з суб'єктами підприємницької діяльності; незахищеність громадян і підприємств від посягань злочинних формувань, встановлення контролю за їх діяльністю з боку цих структур; корумпованість управлінських структур, адміністративні бар'єри, правова незахищеність суб'єктів економічної діяльності від зловживань, протидії та вимагань 3 боку чиновників державного апарату на всіх його рівнях [22, с. 11]. Підтримуємо зазначену позицію.

Досить тривалий час продовжують існувати головні два підходи до реформування фіскальної політики, що має забезпечити детінізацію економіки та стимулювати їі зростання. Т.В. Сараскіна цілком правильно підкреслила, що перший підхід можна назвати “фіскальним", адже базується на припущенні, що максимальна лібералізація податкової бази не обов'язково веде до пожвавлення бізнесу і легалізації тіньової економіки, тоді ж як різке зниження податкових надходжень коштів до бюджету обов'язково призведе до неможливості фінансування основних його статей $[8$, с. 16]. Другий підхід автором визначений як ліберальний та кардинально іншого спрямування. Його прибічники вважають, що саме різке зменшення податкового тиску дозволить стимулювати підриємницьку активність та запровадити реальні ринкові механізми, як наслідок, це дозволить не тільки збільшити надходження бюджету, а й легалізувати більшу частину тіньової економіки [8, с. 16].

На нашу думку, кожен із запропонованих підходів, в тій чи іншій мірі, недостатньо повно враховує сучасні реалії, адже існуючий комплекс проблем економічного, політичного та правового характеру вимагає застосування комплексного підходу, налагодження роботи контролюючих і правоохоронних органів, а також публічного адміністрування в цій сфері.

Проблема подолання тіньової економіки в Україні стоїть надзвичайно гостро. Слід виділити такі ризики з боку тінізації економіки для результативності реформ: 1) збереження високого рівня тінізації фінансових потоків загрожує досягненню цілей стабілізації державного бюджету та знижує потенціал реформування фінансової системи; 
2) недостатня надійність вітчизняного фондового ринку та страхових інститутів, спричинені їх інтегрованістю у тіньові схеми, $є$ ризиком для запровадження II рівня пенсійної системи та переходу на страхову модель охорони здоров'я; 3) спотворення механізмів конкуренції внаслідок значних масштабів тінізації діяльності економічних суб'єктів та недостатня надійність вітчизняного фондового ринку через високий рівень тінізації фінансових потоків негативно позначаються на результативності реформ, спрямованих на покращення бізнес-клімату та залучення інвестицій; 4) неформальна зайнятість та тінізація заробітних плат негативно позначаються на розмірах страхових внесків до Пенсійного фонду, фондів соціального страхування та обсягах надходжень до бюджету, що негативно впливає на стабільність системи державних фінансів та солідарної пенсійної системи, стримують нагромадження коштів накопичувальної складової пенсійної системи та розвиток іï інвестиційного потенціалу; 5) маніпуляції з розміром офіційних доходів дозволяють нелегально працюючим та працюючим, що отримують частку заробітної плати «у конвертах», необгрунтовано отримувати від держави соціальну підтримку, що може негативно позначитися на результативності вирішення завдань реформи системи соціальної підтримки; 6) тінізація земельних відносин перешкоджає формуванню ефективних механізмів управління ринком землі у контексті земельної реформи, реалізація земельної реформи без належного забезпечення інвентаризації, обліку, оцінки та контролю використання земель сприятиме подальшій тінізації ринку землі та створюватиме умови для легалізації правопорушень [23].

Як бачимо стабілізація економіки України вимагає здійснення комплексу заходів спрямованих на детінізацію фінансових потоків, легалізацію ринку праці та детінізацію земельних відносин. Впровадження дієвих заходів в життя та їх результативність залежатимуть від ефективності взаємодії всіх гілок влади та роботи широкого кола суб'єктів виконавчої гілки влади, що здійснюють адміністрування, 3 урахуванням передового світового досвіду та країн Свропейського Союзу.

Достатньо важливим кроком у цьому напрямку є пропозиції Кабінетом Міністрів України. 3 кінця 2016 року
Урядом держави розпочато реалізацію низки законодавчих ініціатив щодо покращення інвестиційного клімату в Україні за рахунок спрощення податкової системи, підвищення прозорості та якості адміністрування податків, ліквідації поширених схем ухилення від оподаткування, усунення неузгодженостей, а також стосовно перегляду окремих повноважень контролюючих органів у сфері оподаткування, що в першу чергу стосується компетенції Державної фіскальної служби України.

Міністерством фінансів України опрацьовується пакет змін щодо удосконалення податкової системи з метою зменшення тиску на бізнес, створити умови для його розвитку [14] та перетворити Державну фіскальну службу 3 контролюючого органу на сервісну службу [15].

Цілком підтримуємо таку ініціативу, з огляду на що вбачається за доцільне врахувати дане положення в майбутньому базовому законі як цілі утворення даного центрального органу виконавчої влади. На наш погляд, це дозволить закласти законодавче підгрунтя для підвищення якості надання державних послуг громадянам та бізнесу та ліквідування можливість для суб'єктивізму та корупції у роботі податкових та митних органів як складових Державної фіскальної служби України.

Висновки. Державна фіскальна політика періоду становлення незалежності України характеризується достатньо значним тиском на платників податків, що суттєво вплинуло на розвиток тіньового сектору економіки. Для подолання негативної тенденції перерозподілу національного доходу на користь тіньової економіки необхідно провести комплекс заходів, направлених на значну лібералізацію системи оподаткування, поліпшення інвестиційного клімату, поряд 3 цим, посилити кримінальну, адміністративну, фінансову відповідальності за порушення законодавства в сфері оподаткування, ввести контроль за видатками фізичних осіб, налагодити ефективну взаємодію між правоохоронними та контролюючими органами. Особлива роль в проведенні цих та інших заходів, направлених на забезпечення сталого економічного зростання та створення сприятливих умов для розвитку бізнесу в Україні, відводиться проведенню реформи податкової системи та реформуванню Державної фіскальної служби України.

\section{СПИСОК ВИКОРИСТАНИХ ДЖЕРЕЛ:}

1. Декларація про державний суверенітет України: Декларація від 16 липн. 1990 р. № 55-XII. URL: http://zakon3.rada.gov.ua/laws/ show/55-12.

2. Про економічну самостійність Української РСР: Закон УРСР від 3 серпн. 1990 р. № 142-XII. URL: http://zakon2.rada.gov.ua/laws/ show/142-12.

3. Про власність: Закон УРСР від 7 лютог. 1991 р. № 697-XII. URL: http://zakon3.rada.gov.ua/laws/show/697-12.

4. Про підприємництво: Закон УРСР від 7 лютог. 1991 р. від № 698-XII . URL: http://zakon3.rada.gov.ua/laws/show/698-12.

5. Про господарські товариства: Закон України від 19 вересн. 1991 р. № 1576-XII . URL: http://zakon3.rada.gov.ua/laws/show/1576-12.

6. Про підприємства в Україні: Закон УРСР від 27 березн. 1991 р. № 887-XII . URL: http://zakon2.rada.gov.ua/laws/show/887-12.

7. Вдовиченко М. Податкова політика як інструмент макроекономічного регулювання. Реформа міжбюджетних відносин і проблеми розвитку податкової системи України. Матеріали науково-практичної конференції. Ірпінь : Академія державної податкової служби України. 1999. С. $179-182$.

8. Сараскіна Т.В. Організаційно-правові засади діяльності податкової міліції в Україні: дис. ...канд. юрид. наук: 12.00 .07 / Сараскіна Тетяна Василівна. Х., 2000. 189 с.

9. Про оподаткування доходів підприємств і організацій : Закон України від 21 лютог. 1992 р. № 2146-XII . URL: http://zakon3.rada.gov. ua/laws/show/2146-12.

10. Про податок на добавлену вартість : Закон України від 20 грудн. 1991 р. № 2007-XII . URL: http://zakon2.rada.gov.ua/laws/ show/2007-12.

11. Податковий кодекс України : Закон України від 2 грудн. 2010 р. № 2755-VI . URL: http://zakon2.rada.gov.ua/laws/show/2755-17.

12. Про систему оподаткування : Закон України від 25 червн. 1991 р. № 1251-XII . URL: http://zakon2.rada.gov.ua/laws/show/1251-12.

13. Квартальний звіт бізнес-омбудсмена (липень-вересень 2016). URL: https://boi.org.ua/publications/reports/14-kvartalnij-zvt-radibznes-ombudsmena-lipen-veresen.

14. "Мінфін презентував громадськості попередню версію змін до Податкового кодексу". URL: http://www.minfin.gov.ua/news/view/ minfin-prezentuvav--hromadskosti-poperedniu-versiiu-zmin-do-podatkovoho-kodeksu?category=novini-ta-media\&subcategory=vsi-novini.

15. "Уряд схвалив законопроекти, спрямовані на забезпечення реалізації рекомендацій МВФ у питаннях реформування фіскальної служби". URL: http://www.kmu.gov.ua/control/uk/publish/article?art id=248980553\&cat id=244276429.

16. Про утворення Державної фіскальної служби: Постанова Кабінету Міністрів України від 21 травня 2014 року № 160. URL: http://zakon0.rada.gov.ua/laws/show/160-2014-п.

17. Про Державну фіскальну службу України: Постанова Кабінету Міністрів України від 21 травня 2014 року № 236. URL: http://zakon2.rada.gov.ua/laws/show/236-2014-п. 
18. Яковлев І.П. Форми і методи публічного адміністрування у державній митній справі дис. ... канд. юрид. наук : 12.00 .07 / Яковлєв Івано Петрович. О., 2016. 224 с.

19. Якушник І. Особливості розвитку та шляхи удосконалення системи оподаткування в Україні. Реформа міжбюджетних відносин і проблеми розвитку податкової системи України. Матеріали науково-практичної конфреренції. Ірпінь : Академія державної податкової служби України. 1999. С. 148-150.

20. Статистичні дані щодо отриманих Держфрінмоніторингом повідомлень про фінансові операції протягом III кварталу 2015 року. URL: http://www.gp.gov.ua.

21. Основні показники органів досудового розслідування за 2013-2015 роки. Статистична інформація. URL: http://www.gp.gov.ua/ua/ stst2011.html?dir_id=112169\&libid=100820\&c=edit\&_cfo.

22. Рябченко О.П. Проблеми тінізації економіки в період формування ринкових відносин: Курс лекцій. Х. : Університет внутрішніх справ, 1998. 68 с.

23. Щодо пріоритетних напрямів детінізації економіки України. Аналітична записка. URL: http://www.niss.gov.ua/articles/676/. 


\title{
ДІЯ У ПРОСТОРІ ТА ЧАСІ НОРМ, ЯКІ РЕГУЛЮЮТЬ ПОРЯДОК КРИМІНАЛЬНОГО ПРОВАДЖЕННЯ В УМОВАХ НАДЗВИЧАЙНИХ ПРАВОВИХ РЕЖИМІВ
}

\author{
EFFECT IN SPACE AND TIME OF NORMS REGULATING \\ THE PROCEDURE OF CRIMINAL PROCEEDINGS UNDER CONDITIONS \\ OF EXTRAORDINARY LEGAL REGIMES
}

\author{
Тетерятник Г.К., к.ю.н., доцент, \\ завідувач кафедри кримінального процесу \\ Одеський державний університет внутрішніх справ
}

\begin{abstract}
У статті досліджені особливості дії норм, які регулюють порядок кримінального провадження в умовах надзвичайних правових режимів у просторі та часі. Звернена увага на нормативну недосконалість врегулювання правовідносин в умовах надзвичайних правових режимів, що є свідченням порушення принципу правової визначеності, до критеріїв якого належить якість законодавства, високий рівень законодавчої техніки, однозначність, точність формулювань правових норм.

Констатовано, що введення надзвичайних правових режимів характеризується відносною раптовістю, підвищеним ступенем небезпеки для суспільства та держави, вимагає приведення у дію «нетипових» механізмів праворегулювання.

Проаналізовано дію кримінального процесуального законодавства в умовах надзвичайних правових режимів у просторі та констатовано, що його розуміння є неоднозначним. Внесення низки нових правових дефініцій, якими насичене надзвичайне законодавство з часу тимчасової окупації частини території України та проведення АТО / ООС, які неузгоджені між собою, вказує на відсутність у законодавця системного підходу до розробки нормативно-правових актів, норм в умовах надзвичайних правових режимів.

Констатовано поліджерельність нормативного регулювання кримінальних процесуальних відносин в умовах дії надзвичайних правових режимів, їх фрагментарність, наявність прогалин, суперечностей, стихійність та ретроспективність прийняття норм, які б враховували особливості провадження в таких умовах. Часткове унормування процесуальних питань лише стосовно АТО / ООС та тимчасово окупованих територій свідчить про те, що законодавець, вносячи необхідні зміни, яких вимагає практика, не враховує необхідності врегулювання правовідносин при виникненні надзвичайних ситуацій у майбутньому.

Зроблено висновок, що у випадку здійснення кримінального провадження щодо кримінальних правопорушень, які вчиняються на тимчасово окупованих територіях, з урахуванням принципів mutatis mutandis та ad hoc на нього поширюються норми кримінального процесуального законодавства України, міжнародних нормативно-правових актів, призначених для таких випадків.

Ключові слова: надзвичайні правові режими, досудове розслідування, кримінальне провадження, правове регулювання, дія кримінальних процесуальних норм у просторі та часі.
\end{abstract}

The article examines the features of the rules governing the procedure of criminal proceedings in emergency legal regimes in space and time. Attention is drawn to the regulatory imperfection of the legal relationship in emergency legal regimes, which is evidence of a violation of the principle of legal certainty, the criteria of which include the quality of legislation, high level of legislative technique, unambiguity, accuracy of legal wording.

It is stated that the introduction of emergency legal regimes is characterized by relative suddenness, increased danger to society and the state, requires the implementation of «atypical» mechanisms of legal regulation.

The effect of criminal procedural legislation in the conditions of emergency legal regimes in space is analyzed and it is stated that its understanding is ambiguous from the standpoint of introducing a number of new legal definitions, which saturate emergency legislation since the temporary occupation of Ukraine and ATO / OOS.

The multi-source normative regulation of criminal procedural relations in the conditions of special legal regimes, their fragmentation, the presence of gaps, contradictions, spontaneity and retrospective adoption of norms that would take into account the peculiarities of proceedings in such legal regimes. Partial standardization of procedural issues only in relation to ATO / OOS, indicates that the legislator, making the necessary changes required by the practice in the ATO, does not take into account the settlement of such legal relations in the event of future emergencies.

It is concluded that in the case of criminal proceedings for criminal offenses committed in the temporarily occupied territories, taking into account the principles of mutatis mutandis and ad hoc, it is subject to the rules of criminal procedure legislation of Ukraine.

Key words: emergency legal regimes, pre-trial investigation, criminal proceedings, legal regulation, effect of criminal procedural norms in space and time.

Постановка проблеми та їі актуальність. У 2014 році на території України розпочалися непередбачувані соціальнополітичні події: тимчасова окупація АРК та м. Севастополя, окремих територій Донецької та Луганської областей. 14 квітня 2014 року Указом Президента України «Про рішення Ради національної безпеки і оборони України від 13 квітня 2014 року «Про невідкладні заходи щодо подолання терористичної загрози і збереження територіальної цілісності України» на території України було введено АТО [1].

Неврегульованим залишається правовий статус фактично окупованих окремих районів Донецької та Луганської областей. Режим антитерористичної операції не надає органам влади належних інструментів для вирішення економічних та соціальних питань у зоні операції» [4]. Таким чином, один надзвичайний правовий режим АТО було змінено на інший - ООС, із визначенням відповідних повноважень для державних органів та осіб, які підпадають під дію зазначеного закону.

Визнання тимчасової окупації Російською Федерацією АРК та м. Севастополя не зняло з України обов'язків щодо забезпечення прав і законних інтересів громадян на окупованих територіях, у тому числі, і при здійсненні кримінального провадження.

Аналіз нормативних джерел, наукових досліджень, слідчої та судової практики дозволяє констатувати, що екстраординарність ситуації, пов'язаної із введенням надзвичайних правових режимів на території України, обумовила необхідність розробки та прийняття цілої низки нормативно-правових актів, направлених на регулювання правовідносин, у тому числі, кримінальних процесуальних в таких неординарних обставинах. Натомість викликана необхідністю швидкість прийняття таких актів, багатоаспектність проблем, 3 якими стикнулася українська держава, вплинули на якість прийнятого законодавства та однозначність його визначеності, у тому числі - щодо дії у просторі та часі.

Аналіз останніх досліджень і публікацій. Окремим аспектам указаної проблематики присвячені роботи А. М. Безносюка, К. Д. Волкова, Г. О. Ганової, В. В. Гутніка, О. В. Капліної, А. Г. Каткової, О. В. Лазукової, 
М. О. Лисенкова, А. В. Матіоса, О. В. Одерія, М. А. Погорецького, О. М. Толочка, В. М. Трофименка, М. С. Туркота, I. В. Савєльєвої, М. С. Цуцкірідзе, І. В. Цюприка, О. Г. Шило, О. Ф. Шкітова, М. О. Янкового та ін. Проте комплексного аналізу щодо дії норм, які регулюють порядок кримінального провадження в умовах надзвичайних правових режимів, у просторі та часі у кримінальній процесуальній науці ще не здійснювалось, що свідчить про існування науково-прикладної проблеми, яка потребує комплексного теоретичного вивчення.

Метою та завданням статті є дослідження особливостей дії норм, які регулюють порядок кримінального провадження в умовах надзвичайних правових режимів, у просторі та часі, виявлення недоліків правового регулювання та формулювання пропозицій щодо їх усунення.

Виклад основного матеріалу. Відповідно до Закону України «Про тимчасові заходи на період проведення антитерористичної операції» було визначено, що період проведення антитерористичної операції - час між датою набрання чинності Указом Президента України «Про рішення Ради національної безпеки і оборони України від 13 квітня 2014 року «Про невідкладні заходи щодо подолання терористичної загрози і збереження територіальної цілісності України» від 14 квітня 2014 року № 405/2014 та датою набрання чинності Указом Президента України про завершення проведення антитерористичної операції або військових дій на території України, а територія проведення антитерористичної операції - територія України, на якій розташовані населені пункти, визначені у затвердженому Кабінетом Міністрів України переліку, де проводилася антитерористична операція, розпочата відповідно до Указу Президента України «Про рішення Ради національної безпеки і оборони України від 13 квітня 2014 року «Про невідкладні заходи щодо подолання терористичної загрози і збереження територіальної цілісності України» від 14 квітня 2014 року № 405/2014 [2].

АТО проводилася до 30 квітня 2018 року, з цієї дати відповідно до ЗУ «Про особливості державної політики iз забезпечення державного суверенітету України на тимчасово окупованих територіях у Донецькій та Луганській областях» № 2268-VIII від 18.01.2018р. [3] була розпочата OОС. У пояснювальній записці до законопроекту «Про особливості державної політики із забезпечення державного суверенітету України на тимчасово окупованих територіях у Донецькій та Луганській областях» № 7163 від 04.10.2017 р. зазначається, що «за масштабами, характером та тривалістю проведення антитерористична операція не відповідає завданням звільнення окупованих територій окремих районів Донецької та Луганської областей. Унаслідок значних масштабних зіткнень, застосування противником важких озброєнь та військової техніки головна роль в операціях у зоні антитерористичної операції належить Збройним Силам України. Керівництво операцією здійснює представник Служби безпеки України як головного органу в системі боротьби з терористичною діяльністю.

Зміни до Розділу IX-1 та ст. 615 КПК України відповідно із вказівкою на змінений правовий режим були внесені лише Законом України «Про внесення змін до Кримінального процесуального кодексу України щодо вдосконалення окремих положень у зв'язку із здійсненням спеціального досудового розслідування» № 1422-IX від 27 квітня 2021 року, відповідно до ст. 15 якого назву та текст розділу IX- 1 після слів «антитерористичної операції» доповнено словами «чи заходів із забезпечення національної безпеки і оборони, відсічі і стримування збройної агресії Російської Федерації у Донецькій та Луганській областях» [5]. Таким чином, протягом майже трьох років вищевказаний розділ в умовах встановлення іншого правового режиму - ООС регулював правовідносини в умовах АТО. Така нормативна недосконалість є свідченням порушення принципу правової визначеності, до критеріїв якого належить якість законодавства, високий рівень законодавчої техніки, однозначність, точність формулювань правових норм.

У науковій літературі аргументовано звертається увага на той факт, що відсутність у КПК України положень про те, що кримінальний процесуальний закон, який скасовує права, що належать учасникам процесу, або зменшує їх обсяг чи обмежує їх використання додатковими умовами, зворотної сили не має, тобто не поширюється на провадження, розпочате до видання такого закону, є слабким місцем національного регулювання дії кримінального процесуального закону в часі [6, с.4]. Введення надзвичайних правових режимів характеризується відносною раптовістю, підвищеним ступенем небезпеки для суспільства та держави, вимагає приведення у дію «нетипових» механізмів праворегулювання. Якщо ми звернемося до ст. 615 КПК України, відповідно до якої в умовах визначених надзвичайних правових режимів та відповідних обставин, окремі повноваження слідчого судді щодо обмеження прав учасників провадження делегуються відповідному прокурору, то можемо констатувати обмеження прав учасників, інтересів яких стосуються такі рішення у частині забезпечення судового контролю.

У конституційному зверненні Кисельова А.О. звертається увага на те, що ст. 615 КПК України не визначено, чи розповсюджується дія статті виключно на осіб, що підозрюються у скоєнні злочинів в районі проведення АТО та перебувають в районі проведення АТО, чи на осіб, які покинули район проведення АТО, але перебувають під підозрою у скоєнні злочину в районі проведення ATO [7]. Слід констатувати, що неоднозначним є і розуміння дії кримінального процесуального законодавства в умовах надзвичайних правових режимів у просторі. За загальним правилом щодо дії кримінального в просторі відповідно до ч. 1 ст. 4 КПК України кримінальне провадження на території України здійснюється 3 підстав та в порядку, передбачених цим Кодексом, незалежно від місця вчинення кримінального правопорушення. Тобто дія КПК України поширюється на всю територію України, незалежно від місця вчинення кримінального правопорушення. У ч.ч. 2-4 КПК України містяться спеціальні норми щодо чинності кримінального процесуального закону у просторі. У той же час, тимчасова окупація частини території України та проведення АТО / ООС внесли цілу низку нових правових дефініцій, якими насичене надзвичайне законодавство.

Учені акцентують увагу на той факт, що українське законодавство оперує такими термінологічними зворотами, як «район проведення антитерористичної операції», «територія проведення антитерористичної операції», «зона проведення антитерористичної операції» [8, с.194196], «районі здійснення заходів із забезпечення національної безпеки і оборони, відсічі і стримування збройної агресії Російської Федерації у Донецькій та Луганській областях», «тимчасово окуповані території», «лінія зіткнення», «неконтрольована територія» та ін.

Поняття «антитерористична операція» визначене у Законі України «Про боротьбу 3 тероризмом» від 20 березня 2003 р. як комплекс скоординованих спеціальних заходів, спрямованих на попередження, запобігання та припинення терористичної діяльності, звільнення заручників, забезпечення безпеки населення, знешкодження терористів, мінімізацію наслідків терористичної діяльності [9]. В У зазначеному нормативному акті визначено, що районом проведення АТО є визначені керівництвом антитерористичної операції ділянки місцевості або акваторії, транспортні засоби, будівлі, споруди, приміщення та території чи акваторії, що прилягають до них і в межах яких проводиться зазначена операція» [9].

У Законі України «Про тимчасові заходи на період проведення антитерористичної операції» від 2 вересня 2014 р. 
йдеться уже про «територію проведення антитерористичної операції» та «зону проведення антитерористичної операції». Останнє поняття не розкривається у чинному законодавстві. Територією проведення антитерористичної операції $є$ територія України, на якій розташовані населені пункти, визначені у КМУ переліку, де проводилася антитерористична операція, розпочата відповідно до Указу Президента України «Про рішення Ради національної безпеки і оборони України від 13 квітня 2014 року «Про невідкладні заходи щодо подолання терористичної загрози і збереження територіальної цілісності України» від 14 квітня 2014 року № 405/2014, саме рішення є таємним [3].

Привертає увагу той факт, що розпорядженням КМУ № 1053-р від 30 жовтня 2014 року затверджено перелік населених пунктів, на території яких здійснювалася АТО [10], тобто по суті доступ до інформації про те, яка територія входила до району проведення АТО була оприлюднена після 6 місяців проведення АТО.

Крім того, 05 листопада 2014 року Розпорядженням КМУ № 1079-р від 05 листопада 2014 року дію вищезазначеного Розпорядження КМУ було зупинено [11] і лише 02 грудня 2015 року КМУ Розпорядженням № 1275-р повторно затвердив перелік населених пунктів, на території яких здійснювалася АТО [12]. Звідси випливає, що у період часу з 05 листопада 2014 року по 02 грудня 2015 року у питанні визначення території проведення АТО існував правовий вакуум [13].

У той же час, по суті, ст. 615 КПК України не змінювала свого змісту та застосовувалася впродовж цього періоду, хоча території, на яких проводилася АТО і не були визначені [14].

Відповідно до ст. 5 КПК України процесуальна дія проводиться, а процесуальне рішення приймається згідно з положеннями цього Кодексу, чинними на момент початку виконання такої дії або прийняття такого рішення, а допустимість доказів визначається положеннями КПК України, які були чинними на момент їх отримання. Водночас, у випадках коли кримінальне провадження здійснювалося до введення надзвичайного правового режиму, а продовжується в умовах надзвичайного правого режиму, а також може бути завершене уже після припинення такого, процесуальні відносини регулюються нормами, різними за територіальною та темпоральною дією [15, с.42-43].

Відповідно до ЗУ «Про забезпечення прав і свобод громадян та правовий режим на тимчасово окупованій території України» від 15 квітня 2014 року № 1207-VII перебування на території України підрозділів збройних сил інших держав 3 порушенням процедури, визначеної Конституцією та законами України, Гаазькими конвенціями 1907 року, IV Женевською конвенцією 1949 року, а також всупереч Меморандум про гарантії безпеки у зв'язку 3 приєднанням України до Договору про нерозповсюдження ядерної зброї 1994 року, Договору про дружбу, співробітництво і партнерство між Україною і Російською Федерацією 1997 року та іншим міжнародно-правовим актам $є$ окупацією частини території суверенної держави Україна та міжнародним протиправним діянням 3 усіма наслідками, передбаченими міжнародним правом [16].

Слід зазначити, що окупація АРК та м. Севастополя та збройний конфлікт у Донецькій та Луганській областях розглядаються у взаємозв'язку та взаємообумовленості [3]. Держава-агресор не визнає факту своєї присутності на Сході України та участі у збройних протистояннях [17] внаслідок чого, факт здійснення нею контролю над збройними формуваннями самопроголошених республік має бути доведений Україною на рівні міжнародних судових інстанцій, на противагу із ситуацією у Криму [18] .

Як справедливо зауважують правники: «У порівнянні iз анексією та окупацією Криму, події на сході за цей період так і не отримали однозначної правової кваліфікації. На національному рівні у профільному законодав- стві йде мова про «збройну агресію Російської Федерації» та «тимчасову окупацію територій» [3], при цьому застосовується законодавство «мирного часу». Натомість Офіс Прокурора Міжнародного кримінального суду попередньо кваліфікує ситуацію на Донбасі як поєднання збройного конфлікту міжнародного (протистояння між збройними силами Російської Федерації та України) та неміжнародного характеру (протистояння з озброєними групами, які діють на сході України, «ДНР» та «ЛНР»)» [19; 20].

Необхідність отримання доказів щодо участі РФ у збройному конфлікті на території України для надання іx МКС також $є$ фактором, який впливає на організацію та процес розслідування кримінальних правопорушень, шо вчиняються, як на тимчасово окупованих, так і на підконтрольних Україні територіях. І навіть виводить в інший ракурс сприйняття та кваліфікацію багатьох категорій злочинів, які з урахуванням обстановки збройного конфлікту можуть розглядатися як воєнні злочини, злочини проти миру тощо (детальніше про це в інших підрозділах роботи). Уже зазначене вказує на дію норм міжнародного кримінального та міжнародного гуманітарного права, які застосовуються у випадках окупації, збройного конфлікту та необхідність пошуку нових процесуальних та криміналістичних підходів до розслідування та судового розгляду кримінальних правопорушень, які вчиняються на тимчасово окупованих територіях.

Ситуація щодо визнання окупації РФ АРК та окремих територій Донецької і Луганської областей відрізняється. Якщо РФ поширення своєї юрисдикції на територію АРК по факту визнано, то за попередньою кваліфікацією прокурора МКС, конфлікт на Сході України - це змішаний збройний конфлікт з елементами міжнародного та не міжнародного [21].

Водночас окуповані території України з урахуванням суверенітету держави, визнаному на міжнародному рівні $\epsilon$ невід'ємною частиною України. І відповідно до ЗУ «Про забезпечення прав і свобод громадян та правовий режим на тимчасово окупованій території України» від 15 квітня 2014 року № 1207-VII тимчасово окупована територія України є невід'ємною частиною території України, на яку поширюється дія Конституції та законів України (ст. 1).

Відповідно до ст. 5 КПК України процесуальна дія проводиться, а процесуальне рішення приймається згідно з положеннями цього Кодексу, чинними на момент початку виконання такої дії або прийняття такого рішення, а допустимість доказів визначається положеннями КПК України, які були чинними на момент їх отримання. Водночас, у випадках коли кримінальне провадження здійснювалося до введення надзвичайного правового режиму, а продовжується в умовах надзвичайного правого режиму, а також може бути завершене уже після припинення такого, процесуальні відносини регулюються нормами, різними за територіальною та темпоральною дією. Учені характеризують дію норм кримінального процесуального законодавства в умовах надзвичайних правових режимів їі як «юридичну активацію», у разі введення в дію одного з правових режимів та «юридичну деактивацію», обумовлену рішенням про скасування такого правового режиму [15, с. $42-43]$.

Враховуючи усе вищезазначене, слід акцентувати увагу на тому, що дія кримінального процесуального закону у часі та у просторі в умовах надзвичайних правових режимів не відповідає положенням ст. ст. 4, 5 КПК України. Адже введення виключень щодо кримінального провадження в умовах надзвичайних правових режимів передбачається надзвичайними законами, утім ч. 1 ст. 4 КПК України визначає, що «Кримінальне провадження на території України здійснюється з підстав та в порядку, передбачених цим Кодексом, незалежно від місця вчинення кримінального правопорушення», а ч. 1 ст. 5 КПК України, що «Процесуальна дія проводиться, а процесуальне рішення приймається згідно з положеннями цього 
Кодексу, чинними на момент початку виконання такої дії або прийняття такого рішення». Більш того, наприклад, у ст. 4 ЗУ «Про здійснення правосуддя та кримінального провадження у зв'язку з проведенням антитерористичної операції» зазначається, що «Органи досудового розслідування, які здійснюють досудове розслідування кримінальних правопорушень відповідно до положень статті 2 цього Закону, в разі зміни меж району або завершення антитерористичної операції продовжують досудове розслідування таких кримінальних правопорушень», а у ст. 2 зазначеного нормативного акту вказано: «Підслідність кримінальних правопорушень, вчинених в районі проведення антитерористичної операції, у разі неможливості здійснювати досудове розслідування визначається Генеральним прокурором. Матеріали досудового розслідування щодо зло- чинів, кримінальні провадження щодо яких знаходяться на стадії досудового слідства, у разі неможливості здійснювати досудове розслідування передаються органам досудового розслідування, визначеним Генеральним прокурором, протягом десяти робочих днів 3 дня визначення підслідності». Своєю чергою КПК України, ані у ст. 216, яка визначає підслідність кримінальних проваджень, ані у перехідних положеннях, ані в інших нормах не містить жодного посилання на ad hoc для таких випадків.

3 урахуванням усього вищезазначеного, вважаємо, що доцільно внести зміни до ч. 1 ст. 4 КПК України, а також ч. 1 ст. 5 КПК України, визначивши правила-виключення для дії закону у просторі та часі, які де-факто на сьогодні існують, натомість де-юре у нормах КПК України не закріплені.

\section{ЛITEPATYPA}

1. Про рішення Ради національної безпеки і оборони України від 13 квітня 2014 року «Про невідкладні заходи щодо подолання терористичної загрози і збереження територіальної цілісності України»: Указ Президента України від 14 квітня 2014 року № 405/2014 URL: https://zakon.rada.gov.ua/laws/show/405/2014\#Text

2. Про тимчасові заходи на період проведення антитерористичної операції; Закон України від 2 вересня 2014 року № 1669-VII. URL: https://zakon.rada.gov.ua/laws/show/1669-18\#Text

3. Про особливості державної політики із забезпечення державного суверенітету України на тимчасово окупованих територіях у Донецькій та Луганській областях: Закон України від 18.01.2018 p.URL: № 2268-VIII https://zakon.rada.gov.ua/laws/show/2268-19\#Text

4. Пояснювальна записка до законопроекту «Про особливості державної політики із забезпечення державного суверенітету України на тимчасово окупованих територіях у Донецькій та Луганській областях» № 7163 від 04.10.2017p. URL: https://ips.ligazakon.net/ document/GH5IZ00A?an=8

5. Про внесення змін до Кримінального процесуального кодексу України щодо вдосконалення окремих положень у зв'язку із здійсненням спеціального досудового розслідування: Закон України № 1422-IX від 27 квітня 2021 року. URL: https://zakon.rada.gov.ua/laws/ show/1422-20\#n47

6. Баулін О. Зворотна дія кримінального процесуального закону як гарантія прав людини у кримінальному провадженні. Науковий часопис Національної академії прокуратури України. 2016. № 4(12). C. 1- URL:http://www.chasopysnapu.gp.gov.ua/chasopys/ua/ pdf/12-2016/baulin.pdf.

7. Конституційне звернення Кисельова A.O. URL: https://ccu.gov.ua/sites/default/files/ndf/18-2424.pdf

8. Родіонова Т. В. Місце вчинення злочину за кримінальним правом України: дис.... канд. юрид. наук: 12.00 .08 (081 - Право), Одеса, 2018. $247 \mathrm{C}$.

9. Про боротьбу з тероризмом: Закон України від 20.03.2003 № 638-IV. URL: https://zakon.rada.gov.ua/laws/show/638-15\#Text

10. Про затвердження переліку населених пунктів, на території яких здійснювалася антитерористична операція: розпорядженням Кабінету Міністрів України № 1053-р від 30 жовтня 2014 року. URL: http://zakon2.rada.gov.ua/laws/show/1053-2014-\%D1\%80 (дата 3вернення: 25.10.2017).

11. Про зупинення дії розпорядження Кабінету Міністрів України від 30 жовтня 2014 р. № 1053 № 1079-р від 05 листопада 2014 року. URL: http://zakon2.rada.gov.ua/laws/show/ 1079-2014-\%D1\%80.

12. Про затвердження переліку населених пунктів, на території яких здійснювалася антитерористична операція, та визнання такими, що втратили чинність, деяких розпоряджень Кабінету Міністрів України: розпорядження Кабінету Міністрів України № $1275-p$ від 02 грудня 2015 року: http://zakon2.rada.gov.ua/laws/show/1275-2015- \%D1\%80/paran8\#n8.

13. Одерій О.В., Клечановський І.С., Клечановська Ю.А. Практика застосування статті 615 Кримінального процесуального кодексу україни (теоретико-прикладний аспект). Криміналістика і судова експертиза. 2017. Вип. 62. С. 10-20

14. Хаваліц О. В. Прокурорський нагляд за додержанням законів при розслідуванні кримінальних правопорушень терористичного характеру : дис. канд. юрид. наук: 12.00.09. Луцьк, 2016. 232 с.

15. Лазукова О. В. Особливий режим досудового розслідування в умовах воєнного, надзвичайного стану або у районі проведення антитерористичної операції: дис...канд. юрид. наук : 12.00.09 . Х., 2018. 276 с.

16. Про забезпечення прав і свобод громадян та правовий режим на тимчасово окупованій території України: Закон України від 15.04.2014 p. № 1207-VII. URL: https://zakon.rada.gov.ua/laws/show/1207-18\#Text

17. Путин: российской армии на Донбассе нет // Гордон. URL: http:// gordonua.com/news/war/putin-rossiyskoy-armii-na-territoriidonbassa-net-tam-sozdany-miliceyskieformirovaniya-kotorye-gotovy-otrazit-lyubye-krupnomasshtabnye-voennye-akcii-222066.html

18. Резолюція Генеральної Асамблеї ООН «Територіальна цілісність України» № $68 / 262$ від 27.03.2014p. URL:https://www.un.org/en/ ga/search/view_doc.asp?symbol=A/RES/68/262

19. Звіт Оффісу прокурора Міжнародного кримінального суду щодо дій з попереднього розслідування за 2019 p. URL: https://www.icccpi.int/itemsDocuments/191205-rep-otp-PE.pdf.

20. Принцип компліментарності: стандарти міжнародного правосуддя в Україні. URL: http://justiceforthefuture.org.ua/uploads/ MaterialDocument/ULAG_complementarity web ua 00426 1594216073.pdf

21. Перешкоди в реалізації прав і свобод осіб на окупованій території Кримського півострова та тимчасово непідконтрольних територіях Донецької та Луганської областей (реєстрація фактів народження і смерті). Аналітичний звіт URL: https://helsinki.org.ua/wp-content/ uploads/2018/02/Zvi1t.pdf. $40 \mathrm{c}$. 


\section{ПРАВА ДЕРЖАВНИХ СЛУЖБОВЦІВ ПРАВООХОРОННИХ ОРГАНІВ ЯК ЕЛЕМЕНТ АДМІНІСТРАТИВНО-ПРАВОВОГО СТАТУСУ}

Статтю присвячено дослідженню правам державних службовців правоохоронних органів, як одному із обов'язкових елементів їх адміністративно-правового статусу.

Наголошено, що серед науковців досі відсутній єдиний правовий підхід щодо визначення змісту таких понять, як "правовий статус" та "адміністративно-правовий статус".

Правовий статус визначено, як загальну, комплексно-універсальну, різноаспектну, цілісну категорію, що має чітку структуру та визначає принципи взаємодії між суб'єктами суспільних відносин, а також місце кожного в існуючій системі правових відносин.

Зазначено, що одним із різновидів адміністративно-правового статусу особи є статус державного службовця правоохоронного органу під яким можна розуміти сукупність прав і обов'язків, гарантій, закріплених за державними службовцями правоохоронних органів законами, підзаконними нормативно-правовими актами, положеннями, посадовими інструкціями, статутами.

Запропоновано до основних елементів адміністративно-правового статусу державного службовця правоохоронного органу віднести: права, обов'язки, гарантії.

Визначено, що систему прав, державних службовців правоохоронних органів складають: 1) конституційні права, та ті, яких закріплено в законодавстві про державну службу, що є загальними для усіх державних службовців; 2) права, яких закріплено спеціальними актами законодавства, якими врегульовано діяльність правоохоронних органів в цілому, або окремих правоохоронних органів, дія яких розповсюджується на усіх державних службовців правоохоронних органів або тільки на окремих, які проходять службу у відповідному правоохоронному органі.

Вказано, що права, якими наділені державні службовці правоохоронних органів можна класифбікувати на певні різновиди, зокрема: за сферою впливу (на юридичні, економічні, соціальні, ідеологічні (морально-духовні), політичні тощо); за специфікою правового статусу (права, що властиві працівникам правоохоронних органів як державним службовцям (загальні), i ті, що забезпечують їхній особливий правовий статус як працівників правоохоронного органу в якому вони проходять службу).

Ключові слова: державний службовець, правоохоронний орган, адміністративно-правовий статус, гарантії, права, обов'язки.

\section{RIGHTS OF CIVIL LAW ENFORCEMENT SERVANTS AS AN ELEMENT OF ADMINISTRATIVE AND LEGAL STATUS}

The article is devoted to the study of the rights of civil servants of law enforcement agencies, as one of the mandatory elements of their administrative and legal status.

It is emphasized that among scholars there is still no single legal approach to determining the content of such concepts as "legal status" and "administrative and legal status."

The legal status is defined as a general, integrated, multifaceted, holistic category that has a clear structure and defines the principles of interaction between the subjects of public relations, as well as the place of each in the existing system of legal relations.

It is noted that one of the types of the administrative and legal status of a person is the status of a civil servant of a law enforcement agencies, which can be understood as a set of rights and responsibilities, guarantees assigned to civil servants of law enforcement agencies by laws, regulations, job descriptions, statutes.

It is proposed to include the following elements of the administrative and legal status of a civil servant of a law enforcement agency: rights, responsibilities, guarantees.

It is determined that the system of rights of civil servants of law enforcement agencies consists of 1) constitutional rights, and those enshrined in the legislation on civil service, which are common to all civil servants; 2) rights enshrined in special acts of legislation governing the activities of law enforcement agencies as a whole, or individual law enforcement agencies, the effect of which extends to all civil servants of law enforcement agencies or only to individuals serving in the relevant law enforcement agency.

It is stated that the rights granted to civil servants of law enforcement agencies can be classified into certain types, in particular: by a sphere of influence (legal, economic, social, ideological (moral and spiritual), political, etc.); according to the specifics of the legal status (rights that are inherent in law enforcement officers as civil servants (general), and those that provide their special legal status as employees of the law enforcement agency where they serve).

Key words: civil servant, law enforcement agency, administrative and legal status, guarantees, rights, responsibilities.

Актуальність теми дослідження. Чітке визначення прав за державними службовцями правоохоронних органів сприяє не тільки кращому виконанню повноважень та завдань, покладених на відповідний правоохоронний орган, а й - дозволяє краще контролювати їх виконання, та у разі виявлення порушень, застосовувати до винних заходи дисциплінарного впливу. 3 огляду на зазначене, набуває актуальності дослідження сутності прав, якими наділені державні службовців, що проходять службу в правоохоронних органах як елементу їх адміністративно-правового статусу, здійснення їхньої класифікації.

Аналіз останніх досліджень. Дослідженням окремих питань, пов'язаних із адміністративно-правовим статусом деяких суб'єктів адміністративного права займалися такі науковці, як В.Б. Авер'янов, А.М. Авторгов, Н.О. Армаш, Д.М. Бахрах, Ю.П. Битяк, Т.О. Гуржій, С.Д. Гусарєв, Я.С. Золотарьова, С.В. Додін, Д.С. Каблов, С.Ф. Констан- тінов, Л.В. Крупнова, У.І. Ляхович, М.І. Іншин, А.В. Панчишин, Ю.А. Тихомиров та інші.

Постановка завдання (формулювання цілей статті). Метою статті є розкриття сутності прав державного службовця правоохоронного органу як необхідного структурного елементу його адміністративно-правового статусу. Основними завданнями автор ставить перед собою визначення правової природи такого структурного елемента адміністративно-правового статусу як права державних службовців правоохоронних органів, визначення можливих критеріїв їх класифікації та розкриття загальних положень щодо обов'язків службовців правоохоронної сфери.

Виклад основного матеріалу. Одним із видів правового статусу певної категорії осіб є вид професійної діяльності, яким є державна служба в правоохоронних органах. Необхідність дослідження правового статусу державних службовців у цілому, у тому числі правоохоронних органів, обумовлена наявністю певного кола спеціальних прав 
та обов'язків, якими вони наділені для виконання своїх службових повноважень; наділення їх підвищеною відповідальністю за порушення або неналежне виконання обов'язків; наявністю особливих пільг та соціально-правового забезпечення.

Серед науковців досі відсутній єдиний правовий підхід щодо визначення змісту таких понять, як "правовий статус" та "адміністративно-правовий статус".

Наприклад, поняття "правовий статус" тлумачиться як: сукупність прав та обов'язків фізичних чи юридичних осіб [1, с. 44]; система закріплених у нормативноправових актах і гарантованих державою прав, свобод, обов'язків та відповідальності індивіда [2, с. 409; 3, с.81].

За допомогою застосування категорії "правовий статус" можливим $€$ визначення співвідношення особи та права, за допомогою якого держава окреслює для суб'єкта межі можливої поведінки, його становище щодо інших суб'єктів права, і залежно від індивідуальних або типових ознак, які властиві суб'єктові, у праві відбивається повнота правового становища особи, іiі певна уніфікація або обмеження. По суті, правовий статус - це загальна, комплексно-універсальна, різноаспектна, цілісна категорія, що має чітку структуру та визначає принципи взаємодії між суб'єктами суспільних відносин, а також місце кожного в існуючій системі правових відносин. Із цього визначення можна виокремити такі риси, що характеризують термін “правовий статус»: чітка структурованість цієї категорії; глобальність та універсальність; обумовленість взаємозв'язку між суб'єктами суспільних відносин і визначення місця кожного суб'єкта у системі права $[4$, с. 95$]$.

Немає одностайності серед правознавців і щодо визначення терміну "адміністративно-правовий статус”. Так, наприклад, Ю.О. Тихомиров адміністративноправовий статус громадянина визначає як встановлені законом та іншими правовими актами права, обов'язки та відповідальність громадянина, яка забезпечує його участь в управлінні державою та задоволення публічних та особистих інтересів завдяки діяльності державних органів [5, с. 345-346]. Васильєв А.С. вважає, що зміст адміністративно-правового статусу громадянина - це конкретизовані й деталізовані конституційні права, свободи й обов'язки громадян, закріплені в нормах адміністративного права, а також гарантії реалізації цих прав i свобод,забезпечені механізмом їхнього захисту органами держави та місцевого самоврядування [6, с. 119; 3, c. 81].

Серед науковців виділяється “правовий статус працівника органів внутрішніх справ", як це визначена у нормативно-правових актах система прав, свобод, обов'язків, обмежень, морально-правових вимог і гарантій професійної діяльності окремої категорії працівників служб та підрозділів системи МВС України, що виконують правоохоронні завдання в сфері охорони громадського порядку, забезпечення громадської безпеки та боротьби з правопорушеннями, їх соціально-правовий захист і особливості юридичної відповідальності [7, с. 48].

Одним із різновидів адміністративно-правового статусу особи є статус державного службовця правоохоронного органу під яким можна розуміти сукупність прав i обов'язків, гарантій, закріплених за державними службовцями правоохоронних органів законами, підзаконними нормативно-правовими актами, положеннями, посадовими інструкціями, статутами.

Таким чином, права є структурним елементом адміністративно-правового статусу державного службовця правоохоронного органу, який поряд із обов'язками та гарантіями розглядається як вихідний та загальноприйнятий елемент.

За одним із наведених у Словнику української мови значень "права" - це обумовлена певними обставинами підстава, здатність, можливість робити, чинити що-небудь, користуватися чим-небудь [8].

Натомість в розумінні Порядку розроблення посадових інструкцій державних службовців категорій “Б” та "B", затвердженого наказом Національного агентства України з питань державної служби 11.09.2019 p. № 172-19 права це можливість вчиняти дії чи бездіяльність під час проходження державної служби [9].

Щодо прав як елементу адміністративно-правового статусу державного службовця правоохоронного органу, то під ними розуміються гарантовані адміністративно-правовою нормою межі можливої або дозволеної поведінки особи, що встановлюється для забезпечення публічного інтересу та виконання визначених функцій державного органу. Права державного службовця правоохоронного органу конкретизуються через надані їм правомочності.

На думку M.I. Іншина для чіткого визначення статусу державного службовця, доцільно виділити серед елементів його статусу загальні та особливі (основні, неосновні або додаткові) права, обов'язки та обмеження, гарантії, економічне забезпечення та відповідальність [7, с. 45].

Вважаємо за можливе виокремити загальні права, яких набуває будь-який державний службовець, зокрема:

право на належні для роботи умови служби та їх матеріально-технічне забезпечення;

право на оплату праці залежно від займаної посади державної служби, результатів службової діяльності, стажу державної служби та рангу державного службовця;

право на відпустку, соціальне та пенсійне забезпечення відповідно до закону;

право на просування по службі з урахуванням професійної компетентності та сумлінного виконання своїх посадових обов'язків і т.д.

Спеціальними правами державних службовців правоохоронних органів, яких опосередковано специфікою служби в правоохоронному органі $є$ :

право на отримання від державних органів, підприємств, установ та організацій, органів місцевого самоврядування необхідної інформації 3 питань, що належать до його повноважень, у випадках, встановлених законом;

право на безперешкодне ознайомлення з документами про функціонування підприємств, установ, організацій незалежно від форми власності;

право на проведення службового розслідування за його вимогою 3 метою зняття безпідставних, на його думку, звинувачень або підозри;

право на носіння зброї;

право на застосування заходів державного захисту і т.д.

Перелік спеціальних прав державного службовця правоохоронного органу закріплено у законах та підзаконних нормативно-правових актах, якими врегульовано діяльність відповідного правоохоронного органу, положеннях про структурні підрозділи державних органів, посадових інструкціях, затверджених керівниками державної служби в цих органах, а також дисциплінарних статутах (за наявності). До прикладу, в Митному кодексі України [10], Положенні про Державну митну службу України, затвердженої постановою Кабінету Міністрів України від 06.03.2019 p. № 227 [11] та ін.

В свою чергу права, якими наділені державні службовці правоохоронних органів можна класифікувати на певні різновиди, зокрема: за сферою впливу (на юридичні, економічні, соціальні, ідеологічні (морально-духовні), політичні тощо); за специфікою правового статусу (права, що властиві працівникам правоохоронних органів як державним службовцям (загальні), і ті, що забезпечують їхній особливий правовий статус як працівників правоохоронного органу в якому вони проходять службу).

У своїй сукупності загальні та спеціальні права утворюють єдиний елемент адміністративно-правового статусу державного службовця правоохоронного органу. 
Висновки. Таким чином, можна прийти до висновків, що права як елемент адміністративно-правового статусу державного службовця правоохоронного органу розглядаються як гарантовані адміністративно-правовою нормою межі можливої або дозволеної поведінки особи, що встановлюється для забезпечення публічного інтересу та виконання визначених функцій державного органу.

Виокремлено: 1) загальні права, яких набуває будьякий державний службовець, та 2) спеціальні права державних службовців правоохоронних органів, яких опосередковано специфікою служби в правоохоронному органі.
Систему прав державних службовців правоохоронних органів складають: 1) конституційні права, та ті, яких закріплено в законодавстві про державну службу, що $є$ загальними для усіх державних службовців; 2) права, яких закріплено спеціальними актами законодавства, якими врегульовано діяльність правоохоронних органів в цілому, або окремих правоохоронних органів, дія яких розповсюджується на усіх державних службовців правоохоронних органів або тільки на окремих, які проходять службу у відповідному правоохоронному органі.

\section{ЛITEPATУPA:}

1. Про судоустрій та статус суддів : Закон України від 07.07.2010 p. № 2453-VI. URL: https://zakon.rada.gov.ua/laws/show/1402-19\#Text

2. Загальна теорія держави та права : [підручник для студентів юридичних вищих навчальних закладів] / [М.В. Цвік, О.В. Петров, Л.В. Авраменко та ін.] ; за ред. М.В. Цвіка, О.В. Петришина. Х. : Право, 2009. 584 с.

3. Золотарьова Я.С. Адміністративно-правовий статус державних службовців судових органів : теоретичний аспект. Науковий вісник Ужгородського національного університету, 2015. Випуск 34. Том 2.

4. Панчишин А.В. Поняття, ознаки та структура категорії “правовий статус". Часопис Київського університету права. 2010 . № 2. Ст. 95-98.

5. Тихомиров Ю.А. Курс административного права и процесса / Ю.А. Тихомиров. М., 1998. 799 с.

6. Васильев А.С. Административное право Украины / А.С. Васильев. Х. : Одиссей, 2002. 288 с.

7. Іншин M.I. Поняття та елементи статусу державного службовця органів внутрішніх справ. URL: http://dspace.univd.edu.ua/ xmlui/bitstream/handle/123456789/2770/Poniattia\%20ta\%20elementy\%20statusu\%20derzhavnoho\%20sluzhbovtsia\%20_Inshyn\%20_2006. pdf? sequence $=2$

8. Словник української мови. URL: http://sum.in.ua/s/pravo.

9. Порядок посадових інструкцій державних службовців категорій "Б” та "В": наказ Національного агентства України з питань державної служби 11.09.2019 р. № 172-19. URL: https://zakon.rada.gov.ua/laws/show/z1077-19/ed20190911\#n22

10. Митний кодекс України: Закон України від 13.03.2012 p. № 4495-VI. : URL: https://zakon.rada.gov.ua/laws/show/4495-17/ed20210328

11. Положення про Державну митну службу України: постанова Кабінету Міністрів України від 06.03.2019 р. № 227. URL: https://zakon.rada.gov.ua/laws/show/227-2019-\%D0\%BF\#Text. 
УДК 340.15

DOI https://doi.org/10.32782/2524-0374/2020-4/101

\title{
ВИЗНАЧЕННЯ МІСЦЯ ЮРИДИЧНОЇ ОСВІТИ В СТРУКТУРІ ПРАВОВОЇ СИСТЕМИ DETERMINATION OF THE LEGAL EDUCATION PLACE IN THE LEGAL SYSTEM'S STRUCTURE
}

\author{
Кравченко I.O. \\ доктор юридичних наук, \\ доцент кафедри адміністративного та інформаційного права \\ Сумського національного аграрного університету
}

Принцип верховенства права має фундаментальне значення для формування правової держави. Процес формування правової держави є тривалим та зумовлений проведенням економічних, політичних, правових, соціальних, освітніх реформ, в тому числі, потребує модернізації підготовки юристів, але з урахуванням розвитку та становленням національної правової системи, зближенням правових систем, процесу інтеграції у європейський освітній простір, розширення міжнародного співробітництва в усіх сферах, введення норм і принципів міжнародного співробітництва до національної правової системи. Зазначена тема є актуальною у зв'язку з сучасними процесами модернізації національної юридичної освіти, які впливають на формування національної правової системи.

Метою статті $є$ уточнення місця юридичної освіти в структурі правової системи на основі аналізу думок провідних науковців.

У статті розглянуто різні підходи до структурування правової системи. Автор статті доводить, що правова система є поліструктурним утворенням, яке складається з різних компонентів, які будуть утворювати підсистеми, які в свою чергу складаються з окремих елементів. Юридична освіта, в свою чергу, є структурним утворенням з чіткими взаємозв'язками між її елементами та містить потенціал для розвитку правової системи. Звертається увага, що існує принаймні два підходи: перший, юридична освіта є окремим структурним елементом правової системи; другий, що юридична освіта є елементом правової культури, а остання є структурним елементом правової системи.

Під впливом соціально-економічних та політико-правових факторів відбуваються зміни в системі вищої освіти, які впливають на зміст, форми та напрями розвитку юридичної освіти, яка є безпосереднім джерелом правосвідомості в системі правової культури, виконує функції накопичення ії історичних досягнень та передачі ̈̈х наступному поколінню. У зв'язку з цим юридична освіта виступає основою відтворення правової культури суспільства, має прямий вплив на розвиток права, сприйняття його суспільством та роботу законодавчих та правоохоронних державних органів. Якщо правову систему розглядати як сукупність правових явищ, то юридична освіта визначає вектор її розвитку. Окрім того, якісна юридична освіта не може існувати без науки, а без науки немає досконалої правової системи.

Ключові слова: юридична освіта, правова система, структура правової системи, модернізація юридичної освіти, інтеграція юридичної освіти.

The rule of law principle is fundamental for the formation of the constitutional state. The process of constitutional state formation is long and conditioned by economic, political, legal, social, educational reforms, including the need to modernization in training of lawyers, but taking into account the development and formation of the national legal system, convergence of legal systems, integration into the European educational space, expansion of international cooperation in all spheres, introduction of norms and principles of international cooperation into the national legal system. This topic is relevant because of connection with the current processes of national legal education modernization, which affect the formation of the national legal system.

The purpose of the article is to clarify the place of legal education in the structure of the legal system based on the analysis of the leading scholars' opinions.

The article considers different approaches to structuring the legal system. The author of the article argues that the legal system is a polystructural entity, which consists of various components that will form subsystems, which in turn consist of individual elements. Legal education is a structural entity with clear links between its elements and has the potential to develop the legal system. It is noted that there are at least two approaches: first, legal education is a separate structural element of the legal system; the second, legal education is an element of legal culture, and the latter is a structural element of the legal system. Under the influence of socio-economic and political-legal factors there are changes in the higher education system that affect the content, forms and directions of legal education, which is a direct source of legal awareness in the system of legal culture, performs the functions of accumulation of its historical achievements passing them on to the next generation. In this regard, legal education is the basis for the reproduction of the legal culture of society, has a direct impact on the development of law, its perception by society and the work of legislative and law enforcement agencies. We consider the legal system as a set of legal phenomena, so legal education determines the vector of its development. In addition, quality legal education cannot exist without science, and without science there is no perfect legal system.

Key words: legal education, legal system, structure of legal system, modernization of legal education, integration of legal education.

Постановка проблеми. Принцип верховенства права має фундаментальне значення для формування правової держави. Процес формування правової держави є тривалим та зумовлений проведенням економічних, політичних, правових, соціальних, освітніх реформ, в тому числі, потребує модернізації підготовки юристів, але з урахуванням розвитку та становленням національної правової системи, зближенням правових систем, процесу інтеграції у європейський освітній простір, розширення міжнародного співробітництва в усіх сферах, введення норм і принципів міжнародного співробітництва до національно правової системи. Зазначена тема є актуальною у зв'язку 3 сучасними процесами модернізації національної юридичної освіти, які впливають на формування національної правової системи.

В умовах трансформації суспільних відносин та модернізації юридичної освіти України, протягом останніх років, дослідження юридичної освіти як елемента пра- вової системи потребує уточнення та визначення місця юридичної освіти в структурі правової системи. Питання щодо структури правової системи супроводжується плюралізмом думок науковців, тому необхідно звернути увагу насамперед на те, що розуміють під правовою системою, 3'ясувати в чому іiі сутність та феноменальність, проаналізувати різні концепції щодо елементів правової системи і довести, що юридична освіта є одним із структурних елементів правової системи.

Аналіз останніх досліджень і публікацій. Проблематика юридичної освіти в різноманітних аспектах, викликає жвавий інтерес сучасних науковців-правознавців. Питанню визначення юридичної освіти як елементу правової системи присвячені праці Дячишина Я.В., Карташова В.Н., Лук'янова В.Д., Осики I.В., Павлишина О. В., Садовської О.М., Скакун О.Ф., Сунєгіна С.О., Удовики Л.Г., Фрідмена Л., Харитонової О.I., Харитонова Є.О., Хаустової М., Яковюка I. 
Виклад основного матеріалу. Юридична освіта $\epsilon$ багатогранним суспільним (суспільно-політичним, соціально-педагогічним) явищем, отже, складним об'єктом, що вимагає комплексного дослідження шляхом реалізації системного підходу. Погоджуючись 3 думкою Л.Т. Рябовол, що юридичну освіту розглядають як: складник правової освіти у широкому розумінні; галузь вищої освіти; освітній рівень (рівень фахової освіти), здобутий в результаті послідовного й цілеспрямованого процесу засвоєння системи правових знань, поглядів, переконань, умінь i навичок, формування особи, як громадянина, здатного до професійно-правової діяльності; безперервний процес спеціалізованого теоретичного і практичного навчання, що здійснюється у вищих навчальних закладах, де зосереджено висококваліфікований науковий і науково-педагогічний персонал, забезпечується поєднання навчального процесу з науково-практичною діяльністю та готуються компетентні кадри у галузі права відповідно до стандартів вищої освіти; фундамент юридичної професії, запорука професійної компетентності юриста й середовище формування нового покоління правників; один з інструментів реалізації соціальної функції права; критерій соціальної стратифікації; специфічний вид підприємницької діяльності; шлях розбудови політичної кар'єри; спосіб реалізації особистих амбіцій тощо [8, с. 379]. Необхідно додати, що юридичну освіту необхідно розглядати у контексті елемента правової системи.

Слушними $є$ положення сформульовані українською дослідницею Л. Удовикою, що правова система є гранично загальним поняттям, позитивним виміром правової реальності, що в найбільш узагальненому вигляді відображає єдність компонентів і елементів у формальному й структурному вигляді [13, с. 12].

I. Яковюк же зазначає, що правова система являє собою складне структурне, багатошарове утворення, що становить сукупність взаємопов'язаних, але відносно автономних елементів, які об'єднані спільними цілями і яким властиві саморозвиток і самоорганізація. Правова система - це не застигла, статична сфера життєдіяльності суспільства. Для неї характерними є зміни, які призводять до складних сполучень ії елементів, що обумовлено об'єктивними закономірностями розвитку суспільства $[17$, с. 43$]$.

Разом $з$ тим, не можна не погодитися з думкою М. Хаустової, що всі елементи правової системи тісно пов'язані один $з$ одним, є взаємозалежними, втім мають і відносну самостійність. Усі вони виконують загальні і специфічні функції у правовій системі, характеризуються єдністю й розходженням, сприяють ефективності дії всього розглянутого утворення. Науковця, орієнтуючись на методологічний арсенал системного підходу, вирізняє такі складники в дослідженні правової системи: суб'єктний; нормативний; інтелектуально-психологічний; діяльнісний; результативний [16, с. 54].

Узагальнюючи думки теоретиків та компаративістів, під правовою системою розуміють сукупність всіх правових явищ в державі, сформованих на системному підході та всі ії елементи перебувають у сталих зв'язках між собою. Звичайно, що це поняття є достатньо складним i включає як статичні, так і динамічні структурні елементи: право, систему права, правові відносини, правове виховання, правову ідеологію та свідомість, юридичну практику і діяльність, юридичну освіту тощо.

Принагідно зауважимо, що дискурс, щодо елементів правової системи продовжується у науковому середовищі, що дозволяє поглянути на це правове явище в контексті сучасної наукової та інтегративної перспективи та створює нові можливості для вивчення його природи та основних властивостей.

Взаємозв'язок елементів правової системи, їх функціонування зумовлюють саме існування правової системи, оскільки ізольовано, в розрізненому вигляді, вона існувати не може. Тому при дослідженні даної категорії доцільне застосування системно-структурного підходу, вивчення правової системи як в цілому, так і їі складових частин. Системний підхід у даному разі $є$ одним із інструментів дослідження об'єкта як складного явища, що містить елементи, взаємозв'язок між якими забезпечує їх цілісність [7, c. 7].

Як вже зазначалось, питання про структуру правової системи є дискусійним у вітчизняній та зарубіжній науковій літературі. Різноманітність концепцій з цього питання пов'язано 3 аксіологічними особливостями правової системи, історичними особливостями ґенези, взаємодією правової системи з іншими елементами суспільства і держави. Сучасні науковці у питанні щодо елементів правової системи виділяють два основних підхода: перший, коли основним елементом є право, другий, коли основним елементом виступають суб'єкти права.

Як зазначає Я. Дячишин, найважливішою частиною правової системи виступає іiі структура. Це така ії будова, розташування елементів і зв'язків, яка забезпечує іії цілісність, збереження основних властивостей і функцій під час впливу на неї різноманітних чинників реальної дійсності (економічних і політичних, національних і релігійних, внутрішніх і зовнішніх, об'єктивних і суб'єктивних тощо) $[1$, с. 8]. Зазначена позиція вимагає уточнення, на нашу думку, структура не може визначатися частиною правової системи, адже під структурою, як правило, розуміють взаємозв'язок складових частин цілого або визначають, як будову чого-небудь, тобто окремі елементи утворюють структуру правової системи.

В.Н. Карташов визначає структуру правової системи як будову, розташування елементів і зв'язків, які забезпечують іiі цілісність, збереження основних властивостей і функцій при впливі на неї різноманітних факторів реальної дійсності (економічних і політичних, національних i релігійних, внутрішніх і зовнішніх, об'єктивних і суб'єктивних і т. д.). Науковець окремо виділяє елементи, тобто умовно неподільні складові і компоненти, як укрупнені утворення об'єднані у підсистеми. До основних компонентів відносять: 1) об'єктивне право, взяте в єдності і взаємодії його змісту і форми; 2) юридична практика (діяльність і соціально-правовий досвід), що здійснюється в рамках правових відносин та інших юридичних зв'язків; 3. правосвідомість, яка знаходить вираз і в об'єктивному праві, і в юридичній діяльності, і в правовідносинах, і в юридичній культурі тощо [3, с. 59-60].

Науковець В.М. Синюков виділяє достатньо широке коло елементів, які утворюють правову систему: система законодавства; структура юридичних, в тому числі, правоохоронних відомств та організацій; регіональна і місцева правова інфраструктура; наглядова і контрольна підсистема; система профілактики правопорушень і соціальний контроль; система правового інформування і правових комунікацій; організація юридичної реабілітації правопорушників; інфраструктура забезпечення прав людини; альтернативні способи вирішення спорів; система юридичної освіти, перепідготовки та підвищення кваліфікації кадрів; «мозкові центри» генезису, відтворення і зберігання правової ідеології; принципи пануючого правосвідомості; система канонічного правового регулювання; способи юридичної легалізації соціальних фактів. На думку науковця такий підхід не суперечить наявними в літературі, але відрізняється більшим ступенем обліку будови і функціонування правових інститутів і специфіки правової традиції [10, с. 198]. Юридичну освіту автор визначає як додатковий елемент.

Такий же широкий підхід до сукупності елементів правової системи закладений у працях О.I. Харитонової та Є.О. Харитонова: 1) право як сукупність створених державою норм, що перебуває під іiі охороною; 
2) законодавство як форма вираження цих норм (нормативні акти); 3 ) правові інституції, що здійснюють правову політику держави; 4) судова та інша юридична практика; 5) механізм правового регулювання; 6) правореалізаційний процес (включаючи акти застосування i тлумачення; 7) права, свободи і обов'язки громадян (право в суб'єктивному значенні); 8) система функціонуючих у суспільстві правовідносин; 9) законність і правопорядок; 10) правова ідеологія (правосвідомість, юридичні доктрини, теорії, правова культура тощо); 11) суб'єкти права (індивідуальні і колективні); 12) системні зв'язки, які забезпечують єдність, цілісність та стабільність системи; 13) інші правові явища (юридична відповідальність, правосуб'єктність, правовий статус, законні інтереси тощо), які утворюють «інфраструктуру правової системи» [15, с. 26-27]. Перелік елементів не місить юридичну освіту, але включає правову культуру. Відомо, що однією з форм правової культури є професійна правова культура, тобто вона притаманна спільноті людей, які професійно здійснюють юридичну діяльність, мають фахову освіту і досвід практичної діяльності.

Так О.В. Павлишин, розкриває поняття правової культури у семіотико-правовому контексті через певну систему елементів, ключовими 3 яких є: ідея права, яка утворює змістовну основу правової культури; авторитет права, повага до його першооснов; правосвідомість, що адекватна правовій системі; правові традиції, потреби й навички діяльності відповідно до закону; власне поведінка громадян у режимі законності, відповідно до правових установок та переконань; діяльність інших соціальних суб'єктів у дотриманні законності, відповідно до правових установок і переконань; правова активність населення, посадових осіб та законодавців, урядовців; правові знання, уявлення, цінності та погляди, юридична освіта та ін. [6, с. $84-85]$.

Дослідниця І.В. Осика виділяє наступні умови підвищення правової культури, серед яких виділяє у сфері юридичної науки та юридичної освіти: 1) у сфері загальнодержавної стратегії: спрямованість державної політики на захист інтересів особистості, вироблення єдиної правової політики, забезпечення добробуту громадян, дотримання Конституції і законів всіма державними органами; 2) у сфері правотворчості: професіоналізація законодавчої діяльності, надання населенню права законодавчої ініціативи, поширення знань в області юридичної техніки, широке публічне висвітлення законопроектної діяльності, посилення юридичної відповідальності за порушення прав і свобод громадян; 3) у сфері правозастосування: ліцензування юридичної діяльності, розвиток судової системи, проведення практичних семінарів для працівників державних органів, створення консультативних рад при міністерствах та інших центральних органах виконавчої влади; 4) у сфері юридичного виховання: підвищення загальної моральності громадян, популяризація правових знань (у тому числі через засоби масової інформаціï), використання рольових ігор і практичних ситуацій, застосування методів реклами i “public relations", розвиток сімейного правового виховання; 5) у сфері юридичної науки і юридичної освіти: подальший розвиток наукових досліджень у галузі правової культури, подолання розриву між наукою і практикою, підвищення ефективності вищої юридичної освіти, поглиблення вивчення юридичних дисциплін у неюридичних закладах вищої освіти і загальноосвітніх установах; 6) у сфері громадянського суспільства й особистої ініціативи: розвиток системи громадських організацій, активне відстоювання особистістю своїх прав, боротьба з будь-якими проявами беззаконня і свавілля [5, с. 9-10].

С. О. Сунєгін, базуючись на інструментальному підході до характеристики правової системи, доводить, що елементи правової системи поділяються на статичні та динамічні залежно від способу вираження правових засобів, за допомогою яких забезпечується досягнення соціально корисних цілей. Автор обгрунтовує думку про те, що правова система завжди має у своїй структурі дві групи взаємодіючих, взаємозалежних та взаємообумовлених елементів (правових засобів): перші - це стійкі, субстанційні та стабільні елементи (статичні), які складають принциповий стрижень правової системи, мають інформаційний характер, відображають певні юридичні моделі або ідеальні зразки, які тільки в процесі їхнього використання можуть привести до досягнення поставлених цілей, та залишаються відносно незмінними впродовж тривалого періоду часу; другі - це рухливі або динамічні правові засоби (правовідносини, правотворчість, правозастосування та інша юридична діяльність), які перебувають у постійній кількісній та якісній зміні і відображають реальний та конкретний результат функціонування статичної частини правової системи у суспільстві, при цьому організаційний елемент правової системи складають система органів законодавчої, виконавчої та судової влади у відповідних країнах, а також науково-дослідні інститути юридичного профілю, зокрема університети, вищі навчальні заклади, що здійснюють підготовку професійних юристів та наукову діяльність у галузі юриспруденції $[12$, с. 6 , с. 9$]$.

Поділ елементів правової системи на статичні та динамічні підтримує і О.В. Петришин, він стверджує, що всі елементи правової системи $є$ неоднорідними, а центральним елементом будь-якої правової системи $є$ право, існування якого обумовлює розвиток усіх інших елементів. Через це можна стверджувати, що право існує та розвивається у вигляді правової системи. Іншими структурними елементами правової системи є правосвідомість, правова культура, юридична наука та освіта, нормотворчість, джерела права, юридична практика, правозастосування, правові відносини, правопорядок тощо [2, с. 515].

Так, на думку O.М. Садовської, загальнотеоретичне моделювання правової системи стало підставою єдності iï нормативної, інституціональної та ідеологічної складових. У своїй науковій праці, характеризуючи правову систему Італії, авторка наголошує, що юридична освіта та правова професія, разом з правою культурою $є$ ідеологічною частиною правової системи, а фахова правова освіта $є$ провідним елементом ідеологічної частини правової системи та базується на принципі безперервності освіти [9, с. 4-5].

В юридичній науці на кінець ХХ століття склався ще один підхід до розуміння та структурування елементів правової системи. В рамках цього підходу, при наявному різноманітті поглядів щодо структури правової системи, більшість науковців виділяють інституціональну (суб'єктивну), нормативну (регулятивну), ідеологічну (доктринальну), функціональну (соціологічну, практичну) підсистеми.

До інституиіональної (суб 'єктивної) підсистеми включають суб'єктів права разом з їх правами та обов'язками, правовим статусом та особливостями юридичної відповідальності останніх.

До нормативної (регулятивної) підсистеми відносять сукупність усіх норм і принципів права, мають форму нормативно-правових актів, прецедентів, правових договорів, правових звичаїв та врегульовують відносини між суб'єктами права.

Ідеологічна (доктринальна) підсистема - сукупність уявлень та поглядів на право та правові явища, що виявляються через правову культуру, правову психологію, правову ідеологію, правові цінності.

Функиіональна (сочіологічна, практична) підсистема представлена процесами правотворчості, реалізації та застосуванні права, тлумаченні права, юридичною практикою. 
Всі ці підсистеми є взаємозалежними і в єдності утворюють цілісну систему, але науковці обгрунтовують і інші підсистеми, які відіграють не менш важливу роль у формуванні правової системи. Так О.Ф. Скакун, окрім перелічених підсистем виділяе ще комунікативну (інтегральну) niдсистему, як закономірності взаємовідносин між взаємодіючими та взаємообумовленими підсистемами, зв'язків правової системи 3 політичною, економічною та іншими системами суспільства, зв'язків 3 міждержавними системами [11, с. 48].

Д.В. Лук'янов, виокремлює інфраструктурну та результативну складові. Інфраструктурну підсистему утворюють елементи, що сприяють належному функціонуванню правової системи (юридична освіта, юридична наука юридична професія та ін..), а результативна підсистема відображає результати дії права, ступень його соціальної значущості та відповідності інтересам соціуму (судова та інша юридична практика, стан правопорядку та ін.) [4, с. 157-158].

У західній компаративістиці, менше ніж у східноєвропейській науці, приділяється увага такій категорії як структура правової системи, західні правознавці більше уваги приділяють типології правових систем.

Характеризуючи американську правову систему, Л. Фрідмен визначав, що саме структура правової системи - іiі скелет або каркас - $\epsilon$ довгостроково існуючою частиною, що надає форму і визначеність цілому. Структуру правової системи автор визначає як сукупність елементів, які утворюють наступний ряд: кількість і компетенція судів, їх юрисдикція, способи апеляції, організацію і компетенції легіслатур та інші елементи, тобто структура $\epsilon$ вид перетину системи, яка заморожує дію [14, с.10].
Погоджуючись 3 думкою російського науковця В.М. Синюкова, необхідно зазначити, що важливим елементом відтворення правової системи є юридична освіта. Історичні традиції юридичної освіти, його соціокультурний статус в механізмі формування національних юридичних цінностей визначає характер правової системи, вектори їі розвитку. Підготовка юридичних кадрів - потужний канал оновлення правової культури, і від того, які джерела його поповнюють, в значній мірі залежить, яким бути правовому укладу [10, с.586].

Здійснений огляд, на нашу думку, підтверджує висновок про відсутність в юридичній науці єдиного розуміння місця юридичної освіти в структурі правової системи. Існує принаймні два підходи: перший, юридична освіта $\epsilon$ окремим структурним елементом правової системи; другий, що юридична освіта $\epsilon$ елементом правової культури, а остання $є$ структурним елементом правової системи.

Висновки. Під впливом соціально-економічних та політико-правових факторів відбуваються зміни в системі вищої освіти, які впливають на зміст, форми та напрями розвитку юридичної освіти, яка є безпосереднім джерелом правосвідомості в системі правової культури, виконує функції накопичення іiї історичних досягнень та передачі їх наступному поколінню. У зв'язку з цим юридична освіта виступає основою відтворення правової культури суспільства, має прямий вплив на розвиток права, сприйняття його суспільством та роботу законодавчих та правоохоронних державних органів. Якщо правову систему розглядати як сукупність правових явищ, то юридична освіта визначає вектор іiї розвитку. Окрім того, якісна юридична освіта не може існувати без науки, а без науки немає досконалої правової системи.

\section{ЛITEPATУРA}

1. Дячишин Я.В. Теоретико-методологічні проблеми формування правової системи суспільства: автореф. дис. ... канд. юрид. наук. Львів, 2014. 25 с.

2. Загальна теорія права : підручник / [О. В. Петришин, Д. В. Лук'янов, С. І. Максимов, В. С. Смородинський та ін.]; за ред. О. В. Петришина. Харків : Право, 2020. 568 с.

3. Карташов В.Н. Теория правовой системы общества : учебное пособие. В 2-х т. Т. 1. Ярославль: ЯрГУ, 2005. 547 с.

4. Лук'янов В.Д. Загальна теорія права: посібник. Харків : Право, 2019. 172 с.

5. Осика І.В. Правова культура у формуванні правової, соціальної держави: авторефр. дис. ... канд. юрид. наук. Київ, 2004. 24 с.

6. Павлишин О. В. Правова культура як показник рівня розвитку системи юридичної освіти (семіотико-правовий аспект). Юридична психологія та педагогіка. 2013. № 2. С. 82-93.

7. Правові системи сучасності: навчальний посібник для магістрів права/ Відп. ред. Ю.С. Шемшученко. Київ: Видавництво «Юридична думка», 2012. 492 с

8. Рябовол Л.Т. Система вищої юридичної освіти в Україні. Часопис Київського університету права. 2016.№2. С.379-383

9. Садовська О.М. Правова система Італії: загальнотеоретична характеристика основних елементів: автореф. дис. ... канд. юрид. наук. Харків, 2001. 26 с.

10. Синюков В.Н. Российская правовая система. Введение в общую теорию. Москва: Норма, 2010. 672 с.

11. Скакун О.Ф. Общее сравнительное правоведение: основные типы (семьи) правовых систем мира. Киев: Видавничий дім «lн Юре», 2008.464 c.

12. Сунєгін С.О. Теоретико-правова характеристика статичних та динамічних елементів в романо-германській правовій сім'ї: авторефр. дис. ... канд. юрид. наук. Київ, 2011. 24 с.

13. Удовика Л.Г. Формування теорії правової системи у юридичній науці (Частина 1). Часопис Київського університету права. 2019. №3. C. $12-20$

14. Фридмэн Л. Введение в американское право : пер. с англ. / Под ред. М. Калантаровой. Москва, 1993. 286 с.

15. Харитонова О.І., Харитонов Є.О.. Порівняльне право Європи: Основи порівняльного правознавства. Європейські традиції. Харків: «Одіссей», 2002. 592 с.

16. Хаустова М. Структура правової системи суспільства. Вісник Академії правових наук України. 2010. № 1(60). С. 49-58.

17. Яковюк І. Правова культура іїї вплив на розвиток правової системи. Вісник Академії правових наук України. 2008. № 1(52). С. 43-56. 


\title{
ЗНАЧЕННЯ ТА СТРУКТУРА КРИМІНАЛІСТИЧНОЇ ХАРАКТЕРИСТИКИ СТВОРЕННЯ, КЕРІВНИЦТВА ЗЛОЧИННОЮ СПІЛЬНОТОЮ ЧИ ЗЛОЧИННОЮ ОРГАНІЗАЦІЕЮ, А ТАКОЖ УЧАСТІ У НІЙ
}

\author{
SIGNIFICANCE AND STRUCTURE OF CRIMINALISTIC CHARACTERISTICS OF \\ CREATION, LEADERSHIP BY A CRIMINAL COMMUNITY \\ OR CRIMINAL ORGANIZATION, AS WELL AS PARTICIPATION IN IT
}

\author{
Рубель А.М., начальник \\ Головного управління Нациіональної полічії в Харківській області
}

\begin{abstract}
У статті підкреслено, що при формуванні криміналістичної методики створення, керівництва злочинною спільнотою чи злочинною організацією, а також участі у ній, необхідно враховувати взаємозв'язок між закономірностями злочинної діяльності та діяльності з виявлення та досудового розслідування кримінальних правопорушень. Обґрунтовано, що криміналістична методика, будучи видовою, обов'язково повинна містити відомості про криміналістичну характеристику досліджуваної категорії кримінальних правопорушень та особливості процесу їх виявлення, розкриття та розслідування. Тільки в такому разі вона буде інформативною та відзначатися значною практичною цінністю. При формуванні криміналістичної характеристики потрібно досліджувати й використовувати в якості основи результати узагальнення досвіду розслідування створення, керівництва злочинною спільнотою чи злочинною організацією, а також участі у ній. З'ясовано значення криміналістичної характеристики створення, керівництва злочинною спільнотою чи злочинною організацією, а також участі у ній. Вказано, що в наукових працях відсутня єдність щодо визначення структури криміналістичної характеристики, через що виникають певні труднощі як при формуванні, так і використанні відповідних криміналістичних характеристик у практичній діяльності з виявлення, розкриття та розслідування кримінальних правопорушень. Виокремлено структурні елементи криміналістичної характеристики створення, керівництва злочинною спільнотою чи злочинною організацією, а також участі у ній. Підкреслено, що зміст криміналістичної характеристики становлять типові відомості про елементи механізму вчинення окремого різновиду кримінального правопорушення, які $є$ криміналістично значимими та дозволяють вирішити основні тактичні завдання, спрямовані на пошук і збирання доказів, а також встановлення всіх обставин учинення конкретного протиправного діяння.

Ключові слова: створення, керівництво злочинною спільнотою чи злочинною організацією, а також участь у ній, криміналістична методика, криміналістична характеристика, досудове розслідування, кримінальне провадження, механізм кримінального правопорушення.
\end{abstract}

In the article has been emphasized that when forming a forensic methodology of creation, management of a criminal community or criminal organization, as well as participation in it, it is necessary to take into account the relationship between the laws of criminal activity and activities to detect and investigate criminal offenses. When forming a forensic characterization, it is necessary to study and use as a basis the results of generalization of the experience of investigating the creation, management of a criminal community or criminal organization, as well as participation in it. The significance of the forensic characteristics of the creation, leadership of a criminal community or criminal organization, as well as participation in it, has been clarified. The forensic characteristics of creation, management of a criminal community or criminal organization, as well as participation in it, plays an important role in the practice of law enforcement and the judiciary. The information contained in the forensic description plays a tentative role in determining the main directions and planning the investigation of creation, management of a criminal community or criminal organization, as well as participation in it. It has been pointed out that in scientific works there is no unity in determining the structure of forensic characteristics, due to which there are some difficulties both in the formation and use of relevant forensic characteristics in practice to detect, detect and investigate criminal offenses. The content of the forensic characteristics of the creation, leadership of a criminal community or criminal organization, as well as participation in it, is directly determined by the nature of organized crime in general and the specifics of the mechanism of criminal offenses committed by criminal groups in particular. The structural elements of the forensic characteristics of the creation, management of a criminal community or criminal organization, as well as participation in it have been highlighted. Forensic characteristics of the creation, leadership of a criminal community or criminal organization, as well as participation in it, should contain the following basic elements: the identity of the offender, the identity of the victim, typical methods and a trace of the crime.

Key words: creation, management of a criminal community or criminal organization, as well as participation in it, forensic methodology, forensic characteristics, pre-trial investigation, criminal proceedings, the mechanism of a criminal offense.

Постановка проблеми. Враховуючи особливу суспільну небезпеку створення, керівництва злочинною спільнотою чи злочинною організацією, а також участі у ній, та відсутність в криміналістичній науці рекомендацій щодо їх своєчасного виявлення й ефективного розслідування, перед криміналістичною наукою постало важливе завдання, яке полягає в розробленні відповідної криміналістичної методики. Така методика, будучи видовою, обов'язково повинна містити відомості про криміналістичну характеристику досліджуваної категорії кримінальних правопорушень та особливості процесу їх виявлення, розкриття та розслідування. Тільки в такому разі вона буде інформативною та відзначатися значною практичною цінністю. У зв'язку з цим особливо актуальним $\epsilon$ питання про структуру та значення в методиці розслідування криміналістичної характеристики створення, керівництва злочинною спільнотою або злочинною організацією, а також участі у ній.

Аналіз останніх досліджень і публікацій. Поняття, сутність, значення криміналістичної характеристики кри- мінальних правопорушень та іiі місце в структурі окремої методики розслідування неодноразово досліджували в своїх працях такі вчені, як: О.О. Алєксєєв, В.П. Бахін, П.В. Берназ, Р.С. Бєлкін, В.К. Весельський, Л.Я. Драпкін, В.А. Журавель, О.Н. Колесниченко, В.О. Коновалова, М.О. Ларкін, К.С. Логінов, А.Ф. Облаков, О.В. Пчеліна, В.В. Пясковський, Є.В. Пряхін, В.П. Сабадаш, А.В. Старушкевич, М.І. Скригонюк, В.Ю. Шепітько, М.П. Яблоков та інші. Проте багато питань ще викликають наукові спори. Зокрема, не досягнуто одностайності у визначенні поняття та сутності криміналістичної характеристики. Разом із тим відсутні напрацювання 3 криміналістичного аналізу створення, керівництва злочинною спільнотою або злочинною організацією, а також участі у ній та формування відповідної криміналістичної характеристики. Тому в цій статті ставимо перед собою наступне наукове завдання - з'ясувати значення і визначити структуру криміналістичної характеристики створення, керівництва злочинною спільнотою або злочинною організацією, а також участі у ній. 
Виклад основного матеріалу дослідження. Говорячи про теоретичні передумови формування криміналістичної характеристики створення, керівництва злочинною спільнотою чи злочинною організацією, а також участі у ній, важливо визначити не тільки сутність криміналістичної характеристики, а й ї̈ значення, зокрема під час розслідування виокремленого злочину. В цілому варто відзначити, що важлива роль криміналістичної характеристики кримінальних правопорушень відзначається всіма вченимикриміналістами. При цьому різняться тільки роз'яснення, в чому саме проявляється практичне значення криміналістичної характеристики.

Одні вчені обмежуються вказівкою на загальне значення криміналістичної характеристики як в окремій криміналістичній методиці, так і для виявлення, розкриття, розслідування та попередження кримінальних правопорушень, без його деталізації. Як приклад, П.В. Берназ, визначаючи поняття криміналістичної характеристики злочину, зазначає, що вона, будучи одним із найважливіших елементів криміналістичної методики, є «взаємопов'язаною сукупністю індивідуальних особливостей певної категорії злочинів, що характеризують обстановку, спосіб і механізм вчинення та приховування злочину, осіб злочинця і потерпілого та має значення для виявлення, розкриття та розслідування злочину» [1, с. 35]. К.С. Логінов акцентує увагу на тому, що криміналістична характеристика злочинів $\epsilon$ «науково-інформаційним базисом діяльності правоохоронних органів з розкриття, розслідування та попередження злочинів окремих видів» [2, с. 35].

У той же час інша група науковців указує, в чому саме полягає значення криміналістичної характеристики кримінальних правопорушень у слідчій діяльності. Зокрема, Р.С. Бєлкін вказує, що криміналістична характеристика злочинів має «лише орієнтаційне значення» [3, с. 305]. Це пояснюється тим, що відомості про типові ознаки механізму вчинення кримінального правопорушення окремої категорії відіграють роль помічника в практичній діяльності слідчого (дізнавача, детектива), тим самим допомагаючи йому визначити вектор (напрям) розслідування на конкретному, зазвичай початковому, етапі розслідування з урахуванням обсягу та змісту наявної вихідної інформації про вчинене протиправне діяння.

Наведеної вище позиції дотримується й В.П. Бахін, який детально охарактеризував практичне значення криміналістичної характеристики кримінальних правопорушень. На його думку, таке значення криміналістичної характеристики виражається в тому, що при розслідуванні конкретного кримінального протиправного діяння слідчий, по-перше, зіставляє наявні в нього відомості iз системою узагальнених даних про правопорушення цього різновиду, які вчинялися раніше, по-друге, виділяє аналогічні кримінальні правопорушення за криміналістично значущими ознаками, які співпали, по-третє, визначає характерні, хоча ще невідомі в даному розслідуванні, обставини [4, с. 17]. Іншими словами, як відзначає П.В. Берназ, криміналістична характеристика злочину в слідчій діяльності використовується як інструмент для висунення слідчих версій та формування обставин, які підлягають встановленню [1, с. 35].

3 вищенаведеним у цілому варто погодитися, оскільки криміналістична характеристика кримінальних правопорушень, зокрема створення, керівництва злочинною спільнотою чи злочинною організацією, а також участі у ній, дозволяє зорієнтуватися на початку досудового розслідування, коли відсутня достатня інформація про всі обставини вчинення конкретного протиправного діяння, але розслідувати потрібно. В такій ситуації важливо вірно визначити спрямування досудового розслідування й вжити всіх наявних засобів для збирання всіх доказів кримінального правопорушення з мінімізацією можливостей їх утрати чи видозмінення. Тому повністю поділяємо думку В.П. Сабадаша, М.О. Ларкіна з приводу того, що криміналістична характеристика $\epsilon$ тим вихідним началом у криміналістичній методиці, 3 якого «розпочинається формування напряму розслідування, використання якого має прикладне, пошукове та оціночне значення під час розслідування злочинів, аналізу його результатів» і яке «слугує основою для планування розслідування і висування слідчих версій» [5, с. 153].

Ще одним важливим питанням під час формування криміналістичної характеристики кримінальних правопорушень, зокрема створення, керівництва злочинною спільнотою чи злочинною організацією, а також участі у ній, є з'ясування іiї структурного наповнення. В науковій літературі відсутня однозначна позиція стосовно визначення змісту криміналістичної характеристики. Зокрема, В.Ю. Шепітько в криміналістичному енциклопедичному словнику пропонує в системі криміналістичної характеристики злочинів виділяти такі основні елементи, як спосіб злочину, місце та обстановка, час учинення злочину, знаряддя і засоби, предмет посягання, особа потерпілого, особа злочинця, сліди злочину (у широкому розумінні) [6, с. 121]. О.О. Алєксєєв, В.К. Весельський, В.В. Пясковський наголошують, що «до змісту криміналістичної характеристики злочинів, як практичного інструменту розслідування, а не наукової категорії криміналістики, необхідно віднести тільки ті елементи, що відрізняються чітким пошуково-розшуковим спрямуванням», у зв'язку 3 чим зазначені автори відносять до елементів криміналістичної характеристики: предмет злочинного посягання, спосіб вчинення злочину, слідову картину події, характеристику особи злочинця [7, с. 14]. Заслуговує уваги й твердження М.П. Яблокова та В.Я. Колдіна, згідно з яким «в основі криміналістичної характеристики злочину лежать дані вивчення залишених ним матеріальних та ідеальних слідів-наслідків як результату взаємодії його суб'єкта 3 іншими особами, матеріальними й іншими об'єктами навколишнього середовища в умовах обстановки, що склалася, й які вказують на криміналістично значимі ознаки злочину, злочинця, різні обставини, в тому числі й несуттєві для його кримінально-правової кваліфікації, але важливі для розкриття злочину, а також виявлені дані про характер і закономірності прояву вказаної інформації» $[8$, с. 63]. У такий спосіб учені вказують, що криміналістична характеристика незалежно від виду злочину містить дані про спосіб, механізм і обстановку вчинення злочину, типологічні, поведінкові й інші особливості їх суб'єктів [8, с. 65].

Також окремі вчені пропонують в структурі криміналістичної характеристики кримінальних правопорушень окремого виду (групи) виділяти не просто елементи, а цілі інформаційні блоки. Як приклад, М.П. Яблоков у криміналістичній характеристиці організованої злочинності умовно виокремлює чотири інформаційні блока:

- предметно-технологічний, який визначає об'єктивноцільову спрямованість злочинної діяльності, особливості процесу іiї вчинення і включає інформацію про об'єкти й цілі основної протиправної діяльності, способи, механізм і обстановку вчинення злочинів;

- організаційно-управлінський містить інформацію про організоване злочинне об'єднання як специфічний елемент злочинної діяльності, а саме про організаційноструктурну будову, функціональний розподіл обов'язків між його членами, вид управління, тощо;

- суб'єктивно-особистісний включає інформацію про специфічні типологічні риси членів таких злочинних угруповань;

- організаційно-корупційний характеризує особливості корупційних зв'язків злочинної спільноти [8, с. 697-698].

На нашу думку, з вищенаведеними позиціями можна погодитися тільки в тій частині, що зміст криміналістичної характеристики становлять типові відомості про 
елементи механізму вчинення окремого різновиду кримінального правопорушення, які $є$ криміналістично значимими та дозволяють вирішити основні тактичні завдання, спрямовані на пошук і збирання доказів, а також встановлення всіх обставин учинення конкретного протиправного діяння. Разом із тим вважаємо, що помилковими є спроби виокремлення типового переліку елементів криміналістичної характеристики, оскільки він $є$ «гнучким, динамічним», а значить може варіюватися залежно від багатьох факторів, основним серед яких $є$ вид (група) кримінального правопорушення, що, в свою чергу, безумовно вказує на специфіку механізму його вчинення. Тому, на наш погляд, найбільш удалий підхід до виокремлення елементів криміналістичної характеристики кримінальних правопорушень полягає в тому, що перелік таких елементів «... не може бути жорстким, суворо визначеним, однак він повинен відображати специфічні властивості конкретного виду (групи) злочинів» [9, с. 58]. Більше того, як Ю.В. Алябов вірно підкреслює, перелік елементів криміналістичної характеристики, притаманних усім злочинам групи (роду), має відповідати у своїй основі елементам складу злочину та предмета доказування, проте з урахуванням предмета, який досліджує криміналістика, що конкретизує та перетворює положення інших наук (кримінального права, кримінального процесу, кримінології) для практичних цілей виявлення, розкриття й розслідування злочинів певного виду [9, с. 58].

Виходячи 3 вищенаведеного, змістовне наповнення криміналістичної характеристики створення, керівництва злочинною спільнотою чи злочинною організацією, а також участі у ній, напряму зумовлене характером організованої злочинності в цілому та специфікою механізму вчинення кримінальних правопорушень, учинених злочинними угрупованнями, зокрема. Насамперед мова йде про те, що злочини, передбачені ст. 255 КК України, вчиняються виключно в складі злочинної організації або злочинної спільноти. Відповідно особа злочинця є учасником такого злочинного угруповання, займає своє місце в його ієрархії залежно від свого авторитету та покладених на неї функцій. Більше того, способи створення, керівництва, а також участі в злочинній організації чи злочинній спільноті теж будуть залежати від ролі злочинця, яку він виконує в цьому угрупованні, а також від сфери його функціонування. При цьому, як будь-яке протиправне діяння, злочини, передбачені ст. 255 КК України, з урахуванням 3 обстановкою, в якій вони вчиняються, а також використаних знарядь і засобів залишають в навколишньому середовищі характерні сліди. Якщо ж вести мову про особу потерпілого від створення, керівництва злочинною спільнотою чи злочинною організацією, а також участі у ній, варто зазначити, що вона, передусім, залежать від декількох факторів, а саме: виду конкретного кримінального правопорушення, яке вчиняється злочинною спільнотою чи злочинною організацією; сферою функціонування злочинного угруповання; наявністю та характером зв'язків особи потерпілого зі злочинною організацією/ спільнотою чи окремими ії учасниками. Тому вважаємо, що криміналістична характеристика створення, керівництва злочинною спільнотою чи злочинною організацією, а також участі у ній, повинна містити такі основні елементи: особа злочинця, особа потерпілого, типові способи та слідова картина злочину.

Висновки. Отже, криміналістична характеристика створення, керівництва злочинною спільнотою чи злочинною організацією, а також участі у ній, з урахуванням специфіки механізму їх учинення містить узагальнені відомості про типові ознаки особи злочинця та потерпілого, способів і слідової картини вказаних кримінальних правопорушень із зазначенням їх якісно-кількісних (кореляційних) залежностей. Основне значення криміналістичної характеристики кримінальних правопорушень, у тому числі названих, полягає в тому, що вона відіграє орієнтовну роль при визначенні напряму розслідування й обранні відповідного алгоритму дій.

\section{ЛITEPATУPA}

1. Берназ П.В. Поняття «криміналістична характеристика злочину». Південноукраїнський правничий часопис. 2017. № 2. С. 34-38.

2. Логинов К.С. К вопросу о криминалистической характеристике кредитного мошенничества. Вектор науки ТГУ. Серия: Юридические науки. 2017. № 4 (31). С. 35-38.

3 Белкин Р.С. Курс криминалистики. В 3 т. Т. 3 «Криминалистические средства, приемы и рекомендации». М.: Юристъ, 1997. 480 с.

4. Бахин В.П. Криминалистическая характеристика преступлений как элемент расследования. Вестник криминалистики. 2000. № 1. С. 16-22.

5. Сабадаш В.П., Ларкін М.О. Криміналістика: навч. посіб. К.: Центр учбової літератури, 2013. 228 с.

6. Шепітько В.Ю. Криміналістика. Енциклопедичний словник (українсько-російський і російсько-український) / за ред. акад. НАН України В.Я. Тація. Харків: Право, 2001. 560 с.

7. Алєксєєв О.О., Весельський К.В., Пясковський В.В. Розслідування окремих видів злочинів: навч. посіб. К.: «Центр учбової літератури», 2013. 278 c.

8. Криминалистика: учебник / под ред. Н.П. Яблокова. 4-е изд., перераб. и доп. М.: Норма: ИНФРА-М, 2013. 752 с.

9. Алябов Ю.В. Криміналістична характеристика злочинів проти довкілля: сутність і практичне значення. Судова та слідча практика в Україні. 2016. Випуск 1. С. 56-61. 


\title{
ЗАСТЕРЕЖЕННЯ ПРО ПУБЛІЧНИЙ ПОРЯДОК В МІЖНАРОДНОМУ ПРИВАТНОМУ ПРАВІ УКРАЇНИ ТА СС
}

\author{
PUBLIC POLICY CLAUSE IN UKRAINIAN \\ AND EU PRIVATE INTERNATIONAL LAW
}

Бігняк О.В. д.ю.н., професор

Владишевська В.В., асистент кафедри організації судових, правоохоронних органів та адвокатури

Національного університету «Одеська юридична академія»

У статті проводиться порівняльний аналіз положень про публічний порядок в міжнародному приватному праві України та Європейського Союзу.

Інститут публічного порядку фрігурує в міжнародному приватному праві більшості держав як загальне застереження, що перешкоджає застосуванню іноземних матеріально-правових норм, якщо наслідки їх застосування суперечать публічному порядку цієї держави. Зазначається, що інститут публічного порядку виконує превентивну функцію в контексті вкрай негативних наслідків застосування іноземного права або рішень іноземних судів. Наведено складові елементи змісту поняття публічного порядку, а саме: фундаментальні принципи національного права; загальновизнані принципи моралі та справедливості; законні інтереси фрізичних і юридичних осіб; загальновизнані принципи й норми міжнародного права, які є частиною правової системи держави.

Підкреслюється, що, незважаючи на гармонізацію права на рівні $Є С$, норми колізійного права ЄС містять інститут публічного порядку, що дозволяє компетентному суду відмовлятися від використання норми іноземного права, коли він приходить до висновку, що їх застосування суперечить основам національної правової системи. При цьому публічний порядок $є$ територіальною концепцією (тобто існує особливий публічний порядок для кожної держави-члена), яка може з часом розвиватися. Таким чином, Європейський суд визнає, що держави-члени можуть змінювати зміст свого публічного порядку, якщо це може знадобитися задля розвитку членів їхніх громад i їх діяльності. У зв'язку з цим зазначається, що публічний порядок - це не тільки територіальна концепція (притаманна кожній державічлену), але також концепція, що з часом змінюється та набуває нового змісту.

Зроблено висновок, що як в праві України, так і праві ЄС для застосування застереження про публічний порядок необхідно в кожному конкретному випадку обґрунтувати, що застосування тієї чи іншої норми іноземного права призведе поза всякими сумнівами (явно) до результатів, несумісним з національним правопорядком.

Ключові слова: публічний порядок, ordre public, застереження про публічний порядок, колізійні норми, надімперативні норми, Регламент Рим I, Регламент Рим II.

The article provides a comparative analysis of the provisions on public order in private international law of Ukraine and the European Union.

The institution of public order appears in the private international law of most states as a general caveat that prevents the application of foreign substantive law if the consequences of their application are contrary to the public order of that state. It is noted that the institution of public order performs a preventive function in the context of extremely negative consequences of the application of foreign law or decisions of foreign courts. The constituent elements of the content of the concept of public order are given, namely: fundamental principles of national law; generally accepted principles of morality and justice; legitimate interests of individuals and legal entities; generally accepted principles and norms of international law, which are part of the legal system of the state.

It is emphasized that, despite the harmonization of law at EU level, EU conflict-of-law rules contain the institution of public policy, which allows a competent court to refuse to apply rules of foreign law when it concludes that their application is contrary to national law. In this case, public order is a territorial concept (i.e. there is a special public order for each EU Member State), which may evolve over time. Thus, the European Court recognizes that EU Member States may change the content of their public policy if this may be necessary for the development of members of their communities and their activities. In this regard, it is noted that public order is not only a territorial concept (specific to each EU Member State), but also a concept that changes over time and acquires a new meaning.

It is concluded that both Ukrainian law and EU law to apply the public policy clause in each case must justify that the application of a rule of foreign law will undoubtedly (clearly) lead to results incompatible with national law.

Key words: public policy, ordre public, public policy clause, conflict of laws rules, mandatory norms, Rome I Regulation, Rome II Regulation.

В Україні і в більшості європейських держав іноземне право, що підлягає застосуванню на основі власних колізійних норм, повинно застосовуватися так само, як воно застосовується в країні свого походження, «у себе на батьківщині» - на цьому наполягала ще в 1929 році Постійна палата міжнародного правосуддя. В справах по сербським i по бразильським позикам (в яких Палата застосувала відповідно право Сербії і Бразиліі), вона підтвердила, що будь-яке питання, яке може виникнути в процесі застосування іноземного права, має вирішуватися відповідно до цього права. Таким чином, суддя, перед яким стоїть завдання вирішити справу на основі норм іноземного права, повинен ніби то встати на місце іноземного судді і вирішити справу так, як вирішив би іiї іноземний суддя, який застосовує рідні для нього норми права [1, с. 52; 2].

Однак у кожній країні міжнародне приватне право знає інструменти, які дозволяють захищати конкретні інтереси і цінності власного правопорядку і які можуть виключати застосування іноземного права або обмежувати сферу його застосування [3, с. 144]. Ці інструменти можуть привести або до нав'язування застосування - всупереч вирішенню, що випливає з норм колізійного права - власного регулювання (це має місце в разі застосування так званих надімперативних норм), або до виключення застосування іноземного права через необхідність віддавати пріоритет принципам власного правопорядку. Положення про публічний порядок є саме таким загальноприйнятим інструментом, який дозволяє виключити застосування положень іноземного права. Цей інститут відомий також міжнародному приватному праву України (ст. 12 Закону України «Про міжнародне приватне право» [4], ст. 228 ЦК України [5], ст.ст. 468, 478 ЦПК України [6], ст. 34 Закону України «Про міжнародний комерційний арбітраж» [7]). Його мета - захист від неприйнятних (з точки зору основних принципів правового порядку держави суду і прийнятих в ньому цінностей) наслідків застосування іноземного права, визначеного в якості компетентного відповідно до норми колізійного права. Таким чином, положення про публічний порядок - це, перш за все, інструмент, який коригує звичайні правила визначення та застосування права, що підлягає застосовуванню [8, с. 374].

Інститут публічного порядку фігурує в міжнародному приватному праві більшості держав як загальне застереження, що перешкоджає застосуванню іноземних матеріально-правових норм, якщо наслідки їх застосування суперечать публічному порядку цієї держави. Відомий 
в будь-якій системі міжнародного приватного права, незалежно від того, сформульований він в конкретному правовому положенні, інститут публічного порядку спрямований на захист універсальних цінностей, на яких заснований правопорядок цієї країни. Отже, інститут публічного порядку виконує превентивну функцію в контексті вкрай негативних наслідків застосування іноземного права або рішень іноземних судів.

В чинному Законі України «Про міжнародне приватне право» положення про публічний порядок передбачено статтею 12, де говориться, що «норма права іноземної держави не застосовується у випадках, якщо іiї застосування призводить до наслідків, явно несумісних з основами правопорядку (публічним порядком) України». Передбачається, що застосування застереження повинно бути обмежено тільки самими грубими протиріччями, тому застереження слід використовувати тільки у виняткових випадках, тому «відмова в застосуванні права іноземної держави не може грунтуватися лише на відмінності правової, політичної або економічної системи відповідної іноземної держави від правової, політичної або економічної системи України» (ч. 2 ст. 12 Закону).

Застереження про публічний порядок захищає основоположні принципи правового порядку не тільки при зіткненні з юрисдикцією іноземного закону, а й в інших контекстах. Зокрема, воно захищає свій власний правовий порядок в разі, якщо визнання або виконання рішення іноземного суду буде явно суперечити публічному порядку (ordre public) держави (п. a) ч. 1 ст. 45 Регламенту Брюссель 1 біс) [9]. Протиріччя публічному порядку також $є$ підставою для скасування і відмови у визнанні або у виконанні арбітражного рішення (п. а) ч. 1 ст. 478 ЦПК України). Варто зазначити, що стосовно рішень іноземного суду в якості підстави для відмови у задоволенні клопотання про надання дозволу на примусове виконання рішення іноземного суду в Цивільному процесуальному кодексі України використано не поняття «публічного порядку», а загроза «інтересам України» (п. 7 ч. 2 ст. 468 ЦПК України).

За своїм характером стаття про публічний порядок $€$ загальною і не має конкретного змісту. В законодавстві країн світу майже не робиться спроб надати визначення цьому поняттю. Як зазначає В. І. Кисіль, «через неузгодженість доктринальних підходів законодавці більшості країн вдаються лише до загальних формулювань, тому застереження ordre public так нагадують одне одного в різних законодавствах» [10, с. 197]. У зв'язку з цим застереження про публічний порядок порівнюють до «хамелеона, який з часом змінюється і набуває різні кольори в різних країнах» $[11$, с. 455]. 3 іншого боку, Л. А. Лунц зазначає, що закон, судова практика та доктрина всіх без винятку держав світу одностайно розуміють сутність публічного порядку так: іноземний закон, до якого відсилає колізійна норма, не може бути застосованим і засновані на ньому права не можуть бути визнані судом вітчизняної держави, якщо таке застосування закону чи визнання прав суперечило б публічному порядку цієї держави [12, с. 269].

Проте в доктрині міжнародного приватного права наводяться складові поняття публічного порядку, зокрема, В. I. Кисіль виділяє наступні елементи правопорядку України:

1) основні фундаментальні принципи національного права України, які охоплюють такі імперативні норми публічного, приватного та процесуального права, що становлять скелет правопорядку в Україні;

2) загальновизнані принципи моралі та справедливості, важливі для українського правопорядку й панівні в українському суспільстві;

3) законні інтереси українських фізичних і юридичних осіб, української держави та українського суспільства захист яких $\epsilon$ основним завданням української правової системи;
4) загальновизнані принципи й норми міжнародного права, які $\epsilon$ частиною української правової системи, й особливо міжнародно-правові стандарти прав людини [10, c. 198-199].

Спроби конкретизувати зміст поняття публічного порядку робляться й в судовій практиці. Так, згідно 3 роз'ясненнями, викладеними в П. 12 Постанови Пленуму Верховного Суду України «Про практику розгляду судами клопотань про визнання й виконання рішень іноземних судів та арбітражів і про скасування рішень, постановлених у порядку міжнародного комерційного арбітражу на території України» від 24 грудня 1999 року, під публічним порядком належить розуміти правопорядок держави, визначальні принципи та засади, які становлять основу сформованого в ній ладу (стосуються іiі незалежності, цілісності, самостійності й недоторканності, основних конституційних прав, свобод, гарантій тощо) [13].

У постанові від 20 вересня 2019 року Верховний Суд у складі Касаційного цивільного суду був більш конкретним та запропонував розуміти під публічним порядком правопорядок держави, визначені принципи і засади, які становлять основу існуючого у ній ладу (стосуються її незалежності, цілісності, самостійності й недоторканості й основних конституційних прав, свобод, гарантій тощо). Публічний порядок будь-якої держави включає фундаментальні принципи і засади правосуддя, моралі, які держава має намір захистити навіть тоді, коли це не має прямого стосунку до самої держави; правила, які забезпечують фундаментальні політичні, соціальні та економічні інтереси держави; обов язок держави з дотримання своїх зобов 'язань перед іншими державами та міжнародними організаціями [14].

Одним з небагатьох документів, в яких наводиться елементи публічного порядку, є Рекомендації Асоціації міжнародного права щодо застосування публічного порядку як підстави для відмови у визнанні або примусовому виконанні міжнародного арбітражного рішення [15], які вказують, що міжнародний публічний порядок будь-якої держави включає в себе:

(I) фундаментальні принципи, які стосуються справедливості або моралі, які ця держава бажає захищати, навіть якщо вона не була безпосередньо залучена в спір;

(II) правила, призначені для обслуговування основних політичних, соціальних або економічних інтересів держави, відомі як lois de polis або «правила публічного порядку»; i

(III) обов'язок держави дотримуватися своїх зобов'язань перед іншими державами або міжнародними організаціями (пункт 1 (d)) [15, c. 256].

Внаслідок такого нечіткого визначення і тлумачення наповнення концепції публічного порядку конкретним змістом $€$ і повинно залишатися в першу чергу завданням суду. Визначення того, що становить основні цінності правопорядку держави в мінливих соціальних, економічних і політичних реаліях, повинно проводитися під час застосування закону в індивідуальних обставинах конкретної справи [16, с. 249]. Таким чином, загальний характер застереження про публічним порядком $є$ не його недоліком, а, скоріше, його іманентною властивістю, без якої воно не могло б виконувати відведену йому еластичну функцію в системі колізійного права [17, с. 153].

В цьому відношенні широковідомі зауваження англійського судді Берроу, який ще в 1824 році попереджав, що публічний порядок подібний неслухняному коню: «якщо ви сядете на нього верхи, ніколи не дізнаєтеся, куди він вас понесе» $[18$, с. 971]. Отже, положення про публічний порядок слід використовувати з обережністю. Тільки в індивідуальних обставинах конкретної справи можна встановити, чи виправдане використання застереження, тому що в кожному разі суддя повинен оцінювати, якою мірою індивідуальні наслідки застосування іноземного 
права, а не норми іноземного права, що розуміються абстрактно, суперечили б правопорядку держави суду.

Таким чином, положення про публічний порядок $є$ відступленням від загальних принципів міжнародного приватного права, згідно з якими певні правові відносини 3 іноземним елементом регулюються правом, вказаним відповідною нормою колізійного права, що призводить до ситуації, коли суди не завжди застосовують матеріальноправові норми свого власного приватного права, але в рівній мірі застосовують іноземне право - залежно від того, який закон колізійні норми, що діють в місці знаходження суду, вказують як право, яке має найбільш тісний зв'язок 3 правовідносинами» (див., напр., ст. 12 Закону України «Про міжнародне приватне право).

Незважаючи на гармонізацію права на рівні $С \mathrm{C}$, норми колізійного права $Є С$ містять вищезгаданий інститут, що дозволяє компетентному суду відмовлятися від використання норми іноземного права, коли він приходить до висновку, що їх застосування суперечить основам національної правової системи.

Відповідно до ст. 21 Регламенту Риму I [19] i ст. 26 Регламенту Риму II [20], у застосуванні вказаного цим Регламентом положення права будь-якої країни може бути відмовлено лише в тому випадку, якщо таке застосування є явно не сумісним з публічним порядком суду.

Поняття публічного порядку в міжнародному приватному праві ЄС «слід розуміти як публічний порядок, завдання якого, в зв'язку 3 його положенням, полягає в запобіганні вкрай негативних наслідків іноземного права (матеріально-правова стаття про публічний порядок) або іноземних судових рішень (процесуальна стаття про публічний порядок)» [21, с. 440]. Різниця між матеріально-правовим та процесуальними положеннями про публічний порядок точно описана А. Белоглавеком: «застосування матеріально-правового застереження про публічний порядок розглядається в ситуації, коли наслідки його порушення можуть бути допущені тільки гіпотетично, в той час як у другому випадку (процесуальне застереження про публічний порядок) мова йде про наслідки конкретного рішення» [21, с. 458].

Межі положення про публічний порядок визначають цінності, на яких заснована ця правова система і без яких вона втратить свою аксіологічну, етичну і культурну ідентичність [22, с. 167]. Доктрина зазвичай виходить 3 того, що застереження про публічний порядок виключає застосування компетентного права в ситуаціях, коли його застосування привело б до наслідків, явно несумісних з правовим порядком держави, в якій суд виносить рішення по справі. Таким чином, це свого роду «запобіжний клапан» або «фільтр» іноземного права [23, с. 59]. Це застереження $\epsilon$ винятком $з$ принципу застосування іноземного права та, як виняток, не може тлумачитися широко.

Застереження про публічний порядок, як і всі загальні положення, $\epsilon$ розпливчастим і залишено на розсуд суду [24, с. 24], проте вимога дотримання правопорядку не означає повного дотримання всіх чинних положень закону, а тільки основних принципів правового порядку, які слід розуміти як принципи і засади, які становлять основу існуючого у ній ладу (стосуються iï незалежності, цілісності, самостійності й недоторканості й основних конституційних прав, свобод, гарантій тощо), фундаментальні принципи і засади справедливості і правосуддя. Як зазначив Верховний Суд України, ці положення покликані встановити правовий бар 'єр на шляху рішень, ухвалених всупереч кардинальним процесуальним і матеріально-правовим принципам, на яких тримається публічний порядок [14].

При розгляді конкретної справи може виявитися, що, незважаючи на значні відмінності між застосовуваним правом і національним законодавством, застосування іноземного права не призведе до наслідків, що суперечать основоположним принципам публічного порядку держави правозастосування. У такій ситуації немає підстав для застосування статті 21 Регламенту Рим І. Отже, підставою для відмови в застосуванні іноземного права на підставі статті про публічний порядок не може бути:

1) той факт, що конкретний інститут іноземного права невідомий в цій правовій системі,

2) ситуація, при якій застосування іноземного права буде менш сприятливим для громадянина, ніж застосування національного закону, або

3) суб'єктивне переконання судді в «неадекватності» іноземної правової системи [25, с. 163]

Таким чином, хоча положення про публічний порядок також було включено до нормативних актів СС, оцінка наслідків застосування іноземного права проводиться в кожному випадку з точки зору правового порядку країни суду. Основним наслідком застосування застереження про публічний порядок буде відмова суду застосувати положення іноземного права. Це не означає автоматичного виключення застосування іноземного права [22, с. 80].

Зазначимо, що «протиріччя» публічно порядку - це не просто невідповідність, оскільки «зазвичай, міжнародне приватне право передбачає застосування матеріальних норм іншого змісту, ніж той, які мають свої власні матеріальні норми» [22, с. 83]. Тому в Регламентах Рим I та Рим II застосовується формулювання «явної несумісності».

В пункті 32 Регламенту Рим II міститься керівництво щодо тлумачення при застосуванні положення про публічний порядок, відповідно до якого: «міркування громадського інтересу виправдовують в виняткових обставинах використання судами держав-членів таких механізмів, як застереження про публічний порядку і переважаючі імперативні положення. Зокрема, застосування положення права, зазначеного цим Регламентом, яке спричинило б призначення суми, що сплачується в порядку відшкодування шкоди, що має характер повчального заходу або покарання і $€$ надмірною по відношенню до розміру завданого збитку, може з урахуванням обставин справи і правопорядку держави-члена суду, який розглядає справу, визнаватися таким, що суперечить публічному порядку суду» [20].

В цьому контексті цікавим $є$ приклад застосування категорії публічного порядку в Справі Інгмара [26], в якій Європейський суд розглядав спір з контракту, укладеного між компанією зі Сполучених Штатів Америки і агентом, що знаходився в Сполученому Королівстві Великої Британії та Ірландії. За обраним сторонами правом контракт регулювався законодавством Каліфорнії. Контракт був розірваний американською компанією, внаслідок чого агент заявив вимогу про стягнення компенсації, хоча право Каліфорнії не передбачає будь-якої компенсації в такому випадку. Суд застосував Директиву № 86/653/ЄЕС від 18 грудня 1986 року про зближення законодавства держав-членів СС щодо незалежних комерційних агентів [27] i вирішив, що європейський публічний порядок вимагає виплати компенсації при розірванні агентського договору за відсутності вини агента, а отже, в цьому конкретному пункті законодавство Каліфорнії не застосовується і замінюється обов'язковою нормою Співтовариства.

Відповідно до практики Європейського суду, застереження про публічний порядок повинне використовуватися тільки у виняткових випадках (рішення Європейського суду від 4 лютого 1988 року по Справі 145/86, Horst Ludwig Martin Hoffmann v. Adelheid Krieg [28]) і таким чином, щоб воно не становило перешкоду для застосування цього положення (рішення Європейського суду від 2 червня 1994 р. по Справі C-414/92, Solo Kleinmotoren GmbH v. Emilio Boch [29]).

Разом 3 тим зазначимо, що згідно з переважною точкою зору, «концепції публічного порядку на національному рівні достатньо для захисту прав людей, і тому немає необхідності запроваджувати специфічний європейський 
публічний порядок» [22, с. 170]. I це зрозуміло, оскільки членство в Європейському Союзі призводить до зближення правових систем держав-членів, отже, ситуації, в яких може використовуватися положення про публічний порядок, природно, обмежені.

Проте це не означає, що концепція і межі застереження про публічний порядок знаходяться поза контролем інститутів ЄС. Європейський суд дотримується традиційної точки зору, заявляючи, що публічний порядок є територіальною концепцією (тобто існує особливий публічний порядок для кожної держави-члена), яка може $з$ часом розвиватися. Таким чином, Свропейський суд визнає, що держави-члени можуть змінювати зміст свого публічного порядку, якщо це може знадобитися задля розвитку членів їхніх громад і їх діяльності. Ось чому зазвичай зазначається, що публічний порядок - це не тільки територіальна концепція (притаманна кожній державі-члену), але також концепція, чутлива до часу: ніхто не знає, яким буде публічний порядок завтра.

Проте вже в 1977 році Суд почав втручатися в сам зміст публічного порядку держав-членів ЄС. У Справі Бушері [30] Європейський суд пояснює: «концепція передбачає, крім порушення публічного порядку, яке представляе собою будь-яке порушення закону, реальну $i$ досить серйозну загрозу, що зачіпає фундаментальні інтереси сусnільства» (курсив наш). Цим рішенням Суд почав обмежувати свободу держав-членів ЄС визначати зміст свого публічного порядку. Тепер необхідні два єдиних критерія для того, щоб будь-яке правило характеризувалося як публічний порядок:

по-перше, воно повинно враховувати реальну і досить серйозну небезпеку, а не просто будь-яке порушення правила;

по-друге, мета застереження про публічний порядок повинна полягати в захисті фундаментальних інтересів суспільства.

Підсумовуючи, можна зазначити, що як в Україні, так i в державах-членах ЄС категорії «публічний порядок» приділяється багато уваги, попри це, сьогодні все ж таки виникає чимало питань, що залишаються без відповіді.

Досвід України та держав-членів СС свідчить, що законодавець, віддаючи належне значенню нормі про публічний порядок, обмежується найзагальнішими визначеннями «публічного порядку». Проте сучасне законодавство прагне сформулювати обмежувачі застосування застереження про публічний порядок.

По-перше, звернення до застереження про публічний порядок обумовлюється не протиріччям самих норм іноземного права основам вітчизняного правопорядку, а наслідком їх застосування: суд має право застосувати застереження тільки тоді, коли застосування норм іноземного права може привести до результату, що порушує публічний порядок. Цей аспект присутній як в міжнародному приватному праві України, так і Європейського Союзу.

По-друге, суд вправі звернутися до застереження про публічний порядок, якщо застосування іноземного права явно не сумісне 3 національним правопорядком. Це - новий обмежувач, який знайшов віддзеркалення як в законодавстві України, так й в колізійних регламентах ЄС. Вимога «явною несумісності» зобов'язує суд довести, що існує несумісність без всяких сумнівів, і тим самим виключає широке застосування застереження про публічний порядок.

По-третє, Закон України «Про міжнародне приватне право» додатково містить вказівку (що відсутня в колізійних регламентах $(С)$ на те, що відмова в застосуванні норми іноземного права не може грунтуватися лише на відмінності правової, політичної або економічної системи відповідної іноземної держави від правової, політичної або економічної системи власної держави. Закріплення цього положення має серйозне значення для обмеження випадків застосування застереження про публічний порядок. Поки існує безліч національних держав 3 різними політичними, економічними і правовими системами, неприпустимо застосовувати застереження на підставі лише однієї констатації відмінності в системах, оскільки це може привести до повного заперечення застосування іноземного права взагалі і заперечення міжнародного приватного права зокрема.

Таким чином, для застосування застереження необхідно в кожному конкретному випадку обгрунтувати, що застосування тієі чи іншої норми іноземного права призведе поза всякими сумнівами (явно) до результатів, несумісним з національним правопорядком.

\section{תITEPATYPA}

1. Payment of Various Serbian Loans Issued in France (Fr. v. Yugo.), Judgment. 1929. July 12. P.C.I.J. (ser. A). № 20

2. Payment in Gold of Brazilian Federal Loans Contracted in France (Fr. v. Braz.). 1929. July 12. P.C.I.J. (ser. A). № 21.

3. Mosconi F. Exception to the operation of choice of law rules, Recueil des Cours. 1989. Vol. 217. P. 143-200.

4. Про міжнародне приватне право: Закон України від 23 червня 2005 р. Відомості Верховної Ради України. 2005. № 32. Ст. 422.

5. Цивільний кодекс України: Закон України від 16 січня 2003 року. Відомості Верховної Ради України. 2003. № № 40-44. Ст. 356.

6. Цивільний процесуальний кодекс України: Закон України від 18 березня 2004 року. Верховна Рада України. № 1618-IV. URL: https://zakon.rada.gov.ua/laws/card/1618-15.

7. Про міжнародний комерційний арбітраж: Закону України від 24 лютого1994 року. URL: https://zakon.rada.gov.ua/laws/card/4002-12.

8. Blom J. Public Policy in Private International Law and Its Evolution in Time. Netherlands International Law Review. 2003. Vol. 50 (3). P. 373-399

9. Regulations Regulation (EU) No 1215/2012 of the European Parliament and of the Council of 12 December 2012 on Jurisdiction and the Recognition and Enforcement of Judgments in Civil and Commercial Matters (recast). URL: https://eur-lex.europa.eu/LexUriServ/LexUriServ.do? uri=OJ:L:2012:351:0001:0032:en:PDF.

10. Міжнародне приватне право. Загальна частина : підручник / за заг. ред. А.С. Довгерта, В.І. Кисіля. Київ : Алерта, 2012. 376 с.

11. Dutoit B. L'ordre public: cameleon du droit international prive. Un survol de la jurispru-dence Suisse. Mélanges Guy Flattet : recueil de travaux offerts à M. Guy Flattet, professeur honoraire à l'Université de Lausanne. Lausanne: Diffusion Payot, 1985. 551 p.

12. Лунц Л.А. Курс международного частного права : в 3 т. Москва : Спарк, 2002. Т. 1. 1007 с.

13. Про практику розгляду судами клопотань про визнання й виконання рішень іноземних судів та арбітражів і про скасування рішень, постановлених у порядку міжнародного комерційного арбітражу на території України : Постанова Пленуму Верховного Суду України від 24.12.1999 № 12. URL: https://zakon.rada.gov.ua/laws/show/v0012700-99.

14. Постанова Верховного Суду у складі Касаційного цивільного суду у справі №824/256/2018, доступна за посиланням: http://reyestr. court.gov.ua/Review/84375511.

15. Resolution of the ILA on Public Policy as a Bar to Enforcement of International Arbitral Awards. Arbitration International. 2003. Vol. 19. Issue 2. P. 213-215

16. Nygh P. E. Conflict of laws in Australia / 6th ed. Sydney : Butterworths, 1995. 600 p.

17. Mayer P., Heuze V. Droit International Privé / 11ème édition (précis domat). LGDJ, 2014. 788 p.

18. Briggs A. Public Policy in the Conflict of Laws: a Sword or a Shield, Singapore Journal of International and Comparative Law. 2002 Vol. 6. P. 953-978

19. Регламент (ЄС) № 593/2008 Європейського Парламенту та Ради «Про право, яке підлягає застосуванню до договірних зобов'язань» («Рим |»). URL: http://zakon3.rada.gov.ua/laws/show/994_905. 
20. Регламент (ЄC) N 864/2007 Європейського Парламенту і Ради «Щодо права, яке підлягає застосуванню до позадоговірних зобов'язань («Рим II»)». URL: https://zakon.rada.gov.ua/laws/show/994_907\#top.

21. BělohlávekA. J. Rome Convention-Rome I Regulation: commentary : new EU conflict-of-laws rules for contractual obligations. Huntington, N.Y.: Juris, 2010

22. Czepelak M. Międzynarodowe prawo zobowiązań Unii Europejskiej. Warszawa: LexisNexis, 2012. 397 s.

23. Pazdan M. Prawo prywatne międzynarodowe. Warszawa: LexisNexis, 2010. 386 s.

24. Boer, de. T. M. Party autonomy and its limitations in the Rome II regulation. Yearbookof Private International Law. 2007. Vol. 9. P. 19-29.

25. Grzybczyk K. Prawo właściwe dla autorskoprawnej umowy licencyjnej. Warszawa: Wolters Kluwer, 2010. $223 \mathrm{~s}$.

26. IngmarCase (C-381/98, Ingmar2000 [ECR] I-0930). URL:https://eur-lex.europa.eu/legal-content/EN/TXT/?uri=CELEX\%3A61998CJ0381.

27. Директива Совета № 86/653/ЕЭС о сближении законодательств государств-членов ес в отношении независимых коммерческих агентов (Брюссель, 18 декабря 1986 года). URL: https://www.alppp.ru/law/grazhdanskoe-pravo/mezhdunarodnoe-chastnoe-pravo/11/ direktiva--86653ees-soveta-evropejskih-soobschestv.html.

28. Case 145/86 Horst Ludwig Martin Hoffmann v. Adelheid Krieg. URL: https://curia.europa.eu/juris/showPdf.jsf;jsessionid=50615EE045E9 4EC2AA4BDB52F5C46A8F?text=\&docid=94766\&pagelndex=0\&doclang=EN\&mode=lst\&dir=\&occ=first\&part=1\&cid=1235796

29. Case C-414/92. Solo Kleinmotoren GmbH v. Emilio Boch (Reference for a preliminary ruling from the Bundesgerichtshof). URL: https:// curia.europa.eu/common/recdoc/convention/gemdoc94/pdf/04-z-en-94.pdf.

30. Case 30/77, Regina v. Pierre Bouchereau [1977]. URL: https://eur-lex.europa.eu/legal-content/EN/TXT/?uri=CELEX\%3A61977CJ0030 


\title{
УЧАСНИКИ ГОСПОДАРСЬКИХ ТОВАРИСТВ ЯК СУБ'ЄКТИ ВІДПОВІДАЛЬНОСТІ (ЦИВІЛЬНО-ПРАВОВИЙ АСПЕКТ)
}

\author{
PARTICIPANTS OF BUSINESS ASSOCIATIONS AS SUBJECTS OF LIABILITY \\ (CIVIL LAW ASPECT)
}

\author{
Бурносенкова I.А., юрист \\ ТОВ «Юридична фірма АНК»
}

У статті аналізується правовий статус учасників господарських товариств як суб'єктів відповідальності за цивільним правом України. Визначено коло учасників господарських товариств за Цивільним кодексом України, законами України «Про господарські товариства», «Про акціонерні товариства», «Про товариства з обмеженою та додатковою відповідальністю». До елементів правового статусу учасників господарських товариств віднесено такі елементи: 1) цивільна правосуб'єктність; 2) основні права, обов'язки та законні інтереси; 3) гарантії прав і законних інтересів; 4) відповідальність за належне виконання своїх обов'язків.

Норми про цей та інші елементи правового статусу учасників господарських товариств закріплені в актах цивільного законодавства України, включаючи норми цивільного права, що містяться в комплексних законодавчих та інших нормативно-правових актах, актах господарського законодавства, статутах товариств.

Проаналізовано окремі елементи правового статусу учасників господарських товариств як суб'єктів цивільно-правової відповідальності. Охарактеризовано нормативне закріплення прав і обов'язків учасників господарських товариств, відповідальності учасників товариств за невиконання своїх обов'язків, передбачених у законодавчих актах і статутах товариств.

Зазначено, що учасники господарських товариств несуть відповідальність як за порушення майнових, так і немайнових прав товариства. Прикладом першого виду відповідальності може бути відповідальність за невнесення вкладів. Прикладом другого виду відповідальність за поширення недостовірної інформації, розголошення комерційної таємниці та конфіденційної інформації про діяльність товариства.

Ключові слова: юридичні особи, господарські товариства, учасники господарських товариств, правовий статус, цивільна відповідальність, законодавство України.

The article analyses the legal status of participants of business associations as subjects of liability under the civil law of Ukraine. The range of participants of business associations is determined according to the Civil Code of Ukraine, the laws of Ukraine "On Business Associations", "On Joint Stock Companies", "On Limited and Additional Liability Companies". The elements of the legal status of participants of business associations include the following elements: 1) legal personality; 2) fundamental rights, responsibilities and legitimate interests; 3) guarantees of rights and legitimate interests; 4 ) responsibility for the proper performance of their duties.

Norms on these and other elements of the legal status of participants of business associations are enshrined in acts of civil legislation of Ukraine, including norms of civil law contained in complex legislative and other normative-legal acts, Commercial law acts, charters of companies.

Particular elements of the legal status of participants of business associations as subjects of civil liability were analysed. The normative consolidation of rights and obligations of participants of business associations, responsibility of participants of companies for non-fulfilment of their obligations, enshrined in the legislative acts and the charter of the company, was characterized.

Mentioned, that participants of business associations are liable for violations of both property and non-property rights of the company. An example of the first type of liability may be liability for non-contribution. An example of the second type - liability for dissemination of inaccurate information, disclosure of trade secrets and confidential information about the activity of the company.

Key words: legal entities, business associations, participants of business associations, legal status, civil liability, legislation of Ukraine.

Постановка проблеми. Останніми роками законодавство України у сфері регламентації господарських товариств як основних учасників цивільного обігу зазнало значних змін. Законом України «Про товариства з обмеженою та додатковою відповідальністю» від 6 лютого 2018 року № 2275-VIII [1] визначено правовий статус товариств 3 обмеженою відповідальністю та товариств 3 додатковою відповідальністю, порядок їх створення, діяльності та припинення, права та обов'язки їх учасників. Зазначеним Законом було визнано таким, що втратив чинність Закон України «Про господарські товариства» від 19 вересня 1991 року № 1576-XII [2] в частині, що стосується товариств з обмеженою відповідальністю та товариств 3 додатковою відповідальністю. Зміни також внесено до Цивільного кодексу України [3] та Господарського кодексу України [4]. Зокрема, Законом № 2275-VIII було викладено в новій редакції статтю 100 «Вихід та виключення 3 товариства», із Цивільного кодексу України було виключено назву підрозділу $4 \S 1$ глави 8 «4. Товариство 3 обмеженою відповідальністю» та статті 140-151, а також внесено інші зміни. Оновлення чинного законодавства України в цій сфері, необхідність грунтовної розробки теоретичних і практичних проблем правового статусу господарських товариств, внесення конкретних пропозицій щодо вдосконалення законодавства 3 урахуванням позитивного законодавчого зарубіжного досвіду зумовлюють актуальність і доцільність окремого спеціального дослі- дження відповідальності учасників господарських товариств як елементу їх правового статусу.

Стан наукової розробки проблеми. Проблеми юридичних осіб, у тому числі господарських товариств, досліджуються у наукових працях О.А. Беляневич, Т. В. Боднар, В. І. Борисової, В. А. Васильєвої, І. В. Венедіктової, О. М. Вінник, М. К. Галянтича, А. Б. Гриняка, О. В. Дзери, Ю. М. Жорнокуя, А. В. Зеліско, О.І. Зозуляк, І. Р. Калаура, І. С. Канзафарової, В. М. Коссака, А. В. Коструби, О. О. Кота, О. В. Кохановської, Н. С. Кузнєцової, I. М. Кучеренко, В. В. Луця, Р. А. Майданика, С.О. Мічуріна, І. В. Спасибо-Фатєєвої, Ю.В. Соколовської, Р. О. Стефанчука, С. О. Харитонова, О. І. Харитонової, Я. М. Шевченко, Б.В. Шуби, О. С. Яворської, В. Л. Яроцького та інших. У своїх роботах учені характеризують окремі аспекти правового статусу господарських товариств.

Дослідженню зазначеної проблематики присвячені такі дисертації: докторська дисертація А.В. Зеліско «Підприємницькі юридичні особи приватного права як суб'єкти цивільних правовідносин» (2017р.) [5]; кандидатські дисертації Н. В. Щербакової «Правове регулювання злиття та приєднання господарських товариств» (2006р.) [6], І.Б. Саракун «Здійснення корпоративних прав учасниками (засновниками) господарських товариств (цивільно-правовий аспект)» (2007) [7], С.С. Кравченко «Юридична природа прав учасників господарських товариств» (2007) [8], Ю.Ю. Симонян «Корпоративні відносини у командит- 
них товариствах (цивільно-правовий аспект)» (2010) [9], Н. I. Шевченко «Правове регулювання припинення господарських товариств шляхом реорганізації» (2012 р.) [10], Л. В. Сіщук «Правонаступництво в корпоративних правовідносинах» (2014р.) [11], Д. В. Жекова «Припинення юридичних осіб за цивільним законодавством України» (2015 p.) [12], Ю.В. Соколовської «Учасники підприємницьких товариств як суб'єкти цивільно-правової відповідальності у корпоративних відносинах» (2019) [13], Р.С. Лукашова «Товариства 3 обмеженою і додатковою відповідальністю як суб'єкти цивільного права» (2020р.) [13] та ін.

На дисертаційному рівні спеціальному дослідженню проблем відповідальності учасників господарських товариств присвячена кандидатська дисертація Б.В. Шуби «Відповідальність учасників господарських товариств як засіб захисту інтересів його кредиторів (порівняльно-правовий аналіз німецького і українського права)» (2005) [14]. У зазначеній дисертації досліджено окремі аспекти відповідальності учасників господарського товариства у порівняльно-правовому аспекті. Водночас у науці цивільного права залишаються недостатньо дослідженими низка інших теоретичних і практичних питань правової регламентації відповідальності учасників господарських товариств.

Метою статті $\epsilon$ характеристика правового статусу учасників господарських товариств як суб'єктів відповідальності за цивільним правом України.

Виклад основного матеріалу. Відповідно до частини другої ст. 83 Цивільного кодексу України (далі - ЦК України) товариством є організація, створена шляхом об'єднання осіб (учасників), які мають право участі у цьому товаристві. Товариство може бути створено однією особою, якщо інше не встановлено законом.

Статтею 84 ЦК України господарські товариства віднесено до підприємницьких товариств. Згідно з частиною першою цієї статті товариства, які здійснюють підприємницьку діяльність з метою одержання прибутку та наступного його розподілу між учасниками (підприємницькі товариства), можуть бути створені лише як господарські товариства (повне товариство, командитне товариство, товариство 3 обмеженою або додатковою відповідальністю, акціонерне товариство) або виробничі кооперативи чи сільськогосподарські кооперативи, сільськогосподарські кооперативні об'єднання, що діють 3 метою одержання прибутку.

Поняття та види господарських товариств передбачені ст. 1 Закону України «Про господарські товариства», яка втратила чинність у частині, що стосується акціонерних товариств, на підставі Закону № 514-VI від 17.09.2008. Як уже відзначалося, Закон втратив чинність у частині, що стосується товариств 3 обмеженою відповідальністю та товариств 3 додатковою відповідальністю на підстав Закону № 2275-VIII від 06.02.2018. Відповідно до частини першої ст. 1 Закону України «Про господарські товариства» господарським товариством $є$ юридична особа, статутний (складений) капітал якої поділений на частки між учасниками.

Господарськими товариствами цим Законом визнаються підприємства, установи, організації, створені на засадах угоди юридичними особами і громадянами шляхом об'єднання їх майна та підприємницької діяльності 3 метою одержання прибутку (ч. 2 ст. 1).

Згідно $з$ частиною третьою ст. 1 Закону до господарських товариств належать: акціонерні товариства, товариства 3 обмеженою відповідальністю, товариства 3 додатковою відповідальністю, повні товариства, командитні товариства.

Виходячи зі змісту ст. 3 Закону України «Про господарські товариства», учасниками товариства можуть бути підприємства, установи, організації, а також громадяни, крім випадків, передбачених законодавчими актами України (ч. 1).
У частини четвертій ст. 3 Закону зазначається, що іноземні громадяни, особи без громадянства, іноземні юридичні особи, а також міжнародні організації можуть бути учасниками господарських товариств нарівні 3 громадянами та юридичними особами України, крім випадків, встановлених законодавчими актами України.

Згідно з частиною четвертою цієї статті господарське товариство, крім повного і командитного товариств, може бути створене однією особою, яка стає його єдиним учасником.

Правовий статус учасників господарських товариств складається 3 декількох елементів. Представники теорії права виділяють такі структурні елементи правового статусу: 1) правосуб'єктність; 2) систему прав, обов'язків і законних інтересів; 3) систему гарантій прав та обов'язків суб'єктів права; 4) їхню юридичну відповідальність [15, с. 9].

Окрім цього, у загальній теорії права виділяють широкий та вузький підходи до визначення правового статусу особи. М.I. Матузов дає найбільш широке розуміння правового статусу, включаючи до його змісту відповідні правові норми, правосуб'єктність, загальні для всіх громадян суб'єктивні права, свободи, обов'язки, законні інтереси, громадянство, юридичну відповідальність, правові принципи, правовідносини загального характеру [16, с. 59].

Прибічником вузького розуміння правового статусу суб'єкта виступає С.С. Алексєєв, на думку якого, правовий статус особи передбачає наявність у неї правосуб'єктності та певного кола основних прав, які визначають іiї правове становище у суспільстві або у даній сфері у суспільному житті [17, с. 86].

$€$ й інші точки зору в науковій літературі щодо елементів правового статусу особи. Так, Л.Д. Воєводін включив до структури правового становища (статусу) особистості громадянство, правосуб'єктність (праводієздатність), основні права, свободи, обов'язки особи і гарантії їх peалізації [18, с. 27-38].

На нашу думку, елементами правового статусу учасників господарських товариств варто визнавати такі елементи: 1) цивільну правосуб'єктність; 2) основні права, обов'язки та законні інтереси; 3) гарантії прав і законних інтересів; 4) відповідальність за належне виконання своїх обов'язків.

Усі елементи правового статусу учасників господарських товариств закріплюються в актах цивільного законодавства України, включаючи норми цивільного права, що містяться в комплексних законодавчих та інших нормативно-правових актах

У законодавчих актах термін «правовий статус» застосовується досить часто, проте законодавець не виокремлює чітко структурні елементи цього поняття. Так, частиною першою ст. 1 Закону України «Про товариства 3 обмеженою та додатковою відповідальністю» передбачено, що цей Закон визначає правовий статус товариств 3 обмеженою відповідальністю та товариств 3 додатковою відповідальністю (далі - товариство), порядок їх створення, діяльності та припинення, права та обов'язки їх учасників. Відповідно до частини другої цієї статті правовий статус товариств 3 обмеженою відповідальністю та товариств 3 додатковою відповідальністю у сферах страхової та інвестиційної діяльності, в галузі виробництва сільськогосподарської продукції, а також в інших сферах діяльності, порядок їх створення, діяльності та припинення регулюються цим Законом з урахуванням особливостей, передбачених спеціальними законами.

Потрібно відзначити, що, виходячи зі змісту актів чинного законодавства, у зміст терміну «правовий статус» законодавець вкладає інший сенс, зазвичай обмежуючись визначенням того чи іншого поняття. Наприклад, у ст. 3 «Правовий статус акціонерного товариства» у частині першій закріплено поняття акціонерного товариства як господарського товариства, статутний капітал якого поділено на визначену кількість часток однакової номі- 
нальної вартості, корпоративні права за якими посвідчуються акціями. В інших частинах ст. 1 Закону зазначені вище елементи правового статусу цього виду господарських товариств чітко не виділяються. До елементів правового статусу можна віднести норми, закріплені в частині третій ст. 1 Закону про створення акціонерного товариства, зокрема, положення абзацу третього, відповідно до якого товариство вважається створеним і набуває прав юридичної особи з дати його державної реєстрації в установленому законодавством порядку.

У ст. 3 Закону до правового статусу акціонерного товариства відносяться й норми про відповідальність, закріплені в частині другій цієї статті. Відповідно до абзацу першого частини другої ст. 3 акціонерне товариство не відповідає за зобов'язаннями акціонерів. До товариства та його органів не можуть застосовуватися будь-які санкції, що обмежують їх права, у разі вчинення акціонерами протиправних дій, крім випадків, визначених законом.

Згідно з абзацом другим частини другої ст. 3 акціонери не відповідають за зобов'язаннями товариства і несуть ризик збитків, пов'язаних з діяльністю товариства, тільки в межах належних їм акцій. До акціонерів не можуть застосовуватися будь-які санкції, що обмежують їх права, у разі вчинення протиправних дій товариством або іншими акціонерами.

Елементом правового статусу учасників господарських товариств $є$ система їх прав та обов'язків. Права та обов'язки учасників товариства закріплені відповідно ст. ст. 10 і 11 Закону України «Про господарські товариства». Нормами Розділу V Закону України «Про акціонерні товариства» передбачені права та обов'язки акціонерів. Права та обов'язки учасників товариства 3 обмеженою та додатковою відповідальністю встановлені статтями 5 і 6 Закону України «Про товариства 3 обмеженою та додатковою відповідальністю».

За чинним законодавством цивільна відповідальність настає за порушення майнових і особистих немайнових прав. Згідно з частиною п’ятою ст. 1 Закону України «Про господарські товариства» господарські товариства можуть набувати майнових та особистих немайнових прав, вступати в зобов'язання, виступати в суді та третейському суді від свого імені.

Важливим у теоретичному та прикладному аспектах $\epsilon$ визначення випадків відповідальності учасників господарських товариств за порушення майнових та особистих немайнових прав господарських товариств. Зазначені права передбачені нормами Цивільного кодексу України, інших законів України.

Як уже відзначалося, питання відповідальності учасників господарського товариства у порівняльно-правовому аспекті досліджено вітчизняним науковцем Б.В. Шубою. Учений виокремив і дослідив такі випадки відповідальності учасників товариства, що мають корпоративно-правову природу: відповідальність по зобов'язанням товариства, що обумовлюється вибором певної організаційно-правової форми самого товариства; відповідальність учасників за невнесення внесків в статутний капітал товариства; відповідальність учасників у випадку надання товариству анти- кризового фінансування; відповідальність учасників залежного товариства по його зобов'язанням [14, с. 15].

Учений грунтовно дослідив зазначені види відповідальності учасників господарського товариства у порівняльно-правовому аспекті за українським та німецьким правом і сформулював пропозиції про вдосконалення чинного законодавства України в цій сфері.

Сучасне дослідження цивільно-правової відповідальності учасників підприємницьких товариств у корпоративних відносинах виконане Ю.В. Соколовською (2019). Вчена у кандидатській дисертації визначила підстави, умови, форми і види цивільно-правової відповідальності учасників підприємницьких товариств, проаналізувала теоретичні та практичні питання цивільно-правової відповідальності учасників підприємницьких товариств у зобов'язальних відносинах та відповідальності зазначених осіб у корпоративних відносинах.

Норми про відповідальність учасників господарських товариств закріплені в різних законодавчих актах. Так, відповідно до абзацу третього частини другої ст.3 Закону України «Про акціонерні товариства» акціонери, які не повністю оплатили акції, у випадках, визначених статутом товариства, відповідають за зобов'язаннями товариства у межах неоплаченої частини вартості належних їм акцій.

Статтею 2 Закону України «Про товариства з обмеженою та додатковою відповідальністю» передбачена відповідальність учасників товариства, які не повністю внесли вклади. Відповідно до частини першої цієї статті учасники товариства, які не повністю внесли вклади, несуть солідарну відповідальність за його зобов'язаннями у межах вартості невнесеної частини вкладу кожного з учасників.

Водночас потрібно звернути увагу на те, що учасники господарських товариств можуть бути притягнуті до відповідальності не тільки за порушення майнових прав, а й особистих немайнових прав цих товариств. Одним iз випадків такої відповідальності може бути поширення учасником господарського товариства недостовірної інформації або інформації, що порочить ділову репутацію товариства, розголошення комерційної таємниці та конфіденційної інформації про діяльність товариства.

Висновки. Таким чином, одним із елементів правового статусу учасників господарських товариств $\epsilon$ відповідальність за належне виконання своїх обов'язків. Норми про цей та інші елементи правового статусу учасників господарських товариств закріплені в актах цивільного законодавства України, включаючи норми цивільного права, що містяться в комплексних законодавчих та інших нормативно-правових актах, актах господарського законодавства, статутах товариств.

Учасники господарських товариств несуть відповідальність як за порушення майнових, так і особистих немайнових прав товариства. Прикладом першого виду відповідальності може бути відповідальність за невнесення вкладів. Прикладом другого виду - відповідальність за поширення недостовірної інформації, розголошення комерційної таємниці та конфіденційної інформації про діяльність товариства.

\section{ЛITEPATYPA:}

1. Про товариства з обмеженою та додатковою відповідальністю: Закон України від 6 лютого 2018 року № 2275-VIII. Biдомості Верховної Ради України. 2018. № 13. Ст. 69.

2. Про господарські товариства: Закон України від 19 вересня 1991 року № 1576-XII. Відомості Верховної Ради України. 1991. № 49. Ст. 682.

3. Цивільний кодекс України від 16 січня 2003 року №435-IV. Відомості Верховної Ради України. 2003. №№ 40-44. Ст.356.

4. Господарський кодекс України від 16 січня 2003 року №436-IV. Відомості Верховної Ради України. 2003. № 18, № 19-20, № 21-22. Ст. 144.

5. Зеліско А.В. Підприємницькі юридичні особи приватного права як суб'єкти цивільних правовідносин : дис. ... докт. юрид. наук : 12.00.03. Київ, 2017. $571 \mathrm{c}$.

6. Щербакова Н.В. Правове регулювання злиття та приєднання господарських товариств: автореф. дис. ...канд. юрид. наук: 12.00.04 / Інститут економіко-правових досліджень НАН України. Донецьк, 2006. 20 с.

7. Саракун І.Б. Здійснення корпоративних прав учасниками (засновниками) господарських товариств (цивільно-правовий аспект) : автореф. дис. ...канд. юрид. наук: 12.00 .03 / Науково-дослідний інститут приватного права і підприємництва Академії правових наук України. Київ, 2007. 
8. Кравченко С.С. Юридична природа прав учасників господарських товариств: дис. ...канд. юрид. наук: 12.00 .03 / Інститут держави і права ім. В.М. Корецького НАН України. К., 2007.

9. Симонян Ю.Ю. Корпоративні відносини у командитних товариствах (цивільно-правовий аспект) : автореф. дис. ...канд. юрид. наук: 12.00.034 / Одеська національна юридична академія. Одеса, 2010.

10. Шевченко Н.І. Правове регулювання припинення господарських товариств шляхом реорганізації: автореф. дис. ...канд. юрид. наук: 12.00.04. Київ, 2012.

11. Сіщук Л.В. Правонаступництво в корпоративних правовідносинах: дис. ...канд. юрид. наук: 12.00.03. Київ, 2014.

12. Жеков Д. В. Припинення юридичної особи за цивільним законодавством України : авторефр. дис. ... канд. юрид. наук : 12.00 .03 / Нац. ун.-т «Одеська юридична академія». Одеса, 2015. 20 с.

13. Соколовська Ю.В. Учасники підприємницьких товариств як суб'єкти цивільно-правової відповідальності у корпоративних відносинах: дис. ....канд. юрид. наук: 12.00.03 / Навчально-науковий юридичний інститут ДВН3 «Прикарпатський національний університет імені Василя Стефаника». Івано-Франківськ, 2019. 259 с.

14. Лукашов Р.С. Товариства з обмеженою та додатковою відповідальністю як суб'єкти цивільного права: автореф. дис. ...канд. юрид. наук: 12.00.03. Тернопіль, 2020. 20 с.

15. Шуба Б.В. Відповідальність учасників господарського товариства як засіб захисту інтересів його кредиторів (порівняльно-правовий аналіз німецького та українського права): 12.00.03 / Національна юридична академія України ім. Ярослава Мудрого. Харків, 2005. 20 с.

16. Окунєв І.С. Загальнотеоретичні засади правового статусу суб'єктів права: авторефр. дис. ...канд. юрид. наук: 12.00 .03 / Ін-т законодавства ВР України. К., 2010. 20 с.

17. Матузов Н.И. Правовая система и личность. Саратов: Изд-во Сарат. ун-та, 1987. 294 с.

18. Алексеев С.С. Государство и право: Начальный курс. 3-е изд. М.: Изд-во «Проспект», 2015. 152 с.

19. Воеводин Л.Д. Юридический статус личности в России: Учебное пособие. М.: Издательство МГУ, Издательская группа ИНФРА•М-НОРМА, 1997. 304 c. 


\title{
ДОКТРИНАЛЬНІ ПІДХОДИ ДО РОЗКРИТТЯ СУТНОСТІ КАТЕГОРІї «ШТУЧНИЙ ІНТЕЛЕКТ»
}

\author{
DOCTRINAL APPROACHES TO DEFINING \\ THE CATEGORY OF "ARTIFICIAL INTELLIGENCE"
}

\author{
Власик Д.О., аспірант кафедри права інтелектуальної власності \\ та патентної юстиції \\ Національного університету «Одеська юридична академія»
}

\begin{abstract}
У статті проаналізовано різні наукові підходи до визначення категорії «штучний інтелект». Зазначено, що штучний інтелект розглядається також як сучасна нова сфера наукових досліджень. Аналіз наукових розвідок у сфері штучного інтелекту дозволяє виділити такі підходи до його розуміння. По-перше, це визнання штучного інтелекту об'єктом права та заперечення проти визнання його суб'єктом права. Враховуючи, що ітучний інтелект зародився саме як результат інтелектуальної творчої діяльності людини, наукові дослідження в першу чергу ґрунтувались на визначення його правової природи як об'єкта права. В основі штучного інтелекту виділяються комп'ютерні програми, програмне забезпечення, яке наділено властивостями для вибору алгоритму дій відповідно до заданих умов та удосконалення з метою вибору оптимального рішення задач, які виникають.

Штучний інтелект є об'єктом права та як результат інтелектуальної, творчої діяльності підлягає правовій охороні. По-друге, це визнання штучного інтелекту і об'єктом і суб'єктом правовідносин. Враховуючи, що в результаті діяльності штучного інтелекту можуть з'являтись нові об'єкти, питання щодо сутнісної переоцінки штучного інтелекту має важливе практичне значення. Діяльність штучного інтелекту не обмежується виключно створенням музичних чи пісенних композицій. Сьогодні індустрія штучного інтелекту прагне розширити його можливості в різних сферах, досягаючи рівня здатності до мислення та прийняття штучним інтелектом самостійних рішень у заданій сфрері. Наділення штучного інтелекту статусом квазі-суб'єкта є вимогою часу та необхідною умовою для визначення правової природи результатів їх діяльності. Визнання штучного інтелекту квазі-суб'єктом потребує комплексного підходу, який включає зокрема прийняття спеціального законодавства у зазначеній сфері, визначення можливої відповідальності штучного інтелекту та забезпечення державного контролю за діяльністю штучного інтелекту.
\end{abstract}

Ключові слова: штучний інтелект, комп'ютерна програма, права інтелектуальної власності.

Various scientific approaches to defining the category of "artificial intelligence" are analyzed. Analysis of scientific research in the field of artificial intelligence makes it possible to single out such approaches to understanding it. It is noted that artificial intelligence is considered as a modern new field of scientific research. Firstly, this is the recognition of artificial intelligence as an object of law and an objection to its recognition as a subject of law. Artificial intelligence is an object of law and, as a result of intellectual, creative activity, is subject to legal protection. Secondly, it is the recognition of artificial intelligence as an object and subject of legal relations. Considering that as a result of the activity of artificial intelligence, new objects may appear, the question of the essential reevaluation of artificial intelligence is of great practical importance. The activity of artificial intelligence is not limited to the creation of musical or song compositions. Today, the artificial intelligence industry seeks to expand its capabilities in various areas, reaching the level of the ability to think and make independent decisions by artificial intelligence in this area. Giving artificial intelligence the status of a quasi-subject is a requirement of the time and a necessary condition for determining the legal nature of the results of their activities and, most importantly, determining the fate of such artificial intelligence. The recognition of artificial intelligence as a quasi-subject requires an integrated approach, including, in particular, the adoption of special legislation in this area, the determination of the possible responsibility of artificial intelligence and the provision of state control over the activities of artificial intelligence.

Key words: artificial intelligence, computer program, intellectual property rights.

В сучасних умовах майже не можливо уявити життя без використання комп'ютерів, комп'ютерних програм, Всесвітньої мережі Інтернет. Технічний розвиток привніс в повсякденне життя чимало пристроїв, які стрімко зайняли своє місце, спростили спілкування, обмін інформацією з однієї сторони, та породив чисельні виклики, які стоять перед суспільством - 3 іншої. Інноваційна творча діяльність, забезпечуючи суспільство новими винаходами, відкриттями та розробками все більше грунтується на використанні комп'ютерних програм та новітніх технологій, які зазнають постійної модернізації. У сфері інтелектуальної діяльності непоодинокими є випадки, коли нові об'єкти створюються безпосередньо комп'ютерними програмами, а правильніше зробити акцент - штучним інтелектом. У 2018 році Європейська комісія з ефективності правосуддя прийняла Європейську етичну хартію 3 використання штучного інтелекту в судових системах та оточуючих реаліях. Визнаючи зростаюче значення штучного інтелекту у суспільстві та очікувані переваги його використання в повній мірі для підвищення та якості правосуддя, Європейська комісія 3 ефективності правосуддя офіційно прийняла 5 основоположних принципів, які мають бути покладені в основу залучення штучного інтелекту в судовій системі[1]. Враховуючи поширеність використання штучного інтелекту (далі Ш) для вирішення проблемних питань в різних сферах суспільного життя, а також наділення ШІ можливістю самостійного прийняття рішень, у наукових розвідках все активніше почало обговорюватись питання щодо можливості наділення Ш статусом суб'єкта правовідносин, а не об'єкта.

Питанням визначення сутності Ш присвячені наукові публікації Баранова О.А. У наукових дослідження, присвячених Інтернет-відносинам, відносинам інтелектуальної власності та ІТ-правовідносин Харитонов Є.О. та Харитонова O.I. розкривається сутність штучного інтелекту через призму співвідношення 3 правовим статусом рабів. Питання правового регулювання відносин за участю Ш в зарубіжних країнах досліджувались у працях Городиського I.M., Теличко О.А., Чабаненко Ю.С.

Разом 3 тим у сучасній науці цивільного права єдиного підходу щодо визначення сутності Ш не вироблено, що обумовлює актуальність та практичну затребуваність дослідження правової природи Ш, оскільки наукові напрацювання у подальшому можуть виступити підгрунтям для розробки законодавства для регулювання відносин у зазначеній сфері.

При визначенні сутності ШІ найбільш дискусійним $€$ питання щодо визнання його об'єктом або суб'єктом правовідносин.

В Концепції розвитку штучного інтелекту в Україні, схваленої розпорядженням Кабінету Міністрів України від 2 грудня 2020 р.№ 1556-р. Ш визначено як організовану сукупність інформаційних технологій, із застосуванням якої можливо виконувати складні комплексні 
завдання шляхом використання системи наукових методів досліджень і алгоритмів обробки інформації, отриманої або самостійно створеної під час роботи, а також створювати та використовувати власні бази знань, моделі прийняття рішень, алгоритми роботи з інформацією та визначати способи досягнення поставлених завдань.

В першу чергу при визначенні ШІ слід виходити з того, що розглядається як нова сфері наукових досліджень.

Штучний інтелект - це одна з новітніх областей науки. В даний час тематика штучного інтелекту охоплює величезний перелік наукових напрямків, починаючи $з$ таких завдань загального характеру, як навчання і сприйняття, i закінчуючи такими спеціальними завданнями, як гра в шахи, доказування математичних теорем, створення поетичних творів і діагностика захворювань. У штучному інтелекті систематизуються і автоматизуються інтелектуальні завдання і тому ця область стосується будь-якої сфери інтелектуальної діяльності людини. У цьому сенсі штучний інтелект $\epsilon$ воістину універсальною науковою областю. Філософи використовують термін слабкий штучний інтелект для позначення гіпотези про те, що машини можуть мати здатність діяти інтелектуально, і термін сильний штучний інтелект - для позначення гіпотези, що такі машини можна розглядати як такі, що дійсно володіють розумом (а не імітують розумну діяльність) [2].

Мороз О.Я. зазначає, що ШІ - це метафорична назва одного $з$ найприоритетніших наукових напрямів, потужний арсенал теоретичних і технічних засобів якого сконцентрований на вирішенні складного комплексу актуальних проблем, які різняться рівнем абстракції (від логіко-математичних, скажімо «геделівського типу», до техніко-технологічних) і пов'язані передусім із дослідженням розумової сфери людини: функціонування мозку (як органу мислення), комп'ютеризації інтелектуальної діяльності, імітації, моделювання ментальних процесів еtс. Як комплексний напрям, що склався в кібернетиці (в загальному спектрі іï широкомасштабних досліджень сфери мислення), а відтак, перебуваючи (принаймні номінально) під iї егідою та набуваючи в процесі прискореного розвитку дедалі більш самостійного характеру, ШІ став науковою основою створення інформаційно-комп'ютерних систем і технологій [3, С.21]

Джордж Ф. Люгер визначає штучний інтелект як область комп'ютерної науки, що займається автоматизацією розумної поведінки. Автор зазначає, що незважаючи на різноманітність проблем, які виділяються у дослідженнях штучного інтелекту, у всіх галузях цієї сфери спостерігаються деякі загальні риси, а саме: використання комп'ютерів для доведення теорем, розпізнавання образів, навчання та інших форм міркувань; увага до проблем, які не піддаються алгоритмічним рішенням [4].

Штучний інтелект (Artificial Intelligence, AI) як науковий напрямок існує з 1956 року, коли британський математик Алан Тьюрінг опублікував свою статтю «Саn the Machine Think?»( «Чи може машина мислити?»). Також він запропонував тест перевірки програми на інтелектуальність. Він полягав у наступному: організовувалось «спілкування» між людиною і комп'ютерною програмою, які розміщувалися в різних кімнатах, і до тих пір, поки дослідник не визначав, хто за стіною - людина чи програма, поведінку останньої вважалося інтелектуальною. Виходячи 3 цього, Тьюринг запропонував наступний критерій інтелектуальності програми: «Якщо поведінка обчислювальної машини, що відповідає на питання, неможливо відрізнити від поведінки людини, яка відповідає на аналогічні питання, то вона володіє інтелектом» [5, с. 7].

Враховуючи, що Ш зародився саме як результат інтелектуальної творчої діяльності людини, наукові дослідження в першу чергу грунтувались на визначення його правової природи як об'єкта права.
Першоосновою штучного інтелекту є комп'ютерні програми, програмне забезпечення. Відповідно до усталено практики на рівні міжнародного та національного законодавства комп'ютерні програми охороняються як об'єкти авторського права. Разом з тим сучасні технологічні рішення отримують правову охорону не лише як об'єкти авторського права, а й як об'єкти промислової власності. Особливість штучного інтелекту полягає в можливості вибору певних алгоритмів дій, прийняття тих чи інших рішень, що свідчить про властивості «мислення».

Ключовими аргументами на користь того, що Ш зі своєю природою тяжіє до об'єктів правовідносин чи інструментів їх здійснення є, по-перше, те, що ШІ - це результат діяльності людини, щодо якого у особи виникають певні права і обов'язки; i, по-друге - $з$ огляду на положення Резолюції Європарламенту № 2015/2103, суб’єктом притягнення до відповідальність за шкоду, заподіяну ШІ, пропонується встановити не електронну особу. Ці тези $€$ підставою для того, щоб констатувати, що слабкий Ш за своїми ознаками та функціональним призначенням більш тяжіє об'єкта права, щодо сильного ШІ, то він містить ознаки як суб'єкта, так і об'єкта права [6].

Штучний інтелект може бути об'єктивованим в об'єкті робототехніки або спілкуватися з людиною та оточуючим світом через інформаційні повідомлення, але вже незалежно від людини він наділений здатністю змінювати свій світ, світ людини та всесвіт навколо себе. Цієї ознаки, а саме здатності впливати на навколишнє середовище, навіть нині бракує юридичній особі (корпорації), але це не заважає останній визнаватися суб'єктом правовідносин. Тому аж ніяк не повинна виглядати дивною можливість визнання штучного інтелекту таким самим самостійним суб'єктом правовідносин, в тому числі у царині кримінального права, під назвою електронна особа (особистість) [7].

Попри те, що ШІ грунтується саме на комп'ютерних програмах, які набувають здатності саморозвитку та вибору алгоритму дій, через їх стрімке удосконалення та розширення функціоналу, все частіше постає питання щодо визнання їх суб'єктами права.

Азьмук Н. А. зазначає, що розвиток цифрових технологій впливає на ринок праці та змінює процес праці. 3'являється новий об'єкт - штучний інтелект, який за умови регламентації його статусу та у певних сферах діяльності може стати суб'єктом [8, с.142].

Здається недоцільним вести мову про загальну правосуб'єктність ШІ, розглядаючи роботів як гіпотетичних учасників будь-яких правовідносин. Досить складно уявити роботів суб'єктами конституційних, адміністративних, карних тощо відносин. Натомість, «природною» $€$ їхня участь у цивільних правовідносинах, оскільки, власне, для оптимізації цивільного обігу і створювався Інтернет речей. Отже першою видозміною має бути постановка питання про визнання ШІ суб'єктом цивільних правовідносин. (Власне, використовуваний у дискусії термін «фізична особа» також запозичений з цивілістики). при сприятливих умовах розвитку людства проблема визнання Штучного інтелекту суб'єктом права вже в недалекому майбутньому може постати на повний зріст [9, с. 24 -25 ].

Діордіца І.В. дослідивши питання адміністративноправового регулювання кібербезпеки України, зробив висновок про те, що штучний інтелект має розглядатись вже зараз як рівноправний учасник правовідносин і відповідно до цього мають бути прописані його правила співжиття 3 біологічною людиною (представником нашого виду). Автоматизація та переведення державних ресурсів багатої країн на платформи блокчейн, які за своєю здатністю унеможливлюють здійснення державного контролю створюють умови для встановлення такого контролю з боку штучного інтелекту і фактична цифровізація світу може відбуватися не за правилами і моделями, які нама- 
лювала собі людина, а за тими, як це змоделює і обгрунтує сам для себе штучний інтелект. Своє бачення і наукову позицію автор аргументує тим, що наука і її цінність полягає у передбаченні і формуванні прогнозних моделей і сценаріїв розвитку різноманітних подій із відповідними механізмами реагування держави. За такого підходу ми не відстаємо, ми не реагуємо, а діємо проактивно, адже за даного випадку ми формуємо майбутнє і реальність i штучний інтелект приходить до нас в світ і буде функціювати за нашими правилами [10, с.141-142].

Радутний О.Е. в роботі Artificial Intelligence (штучний інтелект) та інші загрози (кримінально-правовий вимір) робить висновки про те, що: штучний інтелект (електронна особа, особистість) може бути наділений здатністю усвідомлювати фактичну сторону, усвідомлювати суспільну небезпечність своєї дії або бездіяльності та їх наслідків, керувати своєю поведінкою за можливість вибору (наявність декількох варіантів поведінки); штучний інтелект (електронна особа, особистість) може бути визнаний суб'єктом злочину; визнання штучного інтелекту (електронної особи, особистості) суб'єктом злочину буде доцільним та обгрунтованим лише за умови переопрацювання всієї системи кримінального права поза спокусливого наслідування науковій або політичній моді [11].

Попри те, що все частіше обговорюється можливість наділення ШІ ознаками суб'єкта права, більшість країн відмовляються реєструвати авторське право на роботи, створені алгоритмами на основі штучного інтелекту. Наприклад, у Сінгапурі, у справі Asia Pacific Publishing Pte Ltd v Pioneers \& Leaders (Publishers) Pte зазначено, що робота не може бути об'єктом авторського права, якщо iіi належним чином не створила людська істота. Більше того, суд у мотиваційній частині наголосив, що “нерідко, у випадках, коли застосовують високий ступінь автоматизації, не буде оригінальних робіт з тієї простої причини, що не існує ідентифікованих авторів“. Схожої позиції дотримуються і австралійські суди. Зокрема, у Acohs Pty Ltd v Ucorp Ptd Ltd суд зазначив, що авторами не можуть бути навіть розробники програми, яка грунтується на штучному інтелекті, адже їхня діяльність для розробки самої програми суттєво відрізняється від, до прикладу, складання самою програмою віршів [12].

Розвиток відносин у сфері створення та використання Ш породжує чимало проблемних питань, на які наразі не винайдено однозначних відповідей. Аналіз наукових розвідок у сфері Ш дозволяє виділити такі підходи до його розуміння. По-перше, це визнання ШІ об'єктом права та заперечення проти визнання його суб'єктом права. Не викликає жодних сумнівів, що Ш $є$ об'єктом права та як результат інтелектуальної, творчої діяльності підлягає правовій охороні. Наразі ШІ не визнано самостійним об'єктом права інтелектуальної власності, однак це не обмежує право їх винахідників та розробників на захист таких результатів інтелектуальної діяльності. По-друге, це визнання ШІ і об'єктом і суб'єктом правовідносин. Враховуючи, що в результаті діяльності ШІ можуть з'являтись нові об'єкти, питання щодо сутнісної переоцінки ШІ має важливе практичне значення. Діяльність ШІ не обмежується виключно створенням музичних чи пісенних композицій. Сьогодні індустрія ШІ прагне розширити його можливості в різних сферах, досягаючи рівня здатності до мислення та прийняття Ш самостійних рішень у заданій сфері. Залучення ШІ до винесення рішень справам досвід позитивний з позиції пришвидшення розгляду справ та розвантаження судів, однак породжує чимало питань щодо можливості оскарження таких рішень, зокрема й у випадку допущених помилок чи неповного врахування всіх обставин. У зв'язку з чим наділення ШІ статусом квазі-суб'єкта $\epsilon$ вимогою часу та необхідною умовою для визначення правової природи результатів їх діяльності та, що найголовніше, визначення долі такого Ш. Визнання ШІ квазі-суб'єктом потребує комплексного підходу, який включає зокрема прийняття спеціального законодавства у зазначеній сфері, визначення можливої відповідальності ШІ та забезпечення державного контролю за діяльністю ШІ. На окрему увагу також заслуговує питання визнання природи та приналежності об'єктів, які є результатом діяльності Ш, оскільки вони $є$ поєднанням творчого доробку автора - фізичної особи, яка $\epsilon$ розробником Ш або користувачем, який задав необхідні параметри для створення нового об'єкта, а також результатом дій ШІ.

\section{ЛITEPATУPA}

1. Европейская этическая хартия об использовании искусственного интеллекта в судебных системах и окружающих их реалиях Принята на 31-м пленарном заседании ЕКЭП (Страсбург, 3-4 декабря 2018 года) https://rm.coe.int/ru-ethical-charter-en-version-17-12-2018mdl-06092019-2-/16809860f4 C. 34; 56; 1271-1272.

2. Рассел Стюарт, Норвиг Питер Искусственный интеллект: современный подход, 2-е изд.. : Пер. с англ. - М. : Издательский дом "Вильямс", 2007. 1408 с. http://213.230.96.51:8090/files/ebooks/dasturlash/lskusstvennyi\%20intellekt\%20sovremennyi\%20podkhod\%20 aima-2\%202-e\%20izd.pdf

3. Мороз О.Я. Штучний інтелект versus природний інтелект (майбутнє людини в контексті викликів інтелектуальних супертехнологій. Політологічний вісник, 2014. Випуск 72. С.18-35.

4. Джордж Ф. Люгер Искусственный интеллект. Стратегии и методы решения сложных проблем. 4-е издание. Перевод с англ. Издательский дом «Вильямс». 2003. 864 с.

5. Казаков П.В. Основы искусственного интеллекта: учеб. пособие / П.В. Казаков, В.А. Шкаберин. Брянск: БГТУ, 2007. 196 с.

6. Гринчук А. Штучний інтелект як об'єкт правового регулювання: поняття, види та ознаки. Журнал східноєвропейського права. 2019. № 70. С. 282-287.

7. Радутний О.Е. Мораль і право для штучного інтелекту та цифрової людини: закони робототехніки та «проблема вагонетки». Інформація і право/ 2019. № 3(30). С. 78-95.

8. Азьмук Н.А. Штучний інтелект у процесі праці у цифровій економіці: нові виклики та можливості. Економічний вісник Донбасу. 2019. №3(57). С. 137-145.

9. Харитонов Є. Харитонова О. Правовідносини та штучний інтелект: «суб'єктивізація» об'єкту. ІІнтернет речей: проблеми правового регулювання та впровадження : Матеріали Третьої науково-практичної конференції. 21 листопада 2019 р. м. Київ. / Упоряд. : В. М. Фурашев, Дорогих С.О., С. Ю. Петряєв. - Київ: Національний технічний університет України «Київський політехнічний інститут імені Ігоря Сікорського» Вид-во «Політехніка». 2019. - С. 23-26.

10. Діордіца І.В. Адміністративно-правове регулювання кібербезпеки України: Дис. доктора наук 12.00.07. Запоріжжя. 2018. 521 с.

11. Радутний O.E. Artificial Intelligence (штучний інтелект) та інші загрози (кримінально-правовий вимір). IT право: Проблеми і перспктиви розвитку в Україні. (Друга міжнародна щорічна конференція) 17 листопада 2017 p. http://aphd.ua/publication-354

12. Чи може штучний інтелект бути автором твору? https://cedem.org.ua/consultations/shtuchnyj-intelekt-avtor-tvoru 


\title{
ПРИРОДА ПРАВОВИХ КОНФЛІКТІВ У СФЕРІ ОСВІТИ
}

\author{
THE NATURE OF LEGAL CONFLICTS IN THE FIELD OF EDUCATION
}

\author{
Грезіна О., аспірант кафедри загальної теорії права та держави
}

Національного університету «Одеська юридична академія»

\begin{abstract}
У статті розглянуто правову специфіку конфліктів у сфері освіти, підстави і причини виникнення правових конфліктів, у тому числі за галузевим принципом. Зазначено необхідність розмежування причин та передумов правових конфрліктів. Форма вирішення правового конфлікту може мати лише правовий характер. Автором статті здійснюється загальнотеоретичний аналіз розвитку правового конфлікту. 3'ясовано особливості правового конфрлікту. Досліджено суперечності, конфолікти між учасниками освітнього процесу. Наголошується, на необхідність проведення комплексного дослідження виникнення правових конфліктів у сфері освіти. Наведено аналіз класифікацій конфрліктів у ссері освіти за різними рівнями та критеріями. Класифбікувати складні консфлікти можна за кількома критеріями, серед них можна визначити окремо конфлікти поведінки, діяльності, конфллікти взаємин , також можна додати ті конфлікти, що зумовлені слабкою організацією освітнього процесу в школах, конфллікти мотиваційні. У навчанні бувають конфрлікти між учнями та вчителями, між адміністрацією та вчителями тощо. Підбиваючи підсумки дослідження, причиною того, що людина не захищає свої права полягає в тому, що в процесі освітнього процесу учасники впевнені , що протистояти системі неможливо.

Автор статті звертає увагу на окремі негативні тенденції із необґрунтованими скаргами учасників освітнього процесу. Акцентовано увагу на необхідності виокремити умови та фактори конструктивного вирішення правового конфлікту, об'єднання зусиль для розв'язання проблем усіх учасників освітнього процесу. Зроблено висновок, що причини виникнення правових конфрліктів слід розглядати як комплексний об'єкт. Передумовою правового конфлікту слід розглядати конфолікт інтересів учасників освітнього процесу, викликаних специффікою об’єкта правого регулювання. Конфлікт інтересів проявляється залежно від виду правовідносин, в рамках якого виникає та розвивається правовий конфолікт.
\end{abstract}

Ключові слова: конфрлікт, правовий конфрлікт у сфері освіти, конфрлікт інтересів, освітній процес, захист прав учасників освітнього процесу.

The article considers the legal specifics of conflicts in the field of education, the grounds and causes of legal conflicts, including the sectoral principle. The need to distinguish between the causes and preconditions of legal conflicts is noted. The form of resolving a legal conflict can only be of a legal nature. The author of the article carries out a general theoretical analysis of the development of legal conflict. The peculiarities of the legal conflict have been clarified. Contradictions and conflicts between the participants of the educational process are studied. It is emphasized the need for a comprehensive study of legal conflicts in the field of education. The analysis of classifications of conflicts in the field of education by different levels and criteria is given. Complex conflicts can be classified according to several criteria, among them can be identified separately conflicts of behavior, activities, conflicts of relationships, you can also add those conflicts that are due to poor organization of the educational process in schools, motivational conflicts. In teaching, there are conflicts between students and teachers, between the administration and teachers, and so on. Summing up the results of the study, the reason that people do not protect their rights is that in the educational process, participants believe that it is impossible to resist the system.

The author of the article draws attention to some negative trends with unfounded complaints of participants in the educational process. Emphasis is placed on the need to identify the conditions and factors for a constructive solution to the legal conflict, to unite efforts to solve the problems of all participants in the educational process. It is concluded that the causes of legal conflicts should be considered as a complex object. The precondition of a legal conflict should be considered the conflict of interests of participants in the educational process, caused by the specifics of the object of legal regulation. Conflict of interest manifests itself depending on the type of legal relationship within which the legal conflict arises and develops.

Key words: conflict, legal conflict in the field of education, conflict of interests, educational process, protection of the rights of participants in the educational process.

Постановка проблеми. Сучасна освіта $є$ одним 3 основних напрямків діяльності сучасної держави, оскільки виступає інститутом соціалізації особистості, основою професійного становлення та зростання людини. Забезпечення суспільного прогресу передбачає розвиток інституту безперервної освіти та постійне підвищення освітнього рівня громадян. Міжнародні стандарти, позитивний західний досвід сприяють концептуальному розвитку системи освіти в Україні та створюють умови якісного освітнього процесу та супутніх йому елементів. У зв'язку з цим актуалізується питання щодо формування освітніх практик, які визначають механізми забезпечення та реалізації прав усіх учасників освітнього процесу. Однак, особливо гостро питання про дотримання прав та гарантій суб'єктів освітніх відносин виникає в умовах конкретних протиріч, розбіжностей, які часто переростають у конфліктні ситуації. Місце та роль конфлікту у соціальних відносинах важко переоцінити. Невипадково сьогодні конфлікт розглядається як форма суспільного життя і навіть виступає як основа суспільного розвитку.

Аналіз останніх досліджень. Найбільшою увагою серед науковців користується тема пошуку причин виникнення конфлікту інтересів учасників освітнього процесу, а не власне правових конфліктів. Серед наукової спільноти, дослідженням правових конфліктів у сфері освіти займалися такі науковці, як В. Андрушко, Г. Вільський, Л.В. Голяк, О.В. Лісовець, Т. Є. Оболенська, Ю.М. Рижук, О.А.Чабанюк.

Постановка завдання. Слід зазначити, що в Україні вивчення освітніх конфліктів з погляду їх правового опосередкування, здійснюється в основному, в міждисциплінарному аспекті, що передбачає цілий комплекс предметних галузей. Тому очевидною стає потреба у визначенні як власне юридичної категорії конфлікту у сфері освіти, а й у створенні низки процесуальних елементів та конкретних правових інструментів їх вирішення.

Виклад основного матеріалу. Існує основна проблема у навчанні - як навчати и чому навчати. Виконує обов'язки система освіти і виховання, а голосним замовником є само суспільство. Тому, відповідно, конфлікти виникають саме між суспільством та системою освіти - на макрорівні. Якщо звернути увагу на мезорівень (середній) - там виникають суперечки між адміністрацією навчальних закладів (середнього та вищого ступеню) та викладачами. Далі макрорівень (нижній) - у системах «учитель (викладач) учень (студент)», «батько (мати) - учень (студент)». Усі наведені вище приклади є конфліктами вертикального рівню $[7$, с. 4$]$.

На кожному рівні $є$ як вертикальні конфлікти, так і горизонтальні. Наприклад, суперечності між громадянським 
суспільством і вищою керуючою ланкою, керівними структурами; також існують конфлікти, що стосуються політики держави у освіті або виховання. Конфлікти між різними рівнями управлінських підсистем освіти - це стосується середнього рівню системи, а до нижчого відносяться конфлікти між людьми, а саме між учителями, батьками, учнями. Якщо детальніше розглянути систему вищої освіти, батьки вже не мають такого суттєвого впливу, як у середній, тому у цій категорії інші групи конфліктив, а саме: «суспільство3ВО»; «ректорат - колектив ЗВО»; «студент - викладач», «викладач - викладач», «студент - студент». Проміжними варіантами є конфлікти між ректоратом і деканатом, кафедрою і деканатом, деканатом і колективом факультету між ректоратом і колективом 3ВО та інше [2, с. 5].

Відсутність концепції освітньої політики, що $є$ цілою та послідовною і має певну стратегію, напрям розвитку, може бути причиною конфліктів на рівні «суспільство освіта». Передумови для конфліктів у навчальному процесі $є$ різні. Люди $з$ високим рівнем інтелекту та ступенем освіченості, що не можуть реалізувати свої здібності за незатребуваністю; відсутність фінансування і забезпечення матеріально-технічним обладнанням на достатньому рівні для комфортного навчання - це сприяє на незадовільність людей системою і змушує використовувати протести проти системи: голодування, мітинги, трудові конфлікти, закриття навчальних закладів, незадовільність оплатою праці та інше [2, с. 4].

Недостатне та нерегулярне фінансування закладів освіти є причиною їх деградації, тому що застаріває матеріально-технічна база, викладачі мають низький статус у суспільстві і низьку заробітну плату та вимушені шукати джерела додаткового заробітку для нормального рівня життя; через це падає їх мотивація залишатися й поліпшати свої навички, здібності і навіть вести свою діяльність саме в цій країні. На психологічному та моральному рівні всі ці пункти мають дуже негативний вплив на навчальний заклад, провокуючи конфлікти та знижуючи рівень кваліфікації як викладачів, так і учнів/студентів закладів. Такі випускники мають значне відставання творчого та інтелектуального рівня, що не відповідає потребам і запитам суспільства. Також система освіти є досить негнучкою системою, що тяжко переносить зміни та нововведення - в наслідок цього фахівці не є затребуваними, не можуть реалізувати себе в обраній сфері. Конфлікти по лінії взаємодії «ректорат - колектив 3ВО» в основному стосуються стилю керівництва навчальним закладом, соціально-психологічного клімату в колективі. Конфлікти типу «викладач - викладач» мають природу професійної ієрархії та залежать від індивідуальних якостей викладацького складу. Підставами є розбіг поглядів та понять старшого та молодшого поколінь, нетерпимість, різний рівень фахової підготовки та професійного рівня. Специфіка конфліктів типу «викладач - студент» і «студент викладач» полягає в тому, що студент переважно є самостійним суб'єктом педагогічного процесу, який критично оцінюе якість, зміст, актуальність, важливість пропонованих йому знань. Зокрема викладачі, що мають високий статус у навчальному закладі може не мати відповідний йому рівень соціального благополуччя та забезпечення. Передумовами конфліктів між викладачем і студентом $\epsilon$ успішність студентів, невідповідність справжнього рівню освіти очікуванням, конфлікт поколінь [2, с. 4].

Що стосовно мезорівня, при зіткнені вимог, інтересів педагогів, батьків та керівників, які виникають у навчально-освітньому процесі, у середній школі виникають суперечки. Ці конфлікти потребують гармонізації відносин у системах: «учитель - учень», «учитель - учні», «учитель - учитель», «учитель - батьки», «учитель керівник». Їх поділяють на прості та складні.

Конфлікти, які вирішує вчитель без допомоги батьків та керівництва, не викликаючи протидії учнів - прості, як приклад можна навести припинення бійки, свар між учнями. Складні конфлікти класифікують за різними критеріями, виокремлюючи серед них конфлікти поведінки, вчинків, конфлікти взаємин, конфлікти діяльності, а також мотиваційні конфлікти, конфлікти, зумовлені слабкою організацією навчання в школі і конфлікти взаємодії між учнями й учителями, між учителями та адміністрацією школи [8].

1. Конфлікти діяльності. Це стосується відповідальності учнів або студентів, коли вони виконують навчальні завдання на певному рівні, їх бажання до пізнання та засвоєння інформації, ix неготовність виправити власні помилки оперативно. Учні мають образу на викладачів та можуть створити суперечку.

2. Конфлікти поведінки, вчинків. Порушення учнями навчальної дисципліни та правил навчального закладу $€$ передумовами для конфліктів з викладачами на іншими здобувачами. Груба поведінка, неповажність, агресія протести проти низької оцінки, що поставив викладач, - будь що може перетворитися у суперечку.

3. Конфлікти взаємин. Виникають ці конфлікти у сфері емоційно особистісних стосунків учнів і вчителів. Постійні конфлікти діяльності або вчинків, поведінки впливають на всю взаємодію між учнями та вчителями, учнями та учнями, і породжують проблеми відносин між ними.

4. Мотиваційні конфлікти. Вони $є$ наслідком ставлення учнів та педагогів до навчального процесу. Іноді призводять до взаємної неповаги, протиріч, навіть до боротьби.

5. Конфлікти, зумовлені слабкою організацією навчання в школі. У довгому процесі навчання людина з стикається 3 чотирма конфліктини періодами та долає їх. Першим рівнем $є$ зміна діяльності, коли першокласник починає мати нові обов'язки щодо навчання у школі, і бажає надати опір, незадовільнений зупиненням ігрової діяльності. Подолавши цей період, він звикає до процесу, обов'язків, вимог та викладачів. Далі, у зв'зку зі вступом до середньої школи, треба адептуватися до викладачів-предметників, знаходити підхід до кожного, а також опановувати нові предмети, що з'являються у його навчальному процесі. Цей період продовжується до закінчення дев'ятого класу - здобування незакінченої середньої освіти. Після цього людина вирішує: продовжити навчання або починати доросле життя. Якщо людина обирає перший вариінт, виникає наступний період - найбільш стресовий для більшості учнів - вибір майбутньої професії, складання випускних екзаменів, вибір вищого навчального закладу, і в деяких випадках складання вступних іспитів у ЗВО. Також цей період $є$ початком особистого та інтимного життя людини.

6. Конфлікти взаємодії між учнями й учителями, між учителями та адміністрацією школи. В основі їх суб'єктивні причини. Найпоширеніші

серед школярів «конфлікти лідерства» - боротьба 2-3 лідерів та їх угруповань за першість у класі. У середніх класах можуть конфліктувати група хлопчиків і група дівчаток або 3-4 підлітки з класом чи навіть один учень і класс [3, с. 57].

Конфлікти «учитель - учень» можуть бути мотиваційними, особистісно-етичними. Учителя не завжди надають значення таким речам, як дотримання свого слова, розкривання таємниць, що довірили їм діти, поважне ставлення до учнів, назважаючи на різницю у віку. Конфлікти між учителями можуть бути породжені виробничими й інтимно-особистісними чинниками. У начальній, середній та старшій школі нерідко бувають конфлікти між учителями та учнями, непорозуміння. У взаємодії «учитель - адміністратор» (завуч, директор) проблеми спричинює здебільшого фактор субординації. Зараз у навчальний процес запроваджується велика кількість інновацій та нововведень, які провокують незадовільність учнів та/ або учителів, конфлікти між ними. Щоб ефективно уникнути або подолати конфлікти люди можуть використову- 
вати знання психологічної природи конфліктів, її динаміки, структури [3, с. 59].

Найголовнішим для вчителів $є$ порушення прав, пов'язаних з умовами праці: залучення до надурочних робіт $32 \%$ респондентів, виконання робіт, не передбачених трудовою угодою - $29 \%$, перевищення норм наповнюваності класів-26\%. Не менш поширені порушення, пов'язані з оплатою праці: невиплата доплат за суміщення і заміни (22\% тих, хто відзначає, що має досвід порушення власних прав), затримка зарплатні, виплат і компенсацій - $21 \%$, невиплата передбачених законодавством надбавок - $16 \%$. Для вчителів сільських шкіл актуальні також такі порушення як незабезпеченість безоплатним житлом - 51\%, неможливість придбання продуктів харчування за пільговими цінами $-47 \%$. Порушення прав викладачів 3ВО також насамперед пов'язані з умовами праці: перевищення максимального наукового та педагогічного навантаження $-44 \%$, перевищення річного робочого часу через виконання навчальних, методичних та організаційних робіт - $34 \%$, залучення до робіт, не обумовлених трудовим договором - $21 \%$. Не менше хвилюють працівників ЗВО порушення оплати праці: ненадання матеріальної підтримки на виконання наукових досліджень (40\%), непрозорість системи доплат, надбавок і премій (33\%), перешкоджання чи обмеження проведення наукової роботи (20\%) [7].

Щодо учнів, найчастіше порушується право на безкоштовну освіту: $84 \%$ батьків зазначили, що мали досвід поширення платних послуг та вимагання благодійних внесків; 40\% розповіли, що від них незаконно вимагали оплату за навчання у державних i комунальних навчальних закладах. Друге місце за поширеністю посідають порушення соціальних прав та гарантій: неналежний рівень харчування - 54\% батьків та медичного обслуговування - 64\%, жорстоке поводження 3 учнями в межах школи - 21\%. Порушення права на якісну освіту батьки вбачають у тому, що в школах бракує кваліфікованих учителів - 38\%. А ось саме право на освіту порушується не так часто. Лише $12 \%$ опитаних батьків зіштовхувалися $з$ випадками незаконної відмови у зарахуванні дитини до школи і $27 \%$ - 3 перевіркою знань на вступній співбесіді [7].

На відміну від учнів, головним порушенням прав студентів $€$ порушення права на якісну освіту: невідповідність послуг наявним стандартам - $62 \%$, невиконання нормативів матеріально-технічного та фінансового забезпечення ЗВО - 60\%, формальне здійснення практичної підготовки $-52 \%$. Серед порушень соціальних прав та гарантій студентів найактуальніше - нестача місць у гуртожитках $51 \%$. 3 порушенням права на безкоштовну освіту зіштовхувалися $34 \%$ опитаних. У них незаконно вимагали оплату за навчання в державних та комунальних закладах. Також порушенням своїх прав студенти вважають перевантаженість навчальних курсів - 44\%, перевищення нормативів співвідношення студентів і викладачів - 40\%, підвищення плати за навчання протягом терміну навчання - 39\% [7].

Усі учасники навчального процесу вважають, що головний порушник їхніх прав - держава. А ось щодо другого місця думки розходяться. Вчителі шкіл та викладачі вишів віддають його Міністерству освіти і науки (28 і 43\%, відповідно), студенти звинувачують керівництво вишів $20 \%$, а батьки учнів - керівництво шкіл - 22\% [7].

Основним гравцем у боротьбі за захист своїх прав учасники опитування вважають профспілки. На жаль, неурядові організації поки що не відомі широкому загалу, а отже не стали активними учасниками цього процесу. Найбільш поінформованими виявилися викладачі 3ВО $38 \%$ їх знають про існування такої допомоги [7].

Слушною, на наш погляд, є думка Л.В. Голяк, яка пропонує внести зміни до Конституції України, якими передбачити можливість створення спеціалізованих омбудсменів на загальнодержавному, регіональному, муніципальному рівнях [4, с. 155].

Як зазначає науковець О. Лісовець, в українських школах накопичено деякий досвід роботи шкільних омбудсменів на громадських засадах [6, с. 92].
В ідеалі, спілкування дирекції школи, класного керівника та інших вчителів з одного боку, учнів і їх батьків 3 іншого, має носити партнерський характер. Проте, через низку чинників економічного та соціального характеру, у цих відносинах часто виникають конфлікти. При вирішенні конфліктних ситуацій окремі учні та їх батьки зловживають своїми правами, користуючись статусом вчителя, адже останній - публічна особа і кожна його дія та висловлювання знаходяться під пильною увагою. Вказане стосується не лише робочого місця, адже згідно змісту п.3 ст.41 Кодексу законів про працю України, підставою для звільнення працівника, який виконує виховні функції, може стати вчинення аморального проступку поза місцем праці у позаробочий час. Захопившись пропагуванням і відстоюванням прав дитини, якою у відповідності до Конвенції про права дитини, Сімейного кодексу України, особа визнається аж до 18 років, часто забуваємо, що учні наділені також і обов'язками. Натомість, педагогу гарантоване широке коло прав [5, с. 65].

Демократизація суспільних відносин у сфері освіти має і окремі негативні тенденції. Так, почастішали випадки звернення із необгрунтованими скаргами на дії чи бездіяльність вчителів до найрізноманітніших органів від міського управління освіти і профільного міністерства, до органів прокуратури. При цьому заявнику достатньо викласти своє бачення подій; доводити факти він не зобов'язаний, перевірка обставин справи - обов'язок уповноваженого органу. Подання скарги, як правило, має наслідком детальну перевірку особи і педагогічної діяльності вчителя i, на перший погляд, не спричиняє жодних правових наслідків для заявника. Слід зазначити, що кількість звернень до суду з цих питань - мінімальна. Таким чином, ініціювання щодо вчителя перевірки не має викликати у нього стану пригніченості та розпачу. До ситуації необхідно поставитись конструктивно. Слід активно захищатись: збирати свідчення вдячних випускників, демонструвати досягнуті успіхи і отримані заохочення тощо. Слід зробити хід у відповідь - наприклад, за наявності підстав, звернутись зі скаргою на дії батьків до органів опіки та піклування. Можна звернутися до суду за спростуванням недостовірної інформації $[5$, с. 73$]$.

Згідно п. 15 Постанови Пленуму Верховного Суду України № 1 від 27.02.2009 року «Про судову практику у справах про захист гідності та честі фізичної особи, а також ділової репутації фізичної та юридичної особи» недостовірною вважається інформація, яка не відповідає дійсності або викладена неправдиво, тобто містить відомості про події та явища, яких не існувало взагалі або які існували, але відомості про них не відповідають дійсності (неповні або перекручені) [1].

Як засвідчило дослідження, основна причина неготовності захищати свої права - впевненість учасників освітнього процесу в неможливості подолати систему.

Одним із основних засобів впливу на прийняття рішення про скаргу щодо недотримання прав учасників освітнього процесу є гласність, поширення інформації про порушення прав, здійснення постійного моніторингу стану дотримання та захисту прав у закладах освіти.

Висновки. У підсумку зазначимо, що передумовою правового конфлікту слід розглядати конфлікт інтересів учасників освітнього процесу, викликаних специфікою об'єкта правого регулювання. Конфлікт інтересів проявляється залежно від виду правовідносин, в рамках якого виникає та розвивається правовий конфлікт. В Україні вивчення правових конфліктів у сфері освіти здійснюється в основному, в міждисциплінарному аспекті, що передбачає цілий комплекс предметних галузей. Україна тільки починає розвиватись у цьому напрямку. Тому слід ретельно вивчати практику інших країн, щоб знизити кількість скарг учасників освітнього процесу про порушення їх прав. 


\section{ЛІТЕРАТУРА}

1. Постанови Пленуму Верховного Суду України № 1 від 27.02.2009 року «Про судову практику у справах про захист гідності та честі фізичної особи, а також ділової репутації фізичної та юридичної особи». URL: http://zakon2.rada.gov.ua/laws/

2. Андрушко В. Освіта України в світлі суспільних проблем і суперечностей. Освіта. 2002. № 5. С. 4-5

3. Вільський Г. Особливості сучасного етапу розвитку вищої освіти України. Вища щкола. 2009. № 3. С. 57-62

4. Голяк Л.В. Інститут спеціалізованого омбудсмена: світовий досвід організації та діяльності: монографія. Львів. Видавництво «ЗУКЦ». 2011. 304 с.

5. Комбарова Ю.В. Правові основи вирішення конфліктів вчителів, учнів та їх батьків. Правовий путівник для освітян. 2012.160 с.

6. Лісовець О. В. Перспективи реалізації моделі шкільного омбудсмена в Україні. Соціальна робота в Україні: теорія і практика. 2012. № 2. C. $90-98$.

7. Онищенко O. URL: https://dt.ua/EDUCATION/doslidzhennya-problemi-sferi-osviti-negativno-vplivayut-na-realizaciyu-prav-gromadyan-_.html

8. Оболенська Т. Є., Рижук Ю.М., Чабанюк О.А. Омбудсмен по правам студентів у механізмі забезпечення якості вищої освіти. Студентоцентризм у системі забезпечення якості освіти в економічному університеті : зб. матеріалів Всеукр. наук.-метод. конф. за міжнар. участю, (Київ, 2-3 берез. 2016 р.). ДВНЗ «Київ. нац. екон. ун-т ім. В. Гетьмана»; редкол.: А. М. Колот, Т. В. Гуть. Київ: КНЕУ. 2016. C. 34-39. 


\title{
ДЕЯКІ АСПЕКТИ ОСКАРЖЕННЯ НОРМАТИВНО-ПРАВОВИХ АКТІВ В ПОРЯДКУ АДМІНІСТРАТИВНОГО СУДОЧИНСТВА
}

\author{
SOME ASPECTS OF APPEALS OF REGULATORY LEGAL ACTS \\ IN THE PROCEDURE OF ADMINISTRATIVE JUDICIARY
}

\author{
Букіна Л.Є., аспірант \\ Університет митної справи та фінансів
}

\begin{abstract}
У статті проаналізовано окремі аспекти процесуального законодавства, яке регламентує провадження щодо оскарження нормативно-правових актів. Констатовано, сьогодні значна кількість нормативно-правових актів, що приймаються публічною адміністрацією не відрізняється належною якістю, інколи містять суперечливі та колізійні положення, які не тільки важно застосовувати, але й якими порушуються, визначені у Конституції України права людини. Важливим інструментом захисту прав людини від таких неякісних рішень суб'єктів владних повноважень $є$ адміністративне судочинство.. Визначено, Значення провадження щодо оскарження нормативно-правових актів надає особі широкої можливості захистити свої порушені права та інтереси шляхом звернення до суду у разі прийняття незаконних та неправомірних рішень, що містять норми права, суб'єктами владних повноважень, що є свідченням ступеню розвитку демократії в нашій державі. Звернуто увагу, що можливість оскарження нормативно-правових актів є гарантією забезпечення законності в нашій державі, створює в державі механізм контролю з боку судової влади за законністю рішень, які приймаються органами державної влади та місцевого самоврядування, а також уповноваженими на це іншими суб'єктами.

Теоретично обґрунтовано, процесуальні стадії провадження щодо оскарження нормативно-правових актів та висвітлено їх особливості. Висвітлено завдання, провадження щодо оскарження нормативно-правових актів та його значення. Сформульовано зміст поняття провадження щодо оскарження нормативно-правових актів.
\end{abstract}

Ключові слова: адміністративне судочинство, провадження, нормативно-правовий акт, суб'єкт владних повноважень, оскарження.

The article analyzes some aspects of procedural legislation that regulates the procedure for appealing against regulations. It is stated that today a significant number of normative legal acts adopted by public administration do not differ in quality, sometimes contain contradictory and conflicting provisions, which are not only important to apply, but also violate human rights defined in the Constitution of Ukraine. An important tool for protecting human rights from such poor decisions of the subjects of power is administrative proceedings, containing the rule of law, the subjects of power, which is evidence of the degree of development of democracy in our country. It is noted that the possibility of appealing against legal acts is a guarantee of legality in our country, creates in the state a mechanism of judicial control over the legality of decisions made by public authorities and local governments, as well as other authorized entities.

Theoretically substantiated, the procedural stages of the proceedings on the appeal of regulations and highlighted their features. The tasks, proceedings on appeal of normative legal acts and its significance are covered. The content of the notion of proceedings on appeals of normative legal acts is formulated.

Key words: administrative proceedings, proceedings, normative legal act, subject of power, appeal.

Постановка проблеми. У ст. 55 Конституції України, зазначається, що права і свободи людини і громадянина захищаються судом;кожному гарантується право на оскарження в суді рішень, дій чи бездіяльності органів державної влади, органів місцевого самоврядування, посадових і службових осіб. Це конституційне положення дозволяє зробити висновок, що в адміністративному суді можуть бути оскаржені будь-які рішення, дії чи бездіяльність суб'єктів владних повноважень. Одним із видів рішень суб'єктів владних повноважень $є$ нормативно-правовий акт.

Нажаль так склалося у вітчизняній правовій традиції, що сьогодні значна кількість нормативно-правових актів, що приймаються публічною адміністрацією не відрізняється належною якістю, інколи містять суперечливі та колізійні положення, які не тільки важно застосовувати, але й якими порушуються, визначені у Конституції України права людини. Важливим інструментом захисту прав людини від таких неякісних рішень суб'єктів владних повноважень $є$ адміністративне судочинство. Для оскарження нормативно-правових актів суб єктів владних повноважень закон передбачає особливий порядок адміністративного провадження, який встановлено статтею 264 КАС України.

Аналіз останніх досліджень і публікацій. Правотворча діяльність суб'єктів владних повноважень та оскарження їх рішень привертали увагу багатьох науковців, черед яких варто виділити таких, як В.Б. Авер'янов, Ю.П. Битяк, В.М.Бевзенко, Є.А. Гетьман, В.В. Зуй, В.К. Колпаков, Т.П. Мінка, Р.С. Мкртчян, О.М.Пасенюк, А.Й. Присяжнюк, Я.С. Рябченко, М.І. Смокович та інші.

Проте незважаючи на вагомий внесок даних досліджень у науку адміністративного права, окремі аспекти оскарження нормативно-правових актів в порядку адміністративного судочинства потребують додаткового вивчення.

Метою статті є висвітлення окремих аспектів провадження щодо оскарження нормативно-правових актів в адміністративному судочиснтві.

Виклад основного матеріалу. Відповідно змісту частини першої ст. 264 КАС України порядок оскарження нормативно-правових актів поширюється на розгляд адміністративних справ щодо законності (крім конституційності) постанов та розпоряджень Кабінету Міністрів України, постанов Верховної Ради Автономної Республіки Крим; законності та відповідності правовим актам вищої юридичної сили нормативно-правових актів міністерств, інших центральних органів виконавчої влади, Ради міністрів Автономної Республіки Крим, місцевих державних адміністрацій, органів місцевого самоврядування, інших суб єктів владних повноважень [1].

Частиною другою статті 264 КАС України передбачено, що право оскаржити нормативно-правовий акт мають особи, щодо яких його застосовано, а також особи, які $\epsilon$ суб єктом правовідносин, у яких буде застосовано цей акт. Відповідно до частини третьої статті 264 КАС України, нормативно-правові акти можуть бути оскаржені до адміністративного суду протягом усього строку їх чинності [1].

Аналіз статистичних показників розгляду Верховним Судом України адміністративних справ (за класифікацією Верховного Суду України) показує, що найчастіше предметом перегляду були рішення у справах зі спорів фізичних чи юридичних осіб із суб'єктами владних повноважень щодо оскарження його рішень (нормативноправових актів чи актів індивідуальної дії). У загаль- 
ній кількості цих справ вирізняються 156 справ щодо оскарження рішень Державної фіскальної служби України, 11 справ - Державної фінансової інспекції України, 24 справи - Пенсійного фонду України, 3 справи - Антимонопольного комітету України, 20 справ - органів місцевого самоврядування, 24 справи - інших органів державної влади, 1 справа - Кабінету Міністрів України. Із них у 111 справах, або 44 \% загальної кількості розглянутих справ цієї категорії, судові рішення Вищого адміністративного суду України скасовано [2]. Як слушно зазначає O.В. Рой, наведені статистичні дані підтверджують існування проблем у сфері оскарження правових актів, що існує навіть на стадії касаційного оскарження [3, с. 75-76].

До адміністративних судів можуть бути оскарженні будь-які нормативні та індивідуальні правові акти з мотивів їх неконституційності, незаконності чи невідповідності правовому акту вищої юридичної сили, крім випадків, коли до таких актів передбачено застосування іншого порядку судового провадження.

Особливості провадження у справах про оскарження нормативно-правових актів визначено у ст. 264 КАС України

Відповідно до ч. 1 ст. 264 КАС України правила цієї статті поширюються на розгляд адміністративних справ щодо: 1) законності (крім конституційності) постанов та розпоряджень Кабінету Міністрів України, постанов Верховної Ради Автономної Республіки Крим; 2) законності та відповідності правовим актам вищої юридичної сили нормативно-правових актів міністерств, інших центральних органів виконавчої влади, Ради міністрів Автономної Республіки Крим, місцевих державних адміністрацій, органів місцевого самоврядування, інших суб'єктів владних повноважень [1].

Слід зауважити, що право оскаржити нормативноправовий акт мають особи, щодо яких його застосовано, а також особи, які є суб'єктом правовідносин, у яких буде застосовано цей акт. Нормативно-правові акти можуть бути оскаржені до адміністративного суду протягом всього строку їх чинності.

Отже, порядок оскарження нормативно-правових актів чітко прописаний у КАС України. Цей порядок утворює особливу процедуру, провадження 3 розгляду адміністративних справ щодо оскарження нормативно-правових актів.

Під оскарженням розуміють звернення до державних органів та органів об'єднань громадян зі скаргою 3 приводу незаконності чи необгрунтованості рішень і дій службових осіб [4, с. 20].

Оскаржуючи нормативно-правовий акт суб'єкт звернення ініціює публічно-правовий спір.

Адміністративно-правовий спір між громадянином і суб'єктом владних повноважень виникає внаслідок дії незаконного нормативно-правового акту. Публічно-правовий характер цієї категорії справ має дві сторони: з одного боку - суб'єкт владних повноважень, який видав нормативно-правовий акт; з другого - особа, щодо якої застосовано нормативно, правовий акт, а також особи - суб'єкти правовідносин, у яких буде застосовано цей акт [4, с. 20].

Суб'єктами владних повноважень у цьому спорі виступають органи виконавчої влади, Верховної Ради Автономної Республіки Крим, органи місцевого самоврядування та інші суб' єкти владних повноважень.

Предметом розгляду цієї категорії публічно-правових спорів будуть, згідно зі ст. 264 КАС України: законність (крім конституційності) постанов та розпоряджень Кабінету Міністрів України (крім рішень Кабінету Міністрів України, ч. 1 ст. статті 266-1 КАС України, постанов Верховної Ради Автономної Республіки Крим; законність та відповідність правовим актам вищої юридичної сили нормативно-правових актів міністерств, інших центральних органів виконавчої влади, Ради міністрів Автономної Республіки Крим, місцевих державних адміністрацій, органів місцевого самоврядування, інших суб'єктів владних повноважень.
Варто підтримати Н. Блажівську зазначає, що оскарження нормативно-правових актів $€$ однією 3 найважливіших категорій справ, які підлягають розгляду в адміністративних судах, що обумовлено «надзвичайно великим ступенем впливу результатів розгляду судом таких справ на систему правового регулювання та суспільство в цілому» та відповідно мають «підвищений соціальний ефект» $[5$, с. 66$]$.

Як і будь-яке провадження в адміністративному судочинстві провадження щодо оскарження нормативно-правових актів складається із врегульованих нормами КАС України процесуальних стадій, етапів та дій.

Відповідно до КАСУ провадження у справах з оскарження нормативно-правових актів включає такі стадії: 1) порушення адміністративної справи (звернення до адміністративного суду та відкриття провадження у справі); 2) підготовка справи до судового розгляду (підготовче провадження); 3) судовий розгляд справи; 4) перегляд судового рішення (апеляційне оскарження, касаційне оскарження); 5) виконання судового рішення [4, с. 29]. Кожна з цих стадій містить свої власні завдання і складається із процесуальних етапів та дій. Процесуальний етап у межах кожної із стадій провадження містить свое локальне завдання, спрямоване не досягнення мети відповідної процесуальної стадії. Взагалі, процесуальні стадії провадження 3 оскарження нормативно-правових актів врегульовані загальними правилами, передбаченими адміністративнопроцесуальними нормами, однак потрібно враховувати й особливості, встановлені у ст. 264 КАС України.

Особливості провадження з оскарження нормативноправових актів містяться у статті 264 КАС України, як зазначалося вище. За приписами ч. 8 ст. 264 КАС України адміністративна справа щодо оскарження нормативноправових актів вирішується за правилами загального позовного провадження. Поряд з цим вказане провадження має свої особливості [1].

Особливостями цього провадження є об'єкт оскарження - нормативно-правовий акт, що прийнятий органами виконавчої влади, Верховної Ради Автономної Республіки Крим, органами місцевого самоврядування та іншими суб'єктами владних повноважень. Суб'єктом звернення $є$ особа, щодо якої застосовано нормативноправовий акт, а також, ті особи, які є суб'єктом правовідносин, у яких буде застосовано останній.

Стадія порушення адміністративної справи 3 оскарження нормативно-правового акту розпочинається з таких дій, після отримання судом позовної заяви: з'ясування суддею підстав для відкриття провадження у справі та прийняття рішення щодо можливості відкриття провадження в адміністративний справі. У разі відкриття провадження в адміністративній справі щодо оскарження нормативноправового акта суд зобов'язує відповідача опублікувати оголошення про це у виданні, в якому цей акт був або мав бути офіційно оприлюднений. Оголошення повинно містити вимоги позивача щодо оскаржуваного акта, реквізити нормативно-правового акта, дату, час і місце судового розгляду адміністративної справи. Оголошення має бути опубліковано не пізніш як за сім днів до підготовчого засідання, а у випадку, визначеному частиною десятою ст. 264 КАС України, - у строк, визначений судом. Якщо оголошення опубліковано своєчасно, вважається, що всі заінтересовані особи належним чином повідомлені про судовий розгляд справи. Скарги на судові рішення в цій справі заінтересованих осіб, якщо вони не брали участі у справі, залишаються без розгляду[1].

Стадія підготовки справи до судового розгляду поєднує в собі декілька правових процедур: 1) прийняття судом заходів для всебічного і об'єктивного розгляду справи; 2) прийняття судового рішення за результатами підготовки адміністративної справи до розгляду, 3) доведення ухвали до відома особам, які беруть участь у справі; 4) можливе 
прийняття рішення суддею про зупинення дії нормативноправового акту повністю чи окремих його положень для забезпечення позову [4, с. 76]. Метою вказаної стадії $є$ підготовка справи таким чином, щоб їі можна було розглянути протягом одного судового засідання. Тому на цій стадії вчиняються процесуальні дії, під час яких суддя уточнює підстави та предмет позову; з'ясовує обставини справи та докази, які надали сторони, на їх підтвердження тощо.

Згідно з ч. 10 ст. 264 КАС України Якщо у процесі розгляду справи щодо нормативно-правового акта суд виявить, що інші нормативно-правові акти, прийняті відповідачем, чи їх окремі положення, крім тих, щодо яких відкрито провадження в адміністративній справі, безпосередньо впливають на прийняття рішення у справі і без визнання таких нормативно-правових актів протиправними неможливий ефективний захист прав позивача, суд визнає такі акти чи їх окремі положення протиправними в порядку, визначеному цією статтею[1].

Стосовно можливості зупиняти дію актів нормативно-правового характеру в якості заходу до забезпечення позову висловлюються думки про недоцільність надання суду такого права. Зокрема, зазначається про те, що оскарження нормативно-правового акту впливає на права та законні інтереси невизначеного кола осіб, оскільки з ініціативи однієї особи може бути скасований або змінений елемент правової системи держави, дія якого поширюється на невизначене коло осіб, які безпосередньо участі у справі не беруть. Тобто зупинення дії оскаржуваного нормативно-правового акту стосується не тільки позивача, але й інших осіб, тому не може бути визнане адекватним та пропорційним. Взагалі зупинення дії нормативно-правового акту стосується виключно компетенції нормотворчого органу, а саме суб'єктів владних повноважень, які видали даний нормативно-правовий акт. [4, с. 93]

Що стосується процедурних аспектів, пов'язаних з оскаржуваним нормативно-правовим актом, то перевірці судом підлягають такі моменти:

- чи наділено відповідача законом або іншим нормативно-правовий актом повноваженням приймати відповідний нормативно-правовий акт, а також яким є статус відповідного суб'єкта владних повноважень (колегіальний орган чи посадова особа);

- чи дотримано відповідачем встановлених правотворчих процедур прийняття нормативно-правового акту - підготовка проекту нормативно-правового акту, обговорення (з дотриманням вимог щодо належного кворуму на засіданні колегіального органу або оприлюднено згідно законодавством для обговорення з громадськістю проекту акту), та ухвалення нормативно-правового акту;

- чи дотримано вимог стосовно оформлення нормативно-правового акту як юридично цілісного і структурно завершеного акта (письмова форма, вид конкретного нормативно-правового акту, наявність відповідних реквізитів, у тому числі дата прийняття та номер документа, підпис уповноваженої посадової особи);

- чи набрав чинності нормативно-правовий акт, який оскаржено до адміністративного суду;

- чи дотримано вимоги щодо підписання та оприлюднення нормативно-правового акту[4, с. 79];

- чи відповідає нормативно-правовий акт нормам Конституції України та законам України.

За наслідками розгляду справи суд може визнати нормативно-правовий акт протиправним (незаконним чи таким, що не відповідає правовому акту вищої юридичної сили) та нечинним повністю або в окремій його частині. Рішення суду у справах щодо оскарження нормативно-правових актів оскаржується у загальному порядку.

Висновок. Отже, підсумовуючи вищевикладене слід зазначити, що під провадженням щодо оскарження нормативно-правових актів слід розуміти врегульовану нормами адміністративного-процесуального права порядку реалізації права на звернення особи з приводу незаконності чи необгрунтованості нормативно-правового акту, і який складається з сукупності процесуальних стадій, дій та етапів, спрямованих на досягнення правового результату даного провадження.

Можливість оскарження нормативно-правових актів $€$ гарантією забезпечення законності в нашій державі, створює в державі механізм контролю 3 боку судової влади за законністю рішень, які приймаються органами державної влади та місцевого самоврядування, а також уповноваженими на це іншими суб'єктами. Значення провадження щодо оскарження нормативно-правових актів надає особі широкої можливості захистити свої порушені права та інтереси шляхом звернення до суду у разі прийняття незаконних та неправомірних рішень, що містять норми права, суб'єктами владних повноважень, що є свідченням ступеню розвитку демократії в нашій державі.

\section{תITEPATYPA}

1. Кодекс адміністративного судочинства України від 06.07.2005 p. № 2747-VI URL: https://zakon.rada.gov.ua/laws/show/2747-15\#Text

2. Аналітичний огляд стану здійснення адміністративного судочинства у 2015 році / Загальні показники розгляду Верховним Судом України заяв про перегляд судових рішень Вищого адміністративного суду України та результати їх перегляду. URL: http://www.vasu.gov. ua/sudovapraktika/statistika/anlit_ogljad_adminsudochinstva_2015/

3. Рой О.В. Правові акти суб'єктів владних повноважень як предмет публічно-правового спору. дис. канд.юрид.наук - Науководослідний інститут інформатики і права Національної академії правових наук України, Київ, 2019. с. 269

4. Рябченко Я.С. Оскарження нормативно-правових актів в адміністративному судочинстві. дис. канд. юрид.наук. 12.00.07., Харків, 2010. c. 158

5. Блажівська Н. Процедура розгляду справ про оскарження нормативно-правових актів потребує вдосконалення. Вісник Вищого адміністративного суду України. 2009. № 1. С. 64-66. 


\title{
ПРАВОВА ОХОРОНА ТЕЛЕФОРМАТУ ЯК ОБ'СКТА ПРАВА ІНТЕЛЕКТУАЛЬНОЇ ВЛАСНОСТІ
}

\section{LEGAL PROTECTION OF TV FORMAT AS INTELLECTUAL PROPERTY}

\author{
Літвіщенко Г.О., аспірантка кафедри права інтелектуальної власності \\ та корпоративного права \\ Національного університету «Одеська юридична академія»
}

\begin{abstract}
У статті телесормат розглянуто як комплексну категорію, яка поєднує різні результати творчої, інтелектуальної діяльності. Визначено, що у доктринальних дослідженнях, присвячених сутності телеформату, пропонується виділяти дві категорії складових елементів телеформату. Перша категорія - це об'єкт, який не підлягає охороні. До таких об'єктів віднесено ідею. Визначення формату телепрограми виключно як ідеї не дозволить забезпечити його правову охорону. Попри те, що саме ідея виступає основою подальшого розроблення певних об'єктів права інтелектуальної власності, визначаючи їх специфіку та унікальність, виключні права на неї не виникають. 3 однієї сторони - це суттєво обмежує можливості авторів щодо охорони ідейного задуму, внаслідок чого створюються майже тотожні результати творчої діяльності, свідченням чому є телефрормати та чимало телевізійних програм, що на них ґрунтуються, які вирізняються окремими елементами. 3 іншої сторони - визнання ідеї самостійним об'єктом права інтелектуальної власності призведе до суттєвих обмежень у творчій сфері, що негативно позначиться на створенні нових об'єктів права інтелектуальної власності.

До другої категорії складових елементів телеформатів віднесено об'єкти, які підлягають правовій охороні. До них можуть бути віднесені - сценарій, викладений у письмовій формі, музика, зображення, комерційне найменування, образ ведучих, персонажі тощо.

Враховуючи поширеність телеформатів у сфері телебачення та важливість забезпечення прав їх розробників вважається доцільним закріпити телеформат на законодавчому рівні як самостійний складний об'єкт права інтелектуальної власності, який може об'єднувати результати творчої діяльності різних категорій.
\end{abstract}

Ключові слова: телеформат, ідея, охорона, авторські права, телевізійна програма, автор.

In the article TV program format is considered as a complex category that combines different results of creative, intellectual activity. It is determined that in doctrinal researches devoted to the essence of TV program format, it is offered to allocate two categories of constituent elements of TV program format. The first category is an object that is not subject to protection. Such objects include the idea. Determining the format of a TV program solely as an idea will not allow to ensure its legal protection. Despite the fact that it is the idea that is the basis for the further development of certain objects of intellectual property law, defining their specificity and uniqueness, exclusive rights to it do not arise. On the one hand, this significantly limits the authors' ability to protect the ideological concept, as a result of which almost identical results of creative activity are created, as evidenced by television formats and many television programs based on them, which differ in individual elements. On the other hand, the recognition of an idea as an independent object of intellectual property law will lead to significant restrictions in the creative field, which will negatively affect the creation of new objects of intellectual property law.

The second category of constituent elements of TV program format includes objects that are subject to legal protection. These may include a written script, music, images, trade names, presenters, characters, and so on. Taking into account the prevalence of TV program format in the field of television and the importance of ensuring the rights of their developers, it is considered advisable to consolidate the TV program format at the legislative level as an independent complex object of intellectual property rights, which can combine the results of creative activities of different categories.

Key words: TV program format, idea, protection, copyright, television program, author.

Одним із найпоширеніших та затребуваних засобів масової інформації $є$ телебачення. Мільйони глядачів 3 усього світу дізнаються про новини, отримують можливість для культурного, духовного збагачення, набуття нових знань завдяки перегляду різної інформації. Сьогодні телеканали як спеціалізовані, так і широкого програмного спектру намагаються максимально розширити змістовність поширюваної інформації з метою формування постійної аудиторії телеглядачів та постійного іiі розширення. Розвиток телебачення, діяльність якого нерозривно пов'язана 3 використанням об'єктів права інтелектуальної власності, обумовив появу нових результатів творчої діяльності, які не отримали належного правового регулювання. Одним з таких об'єктів є телеформат. Незважаючи на те, що на законодавчому рівні телеформат не визначено як об'єкт авторського права, на практиці вже формується судова практика щодо захисту прав та інтересів розробників телеформатів. У зв'язку з чим важливе практичне значення має розкриття сутнісних ознак телеформату як результатів творчої діяльності для визначення умов їх правової охорони, обсягу прав авторів та порядку використання у сфері телебачення, що визначає мету даного дослідження.

Сьогодні на телеканалах можна побачити чимало телепрограм та шоу, які змінюють одна одну, є чимось схожими або транслюються з несуттєвими відмінностями як національними, так і зарубіжними телеканалами. Популярні в різний час в української телевізійної аудиторії телепро- грами розроблені на основі зарубіжних телевізійних форматів. Так, на основі форматів зарубіжних телепрограм розроблені, зокрема, відомі вітчизняному глядачу програми різних напрямів: шоу талантів («Master Chief Junior» («Мастер Шеф. Діти», «The Voice» («Голос), реаліті-шоу («The Biggest Looser» («Зважені та щасливі»), телесеріали «Yo soy Betty, la fea» («Моя улюблена Страшко») і подібні до них. Це свідчить про те, що суспільні відносини з приводу формату об'єктивно існують як на міжнародному (транскордонному), так і на національному рівні.

Щодо окремих телевізійних передач через їх концептуальну схожість виникли спори, які вирішувались в судовому порядку. Серед найбільш відомих справ, рішення по яким започаткували практику захисту телеформатів в Україні, слід відзначити зокрема: спори щодо захисту прав на телешоу «Караоке на майдані», «Ревізор» та «Інспектор Фреймут».

В 2000 р. в Німеччині була заснована міжнародна неурядова організація - Асоціація по визнанню і захисту формата (The Format Recognition and Protection Association; FRAPA), що об'єднала найбільші продюсерські компанії світової телевізійної індустрії. У 2010 р. між FRAPA і Всесвітньою організацією інтелектуальної власності (BOIB) було укладено угоду про співпрацю, відповідно до якої ВОIВ надала послуги Центру ВОIB з арбітражу та посередництва як форуму для вирішення «форматних» суперечок. У діяльності цих організацій, так само як в судовій практиці і в роботах зарубіжних вчених, фор- 
мат аудіовізуального твору іменується як «телеформат» (TV-format), «телевізійний формат» (television format) i «формат телепрограми» (television program format) - всі ці три терміни використовуються як синоніми [1].

Як зазначає Шаповал Д. крім міжнародних судових напрацювань, поняття телеформату не знайшло законодавчого закріплення ані в міжнародному праві, ані в національному законодавстві країн. Пов'язано це, в першу чергу, з багатогранністю певних складових елементів телеформату, комбінація та послідовність розміщення (появи, застосування тощо) яких $є$ характерною рисою саме для певного телевізійного продукту, надаючи йому при цьому можливість ідентифікації серед інших подібних об'єктів.

Дійсно, на сьогодні вітчизняне законодавство не дає чіткого визначення поняття «телевізійний формат», а судова практика, що стосується проблем правової охорони телеформатів, поки що не відрізняється особливою різноманітністю. Більше того, Закон України «Про авторське право і суміжні права» навіть не згадує таке поняття [2].

На відсутність визначення поняття «телевізійного формату» звернула увагу Н. Федорова, причому така проблема характерна як для України, так і для інших країн. Тому у юридичній науці ставлення до терміну «телеформат» більш прагматичне. Сам телеформат частіше звужують для зручності вирішення конкретних справ, по суті прирівнюючи його до ідеї, до структури або концепції, які за Європейськими законами і законами України можуть використовуватися вільно. 3 цієї причини телеформат, на думку вченої, не розглядається як правовий об'єкт в українському законодавстві [3].

При цьому виділено основні елементи/ознаки телеформату, до яких віднесено: загальна ідея, сюжет, виражений в об'єктивній формі (сценарій); шаблон відтворення певних серій телепрограми, а також інших втілень телепрограми; унікальне ім'я телепрограми, яке може бути зареєстроване як об'єкт авторського права та/або торговельна марка; призначений для багаторазового втілення різноманітними способами [4].

У запропонованому підході до розкриття сутності телеформату виділено його складові, які підлягають правовій охороні як об'єкти права інтелектуальної власності, а також такі результати, які попри творчий характер відповідно до чинного законодавства не підлягають правовій охороні (загальна ідея).

Охороноздатні та неохороноздатні складові телеформатів визначено також у дослідженні А. Силкіної, яка 3 огляду на відсутність єдиного режиму охорони формату, вважає, що при захисті формату як об'єкта права інтелектуальної власності необхідно розділити об'єкти на групи відповідно до порушеного права. Так, усі елементи телевізійного формату поділяються на охоронювані об'єкти (сценарій, музика, зображення, комерційне найменування, образ ведучих, персонажі тощо) i ті, які не підлягають охороні авторським правом (ідея, бізнес-інформація) [5].

Проблема запозичення ідеї є однією з найбільш гострих у сфері відносин інтелектуальної власності. Попри те, що саме ідея виступає основою подальшого розроблення певних об'єктів права інтелектуальної власності, визначаючи їх специфіку та унікальність, виключні права на неї не виникають. 3 однієї сторони - це суттєво обмежує можливості авторів щодо охорони ідейного задуму, внаслідок чого створюються майже тотожні результати творчої діяльності, свідченням чому є телеформати та чимало телевізійних програм, що на них грунтуються, які вирізняються окремими елементами. 3 іншої сторони - визнання ідеї самостійним об'єктом права інтелектуальної власності призведе до суттєвих обмежень у творчій сфері, що негативно позначиться на створенні нових об’єктів права інтелектуальної власності.

Як зазначає Ульянова Г.О. ідея - це особливий вид інформації, яка вирізняється творчою складовою, на під- ставі якої з'являється новий об'єкт, який залежить від об'єктивної форми вираження і без об'єктивізації не зможе отримати правову охорону. При цьому пропонує складовою права на свободу творчості визнати право на інтерпретацію ідеї, сутність якого полягає у визнанні правомірним використання ідеї з метою її творчої переробки, удосконаленням форми іiі вираження, внаслідок чого з'являється новий охороноздатний об'єкт права інтелектуальної власності [6, с.95-96].

В цьому аспекті важливе практичне значення має підхід до визначення сутності телеформату Штефан А., яка зазначає, що формат телевізійної передачі - це значно більше, ніж ідея або концепція, він не просто відповідає на питання, якою ця телепередача може бути. Будь-який твір, зокрема, сценарій телепередачі, також втілює певну концепцію, вміщує якусь ідею, яку автор хоче донести до публіки. Проте ідея ніколи не вміщує в себе твір чи його окремі охоронювані елементи. Первинний задум в процесі створення сценарію та телепередачі може змінюватися, доповнюватися, автор може відмовитися від якихось деталей і віддати перевагу зовсім іншим, тому кожен створений об'єкт є не ідеєю, а конкретним результатом її втілення. Основу телеформату складає не сама по собі концепція, а готовий продукт у вигляді телепередачі. Сукупність об'єктів, що входять до формату, послідовно і детально пояснюють, які дії слід вчинити для виготовлення цієї ж телепередачі для свого внутрішнього ринку. Тому телеформат - це чітка інструкція, яка розкриває технологію виробництва телепередачі, а не просто іiї ідею $[7$, с. 50].

Застосовуючи комплексний підхід до захисту телеформату, більшість правоволодільців реєструють як торгові знаки назву телевізійного формату. Та на практиці існують певні труднощі захисту назви формату як торгового знака. Придумуючи назву, важливо, щоб вона не було описовим позначенням. Наприклад, у справі $A E T N$ Television Network v Channel Four Television Corporation суд відмовив у забороні використання назви реаліті шоу Intervention у назві іншого реаліті-шоу Intervention: We're coming to get you, аргументуючи тим, що «inter-vention» поняття описове. Аналогічно зі словами «танці», «голос», «талант» багатьма іншими, що часто використовуються в назвах шоу. Тому й існує багато різних форматів з однаковими так званими коренями «Танцють всі», «Танці із зірками», «Танці

на льоду». На відміну від шоу Inter-vention, творці шоу American Idol змогли в Канаді опротестувати реєстрацію торгової марки Canadian Idol [8].

Виходячи 3 аналізу практики, телеформат $€$ частиною телепрограми, а завдяки сукупності різноманітних ознак, що його характеризують, наділяє таку телепрограму унікальними відмінними рисами, що перетворюють iï у подальшому на телеформат. Так, останній включає в себе жанр, стиль, драматургічну конструкцію, хронометраж, графіку, музику, тематичні та сюжетні переваги й обмеження (набір різних сюжетів), образ ведучого (якщо такий є) тощо. Телеформат відрізняється від телепрограми, у першу чергу, своїм змістом: зміст окремого випуску будь-якої телепередачі завжди одиничний, оригінальний, а телеформат - універсальний і технологічний, це колективний проект, основу якого становить оригінальна ідея, втілена у вигляді сценарію і подальшого відзнятого за сценарієм «пілотного» випуску [9].

Оскільки авторами телеформату $\epsilon$ режисер-постановник, сценарист, а також автор спеціально створеного для формату музичного твору, то власником усього комплексу майнових прав на телевізійний формат (відповідно до договору) $є$ його виробник, яким може бути будь-яка особа, у тому числі юридична, яка взяла на себе ініціативу і відповідальність за виготовлення такого твору, однак лише в межах використання певного телеформату [10]. 
У Великобританії були спроби врегулювати дане поняття, проте вони так і залишились на етапі законопроекту. Передбачалось введення двох визначень «форматна програма» та «форматна пропозиція». Під форматною програмою малась на увазі телепередача, що створювалась для повторення і розпізнавання як серії, що наділена певним рівнем оригінальності. Форматна пропозиція записаний план для форматної програми. Верховний суд Німеччини у рішенні по справі Sendeformat в 2003 році зазначив, що телеформат - це сукупність характерних ознак телепрограми, які формують шаблон кожної наступної передачі та дають змогу іiі вирізнити серед інших телепрограм. Як об'єкт права інтелектуальної власності, який включає не лише центральну ідею програми/шоу, але й сукупність різноманітної інформації тлумачив телеформат суд Бразилії в 2004 році у справі щодо формату передачі «Великий Брат» (Big Brother) [11].

Документація, яка втілює формат (виробнича біблія), може включати в себе об'єкти авторських і суміжних прав, промислову власність, ноу-хау, інші результати інтелектуальної діяльності, конфіденційну інформацію тощо. При цьому, цілком очевидно, режим охорони формату не повинен об'єднувати елементи всіх перерахованих інститутів. Однак охороняти формат різними правовими інститутами одночасно згідно зі світовою судовою практикою, потрібно і можливо.

У найзагальнішому вигляді телевізійний формат може бути охарактеризований як унікальна сукупність стійких елементів аудіовізуального твору (телешоу, серіалу тощо), на основі якої можливе створення самостійної серії аудіовізуальних творів в будь-якій точці світу з урахуванням національних (локальних) особливостей конкретного регіону [12].

Відмінності в складі формату результатів дозволяють виділити чотири стадії створення формату:

1) поява неохоронюваної ідеї;

2) виклад ідеї у вигляді «паперового» формату - твору;

3) розробка формату програми шляхом доповнення «паперового» формату іншими результатами інтелектуальної діяльності;

4) переробка формату програми до аудіовізуального твору і випуск у світ епізодів.
Незважаючи на поширеність виробництва форматів телевізійних програм і реалізації прав на них єдність правової кваліфікації телеформату відсутня навіть за умови достатнього ступеня єдності в розумінні його призначення (виготовлення локальної версії успішної телепрограми 3 місцевими ведучими, учасниками, акторами і з урахуванням культурних особливостей конкретного регіону), складу (як охоронювані правом інтелектуальної власності, так i такі, що не охороняються, елементи, наприклад: дизайн декорацій, сценарій, музична тема і технологія виробництва, правила гри, критерії підбору учасників - відповідно) і способу фіксації (у вигляді опису, ескізів, фотографій, відео-, кіно-, телезаписів тощо у виробничій біблії).

Натомість акумулюючи погляди щодо розуміння поняття «телеформат», можна зазначити, що на сьогодні формулюються чотири підходи до розуміння формату телевізійної програми:

1) як ідеї, яка не підлягає правовій охороні;

2) як структури телепрограми;

3) як зовнішнього вигляду телепрограми;

4) як складного об'єкта права інтелектуальної власності.

Так, прихильники останнього підходу розглядають телевізійний формат як складний об'єкт права інтелектуальної власності, що становить сукупність елементів, комбінація яких є характерною саме для цього об'єкту та вирізняє його серед інших подібних об'єктів. Серед них прийнято виділяти власне об'єкти авторського права (сценарії, декораціі), торговельну марку (назву), комерційну таємницю, ноу-хау (інформацію).

При цьому формат телевізійної програми, будучи результатом розумових зусиль творців, виражений ззовні у об'єктивній формі (наприклад, у вигляді сценарію, синопсиса, дизайну декорацій, відеозапису епізоду, інших елементів формату), володіє схожістю з рядом охоронюваних результатів інтелектуальної діяльності і сам визнається таким судовою практикою.

Враховуючи поширеність телеформатів у сфері телебачення та важливість забезпечення прав їх розробників вважається доцільним закріпити телеформат на законодавчому рівні як самостійний складний об'єкт права інтелектуальної власності, який може об'єднувати результати творчої діяльності різних категорій.

\section{ЛITEPATYPA}

1. Гаврилов Э. «Формат» аудиовизуального произведения и некоторые вопросы права интеллектуальной собственности. СПС «КонсультантПлюс», 2016

2. Про авторське право і суміжні права: Закон України. URL: https://zakon.rada.gov.ua/laws/show/3792-12\#Text

3. Федорова Н. В. Суб'єктний склад на телеформат як об'єкт авторського права. Цивільне судочинство у світлі судової реформи в Україні : матеріали Міжнар. наук.-практ. конф. ім. Ю. С. Червоного (м. Одеса, 18 груд. 2015 р.) / уклад. : І. В. Андронов, М. В. Волкова, Р. Ф. Гонгало ; МОН України ; НУ ОЮА. Одеса : Фенікс, 2015. С. 136-139.

4. Шаповал Д. Телесормат. Українські реалії та закордонний досвід: https://uz.ligazakon.ua/ua/magazine_article/EA008604

5. Силкіна А. Способи захисту телеформату у праві інтелектуальної власності. Підприємництво, господарство $і$ право 2021. №3. C. $60-64$.

6. Ульянова Г.О. Методологічні проблеми цивільно-правового захисту прав інтелектуальної власності від плагіату : дис. ... докт. юрид. наук : 12.00.03. 2015. 445 с.

7. Штефран А. Формат телепередачі: сутність, зміст, правова охорона. Теорія і практика інтелектуальної власності. 2016. № 1. С. 48-58.

8. Федорова Н. Телеформат як об'єкт правової охорони. Теорія і практика інтелектуальної власності. 2014. №4. С.29-34.

9. Федорова Н. Телеформат чи телепрограма? Теорія і практика інтелектуальної власності. 2020. № 1. С.13-20.

10. Яковець А. В. Телевізійна журналістика: теорія і практика: підручник. Київ. Києво-Могилянська академія, 2007. С. 121.

11. Верескун (Крекотень) М. Телефрормат: бути чи не бути? 2015. https://webcache.googleusercontent.com/search?q=cache:dYCILAqs AylJ:https://www.freelawyer.ua/news/747+\&cd=21\&hl=ru\&ct=clnk\&gl=ua;

12. Ананьева А. Формат аудиовизуального произведения. ИС. Авторское право и смежные права. 2017. № 4. С. 15-22. 


\title{
ЗАКОНОДАВЧІ ЗАСАДИ КОЛЕКТИВНОГО УПРАВЛІННЯ АВТОРСЬКИМИ ТА СУМІЖНИМИ ПРАВАМИ
}

\section{LEGISLATIVE PRINCIPLES OF COLLECTIVE MANAGEMENT OF COPYRIGHT AND RELATED RIGHTS}

\author{
Подолєв О.О., аспірант кафедри права інтелектуальної власності \\ та корпоративного права \\ Національний університет «Одеська юридична академія»
}

\begin{abstract}
У статті проаналізовано правові аспекти діяльності організацій колективного управління авторськими та суміжними правами. На основі аналізу наукових досліджень, положення законодавства, судової практики визначено проблемні питання у сфері управління авторськими і суміжними правами. Однією з найпоширеніших проблем у сфері колективного управління правами на об'єкти авторського права та суміжних прав є наявність кількох організацій, уповноважених на управління правами. За таких умов користувач може отримати вимогу про виплату винагороди за комерційне використання об'єктів авторського права і суміжних прав від кількох організацій колективного управління авторським правом і суміжними правами. Обґрунтовано, що в організації діяльності організацій колективного управління авторськими та суміжними правами особливе значення має встановлення порядку розподілу та використання грошових коштів. За загальним правилом інформацію про отримання та розподіл коштів відображається у щорічних звітах ОКУ та передбачає зокрема дані про: зібрані кошти, розподілені кошти, кошти, які залишились не виплаченими та акумулюються на окремих рахунках. В частині коштів, які спрямовані на забезпечення діяльності виділяються зокрема плата за управління правами; суми, утримані з метою надання соціальних, культурних та освітніх послуг. Встановлено, що на законодавчому рівні відсутні чіткі правила розподілу коштів на забезпечення діяльності організацій колективного управління авторськими та суміжними правами. У законі України "Про ефективне управління майновими правами правовласників у сфері авторського права та (або) суміжних прав" вимагають уточнення положення про розподіл прибутку від прав, зібраного акредитованою організацією за приватне копіювання (відтворення в домашніх умовах та в особистих цілях твір та виконань, зафіксованих) у фонограмах, відеограмах, а також аудіовізуальних творах).

Ключові слова: організації колективного управління авторськими та суміжними правами, майнові права, комерційне використання об'єктів авторського права та суміжних прав, авторська винагорода.
\end{abstract}

The article analyzes the legal aspects of the activities of collective management organizations. On the basis of scientific research, provisions of legislation, judicial practice and problematic issues in the field of management of copyright and related rights are highlighted. One of the most common problems in the field of collective management of rights to objects of copyright and related rights is the presence of several organizations authorized to manage rights. In such conditions, the user may receive a claim for payment of remuneration for the commercial use of objects of copyright and related rights from several collective management organizations of copyright and related rights. It has been substantiated that in organizing the activities of organizations for collective management of copyright and related rights, the establishment of the procedure for the distribution and use of funds is of particular importance. As a general rule, information on the receipt and distribution of funds is reflected in the annual reports of the OCU and includes data on: funds collected, distributed funds, funds that remained unpaid and accumulated in separate accounts. In the part of funds that are aimed at ensuring the activities are allocated, in particular, fees for rights management; amounts withheld for the purpose of providing social, cultural and educational services. It was established that at the legislative level there are no clear rules for the distribution of funds to ensure the activities of organizations for collective management of copyright and related rights. The Law of Ukraine "On the effective management of property rights of copyright holders and (or) related rights" requires clarification of the provision on the distribution of profits from rights collected by an accredited organization for private copying (reproduction at home and for personal purposes of a work and performances recorded in phonograms, videograms, as well as audiovisual works).

Key words: organizations of collective management of copyright and related rights, property rights, commercial use of objects of copyright and related rights, royalties.

Одним із важливих майнових прав інтелектуальної власності є право на отримання винагороди за використання результатів творчої, інтелектуальної діяльності. Можливість отримання справедливої винагороди за результати творчої діяльності має важливе значення не лише 3 позиції фінансового забезпечення творців, а й стимулювання їх подальшої творчої діяльності, створення умов для появи нових об'єктів. Як свідчить рівень поширення піратської, контрафактної продукції в сучасних умовах рівень культури використання чужих результатів творчої, інтелектуальної діяльності не є достатньо високим, що завдає чималої шкоди не лише правовласникам, а й негативно позначається на міжнародному іміджі країни. Масштаби використання об'єктів авторського права, особливо з розвитком мережі Інтернет, не дозволяють автору самостійно відстежити всі випадки використання його творів 3 комерційною метою та відповідно отримати належну винагороду. У зв'язку з чим важливе значення має забезпечення ефективної діяльності організацій колективного управління авторськими та суміжними правами.

Для діяльності організацій колективного управління авторськими та суміжними правами (далі ОКУ) знаковою подією стало прийняття у 2018 році Закону України «Про ефективне управління майновими правами правовласників у сфері авторського права і (або) суміжних прав» (далі Закон України № 943-IX). 3 прийняттям Закону визначено більш повно порівняно з Законом України «Про авторське право i суміжні права» види організацій колективного управління, їх правовий статус та порядок реалізації покладених на них функцій. Разом $з$ тим, щоб визначити стан правового забезпечення діяльності ОКУ вважається за необхідне проаналізувати доктринальні підходи до визначення напрямів діяльності таких організацій, а також судової практики застосування законодавства у сфері колективного управління авторськими та суміжними правами.

Серед наукових досліджень, присвячених питанням колективного управління авторськими та суміжними правами слід відзначити монографічну роботу Майданик Л.Р. «Колективне управління майновими авторськими і суміжними правами за цивільним законодавством України» 2013 р. [1]. Окремі питання діяльності організацій колективного управління досліджувались в наукових працях Яворської О. [2], В. Дроб'язко [3], Денисової Р. [4], Бондаренко С. [5]. Разом 3 тим, зміни, внесені Законом України № 943-IX потребують комплексного дослідження з урахуванням аналізу судової практики.

Правові засади колективного управління авторськими та суміжними правами було закладено Законом Укра- 
їни «Про авторське право і суміжні права». Враховуючи недостатньо повне визначення всіх умов діяльності ОКУ на рівні зазначеного Закону на практиці виникало чимало дискусійних питань щодо розподілу повноважень між різними ОКУ, визначення умов фінансового забезпечення ïх діяльності, акумулювання невиплаченої винагороди, повноважень ОКУ на збір та фіксацію доказів неправомірного використання об'єктів авторського права та суміжних прав з комерційною метою тощо.

В першу чергу, аналізуючи положення Закону України № 943-IX слід звернутись до визначення правового статусу ОКУ та видів колективного управління, яке також впливає на визначення виду та повноважень ОКУ.

Відповідно до Закону України № 943-ІХ ОКУ є неприбутковою організацією, утворюється в організаційно-правовій формі громадського об'єднання (громадська організація або громадська спілка) зі статусом юридичної особи, єдиним видом діяльності якої $є$ виконання завдань і функцій, визначених зазначеним Законом. При цьому статус ОКУ визначається залежно від виду колективного управління авторськими та /або суміжними правами.

Наразі на рівні закону встановлено 3 види колективного управління авторськими та /або суміжними правами: добровільне колективне управління майновими авторськими та суміжними правами може здійснюватися в будьякій сфері управління правами, крім тих, у яких здійснюється розширене або обов'язкове колективне управління;

розширене колективне управління - здійснюється виключно у сферах, визначених Законом України № 943-IX; обов'язкове колективне управління - здійснюється виключно у сферах, визначених Законом України № 943-IX.

На відміну від добровільного управління майновими авторськими та суміжними правами, розширене та обов'язкове колективне управління може здійснюватись акредитованими ОКУ, при цьому одна ОКУ може бути акредитована на здійснення розширеного чи обов'язкового колективного управління у декількох сферах.

Існування значної кількості організацій сьогодні створюють усі передумови для розвитку ринкових відносин 3 явно вираженою конкуренцією. А ОКУ за своєю суттю $\epsilon$ некомерційними організаціями. У такому розрізі говорити про доцільність існування конкуренції недоцільно. Основним призначенням інституту колективного управління, а отже, і відповідних організацій, є забезпечення суб'єктам авторських і суміжних прав реалізації їх майнових прав, а також надання можливості використовувати третім особам відповідні об'єкти авторських і суміжних прав $[4$, с.20].

Слід зазначити, що до прийняття Закону України № 943-IX було розроблено проект закону «Про внесення змін до Закону України "Про авторське право і суміжні права" щодо діяльності організацій колективного управління» від 18.04.2016 № 4461 [6], який зокрема передбачав створення однієї ОКУ, яка буде представляти інтереси авторів, виконавців та інших правовласників. Досліджуючи правові засади діяльності ОКУ, Плотнікова М. щодо зазначених положень проекту закону відзначила, що однозначним позитивним моментом таких законодавчих змін $\epsilon$ ліквідація можливості існування нескінченої кількості організацій колективного управління. Чітке визначення сфер розширеного колективного управління, можливість правовласника заборонити здійснювати розширене колективне управління (за винятком «збору за чисті носії»), визначення ОКУ ставок колективної винагороди на умовах публічного договору (не Кабінет Міністрів України, а правовласники вирішуватимуть, якими повинні бути відрахування за використання фонограм, опублікованих із комерційною метою), ліквідація державного контролю за діяльністю ОКУ і запровадження публічного контролю в цій сфері. Зазначені положення сприятимуть збільшенню самоорганізаційних засад у сфері колективного управління майновими авторськими та (або) суміжними правами [7].

Діяльність декількох організацій колективного управління на практиці призводить до того, що користувачі, укладаючи договір з однією ОКУ, отримують звернення щодо нарахування та необхідність виплати винагороди від іншої ОКУ. Відсутність чіткого розмежування сфер діяльності різних ОКУ за таких умов негативно позначається на користувачах, оскільки постає потреба доводити правомірність використання об'єктів авторського права та суміжних прав 3 комерційною метою на законних засадах.

Розглядаючи справу приватної організації «Організація колективного управління авторськими та суміжними правами» про захист прав приватного підприємства «СВIТОВА МУЗИКА» до відповідача про стягнення 223380грн компенсації за порушення майнових авторських прав шляхом публічного виконання/використання (без відповідного дозволу правовласника та без виплати авторської винагороди) твору, майнові авторські права на який належить ПП «СВIТОВА МУЗИКА» та заперечення відповідача на позов, який зазначив, що на підставі договору, укладеного між відповідачем та ВГО «Агентство охорони прав виконавців», відповідач отримав право на використання об'єктів авторського права та суміжних прав на території України за плату терміном на один рік, Господарський суд Тернопільської області зазначив, що надавши організаціям колективного управління можливість дозволяти використання об'єктів авторського права, які хоча й не перебувають в їх управлінні, але не вилучені 3 нього в установленому порядку, законодавець врахував специфіку діяльності суб'єктів господарювання, які здійснюють постійне використання великої кількості різноманітних об'єктів авторського права, завчасне визначення переліку яких (із встановленням правовласників та одержанням необхідного дозволу від кожного $з$ них) є надмірно складним або взагалі неможливим (телерадіоорганізації; особи, що здійснюють ретрансляцію телерадіопрограм; власники закладів, де відбувається публічне виконання творів, тощо). Такий підхід водночас забезпечує дотримання прав суб'єктів авторського права - як щодо дозволу на використання творів, так і стосовно отримання винагороди та дозволяє суб'єктам господарювання здійснювати використання необмеженого переліку творів без порушення майнових авторських прав, уклавши відповідний договір 3 однією організацією колективного управління [8].

Не менш важливим питанням у сфері діяльності ОКУ $€$ визначення фінансових засад їх діяльності, оскільки 3 однієї сторони ОКУ створюються як некомерційні організації, з іншої - для забезпечення їх функціонування потребують відповідного фінансування.

Досліджуючи діяльність ОКУ, Яворська О. зазначає, що оскільки такі організації не можуть мати на меті одержання прибутку, то на законодавчому рівні з метою уникнення зловживань має бути зазначене джерело формування ресурсів на функціонування організації. Адже вона буде виконувати різні дії, спрямовані на управління майновими правами. Їх виконання забезпечуватимуть відповідні фахівці, які мають право на винагороду на підставі трудового чи цивільно-правового договору. Варто окреслити і загальні правові вимоги щодо взаємовідносин організації колективного управління та ії членів, організації та інших осіб, з якими вона вступатиме у правовідносини щодо управління майновими правами. Належне правове забезпечення створення, функціонування та припинення організацій колективного управління забезпечить ефективну та прозору їх роботу [2, с. 28].

Враховуючи, що ОКУ не має спеціального фінансування, спрямованого на забезпечення їх діяльності, такі видатки формуються за рахунок коштів, які вона може отримати. На законодавчому рівні як правило визначаються загальні напрями витрати коштів та джерела їх форму- 
вання. За загальним правилом інформацію про отримання та розподіл коштів відображається у щорічних звітах ОКУ та передбачає зокрема дані про: зібрані кошти, розподілені кошти, кошти, які залишились не виплаченими та акумулюються на окремих рахунках. В частині коштів, які спрямовані на забезпечення діяльності виділяються зокрема плата за управління правами; суми, утримані з метою надання соціальних, культурних та освітніх послуг.

Відповідно до ст15 Директиви 2014/26/EU Європейського Парламенту та Ради від 26.02.2014 про колективне управління авторськими та суміжними правами та мультитериторіальне ліцензування прав на музичні твори 3 метою онлайнового використання на внутрішньому ринку 18.05.2014 передбачено заборону ОКУ проводити утримання коштів, крім плати за управління, з доходів від прав, отриманих від управління правами на основі угод про представництво, або з прибутку від інвестування доходів від прав, якщо тільки інша організація з колективного управління, яка $є$ стороною угоди про представництво не дасть прямої згоди на такі утримання [9].

Законом України № 943-ІХ однією з умов ефективного управління визначено поряд із забезпеченням ОКУ збирання, розподілу та виплати доходу від прав правовласникам у найбільш швидкий, ефективний і точний спосіб, визнано обгрунтовані витрати. Витрати організацій колективного управління на придбання товарів, робіт і послуг відповідають критерію ефективності управління, якщо вони здійснюються з використанням процедур, встановлених Законом України «Про публічні закупівлі». Слід відзначити, що окремі статті витрат, які здійснюють ОКУ 3 метою реалізації покладених на них функцій, визначено в Законі України № 943-IX в частині складання щорічного звіту про діяльність організацій. До можливих витрат ОКУ віднесено, зокрема: операційні та фінансові витрати, здійснені організацією, з розподілом за категоріями прав, якими вона здійснює управління. У разі якщо витрати $\epsilon$ непрямими або такими, що не можуть бути віднесені до жодної з категорій прав, - 3 обгрунтуванням таких витрат; операційні та фінансові витрати в частині безпосереднього управління правами з розподілом за категоріями прав, якими управляє організація. У разі якщо витрати $\epsilon$ непрямими і такими, що не можуть бути віднесені до жодної з категорій прав, - з обгрунтуванням таких витрат; операційні і фінансові витрати, здійснені щодо інших, ніж управління правами, послуг. У разі використання частини суми зібраних коштів на культурні, соціальні, навчальні цілі до щорічного звіту про діяльність організації колективного управління додається спеціальний звіт з детальною інформацією про напрями використання таких коштів із зазначенням витрачених сум за кожним напрямом. Таким чином на законодавчому рівні чітко не визначено статті видатків, які може робити ОКУ з метою забезпечення їх діяльності.

Слід також відзначити, що окремі положення Закону України № 943-IX в частині розподілу зібраної винагороди можуть призводити на практиці до виникнення спірних ситуацій щодо визначення кола суб'єктів, які мають право на отримання винагороди за використання об'єктів авторського права та суміжних прав. Відповідно до ст. 23 ч.6 Закону України № 943-IX передбачено категорії правовласників, між якими розподіляється дохід від прав, зібраного акредитованою організацією за приватне копіювання (відтворення в домашніх умовах і в особистих цілях творів і виконань, зафіксованих у фонограмах, відеограмах, а також аудіовізуальних творів), а саме: особи, що володіють майновими авторськими правами на музичні твори; особи, що володіють майновими авторськими правами на аудіовізуальні твори; автори і виконавці аудіовізуального твору чи їх спадкоємці; особи, що володіють майновими суміжними правами на фонограми (відеограми); виконавці творів, зафіксованих у фонограмах (відеограмах), чи їх спадкоємці. На практиці автор аудіовізуального твору може одночасно й бути особою, що володіє майновими авторськими правами на аудіовізуальний твір, крім того, якщо автор такого твору передав права, виходячи зі змісту статті він має право на відрахування на рівні особи, якій такі права передано.

Таким чином, питання розподілу коштів та їх збору потребують більш детальної регламентації. Слід відзначити, що з прийняттям Закону України № 943-ІХ достатньо повно визначено правові засади діяльності ОКУ. Однак, як свідчить судова практика, через різний статус ОКУ та визначені сфери їх діяльності не виключено випадки, за яких правами на певний результат управляють різні ОКУ, внаслідок чого виникають складнощі у користувачів.

\section{ЛITEPATУPA}

1. Майданик Л.Р. Колективне управління майновими авторськими і суміжними правами за цивільним законодавством України : монографрія, Київ. нац. ун-т ім. Т. Шевченка. Київ : Алерта, 2013. 247 с.

2. Яворська О. Управління майновими правами субєктів авторського права і суміжних прав. Підприємництво, господарство і право. 2016. №7. С.26-30.

3. В. С. Дроб'язко Колективне управління авторським правом і суміжними правами. Зарубіжний досвід. К. : ТОВ “Лазурит-Поліграф”, 2010. $166 \mathrm{c}$

4. Денисова Р. О. Колективне управління майновими авторськими та (або) суміжними правами в Україні. Право та інноваційне суспільство. 2016. № 2 (7). C.8-23. http://apir.org.ua/wp-content/uploads/2016/12/Denysova7.pdf

5. Бондаренко С. Державне регулювання діяльності організацій колективного упрвління правами суб'єктів авторського права та суміжних прав в Україні. Інфрормація і право. 2014. № 2 (11).

6. Про внесення змін до Закону України «Про авторське право і суміжні права» щодо діяльності організацій колективного управління: Проект Закону № 4461 від 18.04.2016. http://w1.c1.rada.gov.ua/ pls/zweb2/webproc34?id=\&pf3511=58776\& pf35401=384348

7. Плотнікова М. Деякі питання розширення дії самоорганізаційних засад колективного управління майновими авторськими та (або) суміжними правами. Підприємництво, господарство і право. 2016. №11. С.39-43.

8. Рішення Господарського суду Тернопільської області. Справа № 921/440/18https://reyestr.court.gov.ua/Review/78929137

9. Директива 2014/26/EU Европейского Парламента и Совета от 26.02.2014 о коллективном управлении авторскими и смежными правами и мультитерриториальном лицензировании прав на музыкальные произведения в целях онлайнового использования на внутреннем рынке 18.05.2014. Перевод Тарасов Д.А., 2014. http://lexdigital.ru/2014/109/ 
Запорізький національний університет

Міністерства освіти і науки України

\section{Електронне наукове фахове видання «Юридичний науковий електронний журнал»}

№ 4, 2020 